\title{
Torres de Água Incursão em sua Arquitetura
}

Dissertação apresentada à Faculdade de Arquitetura e Urbanismo da Universidade de São Paulo para obtenção do título de Mestre em Arquitetura e Urbanismo

Orientador: Prof. Dr. Francisco Spadoni Área de Concentração: Projeto de Arquitetura 
Autorizo a reprodução e divulgação total ou parcial deste trabalho, por qualquer meio convencional ou eletrônico, para fins de estudo e pesquisa, desde que citada a fonte.

E-mail: tiagooliveandrade@gmail.com

Catalogação na Publicação

Serviço Técnico de Biblioteca

Faculdade de Arquitetura e Urbanismo da Universidade de São Paulo

Andrade, Tiago de Oliveira

Torres de Água: Incursão em sua Arquitetura / Tiago de Oliveira Andrade; orientador Francisco Spadoni. - São Paulo, 2019.

$2 \mathrm{v}$. il..

Dissertação (Mestrado) - Faculdade de Arquitetura e Urbanismo da Universidade de São Paulo. Área de concentração: Projeto da Arquitetura.

1. Torre de Água. 2. Reservatório Elevado. 3. Projeto de Arquitetura. 4. Infraestrutura. I. Spadoni, Francisco, orient. II. Título.

Elaborada eletronicamente através do formulário disponível em: <http://www fau.usp.brifichacatalografica/> 
FOLHA DE APROVAÇÃO

ANDRADE, Tiago de Oliveira. Torres de Água: Incursão em sua Arquitetura. Dissertação (Mestrado). Faculdade de Arquitetura e Urbanismo da Universidade de São Paulo. Programa de Pós-graduação da Faculdade de Arquitetura e Urbanismo. Área de Concentração: Projeto de Arquitetura.

Aprovado em:

Banca Examinadora:

Prof. Dr.

Instituição:

Julgamento:

Assinatura:

Prof. Dr.

Instituição:

Julgamento:

Assinatura:

Prof. Dr.

Instituição:

Julgamento:

Assinatura: 

"Nas ordens da cidade, existe a arquitetura da água. Eu vejo uma cidade que é proposta para 300 mil pessoas. Eu sei que não está correta. Por quê? Porque eu não consigo perceber a ordem da água. Não consigo entender como um lugar no deserto não possa ter entre seus mais gloriosos edifícios suas torres de água, o centro de onde a água é obtida."

Louis I. Kahn, $1^{\circ}$ Congresso Internacional de Arquitetos, Irã, 1970. ${ }^{1}$

\footnotetext{
1 "In the orders of the city, there is the architecture of water. I look at the village which is proposed for three hundred thousand people. I know it isn't right. Why? Because I cannot see how a place in the desert can not have as its most glorious buildings its water towers, its center from where the water is gotten." (KAHN, Louis. First International Congress of Architects, Isfahan, Iran. Palestra 1970. In: WURMAN, Richard Saul. What Will Be Has Always Been: The Words of Louis I. Kahn. New York: Access Press / Rizzoli International Publications, 1986, p. 97).
} 



\section{AGRADECIMENTOS}

À Carolina, não apenas pela sua ajuda, mas por seu companheirismo e amor. Sem ela este trabalho não seria concluído.

Aos meus pais pela educação, amor e apoio incondicionais.

À minha mãe, Fatima, participando ativamente desta dissertação.

Ao meu pai, José, por me indicar o caminho dos livros.

À Juliana e ao Luis pelo apoio e por saber esperar.

Ao professor Francisco Spadoni, pela orientação e pelas contribuições ao longo da pesquisa.

Aos professores Miguel Antonio Buzzar e Rafael Antonio Cunha Perrone pelas sugestões e contribuições no exame de qualificação.

Aos amigos do escritório, Bianca e Rômulo, pela paciência e pelo apoio.

Aos professores e funcionários do Programa de Pós-Graduação em Arquitetura e Urbanismo da FAUUSP pelas contribuições nos mais diversos aspectos. 



\section{RESUMO}

O objeto de estudo desta pesquisa é a Torre de Água, parte integrante fundamental de sistemas públicos ou privados de abastecimento de água, sistemas infraestruturais vitais para o suporte da vida e cuja existência constitui uma das bases materiais para a existência das cidades.

Apesar de sua inegável importância e utilidade, o estudo das torres de água como objeto arquitetônico e tema de projeto têm sido relegados em trabalhos acadêmicos não sendo exploradas com a atenção requerida.

A pesquisa busca analisar a arquitetura das Torres de Água, reconstruindo as origens históricas do objeto e identificando a pluralidade de soluções construtivas, tipologias, linguagens e paradigmas arquitetônicos decorrentes das transformações arquitetônicas, culturais, das inovações tecnológicas e das preocupações sócio-ambientais, flagrando o modo como a arquitetura das torres de água se transforma em meio a todas estas mudanças, desde a implantação dos primeiros sistemas modernos de abastecimento de água, em meados do século XIX, até a atualidade.

Palavras chave: Torre de água, castelo de água, reservatório elevado, projeto de arquitetura, infraestrutura. 



\section{ABSTRACT}

The object of study of this research is the Water Tower, a fundamental part of public or private water supply systems, infrastructural systems vital for the support of life and whose existence constitutes one of the material bases for the existence of the cities.

Despite its undeniable importance and usefulness, the study of water towers as an architectural object and design theme has been relegated in academic works not being explored with the required attention.

The research seeks to analyze the architecture of the Water Towers, reconstructing the historical origins of the object and identifying the plurality of constructive solutions, typologies, languages and architectural paradigms resulting from architectural and cultural transformations, technological innovations and socioenvironmental concerns, drawing attention to the way in which the architecture of the water towers transforms in the middle of all these changes, from the introduction of the first modern systems of water supply, in the middle of the XIX century, until the present time.

Key words: Water towers, elevated reservoir, elevated tank, architecture project, infrastructure. 

ABNT: Associação Brasileira de Normas Técnicas

AWWA: American Water Works Association

a.C.: antes de Cristo

ca.: cerca

CB\&l: Chicago Bridge and Iron Company

$\mathrm{cm}$ : centímetro

d.C.: depois de Cristo

ETA: Estação de Tratamento de Água

fig: figura

km: quilômetro

I/s: litros por segundo

m: metro

m.c.a.: metro de coluna de água

$\mathrm{mm}$ : milímetro

$\mathrm{m}^{2}$ : metro quadrado

$\mathrm{m}^{3}$ : metro cúbico

$\mathrm{m}^{3} / \mathrm{min}$ : metro cúbico por minuto

n.: nascido

NB: Procedimento Brasileiro

NBR: Norma Técnica Brasileira

NTS: Norma Técnica SABESP

SABESP: Companhia de Saneamento Básico do Estado de São Paulo SANEPAR: Companhia de Saneamento do Paraná 



\section{LISTA DE FIGURAS}

\section{INTRODUÇÃO}

1:

Torre de Água em área rural da França. Fotografia de Jo Brunenberg.

Fonte: https://www.jobrunenberg.com/chateau-deau-de-france\#83

\section{PRIMEIRA PARTE: DEFINIÇÃO E FUNÇÃO DAS TORRES DE ÁGUA}

\subsection{Torre de Água: uma definição}

\subsection{1:}

"Torre de Água" na cidade de Chester, Inglaterra.

Fonte: https://www.antiquemapsandprints.com/ekmps/shops/richben90/images/cheshire-chester-cathedral-water-tower-oldprint-1860-35311-p.jpg

\subsection{2:}

Página da revista The Builder com o projeto para a Torre de Água de Worthing, Inglaterra, 1857.

Fonte: Worthing Water-Tower and Engine-House. The Builder, London, v. 14, p. 243, 2 maio 1857.

\subsection{3:}

José Luís Fleury de Oliveira, "caixa d'água".

Fonte: CORONA, Eduardo; LEMOS, Carlos A. C.. Dicionário da Arquitetura Brasileira. São Paulo: EDART, 1972, p. 95.

\subsection{Função e Funcionamento da Torre de Água}

\subsection{1:}

Sistema de abastecimento de água operando inteiramente por gravidade.

Fonte: Autor, 2018.

\subsection{2:}

Sistema de abastecimento de água com captação em um curso de água e bombeamento da água para as unidades seguintes e distribuição final.

Fonte: Autor, 2018.

\subsection{3:}

Sistema de abastecimento de água com captação em curso de água, recalque para a etapa de tratamento e posterior distribuição da água potável por gravidade.

Fonte: Autor, 2018.

\subsection{4:}

Gráfico da variação do volume de água no reservatório em função da curva de consumo e adução contínua.

Fonte: Autor, 2018.

\subsection{5:}

Gráfico de Curva de Demanda.

Fonte: Autor, 2018.

\subsection{6:}

Sistema de abastecimento de água em área de planície com utilização de uma torre de água para distribuição de água por gravidade.

Fonte: Autor, 2018. 


\subsection{7:}

Sistema de abastecimento de água com utilização de uma torre de água para distribuição de água por gravidade para atendimento do bairro alto de uma cidade.

Fonte: Autor, 2018.

\subsection{8:}

Quadro de Tipologias de Reservatórios.

Fonte: Autor, 2018.

\subsection{9:}

Sistemas estruturais para torres de água.

Fonte: Autor, 2018.

\subsubsection{0a:}

Elementos da torre de água de montante.

Fonte: Autor, 2018

\subsubsection{0b:}

Elementos da torre de água de jusante.

Fonte: Autor, 2018

\subsubsection{1a:}

Torre de água de montante.

Fonte: Autor, 2018.

\subsubsection{1b:}

Torre de água de jusante.

Fonte: Autor, 2018.

\subsubsection{2:}

Alternativas de escadas para acesso aos reservatórios de torres de água.

Fonte: RIENKS, H.. Nederlandse Watertorens. RDMZ RV, Amsterdam, n. 14, RVblad, p. 9, 1989.

\section{SEGUNDA PARTE: HISTORIA}

\subsection{Infraestrutura da Água}

\subsection{1:}

Travessia de aquedutos perto de Roma.

$\mathrm{Na}$ estrutura da parte inferior direita da imagem estão os três canais sobrepostos dos aquedutos Aqua Marcia, Aqua lulia e Aqua Tepula, a outra estrutura contém os canais dos aquedutos Aqua Claudia e Anio Novus. Pintura de Michael Zeno Diemer, cerca de 1910.

Fonte: Wellcome Collection. Disponível em: https://iiif.wellcomecollection.org/image/V0031040.jpg/full/full/0/default.jpg

\subsection{2:}

Máquinas para Elevação Artificial de Água.

a) Roda de Água

b) Nora

c) Parafuso de Arquimedes

d) Bomba de Ctesíbio

Fonte: da edição de Vitruvius por Fra Giocondo, Veneza, 1511.

\subsection{3:}

Carregadores de água da Idade Média.

Fonte: VEEN, Henk van Der. Watertorens in Nederland. Rotterdam: Uitgeverij 010, 1989, p. 18. 


\subsection{4:}

"Estação Hidráulica" de Lübeck.

Detalhe da panorâmica Lubecca Urbis Imperialis de Elias Diebel, Lübeck, 1552. Xilogravura em 24 partes.

Fonte: https://upload.wikimedia.org/wikipedia/commons/5/5b/WP_Diebel_L\%C3\%BCbeck.jpg

\subsection{5:}

Sistemas de Bombeamento nos séculos XV e XVI.

a) Bomba de Corrente

b) Bomba de Pistão

Fonte: AGRICOLA, Georgius. De Re Metallica. New York: Dover Publications, 1950, p. 197 e 189.

\subsection{6:}

London Bridge Waterworks.

Fonte: GARNETT, William. Little Book on Water Supply. Cambridge: Cambridge Univesity Press, 1922, p. 117.

\subsection{7:}

"Estação Hidráulica" La Samaritaine.

Fonte: http://www.art-et-histoire.com/seguin/pt17pnf.jpg

\subsection{8:}

La Samaritaine, secção no lado do Louvre.

Fonte: Musée Carnavalet, Paris. Disponível em: http://parismuseescollections.paris.fr/fr/musee-carnavalet/oeuvres/lasamaritaine-profil-du-cote-du-louvre-1er-arrondissement-act\#infos-principales

\subsection{9:}

Uma típica "estação hidráulica" do século XVI.

Fonte: RAMELLI, Agostino. Le Diverse et Artificiose Machine del Capitano Agostino Ramelli. Paris, 1588, fig. IX.

\subsection{Precursores das Torres de Água}

\subsection{1:}

Máquina para fabricação de tubos de madeira, na gravura de um livro de 1661.

Brocas de diversos tamanhos, giradas por um mecanismo impulsionado por roda de água, perfuram o tronco.

Fonte: BÖCKLER, Georg Andreas. Theatrum machinarum novum. Nuremberg: Paul Fürst, 1661, gravura 77.

\subsection{2:}

Fragmentos de tubos de chumbo encontrados em escavações feitas em Roma.

Fonte: DUPUIT, Jules. Traité Theórique et Pratique de la Conduite et de la Distribution des Eaux: Atlas. Paris: CarillianGoeury et V. Dalmont, 1854, p. 4.

\subsection{3:}

"Wasserkünst" de Brunswick, 1527.

Fonte: VEEN, 1989, p.14.

\subsection{4:}

Blausternwerk, construído em Nuremberg, 1580.

Fonte: BECHER, Bernhard; BECHER, Hilla. Die Architektur der Förder und Wassertürme. München: Prestel, 1971, p. 331.

\subsection{5:}

"Estação Hidráulica" com tanque coletor de água.

Fonte: RAMELLI, 1588, fig. V.

\subsection{6:}

Corte da "estação hidráulica" de Hanôver, 1794.

Fonte: BECHER, 1971, p. 332. 


\subsection{7:}

Torre de Água da York Buildings Waterworks Company.

The Thames Towards Westminster Bridge (ca. 1746), por Canaletto.

Fonte: http://www.artfixdaily.com/images/pr/aug28_Canaletto_London_the_Thames_towards_Wes20972x710.jpg

\subsection{8:}

Corte da "estação hidráulica" do Hofgarten Veitshöchheim, Alemanha,1767.

Fonte: http://www.veitshoechheim-blog.de/article-stra-ensperrma-nahmen-in-der-tiergartenstra-e-ursache-ist-der-historischeabwasserkanal-aus-dem-vei-124446195.html

\subsection{9:}

Philadelphia Waterworks, 1800.

Fonte: Philadelphia Water Departmente Historical Collection. Disponível em: http://www.phillyh2o.org/backpages/figures/Fig07_20040570221042_withnos.jpg

\subsubsection{0:}

Motor a vapor de Watt para bombeamento de água instalado na Chelsea Waterworks, Londres, 1803 Fonte: REES, Abraham. The Cyclopaedia; or Universal Dictionary of Arts, Sciences and Literatutre. Plates, v. 4. London: 1820, p. 255.

\subsection{Torres de Água no Século XIX}

\subsection{1:}

Estação de Água Ferroviária.

Fonte: VON RÖLL, Victor. Enzyklopädie des Eisenbahnwesens: Zehnter Band - Übergangsbrücken-Zwischenstation. Berlin: Urban \& Scharzenberg, 1923. 10 v, p. 288.

\subsection{2:}

Grua Hidráulica da Ferrovia de Oldenburg, Alemanha, ca. 1850.

Fonte: VON WALDEGG, Edmund Heusinger. Handbuch für specielle Eisenbahn-Technik. Leipzig: Verlag von Wilhelm Engelmann, 1870, prancha 47.

\subsection{3:}

Reservatório retangular de ferro fundido.

Fonte: Ibidem, prancha 47

\subsection{4:}

Estações de Águas das Ferrovias Inglesas.

Fonte: https://c1.staticflickr.com

\subsection{5:}

Corte de Estação de Água das Ferrovias Alemãs.

Fonte: VON RÖLL, 1923. 10 v, p. 288.

\subsection{6:}

Estações de Água das Ferrovias Alemãs, ca. 1850.

a) Estação Kaiserslautern-Eisiedlerhof

b) Estação Volksmarsen-Hessen

Fonte: BECHER, Bernd; BECHER, Hilla. Water Towers. Cambridge: Mit Press, 1988, f. 132 e 134.

\subsection{7:}

Projeto para a torre de água de Worthing, 1857.

Exemplo típico da primeira geração de torres de água inglesas para abastecimento público.

Fonte: Worthing Water-Tower and Engine-House. The Builder, London, v. 14, p. 243, 2 maio 1857.

\subsection{8:}

Torres de Água de Hartlepool, Inglaterra, 1850 (esquerda), 1870 (direita) e 1890 (centro).

Fonte: BARTON, Barry. Water Towers of Britain. Londres: Newcomen Society, 2003, p. 42. 


\subsection{9:}

Torre de Tower Hill, Ormskirk, Inglaterra, ca. 1853.

Fonte: http://4.bp.blogspot.com/-Wa36lhR_ueg/ULdvCT-VZwl/AAAAAAAACUI/DGje2rL6eo0/s400/1779797_1311b4c0.jpg

\subsubsection{0:}

Situação atual de Torre de Tower Hill, Ormskirk, Inglaterra.

Fonte: https://en.wikipedia.org/wiki/Tower_Hill_Water_Tower

\subsubsection{1:}

William Lindley, Torre de Água do Berliner Tor, Hamburgo, Alemanha, 1853-55. Foto (ca. 1890). Fonte: HÖHNS, Ulrich. Konstrukteur der modernen europaischen Stadt. William Lindley (1808-1900). Bauwelt, Berlin, v. 100, n. $39-40,2008$, p. 2.

\subsubsection{2:}

William Lindley, Torre de Água do Berliner Tor, Hamburgo, Alemanha, 1853-55. Planta, Cortes e Elevação.

Fonte: BECHER, 1971, p. 341.

\subsubsection{3:}

Tirantes e ancoragens dos reservatórios retangulares de ferro fundido.

Fonte: RIENKS, 1989, p. 10.

\subsubsection{4}

a) Jumbo Water Tower, Colchester, Inglaterra, 1882.

b) Torre de Água de Wivenhoe, Inglaterra, 1901

c) Torre de Água da Horncastle Road, Linconshire, Inglaterra, 1905.

Fonte: http://s0.geograph.org.uk e https://c1.staticflickr.com

\subsubsection{5:}

Corte, planta e detalhes construtivos da Jumbo Water Tower, Colchester, Inglaterra, 1882.

Fonte: Colchester Water Tower. The Engineer, London, v. 57, n. 15, fev. 1884, p. 129.

\subsubsection{6:}

Appleton Water Tower, Sandringham, Inglaterra, 1877.

Fonte: https://i.pinimg.com/originals/03/c6/95/03c695064ba3a1482ca7854ddddc49b4.png

Figura 2.3.17:

Werner Kümmel, Torre de Água de Altona, Hamburgo, Alemanha, 1859.

Fonte: Architekturmuseum der Technische Universität Berlin. Disponível em: https://architekturmuseum.ub.tuberlin.de/P/114066.php

\subsubsection{8:}

Torre de Água de Lübeck, Alemanha, 1867. Plantas, Corte e Elevação.

Fonte: ERBKAM, G.. Hochreservoir der Stadt-Wasserkunst in Lübeck. Atlas zur Zeitschrift für Bauwesen. Berlin: Ernst \& Korn, v. 20 , p. $45-46,1870$.

\subsubsection{9:}

Bernhard Salbach, Torre de Água de Halle, Alemanha, 1868.

Fonte: SALBACH, Bernhard. Das Wasserwerk der Stadt Halle: erbaut in den Jahren 1867 und 1868. Halle: G. Knapp, 1871.

\subsubsection{0:}

Johann Georg Poppe, Torre de Bremen, Alemanha, 1872.

Fonte: MERKL, Gerhard et al. Historische Wassertürme: Beiträge zur Technikgeschichte von Wasserpeicherung und Wasserversorgung. München: Oldenburg, 1985, p. 174.

\subsubsection{1:}

Torre de Krefeld, Alemanha, 1876.

Fonte: Ibidem, p. 200. 


\subsubsection{2:}

Jules Dupuit, Reservatório de Fundo Suspenso, Paris-Chaillot, 1854.

Fonte: DUPUIT, 1854, p. 11.

\subsubsection{3:}

Reservatório de fundo suspenso e detalhe dos anéis de pressão e de suporte.

Fonte: VON WALDEGG, 1870, prancha 47.

\subsubsection{4:}

Esforços atuantes nos anéis de suporte e de pressão dos reservatórios de fundo suspenso. Fonte: KOTTENMEIER, E.. Der Stalbehälterbau. Der Stahlbau, Berlin, v. 3, n. 2, 1930, p. 17.

\subsubsection{5:}

Diferentes tipologias de anéis de suporte e pressão de reservatórios de fundo suspenso.

Fonte: BECHER, 1971, p. 351.

\subsubsection{6:}

Torre de Água da Chemins de Fer du Midi, França, 1857.

Fonte: Série des Gares et Stations n 13. Nouvelles Annales de la Construction, Paris, v. 3, n. 3, jan. 1857, pranchas 5-6.

\subsubsection{7:}

Torres de Água da Estação de Hânover, Alemanha, ca. 1889. Plantas, cortes e elevações.

Fonte: ERBKAM, G.. Wasserversorgung des Bahnhofs Hannover. Atlas zur Zeitschrift für Bauwesen. Berlin: Ernst \& Korn, v. 39, p. 68, 1889.

\subsubsection{8:}

Torre de Água das Ferrovias Belgas, ca. 1881.

Fonte: VAN CRAENENBROECK, W.. Eenheid in Verscheidenheid: Watertorens in Belgie. Brussel: Navewa, 1991, p. 80.

\subsubsection{9:}

Torres Ferroviárias com Reservatório de Fundo Suspenso

a) Sézanne, Marne, França, ca. 1890.

b) Seine et Marne, França, ca. 1890

Fonte: BECHER, 1988, f. 60 e 61.

\subsubsection{0:}

Adolf Thiem, Torre de Água de Estrasburgo, 1878. Corte e elevação.

Fonte: Ibidem, p. 350.

\subsubsection{1:}

Otto Intze, Torre de Água de Essen, Alemanha, 1884. Planta, corte, elevação e detalhes.

Fonte: Ibidem, p. 352.

\subsubsection{2:}

Otto Intze, Torre de Água de Essen, Alemanha, 1884. Aspecto na década de 1920.

Fonte: https://twitter.com/essen_ruhr/status/594492323406446592

\subsubsection{3:}

Otto Intze, Torre de Água de Essen, Alemanha, 1884. Foto de Bernd e Hilla Becher, 1965. Fonte: BECHER, 1988, f. 124.

\subsubsection{4:}

Gustav Halmhuber, Torre de Água de Mannheim, Alemanha, 1886. Plantas e corte.

Fonte: ERBKAM, G.. Wasserthurm in Mannhiem. Zeitschrift für Bauwesen. Berlin: Ernst \& Korn, v. 42, p. $31,1892$. 


\subsubsection{5:}

Gustav Halmhuber, Torre de Água de Mannheim, Alemanha, 1886. Foto de Bernd e Hilla Becher, 1965.

Fonte: BECHER, 1988, f. 110.

\subsubsection{6:}

Catedral de São Pedro (Wormser Dom), Worms, Alemanha, 1110-1181.

Fonte: https://s3.amazonaws.com/gs-waymarking-images/397b319e-50b4-4013-85a0-db927244b1da.jpg

\subsubsection{7:}

Karl Christian Hoffmann, Torre de Água de Worms, Alemanha, 1888.

Fonte: https://www.worms.de/de-wAssets/img/kultur/historische_aufnahmen/wasserturm_foto-fueller_Stadtarchiv00004.jpg

\subsubsection{8:}

Karl Christian Hoffmann, Torre de Água de Worms, Alemanha, 1888. Corte e Elevação.

Fonte: MERKL, 1985, p. 189

\subsubsection{9:}

George F. Deacon, "Norton Tower", Liverpool, Inglaterra, 1890.

Fonte: HOBBS, Aubrey Thomas (Ed.). Manual of British Water Supply Practice. Cambridge: Heffer \& Sons, 1954, p. 531.

\subsubsection{0:}

George F. Deacon, "Norton Tower", Liverpool, Inglaterra, 1890. Detalhes dos painéis de ferro fundido do reservatório.

Fonte: The Norton Tower of the Vyrnwy-Liverpool Water Supply. The Engineer, London, v. 72, n. 12, 1891 , p. 234.

\subsubsection{1:}

George F. Deacon, "Norton Tower", Liverpool, Inglaterra, 1890. Corte.

Fonte: Ibidem, p. 231.

\subsubsection{2:}

George F. Deacon, "Norton Tower", Liverpool, Inglaterra, 1890. Detalhes.

Fonte: Ibidem, p. 230.

\subsubsection{3:}

Reginald Blomfield, "Westgate Tower", Lincoln, Inglaterra, 1904.

Fonte: https://gb.fotolibra.com/images/previews/656350-westgate-water-tower-lincoln.jpeg

\subsubsection{4:}

Reginald Blomfield, "Westgate Tower", Lincoln, Inglaterra, 1904. Vista do interior.

Fonte: https://c1.staticflickr.com/7/6106/6253603890_60080e3522_b.jpg

\subsubsection{5:}

"Salt Water Tank", Base Naval de Portsmouth, Inglaterra, 1843.

Fonte: https://www.picclickimg.com/d//400/pict/222904171812_/Hampshire-Portsmouth-Dockyard-Police-Fire-Brigade.jpg

\subsubsection{6:}

"Salt Water Tank", Base Naval de Portsmouth, Inglaterra, 1843. Situação atual.

Fonte: https://portsmouthdockyard.org.uk/Old\%20Fire\%20Station\%200018.jpg

\subsubsection{7:}

Torre de Água da Oxford Rewley Road Station, Buckinghamshire Railway, Inglaterra, 1851.

Fonte: http://www.disused-stations.org.uk/o/oxford_rewley_road/oxford(c1935)rewley_road_old5.jpg 


\subsubsection{8:}

Isambard Kingdom Brunel, Torres de Água do Crystal Palace, Sydenham, 1856.

Fonte: http://img.thedailybeast.com

\subsubsection{9:}

Isambard Kingdom Brunel, Torres de Água do Crystal Palace, Sydenham, 1856. Plantas e cortes.

Fonte: Engineering Details at the Crystal Palace. The Engineer, London, v. 91, fev. 1901.p 109.

\subsubsection{0a:}

Joseph Paxton, Crystal Palace, Londres, 1851.

Detalhe do módulo de fachada.

Fonte: https://sustpractice.files.wordpress.com/2015/03/000000012.jpg

\subsubsection{0b:}

Isambard Kingdom Brunel, Torres de Água do Crystal Palace, Sydenham, 1856.

Detalhe do módulo de fachada.

Fonte: BUCHANAN, Angus; JONES, Stephen K.; KISS, Ken. Brunel and the Crystal Palace. Industrial Archaeology Review, London, v. 17, n. 1, 1994, p. 14

\subsubsection{1:}

Isambard Kingdom Brunel, Torres de Água do Crystal Palace, Sydenham, 1856. Detalhe do contraventamento.

1. Coluna tubular de ferro fundido, $\varnothing 300 \mathrm{~mm}$

2. Painel intermediário de ferro fundido

3. Diafragma de ferro forjado

4. Barra de contraventamento vertical

5. Barra de contraventamento horizontal, $\varnothing 45 \mathrm{~mm}$

Fonte: Ibidem, p. 15.

\subsubsection{2:}

Demolição da torre norte do Crystal Palace, 1941.

Fonte: https://www.gettyimages.ie/detail/news-photo/historic-buildings-pic-16th-april-1941-the-north-tower-of-newsphoto/79656737

\subsubsection{3:}

Justaposição da torre de Brunel na gravura Comparative View of the Principal Buildings in the World, de John Emslie, Londres, 1850.

Fonte: Autor, 2018.

\subsubsection{4:}

Torre de Água da Swindon Works, Great Western Railway, Inglaterra, 1871.

Fonte: http://www.cornwallrailwaysociety.org.uk/uploads/7/6/8/3/7683812/7203832_orig.jpg

\subsubsection{5:}

Torre de Água da estação de Kemble, Great Western Railway, Inglaterra, 1882.

Fonte: https://mapio.net/images-p/34392170.jpg

\subsubsection{6:}

Torre de Água de Pelotas, Rio Grande do Sul, Brasil, 1875.

Fonte: http://publicador-api.pelotas.com.br/storage/beba2d7da041b4e5643d7c468712dc4d3be25678.jpg

\subsubsection{7:}

Torre de Água de Rio Grande, Rio Grande do Sul, Brasil, 1876.

Fonte: http://www.riogrande.rs.gov.br/pagina/index.php/atrativos-turisticos/detalhes+8555,,caixa-dagua.html

\subsubsection{8:}

John William Hart, Torre de Água de Xangai, China, 1881.

Fonte: https://www.virtualshanghai.net/Asset/Preview/dblmage_ID-20810_No-1.jpeg 


\subsubsection{9:}

John William Hart, Torre de Água de Xangai, China, 1881. Planta e Elevação.

Fonte: BURTON, W. K.. The water supply of towns and the construction of water works. 2. ed. London: Crosby, Lockwood and Son, 1898, p. 144

\subsubsection{0:}

Interação de Esforços no Anel de Suporte do Reservatório Tipo Intze.

Fonte: KOTTENMEIER, 1930, p. 18.

\subsubsection{1:}

Otto Intze, Torre de Água de Remscheid, 1883.

Fonte: INTZE, Otto. Nachweis über die Konstruktion und die Verbreitung von 280 Wasserthürmen und Gasbehältern nach dem System und den Berechnungen von Professor O. INTZE in Aachen. Aachen: F. A. NEUMAN / C. H. Georgi, $1894,19$.

\subsubsection{2:}

Otto Intze, Torre de Água de Remscheid, 1883. Corte.

Fonte: MERKL, 1985, p. 43.

\subsubsection{3:}

Otto Intze, Torre de Água de Neu-Stassfurt, 1883. Corte e Elevação.

Fonte: INTZE, 1894, p. 20.

\subsubsection{4:}

Primeira Geração de Torres de Água Equipadas com Reservatórios tipo Intze I.

a) Walter Pfeffer, Torre de Bremerhaven, AL, 1884.

b) Max Menzner, Torre de Riesa, Leipzig, AL, 1889.

c) P. Schmick, Torre de Wandsbek, Hamburgo, AL, 1891.

d) U.W.M., Torre de Tiel, Utrecht, HOL, 1890.

e) J.A. Mulock Houwer, Torre de Deventer, HOL, 1893.

f) H.P.N. Halbertsma, Torre de Meppel, HOL, 1893.

Fonte: Ibidem.

\subsubsection{5:}

H.P.N. Halbertsma, Torre de Água de Sneek, Holanda, 1908. Plantas, corte e elevação.

Fonte: https://i.pinimg.com/originals/d4/bc/74/d4bc748a2353270497c1b552b0bc98ec.jpg

\subsubsection{6:}

Torre de Água Ferroviária com Reservatório Tipo Intze de $500 \mathrm{~m}^{3}$. Corte Típico. Fonte: KOTTENMEIER, 1930, p. 18.

\subsubsection{7:}

Torre de Água Ferroviária com Reservatório Tipo Intze. Detalhes Construtivos.

Fonte: SCHOKLITSCH, Armin. Tratado de Arquitectura Hidráulica. Tomo Primero. Barcelona: Gustavo Gili, 1946, p. 319.

\subsubsection{8:}

Torres de Água Ferroviárias Equipadas com Reservatórios tipo Intze I.

a) Estação de Landau, AL, 1887.

b) Estação de Neustadt, AL, 1887

Fonte: INTZE, 1894.

c) Estação de Estação de Pfalzfeld Rheinland-Pfalz, AL, 1906.

d) Estação de Wittingen, AL, ca. 1902.

Fonte: BECHER, 1988.

\subsubsection{9:}

Torres de Água Ferroviárias Equipadas com Reservatórios Aparentes tipo Intze I.

a) Estação de Köln-Gereon, AL, 1888.

b) Estação de Lahnstein, AL, ca. 1890

Fonte: BECHER, 1988. 


\subsubsection{0:}

Louis de la Censerie, Torres Gêmeas da Estação Central da Antuérpia, 1895.

Fonte: INTZE, 1894, p. 64.

\subsubsection{1:}

Reservatórios Intze Tipo I e Tipo II.

Fonte: MERKL, 1985, p. 87.

\subsubsection{2:}

Otto Intze e Heinrich Friedrich Damert, Torre de Düren, Alemanha, 1885.

Fonte: BECHER, 1971, p. 358.

\subsubsection{3:}

Torre de água de Lübeck com o novo reservatório Intze I sobre o antigo reservatório de fundo plano (1889).

Fonte: MERKL, 1985, p. 91.

\subsubsection{4:}

Torre de água de Lübeck, Alemanha, 1889.

Fonte: https://upload.wikimedia.org/wikipedia/de/9/9b/WP_Wasserkunst_L\%C3\%BCbeck_1900.jpg

\subsubsection{5:}

Torre de água de Lübeck, Alemanha, 1889. Detalhes.

Fonte: INTZE, 1894, p. 26.

\subsubsection{6:}

Torre de água de Remscheid com o novo reservatório Intze II sobre o antigo reservatório tipo Intze I (1907).

Fonte: MERKL, 1985, p. 92.

\subsubsection{7:}

Torre de Água de Mülheim, Alemanha, 1885.

Fonte: BECHER , 1971, p. 359.

\subsubsection{8:}

Torre de Água de Essen-Steele, Alemanha, 1898. Corte.

Fonte: MERKL, 1985, p. 206.

\subsubsection{9:}

Torre de Água de Essen-Leithe, Alemanha, 1898.

Fonte: BECHER, 1988, f. 83.

\subsubsection{0:}

Torre de Água de Alsdorf, Alemanha, 1910.

Fonte: BECHER, 1971, f. 176.

\subsubsection{1:}

Franz Xaver Borkowitz, Torre de Água de Favoriten, Viena, 1898.

Fonte: https://media04.meinbezirk.at/article/2013/09/15/7/4863967_XXL.jpg

\subsubsection{2:}

Franz Xaver Borkowitz, Torre de Água de Favoriten, Viena, 1898. Corte.

Fonte: MERKL, 1985, p. 208. 


\subsection{Torres de Água no Século XX e na Atualidade}

\subsection{1:}

Hiperboloide de revolução de uma folha gerado pela rotação de uma geratriz reta.

Fonte: BECKH, Matthias. Hyperbolic Structures: Shukhov's lattice towers - forerunners of modern lightweight construction.

West Sussex: John Wiley \& Sons, 2015, p. 26.

\subsection{2:}

Vladimir G. Shukhov, Torre de Água da All-Russia Exhibition, Rússia, 1896.

Fonte: http://www.beaudouin-architectes.fr/wp-content/gallery/enseign-shukhov/diapositive072.jpg

\subsection{3:}

Vladimir G. Shukhov, Torre de Água da All-Russia Exhibition, Rússia, 1896.

Fonte: The Nijni-Novgorod Exhibition. The Engineer, London, v. 83, 1897, p. 232.

\subsection{4:}

Torres de Água projetadas por Vladimir G. Shukhov, 1902-1915.

Fonte: http://www.recentering-periphery.org/wp-content/uploads/2012/04/SHUKHOV_BOOK_-3-copia-1.jpg

\subsection{5:}

Vladimir G. Shukhov, Projeto para Torre de Água de Yevpatoria, Ucrânia, 1925.

Fonte: NOZHOVA, Ekaterina; HASSLER, Uta. Networks of Construction: Vladimir Shukhov. München: Hirmer Verlag, 2016, p. 240.

\subsection{6:}

Vladimir G. Shukhov, Projeto para Torre de Água de Orekhovo-Zuyevo, Rússia, 1924.

Fonte: http://vystavki.rgantd.ru/shuhov/images/shuhov-03.jpg

\subsection{7:}

Horace E. Horton, Torre de Paris, Illinois, EUA, 1895.

Fonte: A Steel Water Tower. The Engineering Record, New York, v. 35, n. 18, p. 273-274, fev. 1897.

\subsection{8:}

Horace E. Horton, Torre de Paris, Illinois, EUA, 1895. Planta, Elevação e Detalhes.

Fonte: The Engineering Record, v. 35, n. 18, p. 273-274, fev. 1897.

\subsection{9:}

As Três Marias, Porto Velho, Brasil, 1910.

Fonte: https://biblioteca.ibge.gov.br/biblioteca-catalogo.html?id=442421\&view=detalhes

\subsubsection{0:}

Brasão e Bandeira da Cidade de Porto Velho, Brasil, 1983.

Fonte: https://pt.wikipedia.org/wiki/Bandeira_de_Porto_Velho

\subsubsection{1:}

Anson Marston, Torre do lowa State Agricultural College, EUA, 1898.

Fonte: https://farm3.staticflickr.com/2185/2267150251_aa74b3bace_o_d.jpg

\subsubsection{2:}

Georg Barkhausen, Torre da Mina de Minister Stein, Dortmund, Alemanha, 1899. Fonte: MERKL, 1985, p. 101.

\subsubsection{3:}

Georg Barkhausen, Torre da Mina de Minister Stein, Dortmund, Alemanha, 1899. Planta e Elevação. Fonte: KOTTENMEIER, 1930, p. 20. 


\subsubsection{4:}

Torre de Água da Estação Ferroviária de Bielefeld, Alemanha, 1901.

Fonte: BECHER, 1971, p. 366.

\subsubsection{5:}

Torre de Água da Estação Ferroviária de Hausbergen, Alemanha, 1908.

Fonte: ERBKAM, G.. Verschiebebahnhof Hausbergen und Verlegung der Strecke Straßburg. Atlas zur Zeitschrift für Bauwesen. Berlin: Ernst \& Korn, v. 58, p. 25, 1908

\subsubsection{6:}

Torre de água e estação de bombeamento de água impulsionada pela força do vento. Alemanha, ca. 1910.

Fonte: VON RÖLL, 1923. 10 v, p. 288.

\subsubsection{7:}

Torre de Água de Bremen, Alemanha, 1904-1906.

Fonte: http://digitales-heimatmuseum.de/wp-content/uploads/2017/08/Walle_Wasserturm_5909.jpg

\subsubsection{8:}

Torre de Água de Bremen, Alemanha, 1904-1906. Corte.

Fonte: BECHER, 1971, p. 368.

\subsubsection{9:}

Torre de Água de Grevel, Alemanha, 1904.

Fonte: BECHER, 1988, f. 1.

\subsubsection{0:}

Torre de Água de Grevel, Alemanha, 1904. Elevação.

Fonte: MERKL, 1985, p. 222.

\subsubsection{1:}

Torre de Água de Grevel, Alemanha, 1904.

Fonte: https://img.fotocommunity.com/der-wasserturm-in-dortmund-lanstrop-76c93e86-aa02-4652-969ec62cb85517a3.jpg?height $=1080$

\subsubsection{2:}

Torre de Água Ferroviária equipada com Reservatório Barkhausen Fechado. Fonte: VON RÖLL, 1923. 10 v, p. 291.

\subsubsection{3:}

Torres de Água Ferroviárias equipadas com Reservatório Barkhausen Fechado.

a) Mülheim-Ruhr, AL, 1901.

b) Nienburg-Weser, AL, 1904.

c) Elze-Hildesheim, AL, 1906.

d) Bielefeld, AL, 1906.

Fonte: BECHER, 1988.

\subsubsection{4:}

Torres de Água Ferroviárias de Nienburg-Weser, Alemanha, 1904. Plantas, Corte e Elevação.

Fonte: http://dg3of.de/wp-content/uploads/2018/03/Nienburg-Wasserturm-Planzeichnung.jpg

\subsubsection{5:}

Torre de Água da Estação de Chemnitz, Alemanha, 1906. Elevação e detalhes.

Fonte: BECHER, 1971, p. 373. 


\subsubsection{6:}

Torre de Água da Estação de Chemnitz, Alemanha, 1906. Corte e planta.

Fonte: Ibidem, p. 374.

\subsubsection{7:}

Torre de Água da estação ferroviária de Lübeck, Alemanha, 1907.

Fonte: BECHER, 1988, f. 89.

\subsubsection{8:}

Torres de Água Ferroviárias equipadas com reservatórios tipo Klönne.

a) Bebra, $500 \mathrm{~m}^{3}$, Alemanha, 1910.

b) Crailsheim, $600 \mathrm{~m}^{3}$, Alemanha, 1912

c) Kornwestheim-Stuttgart, $1.100 \mathrm{~m}^{3}$, Alemanha, 1914

Fonte: Ibidem.

\subsubsection{9:}

Torre de Água Ferroviária com Reservatório Tipo Klönne. Detalhes Construtivos Fonte: SCHOKLITSCH , 1946, p. 324.

\subsubsection{0:}

"Estação de Água" ferroviária em Weil-Rheim, Alemanha, 1913.

Fonte: BECHER, 1988, f. 3.

\subsubsection{1:}

"Estação de Água" ferroviária em Weil-Rheim, Alemanha, 1913. Elevação.

Fonte: MERKL, 1985, p. 111.

\subsubsection{2:}

Torres de Água Industriais de Ahlen-Westaflen, Alemanha, 1914.

Fonte: BECHER, 1988, f. 8 e 9.

\subsubsection{3:}

Joseph Monier, Torre de Água em Alençon, França, 1873.

Fonte: WAYSS, Gustav Adolf. Das System Monier: Eisengerippe mit Cementumhüllung. Berlin: A. Seydel \& Cie., 1887, p. 126.

\subsubsection{4:}

Gustav Adolf Wayss e Mathias Koenen, Torre de Água de Lundshut, Alemanha, 1885.

Fonte: Ibidem, p. 117.

\subsubsection{5}

Edmond Coignet, Torre de Água para o Arsenal Naval de Toulon, França, 1898.

Fonte: BECHER, 1971, p. 384.

\subsubsection{6:}

Edmond Coignet, Torre de Água para o Arsenal Naval de Toulon, França, 1898. Corte e detalhes. Fonte: EMPERGER, Fritz. Handbuch für Eisenbetonbau: in Vier Bänden. Erster und Zweiter Teil. Berlin: Wilhelm Ernst \& Sohn, 1907. 4 v, p.458.

\subsubsection{7:}

François Hennebique, Torre de Água de Dinard, França, 1895.

Fonte: Les Réservoirs. Le Beton Armé, Paris, n. 369, nov. 1938, p. 1896.

\subsubsection{8:}

Eduard Züblin, Torre de Água em Scafati, Itália, 1897.

Fonte: MERKL, 1985, p. 120. 


\subsubsection{9:}

Louis Gustave Mouchel, Torre de Meyrick Park, Dorset, Inglaterra, 1900.

Fonte: https://pbs.twimg.com/media/DUTJw5AWsAERo-g.jpg

\subsubsection{0:}

Louis Gustave Mouchel, Torre de Newton-le-Willows, Inglaterra, 1904.

Fonte: BECHER, 1988, f. 206.

\subsubsection{1:}

Louis Gustave Mouchel, Torre de Newton-le-Willows, Inglaterra, 1904. Corte.

Fonte: EMPERGER, 1907, p. 466.

\subsubsection{2:}

Sistema Hennebique para Concreto Armado, 1892-1897.

Fonte: FRAMPTON, Kenneth. Studies in Tectonic Culture. Chicago: Graham Foundation, 1995, p. 122.

\section{Figura 2.4.43:}

Torres de Água Construídas com Sistema Hennebique.

a) Fortaleza, Brasil, 1911-1926.

Fonte: https://1.bp.blogspot.com

b) Hasselt, Bélgica, 1910.

c) Goole, Inglaterra, 1927.

Fonte: BECHER, 1988.

\subsubsection{4:}

"Estações de Água" das Ferrovias Italianas.

Fonte: EMPERGER, 1907, p. 469.

\subsubsection{5:}

Primeiras Torres de Água com Estrutura de Concreto Armado.

a) esqueleto estrutural aparente

b) esqueleto com vãos preenchidos

c) esqueleto com invólucro autônomo de alvenaria

Fonte: RIENKS, 1989, p. 6.

\subsubsection{6:}

Torre de Água tipo Intze (silhueta).

Fonte: Autor, 2018.

\subsubsection{7:}

a) Fosses-la-Ville, Bélgica, 1902.

Fonte: VEEN, 1989.

b) Reisstärkefabrik em Düsseldorf, Alemanha, 1910.

c) Herten, Scherlebeck, Alemanha, 1919.

d) Middleton, Leeds, Inglaterra, 1924.

Fonte: BECHER, 1988.

\subsubsection{8:}

a) Zeebrugge, Bélgica, 1907

b) Saint-Gilles, Bélgica, 1913.

Fonte: VAN CRAENENBROECK, 1991.

C) Emdem, Alemanha, 1911.

Fonte: MERKL, 1985.

d) Rimswell, Inglaterra, 1916.

e) Gawthorpe, Inglaterra, 1928.

Fonte: BARTON, 20087. 


\subsubsection{9:}

a) Waterloo, Bélgica, 1904.

b) Denderleeuw, Bélgica, 1930.

c) Oostende, Bélgica, 1932.

Fonte: VAN CRAENENBROECK, 1991.

d) Heerlen, Holanda, 1917.

e) Nijvel, Holanda, 1917.

f) Roosendaal, Holanda, 1917.

Fonte: VEEN, 1989.

\subsubsection{0:}

Típicas torres de água "tipo Intze". Fonte: Fotos de Bernd e Hilla Becher.

\subsubsection{1:}

Típicas torres de água "tipo Intze".

Fonte: Ibidem.

\subsubsection{2:}

a) Torre de Degerloch, Alemanha, 1911.

b) Torre de Rötha, Alemanha, 1913.

Fonte: MERKL, 1985.

\subsubsection{3:}

Torre de Assendelft, Holanda, 1922. Vista.

Fonte: http://watertorens.eu/torens/Assendelft/Tekeningen.html

\subsubsection{4:}

Torre de Assendelft, Holanda, 1922. Corte.

Fonte: Ibidem.

\subsubsection{5:}

Torre de Hockenheim, Alemanha, 1910. Vista.

Fonte: https://upload.wikimedia.org/wikipedia/commons/4/4a/Wasserturm_Hockenheim_-_panoramio.jpg

\subsubsection{6:}

Torre de Hockenheim, Alemanha, 1910. Corte.

Fonte: EMPERGER, 1923, p. 227.

\subsubsection{7:}

Torre de Água no pátio ferroviário de Heidelberg, Alemanha, 1907. Vista, planta e corte.

Fonte: BECHER, 1971, p. 388.

\subsubsection{8:}

Torre de Água do pátio ferroviário de Hohenbudberg, Alemanha, 1915-1916.

Fonte: BECHER, 1988, f. 123.

\subsubsection{9:}

Torre de Água do pátio ferroviário de Hohenbudberg, Alemanha, 1915-1916. Plantas e corte. Fonte: EMPERGER, 1923, p. 231.

\subsubsection{0:}

Torre de Água do pátio ferroviário de Hohenbudberg, Alemanha, 1915-1916. Detalhe da armadura dos reservatórios.

Fonte: Ibidem, p. 232-233. 


\subsubsection{1:}

Charles-Edouard Jeanneret (Le Corbusier), Torre de Água de Pondesac, França, 1917.

Fonte: http://mfs2.cdnsw.com/fs/C_PHOTOS_2015/csnct-Chateau_d_eau_LECORBUSIER.JPG

\subsubsection{2:}

Charles-Edouard Jeanneret (Le Corbusier), Torre de Água de Pondesac, França, 1917. Vista interior do belvedere em croquis de Jeanneret.

Fonte: Fondation Le Corbusier 22407. Disponível em:

http://www.fondationlecorbusier.fr/CorbuCache/900x720_2049_256.jpg?r=0

\subsubsection{3:}

Charles-Edouard Jeanneret (Le Corbusier), Torre de Água de Pondesac, França, 1917. Elevações e corte.

Fonte: http://www.chateaudeaulecorbusier.sitew.fr/LES_PLANS_.B.htm\#LES_PLANS_BB

\subsubsection{4:}

Charles-Edouard Jeanneret (Le Corbusier), Torre de Água de Pondesac, França, 1917. Vista do interior.

Fonte: Ibidem.

\subsubsection{5:}

Torre de Água de Pondesac (1917) e a nova torre tipo Intze (1940).

Fonte: http://images.sudouest.fr/

\subsubsection{6:}

Otto Greiss, Torre de Água de Mönchengladbach, Alemanha, 1908-1909.

Fonte: https://mapio.net/images-immo-expose/4258835/wasserturm-1200-145-m2-5-zimmer-img-0.jpeg

\subsubsection{7:}

Otto Greiss, Torre de Água de Mönchengladbach, Alemanha, 1908-1909. Plantas, corte e elevação. Fonte: MERKL, 1985, p. 258.

\subsubsection{8:}

Carl Franke, Torre de Água de Plön, Alemanha, 1913. Foto da construção.

Fonte: http://www.gebr-behrend.de/tl_files/website/Bilder/Gebr.\%20Behrend_Wasserturm.jpg

\subsubsection{9:}

Carl Franke, Torre de Água de Plön, Alemanha, 1913. Situação Atual.

Fonte: https://upload.wikimedia.org/wikipedia/commons/1/1e/PI\%C3\%B6n_Wasserturm.jpg

\subsubsection{0:}

Torre de Água de Bardenberg, Alemanha, 1911.

Fonte: https://upload.wikimedia.org/wikipedia/commons/thumb/7/74/Bardenberger_Wasserturm.jpg

\subsubsection{1:}

Torre de Água de Bardenberg, Alemanha, 1911. Elevação e corte.

Fonte: MERKL, 1985, p. 268.

\subsubsection{2:}

Joseph Maria Olbrich, projeto para a Torre de Winterhude, Hamburgo, Alemanha, 1906-1907. Fonte: HAMM, Sara. The Watertower as Decor: Exceeding Generic Concepts in Art Nouveau. In: Historical Lab 3: Art Nouveau \& Decoration, 2006, Riga. Proceedings.... Bruxelles: Bruxelles Urbanisme \& Patrimoine, 2006, p. 3.

\subsubsection{3:}

Ödön Lechner, projeto para a Torre de Rákóczy, Kecskemét, Hungria, 1911.

Fonte: http://www.bacs-kiskun-leveltar.hu/V3/SP07_mbn/Gallery/szbe-01t-3-01p-n.jpg 


\subsubsection{4:}

Hendrik Sangster, Torre de Água de Aalsmeer, Holanda, 1928.

Fonte: https://c1.staticflickr.com/4/3150/3042239955_1d0871c1ec_b.jpg

\subsubsection{5:}

Torres de Água projetadas por Hendrik Sangster, Holanda.

a) Dongen, 1922

b) Etten, 1924.

c) Steenbergen, 1923 .

d) Raamsdonksveer, 1925 .

e) St. Philipsland, 1924.

f) Anna Jacobapolder, 1925.

Fonte: http://www.watertorendongen.nl

\subsubsection{6:}

Ruínas da torre de Steenbergen (1923) destruída pelas tropas alemãs em 1944.

Fonte: http://watertorens.eu/torens/Steenbergen/Steenbergen\%20Oud/index.html

\subsubsection{7:}

Hendrik Sangster, Torre de Água de Naaldwijk, Holanda, 1930.

Fonte: http://watertorens.eu/torens/Naaldwijk/Eigen_fotoos/Album/slides/Naaldwijk_WT159_2017-09-04_AF1_8682.jpg

\subsubsection{8:}

a) F. Henne, Torre de Chaumont-Gistoux, 1923.

b) Camille Bal e Ernest Lamot, Torre de Água da Provinciale Technische Scholen, Boom, 1931.

c) Roland Fourcat, Torre de Sart-Dames-Avelines, 1936.

d) Torre de Brasschaat-Aerdenlei, 1938.

e) Torre de Overijse, 1938.

f) Torre de Wijnegem, 1943.

Fonte: https://upload.wikimedia.org

\subsubsection{9:}

Oskar Menzel, Torre de Água de Winterhude, Hamburgo, Alemanha, 1907-1916.

Fonte: https://upload.wikimedia.org/wikipedia/commons/thumb/4/41/Hamburg_Planetarium.jpg

\subsubsection{0:}

Oskar Menzel, Torre de Água de Winterhude, Hamburgo, Alemanha, 1907-1916. Corte.

Fonte: MERKL, 1985, p. 286.

\subsubsection{1:}

Hans Poelzig, Torre de Água de Winterhude, Hamburgo, Alemanha, 1906-1907. Planta e elevação. Fonte: Architekturmuseum der Technische Universität Berlin. Disponível em: https://architekturmuseum.ub.tuberlin.de/P/118429.php

\subsubsection{2}

Hans Poelzig, Torre de Água de Winterhude, Hamburgo, Alemanha, 1906-1907. Corte.

Fonte: Ibidem. Disponível em: https://architekturmuseum.ub.tu-berlin.de/P/118430.php

\subsubsection{3:}

Hans Poelzig, Torre de Água de Winterhude, Hamburgo, Alemanha, 1906-1907. Perspectiva.

Fonte: Ibidem. Disponível em: https://architekturmuseum.ub.tu-berlin.de/P/118427.php

\subsubsection{4:}

Hans Poelzig, Torre de Água de Winterhude, Hamburgo, Alemanha, 1906-1907. Planta e elevação.

Fonte: Ibidem. Disponível em: https://architekturmuseum.ub.tu-berlin.de/P/118426.php 


\subsubsection{5:}

Hans Poelzig, Torre de Água de Sternschanze, Hamburgo, Alemanha, 1906-1907. Perspectiva.

Fonte: Ibidem. Disponível em: https://architekturmuseum.ub.tu-berlin.de/P/118424.php

\subsubsection{6:}

Hans Poelzig, Torre de Água de Sternschanze, Hamburgo, Alemanha, 1906-1907. Planta e elevação.

Fonte: Ibidem. Disponível em: https://architekturmuseum.ub.tu-berlin.de/P/118422.php

\subsubsection{7:}

Hans Poelzig, Torre de Água de Uhlenhorst, Hamburgo, Alemanha, 1906-1907. Perspectiva.

Fonte: Ibidem. Disponível em: https://architekturmuseum.ub.tu-berlin.de/P/118431.php

\subsubsection{8:}

Hans Poelzig, Torre de Água de Pozen, Polônia, 1910-1911. Planta, corte e elevação.

Fonte: Ibidem. Disponível em: https://architekturmuseum.ub.tu-berlin.de/P/120436.php

\subsubsection{9:}

Hans Poelzig, Torre de Água de Pozen, Polônia, 1910-1911. Vista do interior.

Fonte: Ibidem. Disponível em: https://architekturmuseum.ub.tu-berlin.de/P/120440.php

\subsubsection{0:}

Hans Poelzig, Torre de Água de Pozen, Polônia, 1910-1911. Vista do interior.

Fonte: Ibidem. Disponível em: https://architekturmuseum.ub.tu-berlin.de/P/120451.php

\subsubsection{1:}

Otto Bartning, Torre de Água em Zeipau, Polônia, 1923.

Fonte: GÖSSEL, Peter; LEUTHÄUSER, Gabriele. Arquitectura no Século XX. Colônia: Taschen, 1996, p. 129.

\subsubsection{2:}

Fritz Höger, Torre de Água em Hohenkirchen, 1934.

Fonte: ASCHENBECK, Nils; SCHMIDT, Jens U.. Wassertürme im Nordwesten. Oldberg: Isensee, 2003 , p. 42.

\subsubsection{3:}

Walter Gropius e Adolf Meyer, Fábrica Fagus, Alfeld, Alemanha, 1911-1916.

Fonte: https://1.bp.blogspot.com/-

H7WXWFnmKqO/Vvzap7mW5qI/AAAAAAAAE1M/48zkgqtmnJMStd6qLHhi47qwZH6IDY8Vg/s1600/fagus-werk.jpg

\subsubsection{4:}

Reservatório de Chaminé de $60 \mathrm{~m}^{3}$ em Fábrica de Hamburgo, Alemanha, 1887. Elevação e corte.

Fonte: BECHER, 1971, p. 360.

\subsubsection{5:}

Reservatório de Chaminé de $40 \mathrm{~m}^{3}$ em Fábrica de Düsseldorf, Alemanha, 1892.

Fonte: INTZE, 1894, p. 48.

\subsubsection{6:}

Detalhe Típico de Reservatório de Chaminé de Concreto Armado.

Fonte: EMPERGER, 1907, p. 453-454.

\subsubsection{7:}

Sybold van Ravesteyn, Torre de Água da Estação de Goes, Holanda, 1925.

Fonte: http://watertorens.eu/torens/Goes/Goes\%20van\%20Hertumweg/index.html

\subsubsection{8:}

Sybold van Ravesteyn, Torre de Água da Estação de Breda, Holanda, 1927.

Fonte: BERLAGE, Hendrik Petrus. Moderne Boukunst in Nederland: No 11 - Gebouwen voor Technische Doeleinden.

Rotterdam: W.I. \& J. Brusse N.V., 1932, p. 28. 


\subsubsection{9:}

Sybold van Ravesteyn, Torre de Água da Estação de Roermond, Holanda, 1928.

Fonte: VEEN, 1989, p. 89.

\subsubsection{0:}

Sybold van Ravesteyn, Torre de Água da Estação de Roermond, Holanda, 1928. Maquete.

Fonte: http://watertorens.eu/torens/Roermond/Nieuwe\%20Watertoren/index.html

\subsubsection{1:}

H. J. Groenewegen e B. Merkelbach, Projeto para a Torre de Wassenar, 1927.

Fonte: VEEN, 1989, p. 87.

\subsubsection{2:}

Mart Stam, Projeto para a Torre de Wassenaar, 1927.

Fonte: http://watertorens.eu/torens/Wassenaar/kunst/Wassenaar\%201928-02.jpg

\subsubsection{3:}

Cornelis van Eesteren, Projetos "42500" e "39500" para a Torre de Wassenaar, 1927.

Fonte: VEEN, 1989, p. 87.

\subsubsection{4:}

J. P. L. Hendriks, Torre de Água de Wassenaar, 1927-1928.

Fonte: http://watertorens.eu/torens/Wassenaar/index.html

\subsubsection{5:}

Luiz Nunes, Torre de Água do Alto da Sé, Olinda, Pernambuco, Brasil, 1934-1937.

Fonte: GOODWIN, Philip L. e SMITH, G. E. Kidder. Brazil Builds: architecture new and old 1652-1942. New York: The Museum of Modern Art, 1943, p. 158.

\subsubsection{6:}

Luiz Nunes, Torre de Água do Alto da Sé, Olinda, Pernambuco, Brasil, 1934-1937. Esquema estrutural.

Fonte: VAZ, Rita de Cássia. Luiz Nunes: arquitetura moderna em Pernambuco, 1934-1937. 1988. 1 v. Dissertação (Mestrado) Programa de Pós-graduação em Arquitetura e Urbanismo, Faculdade de Arquitetura e Urbanismo, Universidade de São Paulo, São Paulo, 1988, p. 127.

\subsubsection{7:}

Oscar Niemeyer, Standpipe de Ribeirão das Lajes, Brasil, 1939. Plantas, corte e elevação.

Fonte: NIEMEYER, Oscar. Estudo de um "standpipe". Revista Municipal de Engenharia, Rio de Janeiro, v. 6, n. 5, set. 1939, p. 510-511.

\subsubsection{8:}

Carlos Frederico Ferreira, Conjunto Residencial IAPI da Vila Guiomar, São Paulo, 1940.

Fonte: BOTAS, Nilce Cristina Aravecchia. Concreto, muxarabis e cumeeiras para os industriários: a arquitetura e o urbanismo de Carlos Frederico Ferreira na produção do IAPI. In: Encontro Nacional de Pós-Graduação e Pesquisa em Arquitetura e Urbanismo, 1., 2010, Rio de Janeiro. Anais... . Rio de Janeiro: PROURB, 2010. p. 10.

\subsubsection{9:}

Carlos Frederico Ferreira, Conjunto Residencial do Realengo, Rio de Janeiro, 1942.

Fonte: BOTAS, 2010. p. 12.

\subsubsection{0:}

Carlos Frederico Ferreira, Conjunto Residencial do Realengo, Rio de Janeiro, 1942. Planta e elevação.

Fonte: GOODWIN, 1943, p. 126. 


\subsubsection{1:}

Balizas costeiras dinamarquesas.

Em sentido horário: Haurvig Båke, Løkken Båke, Ringebjerge Båke, Vedersø Båke, Stenbjerg Båke e Gammla Skagen Båke. Fonte: LIEDTKE, Gerd. Richtungs-, Signal- und Landerkennungs. Em alemão. Disponível em: <www.baken-net.com>. Acesso em: 15 nov. 2017.

\subsubsection{2:}

Jørn Utzon, Torre de Água de Svaneke, Dinamarca, 1952.

Fonte: http://static.panoramio.com/photos/large/20819209.jpg

\subsubsection{3:}

Jørn Utzon, Torre de Água de Svaneke, Dinamarca, 1952. Planta, corte e detalhes.

Fonte: FORÉS, Jaime J. Ferrer. Jørn Utzon: Obras y proyectos. Barcelona: Editorial Gustavo Gili, 2006, p. 75.

\subsubsection{4:}

Sistema de formas deslizantes.

Fonte: http://infraestruturaurbana17.pini.com.br/solucoes-tecnicas/8/imagens/i300753.jpg

\subsubsection{5:}

Torre de Água de Havre, França, 1955.

Fonte: BECHER, 1971, p. 395.

\subsubsection{6:}

Torre de Água de Oevel, Bélgica, 1968.

Fonte: BECHER, 1988, f. 211.

\subsubsection{7}

Torre de Água de Putte, Bélgica, 1972.

Fonte: https://upload.wikimedia.org/wikipedia/commons/c/c6/Putte_Pachtersdreef_Watertoren.jpg

\subsubsection{8:}

Alvar Aalto, Torre de Água de Otaniemi, Espoo, Finlândia, 1971.

Fonte: HEIKINHEIMO, Marianna et al. Rakennushistoriaselvitys Otaniemen Vesitorni. Otaniemi: Arkkitehtitoimisto Ark-byroo, 2017, p. 61

\subsubsection{9:}

Alvar Aalto, Torre de Água de Otaniemi, Espoo, Finlândia, 1971. Corte.

Fonte: HEIKINHEIMO, 2017, p. 37.

\subsubsection{0:}

Alvar Aalto, Torre de Água de Otaniemi, Espoo, Finlândia, 1971. Detalhe do reservatório.

Fonte: HEIKINHEIMO, 2017, p. 37.

\subsubsection{1:}

Paulo Mendes da Rocha, Reservatório Elevado de Urânia, Brasil, 1968. Plantas, cortes e elevação. Fonte: PISANI, Daniele. Paulo Mendes da Rocha: obra completa. São Paulo: Editorial Gustavo Gili, 2013, p. 187.

\subsubsection{2:}

Paulo Mendes da Rocha, Reservatório Elevado de Urânia, Brasil, 1968. Maquete.

Fonte: ARTIGAS, Rosa (Org.). Paulo Mendes da Rocha: projetos 1957-1999. 3. ed. São Paulo: Cosac Naify, 2006, p. 45.

\subsubsection{3}

Pier Luigi Nervi, Torre de Água da Fábrica FIAT Mirafiori, Turim, Itália, 1963. Corte.

Fonte: COMBA, Michela (Ed.). Maire Tecnimont: I Progetti FIAT Engineering 1931-1979. Milano: Silvana Editoriale, 2011, p. 202 


\subsubsection{4:}

Pier Luigi Nervi, Torre de Água da Fábrica FIAT Mirafiori, Turim, Itália, 1963. Detalhe dos painéis de ferrocimento do fuste.

Fonte: Depósito elevado para la Fiat. Informes de La Construcción, Madrid, v. 18, n. 172, p. 581-23, jul. 1965.

\subsubsection{5:}

Pier Luigi Nervi, Torre de Água da Fábrica FIAT Mirafiori, Turim, Itália, 1963. Detalhe do Reservatório.

Fonte: COMBA, 2011, p. 10.

\subsubsection{6:}

Pier Luigi Nervi, Torre de Água da Fábrica FIAT Mirafiori, Turim, Itália, 1963. Detalhe das juntas dos painéis do reservatório.

Fonte: Informes de La Construcción, v. 18, n. 172, p. 581-23, jul. 1965.

\subsubsection{7:}

Frei Otto, Projeto de Torre de Água, 1965. Maquete.

Fonte: OTTO, Frei (Ed.). Tensile Structures. Cambridge: MIT Press, 1977, p. 141.

\subsubsection{8:}

Frei Otto, Projeto de Torre de Água, 1965. Detalhe do reservatório.

Fonte: Ibidem, p. 140.

\subsubsection{9:}

Álvaro Siza Vieira, Torre de água da Universidade de Aveiro, Portugal, 1988. Planta, cortes, elevações.

Fonte: TESTA, Peter. Álvaro Siza. São Paulo: Martins Fontes, 1998, p. 146.

\subsubsection{0:}

Álvaro Siza Vieira, Torre de água da Universidade de Aveiro, Portugal, 1988. Fonte: Ibidem, p. 147.

\subsubsection{1:}

CB\&I, Torre de água com reservatório de fundo elíptico suspenso, EUA, 1919.

Fonte: DUBIE, Carol Ann. The Architecture and Engineering of Elevated Water Storage Structures: 1870-1940. 1980. $163 \mathrm{f}$. Dissertação (Mestrado) - Curso de American Civilization, School of Arts and Sciences, The George Washington University, Washington, 1980, p. 113.

\subsubsection{2:}

Torre de água com reservatório de fundo elíptico suspenso, Toledo, Ohio, EUA. Fonte: BECHER, 1988, f. 20.

\subsubsection{3:}

CB\&l, Torre de água com reservatório de fundo elíptico e tampa integrada, EUA, ca. 1930.

Fonte: BECHER, 1971, p. 394.

\subsubsection{4:}

George T. Horton, Patente do Radial-Cone-Bottom Tank, EUA, 1929-1932.

Fonte: UNITED STATES PATENT OFFICE (Washington). George T. Horton. Tank. EUA nº US 1.844.854, 18 abr. 1929, 9 fev. 1932. p. 1.

\subsubsection{5:}

CB\&l, Torre de Água do Brooklyn, Nova lorque, EUA, 1932.

Fonte: DUBIE, 1980, p. 120-122. 


\subsubsection{6:}

CB\&I, Torre de Água do Thomasville, Carolina do Norte, EUA, 1932.

Fonte: https://s3.amazonaws.com/gs-waymarking-images/02668d40-64a3-4648-8807-3b889d04155c_d.jpg

\subsubsection{7:}

George T. Horton, Patentes do para estruturas de suporte do Radial-Cone-Bottom Tank, EUA, 19291932.

Fonte: UNITED STATES PATENT OFFICE (Washington). George T. Horton. Tank. EUA nº US 2.264.667, 17 junho 1938, 2 dez. 1941. p. 1-4.

\subsubsection{8:}

CB\&l, Torre de Água de Gary, Indiana, EUA.

Fonte: BECHER, 1988, f. 152.

\subsubsection{9:}

Construção de um Radial-Cone-Bottom Tank.

Fonte: https://www.dailyherald.com/article/20160114/news/160119568

\subsubsection{0:}

CB\&l, Torre de Água de Longmont, Colorado, EUA, 1939.

Fonte: https://farm2.staticflickr.com/1443/26233883585_2ce2c107ce_b.jpg

\subsubsection{1:}

George T. Horton, Patentes da Watersphere, EUA, 1940-1944.

Fonte: UNITED STATES PATENT OFFICE (Washington). George T. Horton. Elevated Steel Tank. EUA no US 2.341.100 A, 4 nov. 1942, 8 fev. 1944. p. 1-4.

\subsubsection{2:}

CB\&l, Waterspheroid. Perspectiva.

Fonte: CB\&I (Chicago Bridge \& Iron Company). Waterspheroid: Elevated Water Storage. Woodlands: Chicago Bridge \& Iron Company, 2016. Catálogo Técnico.

\subsubsection{3:}

CB\&l, Torre de Água de Northbrook, Illinois, EUA, 1954.

Fonte: https://images-na.ssl-images-amazon.com/images/l/51 irlz9Jb3L.jpg

\section{Figura 2.4.144:}

Torres de Água do tipo Waterspheroid, EUA.

Fonte: BECHER, 1988, f. 144 e 145.

\subsubsection{5:}

George T. Horton, Patentes para Torres de Água, EUA, 1939-1949.

Fonte: UNITED STATES PATENT OFFICE (EUA).

\subsubsection{6:}

Clarence D. Miller e John N. Pirok, Patente do reservatório torisférico, EUA, 1960.

Fonte: UNITED STATES PATENT OFFICE (EUA). Clarence D. Miller. Elevated Storage Tank. EUA no US 2.961.118, 2 out. 1958, 22 nov. 1960. p. 1-2.

\subsubsection{7:}

CB\&I, Torre de Água de Sacramento, Califórnia, EUA, 1962.

Fonte: http://d2ydh70d4b5xgv.cloudfront.net/images/5/6/1962-cb-i-horton-largest-elevated-tank-in-sacramento-ca-photoad-20eb374872512437f41fe88105c688e0.jpg

\subsubsection{8:}

Torres de Água equipadas com reservatório torisférico, EUA.

Fonte: BECHER, 1988, f. 149 e 150. 


\subsubsection{9:}

Eero Saarinen, Torre de Água do Centro Técnico da General Motors, Michigam, EUA, 1955.

Fonte: RAPPAPORT, Nina; STOLLER, Erica. Ezra Stoller: Photographer. New Haven / London: Yale University Press, 2012, p. 96.

\subsubsection{0:}

Ateliers de Construction de Jambes, Torres de Água, Bélgica, 1959-1975.

a) Châtelineau, 1959.

b) Casteau, 1966.

c) Meeuwen, 1970 .

d) Seneffe, 1971.

e) Rhisnes, 1975.

Fonte: VAN CRAENENBROECK, 1991, p. 160.

\subsubsection{1:}

Politechnika Warszawska, Torre de Água de Bania, Tarnów, Polônia, ca. 1979.

Fonte: http://wiezecisnien.eu/wp-content/uploads/2016/01/Tarnow_wodociag_PBsymbol-2.jpg

\subsubsection{2:}

Holger Koch-Nielsen, Torre de Água de Tyrsted, Horsens, Dinamarca, 1983.

Fonte: THOMSEN, Kjeld. Water tower at Tyrsted, Denmark. IABSE Periodica, Zürich, v. 8, n. P-79, 1984, p. 120.

\subsubsection{3:}

Eduardo Torroja, Torre de Água de Fedala, Marrocos, 1956.

Fonte: https://farm6.staticflickr.com/5447/9578016408_a2ba500dab_b.jpg

\subsubsection{4:}

Eduardo Torroja, Torre de Água de Fedala, Marrocos, 1956. Detalhe da armadura.

Fonte: La cuba hiperbólica de Fedala. Informes de La Construcción, Madrid, v. 10, n. 98, p. 581-13, jan/fev. 1958.

\subsubsection{5:}

Eduardo Torroja, Torre de Água de Fedala, Marrocos, 1956. Corte.

Fonte: Ibidem.

\subsubsection{6:}

Eduardo Torroja, Torre de Água de Fedala, Marrocos, 1956. Planta do anel de suporte do reservatório.

Fonte: Ibidem.

\subsubsection{7:}

Eduardo Torroja, Torre de Água de Fedala, Marrocos, 1956. Abóbada de alvenaria e tirantes. Fonte: Ibidem.

\subsubsection{8:}

Eduardo Torroja, Torre de Água de Fedala, Marrocos, 1956. Abóbada de cobertura.

Fonte: Ibidem.

\subsubsection{9:}

Eduardo Torroja, Torre de Água de Fedala, Marrocos, 1956. Maquete.

Fonte: https://pbs.twimg.com/media/DDWkAnFXgAAbpDb.jpg

\subsubsection{0:}

Eduardo Torroja, Projeto para a Torre de Água de Rabat, Marrocos, 1957. Corte e detalhe.

Fonte: BERNARDO, Joaquín Antuña. Prestressed Masonry for Reservoirs: A Project of the Engineer Eduardo Torroja. In: 8th International Seminar nn Structural Masonry, 8., 2008, Istambul. Conference Publication. Istambul: Istanbul Technical University, 2008. p. 14. 


\subsubsection{1:}

Eduardo Torroja, Projeto para a Torre de Água de Rabat, Marrocos, 1957. Sistema construtivo.

Fonte: desenho do autor.

\subsubsection{2:}

Eduardo Torroja, Projeto para a Torre de Água de Marselha, França, 1958. Elevação.

Fonte: BERNARDO, 2002, p. 209.

\subsubsection{3:}

Eduardo Torroja, Torre de Água do Hipódromo de Zarzuela, Madrid, 1941. Corte.

Fonte: http://www.cehopu.cedex.es/etm/pict/img_Ir/l-ETM-115-02_01.jpg

\subsubsection{4:}

Eduardo Torroja, Estudo para Torre de Água do Hipódromo de Zarzuela, Madrid, 1935.

Fonte: BECKH, 2015, p. 22.

\subsubsection{5:}

Eladio Dieste, Torre de Água do Balneário Las Vegas, Uruguai, 1966.

Fonte: TORRECILLAS, Antonio Jiménez (Org.). Eladio Dieste: 1943-1996. Junta de Andalucía: Consejeria de Obras Públicas y

Transportes. Dirección General de Arquitectura y Vivienda, 1996, p. 210.

\subsubsection{6:}

Eladio Dieste, Torre de Água para a Indústria Refrescos del Norte, Salto, Uruguai, 1976.

Fonte: Ibidem, p. 211.

\subsubsection{7:}

Eladio Dieste, Torre de Água do Complejo Habitacional América, Montevidéu, Uruguai, 1976.

Fonte: http://www.fadu.edu.uy/eladio-dieste/obras/tanque-de-agua-complejo-america

\subsubsection{8:}

Daniel Badani e Nicolas Esquillan, Torre de Água de Cocody, Abidjan, Costa do Marfim, 1953.

Fonte: MICHELIS, P. A.. Esthétique de L'Architecture du Béton Armé. Paris: Dunod, 1963, p. 142.

\subsubsection{9:}

Daniel Badani e Nicolas Esquillan, Torre de Água de Cocody, Abidjan, Costa do Marfim, 1953. Corte Fonte: BECHER, 1971, p. 395.

\subsubsection{0:}

Daniel Badani e Nicolas Esquillan, Torre de Água de Cocody, Abidjan, Costa do Marfim, 1953. Foto da obra.

Fonte: MARREY, Bernard. Nicolas Esquilan: Un Ingénieur D’Entrepise. Paris: Picard, 1992, p. 84.

Figura 2.4.171:

Nicolas Esquillan, Torre de Água de Rabat, Marrocos, 1954.

Fonte: MICHELIS, 1963, p. 143.

\subsubsection{2:}

Sune Lindström, Torre de Água de Örebro, Suécia, 1957.

Fonte: https://upload.wikimedia.org/wikipedia/commons/9/9e/Svampen_n\%C3\%A4stan_klar_2.jpg

\subsubsection{3:}

Sune Lindström, Torre de Água de Örebro, Suécia, 1957. Corte.

Fonte: Depósito pretensado Orebro. Informes de La Construcción, Madrid, v. 11, n. 103, p. 581-14, ago/set. 1958.

\subsubsection{4:}

Sune Lindström, Torre de Água de Örebro, Suécia, 1957. Detalhe da Protensão.

Fonte: Ibidem. 


\subsubsection{5:}

Sune Lindström, Torre de Água de Örebro, Suécia, 1957. Evolução da Obra.

Fonte: Ibidem.

\subsubsection{6:}

Sune Lindström, Grupo de Torres de Água na Cidade do Kuwait, Kuwait, 1971.

Fonte: https://kids.nationalgeographic.com/content/dam/kids/photos/articles/Other\%20Explore\%20Photos/R-

Z/Wacky\%20Weekend/Water\%20Towers/ww-water-towers-kuwait.adapt.945.1.jpg

\subsubsection{7:}

Sune Lindström, Grupo de Torres de Água na Cidade do Kuwait, Kuwait, 1971. Corte e elevação. Fonte: THE AGA KHAN AWARD FOR ARCHITECTURE. Water Towers: Kuwait City, Kuwait. Geneva: Aga Khan Foundation, 1980. Project Brief, p. 11.

\subsubsection{8:}

Torres de Água projetadas por Gerhard Leo Linzmeyer.

a) Apucarana, $200 \mathrm{~m}^{3}, 1967$.

b) Mandaguari, 197-

c) Maringá (Praça Pio XII), $300 \mathrm{~m}^{3}, 1974$

d) Paranavaí, 197-.

Fonte: http://site.sanepar.com.br/categoria/imprensa-galeria-de-imagens/reservatorios-de-agua

\subsubsection{9:}

DAE, Torre de Água da Vila Mariana, São Paulo, Brasil, 1966-1968.

Fonte: REVISTA D.A.E.: Revista do Departamento de Águas e Esgotos. São Paulo: SAEC, n. 82, 1971.

\subsubsection{0:}

Simo Lumme, Torre de Água de Roihuvuori, Helsinque, Finlândia, 1976.

Fonte: http://taivasalla.net/2016/2016-03/img/160312_2327.jpg

\subsubsection{1:}

Simo Lumme, Torre de Água de Roihuvuori, Helsinque, Finlândia, 1976. Processo construtivo.

A. Construção do fuste com formas deslizantes

B. Içamento do reservatório (heavy lifting)

1. Macaco hidráulico de protensão

2. Cabo de protensão

3. Reservatório concretado sobre cimbramento

Fonte: https://fi.wikipedia.org/wiki/Roihuvuoren_vesitorni

\subsubsection{2:}

Torre de Água de Roihuvuori, Helsinque, Finlândia, 1976. Unidades de içamento instaladas no topo do fuste.

Fonte: VSL. Concrete Storage Structures: Use of the VSL Special Construction Methods. Berne: VSL International Ltd., 1983, p. 14.

\subsubsection{3:}

Torre de Água de Roihuvuori, Helsinque, Finlândia, 1976. Ancoragem dos cabos de protensão no anel de suporte do reservatório.

Fonte: Ibidem.

\subsubsection{4:}

Torre de Água de Roihuvuori, Helsinque, Finlândia, 1976. Início do içamento do reservatório. Fonte: Ibidem.

\subsubsection{5:}

Fernand Mortelmans, Torre de Água de Mechelen, Bélgica, 1978. Sequência de içamento do reservatório.

Fonte: VSL, 1983, p. 16. 


\subsubsection{6:}

Torre de Água de Wupertal, Alemanha, $1.500 \mathrm{~m}^{3}, 1975$.

Fonte: MERKL, 1985, p. 145.

\subsubsection{7:}

Torre de Água de Cutro, Itália, $2.000 \mathrm{~m}^{3}$, 1980. Corte.

Fonte: AEBERHARD, H.U.. Water tower in Cutro (Italy). IABSE Periodica, Zürich, v. 6, n. C-22, 1982, p. 58.

\subsubsection{8:}

Torre de Água de Cutro, Itália, $2.000 \mathrm{~m}^{3}$, 1980. Elevação do reservatório e unidades de içamento no topo do fuste.

Fonte: Ibidem.

\subsubsection{9:}

Torre de Água de Cutro, Itália, $2.000 \mathrm{~m}^{3}$, 1980. Detalhe da conexão do reservatório com o topo do fuste.
a) espiral
b) anel de suporte do reservatório
c) placa de suporte
d) viga anular no topo do fuste
e) forma para nicho
f) cabeça de ancoragem inferior
g) cabeça de ancoragem superior
h) enchimento de concreto
i) concretagem de união entre fuste e reservatório
Fonte: Ibidem.

\subsubsection{0:}

Torre de Água de Feira de Santana, Bahia, Brasil, 1985.

Fonte: http://www.oas.com/oas-com/oas-engenharia/realizacoes/saneamento/agua/complexo-pedra-do-cavalo-reservatorio/

\subsubsection{1:}

Erkko Virkkunen, Torre de Água de Haukilahti, Espoo, Finlândia, 1967. Esquema da sequência construtiva.

Fonte: PROKKOLA, Janne; LEHTOVUORI, Panu. Haukilahden vesitorni: rakennushistoriaselvitys. Espoo: Livady, 2010, p. 46.

\subsubsection{2:}

Erkko Virkkunen, Torre de Água de Haukilahti, Espoo, Finlândia, 1967. Evolução da obra. Fonte: Ibidem, p. 47.

\subsubsection{3:}

Erkko Virkkunen, Torre de Água de Haukilahti, Espoo, Finlândia, 1967. Restaurante Panorâmico. Fonte: http://www.virkkunenco.fi/project/haukilahden-vesitorni

\subsubsection{4:}

STUP, Torre de Água de Corgenon, Buellas, França, 1957.

Fonte: MICHELIS, 1963, p. 73.

\subsubsection{5:}

Guillaume Gillet, Torre de Água de Belmont, Royan, França, 1960. Estudos.

Fonte: https://expositions-virtuelles.citedelarchitecture.fr/GILLET/02-CHAPITRE-PROJET-02-DOC08.html

\subsubsection{6:}

Guillaume Gillet, Torre de Água de Belmont, Royan, França, 1960.

Fonte: Ibidem. 


\subsubsection{7:}

R. Kessler, Torre de Água de Möglingen, Alemanha, 1964.

Fonte: BECHER, 1988, f. 168.

\subsubsection{8:}

Torre de Água de Jales, São Paulo, Brasil.

Fonte: http://photos.wikimapia.org/p/00/03/45/56/30_full.jpg

\subsubsection{9:}

Torres de água hiperbólicas, França.

a) Saint-Rambert-d'Albon, $600 \mathrm{~m}^{3}, 2009$.

b) Machecoul, $2.500 \mathrm{~m}^{3}, 2012$.

c) Saint Fulgent, $4.000 \mathrm{~m}^{3}, 2016$.

Fonte: https://www.eiffageinfrastructures.com

\subsubsection{0}

Torre de Machecoul e a antiga torre tipo Intze, França, 2012.

Fonte: https://www.jobrunenberg.com/chateau-deau-de-france\#27

\subsubsection{1:}

Torres de água destruídas pelo Estado Islâmico, Síria, 2017.

Fonte: BAUER, Wolfgang. Das große Verhängnis. Zeit Magazin. 2018.

\subsubsection{2:}

Torre de água de Colônia, Alemanha (1872), convertida para hotel em 1990. Fonte: https://i.pinimg.com/originals/25/c1/47/25c14774dd388bfb26b587151b4acbfo.jpg

\subsubsection{3:}

White Arkitecter, Projeto para a Torre de Água de Varberg, Suécia, 2018.

Fonte: https://www.dezeen.com/2018/12/11/white-arkiteker-vaga-concrete-water-tower-sweden/ 



\section{SUMÁRIO}

INTRODUÇÃO

PRIMEIRA PARTE: DEFINIÇÃO e FUNÇÃO

1.1. Torre de Água: uma definição

1.2. Função e Funcionamento da Torre de Água

1.2.1. Reservatório

1.2.2. Estrutura de Suporte 90

1.2.3. Arranjo do Sistema Hidráulico

1.2.4. Cobertura e Revestimento do Reservatório

1.2.5. Ventilação e lluminação do Reservatório

1.2.6. Elementos para Inspeção, Manutenção e Segurança

\section{SEGUNDA PARTE: HISTÓRIA DAS TORRES DE ÁGUA}

$\begin{array}{ll}\text { 2.1. Infraestrutura da Água } & 107\end{array}$

2.2. Precursores das Torres de Água

2.3. Torres de Água no Século XIX

2.3.1. O Papel das Ferrovias no Desenvolvimento das Torres de Água

2.3.2. Torres de Água para Abastecimento Público

2.3.3. Arquitetura das Primeiras Torres de Água

2.3.4. Reservatório de Fundo Suspenso

2.3.5. Primeiras Torres de Água Totalmente Metálicas

2.3.6. Reservatório Tipo Intze

2.4. Torres de Água no Século XX e na Atualidade

2.4.1. Desenvolvimento das Torres de Água Totalmente Metálicas

2.4.2. Primeiras Torres de Água de Concerto Armado

2.4.3. A influência do Art Nouveau, Art Déco e Expressionismo

2.4.4. A influência do Movimento Moderno

2.4.5. Modernas Torres de Água Metálicas

2.4.6. O Uso Moderno da Alvenaria nas Torres de Água

2.4.7. Modernas Torres de Água de Concreto

2.4.8. O Futuro das Torres de Água 



\section{INTRODUÇÃO}

\section{Tecnologia e Infraestrutura}

Desde as primeiras civilizações as tecnologias se fizeram presentes em nosso cotidiano ajudando a moldar nosso modo de vida. Pequenos objetos tecnológicos de nosso dia a dia transformaramse em forças que movimentam a órbita de nossa civilização.

Alguns períodos da história certamente foram mais influenciados pelos avanços tecnológicos do que outros. Assim como as invenções da locomotiva a vapor, do telefone e da fotografia revolucionaram o século XIX, nossa época foi definitivamente transformada com a introdução da tecnologia dos microcomputadores e o advento da internet.

E de fato, nos dias de hoje, quando o assunto é tecnologia, nos lembramos apenas de celulares, notebooks e GPS. Grandes invenções do passado com maior significado histórico como, por exemplo, a cerâmica, o vidro ou o papel, hoje nem estariam inseridos no campo da "tecnologia". Encanamentos e antenas de TV, sobretudo. São raras as ocasiões em que nos lembramos do conjunto de sistemas tecnológicos fundamentais para 0 estabelecimento e manutenção das sociedades contemporâneas.

"A característica mais evidente da tecnologia no mundo (industrial ou pós-industrial) moderno é o grau com que esta tecnologia é ou não é evidente para a maioria das pessoas na maior parte do tempo." 1

Ao relacionarmos as tecnologias prevalecentes na sociedade contemporânea raramente nos lembramos de estradas de rodagem, ferrovias, linhas de transmissão de energia elétrica, sistemas de abastecimento de água ou sistemas de coleta e tratamento de águas servidas. No seu amadurecer e estabelecimento, em um

1 EDWARDS, Paul N.. Infrastructure and Modernity: Force, Time and Social Organization in the History of Sociotechnical Systems. In: MISA, Thomas J.; BREY, Philip; FEENBERG, Andrew (Ed.). Modernity and Technology. Cambridge: Mit Press, 2003, p. 185. 
ritmo cada vez mais acelerado, estas tecnologias tornaram-se praticamente imperceptíveis, desaparecendo nos bastidores de nosso cotidiano.

A civilização naturaliza as tecnologias de uso cotidiano como se tivessem sempre existido e, ainda que, dependendo fundamentalmente destes sistemas tecnológicos para sustentar a vida nas cidades, lembra destes apenas nos momentos de falhas de operação ou acidentes. Estes sistemas são o tecido de conexão e o sistema circulatório da modernidade, tornaram-se infraestruturas, as fundações da vida moderna, conectando as diversas escalas de tempo, espaço e organização social. ${ }^{2}$

$\mathrm{Na}$ arquitetura o termo infraestrutura pode ser entendido tanto como estrutura (caso das fundações que suportam a estrutura de um edifício), quanto como um termo relacionado aos sistemas de instalações prediais (instalações elétricas, hidráulicas, de telefonia e lógica, de ar condicionado, de prevenção e combate a incêndios). No urbanismo o termo infraestrutura é entendido como o conjunto de sistemas tecnológicos que garantem o funcionamento da cidade. Como notou Braga (2006), podemos também incluir na lista de sistemas de infraestrutura todos os sistemas utilizados para circulação de pessoas ou mercadorias: rodoviário, aeroviário, ferroviário, hidroviário, entre outros:

"Infra-estruturas entendidas como as estruturas urbanas físicas perenes construídas pelo poder público ou por concessionárias, a fim de constituir o suporte físico dos serviços urbanos públicos básicos: as redes de circulação de pessoas e produtos, de adução e distribuição de água potável, de coleta e tratamento de águas servidas, de drenagem urbana, de energia elétrica, de gás combustível e de telecomunicações por cabo ou radiodifusão." 3

\footnotetext{
2 Ibid, op. cit., p. 186.

3 BRAGA, Milton Liebentritt de Almeida. Infra-estrutura e Projeto Urbano. 2006. 1 v. Tese (Doutorado) - Programa de Pós-Graduação da Faculdade de Arquitetura e Urbanismo da Universidade de São Paulo, São Paulo, 2006, p. 10.
} 
Complementando, podemos citar também Corullon (2013), que define as infraestruturas como sendo "estruturas físicas que promovem ou permitem fluxos de diferentes naturezas e que constituem a base material para a possibilidade de existência da cidade."

\section{Infraestrutura da Água}

"A água é uma "coisa" indispensável para manter o metabolismo, não apenas de nossos corpos humanos, mas também do mais amplo tecido social. A própria sustentabilidade das cidades e as práticas da vida cotidiana que constituem o "urbano" são baseadas e condicionadas pelo suprimento, circulação e eliminação da água."

Erik Swyngedouw, 2004. ${ }^{4}$

Os modernos sistemas centralizados de abastecimento de água potável remontam a meados do século XIX nas principais capitais da Europa e nas grandes cidades dos Estados Unidos da América. A introdução destes sistemas alterou radicalmente a relação do homem da cidade com a água. A água não mais precisava ser transportada de um poço, fonte pública ou rio para o interior das residências, representando assim uma grande economia de tempo e também diminuindo consideravelmente os riscos de contaminação da água. A disseminação dos sanitários privativos nas residências elevou a qualidade da higiene pessoal, estabeleceu novos padrões de privacidade e reconfigurou o arranjo espacial das residências praticamente definindo assim os padrões sanitários atuais.

A implantação das complexas e extensas redes infraestruturais de abastecimento de água e coleta de águas servidas por toda a extensão do tecido urbano formaria o que Gandy (2004) chama de a "cidade escondida": uma tecnologia madura e funcional que se esconde em quilômetros de tubulações embutidas sob as ruas da cidade e no interior das paredes dos

${ }^{4}$ SWYNGEDOUW, Erik. Social power and the urbanization of water: flows of power. Oxford: Oxford University Press, 2004, p. 1. 
edifícios, fazendo com que o contato com a água, enquanto recurso natural, praticamente desapareça da vida cotidiana e se torne a própria infraestrutura, a "água utilitária". Neste sentido, a "cidade escondida" está intimamente ligada com a hipótese levantada por Edwards (2003) de que "quanto maior é o grau de maturação e uso de uma tecnologia, maior é o grau de invisibilidade desta mesma tecnologia." 5

Segundo Gandy (2004) o planejamento, projeto e construção das modernas redes de infraestruturas tecnológicas que compõem a "cidade escondida" eram, até recentemente, tarefas realizadas exclusivamente por engenheiros, enquanto que outros aspectos "visíveis" do planejamento e do desenho urbano eram amplamente percebidos como o domínio tradicional dos arquitetos e planejadores urbanos.

Neste mesmo sentido a arquiteta e paisagista Anne Whiston Spirn aponta a falta de interesse da arquitetura pelos sistemas infraestruturais de água:

"Os aquedutos da Roma antiga eram monumentos artísticos que celebravam a façanha de trazer água para a cidade; as fontes da Roma barroca comemoravam a reconstrução do sistema público de água. A introdução de sistemas públicos de água para cidades norte-americanas no século XIX foram a ocasião para celebrações e construção de fontes comemorativas em parques urbanos e praças. Estes monumentos marcavam uma conexão entre as pessoas que moravam na cidade e o processo natural que os sustentava. Eles eram funcionais, uma fonte de prazer sensual e de significado simbólico. Hoje, poucos arquitetos e urbanistas se preocupam com sistemas de água e esgoto. No entanto, o impacto destas obras públicas sobre a forma urbana e a sua experiência estética é grande demais para ser ignorada."6

5 EDWARDS, 2003, op. cit., p. 188.

6 SPIRN, Anne Whiston. The Poetics of City and Nature: Towards a New Aesthetic for Urban Design. Landscape Journal, Madison, v. 7, n. 2,1988, p. 122. 
A falta de interesse pelas infraestruturas de abastecimento de água não é exclusividade dos arquitetos e urbanistas, nem parece ser uma novidade. Já no ano 97 d.C. quando Julius Sextus Frontinus é nomeado, pelo imperador romano Nerva Augustus, Comissário das Águas dos Aquedutos de Roma (curator aquarum) ele sugere, em seu célebre tratado De Aquaeductu Urbis Romae, o desprestígio das obras de infraestrutura hidráulica em relação as grandes construções da Antiguidade:

"Quem se aventuraria a comparar as indispensáveis realizações hidráulicas de Roma com as grandes pirâmides do Egito ou as famosas, porém inúteis, obras gregas?"7

Não obstante a grandiosidade e utilidade dos aquedutos e

1

Torre de Água em área rural da França. Fotografia de Jo Brunenberg. demais realizações hidráulicas de Roma, estas infraestruturas nem sempre foram devidamente apreciadas, não merecendo menção entre as tradicionais maravilhas do mundo antigo.

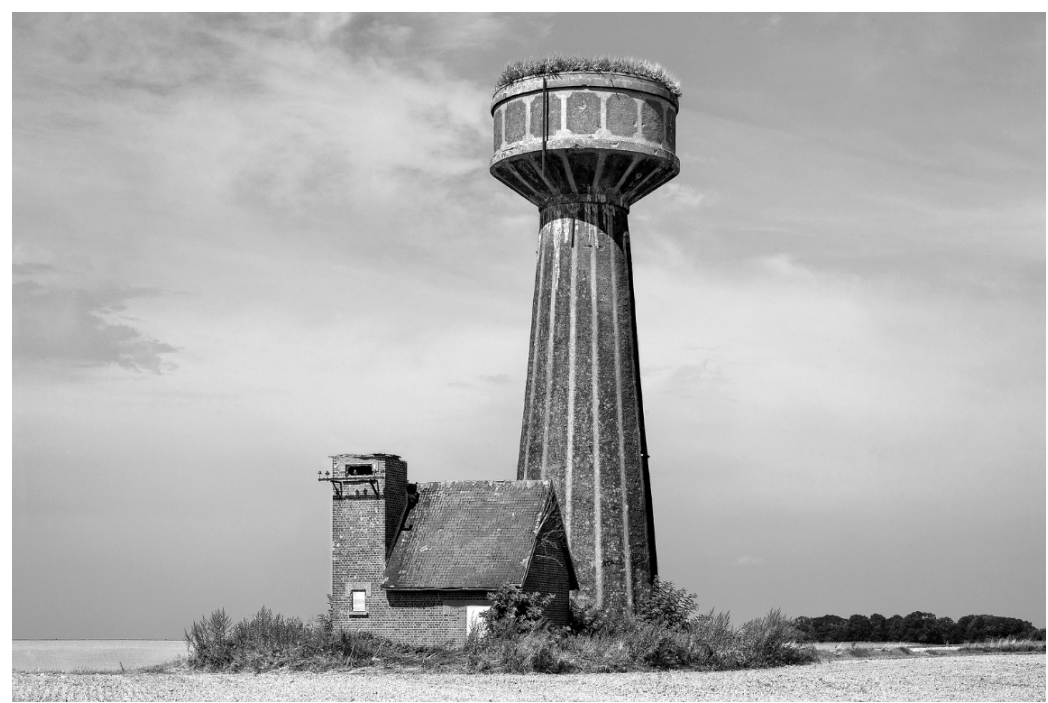

As Torres de Água

Represas, barragens, torres de entrada, adutoras, tanques de clarificação e decantação, estações elevatórias, filtros... Dos diversos elementos que se organizam para formar os sistemas infraestruturais de abastecimento de água podemos considerar as Torres de Água como sendo um dos poucos elos visíveis que

${ }^{7}$ Apud NETTO, José Martiniano de Azevedo. Arquitetura das Torres d'Água. Revista D.A.E.: Revista do Departamento de Águas e Esgotos, São Paulo, v. 21, n. 38 , set. 1960 , p. 7. 
nos lembram da "cidade escondida" de água que acontece sob o tecido urbano de nossas cidades. Embora o uso de reservatórios elevados de água exista desde os tempos antigos em várias formas, o uso moderno das torres de água nos sistemas públicos de abastecimento de água estabeleceu-se apenas em meados do século XIX, devido a uma conjunção de fatores de ordem social e técnica. A Revolução Industrial iniciada em meados do século XVIII na Inglaterra rapidamente se espalhou para vários países europeus e gerou, para além da mecanização dos sistemas de produção e do aumento da produção industrial, um crescimento vertiginoso das cidades e da população urbana, aumentando significativamente a demanda por água potável. Ainda, os avanços no campo da fabricação do ferro, o desenvolvimento das bombas de água impulsionadas pelo vapor, das modernas bombas hidráulicas e dos novos sistemas de encanamentos aptos a lidar com pressões mais elevadas, criaram as bases técnicas e materiais para a implantação dos modernos sistemas centralizados de abastecimento de água. Estes sistemas, assim como muitos da atualidade, exigiam torres de água com grandes reservatórios posicionados acima das áreas de consumo com o objetivo de compensar as flutuações de pressão e de consumo de água.

Embora as torres de água sejam, antes de tudo, infraestruturas técnicas e frequentemente sejam consideradas como edifícios situados na fronteira entre o campo de atuação de engenheiros e arquitetos, a sua forma e aparência não é o resultado isolado de considerações e circunstâncias estritamente técnicas. Toda a produção de máquinas ou equipamentos, barragens de hidrelétricas ou torres de água precisa, inevitavelmente, de recursos formais que se apoiem numa materialidade, e isto, antes ou depois, acaba por se manifestar em sua valorização estética e simbólica:

"Eu fui para o quadro-negro, que é equipamento padrão na Universidade, e desenhei no meio do quadro-negro uma torre de água, a qual tentei fazer tão bonita quanto possível, com um topo amplo e um fundo estreito de onde desenhei aquedutos partindo desta torre como radiação estelar. Eu disse: "Este seria um início 
apropriado para uma cidade na Índia." Não construindo os edifícios em primeiro lugar, não construindo a esperança para a água, o desejo que eu sentia era mais de um símbolo - mais um início - mais um início moderno para a Índia do que o desenho de Balkrishna Doshi e a construção e concepção de formas arquitetônicas deliciosamente concebidas, certamente - mas fora do contexto com o que se pode chamar de um modo de vida que clama pela água como esperança para as árvores, como uma esperança para a agricultura e até mesmo como uma esperança para os próprios edifícios."

Louis I. Kahn, palestra The New Art of Urban Design: Are We Equiped? (1960) ${ }^{8}$

Segundo o arquiteto Lúcio Costa, a presença de uma intenção plástica e de valores estéticos é precisamente o que distingue a arquitetura da simples construção. ${ }^{9}$ Para entender a arquitetura das torres de água, ainda que esta seja baseada em requisitos funcionais, é preciso considerar fatores decisivos como o meio físico e social a que pertencem, as técnicas decorrentes dos materiais empregados, as tendências arquitetônicas e a época de sua construção, uma vez que parece correto afirmar que estruturas tão impressionantes como as torres de água foram projetadas e construídas atentas aos paradigmas arquitetônicos e tecnológicos de seu tempo.

Toda a construção que pretende atender com rigor a um programa específico, visando uma determinada função e atendendo aos requisitos da técnica necessita de um projeto

${ }^{8}$ Esta palestra de Louis Kahn foi realizada durante a conferência "New Forces in Architecture" (1960), organizada pela Architectural League of New York em conjunto com a revista Architectural Forum. $\mathrm{O}$ arquiteto indiano Balkrishina Doshi, ganhador do Prêmio Pritzker em 2018, visitou a Universidade da Pensilvânia em 1960 e nesta visita conheceu Kahn. Doshi trabalhou com Le Corbusier nos projetos para as residências Shodhan (1951-56) e Sarabhai (195155) e também com Kahn no projeto do Instituto Indiano de Administração (1962-74), em Ahmedabad. Para a palestra completa ver KAHN, Louis. The New Art of Urban Design: Are We Equipped? Palestra, 1960. In: TWOMBLY, Robert (org.) Louis Khan Essential Texts. New York: W. W. Norton \& Company, 2003. p. 75-80.

${ }^{9}$ COSTA, Lucio. Arquitetura. Rio de Janeiro: José Olympio Editora, 2011. 
adequado para sua realização. Temas de projeto como a casa, a escola, a indústria, o edifício comercial, o museu e o parque são sinônimos de arquitetura. Desenvolvidos e estudados quase que à exaustão pelos arquitetos, todos são objeto de inúmeros livros, artigos, teses e dissertações. Para o pleno atendimento da função que lhe é destinada a torre de água também necessita de um projeto adequado. Como parte integrante de sistemas públicos ou privados de abastecimento de água, sistemas vitais para suporte da vida e uma das bases materiais para a existência das cidades, podemos considerar as torres de água como objetos tão importantes quanto a casa ou a escola.

Edifícios como as torres de água discutem, acima de tudo, o problema da beleza e da verdade na arquitetura, tornando-se um tema adequado para a pesquisa sobre o "conflito" entre o útil e o belo, entre a forma e a função. ${ }^{10}$ Muitas das estratégias projetuais utilizadas por arquitetos e engenheiros no desafio do desenho destas infraestruturas transcendem as funções programáticas e técnicas do objeto, contribuindo também com procedimentos próprios da prática arquitetônica como, por exemplo, a exploração da forma como meio expressivo, gerador de experiência estética.

Porém, apesar da sua importância, as torres de água ainda não foram estudadas como se deveria e a negligência das torres de água como objeto de estudo no campo da arquitetura é intrigante. Barton (2007), ao elaborar uma das mais recentes pesquisas sobre torres de água na Grã Bretanha, aponta a quase total inexistência de livros sobre torres de água, comenta que até mesmo livros sobre "torres" apresentam todos os tipos possíveis de torres, menos torres de água, e completa: "livros de arquitetura ignoram elas". ${ }^{11}$

Barton elaborou a sua pesquisa como membro do PHEW - Panel for Historical Engineering Works (Painel para Trabalhos

10 GENICOT, L. F.. De watertoren: architectuur, landschap. In: VAN CRAENENBROECK, W.. Eenheid in Verscheidenheid: Watertorens in Belgie. Brussel: Navewa, 1991, p. 135.

${ }^{11}$ BARTON, Barry. Water Towers of Britain. Londres: Newcomen Society, 2003, p. xii. 
Históricos de Engenharia) do Institution of Civil Engineers (Instituição de Engenheiros Civis). O PHEW pesquisa e identifica obras históricas de engenharia que são dignas de registro, divulgação e, em alguns casos, de preservação. Em 1994 os membros do PHEW criaram um subgrupo específico para pesquisar as torres de água na Grã Bretanha, pois estava claro para todos os pesquisadores que este era um tema sobre o qual muito pouco trabalho de pesquisa havia sido realizado e, ainda, muito menos havia sido escrito. ${ }^{12}$

Temos aqui um fato bastante curioso se considerarmos que no tratado De Architectura Libri Decem, considerado o primeiro texto teórico ocidental sobre arquitetura (século I a.C.), o arquiteto romano Marcus Vitruvius Pollio (80 a.C.-15 a.C.) dedica seu Livro VIII exclusivamente ao tema da água, descrevendo as possíveis fontes para se obter uma água de boa qualidade para consumo e as construções necessárias para conduzir, armazenar e distribuir a água captada. Ainda, no Livro $\mathrm{X}$, dedicado à descrição de máquinas e equipamentos, Vitruvius relata toda uma série de engenhos desenvolvidos pelos antigos romanos para viabilizar a captação, condução e elevação artificial de água. Isto demonstra claramente a importância vital da água para as cidades da Roma Antiga e a preocupação de seus planejadores com os sistemas de abastecimento de água. Ainda hoje a água é um recurso vital para o homem e para as cidades, mas temos atualmente uma falta de interesse de arquitetos e urbanistas pelos projetos dos sistemas infraestruturais de abastecimento de água e dos vários equipamentos que os compõem, conforme apontado por Spirn (1988).

A ausência das torres de água nos tratados de arquitetura escritos a partir do final do século XIX, num momento em que as torres de água já haviam se tornado um elemento bastante presente no cenário urbano das grandes capitais europeias, é bastante intrigante.

12 Ibidem, p. ix. 
Em Éléments et Théorie de l'Architecture, escrito por Julien Guadet em 1894, além de programas arquitetônicos como escolas, residências, igrejas, hospitais, presídios, entre outros, também são apresentados os programas surgidos devidos aos avanços sociais e tecnológicos ocorridos durante o século XIX como, por exemplo, as estações de trem, mas não existe qualquer menção às torres de água, um equipamento fundamental para o funcionamento e operação dos primeiros sistemas ferroviários, como veremos a seguir.

No livro Bauentwurfslehre: Grundlagen, Normen, Vorschriften (Lições de Projeto e Construção: Fundamentos, Normas e Regulamentos), de Ernst Neufert, publicado pela primeira vez no ano de 1936 e chegando hoje a sua 42a edição (2018) com constantes atualizações de conteúdo e com traduções em 18 línguas, chama a atenção a ausência das torres de água. Em um tratado de arquitetura onde são apresentados em detalhes os mais variados programas arquitetônicos, de residências unifamiliares a hotéis, de pistas de boliche a estádios olímpicos, de zoológicos a galinheiros, de abrigos antiaéreos a reservatórios de combustíveis, as únicas torres mencionadas são as torres para os campanários de igrejas, nenhuma menção é feita às torres de água. ${ }^{13}$

A ausência de estudos abrangentes sobre as torres de água no campo da arquitetura ou a menção do equipamento nos tratados de arquitetura pode em parte ser explicada pelo fato de que o projeto das torres de água, em um primeiro momento, tenha sido confiado aos mesmos engenheiros que elaboravam os projetos para os sistemas de abastecimento de água e a participação dos arquitetos nestes projetos, quando existia, era limitada ao desenho do "envelope externo" destas construções. Com o passar do tempo, no entanto, este paradigma foi mudando e os arquitetos passaram a ter uma maior participação nos projetos de torres de água. Muitos arquitetos renomados realizaram projetos para torres

13 NEUFERT, Ernst. A Arte de Projetar em Arquitetura. 17. ed. Barcelona: Gustavo Gili, 2009. 17 $7^{a}$ edição em português, correspondente a $35^{a}$ edição alemã. 
de água, citando alguns nomes podemos iniciar com Joseph Maria Olbrich, Hans Poelzig, Walter Gropius e Adolf Meyer, Auguste Perret, Le Corbusier, Mart Stam, Jørn Utzon, Eero Saarinen, Alvar Aalto, Frei Otto, Paulo Mendes da Rocha, Christian de Portzamparc, Álvaro Siza Vieira, entre outros. Diante de nomes como estes, a ausência de estudos abrangentes sobre a arquitetura das torres de água fica ainda mais intrigante.

O estudo das torres de água, apesar de bastante rarefeito, não é completamente inexistente. Pesquisas desenvolvidas por Werth (1971) e Mevius (1985), na Alemanha, Houwink (1973) e Veen (1989), na Holanda, Van Craenenbroeck (1991), na Bélgica e Barton (2007), na Grã-Bretanha, demonstram que, pelos menos, alguns estudos sérios e sistemáticos sobre as torres de água destes países já foram realizados. A única pesquisa sobre torres de água desenvolvida no Brasil até o momento foi uma série de quatro artigos publicados em uma revista especializada em infraestruturas hidráulicas entre os anos de 1960 e 1973. Escritos pelo Eng. José Martiniano de Azevedo Netto e publicados na Revista D.A.E. (Revista do Departamento de Águas e Esgotos) a série de artigos intitulada A Arquitetura das Torres de Água foca na apresentação de torres de água históricas ao mesmo tempo que oferece um panorama geral das tendências de projetos para estes equipamentos na época de sua publicação, com ampla utilização de fotografias das obras realizadas e pouca ou nenhuma informação complementar sobre cada um dos projetos apresentados.

Tendo em vista o recorte temporal (de meados do século XIX até meados do século $X X)$ e o conteúdo apresentado na maioria das pesquisas específicas sobre o tema desenvolvidas até o momento, é importante relacionarmos algumas lacunas historiográficas:

- projetos e obras fora do domínio eurocêntrico não foram considerados;

- materiais de construção alternativos ao concreto armado e a ferro/aço como, por exemplo, a alvenaria cerâmica armada e as 
construções mistas de concreto armado/protendido e alvenaria cerâmica não foram estudados;

- sistemas estruturais inovadores como, por exemplo, as malhas estruturais treliçadas, não foram estudados;

- tipologias de reservatórios desenvolvidas a partir da década de 1950 como, por exemplo, os reservatórios troncônicos, são apresentadas sem grande profundidade;

- sistemas construtivos inovadores como, por exemplo, o sistema de heavy lifting, não são mencionados.

- novas tipologias de reservatórios desenvolvidas a partir da década de 1950 como, por exemplo, os reservatórios hiperbólicos e toroidais, não foram estudadas;

- a influência dos paradigmas arquitetônicos vigentes nos vários períodos e a sua influência na arquitetura das torres de água é pouco considerada, uma vez que as pesquisas produzidas até o momento analisam o objeto principalmente sob o ponto de vista da engenharia;

- a produção de arquitetos renomados não é citada nestes estudos específicos;

- a produção de arquitetos e engenheiros que foram prolíficos projetistas de torres de água é ignorada

Considerando a importância das torres de água como parte integrante fundamental de um sistema infraestrutural vital para o suporte da vida nas cidades modernas e dada a quase inexistência de estudos acadêmicos específicos sobre este tema no campo arquitetônico é necessário preencher esta lacuna historiográfica, especialmente no que tange a atuação dos arquitetos, resgatando a origem histórica do objeto e os fundamentos técnicos e formais que viabilizam a concretização destes equipamentos.

Assim, o objetivo desta pesquisa é analisar a arquitetura das Torres de Água, reconstruindo as origens históricas do 
objeto e identificando a pluralidade de soluções construtivas, tipologias, linguagens e paradigmas arquitetônicos decorrentes das transformações arquitetônicas, culturais, das inovações tecnológicas e das preocupações sócio-ambientais, flagrando o modo como a arquitetura das torres de água se transforma em meio a todas estas mudanças, desde a implantação dos primeiros sistemas modernos de abastecimento de água, em meados do século XIX, até a atualidade.

O presente trabalho se desenvolve em duas partes, além da introdução, conclusão e bibliografia. Na Primeira Parte, inicialmente, apresentamos uma definição do que é uma Torre de Água, as possíveis origens do termo "torre de água" e as variações de nome pelo qual o objeto de estudo é mais conhecido em diversos países e em várias partes do Brasil.

Na sequência serão apresentados os modernos sistemas centralizados para abastecimento público de água, com uma descrição dos elementos básicos que compõem estes sistemas e as variações de esquemas de funcionamento e operação que podem apresentar. A compreensão do funcionamento dos sistemas de abastecimento é essencial para entendermos as várias funções de uma torre de água e para reconhecermos o papel fundamental das torres nestas infraestruturas. Serão apresentados os requisitos técnicos que norteiam a elaboração de projetos de torres de água e a sua implantação nos sistemas de abastecimento de água. Também serão descritos todos os componentes necessários para o adequado funcionamento, operação e manutenção das torres de água desde os seus elementos básicos, como o reservatório e a estrutura de suporte, até o arranjo típico do sistema hidráulico, os elementos de ventilação, iluminação, controle e manutenção que garantem o perfeito funcionamento do equipamento.

Na Segunda Parte será traçado o panorama histórico do desenvolvimento das torres de água, desde meados do século XIX até a atualidade, assim como um quadro geral do desenvolvimento 
das várias tipologias de reservatórios elevados de água e das variadas estruturas de suporte, abordando os diferentes sistemas construtivos e os diversos materiais utilizados, buscando flagrar, sobretudo, a influência das tendências arquitetônicas operantes no momento de concepção das obras apresentadas. A narrativa historiográfica se estrutura aqui a partir de eixos de simultaneidade, uma vez que os avanços materiais e tecnológicos ligados ao projeto e à construção das torres de água não foram implementados de imediato em todas as obras e locais, nem substituíram por completo soluções técnicas anteriores, mas todos passaram a operar lado a lado por um certo período, formando um conjunto de possibilidades técnico-construtivas. O mesmo é válido para o paradigma estético-arquitetônico. As tendências historicistas e o ecletismo arquitetônico do século XIX não foram suplantados de imediato por movimentos modernistas como o Art Nouveau, o Art Déco ou o Expressionismo, da mesma maneira que estes não foram suplantados de imediato pelos novos ideais do Movimento Moderno.

A leitura da Segunda Parte, especificamente a partir da seção 2.4. Torres de Água no Século XX e na Atualidade, deve ser feita em conjunto com o Quadro Referencial de Obras, apresentado como um volume anexo a este. Muitas das obras citadas na Segunda Parte estão incluídas no Quadro Referencial e sua respectiva localização será indicada por uma numeração em negrito oxx inserida ao longo do texto. Considerando que a bibliografia relacionada a história das torres de água produzida até o momento ocupou-se da análise do objeto até meados do século XX, o Quadro Referencial de Obras foi elaborado com o objetivo de ajudar a preencher as lacunas existentes na linha do tempo do desenvolvimento das torres de água do início do século XX até a atualidade.

A bibliografia relacionada ao final do presente trabalho pode, a primeira vista, parecer uma coletânea muito ampla e fragmentada de obras variadas produzidas em épocas mais variadas ainda. Isto, no entanto, é um reflexo da ausência quase total de 
livros e publicações sobre torres de água, algo que a princípio poderia ser considerado um problema, mas acabou por se mostrar como um grande aliado à pesquisa. A falta de fontes recentes sobre o tema acabou gerando uma busca por publicações produzidas em períodos mais distantes, direcionando para uma pesquisa em livros, jornais, revistas e tratados de arquitetura e engenharia do período de transição entre os séculos XIX e XX. Entre as gratas surpresas desta pesquisa podemos citar, por exemplo, os desenhos das Torres de Água do Crystal Palace, de I. K. Brunel (1856), publicado em uma edição de 1901 da revista The Engineer, o projeto para a Torre de Água de Lundshut, de Wayss e Koenen (1885), publicado em Das System Monier, um dos primeiros tratados sobre o concreto armado, escrito no ano de 1887, e também fotografias de algumas das primeiras torres de água equipadas com reservatórios tipo Intze, em uma publicação da empresa alemã F. A. Neuman de 1894, todos estes incluídos no presente trabalho. A bibliografia relaciona as fontes citadas na dissertação bem como as fontes consultadas para montagem do Quadro Referencial de Obras. 
PRIMEIRA PARTE

\section{DEFINIÇÃO E FUNÇÃO}




\subsection{Torre de Água: uma definição}

Para o propósito desta pesquisa é importante definir claramente o que se entende por uma "torre de água". ○ termo "torre de água" utilizado no presente trabalho é aquele a que, à primeira vista, podemos atribuir apenas um significado, nomeadamente uma estrutura construída com o objetivo de elevar um reservatório que armazena uma determinada quantidade de água acima do nível do solo. A torre de água cumpre basicamente duas funções: o armazenamento de uma certa quantidade de água com o objetivo de regularizar vazões de consumo e a criação de uma pressão suficiente para transportar a água armazenada até os pontos de abastecimento mais elevados e mais distantes.

É importante notar que esta definição não faz nenhuma distinção quanto à finalidade precisa para a qual a água é armazenada, podendo esta ser utilizada para o abastecimento público urbano, combate a incêndios, processos industriais ou ainda para o abastecimento individualizado de hospitais, escolas, edifícios públicos, estações de trem, propriedades rurais, entre outros.

É certo que construções com funções similares às torres de água da atualidade existiram com formas e nomes variados na Antiguidade, durante todo o período Medieval e também no Renascimento e que o termo "torre de água" foi utilizado ao longo da história para identificar construções com funções distintas daquelas desempenhadas pelas torres de água atuais. No período medieval uma "torre de água" era um bastião nas muralhas das cidades ou dos castelos que garantia o acesso direto a uma fonte de água fresca como um rio, um lago ou um poço. Uma torre como esta existe até os dias de hoje na cidade de Chester, Inglaterra, junto ao rio Dee (fig. 1.1.1). ${ }^{1}$ Durante os séculos XVI e XVII as "estações hidráulicas", 2 estações de bombeamento cuja função era a de captar a água

${ }^{1}$ BARTON, Barry. Water Towers of Britain. Londres: Newcomen Society, 2003, p. 12.

${ }^{2}$ As "estações hidráulicas" serão descritas em detalhes na Parte 2 do presente trabalho. 
1.1.1

"Torre de Água" na cidade de Chester, Inglaterra.

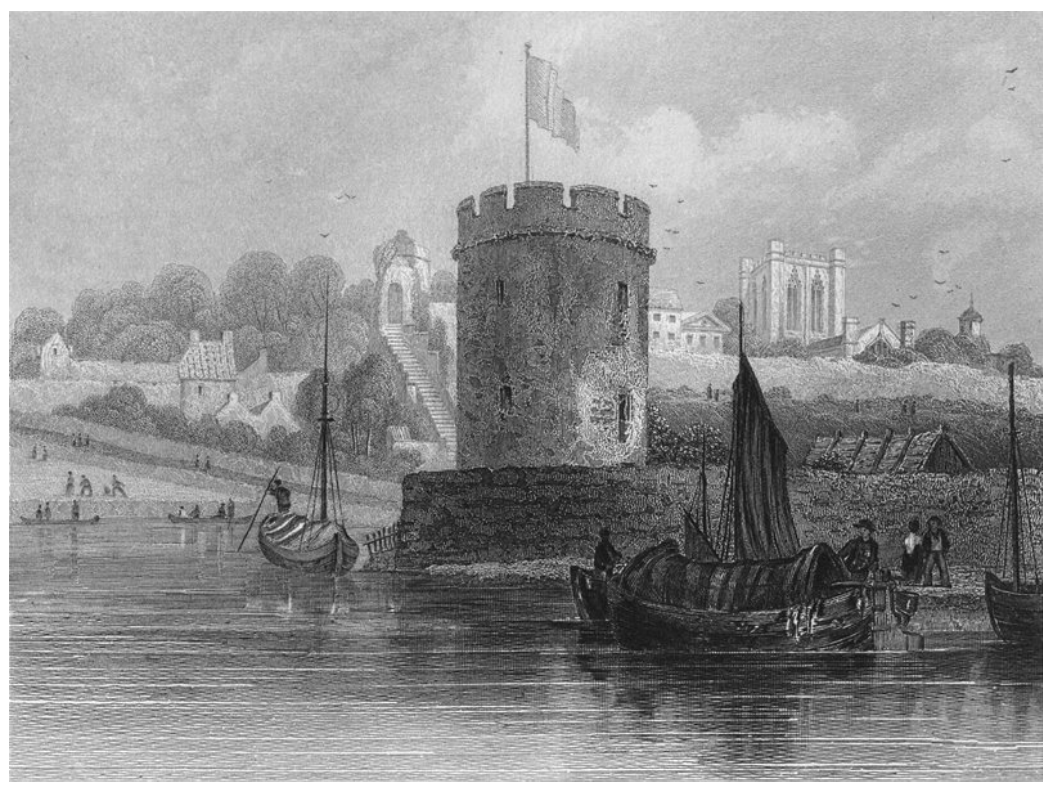

dos rios e córregos para fornecimento imediato às populações das cidades, eram abrigadas em construções semelhantes às torres dos castelos medievais, muitas vezes localizadas no interior das muralhas das cidades, uma medida necessária para proteger estes valiosos engenhos contra os cercos inimigos e contra uma possível destruição em tempo de guerra. ${ }^{3}$

Esta pesquisa, no entanto, não será concentrada nas origens mais remotas e na arqueologia da torre de água desde a Antiguidade. Nosso estudo detalhado das torres de água inicia-se com o advento da ferrovia e com a implantação dos modernos sistemas centralizados de abastecimento público de água, em meados do século XIX. Em ambos os sistemas, ferrovia e abastecimento de água, as torres de água foram introduzidas como um elemento fundamental para viabilizar o funcionamento e operação destas infraestruturas.

O momento exato em que o termo "torre de água" começou a designar um reservatório de água apoiado sobre uma estrutura que o eleva acima do nível do solo é, no entanto, incerto. As primeiras torres de água para abastecimento urbano foram introduzidas na Inglaterra no início da década de 1850. Uma das publicações mais antigas mencionando umas destas torres data

${ }^{3}$ WERTH, Jan. Ursachen und technische Voraussetzungen für die Entwicklung der Wasserhochbehälter. In: BECHER, Bernhard; BECHER, Hilla. Die Architektur der Förder und Wassertürme. München: Prestel-verlag, 1971. p. 331. 


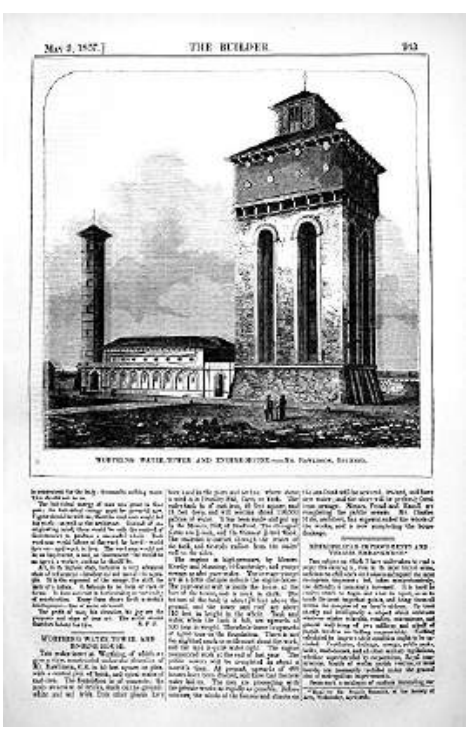

1.1.2

Página de revista The Builder com o projeto para a Torre de Água de Worthing, Inglaterra, 1857. de 1857, a revista The Builder (fig. 1.1.2), que publica na edição do mês de Maio o projeto para a "torre de água" de Worthing (Worthing Water-Tower and Engine-House). ${ }^{4}$ Praticamente na mesma época, a torre do Berliner Tor (1853-55), primeira torre de água construída na Alemanha conforme projeto do engenheiro inglês William Lindley, era designada como sendo um "tanque elevado de água" (wasserhochbehälter). Em 1859, também na Alemanha, nas pranchas do projeto para a torre de água de Altona lê-se "reservatório elevado" (hoch-reservoir). Na Alemanha o termo "torre de água" (wasserturm) parece ter sido adotado como padrão para designar nosso objeto de pesquisa a partir da década de 1890, como mostram as publicações do engenheiro alemão Otto Intze, um dos grandes nomes da história das torres de água. ${ }^{5}$

No início do século $X X$, quando as torres de água já haviam se tornado um elemento bastante comum do cenário urbano da Europa, o uso do termo "torre de água" ainda não era universal. Durante as primeiras décadas do século XX, empresas construtoras como a L. G. Mouchel \& Partners, uma das pioneiras na execução de estruturas de concreto armado, mantinha em seus registros projetos para torres de água arquivados sob os termos "torre de água", "tanque torre" e "reservatório elevado" para obras similares executadas no mesmo período. ${ }^{6}$

Atualmente o termo "torre de água" está disseminado em praticamente toda a Europa, sendo traduzido como wasserturm na Alemanha, water tower na Inglaterra, vesitorni na Finlândia, watertoren na Bélgica e Holanda, vandtårn na Dinamarca, vattentornet na Suécia, entre outros. Na Espanha e em Portugal adota-se o termo "depósito de água" enquanto que na França adota-se "château d'eau" (castelo de água), termo provavelmente derivado do nome latino "castellum aquae", que designava os

\footnotetext{
${ }^{4}$ Worthing Water-Tower and Engine-House. The Builder, London, v. 14, p. 243, 2 maio 1857.

${ }^{5}$ As torres de água de Worthing, do Berliner Tor, Altona e o papel de Otto Intze no desenvolvimento das torres de água serão discutidos em detalhe mais adiante.
}

${ }^{6}$ BARTON, 2003, op. cit., p. 13. 
reservatórios de final de linha dos aquedutos da Roma Antiga, responsáveis pela distribuição da água nas cidades e vilas romanas. No Dictionnaire Historique d'Architecture, escrito por Quatremère de Quincy em 1832, encontramos a seguinte definição para o termo château d'eau:

"É um edifício destinado a receber as águas que são trazidas pelos aquedutos, e dividi-las em diferentes canais, de onde são espalhadas e distribuídas pelos vários usos das cidades e jardins. Esses monumentos são, às vezes, de um tipo que não revela as águas que armazenam; então eles exigem uma decoração e um caráter arquitetônico que indiquem sua natureza e sua destinação. Na maioria das vezes eles são acompanhados por cachoeiras, cascatas e jatos de água." 7

Quatremère de Quincy cita algumas referências de château d'eau como, por exemplo, a fonte Acqua Giulia (33 a.C.), em Roma, um dos pontos de distribuição do aqueduto de mesmo nome; a Fontana di Trevi, projeto de Nicola Salvi (1762), construída no local de uma antiga fonte que marcava o ponto terminal do aqueduto Acqua Vergine (19 a.C.), um dos mais antigos de Roma; e o château d'eau do Palais-Royal ${ }^{8}$ um conjunto de reservatório apoiado sobre o solo e fonte de água construído em Paris no ano de 1710, com projeto de Robert de Cotte, destinado a fornecer água para a cidade e atuar como uma reserva de emergência para extinguir incêndios na Opéra du Palais-Royal. Com o advento dos modernos sistemas centralizados de abastecimento de água, o termo "château d'eau" passou a ser utilizado na França também para designar as novas torres de água que integravam estes sistemas.

\footnotetext{
7 "C'est un bâtiment destiné à recevoir les eaux qui sont apportées par des aqueducs, et à les diviser en différens canaux, d'où elles se répandent et se distribuent pour les divers usages des villes et des jardins. Ces monumens sont quelquefois d'un genre à ne point laisser apercevoir au dehors les eaux qu'ils renferment; alors ils exigent une décoration et un caractère d'architecture qui indiquent leur nature et leur destination. Le plus souvent ils sont accompgnés de cascades, embellis de nappes et de jets d'eau." (QUINCY, Quatremère de. Dictionnaire Historique d'Architecture. Paris: Librairie d'Adrien le Clere et Cie, 1832).

${ }^{8} \mathrm{O}$ château d'eau do Palais-Royal era alimentado com água captada no rio Sena pela "La Samaritaine", uma estação de bombeamento que será apresentada mais adiante.
} 
Os termos "reservatório elevado" e "tanque elevado" são sinônimos para designar a torre de água e vêm sendo amplamente utilizados desde meados do século XIX, especialmente na literatura técnica dedicada ao projeto de sistemas hidráulicos e ao projeto estrutural dos reservatórios e de suas torres. Alguns engenheiros calculistas, no entanto, parecem promover uma espécie de distinção entre os objetos "torre de água" e "reservatório elevado" (ou "tanque elevado") conforme o material de construção utilizado na estrutura. Assim, as "torres de água" seriam construídas em alvenaria ou em concreto armado, como considerado nos tratados de Gustav Adolf Wayss (1897), Fritz Emperger (1907 e 1923) e W. S. Gray (1933), enquanto que "reservatórios elevados" (ou "tanques elevados") seriam construídos em estruturas metálicas, como considerado no tratado de torres de água metálicas de J. N. Hazlehurst (1901 e 1907), talvez um dos primeiros do gênero, e nas pesquisas de E. Kottenmeier (1930). Esta tendência da distinção entre "torre de água" e "tanque elevado" com base na diferença do material de construção utilizado é bastante presente nos Estados Unidos da América, conforme estudo realizado por Dubie (1980). No Brasil o uso do termo "reservatório elevado" é bastante comum, sendo utilizado principalmente em textos técnicos sobre abastecimento de água e nas normas da Associação Brasileira de Normas Técnicas (ABNT).

A ausência do termo "torre de água" em dicionários de arquitetura escritos a partir do início do século XX é bastante intrigante.

No Dictionary of Architecture and Building (Dicionário de Arquitetura e Construção) de Russel Sturgis, publicado em 1905, o termo "torre de água" (water tower) é apresentado em conjunto com o verbete "torre" (tower) e a descrição dada pelo autor corresponde ao do standpipe, um tipo de reservatório vertical que armazena água em toda a sua altura e apresenta um funcionamento ligeiramente diferente da torre de água. As diferenças de funcionamento entre o standpipe e a torre de água serão discutidas mais adiante no presente trabalho. 


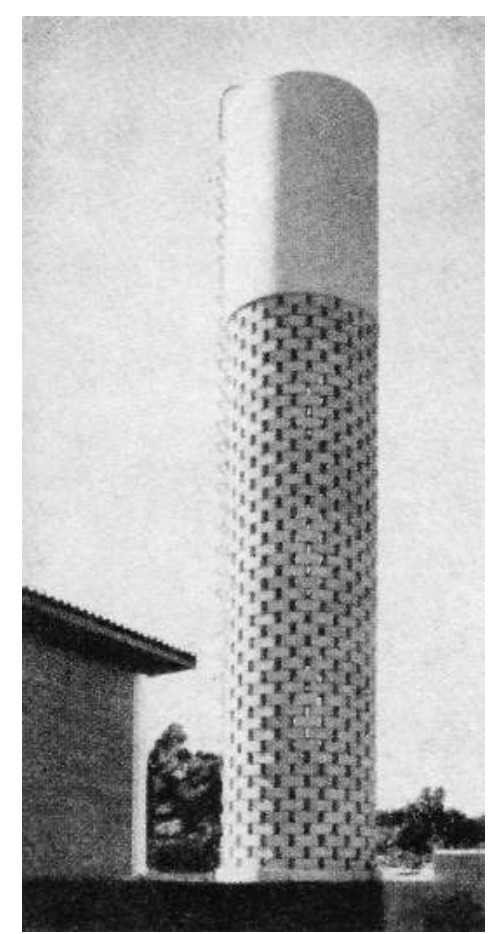

1.1.3

José Luís Fleury de Oliveira, "caixa d'água".
Nos dicionários de arquitetura de Saylor (1963), Pevsner, Fleming e Honour (1976) e Curl (1999), não consta o termo "torre de água" nem nenhum de seus sinônimos. Saylor incluiu em sua obra o termo "château d'eau", que ele define como sendo "a frente arquitetônica de um reservatório de água." 9

Wilfred Koch, em seu Dicionário dos Estilos Arquitetônicos (1985) anota, segundo o seu entendimento, as "tipologias fundamentais de torres": de igreja, com escadaria caracol, de defesa, de residência, de representação e campanária. ${ }^{10}$ Nenhuma menção às torres de água.

Ernest Burden, em seu Dicionário llustrado de Arquitetura (2006), segue o mesmo caminho de Koch (1985) e descreve vários tipos de torres: de cruzeiro, de vigia, de relógio, de sinos, de menagem, de resfriamento, de tiro, de empena, de porta, mas não faz qualquer menção as torres de água ou a qualquer um dos outros nomes pelo qual o objeto é conhecido.

No Dicionário da Arquitetura Brasileira, de Eduardo Corona e Carlos A. C. Lemos (1972), o termo "torre de água" é ausente e o termo mais próximo que pode ser utilizado para nomear nosso objeto de estudo é "caixa d'água":

"Designação genérica para todos os tipos de depósito de água que podem ser empregados nas construções. É confeccionada comumente de alvenaria impermeabilizada ou de concreto armado, sendo também encontrada pré-fabricada, em diversos tamanhos, de cimento-amianto, de concreto armado ou protendido, etc. ${ }^{\prime 11}$

No dicionário de Corona e Lemos, curiosamente, o termo "caixa d'água" é ilustrado com uma foto de uma torre de água (fig. 1.1.3) projetada pelo arquiteto José Luís Fleury de Oliveira. Ainda

\footnotetext{
9 "the architectural front of a water reservoir." (SAYLOR, Henry H.. Dictionary of Architecture. New York: John Wiley \& Sons, 1963).

${ }^{10} \mathrm{KOCH}$, Wilfred. Dicionário dos Estilos Arquitetônicos. São Paulo: Martins Fontes, 2004, p. 222.

${ }^{11}$ CORONA, Eduardo; LEMOS, Carlos A. C.. Dicionário da Arquitetura Brasileira. São Paulo: EDART, 1972, p. 94.
} 
no dicionário o termo "reservatório" é definido como "Depósito. O mesmo que caixa d'água.", e o termo "tôrre" define os elementos verticais utilizados nas construções dos castelos medievais e campanários de igrejas e, modernamente, nas estruturas metálicas para antenas de rádio e televisão. ${ }^{12}$

No entanto, é importante notarmos duas felizes exceções: os dicionários de Lima e Albernaz (1998) e o de Ching (2006).

O Dicionário Ilustrado de Arquitetura de Lima e Albernaz apresenta o termo "castelo-d'água", nome pelo qual a torre de água é conhecida em algumas partes do Brasil:

"Reservatório de água elevado construído sobre torre destinado a distribuir água para um edifício ou um grupamento de edifícios. Quando o reservatório de uma cidade ou localidade não está situado em um ponto elevado é sempre necessário que a água seja bombeada para um castelo-d'água. Deve ter altura suficiente para levar água com pressão até cada prédio que abastece. "13

O termo "castelo de água" também é apresentado no Dicionário Houaiss da Língua Portuguesa, como sendo um sinônimo para "arca-d'água", curioso termo datado de 1639 cuja definição segue abaixo:

"Reservatório de água construído em lugar elevado ou em torre e do qual partiam dutos secundários para alimentar os chafarizes de uma localidade; castelo de água; mãe-d'água."14

No seu Dicionário Visual de Arquitetura, Francis D. K. Ching define a torre de água como sendo:

\footnotetext{
12 Ibidem, p. 407 e 454.

13 LIMA, Cecília Modesto; ALBERNAZ, Maria Paula. Dicionário Ilustrado de Arquitetura. São Paulo: Pro Editores, 1998, v. 1, p. 134.

${ }^{14}$ HOUAISS, Antônio. Dicionário Houaiss da Língua

Portuguesa. São Paulo: Objetiva, 2009, p. 176.
} 
"Torre para cujo interior é bombeada água a uma altura suficiente para se manter uma pressão desejada para sua distribuição a consumidores ou para o combate e incêndios. "15

As definições de Lima e Albernaz (1998) e Ching (2006), no entanto, são incompletas. Ainda que a principal função das torres de água nos sistemas de abastecimento seja a de condicionar as pressões nas áreas mais elevadas, elas desempenham outras funções, conforme mencionado no início deste capítulo. No capítulo seguinte, após uma breve explicação sobre o funcionamento dos modernos sistemas de abastecimento de água, serão descritas as diversas funções que as torres de água desempenham nestes sistemas e serão apresentados os requisitos técnicos que norteiam a elaboração de projetos de torres de água e a sua implantação nos sistemas de abastecimento.

${ }^{15}$ CHING, Francis D. K.. Dicionário Visual de Arquitetura. São Paulo: Martins Fontes, 2003, p. 134. 


\subsection{Função e Funcionamento da Torre de Água}

Embora as torres de água tenham aplicações diferentes, o sistema de funcionamento dos vários tipos de torres de água é praticamente o mesmo. As torres para abastecimento público de água são geralmente as mais complexas, enquanto que as torres de água utilizadas em conjuntos residenciais ou industriais, que muitas vezes fazem parte de sistemas hidráulicos pequenos e simples, podem prescindir de alguns elementos. Nesta parte sobre o seu funcionamento, a torre de água que integra o sistema público de abastecimento de água é considerada como exemplo.

Os sistemas públicos de abastecimento de água têm o objetivo principal de fornecer a população uma água potável de boa qualidade para o seu consumo, em quantidade adequada e pressão suficiente. ${ }^{1}$ Obviamente não se cria a água potável do zero. Afinal, a água é um recurso natural e, como tal, limitado. Não se pode tornar potável a água proveniente de cursos de água que tornaram-se esgotos, pelo menos não de maneira economicamente viável. Até mesmo os aquíferos subterrâneos que até algum tempo atrás eram considerados intocados e livres de poluição, hoje sofrem com a contaminação por substâncias químicas. ${ }^{2}$ Para atingir seus objetivos a indústria da água utiliza numerosas e complexas etapas de produção em um sistema que combina algumas leis simples da hidráulica com as mais sofisticadas técnicas, envolvendo disciplinas diversas como química, biologia, mecânica, eletrônica, informática, engenharia e arquitetura.

Os principais elementos destes sistemas são uma fonte de água bruta, um sistema de captação e transporte da água, um sistema de tratamento para tornar esta água potável, um conjunto de estruturas para armazenar a água tratada e uma rede de tubulações para distribuir esta água para os consumidores.

\footnotetext{
1 TSUTIYA, Milton Tomoyuki. Abastecimento de Água. 3. ed. São Paulo: Departamento de Engenharia Hidráulica e Sanitária da Escola Politécnica da Universidade de São Paulo, 2006, p. 10.

2 VAN CRAENENBROECK, W.. Eenheid in Verscheidenheid: Watertorens in Belgie. Brussel: Navewa, 1991, p. 41.
} 
A fonte de água bruta, ou manancial, é um corpo de água superficial ou subterrâneo de onde é retirada a água para o abastecimento como, por exemplo, rios, lagos, represas ou aquíferos. Quer se trate de água doce dos cursos de água ou das águas subterrâneas, todas tem sempre a mesma origem: a precipitação atmosférica. Uma média anual de 13,4 trilhões de $\mathrm{m}^{3}$ de água cai em solo brasileiro; em ordem de grandeza temos 10,2 trilhões de $\mathrm{m}^{3}$ que evaporam, enquanto que os 3,2 trilhões de $\mathrm{m}^{3}$ restantes acabam nos cursos de água ou penetram no solo para alimentar os lençóis freáticos. ${ }^{3}$ Somadas as contribuições de água provenientes dos países vizinhos é gerada nos rios brasileiros uma vazão de cerca de 6,2 trilhões de $\mathrm{m}^{3}$ por ano. No ano de 2016 a vazão de retirada de água para abastecimento humano urbano, constituída por sistemas de captação e tratamento de água, foi de $488,3 \mathrm{~m} 3 / \mathrm{s}$. Assim, no período de um ano, temos um total de 15,4 bilhões de $\mathrm{m}^{3}$ de água captada nos diversos mananciais para uso da população das cidades brasileiras, o que corresponde a $23,3 \%$ de toda a água retirada no Brasil. ${ }^{4}$

Em situações topográficas favoráveis o manancial pode ser um curso de água localizado em uma área de montanhas, de onde a água pode ser captada e conduzida por gravidade até o sistema de tratamento para posteriormente ser distribuído para os consumidores, localizados em cotas mais baixas, sem a necessidade de recursos de bombeamento. ${ }^{5} \mathrm{~A}$ figura 1.2 .1 mostra um sistema simples de abastecimento de água operando inteiramente por

3 BRASIL. AGÊNCIA NACIONAL DAS ÁGUAS. Conjuntura dos Recursos Hídricos no Brasil 2017. Brasília: Ministério do Meio Ambiente, 2017, p. 6.

4 Do total de água captada nos mananciais para abastecimento humano urbano no Brasil cerca de 20\%, o equivalente a 3 bilhões de $\mathrm{m}^{3}$, é água de consumo, ou seja, é aquela água retirada dos mananciais que não retorna diretamente aos corpos hídricos. O restante, cerca de 12,4 bilhões de $\mathrm{m}^{3}$, retorna aos corpos hídricos na forma de esgoto, por exemplo. A quantidade de água efetivamente consumida nos sistemas de abastecimento urbano alcança $8,8 \%$ do total de água consumida no Brasil, sendo superada pela irrigação $(67,2 \%)$, abastecimento animal $(11,1 \%)$ e indústria $(9,5 \%)$. Ver BRASIL, 2017, op. cit., p. 53-54.

${ }^{5}$ Algumas cidades litorâneas do Estado de São Paulo, como Guarujá e Peruíbe, que têm sua captação de água em mananciais da serra, utilizam este tipo de sistema de abastecimento de água. Ver TSUTIYA, 2006, op. cit., p. 23. 
1.2 .1

Sistema de abastecimento de água operando inteiramente por gravidade.

1.2 .2

Sistema de abastecimento de água com captação em um curso de água e bombeamento da água para as unidades seguintes e distribuição final.

1.2 .3

Sistema de abastecimento de água com captação em curso de água, recalque para a etapa de tratamento e posterior distribuição da água potável por gravidade. gravidade. Em sítios menos favoráveis o manancial pode ser um rio ou um aquífero localizado em nível, ou abaixo, do centro de consumo e, neste caso, será necessário bombear a água bruta até o sistema de tratamento e de lá até o consumidor final. A figura 1.2.2 mostra um sistema simples de abastecimento de água com captação em um curso de água e bombeamento da água para as unidades seguintes e distribuição final. Nestes sistemas a água captada é distribuída aos consumidores por meio de modernos equipamentos de bombeamento conhecidos como "boosters" que operam em conjunto com os chamados tanques hidropneuméticos, viabilizando a distribuição da água para os consumidores em quantidade adequada e em uma pressão suficiente.
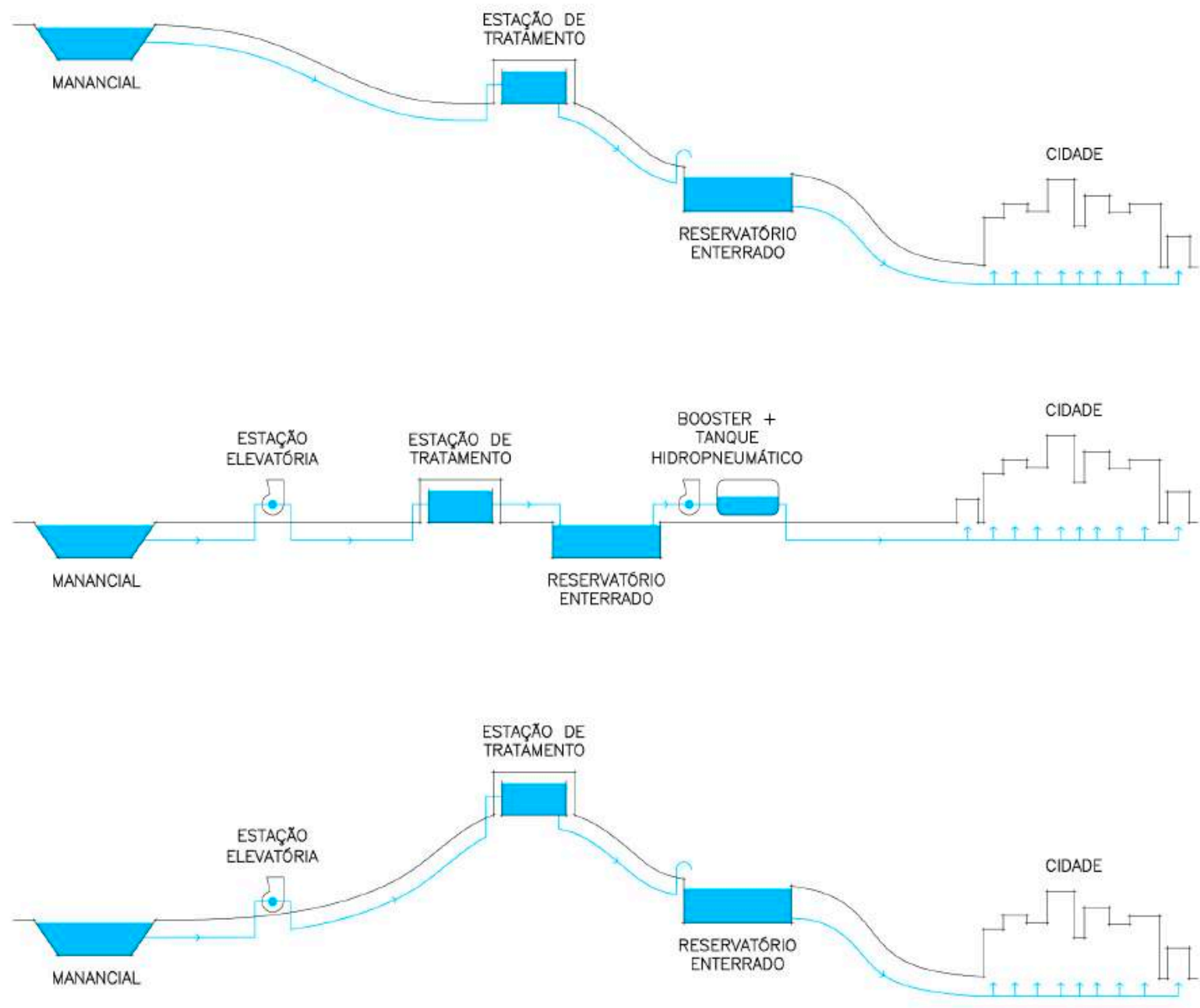
Porém, os sistemas de abastecimento mistos, que operam com a água fluindo em parte por gravidade e em parte por meio de recalque ${ }^{6}$ para as demais unidades do sistema são os mais comuns. Nestes sistemas o manancial pode ser um rio, uma represa ou um aquífero, onde a água captada em cotas mais baixas é recalcada até o sistema de tratamento para ser distribuída por gravidade após o tratamento. ${ }^{7}$ Em alguns casos a distribuição da água tratada pode ser feita também em um sistema misto, com a água fluindo tanto por gravidade quanto por meio de bombeamento. A figura 1.2.3 mostra um sistema simples de abastecimento de água com captação em curso de água, recalque para a etapa de tratamento e posterior distribuição da água potável por gravidade. Em alguns sistemas a água potável pode ainda ter que ser recalcada no trecho compreendido entre as estações de tratamento, localizadas em cotas mais baixas, e os reservatórios de distribuição em posição mais elevada.

Em todas as situações é a característica da topografia do sítio e a localização do manancial em relação ao centro de consumo que acaba por determinar a configuração e as características do sistema de abastecimento que será adotado para fornecer água tratada para a população.

O sistema de captação compreende o conjunto de infraestruturas e equipamentos montadas junto ao manancial para

\footnotetext{
${ }^{6}$ Recalque é o procedimento de transportar um fluído de uma cota de nível inferior para uma cota de nível superior, onde o escoamento do fluído é viabilizado por meio de uma bomba hidráulica.

7 Como exemplo deste tipo de captação e abastecimento podemos citar o Sistema Cantareira, principal produtor de água para a Região Metropolitana de São Paulo. A água bruta captada no manancial formado pelas represas JaguariJacareí, Cachoeira e Atibainha, na região de Bragança Paulista, é recalcada pela Estação Elevatória de Santa Inês, transpondo o obstáculo natural da Serra da Cantareira, até chegar a ETA do Guaraú. Após receber tratamento no Guaraú, a água flui por gravidade para os principais reservatórios de distribuição da cidade: Consolação, Santana, Mooca, Lapa, Pinheiros, Vila Maria, Penha, entre outros. Ver MOREIRA, Renata Maria Pinto. Distribuição de água na Região Metropolitana de São Paulo: tecnologias da universalização e produção do espaço. 2008. 210 f. Dissertação (Mestrado) - Curso de Programa de Pósgraduação da Faculdade de Arquitetura e Urbanismo, Universidade de São Paulo, São Paulo, 2008, p. 117.
} 
a retirada da água destinada ao sistema de abastecimento. Esse sistema opera muitas vezes em conjunto com estações elevatórias, um sistema de bombas hidráulicas que viabilizam o recalque da água para a unidade seguinte. As estações elevatórias são posicionadas no sistema conforme a necessidade de recalque da água, seja bruta ou potável. Em um dado sistema podemos ter estações elevatórias de água bruta posicionadas entre o manancial e a unidade de tratamento, assim como estações elevatórias de água potável posicionadas entre o tratamento e a rede de distribuição, conforme apresentado nas figuras 1.2.3, 1.2.6 e 1.2.7.

O transporte da água entre as unidades de captação, as estações elevatórias e as estações de tratamento, são realizados pelas adutoras, canalizações destinadas a conduzir a água entre as diversas unidades que compõem o sistema de abastecimento de água e que precedem a rede de distribuição. São condutos de trabalham por gravidade ou por recalque. As adutoras podem ser subdivididas em dois grupos, adutoras de água bruta e adutoras de água tratada. O primeiro grupo conduz a água dos pontos de captação até as estações de tratamento, enquanto que o último grupo conduz a água do ponto de tratamento até as estruturas de armazenamento e distribuição.

As estações de tratamento de água (ETAs) podem ser consideradas como verdadeiras "fábricas" para produzir água potável. O processo convencional de tratamento da água é divido em uma série de complexos processos físico-químicos, onde existe um rígido controle de dosagem dos produtos químicos utilizados e um acompanhamento dos padrões de qualidade em cada uma das fases do tratamento. ${ }^{8}$ Este sistema de tratamento, similar a outros processos industriais, opera mais eficientemente com a água fluindo

\footnotetext{
${ }^{8}$ Não cabe aqui detalhar o sistema de funcionamento e operação de uma ETA, pois não é o alvo da presente pesquisa. Os sistemas utilizados são complexos e variam em função da localização do equipamento e, principalmente, em função da qualidade da água bruta captada. A título de exemplo, podemos citar o sistema utilizado pela SABESP em suas ETAs, cujo processo de tratamento da água bruta até a água potável é desenvolvido em nove etapas: précloração, pré-alcalinização, coagulação, floculação, decantação, filtração, pósalcalinização, desinfecção e fluoretação.
} 
pelo sistema com uma vazão constante e é projetado para que água tratada seja fornecida para os consumidores com vazão e pressão constantes. O mesmo vale para os sistemas de bombeamento, projetados para garantir vazões e pressões constantes na rede de abastecimento. E neste ponto temos um dos problemas inerentes a todos os sistemas públicos de abastecimento de água. ${ }^{9}$ É impossível fornecer água para os consumidores em uma vazão constante sem causar problemas de desabastecimento nos horários críticos.

Quem dita o ritmo de consumo de água de uma cidade são os seus habitantes, no desempenho de suas atividades diárias. Os consumidores passam uma parte do dia dormindo e praticamente todos fazem isto ao mesmo tempo. Depois acordam ao mesmo tempo, fazem suas refeições ao mesmo tempo, vão para o trabalho ao mesmo tempo e, no final do dia, chegam em suas casas ao mesmo tempo. O resultado disto é uma grande flutuação no consumo de água ao longo do dia. Os picos no consumo de água ocorrem nas manhãs e no início da noite, aproximando-se de um consumo médio no meio do dia e caindo a praticamente zero em alguns horários da noite. O consumo de água pela população entre 8 e 12 horas é $75 \%$ mais alto do que o consumo médio horário e cai pela metade durante a noite entre 22 e 6 horas. ${ }^{10}$

Para atender as flutuações no consumo de água as tubulações das redes de distribuição são superdimensionadas para suprir as vazões de água necessárias nos horários de pico. $\bigcirc$ superdimensionamento das instalações de tratamento de água ou de bombeamento, por outro lado, não só significa um erro técnico e econômico como também seria impossível na prática. A única maneira de balancear as flutuações de consumo de água com a vazão constante das estações de tratamento e bombeamento de água é com a interposição de um reservatório de água entre o sistema de produção e transporte, em um extremo, e a rede de

\footnotetext{
9 BARTON, Barry. Water Towers of Britain. Londres:

Newcomen Society, 2003, p. 1.

10 VAN CRAENENBROECK, 1991, op. cit., p. 55.
} 


\subsection{4}

Gráfico da variação do volume de água no reservatório em função da curva de consumo e adução contínua. distribuição para a população na outra ponta. ${ }^{11} \bigcirc$ reservatório, recebendo uma vazão contínua de entrada de água, igual a demanda média de água de sua área de influência, é projetado para atingir a sua capacidade máxima de armazenagem durante a noite, disponibilizando água para os consumidores ao longo do dia de maneira a suprir os repentinos picos de consumo de água, garantindo vazões de distribuição superiores à demanda média de consumo. A figura 1.2.4 mostra um gráfico demonstrando como o volume de água armazenado em um típico reservatório de distribuição varia ao longo do dia, sempre atrelado às flutuações no consumo de água. Este é o papel principal dos reservatórios de distribuição nos sistemas públicos de abastecimento de água, uma unidade com a função de regularização de vazões.

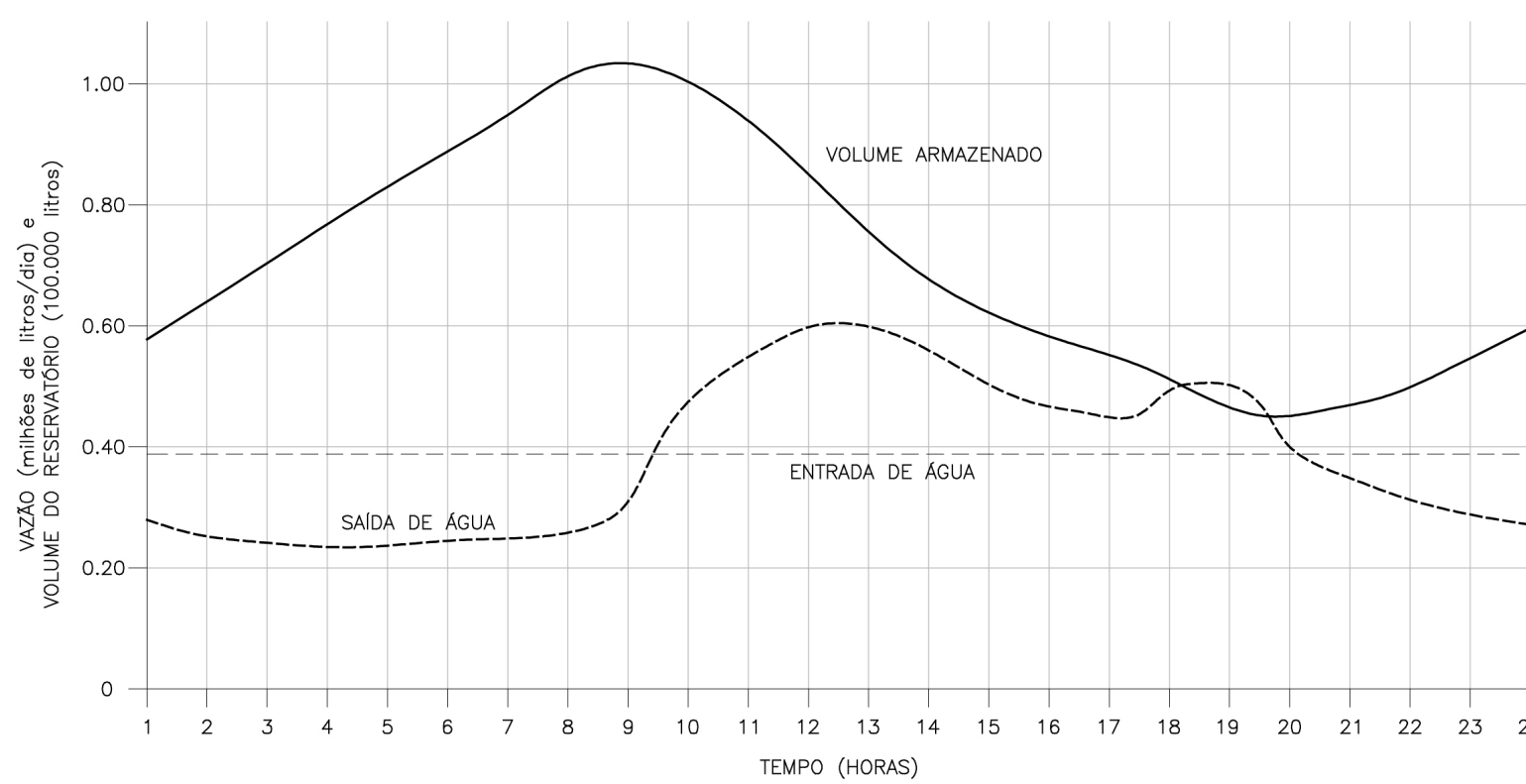

O volume de água armazenada nos reservatórios de distribuição deve ser determinado considerando-se três fatores: volume para atender às flutuações de consumo de água, volume para combate a incêndios e volume para emergências. ${ }^{12}$

O volume de água necessário para atender às flutuações diárias de consumo é chamado de volume útil. Este volume pode ser determinado calculando-se a diferença entre o fluxo constante de entrada de água no reservatório e o fluxo variável da saída de

11 Ibidem; e também BARTON, 2003, op. cit., p.3.

12 TSUTIYA, 2006, op. cit., p. 351. 
1.2 .5

Gráfico de Curva de Demanda. água ao longo do dia, utilizando-se dados conhecidos de vazões de consumo de hora em hora para o dia de maior consumo de água. A somatória das diferenças entre as vazões de entrada e saída, transformadas em volumes, determina a capacidade mínima de armazenamento para o reservatório de distribuição. ${ }^{13}$ A figura 1.2.5 mostra um Gráfico de Curva de Demanda onde foi plotada a curva de variação diária do consumo de água, de hora em hora, sobreposta a linha reta do fluxo constante de entrada de água no reservatório. $\bigcirc$ volume de água consumido nos horários em que a vazão de consumo supera a vazão de entrada corresponde ao volume mínimo que o reservatório deve possuir. Nos casos em que não se dispõem de dados suficientes para o traçado da curva de variação diária do consumo de água podem ser utilizadas as recomendações das normas técnicas para a determinação do volume de armazenagem. No caso do Brasil a norma NB 594/1977 recomenda, nos casos dos reservatórios que recebem um fluxo contínuo de entrada de água, que o volume mínimo de armazenagem, necessário para compensar a variação diária de consumo, deve ser igual ou maior que 1/3 do volume total de água distribuído no dia de maior consumo. ${ }^{14}$

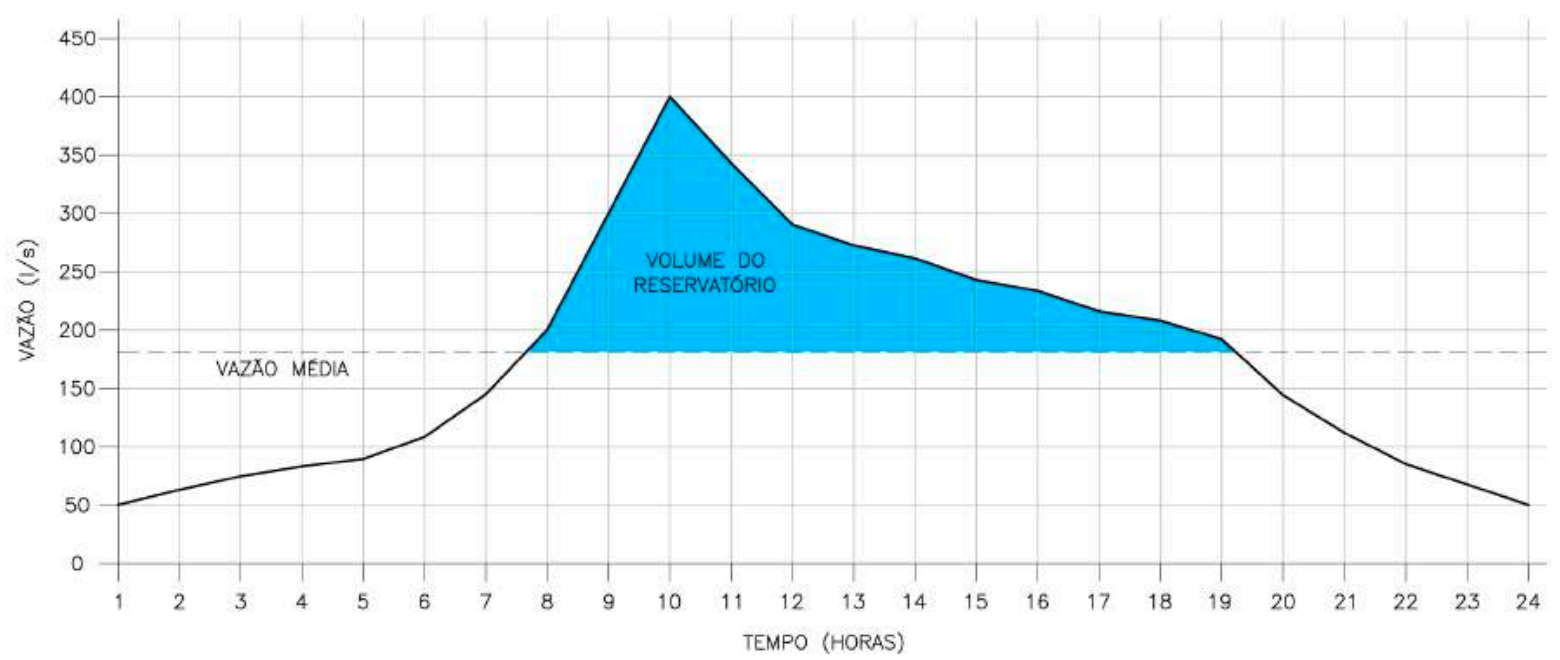

\footnotetext{
13 Para uma explicação detalhada acerca do procedimento de cálculo para determinação do volume útil de reservatórios de distribuição ver: TSUTIYA, 2006, op. cit., p. 352-363.

${ }^{14}$ ASSOCIAÇÃO BRASILEIRA DE NORMAS TÉCNICAS. NB 594: Elaboração de projeto hidráulico de redes de distribuição para abastecimento público. Rio de Janeiro: ABNT, 1977.
} 
O volume adicional de água para combate a incêndios deve ser previsto quando a capacidade dos sistemas de abastecimento não é suficiente para esta finalidade, o que ocorre em sistemas de pequeno e médio portes. Nos sistemas de grande porte normalmente não há necessidade de se prever reserva de incêndio, uma vez que as demandas para combate ao fogo seriam muito baixas face ao porte do sistema, representando uma pequena parte das necessidades máximas diárias. No Brasil, onde incêndios são eventos de frequência relativamente baixa, não se destina um volume de reserva para combate a incêndios. Em outros países a reserva adicional de água para combate a incêndios deve ser considerada nos projetos de reservatórios. Na Espanha, por exemplo, devem ser previstos $120 \mathrm{~m}^{3}$ de água em reservatórios que abasteçam populações inferiores a 5.000 habitantes e reservas de $230 \mathrm{~m}^{3}$ em reservatórios que atendam populações maiores. ${ }^{15}$ A AWWA (American Water Works Association) recomenda que os reservatórios tenham as seguintes vazões, que devem ser mantidas por um período mínimo de tempo, para garantir suprimento de água para combate ao fogo: $>157 \mathrm{l} / \mathrm{s}$ para 2 horas de fogo; 189 $220 \mathrm{l} / \mathrm{s}$ para 3 horas de fogo e $251-755$ para 4 horas de fogo. ${ }^{16}$

Por último deve ser considerado no volume total dos reservatórios de distribuição um volume para emergências. São consideradas emergências nos sistema de abastecimento de água qualquer tipo de interrupção no funcionamento normal do fornecimento de água, como consequência do rompimento de uma adutora, da paralisação de captação ou da estação de tratamento, falta de energia elétrica, entre outros. Em casos de sistemas de abastecimento que operam por meio de bombeamento em alguma de suas etapas, sem fontes de energia elétrica auxiliar, existe a necessidade de se prever um volume significativo para emergências. Alguns países adotam uma reserva de emergência de $25 \%$ do consumo diário previsto. ${ }^{17}$

\footnotetext{
15 TSUTIYA, 2006, op. cit., p. 364.

16 Ibidem.

${ }^{17}$ Ibid., p. 365.
} 
Um fornecimento adequado de água para o consumidor pressupõe, por uma lado, uma pressão suficiente para obter um fluxo razoável de água nas torneiras, mas, por outro lado, uma pressão não muito alta, evitando que as tubulações sejam danificadas por surtos de sobrepressão. A localização dos reservatórios na rede de abastecimento pode influir nas condições de pressão da rede, garantindo pressão ao sistema e reduzindo as variações de pressão. Os sistemas de abastecimento que fornecem a água aos consumidores por gravidade, com os seus reservatórios de distribuição interligados por meio das redes de distribuição aos pontos de consumo de água das edificações (torneiras, chuveiros, etc.), funcionam como um sistema de vasos comunicantes. ${ }^{18}$ Quanto maior for a diferença entre o nível de uma dada edificação e o nível de água no reservatório, maior será a pressão no ponto de consumo.

De acordo com o princípio dos vasos comunicantes, em uma situação ideal de consumo zero, a pressão em um dado ponto da rede hidráulica é determinada pela diferença de altura entre este ponto e o nível de água no reservatório. Esta pressão é chamada de pressão estática.

Já nas situações de pleno funcionamento da rede de distribuição, a movimentação da água nas tubulações provoca uma perda de carga, de modo que a pressão medida na rede é menor do que em uma situação de consumo zero. Neste caso, de maneira simplificada, podemos dizer que a pressão da rede hidráulica em funcionamento é determinada pela pressão estática do sistema

\footnotetext{
18 Vasos comunicantes é o nome dado a um conjunto de recipientes de formas variadas postos em comunicação entre si pelos seus fundos. Quando um líquido homogêneo é vertido em um conjunto de vasos comunicantes e deixado em repouso observa-se que, independente da forma ou do volume dos recipientes, a altura da lâmina de água atinge o mesmo nível em todos e para todos os pontos do líquido que estão na mesma altura, obtém-se também a mesma pressão. Este fenômeno é conhecido como "princípio dos vasos comunicantes" e ocorre devido a gravidade e pressão constantes em cada um dos recipientes conforme o princípio físico da Lei de Stevin que estabelece que a pressão absoluta num ponto de um líquido homogêneo e incompressível, de densidade $\mathrm{P}$ e à profundidade $\mathrm{H}$, é igual à pressão atmosférica mais a pressão efetiva, e não depende da forma do recipiente.
} 
subtraída das perdas de carga resultantes do escoamento da água pela tubulação. Esta pressão é chamada de pressão dinâmica.

A perda de carga nas tubulações é considerável nos horários de pico de consumo devido ao grande fluxo de água na rede e esta perda de carga aumenta progressivamente à medida que as zonas de consumo vão se distanciando do reservatório de distribuição, o que implica em uma queda de pressão nas zonas mais elevadas da rede ou nas zonas mais afastadas dos reservatórios. Assim, em que altura os reservatórios de distribuição devem ser construídos para garantir uma pressão adequada para os consumidores?

A zona de consumo localizada no ponto mais alto da rede de distribuição ou a zona de consumo mais distante do reservatório é que determina o nível de água do reservatório, levando em consideração a pressão mínima necessária para funcionamento adequado do sistema neste ponto mais desfavorável em conjunto com as inerentes perdas de cargas nas tubulações. ${ }^{19}$ As normas técnicas brasileiras determinam que a pressão estática máxima nas tubulações distribuidoras deve ser de 50 m.c.a., enquanto que e a pressão dinâmica mínima oferecida deva ser de 10 m.c.a.. ${ }^{20}$

Se na topografia do sítio ocorre um elevação natural cuja altura é igual ou superior ao nível de água calculado para o reservatório, este pode ser construído apoiado sobre o solo. Se este não for o caso, como ocorre geralmente em áreas de planície, o reservatório deve ser construído sobre uma estrutura que eleve seu nível em relação ao solo: a torre de água. A figura 1.2.6 mostra o arranjo de um sistema simples de abastecimento de água em área de planície com utilização de uma torre de água para distribuição de água por gravidade. Neste sistema, obrigatoriamente, a água tratada deve ser bombeada para o reservatório localizado no alto da torre para posteriormente ser distribuída por gravidade.

\footnotetext{
19 VAN CRAENENBROECK, 1991, op. cit., p. 56.

20 ASSOCIAÇÃO BRASILEIRA DE NORMAS TÉCNICAS. NBR 12218: Projeto de Rede de Distribuição de Água para Abastecimento Público. Rio de Janeiro: ABNT, 1994.
} 

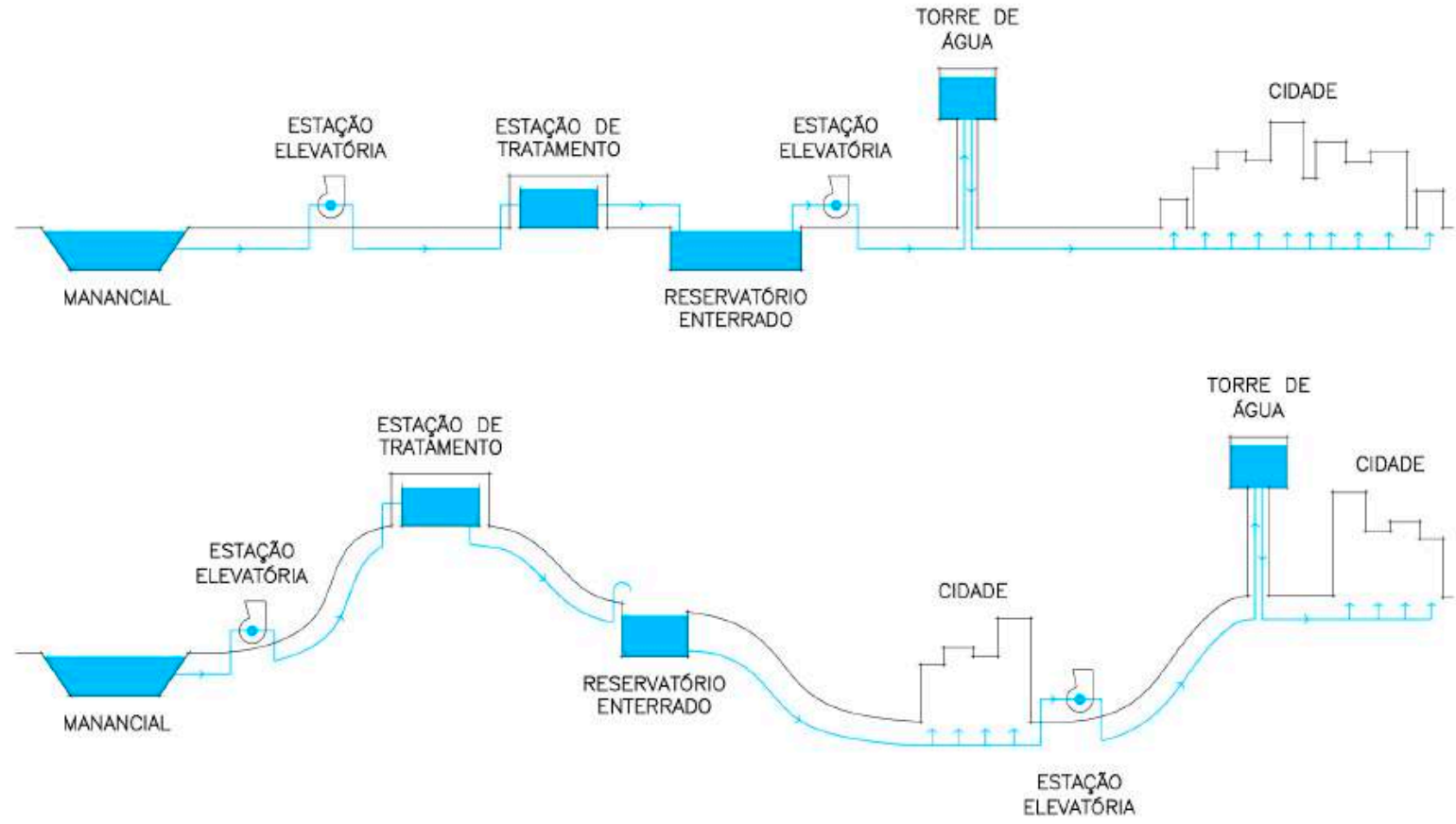

1.2 .6

Sistema de abastecimento de água em área de planície com torre de água para distribuição de água por gravidade.

\subsection{7}

Sistema de abastecimento de água com torre de água para distribuição de água por gravidade para atendimento do bairro alto de uma cidade.
Uma segunda e mais comum razão para se utilizar as torres de água como reservatórios de distribuição reside no fato de que o crescimento das cidades se espalhou para o alto dos morros ou, ainda, já existam ocupações no topo dos morros quando da implantação de um sistema de abastecimento de água. Em qualquer um destes casos um reservatório de distribuição apoiado sobre o solo não teria altura suficiente para fornecer água com pressão adequada para os consumidores e a construção de uma torre de água se faz, portanto, necessária. A figura 1.2.7 mostra um arranjo de um sistema simples de abastecimento de água com utilização de uma torre de água para distribuição de água por gravidade para atendimento do bairro alto de uma cidade. ${ }^{21}$ Assim como no caso anterior, a torre de água faz parte de um sistema de abastecimento alimentado por bomba.

\footnotetext{
${ }^{21}$ Exemplo típico é a torre de água do Reservatório da Avenida, que garante o abastecimento do espigão da Av. Paulista (cota 817,00), na cidade de São Paulo. A ETA do Guaraú, com saída de água na cota 830,00, alimenta o Reservatório da Consolação por gravidade, com N.A. em 790,70. Um conjunto de bombas no reservatório da Consolação recalca a água até o Reservatório da Avenida, um reservatório apoiado em solo com capacidade de armazenamento de $6.500 \mathrm{~m}^{3}$ e N.A. em 817,75, abastecendo por gravidade o território entre este e o Reservatório da Consolação. Para viabilizar o abastecimento de água aos consumidores da Av. Paulista foi construída uma torre de água com capacidade de 500 m³ $^{3}$ e N.A. em 837,75, garantindo a vazão e a pressão necessária na rede de distribuição. Ver, Oswaldo B.. Dados sobre o abastecimento de água de São Paulo. Boletim R.A.E., São Paulo, v. 4, n. 9, p. 32-48, mar. 1940; e também MOREIRA, 2008
} 
As funções dos reservatórios de distribuição e das torres de água são, portanto, absolutamente idênticas e em resumo são: ${ }^{22}$

- Regularizar a vazão

- Segurança no abastecimento

- Reserva de água para incêndio

- Regularizar pressões

Os reservatórios de distribuição têm, em geral, um elevado custo de implantação e o custo/volume armazenado para a construção de uma torre de água é muito maior do que o custo para a execução de um reservatório de distribuição apoiado sobre o solo. Estudos mostram que os custos para construção de um torre de água podem ser até 4 vezes maiores do que os custos para reservatórios apoiados com a mesma capacidade de armazenagem..$^{23}$ Assim a torre de água precisa ser projetada com um maior cuidado. No texto que segue todos os componentes necessários para o adequado funcionamento, operação e manutenção das torres de água, desde os seus elementos fundamentais, como reservatório e estrutura de suporte, são apresentados.

22 TSUTIYA, 2006, op. cit., p. 337.

${ }^{23}$ WERTH, Jan. Ursachen und technische Voraussetzungen für die Entwicklung der Wasserhochbehälter. In: BECHER, Bernhard; BECHER, Hilla. Die Architektur der Förder und Wassertürme. München: Prestel-verlag, 1971. p. 354. 


\subsubsection{Reservatório}

O elemento mais importante da torre de água é o seu reservatório. Para a garantia de uma pressão constante na rede de distribuição, as dimensões e proporções do reservatório e a altura do reservatório em relação a rede de tubos são dados definidores para os projetos das torres de água.

A pressão da água na torneira do consumidor depende da taxa com que ele e o restante da população retiram a água para consumo simultaneamente, do comprimento e do diâmetro das tubulações da rede e, principalmente, da diferença de altura entre o ponto de consumo e o nível de água na torre. É a diferença de altura entre o nível de água no interior do reservatório e o ponto de consumo que cria a pressão que permite que a água seja conduzida pela rede de distribuição. O nível de água no interior do reservatório varia conforme este vai se enchendo ou esvaziando e é importante que a diferença entre o nível de água mais alto e o nível mais baixo da água no interior do reservatório não seja muito grande, mantendo as flutuações de pressão dentro dos limites de operação estabelecidos para o sistema de abastecimento. Uma diferença de nível de água de 8,00 metros é geralmente adotada como um máximo no interior do reservatório. ${ }^{24}$

É bastante comum a construção de torres de água com dois ou mais reservatórios posicionados em alturas diferentes, que podem ser utilizados tanto para abastecer redes de distribuição distintas quanto para atender zonas de abastecimento com necessidades de pressão diferentes.

Além da altura da água no reservatório o volume que este deverá armazenar é informação fundamental para o projeto de torres de água. O reservatório deve armazenar água suficiente para compensar as diferenças entre a entrada de água potável fornecida pelas adutoras e a saída da água distribuída aos consumidores. Em cidades onde o consumo de água é alto devido a grande densidade

${ }^{24}$ VEEN, Henk van Der. Watertorens in Nederland. Rotterdam: Uitgeverij 010, 1989, p. 30. 
populacional e o território é praticamente plano, inviabilizando a construções de reservatórios de distribuição apoiados sobre o solo em pontos elevados do sítio, torres com grandes reservatórios, com capacidades que podem chegar até a $18.000 \mathrm{~m}^{3}$ já foram construídas para viabilizar o abastecimento de água. Em cidades com relevo favorável, que permite a construção de reservatórios de distribuição sobre o solo em cotas elevadas, são construídas torres de menor capacidade, com volumes variando entre 500 e 1.000 $\mathrm{m}^{3}$, que atendem apenas as zonas mais altas do sítio. ${ }^{25} \mathrm{Em}$ ambos os casos o volume do reservatório da torre será determinado pelo tamanho da área que deve abastecer, isto é, sua zona de pressão, e a densidade populacional desta área.

Devido ao elevado custo de construção das torres de água opta-se muitas vezes pela construção de um reservatório apoiado sobre o solo ou enterrado em conjunto com a torre de água, permitindo a divisão do volume de água que precisa ser armazenado. Esta prática é comum no Brasil, onde recomenda-se adotar para o reservatório da torre de água um volume que varia entre $10 \%$ e $20 \%$ do volume total de água previsto para o dia de maior consumo da zona de pressão atendida. ${ }^{26} \mathrm{O}$ restante da água fica armazenado no reservatório de solo, sendo recalcado para a torre conforme necessário.

Os reservatórios das torres de água podem ser construídos em diversos materiais. Atualmente os materiais de construção mais utilizados são o concreto armado (comum ou protendido) e o aço. Outros materiais como a madeira e a alvenaria também podem ser utilizados, assim como construções mistas que combinam o concreto armado com aço ou o concreto armado com alvenaria, por exemplo. A escolha do material de construção do reservatório deve ser feita após a realização de um estudo técnico e econômico, levando em consideração a disponibilidade do material e da mão

\footnotetext{
${ }^{25}$ Como exemplo podemos citar a cidade de São Paulo. Seu relevo favoreceu a construção de grandes reservatórios de água apoiados sobre o solo, que distribuem água por gravidade, e torres de água são utilizadas pontualmente para garantir o abastecimento da zonas mais desfavoráveis.

26 TSUTIYA, 2006, op. cit., p. 365.
} 
de obra na região, a agressividade da água a armazenar e a do ar atmosférico. ${ }^{27}$

A elevada resistência material, a alta resistência a corrosão e o baixo índice de fissuração fazem do concreto protendido o material de preferencia para a construção das torres de água contemporâneas. Seja em concreto armado comum ou em concreto protendido, as paredes e o fundo dos reservatórios de concreto devem ser completamente estanques para possibilitar o armazenamento da água. Esta estanqueidade é obtida por meio da aplicação de um revestimento interno impermeável de argamassa de cimento polimérico. $O$ concreto protendido leva grande vantagem no quesito estanqueidade, uma vez que as tensões de compressão introduzidas no concreto pelo sistema de protensão minimizam ou até mesmo eliminam a fissuras geradas pelos esforços de tração atuantes nas paredes e fundos dos reservatórios.

A elevada resistência material, o baixo peso estrutural total, a facilidade de conformação e a possibilidade de soldagem fazem do aço um material bastante adequado para a construção de reservatórios de torres de água. Mas a fragilidade do aço para corrosão requer precauções especiais. Tintas à base de resina de epóxi cobrem as superfícies internas e externas do reservatório protegendo as chapas de aço contra a corrosão. Além disso, para os reservatórios de maior capacidade, uma proteção catódica galvânica ${ }^{28}$ pode ser utilizada. Eletrodos de cobre que são conectados eletricamente ao reservatório ficam mergulhados na água armazenada. Como resultado o reservatório recebe uma pequena carga elétrica negativa, diminuindo a formação de óxido de ferro.

\footnotetext{
27 Ibid., p. 350.

${ }^{28}$ A proteção catódica galvânica, também chamada de proteção por ânodos de sacrifício, é feita por meio da ligação da estrutura metálica do reservatório com um metal mais eletronegativo (ânodo galvânico) do que o material da estrutura. Assim, a perda de elétrons da estrutura para o meio (o que causa a corrosão) é compensada pela ligação da estrutura metálica ao ânodo de sacrifício, normalmente um eletrodo de cobre ou magnésio. $O$ direcionamento da corrente elétrica preserva o reservatório metálico e a corrosão ocorre no ânodo. A norma técnica NTS 231/2014 da SABESP determina a necessidade de proteção catódica para reservatórios de aço com capacidade igual ou superior a $1.000 \mathrm{~m}^{3}$.
} 
Os reservatórios das torres de água podem se apresentar sob os formatos mais variados: cilindros, esferas, prismas, troncos de cone, etc.. Existem mais de 20 tipologias de reservatórios identificadas. Algumas tipologias de reservatórios, devido ao seu sucesso no aspecto construtivo, serviram de regra para se estabelecer modelos que passaram a ser produzidos em escala industrial, equipando diversas torres de água espalhadas pelo mundo. Exemplos destes reservatórios são os do tipo Intze e os desenvolvidos pela empresa CB\&l, como veremos mais adiante. Mas temos também o caso de reservatórios com formas únicas, singulares, que não se estabeleceram como um modelo a ser copiado como, por exemplo, na torre de água de Valence, 044 França (1963-71), projeto do arquiteto André Gomis e do escultor Philolaos Tloupas.

A grande diversidade de tipologias de reservatórios de água é fruto do desenvolvimento tecnológico dos materiais de construção (ferro e aço no século XIX e o concreto armado no início do século $X X)$ e da busca, no campo da engenharia estrutural, por um "formato ideal" de reservatório, formato este que pudesse garantir o menor consumo de material de construção por $\mathrm{m}^{3}$ de água armazenado.

A maioria dos reservatórios para torres de água, porém, se apresenta na forma de superfícies de revolução ${ }^{29}$ formadas por paredes relativamente finas. Estas superfícies são calculadas usando a Teoria da Membrana, que diz que todas as forças internas exercidas pela pressão da água e pelo próprio peso são apenas esforços de tração ou esforços de compressão atuando no sentido dos "meridianos" e "paralelos" das superfícies curvas. Onde duas superfícies de encontram, são exercidos grandes esforços

29 A superfície de revolução é definida pela rotação de uma curva plana, chamada de meridiano, em torno de um eixo de revolução situado no mesmo plano do meridiano. Os paralelos da superfície são os círculos obtidos seccionando-se a superfície por planos perpendiculares ao eixo de revolução. Cilindros, cones, cúpulas elípticas, hiperboloides de revolução e toróides são exemplos de superfícies de revolução. (KELKAR, Vasant S.; SEWELL, Robert T.. Fundamentals of the Analysis \& Design of Shell Structures. Englewood Cliffs: Prentice-Hall, 1987, p. 47) 
horizontais, que são absorvidos por anéis de pressão, que trabalham sob tração ou sob compressão, de acordo com o caso. ${ }^{30} \mathrm{~A}$ grande vantagem dos reservatórios na forma de superfícies de revolução reside na economia de material de construção, uma vez que reservatórios com plantas circulares consomem menos material/ $\mathrm{m}^{3}$ de água armazenada do que reservatórios com plantas quadras ou retangulares, por exemplo. Isto deve-se ao fato de que nos reservatórios com planta circular existe um equilíbrio de tensões resultantes da pressão da água nas paredes do reservatório e isto se reflete em uma estrutura mais econômica.

A figura 1.2.8 apresenta um quadro com as principais tipologias de reservatórios utilizados em torres de água. O quadro foi elaborado com base em pesquisas anteriores desenvolvidas por Werth (1971) e Merkl (1985), acrescido de novas tipologias e materiais de construção identificados no desenvolvimento do presente trabalho. Os detalhes sobre cada uma das tipologias históricas de reservatórios de torres de água será apresentado em detalhe na Parte 2 do presente trabalho.

Em grandes reservatórios de distribuição de água construídos sobre o solo ou em construções enterradas é comum que o volume armazenado seja dividido em duas câmaras, com entradas e saídas de água independentes, com o objetivo de garantir a distribuição ininterrupta de água quando o reservatório passa por operações de manutenção ou limpeza. Nas torres de água, porém, a divisão do volume armazenado em dois compartimentos separados é incomum, geralmente os reservatórios elevados possuem câmara única. ${ }^{31}$ Nos poucos casos em que ocorre a divisão do reservatório da torre de água em duas câmaras há quase sempre a utilização de reservatórios concêntricos, em que o reservatório interno é separado do reservatório externo por uma parede circular.

Em situações especiais os reservatórios de torres de água são divididos em duas ou mais câmaras por outros motivos:

\footnotetext{
30 VAN CRAENENBROECK, 1991, op. cit., p. 62.

31 TSUTIYA, 2006, op. cit., p. 375.
} 
1.2 .8

Quadro de Tipologias de Reservatórios atendimento de redes de distribuição diferentes, uma câmara para cada rede, ou quando é necessário o atendimento a redes de distribuição diferentes com necessidades de pressão diferentes, onde duas ou mais câmaras são construídas em alturas diferentes para fornecer água com pressões diferentes. ${ }^{32}$

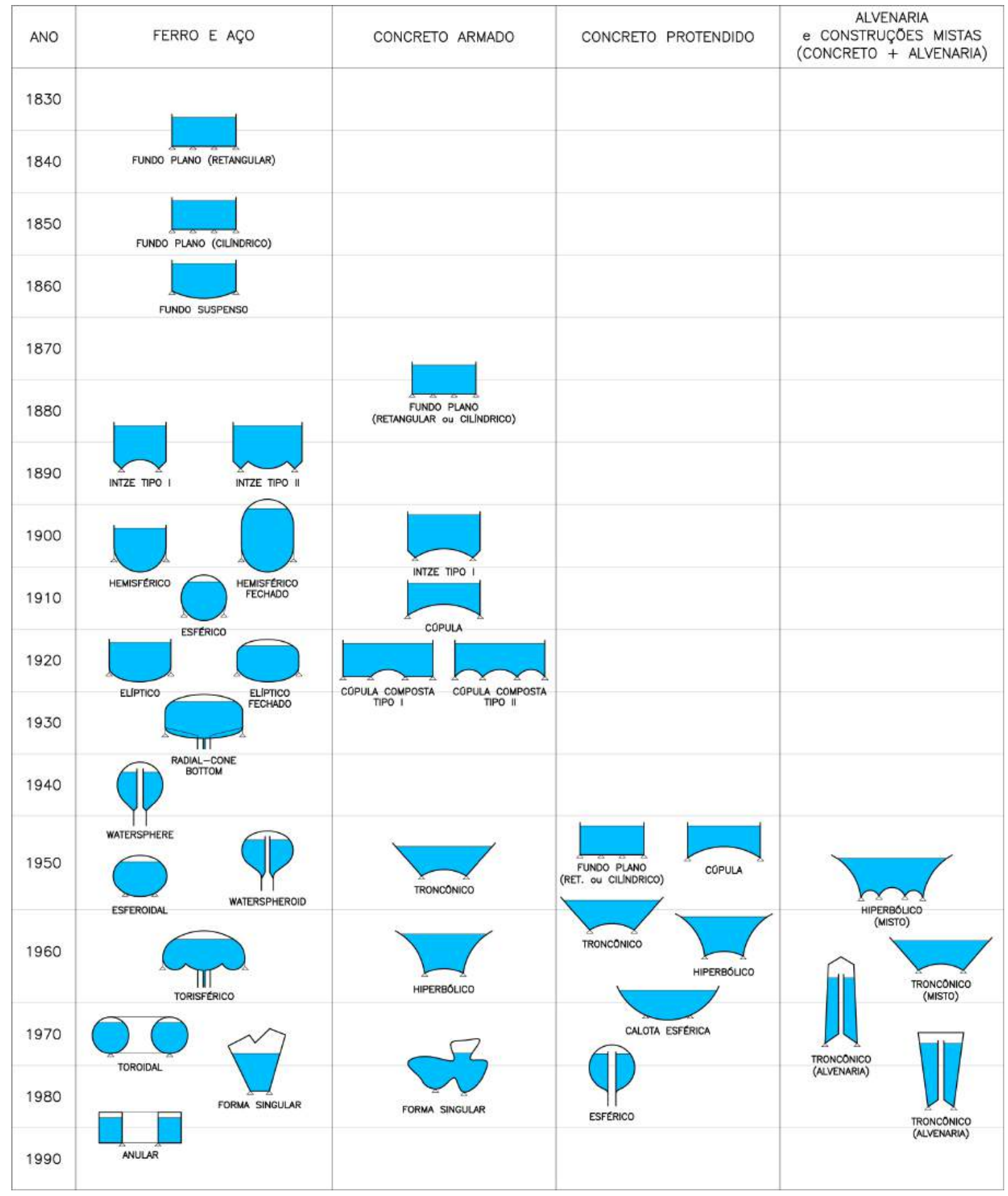

32 VEEN, 1989, op. cit., p. 30. 


\subsubsection{Estrutura de Suporte}

Estruturalmente a torre de água é um tanque apoiado sobre um suporte. A estrutura de suporte do reservatório da torre de água não só recebe o carregamento vertical da água armazenada, mas também a força lateral do vento que, por sua vez, é transferida para a fundação.

Para a avaliação da estabilidade das torres de água, considera-se a situação do reservatório vazio, submetido a uma maior carga de vento, como sendo a situação estrutural mais desfavorável, porque sob estas condições a resultante de esforços horizontais atuantes promove maiores deformações e deslocamentos no eixo vertical da estrutura. O peso do reservatório cheio de água é um grande aliado na estabilidade horizontal das torres de água, uma vez que uma estrutura apoiando um reservatório cheio deforma-se muito menos na horizontal do que a mesma torre com o reservatório vazio quando submetida aos mesmos esforços de vento. ${ }^{33}$

A tipologia do reservatório de água utilizado na torre de água é um fator decisivo no dimensionamento da estrutura de suporte. Isto deve-se à maneira como cada tipo de reservatório transfere a carga da água para a estrutura. Algumas tipologias de reservatórios foram desenvolvidas com o objetivo de transmitir apenas carregamentos verticais para a estrutura de suporte, 0 que torna o dimensionamento destas estruturas mais simples e econômicas. Outras tipologias, no entanto, além de transferir os carregamentos verticais, geram esforços horizontais na estrutura de suporte, que devem ser levados em conta no dimensionamento estrutural. Os detalhes sobre cada uma das tipologias históricas de reservatórios de torres de água será apresentado em detalhe na Parte 2 do presente trabalho.

${ }^{33}$ WERTH, 1971, op. cit., p. 363. 

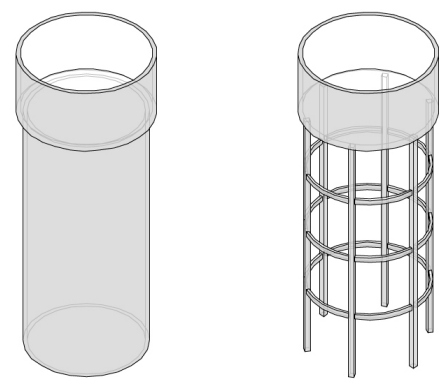

1.2 .9

Sistemas estruturais para torres de água.
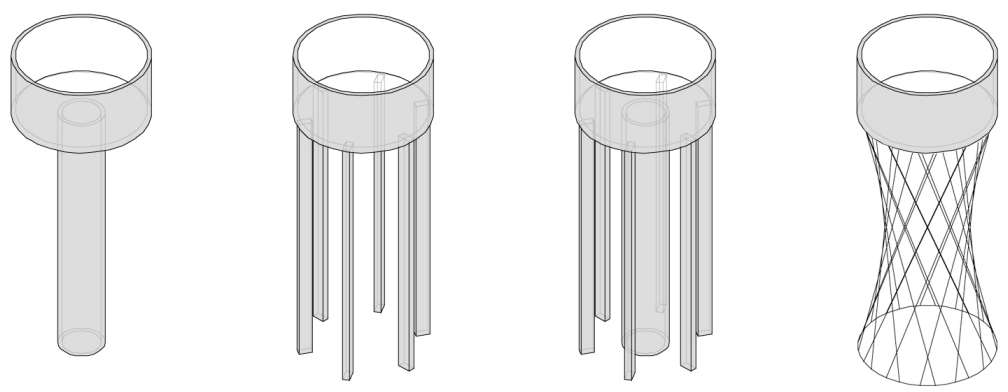

As configurações que o sistema estrutural pode assumir são variadas. Os sistemas estruturais mais comumente utilizados na construção de torres de água são:

a. paredes portantes

b. esqueleto estrutural

c. fustes centrais

d. colunas independentes

e. estruturas combinadas

f. malhas estruturais

A figura 1.2.9 mostra possibilidades da utilização das várias alternativas de sistemas estruturais para apoio de um reservatório de água com formato cilíndrico. Conforme apontado anteriormente, a tipologia do reservatório tem grande influência no dimensionamento da estrutura e, portanto, nem todos os sistemas estruturais são adequados para o suporte de todas as tipologias de reservatórios. O mesmo é válido para o material de construção utilizado na estrutura, alguns materiais são mais adequados para a execução de determinados sistemas estruturais do que outros. Atualmente os materiais de construção mais utilizados são o concreto armado (comum ou protendido) e o aço. Materiais alternativos como a madeira e a alvenaria também podem ser utilizados, assim como construções mistas que combinam o aço com o concreto armado ou a alvenaria com o concreto armado, por exemplo. 
O concreto armado (comum ou protendido) e a alvenaria, por exemplo, são materiais muito mais adequados para a execução de sistemas estruturais como o de paredes portantes. $O$ sistema de esqueleto estrutural pode ser executado com facilidade tanto em materiais como o concreto armado quanto com elementos metálicos de aço. As malhas estruturais são facilmente executadas com perfis metálicos de aço, mas não existe impeditivo para que sejam realizadas também em concreto armado. ${ }^{34}$

${ }^{34}$ Exemplos de torres de água com estrutura de suporte em malhas estruturais de concreto armado são o projeto para a torre do Hipódromo de Zarzuela, na Espanha (Eduardo Torroja, 1935) e a torre de Cockfosters, na Inglaterra (Edmund C. Percey, 1968). 


\subsubsection{Arranjo do Sistema Hidráulico}

A função da torre de água requer um conjunto de tubulações conectado tanto na rede de distribuição de água para os consumidores quanto nas adutoras de água potável do sistema público de abastecimento que alimentam o reservatório. Esta conexão é feita por um sistema hidráulico cujo arranjo, posição e quantidade de tubulações estão diretamente ligados à maneira de operação da torre de água e à sua localização nas redes de abastecimento. Os principais elementos deste sistema são: um tubo para a entrada de água no reservatório (alimentação), um tubo para a saída de água do reservatório (consumo) e um tubo extravasor, para impedir que o reservatório transborde.

\section{Tubulação de Entrada e Saída de Água}

A configuração das tubulações de entrada e de saída de água nas torres de água é determinada exclusivamente pela sua posição na rede de abastecimento, podendo ser feita de duas maneiras distintas.

Num primeiro caso temos dois tubos independentes no reservatório, um tubo para a entrada de água (alimentação) e outro tubo para a saída da água (consumo). O tubo de entrada (item 3, da fig. 1.2.10a), atravessa o reservatório em altura até o nível superior deste último, descarregando a água na forma de uma jato acima da superfície da água. O tubo de saída (item 4, da fig. 1.2.10a), posicionado próximo ao fundo do reservatório, distribui a água armazenada para os consumidores. Neste caso o volume de água armazenado flui completamente por meio do reservatório. ${ }^{35}$ Este é o arranjo hidráulico típico das torres de água de montante ${ }^{36}$ nas redes de abastecimento público de água (fig. 1.2.11a). Uma válvula de fechamento, acionada por uma bóia, operando eletricamente ou hidraulicamente, interrompe a entrada

35 VAN CRAENENBROECK, 1991, op. cit., p. 57.

36 O "reservatório de montante", também conhecido como "reservatório de cabeça", é aquele localizado antes da rede de distribuição, pelo qual passa toda a água destinada ao consumo. Este reservatório possui duas tubulações independentes, uma para a entrada da água e outra para a saída. 

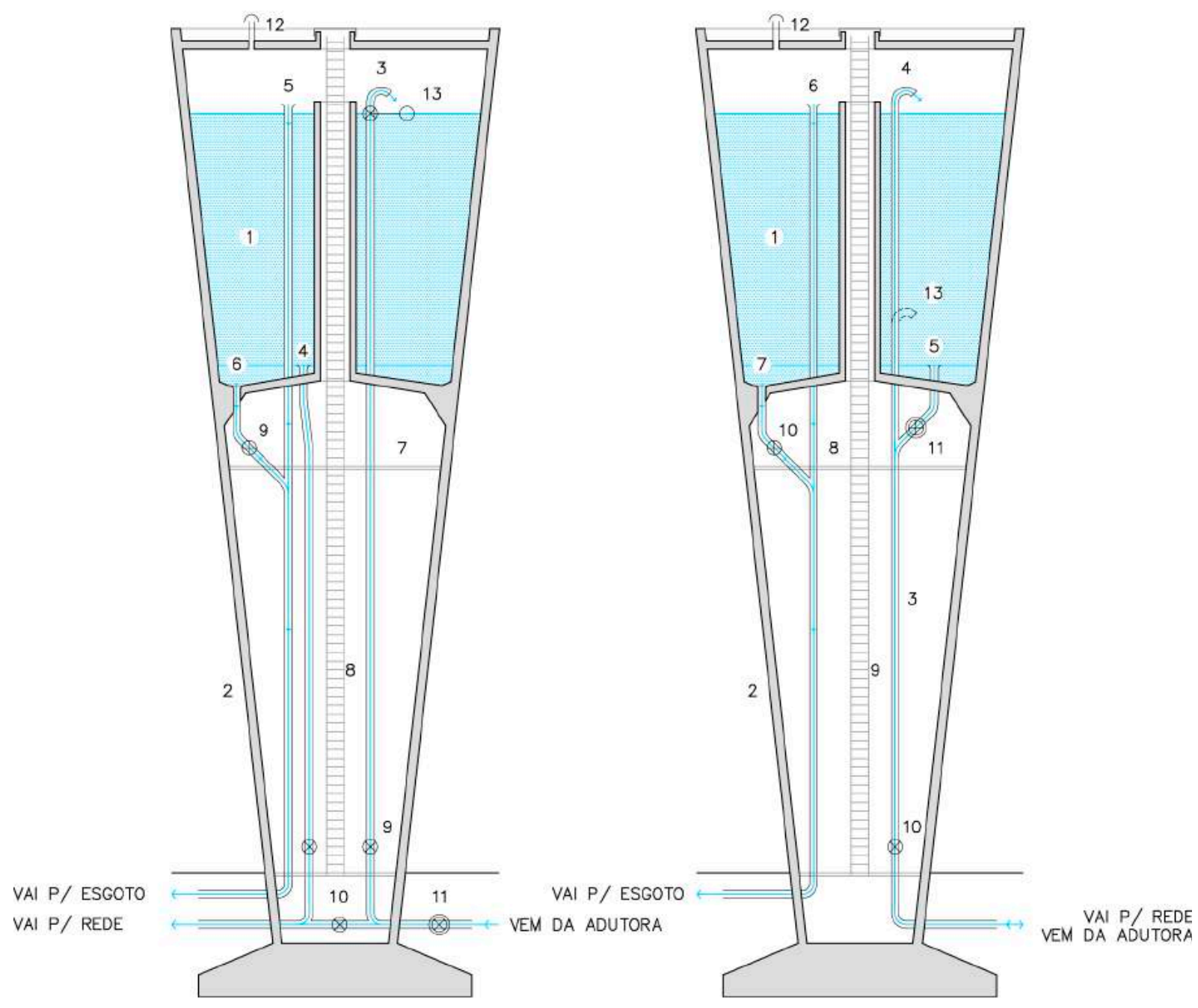

1. RESERVATORIO

2. ESTRUTURA DE SUPORTE

3. ENTRADA DE ÁGUA

4. SAIDA DE AGUA

5. EXTRAVASOR

6. DESCARGA DE FUNDO

7. BARRILETE

8. ESCADA INTERNA

9. VALVULA
10. BYPASS

11. VALVULA ANTI-REFLUXO

12. VENTILAÇAOO

13. VÁLVULA + BOIA

1. RESERVATORIO

2. ESTRUTURA DE SUPORTE 3. TUBULAÇÃO DE ENTRADA O SAIDA DE AGUA 4. RAMO DE ENTRADA 5. RAMO DE SAIDA
6. EXTRAVASOR 7. DESCARGA DE FUNDO 8. BARRILETE 9. ESCADA INTERNA 10. VÁLVULA 11. VÁLVULA ANTI-REFLUXO 13. ENTRADA AFOGADA (OPCIONAL)
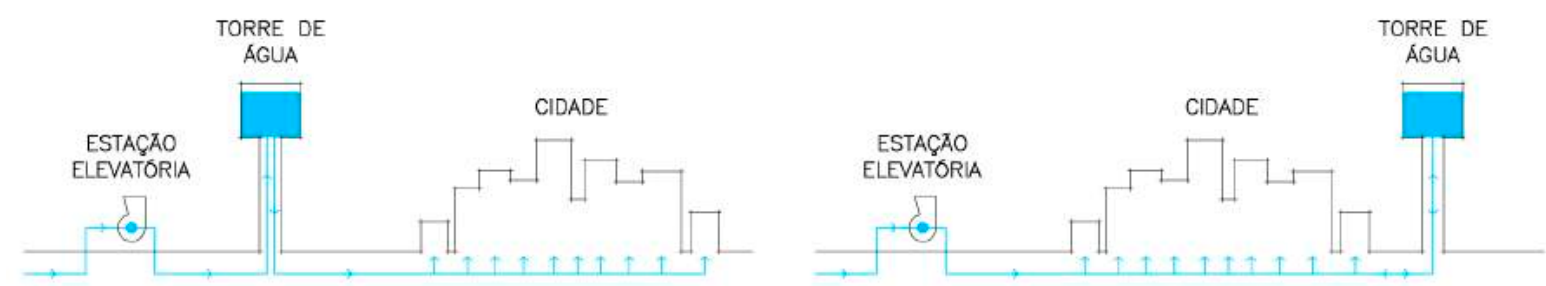
1.2.10a

Elementos da torre de água de montante.

1.2.10b

Elementos da torre de água de jusante.

1.2.11a

Torre de água de montante.

1.2.11b

Torre de água de jusante. de água no reservatório quando o nível de transbordo é atingido. Uma alternativa para a entrada de água no topo do reservatório é a utilização de uma entrada de água no fundo do tanque, chamada de "entrada afogada". A utilização da entrada afogada oferece melhor aproveitamento da linha piezométrica, ${ }^{37}{ }^{38}$ uma vez que diminui a altura de recalque, mas requer a utilização de uma válvula anti-refluxo, com o objetivo de impedir o retorno da água na tubulação de abastecimento. ${ }^{39}$ A tubulação de saída deve se elevar acima do ponto mais baixo do fundo do reservatório com o objetivo de impedir que impurezas depositadas no fundo do tanque entrem na rede hidráulica, contaminando a água, e ainda deve ter sua boca protegida por uma grade ou ralo gradeado fabricado em ferro fundido ou bronze, com área aberta igual ao dobro da secção do tubo de saída. ${ }^{40}$ Tanto os tubos de entrada quanto os tubos de saída devem ser dotados de um sistema de fechamento por válvula localizado sob o reservatório. Próximo ao nível do solo deve ser previsto uma ligação em "bypass", dotada de válvula de fechamento, conectando os tubos de entrada e de saída de água. Esta ligação têm o objetivo de garantir o fornecimento de água para os consumidores diretamente pela tubulação de entrada (alimentação), ligada diretamente as adutoras nas torres de água para abastecimento público, caso o reservatório tenha que ser esvaziado para operações de limpeza ou de manutenção.

No segundo caso temos um único tubo que chega até o reservatório da torre de água (item 3, da fig. 1.2.10b), servindo tanto para a entrada de água (alimentação) quanto para a saída

\footnotetext{
${ }^{37}$ REIS, Eduardo Gomes dos. Normas para projeto e construção de reservatórios de distribuição. Boletim R.A.E.: Boletim da Repartição de Águas e Esgotos, São Paulo, v. 13, n. 23, p. 35-41, jun. 1951, p. 36.

${ }^{38} \mathrm{~A}$ linha piezométrica é uma linha imaginária que representa a carga estática (elevação de energia) de um liquido ideal fluindo em um duto ou canal aberto. Se o líquido estiver fluindo em um tubo sob pressão, a linha de nivelamento da linha piezométrica corresponde a altura em que a água subiria no interior de um pequeno tubo vertical conectado ao tubo sob pressão.

39 ASSOCIAÇÃO BRASILEIRA DE NORMAS TÉCNICAS. NBR 12217: Projeto de Reservatório de Distribuição de Água para Abastecimento Público. Rio de Janeiro: ABNT, 1994, p. 3.

40 REIS, 1951, op. cit., p. 36.
} 
de água (consumo). Neste caso a tubulação de alimentação passa inicialmente por toda a rede de abastecimento, distribuindo água aos consumidores, para finalmente desaguar no reservatório. ${ }^{41}$ Este é o arranjo hidráulico típico das torres de água de jusante ${ }^{42}$ nas redes de abastecimento público que, durante as horas de baixo consumo, são alimentadas com a quantidade de água excedente, armazenando-a (fig. 1.2.11b). Nos horários de pico de consumo, por outro lado, a pressão da rede cai devido ao aumento no consumo de água e a água armazenada no reservatório é enviada para a rede. Este único tubo conectado ao reservatório também pode ser chamado de tubo de distribuição de suprimento. No entanto este tubo único é ramificado em dois sob o reservatório. Um dos ramos prolonga-se até o topo do reservatório para realizar a alimentação de água pelo alto. Alternativamente pode ser utilizada um entrada afogada (item 13, da fig. 1.2.10b), que oferece um melhor aproveitamento da linha piezométrica do sistema de recalque de água. O segundo ramo conecta-se ao fundo do reservatório para realizar a saída da água e é equipado com uma válvula anti-refluxo que impede que o reservatório seja alimentado pelo fundo. ${ }^{43} \mathrm{Com}$ este procedimento garante-se a circulação de água necessária no interior do reservatório.

Em qualquer um dos casos as posições das aberturas de entrada e saída de água dentro do reservatório devem ser escolhidas em função da forma do reservatório, de modo que a água seja constantemente renovada, evitando a formação de áreas de acumulação de água estagnada, onde organismos possam se desenvolver.

\footnotetext{
${ }^{41}$ VAN CRAENENBROECK, 1991, op. cit., p. 57.

42 O "reservatório de jusante", também conhecido como "reservatório de sobras" ou "reservatório final", é aquele localizado depois da rede de distribuição, que recebe e armazena água somente nos períodos em que a vazão de alimentação supera a vazão de consumo e, inversamente, apenas fornece água quando a vazão de consumo supera a vazão de alimentação do sistema. Este reservatório possui uma tubulação única que serve tanto para a entrada quanto para a saída de água, com o sentido de fluxo sendo ditado conforme as demandas de consumo.
}

${ }^{43}$ VAN CRAENENBROECK, 1991, op. cit., p. 59. 


\section{Tubo Extravasor}

O tubo extravasor (item 5, fig. 1.2.10a, e item 6, fig. 1.2.10b) tem uma função dupla. Em primeiro lugar, drenar o excesso de água quando o reservatório atinge seu nível máximo de armazenagem, impedindo o transbordamento da água por cima das paredes do tanque, caso a válvula de fechamento automático da tubulação de entrada não funcione. Além disso, a drenagem controlada por meio do tubo extravasor têm a função de remover periodicamente a camada de poeira que se deposita ao longo do tempo na superfície da água. Ao permitir que o reservatório extravase a poeira flutuando na superfície da água é eliminada.

A altura mínima entre o nível máximo atingido pela água em extravasão e o fundo da cobertura do reservatório ou o topo de suas paredes deve ser de $30 \mathrm{~cm} .{ }^{44} \mathrm{O}$ tubo extravasor também deve ser dimensionado para a vazão máxima de água capaz de alimentar o reservatório em condições normais ou excepcionais de serviço, ${ }^{45}$ ou seja, o diâmetro do tubo extravasor deve ser maior ou igual ao diâmetro do tubo de entrada.

Normalmente o tubo extravasor está conectado, sob o fundo do reservatório, com a tubulação de descarga de fundo, em um único tubo vertical. A água de extravasão coletada deve descarregar, sempre que possível, em conjunto com o sistema de águas pluviais. ${ }^{46}$ Construtivamente 0 extravasor pode ser constituído por um simples tubo vertical, aberto no topo e com um bocal bem largo, que atravessa o reservatório em altura até atingir o nível de transbordo. Pode ainda ser utilizado um sistema de calhas, posicionadas nas próprias paredes do reservatórios, devidamente calculadas para tal e executadas em concreto ou metal (de acordo com o material de fabricação do reservatório),

\footnotetext{
${ }^{44}$ ABNT, NBR 12217, 1994, op. cit., p. 3.

${ }^{45} \mathrm{lbid}$., p. 3.

${ }^{46}$ COMPANHIA DE SANEAMENTO BÁSICO DO ESTADO DE SÃO PAULO. NTS 023: Reservatórios - Elaboração de Projetos. São Paulo: SABESP, 1999, p. 2.
} 
com o seu fundo ligado ao tubo extravasor. ${ }^{47} \mathrm{O}$ tubo extravasor deve estar protegido de maneira a evitar a contaminação da água armazenada no reservatório, seja por refluxo de água contaminada ou pela entrada de animais. ${ }^{48}$

\section{Descarga de Fundo}

A descarga de fundo (item 6, fig. 1.2.10a, e item 7, fig. 1.2.10b) fica localizada no ponto mais baixo do reservatório e têm a função de esvaziar completamente o reservatório para realizar operações de manutenção ou limpeza, eliminando sedimentos e contaminantes acumulados no fundo do tanque. Normalmente o tubo de descarga está conectado, sob o fundo do reservatório, com o tubo extravasor. Uma válvula que pode ser operada a partir do piso do barrilete controla o esvaziamento do reservatório, liberando a entrada da água no tubo extravasor.

Para os reservatórios de distribuição de água para abastecimento público devem ser utilizados tubos de descarga de fundo com um diâmetro mínimo de $15 \mathrm{~cm} .{ }^{49}$ Para os reservatórios com fundos planos é recomendado ainda que o fundo destes seja executado com uma declividade mínima de 0,5\% em direção à descarga de fundo, permitindo o fácil escoamento da água de lavagem e evitando a formação de poças de água que não possam ser drenadas. ${ }^{50}$

Durante as operações de limpeza e manutenção, período em que o reservatório estará vazio, o suprimento de água para os consumidores é realizado diretamente pela tubulação de entrada do reservatório, abrindo-se a válvula de "bypass" existente entre esta última tubulação e o tubo de saída do reservatório que alimenta a rede consumidora.

\footnotetext{
47 REIS, 1951, op. cit., p. 36.

48 SABESP, NTS 023, 1999, op. cit., p. 1.

${ }^{49}$ ABNT, NBR 12217, 1994, op. cit., p. 3.

50 REIS, 1951, op. cit., p. 36.
} 


\subsubsection{Cobertura e Revestimento do Reservatório}

Para garantir a qualidade da água potável armazenada no interior do reservatório, este deve ser protegido do contato com a poluição do ar externo e da luz natural excessiva. Nas torres de água para abastecimento público, que utilizam reservatórios com forma aberta, o reservatório sempre deve ser coberto. A cobertura evita a poluição da água potável por insetos, pássaros e poeira, além de bloquear a entrada da luz solar direta.

A cobertura deve ser projetada de maneira a propiciar o escoamento natural das águas pluviais e impedir a entrada destas águas, e também de animais e corpos estranhos no interior do reservatório. A utilização da cobertura dos reservatórios para outras finalidades é plenamente possível, desde que este uso não comprometa a estrutura do reservatório e nem a qualidade da água armazenada. ${ }^{51}$

No passado era comum que os reservatórios das torres de água recebessem um revestimento externo, sobreposto as paredes do reservatório, com a função de isolamento térmico. objetivo deste revestimento era o de evitar o congelamento da água armazenada no reservatório durante o inverno. A prática, no entanto, mostrou que o isolamento térmico dos reservatórios de água não é estritamente necessário. A renovação constante da água no reservatório causada pelas retiradas constantes para consumo, especialmente nos reservatórios de grande volume, combinada com o calor armazenado na água, impede o congelamento do volume armazenado durante o período de inverno. ${ }^{52} \mathrm{~A}$ camada superficial da água pode sim congelar no interior do reservatório, formando uma placa de gelo que flutua conforme o nível de água do reservatório sobe e desce mas, dificilmente, o volume total de água no reservatório congela, transformando-se em uma grande

\footnotetext{
${ }^{51}$ ABNT, NBR 12217, 1994, op. cit., p. 3.

${ }^{52}$ WERTH, 1971, op. cit., p. 357.
} 
pedra de gelo..$^{53} \mathrm{Em}$ localidades com climas extremamente frios é comum que a água que alimenta o reservatório seja aquecida antes de entrar no tanque. Assim, o tubo de entrada de água, que atravessa o reservatório do fundo até o topo, libera calor e retarda o congelamento da água armazenada.

$\mathrm{Na}$ atualidade são poucos os reservatórios de torres de água que são projetados com revestimentos externos para isolamento térmico. Em casos especiais, em localidades com invernos severos e nos casos em que os reservatórios são projetados para armazenar água por longos períodos de tempo, ainda são utilizados revestimentos para isolamento térmico como, por exemplo, em várias torres de água finlandesas. Ainda que o isolamento térmico do reservatório não seja obrigatório na maioria dos casos, o isolamento térmico das tubulações é de grande importância uma vez que tubos desprotegidos oferecem pouca proteção contra o congelamento da água quando da queda da temperatura abaixo de $0^{\circ} \mathrm{C}$.

Revestimentos externos nos reservatórios de torres de água também podem ser utilizados como uma solução construtiva para combater os efeitos adversos da temperatura externa na própria estrutura do reservatório. A proteção do reservatório contra a radiação solar direta limita as dilatações e a consequente movimentação da estrutura, diminuindo assim a possibilidade da ocorrência de vazamentos. ${ }^{54}$ Os revestimentos externos aplicados aos reservatórios de torres de água tem atualmente uma função mais estética do que técnica.

\footnotetext{
${ }^{53}$ Existem, porém, casos de congelamento total de reservatórios em torres de água ocasionados pela retirada da água em intervalos de tempo muito irregulares ou devido ao armazenamento da água por longos períodos durante o inverno. A maioria de casos de congelamento ocorre com reservatórios metálicos. O aumento do volume que ocorre no congelamento da água acaba por exercer uma pressão maior sobre as paredes do reservatório, que acabam por ceder sob o esforço extra. No rompimento das paredes do reservatório é comum o vazamento de água ainda em estado líquido que, ao ser expulsa para o exterior forma cascatas de gelo quando entra em contato com a atmosfera com temperaturas abaixo de $0^{\circ} \mathrm{C}$.

${ }^{54}$ VAN CRAENENBROECK, 1991, op. cit., p. 59.
} 


\subsubsection{Ventilação e lluminação do Reservatório}

Com a variação do nível da água no interior do reservatório, a quantidade de ar no espaço existente entre a água armazenada e a cobertura da torre de água (ou tampa do tanque) muda. Quando o nível da água cai, mais ar entra no reservatório. Quando o nível de água sobe $\mathrm{o}$ ar é expulso para o exterior. As aberturas de ventilação são portanto necessárias para garantir este fluxo de ar, evitando esforços diferenciais na estrutura do reservatório, devido ao aumento e diminuição da pressão interna. ${ }^{55}$ Outra função da ventilação nos reservatórios é a de refrescar a massa de ar existente sobre a água, evitando a formação de condensação sob a cobertura ou sob a tampa do reservatório.

Para evitar a contaminação da água armazenada as aberturas de ventilação devem ser protegidas por coberturas e telas contra a entrada de contaminantes, tais como, poeira, água da chuva, animais e insetos. Para o dimensionamento das aberturas de ventilação deve ser considerado como valor inicial a máxima vazão de saída de água do reservatório. ${ }^{56}$

Nas torres de água que abrigam reservatórios de forma aberta, isto é, reservatórios sem tampa, as aberturas de ventilação podem ser previstas na própria cobertura da torre de água, na forma de lanternas ou simples tubos que se prolongam acima do nível do telhado. Em alguns casos, quando a parede do reservatório é independente da parede de fechamento da torre de água estas aberturas podem ser previstas na própria fachada da construção, ventilando o estreito corredor formado entre o tanque e as paredes externas da torre. Nos reservatórios de forma fechada estas aberturas estão quase sempre localizadas no ponto mais alto da tampa do tanque, na forma de lanternas ou respiros executados em tubos metálicos.

A iluminação natural nos reservatórios das torres de água deve ser diminuta, preferencialmente inexistente, uma vez que

55 SABESP, NTS 023, 1999, op. cit., p. 1.

${ }^{56}$ ABNT, NBR 12217, 1994, op. cit., p. 3. 
a luz do sol facilita o desenvolvimento de algas no interior do tanque. ${ }^{57}$ Para auxílio das operações de lavagem e manutenção do reservatório devem ser previstos pontos de iluminação artificial, resistentes à umidade e alimentados com tensão elétrica muito baixa, posicionados sob a tampa do reservatório ou sob a cobertura da torre de água e sempre acima do nível máximo de armazenamento de água. ${ }^{58}$

57 VAN CRAENENBROECK, 1991, op. cit., p. 56.

${ }^{58}$ REIS, 1951, op. cit., p. 36. 


\subsubsection{Elementos para Inspeção, Manutenção e Segurança}

Na maioria das torres de água situa-se logo abaixo do reservatório o piso do barrilete (item 7, fig. 1.2.10a). Barrilete é o nome dado no Brasil ao conjunto de tubulações hidráulicas ligadas aos reservatórios e que se derivam para as redes de distribuição. É no barrilete que ficam localizadas as válvulas para controle de abertura e fechamento dos tubos de entrada e saída de água, bem como as válvulas de controle do tubo de esvaziamento do reservatório. A partir do piso do barrilete o fundo do reservatório é facilmente acessível para operações de manutenção.

Em alguns países este piso recebe o nome de "piso de vazamento". Este nome tem origem na outra função deste piso: coletar a água de condensação que "vaza" do reservatório. Em certos climas, com verões bastante úmidos, as superfícies externas do reservatório podem ficar bastante molhadas devido ao vapor de água do ar que se condensa contra as paredes e o fundo frio dos reservatórios. A água de condensação formada é coletada no "piso de vazamento". 59

É necessário garantir o fácil acesso ao interior dos reservatórios para operações de limpeza e manutenção. Nos reservatórios com forma aberta este acesso já é garantido pela própria forma do tanque. Já nos reservatórios de forma fechada é necessário prever no mínimo uma abertura para acesso ao interior do tanque, posicionada acima do nível máximo da água, com dimensões mínimas de $60 \times 60 \mathrm{~cm}$. A abertura para acesso deve ficar posicionada junto a uma das paredes do reservatório, preferencialmente no mesmo alinhamento da área de equipamentos internos do reservatório. ${ }^{60}$

Devem ser previstas escadas internas e externas ao reservatório para facilidade de acesso nas operações de manutenção. A escada interna, que dá acesso ao fundo do reservatório, deve ser permanente, apoiada no fundo, fabricada em material resistente

59 VEEN, 1989, op. cit., p. 30.

${ }^{60}$ ABNT, NBR 12217, 1994, op. cit., p. 3. 
1.2.12

Alternativas de escadas para acesso aos reservatórios de torres de água à corrosão e dotada de guarda-corpo de segurança caso tenha altura superior a 6,00 metros. ${ }^{61}$ Para acesso a cobertura ou ao topo dos reservatórios de torres de água devem ser previstas escadas permanentes externas, protegidas por guarda corpos, ou escadas permanentes, montadas no interior de uma passagem vertical com diâmetro não inferior a 1,00 metro, que conectam o piso do barrilete ao topo ou à cobertura do reservatório, atravessando este em altura (item 8, fig. 1.2.10a). Em muitas torres de água esta passagem vertical é posicionada exatamente no centro do tanque, finalizando em uma espécie de torre ou câmara que dá acesso à cobertura do reservatório. Alternativamente é possível também a utilização de escadas posicionadas no interior da torre, construídas no espaço residual entre as paredes do reservatório e o revestimento externo do tanque, ligando o piso do barrilete ao topo ou cobertura do reservatório. A figura 1.2.12 mostra algumas das soluções de escadas possíveis de serem utilizadas para acesso aos reservatórios das torres de água.

Também devem ser previstas escadas permanentes garantindo a circulação vertical entre o piso ao nível do solo e o piso do barrilete sob o reservatório. No topo das torres de água devem ser previsto sistema de proteção contra descargas atmosféricas e também luz de sinalização de obstáculo elevado.
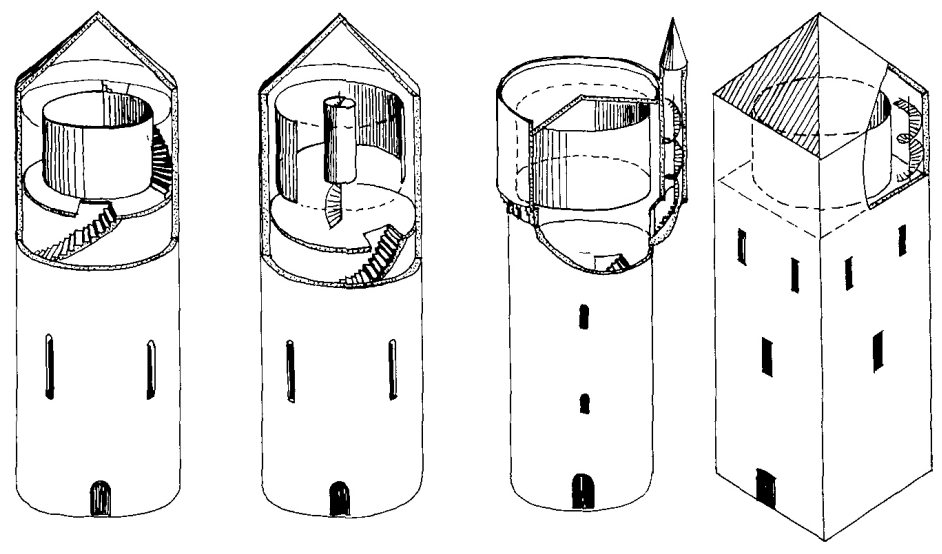

${ }^{61}$ Ibidem. 
SEGUNDA PARTE HISTÓRIA 


\section{HISTÓRIA DAS TORRES DE ÁGUA}

\subsection{Infraestrutura da Água}

A água é um recurso natural vital para a vida humana, tanto para consumo do próprio homem quanto para produção de alimentos, seja na agricultura ou na criação de rebanhos. A disponibilidade deste recurso foi, historicamente, o primeiro fator para surgimento das cidades, sempre estabelecidas em regiões onde as condições hidrológicas eram favoráveis.

" Os seres humanos passaram a maior parte de sua história como caçadores e coletores de alimentos. Somente nos últimos 9.000 a 10.000 anos eles descobriram como cultivar alimentos e criar animais domésticos. Tal revolução provavelmente ocorreu em primeiro lugar nas colinas ao norte da Mesopotâmia. De lá, a revolução agrícola se espalhou para o Vale do Nilo e do Indus. Durante esta revolução agrícola, vilas permanentes substituíram uma existência errante. Cerca de 6.000 a 7.000 anos atrás, aldeias agrícolas do Oriente Próximo e Oriente Médio tornaram-se cidades." 1

Se o suprimento de água por meio de fontes, córregos ou rios não fosse suficiente, o homem obtinha a quantidade de água necessária para o seu consumo armazenando-a. Esta estratégia era adotada especialmente nas regiões onde o intervalo entre as estações chuvosas era muito grande, fato que criava um problema que ameaçava a vida. ${ }^{2}$ A forma mais antiga de sistemas de armazenamento de água eram as cisternas, recessos naturais de terra que armazenavam a água no tempo chuvoso e que, posteriormente passaram a ser construídos artificialmente pelo homem. As primeiras cisternas construídas consistiam

\footnotetext{
${ }_{1}^{1}$ MAYS, L. W.; KOUSTSOYIANNIS, D.; ANGELAKIS, A. N.. A brief history of urban water supply in antiquity. Water Science \& Technology: Water Supply, London, v. 7, n. 1, jan. 2007, p. 1.

2 Uma estratégia adotada ainda hoje. Muitos dos modernos sistemas de abastecimento de água garantem o fornecimento contínuo de água ao longo do ano por meio da armazenagem de grandes volumes de água nos períodos chuvosos para posterior distribuição nas épocas de estiagem.
} 
principalmente em câmaras esculpidas na rocha, com os tetos suportados por colunas de pedra. A disposição de cisternas em subsolo era garantia de água fresca por um maior tempo, devido ao armazenamento da água em temperaturas mais baixas. A grande desvantagem das cisternas era a dependência de um fluxo regular de água para abastecê-la. Este problema foi contornado quando se conseguiu a alimentação constante das cisternas por meio de poços profundos que atingiam os lençóis freáticos. Os primeiros poços deste tipo foram construídos por volta de 4.000 a.C..

Os sistemas infraestruturais urbanos de abastecimento de água começaram a se desenvolver na Idade do Bronze (cerca de 2.800 - 1.000 a.C.) pelas civilizações estabelecidas no território que se estende entre Egito e Índia. Existem vários exemplos de sistemas de abastecimento de água construídos neste período. Na Pérsia, por exemplo, foi desenvolvido um sistema para coletar águas subterrâneas, o chamado "qanat", um sistema sofisticado de poços verticais e túneis horizontais projetados para captar a água e transportá-la por longas distâncias. ${ }^{3}$ Sistemas como estes foram criados com o objetivo de obter água de fontes naturais mais distantes, usando canais terrestres ou subterrâneos para transporte da água. Neste período já era reconhecido que o transporte econômico de grandes quantidades de água só era possível com a ajuda da declividade natural dos terrenos. ${ }^{4}$

Alguns dos primeiros sistemas centrais de abastecimento de água por gravidade foram construídos na Grécia, por volta de 1.500 a.C.. Tirando proveito do terreno montanhoso, aquedutos eram construídos nas encostas das montanhas para transportar a água até os centros urbanos. O sistema de transporte era complementado por sistemas de captação e armazenagem de água da chuva e de águas superficiais e subterrâneas, por meio de cisternas e poços. Os gregos também desenvolveram uma

\footnotetext{
${ }^{3}$ MAYS et al., 2007, op. cit., p. 2.

${ }^{4}$ WERTH, Jan. Ursachen und technische Voraussetzungen für die Entwicklung der Wasserhochbehälter. In: BECHER, Bernhard; BECHER, Hilla. Die Architektur der Förder und Wassertürme. München: Prestel-verlag, 1971, p. 328.
} 
sofisticada rede de distribuição de água utilizando tubulações de terracota.

Porém foram os romanos quem desenvolveram, durante a Antiguidade, as mais avançadas técnicas de engenharia para abastecimento, distribuição de água e saneamento urbano, aplicando-as em projetos de larga escala em todo o território ocupado pela civilização itálica da Roma Antiga. Em nenhum outro lugar do mundo antigo houve tanto uso de água quanto em Roma. A densidade populacional das cidades da Roma Antiga e o os hábitos de higiene da civilização romana criaram uma demanda por água sem precedentes no Mundo Antigo, cujo uso não se limitava apenas à água para beber e cozinhar, mas também para alimentar as fontes, piscinas e banhos públicos das cidades. No ano 100 a.C. estima-se que o uso diário por habitante seria de 1.200 litros, cerca de 6 vezes mais que o consumo atual na maioria das cidades modernas. ${ }^{5}$

Quilômetros de aquedutos de pedra, que superavam os acidentes topográficos e conduziam a água por gravidade, abasteciam as cidades romanas com a água potável proveniente de nascentes, rios ou lagos. Nos pontos finais dos aquedutos a água, depois de passar por um sistema de tanques (piscinae) para sedimentação da areia e de poluentes, era armazenada em tanques chamados de castellum aquae, cuja tarefa era a de distribuir a água por gravidade pelas várias linhas de consumo com pressão estável. Estas linhas de consumo que transportavam a água até as casas particulares, fontes e banhos públicos foram construídas como redes de tubulações subterrâneas, executadas com canos de chumbo ou manilhas de cerâmica. ${ }^{6}$

${ }^{5}$ CAVENDISH, Marshall. Pequena História das Invenções. São Paulo: Abril Cultural, 1976, p. 38.

${ }^{6}$ A utilização de tubos de chumbo era bastante comum, embora os romanos já soubessem que a água transportada nestes tubos representava um perigo à saúde. No tratado De Architectura Libri Decem (século I a.C.), Vitruvius aponta que a água não deve ser conduzida por meio de tubos de chumbo quando se deseja ter uma água salubre. Ver VITRUVIUS. The Ten Books on Architecture. New York: Dover Publications, 2015, p. 247. 


\subsection{1}

Travessia de aquedutos perto de Roma. Na estrutura da parte inferior direita da imagem estão os três canais sobrepostos dos aquedutos Aqua Marcia, Aqua lulia e Aqua Tepula, a outra estrutura contém os canais dos aquedutos Aqua Claudia e Anio Novus. Pintura de Michael Zeno Diemer, cerca de 1910.

A capacidade de armazenamento de água do castellum aquae era limitada, uma vez que o fluxo de água para o consumidor era contínuo e generoso, ${ }^{7}$ não causando nenhum pico de consumo diário, sendo necessário manter uma reserva apenas para compensar pequenas variações no influxo de água. Estes reservatórios, cujo nome latino "castellum aquae" provavelmente derivou para o francês "château d'eau", é um dos precursores dos reservatórios de distribuição e das torres de água, uma vez que desempenha a função de armazenamento e de regularização de vazões e pressões na rede de abastecimento. Para abastecer as áreas mais elevadas do sítio era necessária a criação de reservatórios distribuidores em cotas compatíveis. Comparando-se as cotas de nível finais dos aquedutos romanos na ordem cronológica de sua construção, com o aumento da área abastecida na cidade, temos uma cota inicial de 8,50 metros acima do nível do mar para o aqueduto Aqua Claudia (313 a.C.) para uma cota de 48,10 metros no aqueduto Anio Novus (39 d.C.), o mais elevado da cidade romana. ${ }^{8}$

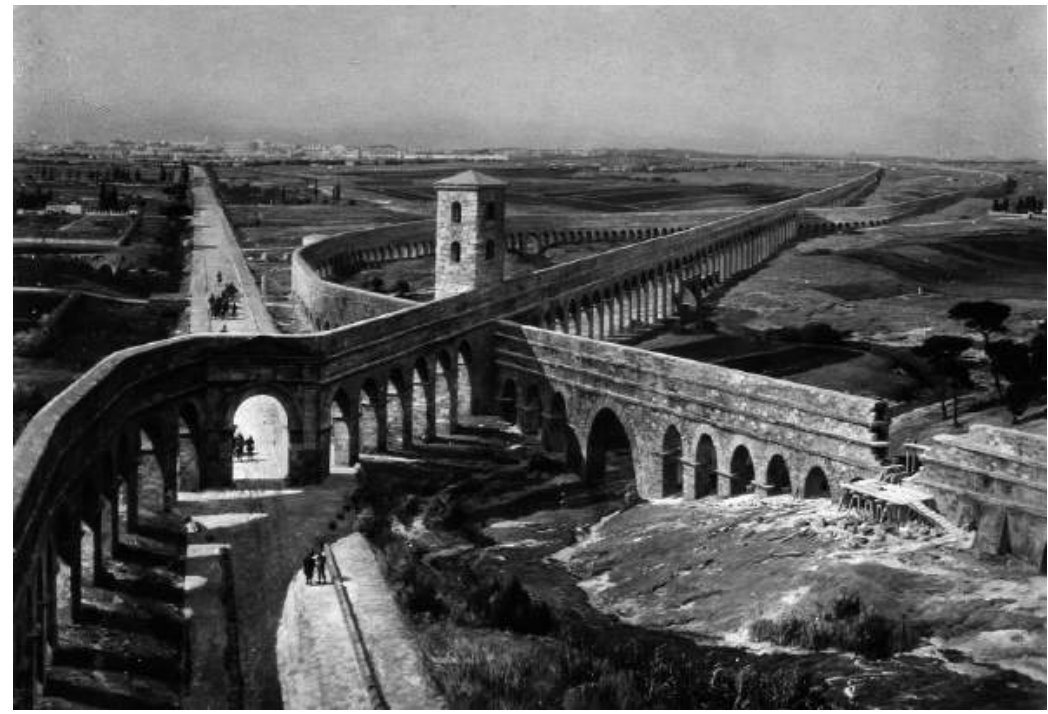

Em cidades romanas como Pompéia, além das fontes públicas de abastecimento de água e dos banhos públicos, algumas casas já contavam com sistema individual de abastecimento, com torneiras na cozinha ou no jardim das residências, alimentadas

\footnotetext{
7 A água corria livremente com fluxo constante tanto nas conexões públicas quanto privadas, gerando um alto desperdício. Esta era a maior razão do elevado consumo per capita de água nas cidades da Roma Antiga. Ver WERTH, op. cit., p. 328.

${ }^{8}$ WERTH, 1971, op. cit., p. 330.
} 

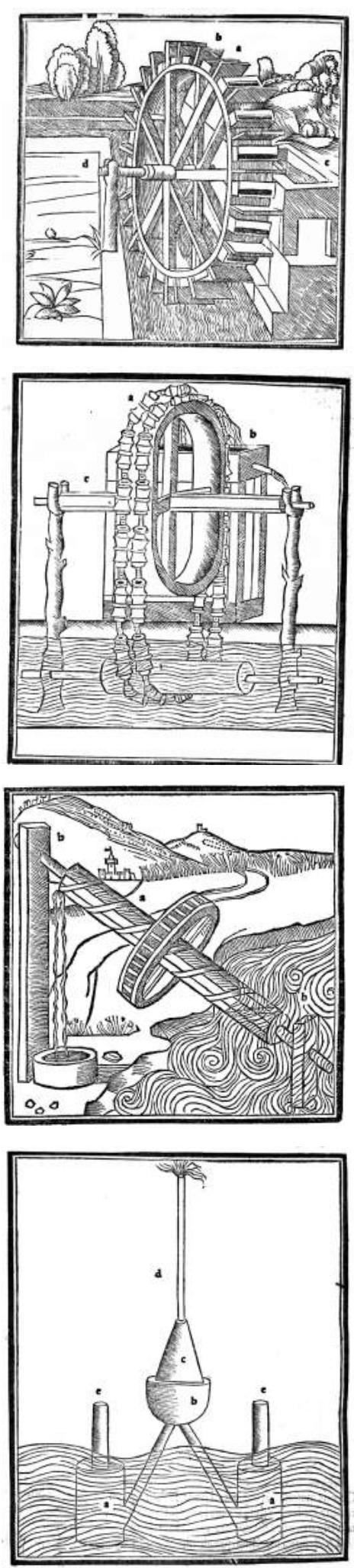

2.1.2

Máquinas para Elevação Artificial de Água, da edição do tratado de Vitruvius por Fra Giocondo, Veneza, 1511.
a) Roda de Água
b) Nora
c) Parafuso de Arquimedes
d) Bomba de Ctesíbio

por uma infraestrutura hidráulica de canos metálicos de chumbo enterrada na via pública. E além dos aquedutos, castellum aquae e fontes, cerca de 14 torres de água primitivas completavam o sistema de abastecimento de água potável para a população. ${ }^{9}$

Ainda que o melhor da engenharia hidráulica de Roma seja representado pelos seus sistemas de abastecimento e aquedutos distribuindo água por gravidade, os engenheiros romanos conheciam e faziam uso de sistemas primitivos de bombeamento que permitiam ao homem transportar a água proveniente dos rios e córregos, localizados nas cotas baixas dos assentamentos, para as áreas de abastecimento localizadas nas cotas mais elevadas dos terrenos. Rodas de água e máquinas de elevação de água, também chamadas de máquinas de força muscular (movidas pelo próprio homem ou por animais) já eram conhecidas e utilizadas para a elevação da água, ainda que em escala bem limitada, destinadas ao recalque de pequenos volumes de água, insuficientes para suprir as necessidades de um centro urbano, por exemplo. No tratado De Architectura Libri Decem, Vitruvius descreve no Livro $X$ algumas das máquinas para elevação de água conhecidas pelos romanos, como a roda de água, a nora, o parafuso de água ou parafuso de Arquimedes e a bomba de Ctesíbio ou bomba de pistão (fig. 2.1.2).

\section{A Lindum Colonia (80 d.C.), um assentamento romano} localizado nas proximidades da atual cidade de Lincoln, na Inglaterra, tinha um sofisticado sistema de abastecimento de água que, muito provavelmente, empregava máquinas para a elevação da água. Um aqueduto de tubos de cerâmica de 150mm de diâmetro, encamisados em concreto, transportavam a água captada no rio Roaring Meg, situado cerca de 20 metros abaixo do nível de Lindum, para um reservatório de distribuição e armazenagem, localizado a 2.000 metros de distância do rio. Claramente algum tipo de bomba deve ter sido utilizada no sistema, mas não existem vestígios que possam fornecer maiores informações sobre a natureza ou o

\footnotetext{
${ }^{9}$ Ver OLSON, Richard. The water-supply system in Roman Pompeii. 2015. 132 f. TCC (Graduação) - Department of Archaeology and Ancient History, Lund University, Stockholm, 2015.
} 


\section{1 .3}

Carregadores de água da Idade Média funcionamento do maquinário. Alguns vestígios apontam para a existência de uma torre, localizada no final do aqueduto, sobre a qual poderia ter existido um reservatório elevado que distribuiria a água armazenada, por gravidade, para toda a cidade de Lindum. ${ }^{10}$ Como esclarecido na primeira parte deste trabalho, a torre de água é parte de um sistema de abastecimento de água alimentado por bombeamento.

Com a queda do Império Romano do Ocidente (476 d.C.) os conhecimentos tecnológicos ligados aos sistemas de abastecimento de água e higiene sanitária retrocederam, principalmente nas ocupações urbanas da Europa. Grande parte da infraestrutura hidráulica construída pelos romanos foi destruída ou sofreu com a falta de manutenção durante as migrações bárbaras. As grandes mudanças sociais e econômicas ocorridas no período deixaram as populações sem os recursos necessários para manter ou reconstruir os sistemas de abastecimento de água. Durante o período da Idade Média Alta, o abastecimento local de água foi realizado por meio de rios, poços ou cisternas. A população retirava a água destas fontes por conta própria ou, se tivessem condições, contratavam carregadores para transportar a água até as suas casas. ${ }^{11}$
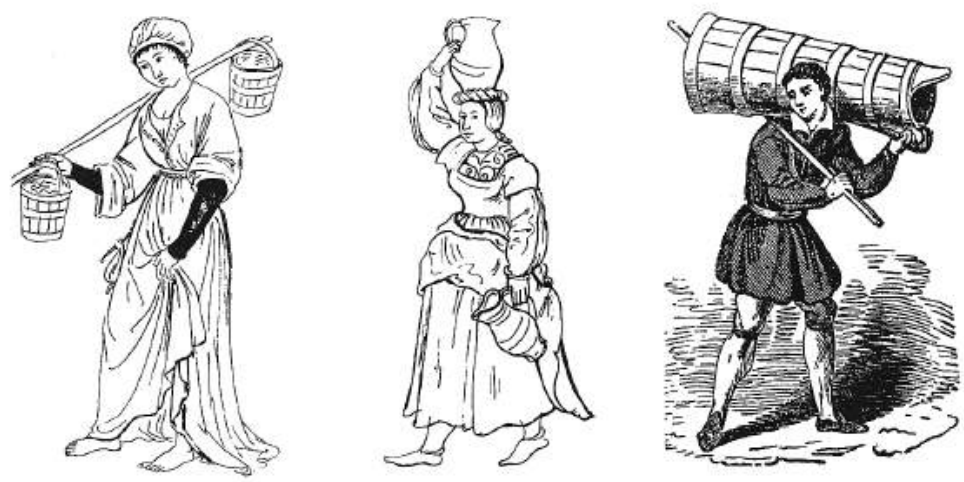

${ }^{10}$ BARTON, Barry. Water Towers of Britain. Londres: Newcomen Society, 2003, p.13; e também THOMPSON, F. H.. The Roman Aqueduct at Lincoln. The Archaeological Journal, London, v. 111, n. 1, p.106-128, jan. 1954.

11 MAGNUSSON, Roberta J.. Water Technology in the Middle Ages: Cities, Monasteries, and Waterworks after the Roman Empire. Baltimore: Johns Hopkins University Press, 2001, p. 2-5. 
O crescimento demográfico das cidades europeias, durante os séculos 11 e 12, combinado com o florescimento do comércio e com as inovações agrícolas que permitiam uma maior produtividade dos solos e das colheitas, consequentemente aumentou a demanda por água e o abastecimento central de água nas cidades se tornou novamente um problema de bem estar público. Para atender as maiores demandas por água, as poucas instalações de fornecimento de água precisavam ser substituídas por sistemas mais eficientes.

A construção de fontes públicas nas cidades europeias foi uma das primeiras respostas para o problema da água. Autoridades e instituições locais como, por exemplo, monastérios, construíram aquedutos e "adutoras", que captavam a água em rios, ribeirões e lagos nos arredores da cidade, e a conduziam até cisternas e fontes públicas. Estes sistemas de abastecimento eram tecnologicamente simples, idealizados conforme os conhecimentos básicos da engenharia hidráulica, baseados na condução da água por gravidade, em baixa pressão, por meio de canais ou tubulações de pedra ou chumbo. A cidade de Londres, por exemplo, iniciou em 1245 a construção de sua primeira grande "adutora" para abastecimento de água, o Great Conduit na mesma época em que outras grandes cidades da Europa implantavam sistemas semelhantes de fontes públicas. $^{12} \bigcirc$ Great Conduit fornecia água para a população por meio de uma cisterna de chumbo construída em Westcheap. A cisterna era alimentada com a água captada nos arredores de Londres, no riacho Tyburn Brook, que era previamente armazenada em um reservatório construído por volta de 1237, para depois ser conduzida para a cisterna por meio de um tubo de chumbo de 6 polegadas de diâmetro. Neste período o abastecimento de água direto para os edifícios era praticamente inexistente em todas as grandes cidades. Alguns palácios e monastérios, no entanto, contavam com suprimento direto de água, por meio de aquedutos e adutoras próprias.

12 TOMORY, Leslie. The History of the London Water Industry, 15801820. Baltimore: John Hopkins University Press, 2017, p. 21. 


\subsection{4}

"Estação Hidráulica" de Lübeck.

Detalhe da panorâmica Lubecca Urbis Imperialis de Elias Diebel, Lübeck, 1552. Xilogravura em 24 partes.
A construção de sistemas de abastecimento de água mais complexos difundiu-se no final do século XIII e durante os séculos $\mathrm{XIV}$ e $\mathrm{XV}$, especialmente na Alemanha, quando o recurso dos rios, fontes de água que ainda não tinham sido utilizadas em todo o seu potencial começou a ser explorada. Para captar a água dos rios, localizados nas cotas mais baixas dos centros urbanos, era necessária a utilização de sistemas de elevação de água capazes de conduzir grandes volumes de água para as cotas mais elevadas dos territórios. As chamadas máquinas de força muscular (máquinas de elevação de água movidas por animais e pelo próprio homem) conhecidas desde a Antiguidade eram extremamente limitadas para esta tarefa. Assim tentou-se adaptar as já conhecidas noras ${ }^{13}$ para operação em larga escala, sendo impulsionadas por rodas de água movidas pela correnteza dos próprios rios. ${ }^{14}$ Ainda que as rodas de água ${ }^{15}$ fossem conhecidas desde o século II a.C., foi somente entre os séculos XI e XIV que o emprego da força hidráulica teve aplicações sem precedentes, sendo utilizado em larga escala para a realização de inúmeras atividades. ${ }^{16}$

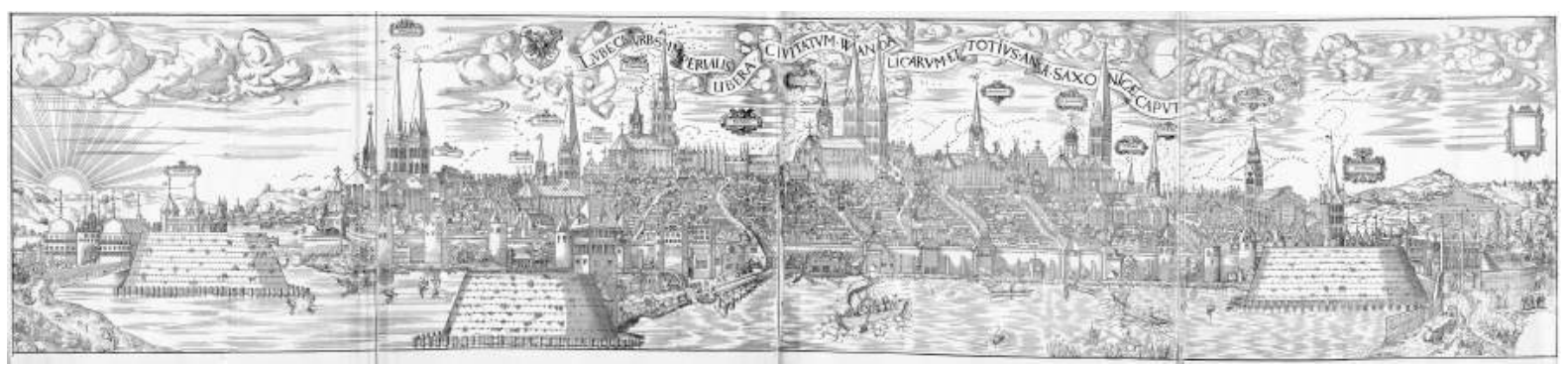

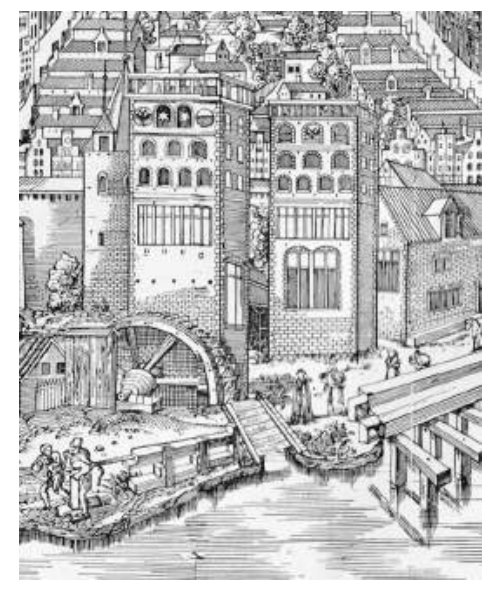

\begin{abstract}
${ }^{13}$ Nora é um engenho para retirada de água de poços, cisternas ou rios composto de uma roda onde estão presos recipientes ou pás que, com o movimento de giro da roda, elevam a água até uma altura correspondente ao seu diâmetro e esvaziam-se em um reservatório ou calha. Na China e Síria já foram relatadas noras com até 21 metros de diâmetro. As noras podem ser impulsionadas pela própria força hidráulica (quando instaladas junto a cursos de água) ou ainda pela força humana ou animal sendo, neste caso, também conhecidas como sakia. A nora surgiu no Egito, por volta de 400 a.C.. No tratado De Architectura Libri Decem (século I a.C.), Vitruvius descreve o aparato no Livro X.

${ }^{14}$ WERTH, 1971, op. cit., p. 330.

${ }^{15}$ A roda de água é um dispositivo circular montado sobre um eixo, contendo em sua periferia aletas ou caixas dispostas de maneira a aproveitar a energia hidráulica da água corrente e atuar como propulsor de máquinas diversas por meio de seu movimento de rotação.
\end{abstract}

${ }^{16}$ CAVENDISH, 1976, op. cit, p. 93. 
O primeiro sistema de elevação de água deste tipo, comumente referido como "estação hidráulica", ${ }^{17}$ foi construído na cidade alemã de Lübeck, em 1249 (fig. 2.1.4). Este sistema consistia de uma nora conjugada a uma roda de água que captava água no rio Trave e abastecia cerca de 200 residências por meio de uma rede de tubos de madeira fabricados com troncos de árvores escavados. Outras cidades alemãs que construíram sistemas similares de abastecimento de água, utilizando noras impulsionadas por rodas de água, foram Hanôver (1352), Breslau (1386), Bremen (1396) e Bautzen (1496). ${ }^{18}$

No decorrer dos séculos XV e XVI muitas destas primeiras "estações hidráulicas" substituíram suas noras por sistemas mais eficientes de elevação de água com a introdução de sistema de bombeamento que se utilizavam de bombas de corrente ou de bombas de pistão (fig. 2.1.5) impulsionadas por rodas de água. Nestas estações de bombeamento a água captada nos rios e córregos era conduzida diretamente para as fontes públicas onde a população podia extrair a água necessária para seu consumo. Sistemas de bombeamento deste tipo já vinham sendo utilizados a bastante tempo na indústria da mineração para a drenagem de água conforme descrito por Georgius Agricola (1494-1555) em seu tratado sobre mineração e metalurgia, De Re Metallica (1556).

A "estação hidráulica" de Augsburg (1412) foi o primeiro sistema de abastecimento a utilizar bombas de pistão para a elevação de água. Seus cilindros operavam verticalmente um ao lado

17 O termo "estação hidráulica", tradução nossa, será utilizado no presente trabalho como um equivalente na língua portuguesa para os termos "wasserkünst" (alemão), "waterworks" (inglês) e "waterwerk" (neerlandês), todos designando, na literatura específica sobre abastecimento de água, as estações de bombeamento de água surgidas na Europa durante os séculos $\mathrm{XV}, \mathrm{XVI}$ e XVII, cuja função era a de captar a água dos rios e córregos para fornecimento imediato às populações das cidades. Ainda que a "estação hidráulica" tenha, em certos aspectos, um funcionamento similar ao das estações elevatórias dos modernos sistemas de abastecimento de água da atualidade, adotamos o termo "estação hidráulica" para diferenciá-lo do termo "estação elevatória", da mesma maneira que ocorre na literatura específica, que traduz este último como "pumpwerk" (alemão), "pumping station"(inglês) e "pompstation" (neerlandês).

18 TOMORY, 2017, op. cit., p. 23. 


\subsection{5}

Sistemas de Bombeamento nos séculos XV e XVI.

a) Bomba de Corrente

b) Bomba de Pistão do outro e seus eixos, montados sobre manivelas, eram movidos pelas rodas de água. Instalações similares foram construídas em Lunenburg (1474), Hanôver (1527) e Hamburgo (1530). ${ }^{19}$

A utilização de bombas nas "estações hidráulicas" foi introduzida na Inglaterra, no final do século XVI, por Peter Morris (morto em 1588). Em 1581 Morris construiu, no primeiro arco da Ponte de Londres, uma roda de água que impulsionava bombas de pistão, que retiravam água do Tâmisa e distribuíam diretamente para residências particulares e para algumas cisternas públicas por meio de uma rede de tubos de madeira e chumbo. ${ }^{20} \mathrm{~A}$ companhia criada por Morris, que seria informalmente chamada de London Bridge Waterworks (fig. 2.1.6) forneceu água para a cidade até 1822 e abriu o caminho para que uma serie de companhias privadas similares fossem criadas. No início do século XIX a cidade já contava com pelo menos 8 companhias privadas de abastecimento de água operando simultaneamente, cada uma abastecendo uma área da metrópole londrina.
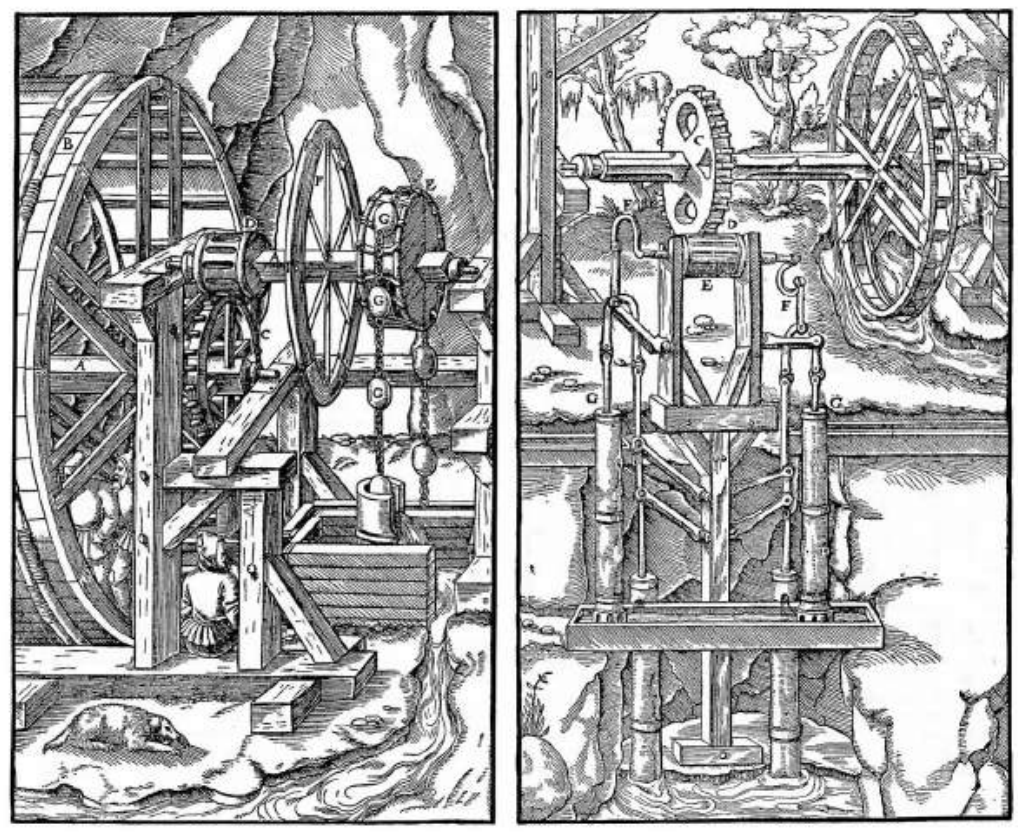

${ }^{19}$ WERTH, 1971, op. cit., p. 330.

20 TOMORY, 2017, op. cit., p. 32-35. 


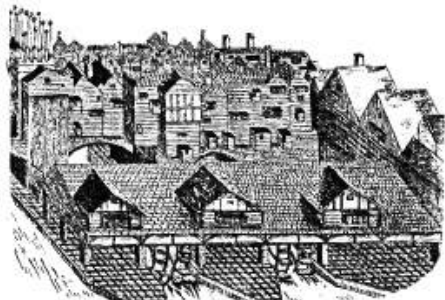

2.1.6

London Bridge Waterworks
Em 1608 foi construída na Pont Neuf, em Paris, uma "estação hidráulica" movida por grandes rodas de água chamada La Samaritaine (figuras 2.1.7, 2.1.8). ${ }^{21} \bigcirc$ nome do edifício é uma referencia a um conjunto de estátuas de bronze existente na fachada, representando Jesus Cristo e a mulher samaritana, sentados um em cada lado da fonte de Jacó. O sistema de bombeamento de água era similar ao utilizado por Morris em Londres. A água captada no Rio Sena, por quatro conjuntos de bombas, era conduzida até o Louvre e alimentava também as fontes e chafarizes do Jardin des Tuileries. Nas situações de vazão média do rio, a roda de água girava a uma taxa de 2,8 voltas por minuto e suas bombas eram capazes de gerar uma pressão de 20 metros de coluna de água. ${ }^{22}$

Nos vários tratados renascentistas dedicados às máquinas, chamados de theatrum mechanorum, ${ }^{23}$ as máquinas hidráulicas tinham um papel significativo. Das 195 máquinas catalogadas em um destes tratados, Le Diverse et Artificiose Machine del Capitano Agostino Ramelli, escrito pelo engenheiro italiano Agostino Ramelli (ca. 1531-1610) em 1588, mais de 100 são máquinas para a elevação artificial de água. A figura 2.1.9 é um dos vários projetos de máquinas catalogadas por Ramelli que ilustra um sistema de bombas de pistão acionadas por roda de água, muito próximo das "estações hidráulicas" do século XVI.

${ }^{21}$ Reconstruída por Robert de Cotte, em 1712, e restaurada por Soufflot em 1771, a La Samaritaine foi demolida em 1813. Existe uma maquete do edifício no acervo do Musée Carnavalet, em Paris, datada de 1772. O edifício representado nas figuras 2.1 .7 e 2.1 .8 (desenho realizado por volta de 1770$1780)$ muito provavelmente ilustra a reconstrução realizada no início do século XVIII.

22 HOUWINK, Pauline. Watertorens in Nederland: (1856-1915). Nieuwkoop: Uitgeverij Heuff, 1973, p. 16.

${ }^{23} \bigcirc$ theatrum mechanorum é o gênero de livros pictóricos de máquinas, que circulava pela Europa no final do século XVI e início do XVII. Em termos básicos, o theatrum mechanorum é um compêndio de descrições e ilustrações de máquinas e aparatos engenhosos cujo propósito era tanto a celebração do engenho humano quanto a catalogação das invenções práticas e suas aplicações. Ver REED, Cory A.. As Imagens Científicas e Tecnológicas do Quixote. Revista USP, São Paulo, n. 67, p. 294-303, set./nov. 2007. Tradução de Silvia Massimini. 
2.1.7

"Estação Hidráulica"

La Samaritaine.

2.1.8

La Samaritaine, secção no lado do Louvre
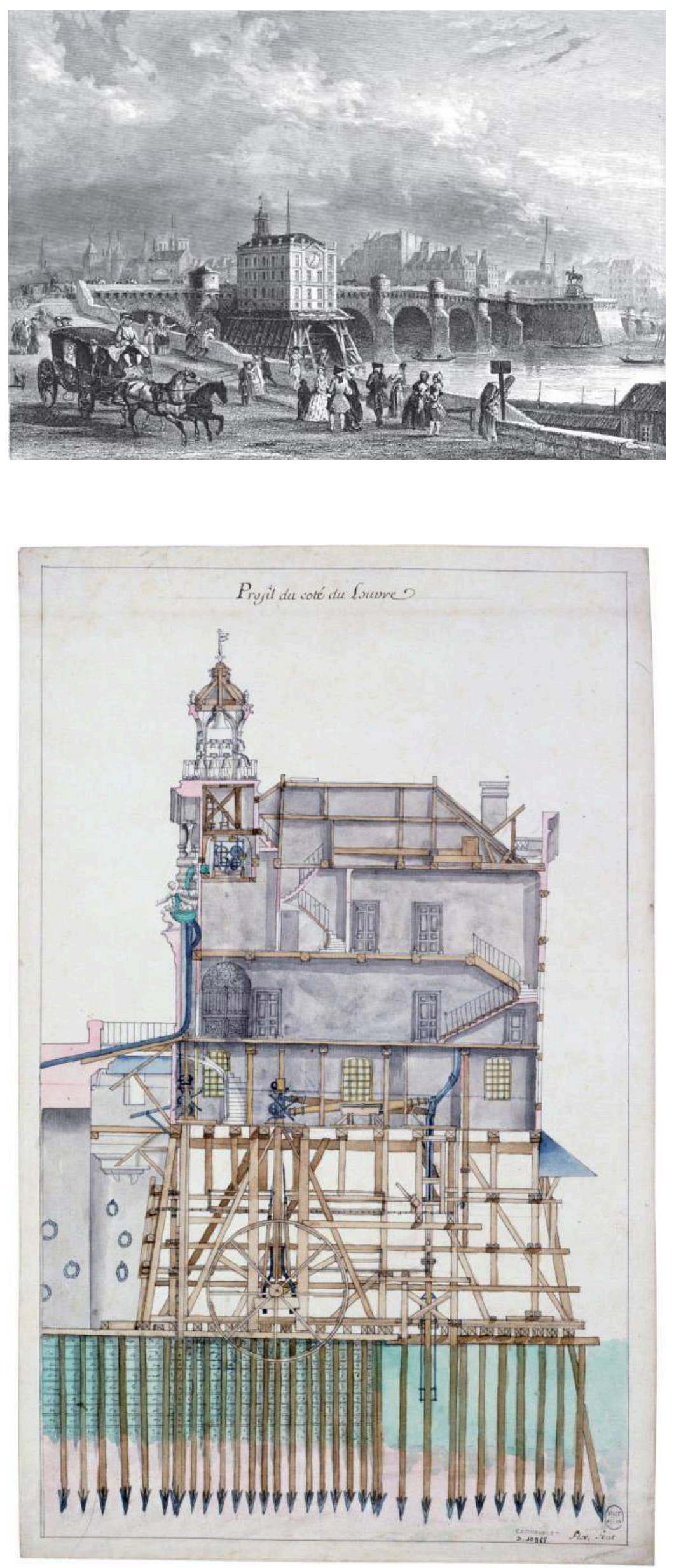


\subsection{9}

Uma típica "estação hidráulica" do século XVI.

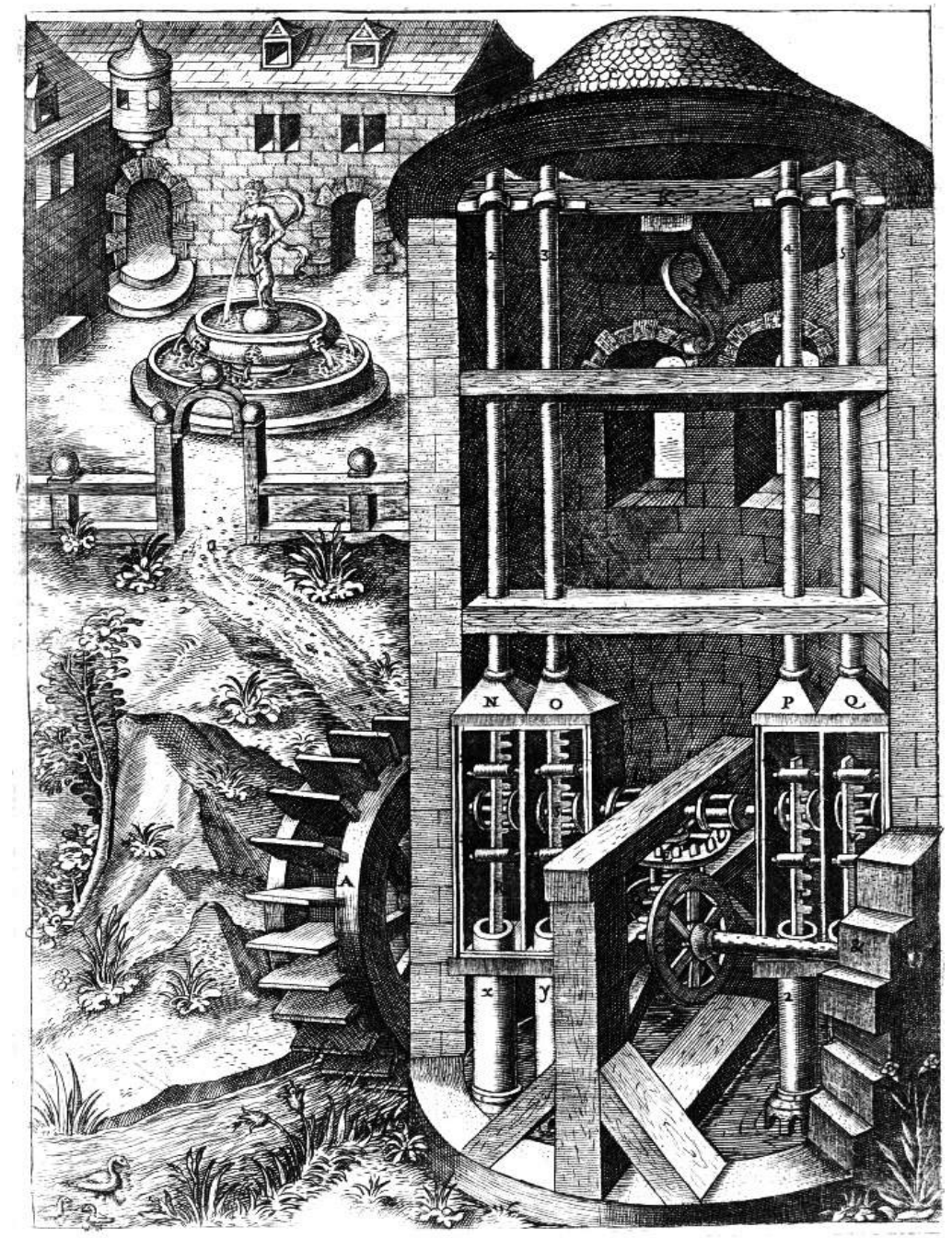




\subsection{1}

Máquina para fabricação de tubos de madeira, na gravura de um livro de 1661. Brocas de diversos tamanhos, giradas por um mecanismo impulsionado por roda de água, perfuram o tronco.

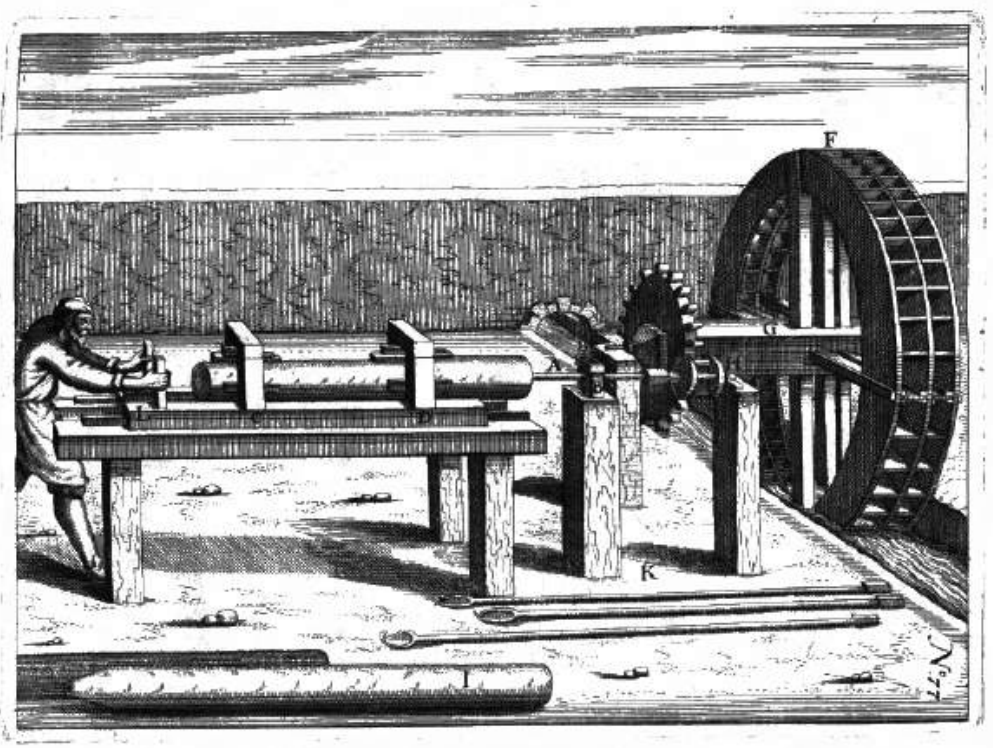

\subsection{Precursores da Torre de Água}

As "estações hidráulicas" alimentavam com água potável as fontes públicas e casas por meio de uma rede de tubulações subterrâneas, formada por tubos de madeira ou de chumbo, que operavam como linhas de pressão fechadas, funcionando pelo princípio de vasos comunicantes.

Os tubos de madeira já eram utilizados na Alemanha desde a Idade Média e eram fabricados com troncos de árvores, principalmente de espécies coníferas, que eram perfurados em seu cerne (fig. 2.2.1). Possuíam uma vida útil relativamente curta, de 12 a 15 anos, um diâmetro interno máximo de $10 \mathrm{~cm}$ e podiam suportar uma pressão máxima de 10 a 15 m.c.a.. Os tubos de madeira tinham ainda outro inconveniente: a água conduzida por eles adquiria um odor de mofo. Já os tubos de chumbo, conhecidos deste a Roma Antiga, eram formados por folhas de chumbo dobradas e soldadas criando uma secção transversal em formato de gota (fig. 2.2.2). Tanto as tubulações de madeira quanto as tubulações de chumbo possuíam baixa resistência à pressão hidrostática e devido a esta característica conseguiam atender somente $\mathrm{O}$ abastecimento de água em baixa pressão, suficiente para alimentar apenas as fontes públicas e o piso térreo dos edifícios. ${ }^{1}$

${ }^{1}$ WERTH, Jan. Ursachen und technische Voraussetzungen für die Entwicklung der Wasserhochbehälter. In: BECHER, Bernhard; BECHER, Hilla. Die Architektur der Förder und Wassertürme. München: Prestel-verlag, 1971, p. 331. 


\subsection{2}

Fragmentos de tubos de chumbo encontrados em escavações feitas em Roma.

\subsection{3}

"Wasserkünst" de Brunswick, 1527.

\subsection{4}

Blausternwerk, construído em Nuremberg, 1580.
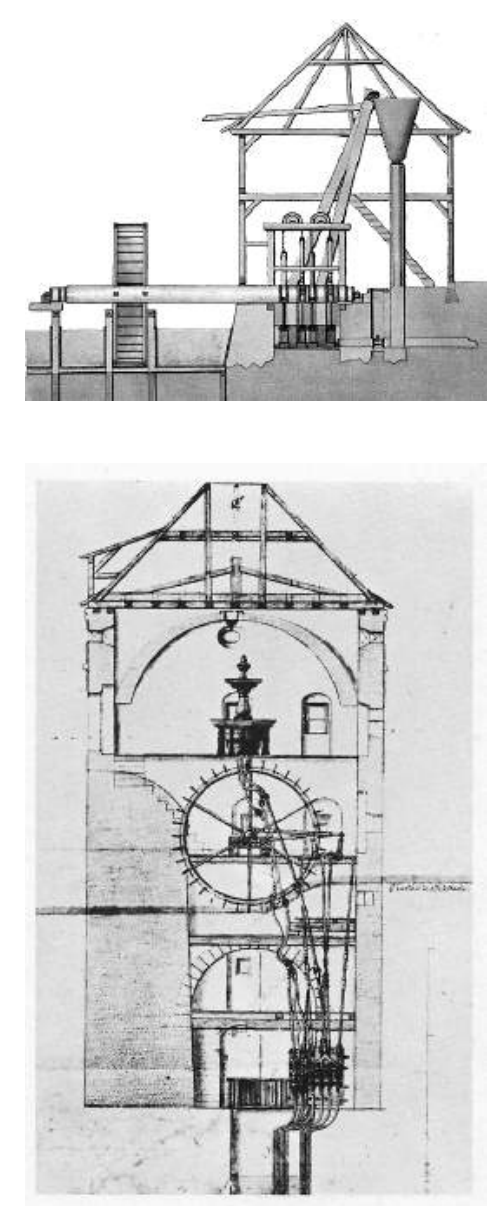

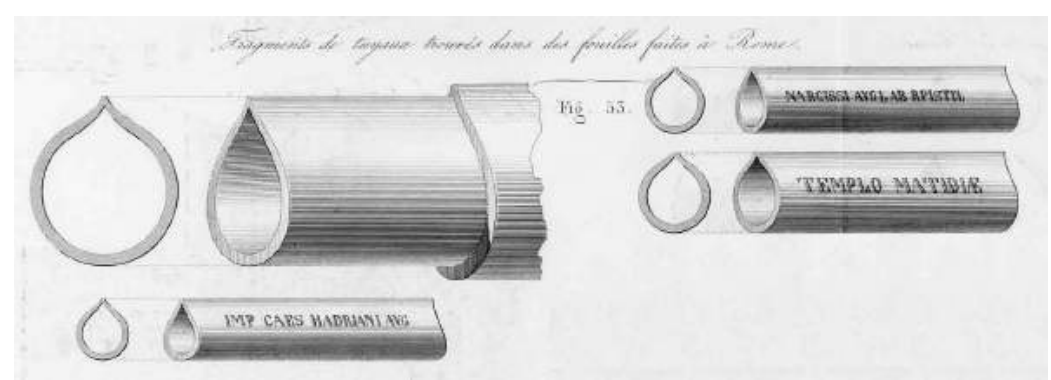

A principal desvantagem destas primeiras "estações hidráulicas" era a conexão direta do sistema de bombeamento com a rede de distribuição. Nestas instalações as ondas de sobrepressão das bombas de água eram transferidas para a rede de tubulações, que eram frequentemente danificadas quando da utilização de tubos de baixa resistência, como os de madeira ou de chumbo. As perdas de água eram significativas devido às juntas com vazamentos e ao vazamento de água pelos próprios tubos.

Com o objetivo de uniformizar as pressões atuantes na rede de distribuição de água introduziram-se tanques abertos nos sistemas, interpostos entre as bombas de água e a rede de distribuição, para compensar os surtos de pressão. ${ }^{2}$ Um dos primeiros exemplares desta solução é o "wasserkünst" de Brunswick (1527), em que a água captada no rio Oker, por meio de bombas de pistão impulsionadas por uma roda de água, é conduzida para um grande funil aberto, de onde a água flui por gravidade para a rede de distribuição (fig. 2.2.3). ${ }^{3}$ Outro exemplo é o Blausternwerk, construído em Nuremberg em 1580, em que a água bombeada cai em dois tanques coletores, em formato de fonte, para depois fluir por gravidade para a rede de distribuição (fig. 2.2.4). O sistema de tanques coletores de água utilizado nestas "estações hidráulicas" também foi descrito por Agostino Ramelli em seu tratado sobre máquinas (1588). A figura 2.2 .5 mostra uma "estação hidráulica" típica do século XVI, com suas partes essenciais: roda de água, bomba de pistão, pequeno tanque coletor elevado e a linha de transferência, que conduzia a água por gravidade até a rede de distribuição. A função do pequeno tanque coletor elevado não

\footnotetext{
2 Ibidem.

${ }^{3}$ VEEN, Henk van Der. Watertorens in Nederland. Rotterdam: Uitgeverij 010, 1989, p. 14.
} 
2.2 .5

"Estação Hidráulica" com tanque coletor de água.

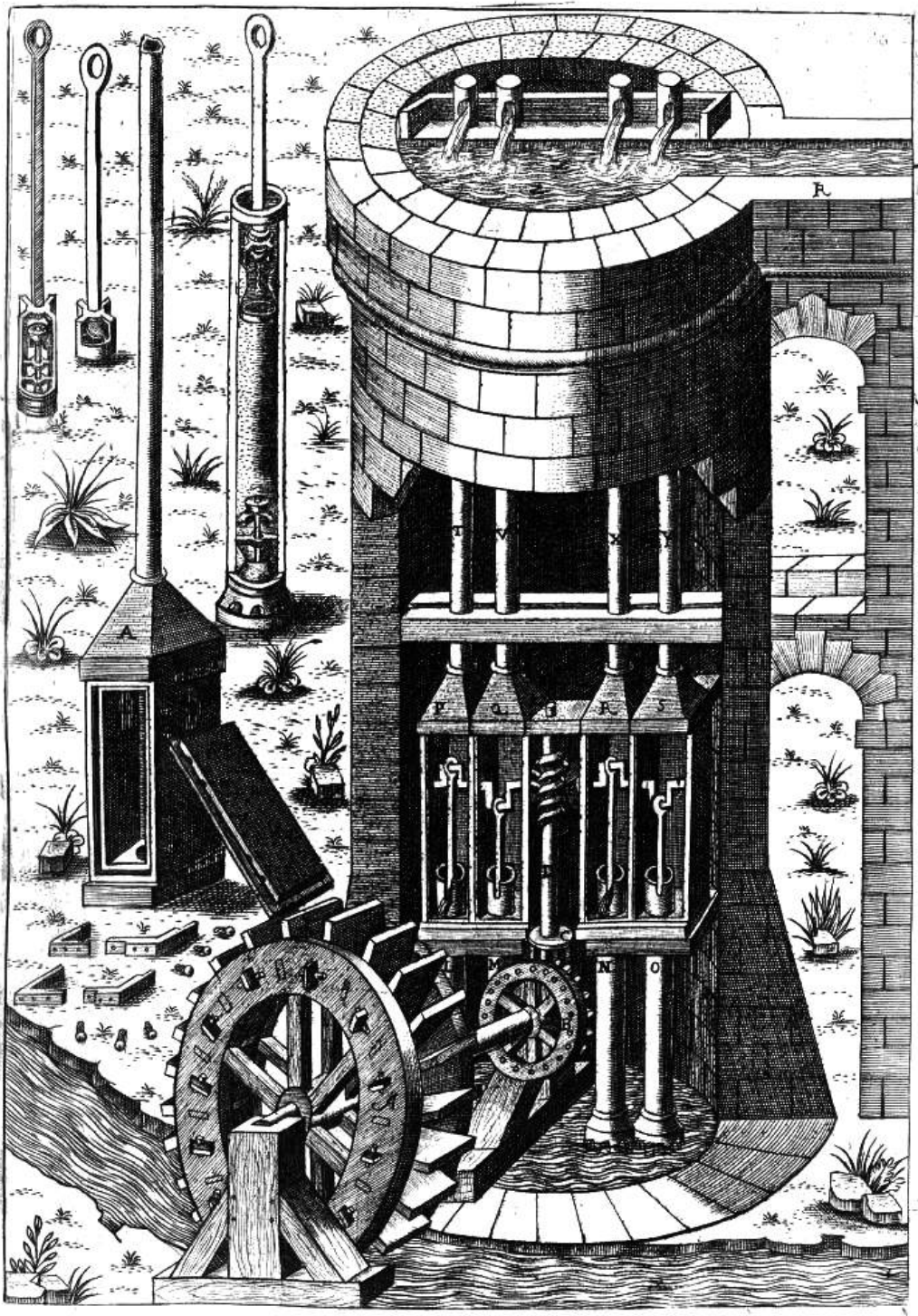

era a de armazenar a água para consumo da população, a sua função era a mesma do castellum aquae romano há mais de 1.500 anos, a estabilização da pressão e a prevenção de flutuações de pressão, provenientes dos sistemas de bombeamento, na rede de distribuição de água. ${ }^{4}$ Os tanques elevados destas estações hidráulicas eram, na maioria dos casos, caixas, cubas ou grandes calhas fabricadas em pedra, cobre, chumbo ou madeira.

No final do século XVIII, os tanques coletores já haviam se convertido em pequenos reservatórios elevados instalados no interior de construções em forma de torre, capazes de garantir a

${ }^{4}$ BAUR, Albert. Historiche Entwicklung der Wasserspeichrung. In: MERKL, Gerhard et al. Historische Wassertürme: Beiträge zur Technikgeschichte von Wasserpeicherung und Wasserversorgung. München: Oldenburg Verlag, 1985. p. 20. 


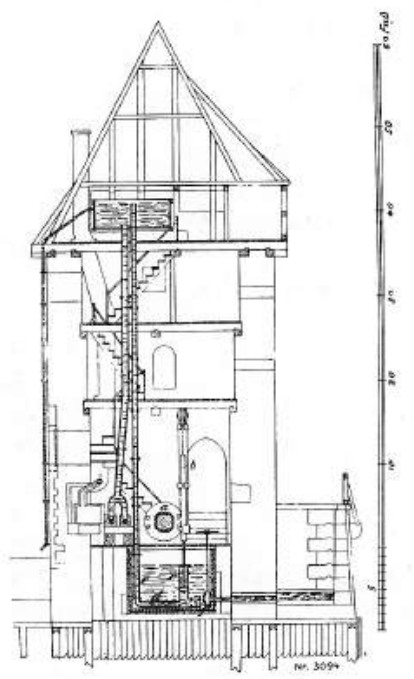

2.2.6

"Estação Hidráulica" com tanque coletor de água. distribuição de água por gravidade com uma pressão uniforme e, ao mesmo tempo, acomodar as grandes máquinas de bombeamento que captavam a água dos rios.

A "estação hidráulica" da cidade de Hanôver, construída em 1794, estava equipada com um reservatório elevado de madeira. $\mathrm{Na}$ figura 2.2.6 temos a representação da construção em torre com o tanque de madeira em seu interior e o arranjo da tubulação hidráulica. A água do rio era captada por bombas de pistão, movidas por uma roda de água, e transportada pela tubulação até o reservatório de madeira, de onde fluía por gravidade para a rede de distribuição. $O$ tanque retangular, com fundo plano apoiado em vigas de madeira, tinha um volume de $9 \mathrm{~m}^{3}$, com dimensões de 2,7 $\times 3,6$ metros e altura de $90 \mathrm{~cm} .^{5}$

Outro exemplo notável de "estação hidráulica" deste período é a torre da York Buildings Waterworks Company, uma empresa privada que operou em Londres entre 1675 e 1829, retirando água do rio Tâmisa para vendê-la no bairro privilegiado em que estava instalada. ${ }^{6}$ Célebres pintores da época, ${ }^{7}$ inclusive Canaletto (1697-1768), retrataram a alta torre de água (fig. 2.2.7) que, em meados do século $X V I I I$, foi parte integrante das instalações da York Buildings Waterworks. A torre octogonal de madeira, com cerca de 20 metros de altura, abrigava em seu topo um reservatório fabricado em chumbo, que era alimentado por

\footnotetext{
5 WERTH, 1971, op. cit., p. 332.

6 TOMORY, Leslie. The History of the London Water Industry, 15801820. Baltimore: John Hopkins University Press, 2017, p. 85.

7 A torre da York Buildings Waterworks Company foi retratada em pinturas de J. P. Malcom (ca.1726), Samuel Scott (ca. 1750) e William James (ca. 1750). Canalleto retratou a torre em pelo menos três de suas pinturas de Londres: The Thames Towards Westminster Bridge (ca. 1746), The City of Westminster from Near the York Water Gate (ca. 1746) e London seen through an Arch of Westminster Bridge (ca.1747).
} 


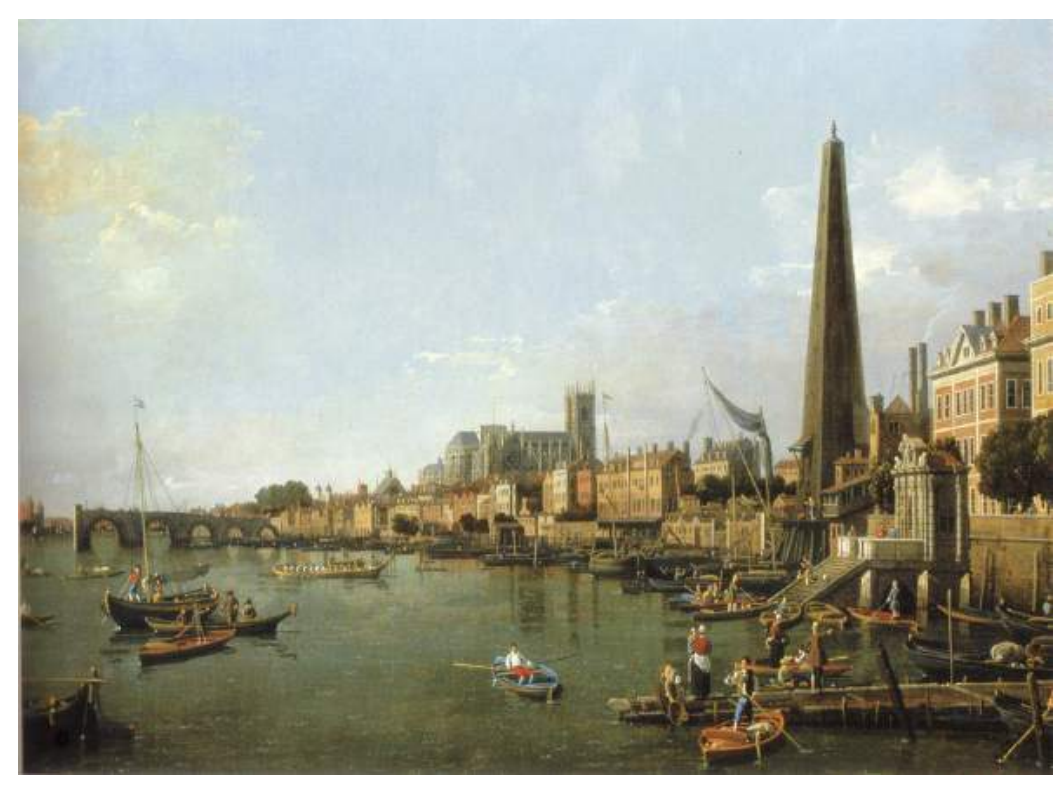

\subsection{7}

Torre de Água da York Buildings Waterworks Company. The Thames Towards Westminster Bridge (ca. 1746), por Canaletto. bombas impulsionadas por cavalos ${ }^{8}$ e fornecia água por gravidade para cerca de 2.500 casas. ${ }^{9}$ Por volta de 1745 o sistema da London Bridge Waterworks, que já havia expandido e contava com conjuntos de rodas de água e bombas instaladas em três arcos da Ponte de Londres possuía também uma torre de água. No topo da torre dois reservatórios de chumbo, com capacidade de 2.000 litros cada, recebiam água para aliviar a pressão da linha principal de abastecimento que partia diretamente das bombas. Nos momentos em que a vazão de consumo superava a vazão de alimentação, a água armazenada nos reservatórios fluía por gravidade para a rede de abastecimento. Se a vazão de alimentação superasse a vazão de consumo os reservatórios enchiam e transbordavam, com a água retornando para o rio Tâmisa. Este sistema evitava que as tubulações de madeira fossem danificadas pela alta pressão da água em situações de baixo consumo de água. ${ }^{10}$ Para Barton (2007) parece claro que outras torres de água deste tipo para abastecimento

\footnotetext{
${ }^{8}$ Fato curioso é que a York Buildings Waterworks Company era uma empresa tecnologicamente avançada para a sua época. Foi a primeira empresa a tentar utilizar motores a vapor para bombeamento de água, instalando em 1713 uma das primeiras bombas hidráulicas a vapor patenteadas por Thomas Savery e posteriormente, em 1725, a máquina atmosférica de Newcomen para bombear água para o reservatório de Marylebone. Ambas as tentativas falharam pois se mostraram muito dispendiosas em termos de combustível (carvão) e sofriam com quebras frequentes, sendo substituídas em definitivo por bombas movidas por cavalos por volta de 1731. Ver TOMORY, 2017, op. cit., p. 116-117.

9 WEINREB, Ben; HIBBERT, Christopher. The London Encyclopaedia. London: Macmillan, 1995, p. 1002.

10 TOMORY, 2017, op. cit., p. 165.
} 


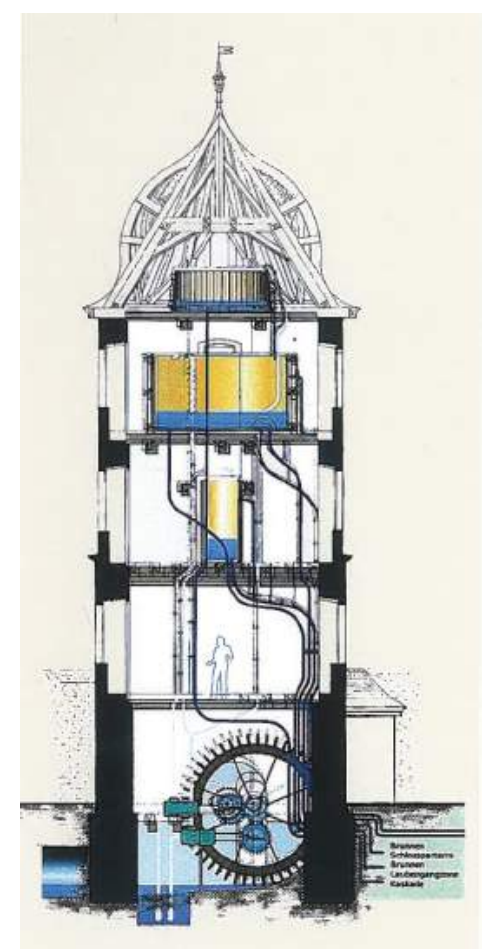

2.2 .8

Corte da "estação hidráulica" do Hofgarten Veitshöchheim, Alemanha, 1767 . público tenham existido durante os séculos XVII e XVIII, mas não foram registradas uma vez que tratavam-se, essencialmente, de estruturas utilitárias e efêmeras.

No Palácio de Veitshöchheim, Alemanha, foi edificada por volta de 1767 uma "estação hidráulica" para abastecer os chafarizes, fontes e cascatas de seu jardim, o Hofgarten Veitshöchheim, construído entre os anos de 1702 e 1780. A edificação em formato de torre (fig. 2.2.8), com aproximadamente 20 metros de altura, possuía três reservatórios elevados em seu interior, localizados em diferentes alturas, garantindo a pressão de água adequada para cada uma das fontes e chafarizes que abastecia. Um sistema de bombas impulsionadas por uma roda de água conduzia, por meio de tubos de chumbo, a água armazenada em um reservatório enterrado para cada um dos reservatórios elevados. Com capacidade total de $45 \mathrm{~m}^{3}$ os reservatórios, fabricados em madeira e revestidos internamente com folhas de cobre, eram reforçados externamente com hastes de ferro fundido. Quando todos os reservatórios estavam cheios, válvulas eram acionadas e a água fluía por gravidade pelas tubulações de chumbo até as fontes e chafarizes do jardim. ${ }^{11}$

A Philadelphia Waterworks, construída por volta de 1800, é outro exemplo de "estação hidráulica" que incorporou reservatórios elevados de água em conjunto com o sistema de bombeamento. No corte do edifício, figura 2.2.9, estão representados dois tanques cilíndricos de madeira, com um volume total de $80 \mathrm{~m}^{3}$, apoiados em um vigamento de madeira de malha bem fechada, posicionado bem acima das bombas. Para Werth (1971) é provável que a utilização de dois tanques menores ao invés de um tanque único de maior capacidade indique a impossibilidade de se fabricar tanques de maiores dimensões com a tecnologia da época.

11 GÜRZ, Dieter. Teilsperrungen in der Tiergartenstrasse: Ursache ist der Sanierungsbedürftige Historische Wasserkanal aus dem Veitshöchheimer Hofgarten. 2014. Disponível em: <http://www.veitshoechheim-blog.de/articlestra-ensperrma-nahmen-in-der-tiergartenstra-e-ursache-ist-der-historischeabwasserkanal-aus-dem-vei-124446195.html>. Acesso em: 25 nov. 2018. 
2.2 .9

Philadelphia Waterworks, 1800.

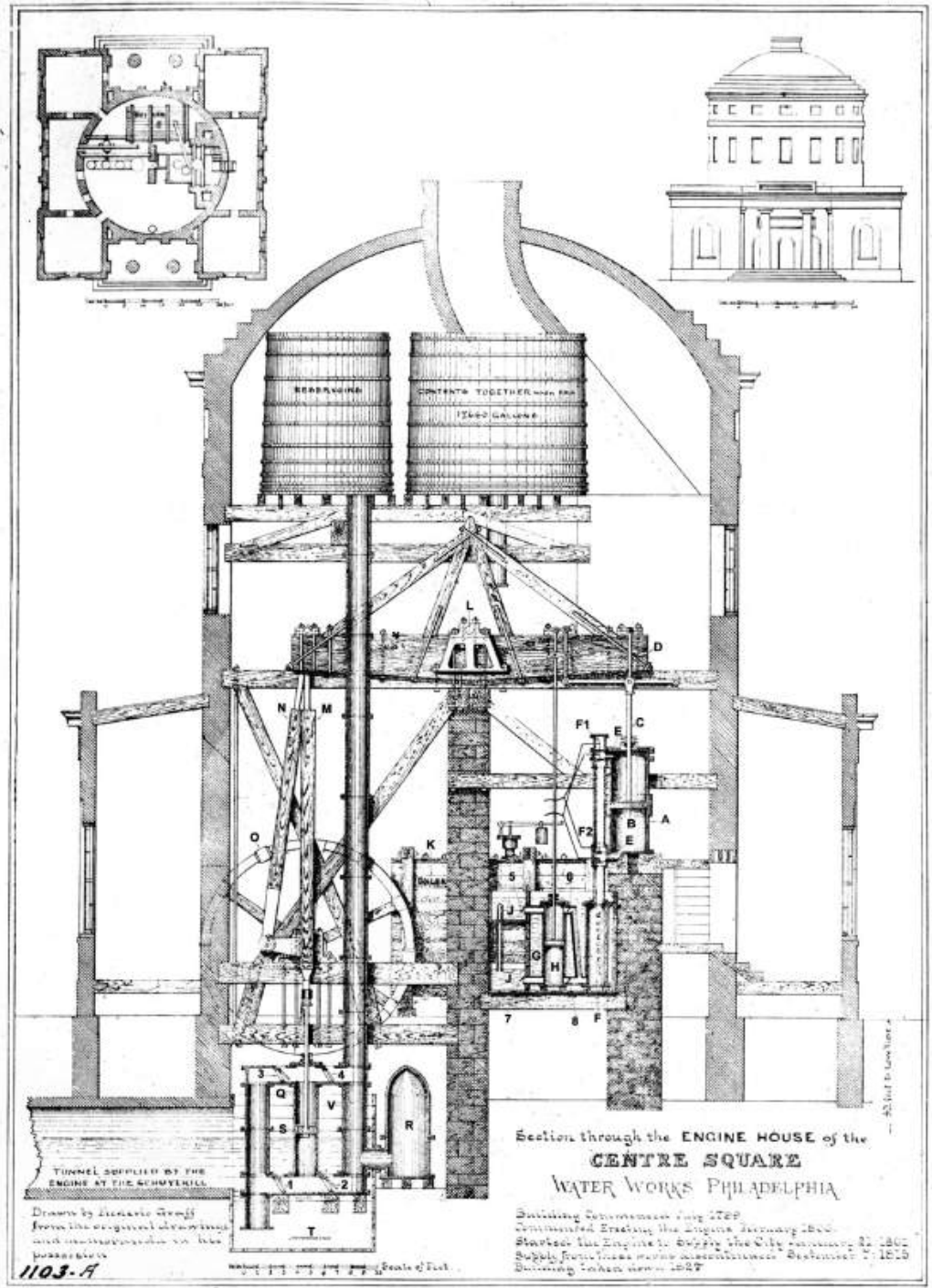

Os tanques de madeira apresentavam, além da baixa resistência mecânica, problemas de selagem permanente das juntas, baixa durabilidade e a água armazenada em seu interior adquiria mau gosto após algum tempo de armazenamento, assim como ocorria com a água potável armazenada em barris de madeira. armazenamento da água em tanques de chumbo representava um perigo à saúde, fato conhecido pelos romanos desde o século I a.C.. Assim, para se construir reservatórios adequados para o armazenamento de água potável seria necessário encontrar materiais apropriados, que aliassem longa vida útil, impermeabilidade e não afetassem o gosto, cor ou salubridade da água armazenada.

A grande desvantagem das primeiras "estações hidráulicas" era a sua insegurança operacional que, aliada à baixa capacidade de armazenamento dos seus reservatórios de água causava 
interrupções constantes no abastecimento de água. ${ }^{12} \mathrm{~A}$ insegurança operacional era fruto da quebra frequente das máquinas de bombeamento e da falta de máquinas e peças de substituição. As máquinas, fabricadas em materiais de baixa resistência mecânica e durabilidade como a madeira e o latão, apresentavam rápido desgaste de suas peças o que demandava um ciclo frequente de manutenção nos equipamentos.

As condições para solucionar estes problemas surgem com o desenvolvimento de novos materiais e máquinas com o início da era tecnológica no século XVIII, que formou a base técnica e material para o futuro desenvolvimento das torres de água. Foi também durante o século XVIII que a análise estrutural como conhecemos hoje começou a ser desenvolvida e utilizada para avaliar a segurança dos edifícios existentes e para auxiliar no projeto de novos edifícios. ${ }^{13}$ Os avanços no campo da fabricação de ferro e as invenções do motor a vapor e dos tubos de ferro fundido foram fundamentais para o desenvolvimento dos modernos sistemas centralizados de abastecimento de água que seriam criados em meados do século XIX.

Embora a produção de ferro fosse conhecida desde a Antiguidade, até meados do século XVIII não era possível produzilo em quantidade suficiente para que pudesse ser utilizado em larga escala como material de construção. Com as modificações introduzidas na Inglaterra durante o século XVIII (o uso do coque no lugar do carvão vegetal, por Abraham Darby em 1718, e o processo de conversão do ferro de coque em ferro maleável no forno revérbero, por Henry Cort em 1783) houve um aumento considerável na produção de ferro e a sua utilização como material de construção se difundiu. $O$ aumento da qualidade e da produção de ferro neste período não foi só uma consequência dos novos processos de fabricação, mas também dos efeitos econômicos da

\footnotetext{
12 WERTH, 1971, op. cit., p. 333.

13 MAINSTONE, Rowland J.. Structural Analysis, Structural Insights, and Historical Interpretation. Journal Of The Society Of Architectural Historians, Oakland, v. 56, n. 3, set. 1997, p. 316.
} 
industrialização e das novas formas de utilização do material. ${ }^{14}$ Os novos métodos de fabricação do ferro asseguraram a Inglaterra, com sua grande produção de coque, um lugar de destaque entre os países produtores de ferro, material este que foi de importância fundamental em todo o processo da Revolução Industrial que se iniciava. ${ }^{15}$

Thomas Savery patenteou em 1698 uma máquina movida a vapor para drenar água das minas de carvão, a Mine's Friend Machine, aparato que não possuía partes móveis e valia-se do vácuo gerado no interior da máquina para elevar a água existente no fundo das minas. Em 1712 foi desenvolvida a máquina atmosférica, por Thomas Newcomen, uma evolução da máquina de Savery, que utilizava o vapor de água para impulsionar um êmbolo num cilindro e depois uma alavanca que permitia a movimentação dos pistões das bombas de sucção de água. A primeira máquina de Newcomen foi construída próxima ao Castelo de Dudley, Inglaterra, para bombear a água das minas de carvão existentes na propriedade de Lord Dudley e logo passou a ser utilizada, em larga escala, para a drenagem das diversas minas inglesas. O motor atmosférico também encontrou utilidade nos sistemas de abastecimento de água de cidades como, por exemplo, Londres, nas instalações de bombeamento das empresas York Buildings Waterworks Company (1725) e Chelsea Waterworks (ca. 1750), entre outras. Mas foi em 1767, com a introdução do motor a vapor desenvolvido por Thomas Watt, que foi encontrado um substituto muito mais adequado para os motores movidos por força muscular, eólica ou hidráulica, um equipamento muito mais potente, com maior confiabilidade operacional e cuja eficiência de combustível era estimada como sendo em quase o dobro da eficiência energética das máquinas de Newcomen. O motor a vapor de Watt era adequado para uma grande variedade de tarefas técnicas e passou a ser utilizado em larga escala para movimentar os maquinários de fundições, minas

\footnotetext{
${ }^{14} \mathrm{KÜHL}$, Beatriz Mugayar. Arquitetura do Ferro e Arquitetura Ferroviária em São Paulo: Reflexões sobre a sua preservação. Cotia: Ateliê Editorial, 1998, p. 20; e também WERTH, op. cit., p. 334.

15 Ibidem.
} 
e fábricas, lançando uma das bases para a revolução técnica, social e industrial que se iniciava no período. O motor de Watt logo foi adaptado para uso nos sistemas de abastecimento de água. Em Paris, em 1872, foi instalado o primeiro motor a vapor de Watt para abastecimento de água, seguido por Londres (1787 e 1803), Filadélfia (1800) e Nova lorque (1804). ${ }^{16}$ A figura 2.2.10 mostra o motor a vapor de Watt construído para as instalações de bombeamento da Chelsea Waterworks Company em 1803, uma das várias companhias privadas que fornecia água para a cidade de Londres na época.

Com a introdução dos motores a vapor nos sistemas de abastecimento de água as estações de bombeamento ganharam uma grande eficiência e agora era possível estender a rede de distribuição de água para zonas mais distantes dos pontos de captação de água e também para os pontos mais elevados dos sítios, uma vez que a pressão de água no sistema poderia ser ampliada. Mas para isto seria necessário, em primeiro lugar, encontrar um material mais resistente que pudesse substituir as frágeis tubulações de madeira e de chumbo, com baixa resistência às pressões hidrostáticas, que vinham sendo utilizadas até $\mathrm{O}$ momento. As tubulações de ferro fundido seriam a resposta para o problema, uma vez que possuíam vida útil muito mais longa e uma maior resistência à pressão, aliadas a menores custos de manutenção.

Os primeiros registros históricos da utilização de tubos de ferro fundido para condução de água foram em Augsbrug, em 1412, e no Castelo de Dillenburg, em 1455. ${ }^{17}$ Em 1553, o Siebenbrunner Hofwasserleitung, um sistema de abastecimento de água para a cidade de Viena, que captava a água em ribeirões e poços nos arredores da cidade e a conduzia para o palácio imperial, mosteiros e para a fonte pública na Margarentenplatz foi construído inteiramente com tubos de ferro fundido. Em 1644 foi construída na França, com tubos de ferro fundido de 200 mm de

\footnotetext{
${ }^{16}$ WERTH, 1971, op. cit., p. 334.
}

17 BAUR, 1985, op. cit., p. 23. 


\subsubsection{0}

Motor a vapor de Watt para bombeamento de água instalado na Chelsea Waterworks, Londres, 1803. diâmetro, uma linha adutora que transportava a água captada pela estação de bombeamento Marly-sur-Seine para abastecer o Palácio de Versailles com suas fontes e jardins. Com $22 \mathrm{~km}$ de extensão a adutora era a maior linha de tubos da época e parte desta tubulação permanece em serviço ainda hoje. ${ }^{18}$

Os tubos de ferro fundido começam a ser utilizados em larga escala durante o século XVIII, quando Isaac Wilkinson conseguiu produzir as primeiras peças fundidas com paredes finas utilizando moldes de areia utilizando o ferro de coque de Darby. Em 1758 Wilkinson patenteou um método para a fabricação de peças tubulares. Por volta de 1790 fundições como, por exemplo, a Gräflich Eisiendelnsche Eisenwerk na Alemanha, já produzia tubos de ferro fundido flangeados com diâmetros de 75, 100 e 125 mm, aptos a suportar pressões de até 65 m.c.a.. ${ }^{19}$

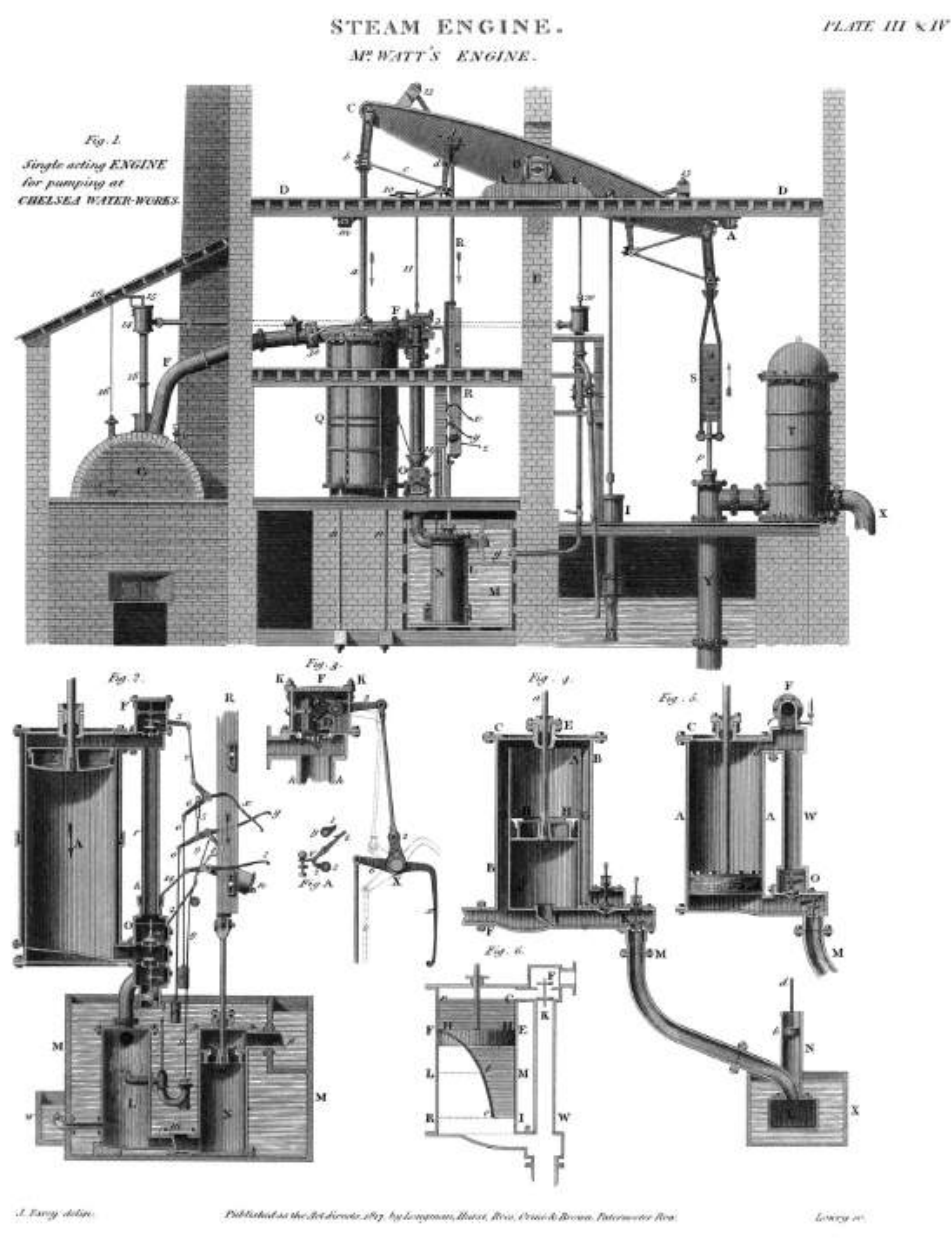

18 NETTO, José Martiniano de Azevedo. Cronologia do Abastecimento de Água (até 1970). Revista D.A.E.: Revista do Departamento de Águas e Esgotos, São Paulo, v. 44, n. 137, p. 106-111, jun. 1984, p. 107.

${ }^{19}$ BAUR, 1985, op. cit., p. 23. 


\subsection{Torres de Água no Século $X I X$}

\subsubsection{O papel das Ferrovias no Desenvolvimento das Torres de Água}

Ainda que as torres de água tenham seus precursores nos reservatórios elevados geradores e reguladores de pressão de água das "estações hidráulicas", faltavam a estes reservatórios uma função essencial, faltava a capacidade de armazenamento de água. ${ }^{1}$ Conforme explicado na primeira parte do presente trabalho, a função do armazenamento de água nos sistemas de abastecimento é a de manter o equilíbrio entre as demandas de entrada e de consumo de água. Em meados do século XIX picos de consumo de água associados às necessidades flutuantes de água surgiriam em vários setores e, inicialmente, no recém-criado setor ferroviário.

Em 1825, na Inglaterra, foi inaugurada a Stockton \& Darlington Railway, a primeira ferrovia pública do mundo a operar serviços de transporte de carga com a utilização da locomotiva a vapor, inventada pelo britânico George Stephenson em 1814. A Liverpool \& Manchester Railway, inaugurada pouco depois, em 1830, foi a primeira ferrovia a operar exclusivamente com locomotivas tracionadas a vapor tanto para o transporte de carga quanto para o transporte de passageiros, concebida com via dupla em toda a sua extensão e com itinerários e horários fixos determinados. desenvolvimento ferroviário na Inglaterra foi muito intenso entre os anos de 1830 e 1850, tendo sido construídos mais de 10.000 km de linhas férreas, período que ficou conhecido como Railway Mania. ${ }^{2}$ Em 1850 praticamente todas as cidades inglesas possuíam pelo menos uma estação de trem. Neste mesmo período outros países também iniciaram a construção de ferrovias como, por exemplo, Bélgica (1835) e Alemanha (1839). Em 1850 a Alemanha já contava com uma malha ferroviária de mais de $5.400 \mathrm{~km}$.

\footnotetext{
1 WERTH, Jan. Ursachen und technische Voraussetzungen für die Entwicklung der Wasserhochbehälter. In: BECHER, Bernhard; BECHER, Hilla. Die Architektur der Förder und Wassertürme. München: Prestel-verlag, 1971, p. 335.

2 Hoje a malha ferroviária inglesa totaliza aproximadamente $16.000 \mathrm{~km}$. As ferrovias inglesas se desenvolveram com intensidade impressionante durante o século XIX, em um curtíssimo espaço de tempo de apenas 20 anos.
} 
O súbito estabelecimento das ferrovias na Europa criou novas e grandes demandas no fornecimento de água para as novas instalações ferroviárias, que não se limitavam apenas à água para consumo nas estações, oficinas, galpões e para a limpeza dos carros mas, especialmente, para alimentação das caldeiras das locomotivas, uma vez que a água é tão essencial para o funcionamento das máquinas a vapor quanto o carvão. Na época, as locomotivas a vapor consumiam em média noves vezes mais água do que carvão. O reabastecimento das locomotivas com água tinha que ser feito durante as rápidas paradas nas estações de trem. Para o abastecimento de uma única locomotiva era necessária uma vazão de água de $3-6 \mathrm{~m}^{3} / \mathrm{min}$., vazão que permitia encher a caldeira da máquina e de seus rebocadores em alguns minutos. As locomotivas tinham caldeiras com capacidades que variavam entre 3-5 $\mathrm{m}^{3}$, enquanto que os rebocadores tinham tanque com volumes variando entre 8-15 $\mathrm{m}^{3}{ }^{3}$ Dependendo da frequência da estação, várias locomotivas eram abastecidas com água ao mesmo tempo.

Era completamente impossível atender às demandas de abastecimento de água das locomotivas contando com a água fornecida pelas instalações públicas de água e desde o início as autoridades ferroviárias deram preferência a um sistema de abastecimento de água independente, com o objetivo de evitar interrupções nas operações e viagens de trens no caso de falhas no fornecimento público de água. Este sistema independente de abastecimento deveria garantir o equilíbrio entre as demandas de entrada e de saída de água, garantir uma segurança de água adicional em caso de emergências e ainda permitir que a água pudesse ser retirada a qualquer momento, sem prejuízo de outras retiradas que afetassem as demais operações ferroviárias. ${ }^{4}$

Todas estas exigências técnicas e funcionais poderiam ser atendidas de uma maneira: com a criação de um reservatório de

\footnotetext{
${ }^{3}$ WERTH, 1971, op. cit., p. 335.

${ }^{4}$ BAUR, Albert. Historiche Entwicklung der Wasserspeichrung. In: MERKL, Gerhard et al. Historische Wassertürme: Beiträge zur Technikgeschichte von Wasserpeicherung und Wasserversorgung. München: Oldenburg Verlag, 1985, p. 25.
} 

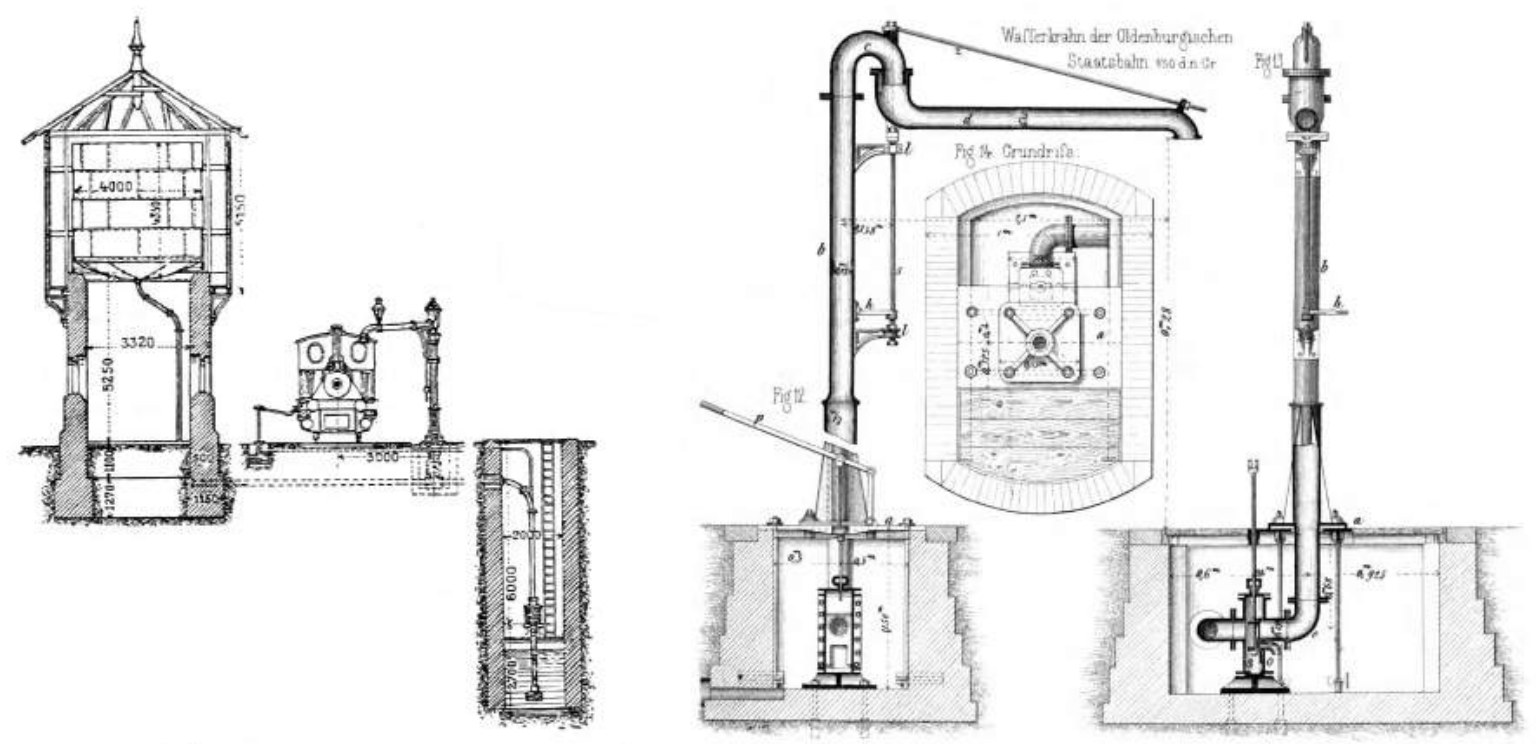

2.3.1

Estação de Água Ferroviária.

2.3.2

Grua Hidráulica da Ferrovia de Oldenburg, Alemanha, ca. 1850. água instalado sobre uma subestrutura semelhante a uma torre, posicionado junto aos trilhos de maneira que pudesse abastecer as caldeiras das locomotivas. Assim surgiram as "estações de água" das ferrovias (fig. 2.3.1), torres de água com reservatórios dimensionados para atender às necessidades diárias de uma estação ferroviária, acrescidos de uma margem de segurança de 25\%, nas quais a água armazenada, fluindo por gravidade com pressão e vazão constantes, poderia ser retirada sempre que necessário. A grande vazão requerida para um rápido abastecimento das caldeiras das locomotivas era viabilizada pela utilização de tubulações de grande diâmetro (cerca de 200 mm), as chamadas "gruas hidráulicas", conectados aos reservatórios elevados das estações de água (fig. 2.3.2). A altura dos reservatórios era determinada pela pressão necessária nas "gruas hidráulicas" e, geralmente, variava entre 5 a 10 metros acima do nível dos trilhos. ${ }^{5}$ Torres com alturas maiores era eventualmente utilizadas quando não era possível construir próximo a via férrea, de modo a compensar a perda de carga devido ao maior distanciamento entre os trilhos e o reservatório elevado. As "estações de água" se espalharam ao longo das linhas ferroviárias europeias, posicionadas em intervalos regulares de modo a garantir um reabastecimento de água das locomotivas em tempo útil, evitando a interrupção de operação da máquina por falta de água. Sempre que possível as "estações de água" eram

${ }^{5}$ WERTH, 1971, op. cit., p. 335. 


\subsection{3}

Reservatório retangular de ferro fundido.
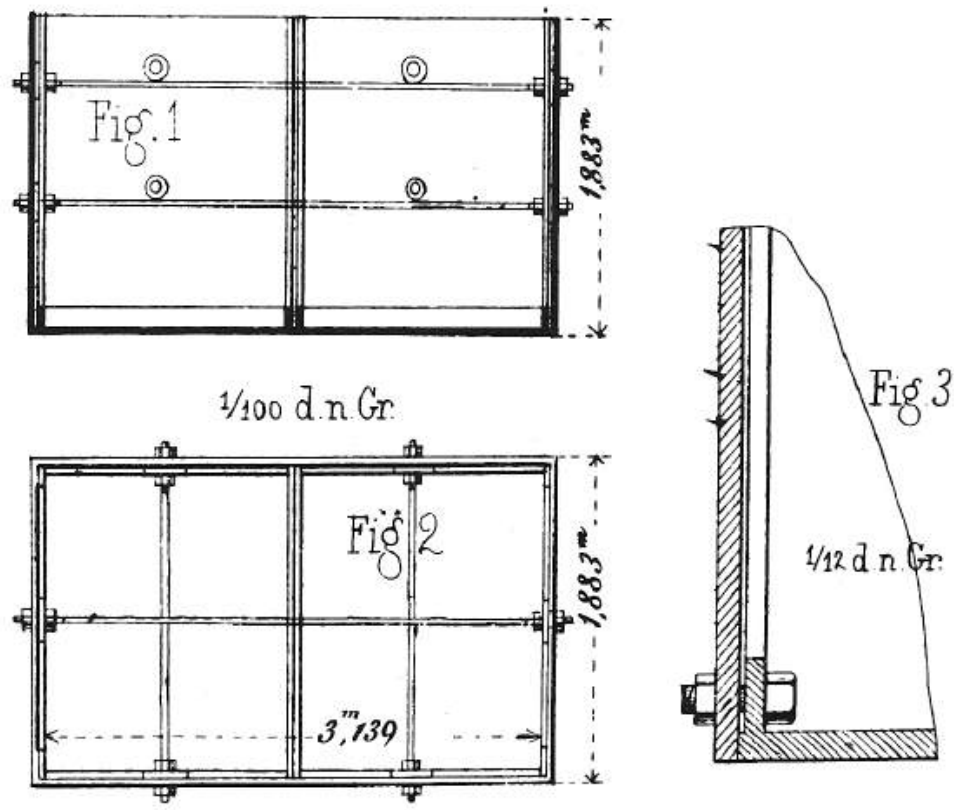

construídas junto das estações de trem, onde as paradas dos trens ocorreriam necessariamente.

Estas primeiras torres de água das ferrovias que foram construídas na Inglaterra a partir de 1830 eram simples reservatórios retangulares de ferro fundido com fundo plano, apoiados em uma subestrutura fechada de alvenaria de pedra ou de tijolos. ${ }^{6}$ A figura 2.3.3 mostra o detalhe construtivo de um destes reservatórios. O reservatório, com volume de $10 \mathrm{~m}^{3}$, foi construído com placas individuais de ferro fundido com flanges em suas bordas que permitiam a união das placas. A união das placas era feita com parafusos, pois a natureza quebradiça do ferro fundido impossibilitava a utilização de rebites metálicos. A vedação entre as placas era obtida com a inserção de tiras de vedação, previamente instaladas, que preenchiam as juntas ao se apertar os parafusos. Embora as flanges aumentassem a resistência à flexão das placas de ferro fundido, o conjunto de paredes planas oferecia pouca resistência à pressão hidrostática lateral, por isso era necessário realizar o travamento das paredes com tirantes de ferro que atravessam o interior do tanque de uma parede até a outra. O fundo plano do reservatório também era submetido a grandes esforços de flexão e era necessário utilizar suportes intermediários

6 Ibid., p. 336. 
de maneira a reduzir o vão livre do fundo do reservatório. Estes suportes consistiam de vigas de ferro fundido ou ferro laminado apoiadas nas paredes da subestrutura que, em muitas ocasiões, eram substituídas por antigos trilhos de trem.

A figura 2.3.4 mostra um conjunto de fotografias de torres de água das ferrovias inglesas construídas em meados do século XIX, sendo que algumas destas são da primeira geração de "estações de água" ferroviárias que sobreviveram até os dias de hoje como, por exemplo, nas estações Curthwaite, em Cumbria (1843), Charfield, em Avon (1844) e nas oficinas da York \& North Midland Railway, em York (1839), ${ }^{7}$ esta última servindo de protótipo para as demais torres de água que foram construídas ao longo desta ferrovia pela empresa York \& North Midland. As maciças e cuidadosamente detalhadas subestruturas de alvenaria destas torres de água eram desenhadas para se adequar ao estilo arquitetônico do edifício da estação adjacente a elas e os seus reservatórios metálicos, sempre aparentes, também recebiam elementos decorativos aplicados nas faces dos painéis de ferro fundido.

As companhias ferroviárias inglesas e francesas privilegiavam a construção das torres de água de maneira independente dos demais edifícios da ferrovia enquanto que no caso das ferrovias alemãs, por outro lado, adotou-se inicialmente a premissa de se construir as torres de água em conjunto com os demais edifícios das estações. Neste último caso os reservatórios elevados eram instalados no sótão de um edifício (figs. 2.3.5, 2.3.6) que abrigava outras funções em seu embasamento como, por exemplo, oficinas ou apartamentos para funcionários da ferrovia. ${ }^{8}$

No entanto, quando as condições de operação da ferrovia exigiam a armazenagem de grandes volumes de água era geralmente adotada a solução de construção de grandes reservatórios metálicos apoiados sobre estruturas semelhantes

\footnotetext{
7 BARTON, Barry. Water Towers of Britain. Londres:

Newcomen Society, 2003, p. 131-132.

${ }^{8}$ WERTH, 1971, op. cit., p. 335.
} 


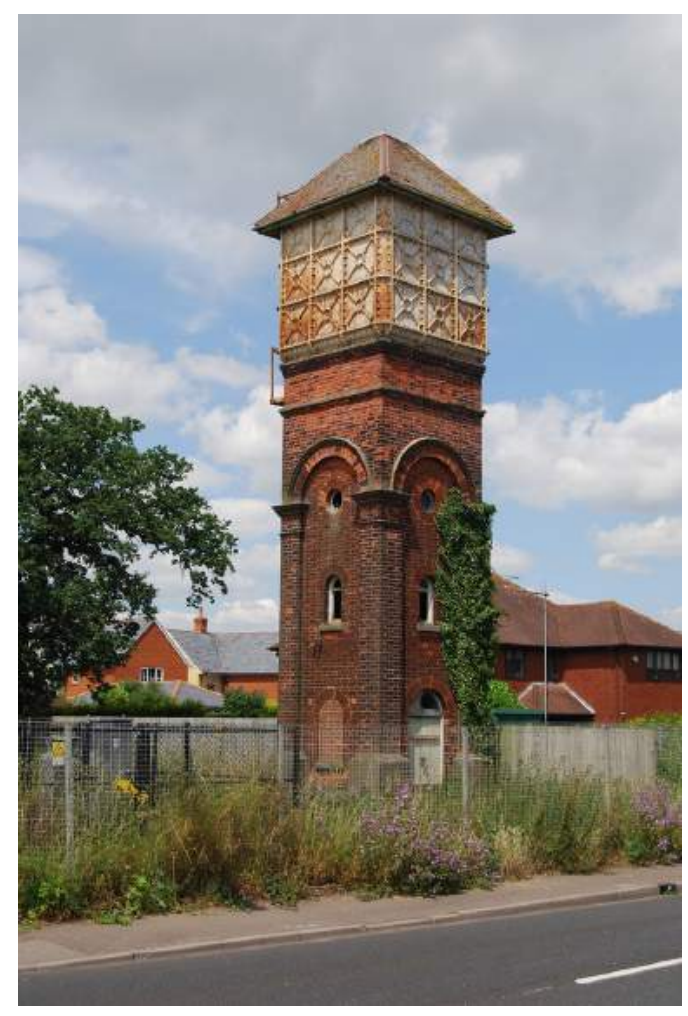

2.3.4

Estações de Águas das Ferrovias Inglesas.
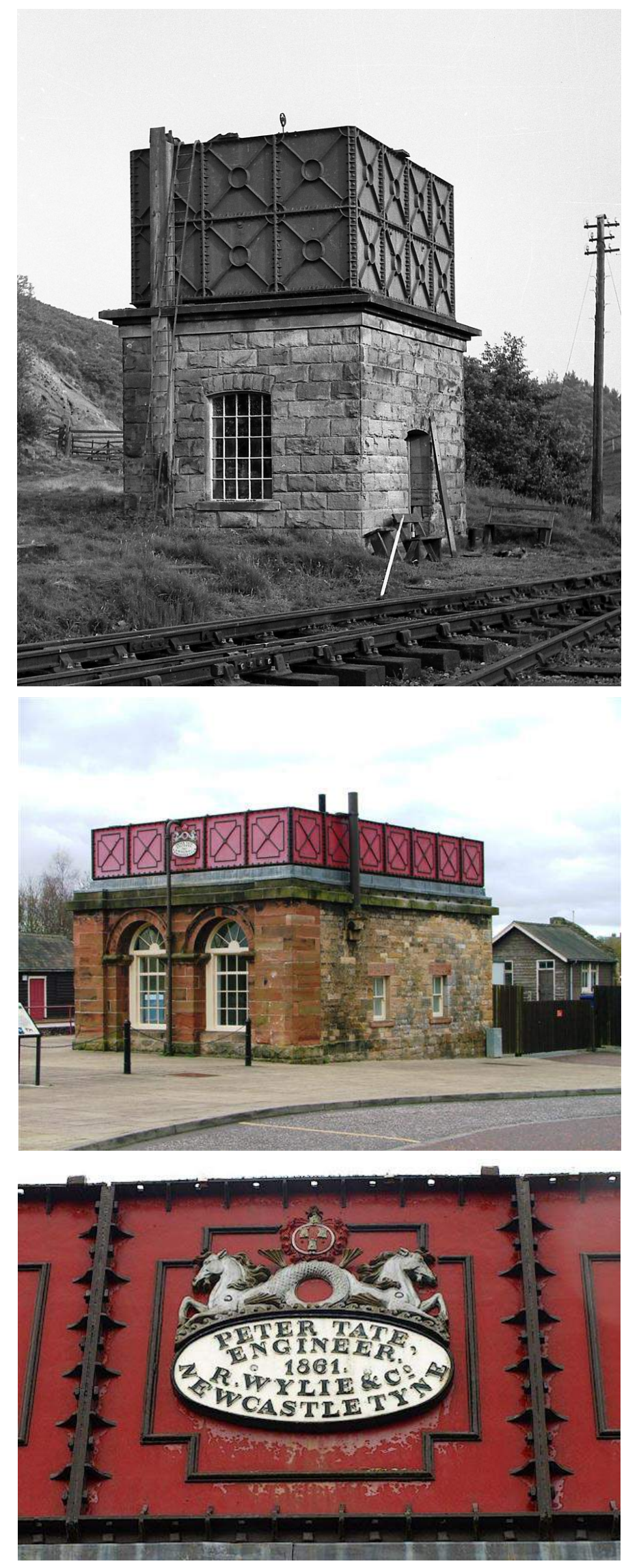


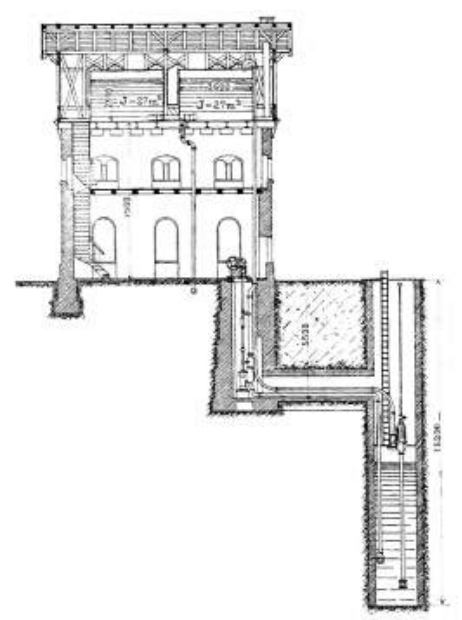

2.3.5

Corte de Estação de Água das Ferrovias Alemãs.

\subsection{6}

Corte de Estação de Água das Ferrovias Alemãs.

a) Estação KaiserslauternEisiedlerhof.

b) Estação Volksmarsen-Hessen. a torres, com plantas circulares ou poligonais. Conforme Werth (1971), principalmente na França e na Alemanha, era comum cobrir e revestir externamente os reservatórios metálicos com um fechamento de madeira ou alvenaria com o objetivo de proteger a água armazenada contra o congelamento nos meses de inverno (figs. 2.3.5, 2.3.6) de modo que, externamente, nenhuma característica do edifício apontasse para a função de um reservatório elevado de água. Como colocado na primeira parte desse trabalho, o congelamento da água nos reservatórios está ligado ao volume de água armazenado, a retirada da água em intervalos irregulares e também ao seu armazenamento por longos períodos de tempo. Além do revestimento externo era comum a instalação de um sistema de pré-aquecimento da água, com a utilização de fornos de carvão abaixo do tanque que, por meio de um sistema de tubos instalados dentre do reservatório, aquecia a água armazenada por meio da circulação de água quente. Em muitos casos a chaminé do forno atravessava o reservatório em altura, liberando calor na água armazenada.

É curioso notar que nos reservatórios metálicos aparentes das estações de água inglesas, sem qualquer tipo de revestimento ou mesmo cobertura, o congelamento da água era evitado apenas com a utilização dos sistemas de aquecimento da água, o que sugere que o revestimento dos reservatórios das torres de águas das ferrovias francesas e alemãs poderia ter também uma função estética, como veremos mais adiante.
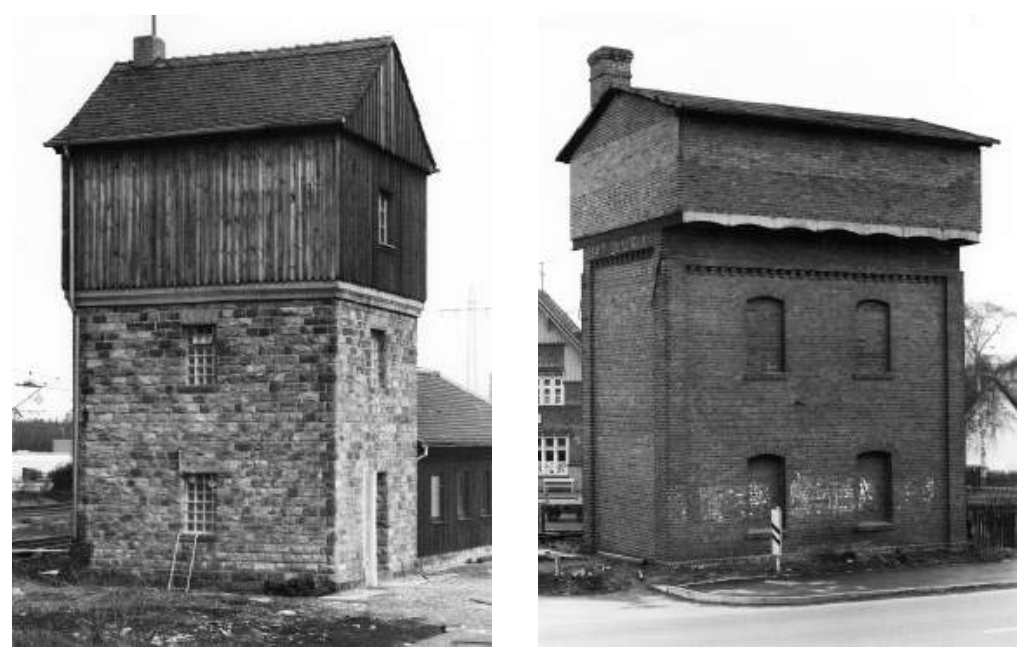


\subsubsection{Torres de Água para Abastecimento Público}

A Revolução Industrial, iniciada em meados do século XVIII na Inglaterra, se espalhou em poucas décadas para os demais países europeus gerando, para além da mecanização dos sistemas de produção e do aumento da produção industrial, um aumento da população urbana. Este crescimento demográfico se acelerou por duas razões: a necessidade de mão de obras nas indústrias, que seria suprida em parte pela migração dos trabalhadores do campo, e também pela diminuição das taxas de mortalidade, causada sobretudo por melhorias de ordem higiênica: melhor alimentação, melhor higiene, melhores moradias e progressos na medicina. ${ }^{9}$

Por volta de metade do século XVIII a Inglaterra possuía cerca de 6,5 milhões de habitantes; em 1801 sua população já era de aproximadamente 8,9 milhões e, em 1831, já contabilizava 14 milhões de habitantes. ${ }^{10} \mathrm{Na}$ Europa continental, a explosão populacional também foi rápida: no início do século XIX, a população europeia era de 187 milhões de habitantes, em meados do século já contabilizava 266 milhões e, em 1900, eram 420 milhões. ${ }^{11}$

Com o aumento da industrialização e $\circ$ incremento demográfico a população das cidades começou a sofrer com condições sanitárias muito desfavoráveis. Houve um aumento significativo da poluição dos rios pelos dejetos industriais e pelo volume cada vez maior de efluentes sanitários que eram despejados nos rios e córregos sem qualquer tipo de controle ou tratamento. A falta de redes de esgotos sanitários nas cidades agravou ainda mais a situação: as águas servidas se infiltravam no subsolo ou fluíam por canais abertos até os rios e córregos da cidade e, em muitos casos, pilhas de dejetos de pessoas e animais se acumulavam nas ruas. A contaminação do solo por poluentes industriais e fezes atingia também os lençóis freáticos. Para o abastecimento de água, a população das cidades contava apenas com os recursos das

\footnotetext{
9 BENEVOLO, Leonardo. História da Arquitetura Moderna. 5. ed. São Paulo: Perspectiva, 2017, p. 21.

10 lbidem.

${ }^{11}$ MIGNOT, Claude. L'Architecture au XIXe Siècle. Paris: Moniteur, 1983, p. 8.
} 
poucas fontes públicas alimentadas por antigos aquedutos, poços domésticos, vendedores de água e a água cada vez mais poluída dos rios, esta última sujeita ainda a variação sazonal da oferta de água, o que agravava ainda mais a situação do abastecimento nas épocas de estiagem. Além da falta de água as cidades sofriam ainda com o risco crescente de epidemias de doenças transmitidas pela água, como a cólera. ${ }^{12} \mathrm{~A}$ população das cidades sabia que a qualidade da água que thes era oferecida deixava a desejar, mas desconhecia a extensão total dos riscos que esta água oferecia à sua saúde. O papel da qualidade da água na saúde pública só transpareceu de fato quando a transmissão de doenças por meio da água contaminada foi comprovada cientificamente em meados do século XIX.13

Os sistemas de abastecimento de água em operação no período da Primeira Revolução Industrial não eram capazes de atender o crescimento vertiginoso da demanda por água potável. A população das cidades estava interessada em obter a água necessária para as suas necessidades domésticas com boa qualidade e o mais próximo possível do local de consumo. Os setores industrial e comercial também contribuíram significativamente para o aumento da demanda por água, uma vez que necessitavam de um serviço de abastecimento confiável que garantisse um fornecimento contínuo e ininterrupto de água, para evitar perdas na produção, e também uma reserva adequada de água para combate a incêndios.

Os incêndios também se tornaram um grande problema no período. Foi somente após as perdas cada vez maiores de vidas humanas, do patrimônio construído e da produção industrial causadas por incêndios, nas cidades densamente povoadas, é que foram tomadas as medidas necessárias para se combater 0 problema. ${ }^{14}$ Entre 1130 e 1666 a cidade de Londres sofreu com

\footnotetext{
${ }^{12}$ WERTH, 1971, op. cit., p. 339; e também GRAY, Harold Farnsworth. Sewerage in Ancient and Medieval Times. Sewage Works Journal, Alexandria, v. 12, n. 5, p.939-946, set. 1940.

${ }^{13}$ MAGNUSSON, Roberta J.. Water Technology in the Middle Ages: Cities, Monasteries, and Waterworks after the Roman Empire. Baltimore: Johns Hopkins University Press, 2001, p. 172.

${ }^{14}$ WERTH, 1971, op. cit.
} 
pelo menos 12 grandes incêndios, ficando conhecida como "barril de pólvora da Europa". Em 1842 a cidade de Hamburgo sofreu com um incêndio devastador que deixou um terço da cidade em ruínas, destruindo 4.000 casas, 1.700 edifícios residenciais, 100 armazéns, 60 escolas e edifícios públicos e, inclusive, as três estações de bombeamento de água existentes. O fogo deixou 20.000 pessoas desabrigadas e provocou 51 mortes.

A demanda crescente por água potável, fruto da explosão populacional nas cidades industriais aliada às novas necessidades de higiene, industriais e de combate a incêndios desencadeou o desenvolvimento dos modernos sistemas de abastecimento de água que seriam implantados nas cidades da Europa. Em um curto período de tempo uma grande quantidade de cidades industriais britânicas como, por exemplo, Leeds (1837), Bradford (1844), Manchester, Glasgow, Sheffield e Dundee (1845), Bristol e Newport (1846), Liverpool, Edimburgo e Leicester (1847) iniciaram a implantação de seus próprios sistemas de abastecimento de água. ${ }^{15}$ Grandes cidades como Hamburgo (1848), Berlim (1852) e Paris (1865), ${ }^{16}$ também iniciaram a implantação de modernos sistemas centralizados públicos de abastecimento de água potável que operariam com fluxo contínuo, atendendo assim a demanda crescente de seus moradores por uma água potável de qualidade.

Os primeiros sistemas de abastecimento público de água das grandes capitais europeias foram influenciados em grande parte pelo sistema de abastecimento de Londres que, desde meados do século XVII, contava com um grande número de companhias de abastecimento privadas que retiravam a água dos rios e de outras fontes para abastecimento da cidade. No início do século XIX, cerca de $75 \%$ das residências londrinas eram abastecidas com a água fornecida por uma série de companhias privadas de

\footnotetext{
${ }^{15}$ BARTON, 2003, op. cit., p. 25.

${ }^{16} \mathrm{O}$ engenheiro francês Eugène Belgrand (1810-1878) foi o responsável pela elaboração dos projetos para o sistema centralizado de abastecimento de água e pelo novo sistema de esgoto sanitário da cidade de Paris, ambos implantados durante gestão do prefeito Georges-Eugène Haussmann (1809-1891), entre os anos de 1853-1870, que realizou grandes transformações na capital francesa.
} 
abastecimento, fazendo de Londres a metrópole com o melhor sistema de abastecimento de água do mundo. ${ }^{17} \mathrm{O}$ sistema londrino, porém, apresentava uma série de problemas: o rio Tâmisa, sua principal fonte de água, estava cada vez mais poluído com rejeitos industriais e com os efluentes do esgoto doméstico que eram despejados no rio sem qualquer tipo de controle ou tratamento; o sistema de abastecimento de água tinha fluxo intermitente, com os bairros recebendo água apenas em determinados dias da semana, operando em um sistema de rodízio; a baixa pressão hidrostática do sistema garantia água apenas para o pavimento térreo das edificações, deixando de atender os andares superiores dos novos edifícios residências e industriais multipisos; as águas poluídas dos rios e a falta de um sistema de esgoto sanitário foram responsáveis por duas grandes epidemias de cólera, uma em 184849 e outra em 1853-54. ${ }^{18}$ Estes problemas do sistema londrino de abastecimento de água seriam sanados somente em 1902, quando o governo estatizou todas as companhias de água e as reuniu em uma única empresa a Metropolitan Water Board, centralizando o abastecimento e estabelecendo o fluxo contínuo de água para todas as áreas da cidade como padrão de funcionamento. A tecnologia desenvolvida pelos ingleses ao longo de dois séculos, no entanto, foi exportada para as grandes capitais da Europa, junto com o conhecimento técnico ligado aos sistemas de abastecimento de água. O engenheiro inglês William Lindley (1808-1900), ${ }^{19}$ por exemplo, foi contratado em 1848 para projetar o sistema de abastecimento de Hamburgo. Berlim, em 1852, contratou a companhia inglesa Fox and Frampton para abastecer a cidade com água potável.

\footnotetext{
17 TOMORY, 2017, op. cit., p. 237-250.

18 BARTON, 2003, op. cit., p. 24; e também MAGNUSSON, 2001, p. 172.

19 William Lindley projetou sistemas de abastecimento de água e esgoto sanitário para mais de 30 cidades europeias como, por exemplo, Frankfurt, Dusseldorf, Praga, Moscou, São Petesburgo, Varsóvia e Budapeste. Em 1842, após o grande incêndio da cidade de Hamburgo, Lindley se tornou membro da Comissão Técnica responsável pela reconstrução do centro da cidade, juntamente com Alexis Chateauneuf e Gottfried Semper.
} 
Durante o século XIX a infraestrutura da água das cidades europeias foi sendo reestruturada com a implantação dos modernos sistemas centralizados de abastecimento de água e dos sistemas de esgotamento sanitário. Se em 1800 um parisiense de classe média obtinha a água para consumo doméstico em uma fonte pública ou poço, e tinha que transportá-la para sua casa em baldes, em 1900 as residências parisienses de classe média já possuíam cômodos sanitários ligados a um sistema de esgoto e eram abastecidas com água potável encanada, que poderia ser retirada da torneira sempre que necessário e na quantidade desejada, fornecida por meio de uma rede centralizada de abastecimento público. Sigfried Giedion, em Mechanization Takes Command, descreve a "revolução da água" que tomou conta das cidades europeias a partir de meados do século XIX:

"Durante a segunda metade do século, as cidades em todos os lugares começaram a ser alimentadas com água por toda a sua extensão. Água corrente entrou pela primeira vez no porão, em seguida nos andares e finalmente em cada apartamento. Palavras são muito estáticas. Apenas um filme poderia retratar o avanço da água através do organismo da cidade, o seu salto para os andares mais elevados, a sua distribuição para a cozinha e finalmente para o banheiro. ${ }^{\prime 20}$

No final do século XIX a maioria das cidades europeias já haviam implantado sistemas públicos centralizados de abastecimento de água. A introdução destes sistemas alterou radicalmente a relação do homem da cidade com a água. A água não mais precisava ser transportada de um poço, fonte pública ou rio para o interior das residências, representando assim uma grande economia de tempo e também diminuindo consideravelmente os riscos de contaminação da água. A disseminação dos sanitários privativos nas residências elevou a qualidade da higiene pessoal, estabeleceu novos padrões de privacidade e reconfigurou o arranjo espacial das residências praticamente definindo assim os padrões sanitários atuais.

20 GIEDION, Sigfried. Mechanization Takes Command: a contribution to anonymous history. 3. ed. New York: Oxford University Press, 1948, p. 684. 
Os sistemas pré-industriais de abastecimento de água tinham como uma de suas características principais o fornecimento intermitente de água em baixas pressões. Como estes sistemas possuíam uma capacidade bastante limitada de armazenamento de água, o fornecimento de água para os consumidores tinha de ser interrompido em ciclos diários para restabelecimento destas reservas ou ainda era necessário operá-los sob um sistema de rodízio, alimentando um bairro a cada dia por um número limitado de horas. Os modernos sistemas centralizados de abastecimento de água implantados durante as décadas de 1830 e 1840 trazia uma nova premissa para a distribuição de água: o fornecimento ininterrupto de água potável, com pressão adequada para atender até pavimentos mais elevados das edificações, tornouse a norma vigente. Manter um fornecimento contínuo de água, com capacidade suficiente para equilibrar todas as flutuações e os picos diários no consumo de água exigia sistemas com grande capacidade de armazenamento de água, característica esta que se tornou um dos fundamentos dos modernos sistemas de abastecimento. Estes sistemas, que captavam a água potável em mananciais distantes, livres da poluição das cidades industriais, armazenavam a água captada em enormes represas e grandes reservatórios de distribuição, conduzindo a água por gravidade para os centros consumidores. ${ }^{21} \mathrm{Em}$ muitos destes sistemas, tanto a captação da água quanto o seu transporte até os reservatórios de distribuição, era realizado por meio de sistemas de bombeamento de água impulsionados por motores movidos a vapor.

Os modernos sistemas centralizados de abastecimento de água desenvolvidos durante a década de 1840 lançaram as bases para os sistemas de abastecimento de água da atualidade. Os sistemas de abastecimento contemporâneos diferem dos sistemas de meados do século XIX apenas na questão tecnológica e material, pois empregam máquinas e equipamentos mais avançados, econômicos e eficientes; utilizam uma nova gama de materiais mais duráveis e resistentes e empregam avançadas técnicas de tratamento de água. A concepção e o funcionamento dos dois

${ }^{21}$ BARTON, 2003, op. cit., p. 25-26. 
sistemas, no entanto, é basicamente a mesma desenvolvida 170 anos atrás, tendo como seus elementos básicos: uma fonte de água bruta, um sistema de captação e transporte da água, um sistema de tratamento para tornar esta água potável, um conjunto de estruturas para armazenar a água tratada e uma rede de tubulações para distribuir esta água para os consumidores.

A capacidade de armazenamento das grandes represas criadas garantiam um suprimento constante de água limpa durante todo o ano. Além disso, estas represas e os reservatórios de distribuição, sempre apoiados sobre o solo, eram construídos em locais com uma situação topográfica favorável, isto é, em sítios mais elevados em relação às cidades, possibilitando um fornecimento ininterrupto de água por gravidade, com vazão e pressão constantes, sem necessidade de recursos de bombeamento entre os reservatórios e os consumidores. Isto explica em parte o motivo pelo qual as torres de água só seriam incorporadas aos sistemas de abastecimento de água cerca de um década depois. ${ }^{22}$

É na década de 1850 que o desenvolvimento das torres de água para abastecimento público como conhecemos hoje inicia-se. Com a expansão das cidades industriais e o consequente aumento das áreas de abastecimento, as redes de distribuição de água tornaram-se inexoravelmente complexas. Em muitas cidades novos bairros periféricos se formavam, muitas vezes espalhando-se para o alto dos morros, gerando situações em que os reservatórios de distribuição, muitas vezes localizados a grandes distâncias dos novos bairros e em cotas inferiores a estes, não teriam a capacidade de garantir um fornecimento de água com a pressão e vazão adequada para os consumidores. Assim, para garantir o abastecimento de água nas zonas mais distantes e nas zonas mais altas das cidades industriais, na ausência de uma condição topográfica favorável para construção de novos reservatórios em cotas mais elevadas, a introdução de torres de água nos sistemas de abastecimento se fez, portanto, estritamente necessária. ${ }^{23}$

\footnotetext{
22 Ibidem.

${ }^{23}$ Idid., p. 32-33.
} 
A introdução de torres de água nos sistemas de abastecimento de água não foi um fenômeno restrito às grandes cidades industriais. Neste mesmo período pequenas cidades afastadas dos grandes centros urbanos, assim como algumas áreas rurais, começaram a contar com sistemas públicos de abastecimento de água. Nestes casos, cujas fontes naturais de água poderiam ser cursos de água ou poços, a construção de represas ou grandes reservatórios de distribuição eram extremamente onerosos e, de certo modo, desnecessários, uma vez que estas pequenas cidades tinham baixa demanda por água, o que se traduzia em reservatórios menores. Assim, a construção de uma torre de água, para armazenar a água necessária para posterior distribuição por gravidade, apresentava-se como uma solução técnica e economicamente mais adequada.

Neste período os sistemas construtivos utilizados para a construção dos reservatórios das primeiras torres de água eram basicamente dois: reservatórios fabricados com painéis modulares pré-fabricados de ferro fundido ou reservatórios fabricados com chapas de ferro forjado ou aço, rebitadas entre si. Ambos os materiais eram fruto de tecnologias industriais estabelecidas e cada um tinha suas vantagens e desvantagens. A escolha do material pelo projetista era determinada, na grande maioria das vezes, pela disponibilidade local do material e da mão de obra específica para a sua execução. ${ }^{24} \mathrm{~A}$ forma dos primeiros reservatórios, em planta, variava entre a quadrada, retangular, poligonal ou circular. Todos os reservatórios, porém, tinham o seu fundo plano. A escolha da forma era determinada principalmente pelo material utilizado, como veremos em detalhe na sequência.

Com raras exceções, as primeiras torres de água, particularmente as menores, eram construções formadas por reservatórios metálicos que eram apoiados em massivas estruturas de alvenaria de pedra ou tijolos. $O$ fundo plano dos primeiros reservatórios elevados, submetido a grandes esforços de flexão,

${ }^{24}$ Ibidem. 


\subsection{7}

Projeto para a torre de água de Worthing, 1857. Exemplo típico da primeira geração de torres de água inglesas para abastecimento público. necessitava de apoios intermediários, de maneira a reduzir o vão livre do fundo do reservatório, evitando deformações nas chapas metálicas. Estes apoios intermediários consistiam de vigas de ferro fundido ou ferro laminado apoiadas nas paredes externas de alvenaria ou, ainda, uma estrutura formada por um conjunto de colunas ou paredes de alvenaria.

Na Inglaterra, optou-se inicialmente pela construção de torres de água com reservatórios fabricados por painéis modulares pré-fabricados de ferro fundido apoiados em subestruturas de alvenaria de pedra ou tijolos. Estas torres de água (fig. 2.3.7) eram virtualmente idênticas as "estações de água" das ferrovias inglesas construídas no decorrer das décadas de 1830 e 1840, suas únicas diferenças eram: maior dimensão, fruto da maior capacidade de armazenagem e a existência de uma cobertura, uma vez que a água potável armazenada nos reservatórios precisava ser protegida contra possíveis contaminantes.

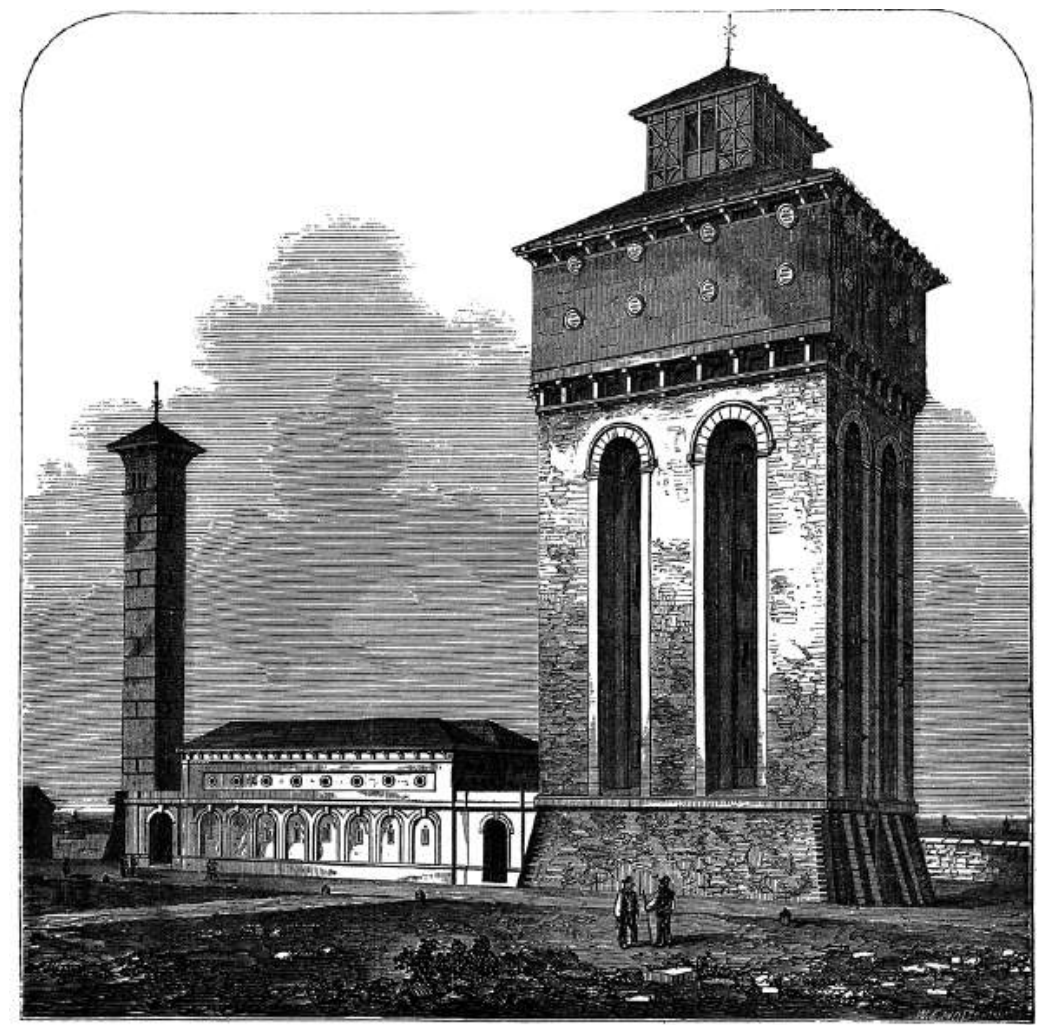




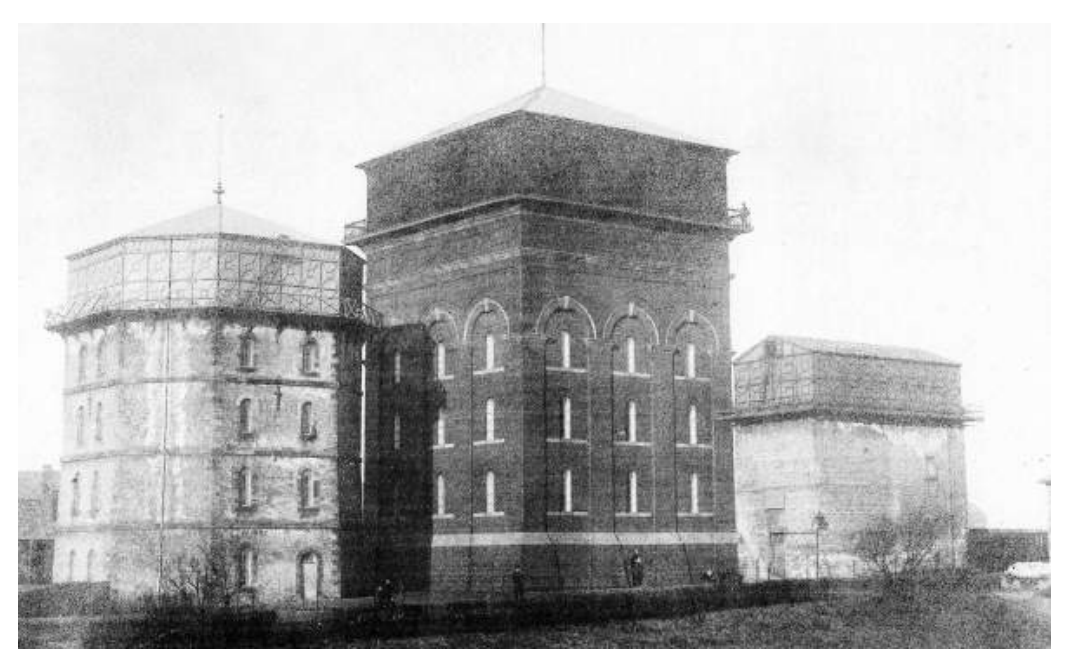

2.3.8

Torres de Água de Hartlepool, Inglaterra, 1850 (esquerda), 1870 (direita) e 1890 (centro).
A torre da cidade industrial de Hartlepool, construída em 1850, é um exemplo típico desta primeira geração de torres de água inglesas. A torre, já demolida, possuía um reservatório de água octogonal com fundo plano, fabricado com painéis modulares de ferro fundido. A figura 2.3.8 mostra o conjunto de três torres de água construídas no centro de Hartlepool, todas com reservatórios fabricados com painéis modulares de ferro fundido construídas em um intervalo de 40 anos, entre 1850 e 1890, o que demonstra o crescimento vertiginoso na demanda por água nas cidades industriais. Como é possível ver na fotografia, todas as três torres de água possuíam reservatórios aparentes, com formatos retangulares ou poligonais, uma solução tipicamente inglesa para construção das torres de água nas cidades industriais. ${ }^{25}$

$\mathrm{Na}$ cidade de Ormskirk, também na Inglaterra, foi construída a torre de Tower Hill (ca. 1853), provavelmente a mais antiga torre da água inglesa para abastecimento público existente na atualidade, ainda que parcialmente. $\bigcirc$ reservatório retangular aparente, em painéis de ferro fundido, era apoiado em uma estrutura em alvenaria de arenito vermelho, com dois estreitos arcos em estilo românico em cada um dos lados, todos com bordas escalonadas e faixas arqueadas, único elemento ainda existente da torre de água já desativada. A estrutura de suporte tem uma altura de 17 metros e o reservatório teria uma altura aproximada de

${ }^{25}$ Ibid., p. 41 


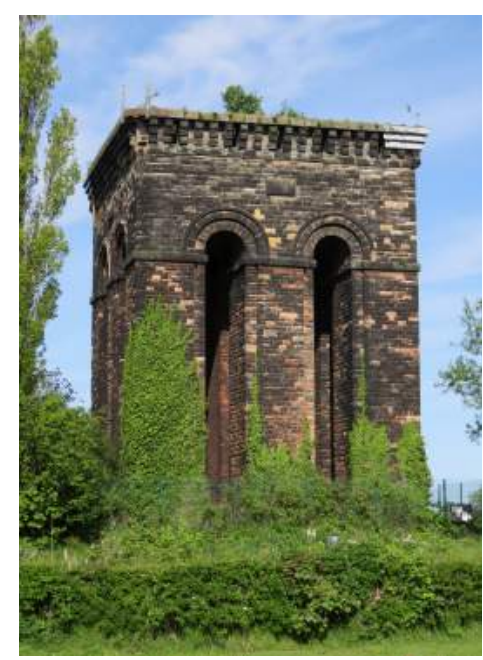

\subsubsection{0}

Situação atual de Torre de Tower Hill, Ormskirk, Inglaterra.

\subsection{9}

Torre de Tower Hill, Ormskirk, Inglaterra, ca. 1853.

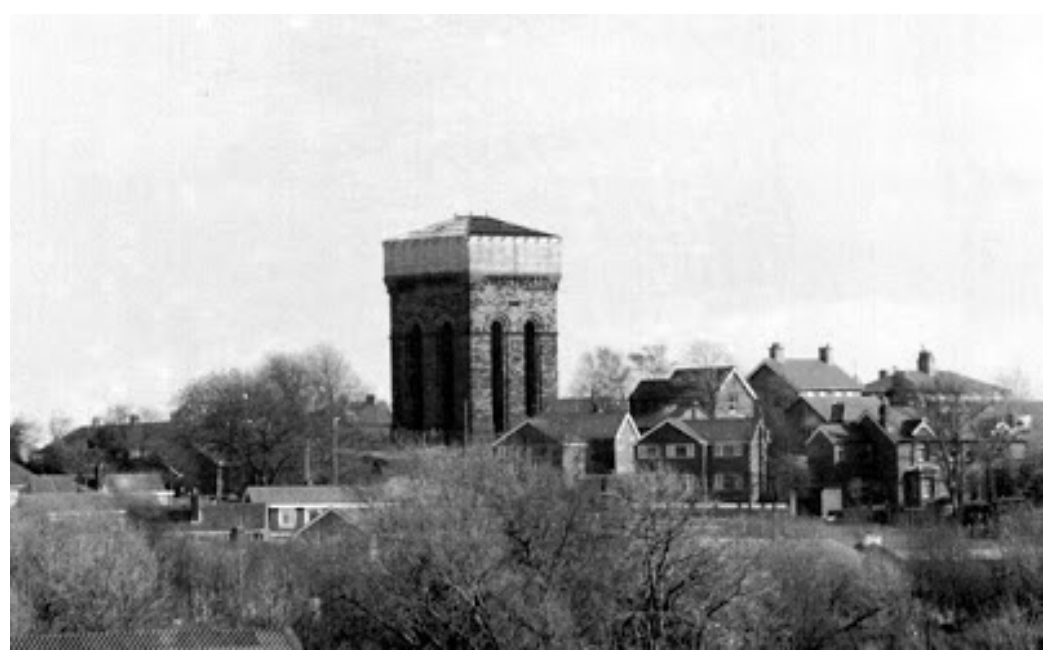

6,20 metros. ${ }^{26} \mathrm{~A}$ figura 2.3.9 mostra a torre de água completa, com o seu reservatório coberto por um telhado de ardósia de quatro águas. Na figura 2.3.10 temos a situação atual da torre de água.

William Lindley projetou e construiu entre os anos de 18531855 a primeira torre de água da Alemanha para abastecimento público, parte do novo sistema que estava sendo implantado na cidade de Hamburgo (fig. 2.3.11). O reservatório de água com um volume de $2.350 \mathrm{~m}^{3}$, foi projetado com um formato cilíndrico e fundo plano, com 30,40 metros de diâmetro e apenas 3,04 metros de altura, com o objetivo de manter as flutuações de pressão da rede hidráulica dentro dos limites estabelecidos e foi fabricado com painéis individuais de ferro fundido com bordas flangeadas parafusados entre si. O fundo plano do tanque era formado por painéis em formato de cunha (segmento de anel) com $19 \mathrm{~mm}$ de espessura, enquanto que a parede era composta por painéis curvos cuja espessura variava entre 22 a 16 mm, de acordo com a pressão hidrostática. Como subestrutura de apoio para o reservatório Lindley projetou uma estrutura formada por 60 colunas de alvenaria dispostas radialmente entre o perímetro externo da torre e a parede concêntrica interna da estrutura, cujo diâmetro era de 15 metros (fig. 2.3.12). Entre as linhas de colunas radiais foram construídas abóbadas de alvenaria (ver corte c-d) e uma cúpula central (ver corte $a-b)$, criando um sistema de suporte direto

${ }^{26}$ STEWART, Gary. Water Tower Plans Thrown out for the Seventh Time. The Advertiser. Ormskirk, 2 ago. 2007; e também BARTON, 2003, op. cit., p. 41 e 101. 


\subsubsection{1}

William Lindley, Torre de Água do Berliner Tor, Hamburgo, Alemanha, 1853-55. Foto (ca. 1890).

\subsubsection{2}

William Lindley, Torre de Água do Berliner Tor, Hamburgo, Alemanha, 1853-55. Planta, Cortes e Elevação. para cerca de 300 pilastras menores que apoiavam o fundo plano do reservatório de ferro fundido. ${ }^{27}$ Diferentemente das torres de água inglesas, o reservatório metálico foi revestido externamente com uma parede de alvenaria posicionada cerca de $60 \mathrm{~cm}$ à frente da parede do reservatório, criando um espaço para manutenção. O telhado de chapa metálica, em forma de cúpula, era suportado por treliças parabólicas fabricadas em ferro forjado, apoiados nas paredes externas de alvenaria.
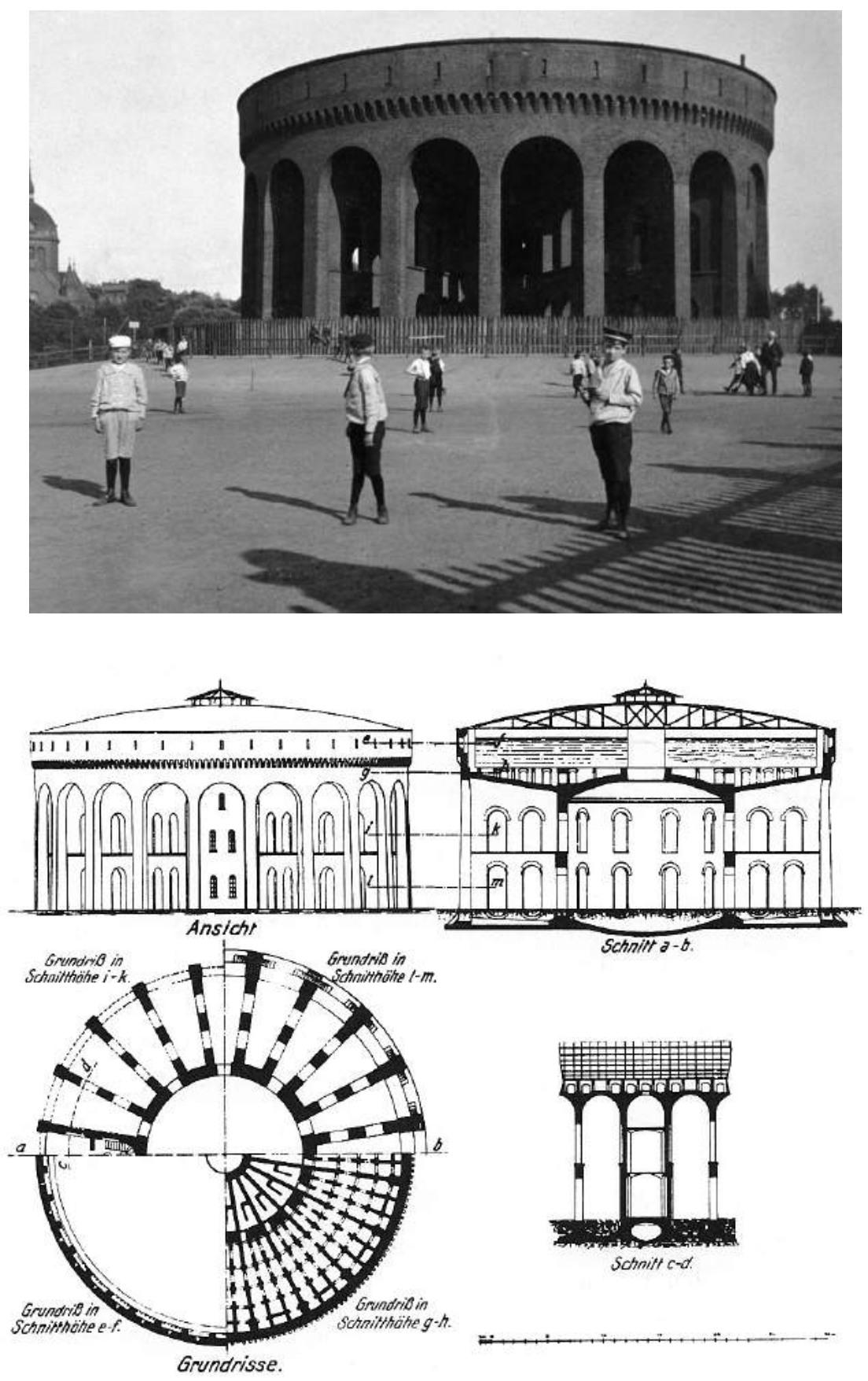

Schnift c-d.

${ }^{27}$ WERTH, 1971, op. cit., p. 341. 


\subsubsection{3}

Tirantes e ancoragens dos reservatórios retangulares de ferro fundido.
Os reservatórios de ferro fundido em formato cilíndrico apresentavam grande vantagem em economia de material em relação aos reservatórios de formato retangular ou quadrado. Com o formato circular a parede do reservatório assumia uma forma que combinava com a pressão hidrostática, uma forma de equilíbrio, trabalhando exclusivamente sob esforços de tração, tornando o seu dimensionamento mais econômico. A parede dos reservatórios circulares assumia uma função estrutural e de vedação, enquanto que nos reservatórios retangulares as paredes tinham uma função essencialmente de vedação, já que as forças da pressão hidrostática eram absorvidas por uma série de tirantes e ancoragens posicionados no interior do reservatório, elementos que eram essenciais para reduzir os esforços de flexão atuantes nas paredes dos reservatórios retangulares. ${ }^{28} \mathrm{~A}$ figura 2.3 .13 mostra o esquema estrutural de um reservatório retangular de ferro fundido onde podemos identificar claramente o sistema de flanges, bem como os tirantes responsáveis por resistir à pressão hidrostática e garantir o travamento das paredes. A economia material dos reservatórios cilíndricos não resultava apenas da ausência de tirantes e ancoragens internas, mas também devido a menor superfície de paredes necessária para armazenar o mesmo volume de água.

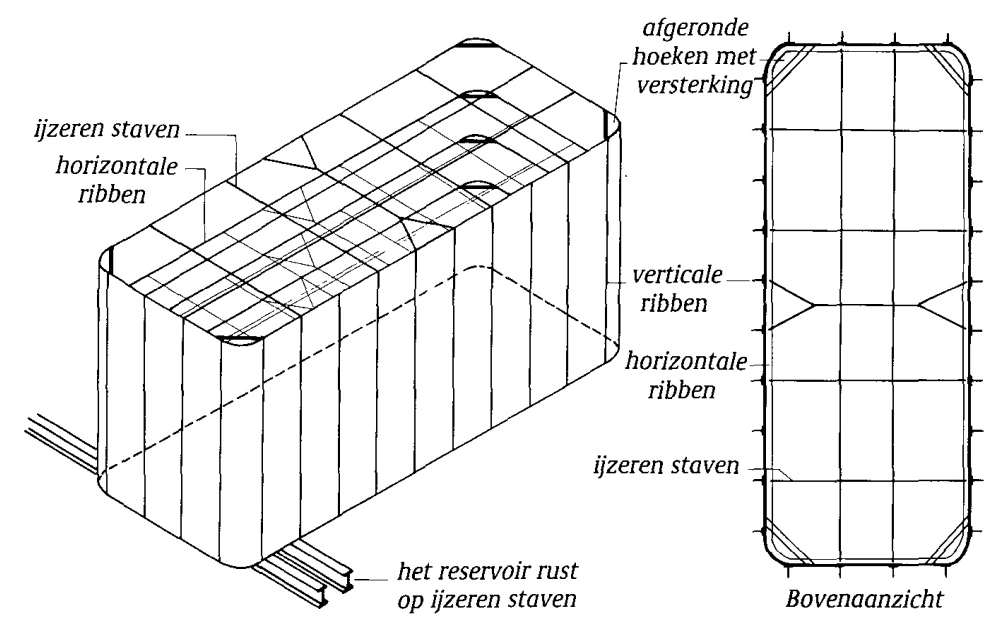

${ }^{28}$ Ibid., p. 337. 
A vantagem dos reservatórios retangulares ou quadrados fabricados com painéis de ferro fundido residia na sua capacidade modular. Painéis de tamanho padronizado produzidos para se construir reservatórios retangulares ou quadrados têm suas flanges posicionadas sempre em ângulo reto em relação ao plano do painel, o que garante a possibilidade de serem agrupados e combinados entre si na quantidade necessária para se formar um tanque, teoricamente, com qualquer área de piso, dimensão ou altura de paredes que se deseje, adequado para armazenar qualquer volume de água que se necessite. ${ }^{29}$ Já os painéis curvos necessitam de flanges posicionadas na direção radial, o que os torna aptos apenas para a construção de reservatórios cilíndricos de um determinado diâmetro, limitando assim a sua utilização e obrigando a fabricação de painéis específicos para diâmetros específicos. Outra vantagem dos reservatórios com formatos retangulares e quadrados residia na facilidade de fabricação, uma vez que é muito mais fácil fundir um painel em uma superfície plana horizontal do que fabricar as placas curvas fundidas necessárias para se construir um reservatório cilíndrico. As juntas entre as flanges dos painéis de ferro fundido eram seladas com a inserção de fios de sisal e chumbo vermelho, ${ }^{30}$ garantindo assim a impermeabilidade do reservatório. Alternativamente as juntas entres os painéis de ferro fundido podiam ser calafetadas com "cimento de ferro" (iron cement), uma espécie de argamassa formada pela mistura de pó de ferro com sal amoníaco, enxofre e água. ${ }^{31}$ Internamente paredes, fundo e demais elementos metálicos no interior dos reservatórios eram pintados com quatro camadas de tinta anticorrosiva.

\footnotetext{
29 BARTON, 2003, op. cit., p. 34-35.

30 O chumbo vermelho, também conhecido como zarcão ou mínio, é um dos nomes populares do composto químico tetróxido de chumbo, de formula $\mathrm{Pb}_{3} \mathrm{O}_{4}$, que apresenta-se como um pó vermelho insolúvel em água e em ácidos. Tintas a base de tetróxido de chumbo, emulsionadas em óleo, eram empregadas na proteção de superfícies metálicas em função de suas propriedades anticorrosivas. Atualmente a utilização de tintas com tetróxido de chumbo é limitada devido à sua toxicidade e as tintas anticorrosivas conhecidas popularmente como "zarcão" empregam outros compostos químicos anticorrosivos (ex. fosfato de zinco) e pigmentos que conferem a tinta a sua coloração avermelhada característica.

${ }^{31}$ Colchester Water Tower. The Engineer, London, v. 57 , n. 15, fev. 1884, p. 133.
} 


\subsubsection{Arquitetura das Primeiras Torres de Água}

A expansão das cidades, o crescimento da população e as grandes mudanças econômicas e sociais decorrentes da Revolução Industrial desencadearam um processo de construção de novas edificações em uma escala sem precedentes na história. Novos tipos arquitetônicos, para além da torre de água, surgiram durante o século XIX como, por exemplo, edificações ferroviárias, pavilhões de exposições, lojas de departamentos e habitações operárias. Toda a população tinha necessidade de suas construções e exigiam, além de moradia, de suas escolas, hospitais, igrejas, museus, salas de concerto, etc. Isto resultou em um grande número de construções pequenas e médias realizadas, na maioria das vezes, sem a participação de arquitetos ou engenheiros, gerando resultados que eram tão numerosos quanto díspares em termos de qualidade formal. ${ }^{32}$

Desde as primeiras décadas do século XIX uma intensa crise se instalou no campo das artes plásticas e da arquitetura, caracterizada por uma crítica aos valores plásticos tradicionais e pela busca por uma unidade de estilo e por uma linguagem própria para a nova época. O desenvolvimento dos estudos arqueológicos e históricos desencadeou o interesse por outras culturas e civilizações, bem como o interesse renovado pela arquitetura grega, romana e gótica, levando a uma grande variedade de correntes estilísticas e a novas possibilidades estéticas. Este processo de pesquisa formal, chamado de historicismo, se estabeleceu como um caminho para uma arquitetura "nova", caracterizada pela imitação e justaposição de todos os estilos arquitetônicos históricos, dando aos arquitetos uma grande liberdade para a criação artística. ${ }^{33} \mathrm{Na}$ quarta década do século XIX elementos de construção góticos e românicos foram reintroduzidos tanto na arquitetura religiosa quanto na secular, se contrapondo ao estilo neoclássico vigente até então. A

\footnotetext{
${ }^{32} \mathrm{KÜHL}$, Beatriz Mugayar. Arquitetura do Ferro e Arquitetura Ferroviária em São Paulo: Reflexões sobre a sua preservação. Cotia: Ateliê Editorial, 1998, p. 20.

33 Ibidem.
} 
reintrodução das formas góticas e românicas, porém, não substituiu e nem se fundiu com o estilo anterior como o ocorrido em épocas passadas, mas todos passaram a operar lado a lado, formando um grande conjunto de hipóteses estilísticas, sempre influenciado pela tradição arquitetônica de cada país. ${ }^{34}$

Dentro deste contexto as primeiras torres de água, esta tipologia arquitetônica recém-surgida, eram projetadas de maneira a torná-las esteticamente mais aceitáveis neste ambiente urbano que estava em pleno desenvolvimento e em um período em que os arquitetos refletiam, não só sobre os novos programas e tipologias mas também sobre a determinação do "estilo" do século. Os arquitetos e engenheiros da época utilizavam-se de princípios de projeto baseados nos conhecidos estilos anteriores utilizando, deliberadamente, formas históricas para a construção das novas torres de água, para que estas não se colocassem como objetos estranhos na cidade, de modo a não perturbar a paisagem urbana. Esta última tarefa, no entanto, tornava-se especialmente complicada quando se consideram as dimensões significativas que as torres de água para abastecimento urbano normalmente atingiam o que, invariavelmente, transformava qualquer torre de água em um marco na paisagem das cidades.

$\mathrm{Na}$ Inglaterra onde, desde as primeiras "estações de água" das ferrovias, existia uma grande preferência pela utilização de reservatórios com formatos quadrados e retangulares para a construção de torres de água, uma solução que contrariava tanto a lógica estrutural quanto o uso eficiente dos materiais de construção. O efeito bastante forte dos painéis aparentes de ferro fundido era, de certa forma, amenizado com a utilização de peças ornamentadas, nas quais eram acrescentados elementos decorativos tais como frisos, molduras, óvalos, contas, etc. Foi desenvolvida ainda uma variação de montagem para esta tipologia

34 BENEVOLO, 2017, op. cit., p. 82; e MEVIUS, Walter. Baustile und Wassertürme. In: MERKL, Gerhard et al. Historische Wassertürme: Beiträge zur Technikgeschichte von Wasserpeicherung und Wasserversorgung. München: Oldenburg Verlag, 1985. p. 155. 

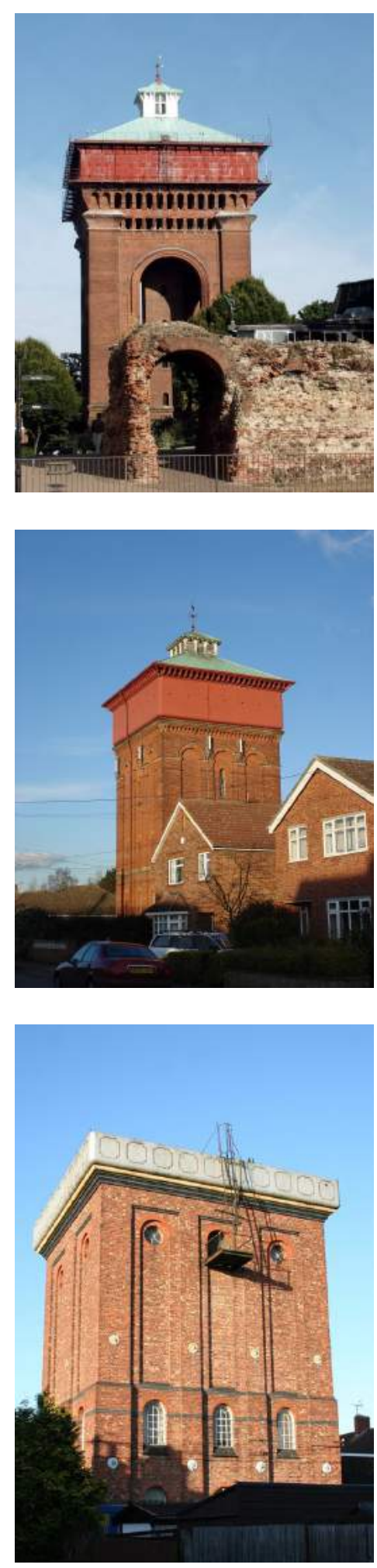

\subsubsection{4}

a) Jumbo Water Tower, Colchester, Inglaterra, 1882.

b) Torre de Água de Wivenhoe, Inglaterra, 1901.

c) Torre de Água da Horncastle Road, Linconshire, Inglaterra,1905. de reservatórios, introduzindo um sistema de painéis de ferro fundido com flanges internas, o que conferia um aspecto mais limpo aos reservatórios aparentes ao mesmo tempo que preservava os elementos decorativos, como os utilizados na "Jumbo Water Tower", em Colchester (1882), na torre de água de Wivenhoe, em Essex (1901) e na torre da Horncastle Road, em Linconshire (1905) (fig. 2.3.14). Os reservatórios recebiam uma cobertura em estrutura de ferro ou madeira para telhados de quatro águas com telhas de ardósia ou cobre. As massivas subestruturas de alvenaria que apoiavam os reservatórios metálicos tinham formas inspiradas em estilos históricos, predominantemente o estilo românico, e eram executadas com materiais em sintonia com a arquitetura local. Na "Jumbo Water Tower", por exemplo, a subestrutura em estilo neorromânico foi executada com tijolos de barro e pedras de arenito vermelho, ${ }^{35}$ mesmos materiais utilizados na grande maioria dos edifícios de Colchester, bem como em suas principais construções medievais e também nas ruinas romanas ${ }^{36}$ existentes na cidade, uma delas, o Balkerne Gate (ca. 70-96 d.C.), localizado bem próximo da torre de água. Estas eram algumas das principais características das típicas torres de água inglesas construídas durante o século XIX, que passaram a ser conhecidas como torres de água "vitorianas", em referência ao reinado da Rainha Vitória entre os anos de 1837 a 1901.

A figura 2.3.15 mostra um corte e alguns detalhes construtivos da "Jumbo Water Tower". No corte vale notar as grandes "mão-francesas" posicionadas no interior do reservatório que, em conjunto com tirantes de ferro forjado de $32 \mathrm{~mm}$ de diâmetro que cruzavam o interior do tanque de parede a parede, tinham a função de suportar a pressão hidrostática gerada pelos $870 \mathrm{~m}^{3}$ de água armazenada. Isto demonstra claramente a forma não material dos reservatórios metálicos retangulares, isto é, a forma escolhida para cumprir a função de armazenamento de água

\footnotetext{
${ }^{35}$ Colchester Water Tower. The Engineer, London,

v. 57, n. 15, fev. 1884, p. 133.

${ }^{36}$ Colchester é a mais antiga cidade romana registrada na Grã-Bretanha (ca. 43-410 d.C.).
} 


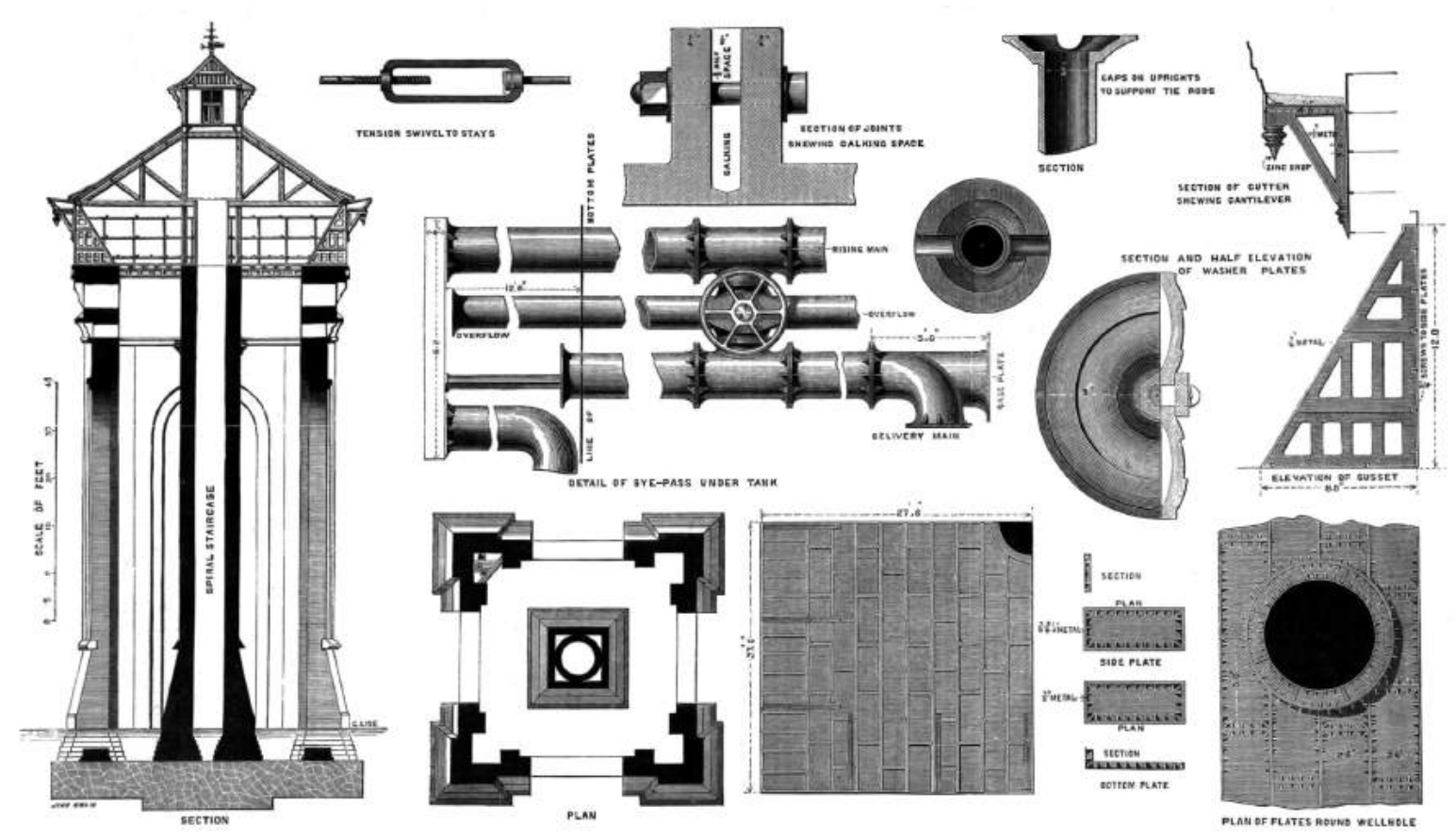

2.3 .15

Corte, planta e detalhes construtivos da Jumbo Water Tower, Colchester, Inglaterra, 1882.

\section{3 .16}

Appleton Water Tower, Sandringham, Inglaterra, 1877.

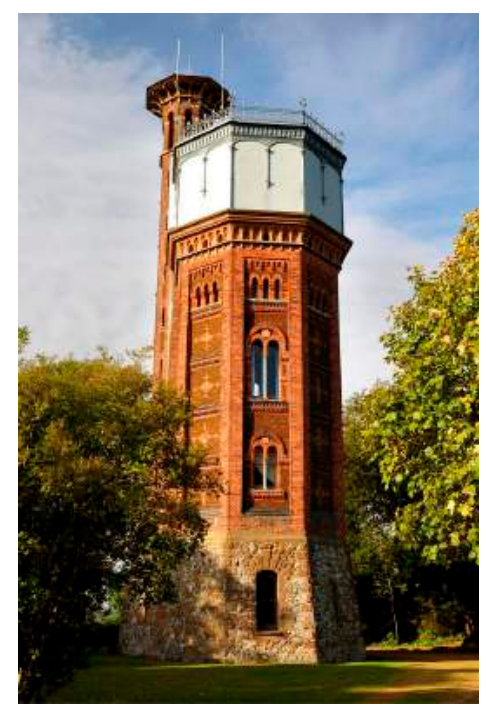

não é a forma mais adequada para o trabalho pleno do material de construção utilizado, neste caso o ferro fundido. O fundo plano do reservatório, submetido a grandes esforços de flexão, era apoiado em um sistema de vigas compostas de ferro forjado, o que tornava a construção deste tipo de reservatório bastante onerosa em termos materiais e tinha o inconveniente de dificultar o acesso, em caso de manutenção, as numerosas juntas existentes entre os painéis de ferro fundido.

Outro exemplo significativo de torre de água "vitoriana" é a "Appleton Water Tower" (figura 2.3.16) construída em 1877 para melhorar o sistema de abastecimento de água do pequeno vilarejo de Sandringham e da Sandringhan House, uma das casas de campo da família real britânica, cuja construção foi finalizada em 1870. A Appleton Water Tower foi projetada por James Mansergh em alinhamento com a arquitetura da Sandringhan House, palácio que é uma mistura peculiar de estilos arquitetônicos, sendo predominante o estilo jacobino. Um aspecto interessante da torre, além do seu reservatório aparente construído com painéis decorados de ferro fundido, é a sua chaminé, que atravessa o tanque em altura para proteger a água do congelamento durante o inverno. ${ }^{37}$

${ }^{37}$ BARTON, 2003, op. cit., p. 49-50. 


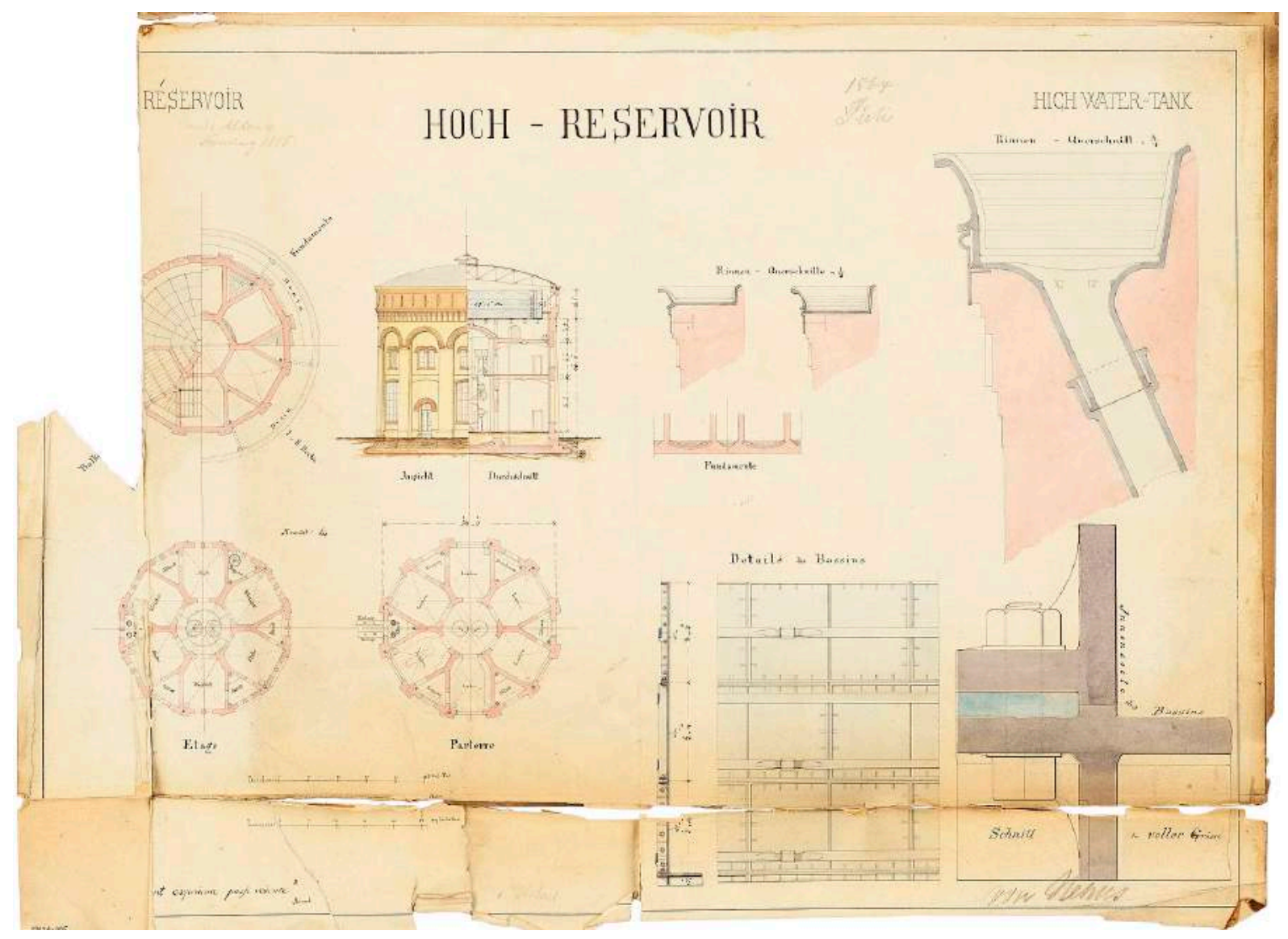

\subsubsection{7}

Werner Kümmel, Torre de Água de Altona, Hamburgo, Alemanha, 1859.
Na Alemanha, por outro lado, as primeiras torres de água construídas diferiam das torres inglesas tanto no que se refere às técnicas construtivas quanto a considerações de natureza estética. Desde a construção da primeira torre de água na cidade de Hamburgo, no Berliner Tor, em 1853, os projetistas alemães adotaram os reservatórios com plantas circulares, mais econômicos, praticamente como um padrão para as torres de água de abastecimento urbano e são raros os casos de torres com reservatórios em formatos quadrados ou retangulares. Nestas primeiras torres de água alemãs os reservatórios de água, em contraste com as torres de água inglesas, eram sempre escondidos no interior destas novas construções.

A torre de água de Altona (fig. 2.3.17), projetada pelo alemão Werner Kümmel (1834-1893), foi fortemente influenciada pela solução de projeto adotada por Lindley na torre de água do Berliner Tor e foi construída em 1859 como parte da expansão do sistema de abastecimento de Hamburgo. O reservatório cilíndrico de ferro fundido, com volume de $376 \mathrm{~m}^{3}$, foi apoiado em uma 
subestrutura circular de alvenaria formada por uma parede externa e por uma parede anular interna, entre as quais eram dispostas 12 paredes radiais intermediárias, formando uma série de cômodos que abrigavam espaços técnicos e a moradia para um zelador. Um vigamento de ferro fundido, com vigas espaçadas a cada $50 \mathrm{~cm}$, apoiado nas paredes radiais, criava o suporte necessário para apoio do fundo plano do reservatório. ${ }^{38} \mathrm{~A}$ torre de água, uma construção austera e robusta, de forte inspiração românica, caracterizava-se por grossas paredes de alvenaria e pequenas aberturas. No lado externo não havia qualquer indício da existência do reservatório metálico, escondido por detrás da espessa parede de tijolos que fazia concessão apenas para pequenos rasgos verticais, lembrando as seteiras dos castelos medievais.

O estilo arquitetônico, o tipo de subestrutura e a tipologia do reservatório de ferro fundido da torre de água de Lübeck (fig. 2.3.18), construída em 1867, são essencialmente os mesmos utilizados na torre de Altona. Construída para garantir uma pressão máxima de 14,30 m.c.a., a torre de água com volume de $1.025 \mathrm{~m}^{3}$, foi complementada com a instalação de um standpipe adicional que permitia, a qualquer momento, aumentar a pressão de suprimento para 34,30 m.c.a., com o objetivo de fornecer água em uma pressão adequada para o combate a incêndios. As tubulações do standpipe foram instaladas no interior de uma estrutura de alvenaria em formato de torre com diâmetro de 4,0 metros, posicionado no centro da construção, garantindo estabilidade estrutural para o conjunto de tubulações e protegendo-as dos efeitos adversos da temperatura externa. ${ }^{39}$

As principais desvantagens dos reservatórios de ferro fundido, fossem cilíndricos ou quadrados, eram o seu grande peso morto (comparado ao ferro forjado e ao aço), a proliferação de juntas entre painéis que precisavam ser seladas para impedir vazamentos e a baixa resistência à tração do material, que resultava necessariamente em paredes com grandes espessuras de material.

\footnotetext{
${ }^{38}$ WERTH, 1971, op. cit., p. 342-343.

39 Ibid., p. 344.
} 

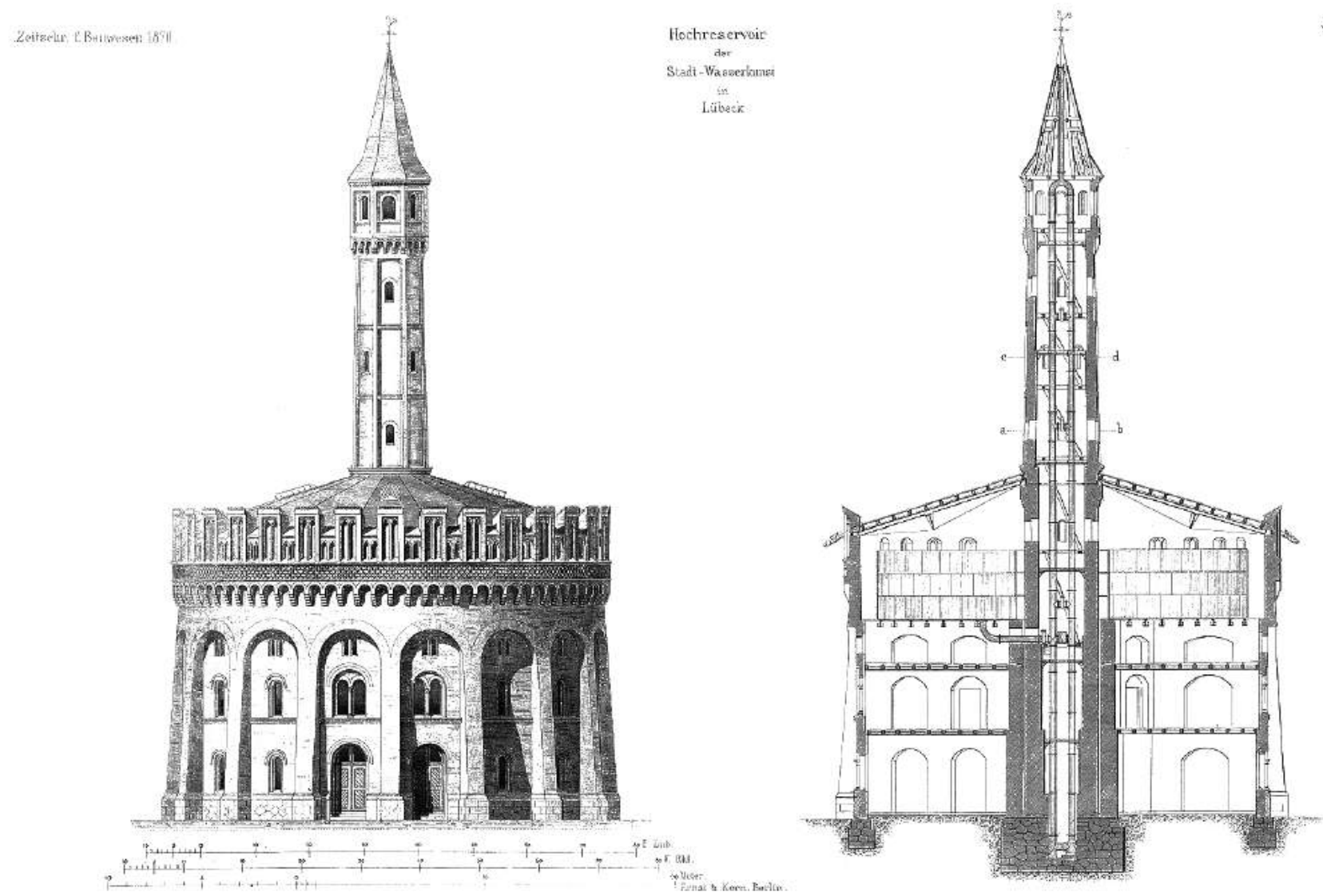

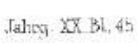

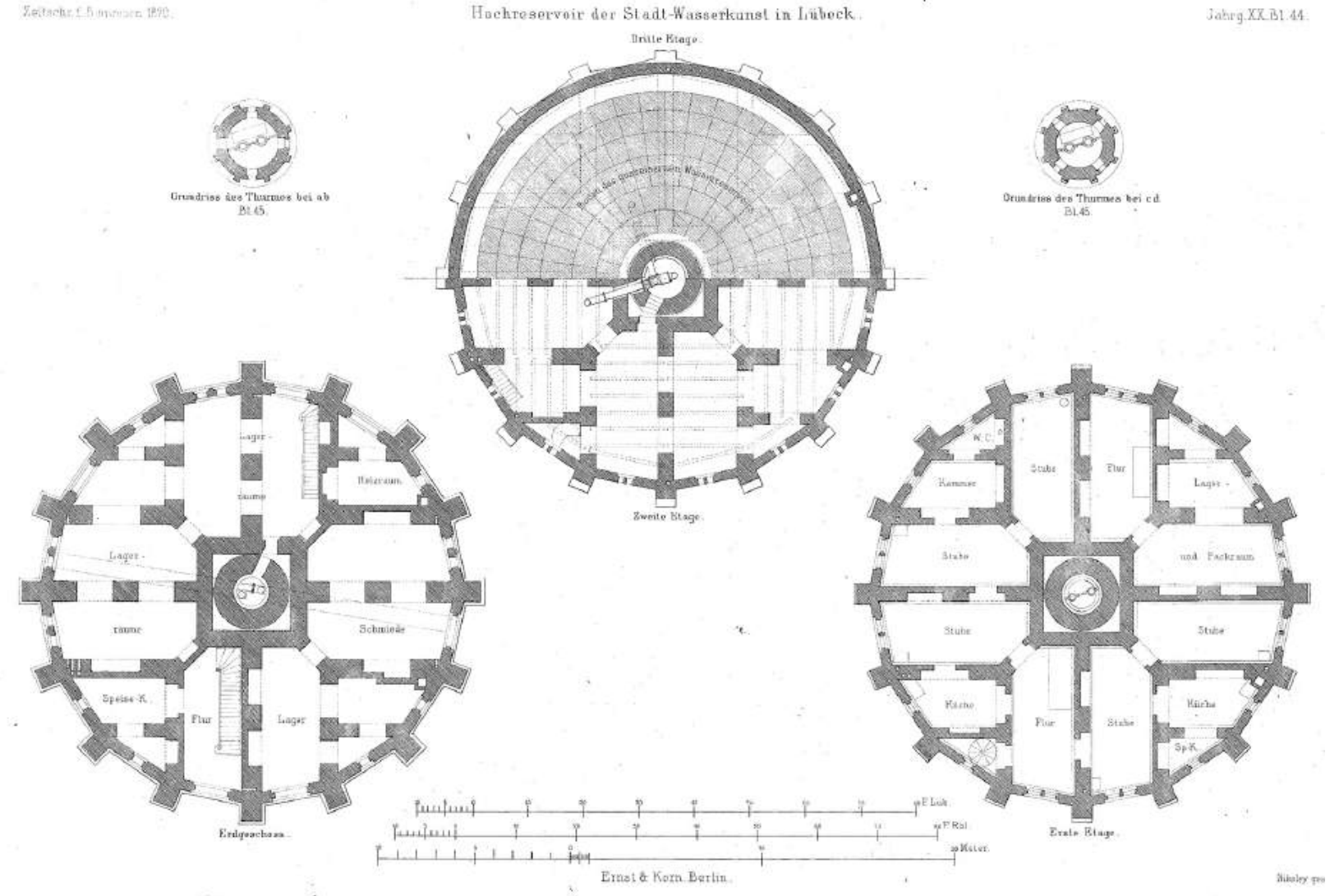


2.3.18

Torre de Água de Lübeck, Alemanha, 1867. Plantas, Corte e Elevação
No entanto, a predileção de alguns projetistas, especialmente na Inglaterra, pelos reservatórios fabricados com painéis de ferro fundido era tamanha que foram construídas torres de água tanto para o abastecimento público de água quanto para as ferrovias utilizando esta tecnologia até meados do século XX, num momento em que outros países da Europa já haviam, a décadas, abandonado este material. Por volta de 1860 o ferro fundido já era considerado obsoleto para a construção de reservatórios de água, sendo rapidamente substituído pelo ferro forjado, um material com uma resistência à tração muito mais elevada, com estrutura material homogênea, com uma resistência à tração e à compressão da mesma ordem de grandeza e com uma alta extensibilidade, permitindo o seu processamento posterior para a fabricação de chapas maiores. Todas estas características garantiam ao ferro forjado a possibilidade de fabricação de reservatórios com menores espessuras de paredes e menor peso total.

Entre os anos de 1850 e 1860 o ferro forjado ou laminado (wrought iron), que é praticamente um aço de baixo teor de carbono, foi utilizado principalmente para a construção de pontes ferroviárias treliçadas. A Britannia Bridge, construída na Inglaterra entre os anos de 1846 e 1850 foi a primeira obra construída exclusivamente em ferro forjado. Porém, devido ao grande número de acidentes com obras deste tipo, era necessário encontrar um material com melhores características. $\bigcirc$ aço já era conhecido desde a Antiguidade mas não estava disponível para fornecimento em larga escala e a preços competitivos por falta de um processo industrial de fabricação. Em 1856, o inglês Henry Bessemer (18131898), inventou um forno que permitia a fabricação do aço em larga escala. Em 1864 os irmãos Martin desenvolveriam um forno com maior capacidade e com o desenvolvimento dos processo de fabricação Siemens-Martin (1867) e Thomas-Gilschrist (1877), o aço rapidamente substituiu o ferro fundido e o ferro forjado na indústria da construção. ${ }^{40}$

40 PFEIL, Walter; PFEIL, Michèle. Estruturas de Aço: Dimensionamento Prático. Rio de Janeiro: LTC - Livros Técnicos e Científicos, 2000, p 2. 
Uma das primeiras torres de água a utilizar um reservatório de água fabricado em ferro forjado foi a torre da cidade de Halle, Alemanha, construída em 1868 (fig. 2.3.19). A utilização do ferro forjado representou uma economia material de cerca de 50\% em relação a um reservatório de igual volume fabricado em ferro fundido. Com volume de $464 \mathrm{~m}^{3}$, o reservatório era formado por chapas planas e curvas, emendadas entre si por fileiras de rebites, seguindo o mesmo tipo de técnica construtiva utilizada na fabricação de caldeiras. Com altura de 15,85 metros, a estrutura da torre de água, executada em alvenaria de tijolos sobre um embasamento de pedra, possuía uma planta octogonal e o reservatório circular de ferro forjado era mantido no interior da construção. No interior, um fuste anular e quatro paredes intermediárias dispostas radialmente, serviam de apoio para o vigamento de ferro forjado utilizado como suporte para o fundo plano do reservatório. ${ }^{41}$ No lado externo nenhum elemento da austera construção em estilo românico apontava para a existência de um reservatório elevado de água. A cobertura do reservatório escondia-se por detrás de ameias e estreitos merlões que, em conjunto com as oito torretas de canto, remetiam a imagem dos castelos medievais, uma atitude própria das tendências historicistas em voga na arquitetura do século XIX.

${ }^{41}$ WERTH, 1971, op. cit., p. 345-346. 
HALLE STADT WASSERWERK

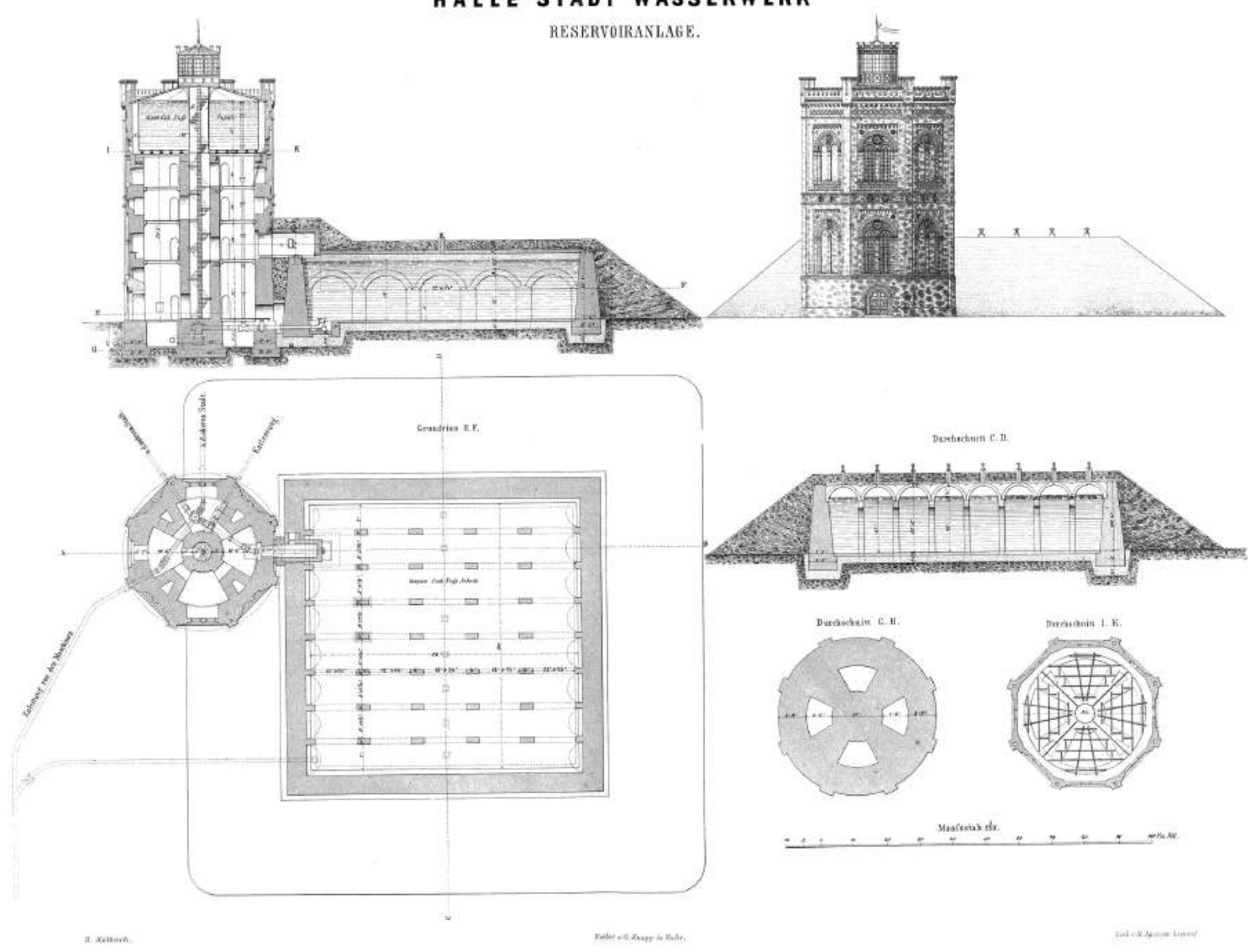

2.3.19

Darchsetanit A. B

Bernhard Salbach, Torre de Água de Halle, Alemanha, 1868.

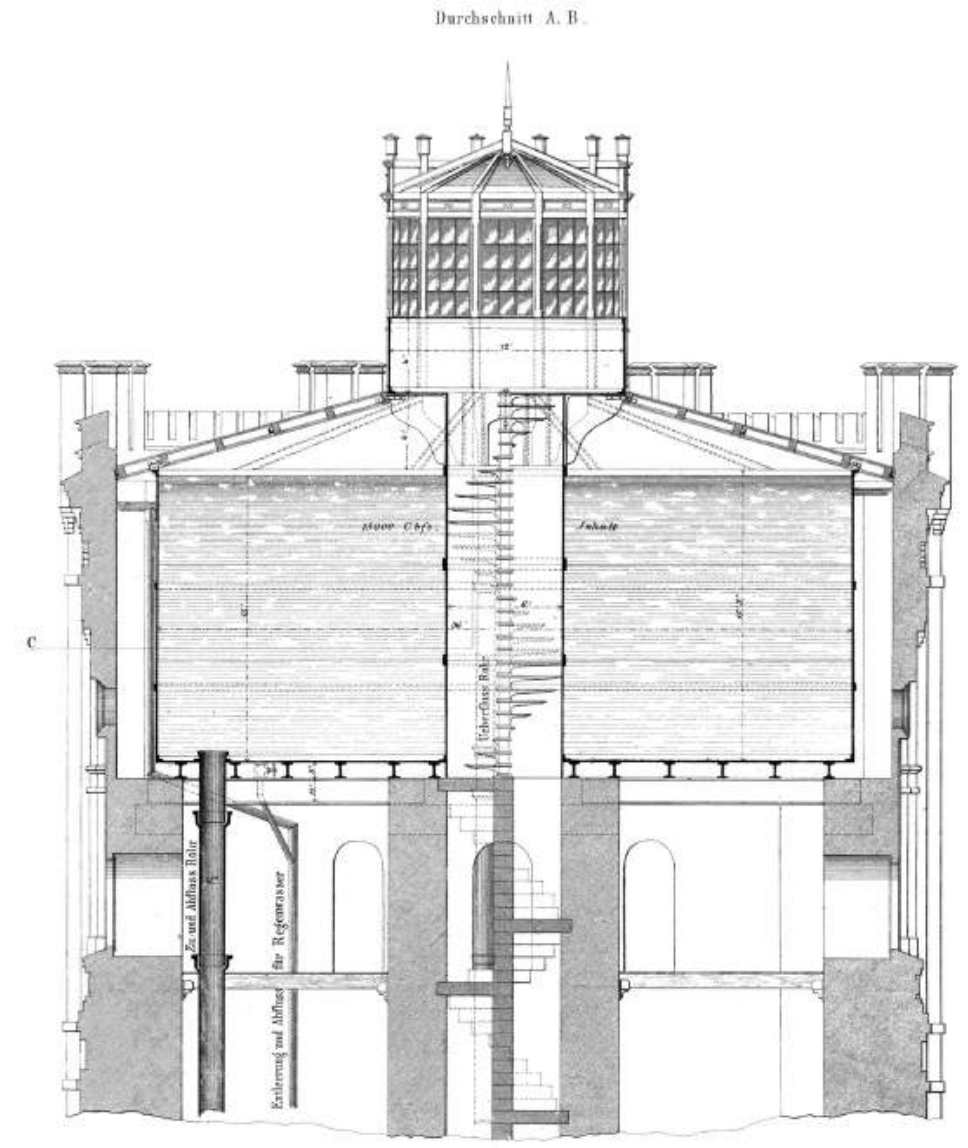




\section{3 .20}

Johann Georg Poppe, Torre de Bremen, Alemanha, 1872.

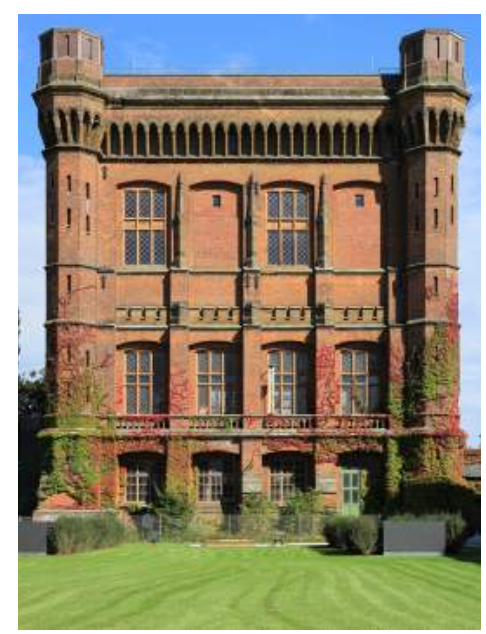

Outros exemplos de torres de água alemãs do mesmo período que empregaram sistemas tecnológicos e soluções arquitetônicas similares são as torres de Bremen (1872) e Krefeld (1876). Em Bremen a torre de água (fig. 2.3.20), com planta quadrada de 35 metros de lado e quase 47 metros de altura, abriga dois reservatórios retangulares de ferro forjado com dimensões de $23 \times 13 \times 3,5$ metros, armazenando um total de $1.700 \mathrm{~m}^{3}$ de água. $\bigcirc$ edifício não cumpria somente a função de armazenamento de água, isto é, no pavimento térreo foi instalado o sistema de bombeamento de água a vapor que alimentava os reservatórios elevados, localizados no quinto pavimento, escondidos por detrás da cornija externa. O projeto arquitetônico da torre coube ao arquiteto Johann Georg Poppe (1837-1915), que elegeu como materiais de construção o tijolo vermelho e o arenito, todos em sintonia com os materiais utilizados nos edifícios seculares da cidade hanseática. ${ }^{42} \bigcirc$ coroamento em ameias do edifício em conjunto com as quatro torretas octogonais posicionadas nas esquinas, assim como na torre de água de Halle, remetem a arquitetura românica dos castelos medievais. ${ }^{43}$
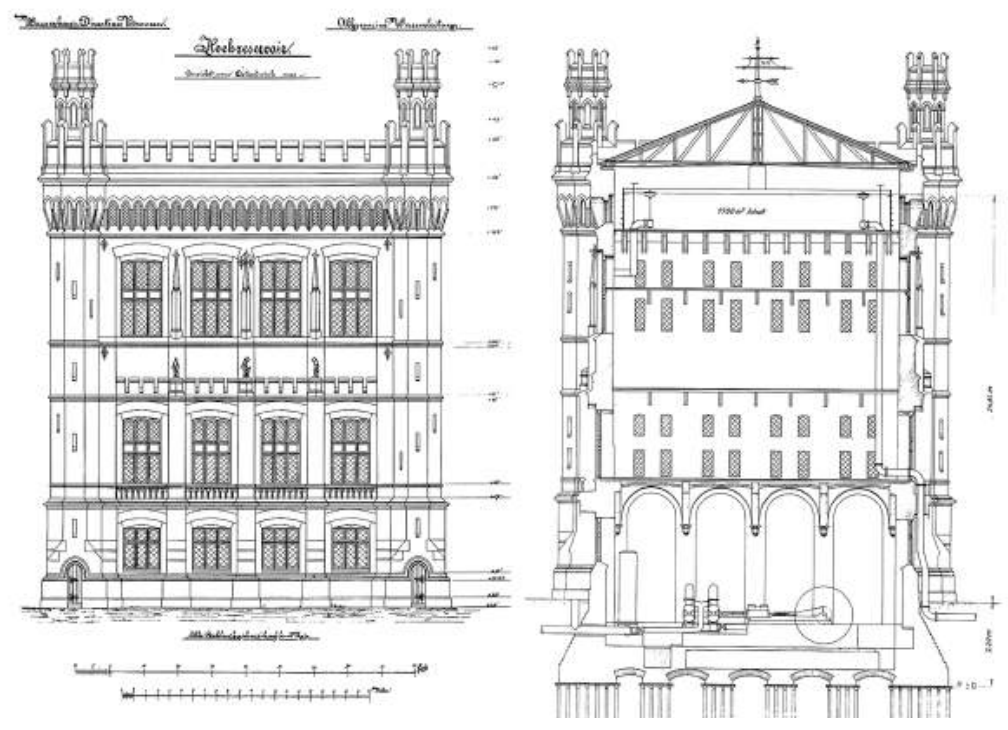

42 GOCKEL, Bernd. Bilddokumente historischer Wassertürme. In: MERKL, Gerhard et al. Historische Wassertürme: Beiträge zur Technikgeschichte von Wasserpeicherung und Wasserversorgung. München: Oldenburg Verlag, 1985, p. 174.

${ }^{43}$ A torre da água de Bremen foi bastante danificada por bombardeios durante a Il Guerra Mundial e no reparo dos danos sofridos foram suprimidas as ameias originais do coroamento de todo o edifício, inclusive nas torretas. A figura 2.3.20 mostra uma fotografia na situação atual do edifício. 


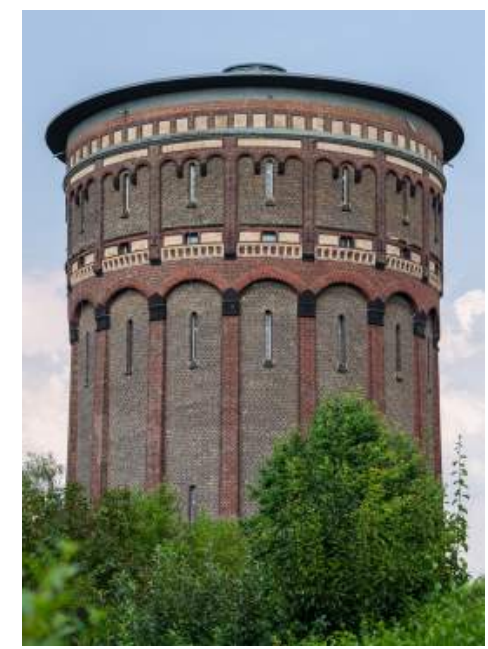

2.3.21

Torre de Krefeld, Alemanha, 1876.

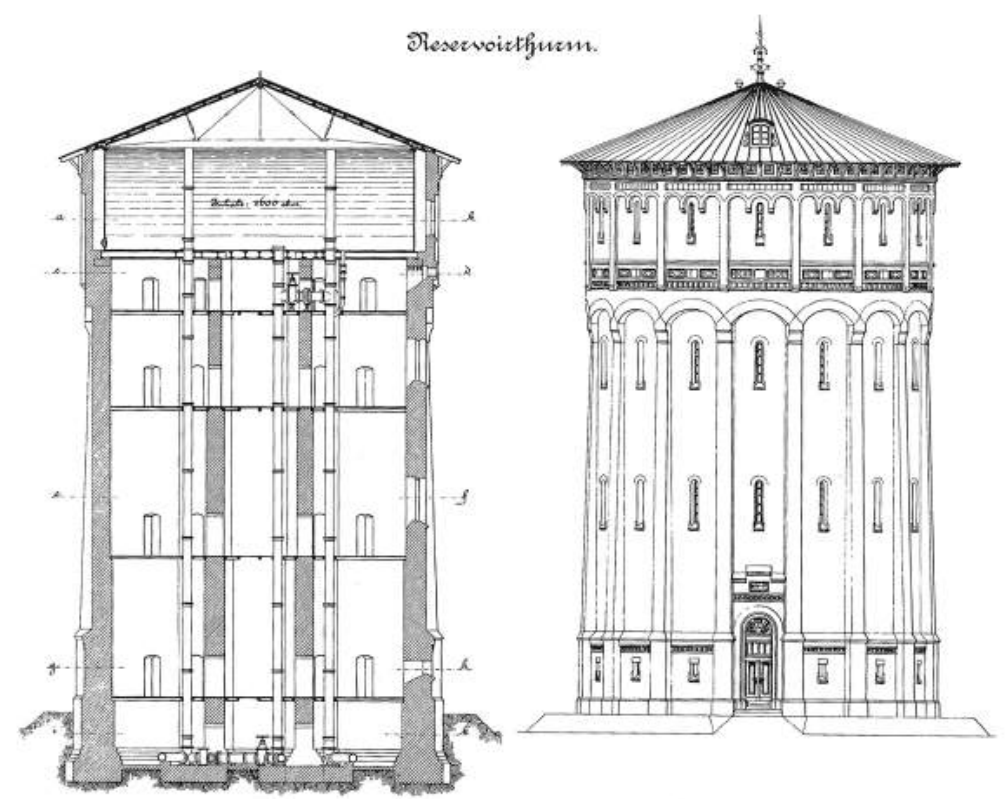

A torre de água de Krefeld (figura 2.3.21), é tão antiga quanto o sistema de abastecimento de água da cidade, cuja construção foi iniciada em 1874. O projeto da torre coube ao engenheiro Bernhard Salbach (1833-1894), que definiu a capacidade do reservatório em $1.600 \mathrm{~m}^{3}$, um volume suficiente para atender a 20\% das necessidades diárias da cidade. O reservatório circular de ferro forjado, com 18,50 metros de diâmetro e uma altura de 6,20 metros, estava apoiado em um sistema de vigas de ferro forjado, apoiado nas várias paredes internas intermediárias. ${ }^{44} \mathrm{Na}$ estrutura em alvenaria de tijolos destacam-se 16 pilastras unidas por arcos abatidos que apoiam as paredes de alvenaria do recinto superior, ambiente que abriga e esconde o reservatório metálico elevado. A fachada é uma expressão óbvia do historicismo do século XIX, ornamentada com frisos feitos com azulejos amarelos, arcos falsos e pequenas aberturas lembrando as seteiras das construções militares medievais. $\bigcirc$ telhado cônico, que internamente é formado por treliças metálicas que repousam na borda do reservatório, se projeta para além da parede externa da torre, apoiado em um conjunto de mãos-francesas de madeira. A visão do "banal" tanque de ferro forjado e de sua estrutura metálica de cobertura não eram admitidas.

${ }^{44}$ GOCKEL, 1985, op. cit., p. 200. 


\subsubsection{Reservatório de Fundo Suspenso}

A desvantagem crucial dos reservatórios de fundo plano consistia no fato de que o fundo plano precisava de um sistema de vigas de suporte estruturalmente independente para resistir aos grandes esforços de flexão atuantes nas chapas de fundo desta tipologia de reservatório. Este sistema de vigas, além de materialmente dispendiosa e de custo elevado, também dificultava a manutenção da parte inferior do reservatório, impedindo o acesso a enorme quantidade de juntas existentes entre os painéis (caso do ferro fundido) ou chapas (caso do ferro forjado ou aço), que demandavam manutenções periódicas. ${ }^{45}$ Assim é natural que os projetistas tenham buscado encontrar novos formatos de reservatórios, mais econômicos, que aproveitassem integralmente as qualidades materiais do ferro forjado e do aço.

Em 1854 o engenheiro francês Jules Dupuit (1804-1866) projetou um reservatório elevado de água (fig. 2.3.22) para uma unidade de pesquisa hidráulica em Paris-Chaillot, França. ${ }^{46} \mathrm{O}$ reservatório desenvolvido por Dupuit era cilíndrico, com um fundo em formato de calota esférica e, portanto, transformava parede e fundo em elementos que trabalhavam apenas sob esforços de tração. Explorando a elevada resistência à tração do aço, os reservatórios de fundo suspenso de Dupuit eram muito mais econômicos e, principalmente, autoportantes, dispensando qualquer tipo de suporte intermediário sob seus fundos, que também passaram a ficar livremente acessíveis por todos os lados. A chapas de aço da parede do cilindro eram normalmente conectadas com as chapas que formavam o fundo em calota esférica por meio de perfis angulares (geralmente cantoneiras em ângulos de $90^{\circ}$ e $120^{\circ}$ ) fixados com rebites (fig. 2.3.23). Estes perfis angulares, dobrados ao longo da parede cilíndrica do reservatório, cumpriam uma outra função: atuavam como um anel de pressão,

${ }^{45}$ BECKH, Matthias. Hyperbolic Structures: Shukhov's lattice towers - forerunners of modern lightweight construction. West Sussex: John Wiley \& Sons, 2015, p. 66.

46 DUPUIT, Jules. Traité Theórique et Pratique de la Conduite et de la Distribution des Eaux. Paris: Carillian-Goeury et V. Dalmont, 1854, p. 242-244. 


\subsubsection{2}

Jules Dupuit, Reservatório de Fundo Suspenso, Paris-Chaillot, 1854. resistindo às grandes tensões meridionais de tração (S) atuantes na superfície em calota do fundo do reservatório (fig. 2.3.24). Para transferir a componente vertical $(V)$ desta tensão meridional para a subestrutura, um anel de suporte em ferro fundido foi posicionado no ponto de conexão entre a parede e o fundo do reservatório, parafusado logo abaixo anel de pressão, dimensionado para resistir simultaneamente à componente horizontal $(H)$ da tensão meridional (S). ${ }^{47}$ Ainda que na época, principalmente na Inglaterra, os reservatórios retangulares de fundo plano ainda estivessem em uso, o surgimento do reservatório de fundo suspenso marca um ponto crucial no desenvolvimento dos reservatórios elevados, momento em que os reservatórios metálicos com plantas circulares, formados por superfícies de revolução, passam a ser a norma a ser seguida.
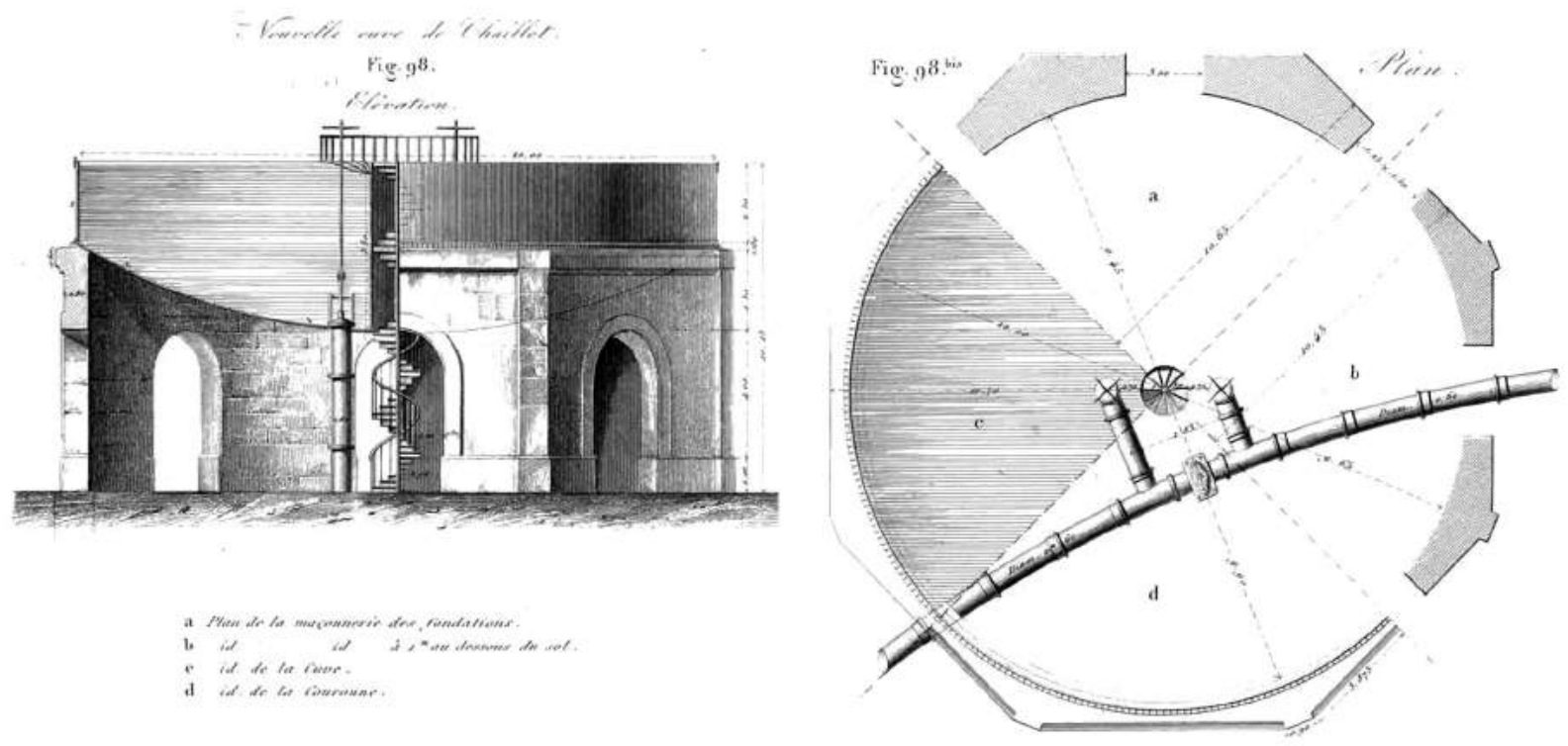

${ }^{47}$ WERTH, 1971, op. cit., p. 350-352. 


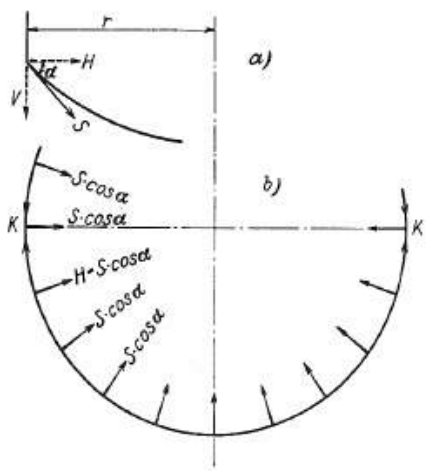

2.3 .24

Esforços atuantes nos anéis de suporte e de pressão dos reservatórios de fundo suspenso.

\subsubsection{3}

Reservatório de fundo suspenso e detalhe dos anéis de pressão e de suporte.

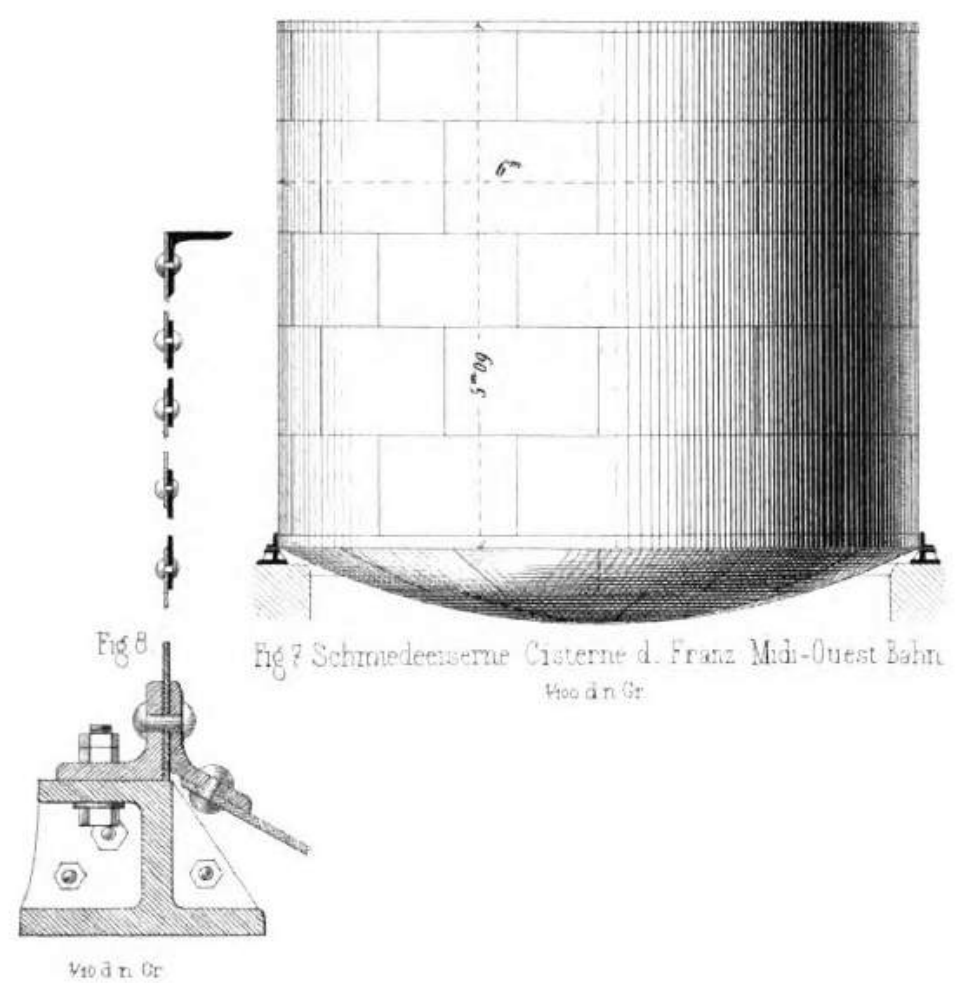

A fraqueza da estrutura do reservatório de fundo suspenso estava localizada no ponto de conexão entre as paredes do tanque com o fundo de dupla curvatura, no chamado anel de suporte que cumpria, simultaneamente, a função de anel de pressão. Este anel de suporte, deformava-se, ampliando ou reduzindo o seu diâmetro conforme a variação do volume de água no interior do reservatório. Ainda, a secção transversal do anel de suporte era determinada pelo volume total do reservatório. Quanto maior a capacidade do reservatório, maior deveria ser a área da secção transversal do anel para resistir aos esforços atuantes. Assim os anéis de suporte e pressão eram reforçados com o acréscimo de outros perfis metálicos de tal forma que pudessem resistir aos esforços atuantes sem a ajuda das paredes do reservatório e evitando danos na subestrutura que poderiam ser causados pela movimentação do conjunto devido à variação dimensional do anel de pressão. A figura 2.3.25 mostra exemplos de anéis de suporte e pressão para reservatórios de fundo suspenso que demonstram a complexidade de construção e fabricação destes anéis. Com o objetivo de simplificar estas complicadas construções em anel, os reservatórios suspensos de grande capacidade eram instalados de 


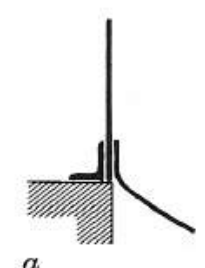

$a$
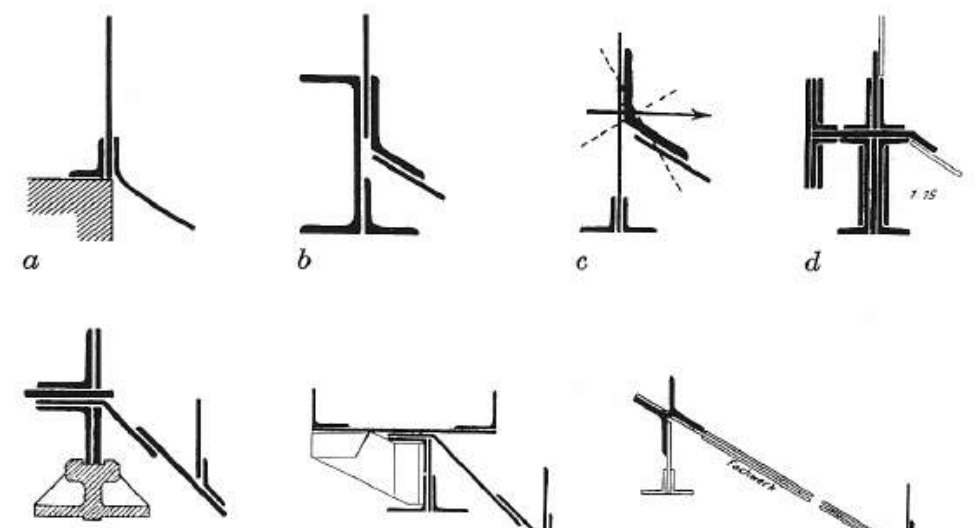

e
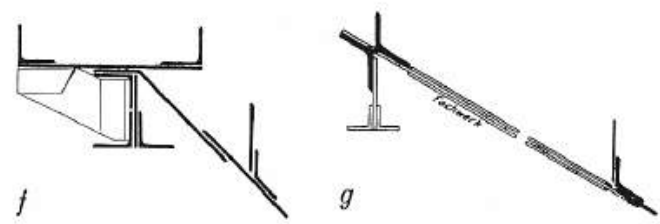

\subsubsection{5}

Diferentes tipologias de anéis de suporte e pressão de reservatórios de fundo suspenso. maneira independente do suporte, fixando ao anel de suporte por meio de uma placa cônica (figs. 2.3.25e, 2.3.25f) ou treliça metálica (fig. 2.3.25g) que descarregava os esforços verticais e horizontais neste último. ${ }^{48}$

A partir de 1857, as torres de água das ferrovias francesas, mais especificamente na Chemins de Fer du Midi, foram equipadas com reservatórios de fundo suspenso (fig. 2.3.26). Estes reservatórios repousavam sobre uma subestrutura octogonal de alvenaria, e eram cobertos por um fechamento de madeira, coroado por um telhado, ambos acompanhando o formato da base de alvenaria. Por volta de 1880 torres de água semelhantes também foram utilizadas nas ferrovias da Bélgica e Alemanha (fig. 2.3.27). A partir de 1890, começou a ser utilizada uma variação desta torre de água, com o reservatório aparente e sem cobertura, repousando sobre uma subestrutura circular de alvenaria (figs. 2.3.28, 2.3.29), que se tornaria padrão nas ferrovias belgas e, posteriormente, nas ferrovias francesas. ${ }^{49}$

48 Ibidem.

49 VAN CRAENENBROECK, W.. Eenheid in Verscheidenheid: Watertorens in Belgie. Brussel: Navewa, 1991, p. 79-83. 


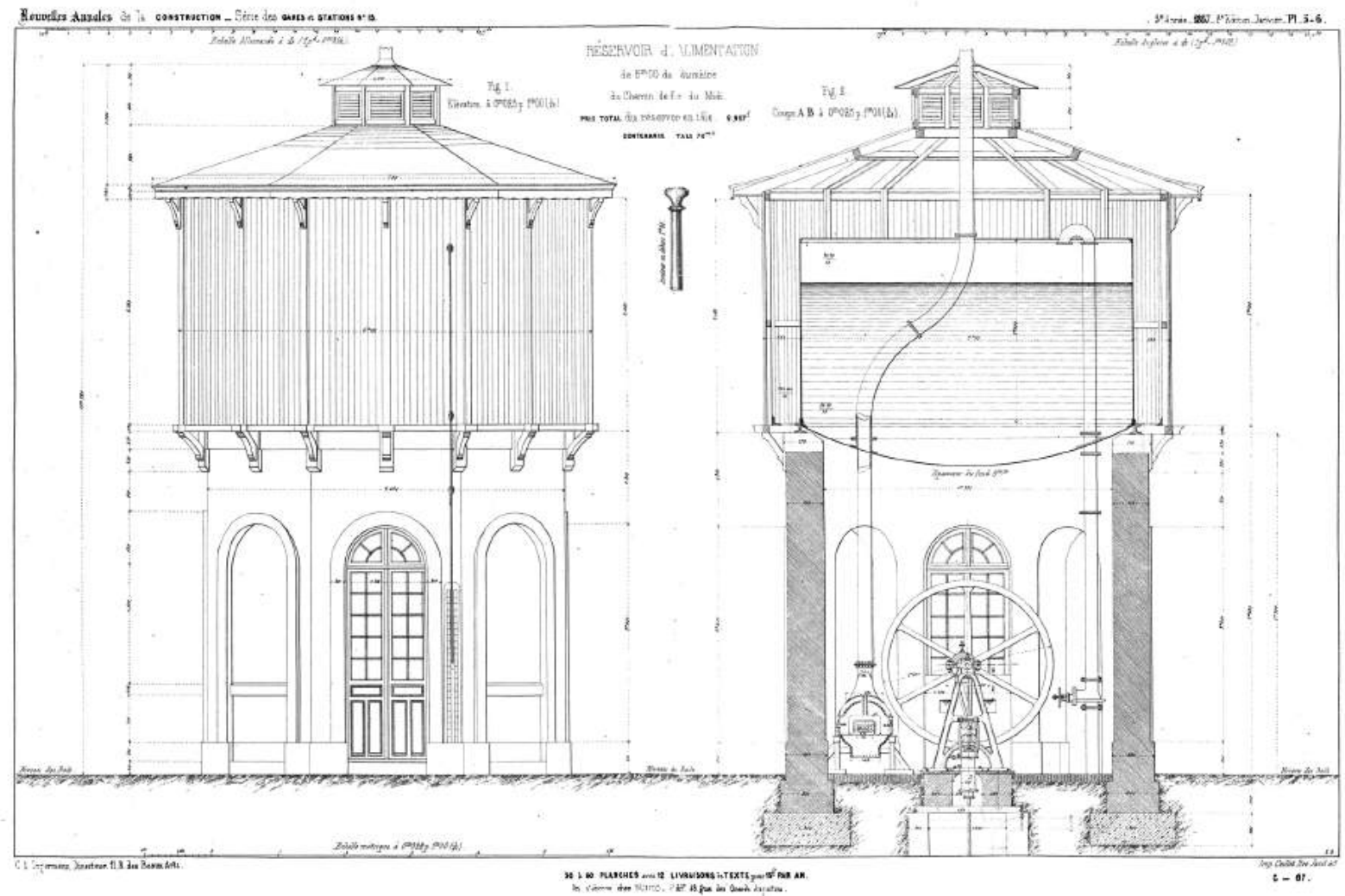

2.3.26

Torre de Água da Chemins de Fer du Midi, França, 1857.

\subsubsection{7}

Torres de Água da Estação de Hânover, Alemanha, ca. 1889. Plantas, cortes e elevações.
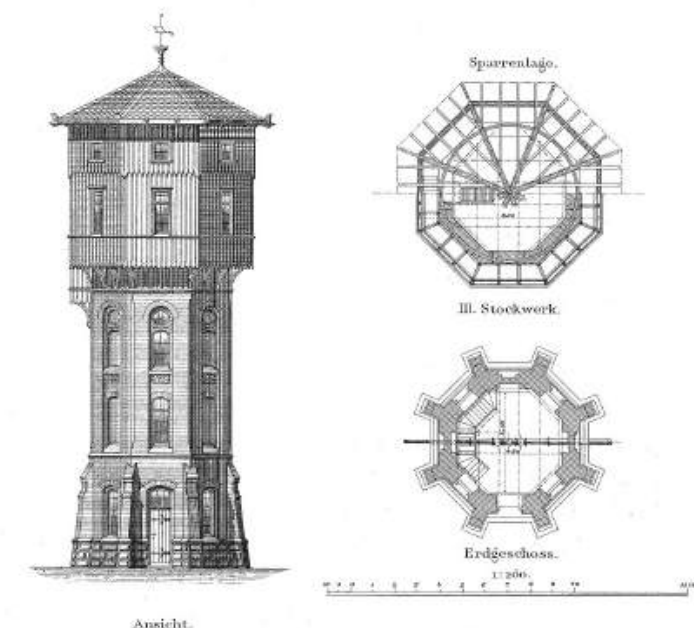

Wusserthurm auf dem Rürgirbahnhof Hainhels.
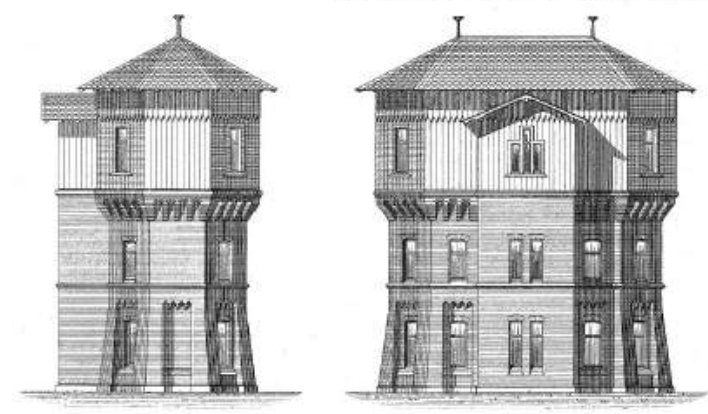

Vorleransichte.
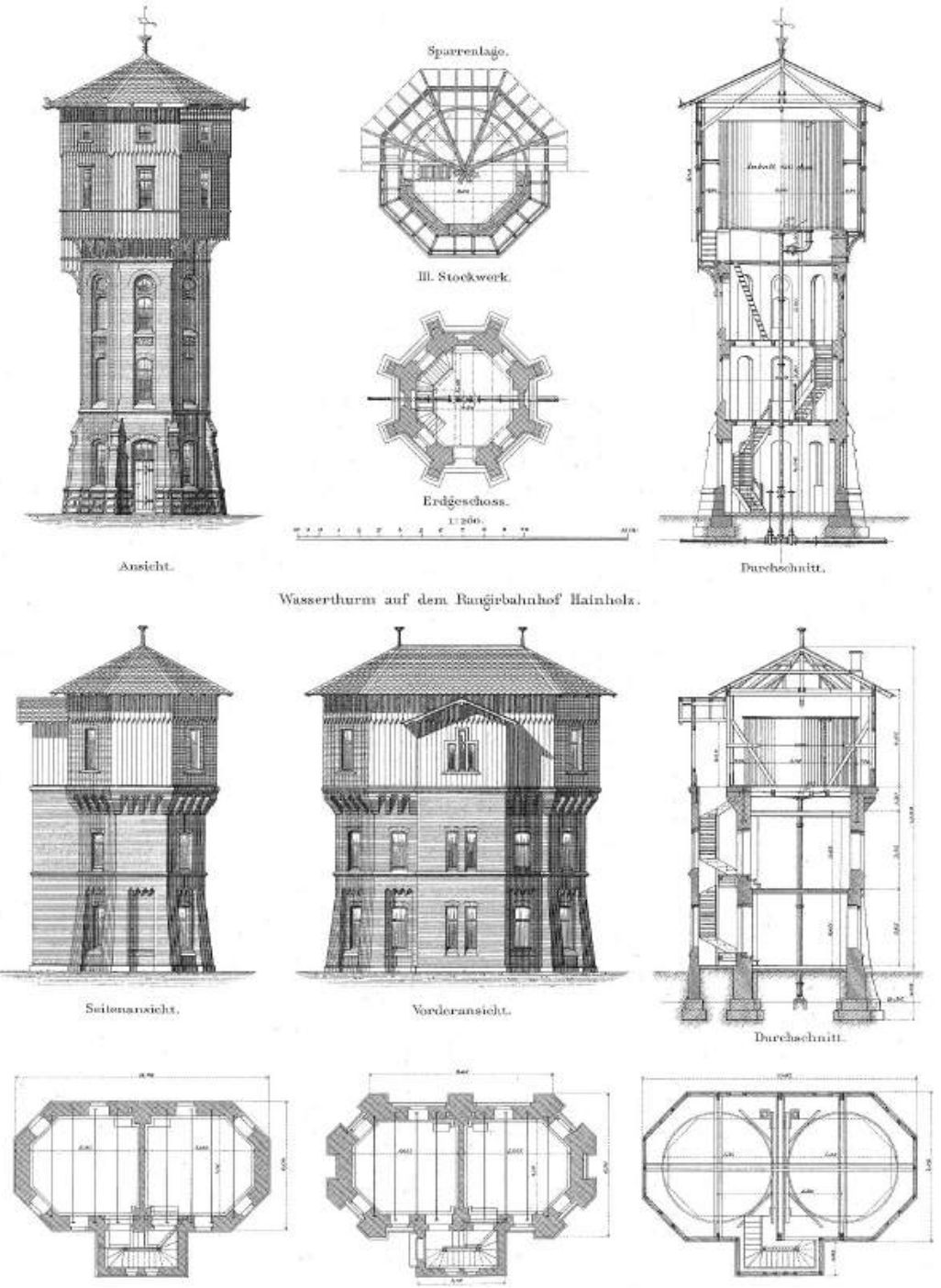


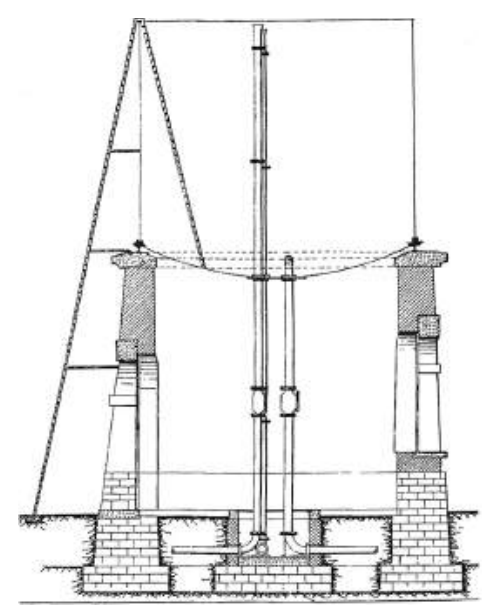

2.3.28

Torre de Água das Ferrovias Belgas, ca. 1881.

Torres Ferroviárias com Reservatório de Fundo Suspenso

a) Sézanne, Marne, França, ca. 1890.

b) Seine et Marne, França, ca. 1890.

\subsubsection{0}

Adolf Thiem, Torre de Água de Estrasburgo, 1878. Corte e elevação.

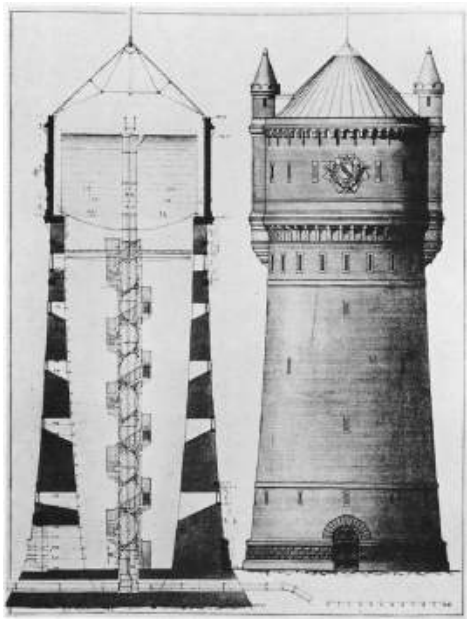

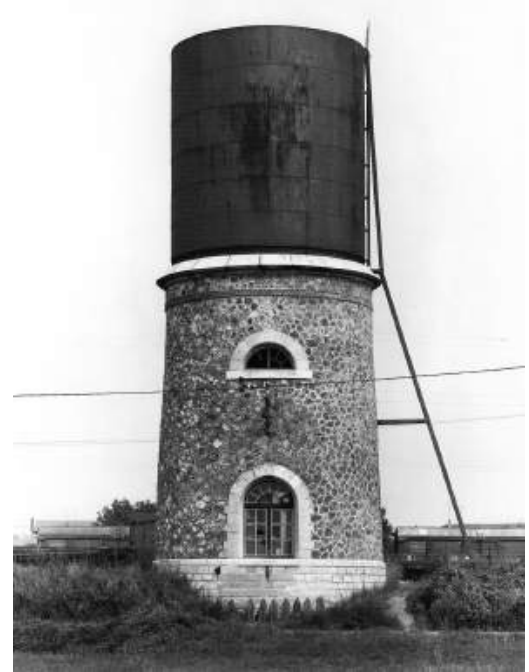

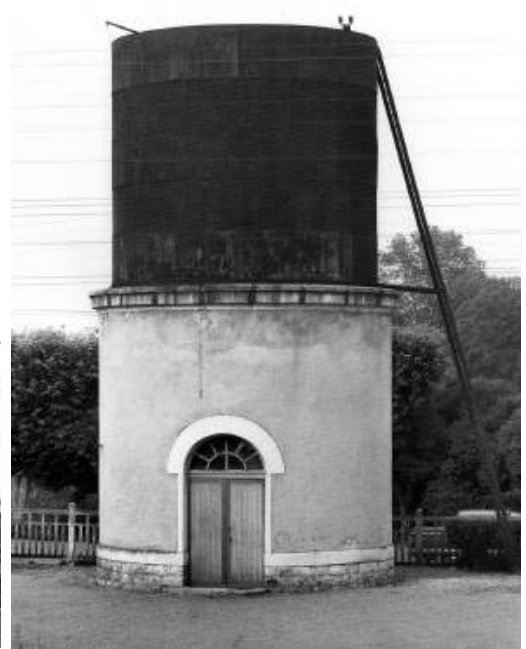

O engenheiro alemão Adolf Thiem (1836-1906), um dos principais especialistas em abastecimento de água de seu tempo, projetou em 1878 para a cidade de Estrasburgo a primeira torre de água para abastecimento público equipada com um reservatório de fundo suspenso com volume de $1.050 \mathrm{~m}^{3}$. Com 54 metros de altura (fig. 2.3.30) a torre de Thiem, com um formato cônico e com um alargamento no trecho correspondente ao recinto do reservatório, assemelhava-se às torres dos castelos medievais. A alvenaria de proteção do reservatório foi apoiada sobre uma cornija em balanço, distante cerca de $70 \mathrm{~cm}$ da parede do reservatório, criando um corredor de manutenção. A subestrutura circular de alvenaria não era enrijecida por paredes internas nem por pisos intermediários e as paredes tinham espessuras variando entre 5,70 e 1,25 metros. ${ }^{50}$ No grande espaço interno do fuste cilíndrico apenas uma escada espiral, construída ao redor das tubulações, conduzia até o piso sob o tanque. Influenciadas pelo projeto de Thiem, cidades alemãs como Berlin (1882, 1886, 1888 e 1893), ${ }^{51}$ Essen (1884), Manheim (1886), Berlin (1886), Worms (1888) e Braunschweig (1901) construíram torres de água equipadas com reservatórios de fundo suspenso.

\footnotetext{
50 WERTH, 1971, op. cit., p. 350.

${ }^{51}$ Algumas das torres de água com reservatórios de fundo suspenso construídas em Berlim neste período foram: Berlin-Westend, $1.000 \mathrm{~m}^{3}$ (1882); Berlin-Steglitz, $2.000 \mathrm{~m}^{3}$ (1886); Berlin-Tempelhofer Berg, 400 m³ (1888) e Berlin-Rixdorf, 2.500 $\mathrm{m}^{3}$ (1894). Ver MERKL, Gerhard et al. Historische Wassertürme: Beiträge zur Technikgeschichte von Wasserpeicherung und Wasserversorgung. München: Oldenburg Verlag, 1985. p. 76.
} 
Em 1884 a empresa F. A. Neuman contratou o engenheiro alemão Otto Intze (1843-1904), professor de engenharia hidráulica da Technische Hochschule Aaachen, para projetar a nova torre de água da cidade de Essen (figs. 2.3.31, 2.3.32), que seria equipada com um reservatório de $2.000 \mathrm{~m}^{3}$, o maior reservatório de fundo suspenso construído até então. Com o objetivo de reduzir os esforços horizontais atuantes no anel de pressão do reservatório, Intze projetou um fundo com grande altura de flecha, cerda de $1 / 4$ do vão, muito maior que as flechas normalmente utilizadas nos reservatórios de menor volume, que giravam em torno de 1/8 a 1/9 do vão. Além disso, substituiu o anel de suporte por uma estrutura treliçada fabricada com cantoneiras (ver o detalhe do suporte e da treliça na figura 2.3.31), garantindo uma maior rigidez ao anel de suporte no sentido do carregamento vertical. ${ }^{52}$ Sob o reservatório de 18 metros de diâmetro nenhum tipo de apoio intermediário de fazia necessário. Mas isso não refletiu na forma do edifício que, externamente, era muito similar a torre de água de Halle (1868): uma planta poligonal, maciças paredes de alvenaria, torretas de canto e uma parede coroada por ameias recobrindo o reservatório, tudo no mesmo austero estilo neo-românico de outras torres do período. Assim como na torre de Bremen, as torretas de canto eram funcionalizadas, abrigando as escadas de acesso ao piso do reservatório e também as tubulações hidráulicas. A torre de água de Essen continua em uso até hoje e por pouco não foi completamente destruída durante a Segunda Guerra Mundial, quando as torretas de canto e o recobrimento de alvenaria do reservatório foram destruídos, o que ofereceu uma oportunidade rara de mostrar em detalhes a construção completa do reservatório metálico (fig. 2.3.33).

52 WERTH, 1971, op. cit., p. 353. 

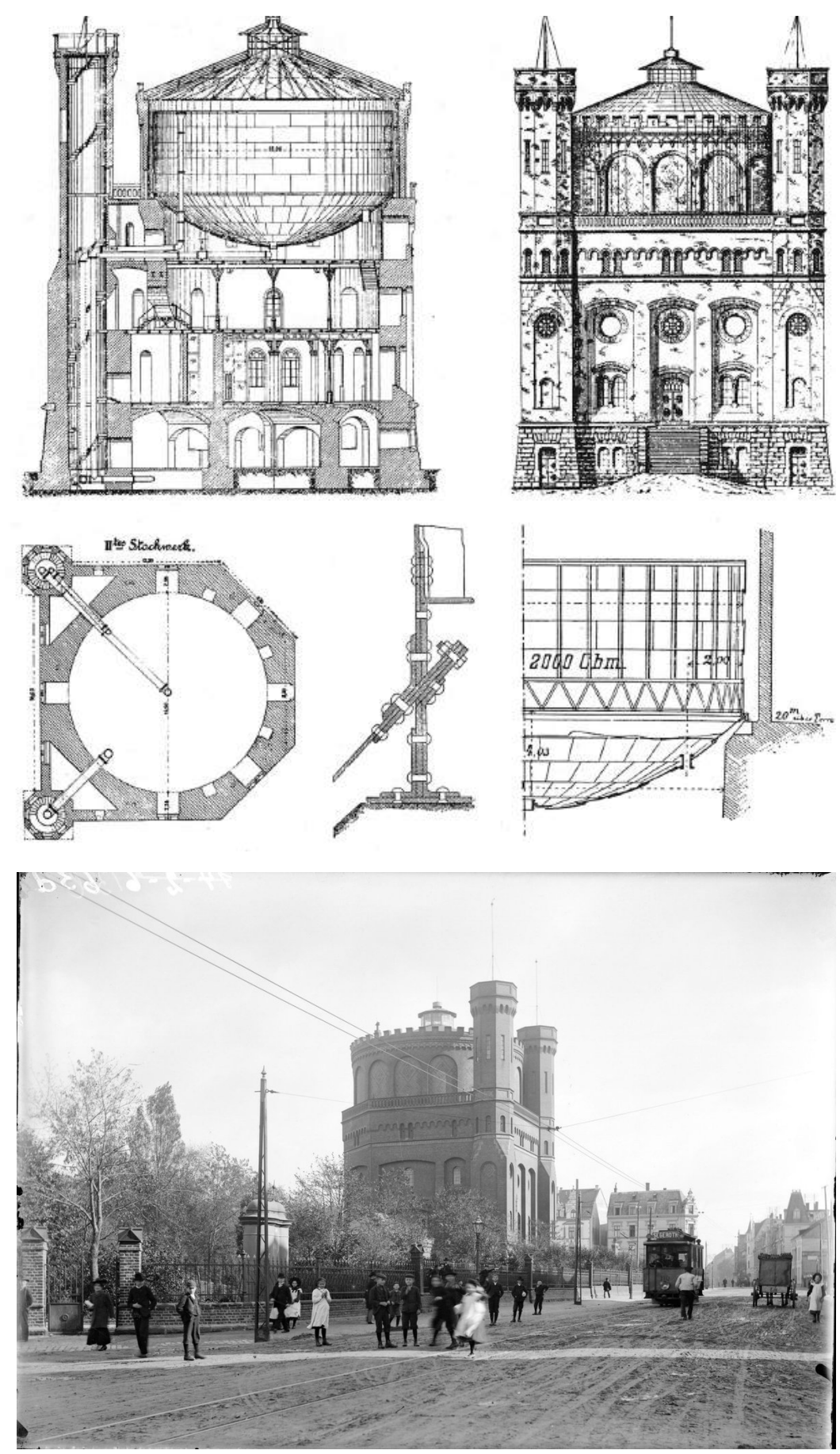

Em 1882 o engenheiro austríaco OskarSmrecker(1854-1935)

Otto Intze, Torre de Água de Essen, Alemanha, 1884. Planta, corte, elevação e detalhes.

\section{3 .32}

Otto Intze, Torre de Água de Essen, Alemanha, 1884. Aspecto

\section{3 .33}

Otto Intze, Torre de Água de Essen, Alemanha, 1884. Foto de Bernd e Hilla Becher, 1965. foi contratado para projetar o sistema de abastecimento público de água de Mannheim. Em seu projeto, Smrecker, determinou a necessidade da construção de uma torre de água no local do antigo Heidelberg Tor, atual Friedrichsplatz, para compensar as flutuações de pressão de rede hidráulica, uma vez que não existiam terrenos naturalmente elevados na área de Mannheim que pudessem acomodar reservatórios geradores de pressão. Para a escolha do projeto arquitetônico da torre foi realizado um concurso nacional 


\subsubsection{5}

Gustav Halmhuber, Torre de Água de Mannheim, Alemanha, 1886. Foto de Bernd e Hilla Becher, 1965.

\subsubsection{4}

Gustav Halmhuber, Torre de Água de Mannheim, Alemanha, 1886. Plantas e corte.

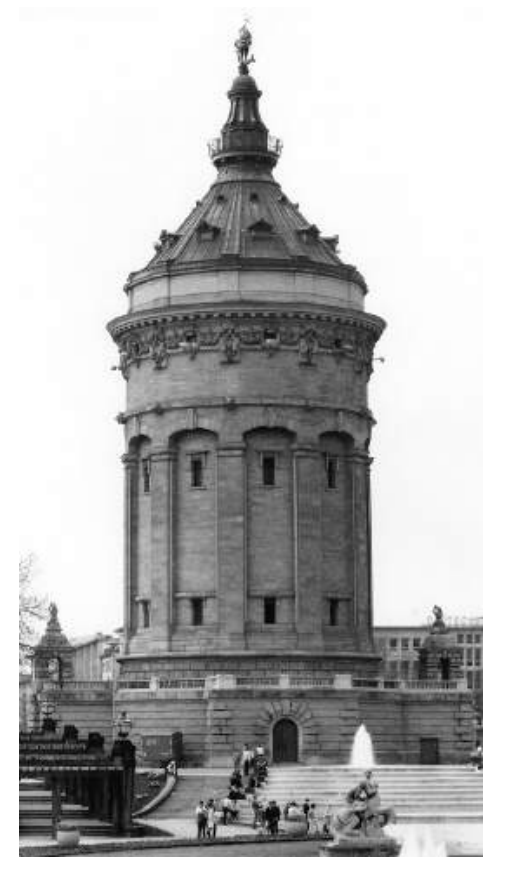

de projetos em 1885, que foi vencido pelo jovem arquiteto de Stuttgart, Gustav Halmhuber (1862-1936). A torre de água (figs. 2.3.34, 2.3.35), construída entre 1886 e 1889, foi posicionada no centro da cidade como um marco e seu projeto faz referência e repete os elementos arquitetônicos ornamentais neo-barrocos do Schloss Mannheim, um dos maiores palácios barrocos da Europa, construído entre os anos de 1720 e $1760 .{ }^{53}$ A Friedrichsplatz, com seus jardins e chafarizes, foi projetada em conjunto com a torre de água, como parte das obras de implantação do sistema municipal de abastecimento de água, um espaço urbano idealizado por Smrecker e Halmhubber com o objetivo de "dar visibilidade às dificilmente notadas obras dos engenheiros. "54

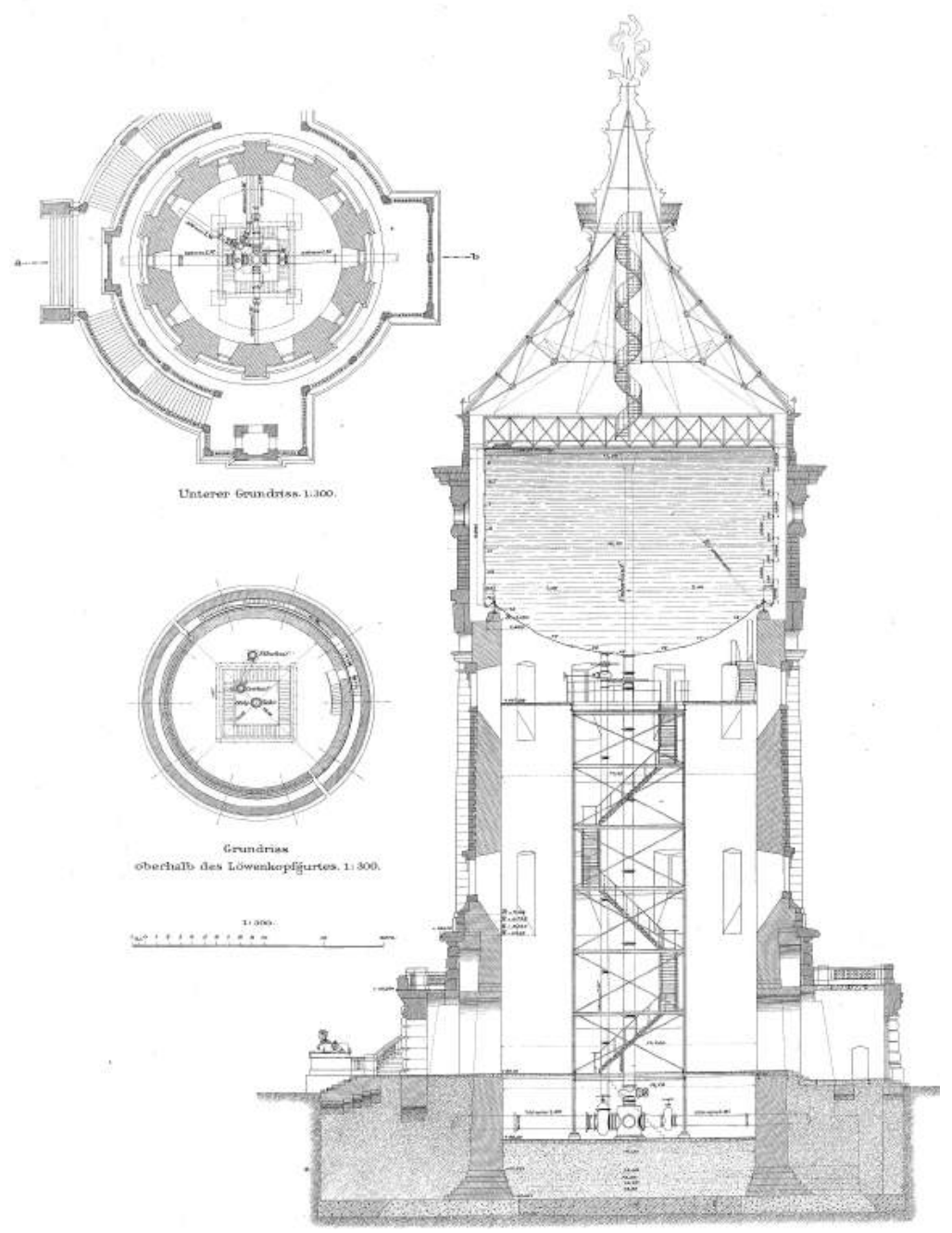

53 MEVIUS, Walter. Baustile und Wassertürme. In: MERKL, Gerhard et al. Historische Wassertürme: Beiträge zurTechnikgeschichte von Wasserpeicherung und Wasserversorgung. München: Oldenburg Verlag, 1985, p. 153; e GOCKEL, 1985, op. cit., p. 186.

${ }^{54}$ Apud MEVIUS, 1985, op. cit., p. 153. 

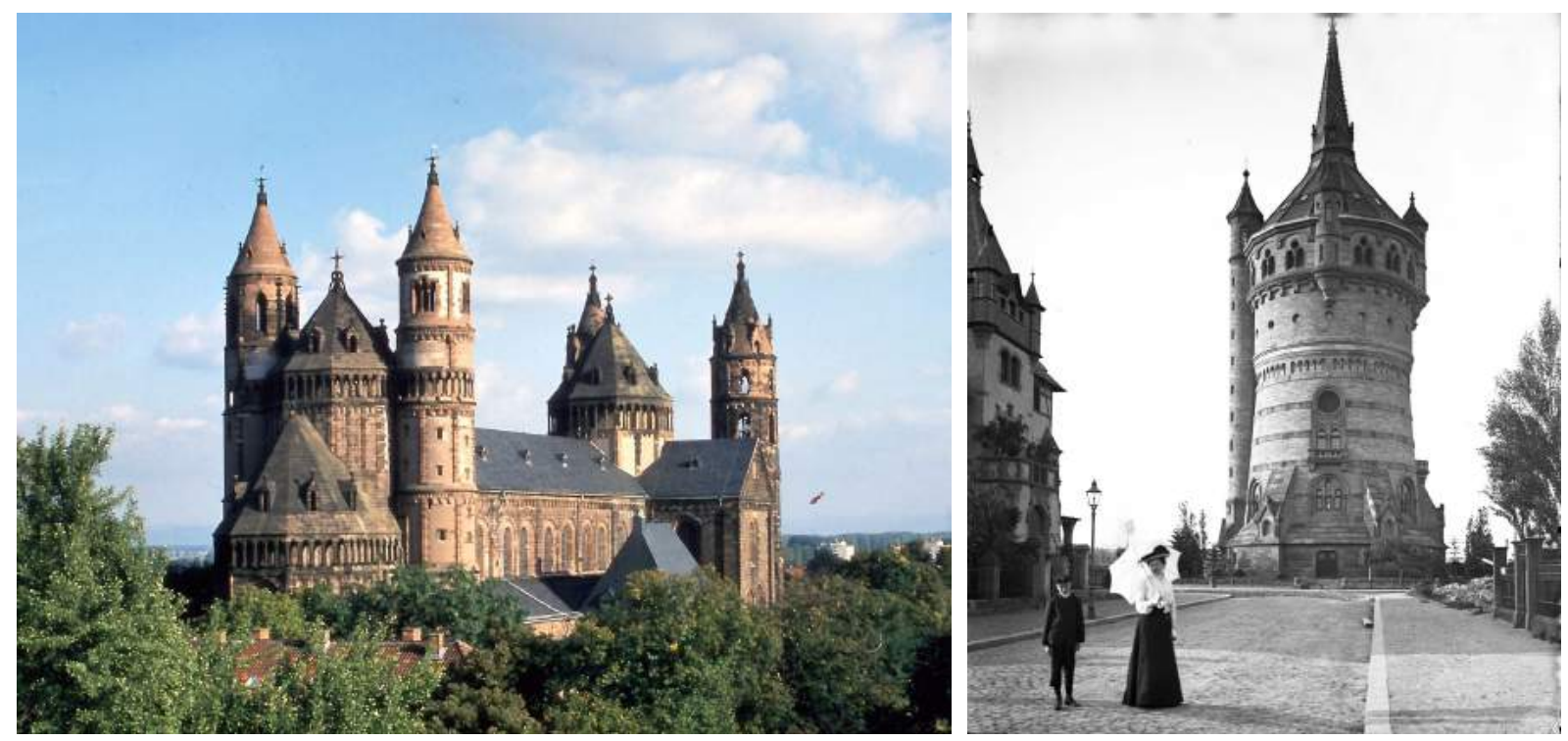

\subsubsection{6}

Catedral de São Pedro (Wormser Dom), Worms, Alemanha, 11101181.

\subsubsection{7}

Karl Christian Hoffmann, Torre de Água de Worms, Alemanha, 1888.
Em, uma cidade cuja paisagem é dominada pelas torres românicas da Catedral de São Pedro (fig. 2.3.36), o arquiteto Karl Christian Hoffmann (1856-1933) projetou em 1888 uma torre de água (fig. 2.3.37) de quase 60 metros de altura com as mesmas formas românicas da catedral. O reservatório de fundo suspenso, totalmente escondido no interior da torre, tem um volume de $1.200 \mathrm{~m}^{3}$, com um diâmetro de 12,90 metros, altura de parede de 9,15 metros e flecha de fundo de aproximadamente 2,35 metros. O corte na figura 2.3.38 mostra o autoportante e estruturalmente eficiente reservatório de fundo suspenso fabricado em ferro forjado que dispensava a utilização de suportes intermediários. $\bigcirc$ volume de água armazenado era suficiente para atender a $36 \%$ do consumo médio diário da cidade, cuja população era de 32.000 habitantes na época. A torre tem um diâmetro de 20,40 metros no seu embasamento e 15,50 metros de diâmetro no nível do anel de suporte do reservatório. A cornija principal, posicionada a uma altura de 31,40 metros, tem um diâmetro de 17,50 metros e é o ponto de transição entre o fuste da torre e a impressionante cobertura com altura de 26,55 metros, praticamente metade da altura total da torre que é de 57,95 metros..$^{55} \mathrm{~A}$ escolha do estilo neorromânico da torre de água, foi defendido por Hoffman com as seguintes palavras:

${ }^{55}$ GOCKEL, 1985, op. cit., p. 188-190. 

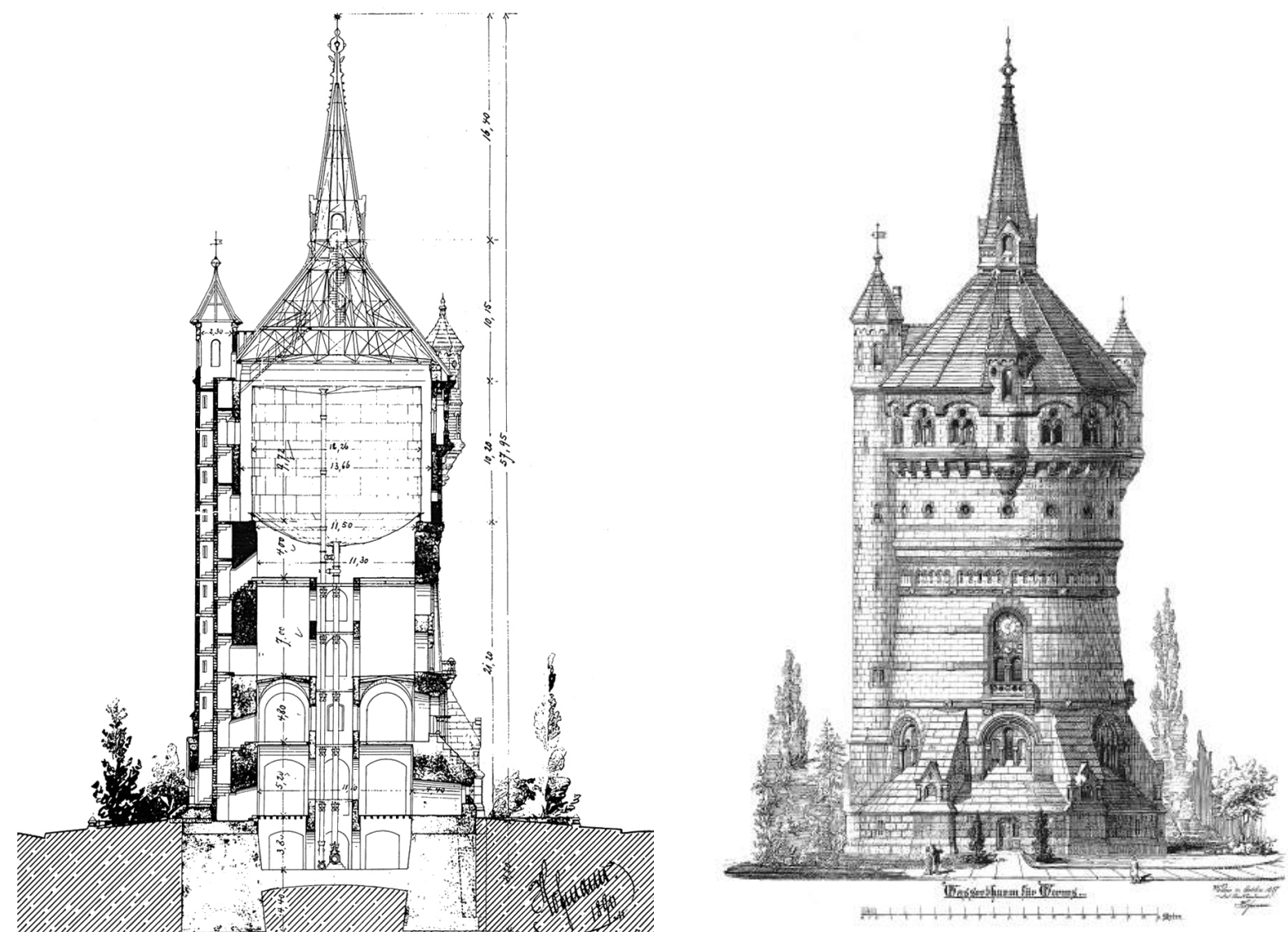

\subsubsection{8}

Karl Christian Hoffmann, Torre de Água de Worms, Alemanha, 1888. Corte e Elevação.
"Embora o objetivo da estrutura seja puramente funcional e técnico, tendo que satisfazer todas as exigências necessárias para seu funcionamento, foi enfatizado pela administração municipal que a aparência externa da construção, cujas dimensões consideráveis atraem muita atenção, não deve se tornar um elemento de indignação para a população da cidade. Como resultado o estilo românico que domina a paisagem urbana de Worms teve força decisiva nas decisões de projeto, formas e materiais." 56

$\mathrm{Na}$ Inglaterra a distinção entre o reservatório e a subestrutura que desde o início tinha se feito presente nas primeiras torres de água inglesas é abandonada quando foram introduzidos os primeiros reservatórios de fundo suspenso. Diferentemente do material que o precedeu, as chapas de ferro forjado não podiam

56 "Obschon der Zweck des Bauwerkes ein rein praktisch-technischer ist und dieses hauptsächlich nur den Ansprüchen der Festigkeit zu genügen hat, so legte die Stadtverwaltung in Anbetracht dessen, daß das Gebäude durch seine erheblichen Abmessungen doch sehr in die Augen fällt, Werth darauf, daß es in der äußeren Gestaltung der Stadt nicht zur Unzierde gereiche. Infolge dessen haben auf die Wahl der Bauformen und Baustoffe die ehrwürdigen Zeugen aus romanischer Zeit, die das Wormser Stadtbild beherrschen, bestimmend eingewirkt." (Justificativa de Karl Christian Hoffmann para o estilo românico adotado na torre de água de Worms, Apud MEVIUS, 1985, op. cit., p. 152-153) 


\subsubsection{9}

George F. Deacon, "Norton Tower", Liverpool, Inglaterra, 1890.

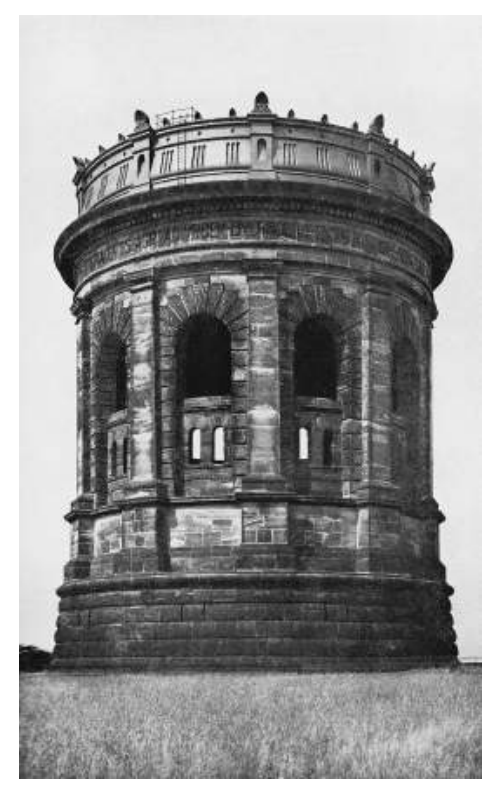

ser facilmente disfarçadas com a aplicação dos "elementos decorativos" que eram normalmente moldados em conjunto com os painéis de ferro fundido e a construção rebitada dos reservatórios trazia consigo uma imagem que era frequentemente associada às ordinárias caldeiras utilizadas nos sistemas de motores a vapor. ${ }^{57}$ Assim, a prática corrente na Europa continental de se projetar torres de água com reservatórios ocultos, pelo menos nos grandes centros urbanos, foi também adotada na Inglaterra.

Em Liverpool, a "Norton Tower" (fig. 2.3.39), projeto de George F. Deacon (1843-1909) construído em 1890, tem uma altura total 35 metros e foi equipada com um reservatório com volume de $2.500 \mathrm{~m}^{3}$ e diâmetro de 25 metros, $^{58}$ um dos maiores reservatórios de fundo suspenso já instalados em uma torre de água. ${ }^{59} \bigcirc$ embasamento cilíndrico foi construída em alvenaria de pedra, arenito vermelho. Acima deste embasamento ergue-se um corpo cilíndrico de pedra de cantaria formando a base para dez pilastras que se elevam até o friso de cobertura, emoldurando arcos plenos construídos com pedras em cunha. Acima do friso uma cornija dentada faz a transição para o reservatório metálico, um exemplar único, onde a parede foi fabricada com painéis de ferro fundido, flangeados internamente e decorados no exterior com tríglifos entre pilastras falsas encimadas por conchas ornamentais (fig. 2.3.40), enquanto que o fundo suspenso em calota esférica foi fabricado com chapas rebitadas de aço doce (mild steel). Um artigo da época publicado na revista The Engineer, de 1891, ressaltou as "excelentes proporções arquitetônicas" da torre de água e também a "decoração de excelente gosto aplicada aos painéis de ferro fundido, em conformidade com o caráter geral das alvenarias de pedra."

\footnotetext{
${ }^{57}$ BARTON, 2003, op. cit., p. 39.

58 HOBBS, Aubrey Thomas (Ed.). Manual of British Water Supply Practice. Cambridge: Heffer \& Sons, 1954, p. 530.

59 Segundo dados compilados por WERTH (1971), o volume do reservatório de fundo suspenso da Norton Tower foi superado apenas pelo reservatório da torre de água de Hamburgo-Winterhude (1916), Alemanha, com volume de $3.000 \mathrm{~m}^{3}$. Neste estudo foram levantados reservatórios de fundo suspenso construídos entre os anos de 1870 e 1934.

60 The Norton Tower of the Vyrnwy-Liverpool Water Supply. The Engineer, London, v. 72, n. 12, 1891, p. 231.
} 


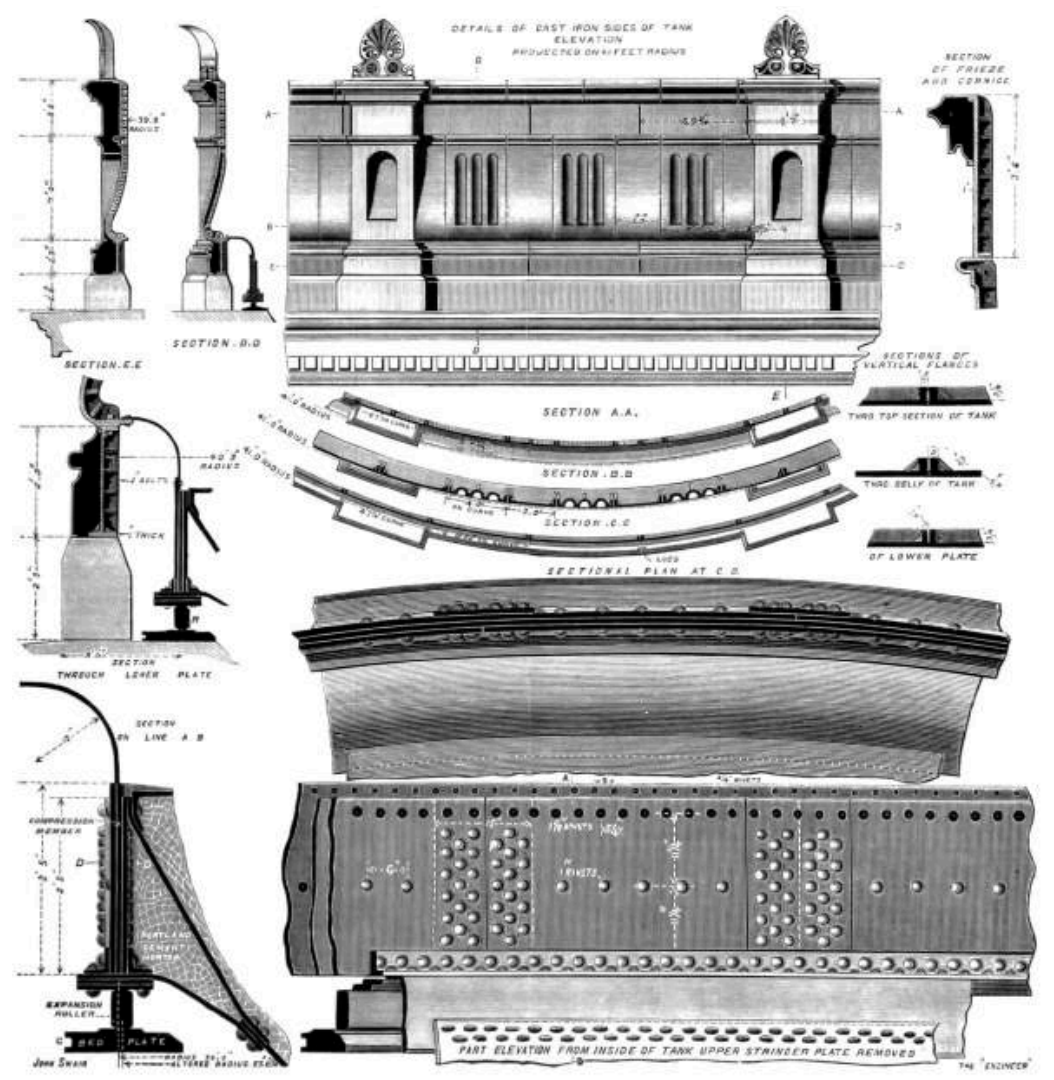

\subsubsection{0}

George F. Deacon, "Norton Tower", Liverpool, Inglaterra, 1890. Detalhes dos painéis de ferro fundido do reservatório.

\subsubsection{1}

George F. Deacon, "Norton Tower", Liverpool, Inglaterra, 1890. Corte

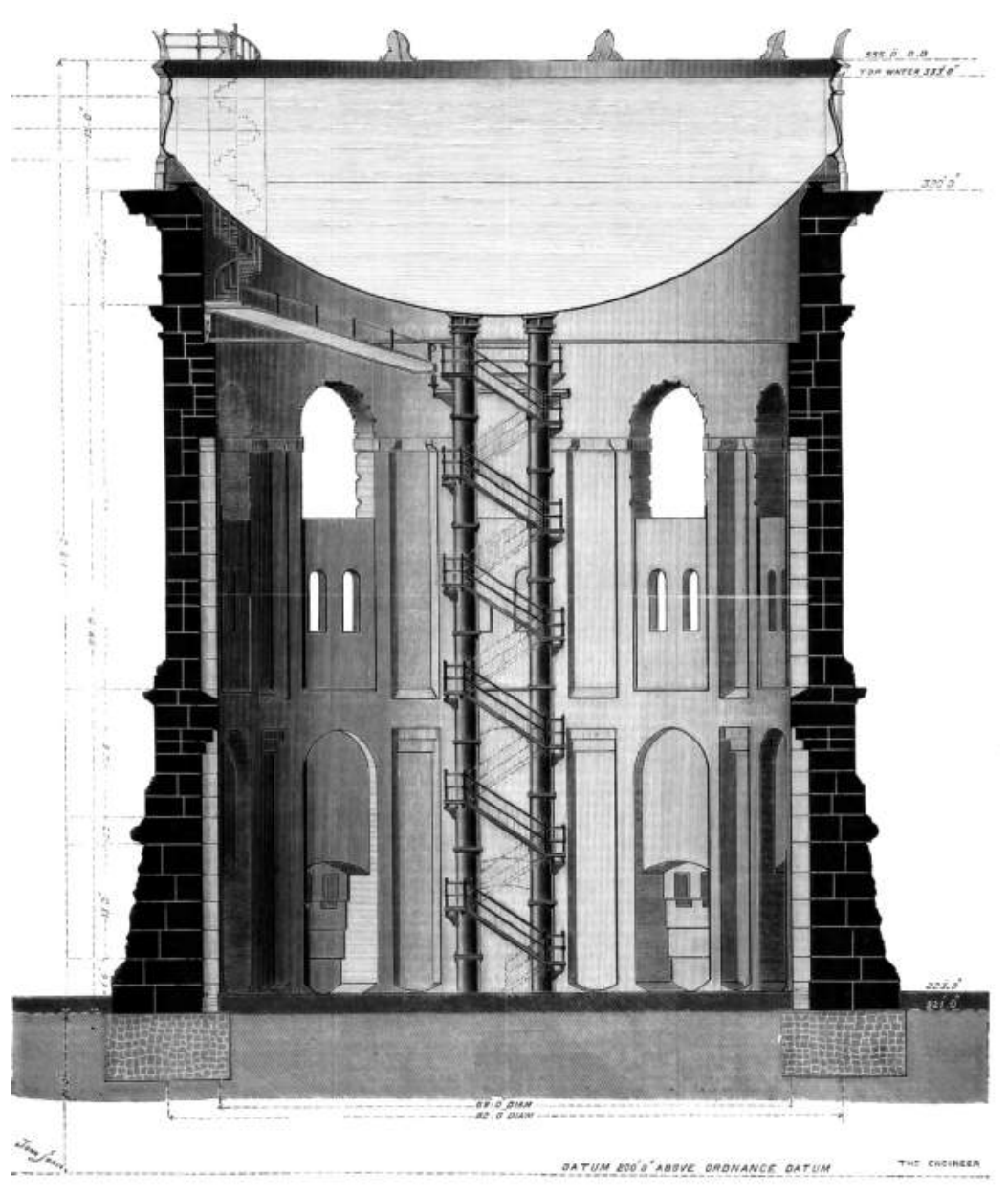




\subsubsection{2}

George F. Deacon, "Norton Tower", Liverpool, Inglaterra, 1890. Detalhes.
Também é digno de nota na "Norton Tower", a sua subestrutura vazada, isto é, o espaço existente entre arcos e pilastras teve o seu vazio preservado, garantindo uma certa transparência, uma solução de projeto completamente oposta à adotada na Europa continental, onde o espaço entre pilastras e arcos era preenchido com alvenarias, resultando em um todo opaco. A solução de uma subestrutura permeável visualmente já havia sido utilizada em outras torres de água inglesas como, por exemplo, na "Jumbo Water Tower" (1882). O corte da torre (fig. 2.3.41) mostra o interior da subestrutura onde uma escada construída ao redor das tubulações hidráulicas levava até uma passarela que conduz até a escada em espiral construída no interior de um túnel vertical que atravessava o reservatório em altura, garantindo acesso ao topo da torre de água. A passarela que conecta as duas escadas tem uma função dupla, atuando também como uma espécie de ponte rolante ou, neste caso, ponte giratória, apoiada nas duas extremidades em um sistema de trilhos em anel e roletes, garantindo acesso para manutenção em toda a superfície do fundo do reservatório (fig. 2.3.42).

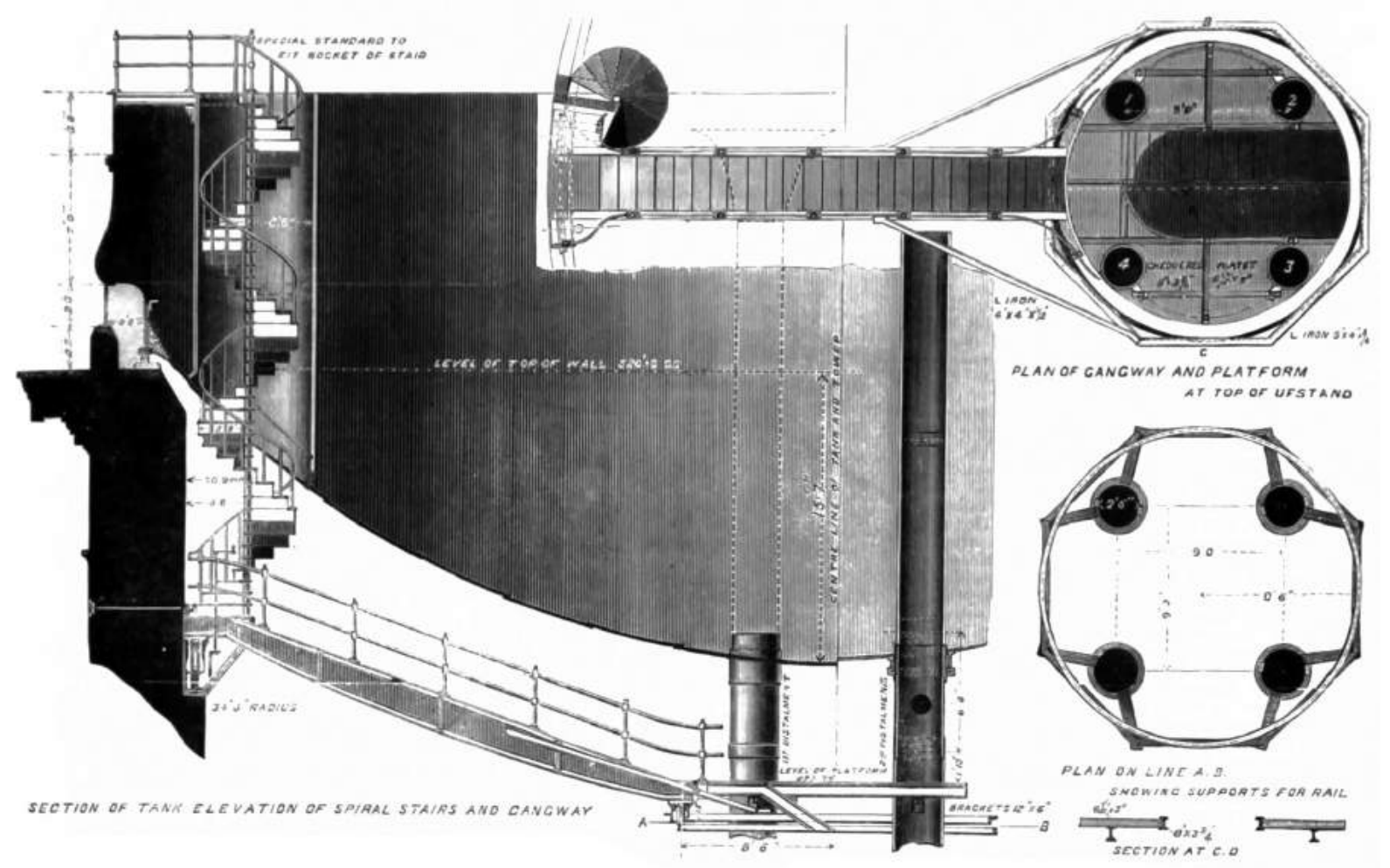



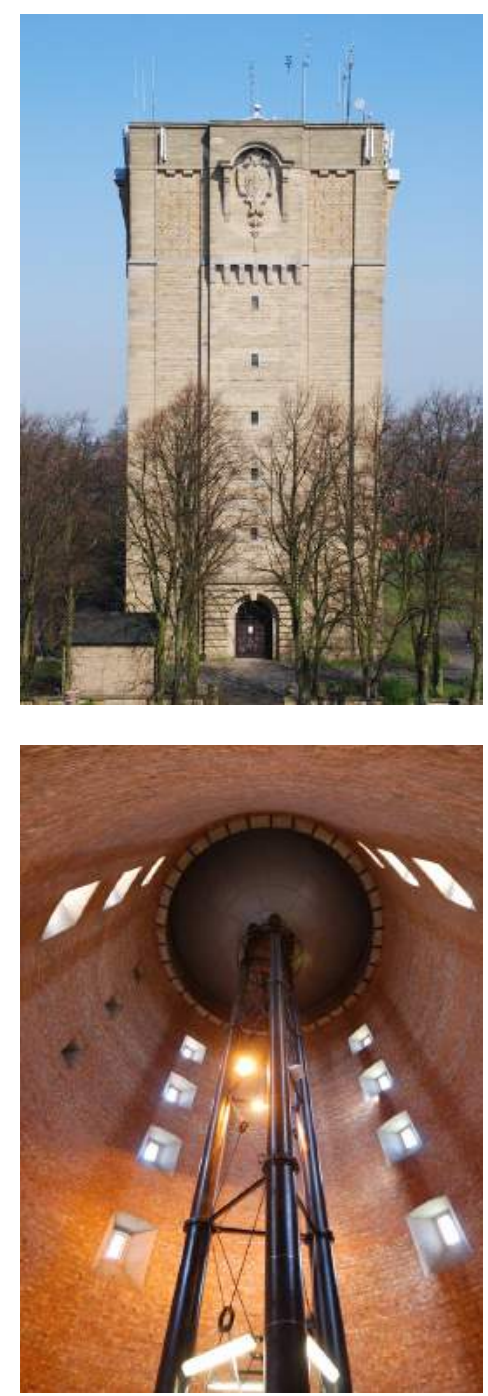

2.3.43

Reginald Blomfield, "Westgate Tower", Lincoln, Inglaterra, 1904.

\subsubsection{4}

Reginald Blomfield, "Westgate Tower", Lincoln, Inglaterra, 1904. Vista do interior.

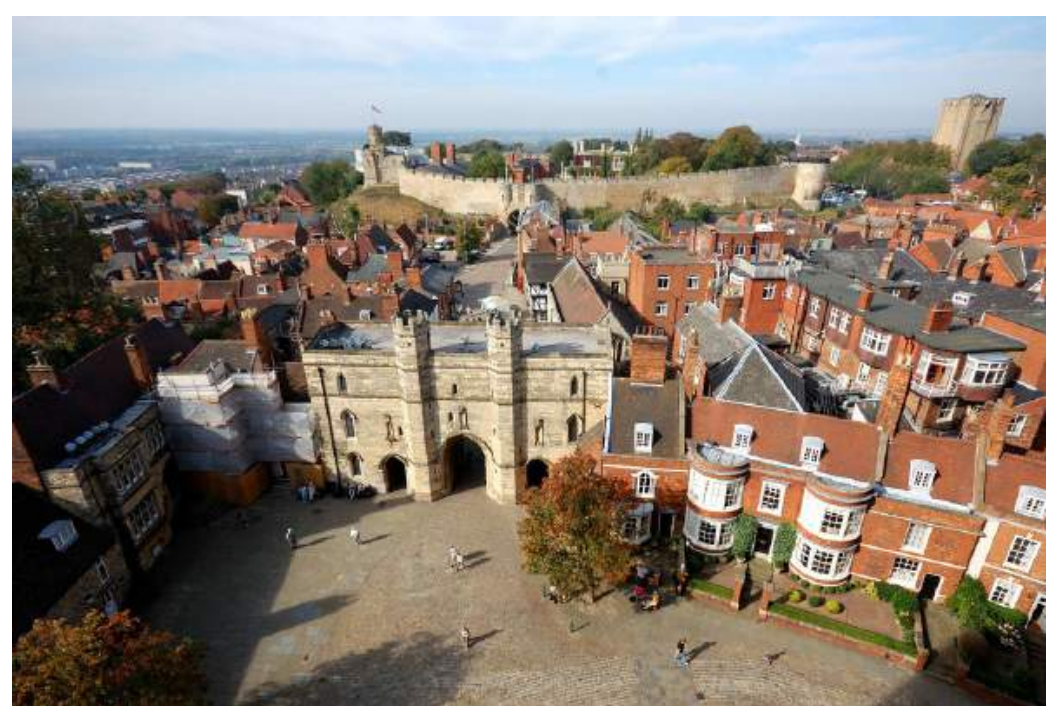

$\mathrm{Na}$ "Westgate Tower" (figura 2.3.43), construída em 1904 na cidade de Lincoln, o reservatório metálico de fundo suspenso está apoiado em um fuste circular de tijolos, ambos encamisados por uma massiva alvenaria quadrada de granito cinza com largura de 17 metros e altura de 35 metros, que faz concessão apenas a poucas e diminutas aberturas que iluminam o interior da torre. Os vazios remanescentes entre o fuste circular e estrutura de granito externa acomodam escadas que dão acesso ao topo do reservatório e à cobertura da torre. O fuste circular abriga apenas as tubulações hidráulicas (figura 2.3.44). $O$ arquiteto Reginald Blomfield (1856-1942), projetou a torre para se assemelhar a uma fortaleza normanda, de modo a dar uma sensação de continuidade à Catedral de Lincoln (1300-1549) e ao castelo medieval do século XI vizinho da torre de água. ${ }^{61}$

A nova tipologia do reservatório de fundo suspenso de Dupuit, estruturalmente eficiente, autoportante e que oferecia a possibilidade do vão livre utilizável sob o reservatório, no entanto, não teve reflexos imediatos na arquitetura das torres de água para abastecimento urbano, que continuaram a ser projetadas e construídas seguindo as experiências anteriores e em conformidade com as tendências arquitetônicas do revivalismo histórico atuante no período. Assim como acontece com muitas inovações técnicas, demorou algum tempo até ser encontrada uma forma resultante

${ }^{61}$ BARTON, 2003, op. cit., p. 38-39. 
que explicitasse a função da torre de água. Assim, não é de se surpreender que tentou-se esconder todos os elementos técnicos da torre de água, considerando uma suposta ausência de forma destes elementos, envolvendo-as com as formas já conhecidas de construções com outras funções. Especialmente na Europa continental, as formas inspiradas em fortificações ou em torres de castelos medievais foram inicialmente utilizadas na construção das primeiras torres de água, o que era claramente expresso nos elementos de coroamento das torres com suas ameias, pináculos e lancetas, bem como nos demais elementos decorativos de suas fachadas, como arcos românicos ou góticos, seteiras, janelas com persianas, frisos e cornijas em tijolo ou pedra. ${ }^{62}$

A expansão das áreas de abastecimento nas cidades industriais em constante crescimento passaram a demandar alturas maiores de torres para fornecer a água com pressão adequada, o que se traduzia em estruturas cada vez mais verticais o que, somado ao momento de revivalismo histórico em curso na arquitetura do século XIX, se prestava perfeitamente à criação de formas que remetiam às torres dos castelos ou das fortalezas medievais.

As torres de água britânicas, por outro lado, refletiam tradições de projetos diferentes daquelas do continente. $\mathrm{Na}$ Inglaterra, onde a Revolução Industrial se iniciou, havia uma tradição bem estabelecida de uma "arquitetura de engenheiros". As fábricas, os edifícios ferroviários, as usinas, as estações de bombeamento, eram todos construídos em uma sólida arquitetura de alvenaria de tijolos aparentes, com ornamentação mínima, e esta tradição construtiva acabou refletida na construção das primeiras torres de água inglesas. ${ }^{63} \mathrm{Em}$ alguns casos como, por exemplo, na "Jumbo Water Tower" e na "Norton Tower", as torres de água eram erguidas como gigantescos arcos abertos, como os utilizados nos primeiros viadutos ferroviários que, frequentemente, remetiam à imagem dos aquedutos romanos.

\footnotetext{
62 WERTH, 1971, op. cit., p. 348.

${ }^{63}$ WITT, Dennis J. de. Fantastic Water Towers: An 1890 Design Competition. Boston: Metropolitan Waterwoks Museum, 2017, p. 96.
} 


\subsubsection{Primeiras Torres de Água Totalmente Metálicas}

É difícil precisar quantas foram e também quais foram as primeiras torres de água totalmente metálicas, isto é, reservatórios de materiais ferrosos apoiados sobre esqueletos estruturais de materiais ferrosos, construídas durante o século XIX. Assim como na construção dos reservatórios de água, o material empregado para a construção dos esqueletos estruturais foi, inicialmente, o ferro fundido; em seguida o ferro forjado, destinado a ser laminado ou prensado em chapas; e, por fim, o aço. Assim como ocorrido com as pontes e viadutos construídos com elementos de ferro fundido ou forjado, pouquíssimos exemplares sobreviveram. Barton (2007) sugere que a falta de exemplares de torres de água construídas totalmente em ferro neste período deve-se a dois motivos principais: eram incomuns e fáceis de desmontar. Devido às próprias características das estruturas metálicas, as torres de água em ferro eram muito fáceis de serem desmontadas e era economicamente vantajoso desmontar uma torre fora de uso para reaproveitar o seu material em uma nova construção, muito diferente do que acontecia com uma torre construída em alvenaria de tijolos ou de pedra. Exemplos de torres de água totalmente metálicas foram raros até o última década do século XIX, quando a produção em massa do aço viabilizou a construção destas estruturas em larga escala.

No decorrer do século XIX, após um período inicial em que a arquitetura do ferro recebia um tratamento formal mais apropriado aos materiais tradicionais (madeira, pedra), suas características técnicas e estéticas passaram a ser bem mais exploradas, fazendo dele um dos únicos materiais do século a atingir expressão formal própria. A linguagem da arquitetura do ferro adquiriu um valor simbólico na medida em que possibilitou uma renovação da linguagem arquitetônica. ${ }^{64}$ As obras apresentadas na sequência registram as primeiras explorações técnicas e estéticas do uso do ferro e do aço como material de construção para as de torres de água.

${ }^{64} \mathrm{KÜHL}$, 1998, op. cit., p. 21. 


\subsubsection{5}

"Salt Water Tank", Base Naval de Portsmouth, Inglaterra, 1843.

\subsubsection{6}

"Salt Water Tank", Base Naval de Portsmouth, Inglaterra, 1843. Situação atual.

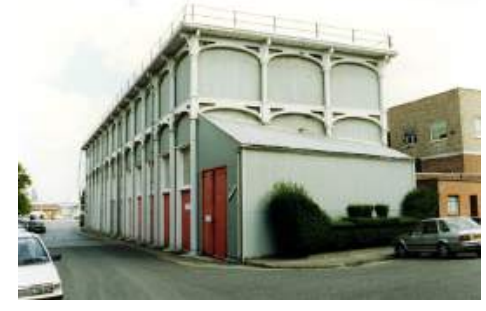

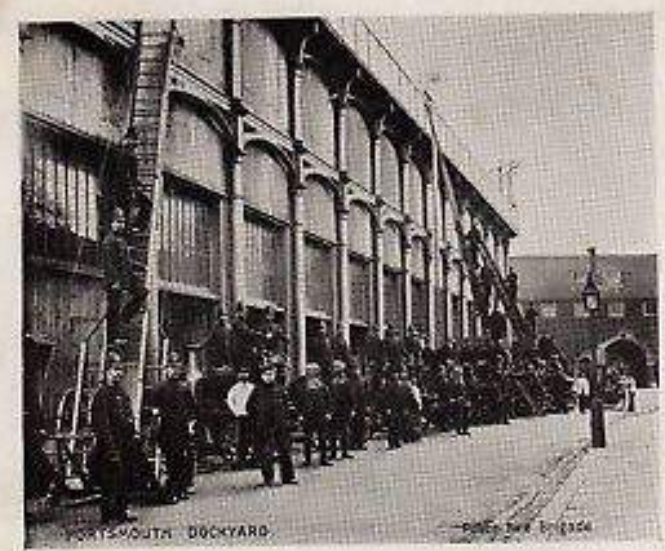

A primeira torre de água totalmente metálica de que se tem registro, chamada de "Salt Water Tank", foi construída em 1843 na Base Naval de Portsmouth, Inglaterra, com a finalidade de combate a incêndios (fig. 2.3.45). O reservatório retangular construído com painéis modulares de ferro fundido tinha um volume de $650 \mathrm{~m}^{3}$ e estava apoiado em um esqueleto estrutural formado por colunas de ferro fundido, travadas por duas linhas de vigas horizontais com um perfil de arco abatido, também fabricadas em ferro fundido. ${ }^{65} \mathrm{Em} 1847$ a torre de água passou a abrigar uma estação de bombeiros e neste momento o vão entre as colunas de ferro foi preenchido com chapas metálicas corrugadas, um dos mais antigos registros do uso deste material. Infelizmente a torre de água perdeu o seu reservatório e somente o esqueleto estrutural foi preservado, permanecendo em uso na Base Naval atualmente (fig. 2.3.46).

Por volta de 1850, nas ferrovias inglesas, surgiram os primeiros exemplares de torres de água com construções similares a do Salt Water Tank, isto é, tanques retangulares construídos com painéis modulares de ferro fundido apoiados em pilares de ferro fundido. Um exemplo é a torre de água da estação ferroviária Oxford Rewley Road, construída em 1851 (fig. 2.3.47). A construtora responsável pelas obras desta estação foi a Fox, Henderson \& Co. que estava, ao mesmo tempo, finalizando a construção do Crystal Palace e utilizou nos vários edifícios da estação componentes

${ }^{65}$ BARTON, 2003, op. cit., p. 141. 


\subsubsection{7}

Torre de Água da Oxford Rewley Road Station, Buckinghamshire Railway, Inglaterra, 1851. similares, mas não idênticos, aos componentes estruturais préfabricados de ferro fundido e de ferro forjado que estavam sendo utilizados no pavilhão de exposições de Joseph Paxton. ${ }^{66}$

A história da Grande Exposição de 1851 e da proposta de Joseph Paxton (1803-1865) para o Crystal Palace são bem conhecidas, mas a participação do engenheiro Isambard Kingdom Brunel (1806-1859) no empreendimento, com sua ajuda na aprovação do revolucionário projeto de Paxton e também na solução dos problemas práticos para a sua construção, é uma história pouco divulgada. Com a desmontagem e reconstrução do Crystal Palace em seu segundo sítio em Sydenham, entre os anos de 1852 e 1854, a contribuição de Brunel seria em uma outra escala, com o projeto do impressionante par de torres de água metálicas (fig. 2.3.48) de 86,50 metros de altura. ${ }^{67}$ Sempre que surgia uma boa oportunidade Brunel, assim como em outros de seus projetos, não tinha o receio de construir algo em um escala que não havia sido experimentada anteriormente e aqui os desejos de Paxton e da Diretoria do Crystal Palace se alinhavam com o temperamento do engenheiro, na busca por uma solução inédita de um par de torres de água de grande altura, as mais altas construídas até então,

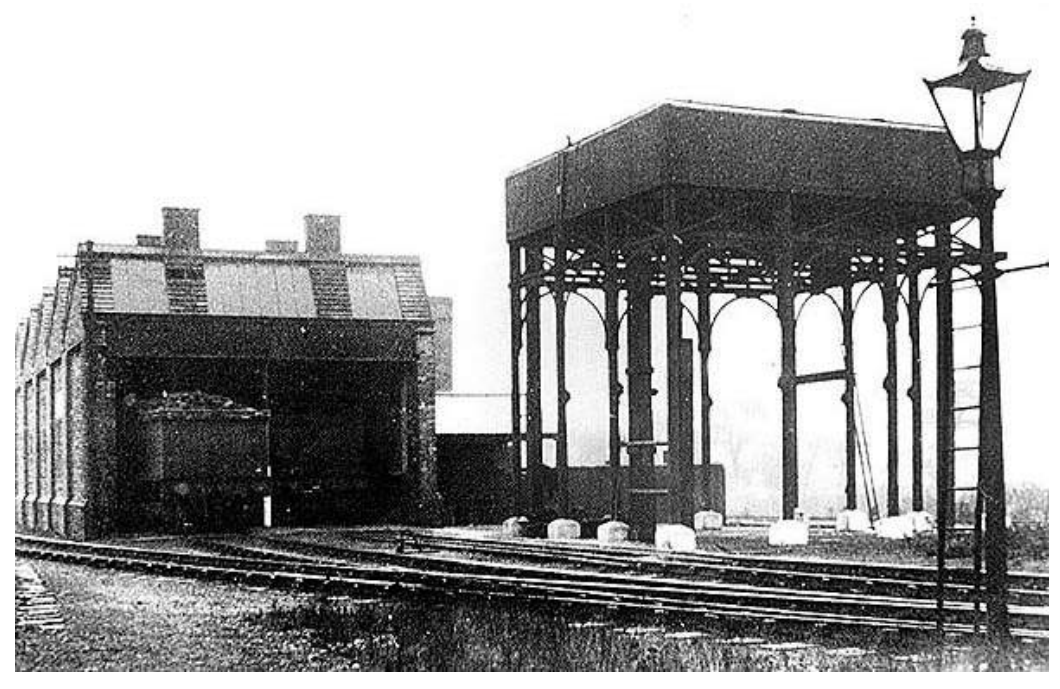

${ }^{66}$ ADDIS, Bill. The Crystal Palace and its Place in Structural History. International Journal of Space Structures, Brentwood, v. 21, n. 1, 2006, p. 16.

${ }^{67}$ Para uma história detalhada da participação de Brunel no projeto do Crystal Palace bem como dos eventos que levaram ao projeto das torres de água pelo engenheiro inglês ver BUCHANAN, Angus; JONES, Stephen K.; KISS, Ken. Brunel and the Crystal Palace. Industrial Archaeology Review, London, v. 17, n. 1, p.7-21,1994. 
com capacidade para armazenar $1.200 \mathrm{~m}^{3}$ de água cada e capazes de gerar uma pressão de água suficiente para impulsionar os jatos de água das fontes ornamentais dos jardins do Crystal Palace a uma altura de mais de 70 metros, para soprar o fole do grande órgão e também para acionar os elevadores hidráulicos do edifício.

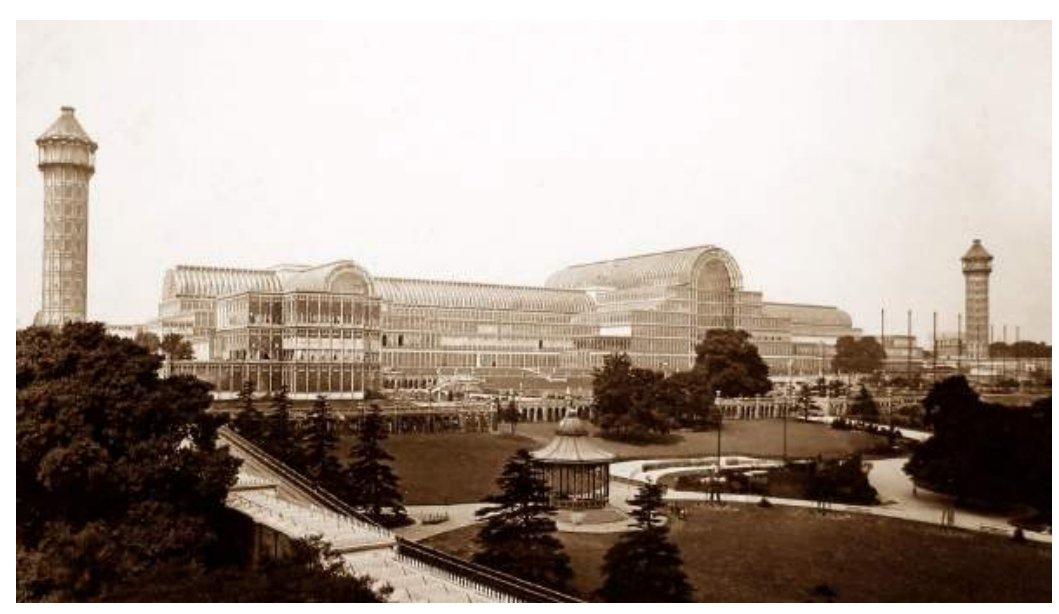

\subsubsection{8}

Isambard Kingdom Brunel, Torres de Água do Crystal Palace, Sydenham, 1856.
Cada uma das torres foi construída ao redor de uma chaminé de tijolos, sem qualquer tipo de ligação estrutural com o esqueleto metálico, que serviam para retirar a fumaça gerada pelo sistema de aquecimento do Crystal Palace. A fundação de cada torre é composta por um anel de concreto, cujas dimensões são: diâmetro externo de 17,70 metros; largura do anel de 3,35 metros e uma altura de $90 \mathrm{~cm}$. Sobre este anel foi construído um anel troncônico de alvenaria de tijolos, altura de 5,50 metros e espessuras de parede variando entre 2,90 metros na base e 1,70 metro no topo (ver corte na fig. 2.3.49). No centro do anel de alvenaria um radier de concreto com espessura de 1,50 metro apoiava a chaminé de tijolos e um arranjo de seis tubos de ferro fundido com 300 mm de diâmetro, que tinham dupla função: atuavam como colunas de sustentação interna da torre e também como tubulações hidráulicas, cinco tubos para entrada e saída de água e um tubo para o transbordo do reservatório. $O$ diâmetro externo da chaminé de tijolos é constante, 2,80 metros, uma vez que também atua como apoio central para a escada helicoidal de ferro fundido e madeira que conduzia do embasamento até o pavimento sob o reservatório. No topo do anel troncônico de alvenaria foram instaladas 12 sapatas de fundação $(2,40 \times 1,20 \mathrm{~m})$ fabricadas em 
ferro fundido, responsáveis por distribuir todo o peso da estrutura metálica para as fundações de alvenaria e concreto. Toda a estrutura metálica era formada por componentes pré-fabricados de ferro fundido muitos semelhantes ao idealizados por Paxton para o Crystal Palace. As colunas cilíndricas de ferro fundido com 300 mm de diâmetro eram flangeadas e foram parafusadas nas sapatas de fundação em pares. Para assegurar a rigidez da estrutura, Brunel uniu cada par de colunas com um painel de ferro fundido, de modo a transformar as 24 colunas simples em um conjunto de 12 colunas compostas desde o nível das fundações até o nível do fundo do reservatório, em todos os 10 andares da torre, cada andar com uma altura de 6,10 metros. A figura 2.3.50a mostra as os módulos da fachada do Crystal Palace de Paxton e na figura 2.3.50b temos os módulos da fachada das torres de Brunel. Para garantir que as colunas trabalhassem em conjunto, um diafragma de ferro forjado com 1,50 metro de largura foi posicionado ao nível do piso de cada um dos pavimentos, com a sua borda exterior sendo parafusada entre as flanges das colunas e a borda interior travada por uma série de tirantes redondos de ferro forjado $(\varnothing 45 \mathrm{~mm})$ formando um polígono estrelado (ver planta na fig. 2.3.49). No plano vertical cada coluna composta era travada na coluna vizinha com um conjunto de barras de contraventamento cruzadas (fig. 2.3.51). ${ }^{68} \mathrm{Em}$ planta a torre consistia de um conjunto de faces planas, alternando painéis de ferro fundido com largura de 1,20 metro (entre eixos de coluna) e painéis com caixilhos de ferro fundido e vidro, com uma largura de 2,40 metros entre eixos de coluna, modulação idêntica a utilizada por Paxton na estrutura do Crystal Palace. O diâmetro de cada torre, do centro ao centro das colunas, era de 14 metros.

${ }^{68}$ Engineering Details at the Crystal Palace. The Engineer, London, v. 91, , fev. 1901, p. 108-109. 

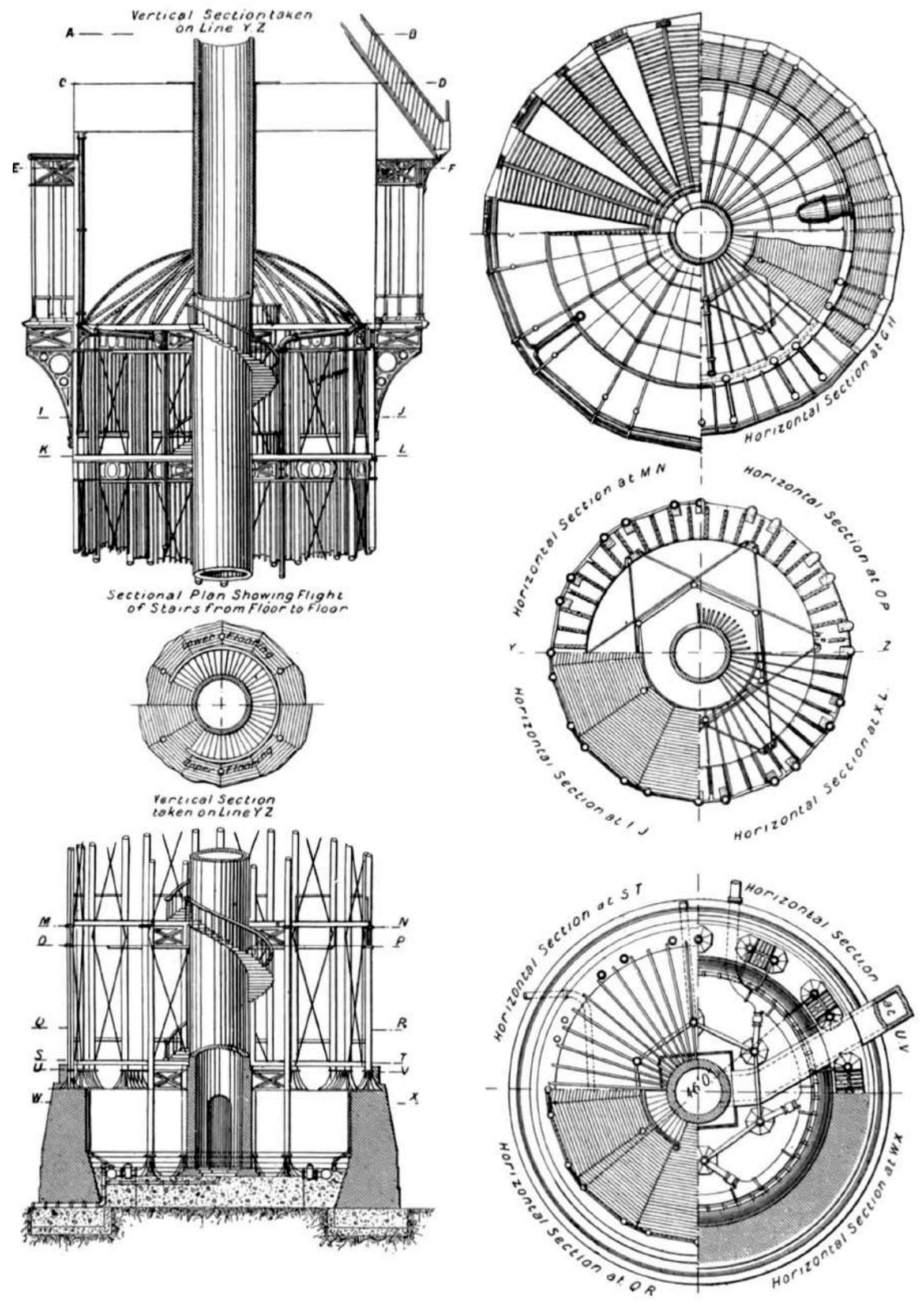

2.3.49

Isambard Kingdom Brunel, Torres de Água do Crystal Palace, Sydenham, 1856. Plantas e cortes. 


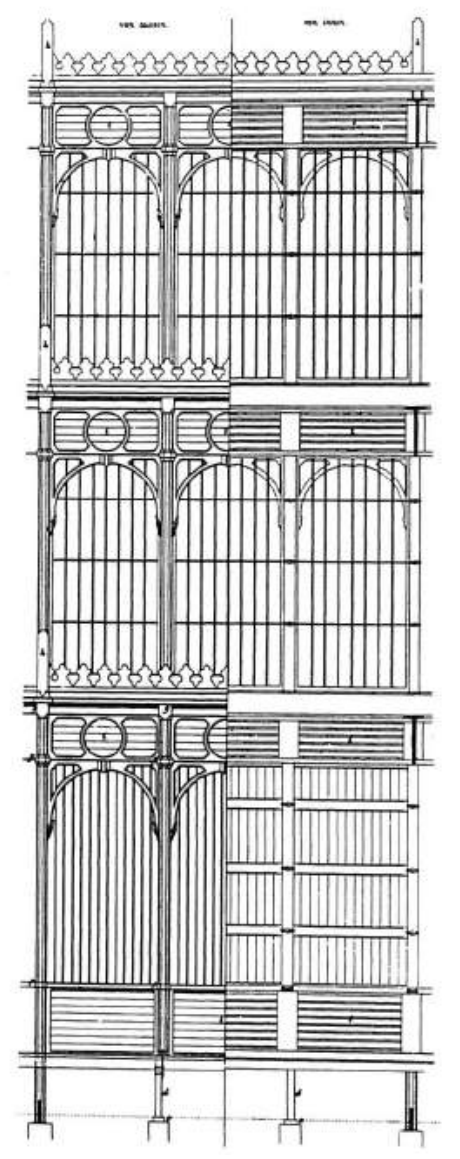

\subsubsection{0a}

Joseph Paxton, Crystal Palace, Londres, 1851. Detalhe do módulo de fachada.

\subsubsection{0b}

Isambard Kingdom Brunel, Torres de Água do Crystal Palace, Sydenham, 1856. Detalhe do módulo de fachada.

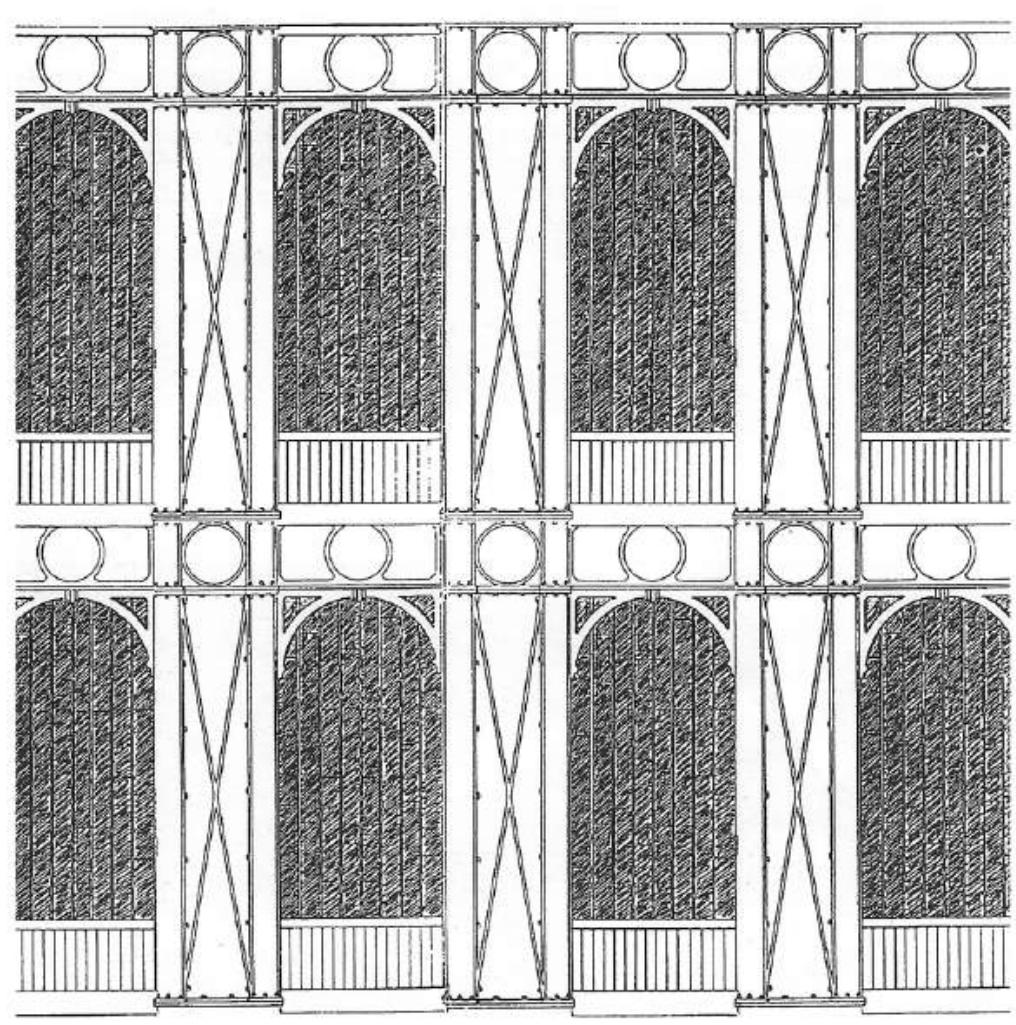

Acima do último nível de colunas foi posicionado o reservatório cilíndrico de ferro forjado, com um diâmetro de 14,35 metros e uma altura de 10,65 metros, uma construção de chapas de $12,5 \mathrm{~mm}$ de espessura rebitadas entre si e enrijecidas na horizontal com perfis tipo cantoneira. $O$ fundo do reservatório era em formato de cúpula (ver corte na fig. 2.3.49), descarregando seu peso diretamente nas colunas externas, sem utilizar a chaminé de tijolos que atravessava pelo meio do reservatório ou as seis colunas internas como pontos de apoio. O fundo em cúpula era enrijecido por uma série de nervuras dispostas no sentido dos meridianos uma vez que o elemento trabalhava majoritariamente sob esforços de compressão. Este talvez seja um exemplo único de reservatório metálico com fundo em cúpula simplesmente apoiado, uma vez que não existe até o momento o registro de algum outro reservatório metálico construído nesta tipologia. ${ }^{69}$

${ }^{69}$ As extensas pesquisas sobre torres de água desenvolvidas por WERTH (1971), MELVIUS (1985), VEEN (1989) e VAN CRAENENBROECK (1991) não relatam a existência de torres de água equipadas com esta tipologia de reservatório e tampouco mencionam as torres da água do Crystal Palace. 


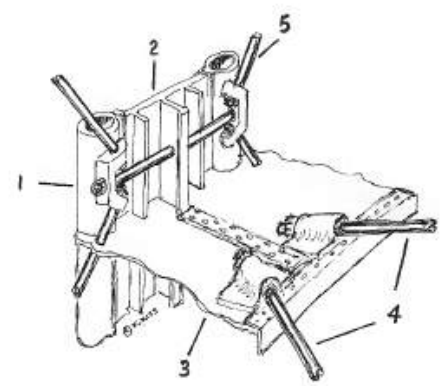

2.3.51

Isambard Kingdom Brunel, Torres de Água do Crystal Palace, Sydenham, 1856. Detalhe do contraventamento.

1.Coluna tubular de ferro fundido, $\varnothing 300 \mathrm{~mm}$

2.Painel intermediário de ferro fundido

3.Diafragma de ferro forjado

4.Barra de contraventamento vertical

5.Barra de contraventamento horizontal, $\varnothing 45 \mathrm{~mm}$

\subsubsection{2}

Demolição da torre norte do Crystal Palace, 1941.

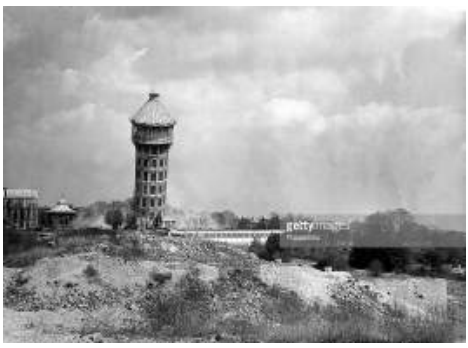

Cúpulas metálicas para compor partes dos fundos de reservatórios de água seriam desenvolvidas apenas no final do século XIX, com o reservatório do tipo Intze, mas o comportamento estático deste era completamente diferente do reservatório da torre de Brunel, como veremos mais adiante. Acima do nível do décimo pavimento, na base do reservatório, uma galeria apoiada em suportes em balanço de projetava para além do plano da fachada da torre. A galeria era acessada por um tubo oval que atravessava o ponto mais baixo do reservatório. Na borda da galeria, um conjunto de esbeltas colunas de ferro fundido apoiava o telhado de ferro e vidro que cobria o reservatório. No topo da torre uma tampa ornamental de ferro fundido com 4,25 metros de altura por 4,90 metros de diâmetro arrematava a chaminé de tijolos. ${ }^{70}$

As duas torres entraram em operação em 1856 e foram consideradas por muitos engenheiros da época como sendo estruturas muito esbeltas, mas ambas as torres ficaram em operação por muitos anos e foram as únicas estruturas que sobreviveram ao incêndio que destruiu o Crystal Palace em 30 de Novembro de 1936. Durante a Segunda Guerra Mundial, a necessidade de ferro velho para fabricação de armamentos e o medo de que as torres pudessem servir como referências de navegação para os bombardeiros da Luftwaffe que castigavam Londres no período levou à demolição das torres de água em 1941 (fig. 2.3.52). ${ }^{71}$

As torres de Brunel podem ser consideradas como um feito extraordinário para a engenharia da época bem como para o universo das torres de água. Foram as mais altas torres de água construídas durante o século XIX e mantiveram este posto

\footnotetext{
70 BUCHANAN, 1994, op. cit., p. 15.

71 CHRISTOFER, John. The Lost Works of Isambard Kingdom Brunel. Gloucestershire: Amberley Publishing, 2011, p. 92. Na plataforma de compartilhamento de vídeos YouTube, estão disponíveis dois vídeos que registram a demolição da torre norte do Crystal Palace: https:// www.youtube.com/watch?v=nU0nPcD4o7k e https://www.youtube.com/ watch?v=tzSM38hCIPc
} 


\subsubsection{3}

Justaposição da torre de Brunel na gravura Comparative View of the Principal Buildings in the World, de John Emslie, Londres, 1850. até meados do século XX. ${ }^{72}$ É possível que tenham sido as mais altas estruturas metálicas construídas até a execução do Viaduto Garabit, por Gustave Eiffel, entre os anos de 1882-1884, com altura de 124,00 metros, recorde de altura quando de sua inauguração. A figura 2.3.53 mostra a justaposição da torre de Brunel na gravura Comparative View of the Principal Buildings in the World (Vista Comparativa dos Principais Edifícios do Mundo), de John Emslie, Londres, 1850.

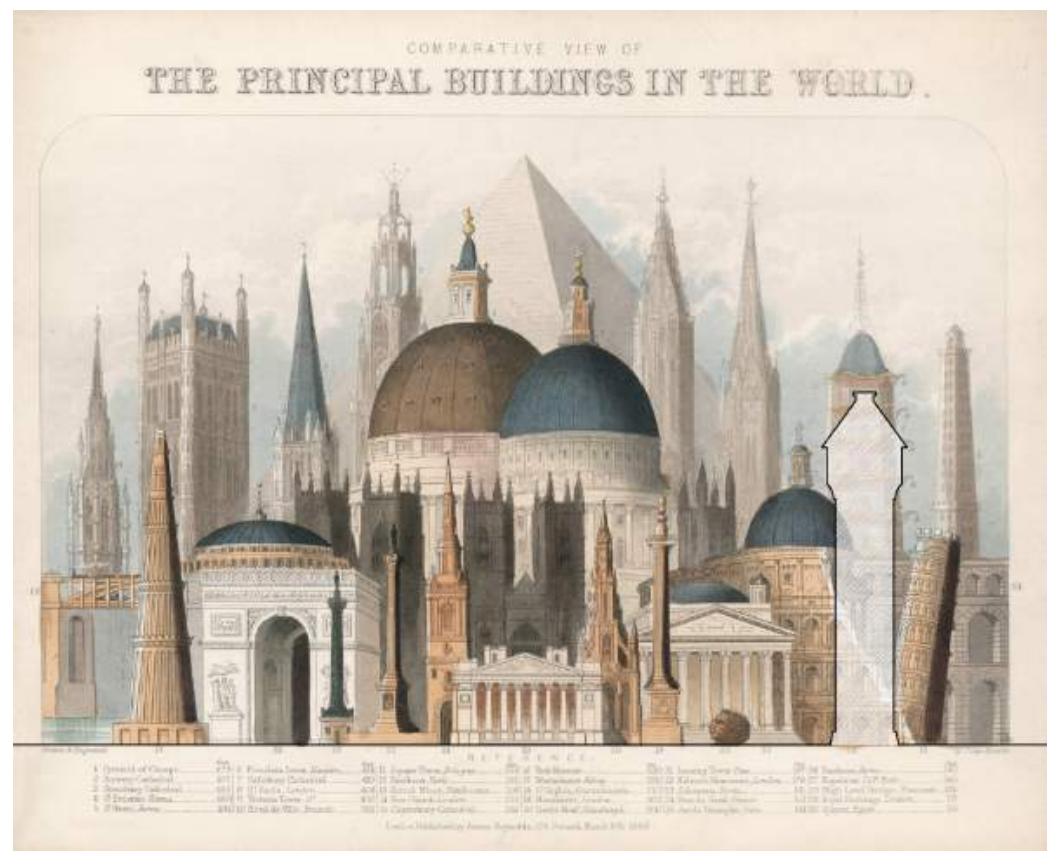

Entre as décadas de 1870 e 1890 as torres de água metálicas de tornaram mais frequentes nas ferrovias inglesas. Ainda que a construção de torres de água totalmente metálicas fosse economicamente competitiva com a construção de torres em alvenaria, as primeiras tinham como vantagem a rápida execução e o baixo peso total , uma característica ainda mais valiosa no caso de obras ferroviárias realizadas em localidades remotas. Reservatórios retangulares construídos com painéis modulares de ferro fundido

\footnotetext{
${ }^{72}$ Seriam necessários mais de 100 anos para que, em 1958, fosse construída um torre de água que superasse em altura a estrutura de Brunel, a torre de água da Usina de Urânio de Oak Ridge, no Tenesse, Estados Unidos, com 111 metros de altura, hoje já demolida. Na atualidade obras recentes como as Torres do Kuwait, projeto de Sune Lindström e Malene Björn (1977) e a Torre de Mechelen, projeto de Fernand Mortelmans (1978), superam em altura total as torres do Crystal Palace mas nenhuma destas estruturas têm seus reservatórios de água localizados em uma cota tão elevada.
} 


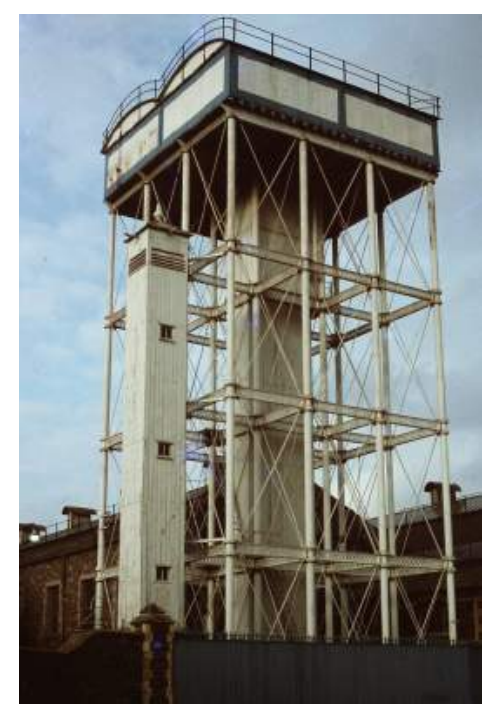

\section{3 .54}

Torre de Água da Swindon Works, Great Western Railway, Inglaterra, 1871.

\subsubsection{5}

Torre de Água da estação de Kemble, Great Western Railway, Inglaterra, 1882. e um sistema de colunas de ferro fundido, todos parafusados em conjunto e travados nos três eixos por vigas treliçadas ou de alma cheia e tirantes de ferro forjado substituíam com vantagens as pesadas e laboriosas subestruturas de alvenaria. As torres de água das oficinas ferroviárias de Swindon (fig. 2.3.54), de 1871, e da estação de Kemble (fig. 2.3.55), de 1882, ambas na ferrovia Great Western Railway, são exemplos de torres de água ferroviárias totalmente metálicas construídas neste período e preservadas até os dias de hoje. ${ }^{73}$

As estruturas metálicas em geral, devido ao seu processo de produção em partes para posterior montagem, acabam por estimular a pré-fabricação de componentes estruturais ou mesmo de edifícios inteiros. Durante o século XIX este princípio de fabricação por partes a serem montadas se desenvolveu com o objetivo reduzir ao máximo o trabalho no canteiro de obras. Incialmente muitos fabricantes de peças estruturais metálicas ofereciam elementos avulsos, tais como colunas, vigas, tubos, etc.. Posteriormente desenvolveu-se a fabricação de edifícios inteiros, tais como estações de trem, mercados, indústrias, armazéns, teatros, etc.. Entre os centros produtores destas estruturas metálicas e de edifícios pré-fabricados em ferro destacam-se a Grã-Bretanha, a França, a Alemanha e a Bélgica. ${ }^{74}$

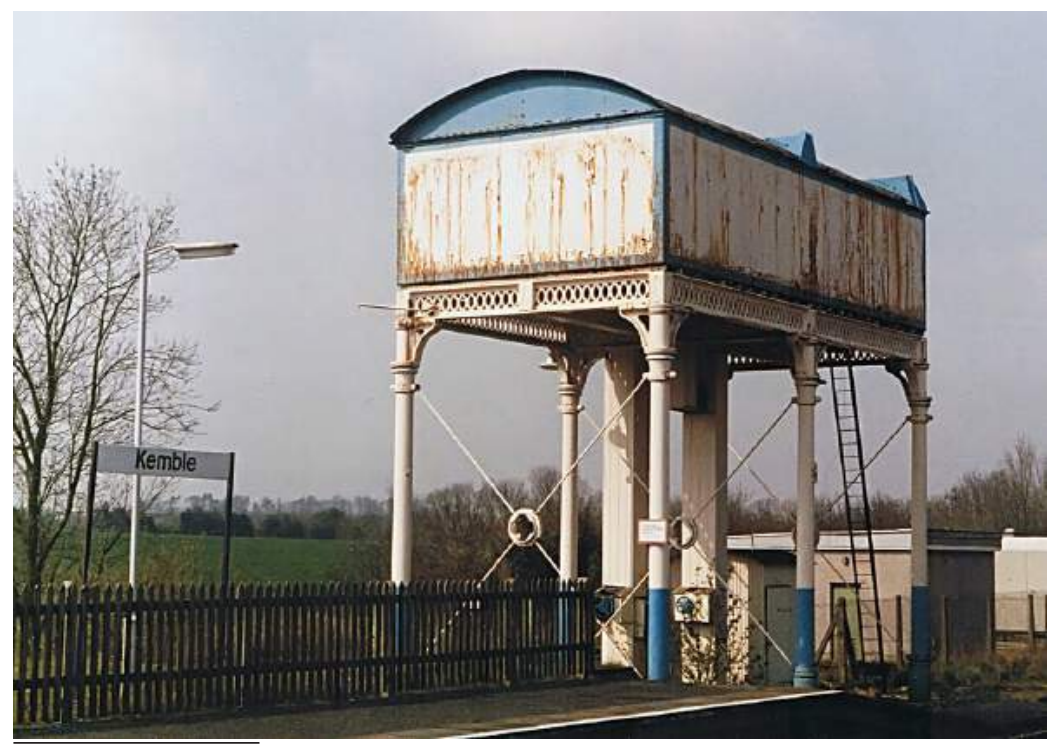

${ }^{73}$ GOULD, Michael H.. The Development of All-Metal Water Towers. Industrial Archaeology Review, London, v. 23, n. 2, 2001, p. 115.

${ }^{74} \mathrm{KÜHL}, 1998$, op. cit., p. 67. 
Estas estruturas e edifícios pré-fabricados atendiam tanto ao mercado interno quanto externo dos países fabricantes mas, principalmente, atendiam a locais onde se tinha a necessidade de construir rapidamente e em grande escala, ou ainda atendiam às localidades onde muitas vezes não se contava com mão de obra qualificada para a construção e onde faltava um parque fabril com tecnologia adequada para a fabricação de estruturas metálicas. O crescimento acentuado de muitas cidades na América e Ásia, localidades onde normalmente não havia mão de obra qualificada para a construção, e onde o contato direto destas cidades com o mercado europeu floresceu devido à produção e exportação de gêneros agrícolas, favoreceu a importação de edifícios em estrutura metálica para sanar a necessidade crescente de novas edificações especializadas. ${ }^{75}$ Entre as tipologias de edificações metálicas exportadas da Europa para o resto do mundo incluem-se as torres de água.

Neste contexto podemos citar como exemplo, no Brasil, as torres de água das cidades de Pelotas (1875) e Rio Grande (1876), ambas no Rio Grande do Sul, construídas para integrar os sistemas de abastecimento de água da Companhia Hidráulica Pelotense e da Companhia Hidráulica Rio-Grandense, respectivamente. As duas torres de água, praticamente idênticas, foram fabricadas pela empresa Hanna, Donald \& Wilson, Paisley, Escócia e são equipadas com um reservatório cilíndrico de fundo plano fabricado em ferro fundido, com altura de 4 metros e diâmetro de 23 metros, encerrando um volume de $1.500 \mathrm{~m}^{3} .^{76}$ Cinco anéis em ferro forjado dispostos no lado externo do reservatório têm a função de resistir aos elevados esforços de tração atuantes nos painéis de ferro fundido. No centro do reservatório uma passagem vertical acomoda uma escada caracol que conduz a um mirante no topo

\footnotetext{
75 Ibid., p. 81-83.

76 SILVEIRA, Aline Montagna da. De fontes e aguadeiros à penas d'água: reflexões sobre o sistema de abastecimento de água e as transformações da arquitetura residencial do final do século XIX em Pelotas - RS. 2009. $340 \mathrm{f}$. Tese (Doutorado) - Programa de Pós-graduação em Arquitetura e Urbanismo, Faculdade de Arquitetura e Urbanismo, Universidade de São Paulo, São Paulo, 2009, p. 171-179.
} 

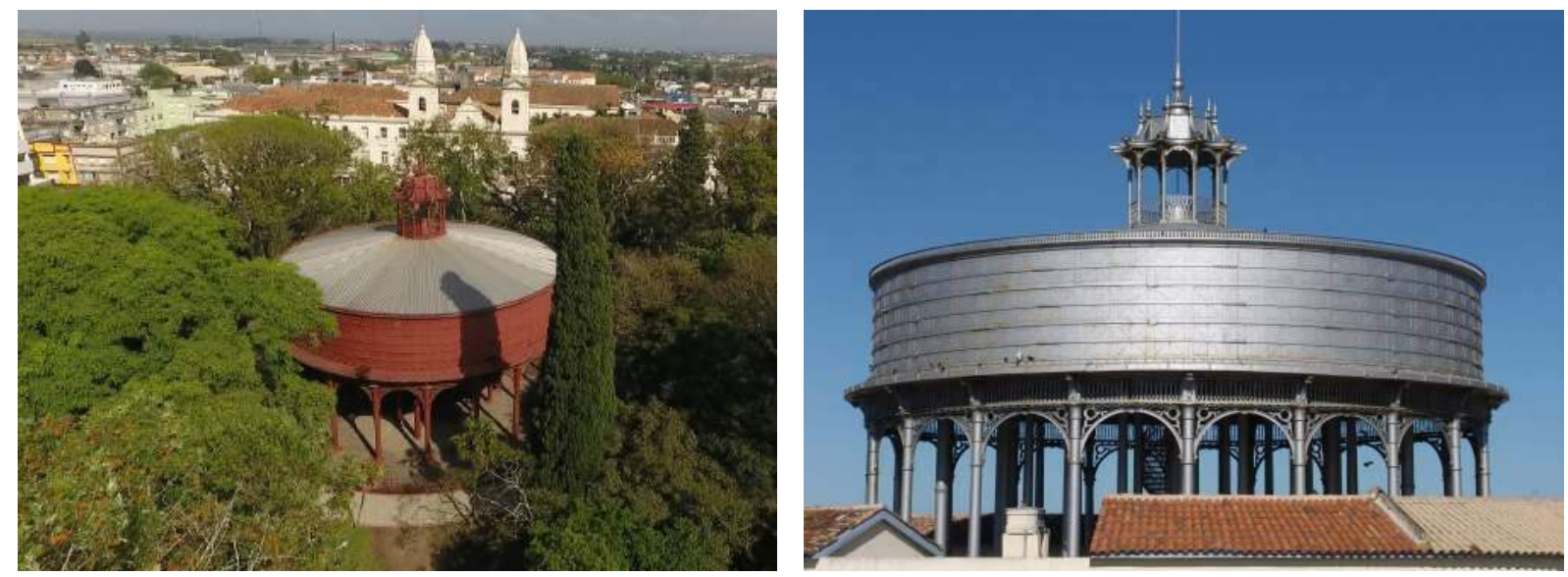

\subsubsection{6}

Torre de Água de Pelotas, Rio Grande do Sul, Brasil, 1875.

\section{3 .57}

Torre de Água de Rio Grande, Rio Grande do Sul, Brasil, 1876.

\subsubsection{8}

John William Hart, Torre de Água de Xangai, China, 1881.

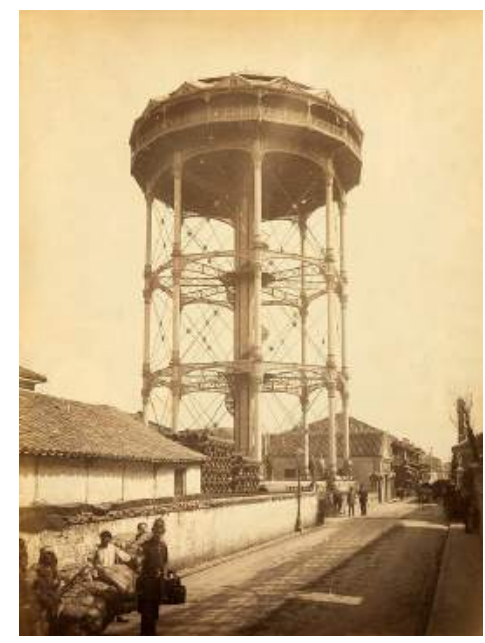

do reservatório. O reservatório está posicionado sobre 45 esbeltas colunas, com 8 metros de altura, que apoia um sistema de vigas de seção I, todas fabricadas em ferro fundido. Nas colunas da periferia arcos decorativos ligam as partes superiores das colunas. As figuras 2.3.56 e 2.3.57 mostram a situação atual das torres de Pelotas e Rio Grande, respectivamente.

A torre de água de Xangai (fig. 2.3.58), construída pela Shangai Waterworks Company em 1881, é um exemplo notável de uma estrutura pré-fabricada de ferro fundido e forjado projetada pelo engenheiro John William Hart. Com uma altura total de 40 metros, a torre armazena $670 \mathrm{~m}^{3}$ de água em um reservatório cilíndrico de ferro forjado com 15 metros de diâmetro e 3,75 metros de altura, fabricado com chapas de ferro forjado rebitadas entre si. A subestrutura em esqueleto metálico (fig. 2.3.59) que apoia o reservatório é octogonal em planta, com um diâmetro de 16 metros entre os centros das colunas. As 24 colunas de ferro fundido estão distribuídas em três níveis, com oito colunas em cada nível. Um tubo central com 1,80 metro de diâmetro, fabricado em chapas rebitadas de ferro forjado, atua como uma rígida coluna central que, ao mesmo tempo que auxilia no travamento da estrutura e no suporte do reservatório, opera como a tubulação de entrada e saída de água, uma construção típica de torre de água de jusante. As colunas são travadas em dois níveis por vigas de ferro fundido no formato de arcos abatidos. No sentido radial, vigas treliçadas de ferro forjado fazem o travamento entre as colunas periféricas e o tubo central. O contraventamento diagonal consistia em barras 


\subsubsection{9}

John William Hart, Torre de Água de Xangai, China, 1881. Planta e Elevação. redondas de ferro forjado com diâmetro de $32 \mathrm{~mm}$, posicionados em cada um dos quadros formados pelas colunas e vigas, tanto da fachada quanto no sentido do vigamento radial. A cobertura da torre era bastante leve, com telhas em chapa metálica corrugada apoiadas em treliças construídas com cantoneiras de ferro forjado. ${ }^{77}$
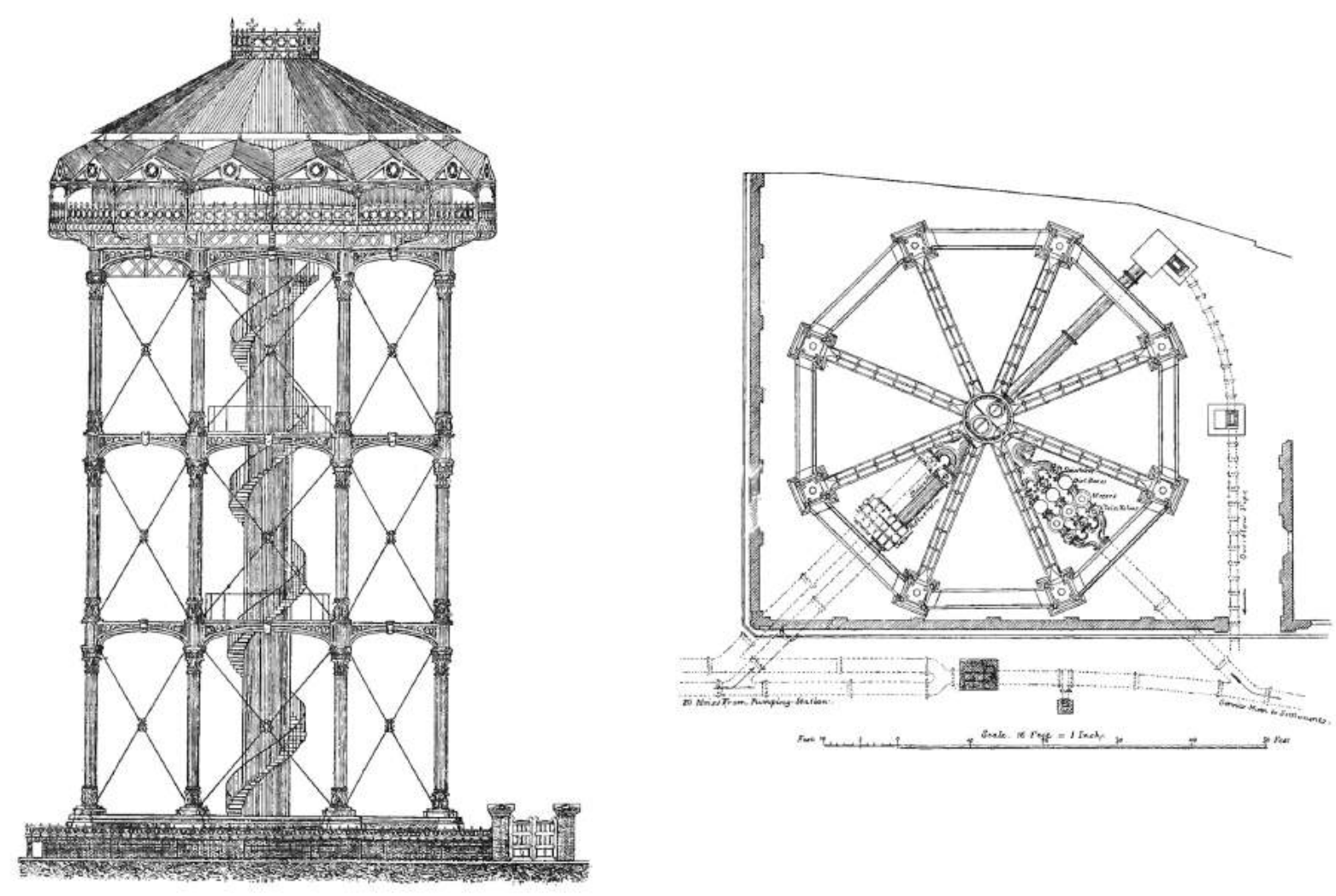

77 BURTON, W. K.. The water supply of towns and the construction of water works. 2. ed. London: Crosby, Lockwood and Son, 1898, p. 140-144. 


\subsubsection{Reservatório Tipo Intze}

Desde que os reservatórios passaram a ser construídos com o fundo suspenso observou-se, especialmente nos exemplares com volumes maiores, que a subida e descida do nível de água faziam com que o anel de pressão e suporte se movimentasse devido à variação da carga atuante no anel. Esta movimentação contínua do anel de pressão e suporte levava ao vazamento dos reservatórios ao longo do tempo devido aos deslocamentos das juntas entre as chapas. ${ }^{78}$ Observou-se também um afundamento do fundo do reservatório, que também variava conforme a quantidade de água armazenada no tanque. Na torre de água de Essen, por exemplo, uma flecha de $17 \mathrm{~mm}$ era normal no fundo do reservatório quando este estava completamente cheio. Para poder absorver todas estas deformações e movimentações dos fundos dos tanques suspensos as tubulações hidráulicas passaram e ser apoiadas em estruturas independentes e foram equipadas com juntas elásticas de dilatação, que evitavam danos ao sistema de tubos. Existia ainda um problema construtivo na montagem dos fundos suspensos: as chapas metálicas, originalmente planas, não podiam ser levadas à sua forma final sem deformação e tinham que ser pressionadas e esticadas durante a montagem. ${ }^{79}$ Ao longo dos anos os projetistas procuraram, por meio de várias soluções construtivas, eliminar os problemas de construção dos reservatórios de fundo suspenso sem encontrar uma solução totalmente satisfatória.

Em 1883, o projeto para uma nova torre de água na cidade de Remscheid, Alemanha, deu ao engenheiro Otto Intze a oportunidade de estudar novos formatos de reservatórios, com o objetivo de encontrar uma forma mais econômica e eficiente que se apresentasse como uma alternativa para os reservatórios de fundo suspenso. Intze inverteu o fundo suspenso para formar um fundo apoiado, isto é, uma cúpula carregada por esforços de compressão, com os componentes horizontais da carga atuando na direção externa do anel de suporte. Com o acréscimo de um fundo cônico,

\footnotetext{
${ }^{78}$ BECKH, 2015, op. cit., p. 66.

79 WERTH, 1971, op. cit., p. 354.
} 


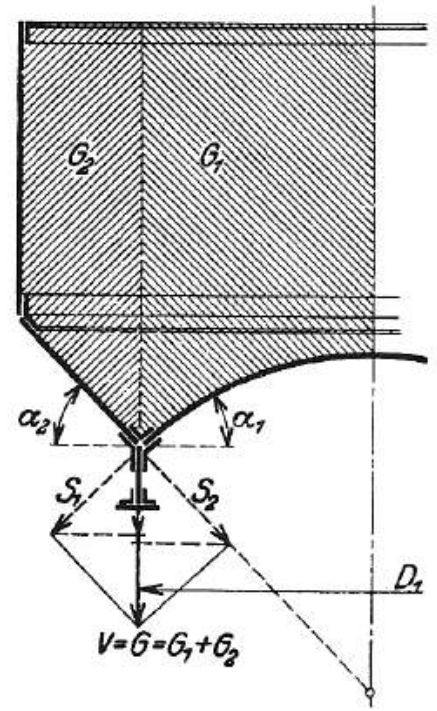

2.3.60

Interação de Esforços no Anel de Suporte do Reservatório Tipo Intze. em balanço, pelo lado externo do anel de suporte, Intze conseguiu reduzir significativamente os esforços horizontais atuantes no anel de suporte, pois, enquanto o fundo externo em cone comprimia o anel de suporte, o fundo interno em cúpula tracionava o anel simultaneamente. Com a escolha adequada do diâmetro do anel de suporte D1 e dos ângulos de inclinação 1 e 2 (fig. 2.3.60) é possível cancelar completamente os esforços horizontais atuantes no anel de suporte que seriam transmitidos para a subestrutura de apoio do reservatório que, portanto, recebem apenas carregamentos verticais facilitando a tarefa de dimensionamento estrutural. ${ }^{80}$

A torre de água construída na cidade de Remscheid (fig. 2.3.61) recebeu em 1883 o primeiro reservatório tipo Intze, que tinha um volume de $400 \mathrm{~m}^{3}$. A forma externa da nova torre de água, no entanto, não era muito diferente das torres de água anteriores e das demais em construção no período. Externamente nada apontava para a existência de uma nova tipologia de reservatório apesar da necessidade de uma subestrutura totalmente diferente da empregada em torres anteriores, já que o pequeno diâmetro do anel de suporte do tanque exigia o acréscimo de um fuste interno especial para apoio do reservatório. O reservatório, que tinha uma altura de 10,50 metros e um diâmetro de 7,50 metros, exigia um anel de suporte de apenas 3,20 metros de diâmetro. ${ }^{81} \mathrm{O}$ fuste interno e o reservatório foram revestidos com um fechamento circular de alvenaria (fig. 2.3.62), sem qualquer tipo de função estrutural, decorada de acordo com as tendências historicistas em voga na arquitetura do período.

\footnotetext{
80 lbidem, p. 355.

${ }^{81}$ MERKL, 1985, op. cit., p. 82.
} 
2.3.61

Otto Intze, Torre de Água de Remscheid, 1883.

\subsubsection{2}

Otto Intze, Torre de Água de Remscheid, 1883. Corte.
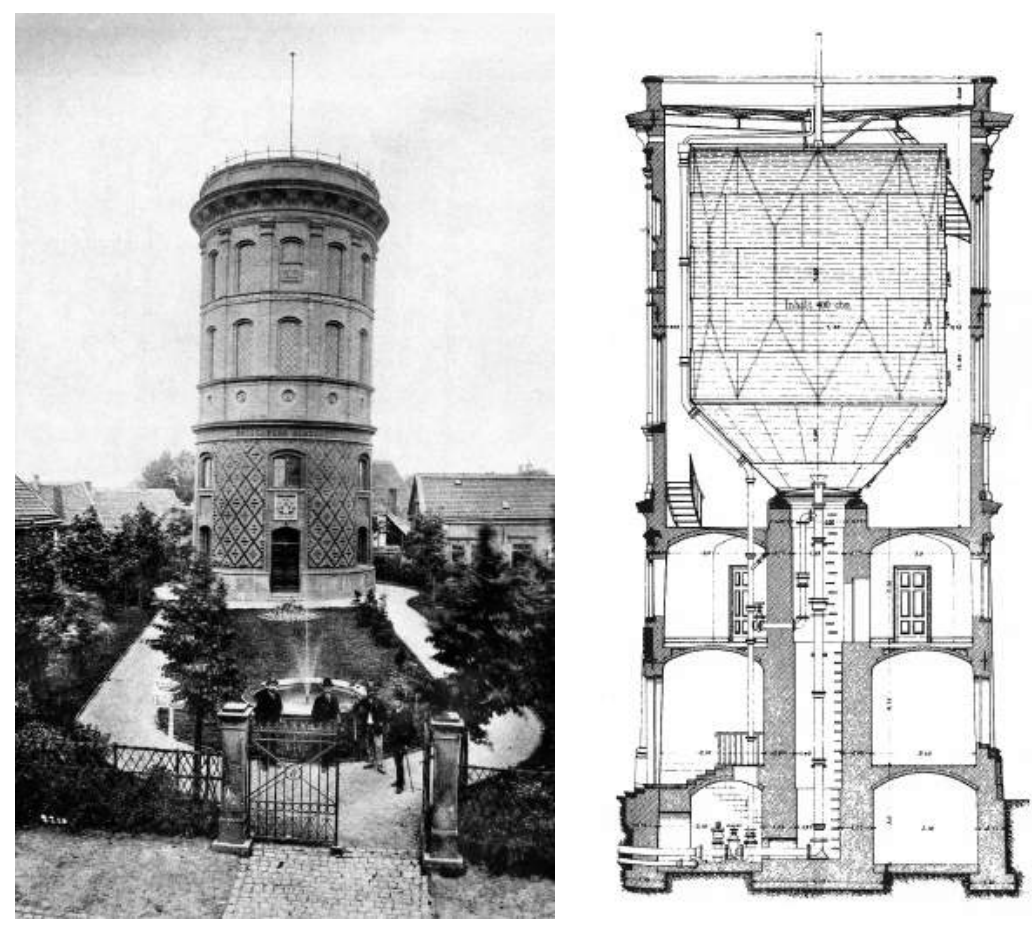

Neste mesmo ano uma segunda torre de água projetada por Otto Intze foi construída nas minas de sal de Neu-Stassfurt, ${ }^{82}$ Alemanha (fig. 2.3.63). O reservatório de $600 \mathrm{~m}^{3}$ que equipava a torre foi apoiado sobre uma susbestrutura circular de alvenaria de tijolos e foi revestido extremamente com um fechamento decorativo de madeira, semelhante ao utilizado nas torres de água das ferrovias alemãs. Esta torre, porém, já apresentava as características formais que estariam presentas na maioria das torres equipadas com os reservatórios da tipologia Intze: o reservatório projetado para além do plano da alvenaria de base, em balanço, e o fuste troncônico que se afunilava em direção ao apoio do reservatório. O revestimento em madeira, posicionado à frente da parede do reservatório, enfatizava ainda mais a cabeça saliente da torre de água. A constrição do fuste da torre de água na altura do anel de suporte tinha reflexos na subestrutura de alvenaria. Considerando que o diâmetro do anel de suporte era muito inferior ao diâmetro do reservatório, o diâmetro do fuste de alvenaria poderia ser reduzido para igualar o diâmetro do anel de suporte: uma solução estrutural ideal para a transmissão de cargas

82 INTZE, Otto. Nachweis über die Konstruktion und die Verbreitung von 280 Wasserthürmen und Gasbehältern nach dem System und den Berechnungen von Professor O. INTZE in Aachen. Aachen: F. A. NEUMAN / C. H. Georgi, 1894 , p. 20 e 67. 
2.3.63

Otto Intze, Torre de Água de NeuStassfurt , 1883. Corte e Elevação. diretamente para as fundações e que gerava, ao mesmo tempo, uma economia substancial de material na execução das alvenarias. Assim, podemos considerar a forma da típica torre de água tipo Intze como um reflexo do comportamento estático do reservatório de água.
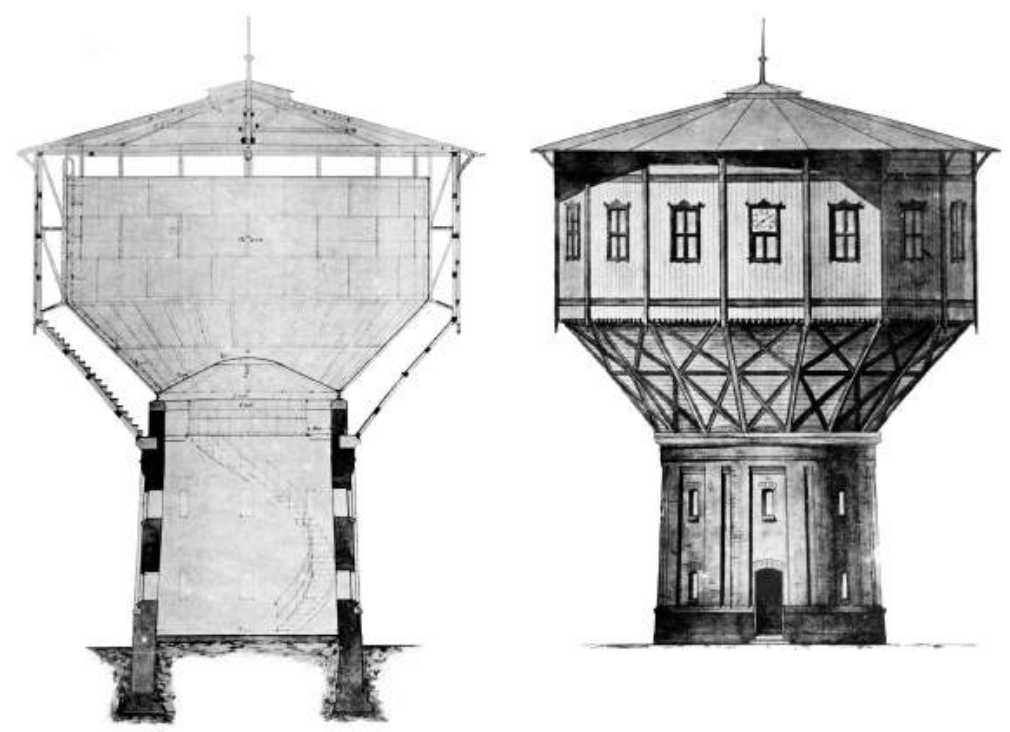

A nova tipologia de reservatório de Intze também se mostrou bastante econômica no consumo de aço para construção do reservatório. A redução no consumo de material metálico era de cerca de $10 \%$ para reservatórios com volumes acima de $1.000 \mathrm{~m}^{3}$ e de $25 \%$ para tanques abaixo deste volume, uma economia que era devida à sua forma estruturalmente eficiente e ao seu anel de suporte mais leve e mais simples. ${ }^{83}$

Ainda no ano de 1883, Otto Intze obteve na Alemanha a patente da nova tipologia de reservatório e, posteriormente, conseguiu patentear seu invento também nos Estados Unidos no ano de $1886 .{ }^{84}$ A empresa F. A. Neuman, da cidade de Aachen, adquiriu a patente do reservatório tipo Intze na Alemanha e tornouse líder na fabricação de reservatórios para armazenagem de água, óleo e gás. A empresa transformou o reservatório em um grande sucesso comercial e o tipo Intze tornou-se a tipologia dominante para a construção de reservatórios elevados de água na Europa até as primeiras décadas do século XX. Entre os anos de 1883

\footnotetext{
${ }^{83}$ WERTH, 1971, op. cit., p. 355.

84 UNITED STATES PATENT OFFICE (Washington). Otto Intze. Fluid Reservoir. EUA n US 348.912 A, 13 jun. 1885, 7 set. 1886. p. 1-4.
} 
e 1894, a companhia fabricou 216 reservatórios tipo Intze que foram instalados em torres de água construídas em vários países europeus. ${ }^{85} \mathrm{Um}$ dos maiores clientes da F. A. Neuman foram as ferrovias alemãs que adquiriram cerca de 85 reservatórios, com volumes variando entre 15 e $1.000 \mathrm{~m}^{3}$, para equipar as "estações de água" ferroviárias. ${ }^{86}$

Como exemplos da primeira geração de torres de água (fig. 2.3.64) para abastecimento público a utilizar reservatórios do tipo Intze podemos citar, na Alemanha, as torres de Bremerhaven $\left(650 \mathrm{~m}^{3}\right)$, projeto de Walter Pfeffer (1884); Riesa $\left(500 \mathrm{~m}^{3}\right)$, em Leipzig, projeto de Max Menzner (1889) e Wandsbek (750 m³), em Hamburgo, projeto de P. Schmick (1891). ${ }^{87} \mathrm{Na}$ Holanda temos as torres de Tiel $\left(300 \mathrm{~m}^{3}\right)$, em Utrecht (1890); Deventer $\left(500 \mathrm{~m}^{3}\right)$, projeto de J. A. Mulock Houwer (1893) e Meppel $\left(200 m^{3}\right)$, projeto de H. P. N. Halbertsma (1893). ${ }^{88}$ A figura 2.3.65 mostra os desenhos da torre de Sneek, Holanda, projeto de H. P. N. Halbertsma de 1908, outro exemplo típico da primeira geração de torres de água com reservatório tipo Inzte.

\footnotetext{
${ }^{85} \mathrm{Na}$ Europa, entre o ano de 1883 e o final da década de 1910, a F. A. Neuman fabricou e exportou tanques tipo Intze para Holanda, Bélgica, Dinamarca, Áustria, Suécia, Suíca, França, Portugal, Rússia, entre outros países. Em 1902 a Neuman, como o único fabricante de tanques tipo Intze no mercado, oferecia tanques padronizados com volumes de 15, 30, 50, 75, 100, 150, 200, 300, 400, 500, 750 e $1.000 \mathrm{~m}^{3}$. Na América forneceu reservatórios na tipologia Inzte destinados ao armazenamento de gás para a cidade de Guayaquil, Equador (F. A. NEUMAN, 1894, op. cit., p. 67-71). No Brasil, na cidade de Rio Grande (RS), a Fábrica Nacional de Tecidos e Panos de Rheingantz e Vater, empresa fundada pelo descendente de alemães Carlos Guilherme Rheingantz e pelo alemão Hermann Vater, iniciou operações em 1874 no setor de produção de tapetes, exportando produtos para os Estados Unidos e Europa (PAULITSCH, 2003, p. 62). Nas antigas instalações fabris da empresa construídas em 1910 conforme projeto do arquiteto alemão Theo Wiederspahn (hoje em situação de abandono após a falência da empresa na década de 1960) muitos dos materiais de construção utilizados foram importados da Europa como, por exemplo, a cobertura e a estrutura metálica vindas na Inglaterra. Existe na fábrica uma torre de água equipada com um reservatório metálico tipo Intze. É provável que, devido a origem alemã dos fundadores da empresa e do autor do projeto, o reservatório tenha sido importado da Alemanha, fazendo deste um exemplar único de tanque metálico tipo Intze no Brasil.

86 INTZE, 1894, op. cit., p. 67-71.

87 Ibidem.

${ }^{88}$ VEEN, Henk van Der. Watertorens in Nederland.

Rotterdam: Uitgeverij 010, 1989, p. 51-52.
} 

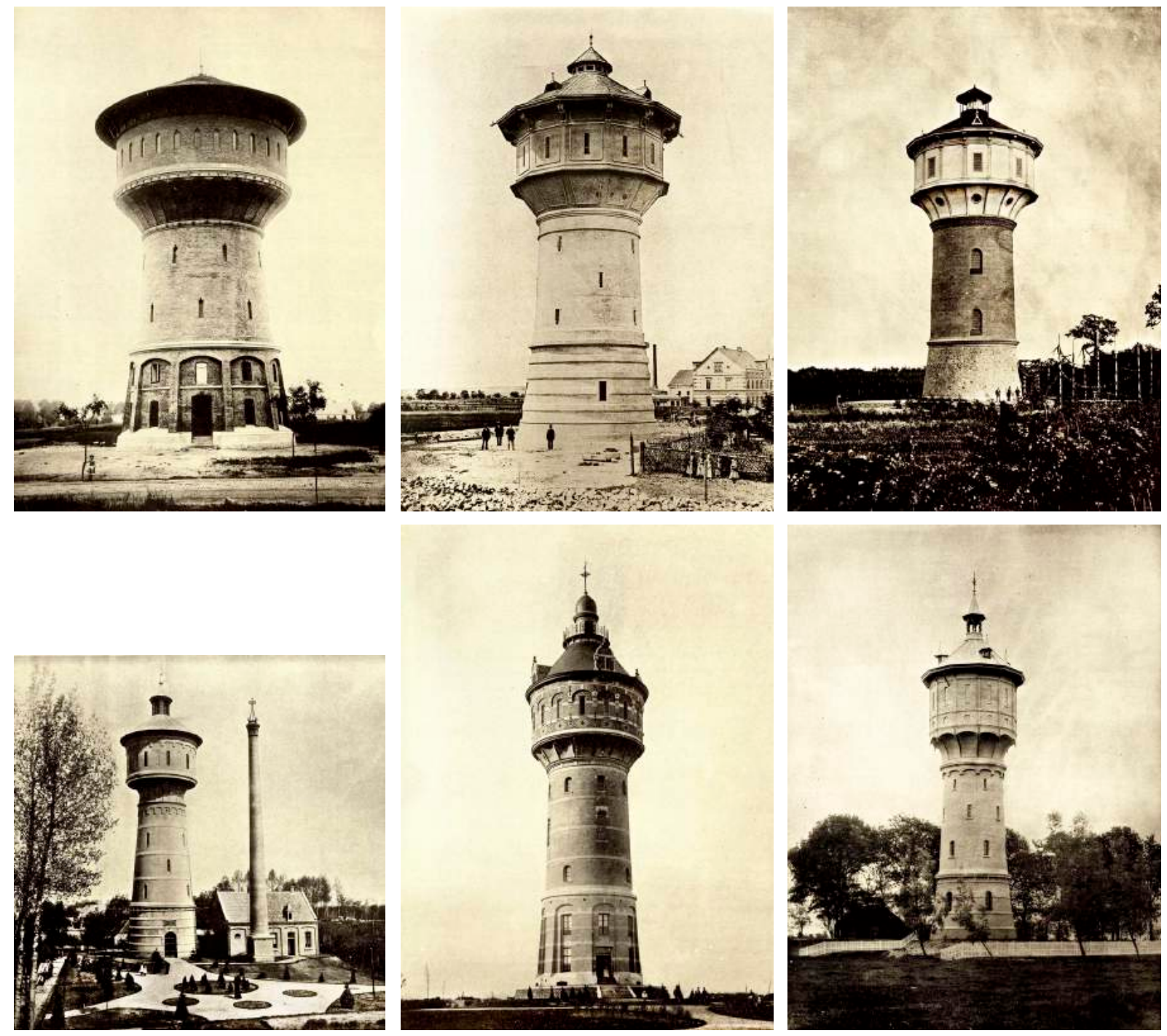

\section{3 .64}

Primeira Geração de Torres de Água Equipadas com Reservatórios tipo Intze I.

a)Walter Pfeffer, Torre de Bremerhaven, AL, 1884.

b) Max Menzner, Torre de Riesa, Leipzig, AL, 1889

c) P. Schmick, Torre de Wandsbek, Hamburgo, AL, 1891.

d) U.W.M., Torre de Tiel, Utrecht, HOL, 1890.

e) J.A. Mulock Houwer, Torre de Deventer, HOL, 1893.

f) H.P.N. Halbertsma, Torre de Meppel, HOL, 1893. 


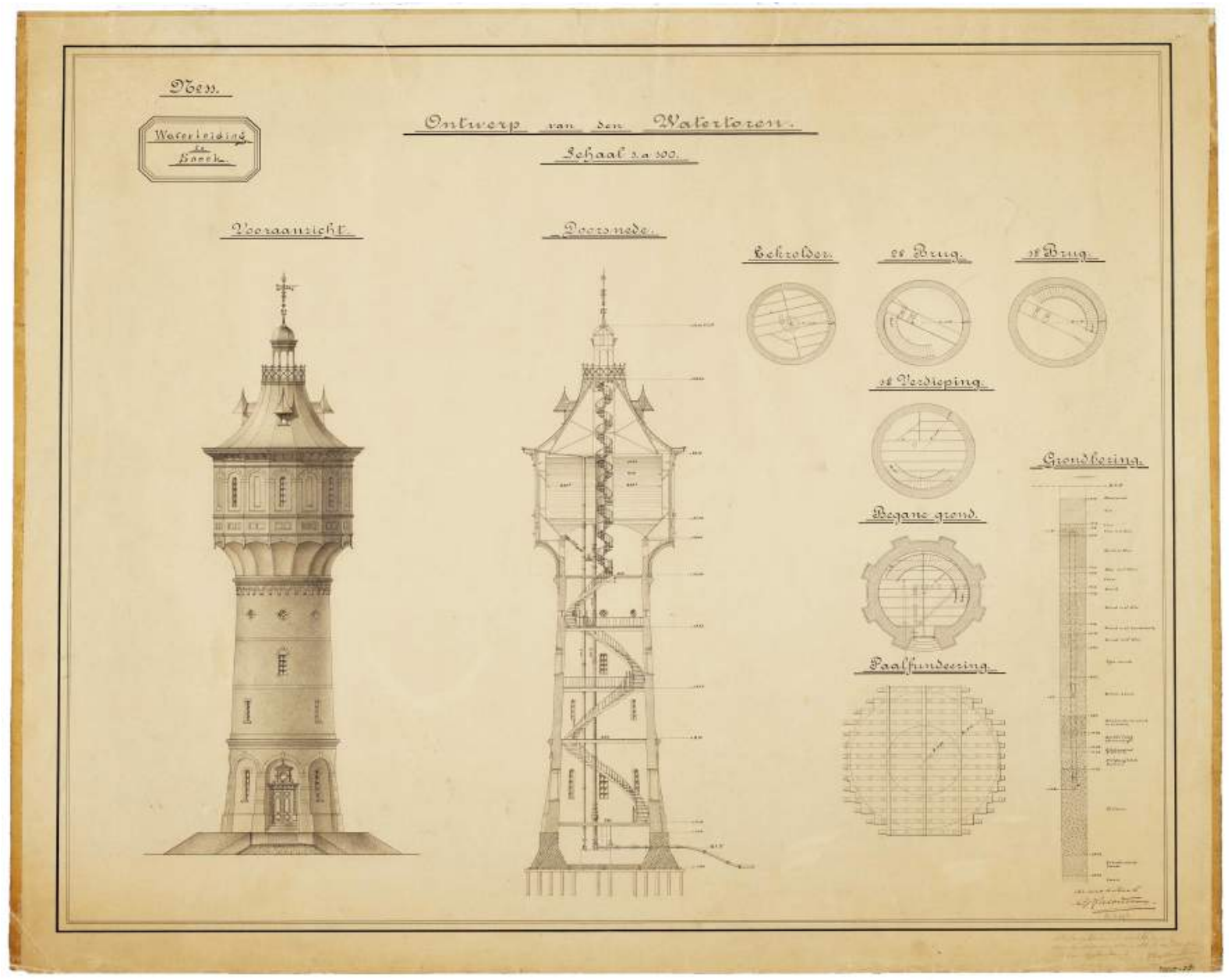

\section{3 .65}

H.P.N. Halbertsma, Torre de Água de Sneek, Holanda, 1908. Plantas, corte e elevação.
A F. A. Neuman, como fabricante única de tanques tipo Intze na Europa, iniciou uma cooperação com várias empresas do setor ferroviário e definiu volumes padrão de reservatórios (100, $150,200,300,400$ e $500 \mathrm{~m}^{3}$ ) para atendimento das necessidades do setor, permitindo que a empresa iniciasse uma produção em massa de reservatórios em um período onde a produção em série de reservatórios de água com esta tecnologia era praticamente inexistente. ${ }^{89} \mathrm{~A}$ figura 2.3.66 mostra uma secção típica das torres de água ferroviárias que foram utilizadas principalmente na Alemanha, mas também em países como Holanda e Bélgica, equipadas com reservatórios padronizados tipo Intze.

89 WERTH, 1971, op. cit.. 


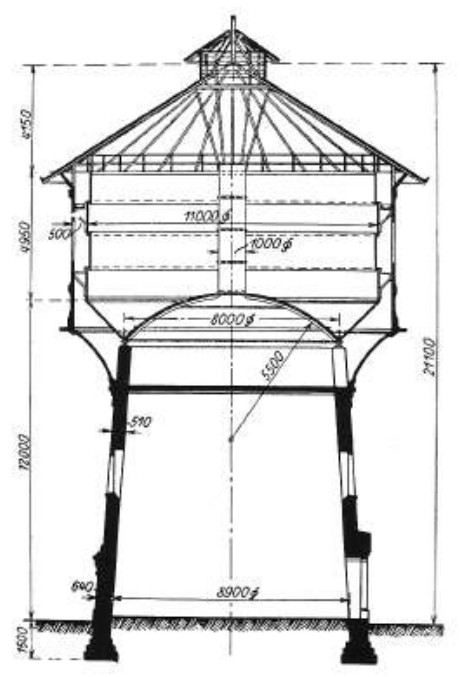

\subsubsection{6}

Torre de Água Ferroviária com Reservatório Tipo Intze de 500 m3. Corte Típico.

\section{3 .67}

Torre de Água Ferroviária com Reservatório Tipo Intze. Detalhes Construtivos

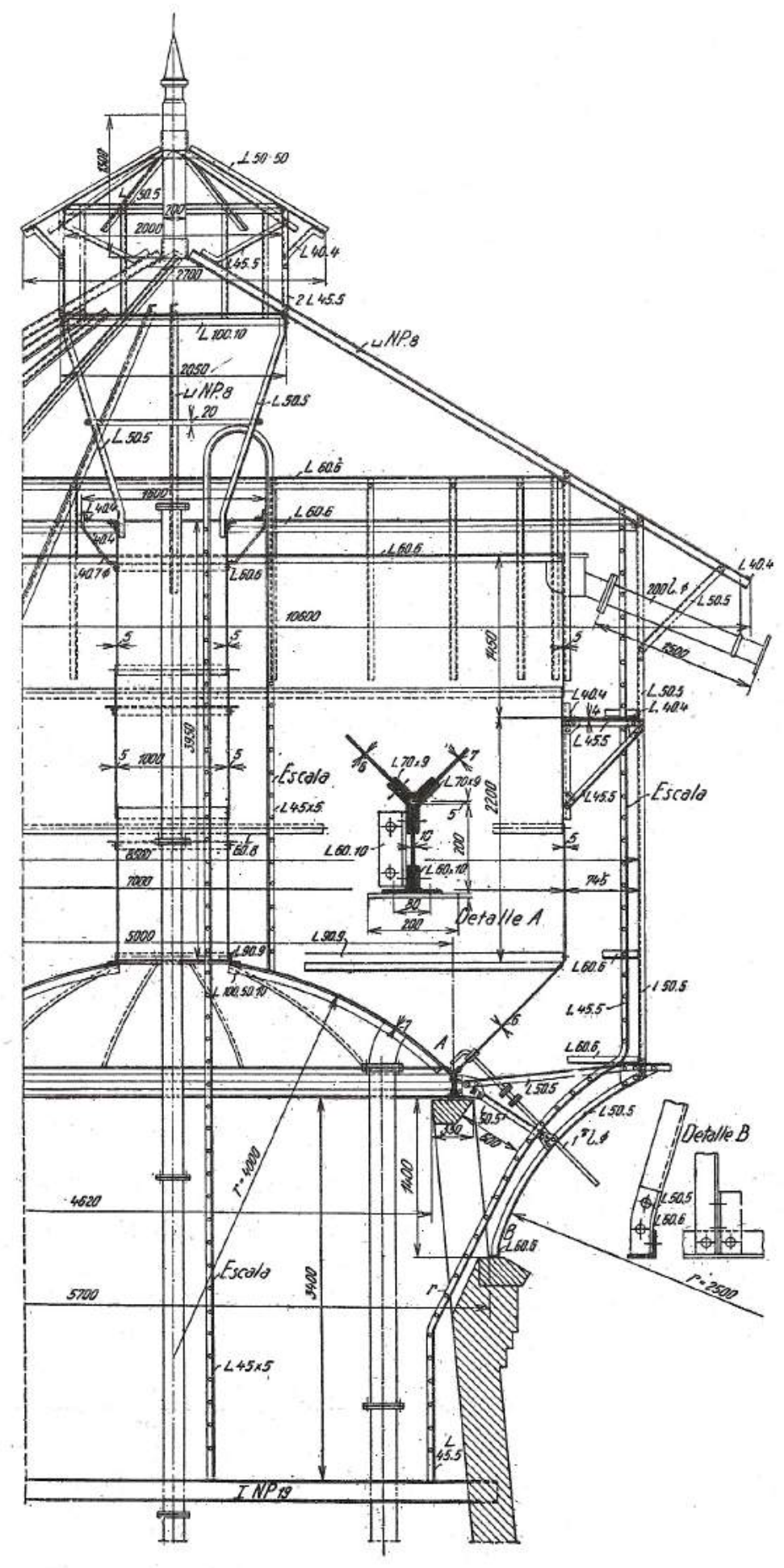


A estrutura de suporte destas torres consistia de um fuste troncônico, que se afilava em direção ao apoio do reservatório, executado em alvenaria autoportante de tijolos. O acesso ao topo do reservatório era realizado por uma passagem vertical, um cilindro centralizado no interior do tanque com diâmetro aproximado de 1,00 metro, solução de projeto que se tornaria um padrão para os reservatórios tipo Intze. Este cilindro estava submetido a uma grande pressão hidrostática sendo assim necessário o seu reforço com perfis tipo cantoneira rebitados em sua parede. $O$ fundo em cúpula, submetido a grandes esforços de compressão, era reforçado com nervuras de enrijecimento tanto no sentido dos meridianos quanto dos paralelos. O revestimento externo dos reservatórios poderia ser feito em madeira, alvenaria ou ainda estuque, este último sendo aplicado sobre um leve esqueleto de ferro apoiado na parede externa do reservatório. A estrutura de cobertura era executada com um sistema simples de vigas tipo $U$, que repousavam nas paredes internas e externas do reservatório servindo de apoio para chapas metálicas ou de madeira que eram recobertas, possivelmente, com telhas feltro-asfálticas. A figura 2.3.67 mostra os detalhes construtivos das soluções de projetos descritas acimas, soluções estas que também eram utilizadas nas torres de água para abastecimento público de água. As torres de água das estações de Landau (1887), Neustadt (1887), 90 Wittingen (ca. 1902) e Pfalzfeld Rheinland-Pfalz (1906), ${ }^{91}$ todas na Alemanha, são exemplos característicos deste tipo de construção (fig. 2.3.68).

\footnotetext{
90 INTZE, 1894, op. cit..

${ }^{91}$ WERTH, 1971, op. cit., p. 356.
} 

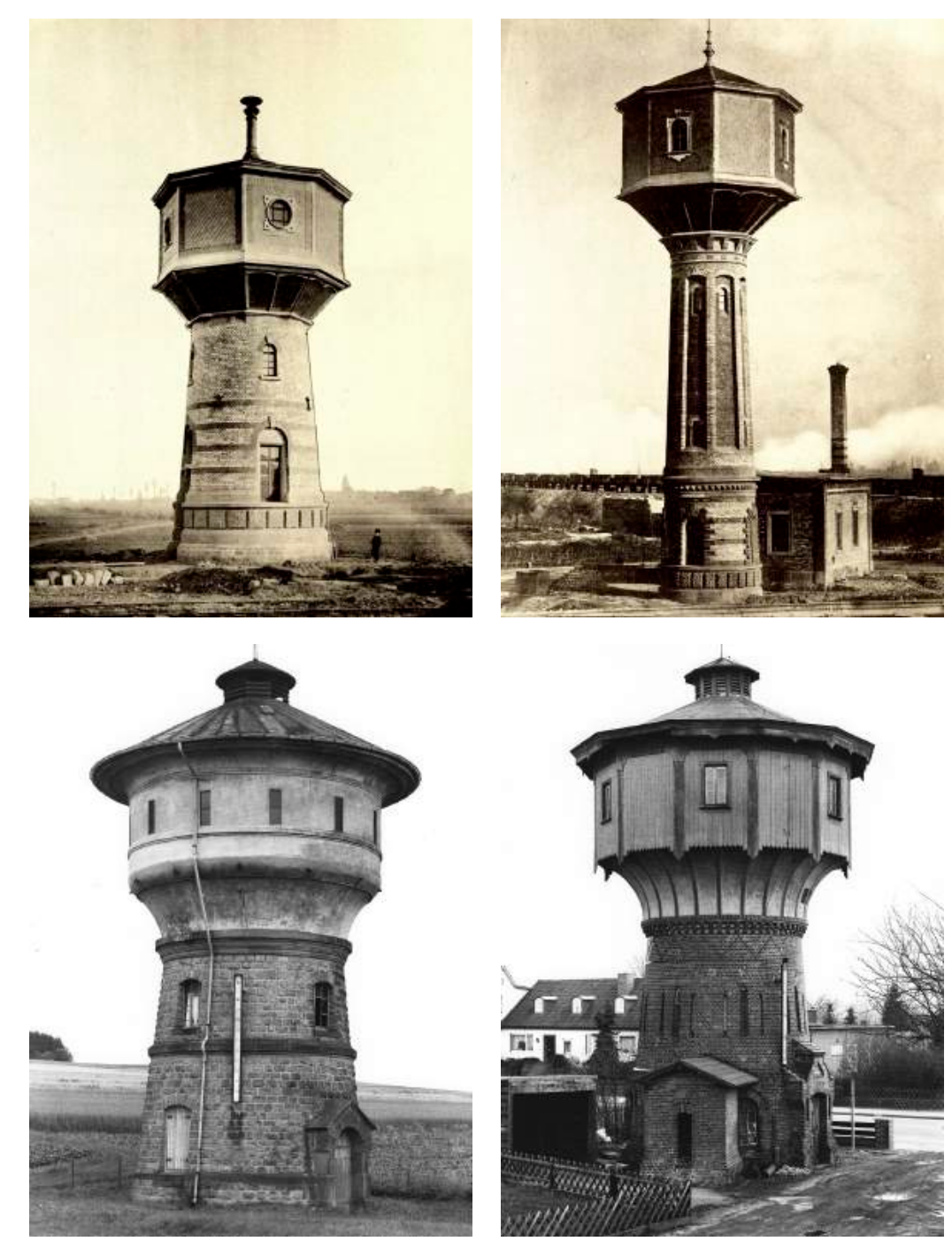

\subsubsection{8}

Torres de Água Ferroviárias Equipadas com Reservatórios tipo Intze I.

a) Estação de Landau, AL, 1887.

b) Estação de Neustadt, AL, 1887.

c) Estação de Estação de Pfalzfeld Rheinland-Pfalz, AL, 1906.

d) Estação de Wittingen, $A L$, ca. 1902.

A experiência de se construir "estações de água" com reservatórios aparentes fabricados em chapas rebitadas de aço, sem qualquer tipo de revestimentos decorativo externo, que havia sido iniciada nas ferrovias francesas e belgas também foi aos poucos sendo introduzida nas ferrovias alemãs e também nas instalações industriais de vários países europeus. As torres de água das estações de Köln-Gereon (1888) e Lahnstein (ca. 1890), na Alemanha, são exemplos de construções onde os reservatórios Intze foram instalados aparentes (fig. 2.3.69).

Um dos exemplos mais curiosos de torres ferroviárias foram as torres gêmeas (fig. 2.3.70) da Estação Central da Antuérpia, projetadas pelo arquiteto belga Louis de la Censerie (1838-1909) e, infelizmente, demolidas em 1963. ${ }^{92}$ Construídas em 1895, no início

\footnotetext{
92 VAN CRAENENBROECK, 1991, op. cit., p. 85.
} 

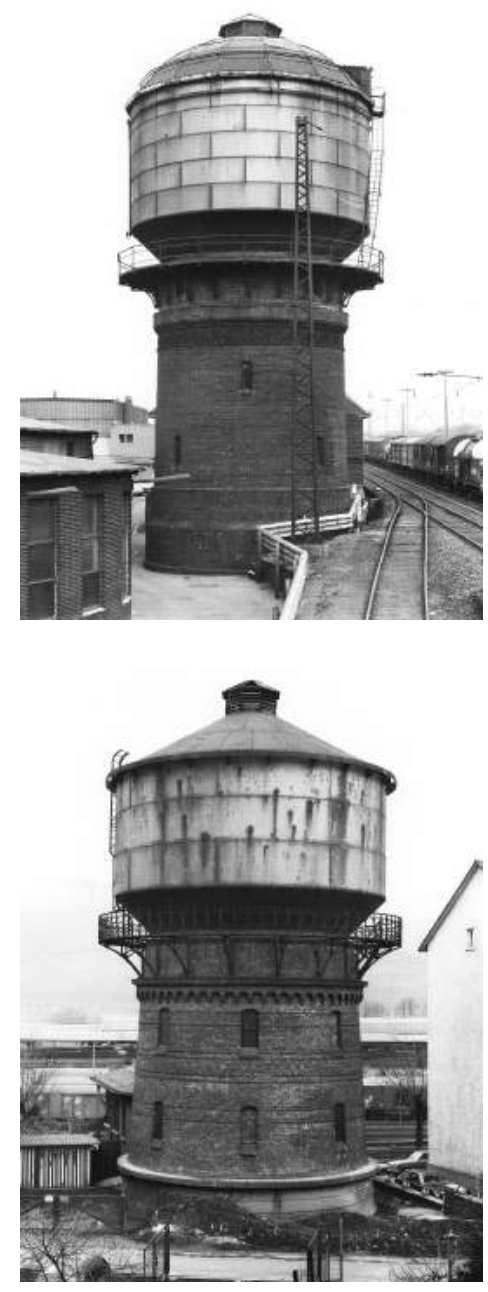

2.3.69

Torres de Água Ferroviárias Equipadas com Reservatórios Aparentes tipo Intze I.

a) Estação de Köln-Gereon, AL, 1888.

b) Estação de Lahnstein, $A L$, ca. 1890. das obras para elevação de nível da ferrovia na cidade, as torres gêmeas de la Censerie tinham os seus fustes de alvenaria unidos por uma estrutura em arco formando um enorme portal puramente decorativo, uma vez que este, posicionado em um passeio entre a rua Simonsstraat e o futuro aterro da via férrea elevada, não ofereceriam acesso a parte alguma. Quando as obras da elevação da via férrea foram concluídas, la Censerie projetou ainda uma ponte conectando as torres com nível dos trilhos da ferrovia. Os fustes das torres eram sobrecarregados com elementos decorativos ecléticos e os reservatórios tipo Intze com volume de $300 \mathrm{~m}^{3}$ cada, apesar de terem sido instalados aparentes, tiveram suas paredes decoradas com pinturas e frisos e foram cobertos com um telhado cônico, coroado por uma espécie de pináculo.

Otto Inzte elaborou em 1885 uma variação de seu design inicial com o objetivo de reduzir a quantidade de material que era utilizada na fabricação de reservatórios com volumes acima de 500 $\mathrm{m}^{3}$, uma vez que reservatórios acima desta capacidade exigiam uma grande quantidade de nervuras de reforço da cúpula para resistir aos esforços de compressão aos quais o fundo estava submetido. Além disto, nos reservatórios com grandes volumes, a altura do fundo em cúpula era considerável o que se refletia na perda de parte do volume utilizável do reservatório. Intze criou então um reservatório que preservava o princípio Intze patenteado, acrescentado um fundo suspenso centralizado com os demais planos de fundo do reservatório. Esta tipologia de tanque passou a ser conhecida como Intze tipo II. A figura 2.3.71 mostra as duas variações de reservatórios Intze, tipo I e tipo II. Com este novo desenho do fundo do reservatório obteve-se um reservatório muito mais leve, sem gerar alterações nos esforços atuantes e no funcionamento estático do anel de suporte. No ponto de conexão entre o fundo suspenso e o fundo em cúpula era necessário um anel de pressão adicional mas este, devido ao seu pequeno diâmetro, poderia ser facilmente executado um perfil do tipo cantoneira..$^{93}$

${ }^{93}$ WERTH, 1971, op. cit., p. 358. 


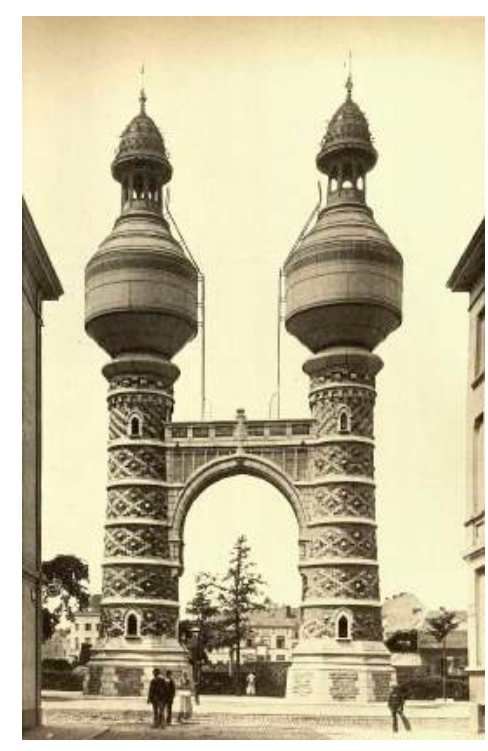

\subsubsection{0}

Louis de la Censerie, Torres Gêmeas da Estação Central da Antuérpia, 1895.

\subsubsection{1}

Reservatórios Intze Tipo I e Tipo II.
O primeiro reservatório Intze tipo II, com um volume de $550 \mathrm{~m}^{3}$, foi instalado na torre de água de Düren, Alemanha (fig. 2.3.72). Construída em 1885 conforme projeto de Otto Intze e Heinrich Friedrich Damert a torre tinha uma altura total de 50 metros e um diâmetro de 15,40 metros na base de seu fuste troncônico construído em alvenaria de tijolos. O revestimento ornamental do reservatório tinha o formato octogonal e foi executado em alvenaria de tijolos, apoiada em um esqueleto metálico fixado contra a parede do reservatório e também ao topo do fuste da torre. A transição do fuste e da cabeça saliente da torre exibia a típica "meia-cana" que se tornou uma solução corrente de projeto nas torres equipadas com reservatórios tipo Intze I ou II. Esta "meiacana", possivelmente, era executada em estuque, uma solução construtiva presente em outros exemplares da época. $\bigcirc$ telhado praticamente plano, escondido por detrás de uma cornija apoiada em mísulas decorativas, estava apoiado no anel de pressão do fundo suspenso do reservatório, em uma estrutura cônica formada por perfis de ferro em secção T. A torre de Düren foi demolida em 1951 devido aos grandes danos sofridos durante a Segunda Guerra Mundial.
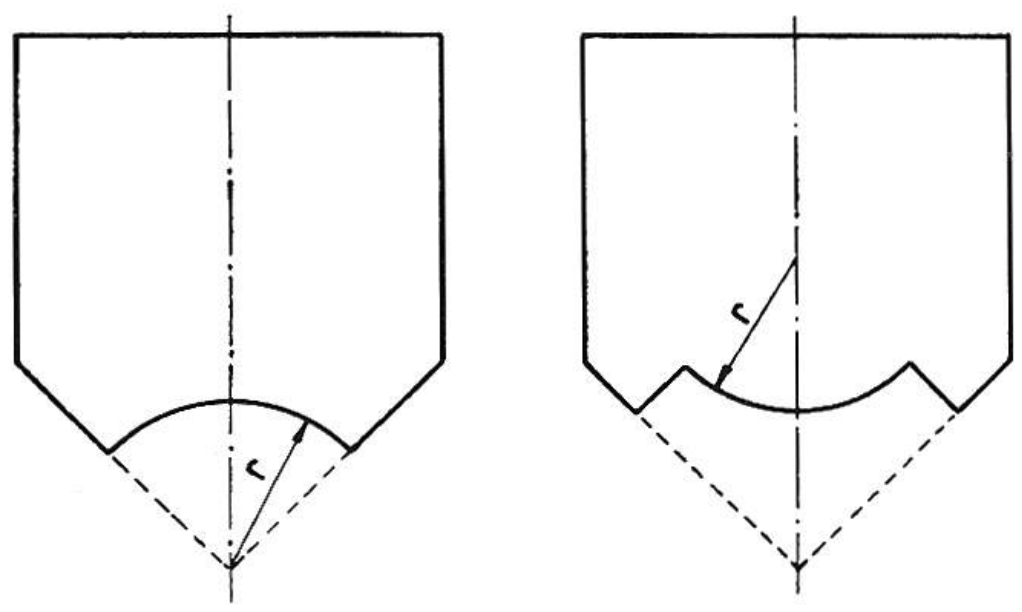

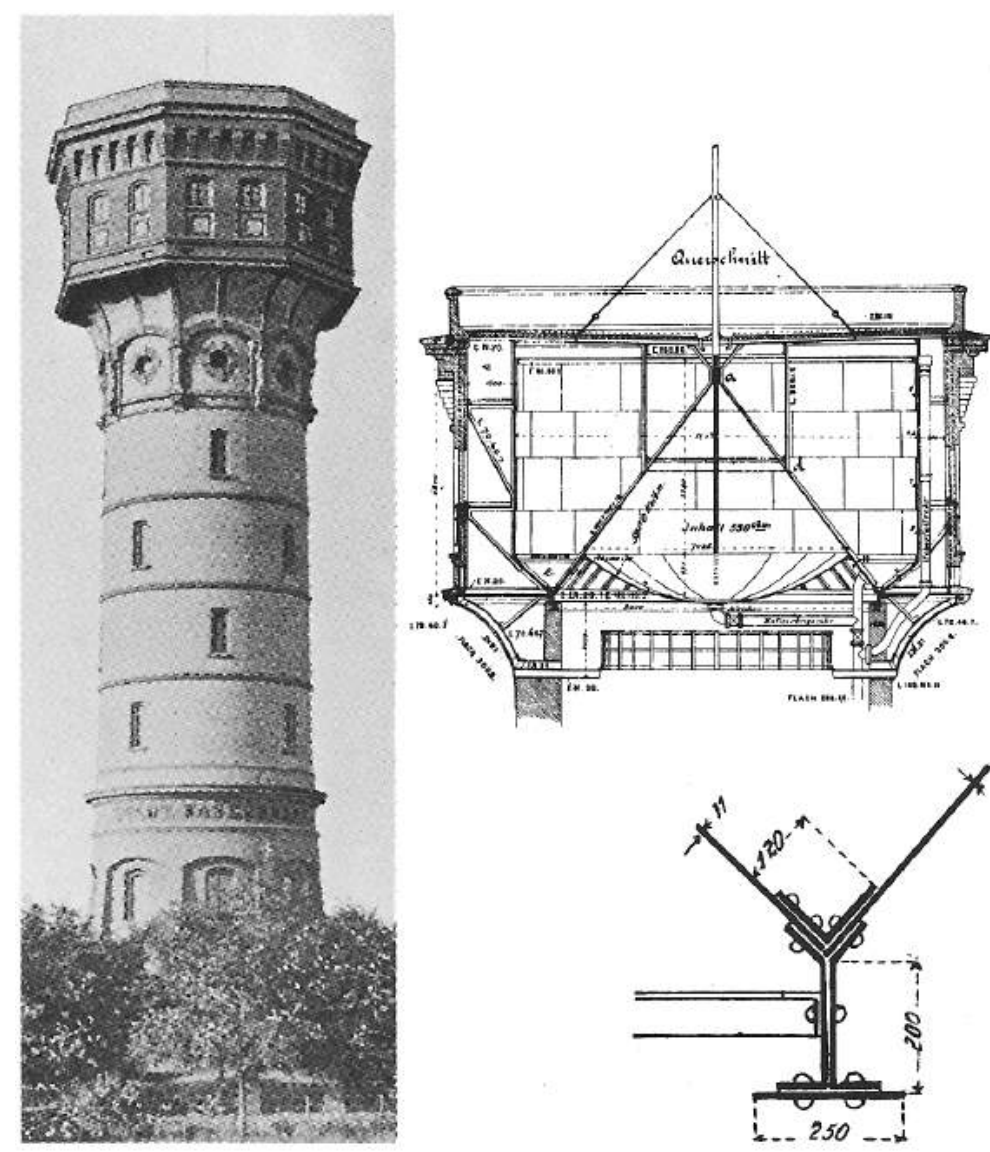

2.3.72

Otto Intze e Heinrich Friedrich Damert, Torre de Düren, Alemanha, 1885.
Outros exemplos de torres de água construídas neste período para abastecimento público a utilizar reservatórios do tipo Intze II são a Torre de Schiedam $\left(600 \mathrm{~m}^{3}\right)$, Amsterdam (500 m³) e Leeuwarden $\left(500 \mathrm{~m}^{3}\right)$, todas na Holanda, projetadas pelo arquiteto J. Verheul e pelo engenheiro H. P. N. Halbertsma, ${ }^{94}$ entre os anos de 1886 e 1888.95

A expansão das áreas de abastecimento, a necessidade de maiores pressões nas redes de distribuição e o aumento do consumo de água motivados pelo constante crescimento dos centros urbanos, obrigou o aumento da capacidade de armazenamento

\footnotetext{
${ }_{94}$ Muito atuante na Holanda entre os anos de 1880 e 1920, o engenheiro H. P. N. Halbertsma (1853-1929) era um especialista no campo do abastecimento de água e discípulo de Otto Intze, tendo sido seu aluno na Technische Hochschule Aaachen. Foi responsável pelo introdução dos reservatórios tipo Intze na Holanda, onde projetou os sistemas de abastecimento público de água de várias cidades que, na maioria dos casos contavam com torres de água. Projetou pelo menos 12 torres de água sempre em colaboração com algum arquiteto, sendo o arquiteto Jan Verheul (1860-1948) seu maior colaborador. Ver VEEN, 1989, op. cit., p. 52.
}

95 VEEN, 1989, op. cit., p. 49 


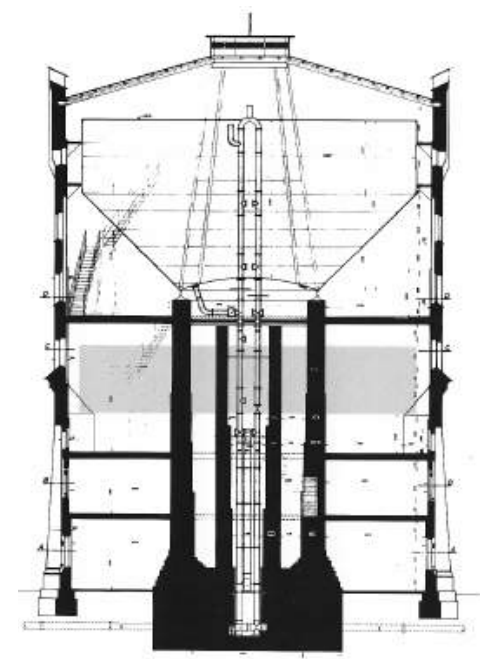

2.3.73

Torre de água de Lübeck com o novo reservatório Intze I sobre o antigo reservatório de fundo plano (1889). das torres de água de muitas cidades. Os reservatórios tipo Intze mostraram-se muito adequados para esta tarefa, uma vez que a versatilidade de seu design, que permitia um diâmetro de anel de suporte variável e um diâmetro variável do reservatório, garantia a possibilidade de instalação de um novo reservatório de maior capacidade em qualquer torre de água já existente.

Uma das primeiras torres de água a ter o seu reservatório substituído foi e torre da Cidade de Lübeck (1867), que foi ampliada em 1889. O reservatório original de ferro fundido com fundo plano, com volume de $1.025 \mathrm{~m}^{3}$ (em cinza na fig. 2.3.73) foi substituído por um reservatório tipo Intze I, com volume de $2.100 \mathrm{~m}^{3}$. Para apoio do novo reservatório foi executado um novo fuste circular em alvenaria no interior da torre com um diâmetro de 8,00 metros, dimensão correspondente ao anel de suporte do reservatório. A parede externa da torre foi elevada em 29,00 metros para envolver o novo reservatório instalado. ${ }^{96}$ Assim a forma típica do reservatório Intze não foi expressa na fachada da torre e a sua forma original foi completamente alterada (fig. 2.3.74) A nova parede, coroada por ameias semelhantes às da fachada original, foi executa com tijolos de duas cores, formando faixas decorativas em espiral e sua superfície lisa faz concessão apenas a pequenas aberturas que lembram as seteiras dos castelos medievais. A estrutura de suporte do novo telhado foi concebida como uma torre em treliça metálica, posicionado no interior do reservatório, ancorada no anel de suporte (fig. 2.3.75).

Situação semelhante ocorreu na torre de água de Remscheid, Alemanha (1883). O reservatório Intze original da torre (em cinza na fig. 2.3.76), com volume de $400 \mathrm{~m}^{3}$ já não era mais suficiente para atender à demanda por água da cidade e era necessário um novo reservatório com capacidade de $1.500 \mathrm{~m}^{3}$. As obras de expansão da torre iniciaram-se em 1907. Para viabilizar o novo reservatório, sem a interrupção nas operações do sistema de abastecimento de água, uma nova torre foi construída em volta

${ }^{96}$ WERTH, 1971, op. cit., p. 359 
da torre antiga e um novo reservatório do tipo Intze II foi instalado sobre o antigo. Após a reconstrução, o antigo reservatório foi removido e remontado em um nova torre de água no bairro de Hasten. ${ }^{97}$

2.3.74

Torre de água de Lübeck, Alemanha, 1889.

\subsubsection{5}

Torre de água de Lübeck, Alemanha, 1889. Detalhes.
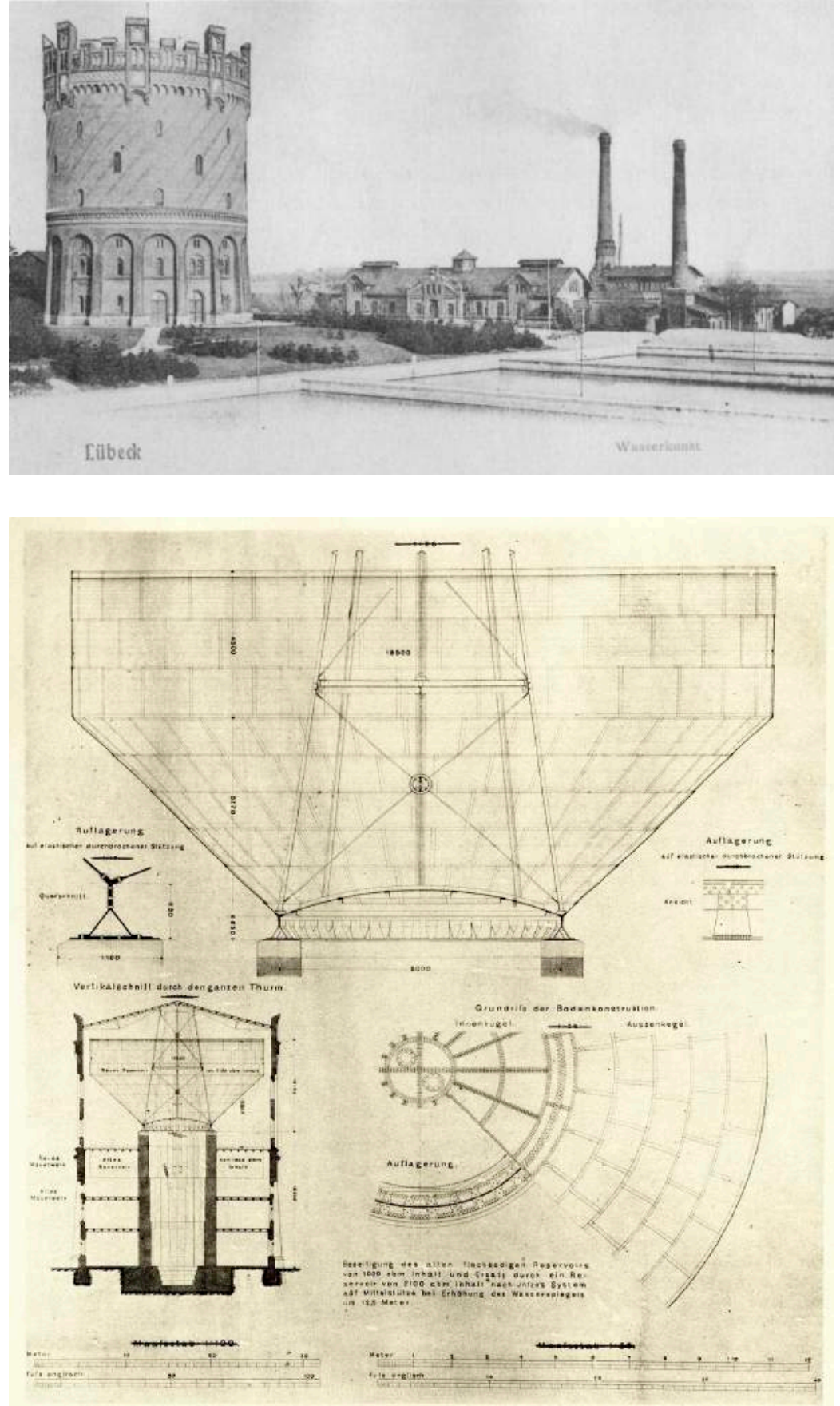

${ }^{97}$ MERKL, 1985, op. cit., p. 91-93. 


\subsubsection{6}

Torre de água de Remscheid com o novo reservatório Intze II sobre o antigo reservatório tipo Intze I (1907).

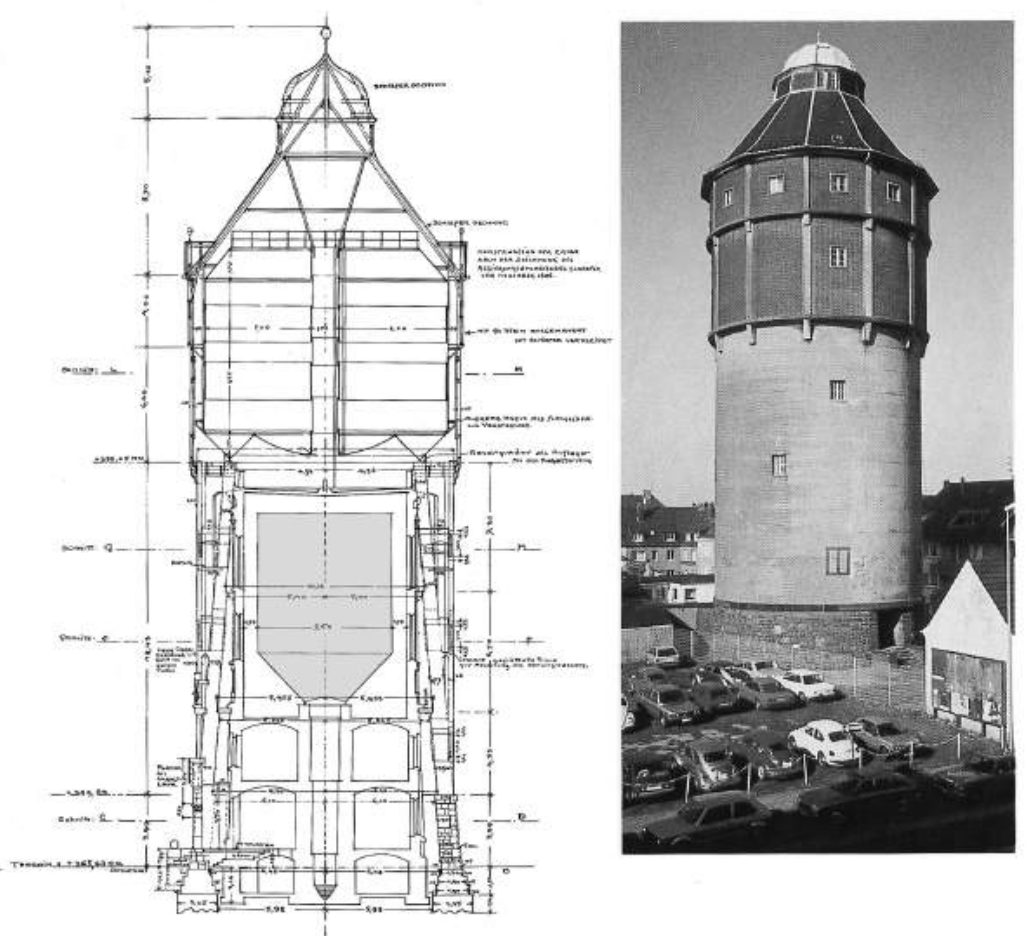

Em 1895 a torre da cidade de Mülheim, Alemanha, passou uma situação semelhante mas, ao invés de se substituir o antigo reservatório de fundo suspenso, decidiu-se continuar usando este e construir um segundo reservatório tipo Inzte II, com volume de $800 \mathrm{~m}^{3}$. O novo reservatório Intze teria um anel de suporte com o mesmo diâmetro do fuste de torre antiga e a altura desta teria quer ser ampliada em 7,70 metros, superando a altura do reservatório existente, atingindo a cota apoio do novo tanque. Ao invés de se construir uma nova parede optou-se pela construção de uma estrutura metálica, $75 \%$ mais leve que a alvenaria de tijolos e muito mais econômica. $\bigcirc$ reservatório existente acabou ficando visível pelo exterior e o novo reservatório Intze também não foi revestido por motivos de economia (fig. 2.3.77). Com 10,60 metros de diâmetro no anel de suporte e 13,00 metros de diâmetro total, o reservatório Intze foi apoiado em um esqueleto estrutural formado por 12 colunas fabricadas em ferro forjado, contraventadas por travessas horizontais e diagonais. É importante notar neste projeto que, soluções adotadas por razões puramente técnicas e econômicas refletiram em um dos primeiros usos visíveis de estruturas metálicas em uma torre de água para abastecimento público construída no centro de uma cidade europeia. ${ }^{98}$

98 WERTH, 1971, op. cit.. 


\subsubsection{7}

Torre de Água de Mülheim, Alemanha, 1885.

\subsubsection{8}

Torre de Água de Essen-Steele, Alemanha, 1898. Corte

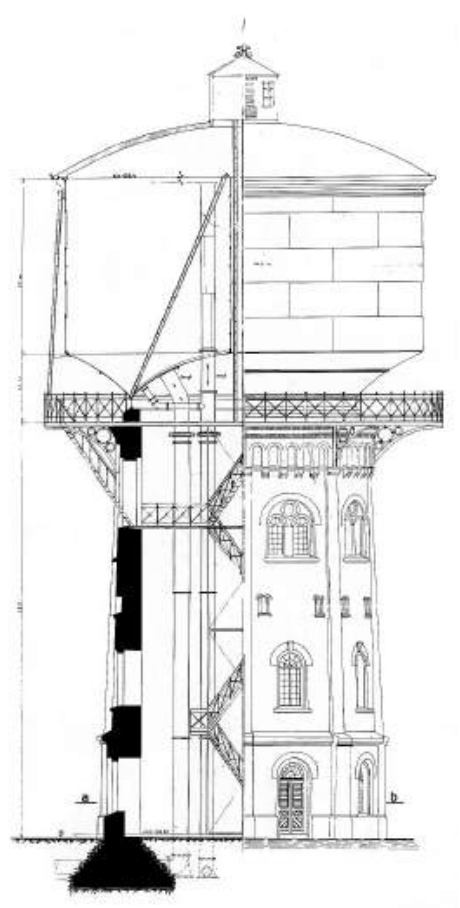

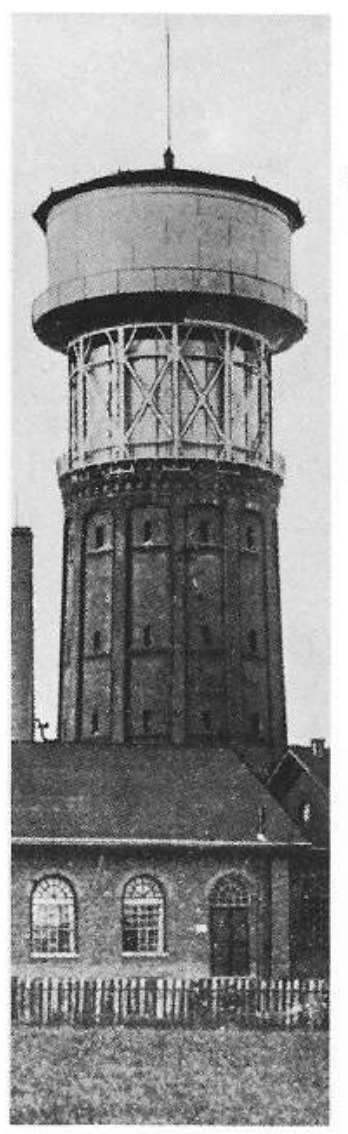

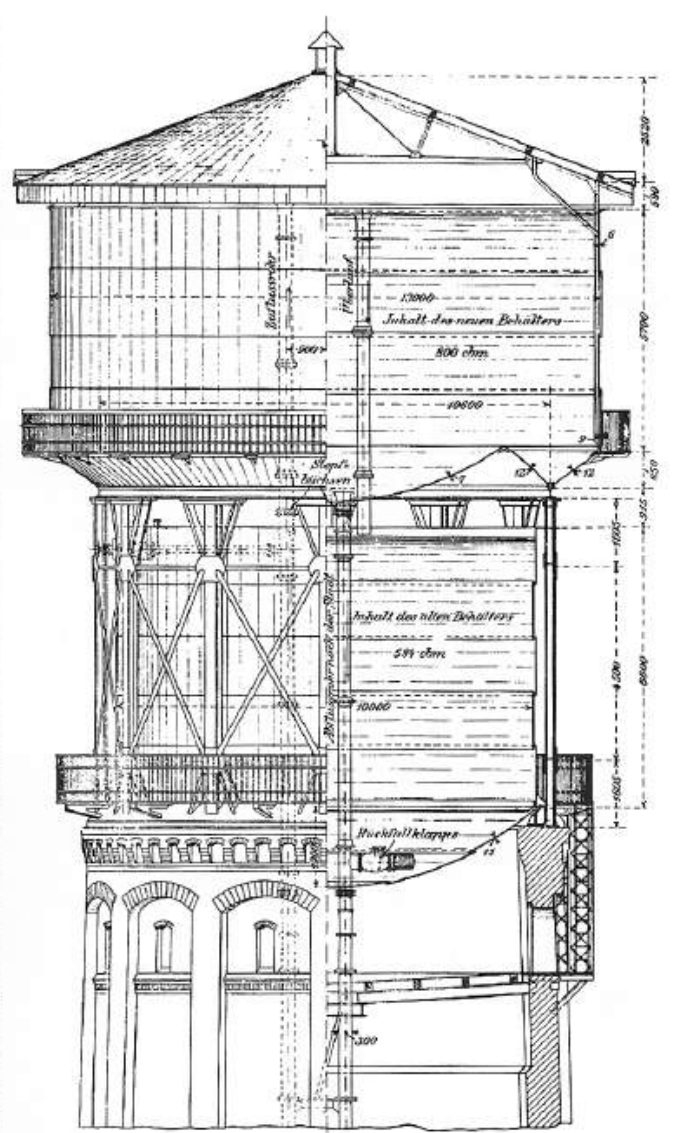

O precedente da torre de água de Mülheim abriu caminho para que outras torres de água para abastecimento público em outras cidades da Alemanha fossem construídas sem a utilização de revestimentos externos decorativos em seus reservatórios. As torres de Essen-Steele (1898) com volume de $1.000 \mathrm{~m}^{3}$ (fig. 2.3.78), Essen-Leithe (1898) com volume de $2.200 \mathrm{~m}^{3}$ (figs. 2.3.79) e a torre de Alsdorf (1910) com volume de $1.000 \mathrm{~m}^{3}$ (fig. 2.3.80), todas construídas após a torre de Mülheim, deram um importante passo para a mudança do paradigma estético que estava prestes a acontecer no universo das torres de água urbanas.

Havia, porém, uma grupo de críticos das torres de água que utilizavam os reservatórios tipo Intze, formado tanto por arquitetos quanto por engenheiros, que consideravam a cabeça saliente destas torres como uma solução formal inadequada para a construção destas edificações. Sendo assim não era incomum encontrar projetos de torres de água que utilizassem soluções formais nas quais o formato típico do reservatório tipo Intze não era expresso. As já comentadas torres de água de Remscheid (1884 e 1907) e a 


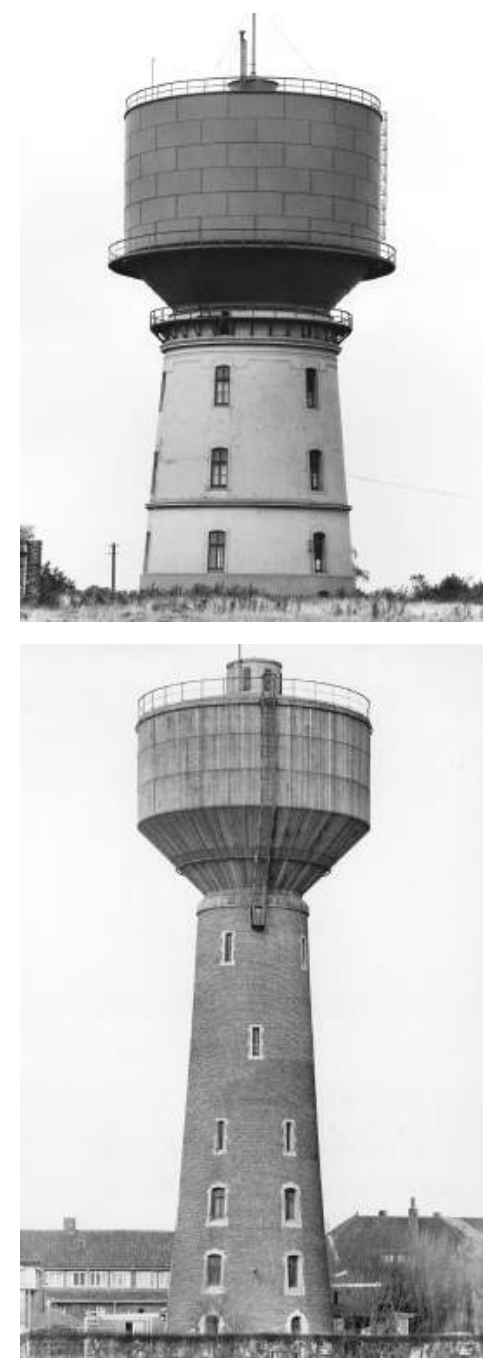

2.3.79

Torre de Água de Essen-Leithe, Alemanha, 1898.

\subsubsection{0}

Torre de Água de Alsdorf, Alemanha, 1910. torre de Lübeck (1889) exemplificam esta posição. Mas vale ainda comentar sobre outro exemplo, a torre de água de Favoriten (fig. 2.3.81, 2.3.82), em Viena, construída em 1898 segundo projeto de Franz Xaver Borkowitz (1838-1909). Com altura total de 67 metros, uma das mais altas da Europa, a torre de água foi equipada com um reservatório tipo Intze I, com volume de $1.000 \mathrm{~m}^{3}$, apoiado em um fuste cilíndrico de alvenaria com altura de 25 metros e 1,20 metro de espessura média de parede. ${ }^{99} \mathrm{~A}$ cornija principal, posicionada a uma altura de 36,50 metros é o ponto de transição entre o fuste da torre e a impressionante cobertura com altura de 30,50 metros, revestida com um mosaico de azulejos coloridos de cinco cores e coroada por uma lanterna e um mirante. $O$ acesso ao topo do reservatório de feito por meio de um rampa em espiral com largura de 1,00 metros e comprimento de 203 metros, uma solução de circulação vertical atípica em torres de água. A alvenaria de tijolos de barro da parede externa da torre exibe elementos ornamentais em pedra como faixas, cornijas, pináculos e é sobrecarregada com elementos decorativos próprios do ecletismo arquitetônico do período, seguindo a mesma tendência presente nos demais edifícios públicos construídos em Viena na época. Externamente não existe qualquer indício da existência de um tanque tipo Intze no interior da torre ou mesmo qualquer tipo de indício da função da edificação. A construção poderia facilmente acomodar um reservatório de fundo suspenso como ocorre nas torres de Worms (1888) ou Mannheim (1886), duas obras que apresentam grande semelhança formal e estilística com a torre de Favoriten, ou até mesmo um reservatório de fundo plano.

Com exceção dos casos isolados das torres de água das cidades de Mülheim (1895), Essen-Steele (1898), Essen-Leithe (1898) e Alsdorf (1910), todas as torres de água destinadas ao abastecimento público de água construídas neste período em países como Alemanha, Holanda e Bélgica, recebiam, sem exceções, revestimento externos em madeira ou alvenaria que escondiam os reservatórios metálicos. A prática já havia demonstrado, desde as

99 MERKL, 1985, op. cit., p. 208. 


\subsubsection{2}

Franz Xaver Borkowitz, Torre de Água de Favoriten, Viena, 1898. Corte.

\subsubsection{1}

Franz Xaver Borkowitz, Torre de Água de Favoriten, Viena, 1898.
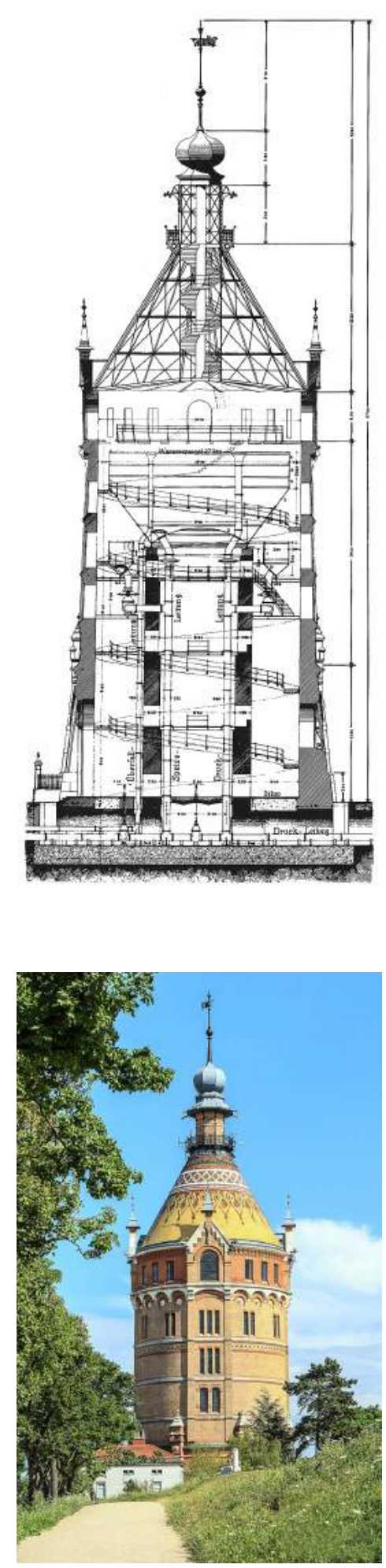

primeiras torres de água para abastecimento público construídas na Inglaterra, que a proteção externa dos reservatórios contra os efeitos adversos da temperatura poderia ser eliminada, uma vez que o calor armazenado na água, combinado com a sua retirada constante, eram suficientes para impedir o congelamento do conteúdo armazenado nos reservatórios. ${ }^{100}$ Na Alemanha, Bélgica, Holanda e Inglaterra grande parte das torres de água destinadas ao abastecimento de água de instalações ferroviárias e industriais já haviam abandonado a proteção externa dos reservatórios. Assim é possível dizer que a prática da utilização de revestimentos dos reservatórios metálicos das torres de água para abastecimento público tinha, em grande medida, uma finalidade muito mais estética do que técnica. Fica claro que a utilização de reservatórios aparentes de aço, seja do tipo Intze ou de qualquer outra tipologia, ainda não atendiam completamente aos padrões estéticos da época e não podiam ser incorporados facilmente aos novos edifícios sem alguns "ajustes". Por esta razão os "banais" tanques metálicos eram escondidos por trás de uma camada de ornamentos decorativos, cujo desenho era influenciado principalmente pelos estilos históricos preferidos na virada do século como, por exemplo, o gótico, o românico ou o renascimento alemão. ${ }^{101}$

\footnotetext{
100 WERTH, 1971, op. cit., p. 357.

101 lbid., p. 358.
} 


\subsection{Torres de Água no Século XX e na Atualidade}

\subsubsection{Desenvolvimento das Torres de Água Totalmente Metálicas}

No período de transição entre os séculos $X I X$ e $X X$, a construção industrial metálica fez importantes contribuições em favor de uma nova estética. Mas esta nova estética que era vista como um mal necessário na construção de pontes, viadutos, fábricas e etc., isto é, em edifícios puramente funcionais, não era aceita nas demais construções e foi, inicialmente, radicalmente rejeitada nas construções representativas, religiosas, residenciais, etc.. ${ }^{1}$ Neste período delineavam-se duas tendências estéticas antagônicas: o "ecletismo", uma apropriação formal dos estilos arquitetônicos históricos e uma nova corrente, chamada de "racionalista", que procurava uma nova arquitetura com características próprias da época, utilizando os novos materiais e desenvolvendo novas formas e programas adaptados às novas necessidades surgidas durante o século XIX. O emprego das estruturas metálicas aparentes era privilegiada pelo grupo dos "racionalistas", formado por engenheiros em sua maioria mas contando com a participação de alguns arquitetos. ${ }^{2}$

A Exposição Universal de 1889, marca o apogeu da construção metálica no século XIX e a Torre Eiffel, um grande sucesso popular, acirrou a disputa entre as correntes "racional" e "eclética", esta última figurando como grande crítica das obras dos engenheiros, que seriam apenas utilitárias e sem qualquer intenção plástica ou estética. ${ }^{3}$ No livro L'Architecture métallique au XIXe Siècle et L'Exposition de 1889, à Paris, o engenheiro e arquiteto belga Arthur Vierendeel, importante membro da corrente "racionalista" se manifesta em favor de uma nova arquitetura metálica:

\footnotetext{
1 MEVIUS, Walter. Baustile und Wassertürme. In: MERKL, Gerhard et al. Historische Wassertürme: Beiträge zur Technikgeschichte von Wasserpeicherung und Wasserversorgung. München: Oldenburg Verlag, 1985., p. 156.

${ }^{2}$ KÜHL, Beatriz Mugayar. Arquitetura do Ferro e Arquitetura Ferroviária em São Paulo: Reflexões sobre a sua preservação. Cotia: Ateliê Editorial, 1998, p. 37.

${ }^{3}$ Ibidem.
} 

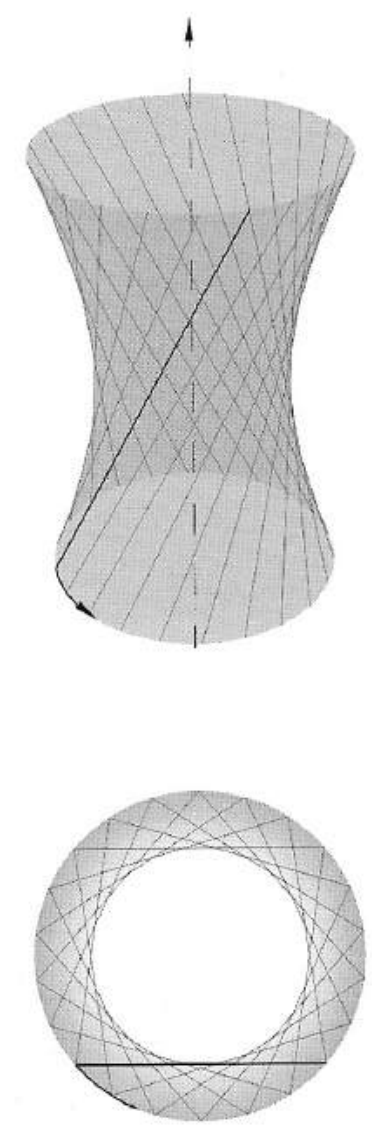

\subsection{1}

Hiperboloide de revolução de uma folha gerado pela rotação de uma geratriz reta.
"Cabe a nós, arquitetos e engenheiros, dar continuidade ao trabalho que começou: cabe a nós tirar do metal suas últimas consequências construtivas e sua quintessência estética, em uma palavra, apressar o pleno desenvolvimento desse estilo de que vemos despontar o amanhecer no horizonte. Vamos penetrar no espírito dos gregos e dos góticos e, aplicando o progresso da ciência e da indústria modernas, renovar as formas arquitetônicas. Inovar com ousadia, aí está a fonte do progresso; se os primeiros ensaios não atenderem às nossas expectativas, inovemos mesmo assim e, se o sucesso não coroar nossos esforços, paciência! $E$ amaldiçoados sejam aqueles que falarem mal disso." ${ }^{4}$

Neste mesmo período a arquitetura das torres de água também seria influenciada neste sentido. Enquanto que nos grandes centros urbanos da Europa Ocidental os reservatórios elevados de água se escondiam por detrás de revestimentos cenográficos influenciados pelo historicismo e pelo ecletismo arquitetônico em voga no período, as novas torres de água em construção nos Estados Unidos de América, na Rússia e nas indústrias e minas da Alemanha seriam projetadas com uma nova estética. Seguindo as diretrizes da nova estética propagada pelos engenheiros, estas novas torres de água utilizavam o ferro e o aço em construções despidas de qualquer tipo de ornamentação, aproveitando os novos materiais no limite de suas possibilidades técnicas.

Em 1896 o engenheiro russo Vladimir G. Shukhov (18351939) desenvolve uma estrutura inovadora, sem precedentes na história da construção: a torre em malha hiperbólica. A superfície de dupla curvatura de um hiperboloide de revolução de uma folha (fig. 2.4.1) pode ser criada girando-se uma linha inclinada sobre

\footnotetext{
4 "A nous, architectes et ingénieurs, de poursuivre l'oeuvre commencée, à nous de tirer du métal ses dernières conseéquences constructives et sa quintessence estheétique, à nous, en un mot, de hâter le plein épanouissement de ce style dont nous voyons poindre l'aurore à l'horizon. Péneétrons-nous de l'esprit des Grecs et des Gothiques et par l'application des progrès de la science et de l'industrie modernes renou- velons les formes architecturales. Innovons avec hardiesse, là est la source du progrès; si les premiers essais ne reépondent pas à notre attente, innovons encore quand même, et si le succès ne couronne pas nos efforts, patience! et honnis soient ceux qui en mal parleront." , VIERENDEEL, Arthur. L'Architecture métallique au XIXe Siècle et L'Exposition de 1889, à Paris. Bruxelles, Ramlot, 1890, p. 98.
} 

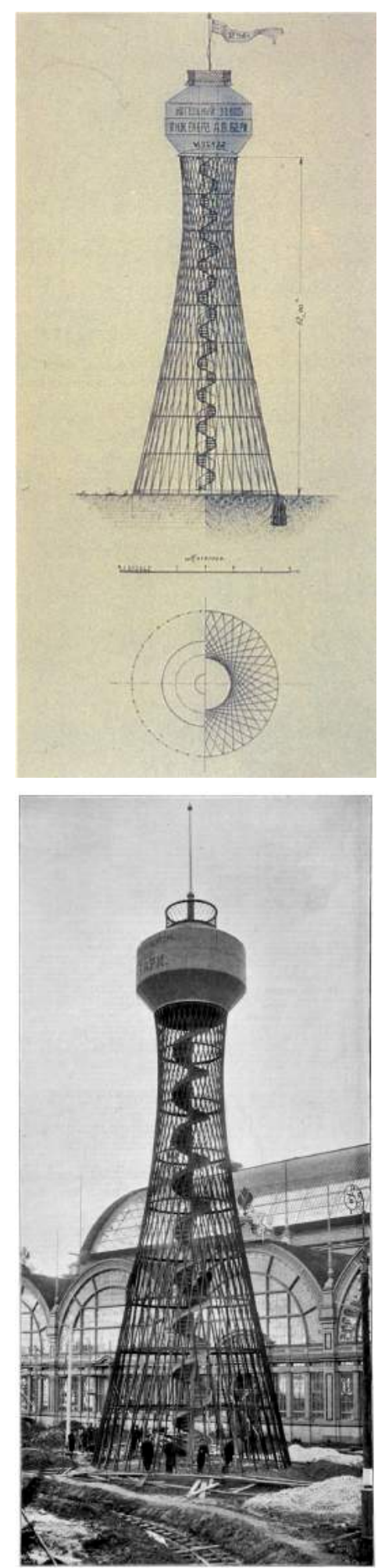

\subsection{2}

Vladimir G. Shukhov, Torre de Água da All-Russia Exhibition, Rússia, 1896.

\section{4 .3}

Vladimir G. Shukhov, Torre de Água da All-Russia Exhibition, Rússia, 1896. um eixo vertical. Utilizando este princípio Shukhov criou uma malha estrutural formada por duas famílias de retas inclinadas em sentidos opostos, resultando em uma estrutura extremamente leve, com grande estabilidade e de construção fácil e rápida. Shukhov solicitou a patente de sua nova estrutura descrevendo-a da seguinte maneira: "Uma torre em malha estrutural, caracterizada por elementos de sustentação de carga que consistem de peças retas de madeira, tubos de ferro ou perfis cantoneira que cruzam-se uns sobre os outros, posicionados na geratriz do sólido da revolução, assumindo a forma de uma torre." Ainda na patente, Shukhov relaciona os usos possíveis usos para a estrutura: "A principal utilização para estas estruturas seria para torres de água ou faróis de navegação." 5

Ainda em 1896 Shukhov constrói a sua primeira torre utilizando a nova estrutura: uma torre de água (fig. 2.4.2, 2.4.3) para a All-Russia Exhibition, em Nizhny Novgorod, Rússia. A estrutura em malha hiperbólica, executada inteiramente em aço, é composta por um conjunto de 80 perfis cantoneira com dimensões de 76 x $76 \times 10 \mathrm{~mm}$, travados verticalmente a cada 2,75 metros por anéis horizontais formados por pares de perfis cantoneira. Os diâmetros do hiperboloide de revolução são: 10,65 metros na base; 4,25 metros no topo e 3,65 metros na garganta. $O$ peso total da estrutura é de 35 toneladas. Com uma altura total de 30,60 metros, sendo 26,50 de estrutura, a torre de água foi equipada com um reservatório tipo Intze I com volume de $140 \mathrm{~m}^{3}$. Os reservatórios do tipo Intze e os reservatórios de fundo suspenso eram tipologias ideais de tanques para equipar as torres de água de Shukhov, uma vez que estas tipologias utilizam anéis de suporte contínuos, uma solução estrutural que distribui a carga vertical uniformemente na estrutura em malha hiperbólica, possibilitando uma torre com elementos mais esbeltos e eficientes. Uma escada em espiral no centro da estrutura atravessava o reservatório em altura e conduzia

\footnotetext{
${ }^{5}$ Apud BECKH, Matthias. Hyperbolic Structures: Shukhov's lattice towers - forerunners of modern lightweight construction. West Sussex: John Wiley \& Sons, 2015, p. 19.
} 
até um mirante no topo da torre de água. ${ }^{6}$ Depois de finalizada a exposição a torre foi desmontada e transladada na cidade de Polibino, sul da Rússia, onde permanece montada até os dias de hoje.

A leveza da estrutura desenvolvida por Shukhov, conjugada com a facilidade de sua execução, iniciou um série de mais de 200 torres de água construídas em várias partes da Rússia e em suas colônias entre os anos de 1896 e o final da década de 1920. Apesar do grande número de torres projetadas por Shukhov e do processo industrial envolvido em sua construção, duas torres de água dificilmente eram iguais. ${ }^{7}$ A geometria da torre e os elementos estruturais eram determinados especificamente para cada projeto em função de características como, por exemplo, tipo de reservatório, volume de água a armazenar e altura do nível de água, esta última definida conforme as necessidades de pressão da rede de distribuição de água.

A figura 2.4.4 mostra algumas das torres de água projetadas e construídas por Shukhov entre os anos de 1902 e 1915. Estas torres, com alturas variando entre 10,00 e 36,00 metros, com capacidade para armazenar entre 60 e $600 \mathrm{~m}^{3}$ de água, foram construídas na Rússia, Ucrânia e Bulgária. Shukhov também projetou e construiu algumas torres com reservatórios sobrepostos, com dois segmentos de hiperboloides de revolução posicionados um sobre o outro. A primeira torre de água a utilizar esta solução foi a da cidade de Yaroslavl (1911), 005 na Rússia. Outro exemplo é a torre de Yevpatoria, Ucrânia, projeto de 1925 (fig. 2.4.5). ${ }^{8} \mathrm{~A}$ versatilidade das estruturas de Shukhov permitiam até a utilização de reservatórios de fundo plano com o acréscimo de suportes diagonais intermediários na cabeça das torres, como na torre de água (fig. 2.4.6) de Orekhovo-Zuyevo, Rússia, projetada em 1924.

\footnotetext{
${ }^{6}$ The Nijni-Novgorod Exhibition. The Engineer, London, v. 83, mar. 1897, p. 292-293.

7 BECKH, 2015, op. cit., p. 22.

8 NOZHOVA, Ekaterina; HASSLER, Uta. Networks of Construction: Vladimir Shukhov. München: Hirmer Verlag, 2016, p. 128-131 e 230-231.
} 

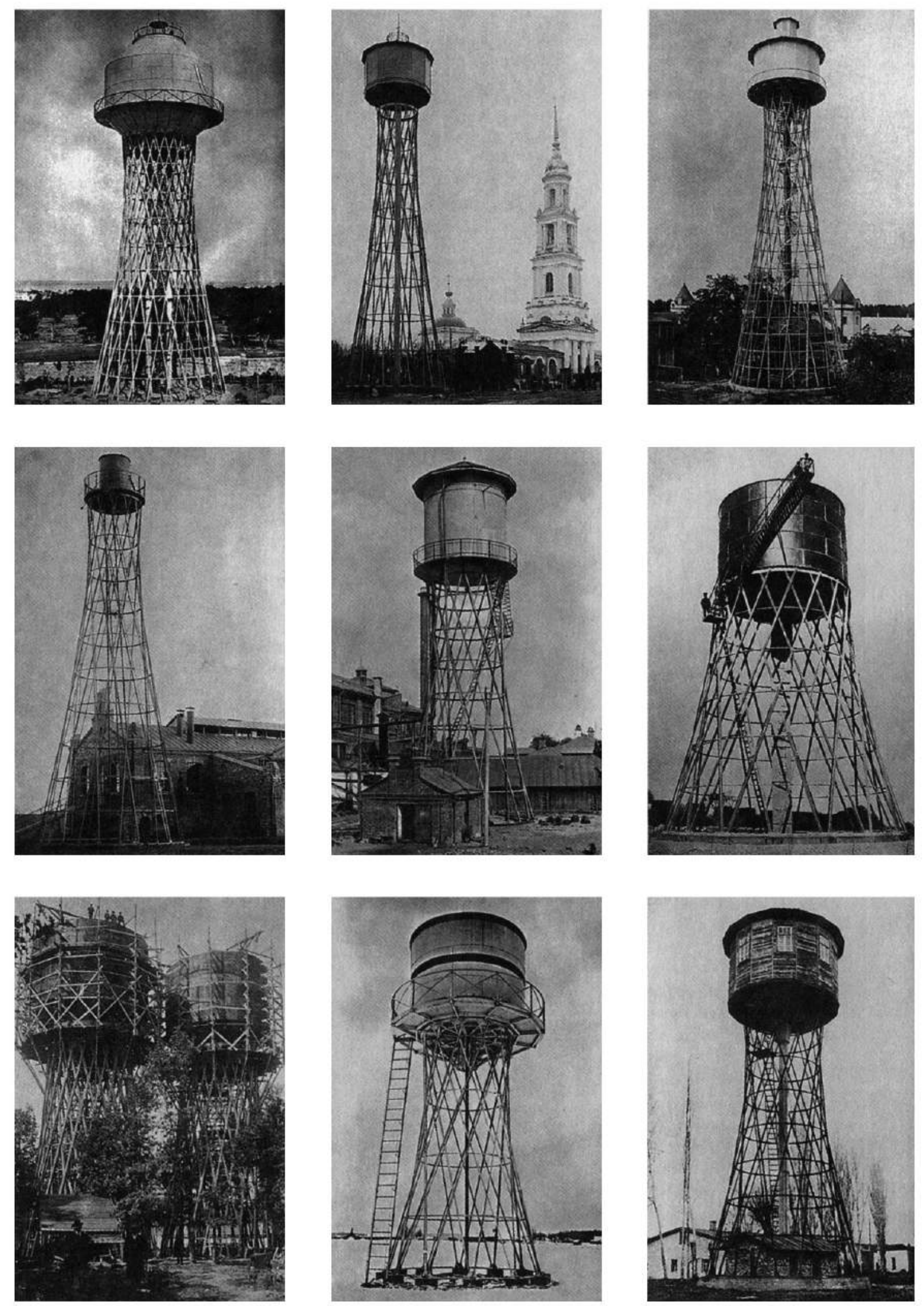

2.4.4.

Torres de Água projetadas por Vladimir G. Shukhov, 1902-1915. 

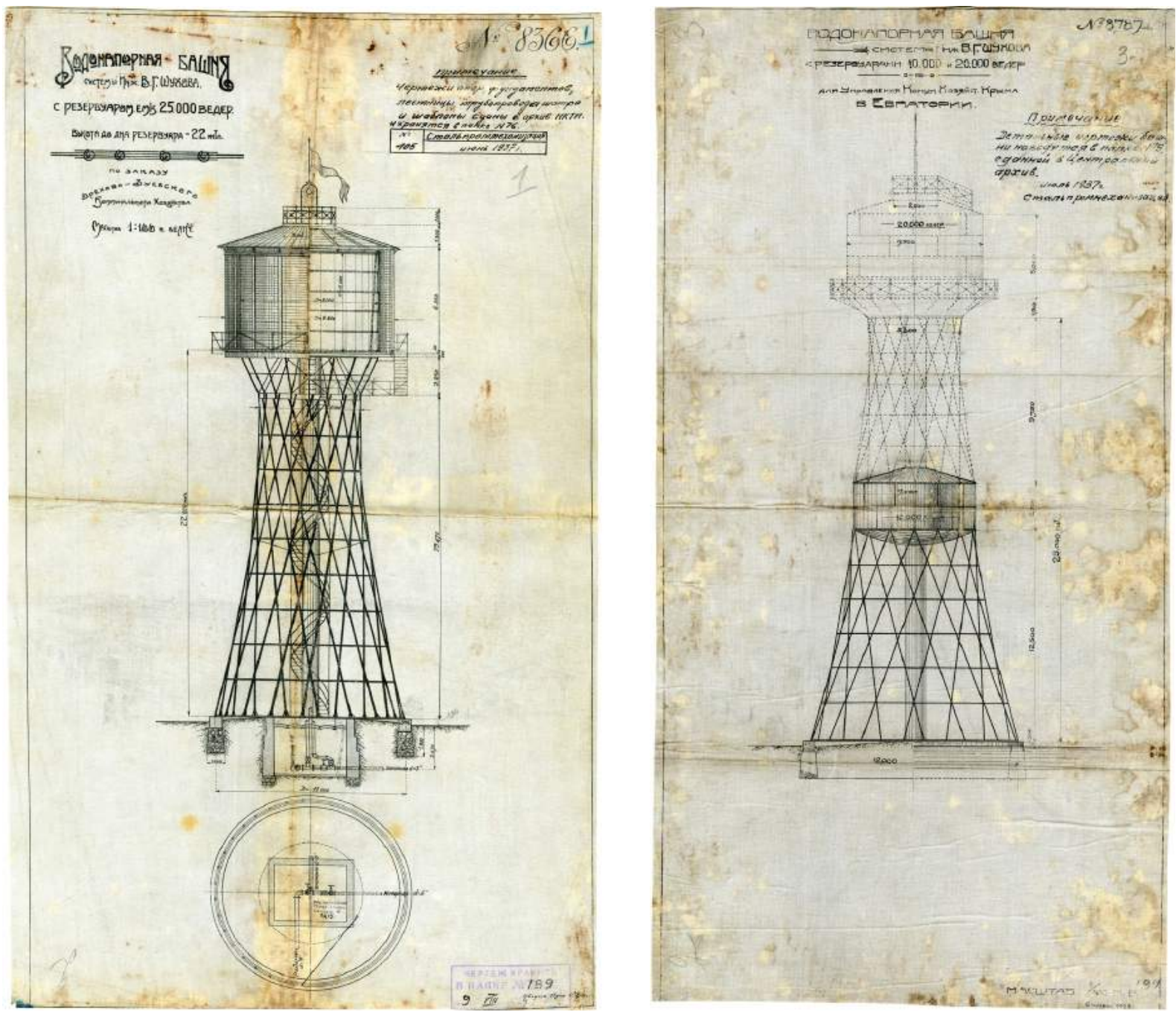

\section{4 .5}

Vladimir G. Shukhov, Projeto para Torre de Água de Yevpatoria, Ucrânia, 1925.

\subsection{6}

vadimir G. Shukhov, Projeto para Torre de Água de OrekhovoZuyevo, Rússia, 1924.
Segundo Beck (2007) outro motivo que colaborou para o grande sucesso das estruturas de Shukhov na Rússia e em suas colônias foi a questão estética. Neste período houve na Rússia uma proliferação de cidades que se utilizaram destas inovadoras estruturas funcionais como atrações arquitetônicas que embelezavam o espaço urbano das pouco verticalizadas cidades russas. Isto demonstra uma atitude mais aberta dos russos pela estética das novas estruturas da engenharia, exatamente o oposto do que acontecia nos países da Europa Ocidental, onde torres de água como as projetadas por Shukhov não seriam facilmente aceitas nos grandes centros urbanos, motivo que também ajuda a explicar o fato desta produção ter sido restrita aos territórios russos. Ainda assim, as estruturas de Shukhov seriam futuramente recuperadas e reinterpretadas por alguns arquitetos e engenheiros em torres de água construídas nas décadas de 1960 e 1970 como veremos mais adiante. 
Paralelamente ao desenvolvimento das estruturas de Shukhov, uma nova tipologia de reservatório elevado de água foi desenvolvida quase que simultaneamente nos Estados Unidos e na Alemanha, o reservatório de fundo hemisférico suspenso, um desenvolvimento do tanque de fundo suspenso de Jules Dupuit, idealizado logo de início considerando o uso exclusivo do aço e a estrutura em esqueleto metálico como premissas de projeto para as torres de água que seriam equipadas com o novo tipo de tanque.

Ainda que a tipologia Intze tivesse sido bem sucedida do tanto do ponto de vista comercial quanto estrutural, este tipo de reservatórios não estava completamente livre de defeitos em pontos específicos. Uma das desvantagens do fundo Intze eram as diferenças de curvatura entre as partes dos seu fundo: com duas curvaturas de raios diferentes para o tipo I e três curvaturas diferentes para o tipo II, o que onerava a linha de produção. Os anéis de fixação dos cantos, nos pontos de transição entre a parede e os plano de fundo, tinham uma composição complicada sendo formados, nos casos mais simples, por pelos menos sete perfis cantoneiras que precisavam ser calandrados para se adaptar ao diâmetro do reservatório. Ainda havia um terceiro problema: alguns pontos no fundo do reservatório em que um dos dois esforços atuantes (compressão e tração) era preponderante, sendo assim necessário criar nervuras de reforço para resistir a esforços pontuais. ${ }^{9}$

O novo reservatório de fundo hemisférico suspenso apresentava as seguintes características: fundo livre de anéis de suporte e fixação; transição sem dobras entre a parede e o fundo do reservatório; fundo trabalhando exclusivamente sobre esforços de tração; fundo fácil de produzir devido ao raio único de curvaturas das chapas de aço; livre acesso a todas as partes do reservatório; estrutura de suporte conectada diretamente a parede do reservatório, que atuava como um sistema de vigas de

${ }^{9}$ WERTH, Jan. Ursachen und technische Voraussetzungen für die Entwicklung der Wasserhochbehälter. In: BECHER, Bernhard; BECHER, Hilla. Die Architektur der Förder und Wassertürme. München: Prestel-verlag, 1971, p. 363. 


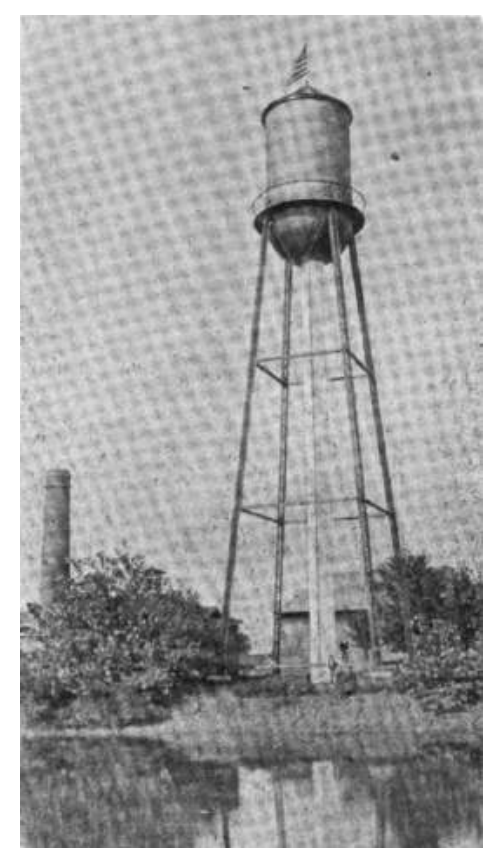

2.4.7

Horace E. Horton, Torre de Paris, Illinois, EUA, 1895. suporte de carga, ligada diretamente a suportes pontuais verticais ou ligeiramente inclinados.

A primeira torre de água construída com esta tipologia de reservatório data de 1894, uma obra edificado na cidade de Fort Dodge, lowa, nos Estados Unidos, conforme projeto do engenheiro Horace E. Horton (1843-1912), fundador da empresa CB\&l (Chicago Bridge \& Iron Company)..$^{10}$ Esta torre recebeu pouca cobertura da mídia na época, mas era muito similar a uma segunda torre (fig. 2.4.7) construída por Horace Horton para a cidade de Paris, Illinois, em 1895, e posteriormente publicada em um artigo da revista The Engineering Record no ano de 1897. O reservatório, com volume de $400 \mathrm{~m}^{3}$, tinha um diâmetro de 6,70 metros e uma altura total de 12,50 metros, medidos do ponto mais baixo do fundo hemisférico até o topo do telhado cônico de chapa metálica. Quatro colunas ligeiramente inclinadas apoiavam o reservatório e eram fixadas diretamente na parede cilíndrica do reservatório, que atuava como uma viga de suporte de carga. Com este arranjo foi possível pela primeira vez aproveitar o potencial de suporte da parede do reservatório, tornando o anel de suporte desnecessário. Isto foi fundamental para a adaptação dos reservatórios de fundo hemisférico suspenso nas estruturas em esqueleto metálico. Cada coluna tinha um comprimento de 35,40 metros e era travada em dois níveis por vigas duplas de perfis laminados tipo U, formando um sistema de 3 quadros estruturais, contraventados por barras redondas com diâmetro de $41 \mathrm{~mm}$, onde todos os elementos eram ligadas por meio de juntas articuladas, um contraste com o padrão vigente na Europa de se executar conexões rígidas para as barras de travamento. As colunas tinham uma construção composta, treliçada, formada pela união de 2 perfis laminado tipo $U$, com altura de $30 \mathrm{~cm}$, interligados por barras chatas de aço de $63 \times 11 \mathrm{~mm}$ (fig 2.4.8). ${ }^{11} \bigcirc$ guarda corpo treliçado da passarela de manutenção e a

10 DUBIE, Carol Ann. The Architecture and Engineering of Elevated Water Storage Structures: 1870-1940. 1980. 163 f. Dissertação (Mestrado) - Curso de American Civilization, School of Arts and Sciences, The George Washington University, Washington, 1980, p. 98.

11 A Steel Water Tower. The Engineering Record, New York, v. 35, n. 18, fev. 1897, p. 273-274. 


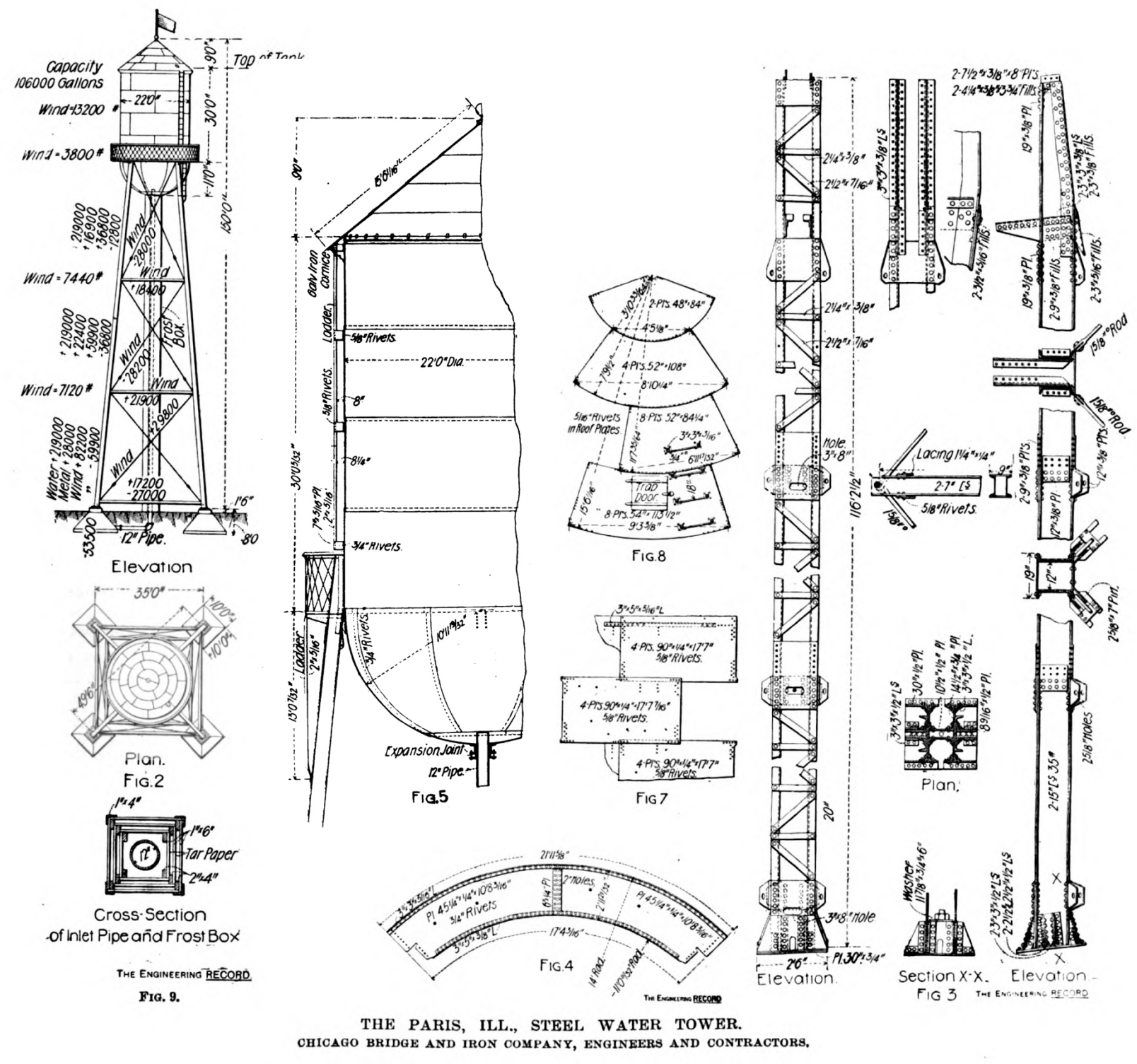

2.4.8

Horace E. Horton, Torre de Paris, Illinois, EUA, 1895. Planta, Elevação e Detalhes.
A simplicidade estrutural da torre de Horace Horton ficou imediatamente aparente e se tornou um protótipo para que a CB\&l iniciasse a produção em larga escala deste tipo de torre de água industrializada. Na primeira década do século a CB\&l já produzia torres de água padronizadas com volumes variando entre 55 e $1.100 \mathrm{~m}^{3}$, que se espalharam pelas cidades estadunidenses. Em 1912 já tinham sido instaladas torres de água similares a de Paris, Illinois, em sistemas de abastecimento público de água de 370 cidades, em 164 indústrias, em 88 ferrovias e muitas outras em usos diversos, chegando a um total de 690 torres de água construídas 


\subsubsection{0}

Brasão e Bandeira da Cidade de Porto Velho, Brasil, 1983.

\subsection{9}

As Três Marias, Porto Velho, Brasil, 1910.
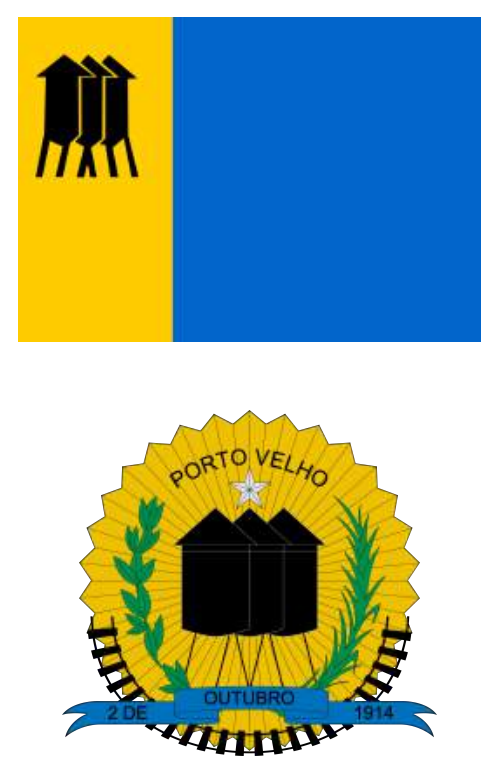

entre 1894 e 1912,12 o que demonstra a grande aceitação do design da torre de Horton nos Estados Unidos, uma solução extremamente econômica e de rápida construção, ideal para um país que se industrializava rapidamente.

Torres de água com fundo hemisférico suspenso produzidas pela CB\&l foram inclusive exportadas para outros países. Entre os anos de 1910 e 1912, no Brasil, durante a construção da Estrada de Ferro Madeira-Mamoré, três torres de água (fig. 2.4.9) foram importadas dos Estados Unidos para integrar a nova rede de abastecimento de água da cidade de Porto Velho, Rondônia. Cada torre tinha capacidade para $200 \mathrm{~m}^{3}$ e abasteceram a cidade com água potável até 1957 quando foram desativas. As três torres de água, que ficaram conhecidas como As Três Marias, se tornaram símbolo da cidade, sendo incluídas no bandeira e no brasão de Porto Velho (fig. 2.4.10), instituídos em 1983 por meio de um concurso público, cujo vencedor foi o poeta Antônio Cândido da Silva.

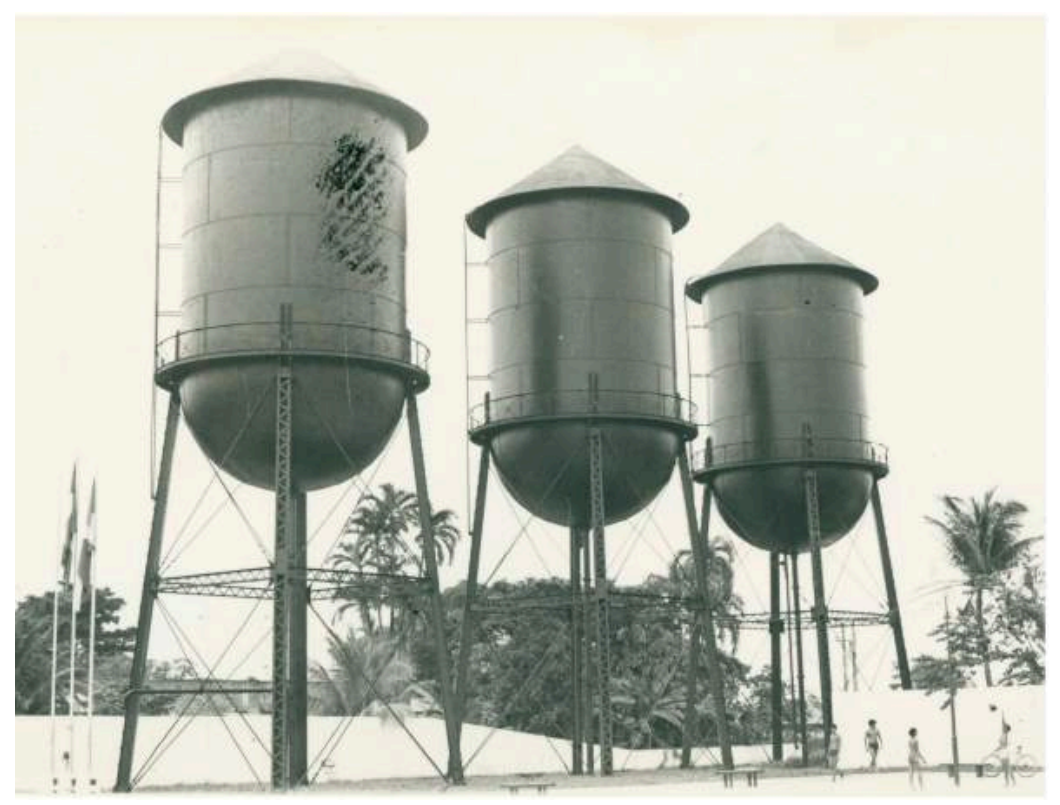

${ }^{12}$ CB\&I (Chicago Bridge \& Iron Company). Engineers and Contractors for Metal Structures. Chicago: Chicago Bridge \& Iron Company, 1912. Catálogo Técnico, p. 41 e 63. 

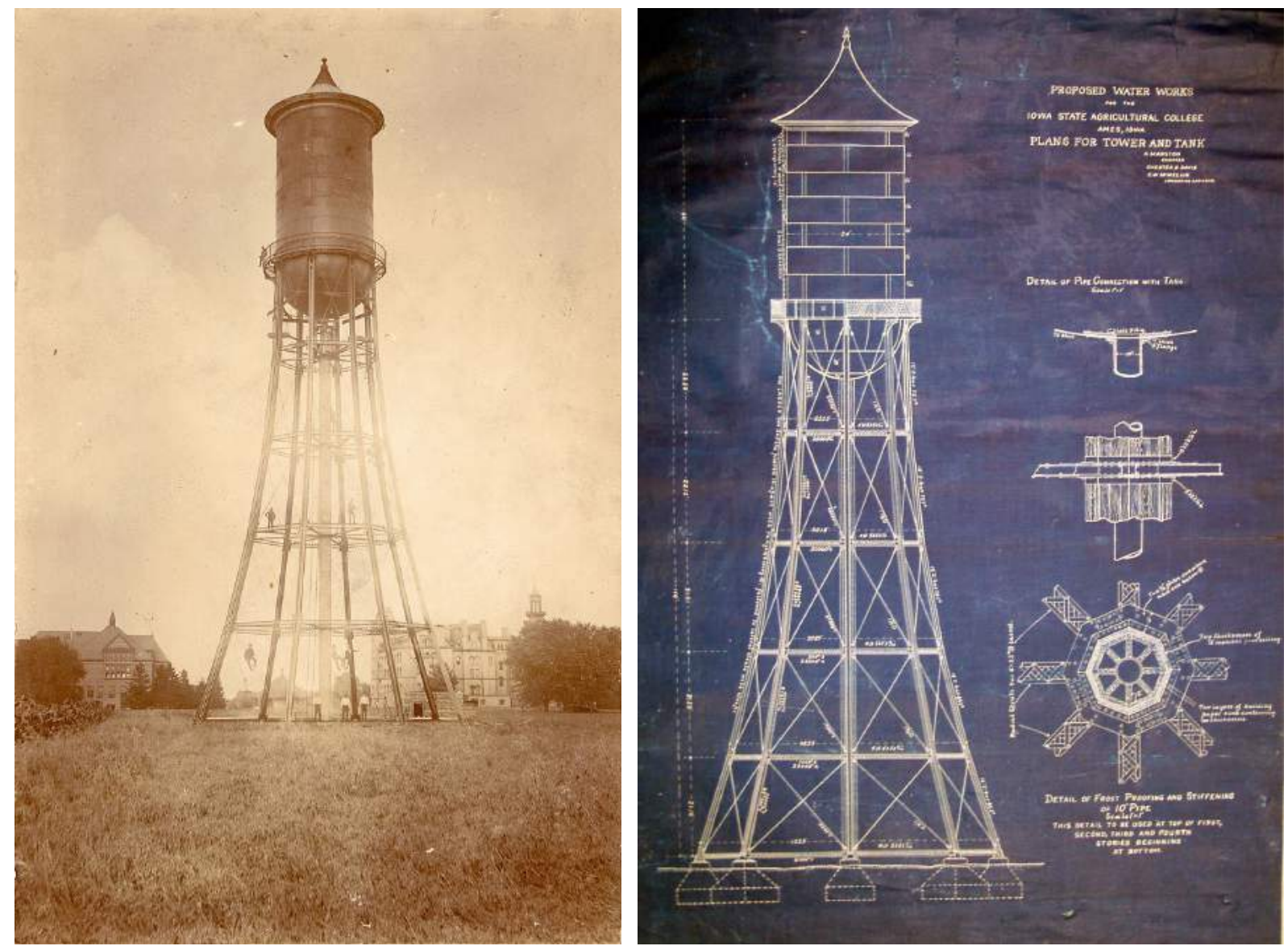

2.4.11

Anson Marston, Torre do lowa State Agricultural College, EUA, 1898.
Em 1898, o engenheiro Anson Marston (1864-1949) projetou uma torre de água (fig 2.4.11) com reservatório de fundo hemisférico suspenso para o lowa State Agricultural College, com uma ligeira variação na estrutura de suporte. Na torre de Marston cada uma das oito colunas de suporte eram compostas de 5 secções retas entre as juntas estruturais, porém montadas com inclinações variáveis que se adaptavam a um arco de círculo com raio de 97 metros, tangente à parede do reservatório criando o aspecto de colunas curvas. Os comprimentos uniformes das colunas entre as juntas estruturais garantia a possibilidade de fabricação em série das colunas viabilizando torres com alturas diferentes. ${ }^{13}$ A obra foi publicada em uma das edições da revista Engineering News de 1898 em conjunto com um texto de Marston, uma defesa de seu projeto:

"A torre fica em um local de destaque no campus da faculdade e à distância é a estrutura mais visível nas proximidades. Por causa disso, o escritor, quando concebeu o projeto, fez

${ }^{13}$ DUBIE, 1980, op. cit., p. 101. 
considerações especiais a respeito da aparência da torre. O único meio legítimo de melhorar a aparência arquitetônica de uma estrutura de engenharia desse tipo é por meio do emprego de linhas agradáveis e proporções graciosas, utilizando apenas detalhes de aparência elegante e forte. O uso do ornamento simulado é desnecessário. O mesmo vale para qualquer tentativa de disfarçar a verdadeira função da estrutura, tentando fazer com que ela pareça algo que não é." 14

Em seu texto Marston faz uma declaração direta em favor de uma nova estética para as torres de água, livre da aplicação de elementos arquitetônicos puramente decorativos e que informe claramente a sua função. Esta tendência de despir as torres de água de "concessões arquitetônicas", evidenciada também nas torres de água de Horace Horton, começava a se manifestar em novos projetos na Europa, especialmente na Alemanha.

Em 1899 o engenheiro Georg Barkhausen (1849-1923) projetou uma torre de água (fig. 2.4.12) com fundo hemisférico suspenso para a mina de carvão Minister Stein, em Dortmund, Alemanha. O reservatório de $520 \mathrm{~m}^{3}$ era constituído por um volume cilíndrico de 10,00 metros de diâmetro e 3,30 metros de altura e um fundo hemisférico curvo. As proporções do reservatório de Barkhausen, isto é, a relação entre as dimensões do volume cilíndrico e o volume hemisférico resultaram de considerações puramente estáticas com o objetivo de conseguir um fundo trabalhando exclusivamente sob esforços de tração. Segundo os cálculos de Barkhausen, a formação de esforços de compressão no fundo hemisférico são evitadas sempre que a altura da parede do cilindro for maior ou igual a $2 / 3$ do raio de curvatura do fundo

14 "The tower stands in a prominent location on the college campus, and from a distance is the most conspicuous structure in the vicinity. On this account the writer, preparing the design, kept prominently in mind the appearance of the tower. The only legitimate means of enhancing the architectural appearance of an engineering structure of this kind are to selectpleasing lines and graceful proportions, and to employ only neat, strong looking details. The use of sham ornament is out of place. The same is true of any attempt to disguise the true purpose of the structure by trying to make it look like something it is not.", MARSTON, Anson. The Elevated Water Tank of the lowa State Agricultural College. Engineering News, New York, v. 39, jan-jun. 1889, p. 371. 
hemisférico. Assim, quando o nível de água cai abaixo deste valor, o equilíbrio de tensões é afetado, e tensões de compressão ocorrem na parte superior do fundo hemisférico, mas estas tensões são baixas devido a carga global mais baixa (menor volume de água armazenado). ${ }^{15}$
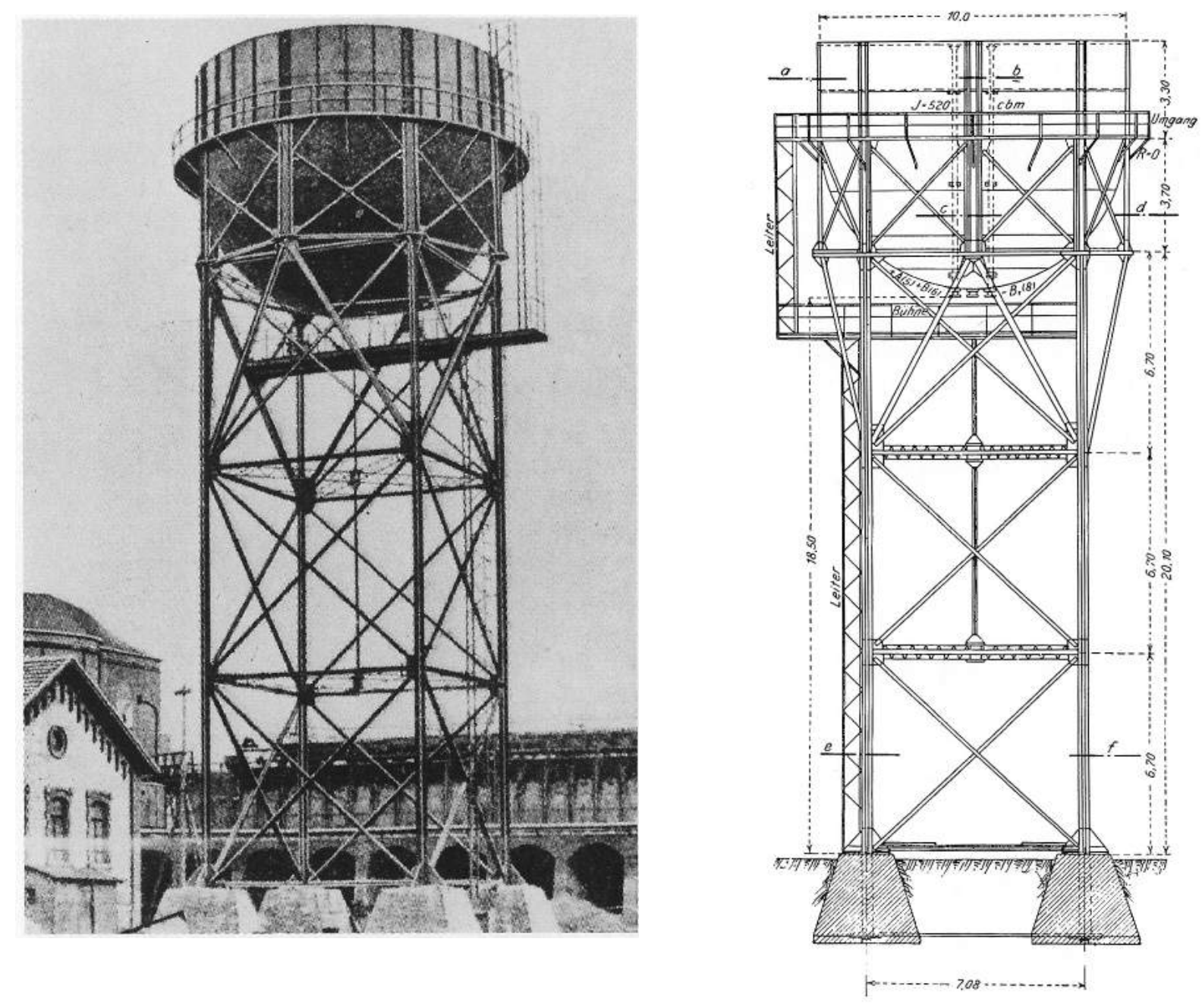

\section{4 .12}

Georg Barkhausen, Torre da Mina de Minister Stein, Dortmund, Alemanha, 1899.

\section{4 .13}

Georg Barkhausen, Torre da Mina de Minister Stein, Dortmund, Alemanha, 1899. Planta e Elevação.

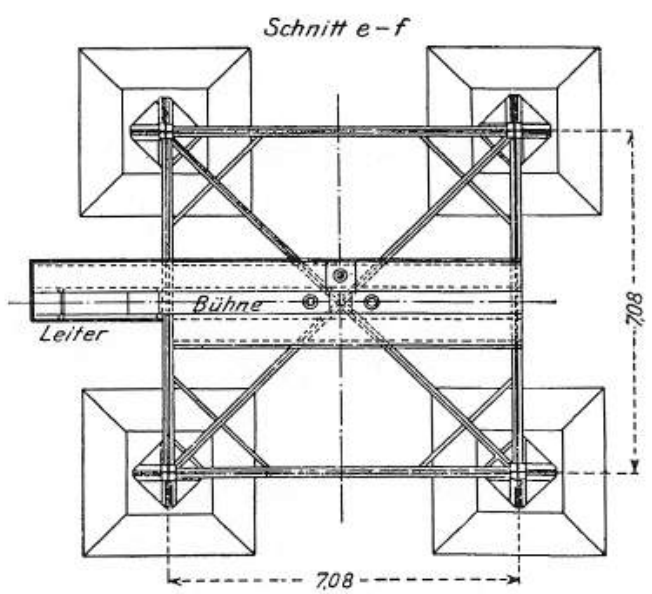

\footnotetext{
${ }^{15}$ WERTH, 1971, op. cit., p. 364-365.
} 
Assim como nas torres estadunidenses, a parede e o fundo do reservatório apresentavam uma transição contínua, livre de dobras, e o anel de suporte, até então indispensável nas tipologias de reservatórios anteriores foi substituído por suportes isolados de aço, conectadas a parede cilíndrica do reservatório. Para o esqueleto estrutural de suporte Barkhausen escolheu uma planta quadrada, com quatro colunas perfeitamente verticais, uma em cada vértice. No trecho superior, com o acréscimo de colunas de suporte adicionais em cada um dos lados da estrutura, ele ampliou a base quadrada criando uma planta octogonal. Estas colunas adicionais foram conectadas aos quatro suportes principais por meio de suportes diagonais trabalhado à compressão. esqueleto estrutural, inscrito na circunferência delimitada pela parede do reservatório, garantia estabilidade suficiente para que as colunas fossem posicionadas verticalmente. As colunas de suporte foram mantidas o mais próximo possível do reservatório para evitar excentricidades e estendiam-se além dos pontos de apoio, atuando como enrijecedores, rebitadas na parede externa do tanque. Entre o nível do solo e nível de transição para as colunas de suporte adicionais, foram criados travamentos horizontais e diagonais formando quadros com altura de 6,70 metros (fig. 2.4.13). ${ }^{16}$ Como se tratava de uma torre de água industrial para uma mina de carvão, foi dispensada até mesmo a cobertura sobre o reservatório. A torre de Barkhausen se parecia mais com uma obra de engenharia do que as torres de Paris, Illinois (1895) ou do lowa State Agricultural College (1898), obras onde o telhado cônico, o guarda-corpo treliçado, as colunas curvas e a bandeira no topo da torre brincavam com o pitoresco.

O projeto da nova torre de Minister Stein, desenvolvido quase que simultaneamente com as torres de Paris, Illinois (1895) nos Estados Unidos da América deixa a dúvida acerca do conhecimento ou não do trabalho de Horace Horton por parte de Barkhausen. $\bigcirc$ fato é que Georg Barkhausen conseguiu patentear seu reservatório e a empresa August Klönne, de Dortmund, obteve a licença para a fabricação do reservatório que, na Europa, passou a ser conhecido como tipo "Barkhausen".

16 Ibidem. 

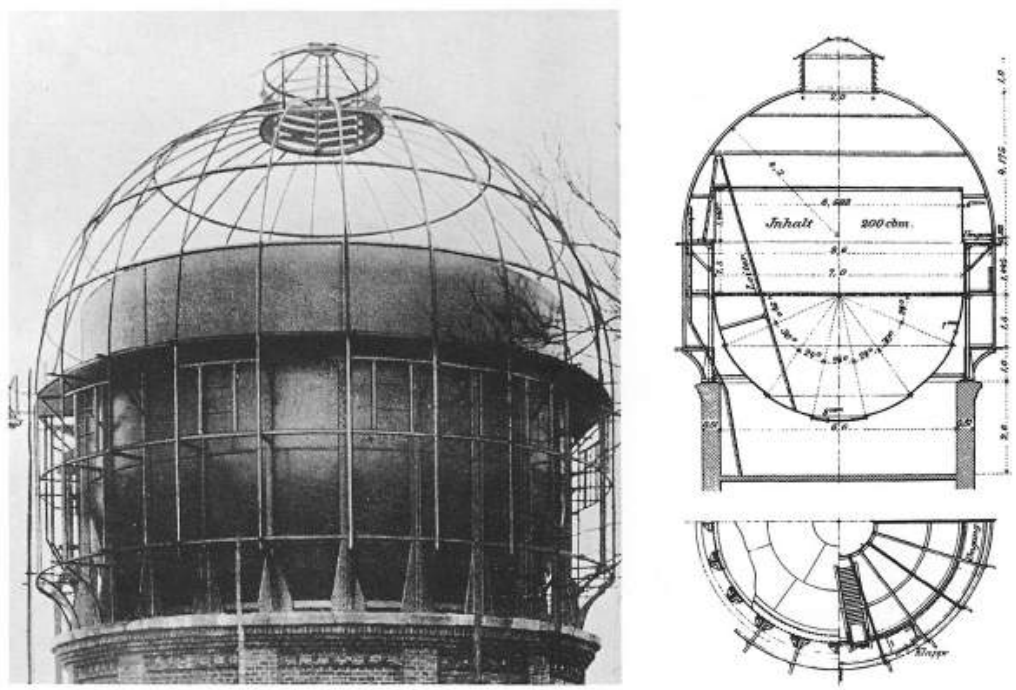

\section{4 .14}

Torre de Água da Estação Ferroviária de Bielefeld, Alemanha, 1901.

\section{4 .15}

Torre de Água da Estação Ferroviária de Hausbergen, Alemanha, 1908.

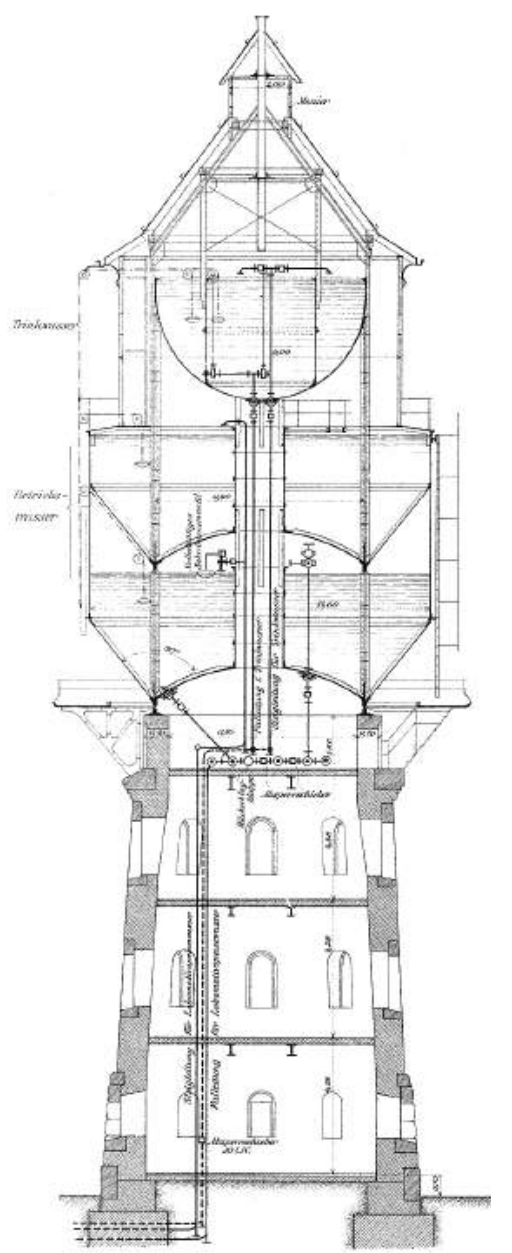

Um dos principais mercados para os reservatórios tipo Barkhausen, foram as ferrovias alemãs. A empresa Klönne produziu inúmeros reservatórios padronizados com volumes variando entre 100 e $300 \mathrm{~m}^{3}$. A instalação destes reservatórios nas torres de água ferroviárias, porém desvirtuou completamente a concepção estrutural do projeto original de Barkhausen. A Klönne utilizou os reservatórios em subestruturas de alvenaria fechada, idênticas as que vinham sendo utilizadas nas "estações de água" equipadas com reservatórios do tipo Intze, em uma solução que não tinha nada de sensato, uma vez que a carga da água armazenada, uniformemente distribuída na parede do reservatório, era concentrada em suportes isolados (assim como na torre de Minister Stein), para depois ser distribuída novamente de volta para a parede da alvenaria da subestrutura, tornando obrigatório o acréscimo de anéis de suporte sobre as alvenarias, para distribuir a elevada carga pontual a que chegava na parede. $\bigcirc$ corte da torre de água (fig. 2.4.14) da estação de Bielefeld (1901), mostra uma típica "estação de água" equipada com um reservatório do tipo Barkhausen de 200 $\mathrm{m}^{3}$. Como de costume, o reservatório metálico foi escondido por detrás de um revestimento, neste caso em concreto, no sistema Monier, com $5 \mathrm{~cm}$ de espessura, moldado sobre uma estrutura em esqueleto metálico. ${ }^{17}$

\footnotetext{
${ }^{17}$ MERKL, Gerhard et al. Historische Wassertürme: Beiträge zur Technikgeschichte von Wasserpeicherung und Wasserversorgung. München: Oldenburg Verlag, 1985, p. 102.
} 


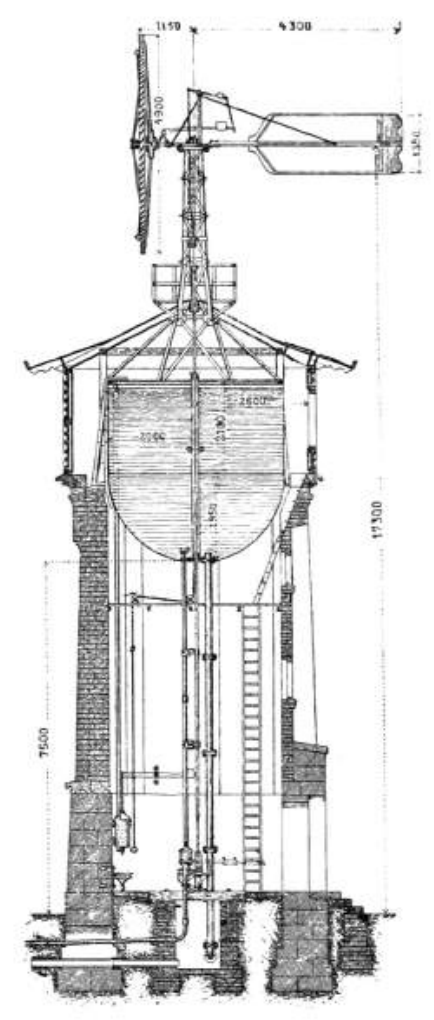

2.4 .16

Torre de água e estação de bombeamento de água impulsionada pela força do vento. Alemanha, ca. 1910.
Os reservatórios tipo Barkausen se difundiram nas ferrovias alemãs e foram utilizados em projetos de "estações de água" bastante curiosas como na Estação Ferroviária Hausbergen (1908), onde a estrutura deveria abrigar três reservatórios sobrepostos, dois da tipologia Intze, tipo I, e um reservatório tipo Barkhausen no topo (fig. 2.4.15). Na Enzyklopädie des Eisenbahnwesens (Enciclopédia do Sistema Ferroviário) de 1923, temos o registro de uma torre de água conjugada a uma estação de bombeamento de água impulsionada pela força do vento (fig. 2.4.16).

Um dos poucos exemplos de torres de água para abastecimento público construídas na Alemanha utilizando o reservatório de fundo hemisférico suspenso foi a torre da cidade de Bremen (fig. 2.4.17) que, para além da sua grande capacidade de $3.000 \mathrm{~m}^{3}$, merece menção por ser a primeira vez que uma estrutura metálica aparente foi utilizada no país em uma torre de água com esta função dentro de uma área urbana. Construída entre os anos de 1904 e 1906, a torre de água foi projetada com uma estrutura metálica semelhante a uma treliça, com oitos colunas principais, espaçadas em 8,00 metros, e mais oito colunas intermediárias, apoiadas em escoras oblíquas, de modo a reduzir e distância entre os apoios do reservatório para 4,00 metros. As colunas foram travadas com um arranjo de barras horizontais e diagonais, formando quadros de contraventamento (fig. 2.4.18). É digno de nota na torre de Bremen a grande utilização do concreto armado, presente nas fundações, no fuste cilíndrico que abriga a escada e também no enchimento do revestimento externo do reservatório. ${ }^{18}$ O início da utilização do concreto armado como material de construção de torres de água será visto mais adiante.

Em 1904 uma torre de água (fig. 2.4.19) para abastecimento público da área rural de Grevel, próximo a cidade de Dortmund, foi colocada em operação. Esta torre, com volume de $2.000 \mathrm{~m}^{3}$, tinha praticamente o mesmo sistema estrutural da torre de água da mina Minister Stein (1899), mas o seu reservatório "Barkhausen" recebeu

${ }^{18}$ WERTH, 1971, op. cit., p. 368. 


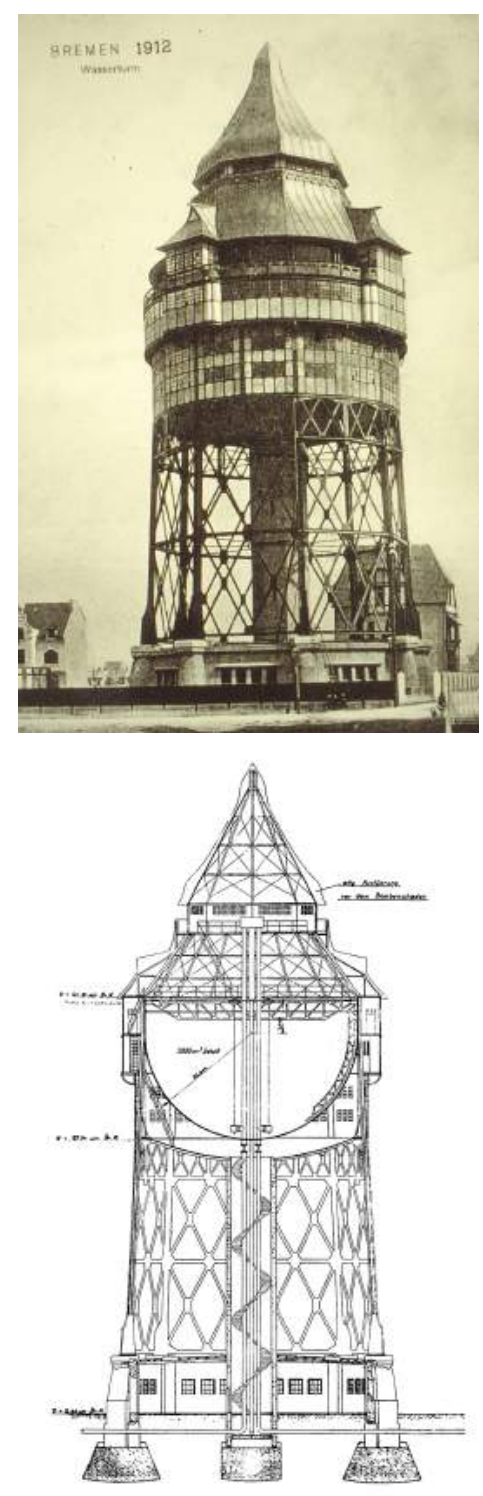

2.4.17

Torre de Água de Bremen, Alemanha, 1904-1906.

\subsubsection{8}

Torre de Água de Bremen, Alemanha, 1904-1906. Corte. uma cobertura integrada em cúpula hemisférica, seguindo a mesma forma do fundo do reservatório, adicionada com o objetivo de proteger a água potável contra a contaminação por poluentes e evitar a entrada da luz. Até então, os reservatórios de fundo plano, fundo suspenso, Intze e Barkhausen não contavam com um fechamento superior e o acréscimo de um telhado ou tampa, executados como uma construção separada, era estritamente necessária para garantir a qualidade da água armazenada. Temos aqui o primeiro exemplar de torre de água a utilizar um reservatório metálico de forma fechada, executando a cobertura em conjunto com o reservatório compondo uma forma estrutural fechada. Esta forma de reservatório fechado também possibilitou ampliar a capacidade de armazenamento, utilizando-se parte do espaço disponível sob a cobertura. $\bigcirc$ reservatório era formado por dois hemisférios com raio de 7,50 metros conectados por um cilindro com um diâmetro de 15,00 metros e altura de 5,00 metros. A estrutura de suporte, com planta quadrada, remetia à torre da mina Minister Stein mas, neste caso, o reservatório era apoiado em 12 pontos de apoio, que transmitiam o carregamento vertical para as quatro colunas principais por meio de escoras oblíquas (fig. 2.4.20). O reservatório possuía apenas uma abertura para entrada e ventilação, um tipo de lanternim, que permitia a entrada e a saída do ar ao mesmo tempo que o nível de água variava, eliminando também o ar viciado acumulado no interior do tanque. ${ }^{19}$ Ainda que seja uma torre de água para abastecimento público a sua localização (fig. 2.4.21), em uma área rural, talvez explique o emprego do esqueleto metálico e também a ausência de elementos decorativos, características que eram incomuns, na Alemanha, em torres de água com esta função neste período. 

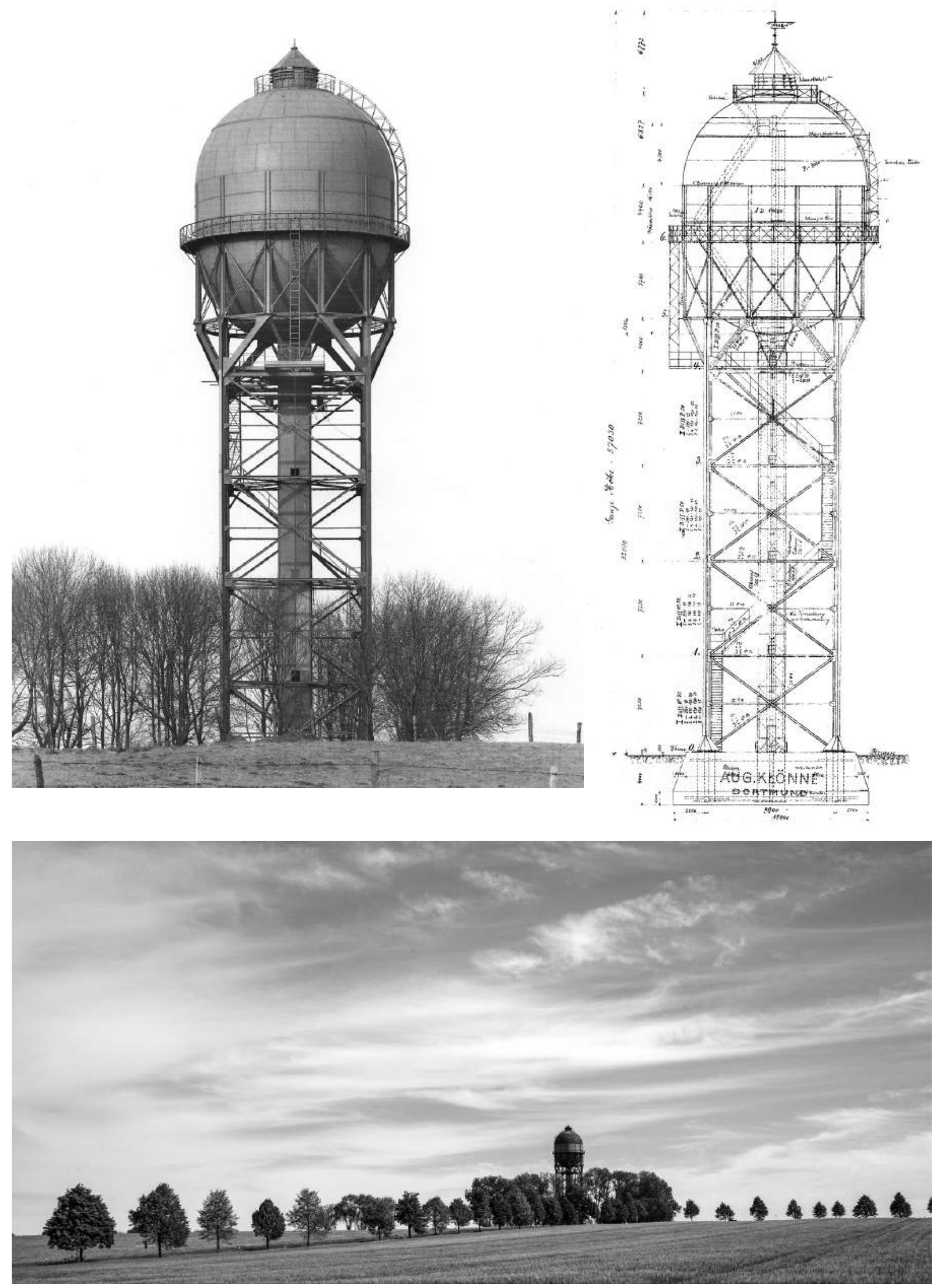

2.4 .19

Torre de Água de Grevel, Alemanha, 1904.

2.4 .20

Torre de Água de Grevel, Alemanha, 1904. Elevação

2.4.21

Torre de Água de Grevel, Alemanha, 1904. 


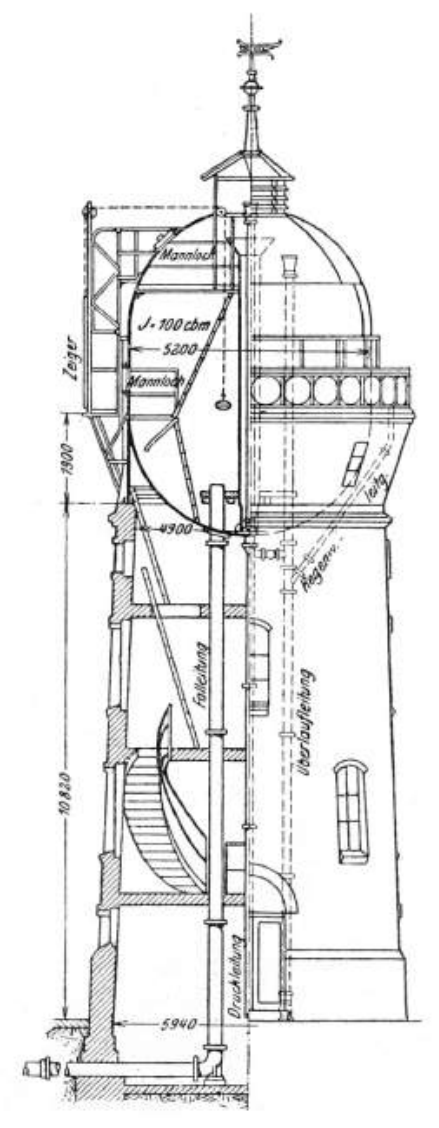

2.4 .22

Torre de Água Ferroviária equipada com Reservatório Barkhausen Fechado.
A forma fechada do reservatório Barkhausen era bastante econômica no consumo de material de construção. $\bigcirc$ consumo de material $/ \mathrm{m}^{3}$ de água armazenada nos reservatórios Barkhausen eram correspondentes ao dos reservatórios de fundo suspenso, de forma aberta, o que ilustra claramente os avanços feitos na construção de reservatório de água desde 1870 em termos de economia de material.

Torres de água equipadas com reservatórios Barkhausen fechados foram utilizadas principalmente em instalações industrias e ferroviárias alemãs. Nesta última, assim como ocorrido com o reservatório Barkhausen aberto, optava-se pela utilização de subestruturas fechadas de alvenaria, em uma instalação que contrariava a lógica estrutural de suportes isolados característica desta tipologia de reservatório. O corte de uma destas torres de água ferroviárias (fig. 2.4.22), mostra esta instalação: a carga da água armazenada, uniformemente distribuída na parede do reservatório, era concentrada em um quadro metálico de suporte, com hastes verticais fixadas lateralmente na parede do reservatório, para depois ser distribuída novamente de volta para a alvenaria da subestrutura. O quadro metálico de suporte estava oculto por detrás de uma parede em forma de tronco de cone invertido, executada em estuque ou em revestimento sistema Monier aplicados sobre um esqueleto metálico, que não tinha qualquer outra função a não ser esconder os suportes metálicos do reservatório. A posição vertical do reservatório na subestrutura tinha origem no ponto de apoio do reservatório, localizado na base da parede cilíndrica, o que resultou em uma solução formal que deixou aparente a metade superior reservatório, de modo que era possível se ter uma ideia do tipo de reservatório utilizado na torre de água, situação incomum nas "estação de água" das ferrovias alemãs até então. ${ }^{20}$

As torres de água das estações ferroviárias de MülheimRuhr (1901), Nienburg-Weser (1904), Elze-Hildesheim (1906) e Bielefeld (1906), todas na Alemanha, são exemplos característicos deste tipo de construção (figs. 2.4.23, 2.4.24).

${ }^{20}$ Idid., p. 371. 


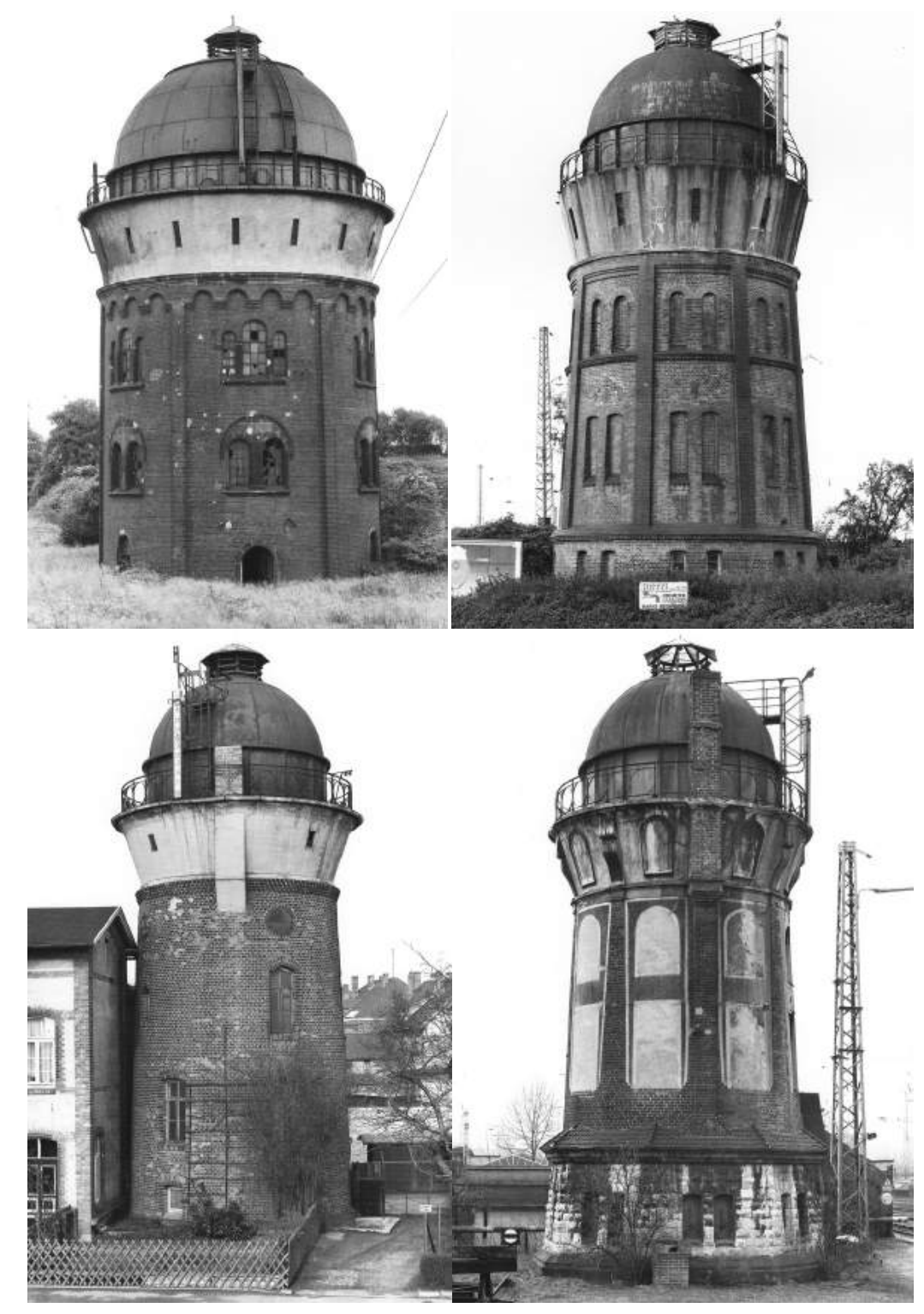

\section{4 .23}

Torres de Água Ferroviárias equipadas com Reservatório Barkhausen Fechado.

a) Mülheim-Ruhr, AL, 1901.

b) Nienburg-Weser, AL, 1904.

c) Elze-Hildesheim, AL, 1906.

d) Bielefeld, AL, 1906.
Oreservatório Barkhausen fechado se mostrou desvantajoso do ponto de vista comercial para a empresa August Klönne pois a altura de lâmina de água excessivamente elevada, desta tipologia de reservatório, levava a grandes flutuações de pressão, o que prejudicava significativamente a sua utilização na maioria das redes públicas de abastecimento de água. A Klönne tentou contornar este problema desenvolvendo uma nova tipologia de reservatório fechado, o reservatório esférico.

A torre de água (fig. 2.4.25), construída em 1906 na estação ferroviária de Chemnitz, Alemanha, foi equipada com um dos primeiros reservatórios esféricos fabricados pela Klönne, com volume de $400 \mathrm{~m}^{3}$, diâmetro de 9,30 metros e uma altura de lâmina de água de 7,75 metros, dentro de uma faixa razoável de 


\section{4 .24}

Torres de Água Ferroviárias de Nienburg-Weser, Alemanha, 1904. Plantas, Corte e Elevação. flutuação de pressão. ${ }^{21} \mathrm{O}$ formato esférico do reservatório garante uma economia significativa de material de construção, uma vez que a esfera é o sólido geométrico que possui a menor relação área de superfície / volume. Outra vantagem do formato vem do uso exclusivo de chapas de dupla curvatura, com o mesmo raio, que contribui de duas maneiras para a uma economia adicional: a curvatura idêntica de todas as chapas metálicas facilita o processo de fabricação; a curvatura dupla proporciona um enrijecimento muito mais elevado, eliminando a necessidade de enrijecimentos nas paredes do reservatório.

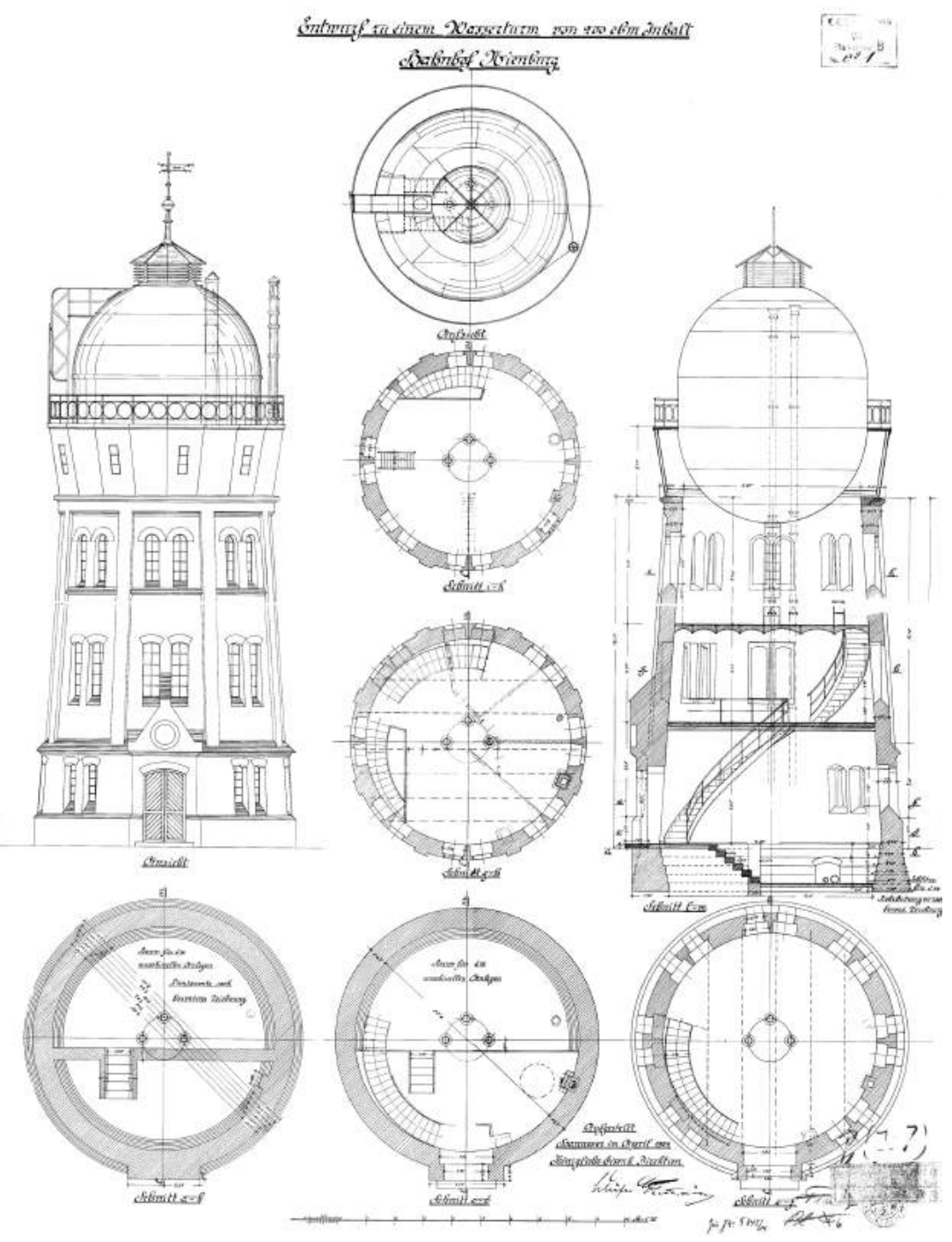

${ }^{21}$ MERKL, 1985, op. cit., p. 109-110. 


\section{4 .25}

Torre de Água da Estação de Chemnitz, Alemanha, 1906. Elevação e detalhes.
Do ponto de vista estático, o reservatório esférico, também conhecido na Europa como tipo "Klönne", enquadra-se como um tipo especial de reservatório Barkhausen. O plano de suporte, porém, não ocorre no equador da esfera, mas sim em um plano mais profundo, com o objetivo de economizar material, criando um anel de suporte com um diâmetro menor. No caso da torre de água de Chemnitz, ao invés dos suportes individuais padrão dos reservatórios Barkhausen, o anel de suporte foi concebido na forma de uma camisa troncônica rígida, conectada tangencialmente à superfície da esfera. Um esqueleto metálico formado por 12 colunas apoiava a camisa metálica, que era enrijecida com cantoneira de aço de $130 \times 130 \times 12 \mathrm{~mm}$, evitando a deformação da camisa na posição das colunas (ver detalhe na fig. 2.4.25). $\bigcirc$ esqueleto estrutural (fig. 2.4.26), com altura de 7,50 metros, tinha uma planta dodecagonal e colunas travadas com um arranjo de barras horizontais e diagonais, formando quadros de contraventamento. ${ }^{22}$ Ironicamente, a estrutura treliçada foi recoberta por paredes finas de tijolos que realçavam os suportes metálicos com a imitação de pilastras e arcos estruturais simulados no coroamento das paredes, criando a imagem de uma pesada alvenaria que na realidade não existia.

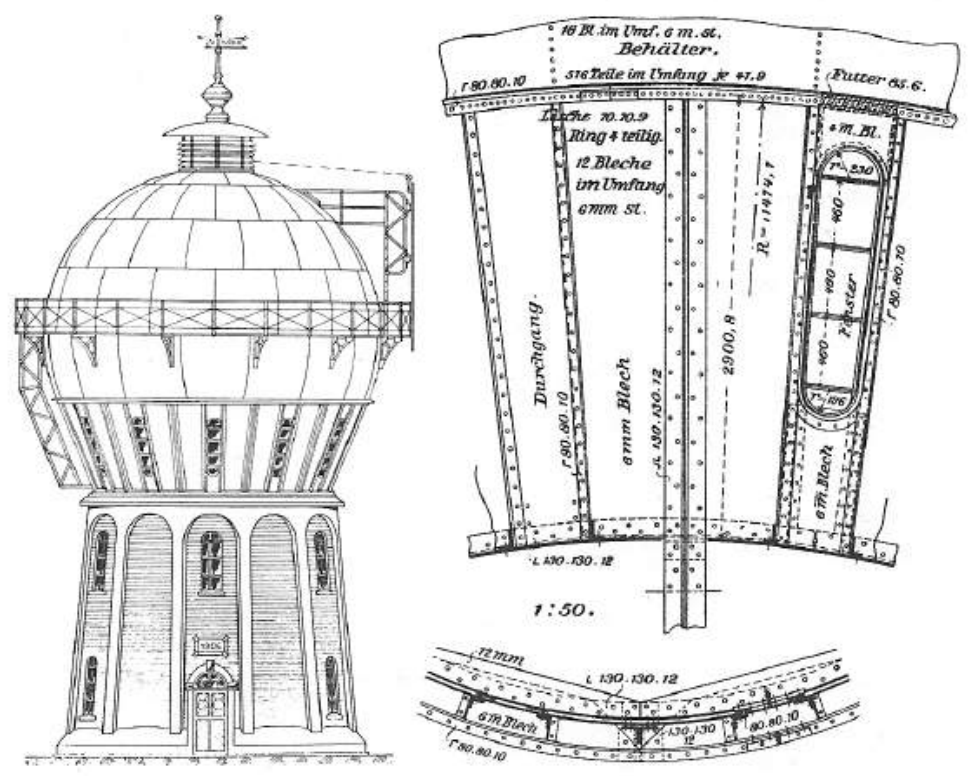

22 WERTH, 1971, op. cit., p. 373-374. 

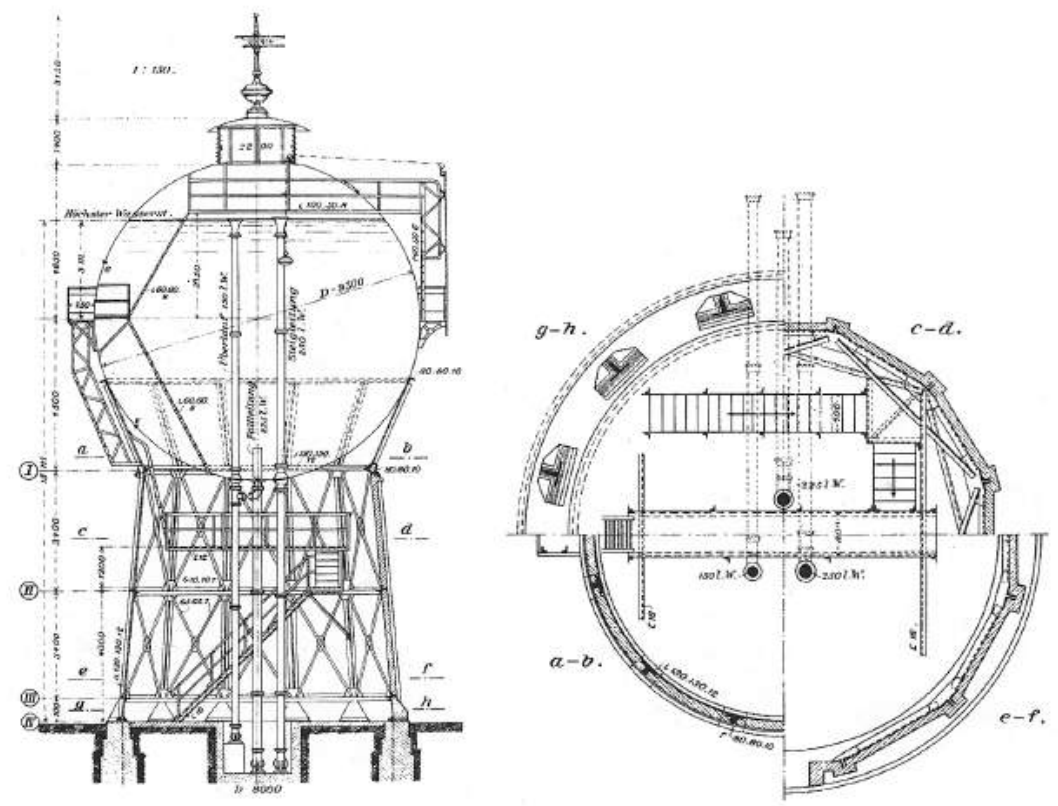

\section{4 .26}

Torre de Água da Estação de Chemnitz, Alemanha, 1906. Corte e planta.

\subsubsection{7}

Torre de Água da estação ferroviária de Lübeck, Alemanha, 1907.

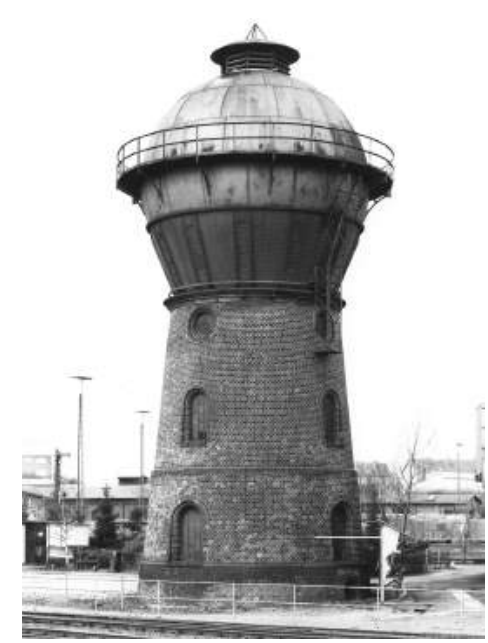

Em muitos casos este reservatórios esféricos foram instalados com a camisa troncônica de suporte apoiada diretamente em paredes autoportantes de alvenaria, uma solução mais lógica e sensata, tanto do ponto de vista estático quanto do ponto de vista econômico, do que a alternativa de se utilizar um esqueleto metálico como estrutura para depois revesti-lo com uma alvenaria cenográfica. Esta construção foi utilizada, por exemplo, na torre de água (fig. 2.4.27) da estação ferroviária de Lübeck, 1907.

Para tornar a fabricação dos reservatório tipo Klönne mais econômicos, optou-se também pela eliminação da camisa troncônica de suporte, apoiando o reservatório diretamente sobre um fuste de alvenaria autoportante ou ainda sobre esqueletos metálicos aparentes. As torres de água das estações ferroviárias de Bebra (1910) com volume de $500 \mathrm{~m}^{3}$, Crailsheim (1912) com volume de $600 \mathrm{~m}^{3}$ e Kornwestheim-Stuttgart (1914) com volume de $1.100 \mathrm{~m}^{3}$, todas na Alemanha, são exemplos característicos de reservatório tipo Klönne apoiados diretamente em fustes de alvenaria autoportante (fig. 2.4.28). A figura 2.4 .29 mostra um detalhe típico de uma torre de água com reservatório tipo Klönne apoiado em uma subestrutura de alvenaria e também do anel de suporte utilizado para apoio do reservatório. 

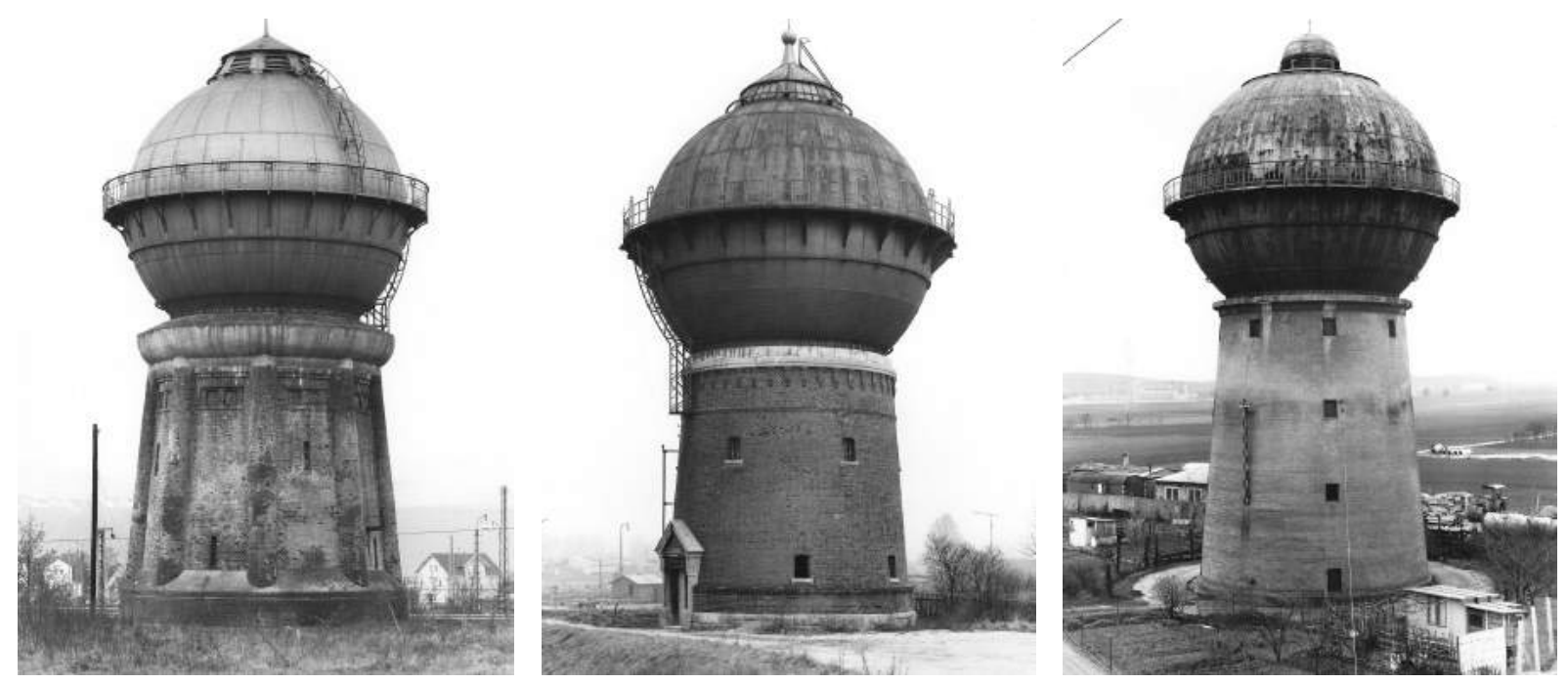

\section{4 .28}

Torres de Água Ferroviárias equipadas com reservatórios tipo Klönne.

a) Bebra, 500 m3, Alemanha, 1910.

b) Crailsheim, $600 \mathrm{m3}$, Alemanha, 1912.

c) Kornwestheim-Stuttgart, 1.100 m3, Alemanha, 1914.

\subsubsection{9}

Torre de Água Ferroviária com Reservatório Tipo Klönne. Detalhes Construtivos.

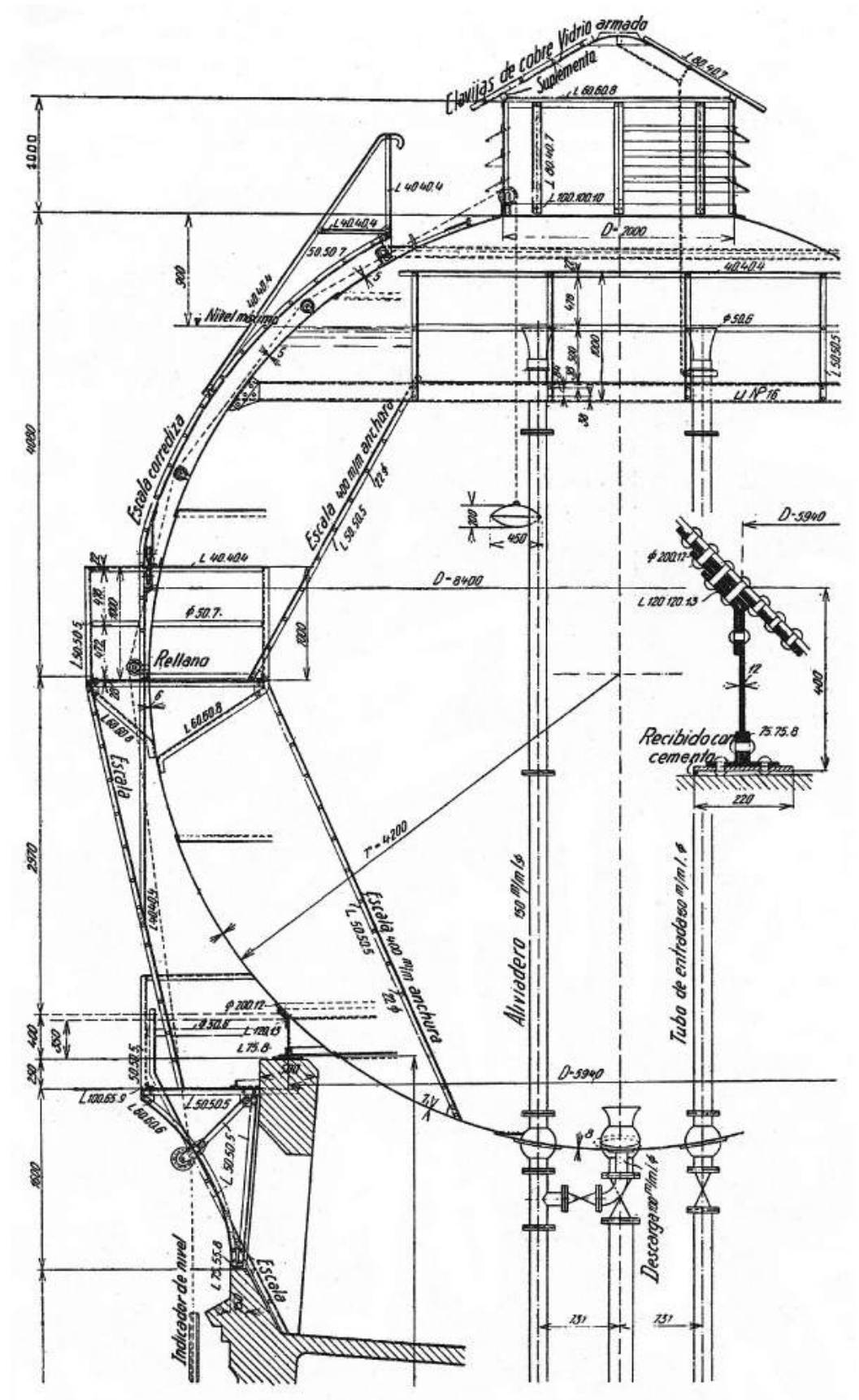




\subsubsection{0}

"Estação de Água" ferroviária em Weil-Rheim, Alemanha, 1913.

\subsubsection{1}

"Estação de Água" ferroviária em Weil-Rheim, Alemanha, 1913. Elevação.
Um "estação de água" (fig. 2.4.30, 2.4.31) equipada com um reservatório esférico, com volume de $500 \mathrm{~m}^{3}$, foi construída na estação ferroviária de Weil-Rheim, em 1913, utilizando como suporte uma estrutura em esqueleto metálico aparente, possivelmente um dos primeiros exemplares de torres de água totalmente metálicas construídas nas ferrovias alemãs. ${ }^{23}$ Nesta o obra o reservatório esférico não era suportado tangencialmente pela camisa troncônica apoiada na estrutura de suporte e o anel de suporte do reservatório teve que assumir também a função de um anel de pressão. A ausência da camisa troncônica que desempenhava a função de distribuir o carregamento vertical nos ponto de apoio teve que ser compensada com a criação de suportes adicionais entre as oito colunas principais da torre, de modo a reduzir o vão do anel de suporte. A cada duas colunas um ponto de apoio adicional foi criado com ao acréscimo de escoras diagonais que transitavam a carga do reservatório até as colunas principais.
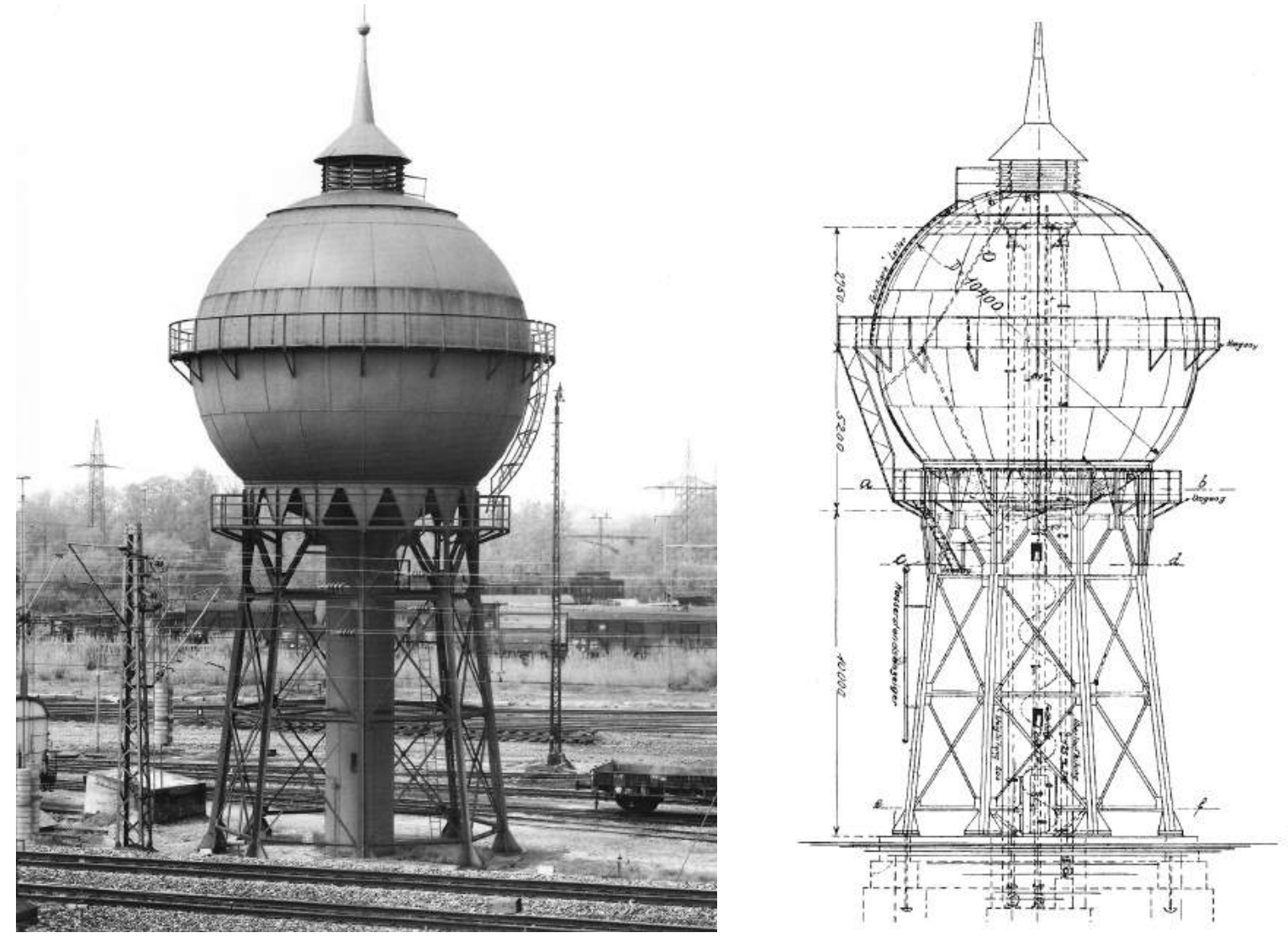

${ }^{23}$ MERKL, 1985, op. cit., p. 111. 
2.4.32

Torres de Água Industriais de Ahlen-Westaflen, Alemanha, 1914.
No centro da estrutura um tubo fabricado em chapas de aço rebitadas abrigava o conjunto de tubulações hidráulicas e uma escada em espiral que conduzia até uma plataforma sob o fundo do reservatório. No topo da torre, uma espécie de lanternim coroado por um pináculo garantia ventilação constante no interior do reservatório.

Numerosas torres de água equipadas com reservatórios

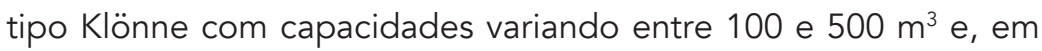
casos extremos até $1.000 \mathrm{~m}^{3}$ de volume, foram construídas para as ferrovias alemãs devido à sua fabricação mais simples e econômica, fazendo deste tipo de reservatório um grande concorrente para os tanques tipo Intze. ${ }^{24}$ Logo o setor industrial e de mineração passou também a utilizar os reservatórios Klönne em torres de água, na grande maioria das vezes montados em esqueletos metálicos de grande altura, uma vez que um dos usos principais para estas torres era o combate a incêndios, o que requeria grandes pressões hidrostáticas. As torres de água industrias (fig. 2.4.32) de AhlenWestaflen (1914) são exemplos deste tipo de construção.
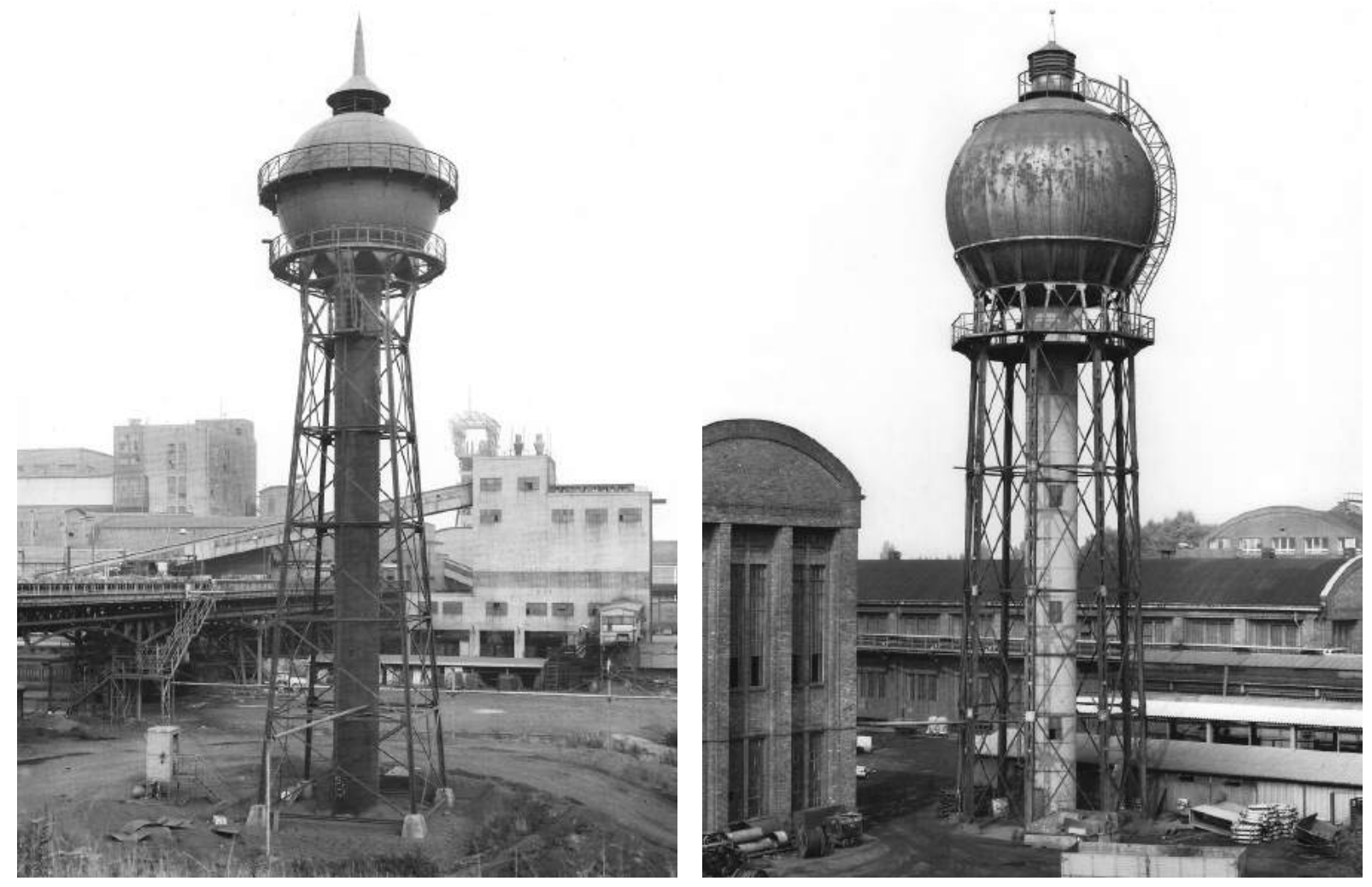

${ }^{24}$ WERTH, 1971, op. cit., p. 375. 


\subsubsection{Primeiras Torres de Água de Concreto Armado}

Até o final do século XIX o ferro e o aço foram os materiais dominantes utilizados na fabricação de reservatórios para torres de água. O ferro, que ficou conhecido como "material de construção do século XIX", viabilizou a construção de estruturas que antes pareciam impossíveis de serem realizadas e gradativamente começaram a substituir as convencionais construções maciças de alvenaria pelas estruturas leves e transparentes. As vantagens do ferro e do aço eram tamanhas que parecia ser impossível deter a sua expansão: economia, padronização, pré-fabricação, grande capacidade de carga, grande campo de aplicação e rapidez de execução.

O emprego do ferro e do aço como material de construção para torres de água tinha, segundo Werth (1971), duas grandes desvantagens que falaram mais alto do que as elevadas propriedades mecânicas do material e do que as suas numerosas vantagens tecnológicas. A primeira desvantagem era a corrosão, combatida com tintas anticorrosivas aplicadas nas superfícies metálicas, que afetava severamente a durabilidade do material, obrigando a realização de manutenções periódicas para conservação adequada das estruturas. A segunda desvantagem era a estética. Foi principalmente devido a questões estéticas que a construção de torres de água metálicas foi abandonada na Europa. Os elementos metálicos padronizados utilizados na construção das torres de água limitava severamente as possibilidades da forma das torres de água. Aos olhos do público as torres de água totalmente metálicas não tinham o mesmo encanto que as monumentais construções em alvenaria de tijolos e pedra que eram marcos na paisagem das cidades.

Um exemplo que ilustra o pouco apreço de que desfrutavam as construções de ferro pode ser ilustrado pelo caso da Torre Eiffel, construída para a Exposição Universal de 1889. A torre foi duramente criticada pela alta intelectualidade francesa em um protesto assinado e numerosos projetos para a Exposição previam 
um revestimento cenográfico para esconder a estrutura metálica da torre. ${ }^{25}$

Na virado do século, a construção em concreto armado surgiu como um substituto para a construção metálica e a arquitetura das torres de água foi profundamente afetada com a introdução do novo material. A plasticidade do novo material e o efeito de massa dos membros estruturais eram uma garantia da adaptação do material às exigências estéticas e as primeiras torres de água construídas em concreto armado desfrutaram desde o início de grande popularidade. Com o concreto armado também estava disponível um método construtivo caracterizado por baixos custos de manutenção, resistência à corrosão e garantia de segurança contra incêndios. A França, considerada o país de origem do material, lideraria o desenvolvimento da construção em concreto armado.

Foi praticamente ao mesmo tempo que o ferro e o concreto tornaram-se materiais de construção viáveis. $\bigcirc$ concreto começou a ser utilizado regularmente na Inglaterra desde a criação das primeiras fábricas de cimento, por volta de 1824, após o desenvolvimento do processo industrial de fabricação do cimento tipo Portland ${ }^{26}$ por Joseph Aspdin (1788-1855). O concreto, uma rocha produzida artificialmente, possui alta resistência à compressão e baixa resistência à tração, limitando a aplicação inicial do concreto em estruturas de fundação trabalhando exclusivamente sob esforços de compressão, que não eram solicitadas por esforço de tração ou flexão. Somente em conjunto com o aço o concreto atingiria todo o seu potencial construtivo.

25 WERTH, 1971, op. cit., p. 377 e BENEVOLO, Leonardo. História da Arquitetura Moderna. 5. ed. São Paulo: Perspectiva, 2017, p. 144-146.

${ }^{26}$ A fama que adquiriu o cimento tipo Portland se deve ao seu uso na construção do Túnel sob o Rio Tâmisa, entre os anos de 1925 e 1843, por Marc Isambard Brunel e Isambard Kingdom Brunel. A construção havia sido iniciada utilizando cimento romano mas em certa altura uma fenda se abriu no teto do túnel. Os Brunel, pai e filho, colocaram toneladas do cimento Portland de Aspdin sobre a fenda, conseguindo veda-lá mesmo debaixo de água, concluindo a obra com felicidade. O túnel com extensão de 360 metros, 23 metros abaixo do nível de água do rio na maré alta, é utilizado ainda hoje pelo metrô londrino. Ver TORAYA, Juan de las Cuevas. A Era do Cimento (1). Arquitextos, São Paulo, ano 03, n. 028.01, Vitruvius, set. 2002. 
Por volta de 1850 o engenheiro francês Joseph-Louis Lambot (1814-1887) iniciou as primeiras experiências de introdução de ferragens em uma massa de concreto. Em 1855 tornou público na Exposição Universal de Paris de 1855 um barco construído com finas paredes que consistiam em uma malha trançada de ferro recoberta por argamassa de cimento. Junto com o barco Lambot apresentou com o pedido de patente do processo, com a intenção de substituir a madeira, sujeita ao ataque da umidade, na fabricação de reservatórios e navios. Lambot nunca conseguiu convencer ninguém a utilizar a sua invenção e a própria Marinha Francesa não acreditava que o "ferro-cimento" era adequado para a construção de embarcações. ${ }^{27}$

Um dos visitantes da exposição, o jardineiro e horticultor francês Joseph Monier (1823-1906), encontrou grande utilidade para a invenção de Lambot e descobriu no "ferro-cimento" um ótimo material para a fabricação de seus vasos e jardineiras. Em 1867. Monier patenteou um sistema de reforço de ferro para concreto e passou a fabricar grande quantidade de vasos e caixas de cimento concreto armado em vários formatos e em diversos tamanhos. As primeiras realizações de Monier foram sempre desta natureza: vasos, bacias, caixas de água e tubos para encanamentos. Ampliando seu campo de atuação para recipientes maiores, Monier começou a executar reservatórios de água em concreto armado com volumes de $25 \mathrm{~m}^{3}$ e depois, em 1868, construindo um reservatório de água com capacidade de $200 \mathrm{~m}^{3}$ para a Maison-Alfort. Outras experiências foram realizadas em 1872 com a construção de um reservatório de $130 \mathrm{~m}^{3} \mathrm{em}$ Bougival com teto em cúpula de concreto armado e finalmente, em 1880 um par de reservatórios de $800 \mathrm{~m}^{3}$ em Sèvres aux Bruyères. Outras patentes foram conseguidas para a fabricação de outros elementos de concreto armado: placas planas (1869), pontes (1873) e escadas (1875). Em 1873 Monier construiu duas torres de água em concreto armado, uma em Nogent-surMarne, com um reservatório de $200 \mathrm{~m}^{3}$ suportado por colunas e

27 VASCONCELOS, Augusto Carlos de. Concreto no Brasil: Recordes Realizações - História. São Paulo: Copiare, 1985, p. 8-9. 


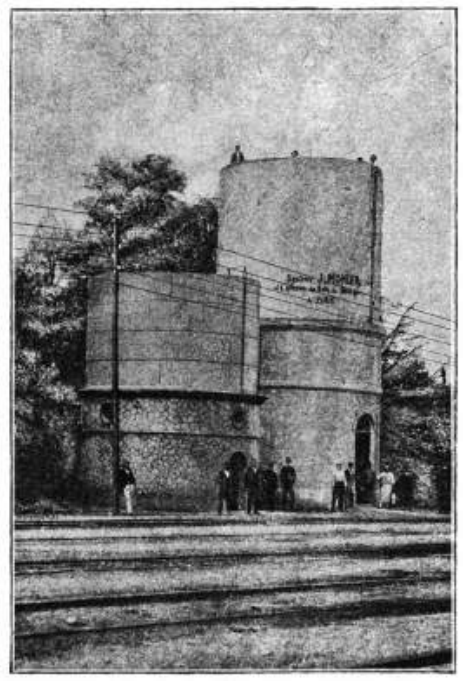

\section{4 .33}

Joseph Monier, Torre de Água em Alençon, França, 1873.

\section{4 .34}

Gustav Adolf Wayss e Mathias Koenen, Torre de Água de Lundshut, Alemanha, 1885. uma torre de água ferroviária com capacidade de $180 \mathrm{~m}^{3}$ para a Compagnie des Chemins de Fer de l'Ouest, em Alençon. ${ }^{28}$

A figura 2.4.33 mostra a torre de Monier em Alençon, construída ao lado de uma "estação de água" ferroviária com um reservatório de ferro forjado de fundo suspenso. O reservatório de concreto armado da torre era cilíndrico, com o fundo plano, e estava apoiado em subestrutura de alvenaria, seguindo o mesmo formato do reservatório. Monier não conseguiu executar um fundo plano autoportante para o reservatório e foi necessária a construção de uma cúpula de concreto para suporte do fundo do reservatório, que foi apoiado sobre a cúpula como uma construção independente. $\bigcirc$ fundo plano demonstra uma manifestação típica de uma construção não material, isto é, Monier encontrou no concreto um substituto para o ferro como material de construção, mas não considerou as propriedade mecânicas diferentes dos dois materiais, que exigiam soluções formais e técnicas diferentes para viabilizar um elemento com a mesma função. ${ }^{29}$

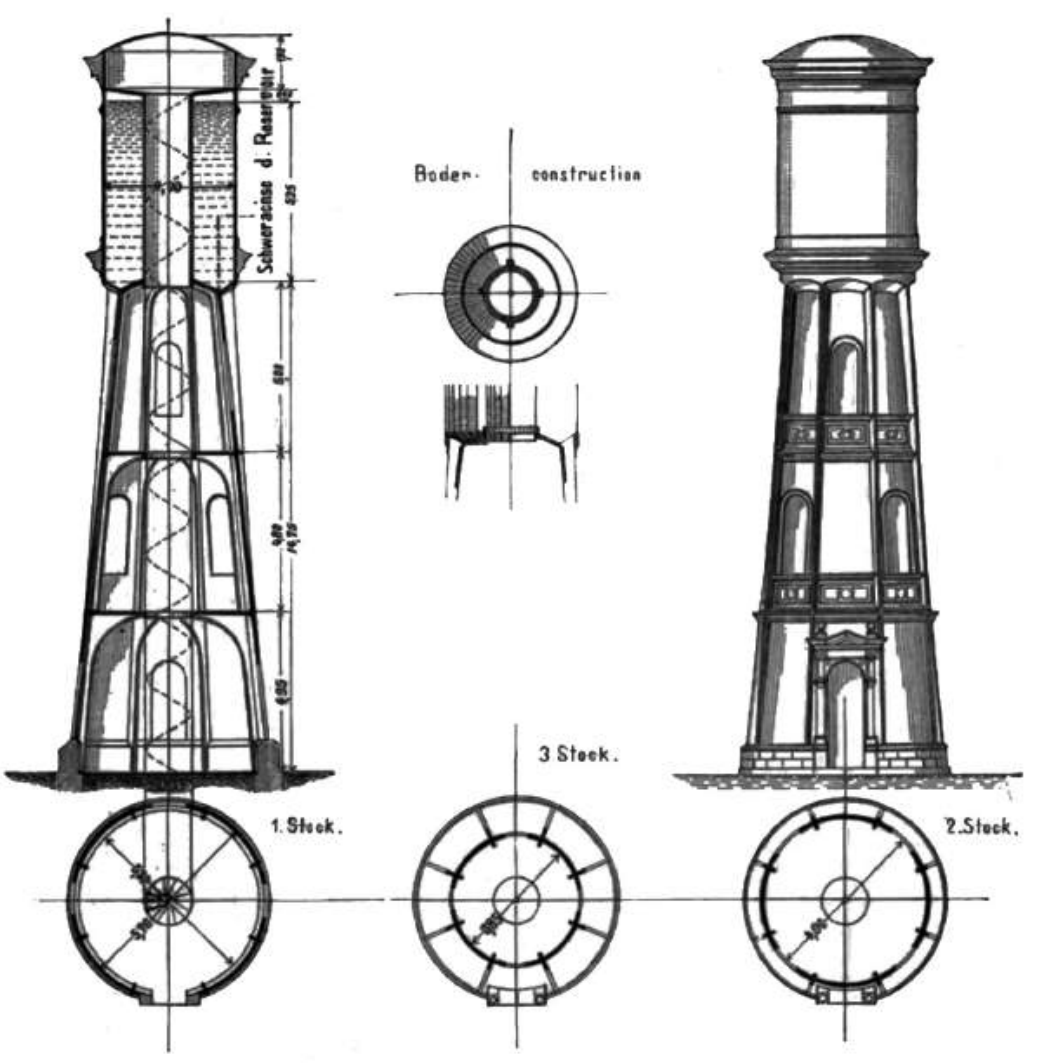

${ }^{28}$ Ibid. , p. 10; e WERTH, 1971, op. cit., p. 378.

${ }^{29}$ WERTH, 1971, op. cit., p. 379. 
O engenheiro alemão Gustav Adolf Wayss (1851-1917) obteve a licença para utilizar as patentes de Monier, fundando uma empresa de construção de concreto chamada de Monierbau und Wayss \& Freytag. Wayss começa a realizar estudos abrangentes sobre o comportamento estático das estruturas de concreto armado em conjunto com o engenheiro Mathias Koenen (1849-1924), o que resulta em um trabalho teórico que explicou pela primeira vez o exato mecanismo de atuação dos materiais no concreto armado, isto é, com o concreto resistindo aos esforços de compressão e o ferro resistindo aos esforços de tração. Em 1887 Wayss publica suas descobertas no livro Das System Monier: Eisengerippe mit Cementumhüllung (O sistema Monier: Esqueleto de Ferro com Revestimento de Cimento). A torre de água de Alençon (1873) de Monier foi publicada no livro de Wayss, mas existe um outro projeto que chama mais a atenção: uma torre de água (2.4.34) projetada integralmente em concreto armado para o integrar o sistema de abastecimento público de água da cidade de Lundshut, Alemanha, no ano de 1885. Wayss descreve a torre de água com as seguintes palavras:

"A torre de água, que é mostrada na pág. 117 em várias figuras, foi projetada e calculada para o Sr. Bauamtmann Scheidemantel para fornecer água para Lundshut, mas ainda não foi possível dissuadir a prefeitura da ideia de execução de um reservatório elevado construído em alvenaria maciça. A subestrutura divida em 3 pavimentos poderia ser utilizada para várias finalidades e, acima desta, seria localizado o reservatório com uma altura total de 6 metros e capacidade para 60.000 litros, enquanto que a altura total do edifício seria de 22 metros. O reservatório, projetado como um cilindro oco, abriga em seu interior uma escada em espiral que conduz até o topo da torre, permitindo acesso ao interior do tanque. O fundo do reservatório, construído de acordo com o sistema Intze, é apoiado em um fuste oco com formato de cone que se alarga em direção à base da torre enquanto que as suas nervuras de reforço servem ao mesmo tempo como suportes para o fundo em cúpula do reservatório e para os arcos de apoio dos 
pisos intermediários. Procura-se desta maneira atingir uma forma construtiva que também seja adequada para o tratamento estético do edifício." 30

A torre de concreto armado projetada por Wayss e Koenen mostrava um projeto estrutural bastante sofisticado para a época se comparada com a torre ferroviária de Alençon (1873) ou mesmo com as torres de água construídas após a obra de Monier, das quais trataremos mais adiante, nas quais os reservatórios de concreto eram apoiados em paredes autoportantes de alvenaria, relativamente baixas, e não em um fuste construído integralmente de concreto como na torre projetada para Lundshut. Esta pesquisa não encontrou indícios de que a torre foi de fato construída e as palavras de Wayss parecem deixar claro que a prefeitura de Lundshut tinha uma preferência pela construção de uma torre de água com uma estrutura convencional de alvenaria, assim é possível que a obra nunca tenha sido realizada. Considerando a data do projeto da torre, 1885 , podemos fazer mais algumas observações bastante pertinentes. Esta teria sido, possivelmente, a primeira torre de água de concreto armado projetada com um reservatório do tipo Intze, uma tipologia que, na construção de concreto armado, seria tão bem sucedida quanto foi na construção metálica em aço, como veremos mais adiante. E digno de nota também a escolha desta tipologia de reservatório, que havia sido inventada em 1883, ou seja apenas dois anos antes. Segundo dados da empresa F. A. Neuman, no final do ano de 1885 apenas 18 torres de água, construídas na Alemanha ou na Holanda, estavam equipadas com reservatórios metálicos tipo Intze fabricados em aço. ${ }^{31}$

30 WAYSS, Gustav Adolf. Das System Monier: Eisengerippe mit Cementumhüllung. Berlin: A. Seydel \& Cie., 1887, p. 115-116.

31 INTZE, Otto. Nachweis über die Konstruktion und die Verbreitung von 280 Wasserthürmen und Gasbehältern nach dem System und den Berechnungen von Professor O. INTZE in Aachen. Aachen: F. A. NEUMAN / C. H. Georgi, 1894, p. 122. 

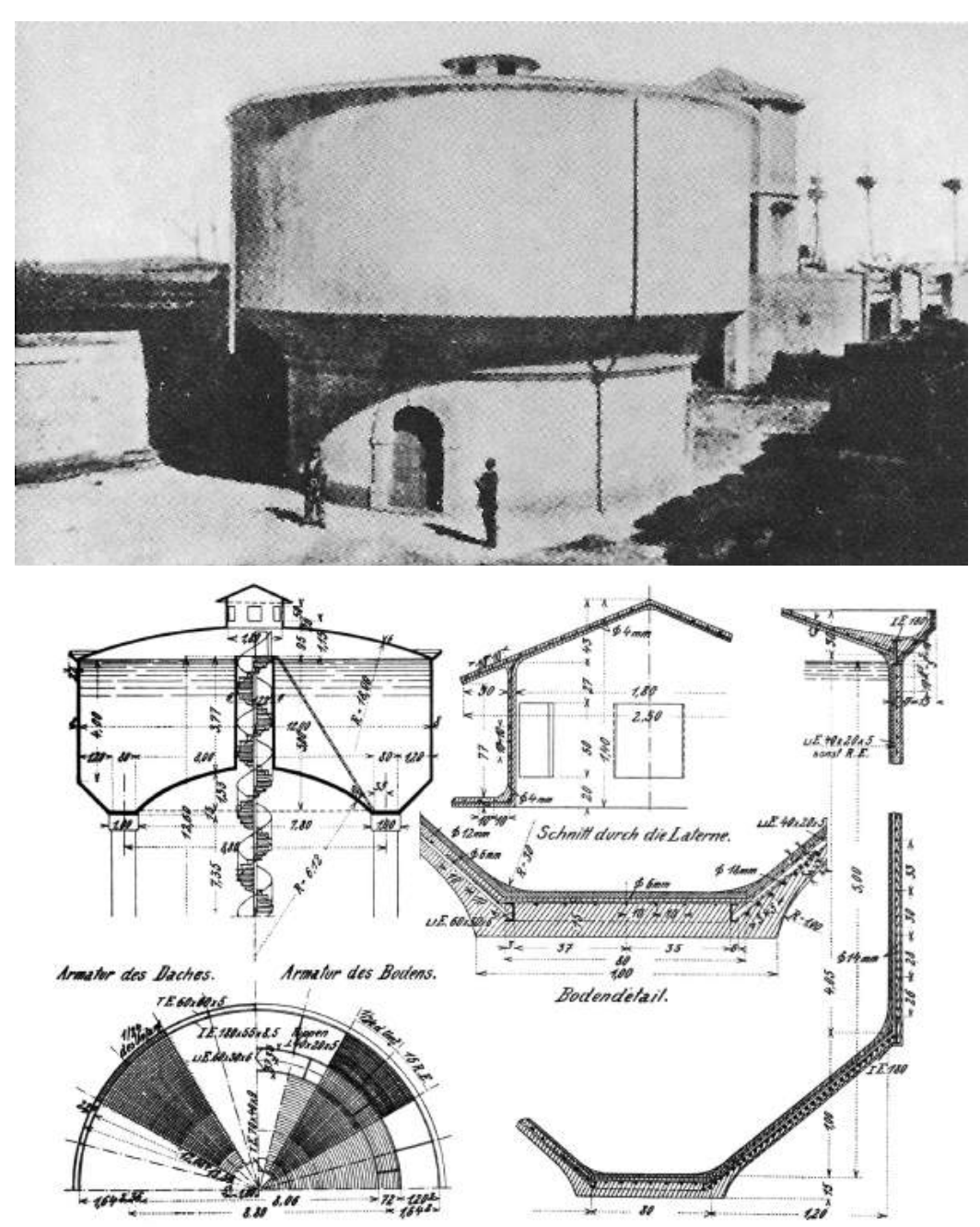

\subsubsection{5}

Edmond Coignet, Torre de Água para o Arsenal Naval de Toulon, França, 1898.

\subsubsection{6}

Edmond Coignet, Torre de Água para o Arsenal Naval de Toulon, França, 1898. Corte e detalhes.
Um outro fato que demonstra o avanço tecnológico da torre de Wayss e Koenen é o lapso temporal entre este projeto e a construção da primeira torre de água equipada com um reservatório tipo Intze de concreto armado, no ano de 1898, segundo projeto do engenheiro francês Edmond Coignet (1856-1915). A figura 2.4.35 mostra uma vista da torre de água que foi construída para o Arsenal Naval de Toulon, no sul da França. O reservatório tipo Intze, com volume de $500 \mathrm{~m}^{3}$, foi apoiado em uma subestrutura fechada, de planta circular, também construída em concreto armado. $\bigcirc$ fundo do reservatório tinha uma espessura de $10 \mathrm{~cm}$, tanto no trecho em cúpula quanto no trecho cônico exterior em balanço (fig. 2.4.36). O anel de suporte e de pressão tinha uma largura de 1,00 metro e uma espessura de $15 \mathrm{~cm}$, sendo reforçado internamente por dois perfis de aço com dimensões de $60 \times 30 \times 6$ mm nos quais a armadura do fundo do reservatório foi fixada. As paredes do reservatório tinham apenas $8 \mathrm{~cm}$ de espessura. $\mathrm{Na}$ intersecção entre o fundo cônico e 


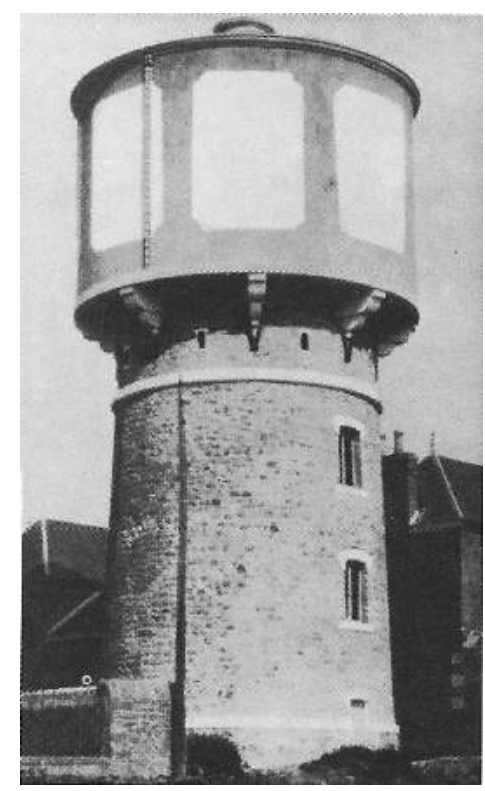

2.4.37

François Hennebique, Torre de Água de Dinard, França, 1895. a parede do reservatório foi criado um anel de tração com perfil de aço tipo I, com dimensões de 180 × 55 × 8,5mm, que tinha a função de resistir aos empuxos horizontais. Um perfil de aço semelhante foi posicionado no topo da parede do reservatório, ponto de apoio da cobertura em cúpula. ${ }^{32}$

Entre os anos de 1892 e 1897 o engenheiro francês François Hennebique (1842-1921) desenvolveu e patenteou um sistema pioneiro de construção em concreto armado integrando elementos separados de construção como o pilar, a viga e a laje em um único elemento monolítico. Este sistema monolítico de construção em concreto, que ficou conhecido como Sistema Hennebique, era baseado na conexão entre as peças individuais, o que resultava em uma maior estabilidade dos esqueletos estruturais, um avanço tecnológico importante para a construção de torres de água. ${ }^{33}$ Hennebique verificou a necessidade de dispor outras armaduras além das armaduras retas de tração, tendo sido o primeiro a propor a utilização de estribos e cavaletes com a finalidade de absorver os esforços cortantes. Foi ainda o criador das vigas com secção $T$, que considerava a laje como mesa colaborante para resistir aos esforços de compressão atuantes em vigas. ${ }^{34}$

Na primeira torre de água (fig. 2.4.37) de Hennebique, construída em Dinard em 1895, a solução de projeto foi bastante semelhante à utilizada na torre de Monier, com uma construção mista, isto é, um reservatório de concreto armado apoiado sobre uma parede autoportante de alvenaria de pedra. ${ }^{35}$ Hennebique, no entanto, conseguiu viabilizar um fundo plano autoportante para o reservatório cilíndrico com volume de $500 \mathrm{~m}^{3}$, utilizando um fuste com um diâmetro ligeiramente menor que o diâmetro do reservatório, de modo que a parede do reservatório ficasse posicionada na extremidade da laje de fundo, em balanço, uma solução estrutural que aliviava a carga total atuante no vão central

\footnotetext{
32 WERTH, 1971, op. cit., p. 384.

33 Ibid., op. cit., p. 378.

${ }^{34}$ VASCONCELOS, 1985, op. cit., p. 17.

${ }^{35}$ WERTH, 1971, op. cit., p. 379.
} 

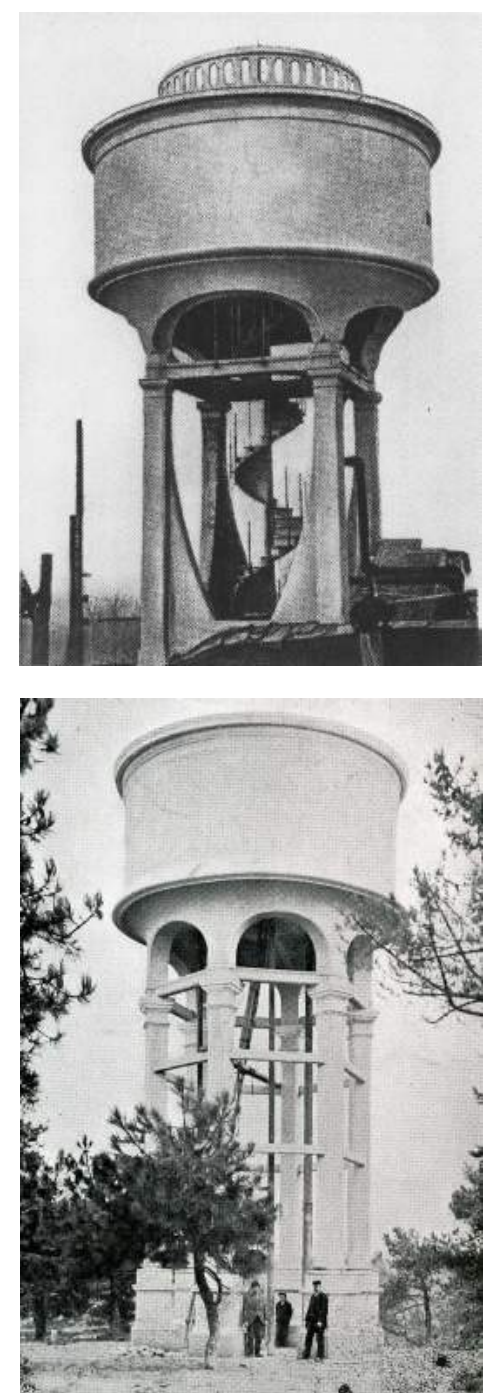

\subsubsection{8}

Eduard Züblin, Torre de Água em Scafati, Itália, 1897.

\subsubsection{9}

Louis Gustave Mouchel, Torre de Meyrick Park, Dorset, Inglaterra, 1900. do fundo do tanque. Externamente a torre de água não era diferente das antigas torres de água equipadas com reservatórios cilíndricos de ferro ou aço.

Hennebique propagou o uso de seu sistema de concreto armado com o treinamento de construtores que eram autorizados a utilizar o seu sistema construtivo por meio do pagamento de licenças comerciais. $\bigcirc$ status da nova tecnologia era tamanho que ser certificado como um "construtor Hennebique" era motivo de grande prestígio. ${ }^{36}$

O Sistema Hennebique teve sua primeira utilização na construção de uma torre de água (fig. 2.4.38) em 1897, para uma indústria em Scafati, Itália, em um projeto do engenheiro suíço Eduard Züblin (1850-1916). ${ }^{37}$ No ano de 1900, uma torre de água (fig. 2.4.39) muito similar a obra Züblin foi construída em Meyrick Park, Dorset, Inglaterra. Esta obra foi executada por um dos sócios de Hennebique na Inglaterra, Louis Gustave Mouchel (18521908). ${ }^{38} \mathrm{Na}$ torre de água, com capacidade de $60 \mathrm{~m}^{3}$, o reservatório cilíndrico tinha 6,40 metros de diâmetro, 3,00 metros de altura e uma parede com espessura de 12 centímetros. $\bigcirc$ reservatório e anel de suporte, moldados em uma única peça, estavam apoiados em seis colunas interligadas por arcos e travadas em três níveis por vigas horizontais retas.

Em 1904 Mouchel construiu a sua segunda torre de água (figs. 2.4.40, 2.4.41) utilizando o Sistema Hennebique, a torre de Newton-le-Willows, Lancashire, a maior torre de concreto da época, capaz de demonstrar todas as possibilidades construtivas de uma estrutura total de concreto armado. Com 36 metros de altura e capacidade para armazenar $1.100 \mathrm{~m}^{3}$ de água, Newton-le-Willows tinha uma estrutura formada por um fuste central e um arranjo de 28 colunas dispostas em dois círculos concêntricos e travadas por vigas

\footnotetext{
${ }^{36}$ FRAMPTON, Kenneth. História Crítica da Arquitetura Moderna. São Paulo: Martins Fontes, 1997, p. 122.

${ }^{37}$ MERKL, 1985, op. cit., p. 119.

${ }^{38}$ BARTON, Barry. Water Towers of Britain. Londres: Newcomen Society, 2003, p. 61-62.
} 


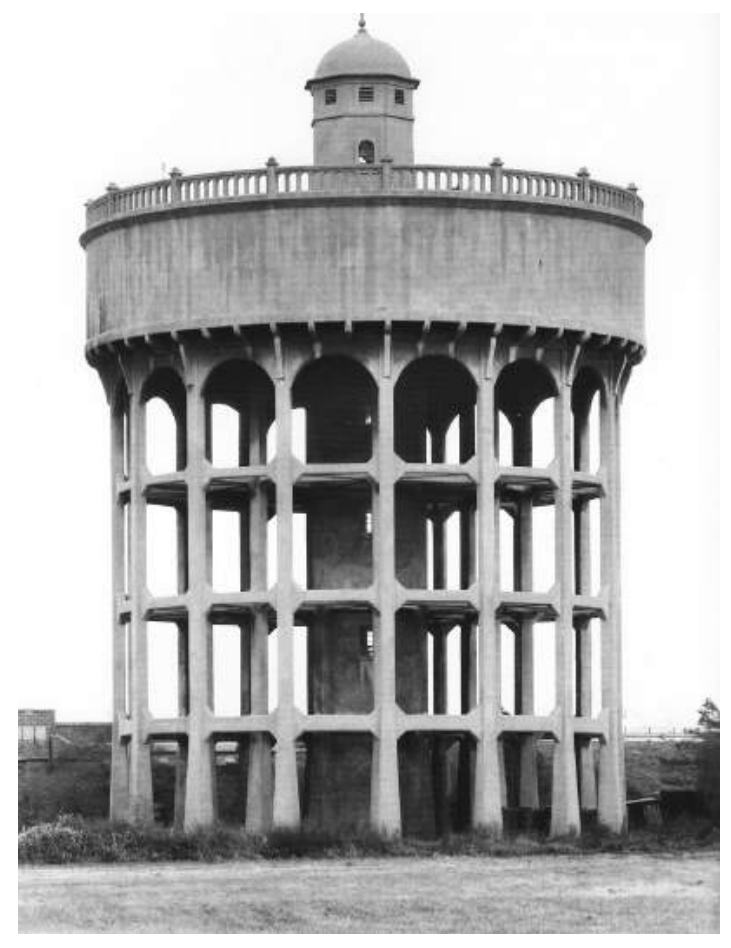

\section{4 .40}

Louis Gustave Mouchel, Torre de Newton-le-Willows, Inglaterra, 1904.

\section{4 .41}

Louis Gustave Mouchel, Torre de Newton-le-Willows, Inglaterra, 1904. Corte.

\section{4 .42}

Sistema Hennebique para Concreto Armado, 1897.
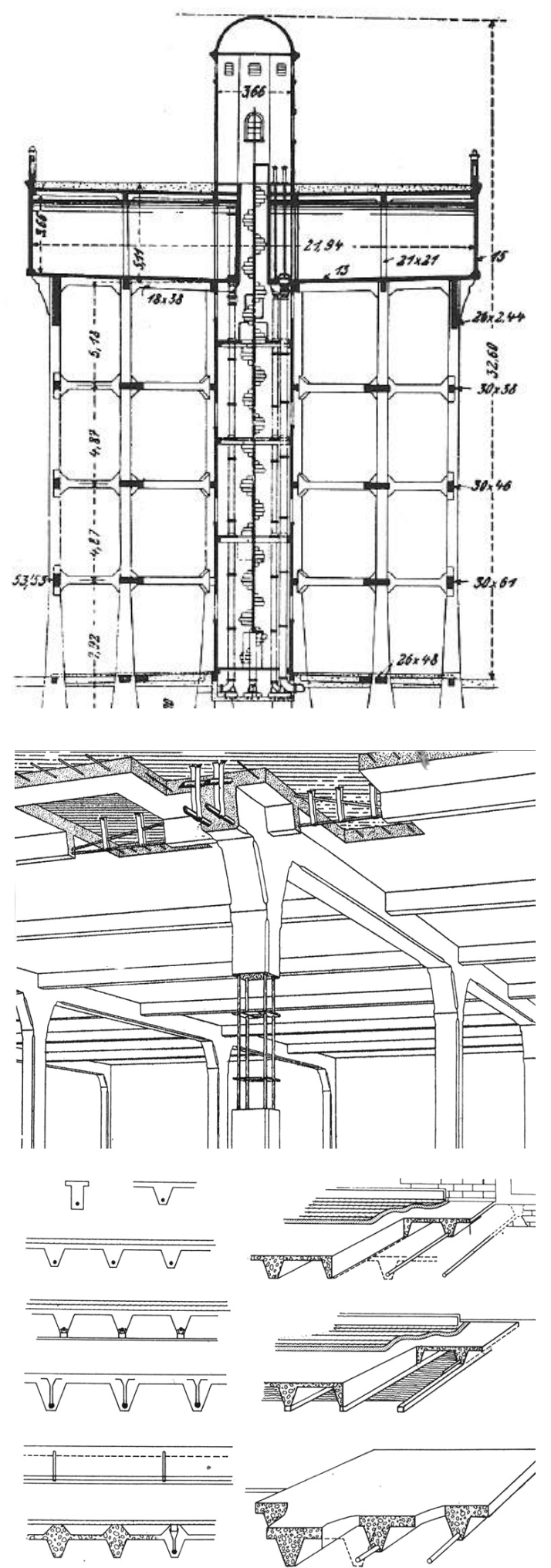

horizontais e por feixes de vigas radiais dispostas em três níveis, um arranjo muito similar aos esqueletos estruturais metálicos, mas sem a utilização de peças de travamento na diagonal. O sistema estrutural em quadros, sem diagonais, se mostrou muito mais adequado para as estruturas de concreto armado, uma vez que passam a não existir elementos trabalhando sob esforços puros 


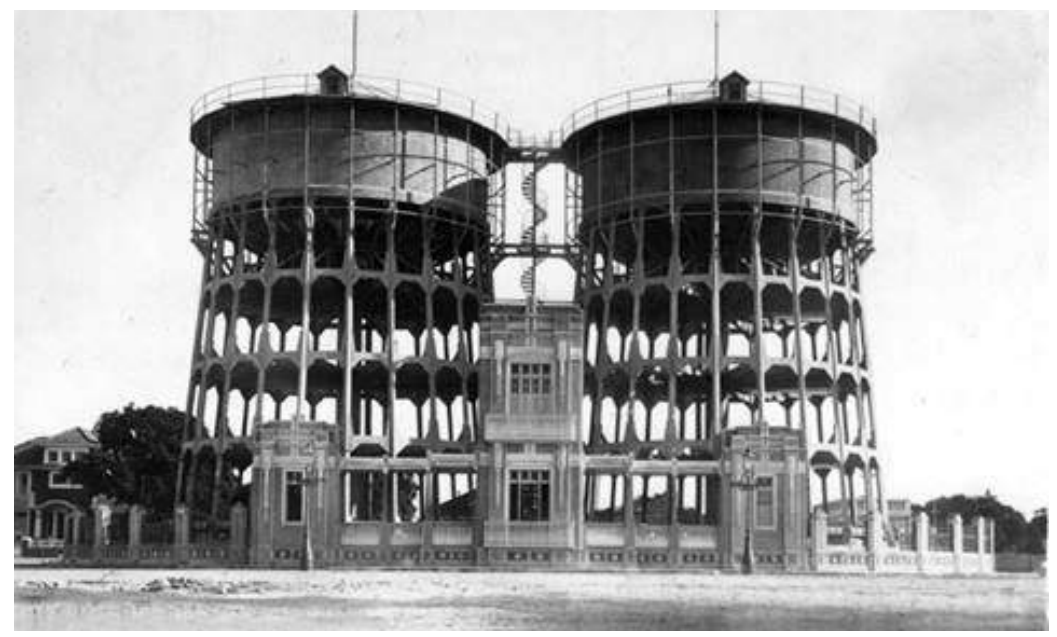

\section{4 .43}

Torres de Água Construídas com Sistema Hennebique:

a) Fortaleza, Brasil, 1911-1926.

b) Hasselt, Bélgica, 1910.

c) Goole, Inglaterra, 1927.
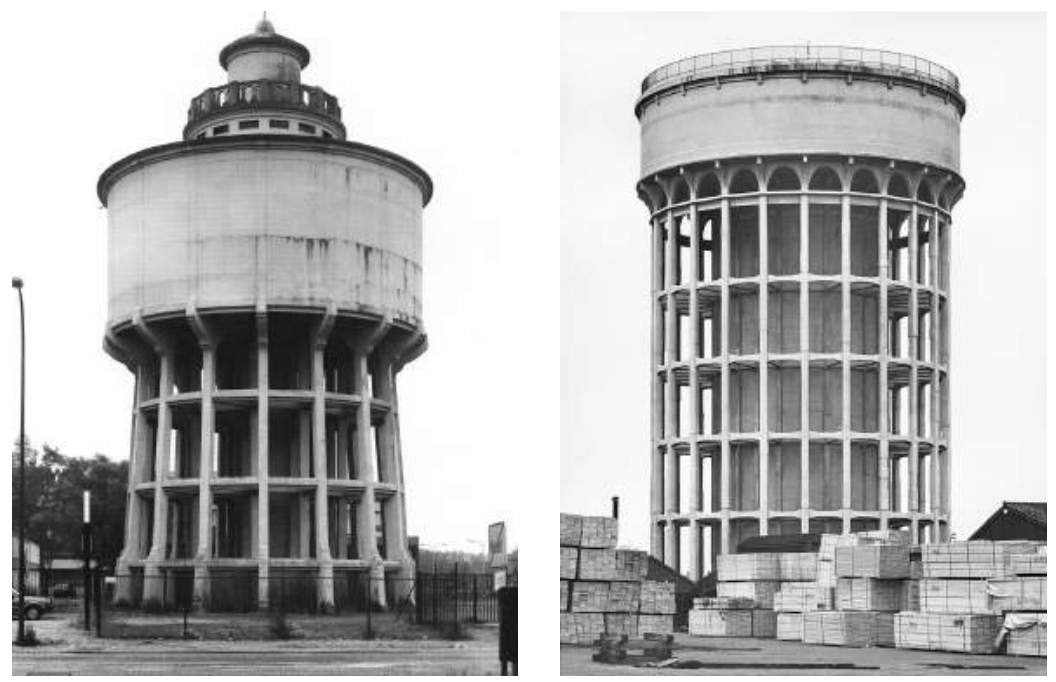

de tração, mas apenas elementos trabalhando sob esforços de compressão ou flexão, permitindo que as propriedades materiais do concreto sejam utilizadas em sua plenitude. A rigidez dos nós estruturais era garantida pela criação de ligações misuladas, uma característica presente na maioria das estruturas executadas com o Sistema Hennebique (fig. 2.4.42). ${ }^{39}$ Entre os anos de 1900 e 1912 a empresa de Mouchel construiu mais de 50 torres de água na Inglaterra utilizando o Sistema Hennebique. ${ }^{40}$ A experiência de Newton-le-Willows levou a construção de torres de água similares destinadas ao abastecimento público como, por exemplo, na cidades de Hasselt (1910) na Bélgica; Fortaleza (1911-1926), no Brasil e Goole (1927), Inglaterra (fig. 2.4.43).

Desde o início da construção das torres de água de concreto armado, uma variedade muito grande de tipos de torre surgiu,

\footnotetext{
${ }^{39}$ WERTH, 1971, op. cit., p. 380.

40 BARTON, 2003, op. cit., p. 78-81.
} 


\subsubsection{4}

"Estações de Água" das Ferrovias Italianas.

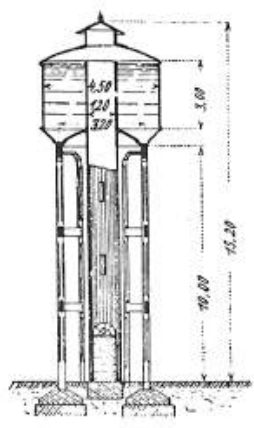

Typ zu: $50 \mathrm{~m}^{3}$

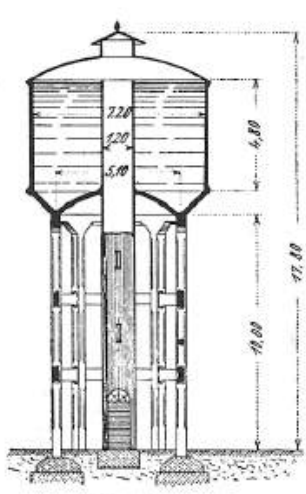

$200 \mathrm{~m}^{3}$

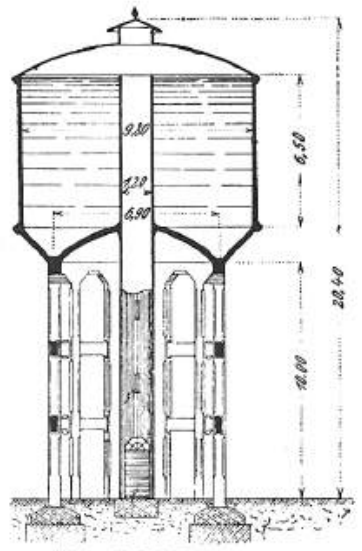

$500 \mathrm{~m}^{3}$ Inhalt especialmente no que diz respeito ao uso da estrutura de suporte aparente e de elementos decorativos ornamentais. Os reservatórios das tipologias de fundo plano ou Inzte foram os mais utilizados nas torres de água construídas durante as primeiras décadas do século 20. Ainda que o professor Intze tenha inicialmente desenvolvido sua tipologia de reservatório considerando o aço como material de construção, o tipo Inzte I de adaptou perfeitamente ao concreto armado e sua utilização nas torres construídas com o novo material foi quase que imediata, como exemplificado pelo projeto da torre de Landshut (1885) e pela torre do Arsenal Naval de Toulon (1898). As torres de concreto armado com reservatórios tipo Intze tornaram-se extremamente populares na França, Bélgica, Áustria e Itália durante as primeiras décadas do século XX. As ferrovias italianas, por exemplo, utilizavam "estações de água" equipadas com reservatórios tipo Intze nas dimensões padrão de 50, 200 e 500 $\mathrm{m}^{3}$, como mostra a figura 2.4.44. ${ }^{41}$ Podemos separar as primeiras torres de água em concreto em três grandes grupos (fig. 2.4.45), como veremos na sequência.

Em um primeiro grupo temos torres de água que apresentavam um reservatório cilíndrico ou poligonal apoiado em um esqueleto de colunas aparentes em uma distribuição circular ou poligonal, que eram interconectadas em dois ou três níveis por vigas anulares e ou radiais. As colunas eram levemente inclinadas em direção ao anel de suporte do reservatório, enfatizando-o,

${ }^{41}$ WERTH, 1971, op. cit., p. 385 


\section{4 .45}

Primeiras Torres de Água com Estrutura de Concreto Armado: a) esqueleto estrutural aparente b) esqueleto com vãos preenchidos c) esqueleto com invólucro autônomo de alvenaria
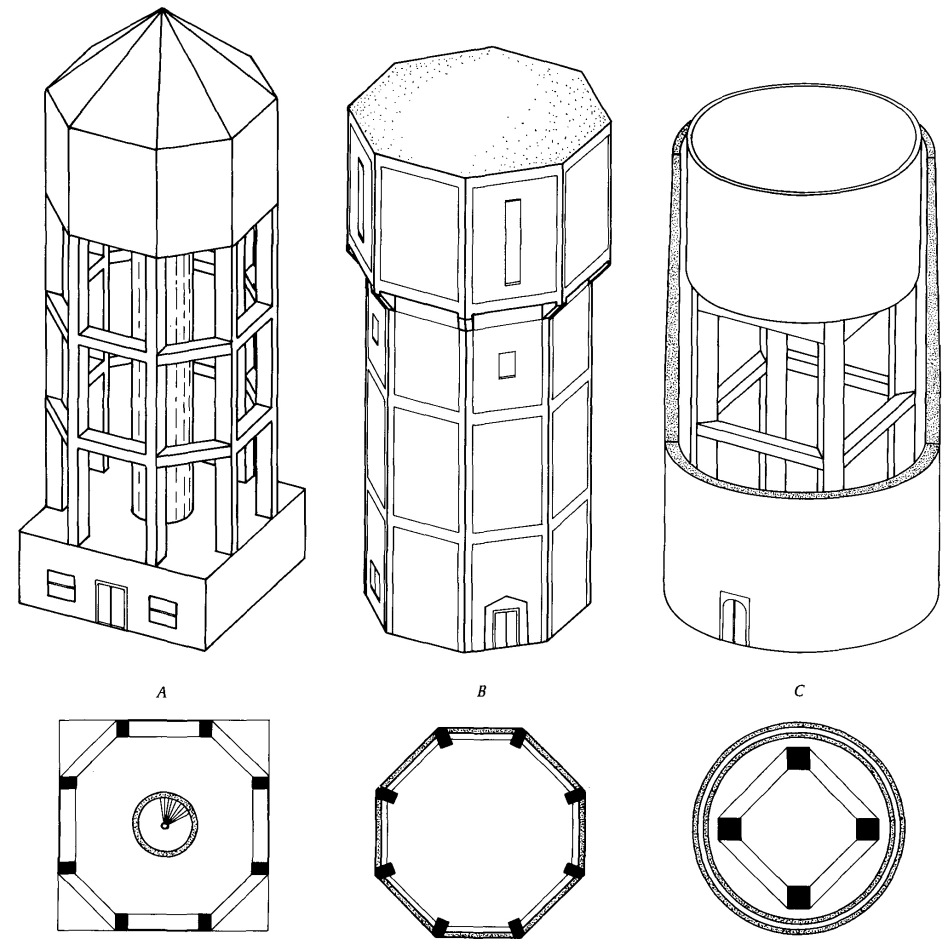

B
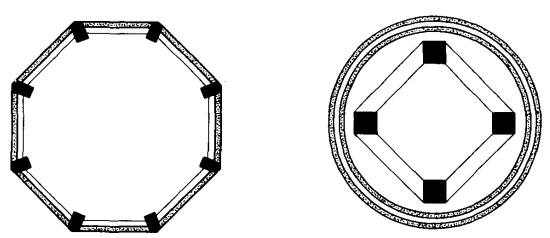

especialmente no tipo Intze, afirmando a separação funcional entre os elementos: estrutura e reservatório. Durante as primeiras décadas do século $X X$, muitas torres similares seriam construídas com ligeiras variações formais que, aos olhos do público em geral, se tornaria um símbolo para a torre de água (fig. 2.4.46). A característica do reservatório projetado em balanço, destacado, contribuiu para isso nas primeiras torres com reservatórios metálicos tipo Intze e contribuiria para a transformação formal das torres de água de concreto no decorrer do século.

Torres como estas foram construídas tanto em centros urbanos quanto em instalações ferroviárias, industrias e em áreas rurais. A diferença de uso e a localização da torre, como de costume, tinha grande influência na arquitetura destas torres. Nas instalações industriais e em áreas rurais verifica-se nas novas torres de concreto armado a mesma tendência arquitetônica presente nas torres metálicas industriais construídas no período: a limpeza das linhas do edifício e a ausência total de elementos decorativos, um design puramente funcional despojado de qualquer artificialidade ou emoção. Para citar alguns exemplos: Fosses-la-Ville (1902) na Bélgica; torre da Reisstärkefabrik (1910) em Düsseldorf, Alemanha; Herten (1919) em Scherlebeck, Alemanha; Middleton (1924) em 


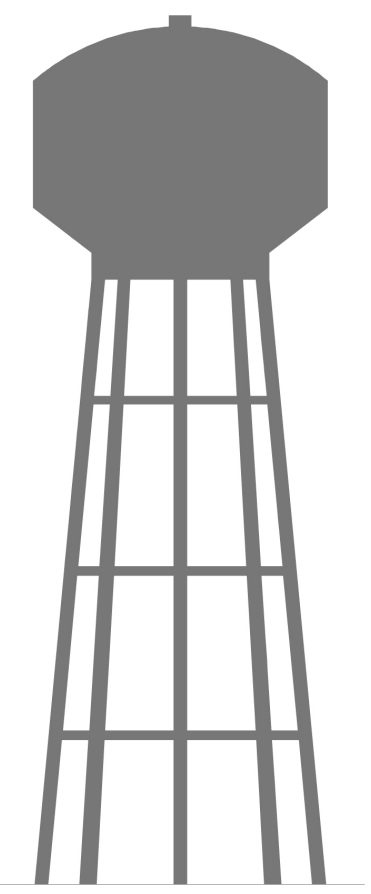

Leeds, Inglaterra (fig. 2.4.47). A diferença entre as torres de água industriais, com outras preocupações técnicas, estéticas e com orçamento reduzido, e as torres de água para abastecimento público de água era significativa. Nestas obras a função ainda é claramente expressa por meio da separação do reservatório saliente da estrutura de suporte, também concebida como um esqueleto estrutural aparente em Sistema Hennebique. No entanto é padrão a aplicação de efeitos decorativos na estrutura, com a acréscimo de sóculos, bases, consoles e frisos ornamentais aos pilares, vigas e na parede do reservatório, próprios do ecletismo arquitetônico do período. O reservatório é, na maioria dos casos, coroado por um cobertura em cúpula e por uma espécie de lanterna. Aqui também o tratamento dado ao concreto é diferente, sempre revestido e pintado. Podemos mencionar aqui as torres de Zeebrugge (1907) e Saint-Gilles (1913), na Bélgica; Emdem (1911), na Alemanha; Rimswell (1916) e Gawthorpe (1928), na Inglaterra (fig. 2.4.48).
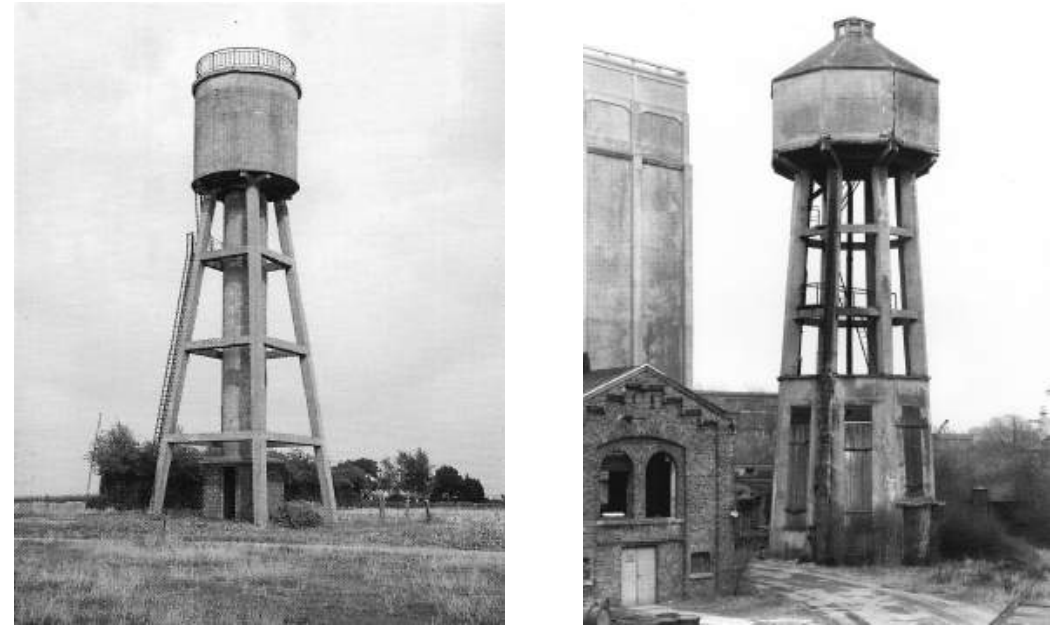

\subsubsection{6}

Torre de Água Intze (silhueta).

\subsubsection{7}

a) Fosses-la-Ville, Bélgica, 1902.

b) Reisstärkefabrik em Düsseldorf, Alemanha, 1910.

c) Herten, Scherlebeck, Alemanha, 1919.

d) Middleton, Leeds, Inglaterra, 1924.

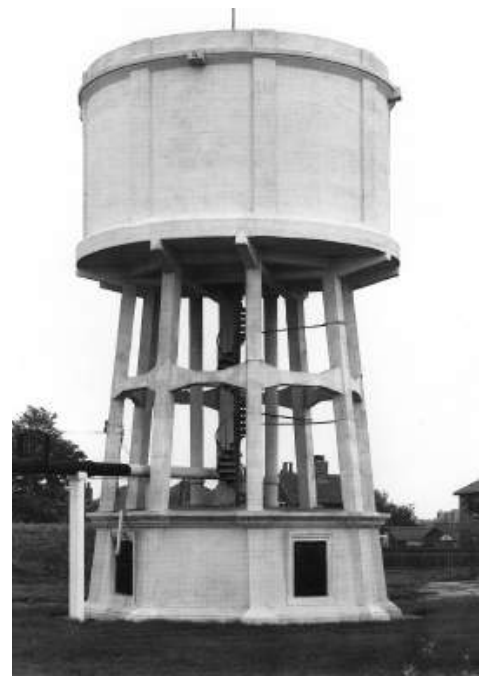



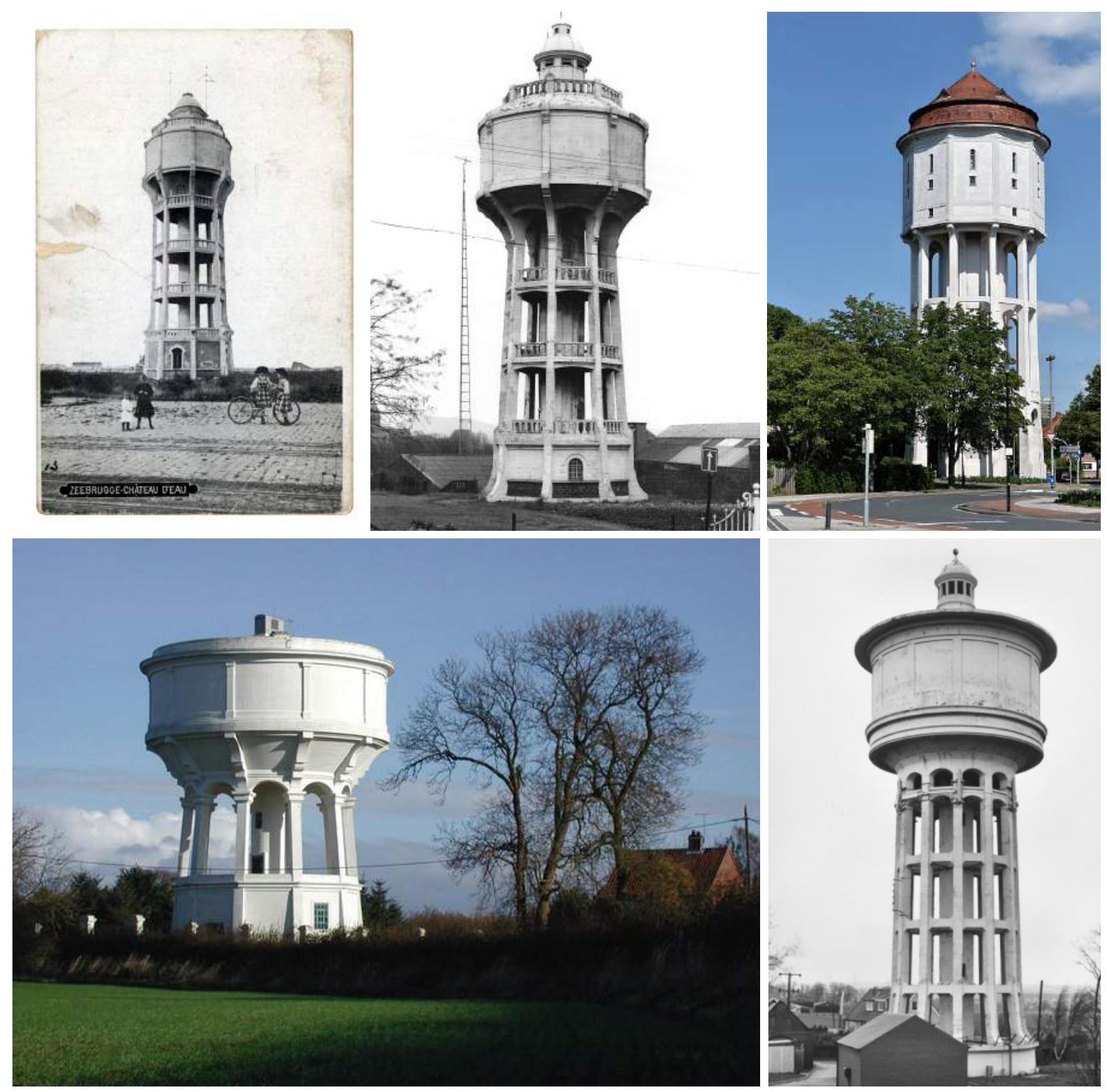

\subsubsection{8}

a) Zeebrugge, Bélgica, 1907.

b) Saint-Gilles, Bélgica, 1913.

c) Emdem, Alemanha, 1911.

d) Rimswell, Inglaterra, 1916.

e) Gawthorpe, Inglaterra, 1928.
No Brasil, são dignas de nota as torres de água da Vila Mariana, da Avenida e do Araçá, 011 construídas em São Paulo entre os anos de 1928 e 1930 (as duas primeiras já demolidas) pela Repartição de Águas e Esgotos. ${ }^{42}$ Trata-se aqui de um projeto de torre-padrão equipada com reservatório tipo Intze de $300 \mathrm{~m}^{3}$, com autoria provável do engenheiro arquiteto Hyppolito Gustavo Pujol Jr. (1880-1952), um dos pioneiros no cálculo de concreto armado no Brasil.

42 NETTO, José Martiniano de Azevedo. Arquitetura das Torres d'Água. Revista D.A.E.: Revista do Departamento de Águas e Esgotos, São Paulo, v. 21, n. 38, p. 7-24, set. 1960 , p. 9. 


\subsubsection{9}

a) Waterloo, Bélgica, 1904

b) Denderleeuw, Bélgica, 1930.

c) Oostende, Bélgica, 1932.

d) Heerlen, Holanda, 1917

e) Nijvel, Holanda, 1917.

f) Roosendaal, Holanda, 1917.
Em um segundo grupo temos o caso de torres de água onde, por razões técnicas e principalmente estéticas, o espaço entre as colunas e vigas era preenchido com alvenaria pintada ou aparente, como nas torres de Waterloo (1904), Denderleeuw (1930) e Oostende (1932), na Bélgica; Heerlen (1915), Nijvel (1917) e Roosendaal (1917) na Holanda (fig. 2.4.49). Em alguns casos, o revestimento completo da estrutura e ausência da ornamentação leva à leitura de uma estrutura que aparenta a forma colunar pura. Independente da capacidade do reservatório, da forma mais ou menos esbelta da subestrutura, do tratamento dado a sua estrutura (aparente ou revestida), este tipo básico, no que se refere ao seu caráter arquitetônico, sofreu poucas intervenções durante o século XX. Com variações do modelo original, esta típica torre de água "tipo Intze", foi espalhada por vários países, principalmente nas instalações industriais, ferroviárias e em áreas rurais a partir da década de 1920 (figs. 2.4.50, 2.4.51). ${ }^{43}$
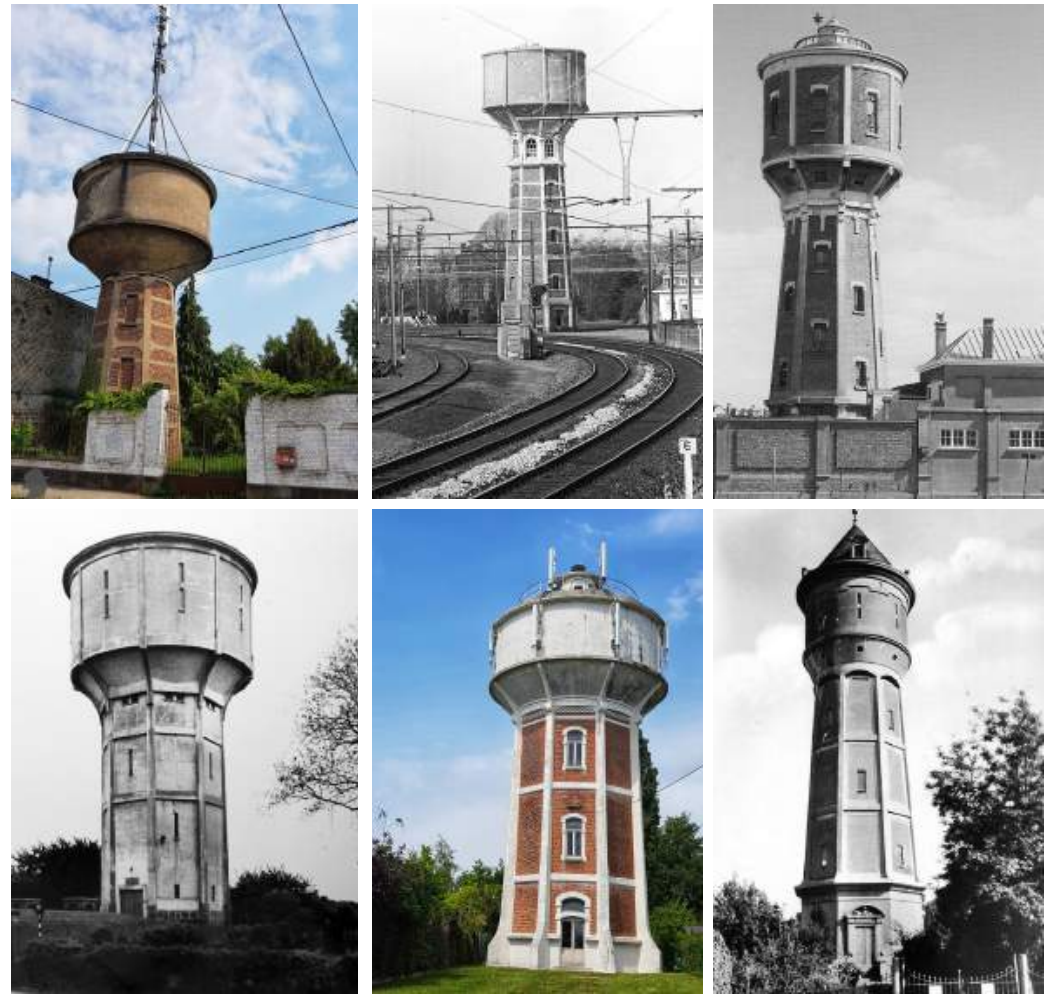

43 GENICOT, L. F.. De watertoren: architectuur, landschap. In: VAN CRAENENBROECK, W.. Eenheid in Verscheidenheid: Watertorens in Belgie. Brussel: Navewa, 1991, p. 146. 

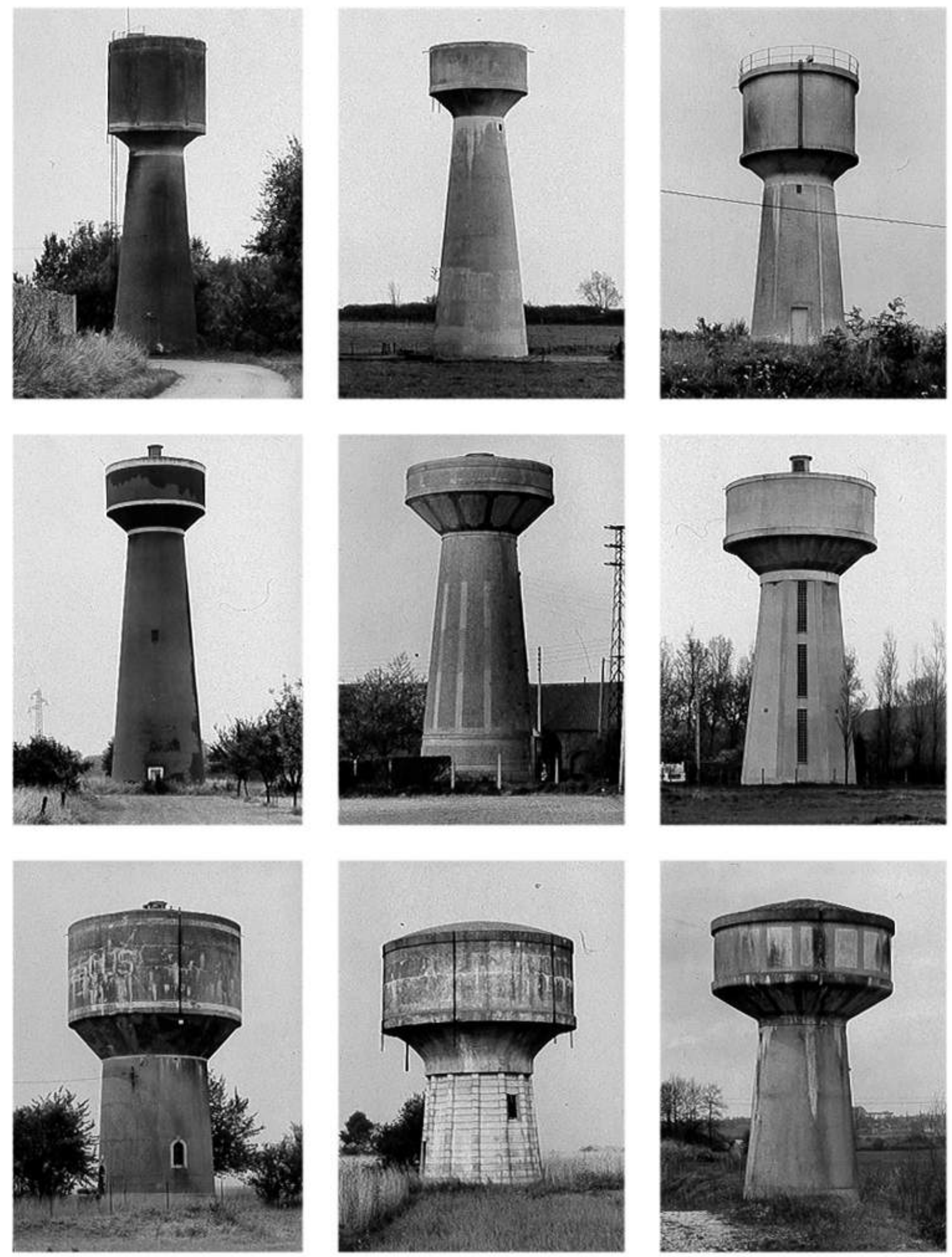

\section{4 .50}

Típicas torres de água "tipo Intze". 

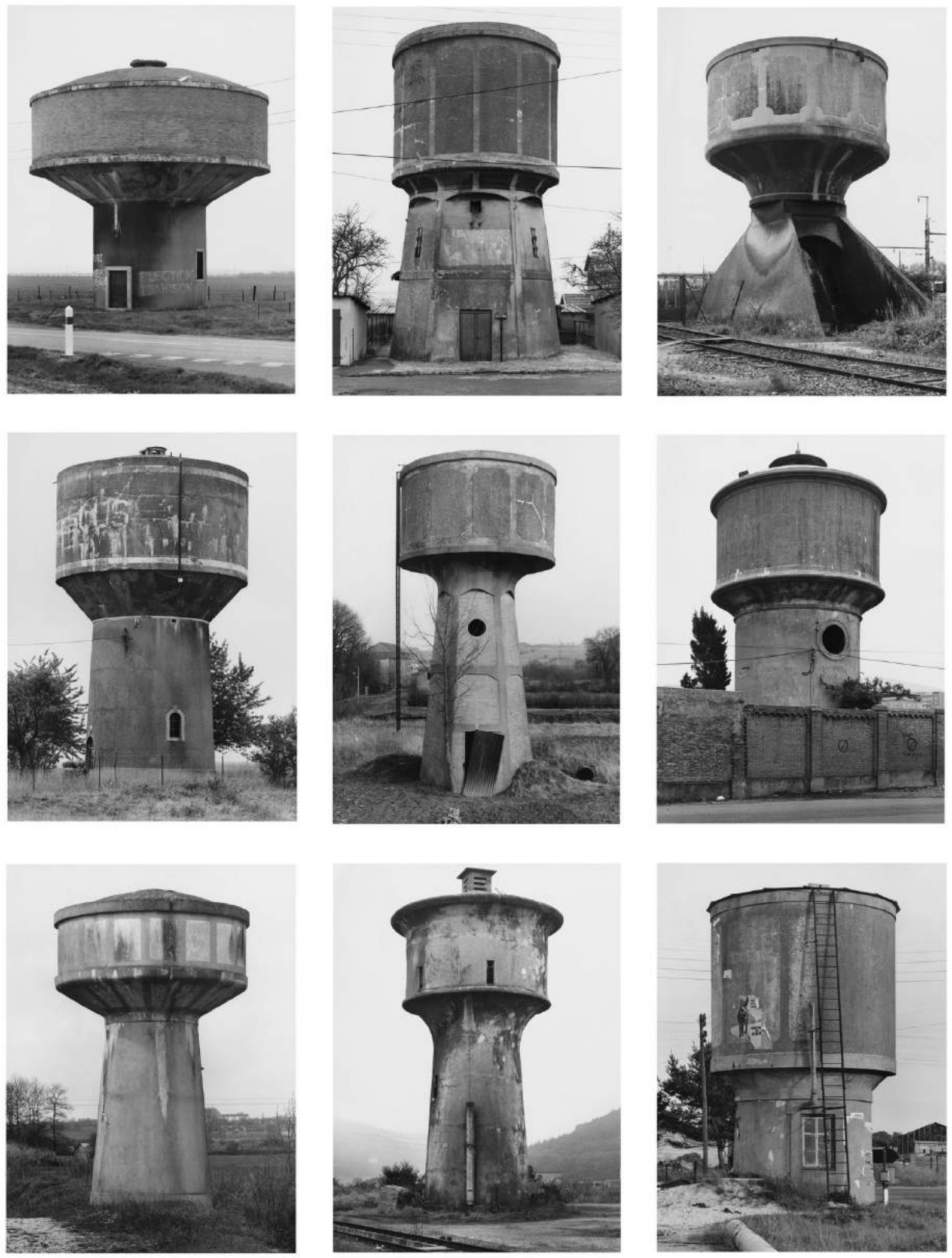

2.4.51

Típicas torres de água "tipo Intze". 

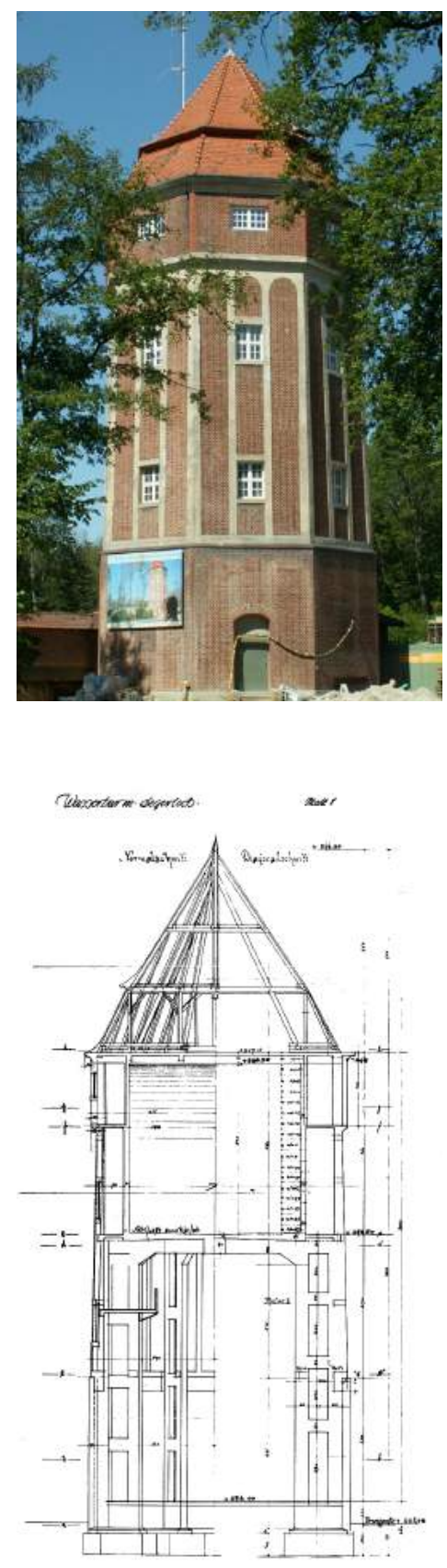

2.4.52a

Torre de Degerloch, Alemanha, 1911.
A construção de torres de água de concreto armado equipadas com reservatórios tipo Intze salientes, ou mesmo com reservatórios de fundo plano, apoiados em esqueletos estruturais aparentes não eram um consenso geral entre engenheiros e arquitetos da época. Muitos tinham ressalvas particulares com a tipologia Intze e consideravam o reservatório saliente uma solução arquitetônica pouco satisfatória e, em muitos casos, tentavam mitigar a projeção do reservatório com o alargamento da estrutura de suporte ${ }^{44}$ uma solução que já havia sido utilizada em torres de água equipadas com reservatórios tipo Intze metálicos como, por exemplo, na torre Favoriten, em Viena (1898).

Em torres de água equipadas com reservatórios de fundo plano, a tarefa de se esconder o tanque e o esqueleto estrutural de concreto armado era mais simples, como podemos perceber nas torres de Degerloch (1911) e Rötha (1913), na Alemanha (figs. 2.4.52a e 2.4.52b). Já no caso de torres com reservatórios na tipologia Intze, este alargamento da subestrutura exigia um suporte cônico (que em muitas vezes adquiria a forma de uma cúpula ou de escoras oblíquas de concreto) para transitar a carga do reservatório para um fuste de diâmetro superior ao diâmetro do anel de suporte do tanque Intze, criando uma situação estática onde a componente horizontal do carregamento tinha que ser absorvida por anel de tração. Na torre da cidade de Assendeflt, Holanda, construída em 1922, uma cúpula em concreto construída sobre um fuste cilíndrico de alvenaria viabiliza a transição do carga do reservatório Intze para o fuste de maior diâmetro (fig. 2.4.53, 2.4.54). Um outro exemplo é a torre de água de Hockenheim (1910), onde a transição de carga do reservatório é realizada por meio de um sistema de arcadas de concreto armado (fig. 2.4.55, 2.4.56).

${ }^{44}$ WERTH, 1971, op. cit., p. 388. 

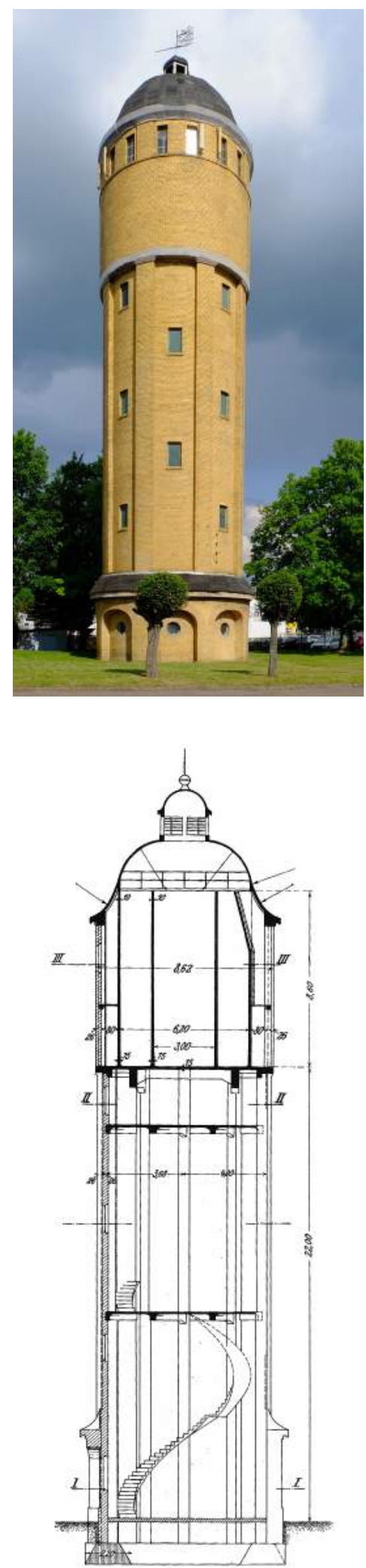

2.4.52b

Torre de Rötha, Alemanha, 1913.
Uma outra alternativa para evitar a temida "cabeça saliente" dos reservatórios tipo Intze era a utilização de uma outra tipologia de reservatório, desenvolvida especialmente para o concreto armado, o reservatório com fundo em cúpula. A cúpula em concreto é um exemplo de construção material, isto é, um elemento que trabalha predominantemente sob esforços de compressão, ${ }^{45}$ permitindo que as propriedades materiais do concreto sejam utilizadas em sua plenitude. Este formato de fundo exige, no entanto, um forte anel de tração capaz de resistir às forças do empuxo lateral da cúpula.

Uma das primeira torres de água (fig. 2.4.57) com um reservatório de concreto com fundo em cúpula foi construída em 1907 no pátio ferroviário de Heidelberg, Alemanha. O reservatório, com capacidade para $500 \mathrm{~m}^{3}$ consistia em um simples cilindro com altura de 9,70 metros, 9,15 metros de diâmetro e um fundo em cúpula com uma flecha de, aproximadamente, 1/9 do diâmetro. No centro do reservatório uma passagem vertical abrigava uma escada em espiral que conduzia até o topo do reservatório. A estrutura de concreto armado era formada por um conjunto de 12 pilares travados por uma laje intermediária e vigas anulares horizontais. Esta estrutura foi completamente escondida no exterior, recoberta por um envelope cilíndrico de alvenaria. ${ }^{46} \mathrm{O}$ envelope externo recebeu ainda quatro faixas simulando gigantescas pilastras, dando a impressão de um fuste formado por uma maciça construção de alvenaria enrijecida, algo que não correspondia com a realidade. O reservatório cilíndrico foi recoberto com um revestimento ornamental em sistema Monier, em formato dodecagonal, onde até mesmo janelas falsas foram aplicadas.

\footnotetext{
45 Para uma cúpula estar totalmente comprimida, tanto na direção dos paralelos quanto dos meridianos, esta deve ter uma abertura angular de no máximo 104 graus. Caso contrário, no sentido dos paralelos inferiores, ocorrerão esforços de tração. Ver REBELLO, Yopanan C. P.. A Concepção Estrutural e a Arquitetura. São Paulo: Zigurate, 2001, p. 143.
}

${ }^{46}$ WERTH, 1971, op. cit.. 
2.4 .53

Torre de Assendelft, Holanda, 1922. Vista.

\section{4 .54}

Torre de Assendelft, Holanda, 1922. Corte

\section{4 .55}

Torre de Hockenheim, Alemanha, 1910. Vista.

\section{4 .56}

Torre de Hockenheim, Alemanha, 1910. Corte.

\section{4 .57}

Torre de Água no pátio ferroviário de Heidelberg, Alemanha, 1907. Vista, planta e corte.
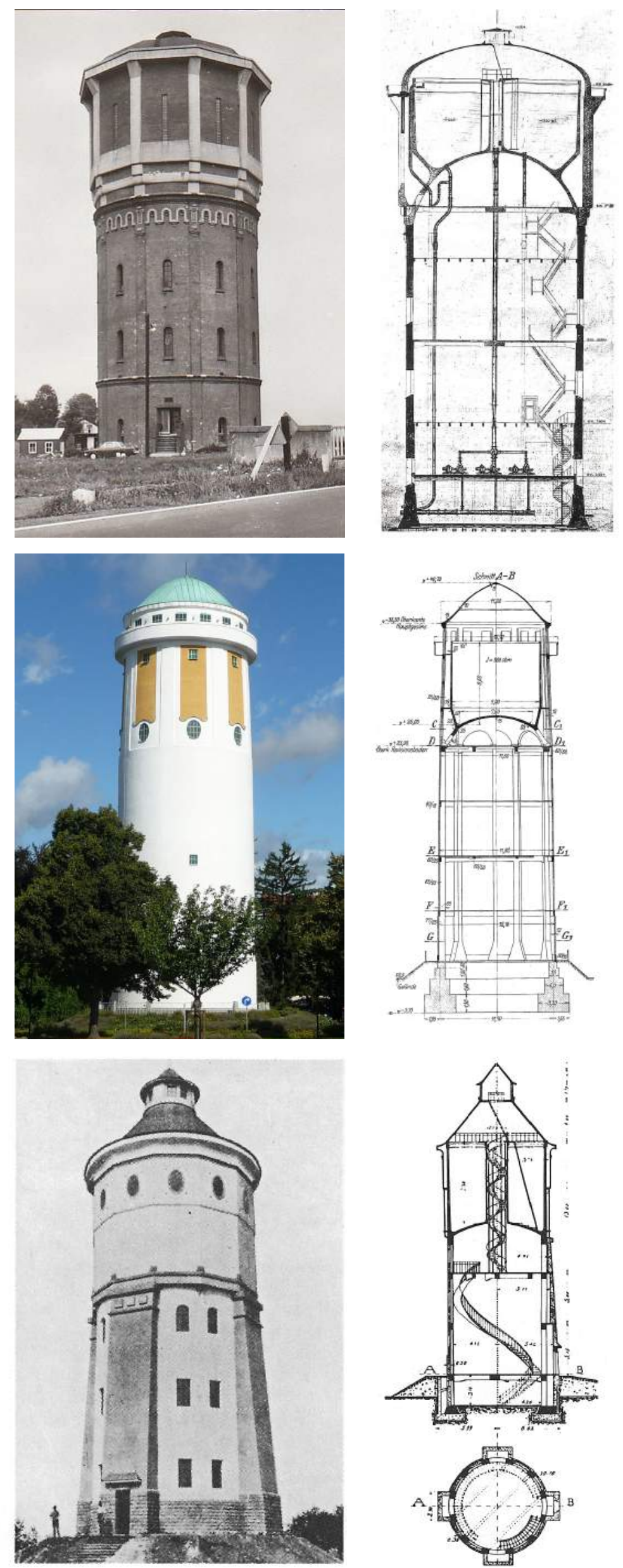


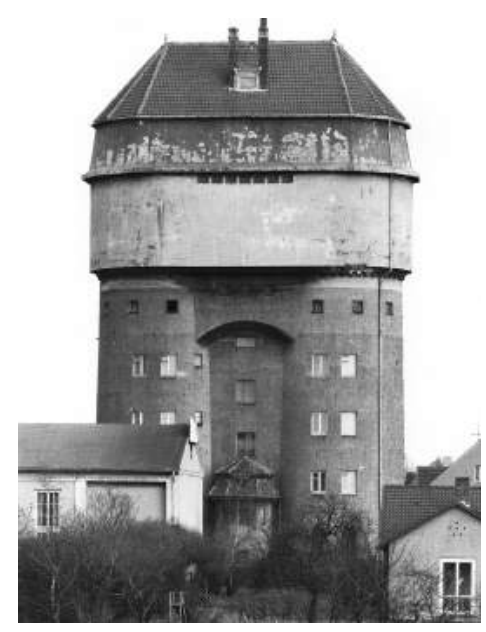

2.4 .58

Torre de Água do pátio ferroviário de Hohenbudberg, Alemanha, 1915-1916.

\subsubsection{9}

Torre de Água do pátio ferroviário de Hohenbudberg, Alemanha, 1915-1916. Plantas e corte.
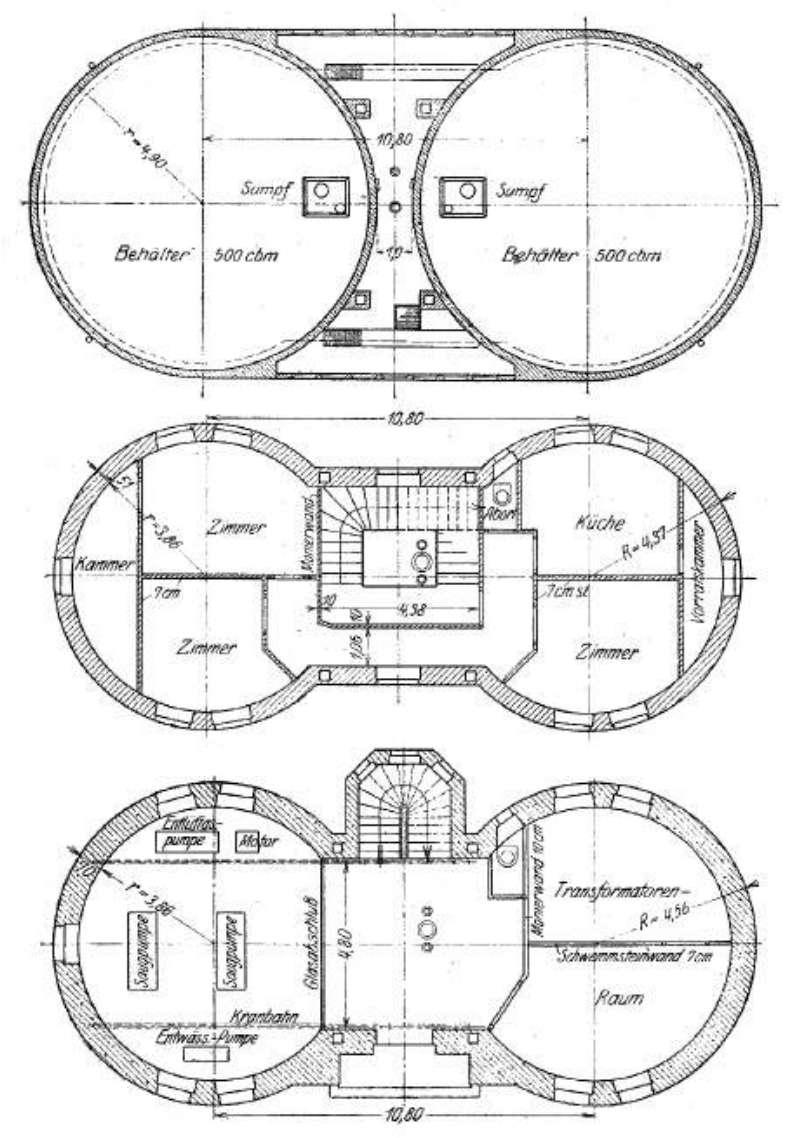
destaque para a elaborada armação do anel de tração inferior.

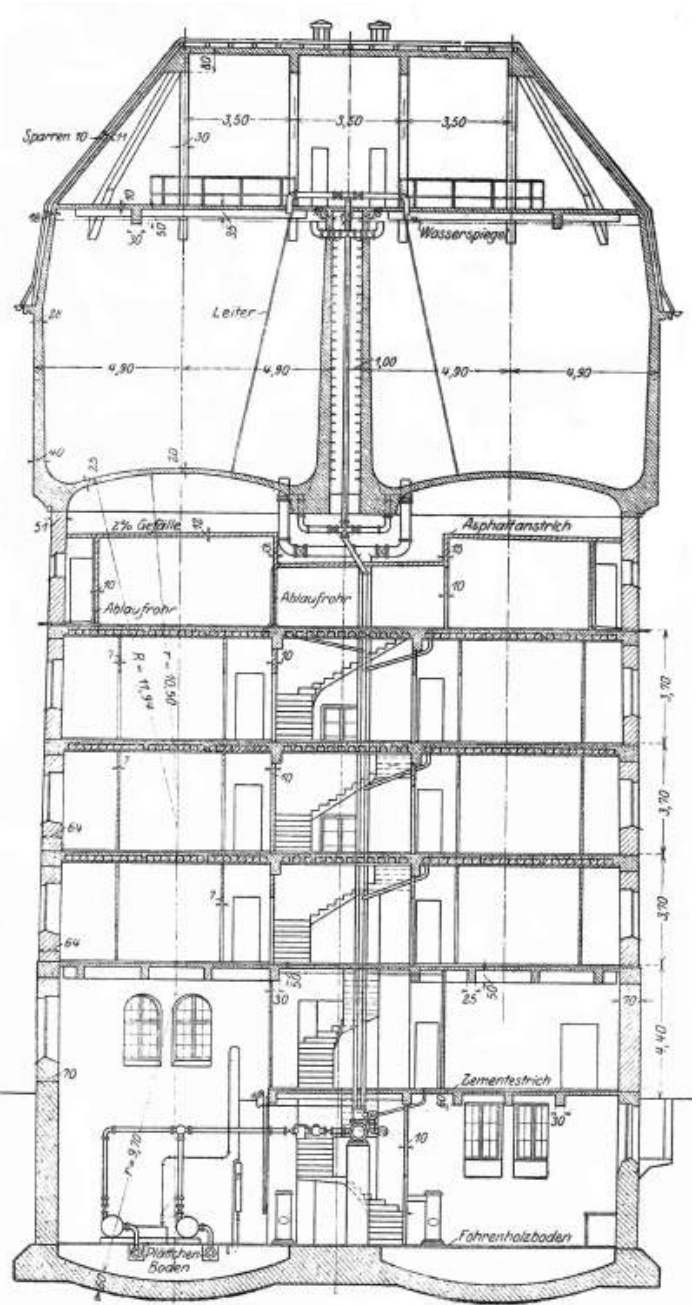

47 EMPERGER, Fritz. Handbuch für Eisenbetonbau: Füfter Band Flüssigkeisbehälter, Röhren, Kanäle. 2. ed. Berlin: Wilhelm Ernst \& Sohn, 1923. 14 v, p. 230-232. 

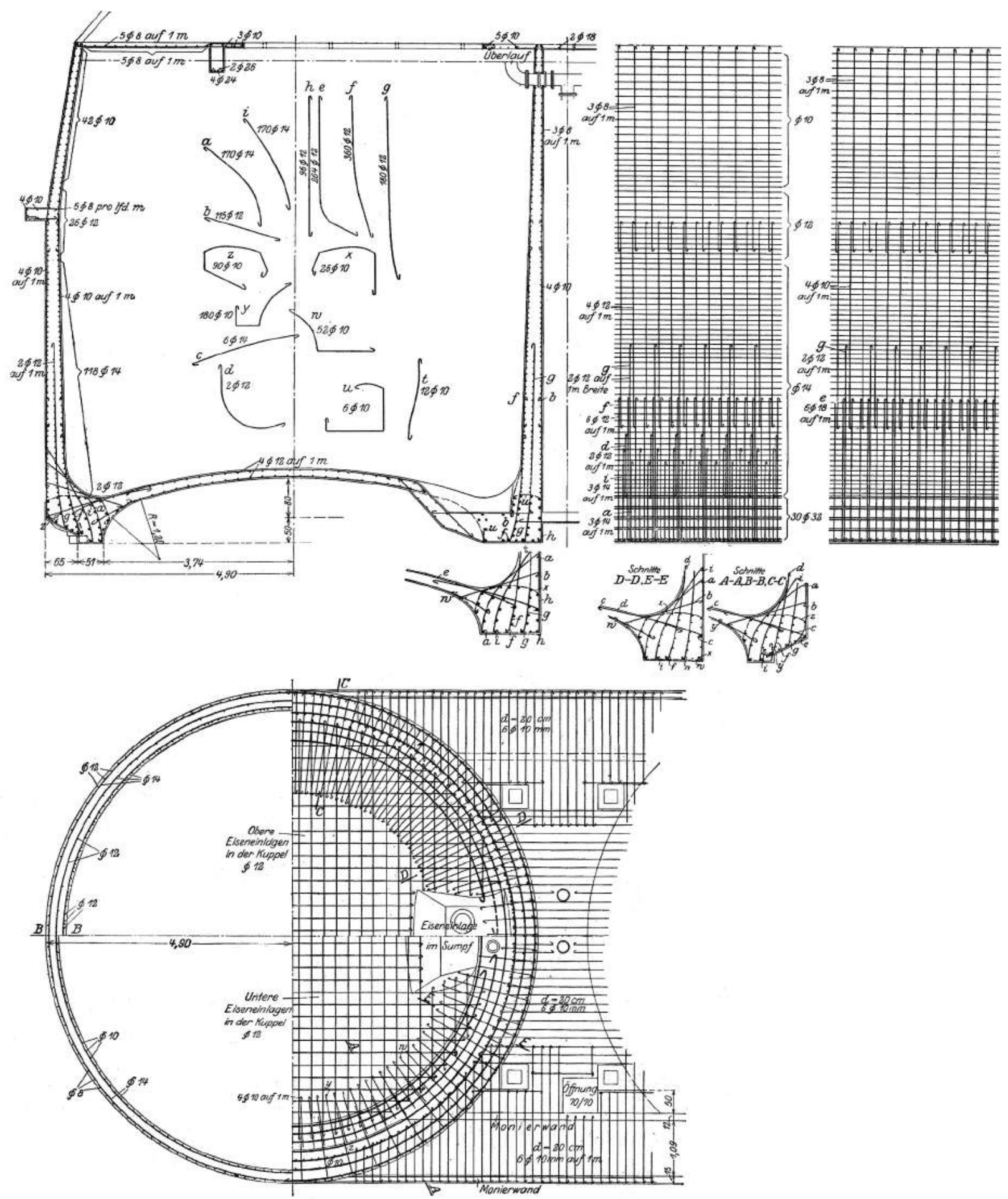

2.4 .60

Torre de Água do pátio ferroviário de Hohenbudberg, Alemanha, 1915-1916. Detalhe da armadura dos reservatórios. 


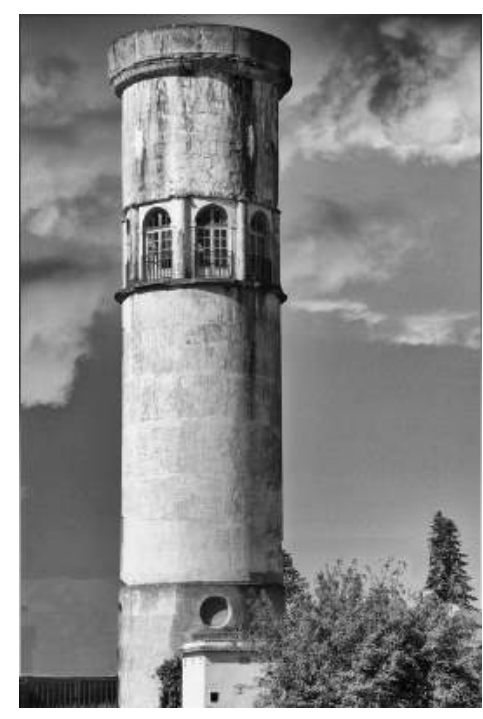

2.4.61

Charles-Edouard Jeanneret (Le Corbusier), Torre de Água de Pondesac, França, 1917.
Merece atenção especial uma torre de água 006 construída no ano de 1917 para o Château de Chavat, uma propriedade rural na comuna francesa de Pondesac, ao sudeste de Bordeaux. A torre foi projetada pelo arquiteto suíço Charles-Edouard Jeanneret (1887-1965) que, quatro anos mais tarde, assumiria o pseudônimo de Le Corbusier. Esta foi a primeira obra do arquiteto construída na França, projetada no período em que trabalhou em conjunto com a Société d'Application du Béton Armé (SABA) entre os anos de 1916-1917. ${ }^{48}$ A SABA construía edifícios, fábricas, represas e postes de concreto utilizados em linhas de transmissão de energia elétrica e Jeanneret prestava serviços para a empresa quando "assuntos arquitetônicos (estéticos) estavam envolvidos". ${ }^{49} \bigcirc$ formato cilíndrico da torre (fig. 2.4.61), coroada por um capitel dórico simplificado, remete as colunas utilizadas no belvedere sob o reservatório, um mirante isolado projetado para se abrir as vistas da propriedade rural e capturar a brisa de verão (fig. 2.4.62), um espaço de fruição em um tipo de edificação que é considerada por muitos como sendo puramente utilitária. Na torre de Pondesac, no entanto, os elementos da fachada se contrapõem à rigidez do esqueleto aparente de concreto armado no interior da torre, que apoia o piso do belvedere e o reservatório cilíndrico com fundo em cúpula (figs. 2.4.63, 2.4.64). Um escada espiral em concreto armado conduz até o piso do belvedere e deste nível é possível acessar a cobertura da torre por uma segunda escada metálica que atravessa o reservatório em altura. A segunda escada, projetada originalmente em espiral, foi substituída por uma simples escada tipo marinheiro quando da execução da obra e a lanterna que coroava a torre de água parece não ter sido executada. Em 1931 a torre da água passou a integrar o sistema de abastecimento público de água da comuna de Pondesac, sendo substituída em 1940 por uma torre de água com maior capacidade (fig. 2.4.65). Em 2005 a torre de água foi tombada como patrimônio histórico e está em curso um projeto de restauração..$^{50}$

\footnotetext{
48 Um história interessante dos primeiros anos da carreia de Le Corbusier pode ser encontrada em BROOKS, H. Allen. Le Corbusier's Formative Years: CharlesEdouard Jeanneret at La Chaux-de-Fonds. Chicago: The Chicago University Press, 1997.

49 lbid., p. 473.

${ }^{50}$ GIACINTO, 2007, op. cit.
} 


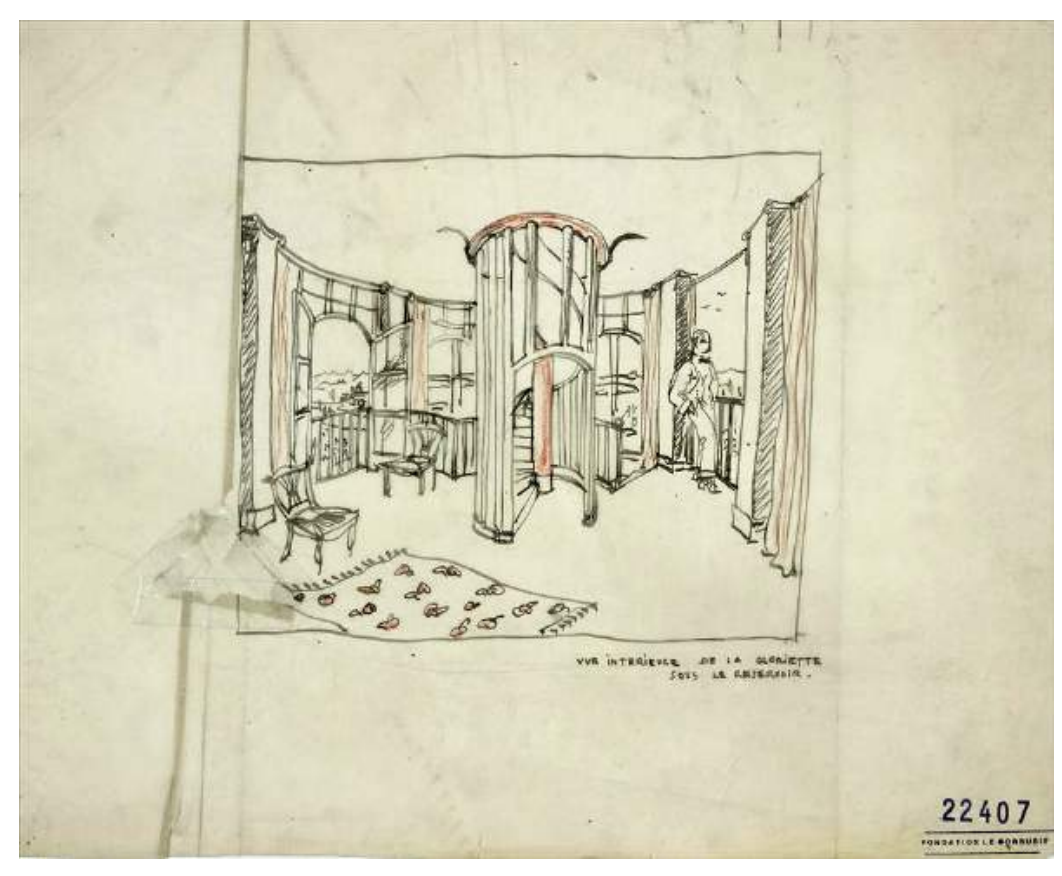

\subsubsection{2}

Charles-Edouard Jeanneret (Le Corbusier), Torre de Água de Pondesac, França, 1917. Vista interior do belvedere em croquis de Jeanneret.

\section{4 .63}

Charles-Edouard Jeanneret (Le Corbusier), Torre de Água de Pondesac, França, 1917. Elevações e corte.

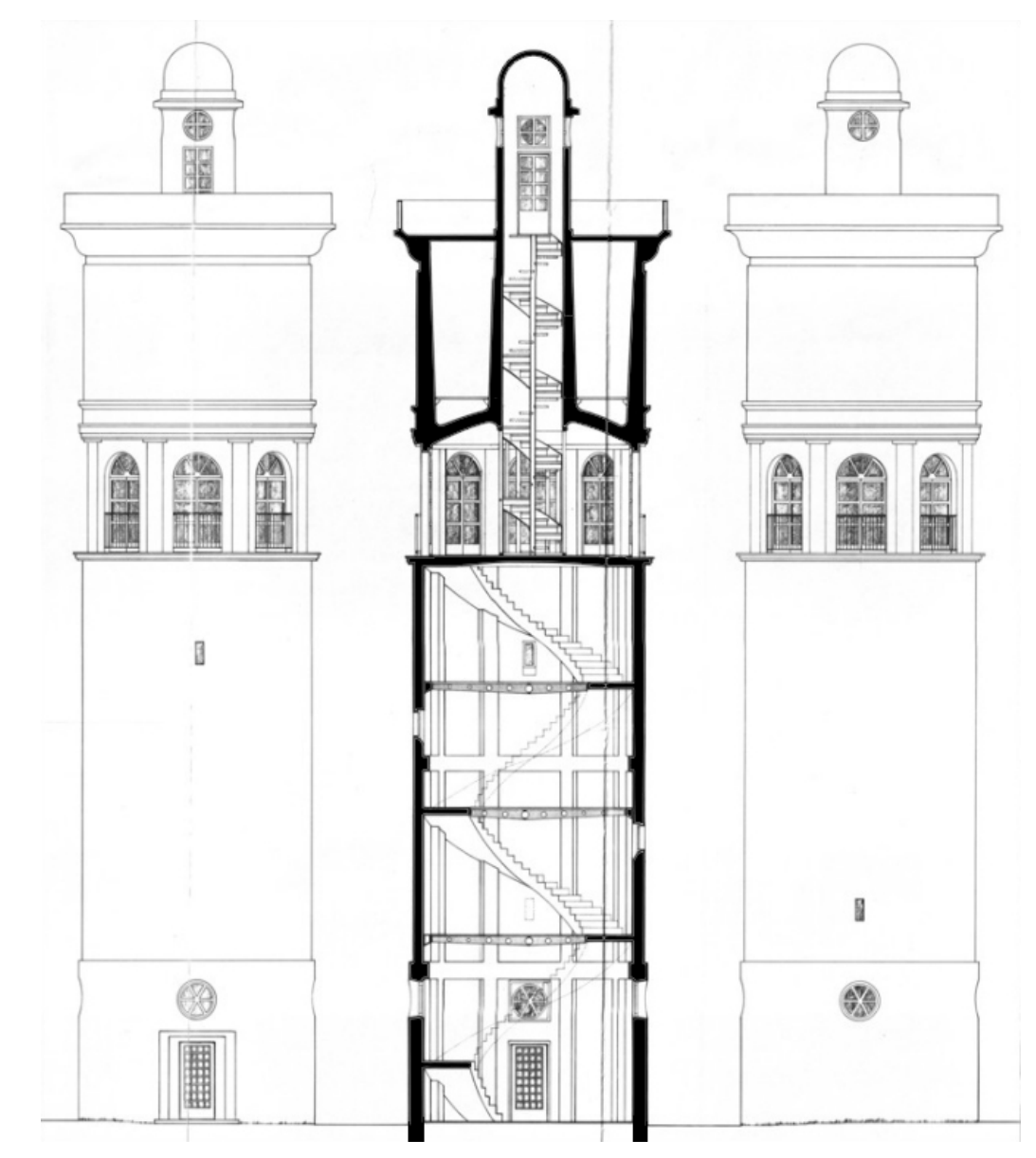




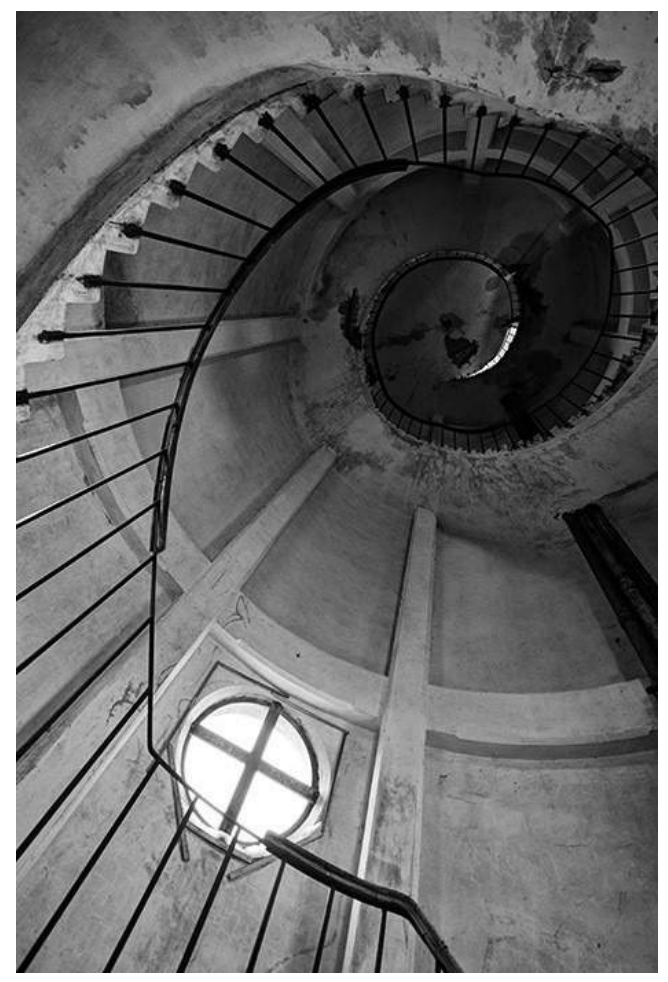

\section{4 .64}

Charles-Edouard Jeanneret (Le Corbusier), Torre de Água de Pondesac, França, 1917. Vista do interior.

\section{4 .65}

Torre de Água de Pondesac (1917) e a nova torre tipo Intze (1940).

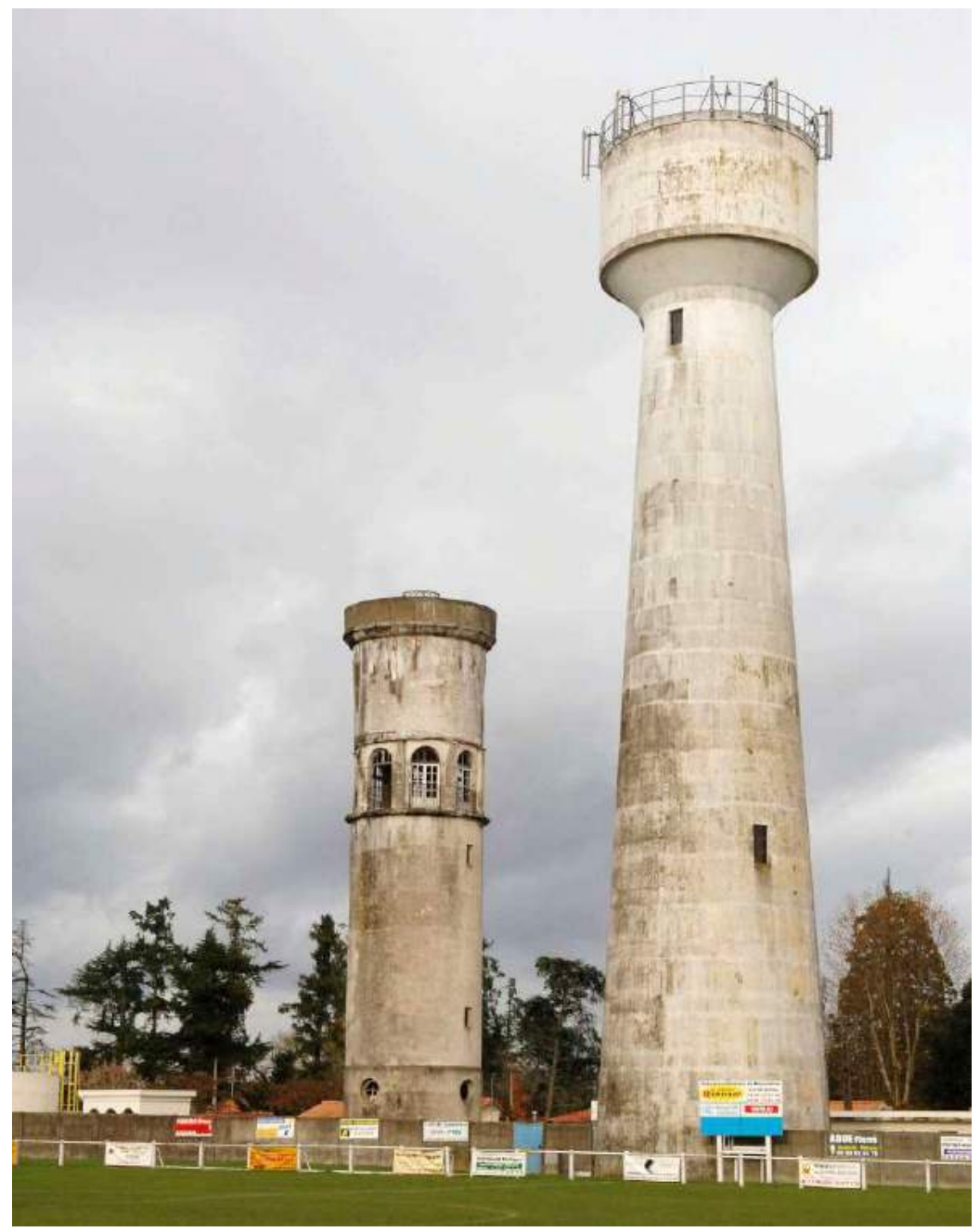




\subsubsection{A influência do Art Nouveau, Art Déco e do Expressionismo}

Na virada do século XX os escritos de John Ruskin e William Morris que propunham que a criação artística deveria estar fundada no trabalho manual e nos esforços de reforma social encontrou um público de mente aberta entre os arquitetos e artistas das novas gerações, estimulando-os a romper com instituições consideradas anacrônicas e com a cultura estética vigente no período. Grupos reformistas de arquitetos e artistas iniciaram movimentos contrários às tendências historicistas e à educação histórico-acadêmica ensinada nas escolas de arquitetura, com a sua orientação estilística voltada para a arquitetura clássica, especialmente sobre a Antiguidade e o Renascimento, com um ensino pautado no projeto de edifícios sem qualquer tipo de ligação com as necessidades programáticas e funcionais dos novos tempos e onde não era oferecido qualquer tipo de instrução sobre os uso dos novos materiais, das novas tecnologias e sobre os modos de se construir e conduzir um trabalho. A aliança entre a arquitetura, o artesanato e as artes decorativas é uma constante na atividade destes jovens arquitetos que procuravam criar uma nova linguagem independente de modelos históricos, se contrapondo ao êxito dos modelos tradicionais, buscando transformar cada edifício em uma "obra de arte total". ${ }^{51}$

Um dos movimentos mais bem sucedidos na tentativa de criar uma arte e uma arquitetura verdadeiramente modernas foi o chamado de Art Nouveau (Jugendstil na Alemanha, Modern Style na Inglaterra, Sezessionstil na Áustria ou ainda Modernisme na Catalunha), movimento que nasce primeiramente na Bélgica, entre 1892 e 1894, com a Casa Tassel do arquiteto Victor Horta (18611947) em Bruxelas e com a decoração da casa do arquiteto Henry Van de Velde (1863-1957) em Uccle. Nestas obras projetadas segundo critérios originais, sem precedentes, a linguagem e os

51 Ver BENEVOLO, 2017, op. cit., p. 148-152; e também COHEN, Jean-louis. O Futuro da Arquitetura desde 1889: Uma história mundial. São Paulo: Cosac Naify, 2013, p. 28. 
elementos do novo estilo Art Nouveau já aparecem coerentemente elaborados. ${ }^{52}$ Materiais como pedra, tijolo, metal, vidro, madeira e cerâmica tornaram-se as peças para novos arranjos compositivos, onde cada um destes materiais era ressaltado por várias estratégias próprias do novo estilo que voltava a sua atenção para o ornamento e para a decoração da superfície. As obras de arte e arquitetura tinham como características constantes: a temática naturalista inspirada na formas de flores, animais e insetos; a utilização de motivos estilísticos derivados da arte japonesa; a morfologia baseada na curva e nas suas variantes (espiral, voluta, etc.); e a recusa da proporção e do equilíbrio simétrico. ${ }^{53}$ Os representantes do movimento Art Nouveau defendiam que mesmo os objetos de nosso cotidiano e as construções estritamente técnicas deveriam ser adornados com a nova decoração artística e encantadoramente abstrata, contrariando o funcionalismo defendido pela engenharia civil. ${ }^{54}$ Esta posição dos arquitetos ligados ao movimento se refletiu também no projeto de algumas torres de água construídas no auge do Art Nouveau entre os anos de 1895 e 1920.

Para a cidade de Mönchengladbach, na Alemanha, o arquiteto Otto Greiss (1876-1945) projetou entre os anos de 1908 e 1909 uma torre de água (fig. 2.4.66, 2.4.67) fortemente influencia da pelo estilo Art Nouveau. Na subestrutura cilíndrica de alvenaria da torre, pilastras escalonadas de tijolos aparentes sobem até o nível do reservatório e descansam em consoles representando animais aquáticos. Um telhado de cobre verde esculpido em formas orgânicas e em várias camadas coroa a torre de 51,00 metros de altura que abriga dois reservatórios, um superior, com volume de $800 \mathrm{~m}^{3}$, e um inferior, apoiado sobre o solo, com capacidade para $2.300 \mathrm{~m}^{3}$ de água, destinado a abastecer as áreas mais baixas de Mönchengladbach. Na fachada da torre não existem indícios da posição do reservatório metálico de fundo suspenso que equipa a

\footnotetext{
52 BENEVOLO, 2017, op. cit., p. 273.

${ }^{53}$ ARGAN, Giulio Carlo. Arte Moderna. São Paulo:

Companhia das Letras, 2013, p. 199.

${ }^{54}$ MEVIUS, 1985, op. cit., p. 156.
} 

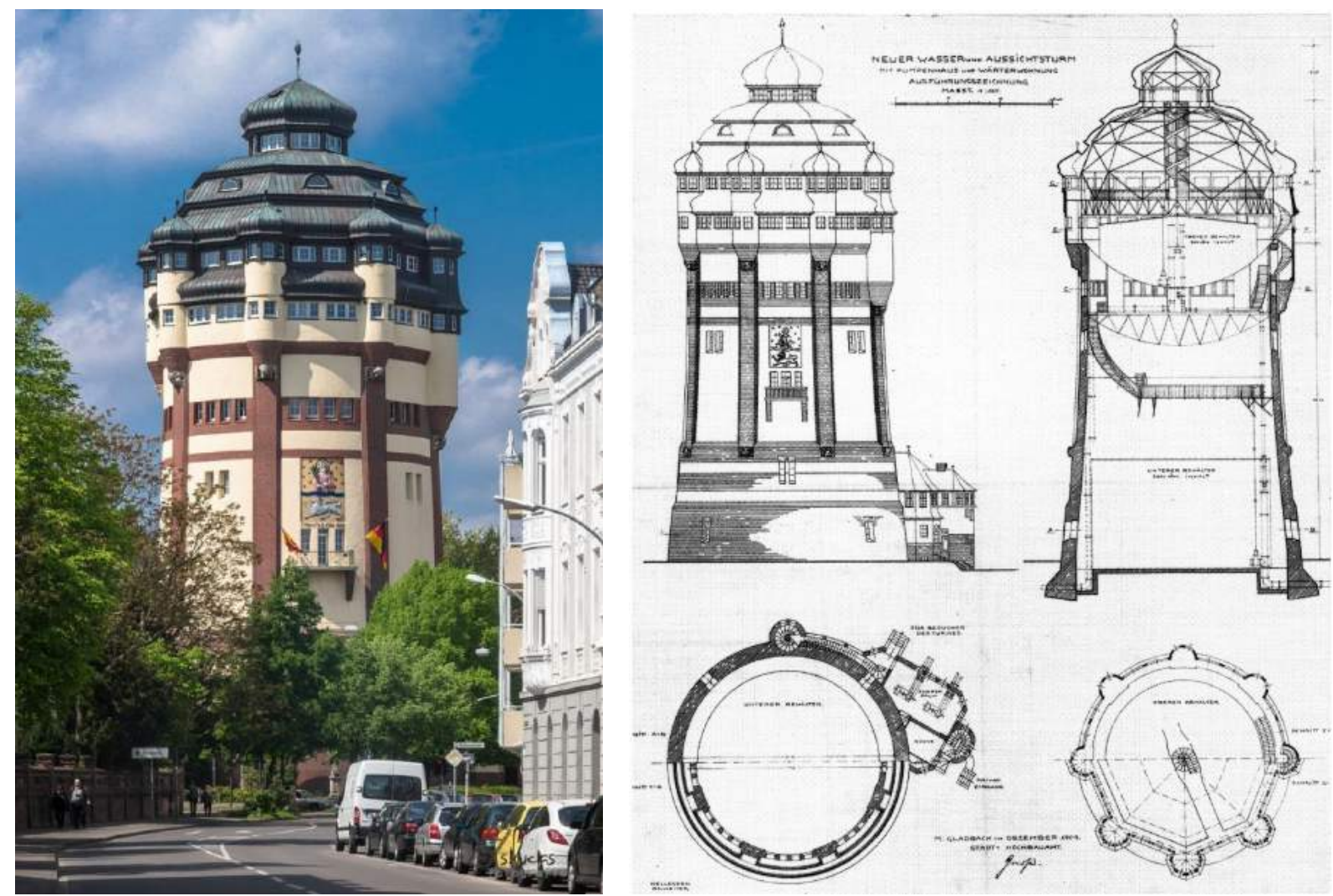

\subsubsection{5}

Otto Greiss, Torre de Água de Mönchengladbach, Alemanha, 1908-1909.

\section{4 .66}

Otto Greiss, Torre de Água de Mönchengladbach, Alemanha, 1908-1909. Plantas, corte e torre. A função do edifício é mascarada. Planejada desde o início para ser construída no ponto mais alto na cidade, Otto Greiss tinha como um de seus objetivos "fazer este edifício utilitário puro se destacar na vida cotidiana e torná-lo o símbolo da cidade". ${ }^{55}$

O engenheiro Carl Franke (1843-1931) projetou em 1913 uma torre de água estilisticamente ligada ao Jugendstil alemão para o sistema de abastecimento público da cidade de Plön. Com 42,50 metros de altura e diâmetro médio de 6,00 metros, a torre está equipada com um reservatório metálico tipo Intze I, com volume de $150 \mathrm{~m}^{3}$. Inicialmente chama a atenção na torre de Plön a sua forma esbelta e a maneira como é feita a mudança entre os principais materiais de construção utilizados na obra: o tijolo, o concreto e a ardósia. Nenhum tipo de embasamento marca a transição entre o terreno e o fuste da torre, como se a torre "crescesse" para fora do solo. Esta situação é enfatizada pelo talude artificial de terra construído no pé do fuste (fig. 2.4.68) que dá a impressão de que

${ }^{55}$ Apud GOCKEL, Bernd. Bilddokumente historischer Wassertürme. In: MERKL, Gerhard et al. Historische Wassertürme: Beiträge zur Technikgeschichte von Wasserpeicherung und Wasserversorgung. München: Oldenburg Verlag, 1985, p. 258. 

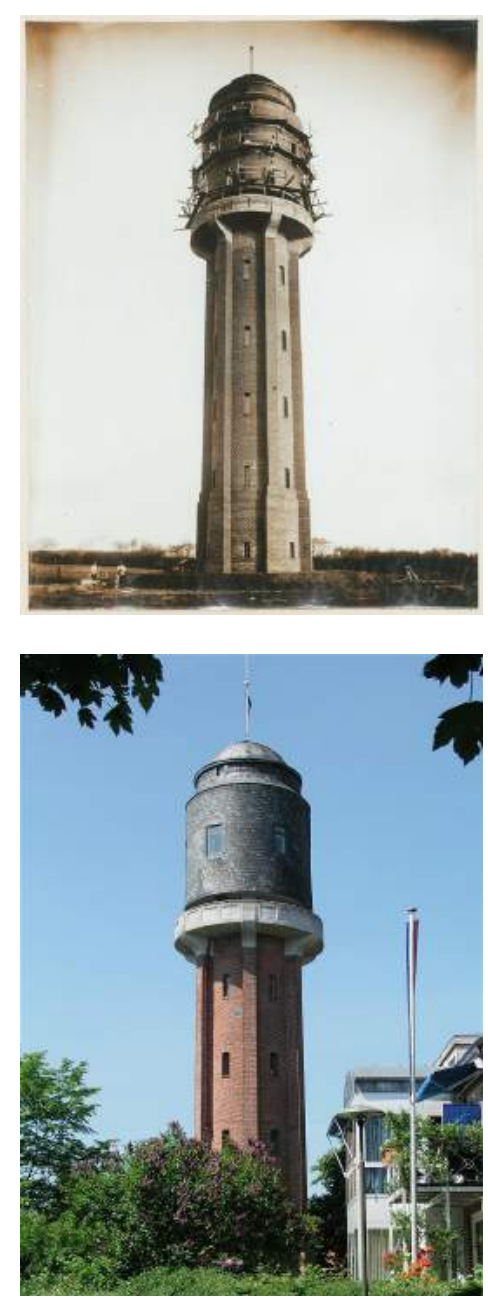

\subsubsection{8}

Carl Franke, Torre de Água de Plön, Alemanha, 1913. Foto da construção.

\subsubsection{9}

Carl Franke, Torre de Água de Plön, Alemanha, 1913. Situação Atual. a torre saiu diretamente do solo como o broto crescente de uma planta. A verticalidade da torre é enfatizada pelos seis contrafortes salientes do fuste, criando a impressão de um fuste mais esbelto do que realmente é. A cabeça da torre que esconde o reservatório é a forma dominante da edificação. Uma galeria com diâmetro maior do que o fuste e a cabeça da torre separa estes dois elementos claramente. A diferença de materiais acentua ainda mais esta divisão com a ardósia negra da cabeça da torres sendo separada dos tijolos vermelhos do fuste pelo concreto aparente do parapeito da galeria. A separação entre a cabeça e o parapeito da galeria ainda é enfatizada pelo ligeiro balanço do revestimento de ardósia da cabeça da torre, que parece flutuar sobre a galeria (fig. 2.4.69). ${ }^{56}$

A torre de água (fig. 2.4.70, 2.4.71) da cidade de Bardenberg, Alemanha, construída entre os anos de 1909 e 1911 é mais um exemplar de torre no estilo Art Nouveau. Com uma altura total de 46,00 metros e um diâmetro na base de cerca de 10,00 metros a torre está equipada com um reservatório metálico tipo "barkhausen" com volume de $750 \mathrm{~m}^{3} .{ }^{57}$ As grandes fundações da torre estão escondidas sob um talude de terra fazendo com que a torre nasça diretamente da terra sem uma base, assim como na torre de Plön. A estrutura de suporte em formato de fuste troncônico foi executada em alvenaria de tijolos, enrijecida por seis contrafortes escalonados em dois níveis. Uma cornija escalonada que se projeta ligeiramente em balanço coroa o fuste e marca a transição para o invólucro metálico de cobre esverdeado que cumpre a dupla função de revestimento e cobertura do reservatório de água. O invólucro metálico se alarga no eixo dos contrafortes do fuste e se comprime no intervalo destes, criando uma superfície orgânica, ondulada e torcida, viabilizada por uma complexa estrutura treliçada de madeira construída sobre o reservatório de água. Assim como na torre de Plön a verticalidade da torre é acentuada pelos potentes

\footnotetext{
56 HAMM, Sara. The Watertower as Decor: Exceeding Generic Concepts in Art Nouveau. In: Historical Lab 3: Art Nouveau \& Decoration, 2006, Riga. Proceedings... . Bruxelles: Bruxelles Urbanisme \& Patrimoine, 2006, p. 4-5.

57 GOCKEL, 1985, op. cit., p. 268.
} 

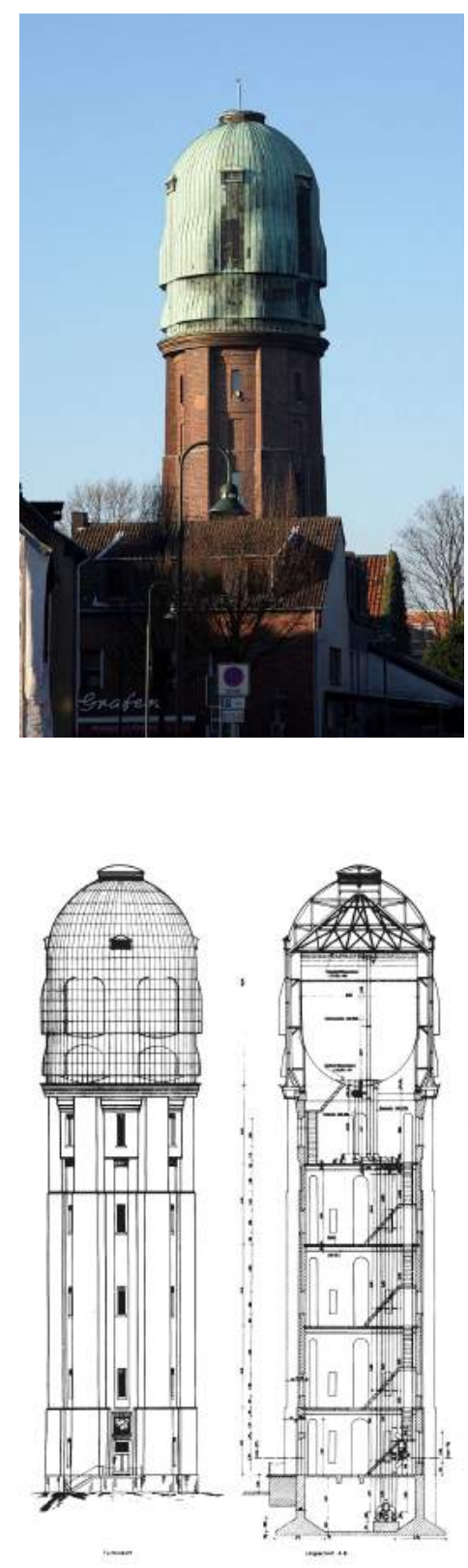

\subsubsection{0}

Torre de Água de Bardenberg, Alemanha, 1911.

\subsubsection{1}

Torre de Água de Bardenberg, Alemanha, 1911. Elevação e corte. contrafortes que são interrompidos apenas pela linhas de transição no escalonamento do fuste..$^{58}$

Nas torre de água de Plön (1913) e de Bardenberg (1911) os princípios fundamentais de projeto são idênticos, ou seja, a torre é projetada com uma distinção clara entre a estrutura de suporte e a cabeça da torre, que abriga o reservatório elevado. É digno de nota nestas duas obras a busca de uma solução formal mediadora entre a simples construção funcional, como a utilizada na torre da cidade de Alsdorf (1910), e a solução formal das torres de água projetadas sob a influência do Historicismo, como a torre Favoriten (1898), em Viena, onde é praticamente impossível ter uma ideia da localização do reservatório e onde a comunicação da função do edifício é mascarada. Em Plön e em Bardenberg o reservatório, apesar de escondido sob um invólucro, é perfeitamente localizável e a cabeça da torre, elevada por um potente fuste, faz uma correspondência com o funcionamento da torre de água, com a água sendo elevada pela força das bombas até a altura do reservatório e armazenada nele, tornando-se a parte mais valiosa da torre de água. Nas duas torres de água, no entanto, os invólucros da cabeça da torre são desenhados com formas completamente distintas do formato dos reservatórios, impossibilitando a apreensão do tipo de reservatório utilizado, da tipologia Intze em Plön e do tipo Barkhausen em Bardenberg.

movimento Art Nouveau pode ser considerado como uma importante transição entre o historicismo do século XIX e as vanguardas modernas do início do século XX, ilustrando um período de grandes mudanças no pensamento artístico e arquitetônico, com a reação de artistas e de arquitetos contra a arte acadêmica e contra o ecletismo historicista. O Art Nouveau conheceu várias tendência localizadas principalmente em países como França, Bélgica, Alemanha, Inglaterra, Espanha e Áustria, gerando uma influência de alcance internacional na arquitetura produzida no início do século XX. Sua influência na arquitetura das torres de água, no

\footnotetext{
${ }^{58}$ HAMM, 2006, op. cit,. p. 6.
} 

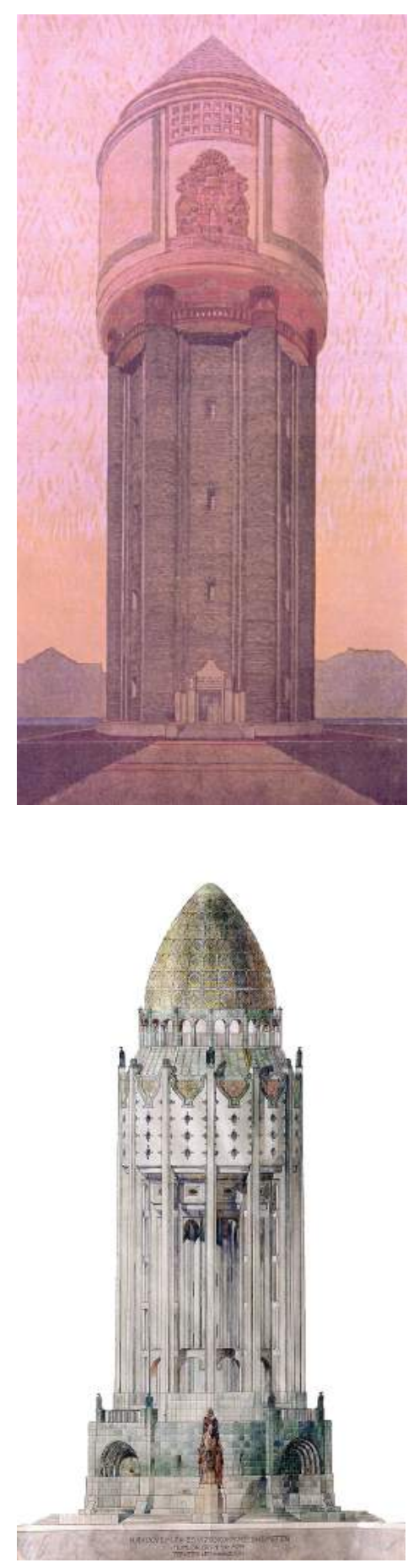

\section{4 .72}

Joseph Maria Olbrich, projeto para a Torre de Winterhude, Hamburgo, Alemanha, 1906-1907.

\section{4 .73}

Ödön Lechner, projeto para a Torre de Rákóczy, Kecskemét, Hungria, 1911. entanto, foi pouco sentida, limitada a algumas obras executados na Alemanha e a alguns projetos não executados, dos quais podemos citar o projeto (fig. 2.4.72) de Joseph Maria Olbrich (1867-1908) realizado em 1907 por ocasião de um concurso ${ }^{59}$ para a construção de uma nova torre de água para o bairro de Winterhude, na cidade de Hamburgo, Alemanha, ${ }^{60}$ e também o projeto de 1911 para a torre de Rákóczy (fig. 2.4.73), na cidade Kecskemét, na Hungria, do arquiteto Ödön Lechner (1845-1914).

Após a Primeira Guerra Mundial, no entanto, a natureza estilizada do design Art Nouveau, que era caro para se produzir, começou a ser abandonada em favor de um modernismo mais ágil, retilíneo e barato, gerando um estilo que viria a ser conhecido como Art Déco. Considerado durante muito tempo como a antítese do Art Nouveau e das vanguardas modernas em geral, o Art Déco, na verdade, tem afinidades com ambos. No plano ideológico os expoentes do Art Déco buscavam eliminar a distinção entre as belas-artes e as artes decorativas, afirmado a importância do artista no design e na produção dos objetos e, assim como outros modernistas, compartilhavam o gosto pelas máquinas, pelos novos materiais, pelas novas tecnologias e pelas formas geométricas. ${ }^{61} \mathrm{O}$ Art Déco teria grande influência na arquitetura das torres de água projetadas e construídas no período pós-Guerra.

Na Holanda, entre as décadas de 1920 e 1930, foi grande o número de torres de água projetadas conforme a linguagem e os elementos do novo estilo Art Déco por arquitetos como Hendrik Sangster (1892-1971), Hermann Friedrich Mertens (1885-1960) e Johannes Hendrik Jurgen Kording (1875-1925). O arquiteto de Haia, Hendrik Sangster, teve a mais prolífica produção entre todos,

\footnotetext{
59 Trata-se do certame realizado no ano de 1907 para escolha de projetos para três novas torres de água para os bairros de Uhlenhorst, Sternschanze e Winterhude, em Hambrugo, Alemanha. Mais adiante falaremos sobre o projeto vencedor para a área de Winterhude, de autoria do arquiteto Oskar Menzel, e também sobre o projeto elaborado pelo arquiteto Hans Poelzig para este mesmo local.

60 HAMM, 2006, op. cit,. p. 3.

${ }^{61}$ DEMPSEY, Amy. Estilos, Escolas \& Movimentos. São Paulo: Cosac Naify, 2003, p. 135.
} 
projetando e construindo 19 torres de água entre os anos de 1922 e 1935, a maioria delas atuando sob contrato da N. V. Waterleiding Maatschappij Noord-West-Brabant (Empresa de Abastecimento de Água Noord-West-Brabant). ${ }^{62}$ Na maioria de seus trabalhos Sangster explorou a liberdade que oferecia a estrutura independente de concreto armado combinada com a cobertura de tijolos aparentes, trabalhando as possibilidades plásticas da alvenaria aparente em conjunto com os elementos estruturais aparentes. Na revista Water en Gas de 1924, Sangster publica um artigo intitulado "Eenige Aanwijzingen voor de Architectuur van Watertorens" (Orientações para a Arquitetura das Torres de Água) onde rejeita a estética dos "tanques com pernas" e defende a construção de edifícios monumentais, adaptados à altura e tamanho dos reservatórios. Segundo ele o reservatório e a cobertura devem ser expressos na fachada das torres, mas sem que isto atrapalhe na unidade e silhueta do todo. ${ }^{63}$ Dá ainda instruções para a concepção do telhado e também para o tratamento do concreto aparente:

"O telhado é uma das partes mais difíceis da torre. Deve coroar o edifício de forma a criar um todo orgânico com a parte inferior. Uma vez que formas contra o céu são altamente visíveis, a linha do telhado deve ser muito limpa. Um detalhe na escala correta, sempre proporcional à altura, intensifica a forma do telhado contra o céu, mas a prudência e a austeridade são absolutamente necessárias neste quesito. Quanto à cor da torre, além do entorno, deve ser levada em conta a cor do concreto, que é o material ideal para a construção dos elementos estruturais da torre. O concreto, quando não estiver completamente oculto atrás dos tijolos, pode ser utilizado para criar detalhes marcantes na obra. Uma vez que não é aconselhável estucar o concreto por causa da reparação dispendiosa, o que provoca ainda uma cor morta, este deverá que ser escovado após a desforma com a escova de aço (a forma deve

\footnotetext{
${ }^{62}$ A relação completa de torres de água projetadas por Hendrik Sangster está disponível em SANGSTER, Bart. Hendrik Sangster: Watertorens en ander werk. Raleigh: Lulu Enterprises, 2013, p. 23.

${ }^{63}$ VEEN, Henk van Der. Watertorens in Nederland. Rotterdam: Uitgeverij 010, 1989, p. 84.
} 


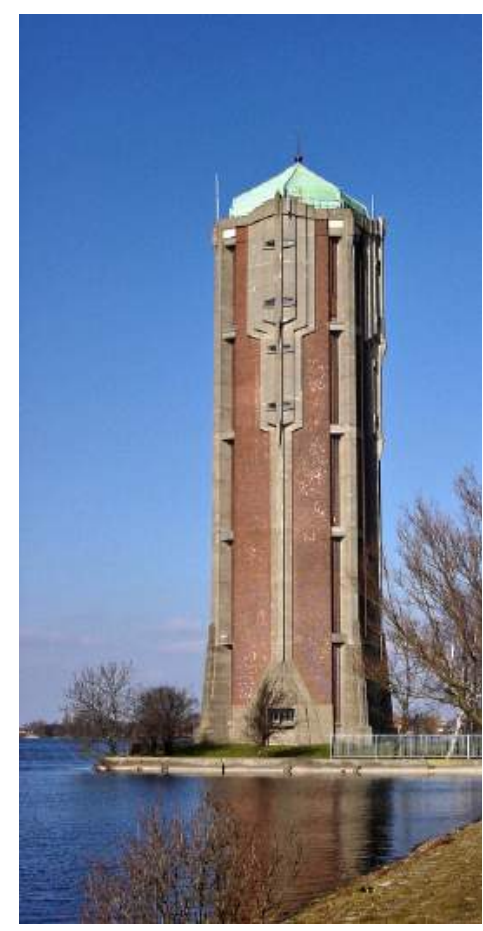

2.4 .74

Hendrik Sangster, Torre de Água de Aalsmeer, Holanda, 1928. ser aplainada e um desmoldante utilizado). Com a cor cinza clara o tijolo vermelho escuro pode ser utilizado criando um contraste de cores bastante forte. O clínquer amarelo acinzentado, hoje amplamente utilizado, tem esta vantagem de garantir uma cor mais clara e alegre que ilumina com a luz do sol quando observada de uma certa distância." 64

Esta teoria foi colocada em prática nas torres de água que Sangster projetou a partir de 1925. A torre de água de Aalsmeer, 010 construída entre os anos de 1926 e 1928 pode ser considerado um de seus melhores trabalhos. A torre é uma estrutura monumental de 50,00 metros de altura que ocupa uma posição privilegiada no complexo de lagos de Westeinderplassen (fig. 2.4.74). A torre de água possui dois reservatórios cilíndricos sobrepostos com fundo plano, construídos em concreto armado. O mais elevado com diâmetro de 10,50 metros e um volume de $520 \mathrm{~m}^{3}$ e o segundo, posicionado logo abaixo do primeiro, com um diâmetro de 10,20 metros e um volume de $480 \mathrm{~m}^{3}$. A estrutura independente de concreto armado consiste de quatro colunas posicionadas nos cantos da torre e quatro colunas mais leves na metade dos planos da fachada, que são conectadas em intervalos regulares por vigas. Aberturas verticais estreitas para a passagem de luz são criadas em um recuo da alvenaria de tijolos nos cantos de torre, uma solução que, ao mesmo tempo, evidencia a

\footnotetext{
64 "Het dak is een der moeilijkste delen van de toren. Het moet een bouwwerk zodanig beëindigen, dat het een organisch geheel vormt met het onderliggende gedeelte. Doordat de vormen tegen de lucht zich sterk aftekenen moet de lijn van het dak heel zuiver zijn. Een detaillering op een schaal, die naar verhouding is tot de hoogte, geeft tegen de lucht een zekere verlevendiging doch is voorzichtigheid en soberheid in dezen alleszins geboden. Wat de kleur van de toren betreft moet behalve met de omgeving rekening worden gehouden met de kleur van het beton, dat wel het aangewezen materiaal is om er de dragende delen van de toren uit op te bouwen. Wordt het beton niet geheel achter de baksteen weggewerkt dan geeft ze aanleiding een sprekend motief te vormen in het geheel. Daar het wegens het dure herstel niet raadzaam is het beton te bepleisteren, hetgeen een doodse kleur veroorzaakt, zal het geboucheerd moeten worden of na het ontkisten met de staalborstel bijgewerkt (de geschaafde bekisting met consistentievet insmeren). Bij deze lichtgrijze kleur kan donkerrode baksteen misstaan alt te grote tegenstelling in kleur. De tegenwoordig veel toegepaste geel grijze klinker heeft dit bezwaar veel minder sterk en geeft een blije kleur welke op verre afstand in de zon lichtend werkt." Apud SANGSTER, 2013, op. cit., p. 24-25.
} 

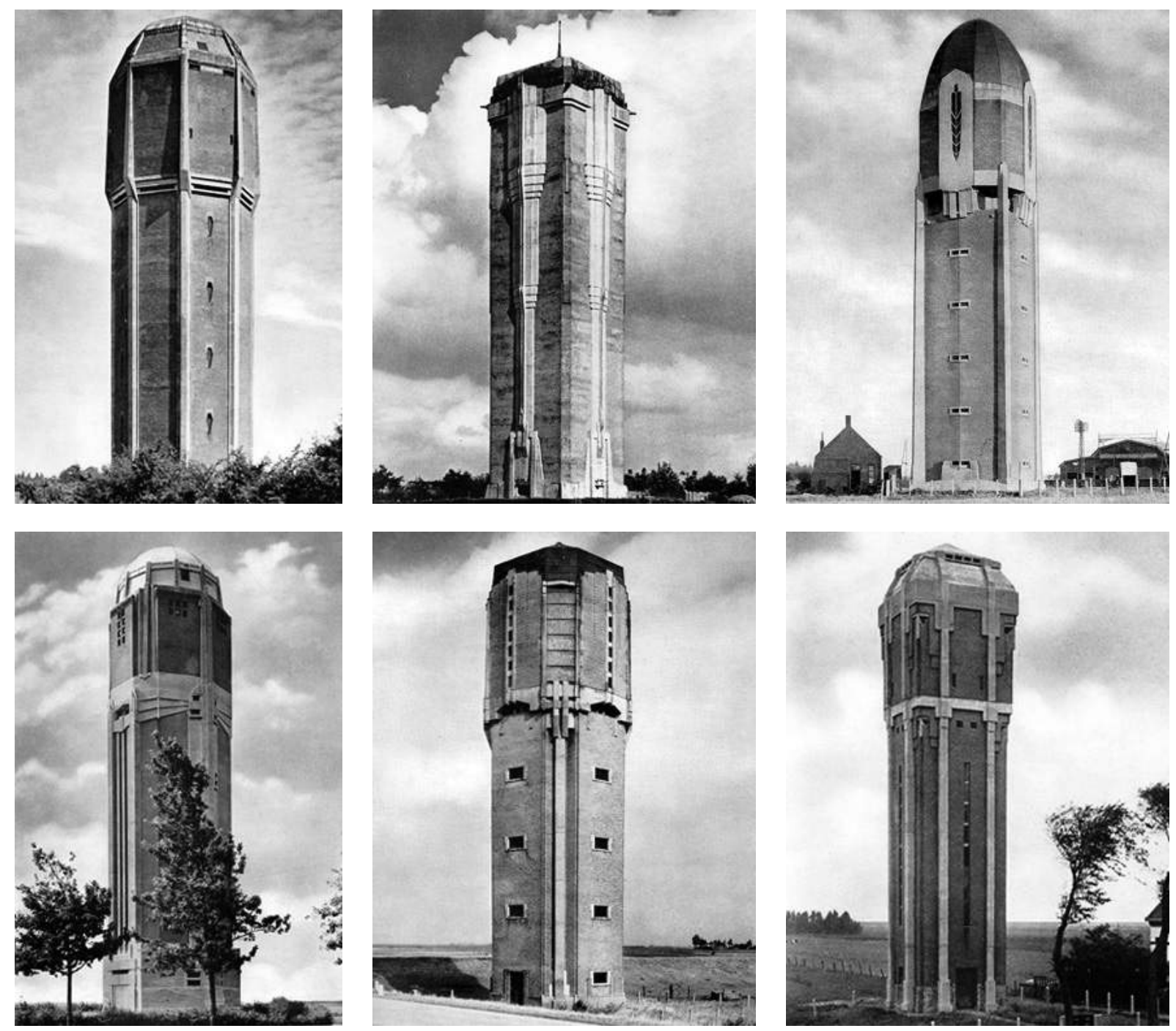

2.4 .75

Torres de Água projetadas por Hendrik Sangster, Holanda.
a) Dongen, 1922.
b) Etten, 1924
c) Steenbergen, 1923.
d) Raamsdonksveer, 1925.
e) St. Philipsland, 1924.
f) Anna Jacobapolder, 1925.

existência do esqueleto estrutural de concreto armado. No interior da torre quatro colunas apoiam a escada que conecta o piso térreo aos reservatórios e ao topo da torre. Do embasamento da torre, construído inteiramente em concreto, erguem-se as paredes de alvenaria de tijolos vermelhos que se estendem até a cobertura. As fachadas, na sua metade superior, são decoradas com motivos de concreto aparente característicos do Art Déco posicionados no nível dos reservatórios de água, uma pista da localização destes. A torre de água é coroada por um telhado de cobre esverdeado em oito águas encimado por uma agulha. Tombada como patrimônio histórico em 1988, a torre de água de água está fora de uso desde 1994.

A figura 2.4.75 mostra fotos de algumas torres projetadas por Sangster tiradas na época de sua construção: Dongen (1922), Etten (1924), Steenbergen (1923), Raamsdonksveer (1925), St. 
Philipsland (1924) e Anna Jacobapolder (1925). No período em que a Holanda permaneceu sob ocupação alemã durante a Segunda Guerra Mundial, muitas torres de água foram utilizadas como postos de observação pelas tropas nazistas. Com a chegada dos exércitos aliados as torres de água de Steenbergen (fig. 2.4.76), Zevenbergen, Fijnaart, Dinteloord, Lage Zwaluwe, Gilze e Almkerk foram carregadas com explosivos e destruídas pelas tropas alemãs que bateram em retirada nos meses de Setembro e Outubro de 1944. Com a destruição destas torres uma parte importante da obra de Hendrik Sangster foi perdida. As torres de água das cidades de Etten, St. Philipsland, Raamsdonksveer também foram completamente descaracterizadas ao longo do tempo com a aplicação de um reboco sobre as superfícies de tijolos aparentes, operação que alterou por completo as obras originais. As últimas torres projetadas por Sangster, no entanto, distanciaram-se de suas orientações de 1924 como, por exemplo, na torre de Naaldwijk (fig. 2.4.77) construída em 1930, uma obra mais alinhada com o expressionismo da Escola de Amsterdã, ${ }^{65}$ e também na torre de Domburg, 012 construída em 1933, onde a localização do reservatório mal era representada e a cobertura, praticamente independente, não formava um todo orgânico com o restante da construção. ${ }^{66}$

Na Bélgica a influência do Art Déco também se fez presente na arquitetura das torres de água, podendo citar, entre outras obras, as torres de Chaumont-Gistoux $\left(250 \mathrm{~m}^{3}\right)$, projeto de F. Henne de 1923; torre de água da Provinciale Technische Scholen, em Boom, projeto de Camille Bal e Ernest Lamot de 1931;

\footnotetext{
${ }^{65}$ A Escola de Amsterdã foi um movimento de renovação da arquitetura ligado ao expressionismo que se desenvolveu nos Países Baixos entre os anos de 1915 e 1930. Os arquitetos ligados a este movimento, influenciados pelo modernismo de Henry van de Velde (1863-1957) e Hendrik Petrus Berlage (18561934), projetavam edifícios com formatos insólitos, nos quais elementos da arquitetura tradicional eram deformados e recompostos e onde predominava o uso do tijolo aparente e do concreto. Assim como os arquitetos expressionistas com quem tinham grande afinidade, eles acreditavam no poder da arquitetura de melhorar a qualidade de vida. Seus principais expoentes foram os arquitetos Michel de Klerk (1884-1923), Pieter Lodewijk Kramer (1881-1961) e Johan van der Mey (1878-1949). Ver COHEN, 2013, op. cit., p. 116-118.

${ }^{66}$ VEEN, 1989, op. cit., p. 86.
} 


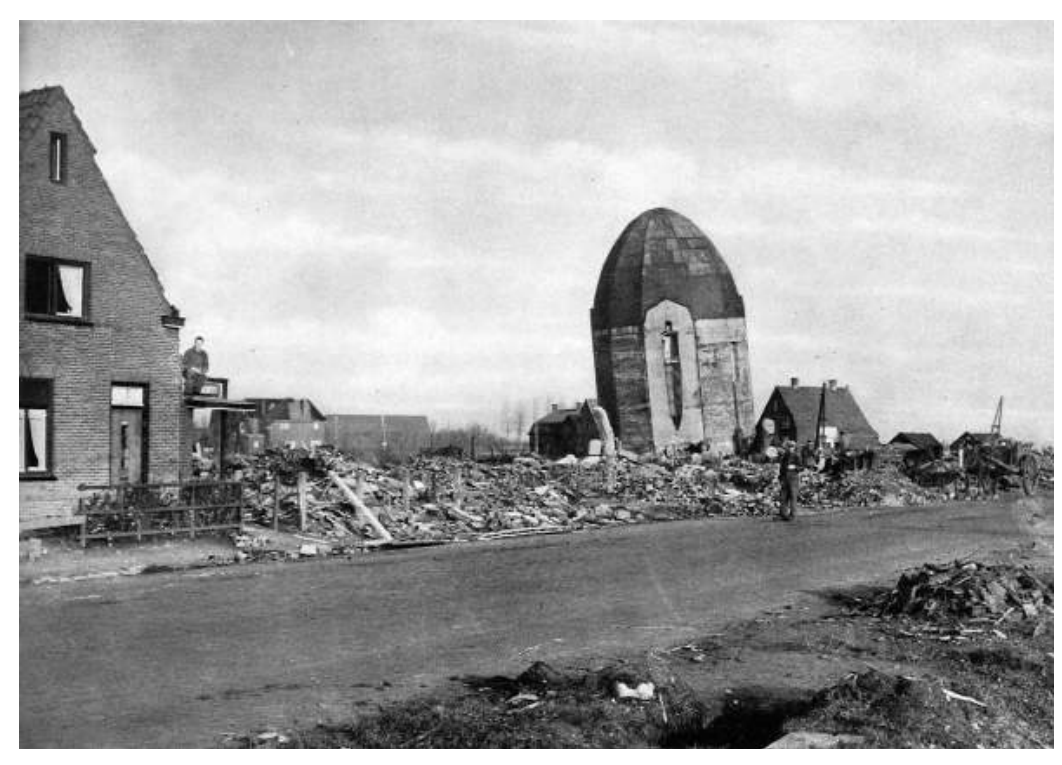

\section{4 .76}

Ruínas da torre de Steenbergen (1923) destruída pelas tropas alemãs em 1944.

\section{4 .77}

Hendrik Sangster, Torre de Água de Naaldwijk, Holanda, 1930.

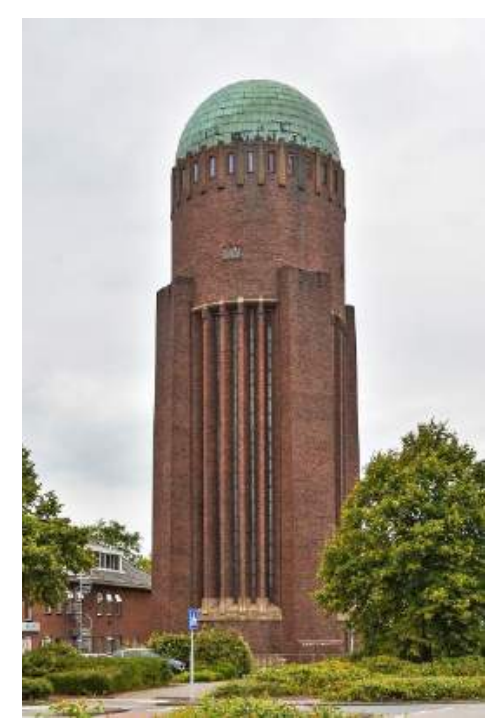

Sart-Dames-Avelines $\left(850 \mathrm{~m}^{3}\right.$ ), projeto de Roland Fourcat de 1936; Brasschaat-Aerdenlei $\left(500 \mathrm{~m}^{3}\right)$, construída em 1938 e Overijse (150 $\mathrm{m}^{3}$ ), construída em 1938 (fig. 2.4.78). ${ }^{67}$

O Expressionismo foi uma corrente artística que abalou a Europa entre o início e os meados do século XX. Uma característica essencial do Expressionismo é a sua busca apaixonada pela verdade interior, ou seja, no lugar de registrar uma impressão do mundo a sua volta, o artista expressava o mundo e a vida em sua arte da maneira como ele os sentiam. Este conceito de arte foi tão revolucionário que "expressionismo" tornou-se um sinônimo para a arte "moderna" em geral. Artistas e arquitetos expressionistas viam-se como criadores de um mundo melhor e acreditavam no poder da arte e da arquitetura de melhorar a qualidade de vida. As raízes do movimento expressionista na arquitetura se encontram no Art Nouveau de Henry van de Velde (1863-1957), Joseph Maria Olbrich (1867-1908) e Antoni Gaudí (1852-1926). A arquitetura expressionista se caracterizava pela qualidade monumental, pelo uso inventivo do tijolo aparente, uso das cores elementares, uso de formas insólitas e pela distorção de formas naturais até a sua abstração. ${ }^{68} \mathrm{O}$ uso extensivo do tijolo aparente é devido à presença de uma forte componente artesanal na raiz do movimento, que busca devolver a liberdade e a dignidade do

\footnotetext{
${ }^{67}$ GENICOT, 1991, op. cit., p. 147.

68 DEMPSEY, 2003, op. cit., p. 70-73.
} 


\section{4 .78}

a) F. Henne, Torre de ChaumontGistoux, 1923.

b) Camille Bal e Ernest Lamot, Torre de Água da Provinciale Technische Scholen, Boom, 1931.

c) Roland Fourcat, Torre de SartDames-Avelines, 1936.

d) Torre de Brasschaat-Aerdenlei, 1938.

e) Torre de Overijse, 1938.

f) Torre de Wijnegem, 1943.
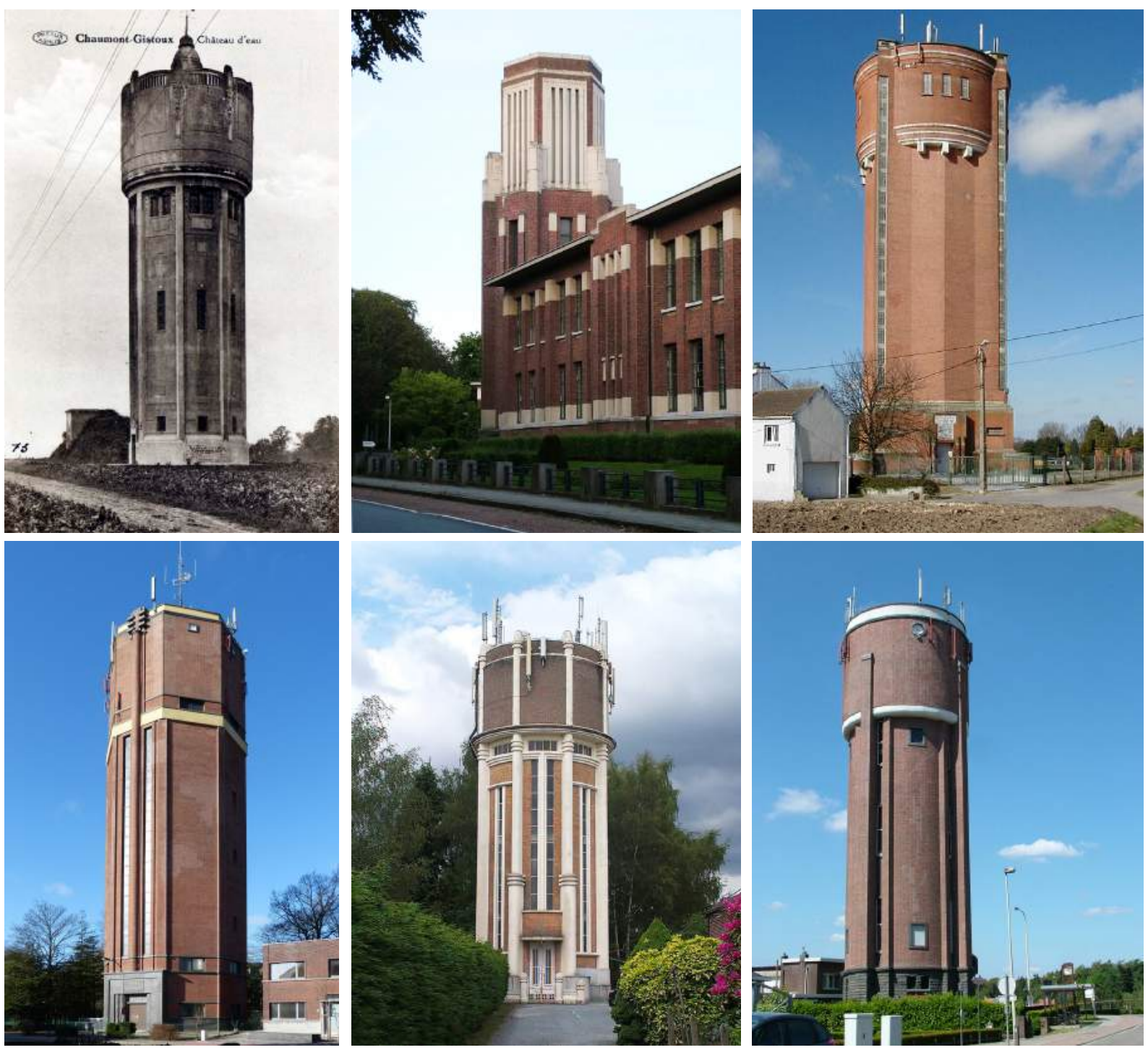
Entre os anos de 1906-1907 a cidade de Hamburgo lançou um concurso para selecionar as melhores propostas arquitetônicas para três torres de água para os bairros de Uhlenhorst, Sternschanze e Winterhude, bairros localizados nas partes mais altas da cidade e não cobertos pelo sistema de abastecimento existente na época. A torre de Winterhude deveria ser construída em conjunto com - Parque da Cidade que estava sendo projetado pelo arquiteto Fritz Shumacher (1869-1947), na época Diretor de Construção em Hamburgo, e pelo paisagista Otto Linne (1869-1937). Foram inscritos 89 propostas para a torre de água de Winterhude e o arquiteto Oskar Menzel (1873-1953) sagrou-se vencedor. ${ }^{69}$
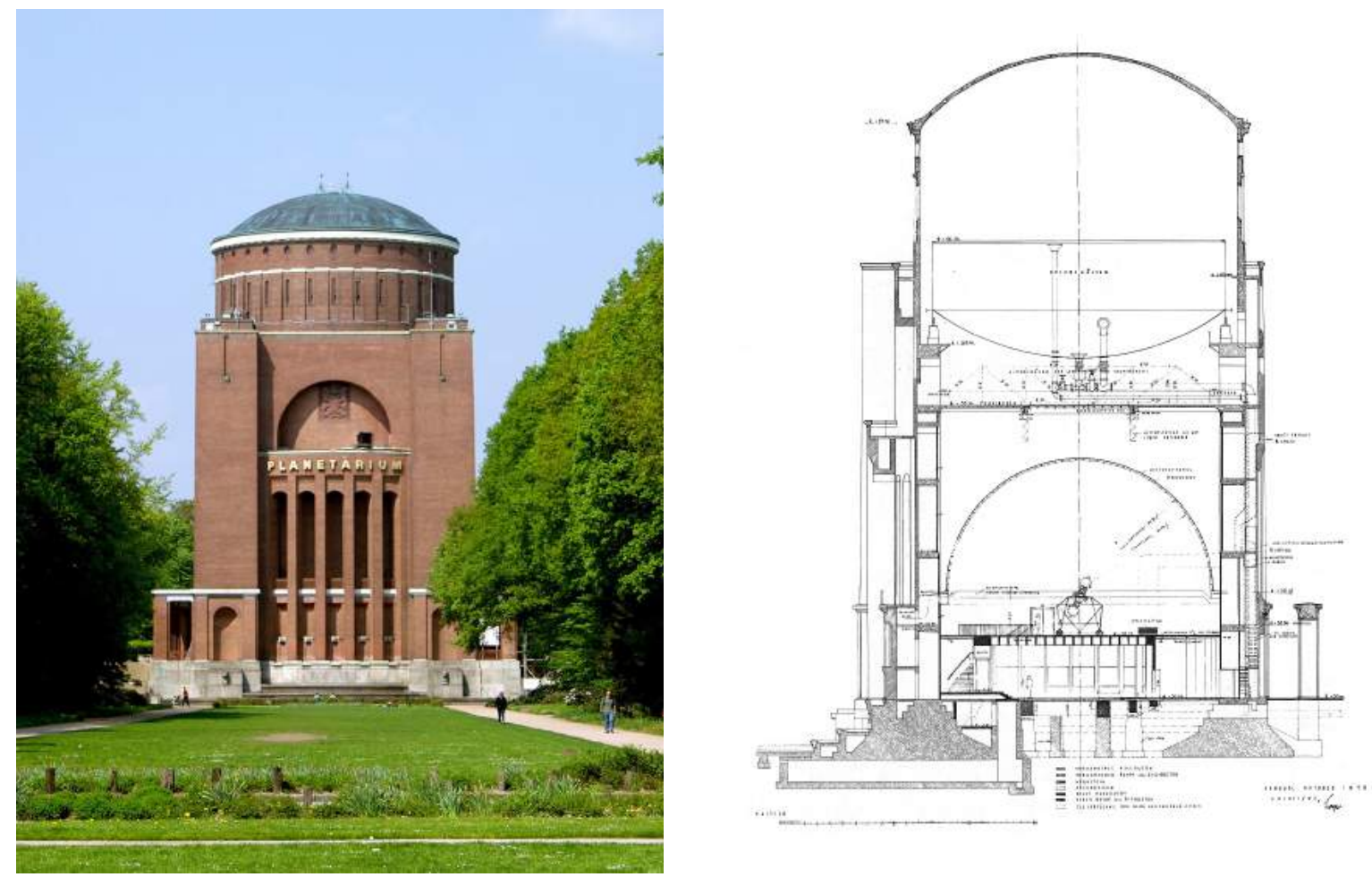

\subsubsection{9}

Oskar Menzel, Torre de Água de Winterhude, Hamburgo, Alemanha, 1907-1916.

\section{4 .80}

Oskar Menzel, Torre de Água de Winterhude, Hamburgo, Alemanha, 1907-1916. Corte.
A torre (fig. 2.4.79) projetada por Menzel é um edifício excepcionalmente monumental, com uma altura total de 64,50 metros, todo em tijolos vermelhos, exceto pelo embasamento em pedra de calcário e a cobertura de cobre esverdeado em formato de cúpula. No tambor cilíndrico que abriga o reservatório de água é aplicado o plano da fachada principal, voltado para o eixo

${ }^{69}$ GOCKEL, 1985, op. cit., p. 286. 


\subsubsection{1}

Hans Poelzig, Torre de Água de Winterhude, Hamburgo, Alemanha, 1906-1907. Planta e elevação.

\section{4 .82}

Hans Poelzig, Torre de Água de Winterhude, Hamburgo, Alemanha, 1906-1907. Corte.
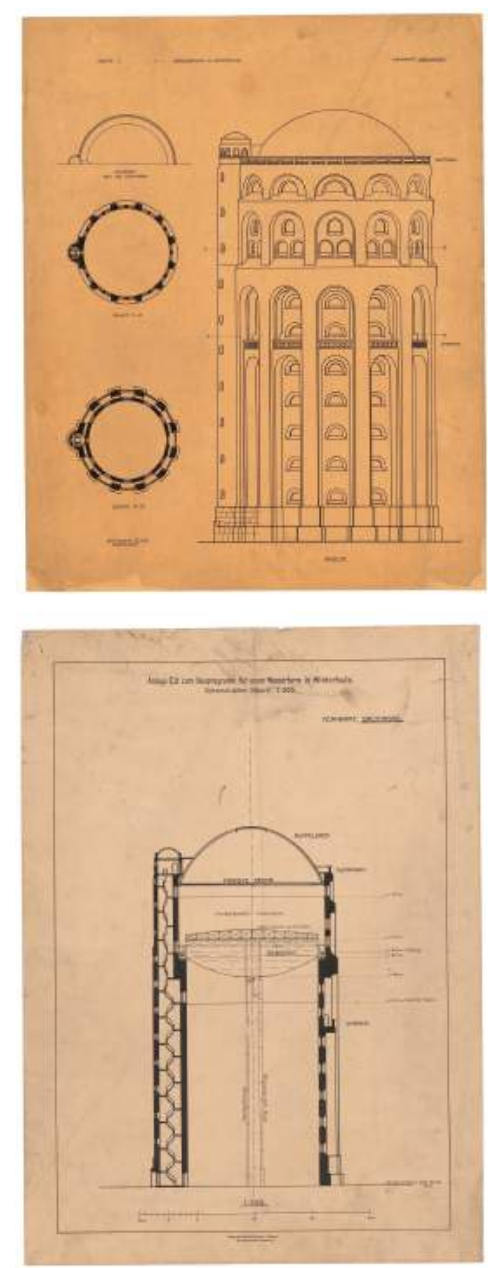

principal do parque da cidade, uma fachada que é estruturada por planos lisos de tijolos que emolduram arcos e nichos colossais. O reservatório metálico com formato cilíndrico e fundo suspenso tem um diâmetro de 23,00 metros e capacidade para armazenar $3.000 \mathrm{~m}^{3}$ de água, o maior exemplar já construído nesta tipologia. Os poucos elementos decorativos presentes na obra e a grande utilização de tijolos aproximam a obra da Reformarchitektur, grupo de tendências arquitetônicas que no início do século $X X$, na Alemanha, buscava uma monumentalidade dos edifícios por meio do uso de materiais e técnicas de construção tradicionais, rejeitando o historicismo e o uso das ordens clássicas. Construída entre os anos de 1912 e 1915, a obra foi concluída apenas em 1916. Em 1928, para ocupar o grande espaço vazio e sem uso sob o reservatório, foi construído um planetário no interior da torre (fig. 2.4.80). O reservatório da torre foi desativado em 1944 devido aos danos sofridos pelo sistema de abastecimento de água de Hamburgo durante a Segunda Guerra Mundial, mas o uso do edifício como planetário permanece até hoje.

Entre as 89 propostas alternativas para a torre de Winterhude estava o projeto de Joseph Maria Olbrich (fig. 2.4.72), que concorreu sob o codinome "Seis Colunas", sobre o qual comentamos anteriormente. Um outro projeto, 002 de codinome "Balthazar", merece a nossa atenção. Esta foi a proposta apresentada por Hans Poelzig (1869-1936), um dos arquitetos alemães mais coerentes e inventivos de sua época, cujos edifícios projetados para a indústria eram caracterizados pelo uso de novas formas para as novas necessidades. Poelzig foi um dos principais expoentes da arquitetura expressionista de seu país e seu trabalho serviu de inspiração para a curta fase expressionista da arquitetura alemã que se desenvolveu no período pós-Primeira Guerra. ${ }^{70}$ "Balthazar" é uma obra tipicamente expressionista, caracterizada pela qualidade monumental e pelo uso amplo e criativo do tijolo aparente, utilizado quase que na totalidade do edifício. A torre (fig 2.4.81) em formato

70 BANHAM, Reyner. Teoria e Projeto na Primeira Era da Máquina. São Paulo: Perspectiva, 2013, p. 121. 


\section{4 .83}

Hans Poelzig, Torre de Água de Winterhude, Hamburgo, Alemanha, 1906-1907. Perspectiva.

\subsubsection{4}

Hans Poelzig, Torre de Água de Winterhude, Hamburgo, Alemanha, 1906-1907. Planta e elevação.
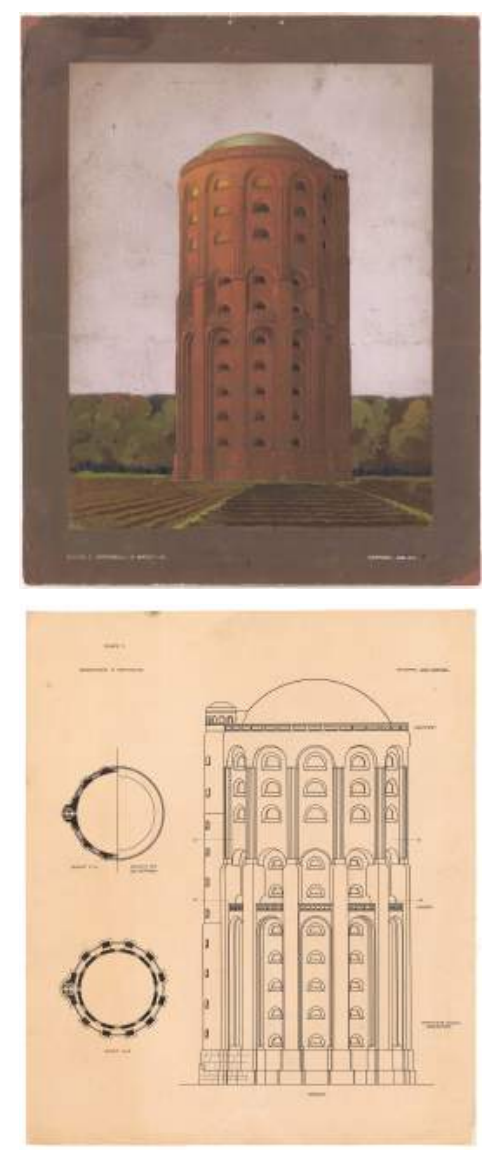

cilíndrico tem um diâmetro aproximado de 30,00 metros e uma altura total de 62,00 metros, coroada por um telhado em formato de cúpula parabólica. As paredes autoportantes são enrijecidas por um conjunto de 12 pilastras encimadas por arcos de volta inteira. Esta pesada arcada, escalonada em profundidade na direção do interior do edifício, é o suporte para as paredes de alvenaria do terço superior da torre, ligeiramente deslocadas em relação às alvenarias inferiores para permitir o apoio do anel de suporte do reservatório e a criação de uma passagem de manutenção de cerca de 1,20 metro entre a parede do reservatório e a fachada da torre (fig 2.4.82). O reservatório metálico de fundo suspenso, cilíndrico, com um diâmetro de 23,00 metros e uma altura de 6,70 metros, está posicionado a 36,00 metros do chão e pode armazenar $2.000 \mathrm{~m}^{3}$ de água. O acesso ao reservatório e ao topo da torre é realizado por meio de uma escada em espiral no interior de um corpo cilíndrico justaposto ao volume principal da torre de água. As aberturas de fachada cuja forma seria recuperada pelo arquiteto no projeto da fábrica de produtos químicos em Luban (1911), são distribuídas em intervalos verticais quase regulares, criando a falsa impressão de um monumental edifício multipisos de caráter, no mínimo, insólito. Exteriormente a fachada fornece poucas pistas acerca da posição ou do tipo do reservatório que a torre de água abriga, uma atitude similar a adotada por Menzel no projeto vencedor do certame, mas diametralmente oposta ao projeto "Seis Colunas", de Olbrich, onde a separação entre reservatório e estrutura de suporte era valorizada e a função do edifício era comunicada. As figuras 2.4 .83 e 2.4.84 mostram uma variação para a fachada da torre de Winterhude, que foi apresentada no certame sob o codinome "Três Reis".

Neste concurso Poelzig apresentou projetos de torres de água para os três bairros de Hamburgo. A torre (figs. 2.4.85, 2.4.86) para o bairro de Sternschanze, que concorreu sob o codinome "Melchior", era uma estrutura mais baixa, com planta hexagonal, mas elaborada com os mesmos materiais e linguagem da torre de Winterhude. No projeto para torre de água (fig. 2.4.87) do bairro de Uhlenhorst temos uma fusão das duas outras propostas, 
uma estrutura mais vertical com uma planta hexagonal. Nas duas propostas temos a presença das monumentais arcadas de tijolos e das singulares aberturas em forma de meio círculo.

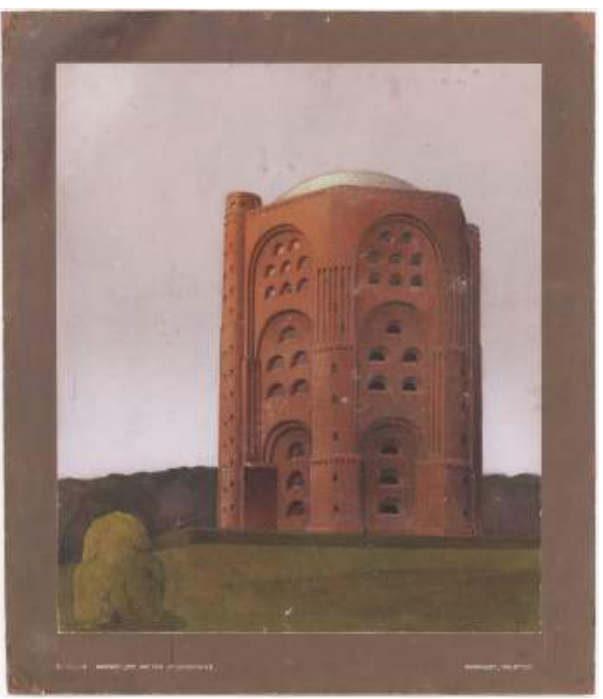

2.4.85

Hans Poelzig, Torre de Água de Sternschanze, Hamburgo, Alemanha, 1906-1907. Perspectiva.

\subsubsection{6}

Hans Poelzig, Torre de Água de Sternschanze, Hamburgo, Alemanha, 1906-1907. Planta e elevação.

\subsubsection{7}

Hans Poelzig, Torre de Água de Uhlenhorst, Hamburgo, Alemanha, 1906-1907. Perspectiva.

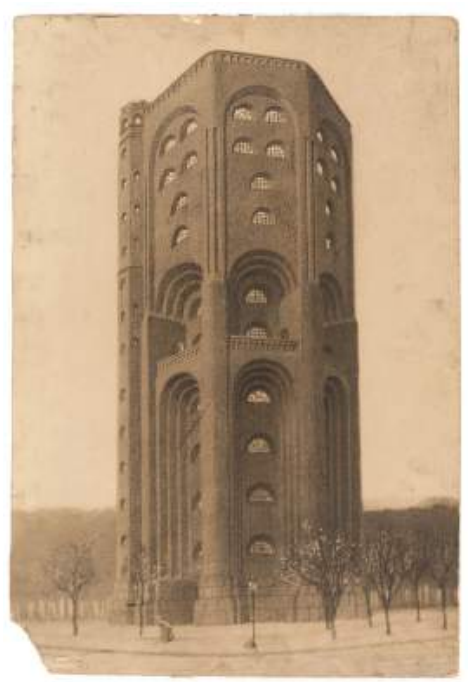

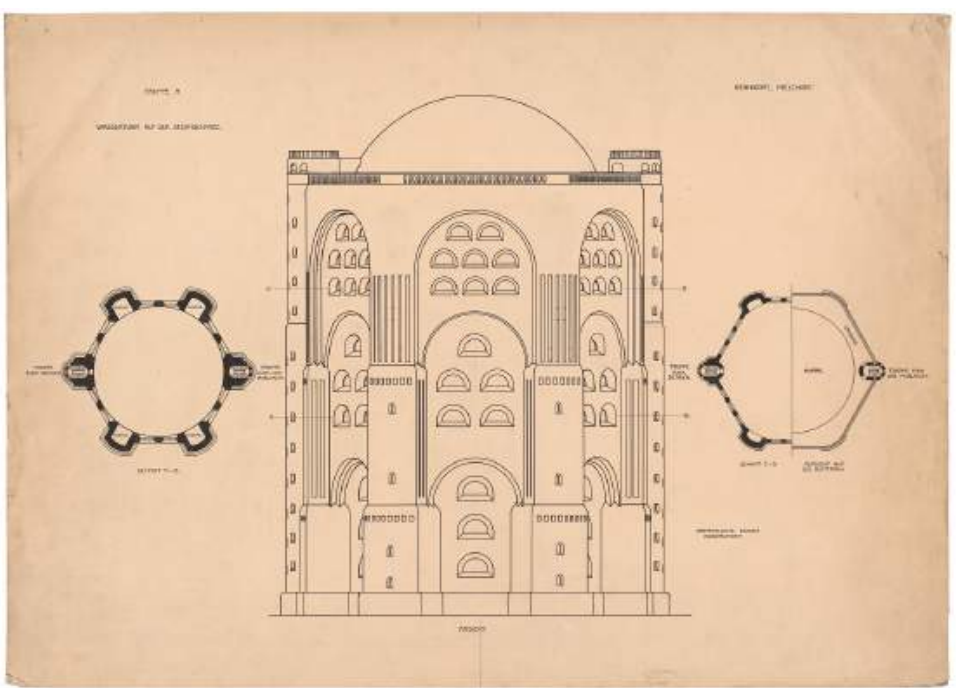

Poelzig projetou em 1911 um grande "pavilhão" destinado à indústria de mineração da Alta Silésia, 003 durante a Exposição de Poznan, na Polônia, um edifício que combina uma finalidade objetiva com uma forma expressiva. $O$ "pavilhão" circular tinha um embasamento com diâmetro de 58,00 metros e uma altura total de 51,20 metros. A dimensão dos andares era variável, com o diâmetro dos pisos diminuindo conforme o edifício ganhava altura. O primeiro piso tinha um diâmetro de 48,00 metros e a último um diâmetro de cerca de 30,00 metros. O topo do edifício, inicialmente projetado para abrigar um restaurante e uma área de observação, foi mais tarde convertido em um reservatório elevado de água e a estrutura passou também a abrigar um mercado municipal em seu embasamento. O corte da figura 2.4 .88 mostra a posição do reservatório cilíndrico de fundo plano que foi instalado no interior da estrutura. Com dimensões aproximadas de 27,00 metros de diâmetro e uma altura de 7,60 metros, e descontado o volume referente ao túnel vertical no centro do tanque, podemos estimar o volume do reservatório em cerca de $4.200 \mathrm{~m}^{3}$, provavelmente um dos maiores reservatórios já construídos nesta tipologia. Foi provavelmente devido a natureza da exposição que Poelzig manteve à mostra o esqueleto metálico com o preenchimento dos vãos estruturais com tijolos de barro sem revestimento e com 
2.4 .88

Hans Poelzig, Torre de Água de Pozen, Polônia, 1910-1911. Planta, corte e elevação. painéis envidraçados. No interior da torre a ênfase dada a estrutura metálica e aos equipamento mecânicos aparentes (fig. 2.4.89, 2.4.90) revela além do atendimento das questões operacionais do equipamento uma disposição para extrair destes elementos possibilidades dramáticas. ${ }^{71}$

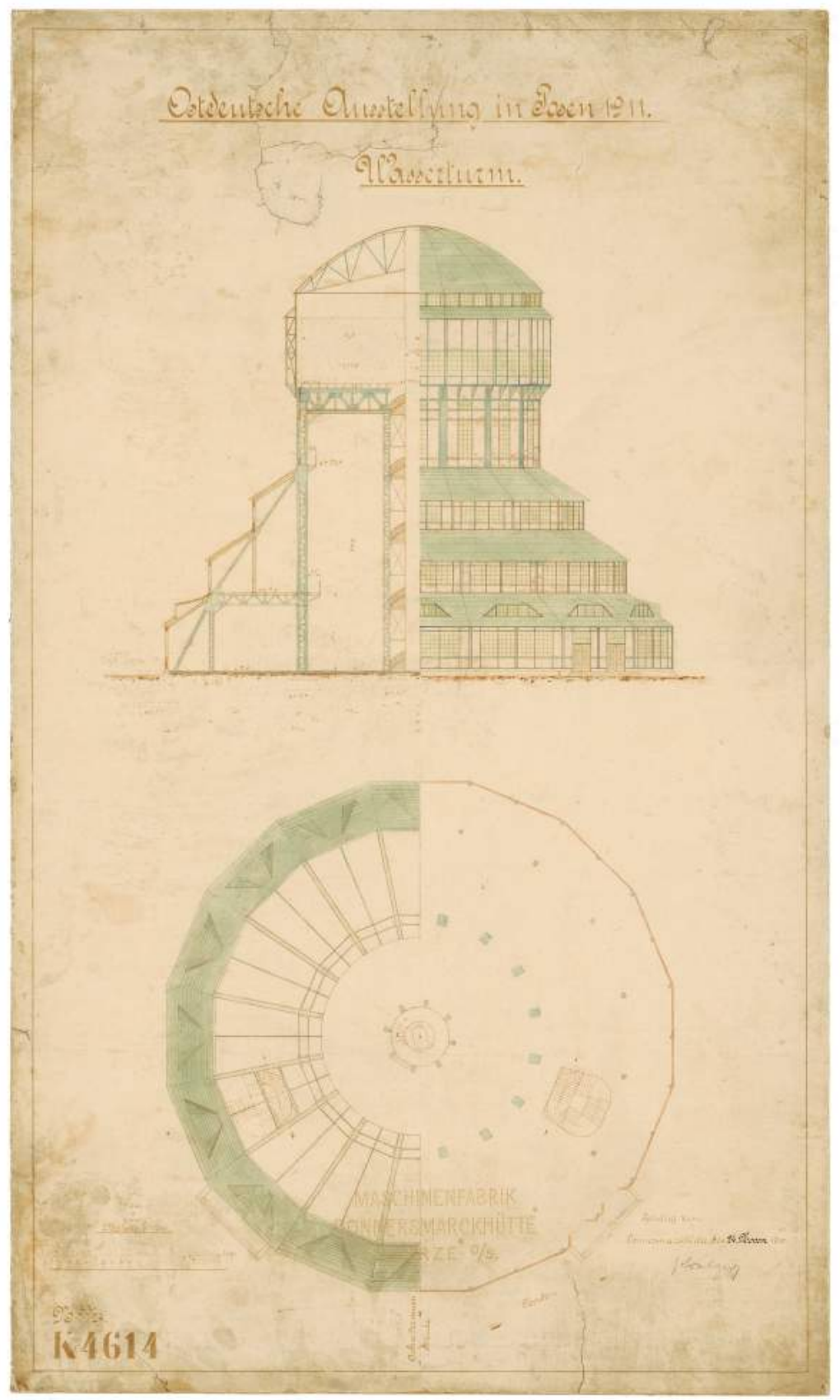

${ }^{71}$ Ibid., p. 121-123. 

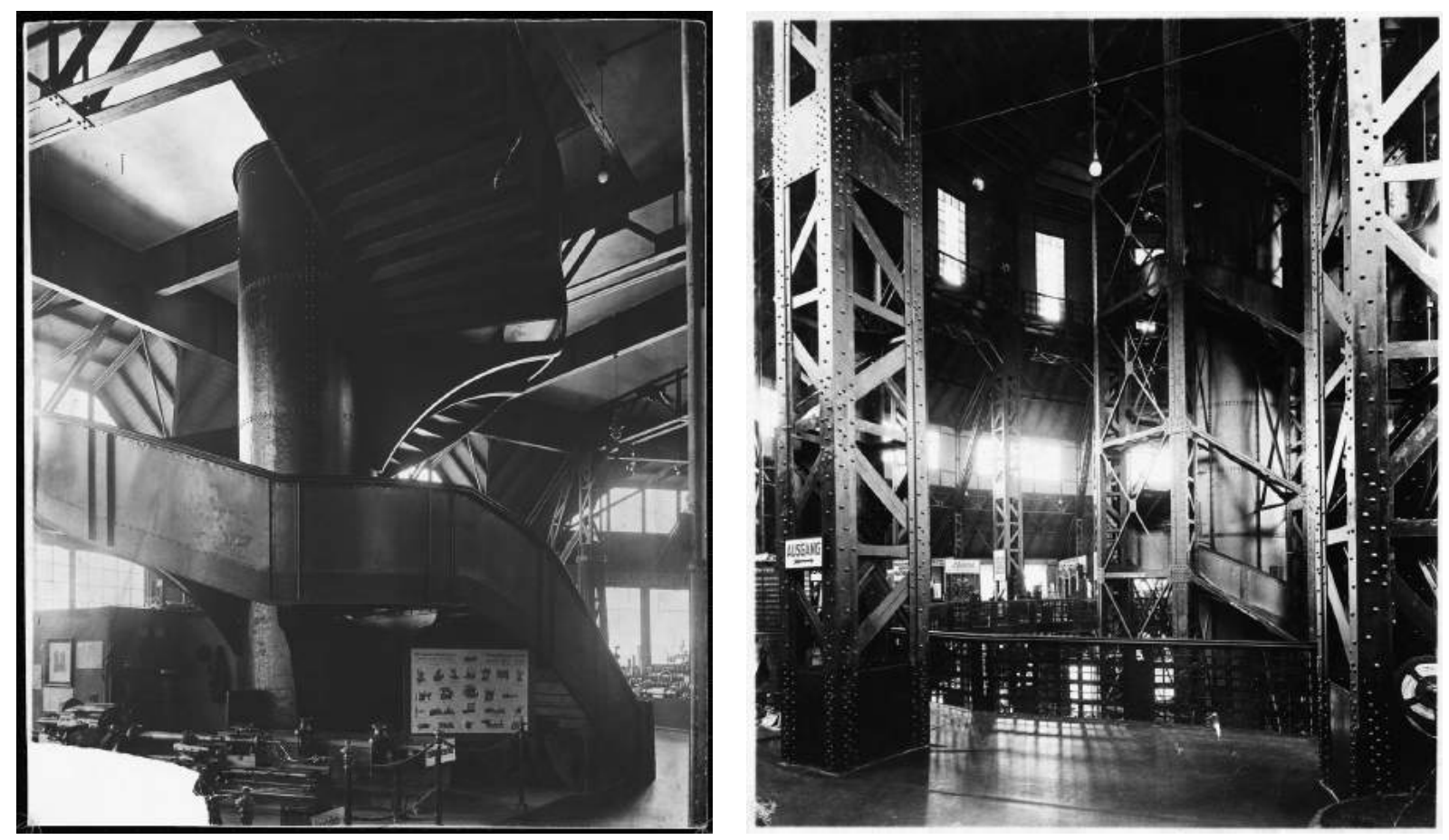

\subsubsection{9}

Hans Poelzig, Torre de Água de Pozen, Polônia, 1910-1911. Vista do interior.

\section{4 .90}

Hans Poelzig, Torre de Água de Pozen, Polônia, 1910-1911. Vista do interior.
Otto Bartning (1883-1959) construiu em 1923 uma pequena torre de água (fig 2.4.91) para uma fábrica de telhas em Zeipau, na Polônia. ${ }^{72}$ Comparada a torre de Winterhude, de Poelzig, com sua superfície moldada e escavada, a torre de água de Zeipau é um obelisco expressionista caracterizado por dobras angulosas e fraturas cristalinas em suas superfícies de tijolos aparentes. O prédio de cinco andares se estreita suavemente para cima e a cobertura do telhado, moldado em duas águas e projetado para além das faces das paredes, acentua a parte superior da torre.

O arquiteto alemão Fritz Höger (1877-1949), um dos expoentes da corrente expressionista alemã no período entreguerras (1919-1939), também aplicou os métodos tradicionais da construção de tijolos para construir torres de água com formas expressivas e dinâmicas. No ano de 1934 Höger construiu uma torre da água (fig 2.4.92) em uma área rural de Hohenkirchen, norte da Alemanha, quando ele ainda era um entusiasta do "movimento" nacional-socialista. Com uma altura de aproximadamente 30,00 metros e uma projeção quadrada de $9 \times 9$ metros, a torre se afila na vertical dividida em sete degraus escalonados. As lesenas

\footnotetext{
${ }^{72}$ GÖSSEL, Peter; LEUTHÄUSER, Gabriele. Arquitectura no Século XX. Colônia: Taschen, 1996, p. 129.
} 


\subsubsection{1}

Otto Bartning, Torre de Água em Zeipau, Polônia, 1923.

\subsubsection{2}

Fritz Höger, Torre de Água em Hohenkirchen, 1934. centralizadas nas fachadas e as gárgulas de concreto posicionadas a meia altura nos cantos da torre conferem ao edifício uma forma assombrosa e inconfundível. Na revista Der Architeckt, Höger escreveu as intenções de seu projeto: "a forma da 'torre de água', crescendo para fora da paisagem, é a forte personificação dos anseios do povo nórdico, a expressão de um gigante silencioso, a expressão do dinamismo do povo germânico setentrional." E continua: "o espírito da própria suástica", deve "brotar com força elementar", do chão, "como um espírito ansioso por uma nova Alemanha."73

O expressionismo frequentemente apresenta características surreais e utópicas, onde a busca por edifícios com uma forma dinâmica e autônoma muitas vezes parece mais importante do que a função prática destas construções, uma posição oposta ao funcionalismo proposto por alguns dos expoentes do Movimento Moderno, cuja arquitetura começava a ganhar visibilidade neste período. ${ }^{74}$
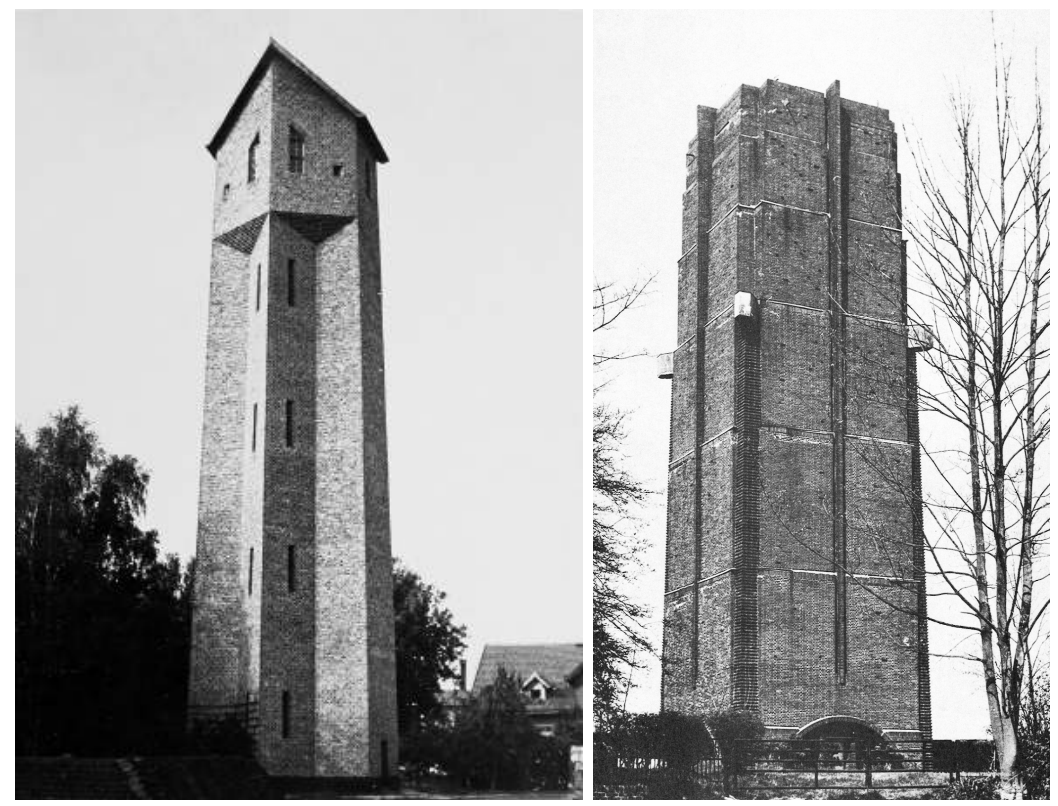

73 "daß dieses Gebilde "Wasserturm" (...) aus der Landschaft emporwächst" und "die stärkste Verkörperung der Sehnsucht der nordischen Menschen, der Ausdruckeinerstillen Gigantik-derAusdruck derDynamik dernordgermanischen Menschen (...) der Geist des Hakenkreuzes selbst (...) mit elementarer Gewalt (...) wie der sehnsüchtige Geist des neuen Deutschland." Apud ASCHENBECK, Nils; SCHMIDT, Jens U.. Wassertürme im Nordwesten. Oldberg: Isensee, 2003, p. 42.

${ }^{74}$ MEVIUS, 1985, op. cit., p. 162. 


\subsubsection{A influência do Movimento Moderno}

O Movimento Moderno, surgido na década de 1920 e operando com grande força até os anos de 1950, surgiu por meio de uma notável convergência de interesses individuais nos Estados Unidos e na Europa. Recorrendo a influências como a dos arquitetos Louis Sullivan e Frank Lloyd Wright, da Escola de Chicago, das teorias de John Ruskin e William Morris e do movimento inglês de Arts and Crafts, inúmeros arquitetos europeus de vanguarda começaram a desenvolver uma arquitetura que consideravam adequada para a vida moderna. Muitos destes arquitetos europeus eram filiados a movimentos progressistas de seus países, tais como a Deutscher Werkbund, Der Ring e Bauhaus na Alemanha, o movimento De Stijl na Holanda e os movimentos M.I.A.R. e Gruppo 7 na Itália. Os principais representantes do movimento na Europa foram os arquitetos Walter Gropius, Le Corbusier e Ludwig Mies Van der Howe. ${ }^{75}$

A arquitetura do Movimento Moderno era caracterizada por formas retilíneas e simples, tetos planos, espaços internos abertos, ausência de ornamentação, planta livre, esqueleto estrutural independente, grandes aberturas e a ampla utilização dos novos recursos materiais e tecnológicos, tais como aço, concreto armado e os grandes panos de vidro. A busca dos arquitetos modernos por novas formas arquitetônicas estava ligada a um interesse por reformas sociais. Seus representantes eram socialistas em seus pontos de vista e utópicos em seus objetivos. A arquitetura moderna que se difundiu de forma esmagadora por todo o mundo desenvolvido no período entreguerras tinha uma aparência homogênea que era enganadora, uma vez que as suas formas planas e suas superfícies despojadas de ornamentos eram facilmente rearticuladas e reinterpretadas para responder à diversidade de situações culturais, climáticas, tecnológicas e econômicas específicas de cada sítio. Esta facilidade de adaptação acabou por se tornar formalista nos casos em que características

${ }^{75}$ BENEVOLO, 2017, op. cit., p. 13-14 e DEMPSEY, 2003, op. cit., p. 142. 
específicas da arquitetura moderna não pudessem ser atendidas devido a limitações econômicas, tecnológicas ou ainda culturais. ${ }^{76}$ Os efeitos e reflexos do Movimento Moderno na arquitetura são sentidos até os dias de hoje e a linhagem de arquitetos modernos, iniciada por nomes como Wright, Le Corbusier e Mies van der Howe, encontra seguidores hoje tanto nos representantes do hightech inglês quanto na arquitetura dos portugueses Álvaro Siza e Souto de Moura, passando por nomes como, por exemplo, Alvar Aalto na Finlândia, Jørn Utzon na Dinamarca e Oscar Niemeyer e Paulo Mendes da Rocha no Brasil.

Talvez o local mais apropriado para começarmos a examinar a influência do Movimento Moderno na arquitetura das torres de água seja na Fábrica Fagus, 005 em Alfeld, Alemanha, geralmente considerada como um dos monumentos fundadores do Movimento Moderno na Europa. Construída entre os anos de 1911 e 1916 conforme projeto de Walter Gropius (1883-1969) e Adolf Meyer (1881-1929), a Fábrica Fagus já foi discutida à exaustão por vários historiadores da arquitetura moderna. ${ }^{77}$ Como bem observou Reyner Banham, a modernidade do grupo de edifícios da fábrica é visível apenas em partes dos blocos, onde são utilizadas paredes envidraçadas. Estes blocos envidraçados contrastam com a nada ousada regularidade neoclássica dos demais edifícios ${ }^{78}$ e também com a solução nada inovadora da torre de água (fig. 2.4.93), projetada como um schornsteinbehälter (reservatório de chaminé).

\footnotetext{
76 FRAMPTON, 1997, op. cit., p. 303.

77 Ver por exemplo: BANHAM, 2013, op. cit., p. 113-

115 e BENEVOLO, 2017, op. cit., p. 375-379.

${ }^{78}$ BANHAM, 2013, op. cit., p. 114.
} 


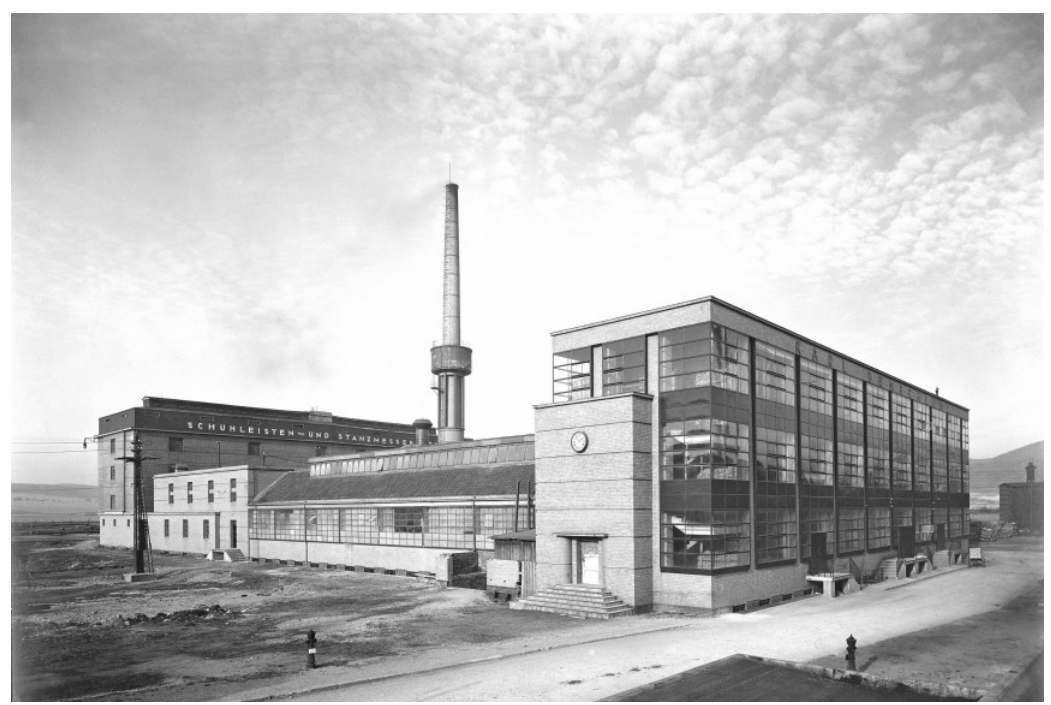

\section{4 .93}

Walter Gropius e Adolf Meyer, Fábrica Fagus, Alfeld, Alemanha, 1911-1916.

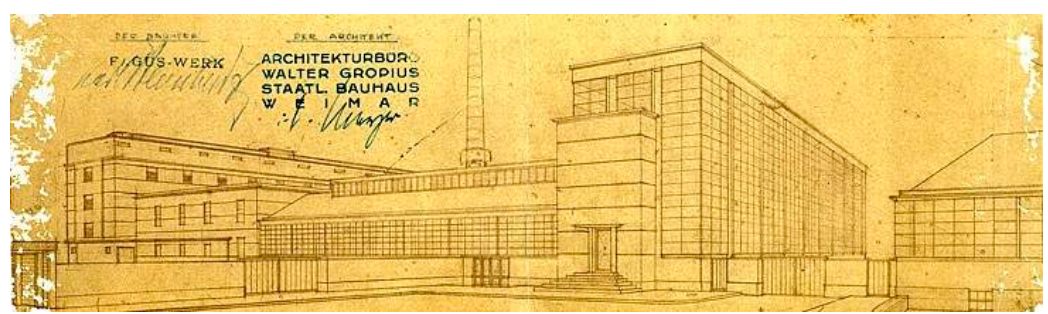

Solução tipicamente alemã o schornsteinbehälter foi desenvolvido no ano de 1885 pelo engenheiro Otto Intze, como um recurso para se aproveitar as chaminés das indústrias como suporte para reservatórios elevados de água, evitando assim a construção das elaboradas e dispendiosas estruturas de suporte. O formato do reservatório de chaminé é basicamente o mesmo do reservatório tipo Inzte I, com acréscimo de um grande vazio central para acomodar a chaminé (figs. 2.4.94, 2.4.95). Ao contrário do que possa parecer, o acréscimo de reservatórios em chaminés se mostrou extremamente vantajoso do ponto de vista estrutural uma vez que a massa de água armazenada aumenta significativamente a estabilidade das chaminés contra os esforços horizontais de vento, isto é, uma chaminé com o reservatório cheio de água se deforma muito menos na horizontal do que com o reservatório vazio, quando esta é submetida aos mesmos esforços de vento. As pesquisas de Otto Intze mostraram também que o carregamento vertical poderia ser absorvido pelas paredes das chaminés sem a necessidade de reforços adicionais na grande maioria dos casos. ${ }^{79}$

${ }^{79}$ WERTH, 1971, op. cit., p. 360-361. 


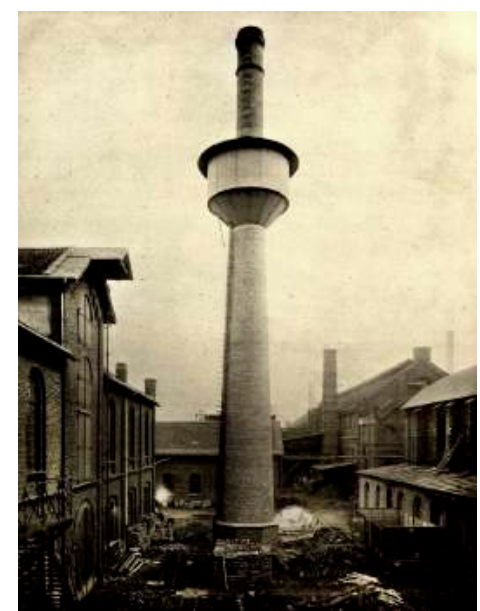

2.4 .95

Reservatório de Chaminé de 40 m3 em Fábrica de Düsseldorf, Alemanha, 1892.

\section{4 .94}

Reservatório de Chaminé de 60 m3 em Fábrica de Hamburgo, Alemanha, 1887. Elevação e corte.

\section{4 .96}

Detalhe Típico de Reservatório de Chaminé de Concreto Armado.
Assim como ocorreu com o reservatório tipo Intze I, o reservatório de chaminé, desenvolvido inicialmente como um tanque de construção metálica, foi adaptado no início do século XX para a tecnologia do concreto armado. Esta é a tecnologia utilizada para o reservatório de chaminé da Fábrica Fagus. A figura 2.4.96 apresenta um detalhe construtivo de um típico reservatório de chaminé executado em concreto armado. O reservatório de chaminé também foi escolhido pelo arquiteto Alvar Aalto (18981976) como solução para a torre de água do Sanatório de Paimio, 013 construído entre os anos de 1929 e 1930.
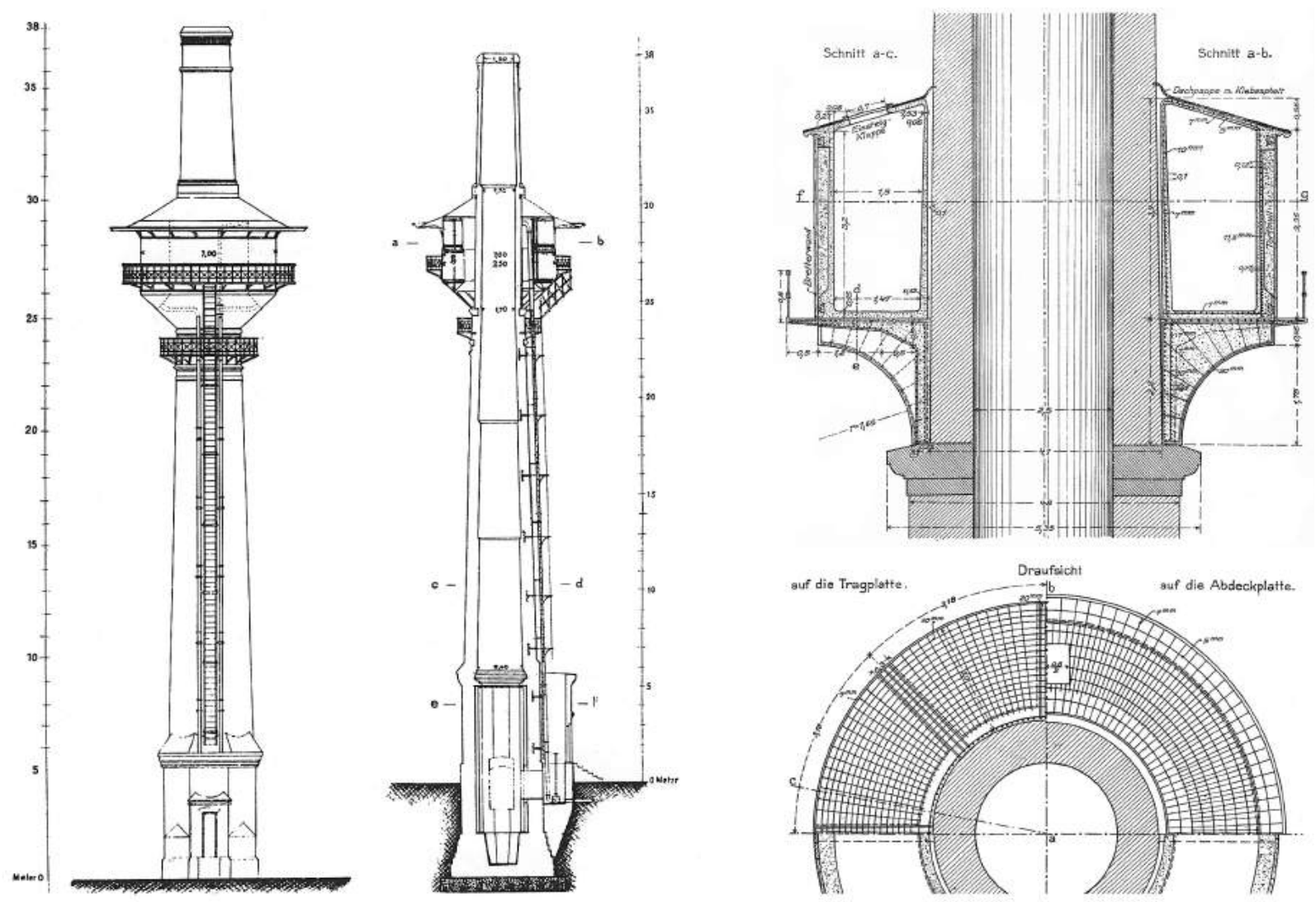

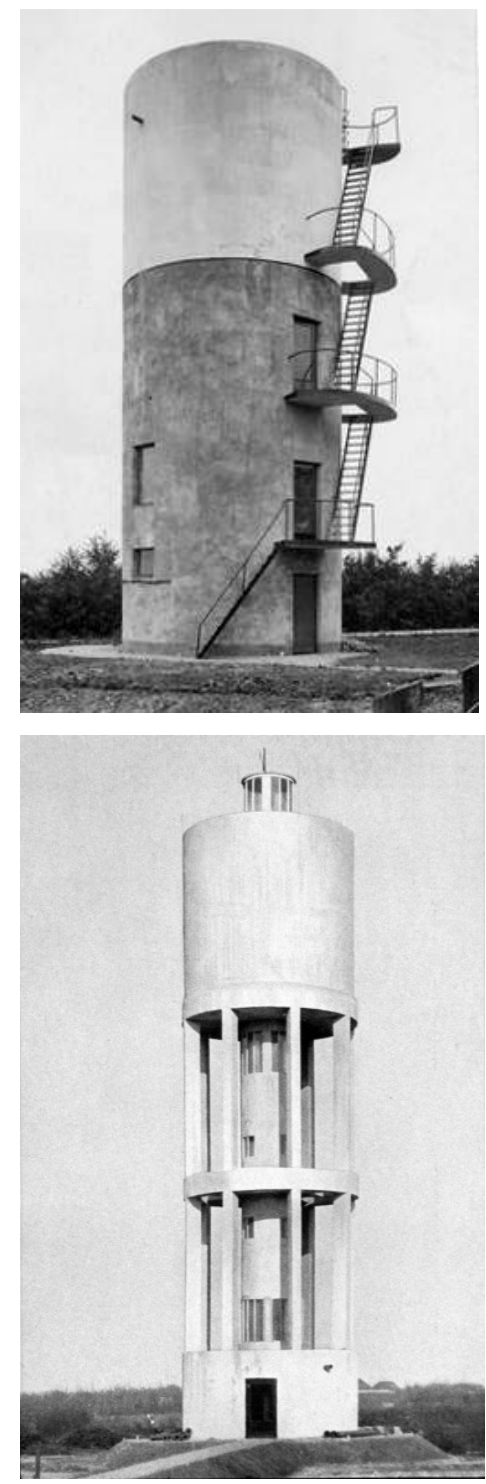

2.4 .97

Sybold van Ravesteyn, Torre de Água da Estação de Goes, Holanda, 1925.

\section{4 .98}

Sybold van Ravesteyn, Torre de Água da Estação de Breda, Holanda, 1927.
Algumas das primeiras torres de água influenciadas pelos ideais do Movimento Moderno surgiram pelas mãos do holandês Sybold van Ravesteyn (1889-1983), um icônico e proeminente arquiteto de instalações ferroviárias que começou a trabalhar para Nederlandse Spoorwegen, principal companhia ferroviária dos Países Baixos, no ano de 1921. Influenciado pelo movimento De Stijl e pelo Construtivismo, Ravesteyn associou-se ao De 8 , um movimento fundado por arquitetos no ano de 1927, em Amsterdã, com o objetivo de promover os ideais do Movimento Moderno. Entre os membros do De 8 estavam os arquitetos Gerrit Rietveld (1888-1964) e J. J. P. Oud (1890-1963). Trabalhando como projetista de estações de trem Ravesteyn projetou uma série de torres de água ferroviárias, um programa padrão neste setor até meados do século $X X .^{80}$

A torre de água (fig. 2.4.97) da estação de Goes (1925) é caracterizada pela simples sobreposição de dois cilindros puros, de mesmo diâmetro. $\mathrm{O}$ cilindro inferior, executado em concreto aparente, tem uma dupla função, servindo como estrutura de suporte para o reservatório de água e também como espaço de uso, abrigando funções de apoio para a estação ferroviária. O reservatório cilíndrico de fundo plano, também executado em concreto armado foi pintado externamente na cor branca. Em Goes opera uma distinção clara entre a estrutura de suporte e o reservatório de água, realizada pelo tratamento distinto do concreto, sem qualquer tipo de alteração formal dos elementos funcionais. Chama à atenção, a aparentemente frágil escada metálica que conecta os pavimentos e conduz ao topo do reservatório.

\footnotetext{
${ }^{80}$ Alternativas tecnológicas para as locomotivas a vapor começaram a surgir na década de 1920. As primeiras locomotivas elétricas começaram a ser introduzidas em redes ferroviárias europeias em 1920. Nos Estados Unidos (1925) e na Alemanha (1935) foram introduzidas as primeiras locomotivas a diesel. Com a recuperação econômica pós-Segunda Guerra Mundial foi iniciado um processo generalizado de substituição do vapor por locomotivas a diesel em muitos países. A utilização de locomotivas elétricas em larga escala ocorre na década de 1960. Até meados do século XX, as locomotivas a vapor tiveram forte presença no setor ferroviário, assim como as "estações de água" que reabasteciam as caldeiras das máquinas a vapor com água.
} 
Em 1927 foi construída a torre de água da estação de Breda, 007 uma obra que teve considerável divulgação em publicações realizadas por expoentes da arquitetura moderna atuantes no período. ${ }^{81}$ Com uma altura total de 31,50 metros e capacidade para armazenar $300 \mathrm{~m}^{3}$ de água, a torre de água (fig. 2.4.98) de Breda tinha a sua estrutura de concreto armado formada for um fuste central e um arranjo de 8 colunas travadas na horizontal por uma viga anular disposta a aproximadamente $1 / 3$ da altura da torre. reservatório cilíndrico de fundo plano tem uma altura equivalente a 1/3 da altura total do edifício. No embasamento um cômodo abriga a casa de manobras e um provável sistema de bombeamento. As faces da parede do reservatório e da parede do cômodo inferior, assim como as faces de pilares e vigas estão todas alinhadas e inscritas dentro de um todo cilíndrico, que faz concessão apenas à lanterna que coroa a torre e dá acesso ao topo do reservatório. O material é homogêneo no todo, com o concreto tendo sido revestido ou pintado na cor branca.

A torre de água (fig. 2.4.99, 2.4.100) da estação de Roermond (1928), guarda certa semelhança com a torre de Goes (1925). O corpo principal da torre, um cilindro com 15,00 metros de altura, repete a solução da sobreposição de volumes que aqui são construídos em materiais diferentes. A estrutura de suporte é executada agora em alvenaria de tijolos vermelhos e o reservatório de água em concreto armado, novamente pintado na cor branca. Em ambos os lados do cilindro foram anexados oficinas e escritórios com plantas em formato de leque, construídos em alvenaria de tijolos vermelhos. Uma escada metálica se desenvolve faceando os vários planos de fachada, criando um percurso dinâmico que conduz do chão até a o topo do reservatório.

\footnotetext{
${ }^{81}$ A torre de água de Breda foi publicada no ano de 1929 no livro Modern Architecture (Arquitetura Moderna), de Bruno Taut (1880-1938). Em 1932 Hendrik Petrus Berlage (1856-1934), inclui a torre de água em sua série de livros Moderne Bouwkunst in Nederland (Arquitetura Moderna na Holanda), em um volume dedicado exclusivamente a edifícios com finalidades técnicas. Anos mais tarde, em 1957, Alberto Sartoris (1901-1998), incluiu a torre de água de Roermond, outra obra de Ravesteyn, na Encyclopedie de L'Architecture Nouvelle: Ordre et Climat Nordiques (Enciclopédia da Nova Arquitetura: Ordem e Clima Nórdicos).
} 


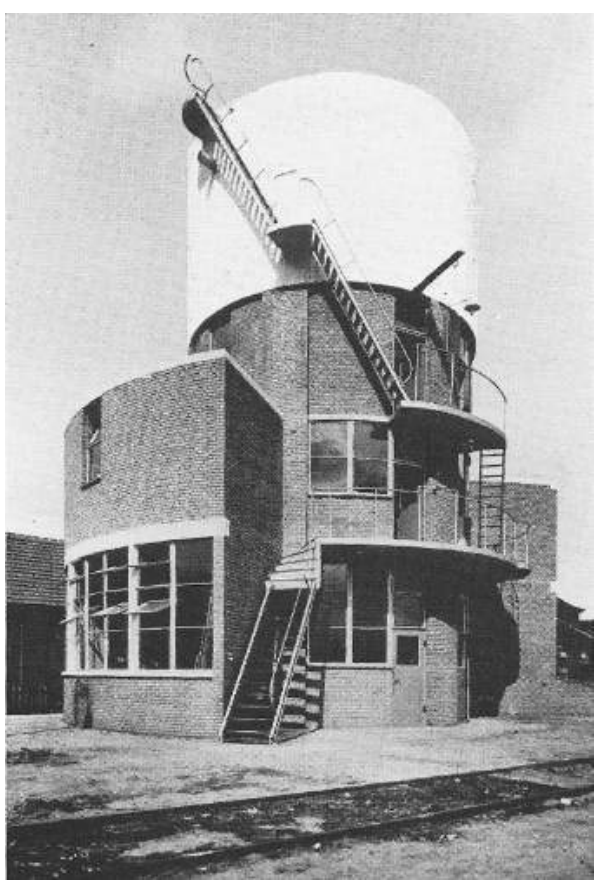

2.4.99

Sybold van Ravesteyn, Torre de Água da Estação de Roermond, Holanda, 1928.

\section{4 .100}

Sybold van Ravesteyn, Torre de Água da Estação de Roermond, Holanda, 1928. Maquete.

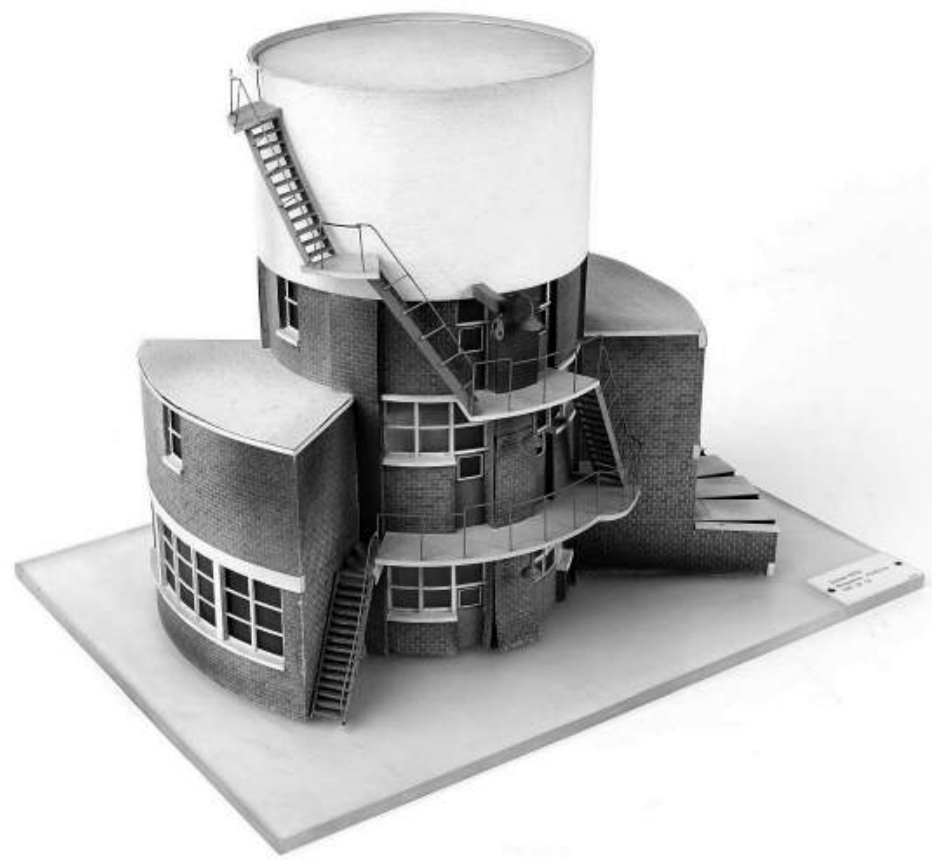

Nesta série de torres de água de Ravesteyn chama a atenção o uso de diferentes estratégias de projeto que acabam surtindo o mesmo efeito: a valorização da separação entre reservatório de água e estrutura de suporte e a comunicação da função do edifício. Em Goes e em Roermond a distinção entre reservatório e estrutura é realizada pelo uso inventivo do concreto na primeira e pelo uso do concreto combinado ao tijolo na segunda, utilizando a mesma solução formal para os elementos estrutura e reservatório. Em Breda o uso do esqueleto estrutural aparente, ainda que no mesmo material do reservatório e do embasamento, garante a distinção entre reservatório e estrutura pela variação formal dos diversos elementos.

Em 1927 foi realizado um concurso de arquitetura para uma nova torre de água para a cidade de Wassenaar, na Holanda. Foram entregues 184 propostas. Praticamente todas as tendências e estilos arquitetônicos estavam representados, inclusive representantes do Movimento Moderno que até aquele momento nunca tinham recebido encargos para projetos de torres de água para abastecimento público de água na Holanda. Os arquitetos H. J. Groenewegen e B. Merkelbach apresentaram um projeto (fig. 2.4.101) de acordo com os princípios funcionalistas no grupo De 8. Mart Stam projetou uma bela torre construtivista, 008 onde o 


\subsubsection{1}

H. J. Groenewegen e B. Merkelbach, Projeto para a Torre de Wassenar, 1927.

\subsubsection{2}

Mart Stam, Projeto para a Torre de Wassenaar, 1927.
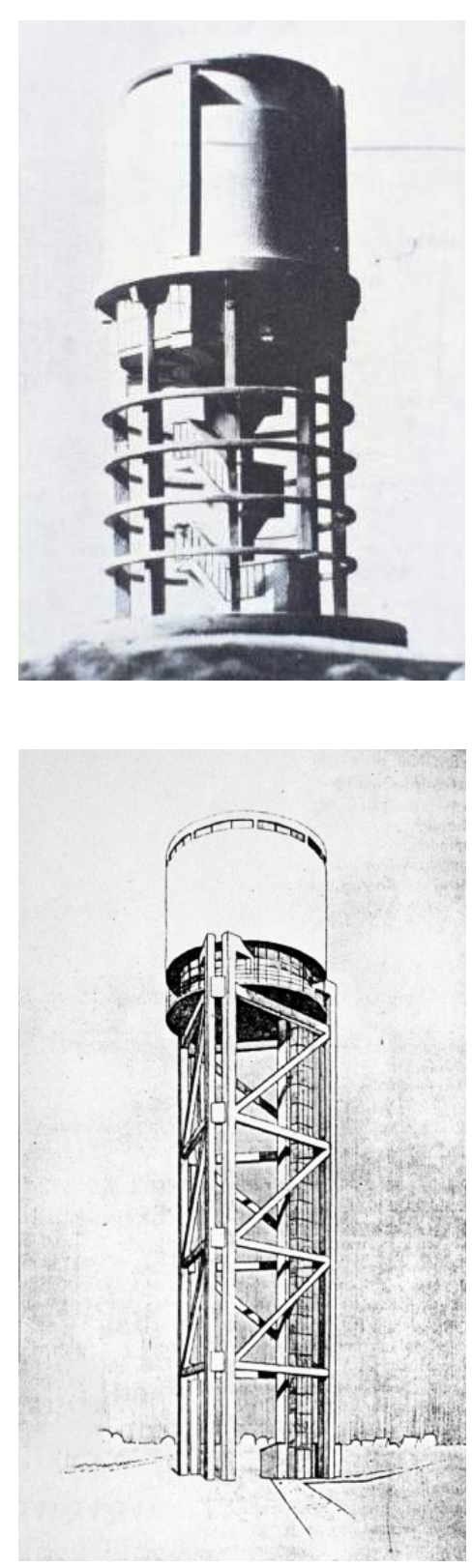

reservatório cilíndrico com fundo em cúpula estava apoiado em um esqueleto estrutural treliçado com planta triangular, ambos construídos em concreto armado. O piso do barrilete e a caixa de escada e tubulações eram fechados com caixilhos de ferro e vidro (fig. 2.4.102). Um terceiro arquiteto moderno, Cornelis van Eesteren, apresentou duas alternativas para a torre de água de Wassenar, uma com uma subestrutura fechada e outra com uma subestrutura aberta, com um custo menor de construção (fig. 2.4.103). Cornelius batizou os seus projetos de "42500" e "39500", respectivamente, uma referencia aos custos de construção de suas torres, dentro do orçamento previsto nas regras do certame, que tinha um teto de 70.000 florins.
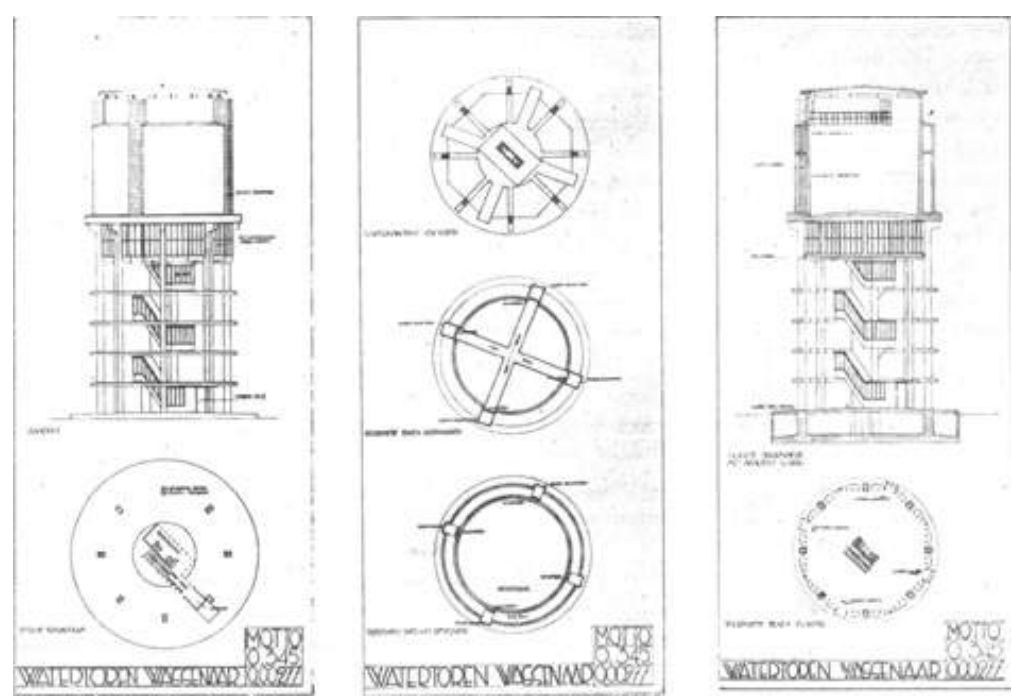

Os projetos de H. J. Groenewegen e B. Merkelbach, Mart Stam e Cornelis van Eesteren caíram fora da competição logo na primeira seleção uma vez que não atendiam aos ideais estéticos do júri que escolheu como vencedor o projeto do arquiteto J. P. L. Hendriks, uma torre (fig. 2.4.104) que mostrava forte influência da arquitetura escandinava e foi de fato construída no ano de 1928. Os arquitetos modernos apresentaram reações furiosas com a escolha do vencedor. $\mathrm{O}$ arquiteto $\mathrm{A}$. H. Van Rood, que também apresentou um projeto moderno para o certame acusou o júri na revista Bouwkundig Weekblad de apreciar a "tristeza da estetização". Cornelius van Esteren se pronunciou na publicação racionalista i10 apresentando seu ponto de vista: "a torre de água, como qualquer outra coisa, deve ter a sua própria forma, originária de sua função 


\subsubsection{3}

Cornelis van Eesteren, Projetos "42500" e "39500" para a Torre de Wassenaar, 1927.

\section{4 .104}

J. P. L. Hendriks, Torre de Água de Wassenaar, 1927-1928.

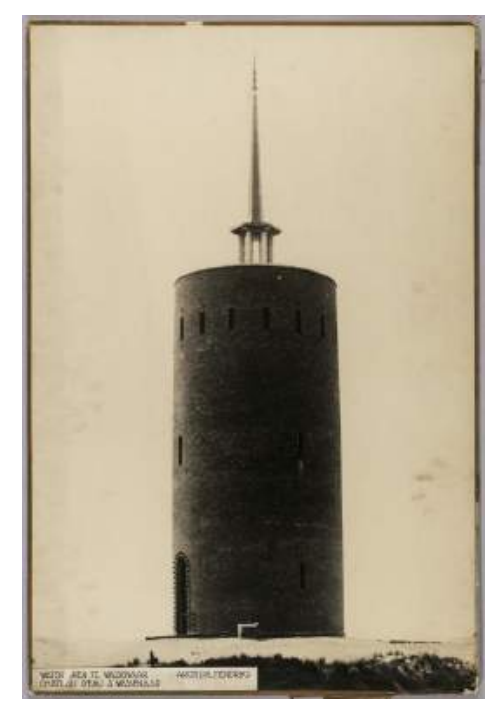

e dos materiais utilizados em sua construção". ${ }^{82}$ Neste período os ideais estéticos dos arquitetos modernos holandeses estavam bem distantes dos ideais estéticos, não apenas do júri do concurso, mas também das companhias de abastecimento e dos órgãos públicos de seu país. Basta lembrar que neste mesmo período o arquiteto Hendrik Sangster, o mais prolífico projetista de torres de água para abastecimento público na Holanda, estava no auge de sua carreira, projetando torres de água em estilo Art Déco.
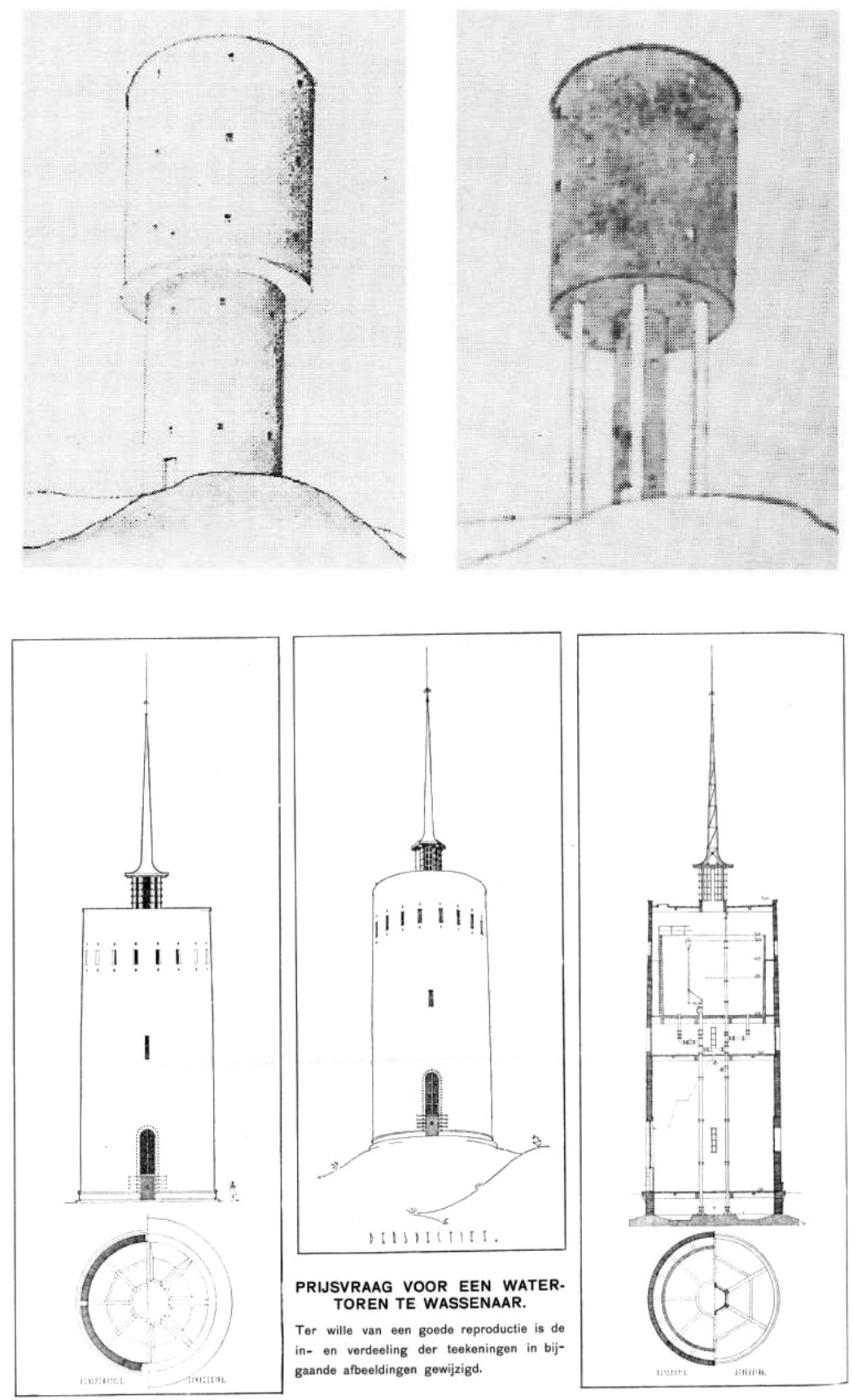

82 VEEN, 1989, op. cit., p. 86-90. 


\subsubsection{5}

Luiz Nunes, Torre de Água do Alto da Sé, Olinda, Pernambuco, Brasil, 1934-1937.

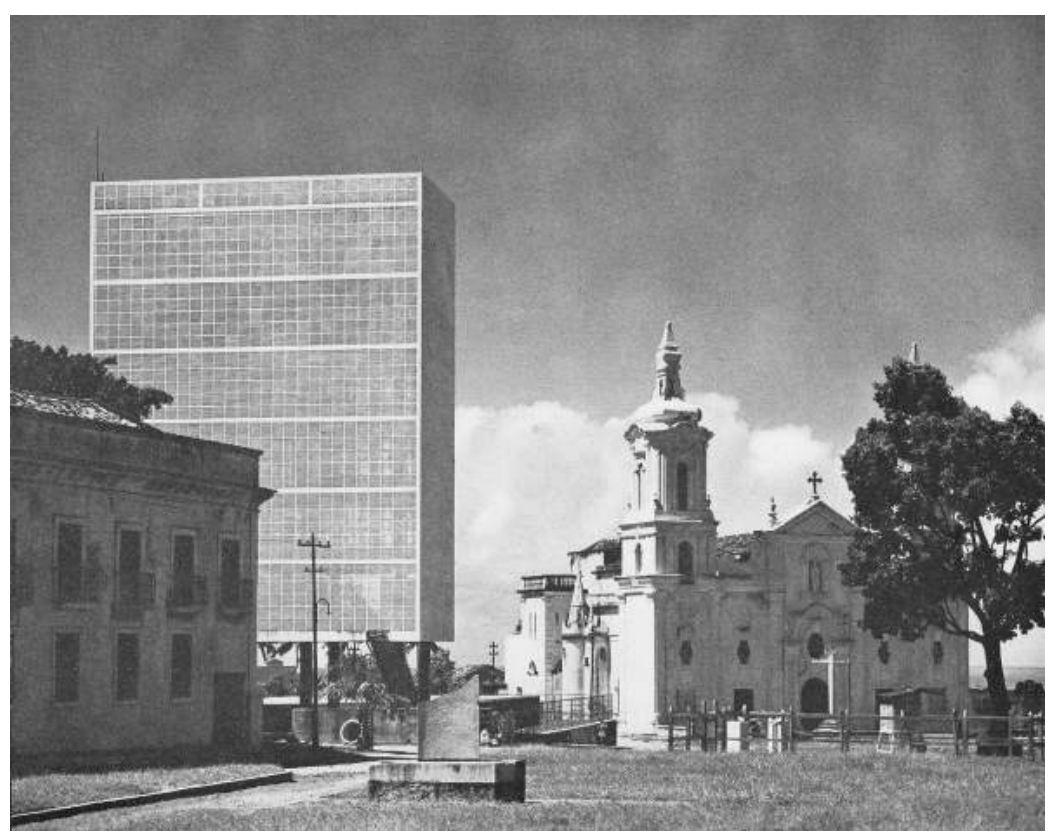

Já no Brasil, especificamente em Pernambuco em meados da década de 1930, a administração modernizante do governador Carlos de Lima Cavalcanti (1892-1967) incumbiu o arquiteto Luiz Carlos Nunes de Souza (1909-1937) da organização de uma inédita repartição de arquitetura que funcionaria de maneira autônoma das tradicionais repartições de engenharia e que seria conhecida inicialmente como DAC (Diretoria de Arquitetura e Construção) e, posteriormente, como DAU (Departamento de Arquitetura e Urbanismo). Luiz Nunes, um adepto do ideário da arquitetura moderna, pretendia que os projetos realizados sob seu comando no DAC/DAU fossem elaborados com o objetivo de introduzir novos métodos construtivos e novos materiais de construção, visando a racionalização dos processos construtivos, o dimensionamento econômico das estruturas e a funcionalidade das plantas. ${ }^{83} \mathrm{Uma}$ das obras realizadas por Luiz Nunes e pela equipe do Departamento de Arquitetura e Urbanismo foi a Torre de Água do Alto da Sé, Olinda, 014 construída em 1937, um equipamento moderno e de grande porte que causou polêmica ao ser implantado em um sítio importante histórico. O local para implantação da torre foi determinado exclusivamente pelas necessidade hidráulicas e houve quem defendesse a construção de uma torre em estilo

${ }^{83}$ SEGAWA, Hugo. Arquiteturas no Brasil: 1900-1990. 3. ed. São Paulo: Edusp, 2010, p. 83 


\section{4 .106}

Luiz Nunes, Torre de Água do Alto da Sé, Olinda, Pernambuco, Brasil, 1934-1937. Esquema estrutural. colonial devido à proximidade com a Sé de Olinda (fig. 2.4.105). O partido adotado para a torre de água segue o ideário da arquitetura moderna de linhas muito sóbrias, ressaltando a sua singularidade no contexto sem entrar em conflito com este..$^{84}$

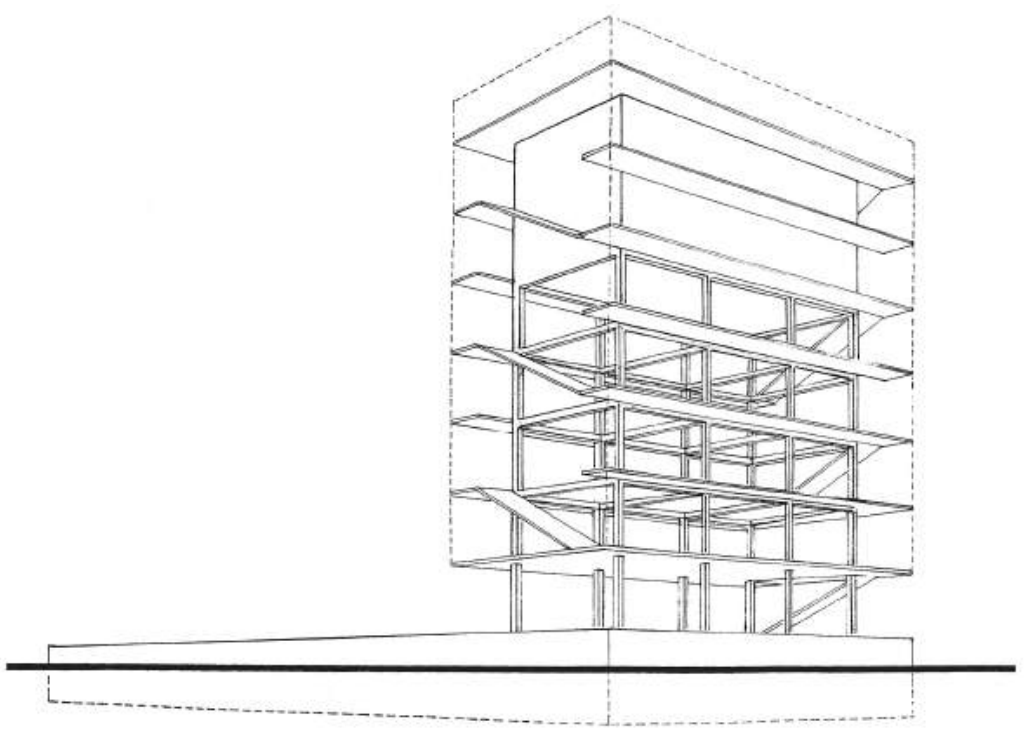

O conjunto edificado é formado por um volume horizontal semienterrado que abriga o reservatório de serviço inferior, apoiado sobre o solo, e pela torre da água propriamente dita, um prisma vertical apoiado sobre pilotis com aproximadamente 18,00 metros de altura e uma planta retangular medindo aproximadamente $6,00 \times 14,00$ metros. O volume sobre pilotis tem as empenas laterais totalmente cegas, enquanto que as fachadas principais são revestidas com cobogós de concreto, com exceção do primeiro pavimento que fica aberto na fachada voltada para a Sé de Olinda, revelando parcialmente a estrutura de concreto armado. A figura 2.4.106 mostra o esquema estrutural da torre de água, com o reservatório retangular de fundo plano ocupando os dois últimos níveis e o sistema de pilares, vigas, escadas e passarelas de circulação em balanço que recebem a "pele" de cóbogos que confere à torre a forma totalmente prismática e guarda certa semelhança com os edifícios multipisos projetados segundo o ideário da arquitetura moderna. A solução de vedação dos vãos

${ }^{84}$ VAZ, Rita de Cássia. Luiz Nunes: arquitetura moderna em Pernambuco, $1934-$ 1937. 1988. 1 v. Dissertação (Mestrado) - Programa de Pós-graduação em Arquitetura e Urbanismo, Faculdade de Arquitetura e Urbanismo, Universidade de São Paulo, São Paulo, 1988, p. 126-127. 
estruturais com o cobogó, utilizada em profusão na arquitetura moderna brasileira, foi utilizada com frequência em torres de água como, por exemplo, na Torre de Pelotas (1927-1952), 009 projeto do Escritório Técnico Saturnino de Brito, e na torre do Anhembi Tênis Clube (1961), projeto de João Batista Vilanova Artigas.

Um dos primeiros projetos de Oscar Niemeyer (1907-1912) foi a "torre de água" de Ribeirão das Lajes, 015 elaborado em 1939 como parte integrante do plano para o novo sistema produtor de água para abastecimento da cidade do Rio de Janeiro e cidades vizinhas a partir da Represa de Ribeirão das Lajes, formada em $1943 .{ }^{85} \mathrm{~A}$ torre de Niemeyer não é estritamente uma torre de água, mas sim um standpipe sendo tomado aqui como exemplo justamente para ilustrar a diferença entre estes dois tipos de equipamento. O standpipe é um prisma retangular ou cilíndrico que nasce ao nível do chão e armazena água em praticamente toda a sua altura, diferente da torre de água, onde o reservatório está elevado do nível do solo por uma estrutura de suporte. Ainda que o standpipe possa cumprir a função de regulação de vazões devido a sua grande capacidade de armazenamento de água e seja capaz de gerar pressões devido à grande altura de sua coluna de água, falta ao standpipe a capacidade para cumprir uma função essencial das torres de água, a função de regulação de pressões na rede abastecimento. No stadpipe de Ribeirão das Lajes, por exemplo, a variação de pressão chega a aproximadamente 26,00 m.c.a., bem acima dos 8,00 m.c.a. recomendado para as redes de abastecimento público de água. ${ }^{86}$ Este standpipe, nunca construído, foi provavelmente previsto no sistema de abastecimento para atuar como um "pulmão" para acomodar os surtos de sobrepressão da adutora de Ribeirão das Lajes, sendo assim localizado em um ponto estratégico na conexão da adutora com as suas ramificações para os diversos pontos de distribuição (ver planta na fig. 2.4.107).

\footnotetext{
85 NIEMEYER, Oscar. Estudo de um "standpipe". Revista Municipal de Engenharia, Rio de Janeiro, v. 6, n. 5, set. 1939, p. 510-511.

86 Uma diferença de nível de água de 8,00 metros é geralmente adotada como um máximo no interior de reservatórios. Ver VEEN, 1989, op. cit., p. 30.
} 
2.4.107

Oscar Niemeyer, Standpipe de Ribeirão das Lajes, Brasil, 1939. Plantas, corte e elevação.
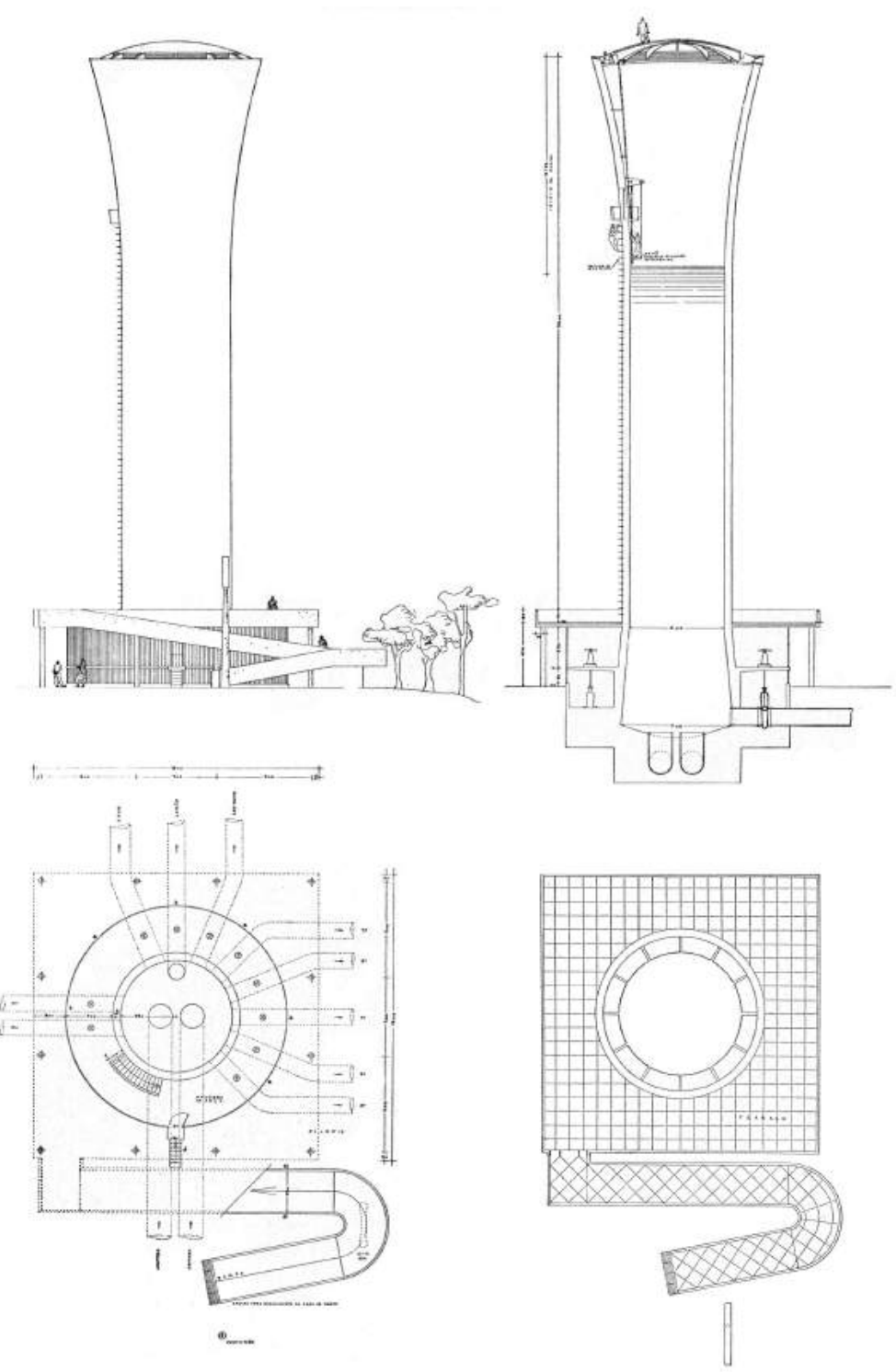

Independente da sutileza na diferença de função, trata-se de um belo projeto (fig. 2.4.107). A torre, na forma de um fuste cilíndrico campaniforme, tem uma altura de aproximadamente 42,00 metros e diâmetros de 7,00 metros na base e 11,00 metros no topo. A parede de concreto armado do fuste tem uma espessura constante de $50 \mathrm{~cm}$ da base até o topo e apoia o sistema de vigas radiais da cúpula de cobertura. No nível do térreo uma sala circular com fechamento envidraçado abriga as válvulas de manobra do sistema hidráulico. A cobertura plana da sala de manobras, com planta quadrada e apoiada sobre pilotis, converte-se em um terraço aberto ao público, acessado por uma rampa externa. A forma da torre de Niemeyer ecoa em duas obras posteriores do arquiteto Carlos Frederico Ferreira (1906-1995), na torre de água 

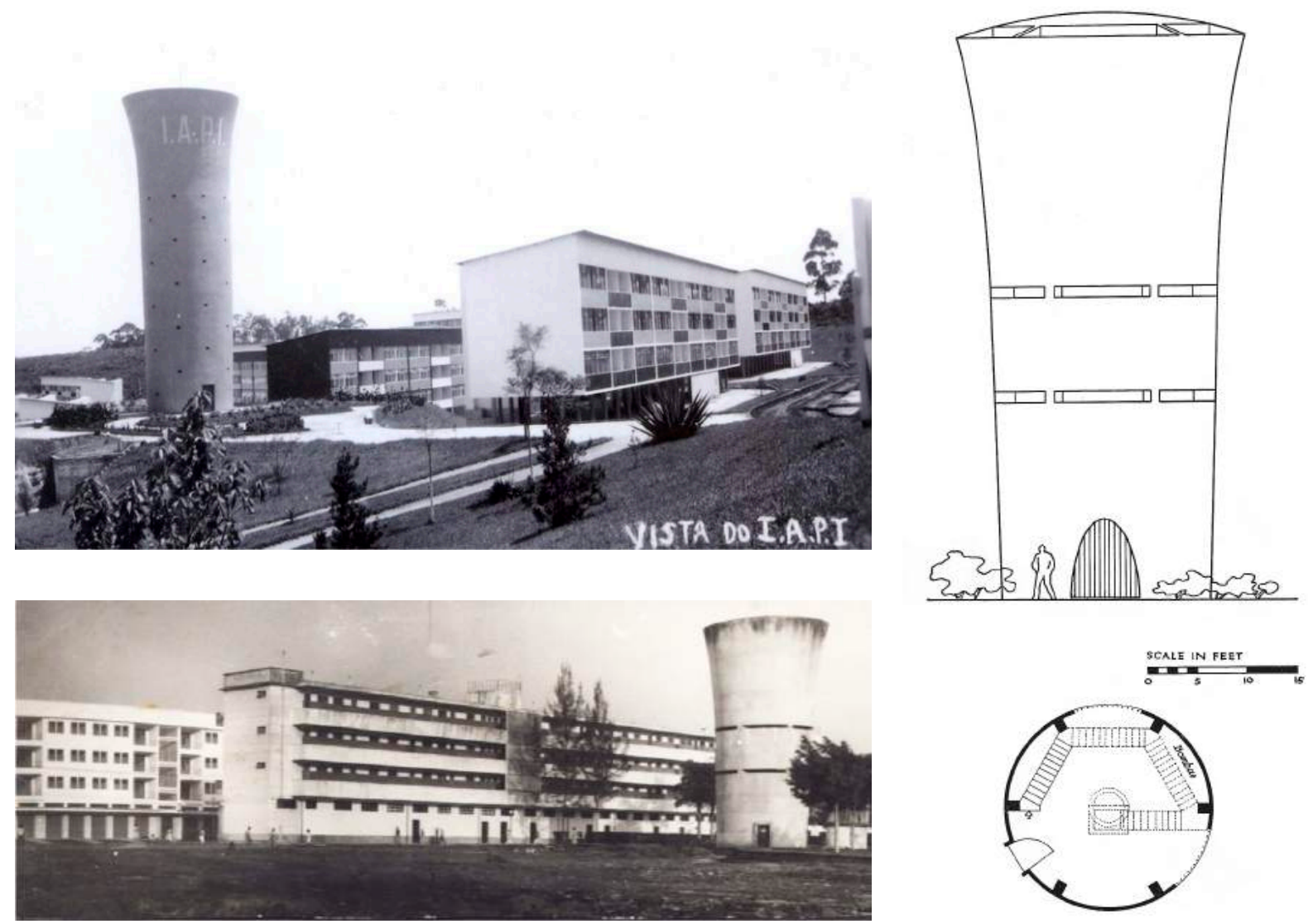

\subsubsection{8}

Carlos Frederico Ferreira, Conjunto Residencial IAPI da Vila Guiomar, São Paulo, 1940.

\section{4 .109}

Carlos Frederico Ferreira, Conjunto Residencial do Realengo, Rio de Janeiro, 1942.

\section{4 .110}

Carlos Frederico Ferreira, Conjunto Residencial do Realengo, Rio de Janeiro, 1942. Planta e elevação. (fig. 2.4.108) para o Conjunto Residencial IAPI da Vila Guiomar, São Paulo (1940) e na torre de água (figs. 2.4.109, 2.4.110) para o Conjunto Residencial do Realengo, Rio de Janeiro (1942). Esta última torre se tornou uma marca registrada, identificando vários conjuntos residenciais do IAPI. ${ }^{87}$

A implantação tardia de modernos sistemas centralizados de abastecimento de água durante meados do século XX não é um fenômeno presente apenas nos países em desenvolvimento. Em 1952, a pequena cidade costeira de Svaneke, na ilha de Bornholm, foi o último município dinamarquês a construir um sistema público de abastecimento de água. Para implantar o sistema foram contratados os engenheiros Preben C. Wistisen e Jørn KlindtJensen que indicaram um amigo de infância de Wistisen, o jovem arquiteto Jørn Utzon (1918-2008), para projetar a torre de água

87 BOTAS, Nilce Cristina Aravecchia. Concreto, muxarabis e cumeeiras para os industriários: a arquitetura e o urbanismo de Carlos Frederico Ferreira na produção do IAPI. In: Encontro Nacional de Pós-Graduação e Pesquisa em Arquitetura e Urbanismo, 1., 2010, Rio de Janeiro. Anais... . Rio de Janeiro: Prourb, 2010. p. 12. 
016 e as estações de bombeamento de água. ${ }^{88}$ Os membros do Conselho Municipal de Svaneke tinham a intenção de construir uma torre de água com tijolos vermelhos aparentes, coberta com um telhado pontiagudo com seteiras, no mesmo espírito das demais edificações da cidade. Alguns conselheiros sugeriram ainda que a torre de água fosse disfarçada para se assemelhar a um moinho de vento. De acordo com um relato posterior de Wistisen, Utzon desprezou "uma ideia tão ridícula e disse que a torre deveria ser mais parecida com as balizas costeiras que eles conheciam tão bem da sua experiência de navegar durante a infância. "89
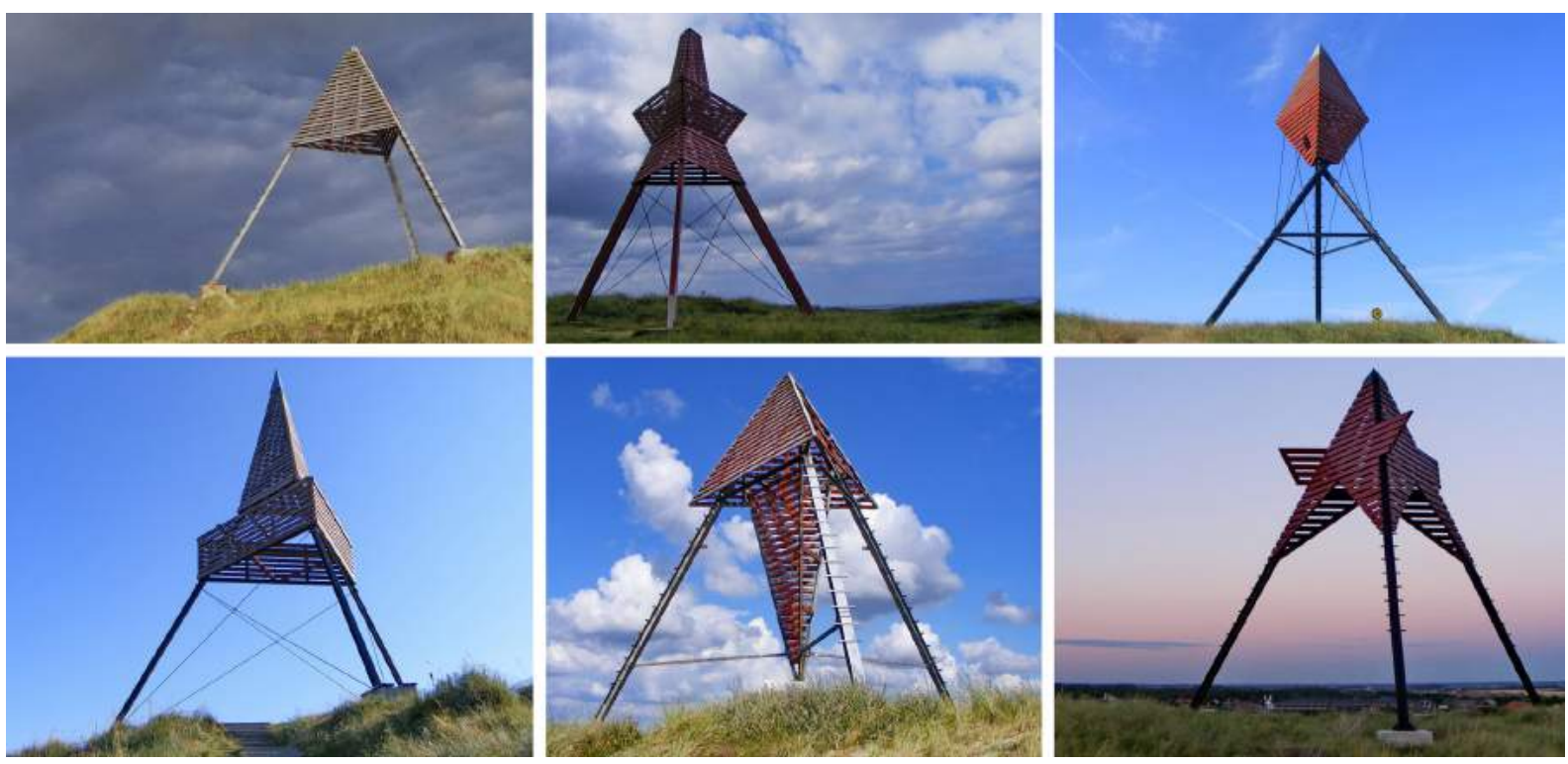

\subsubsection{1}

As balizas costeiras, conhecidas na Dinamarca como båke ou

Balizas costeiras dinamarquesas. Em sentido horário: Haurvig Båke, Løkken Båke, Ringebjerge Båke, Vedersø Båke, Stenbjerg Båke e Gammla Skagen Båke.

fyrbåker, têm sido usadas na costa oeste da península da Jutlândia, Ilhas Kattegat e no arquipélago sueco desde o final do século XVI nos casos em que inexistem marcas de referência distinguíveis ao longo da costa para auxiliar na navegação das embarcações. ${ }^{90} \mathrm{~A}$ figura 2.4.111 mostra uma série de balizas costeiras construídas

\footnotetext{
${ }^{88}$ WESTON, Richard. UTZON: Inspiration - Vision - Architecture. Hellerup, Denmark: Editions Bløndal, 2008, p. 44-45.

89 "Utzon, Wistisen recalls, dismissed such a ridiculous idea out of hand and said the tower should be more like the coastal sea-marks that he and Wistisen knew so well from their experience of sailing as boys." Preben C. Wistisen em entrevista a Richard Weston, 1999. Ver WESTON, 2008, op. cit., p. 44.

90 HANSEN, Hofman. Stykker til Fanøs kultur, natur og historie: Båkerne langs Jyllands vestkyst. 2013. Em Dinamarquês. Disponível em: <http://www.aldus. dk/fanoe/kaaver/jyllands-baaker.html>. Acesso em: 25 nov. 2017.
} 
pela primeira vez na costa oeste da Jutlândia entre os anos de 1884 e 1885 e que hoje são edifícios protegidos pelos órgãos locais de patrimônio cultural. ${ }^{91}$

A torre de água (figs. 2.4.112, 2.4.113) de Svaneke guarda a mesma forma piramidal das balizas costeiras. Suas três delgadas pernas de concreto armado, com dimensões de $100 \times 50 \mathrm{~cm}$, encontram-se no topo da torre a uma altura de 28,85 metros, suportando as paredes laterais de concreto armado do reservatório de água com seu formato de tronco de tetraedro e volume de $120 \mathrm{~m}^{3}$. Um pilar hexagonal, posicionado no centro da projeção da torre, tem função dupla: a primeira é abrigar no seu interior as tubulações hidráulicas e a segunda é criar o suporte necessário para o apoio da escada helicoidal que se estende elegantemente do solo até o barrilete localizado sob o reservatório de água e que, atravessando este por uma passagem circular vertical, atinge a tampa do reservatório ou "plataforma elevada" como o próprio Utzon a batizou.

A torre de Svaneke é uma obra que demonstra claramente uma intenção de se criar uma estrutura expressiva que resolva o programa pretendido. Aqui opera uma distinção clara entre estrutura de suporte e reservatório e a forma piramidal do grande tripé estrutural, que "empurra" o tanque de água para o alto, faz uma correspondência com o funcionamento da torre de água, com a água sendo elevada pela força das bombas até a altura do reservatório e armazenada nele, tornando-se a parte mais valiosa da torre de água.

\footnotetext{
91 Devido as condições severas do clima nas regiões litorâneas as balizas costeiras têm uma vida de serviço relativamente curta, sendo reconstruídas na mesma localização, com sua forma original, a cada 30 anos aproximadamente. Construídas em seus primórdios inteiramente em madeira hoje as balizas passaram a ser reconstruídas utilizando o aço como material estrutural predominante. Mas a madeira ainda tem o seu lugar na confecção dos revestimentos e dos elementos de coroamento. Ver LIEDTKE, Gerd. Richtungs-, Signal- und Landerkennungs. Em alemão. Disponível em: <www.baken-net. com>. Acesso em: 15 nov. 2017.
} 
2.4.112

Jørn Utzon, Torre de Água de Svaneke, Dinamarca, 1952.

\subsubsection{3}

Jørn Utzon, Torre de Água de Svaneke, Dinamarca, 1952. Planta, corte e detalhes.
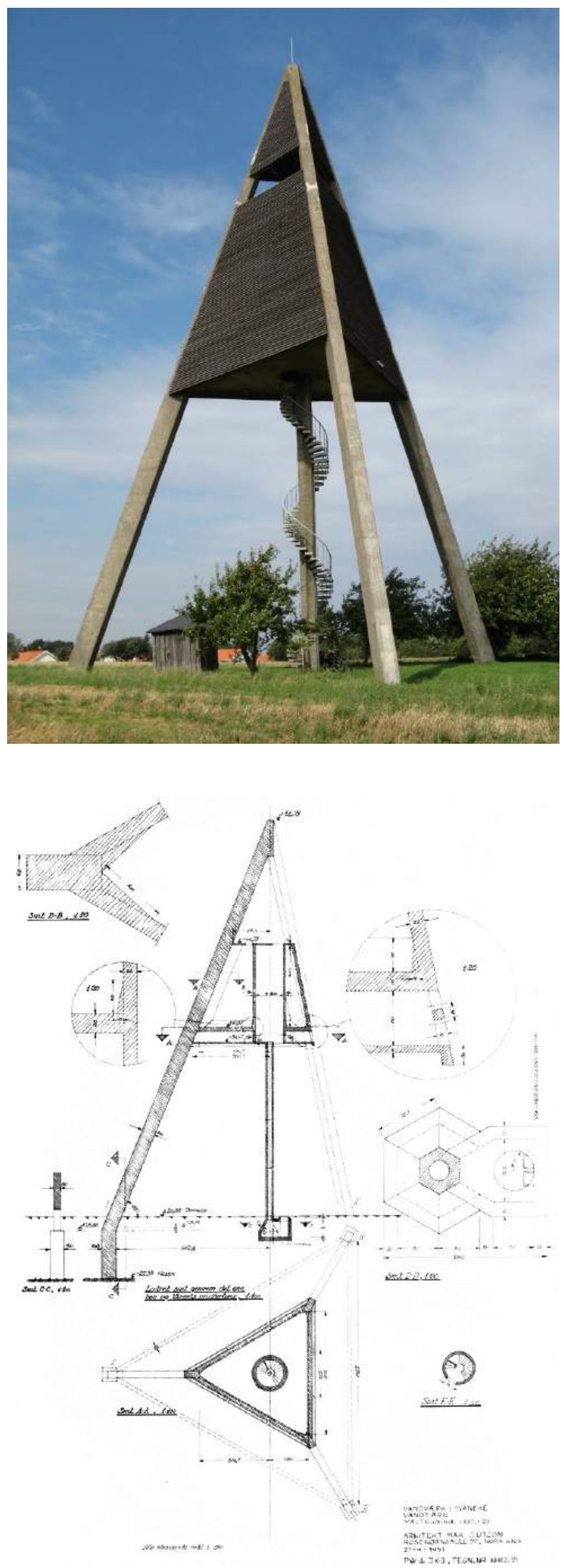

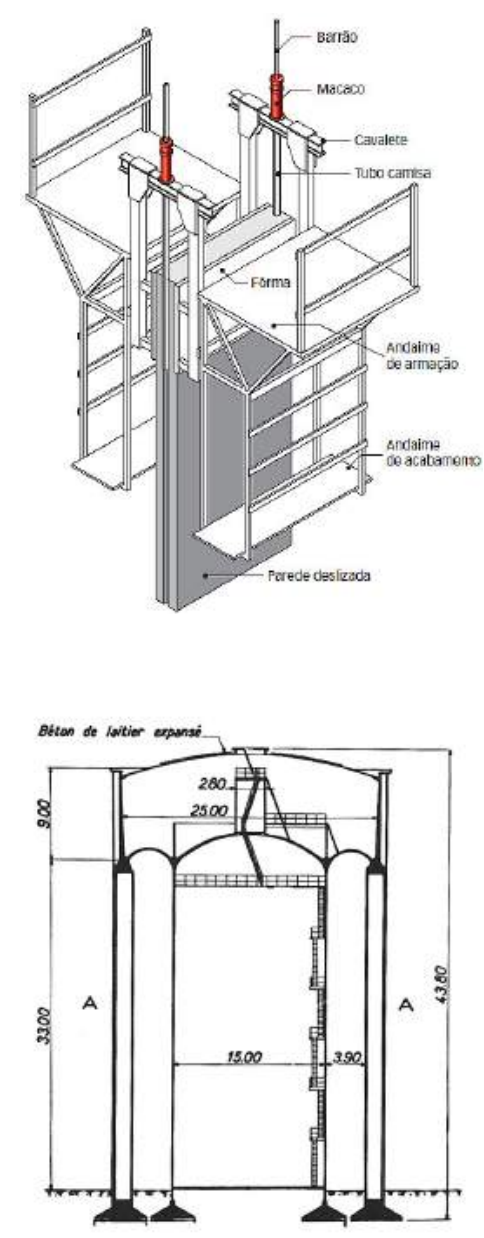

2.4 .114

Sistema de formas deslizantes.

\section{4 .115}

Torre de Água de Havre, França, 1955.
A partir da década de 1950 a forma das torres de água construídas em concreto armado mudou significativamente com o surgimento de subestruturas projetadas como fustes centrais únicos ou em robustas colunas independentes, livres de vigas intermediárias de travamento, dispostas concentricamente em torno de um fuste central. Esta mudança foi causada principalmente pela introdução do método construtivo de formas deslizantes na construção de torres de água. O sistema de formas deslizantes, desenvolvido por volta de 1920 nos Estados Unidos para a construção de silos verticais, provou ser uma alternativa bastante econômica para a execução de estruturas mais altas, uma vez que reduzia significativamente a quantidade de material utilizado para a fabricação de formas e escoramentos. Neste sistema construtivo a forma, que pode ser metálica ou de madeira, é apoiada em cavaletes e andaimes e desliza verticalmente ao longo do perímetro da construção com o auxílio de macacos hidráulicos (fig. 2.4.114). Como a construção deslizante exigia a eliminação de vigas de travamento horizontais para permitir a movimentação vertical da forma ao longos dos pilares, este passaram a ser projetados com um aumento da secção transversal, aumentando assim a sua resistência à flambagem. ${ }^{92} \mathrm{~A}$ já mencionada torre de água de Svaneke (1952) valeu-se do sistema de formas deslizantes para a execução de suas pernas inclinadas.

Exemplos típicos de torres de água que se utilizaram do sistema de formas deslizantes para a construção de uma subestrutura que combina um fuste central com colunas periféricas independentes são as torres de Havre, França, (1955); Oevel (1968) e Putte (1972), ambas na Bélgica (figs. 2.4.115, 2.4.116, 2.4.117, respectivamente).

Outro exemplo deste tipo de construção é a torre de água de Otaniemi, 043 Finlândia, projetada pelo Escritório de Arquitetura

92 WERTH, 1971, op. cit., p. 393. 

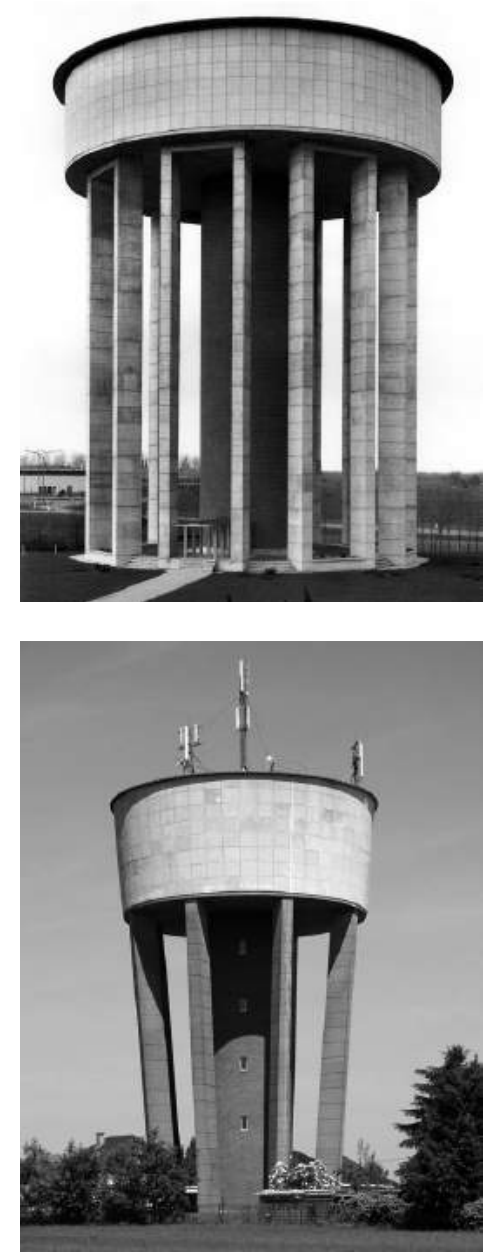

2.4.116

Torre de Água de Oevel, Bélgica, 1968.

\subsubsection{7}

Torre de Água de Putte, Bélgica, 1972.
Alvar Aalto entre os anos de 1968 e $1971 .{ }^{93}$ Além de atender a sua função primeira de armazenar água a torre de água abriga sob o seu reservatório uma central de aquecimento de água e uma série de laboratórios da TKK - Teknillinen Korkeakoulu (Universidade de Tecnologia de Helsinque) distribuídas em um edifício de cinco pavimentos. A torre possui dois reservatórios cilíndricos concêntricos, cada um com capacidade para armazenar $3.000 \mathrm{~m}^{3}$ de água, um para abastecer o campus da TKK e outro para fornecer água para a cidade de Espoo, onde o campus universitário está localizado. A altura da edificação é de 48,00 e o diâmetro externo do volume exterior é de 38,00 metros. O material predominante nas fachadas da torre de água (fig. 2.4.118) é o concreto. As fachadas do edifício inferior são feitas de placas pré-fabricadas de concreto, a escada central e os pilares são de concreto armado moldado in loco e o reservatório de água é revestido com painéis pré-fabricados de concreto que podem ser removidos quando necessário para manutenções na parede do reservatório. O reservatório está apoiado em um fuste central, que abriga o conjunto de escada, elevador e tubulações hidráulicas, e em doze pilares de concerto armado (fig. 2.4.119). Entre os pilares e o fuste central um conjunto de vigas radiais garante o apoio do fundo plano do reservatório. Um volume prismático retangular anexo ao corpo principal da torre, também construído em concreto aparente, abriga as chaminés da central de aquecimento de água. Os reservatórios cilíndricos concêntricos, com um diâmetro externo de 35,80 metros, foram totalmente construídos em concreto protendido, tanto a parede quanto $\circ$

\footnotetext{
${ }^{93}$ Escritório de Arquitetura Alvar Aalto foi fundado em 1923 e permaneceu em funcionamento até a morte de Elisa Aalto, em 1994. Quando Alvar Aalto (1898-1976) começou a envelhecer uma grande parte do trabalho do escritório foi transferida para seus assistentes. $O$ arquiteto Jan Sverker Gardberg, que trabalhou no escritório de Aalto entre os anos de 1963-94, foi o arquiteto encarregado do projeto da torre de água Otaniemi. Naquele período, no final da década de 1960, Aalto estava muito ocupado com o projeto para o Finland Hall, e mal teve tempo para discutir o projeto da torre de água com Gardberg, mas, no entanto, conversaram algumas vezes enquanto o trabalho progredia. Segundo Gardberg, Aalto aprovou os desenhos iniciais e a maquete da torre e ficou bastante satisfeito com o resultado final do trabalho. Para mais detalhes do desenvolvimento do projeto ver: CHARRINGTON, Harry; NAVA, Vezio (Ed.). Alvar Aalto: The Mark of the Hand. Helsinki: Rakennustieto Publishing, 2011, p. 315-318.
} 
fundo, e foram revestidos externamente com placas pré-fabricadas de concreto com uma camada de isolamento térmico na parte interna, ambas instaladas entre os pilares e gerando um volume externo na forma de um prisma dodecagonal (fig. 2.4.120). Todos os elementos verticais, pilares, fuste central, prisma das chaminés e até mesmo as paredes dos reservatórios foram moldadas com sistema de formas deslizantes para concreto. ${ }^{94}$

\subsubsection{8}

Alvar Aalto, Torre de Água de Otaniemi, Espoo, Finlândia, 1971.

\section{4 .119}

Alvar Aalto, Torre de Água de Otaniemi, Espoo, Finlândia, 1971. Corte.

\subsubsection{0}

Alvar Aalto, Torre de Água de Otaniemi, Espoo, Finlândia, 1971. Detalhe do reservatório.
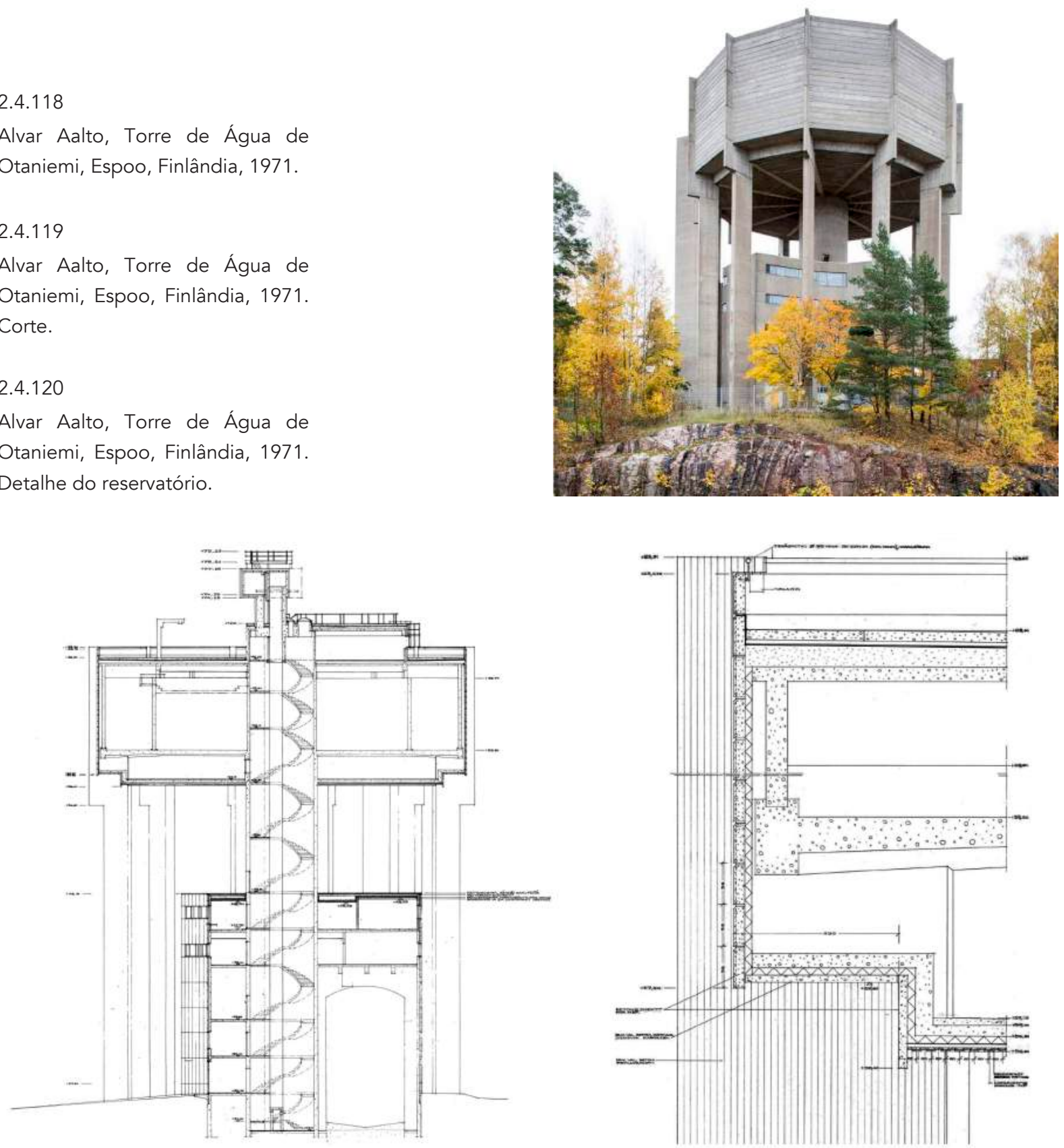

${ }^{94}$ HEIKINHEIMO, Marianna et al. Rakennushistoriaselvitys Otaniemen Vesitorni. Otaniemi: Arkkitehtitoimisto Ark-byroo, 2017, p. 36. 
Este também foi o sistema construtivo escolhido pelo arquiteto Paulo Mendes da Rocha (n. 1928) quando realizou o projeto para o Reservatório Elevado de Urânia 038 em 1968. Mendes da Rocha relata no belo memorial do projeto ${ }^{95}$ que no final da década de 1960 surgiu a necessidade de se construir uma série de torres de água com capacidade para $500 \mathrm{~m}^{3}$ em várias cidades do interior do estado de São Paulo. O DOP (Departamento de Obras e Projetos) já tinha um projeto para estas torres de água, mas tinha desconfiança de que o modelo do reservatório de água, desenhado originalmente na Alemanha e apoiado colunas inclinadas de concreto, ${ }^{96}$ fosse a solução mais adequada para o caso e chamaram o arquiteto para uma discussão. Mendes da Rocha teve a ideia de construir o reservatório elevado de água da mesma maneira que se constroem os silos de concreto para o armazenamento de grãos, isto é, um simples cilindro vertical construído com o sistema de formas deslizantes. Mas havia um inconveniente: a medida padrão das formas deslizantes era de apenas 5,00 metros de diâmetro, sendo que para armazenar os $500 \mathrm{~m}^{3}$ de água seria necessária uma coluna de água com uma altura de aproximadamente 25,00 metros, inviável tanto do ponto de vista estrutural quanto do ponto de vista hidráulico, uma vez que isto resultaria em enormes flutuações de pressão na rede de abastecimento. A solução para o problema não demorou a surgir, como o próprio arquiteto nos conta:

"... posso fazer quantos cilindros eu achar necessário, até atingir os 500 mil litros, e colocar em cada torre o máximo de água que ela aguentar, ligando os reservatórios pelo princípio de vasos comunicantes. Posso fazer um feixe deles que poderão ser construídos em dez, quinze dias. É um projeto lindo! Tenho que primeiro verificar o tamanho da coluna d'água necessária e depois dou o valor arquitetônico à associação dos cilindros. O diâmetro das colunas pode até variar um pouco, não muito, deve ficar próximo dos cinco metros. ${ }^{197}$

95 ROCHA, Paulo Mendes da. Maquetes de Papel. São Paulo: Cosac Naify, 2007, p. 53-58.

96 Provavelmente uma típica torre Intze, com o reservatório apoiado em um esqueleto estrutural, ambos construídos em concreto armado.

97 ROCHA, 2007, op. cit., p. 56. 
No caso da cidade de Urânia foram propostos três cilindros

2.4.121

Paulo Mendes da Rocha, Reservatório Elevado de Urânia, Brasil, 1968. Plantas, cortes e elevação.

\subsubsection{2}

Paulo Mendes da Rocha, Reservatório Elevado de Urânia, Brasil, 1968. Maquete. (fig. 2.4.121). com diâmetros de 5,00 metros e altura total de 40,00 metros, interligados por dois níveis de passarelas, uma embaixo e outra em cima dos reservatórios. Em conjunto com as torres de água o arquiteto também propôs um recinto de visitação pública, um espaço para shows, reuniões e eventos diversos, uma laje de cobertura de 40 × 40 metros cercada de água por três lados em um espelho d'água que se estenderia até as três torres, ficando todas as construções envoltas pela água (fig. 2.4.122).
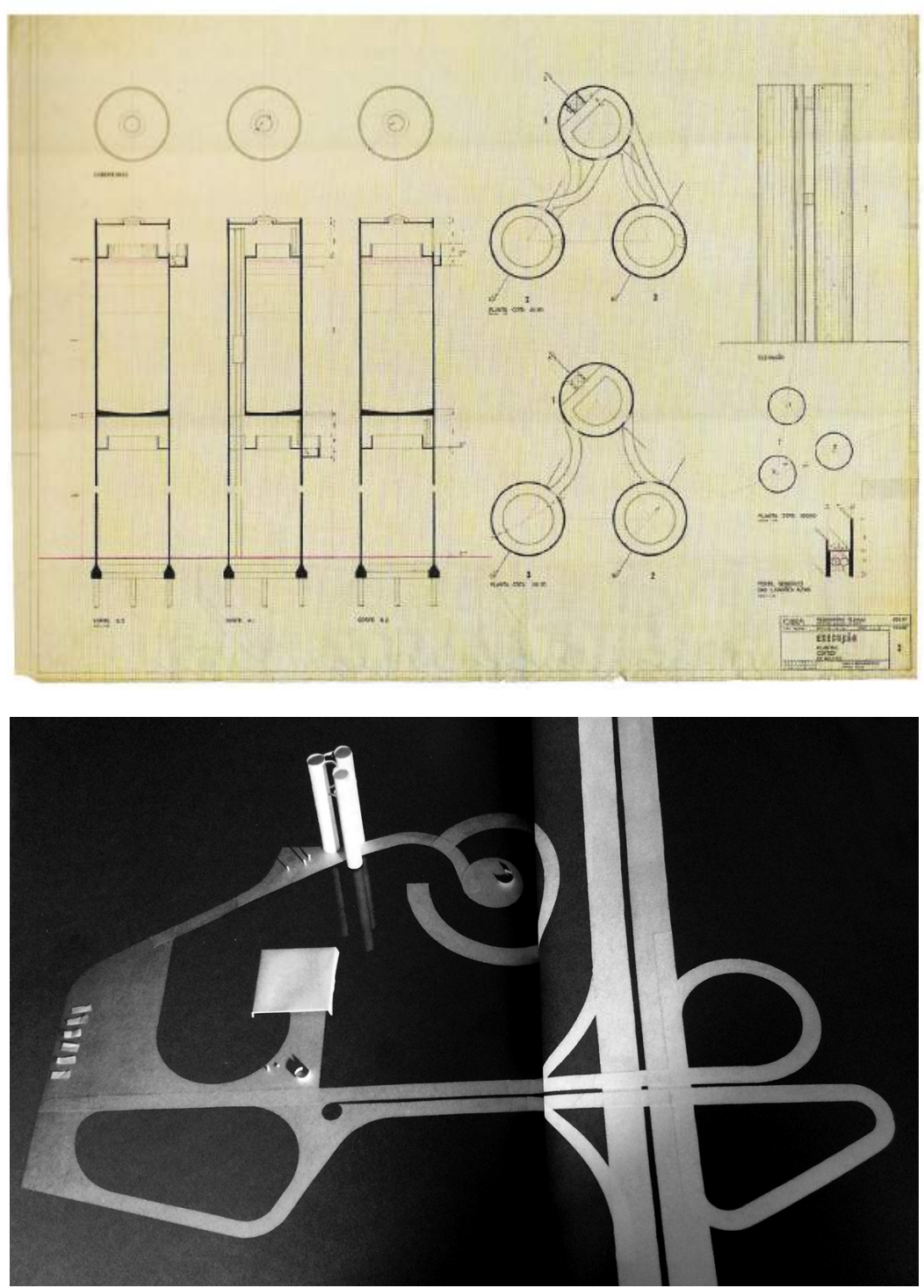
As décadas de 1960 e 1970 foram marcadas pela construção de grandes estádios, aeroportos, pontes rodoviárias, paredes e coberturas de membranas, estruturas espaciais, coberturas autoportantes, arcos parabólicos, todos executados em materiais modernos e altamente tecnológicos como o concreto protendido, alumínio, cabos de aço e materiais sintéticos como as membranas de PVC e o Plexiglass, com projetos assinados por nomes como Buckminster Fuller, Frei Otto, Jørn Utzon, Kenzo Tange, Pier Luigi Nervi, entre outros. Um momento de intensa produção de estruturas criativas durante a qual os projetistas, arquitetos ou engenheiros, prestaram grande atenção ao desenho da forma alinhada com a engenhosidade do desenvolvimento das novas tecnologias construtivas.

Para a fábrica FIAT Mirafiori, em Turim, o engenheiro italiano Pier Luigi Nervi (1891-1979) projetou e construiu uma torre de água 032 entre os anos de 1961 e 1963 utilizando o princípio de pré-fabricação de elementos em um sistema que elimina significativamente a necessidade da utilização de formas e de escoramentos auxiliares para a construção de estruturas de concreto armado. A torre de Mirafiori (fig. 2.4.123), com capacidade para armazenar $2.000 \mathrm{~m}^{3}$ de água, tem 63,00 metros de altura, sendo 45,00 metros de fuste, 13,50 metros de reservatório e mais 3,50 metros do belvedere no topo da estrutura. O fuste cilíndrico de 8,00 metros de diâmetro e $50 \mathrm{~cm}$ de espessura de parede foi concretado com uma forma constituída de painéis pré-fabricados de ferrocimento, com raio de curvatura de 4,00 metros, largura de 1,20 metros, altura de 2,83 metros e uma espessura de apenas $3 \mathrm{~cm}$ (fig. 2.4.124). ${ }^{98} \mathrm{O}$ reservatório (fig. 2.4.125), em forma de parábola de revolução tem uma parede de concreto com uma espessura média de $25 \mathrm{~cm}$ e também foi construído com formas pré-fabricadas de ferrocimento, criando um conjunto formado por cinco séries de painéis triangulares nervurados, com 40 painéis idênticos em cada série. A figura 2.4.126 mostra os detalhes das nervuras de

${ }^{98}$ Depósito elevado para la Fiat. Informes de La Construcción, Madrid, v. 18, n. 172, p. 581-23, jul. 1965. 

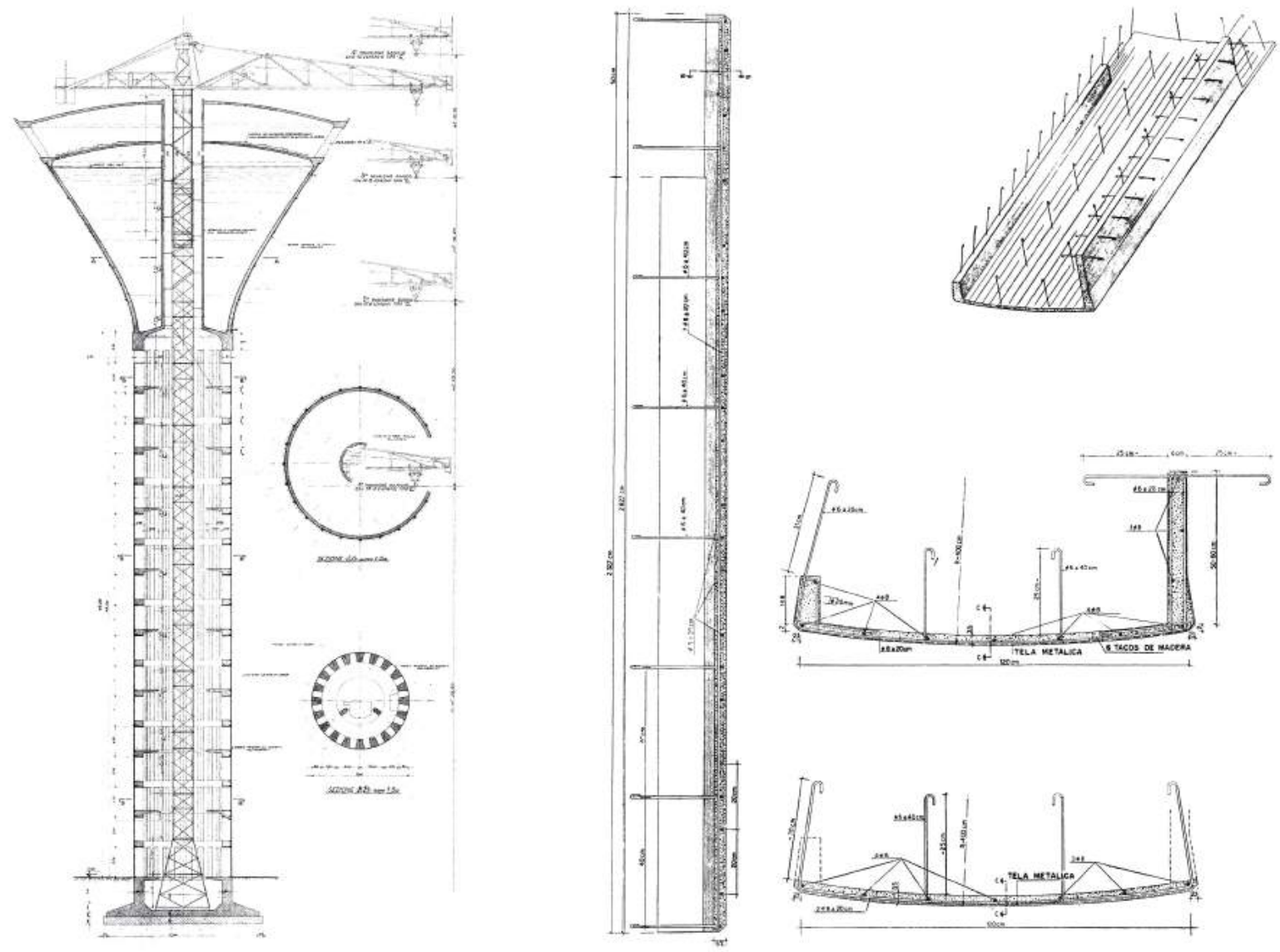

\section{4 .123}

Pier Luigi Nervi, Torre de Água da Fábrica FIAT Mirafiori, Turim, Itália, 1963. Corte.

\subsubsection{4}

Pier Luigi Nervi, Torre de Água da Fábrica FIAT Mirafiori, Turim, Itália, 1963. Detalhe dos painéis de ferrocimento do fuste.

\section{4 .125}

Pier Luigi Nervi, Torre de Água da Fábrica FIAT Mirafiori, Turim, Itália, 1963. Detalhe do Reservatório.

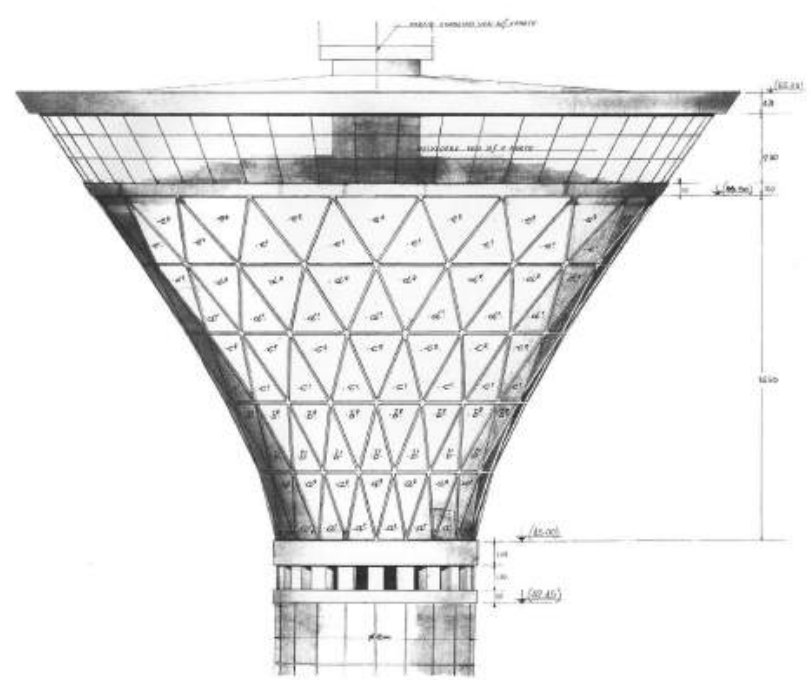



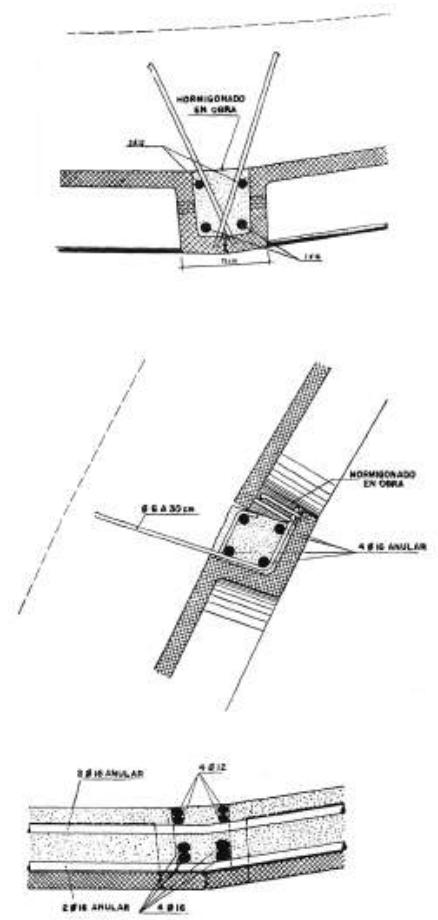

2.4 .126

Pier Luigi Nervi, Torre de Água da Fábrica FIAT Mirafiori, Turim, Itália, 1963. Detalhe das juntas dos painéis do reservatório. ligação entres os painéis. Após a concretagem destas nervuras e da montagem de todos os painéis que compunham a forma do reservatório foi possível concretar a parede do reservatório sem a necessidade de escoramentos externos. A cúpula de cobertura do reservatório e do belvedere também foram executadas com elementos pré-fabricados de curvatura esférica com 2,5 cm de espessura, enrijecidos por nervuras meridionais, e sobre os quais foi concretada uma capa de laje com $4 \mathrm{~cm}$ de espessura. Todos os elementos pré-fabricados de ferrocimento foram fabricados no canteiro de obras, um total de 600 peças, dos quais 340 para o fuste e 200 para o reservatório. ${ }^{99}$

Foi pelas mãos do arquiteto alemão Frei Otto (1925-2015) que surgiu um dos mais inventivos e singulares projetos de torres de água realizados no século XX. Desenvolvido em 1959 e publicado pela primeira vez no livro Zugbeanspruchte Konstruktionen (Estruturas Tensionadas) de 1962, o projeto apresentado na figura 2.4.127 é uma torre de água que, muito provavelmente, não possui antecedentes históricos no que se refere a forma, tipologia de reservatório, sistema estrutural e materiais de construção utilizados. A sofisticada estrutura proposta por Frei Otto é reduzida a um número mínimo de elementos e tira partido da leveza e resistência das membranas sintéticas e da resistência dos cabos de aço apresentando-se como uma alternativa extremamente econômica para a construção de torres de água. Ainda que o custo unitário de cada material seja relativamente alto, a quantidade de cada um dos materiais utilizado é mínima, o que certamente resultaria em uma construção com uma baixíssima relação peso de estrutura/m³ de água armazenada. Trata-se aqui de uma concepção estrutural e formal "material" , isto é, cada um dos elementos propostos trabalha de modo a aproveitar ao máximo as propriedades mecânicas do material de que é feito e a forma de cada um destes elementos é determinada justamente com este objetivo. Os cabos de aço e as membranas dos reservatórios, materiais flexíveis, trabalham

${ }_{99}$ COMBA, Michela (Ed.). Maire Tecnimont: I Progetti FIAT Engineering 19311979. Milano: Silvana Editoriale, 2011, p. 202. 

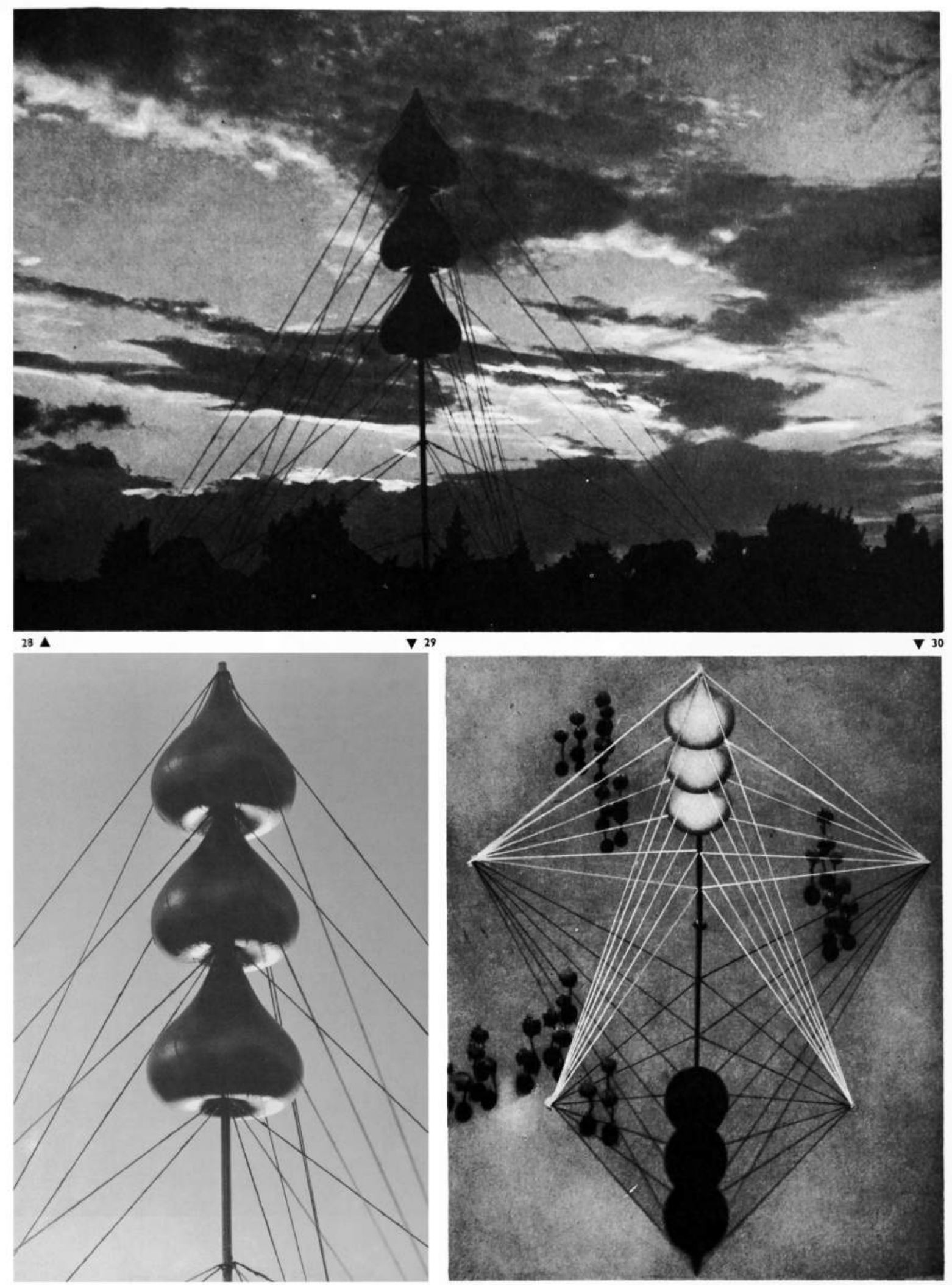


\subsubsection{7}

Frei Otto, Projeto de Torre de Água, 1965. Maquete.

\section{4 .128}

Frei Otto, Projeto de Torre de Água, 1965. Detalhe do reservatório. exclusivamente sob esforços de tração. $\bigcirc$ mastro central, único elemento rígido, com uma secção tubular, trabalha sob esforços de compressão. A altura total do mastro central da torre seria de 40,00 metros e cada reservatório, construído com tecido sintético reforçado com malha de aço, teria um diâmetro de 8,00 metros. ${ }^{100}$ Não existem muitos dados sobre o projeto a não ser a breve descrição do autor que reproduzimos aqui na íntegra:

"Em uma torre de água projetada, um reservatório é suspenso em um mastro guiado. Uma secção transversal vertical é mostrada na secção na Fig. 25, e uma secção horizontal do reservatório na Fig. 26. Para torres esbeltas, facilmente desmontáveis, secções horizontais como na Fig. 27 podem ser utilizadas em casos excepcionais. Nesta solução, três reservatórios podem ser içados entre os cabos de aço. Os reservatórios devem estar interligados, uma vez que níveis diferentes de água resultam em momentos de flexão consideráveis no mastro central. A Figura 28 mostra o projeto completo, a Fig. 29 apenas a parte superior e a Fig. 30 um modelo visto obliquamente de cima." 101102

Nos dias de hoje, quando sabemos que milhares de pessoas não têm acesso à água potável e considerando que algumas das primeiras ações feitas em zonas de emergência são com o objetivo de assegurar o abastecimento de água para populações em risco, é importante desenvolver sistemas de construção econômicos e facilmente transportáveis, montáveis e desmontáveis como este desenvolvido por Frei Otto.

\footnotetext{
100 GLAESER, Ludwig. The Work of Frei Otto. New York: MoMA, 1972, p. 121.

101 "In a projected water tower a container is suspended from a guyed mast. A vertical cross section is shown in section in Fig. 25, and a horizontal section through the container in Fig. 26. For slender, easily dismountable towers, horizontal sections as in Fig. 27 may be adivisable in exceptional cases. In this design three containers can be hoisted between the guying cables. The containers must be interconnected since unequal levels induce considerable bending moments in the central mast. Figure 28 shows the complete project, Fig. 29 only the top, and Fig. 30 a model viewed obliquely from above." OTTO, Frei (Ed.). Tensile Structures. Cambridge: MIT Press, 1977, p. 140.

${ }^{102}$ A numeração de figuras citadas por Frei Otto em seu texto foi reproduzida na integra nas figuras 2.4.127 e 2.4.128.
} 


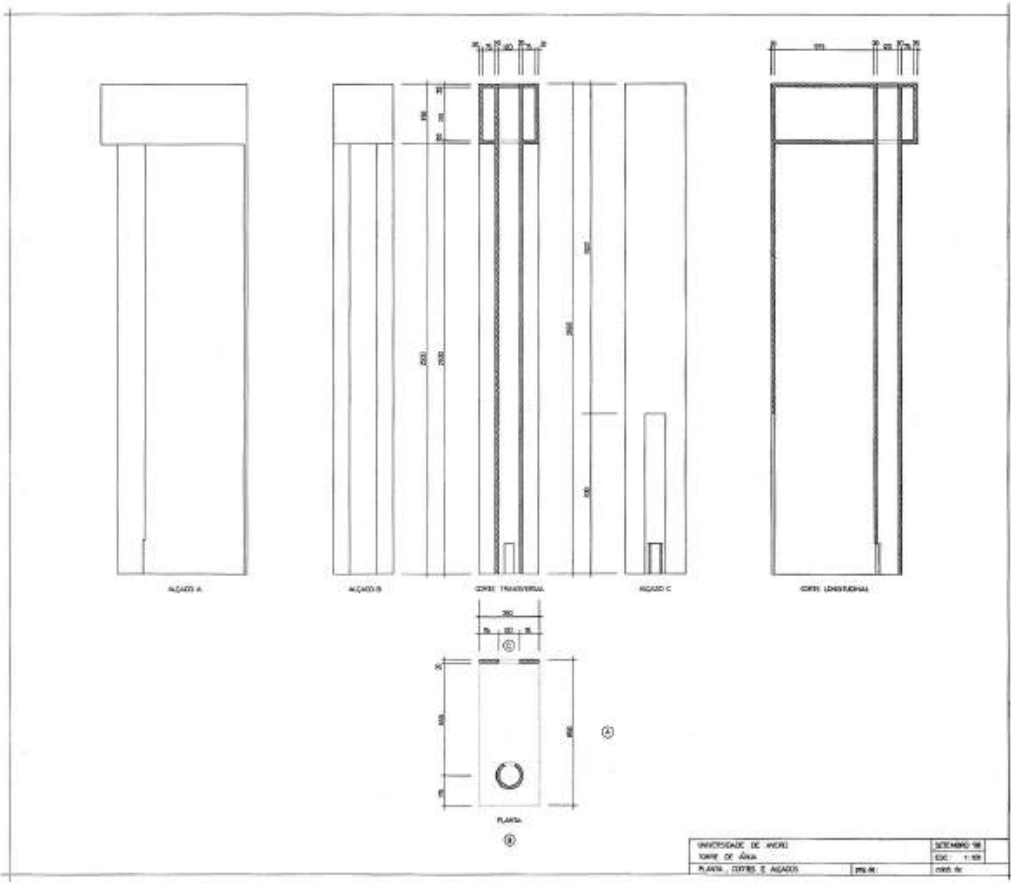

\subsubsection{9}

Álvaro Siza Vieira, Torre de água da Universidade de Aveiro, Portugal, 1988. Planta, cortes, elevações.

\subsubsection{0}

Álvaro Siza Vieira, Torre de água da Universidade de Aveiro, Portugal, 1988.

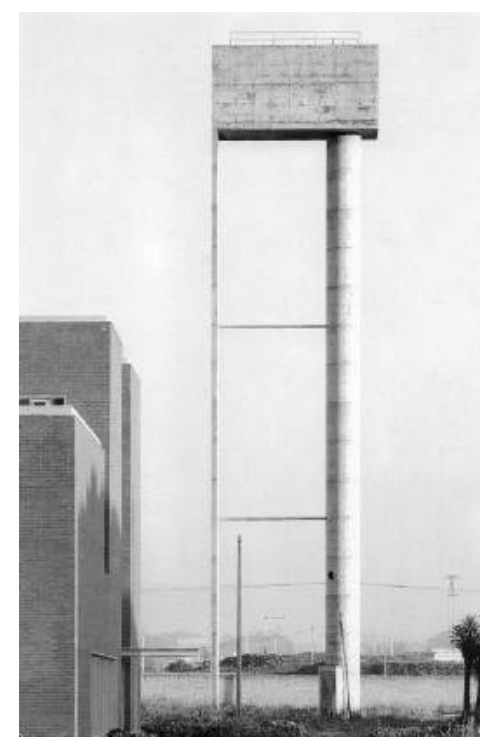

A torre de água da Universidade de Aveiro, 060 projetada pelo arquiteto português Álvaro Siza Vieira (n. 1933) em 1988, também foi concebida com o mínimo de elementos necessários. A construção de concreto armado (figs. 2.4.129, 2.4.130) com acabamento aparente que se eleva de um espelho de água tem uma altura de 28,50 metros e capacidade para armazenar $80 \mathrm{~m}^{3} \mathrm{de}$ água. O reservatório retangular de fundo plano, com dimensões em planta de 8,50 × 3,50 metros e altura de 3,50 metros, é apoiado em dois elementos: uma lâmina vertical de concreto com $20 \mathrm{~cm}$ de espessura e um fuste cilíndrico ôco com diâmetro de 1,60 metro. A lâmina e o fuste são interligados por duas barras de aço posicionadas a $1 / 3$ e 2/3 da altura da estrutura. ${ }^{103}$ É digno de nota na torre de Siza não apenas a distinção clara entre a estrutura de suporte e o reservatório elevado, mas também o tratamento distinto dado aos elementos de apoio, que assumem diferentes funções na edificação. O primeiro elemento, que atua apenas como apoio, é resolvido como uma simples parede. O segundo elemento, que combina funções de apoio e abrigo de tubulações e circulação vertical é resolvido na forma de uma cilindro ôco. Em resumo: formas diferentes para funções diferentes.

${ }^{103}$ TESTA, Peter. Álvaro Siza. São Paulo: Martins Fontes, 1998, p. 146. 


\subsubsection{Modernas Torres de Água metálicas}

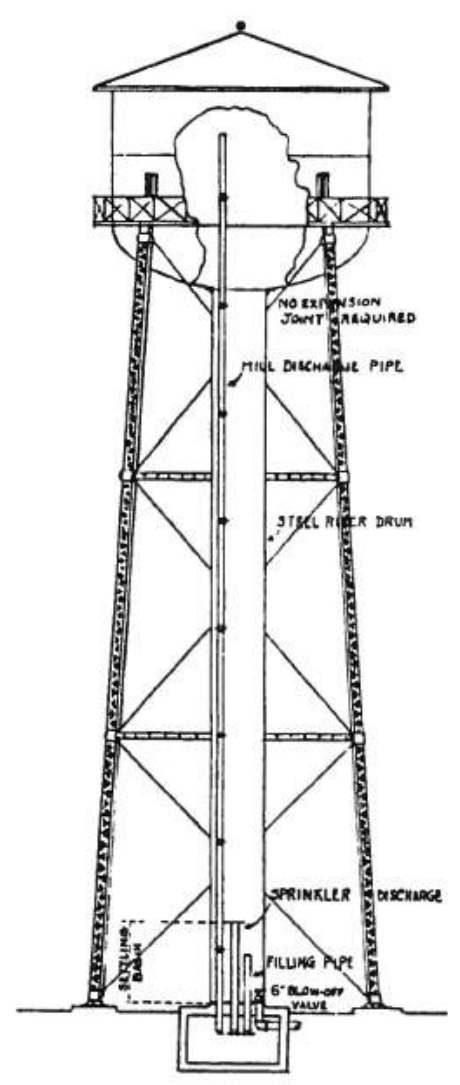

No final da década de 1910 o uso do ferro e do aço para a construção de torres de água começou a entrar em franco declínio na Europa com a introdução do concreto armado. Nos Estados Unidos da América, porém, foi iniciado um período de aperfeiçoamento no design das torres metálicas que culminou com desenvolvimento de reservatórios capazes de armazenar grandes volumes de água e confirmou a hegemonia do aço como material de construção para estas estruturas no país. Segundo Werth (1971), o desenvolvimento de reservatórios de água de grande capacidade nos Estados Unidos foi motivado principalmente pela maior necessidade de água do país, que era cerca de três a quatro vezes maior que o consumo médio dos países europeus, devido à existência de um padrão de vida mais confortável.

As novas tipologias de reservatórios desenvolvidas neste período nos Estados Unidos eram baseadas no reservatório de fundo hemisférico suspenso e no reservatório esférico tipo Klönne. Estas novas tipologias buscavam atingir grandes volumes de armazenagem com baixa profundidade de lâmina de água (inferior a 8,00 metros) aliada ao baixo consumo de material. Por volta de 1930, com a introdução do método de soldagem de chapas metálicas, foi possível substituir o antigo sistema de conexão de peças por meio de rebites. A eliminação das sobreposições de chapas, abas e rebites gerou uma economia de material que pode ser estimada entre 20 e 30\%. Uma outra vantagem do processo de soldagem foi a introdução dos perfis metálicos tubulares, elementos estruturais de grande desempenho que ofereciam maior resistência a momentos, em todas as direções, com menor peso estrutural. ${ }^{104}$

O engenheiro George T. Horton (1873-1945) pode ser considerado o personagem proeminente no desenvolvimento

\subsubsection{1}

CB\&l, Torre de água com reservatório de fundo elíptico suspenso, EUA, 1919. destas novas tipologias de torres de água nos Estados Unidos. Como engenheiro chefe e presidente da CB\&l (Chicago Bridge \& Iron Company), Horton criou novas tipologias de reservatórios que,

104 WERTH, 1971, op. cit., p. 392-393. 

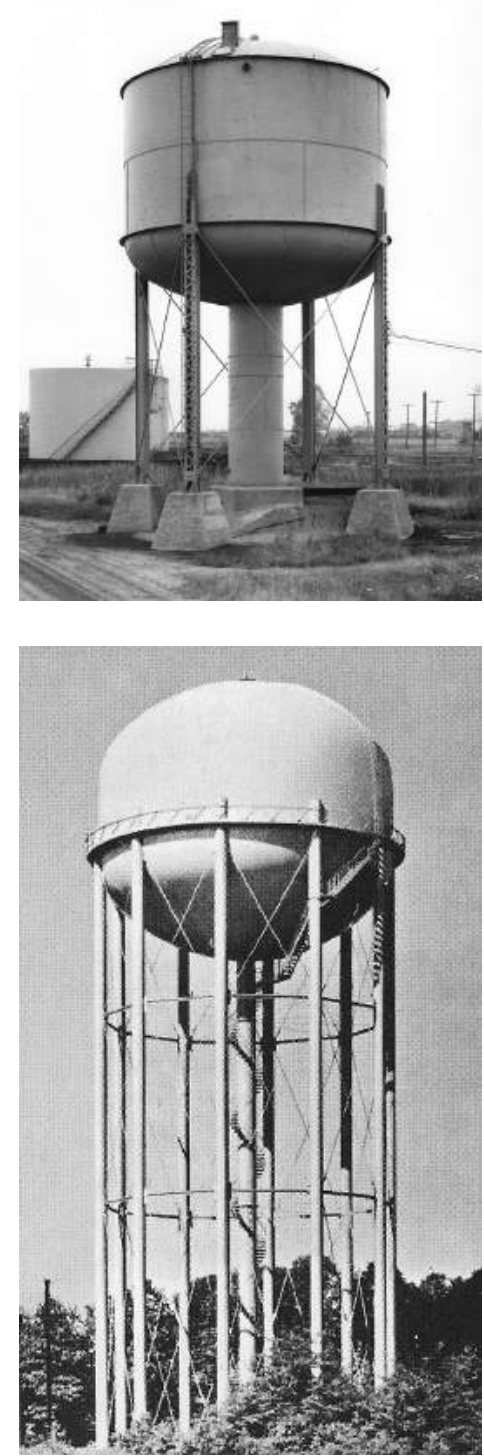

\subsubsection{2}

Torre de água com reservatório de fundo elíptico suspenso, Toledo, Ohio, EUA.

\subsubsection{3}

CB\&l, Torre de água com reservatório de fundo elíptico e produzidas em escala industrial, se espalharam por todo o território estadunidense.

O reservatório de fundo elíptico suspenso (figs. 2.4.131, 2.4.132), desenvolvido em 1907, foi a primeira resposta da CB\&l para a construção de torres de água capazes de armazenar grandes volumes de água e, ao mesmo tempo, controlar as variações de pressões atuantes no interior do reservatório e na rede de abastecimento, devido à menor altura de lâmina de água. Para garantir esta condição os novos reservatórios eram então projetados com pouca altura e com um grande diâmetro. ${ }^{105}$ Esta nova tipologia de reservatório utilizava como estrutura de suporte o mesmo tipo de esqueleto estrutural metálico desenhado pelo fundador da CB\&l, o engenheiro Horace Horton, para a torre de Paris, Illinois (1895). Por volta da década de 1920 as torres de água equipadas com reservatórios de fundo elíptico suspenso já haviam sido introduzidas em vários sistemas de abastecimento público da água das cidades estadunidenses devido, principalmente, às menores flutuações de pressão na rede de abastecimento e aos baixos custos de manutenção oferecidos por este tipo de torre de água. Na década de 1930 tanto a CB\&l como empresas concorrentes, como a W. E. Caldwell \& Co., já ofereciam uma variedade de torres de água padronizadas com reservatórios de fundo elíptico com volumes variando entre 190 e $2.800 \mathrm{~m}^{3}$ e estruturas de suporte com alturas de 15, 23 e 30 metros. $^{106}$ As primeiras torres de água, com reservatórios fabricados com chapas rebitadas e com estruturas de suporte formadas por pilares treliçados compostos, foram sendo substituídas a partir da década de 1930 por torres com reservatórios fabricados com chapas soldadas e estruturas formadas por perfis tubulares de aço (fig. 2.4.133), o que conferiu um aspecto mais limpo e moderno às torres de água fabricadas pelas CB\&l. A transformação formal do reservatório em direção às linhas mais limpas e suaves da Arquitetura Moderna é bastante

\footnotetext{
105 DUBIE, 1980, op. cit., p. 111-112.

${ }^{106}$ CALDWELL, W. E.. Tanks Towers and Tubs: Large water tanks a specialty. Louisville: W. E. Caldwell Co., 1931. Catálogo Técnico, p. 29.
} 


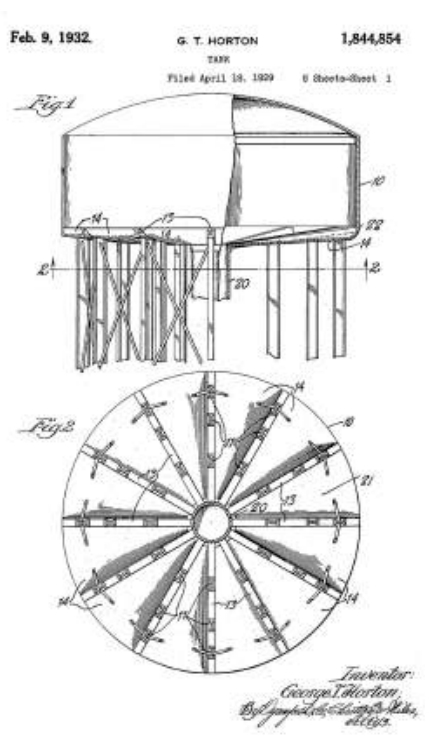

2.4.134

George T. Horton, Patente do Radial-Cone-Bottom Tank, EUA, 1929-1932.

\subsubsection{5}

CB\&l, Torre de Água do Brooklyn, Nova lorque, EUA, 1932. visível, com a substituição do telhado cônico por uma tampa integrada ao reservatório, seguindo a forma do fundo e criando um volume único e puro. Os suportes inclinados também deram lugar a colunas tubulares perfeitamente verticais, alinhadas com a parede do reservatório.

Uma segunda grande inovação da CB\&l no desenho de torres de água para armazenar grandes volumes de água foi introduzida em 1930 com um novo reservatório, o Radial-ConeBottom Tank. O fundo deste reservatório era composto por um conjunto de calhas cônicas, dispostas em formato radial, apoiadas sobre vigas radias de suporte. Estas vigas radiais eram apoiadas em um fuste central no centro da torre e em um ou dois anéis de colunas dispostas concentricamente, sendo que o primeiro anel era ligeiramente recuado em relação a parede do reservatório, criando um pequeno balanço no vigamento. A figura 2.4.134 mostra uma das páginas da patente do Radial-Cone-Bottom Tank solicitada por George Horton no ano de 1929 e obtida em 1932. A primeira torre de água (fig. 2.4.135) equipada com um reservatório nesta tipologia e erguida no Brooklyn, Nova lorque, em 1930, tinha capacidade para armazenar $4.700 \mathrm{~m}^{3}$ de água. $\bigcirc$ fundo do reservatório era formado por 16 calhas cônicas radiais apoiadas em um número igual de vigas. Trinta e duas colunas, distribuídas em dois anéis concêntricos de 16 colunas, mais o fuste central, sustentavam as vigas radiais. Os vértices internos das calhas cônicas estavam conectados ao topo do fuste central e as extremidades unidas à parede do reservatório, que tinha uma altura de 8,20 metros. ${ }^{107}$
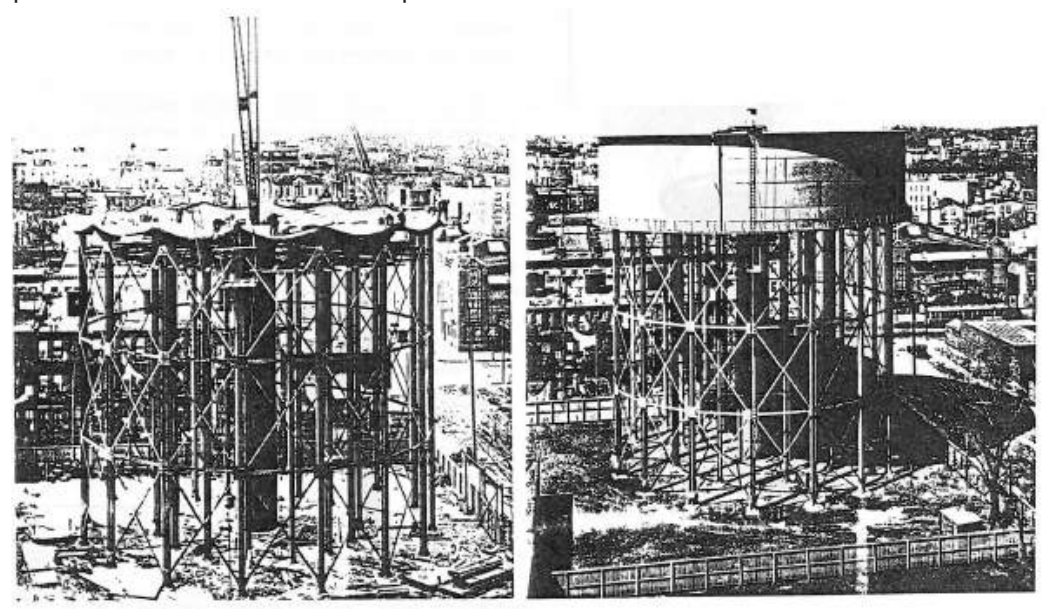

107 DUBIE, 1980, op. cit., p. 119. 


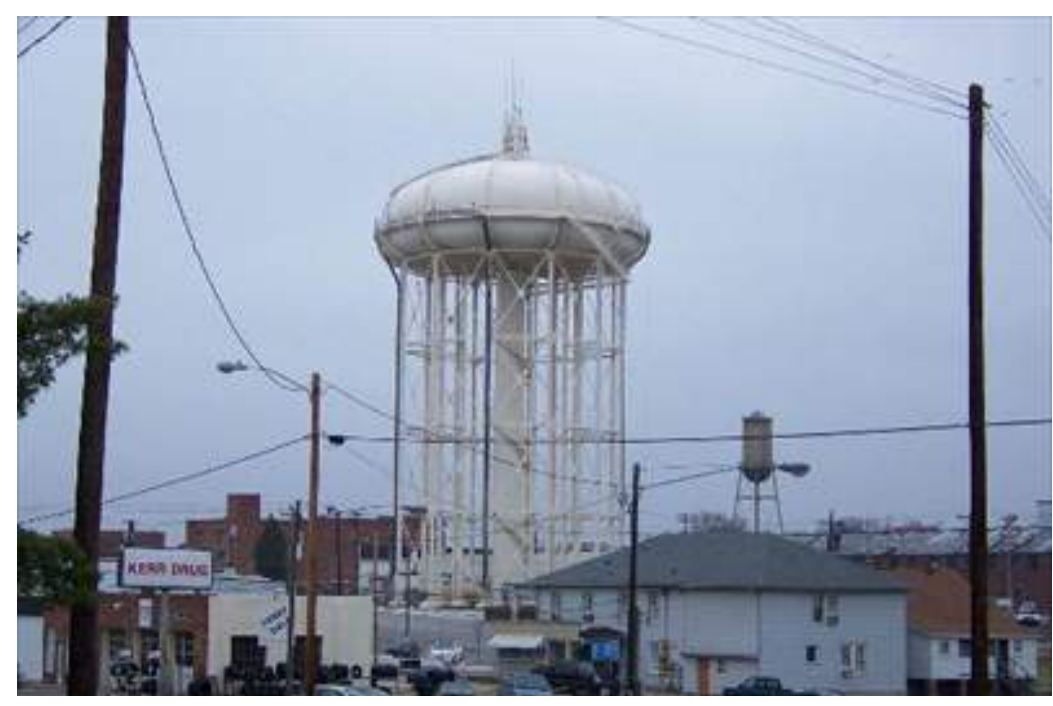

2.4 .136

CB\&l, Torre de Água do Thomasville, Carolina do Norte, EUA, 1932.
Em 1935 a CB\&l construiu outra torre de água com um Radial-Cone-Bottom Tank na cidade de Thomasville, Carolina do Norte, com capacidade para armazenar $3.800 \mathrm{~m}^{3}$ de água. Nesta torre, porém, houve uma mudança significativa do desenho do reservatório, combinando o sistema de suporte do fundo introduzido na torre do Brooklyn com um desenho mais arredondado, que se tornaria o desenho padrão para as torres de água equipadas com o Radial-Cone-Bottom Tank. Na torre de Thomasville (fig. 2.4.136), as calhas radiais, a parede cilíndrica do reservatório e a cobertura em formato de cúpula elíptica foram unidos em uma única superfície formada por chapas de aço soldada, com suaves transições em curva entre cada um dos elementos. ${ }^{108}$

Horton patenteou, em 1938, algumas variações para estruturas de suporte para o seu Radial-Cone-Bottom Tank, utilizando colunas tubulares simples (fig. 2.4.137). Estas patentes deram origem nas décadas seguintes a torres de água onde 0 esqueleto estrutural treliçado foi substituído por grandes colunas tubulares, sem anéis de travamento horizontais, apenas esbeltos contraventamentos diagonais, como na torre de água de Gary, Indiana (fig. 2.4.138). A figura 2.4 .139 mostra a construção de uma torre de água com o seu Radial-Cone-Bottom Tank. Torres como estas eram oferecidas pela CB\&l em tamanhos padronizados, com volumes variando entre 1.900 e $5.700 \mathrm{~m}^{3}$, em incrementos de 950 $m^{3}$.

108 Ibid., p. 121. 


\subsubsection{7}

George T. Horton, Patentes do para estruturas de suporte do Radial-Cone-Bottom Tank, EUA, 1929-1932.

\section{4 .138}

CB\&l, Torre de Água de Gary, Indiana, EUA.

\subsubsection{9}

Construção de um Radial-ConeBottom Tank.
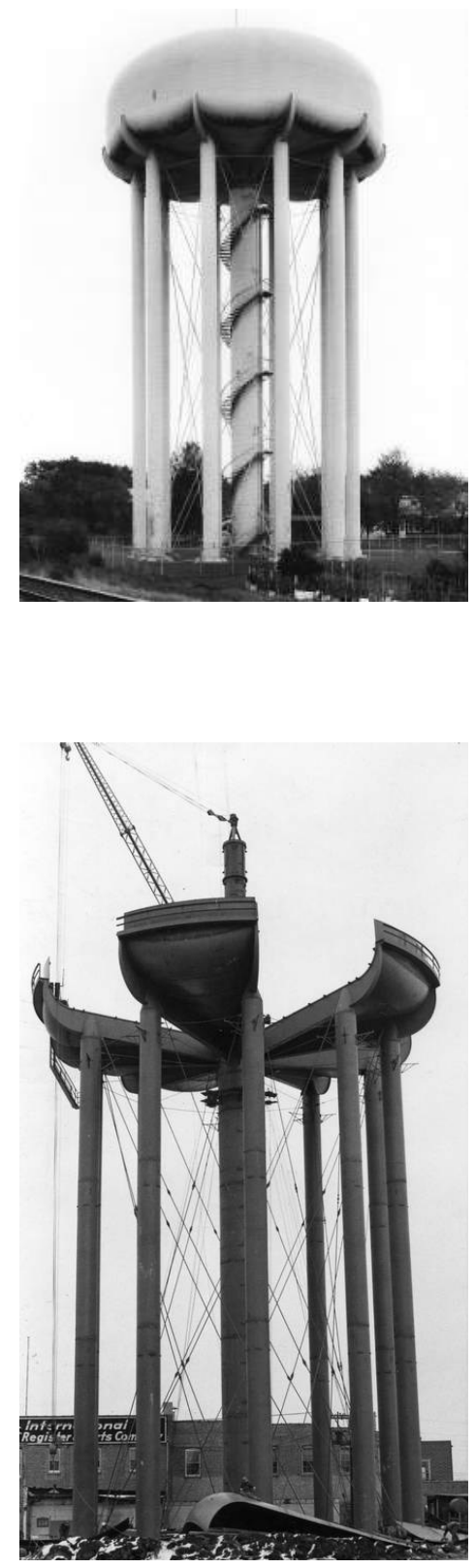
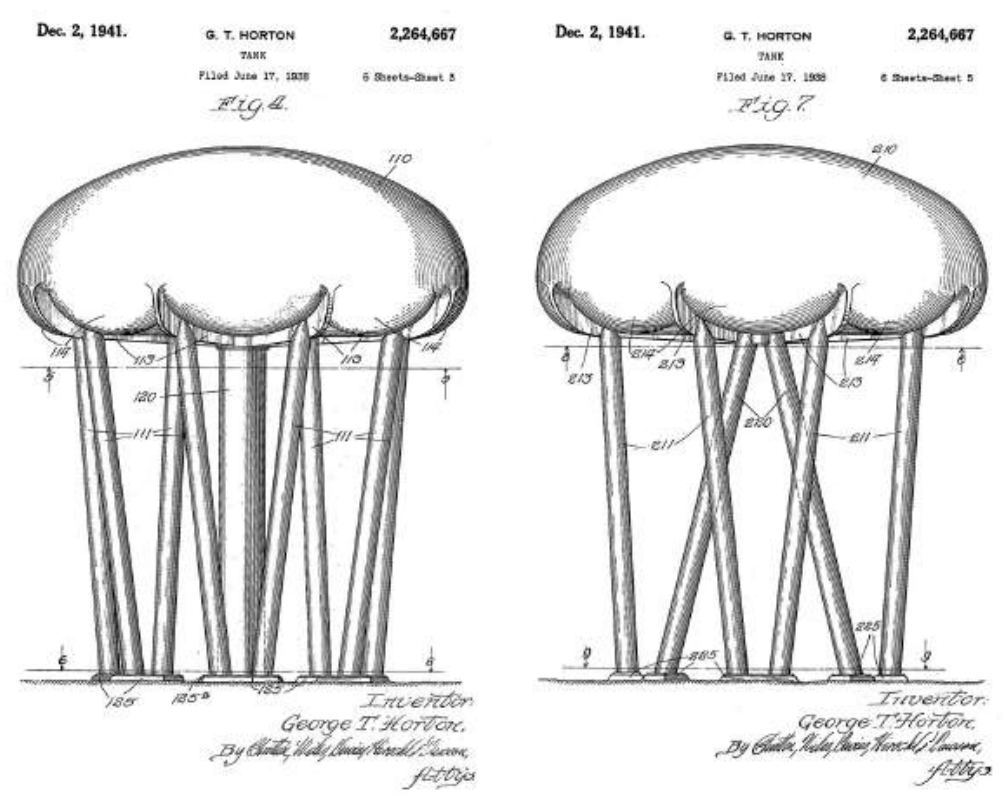

Em 1928 a CB\&l construiu uma pequena torre de água para um acampamento de garotos em Ponka City, Oklahoma, que consistia de um simples reservatório esférico de $115 \mathrm{~m}^{3}$ apoiado em um fuste circular único, com uma altura de 23,00 metros. A forma do reservatório era provavelmente baseada nos reservatórios tipo "klönne" desenvolvidos anteriormente na Alemanha (1906), mas a estrutura de suporte proposta por Horton era inovadora. Uma escada em espiral construída dentro do fuste de suporte estendiase através do reservatório até uma plataforma no topo. O fuste cilíndrico era um método econômico de suportar um tanque elevado e as superfícies das chapas metálicas eram mais fáceis de manter do que as colunas treliçadas que vinham sendo utilizadas até então. A construção desta torre, com as várias chapas de aço unidas por meio de rebites, se mostrou de difícil execução e antieconômica. No final da década de 1930, no entanto, melhorias nos processos de soldagem tornaram possível a construção deste tipo de torre de água em uma construção com chapas de aço totalmente soldadas. ${ }^{109}$

Em 1939 a CB\&l construiu a primeira destas torres com construção totalmente soldada, em Longmont, Colorado (fig.

109 Ibid., p. 138. 


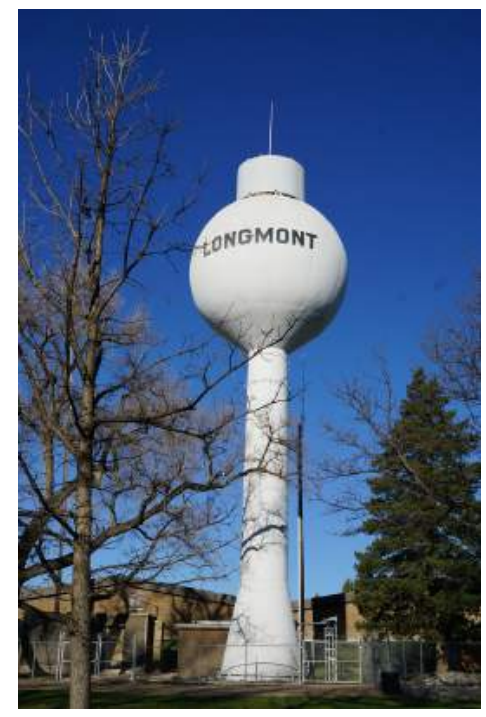

2.4.140). ${ }^{110}$ Entre os anos de 1940 e 1944, Horton registrou uma série de novas patentes (fig. 2.4.141) para a sua mais nova torre de água, que ficaria conhecida comercialmente pelo nome de Watersphere. A CB\&l padronizou a fabricação da Watersphere que estava disponível no mercado em sete tamanhos, com volumes variando entre 95 e $380 \mathrm{~m}^{3}$, e quatro alturas possíveis para o fuste: 15, 23, 30 e 38 metros. A Watersphere se tornou um tipo de torre de água bastante popular nos Estados Unidos e no final da década de 1940 já haviam sido construídas mas de 100 exemplares destas torres em instalações industriais ou em sistemas de abastecimento público de água. ${ }^{111}$

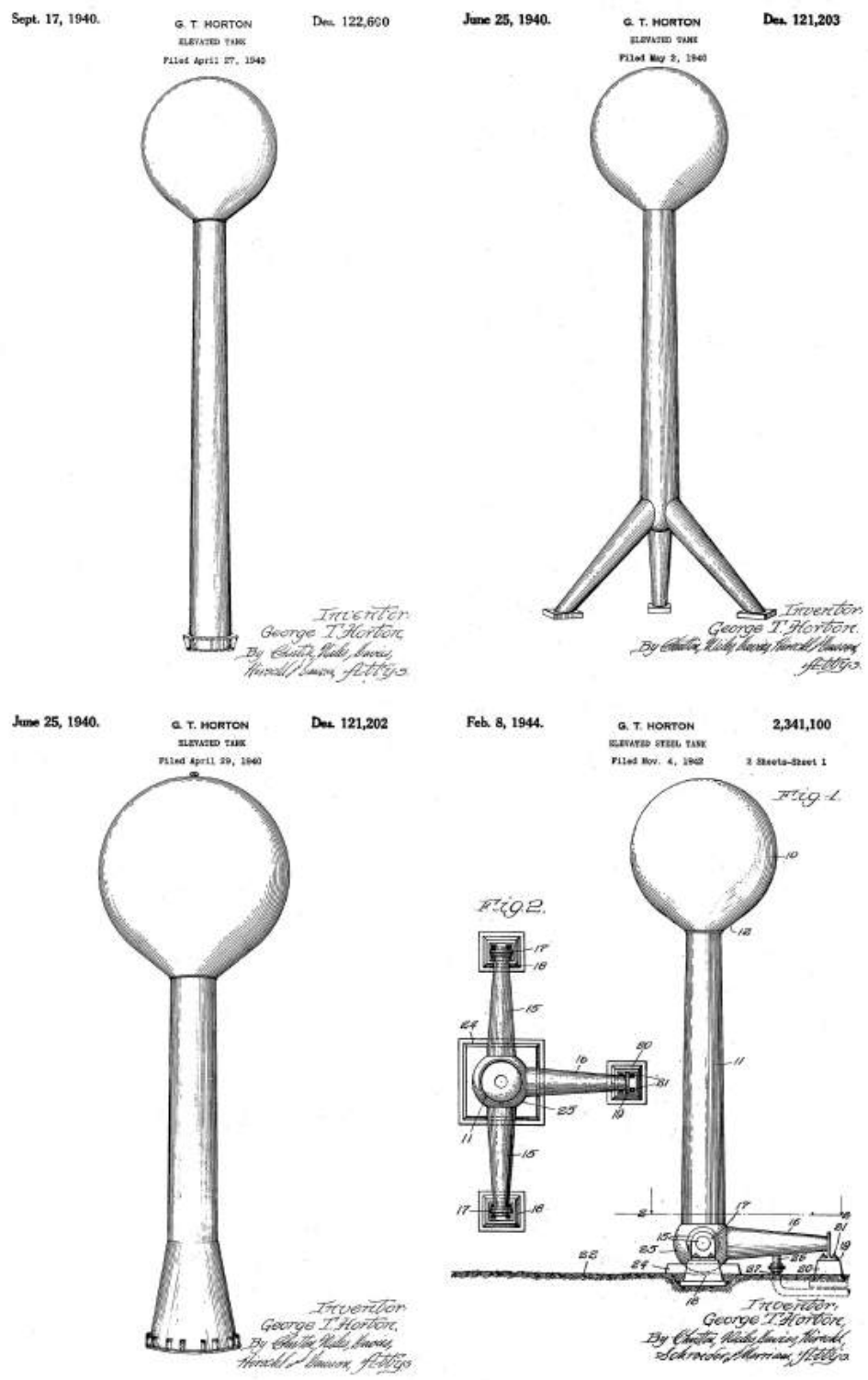

\footnotetext{
110 McVARISH, Douglas. American Industrial Archaeology: A Field Guide. New York: Routledge, 2016, p. 195.

${ }^{111}$ DUBIE, 1980, op. cit., p. 140.
}

4.140

CB\&l, Torre de Água de Longmont, Colorado, EUA, 1939

\subsubsection{1}

George T. Horton, Patentes da Watersphere, EUA, 1940-1944. 

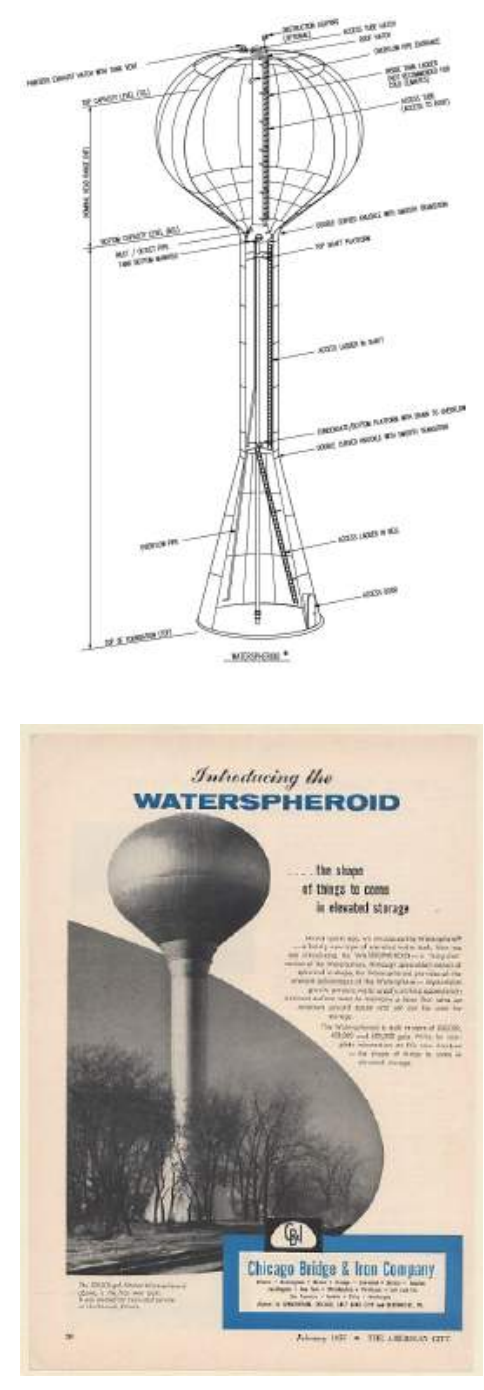

2.4.142

CB\&l, Waterspheroid. Perspectiva.

2.4.143

CB\&l, Torre de Água de Northbrook, Illinois, EUA, 1954.
A forma esférica da Watersphere, no entanto, não era adequada para a construção de reservatórios com volumes elevados já que o aumento do volume do reservatório esférico gerava, obviamente, o aumento da altura de lâmina de água e o consequente aumento da faixa de flutuações de pressões hidrostáticas na rede de abastecimento. Para contornar este problema a CB\&l desenvolveu uma nova tipologia de reservatório (fig. 2.4.142), que seria chamado comercialmente de Waterspheroid, cuja forma era a de uma esfera achatada, com maior diâmetro e menor altura, uma forma que garantia uma menor altura de lâmina de água com uma maior capacidade de armazenamento de água, operando dentro de uma faixa razoável de flutuações de pressão. A primeira torre do tipo Waterspheroid (fig. 2.4.143) foi construída em 1954 na cidade de Northbrook, Illinois, com um volume de $1.900 \mathrm{~m}^{3} .{ }^{112}$ As torres de água do tipo Waterspheroid (fig. 2.4.144) rapidamente substituíram as torres do tipo Watersphere e são fabricadas até os dias de hoje em 12 tamanhos disponíveis, com volumes variando entre 570 e $7.570 \mathrm{~m}^{3}$, a menor com um diâmetro de 10,60 metros e a maior com 28,35 metros. ${ }^{113}$

George Horton desenvolveu uma série de novas tipologias para reservatórios e torres de água durante a sua carreira. Entre as décadas de 1910 e 1950 Horton patenteou vários de seus novos designs (fig. 2.4.145) que, ainda que não realizados, ajudaram a desenvolver novas tipologias para reservatório e estruturas de suporte para torres de água. Na década de 1960 CB\&l introduziu no mercado uma nova tipologia de reservatório de alta capacidade, o reservatório torisférico, com capacidade para armazenar até 11.300 $\mathrm{m}^{3}$ de água. Esta nova tipologia de reservatório, desenvolvida em 1960 pelos engenheiros Clarence D. Miller e John N. Pirok, ${ }^{114}$ ambos da CB\&l, tinha uma forma que resultava da fusão de um

\footnotetext{
112 McVARISH, 2016, op. cit., p. 196.

${ }^{113}$ CB\&I (Chicago Bridge \& Iron Company). Waterspheroid: Elevated Water Storage. Woodlands: Chicago Bridge \& Iron Company, 2016. Catálogo Técnico, p. 5.

114 UNITED STATES PATENT OFFICE (EUA). Clarence D. Miller. Elevated Storage Tank. EUA nº US 2.961.118, 2 out. 1958, 22 nov. 1960. p. 1-6.
} 

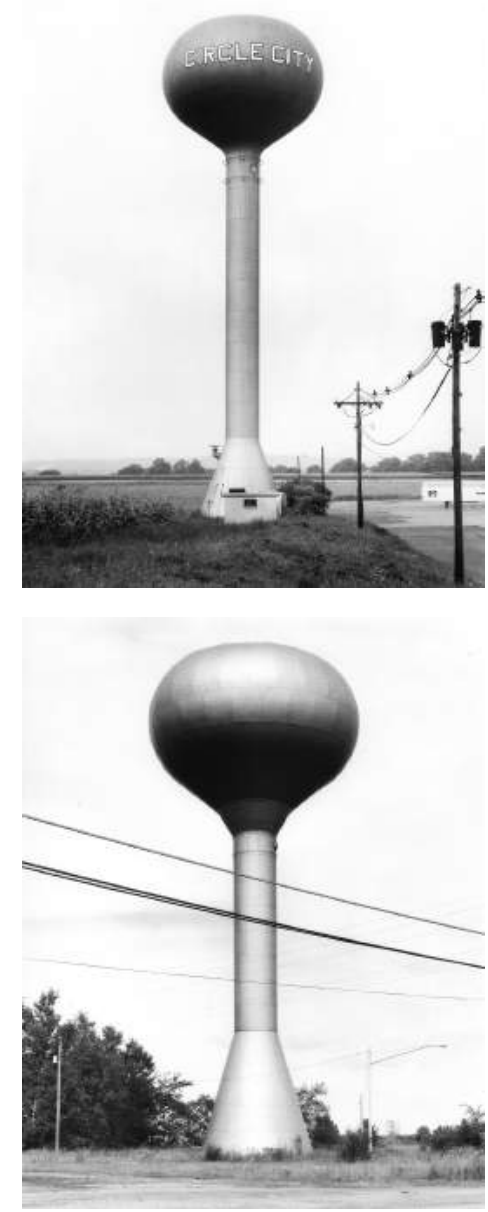

2.4.144

Torres de Água do tipo Waterspheroid, EUA.

\section{4 .145}

George T. Horton, Patentes para Torres de Água, EUA, 1939-1949. fundo suspenso na forma da metade inferior de um toroide ${ }^{115}$, combinado com um fundo central suspenso em forma de calota esférica, e uma cobertura em forma de cúpula elíptica, formando um volume único com uma superfície contínua. A nova tipologia de reservatório torisférico previa duas possibilidades de estruturas de suporte: um fuste central combinado a um anel externo de colunas tubulares ou dois anéis concêntricos de colunas tubulares (fig. 2.4.146). Uma destas torres gigantes, com capacidade para armazenar $11.300 \mathrm{~m}^{3}$ de água e diâmetro de 79,80 metros, foi construída na cidade de Sacramento, Califórnia, em 1962 (fig. 2.4.147). A figura 2.4.148 mostra outros exemplos de torres de água equipadas com o reservatório torisférico construídas em cidades estadunidenses.
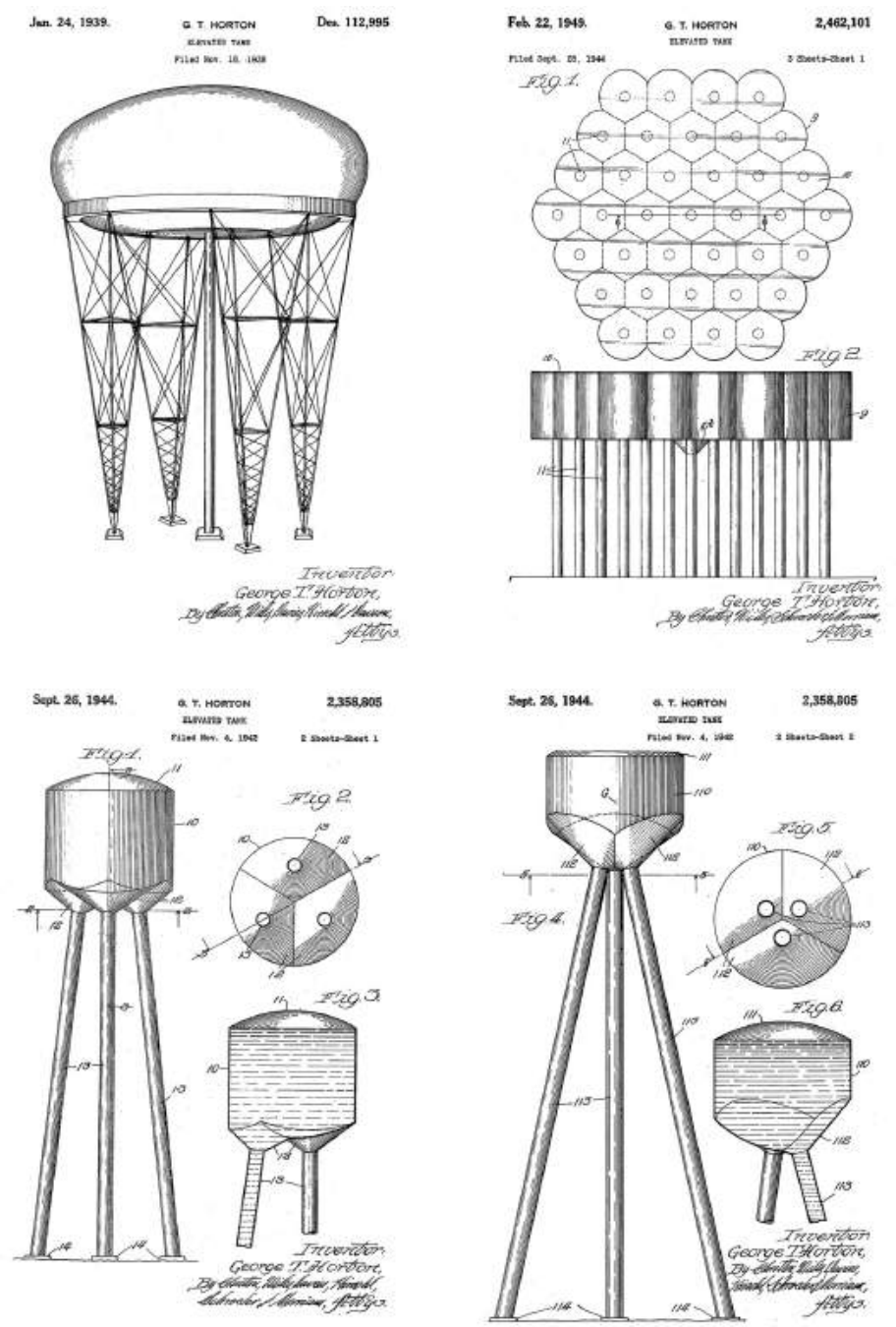

115 Em geometria um toroide é um sólido ou uma superfície gerada pela rotação de uma curva plana fechada em torno de um eixo que lhe é coplanar e não secante. São exemplos de toroides de revolução as boias salva-vidas e as câmaras de pneus. 

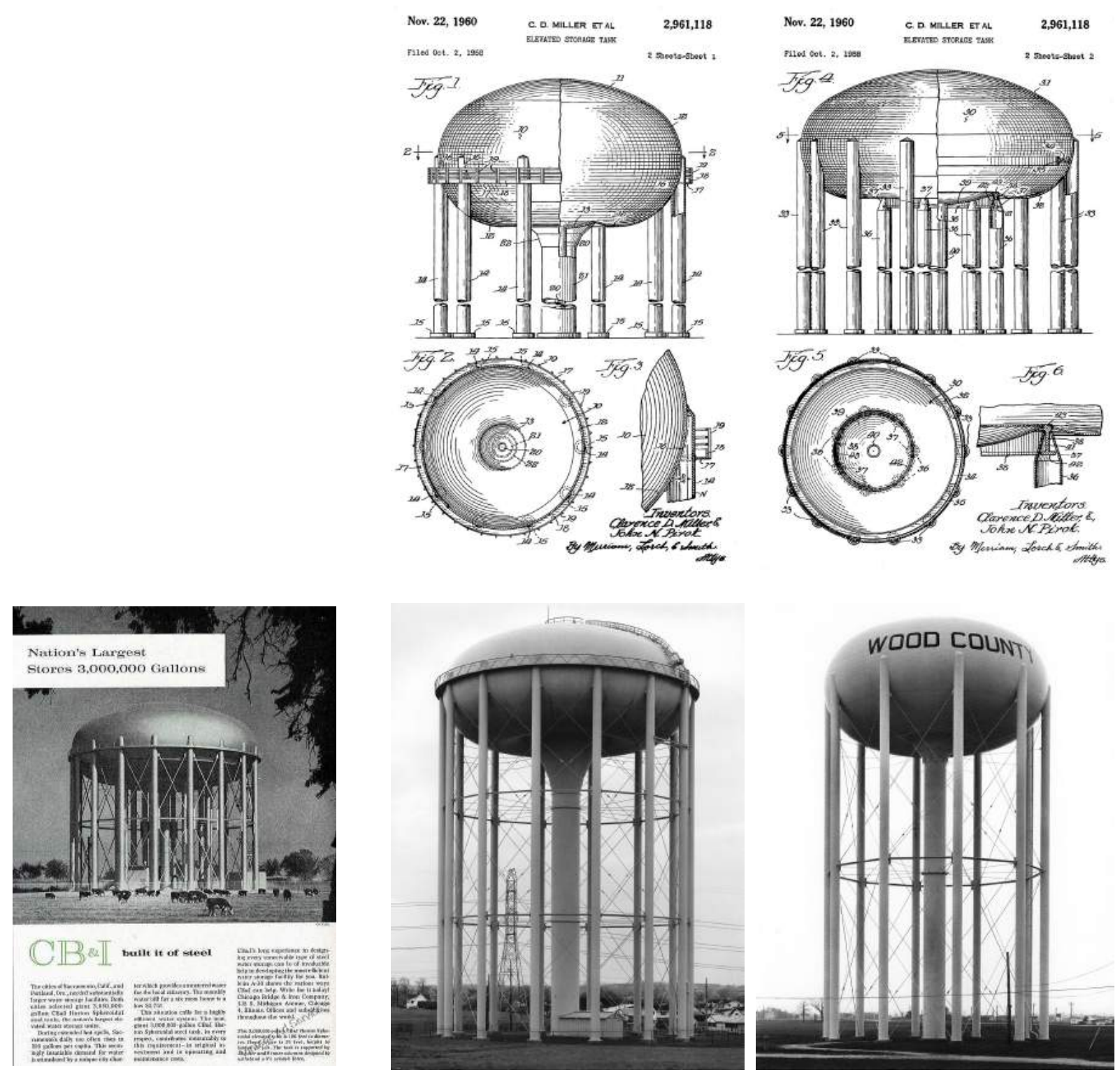

\subsubsection{6}

Clarence D. Miller e John N. Pirok, Patente do reservatório torisférico, EUA, 1960.

\subsubsection{7}

CB\&l, Torre de Água de Sacramento, Califórnia, EUA, 1962.

\subsubsection{8}

Torres de Água equipadas com reservatório torisférico, EUA.

As inovadoras torres da água de George Horton, especialmente a Watersphere e a Waterspheroid caracterizadas pela sua limpeza formal, certamente causaram impacto nas torres de água projetadas a partir da década de 1940 não só nos Estados Unidos mas também na Europa, especialmente naquelas idealizadas pelos arquitetos modernos. Podemos citar como exemplo a torre de água do Centro Técnico da General Motors, Michigam, 018 projetado pelo arquiteto Eero Saarinen (1910-1961) entre os anos de 1945 e 1955. Com uma altura de 40,20 metros, a torre foi construída integralmente com chapas soldadas de aço inox (fig. 2.4.149) e implantada em um gigantesco espelho de água medindo 540 × 170 metros, uma posição de destaque no complexo edificado. O reservatório da torre foi concebido na forma 


\subsubsection{9}

Eero Saarinen, Torre de Água do Centro Técnico da General Motors, Michigam, EUA, 1955. de esferoide oblato apoiado em três colunas de seção circular, a primeira abrigando a escada de acesso ao reservatório, a segunda as tubulações hidráulicas e a última vazia. ${ }^{116}$ Saarinen desenhou uma outra torre de água como parte do seu projeto para o complexo da Bell Laboratories, em New Jersey, 030 construído entre os anos de 1959 e 1962. Com uma altura de 38,70 metros e capacidade para armazenar $1.135 \mathrm{~m}^{3}$ de água, a torre foi executada em chapas de aço carbono soldadas, pintadas na cor branca. ${ }^{117} \mathrm{O}$ partido arquitetônico remete a torre da General Motors, um reservatório apoiado em 3 colunas, mas aqui as colunas têm a secção transversal na forma de gota e o reservatório assume a forma de uma calota esférica.

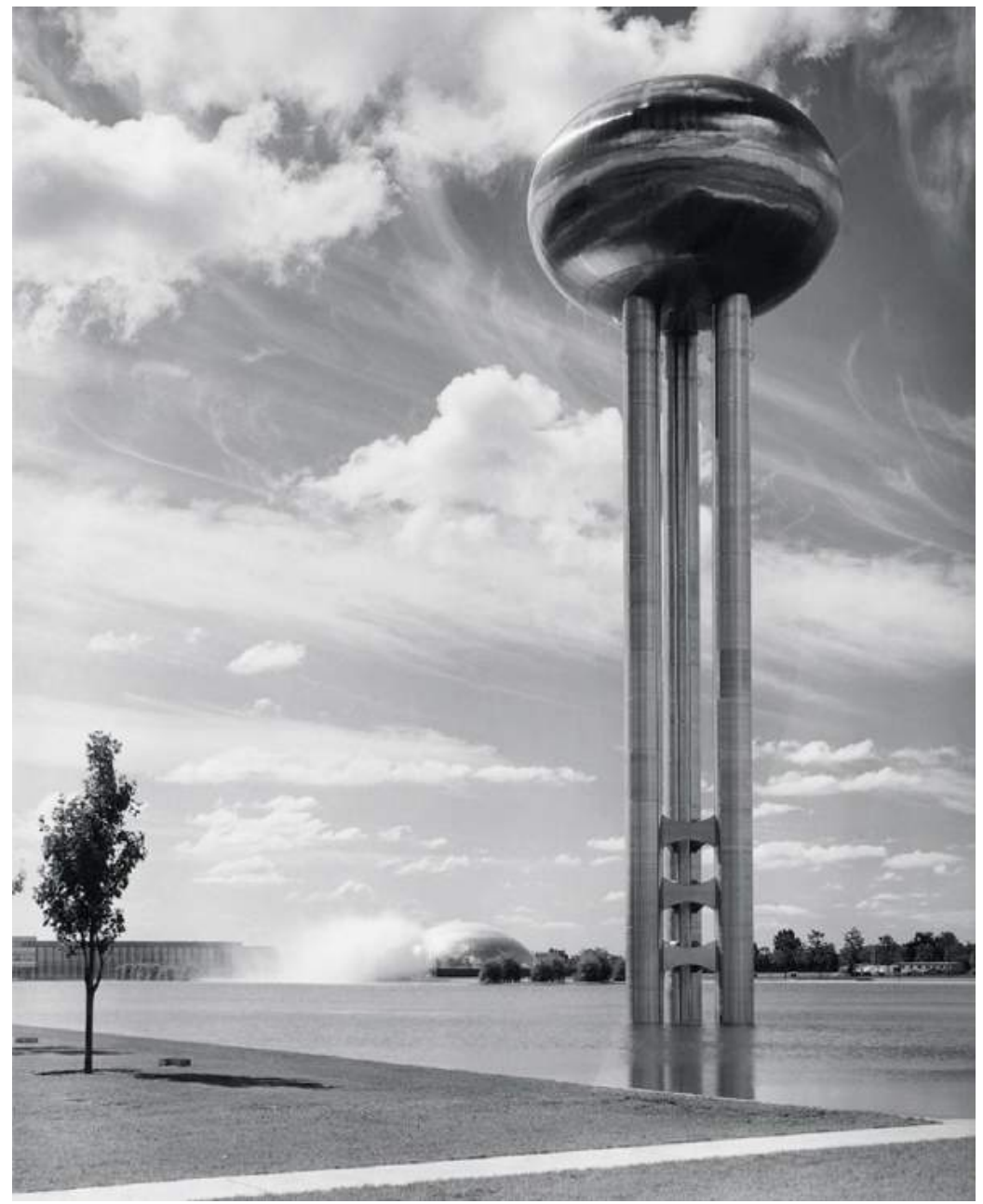

116 General Motors Technical Center. Architectural Forum, New York, v. 101, n. 5, nov. 1954, p. 119.

117 Bell Labs' Mirrored Superblock. Architectural Record, New York, v. 132, n. 10, out. 1962, p. 152. 
2.4 .150

Ateliers de Construction de Jambes, Torres de Água, Bélgica, 1959-1975.

a) Châtelineau, 1959.

b) Casteau, 1966

c) Meeuwen, 1970.

d) Seneffe, 1971.

e) Rhisnes, 1975.

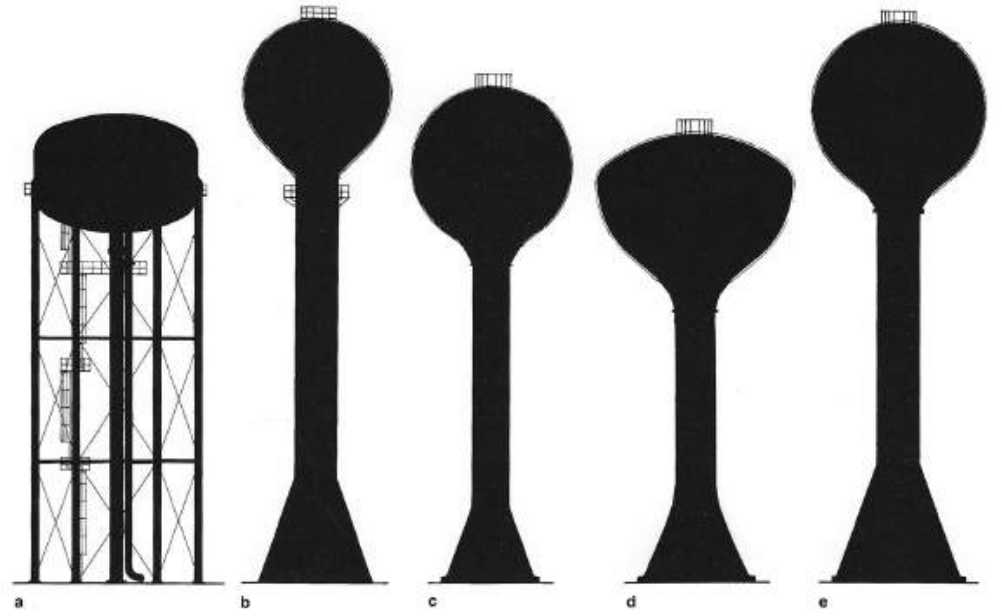

Na Bélgica, entre os anos de 1959 e 1975, cerca de 21 torres de água claramente inspiradas nas torres de George Horton foram projetadas e construídas pelo Ateliers de Construction de Jambes. A figura 2.4.150 mostra parte desta produção. ${ }^{118}$

A torre de água de Eindhoven, Holanda, projetada pelo arquiteto Win G. Quist (n. 1930) em 1970, 042 é uma curiosa torre metálica moderna concebida para atender à necessidade operacional de armazenar $1.500 \mathrm{~m}^{3}$ de água em três níveis diferentes, de modo a atender diversas áreas da cidade com diferentes demandas de pressões hidrostáticas. Como resultado desta demanda, três reservatórios esféricos de 10,00 metros de diâmetro (500 m³ cada) são "espetados" em tubos de aço, cada um a uma altura diferente. Um sistema de treliças e tirantes de aço interligando todos os elementos garante a estabilidade do conjunto. ${ }^{119}$

Mais curiosa e inusitada é a torre de água de Ciechanów, Polônia, 046 projetada em 1972 pelo arquiteto Jerzy Michal Boguslawsky. Aqui um reservatório toroidal construído em chapas de aço é apoiado em um esqueleto estrutural na forma de hiperboloide de revolução de uma folha, remetendo às estruturas das torres de água projetadas por Vladmir Shukhov no início do século XX. A altura do hiperboloide de revolução é de 22,00 metros e seus diâmetros são: 17,70 metros no topo; 11,25 metros na base

\footnotetext{
118 GENICOT, 1991, op. cit., p. 160.

119 VEEN, 1989, op. cit., p. 106.
} 


\subsubsection{1}

Politechnika Warszawska, Torre de Água de Bania, Tarnów, Polônia, ca. 1979.

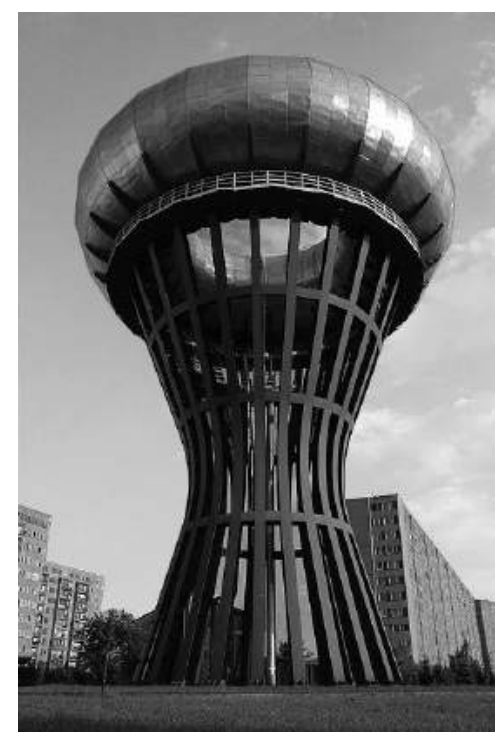

e 7,00 metros na garganta. A estrutura em malha hiperbólica, executada inteiramente me aço, é formada por duas famílias de 32 tubos retos (cada) correndo em direções opostas. Todos os tubos são idênticos, secções circulares com diâmetro de 200 mm. O reservatório toroidal que equipa a torre tem um diâmetro externo de 20,70 metros e uma secção transversal de 6,00 metros de diâmetro, armazenando $1.560 \mathrm{~m}^{3}$ de água. ${ }^{120} \mathrm{O}$ reservatório toroidal da torre de Ciechanów, apesar de inusitado, não é um exemplar único. A torre de água de Bania (fig. 2.4.151), na cidade de Tarnów, também na Polônia, foi projetada pela Politechnika Warszawska (Universidade Politécnica de Varsóvia) no final da década de 1970 com um reservatório toroidal de 28,00 metros de diâmetro externo e uma secção transversal de 8,00 metros de diâmetro, armazenando $3.000 \mathrm{~m}^{3}$ de água. A sua estrutura de apoio, no entanto, é bem distinta da estrutura da torre de Ciechanów, consistindo de com um conjunto de 24 pilares em formato parabólico travados em três níveis por vigas anulares. A torre de Ciechanów foi desativada, mas a torre de Bania permanece em operação, sendo assim a única torre de água com um reservatório desta tipologia em funcionamento na atualidade.

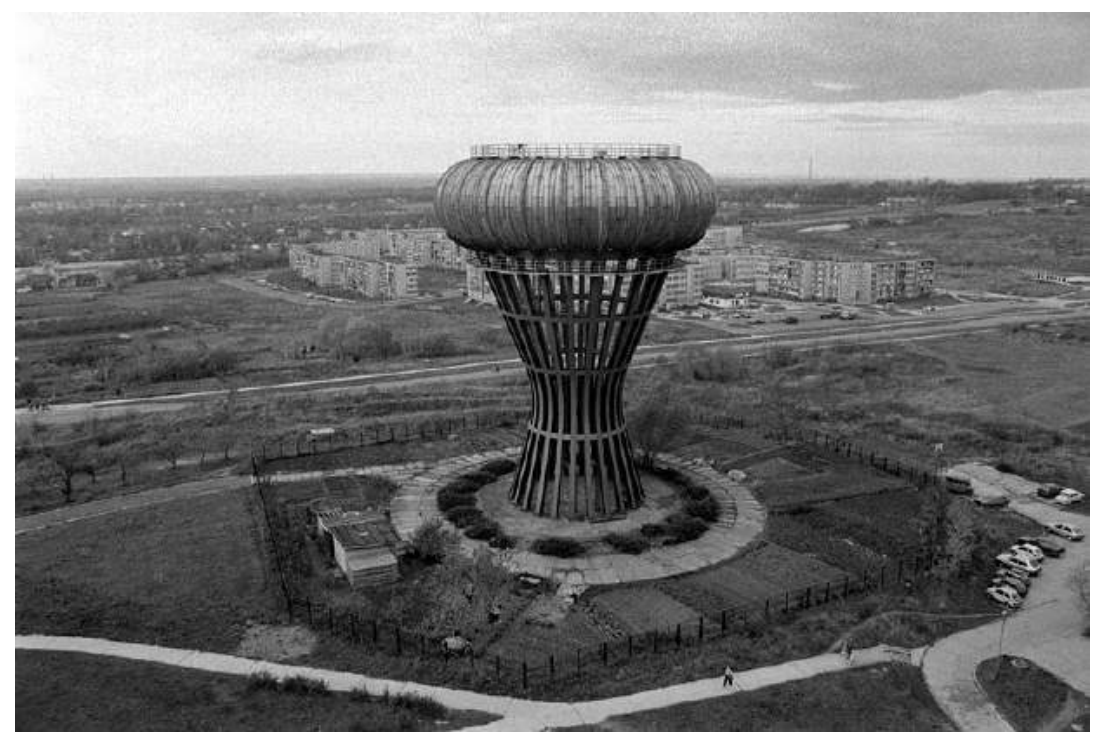

120 KOŹNIEWSKI, Edwin; ORLOWSKI, Marcin. Geometria Poprzez Analizee Obiektów Budowlanych. In: CONFERENCE GEOMETRY GRAPHICS COMPUTER, 22., 2015, Cracow. Proceedings... . Slaska: Silesian University of Technology Publishing, 2015. p. 45. 


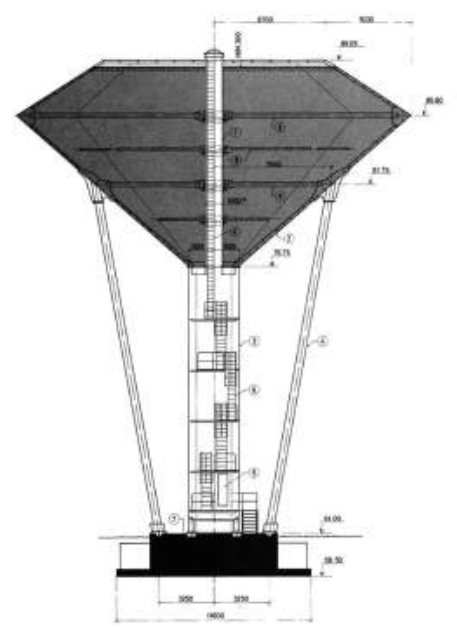

2.4 .152

Holger Koch-Nielsen, Torre de Água de Tyrsted, Horsens, Dinamarca, 1983.
Para o fornecimento de água para a cidade dinamarquesa de Horsens, na Jutlândia (1983), o arquiteto Holger Koch-Nielsen projetou uma torre de água com capacidade de $2.000 \mathrm{~m}^{3} \mathrm{com}$ uma tipologia singular de reservatório metálico, 057 na forma de um diamante lapidado. O reservatório de aço foi apoiado em um delgado fuste central com secção octogonal e em um conjunto de oito colunas tubulares, conectando os vértices do "diamante" ao bloco de fundação da torre. ${ }^{121}$ No interior o reservatório foi necessário o acréscimo de uma série de tirantes e enrijecimentos (fig. 2.4.152) para resistir à pressão hidrostática, uma solução construtiva muito próxima daquela utilizada nos primitivos reservatórios retangulares de ferro fundido utilizados nas torres de água inglesas de meados do século XIX. Aqui temos uma manifestação típico de uma construção não material, isto é, o material utilizado, no caso o aço, exige soluções formais e a aplicação de técnicas construtivas diferentes para o aproveitamento total de suas qualidades, como ocorre nas torres de Horton, Saarinen ou Quist, onde as formas esféricas e curvas da parede e do fundo do reservatório conferem rigidez às finas chapas metálicas, tornando-as capazes de resistir sozinhas aos esforços da pressão hidrostática, sem a necessidade de reforços adicionais no interior do reservatório.

A maioria das torres de água metálicas construídas a partir de meados do século 20 demonstra uma arquitetura não muito distante daquela arquitetura produzida no mesmo período por vários dos projetistas do concreto armado. Na grande maioria dos casos as soluções são elaboradas tendo como premissa o uso correto do material utilizado nas estruturas e a busca por um edifício com uma expressão formal própria, correspondente à sua função, sem ocultar a forma do reservatório e a estrutura de suporte mas, ao contrário, enfatizando a existência destes dois elementos.

${ }^{121}$ MEVIUS, 1985, op. cit., p. 165. 


\subsubsection{O Uso Moderno da Alvenaria nas Torres de Água}

Durante o século XIX a alvenaria, de pedra ou de tijolos cerâmicos, foi o sistema construtivo predominante na construção das estruturas de suporte dos reservatórios nas torres de água. Com o advento do aço e do concreto no final do século o uso da alvenaria estrutural foi abandonado em favor destes dois novos materiais.

O uso da alvenaria cerâmica como estrutura para a construção de torres de água foi retomado de maneira isolada durante as décadas de 1950 e 1960 nas pesquisas estruturais desenvolvidas pelo engenheiro espanhol Eduardo Torroja (18991961) e pelo engenheiro uruguaio Eladio Dieste (1917-2000). As pesquisas de ambos resultaram em torres únicas, onde predomina o uso inventivo da alvenaria cerâmica estrutural e a busca por uma racionalidade construtiva.

No ano de 1956 a Société Marocaine d'Expolatation des Entreprises Fernández encarregou Eduardo Torroja de modificar o projeto para uma torre de água 020 de $3.500 \mathrm{~m}^{3}$ que estava sendo construída na cidade de Fedala, Marrocos. A empresa contratante desejava assegurar a impermeabilidade das paredes e fundo do reservatório que deveria necessariamente ser executado sobre um arranjo circular de 18 colunas de concreto armado já existente. O reservatório original tinha o formato de um tronco de cone invertido e havia sido projetado em concreto armado. Para evitar a fissuração na parede do reservatório Torroja propôs o uso de concreto protendido e a adoção de um reservatório na forma de um hiperboloide de revolução de uma folha (fig. 2.4.153), permitindo a execução de uma protensão dupla ao longo das duas famílias de geratrizes retas do hiperboloide (fig. 2.4.154). Deste modo toda a parede é comprimida em duas direções, evitando o perigo de fissuração sob a ação centrífuga da pressão hidrostática. O tensionamento das armaduras foi feito pela topo da parede do reservatório por meio de ancoragens e macacos hidráulicos do sistema de protensão patenteado tipo Barredo. 


\subsubsection{3}

Eduardo Torroja, Torre de Água de Fedala, Marrocos, 1956.

\subsubsection{4}

Eduardo Torroja, Torre de Água de Fedala, Marrocos, 1956. Detalhe da armadura.

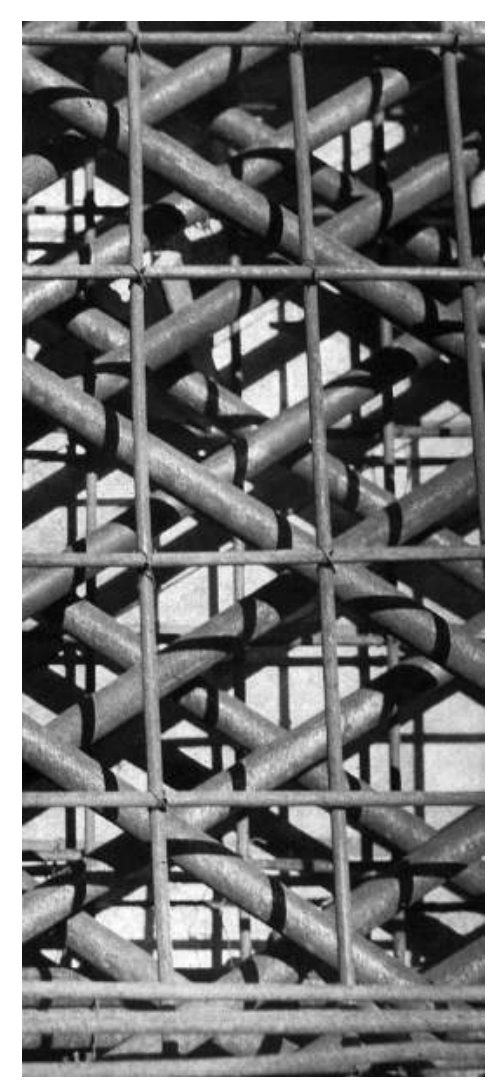

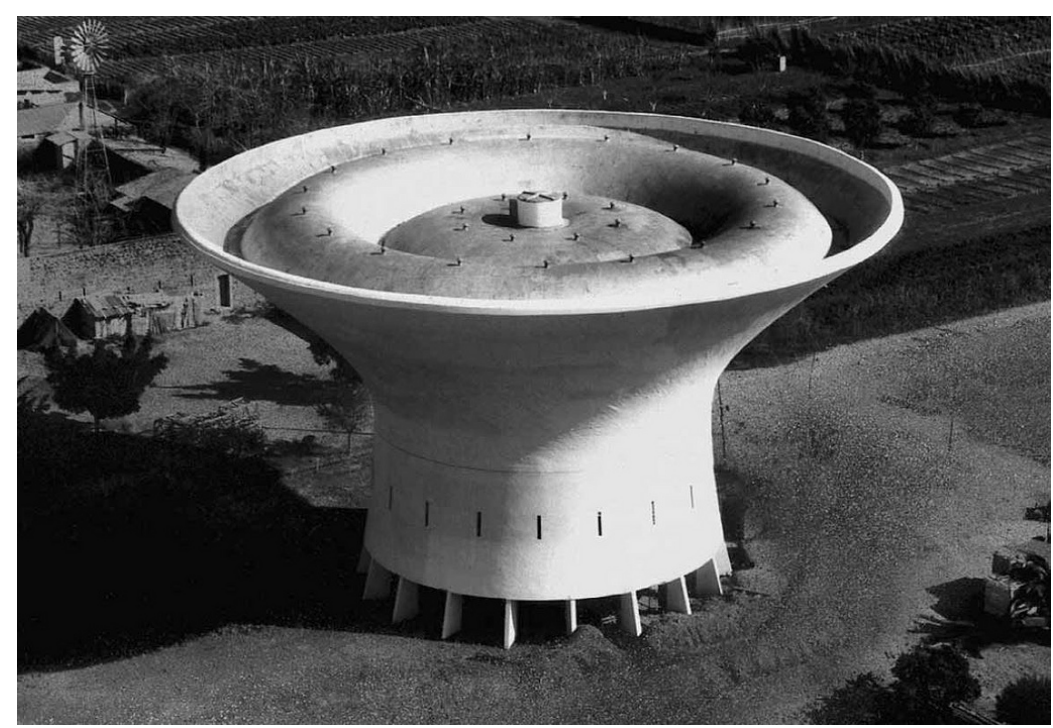

A parede do reservatório tem uma espessura de $28 \mathrm{~cm}$ em sua base, reduzindo gradualmente para $17 \mathrm{~cm}$ na altura do nível máximo da lâmina de água e depois para uma espessura constante de $10 \mathrm{~cm}$ no trecho corresponde ao coroamento. $\bigcirc$ fundo reservatório é formado por uma abóbada toroidal ${ }^{122}$ apoiada externamente no anel de suporte do reservatório e internamente na estrutura da passagem vertical de acesso ao topo do reservatório. Com objetivo de redução de custos a abóbada de fundo, originalmente projetada em concreto armado (fig. 2.4.155), foi substituída por uma abóbada catalã construída com três camadas de alvenaria de tijolos cerâmicos, executada sobre simples suportes radiais de madeira. Para evitar deformações no anel de suporte exterior do reservatório, uma série de tirantes formando um polígono estrelado foi posicionada no ponto de apoio da abóbada toroidal com a base da parede do reservatório (figs. 2.4.156, 2.4.157). A cobertura do reservatório é formada por duas abóbadas toroidais concêntricas que, assim como o fundo do reservatório, foram executadas em alvenaria cerâmica. As abóbadas estão apoiadas em três anéis concêntricos: o central junto da passagem vertical que atravessa o reservatório; um intermediário, apoiado em uma série de pilares

122 Em geometria um toroide é um sólido ou uma superfície gerada pela rotação de uma curva plana fechada em torno de um eixo que lhe é coplanar e não secante. São exemplos de toroides de revolução as boias salva-vidas e as câmaras de pneus. A abóbada toroidal, que pode ser entendida como a metade superior de um toroide de revolução quando este é seccionado perpendicularmente ao seu eixo de rotação, é uma superfície de revolução gerada pela rotação de um semicírculo no espaço em torno de um eixo que seja coplanar e não secante ao semicírculo. 


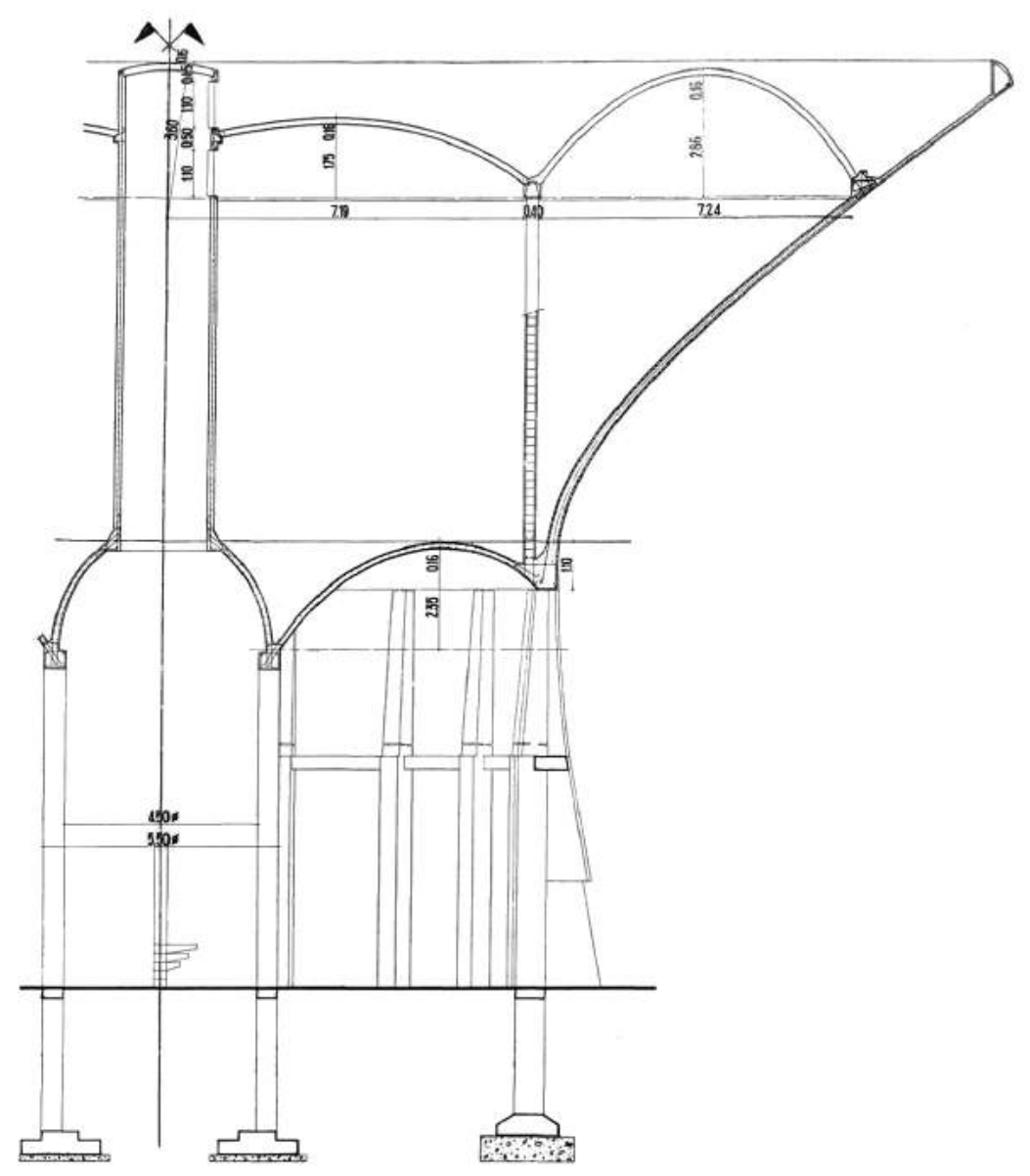

\subsubsection{5}

Eduardo Torroja, Torre de Água de Fedala, Marrocos, 1956. Corte.

\subsubsection{6}

Eduardo Torroja, Torre de Água de Fedala, Marrocos, 1956. Planta do anel de suporte do reservatório.

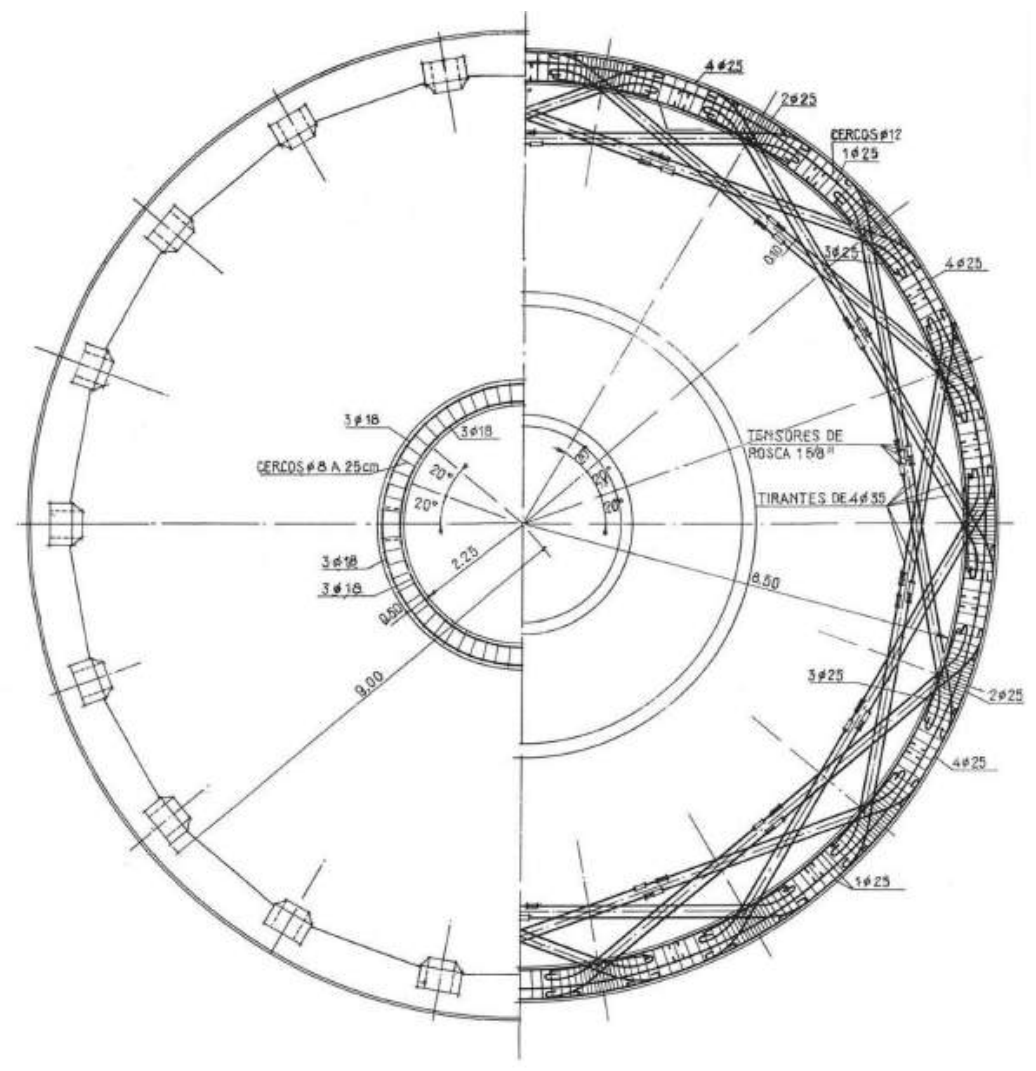




\subsubsection{7}

Eduardo Torroja, Torre de Água de Fedala, Marrocos, 1956. Abóbada de alvenaria e tirantes.

\subsubsection{8}

Eduardo Torroja, Torre de Água de Fedala, Marrocos, 1956. Abóbada de cobertura.

\section{4 .159}

Eduardo Torroja, Torre de Água de Fedala, Marrocos, 1956. Maquete.
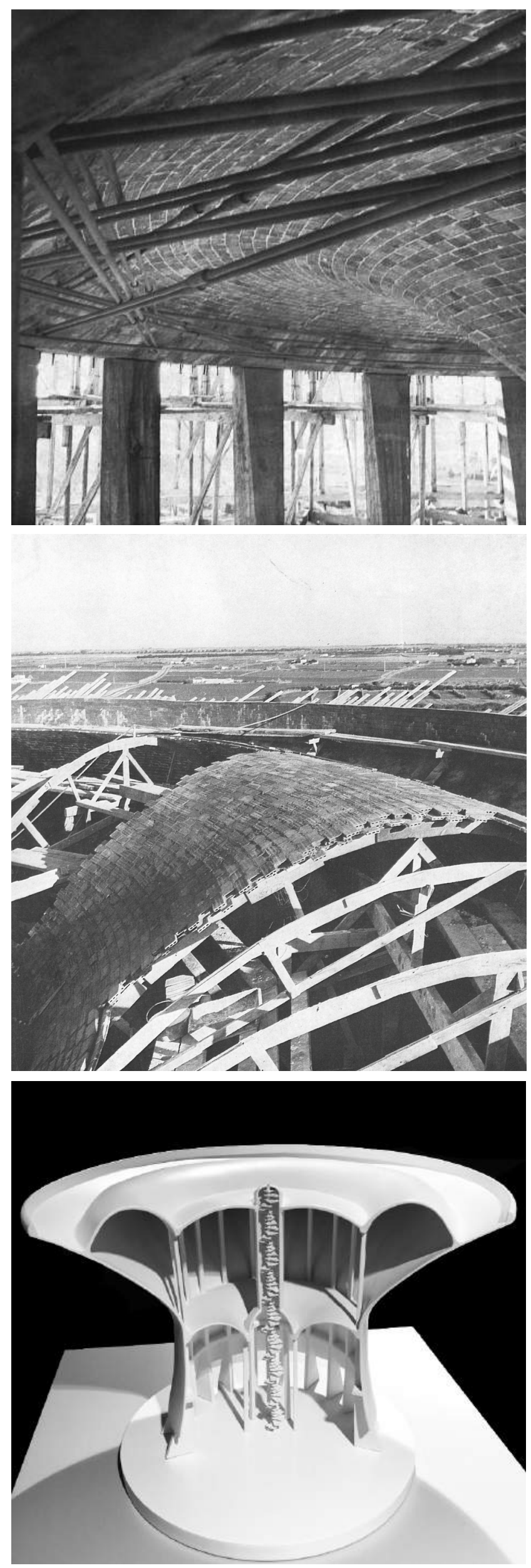
internos ao reservatório; e o terceiro, mais externo, incorporado na parede do reservatório (figs. 2.4.158, 2.4.159). ${ }^{123}$

A construção da torre de água de Fedala, finalizada em 1957 e em uso até os dias de hoje, é um bom exemplo do potencial formal e construtivo encontrado no uso combinado de técnicas avançadas de construção, no caso o concreto protendido, com técnicas mais econômicas e tradicionais de construção, como as abóbadas catalãs de alvenaria cerâmica. Para Torroja, no entanto, a solução estrutural da obra foi um fracasso devido ao enorme custo envolvido no sistema de protensão da parede do reservatório em relação ao projeto original que previa o uso de concreto simplesmente armado. Segundo Torroja o fracasso não era do sistema de protensão, mas sim

"... da minha capacidade imaginativa, restringida pela urgência imposta pelo andamento da obra. "124

Por isso, a partir deste projeto, Torroja iniciou uma pesquisa em busca de sistemas de protensão alternativos que pudessem garantir a compressão das paredes internas dos reservatórios de água evitando fissuras, perdas de água e a corrosão das armaduras. O uso de sistemas de protensão para concreto significa, em geral, a utilização de sistemas construtivos protegidos por meio de patentes industriais. Atualmente os sistemas de protensão são bastante comuns mas há 60 anos o custo destes sistemas era bastante elevado devido aos royalties que eram pagos pela utilização de sistemas de protensão patenteados. ${ }^{125}$

Em 1957, contratado novamente pela Société Marocaine d’Expolatation des Entreprises Fernández para projetar uma torre

${ }^{123}$ La cuba hiperbólica de Fedala. Informes de La Construcción, Madrid, v. 14, n. 137, p. 581-18, jan/fev. 1962.

124 "... mi capacidad imaginativa, coartada entonces por la premura que imponía la marcha de la obra." Apud BERNARDO, Joaquín Antuña. Las Estructuras de Edificación de Eduardo Torroja Miret. 2002. 356 f. Tese (Doutorado) - Escuela Técnica Superior de Arquitectura, Universidad Politécnica de Madrid, Madrid, 2002, p. 207.

125 O número de sistemas de protensão patenteados atualmente é bastante extenso, destacando-se os seguintes: Freyssinet, Barredo, Magnel, BBRV, VSL, Dischinger, Leoba, CCL, Dywidag, entre outros. 


\section{4 .160}

Eduardo Torroja, Projeto para a Torre de Água de Rabat, Marrocos, 1957. Corte e detalhe. de água (fig. 2.4.160) para a cidade de Rabat, Torroja desenvolveu um novo sistema construtivo que possibilitaria a construção de um reservatório de água protendido e impermeável sem a utilização de sistemas de protensão patenteados. A proposta de Torroja consista em uma torre de água no formato de tronco de cone invertido construído com alvenaria armada de tijolos de barro. O fuste da torre é formado por uma parede simples de tijolos de barro reforçada com armaduras de aço posicionadas entre fiadas de tijolos em níveis distintos. O reservatório, com capacidade para armazenar $1.000 \mathrm{~m}^{3}$, tem o formato de tronco de cone invertido e um fundo em cúpula de concreto armado que trabalhava exclusivamente sob esforços de compressão nos dois sentidos. No centro do reservatório uma passagem vertical construída em alvenaria de tijolos garante o acesso ao topo do reservatório, coberto por uma cúpula construída com tijolos cerâmicos. A parede externa do reservatório consiste em 3 camadas: a mais externa, primeira camada, é de alvenaria de tijolos de $25 \mathrm{~cm}$ de espessura, reforçada com barras de aço posicionadas em fiadas intercaladas de tijolos; a segunda camada consiste em uma parede de concreto feita com brita selecionada, onde é injetada uma argamassa especial de cimento com endurecimento rápido, sendo esta injeção feita após a construção da terceira camada interna; a terceira camada interna consiste de uma parede de alvenaria de tijolo com $25 \mathrm{~cm}$ de espessura (ver detalhe na fig. 2.4.160).
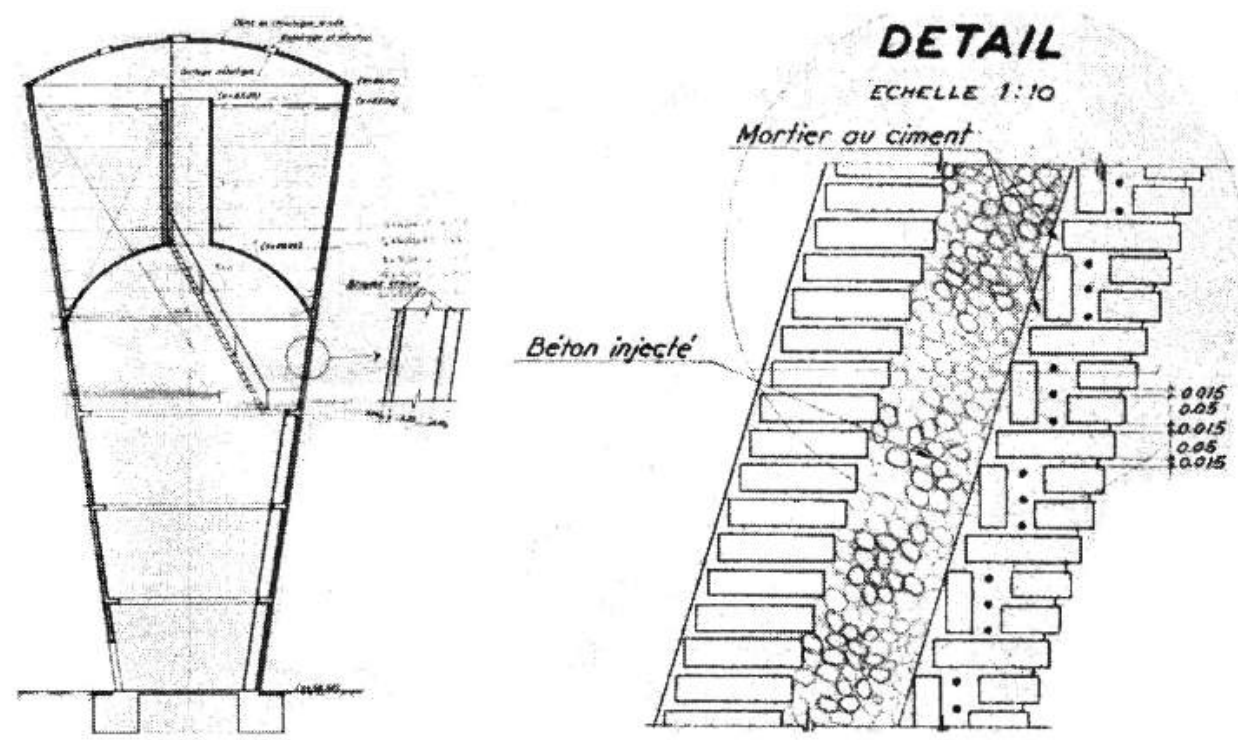


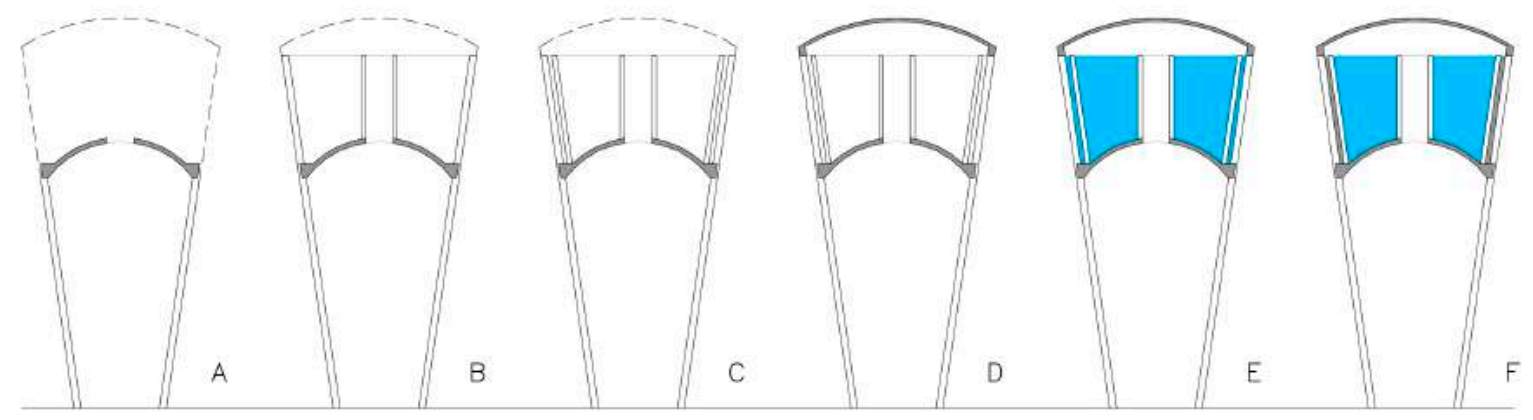

2.4.161

Eduardo Torroja, Projeto para a Torre de Água de Rabat, Marrocos, 1957. Sistema construtivo.
Para entender o sistema original de protensão idealizado por Torraja é necessária a explicação do procedimento construtivo (fig. 2.4.161) da torre de água, pois é somente com a execução das várias etapas na ordem correta que a estrutura funciona conforme planejado. Assim que as fundações são concluídas iniciase a construção do fuste de alvenaria que servirá de apoio para o reservatório de água. Concluído o fuste executa-se a cúpula de concreto armado (fig. 2.4.161, A), o fundo do reservatório, que pode ser moldada sobre formas de madeira ou sobre uma forma perdida executada como uma cúpula de tijolos de barro, o que evita a necessidade de utilização de formas ou andaimes de madeira. Assim que o fundo do reservatório estiver finalizado é possível iniciar a construção das paredes do reservatório. A parede da passagem vertical no centro do reservatório e a primeira camada da parede externa do reservatório são construídas primeiro, simultaneamente, com especial atenção para o correto posicionamento da armadura de aço posicionada entre as fiadas de tijolos na parede externa (fig. 2.4.161, B). Assim que a primeira camada da parede externa for finalizada, inicia-se a construção da terceira camada da parede externa (fig. 2.4.161, C). Neste momento deve ser tomado o cuidado para não deixar cair argamassa na cavidade que será formada entre as duas camadas da parede externa. Conforme a terceira camada vai subindo, a cavidade vai sendo preenchida com brita limpa, selecionada em granulometria adequada, e mangueiras vão sendo posicionadas para permitir o preenchimento posterior da cavidade com argamassa.

Concluída a execução das paredes e também do preenchimento da cavidade da parede externa com brita, o 
reservatório e a cavidade são preenchidos com água (fig. 2.4.161, E). Neste momento a parede externa passa a ser solicitada por esforços de tração decorrentes da pressão hidrostática e algumas trincas começam a surgir. Neste mesmo momento a armadura de aço da camada externa começa a se deformar, alongando-se. Quando a água começa a vazar é necessário adicionar mais água no reservatório para manter a pressão atuando nas paredes do reservatório. A camada interna da parede do reservatório passa a ser submetida a um pequeno esforço de compressão devido à diferença de pressão existente entre a pressão da água no interior do reservatório e a pressão da água misturada com brita que preenche a camada intermediária. Neste momento inicia-se a injeção de argamassa na cavidade da parede externa (fig. 2.4.161, F). A injeção de argamassa inicia-se pela parte de baixo da cavidade e é realizada em camadas sucessivas de aproximadamente $50 \mathrm{~cm}$ de altura. $O$ aumento de pressão devido à maior densidade da argamassa em comparação com a pressão devida à água leva a uma maior deformação e consequentemente a um maior alongamento da armadura de aço colocada na camada exterior do tijolo e, ao mesmo tempo, ao aumento da compressão da camada interna da parede do reservatório. Quando a argamassa começa a endurecer, o efeito da pressão hidrostática desaparece e as armaduras de aço da camada externa, que estão sob efeitos de esforços de tração e sofreram um alongamento tendem a reduzir seu comprimento fazendo com que a parede de concreto criada entre as duas camadas de alvenaria seja protendida. ${ }^{126}$

Neste projeto de Torroja a água é a máquina de construção da própria torre de água: a pressão da água introduz esforços de tração nas armaduras de aço gerando a deformação e o alongamentos destas, então a injeção de argamassa na camada intermediária aumenta esta deformação e alongamento mas, quando a argamassa começa a endurecer e a fixar as barras, estas

${ }^{126}$ BERNARDO, Joaquín Antuña. Prestressed Masonry for Reservoirs: A Project of the Engineer Eduardo Torroja. In: 8th International Seminar nn Structural Masonry, 8., 2008, Istambul. Conference Publication. Istambul: Istanbul Technical University, 2008. p. 11 - 16. 


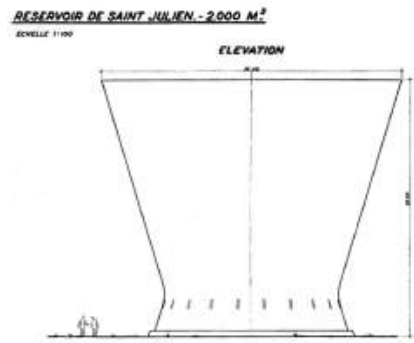

2.4.162

Eduardo Torroja, Projeto para a Torre de Água de Marselha, França, 1958. Elevação. tendem a recuperar o seu comprimento original, protendendo a parede de concreto e garantindo a impermeabilidade do reservatório. Infelizmente esta torre de água nunca foi executada.

Em 1958, contratado pela Société des Eaux de Marseille para projetar uma torre de água (fig. 2.4.162) com capacidade de $2.000 \mathrm{~m}^{3}$ para a cidade de Marselha, Torroja tentou utilizar seu inovador sistema de construção. Esta torre tinha algumas similaridades com a torre de água de Fedala como, por exemplo, o fundo em formato de abóbada toroidal e a cobertura apoiada em suportes internos ao reservatório. Seu formato porém era troncônico e a sua cobertura era formada um conjunto de abóbadas de aresta dispostas radialmente sobre o reservatório. ${ }^{127}$ Novamente o projeto não foi executado.

Torroja fez muitos projetos usando este sistema de construção, mas apenas um foi construído em Madri, no ano de 1958, para a Junta de Energía Nuclear. Com capacidade para armazenar $100 \mathrm{~m}^{3}$, a torre de água tem o formato de um tronco de cone invertido, com uma altura de 19,00 metros e diâmetros de 9,20 metros no topo e 4,00 metros na base, e foi construída quase que integralmente em alvenaria de tijolos. $\bigcirc$ reservatório tem o fundo em formato de abóboda toroidal e foi construído em concreto armado, apoiado em dois anéis de suporte: uma na parede externa da torre e outro no fuste interno da torre, que se estende do chão até o topo do reservatório. A cobertura foi executada com uma cúpula em alvenaria de tijolos. O reservatório ainda existe, mas não está funcionando, foi substituído por um reservatório de maior capacidade durante a década de 1970.128

O sistema de alvenaria protendida desenvolvido por Torroja é um sistema construtivo absolutamente original e que pode servir de inspiração para o desenvolvimento de torres de

\footnotetext{
127 BERNARDO, 2002, op. cit., p. 209.

128 BERNARDO, Joaquín Antuña. Prestressed Constructions without Steel. A Project of the Spanish Engineer Eduardo Torroja. In: INTERNATIONAL CONGRESS ON CONSTRUCTION HISTORY, 3., 2009, Cottbus. Proceedings... . Cottbus: Brandenburg University Of Technology, 2009.
} 


\subsubsection{3}

Eduardo Torroja, Torre de Água do Hipódromo de Zarzuela, Madrid, 1941. Corte. água com sistemas construtivos econômicos, que não necessitam de grandes recursos tecnológicos para a sua execução, algo muito valioso quando consideramos que milhares de pessoas no mundo não têm acesso à água potável e também que o estabelecimento de um sistema para suprimento de água é uma das primeiras medidas para auxiliar populações em situações de emergência.

Uma outra obra de Torroja que merece menção é a torre de água do Hipódromo de Zarzuela, 025 Madrid, construída em 1941. ${ }^{129}$ No centro de um reservatório cilíndrico, semienterrado, com 18,00 metros de diâmetro nasce a torre de água com formato de um hiperboloide de revolução de uma folha. Com uma altura total de 11,00 metros e um diâmetro da base de 5,70 metros, a torre de água tem capacidade para armazenar $67 \mathrm{~m}^{3}$ de água. $\mathrm{O}$ fuste foi executado integralmente em alvenaria autoportante de tijolos maciços de barro. Para viabilizar a execução do reservatório de concreto armado com fundo em cúpula, a parede do fuste é reduzida para metade da espessura no trecho correspondente a parede do reservatório (fig. 2.4.163). Cria-se assim um console para apoio do anel de suporte do reservatório e a meia-parede do fuste assume a função de uma forma externa definitiva para a parede de concreto do tanque. O reservatório é descoberto e o acesso ao seu topo é feito por uma escada tipo marinheiro cujos degraus, fabricados com barras redondas de ferro dobradas em formato $U$, são fixados diretamente na alvenaria do fuste.

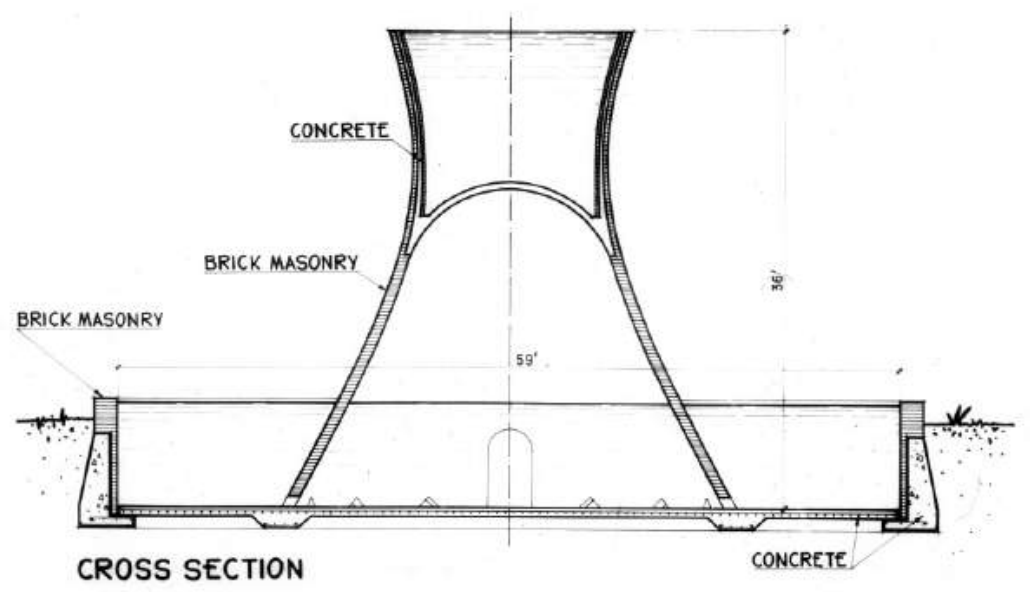

129 CEDEX / CEHOPU (Org.). ETM-115-004 - Reparación de edificios, nuevo abastecimiento y Depósito elevado en el Hipódromo de la Zarzuela [Exp. 246]. Madrid: Centro de Estudios Históricos de Obras Públicas y Urbanismo, 2008e. 


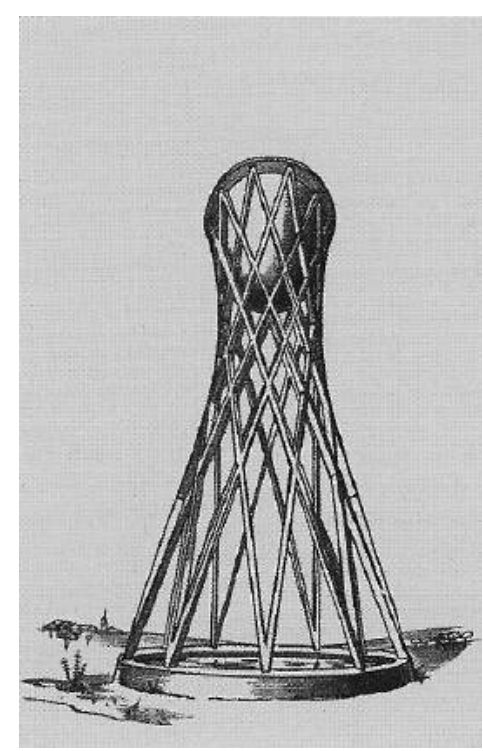

2.4.164

Eduardo Torroja, Estudo para Torre de Água do Hipódromo de Zarzuela, Madrid, 1935.
A torre de Zarzuela merece uma atenção especial não somente pelo seu sistema construtivo, mas principalmente pela sua forma. Após a experiência inicial de Vladmir Shukhov com as estruturas em malha hiperbólica construídas com perfis metálicos, o formato do hiperboloide de revolução de uma folha foi retomado por Torroja no estudo inicial para a torre de Zarzuela (fig. 2.4.164), realizado no ano de 1935, onde o engenheiro espanhol previa um sistema de duas famílias de colunas de concreto dispostas na direção das geratrizes retas do hiperboloide, criando uma malha estrutural para suporte de um reservatório de concreto com fundo hemisférico suspenso. Este projeto não se realizou, tendo sido substituído pela torre de alvenaria construída no ano de 1941. A forma do hiperboloide de revolução, preservada nos dois projetos de Torroja, interessa não apenas pela sua referencia ao trabalho de Shukhov, mas também como uma possível precursora da profusão de torres de água de concreto armado que seriam executadas a partir da década de 1960 em vários países.

Em 1965, o engenheiro uruguaio Eladio Dieste, foi questionado por estudantes de arquitetura de Montevideo sobre a sua posição em relação a Arquitetura Moderna e como esta se enquadrava na realidade nacional e nas questões construtivas:

"A arquitetura que chamamos Moderna surgiu em países de desenvolvimento social, cultural e especialmente industrial completamente diferentes dos nossos. Sua resposta aos problemas dessas sociedades parece-me quase sempre incompleta; geralmente é mais apropriado do ponto de vista tecnológico, mas adequado para eles, nem sempre para nós. (...) Comecei a estudar e a utilizar estruturalmente o tijolo para descobrir um material de possibilidades ilimitadas, quase completamente ignorado pela tecnologia moderna. O que foi feito estruturalmente até agora com o tijolo é pouco e não é bem orientado. Por exemplo, nos Estados Unidos, a tecnologia de produção de tijolos é muito refinada, mas é usada principalmente como material de revestimento. Quando usado estruturalmente, é para repetir em tijolo as formas já descobertas no uso do concreto armado. Uma arquitetura saudável 
não pode ser produzida sem o uso racional e econômico dos materiais de construção." 130

A pesquisa estrutural de Dieste com sistemas de alvenaria cerâmica armada viabilizou a construção de edifícios dos mais variados programas: igrejas, terminais rodoviários, centros comerciais, indústrias, galpões, silos, entre outros. Os reservatórios e as torres de água também se mostraram como excelentes possibilidades de aplicação da sua técnica construtiva. Estudos de Dieste mostraram que a construção de torres de água com o sistema de alvenaria cerâmica armada se apresenta como uma solução bastante econômica, sendo que para reservatórios com volumes variando entre 50 e $300 \mathrm{~m}^{3}$ a construção em alvenaria é mais barata do que uma construção convencional em concreto armado. ${ }^{131}$

O campanário da Igreja de Atlántida (1958) foi a primeira torre projetada e construída por Dieste e a precursora de suas torres de água. A primeira destas, 036 com uma altura de 27,00 metros, foi construída no ano de 1966 no Balneário Las Vegas. Com um formato ligeiramente cônico, a estrutura de suporte é uma casca de tijolos perfurada, com apenas $14 \mathrm{~cm}$ de espessura, que se estende do solo até o nível de fundo do reservatório e, obviamente, tornase um volume sólido no trecho correspondente ao tanque (fig.

130 "La arquitectura que llamamos Moderna surgió en paises de desarrollo social, cultural y sobre todo industrial completamente distintos a los nuestros. Su respuesta a los problemas de esas sociedades me parece casi siempre incompleta; suele ser más adecuada desde el punto de vista tecnológico, pero adecuada para ellos, no siempre para nosotros. (...) Empecé a estudiar y a utilizar estructuralmente el ladrillo, al descubrir un material de ilimitadas posibilidades, casi completamente ignorado por la técnica moderna. Lo que se ha hecho estructuralmente hasta ahora con el ladrilho es poco y no bien orientado. Por exemplo, en Estados Unidos la tecnologia de producción de ladrilho es muy refinada, pero se lo usa sobre todo como material de recubrimento. Cuando se le usa estructuralmente es para repetir en ladrilho las formas ya descubiertas y en uso en hormigón armado. Una arquitectura sana no puede producirse sin uso racional y económico de los materiales de construcción." DIESTE, Eladio. Introducción. In: TORRECILLAS, Antonio Jiménez (Org.). Eladio Dieste: 1943-1996. Junta de Andalucía: Consejeria de Obras Públicas y Transportes. Dirección General de Arquitectura y Vivienda, 1996.

131 TORRECILLAS, Antonio Jiménez (Org.). Eladio Dieste: 1943-1996. Junta de Andalucía: Consejeria de Obras Públicas y Transportes. Dirección General de Arquitectura y Vivienda, 1996, p. 207. 


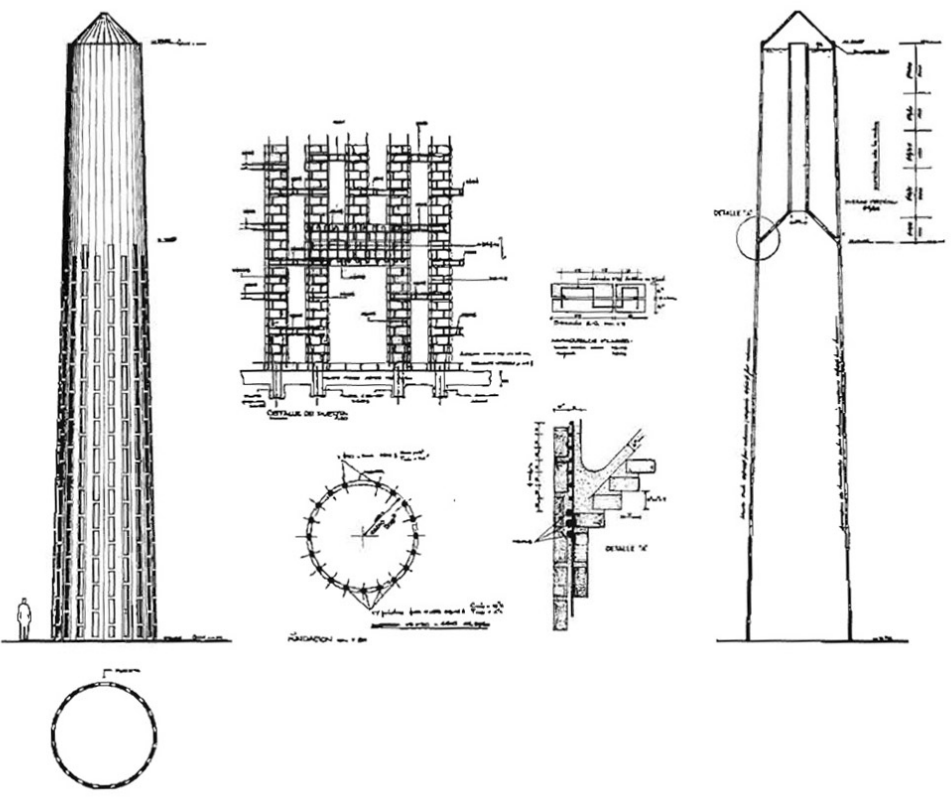

\section{4 .165}

Eladio Dieste, Torre de Água do Balneário Las Vegas, Uruguai, 1966.
2.4.165). O reservatório tem capacidade para armazenar $120 \mathrm{~m}^{3}$ de água e é coberto por um telhado cônico em alvenaria. Uma passagem vertical atravessa o reservatório em altura para permitir o acesso ao topo da torre. ${ }^{132}$

A torre de água (fig. 2.4.166) construída em 1976 para a Indústria Refrescos del Norte, 055 na cidade de Salto, tem uma estrutura de suporte semelhante à da torre de Las Vegas, mas seu reservatório assume e forma de um tronco de cone invertido. As paredes do fuste de 24,00 metros de altura têm apenas $14 \mathrm{~cm}$ de espessura. O reservatório têm capacidade para armazenar $50 \mathrm{~m}^{3}$ de água e é coberto por um teto plano, preservando a passagem vertical existente no interior do reservatório. ${ }^{133}$

As formas das torres de Dieste são definidas segundo considerações estéticas, estáticas e construtivas. Algumas similaridades entre os dois projetos ilustra esta afirmação. A perfuração do fuste das torres assume funções diversas: diminuem a carga de vento atuando na estrutura; as plataformas de trabalho utilizados durante a construção são posicionados nos furos do fuste, sendo movimentadas à medida que a torre vai subindo, sem

\footnotetext{
${ }^{132}$ ANDERSON, Stanford (Ed.). Eladio Dieste: Innovation in Structural Art. New York: Princeton Architectural Press, 2004, p. 152.

133 lbid., p. 154.
} 
necessidade de andaimes adicionais; a largura dos perfurações diminui conforme aumenta a altura da torre, assim é possível manter a mesma área estrutural de alvenaria mesmo com a redução do diâmetro do fuste. A forma troncônica dos reservatórios devese tanto a razões estáticas quanto estéticas: além de diminuir os esforços cortantes atuando no sentido horizontal, a forma, segundo - próprio Dieste, "elimina as desagradáveis deformações de perspectiva das formas cilíndricas. "134 As paredes dos fustes das torres têm uma espessura de apenas $14 \mathrm{~cm}$, consistindo de dois tijolos assentados em espelho com as armaduras de aço, duas barras verticais corridas para cada faixa vertical de alvenaria, posicionadas no interior da junta argamassada. O fundo dos reservatórios é em formato de cúpula, sem armação, construído sem andaime, em anéis sucessivos, defasados em uma largura de meio tijolo em relação ao anel anterior. As paredes do reservatório são ainda mais esbeltas do que as paredes do fuste da torres, com espessura de apenas $11 \mathrm{~cm}$, sendo 5,5 cm de tijolo e 5,5 cm de argamassa de cimento Portland armada com telas de aço eletrosoldada para resistir aos empuxos horizontais da água.

Durante as décadas de 1960 e 1990, Dieste projetou e construiu uma série de torres de água no Uruguai, onde podemos destacar: Conjunto Habitacional Malvin Norte, $300 \mathrm{~m}^{3}$ (1971); Salto, $150 \mathrm{~m}^{3}$ (1976); Agroindústria Massaro, 56 m³ (1976); Complejo Habitacional America, $056200 \mathrm{~m}^{3}$ (1976); Canelones, $100 \mathrm{~m}^{3}$ (1985) e torre do Hipercentro Devoto Sayago, $162 \mathrm{~m}^{3}$ (1995). A figura 2.4.167 apresenta os detalhes construtivos da torre de água do Complejo Habitacional América. No Brasil existe uma torre de água de Dieste construída em conjunto com o antigo Centro Esportivo Pelotense (1994). A torre de água possui altura total de 19,00 metros e capacidade para armazenar $8,7 \mathrm{~m}^{3}$ de água. ${ }^{135}$

\footnotetext{
134 TORRECILLAS, 1996, op. cit., p. 209.

${ }^{135}$ ANDERSON, 2004, op. cit., p. 250.
} 
2.4 .166

Eladio Dieste, Torre de Água para a Indústria Refrescos del Norte, Salto, Uruguai, 1976.

\subsubsection{7}

Eladio Dieste, Torre de Água do Complejo Habitacional América, Montevidéu, Uruguai, 1976.
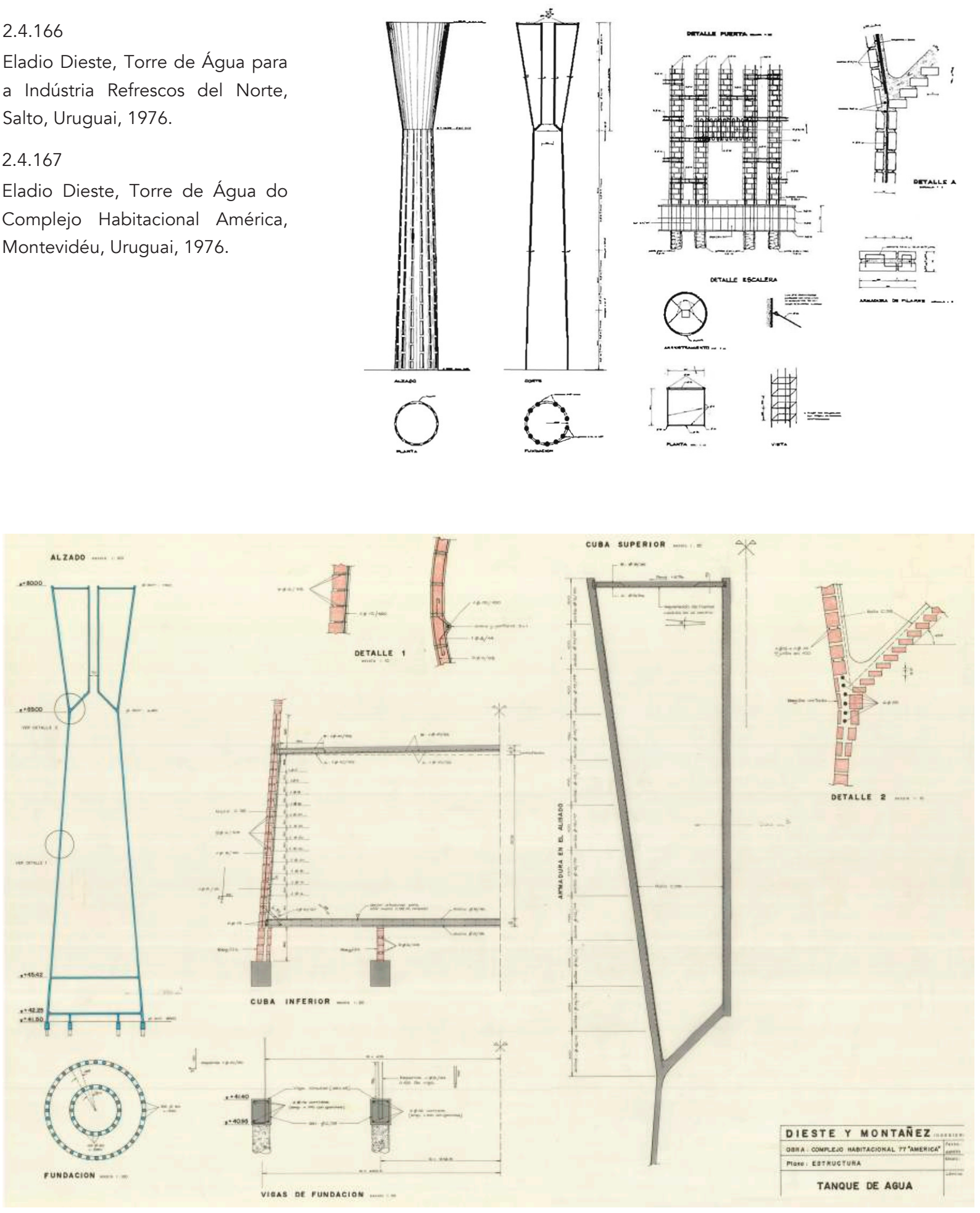


\subsubsection{Modernas Torres de Água de Concreto}

Até meadas do século $X X$ as tipologias disponíveis para a construção de reservatórios elevados de água em concreto armado eram aquelas desenvolvidas no período de transição entre os séculos XIX e XX. As possibilidades de reservatórios disponíveis para concreto armado limitavam-se a três tipos: Intze tipo I, fundo plano e fundo em cúpula. Variações de reservatórios combinando duas destas três tipologias também existiram como, por exemplo, em torres de água que utilizavam reservatórios que combinavam trechos de fundo plano com um trecho de fundo em cúpula. Somente na década de 1950 novas tipologias de reservatórios surgiram, alterando significativamente as formas das torres de água da atualidade.

$\mathrm{Na}$ torre de água de Cocody (figs. 2.4.168, 2.4.169), construída em 1953 na cidade de Abidjan, Costa do Marfim, foi utilizado pela primeira vez o reservatório em formato troncônico. O novo formato de reservatório, proposto pelo arquiteto Daniel Badani (1914-2006) e pelo engenheiro Nicolas Esquillan (19021989), surgiu de dificuldades relativas à falta de materiais de construção na cidade de Abidjan, especialmente de madeira, o que inviabilizada a execução de estruturas de concreto armado com grandes alturas. Badani e Esquillan desenvolveram uma solução que consistia em se construir o reservatório apoiado no solo para depois levanta-lo até a altura necessária por meio de macacos hidráulicos. A forma trôncônica do reservatório também é uma resposta à falta de madeira. A inclinação da parede do reservatório, cerca de $36^{\circ}$, corresponde à inclinação do abatimento natural do concreto, o que torna possível concretar o reservatório em um buraco escavado no terreno sem o emprego de formas para moldar a face interna da parede do tanque. ${ }^{136}$ Esta solução formal, derivada da falta de madeira para execução das formas de concreto, mostrou grandes vantagens tanto do ponto de vista estático quanto do ponto de vista hidráulico. Do ponto de vista estático o formato troncônico

${ }^{136}$ MARREY, Bernard. Nicolas Esquilan: Un Ingénieur

D’Entrepise. Paris: Picard, 1992, p. 83. 
tem a grande vantagem de manter o equilíbrio de pressões no interior do reservatório, uma vez que o trecho em balanço alivia os esforços atuantes no fundo apoiado interno. Do ponto de vista hidráulico obteve-se um formato de reservatório onde a variação do nível de água era bem menor que nas tipologias existentes e isto se traduzia em menores flutuações de pressão na rede de abastecimento. Na torre de Cocody, a utilização de metade do volume de água armazenado equivale a reduzir o nível de água em apenas $1 / 4$ da profundidade total de lâmina de água, assim a maior parte da água é armazenada na área do tanque onde ocorrem as maiores flutuações de consumo devido às retiradas constantes para os usos doméstico e comercial, usos estes que necessitam de uma maior estabilidade na pressão de abastecimento. ${ }^{137}$

O reservatório da torre de Cocody, com uma altura de 6,35 metros e um diâmetro de 13,00 metros na base e 30,00 metros no topo, tem capacidade para armazenar $2.000 \mathrm{~m}^{3}$ de água. A concretagem da parede do reservatório foi executada em faixas de aproximadamente 1,00 metro de largura, com espessuras variando entre 15 e 27 cm, de acordo com a variação da pressão hidrostática no interior do reservatório. Construída em 8 meses (fig. 2.4.170), o reservatório foi levantado à altura pretendida de 26,00 metros com a ajuda se 6 macacos hidráulicos de 100 toneladas cada, em um processo que durou 3 meses, simultâneo ao procedimento de construção do fuste central de suporte. O reservatório é simplesmente apoiado no fuste central, sem qualquer tipo de ligação mecânica entre os dois elementos. Anos mais tarde, com a expansão da área de abastecimento na cidade de Abidjan, a pressão de água gerada pela torre de Cocody tornou-se insuficiente e o reservatório foi erguido mais alguns metros com a ampliação da altura do fuste, utilizando-se o mesmo processo construtivo original. ${ }^{138}$

\footnotetext{
${ }^{137}$ WERTH, 1971, op. cit., p. 395.

138 MARREY, 1992, op. cit., p. 84.
} 


\subsubsection{8}

Daniel Badani e Nicolas Esquillan, Torre de Água de Cocody, Abidjan, Costa do Marfim, 1953.

\subsubsection{9}

Daniel Badani e Nicolas Esquillan, Torre de Água de Cocody, Abidjan, Costa do Marfim, 1953. Corte

\subsubsection{0}

Daniel Badani e Nicolas Esquillan, Torre de Água de Cocody, Abidjan, Costa do Marfim, 1953. Foto da obra.
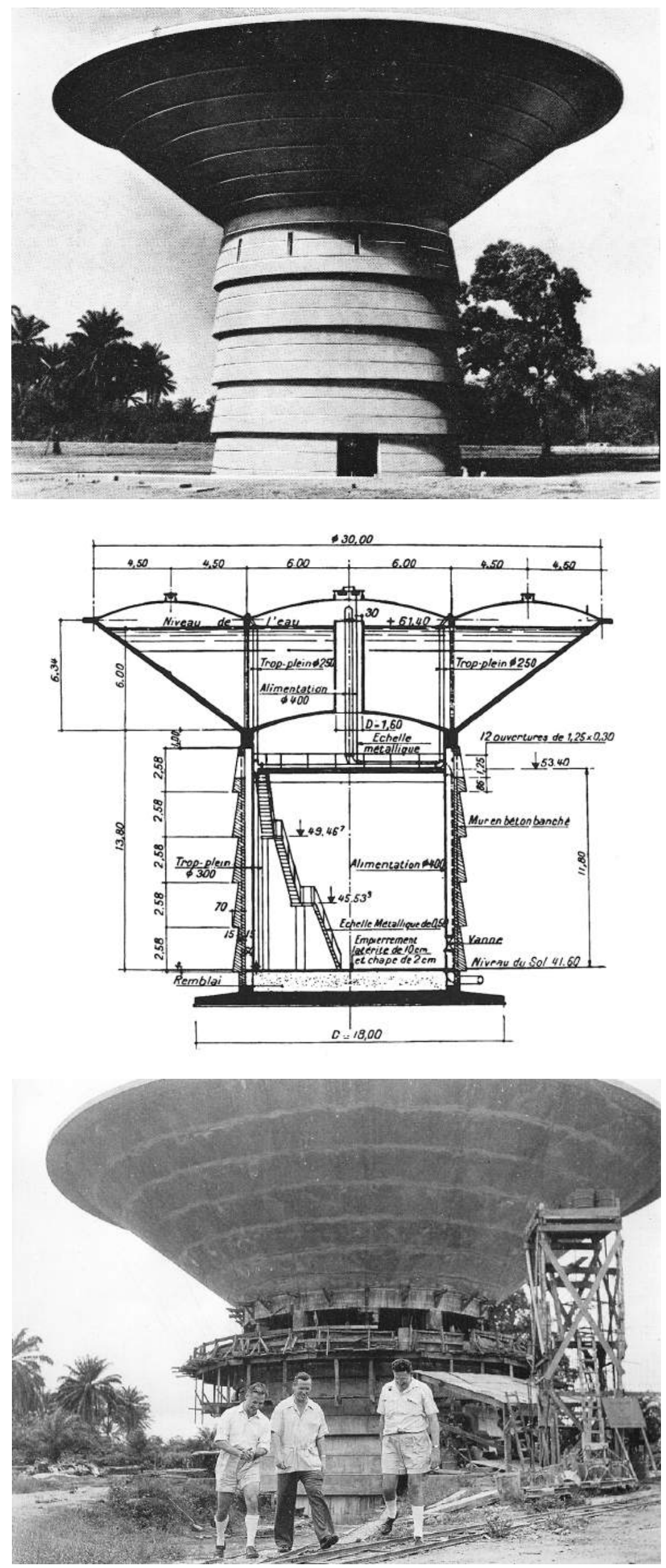


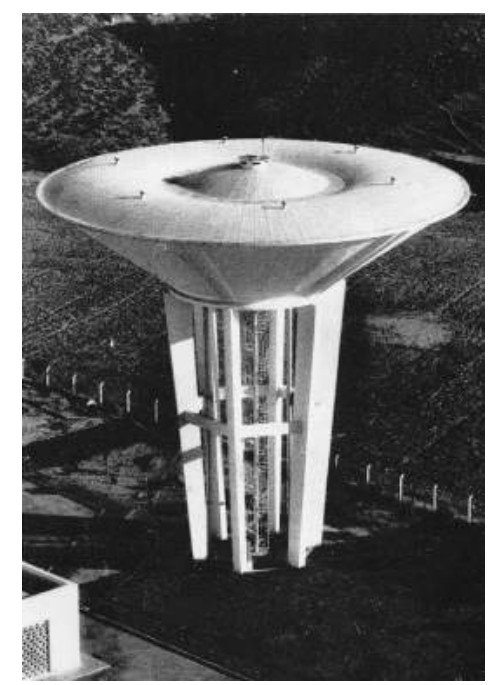

2.4.171

Nicolas Esquillan, Torre de Água de Rabat, Marrocos, 1954.
Em 1954, na cidade de Rabat, no Marrocos, Esquillan projeta e constrói sua segunda torre de água (fig. 2.4.171) equipada com um reservatório de formato troncônico. O reservatório, com volume de $1.000 \mathrm{~m}^{3}$, tem uma altura de 5,75 metros e um diâmetro de 9,44 metros na base e 24,00 metros no topo. Ao invés de utilizar um fuste cilíndrico, Esquillan apoiou o reservatório em um conjunto de 6 colunas separadas, travadas por vigas dispostas a meia altura. Toda a obra foi executada com formas e cimbramentos tradicionais. A inovação aqui fica por conta do material de construção do reservatório, com a utilização de concreto protendido ao invés de concreto simplesmente armado, com o qual foi possível obter uma redução significativa da espessura da parede do reservatório, que varia entre 12 e $20 \mathrm{~cm}$ de acordo com a pressão hidrostática no interior do reservatório. ${ }^{139}$

A tecnologia de protensão, processo pelo qual se aplicam tensões de compressão prévias ao concreto, permite eliminar grande parte das tensões de tração atuantes no concreto, possibilitando a redução das secções transversais dos elementos tracionados em diversos tipos de estruturas. Os primeiros estudos relacionados à proteção de estruturas de concreto armado foram iniciados pelo engenheiro francês Eugène Freyssinet (1879-1962) em meados da década de 1920. Freysssinet obteve a primeira patente do béton précontraint (concreto protendido) no ano de 1928, mas o termo précontrainte (protensão), só seria inventado por ele no ano de 1933. A primeira ponte de concreto protendido foi construída no ano de 1938, em Aue, na Alemanha. O desenvolvimento do concreto protendido acelerou após 1949 e em 1950 foi realizada em Paris a primeira conferência internacional sobre o tema. No ano de 1950 o engenheiro alemão Ulrich Finsterwalder (1897-1988) executa a primeira ponte em concreto protendido no sistema de balanços sucessivos. A partir da década de 1950 o método construtivo se espalhou pelo mundo. ${ }^{140}$

\footnotetext{
139 Ibidem.

140 VERÍSSIMO, Gustavo de Souza; CÉSAR JUNIOR, Kléos M. Lenz. Concreto Protendido: Fundamentos Básicos. Viçosa: Universidade Federal de Viçosa, 1998, p. 4.
} 

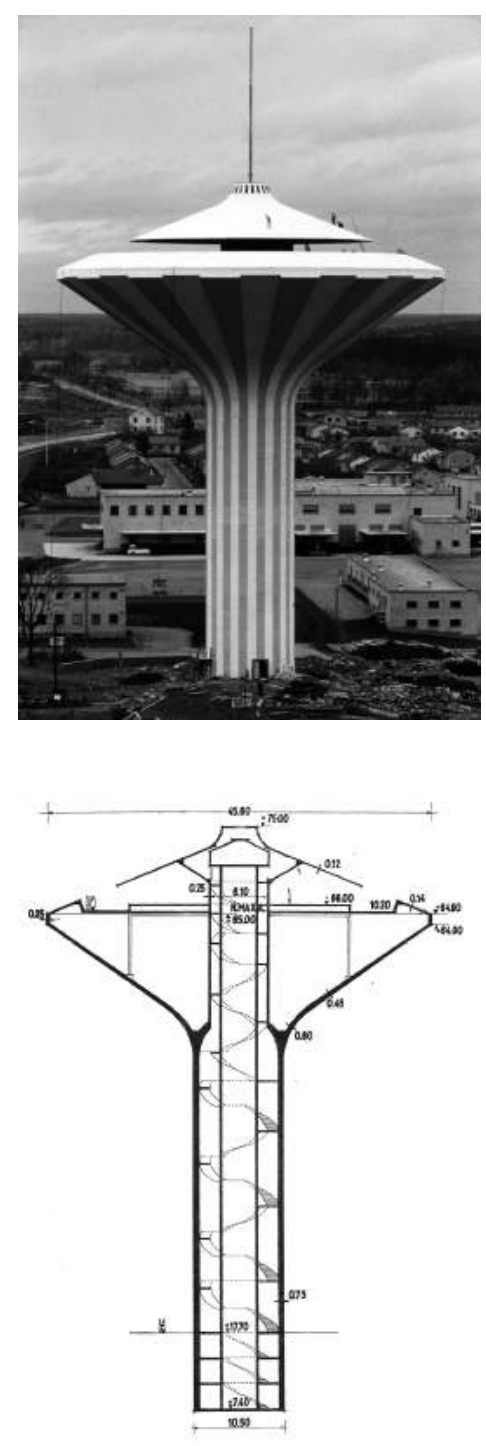

2.4.172

Sune Lindström, Torre de Água de Örebro, Suécia, 1957.

\subsubsection{3}

Sune Lindström, Torre de Água de Örebro, Suécia, 1957. Corte.
Com o método de protensão tornou-se possível reduzir significativamente as tensões de tração atuantes no concreto, viabilizando a construção de reservatórios de água de concreto livres de fissuras. Além disso economias significativas de material podem ser obtidas com a construção de reservatórios maiores, já que as espessuras de parede dos reservatórios cilíndricos pode ser reduzida. No entanto as vantagens econômicas do concreto protendido são obtidas apenas em reservatórios com volumes acima de $1.000 \mathrm{~m}^{3}$, uma vez que para tanques menores não é possível reduzir as espessuras de paredes para valores inferiores às espessuras mínimas necessárias por questões construtivas. ${ }^{141}$ As tipologias de reservatórios preferidas para o concreto protendido são os reservatórios de fundo plano, os com formatos troncônicos e os hiperboloides, que serão discutidos mais adiante.

A torre da cidade de Örebro, Suécia, 021 projetada pelo arquiteto Sune Lindström (1906-1989), é uma prova da eficiência da aplicação da tecnologia do concreto protendido na construção de torres de água (figs. 2.4.172, 2.4.173). Construída em 1957 com uma altura total de 57,00 metros e um diâmetro de 45,60 metros seu reservatório é capaz de armazenar $9.000 \mathrm{~m}^{3}$ de água e foi protendido utilizando o sistema Freyssinet (fig. 2.4.174). $O$ reservatório em forma troncônica foi construído da mesma forma que na torre de Cocody, concretado sobre o solo e em seguida erguido até a altura final ao mesmo tempo em que o fuste era executado com o sistema de formas deslizantes (fig. 2.4.175). 0 fuste central, com diâmetro de 10,50 metros, abriga as tubulações hidráulicas e um conjunto de escadas e elevadores que conduz para um restaurante panorâmico no topo da torre. A operação de elevação do reservatório se mostrou a mais espetacular de todo o trabalho. Foram utilizados 32 macacos hidráulicos, instalados de cabeça para baixo sob o anel de suporte do reservatório, para erguer o tanque de 3.200 toneladas. O processo de elevação era realizado em faixas sucessivas seguindo o seguinte procedimento: todos os macacos elevavam o reservatório em uma altura de 29 cm; aliviava-

${ }^{141}$ WERTH, 1971, op. cit., p. 396. 

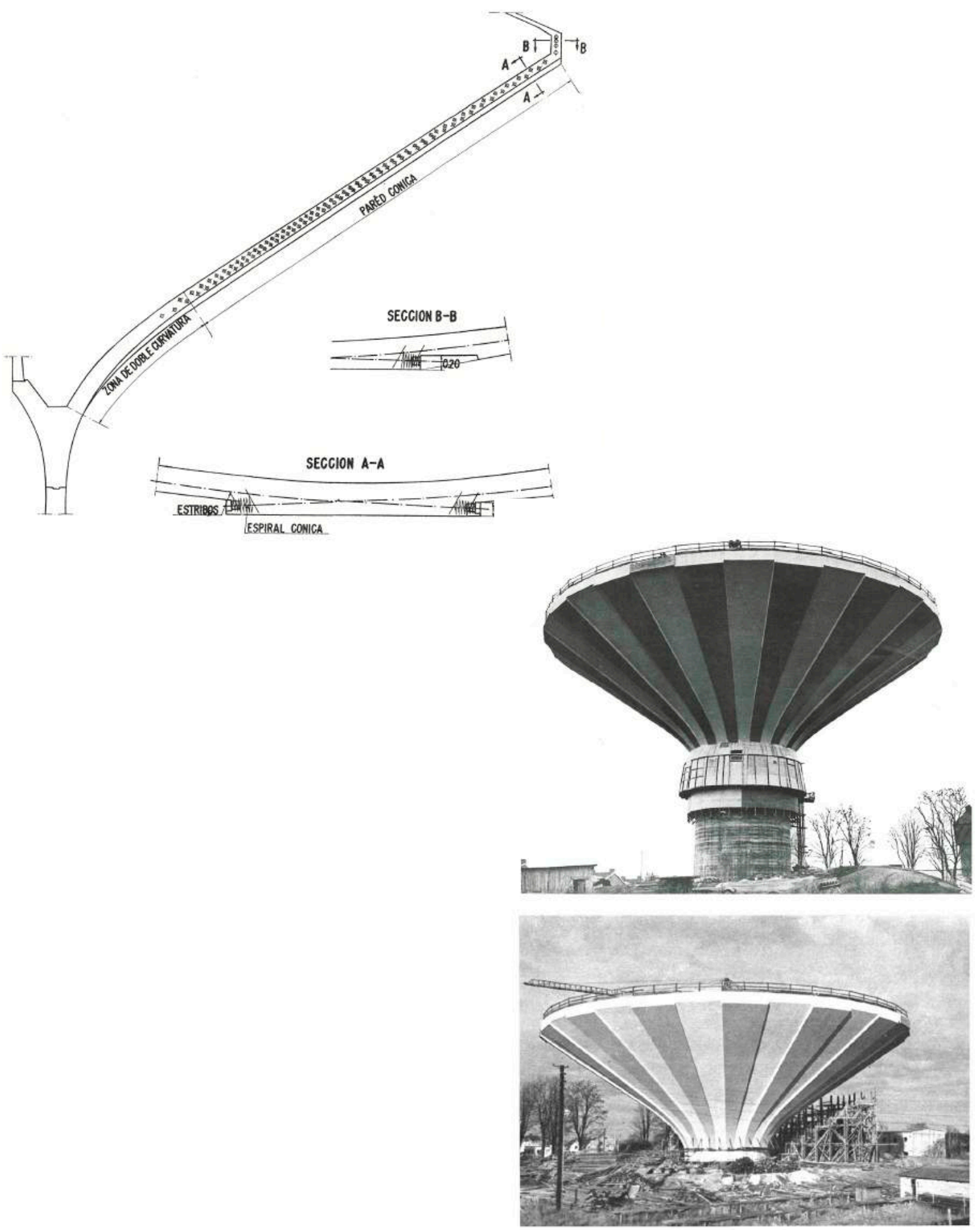

2.4.174

Sune Lindström, Torre de Água de Örebro, Suécia, 1957. Detalhe da Protensão.

\subsubsection{5}

Sune Lindström, Torre de Água de Örebro, Suécia, 1957. Evolução da Obra.

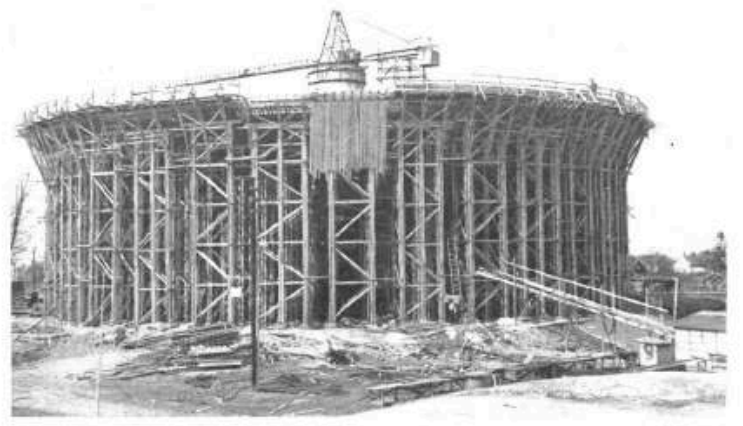


se um dos macacos e instalava-se sob este um cilindro de concreto pré-fabricado; realizava-se o mesmo procedimento para os 31 macacos restantes; após a instalação dos cilindros pré-fabricados de concreto sob todos os macacos, os cilindros eram embebidos em concreto fresco, sendo incorporados ao fuste da torre; novamente, todos os macacos elevavam o reservatório em altura de $29 \mathrm{~cm}$ reiniciando todo o processo. A elevação do reservatório, em passos de $29 \mathrm{~cm}$, durou 3 meses e foram utilizados 4.000 cilindros de concreto para o apoio do reservatório durante a construção do fuste. Assim como na torre de água de Cocody, o reservatório está simplesmente apoiado sobre o fuste e pode ser elevado com a ampliação da altura do fuste se um dia for necessário. ${ }^{142} \mathrm{~A}$ torre que ficou muito conhecida após a sua construção começou a ser chamada na Suécia de Svanpen (cogumelo), devido a sua forma, e acabou por batizar a tipologia de reservatório troncônico com um nome alternativo: "reservatório cogumelo".

Em 1971 Lindström projetou e construiu uma torre praticamente idêntica à torre de Örebro na cidade de Riyadh, Arábia Saudita, mas com um volume de $12.000 \mathrm{~m}^{3}$. Em 1965 o governo do Kuwait contratou empresa sueca VBB para desenvolver e implementar um moderno sistema de abastecimento de água para a Cidade do Kuwait e o arquiteto chefe do projeto foi Lindström. O novo sistema de abastecimento foi implantado durante os anos de 1965 e 1976 e foram construídas 31 torres de água (figs. 2.4.176, 2.4.177) similares a torre de Örebro, cada uma com $3.000 \mathrm{~m}^{3}$ de capacidade, distribuídas em 5 grupos pela Cidade do Kuwait. Em cada grupo a quantidade, a altura e as cores das torres são variáveis, criando conjuntos únicos de torres que servem como uma referencia para cada bairro. Como parte do mesmo projeto, Lindström e a arquiteta Malene Bjørn (19142016), construíram as Kuwait Towers, 052 um conjunto de três torres construídas em um promontório que se projeta no Golfo Pérsico. A torre principal, na forma de uma agulha que perfura duas esferas,

142 Depósito pretensado Orebro. Informes de La Construcción, Madrid, v. 11, n. 103, p. 581-14, ago/set. 1958. 


\subsubsection{6}

Sune Lindström, Grupo de Torres de Água na Cidade do Kuwait, Kuwait, 1971.

\subsubsection{7}

Sune Lindström, Grupo de Torres de Água na Cidade do Kuwait, Kuwait, 1971. Corte e elevação. tem 185,00 metros de altura. A esfera maior, com 30,00 metros de diâmetro, contém em sua parte inferior um reservatório de água de $4.500 \mathrm{~m}^{3}$ e em sua parte superior, a uma altura de 82 metros, um restaurante panorâmico para 90 pessoas, um café e áreas para estar e eventos. A esfera menor, a 123,00 metros de altura, abriga um café panorâmico giratório. A segunda torre tem 140,00 metros de altura e serve exclusivamente como torre de água, com um reservatório esférico de 25,00 metros de diâmetro e volume de $4.500 \mathrm{~m}^{3}$. A terceira torre contém equipamentos para fornecimento de energia e iluminação das torres principais. As duas torres de água têm capacidade para armazenar $9.000 \mathrm{~m}^{3}$ de água. As torres foram construídas em concreto armado e os reservatórios em concreto protendido. ${ }^{143}$
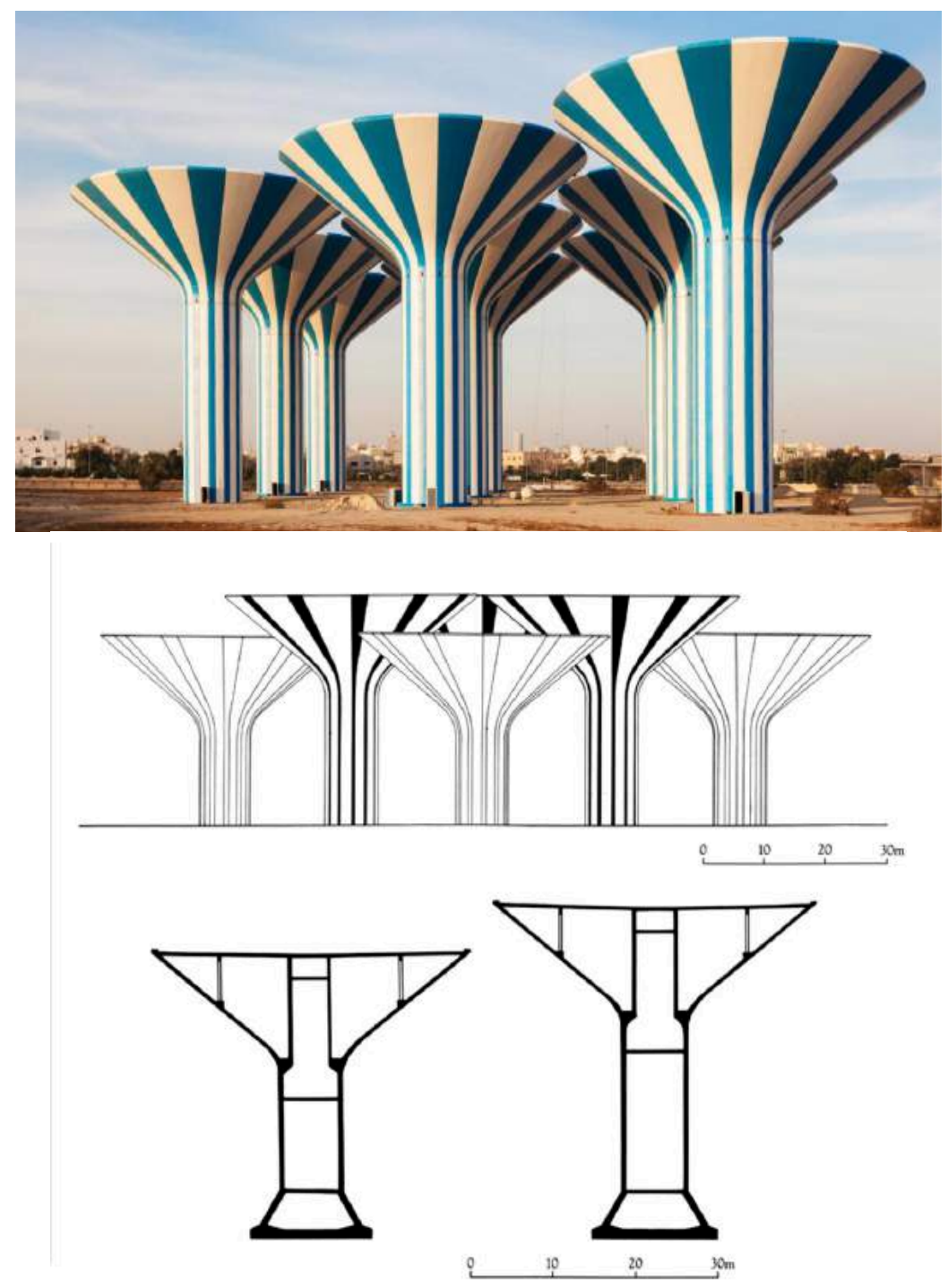

${ }^{143}$ KULTERMANN, Udo. Acqua Arabia. DOMUS: Monthly Review of Architecture Interiors Design Art, Milano, n. 596, p. 44-45, fev. 1976. 
2.4.178

Torres de Água projetadas por Gerhard Leo Linzmeyer.

a) Apucarana, $200 \mathrm{m3}, 1967$.

b) Mandaguari, 197-.

c) Maringá (Praça Pio XII), 300 m3, 1974.

d) Paranavaí, 197-.
Outra obra de Sune Lindström que merece atenção é a torre de água de Khuzam, 051 em Gidá, na Arábia Saudita, construída entre os anos de 1973 e 1977 utilizando o mesmo sistema construtivo das torres de Örebro e de Riyadh. A torre de Khuzam é uma obra de dimensões gigantescas, com uma altura total de 78,00 metros e um reservatório com diâmetro de 55,00 metros, que tem capacidade para armazenar $18.000 \mathrm{~m}^{3}$ de água, recorde mundial em volume da água armazenada para torres construídas em concreto. Operacionalmente, no entanto, a torre estoca normalmente um volume de $13.500 \mathrm{~m}^{3}$ de água. ${ }^{144}$

A tipologia de reservatório troncônico, podendo ser construída sobre o solo para posterior elevação ou sendo construída com auxílios dos tradicionais cimbramentos e formas metálicas ou de madeira, tornou-se uma das tipologias de reservatórios mais bem sucedidas para a construção de torres de água de concreto. Numerosas torres de água já foram construídas com este formato de reservatório em tamanhos diferentes, variando entre 250 e 18.000 $\mathrm{m}^{3}$ de volume de armazenagem. Para citar alguns exemplos: torre de Myllypuro, 034 em Helsinque, projeto de Bertel Saarnio, 13.500 $\mathrm{m}^{3}, 1965$; torres de Alençon, 037 projeto de Serge Ketoff e Maurice Novarina, 3 × 2.000 m³ 1967; torre de Hyllie, 047 em Malmö, projeto de Goran Kjessler e Karl Ivar Stal, 10.200 m³,1973.
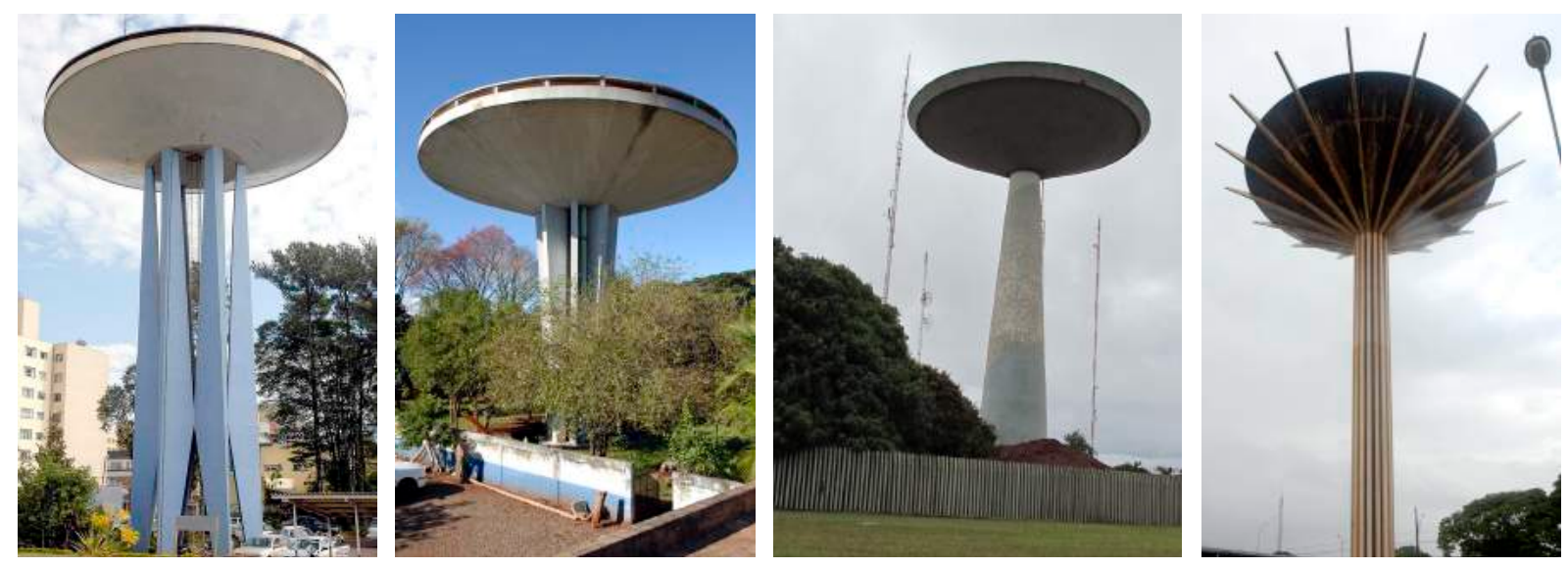

${ }^{144}$ SHAWLY, Hassan H.. Urban Water: Integrated Resource Planning to Meet Future Demand in Jeddah - Saudi Arabia. München: Oldenburg Industrieverlag, 2008, p. 112. 


\subsubsection{9}

DAE, Torre de Água da Vila Mariana, São Paulo, Brasil, 19661968.

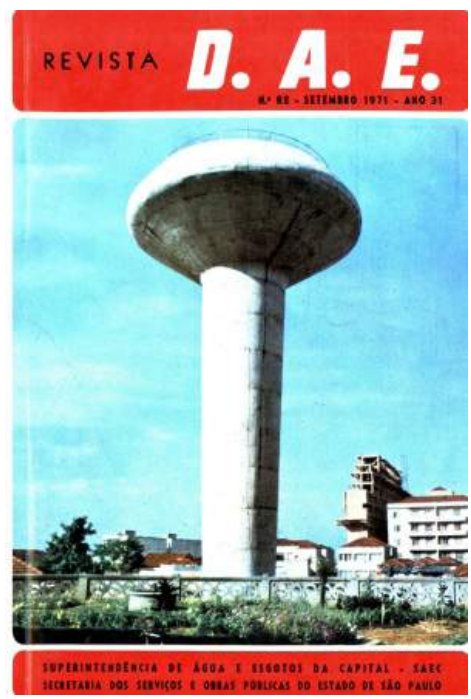

No Brasil podemos citar como exemplo de torres de água com reservatórios troncônicos as das cidades de Ceilândia 049 e Taguatinga (DF); Apucarana, Mandaguari, Maringá (Praça Pio XII) e Paranavaí (fig. 2.4.178) ; todas projetadas pelo engenheiro e arquiteto curitibano Gerhard Leo Linzmeyer (1928-1999) ${ }^{145}$ durante as décadas de 1960 e 1970. ${ }^{146}$ Linzmeyer foi pioneiro no Brasil na utilização do concreto protendido na construção de torres de água, construindo em 1966 a Torre de Água de São José dos Pinhais $(P R)$, primeiro reservatório elevado do país a utilizar a técnica de protensão. Em 1966 o Departamento de Água e Esgotos da Capital (DAE) desenvolveu um projeto-tipo para novas torres de água para a cidade de São Paulo, equipadas com reservatórios de $500 \mathrm{~m}^{3}$ na tipologia "cogumelo", executadas em concreto armado com acabamento aparente. A primeira destas torres-tipo foi construída na Vila Jaraguá entre os anos de 1966 e $1968{ }^{147}$ e, posteriormente, foram construídas torres idênticas em Cidade Ademar e Vila Mariana (fig. 2.4.179), esta última substituindo a antiga torre com reservatório de concreto de $300 \mathrm{~m}^{3}$ na tipologia Intze, construída entre os anos de 1928 e 1930.

145 Gerhard Leo Linzmeyer formou-se em engenharia pela UFPR e estudou arquitetura na Universidade de Karlsruhe, na Alemanha, nos anos de 1956 e 1957. Foi diretor do Departamento de Águas e Esgoto do Estado do Paraná, Diretor Presidente da Companhia de Saneamento do Paraná (SANEPAR) e Secretário de Estado de Viação e Obras Públicas (1975 e 1979). Linzmeyer projetou um grande número de torres de água enquanto atuou na SANEPAR destacando-se, além das obras citadas no texto, as torres de Rolândia e Maringá (PR). A extensão de sua obra no universo das torres de água ainda é desconhecida, merecendo uma pesquisa mais aprofundada.

146 NETTO, José Martiniano de Azevedo. Arquitetura das Torres d'Água (IV). Revista D.A.E.: Revista do Departamento de Águas e Esgotos, São Paulo, v. 33, n. 91, p. 15-27, set. 1973; e também NETTO, José Martiniano de Azevedo. Arquitetura das Torres de Água - III. Revista D.A.E.: Revista do Departamento de Águas e Esgotos, São Paulo, v. 28, n. 70, p. 13-25, dez. 1968.

${ }^{147}$ NETTO, 1968, op. cit., p. 25. 
2.4.180

Simo Lumme, Torre de Água de Roihuvuori, Helsinque, Finlândia, 1976.

\subsubsection{1}

Simo Lumme, Torre de Água de Roihuvuori, Helsinque, Finlândia, 1976. Processo construtivo.

A: Construção do fuste com formas deslizantes

B: Içamento do reservatório (heavy lifting)

1: Macaco hidráulico

2: Cabo de protensão

3: Reservatório concretado sobre cimbramento

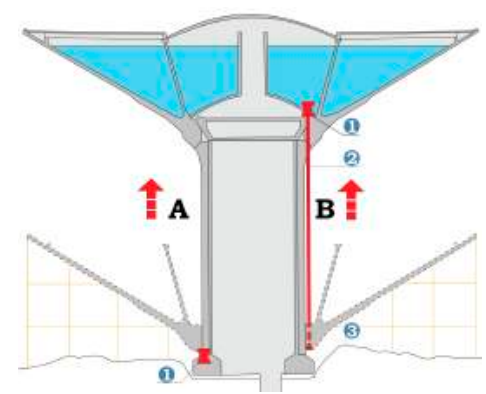

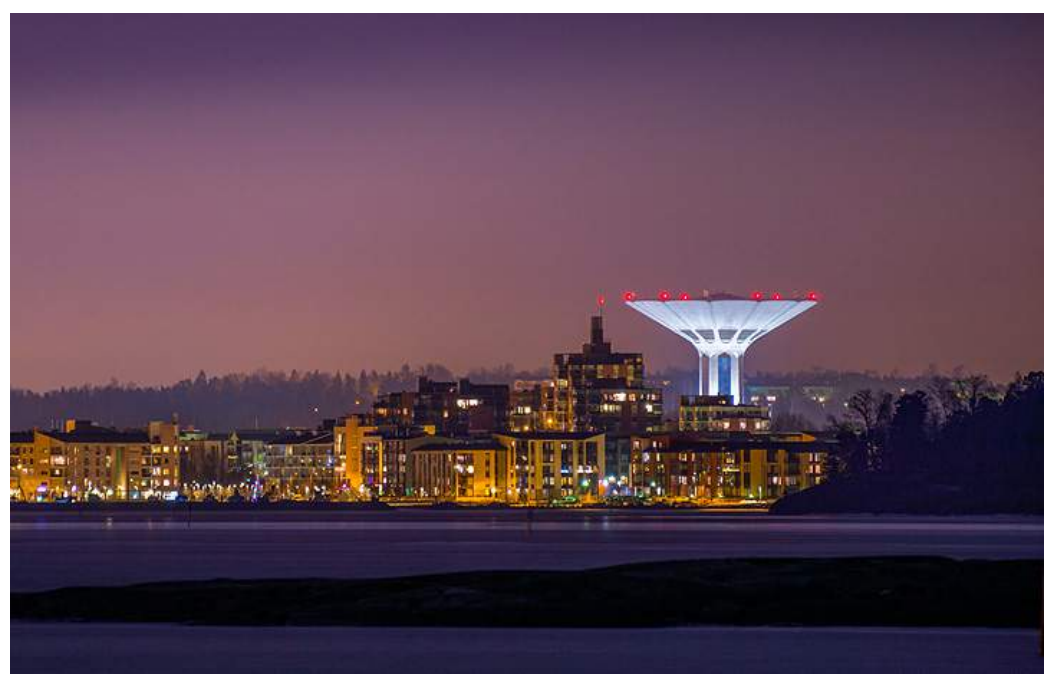

A torre de Roihuvuori, 054 construída na cidade de Helsinque entre os anos de 1976 1977, é um exemplo da mais avançada técnica pra construção de torres de água com reservatórios na tipologia "cogumelo" existente na atualidade, chamada de heavy lifting ou heavy rigging. A torre (fig. 2.4.180) projetada em 1976 pelo arquiteto Simo Lumme e com projeto estrutural do engenheiro Arto Pitkanen é gigantesca: 52,00 metros de altura, 66,70 metros de diâmetro e com capacidade para armazenar $12.600 \mathrm{~m}^{3}$ de água. Em Roihuvuori a construção (fig. 2.4.181) foi iniciada pelo fuste de concreto da torre, com 15,00 metros de diâmetro e uma espessura de parede de $400 \mathrm{~mm}$, executado pelo método de formas deslizantes. Após a finalização do fuste foi construído, ao redor deste e apoiado sobre o solo, o reservatório troncônico, uma peça única com diâmetro de 66,70 metros e um peso de 9.000 toneladas, executado em concreto protendido. No topo do fuste da torre 33 cabos de protensão foram instalados em conjuntos com macacos hidráulicos de protensão, posicionados sobre um anel de concreto protendido (fig. 2.4.182). Os 33 cabos de protensão, formados por 31 fios de $\varnothing 15 \mathrm{~mm}$, foram ancorados no anel de suporte do reservatório (fig. 2.4.183). Bombas hidráulicas acionaram os macacos de protensão e o reservatório foi içado pelos cabos de protensão (fig. 2.4.184) por cerca de 30,00 metros até a sua posição final, em um procedimento de durou 52 horas. ${ }^{148}$

${ }^{148}$ VSL. Roihuvuori Water Tower, Helsinki - Finland: Lifting of the Storage Tank. Berne: VSL International Ltd., 2008. 


\subsubsection{2}

Torre de Água de Roihuvuori, Helsinque, Finlândia, 1976.

Unidades de içamento instaladas no topo do fuste.

\section{4 .183}

Torre de Água de Roihuvuori, Helsinque, Finlândia, 1976.

Ancoragem dos cabos de protensão no anel de suporte do reservatório.

\section{4 .184}

Torre de Água de Roihuvuori, Helsinque, Finlândia, 1976.

Início do içamento do reservatório.
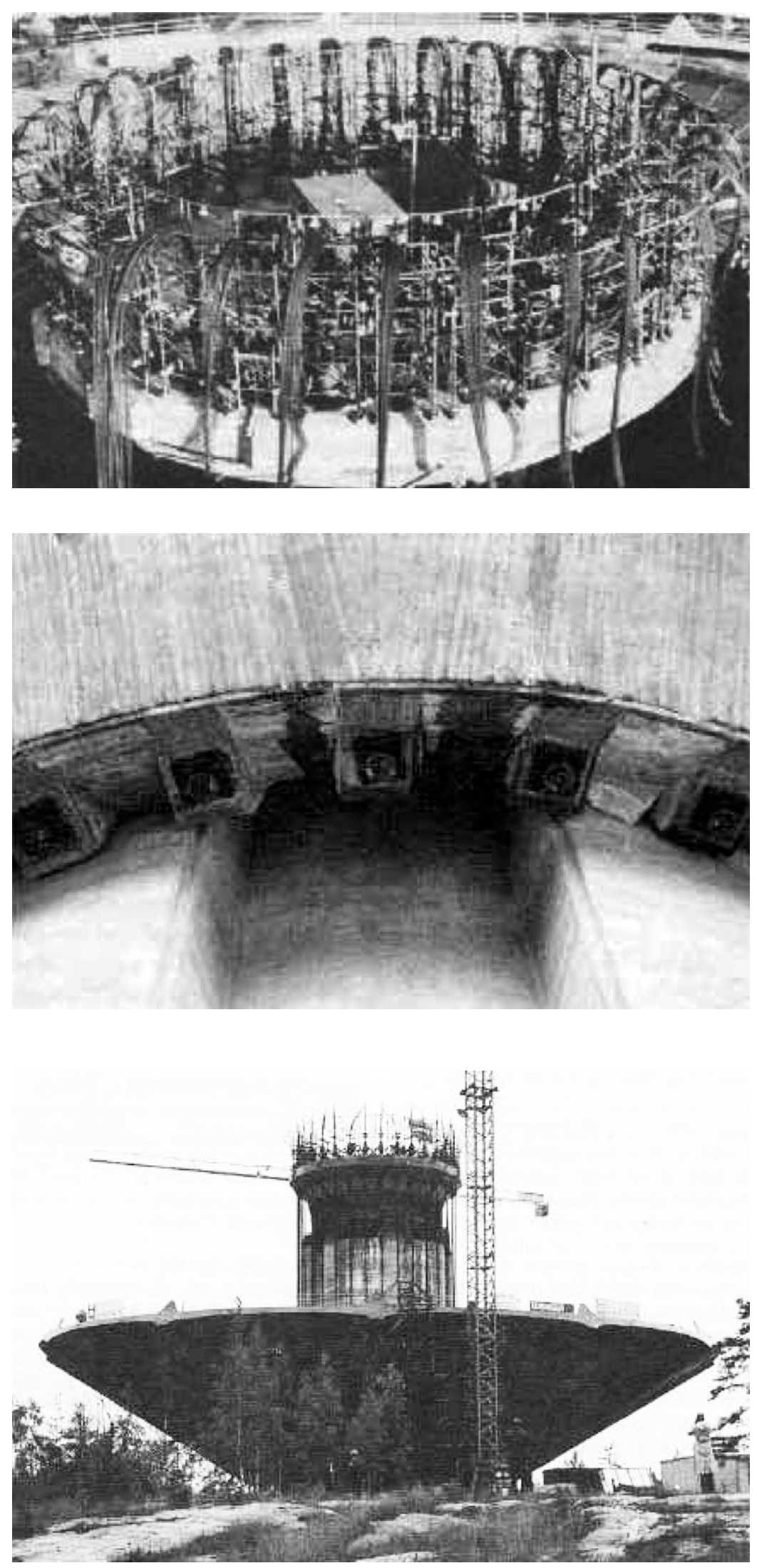

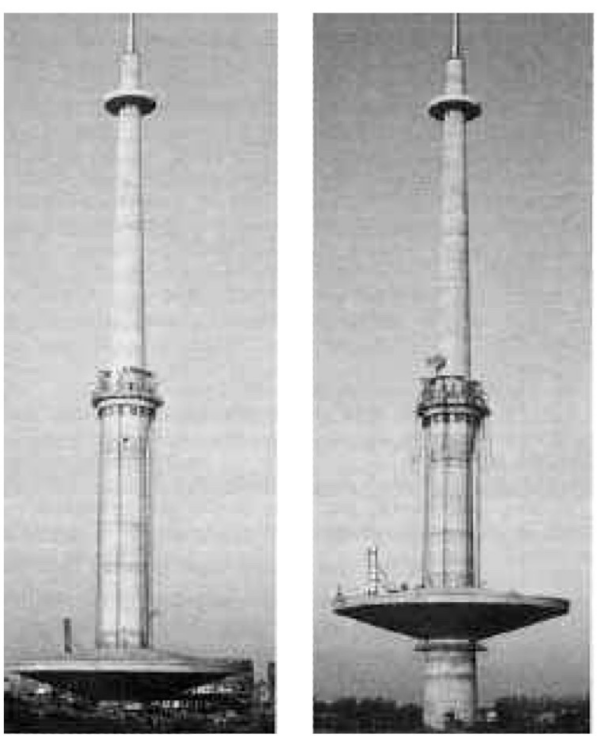

2.7.185

Fernand Mortelmans, Torre de Água de Mechelen, Bélgica, 1978. Sequência de içamento do reservatório.

\section{7 .186}

Torre de Água de Wupertal, Alemanha, 1.500 m3, 1975.

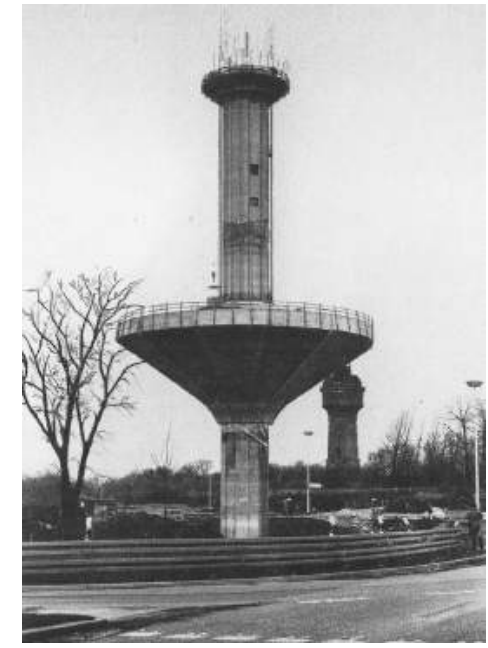

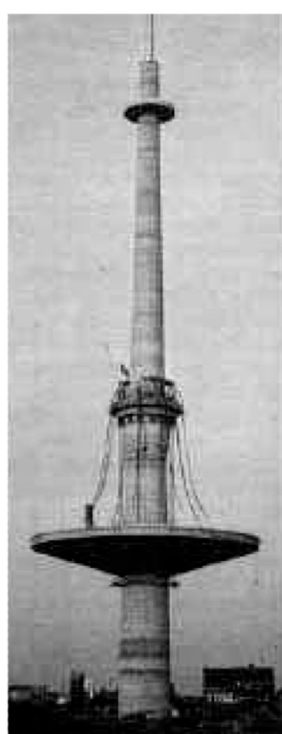
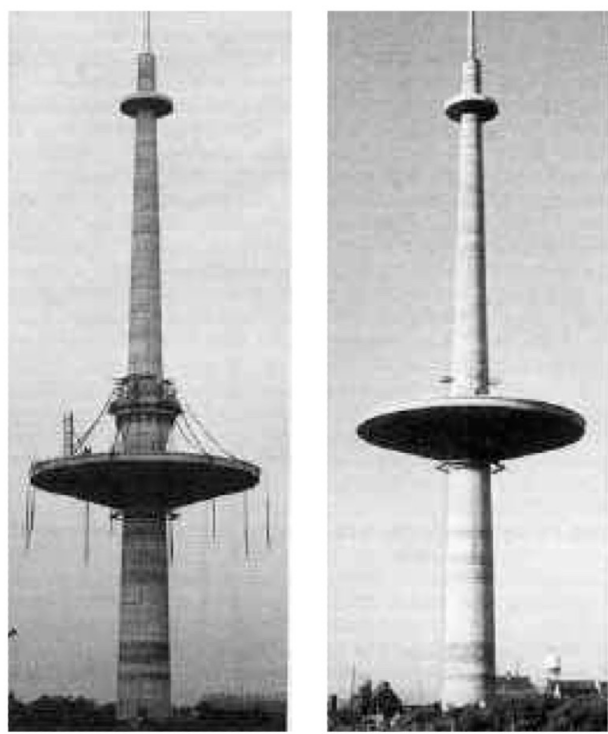

A técnica de heavy lifting é uma alternativa muito econômica para a construção de torres de água com reservatórios tipo "cogumelo" e pode ser utilizada em reservatórios de capacidades variadas. Para citar alguns exemplos: torre de Mechelen, 053 na Bélgica, projeto de Fernand Mortelmans, $2.500 \mathrm{~m}^{3}$, 1978 (fig. 2.4.185); torre de Wupertal (fig. 2.4.186), na Alemanha, $1.500 \mathrm{~m}^{3}$, 1975; torre de água de Cutro, Itália, 2.000 m³, 1980 (fig. 2.4.187, 2.4.188). A figura 2.4.189 mostra um detalhe da ancoragem dos cabos de protensão na ligação entre o topo do fuste e o anel de suporte do reservatório "cogumelo" da torre de água de Cutro. No Brasil a técnica de heavy lifting foi utilizada para a construção da torre de água de Feira de Santana (fig. 2.4.190), Bahia (1985), com um reservatório troncônico de 32,50 metros de diâmetro capacidade para armazenar $3.900 \mathrm{~m}^{3}$ de água.

A primeira utilização da técnica de heavy lifting para a construção de torres de água de concreto não foi em uma torre equipada com um reservatório do tipo "cogumelo", mas sim em uma obra com um reservatório de fundo em formato de calota esférica, na torre de Haukilahti, 039 na cidade de Espoo, Finlândia. A torre projetada pelo arquiteto Erkko Virkkunen (1924-1986) no ano de 1967 inaugurou a técnica que foi utilizada tanto para o içamento do reservatório de $4.100 \mathrm{~m}^{3}$ quanto para o içamento do revestimento externo do reservatório, ambos executados em concreto protendido, sendo que o último foi provavelmente 

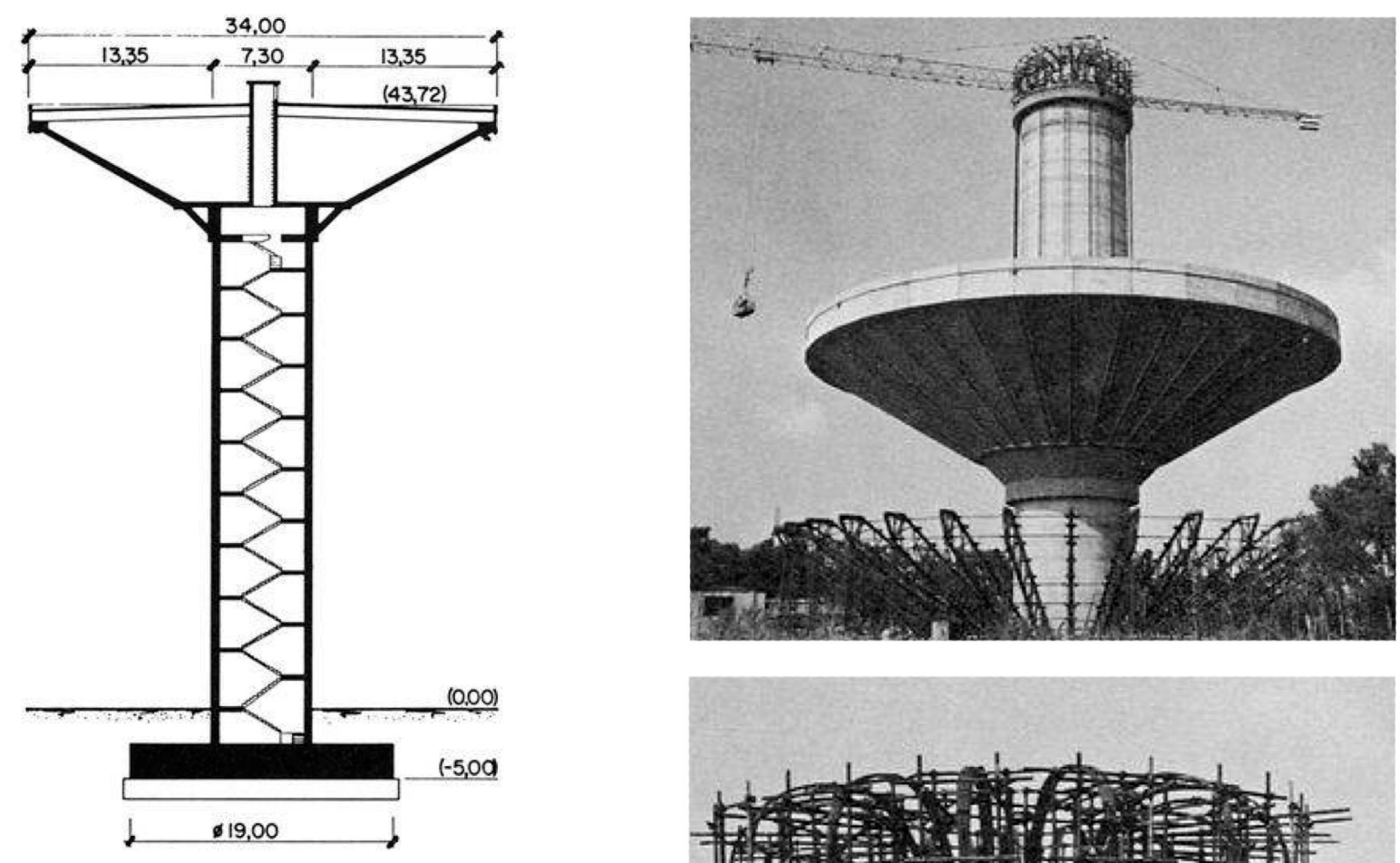

\subsubsection{7}

Torre de Água de Cutro, Itália, 2.000 m3, 1980. Corte.

\subsubsection{8}

Torre de Água de Cutro, Itália, 2.000 m3, 1980. Elevação do reservatório e unidades de içamento no topo do fuste.

\subsubsection{9}

Figura 2.4.189:

Torre de Água de Cutro, Itália, $2.000 \mathrm{~m} 3$, 1980. Detalhe da conexão do reservatório com o topo do fuste.
a) espiral
b) anel de suporte do reservatório
c) placa de suporte
d) viga anular no topo do fuste
e) forma para nicho
f) cabeça de ancoragem inferior
g) cabeça de ancoragem superior
h) enchimento de concreto
i) concretagem de união entre fuste e reservatório
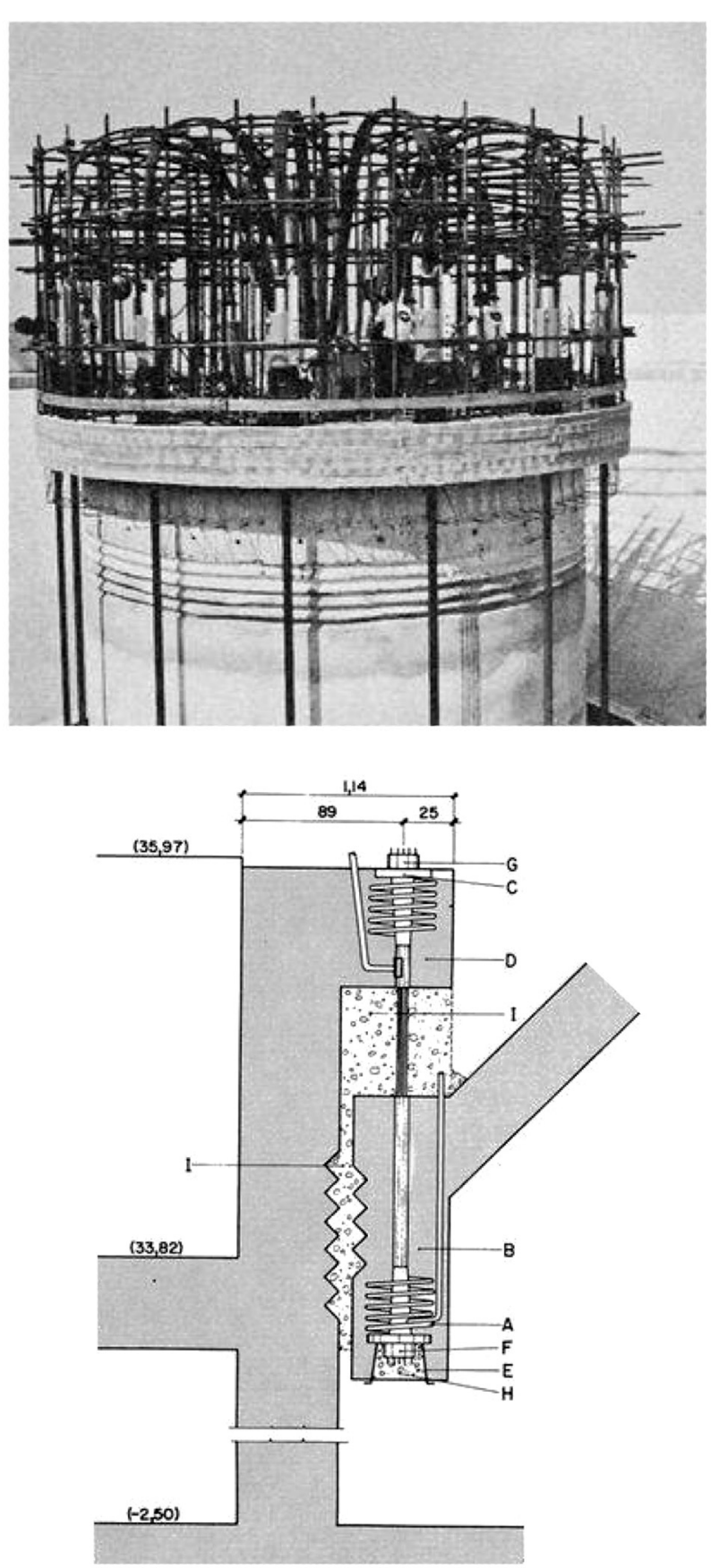


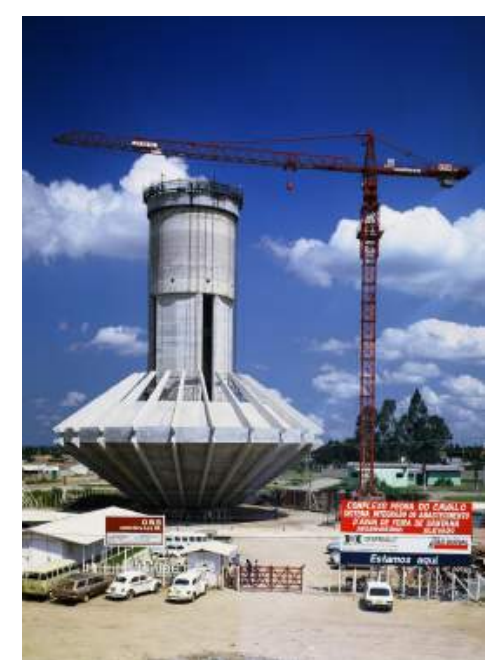

2.4.190

Torre de Água de Feira de Santana, Bahia, Brasil, 1985.

\subsubsection{1}

Erkko Virkkunen, Torre de Água de Haukilahti, Espoo, Finlândia, 1967. Esquema da sequência construtiva. utilizado como isolamento térmico para proteger a água dos efeitos adversos da temperatura durante os severos invernos finlandeses. As figuras 2.4.191 e 2.4.192 mostram a sequência construtiva da torre de água em esquemas e fotos. ${ }^{149} \bigcirc$ reservatório de fundo esférico da torre de Haukilahti, com 45,00 metros de diâmetro, é apoiado em um fuste central e em conjunto de seis colunas distribuídas ao redor do fuste, mantendo a maior parte do tanque em balanço. No topo da torre de água foi instalado um restaurante panorâmico (fig. 2.4.193), assim como na torre de Örebro (1957).
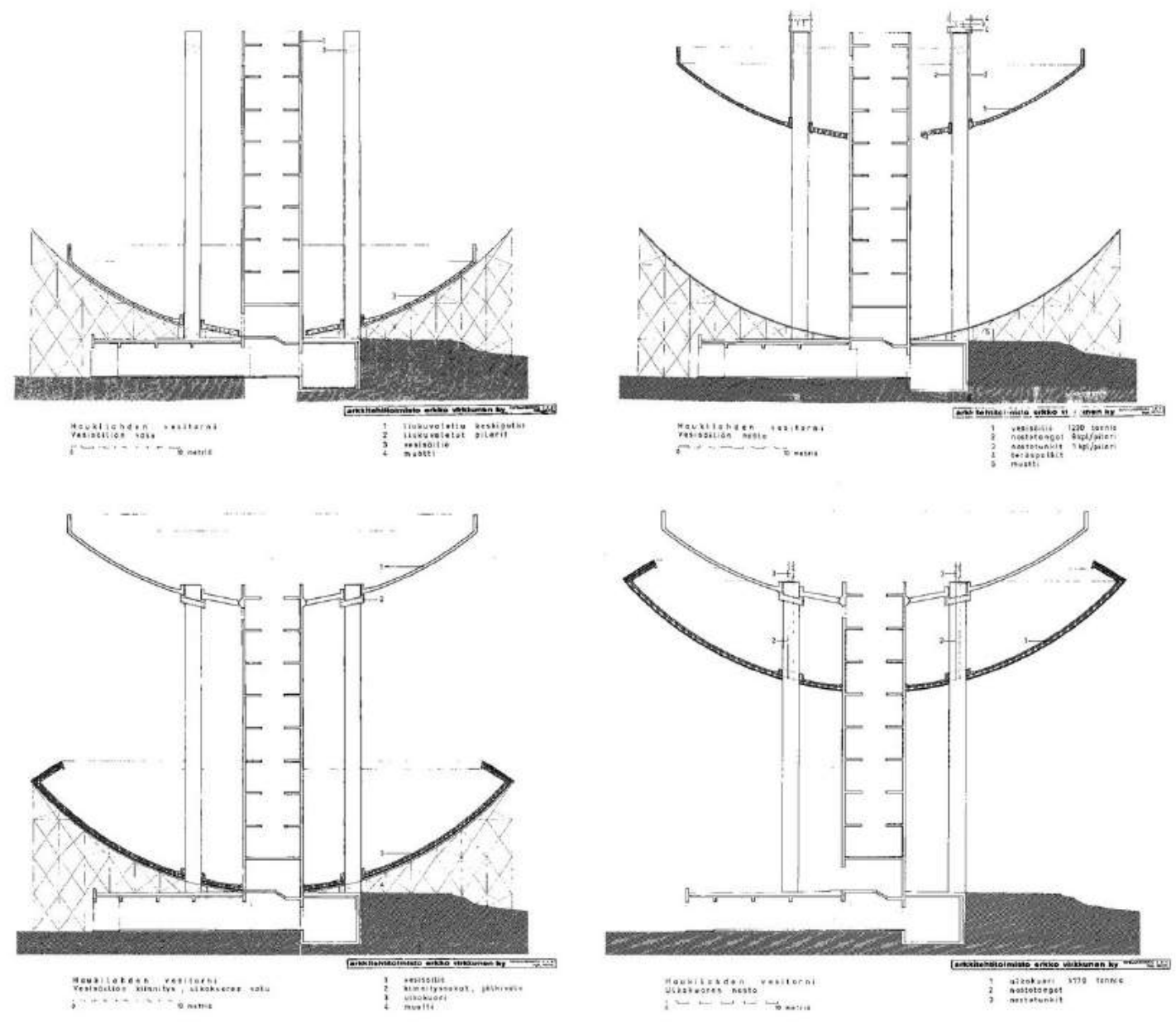

149 PROKKOLA, Janne; LEHTOVUORI, Panu. Haukilahden vesitorni: rakennushistoriaselvitys. Espoo: Livady Osakeyhtiö, 2010. 

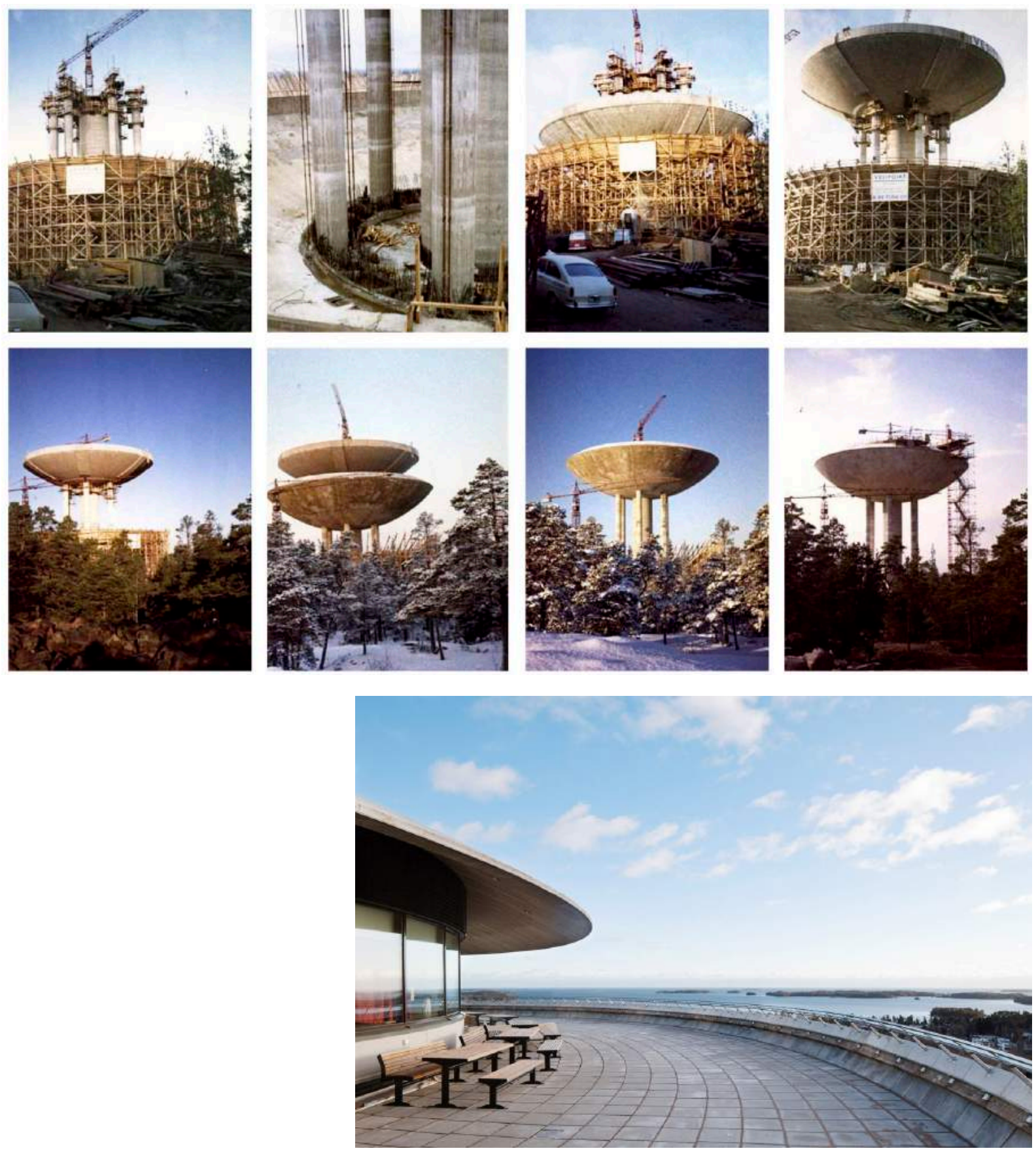

\subsubsection{2}

Erkko Virkkunen, Torre de Água de Haukilahti, Espoo, Finlândia, 1967. Evolução da obra.

\section{4 .193}

Erkko Virkkunen, Torre de Água de Haukilahti, Espoo, Finlândia, 1967. Restaurante Panorâmico.
Uma das tipologias mais recentes de reservatórios de concreto surgiu na década de 1960 com o desenvolvimento das torres de água em formato de hiperboloides de revolução de uma folha. ${ }^{150}$ Nestas torres a subestrutura e o reservatório foram integrados em uma forma única, fluida, uma casca contínua de concreto que, na maioria dos exemplares, elimina a distinção entre os elementos reservatório e estrutura de suporte. Nas novas torres de concreto ecoam as formas das estruturas desenhadas pelo engenheiro russo Vladmir Shukhov no início do século XX,

150 VEEN, 1989, op. cit., p. 42. 


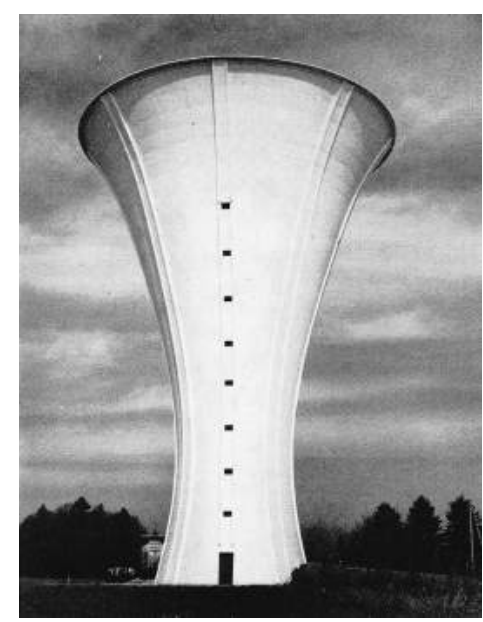

2.4.194

STUP, Torre de Água de Corgenon, Buellas, França, 1957. assim como as duas torres de Eduardo Torroja para o Hipódromo de la Zarzuela, desenhadas em 1935 e 1941. Esta nova tipologia foi construída principalmente na França, mas temos exemplos construídos também na Alemanha, Bélgica, Inglaterra e no Brasil.

Um dos primeiros exemplares de torre de água em formato de hiperboloide de revolução é a Torre de Corgenon (fig. 2.4.194), em Buellas, França, construída em 1957. A casca de concreto da torre, com um diâmetro máximo de 25,00 metros, foi protendida por 12 cordoalhas de 7 fios em cada uma das suas oito nervuras e abriga um reservatório com volume de $1.860 \mathrm{~m}^{3}$. A obra foi projetada pela STUP - Société Technique pour I'Utilisation de la Précontrainte (Sociedade Técnica para o Uso da Protensão), ${ }^{151}$ empresa criada por Eugène Freyssinet em 1943 para difundir o uso do concreto protendido e que, anos mais tarde, se tornaria uma das gigantes da indústria da protensão, a mundialmente conhecida FREYSSINET.

Outro exemplo é a Torre de Belmont, 027 construída na cidade de Royan, França, entre os anos de 1959 e 1960.152 O arquiteto responsável pelo projeto, o francês Guillaume Gillet (1912-1987), já tinha uma certa experiência com o programa, tendo projetado e construído uma torre de água na cidade de Caen, 022 na Normandia, entre os anos de 1955 e 1957. Após realizar uma série de estudos (fig. 2.4.195) para a torre de água, hipóteses variadas para um reservatório troncônico apoiado em robustos pilares com formas variadas, Gillet opta pelo formato de hiperboloide de revolução (fig. 2.4.196). O formato do hiperboloide de revolução é acentuado e articulado pelas finas nervuras da parede de concreto que, pela sua natureza estrutural, permitem criar o "rasgo" horizontal que marca a divisão entre a estrutura de suporte e o reservatório de água.

\footnotetext{
${ }^{151}$ MICHELIS, P. A.. Esthétique de L'Architecture du Béton Armé. Paris: Dunod, 1963, p. 75.

152 Château d'eau Belmont, Royan, France. L'Architecture d'Aujourd'hui, Paris, v. 31, n. 91-92, set-nov. 1960, p. 2.
} 

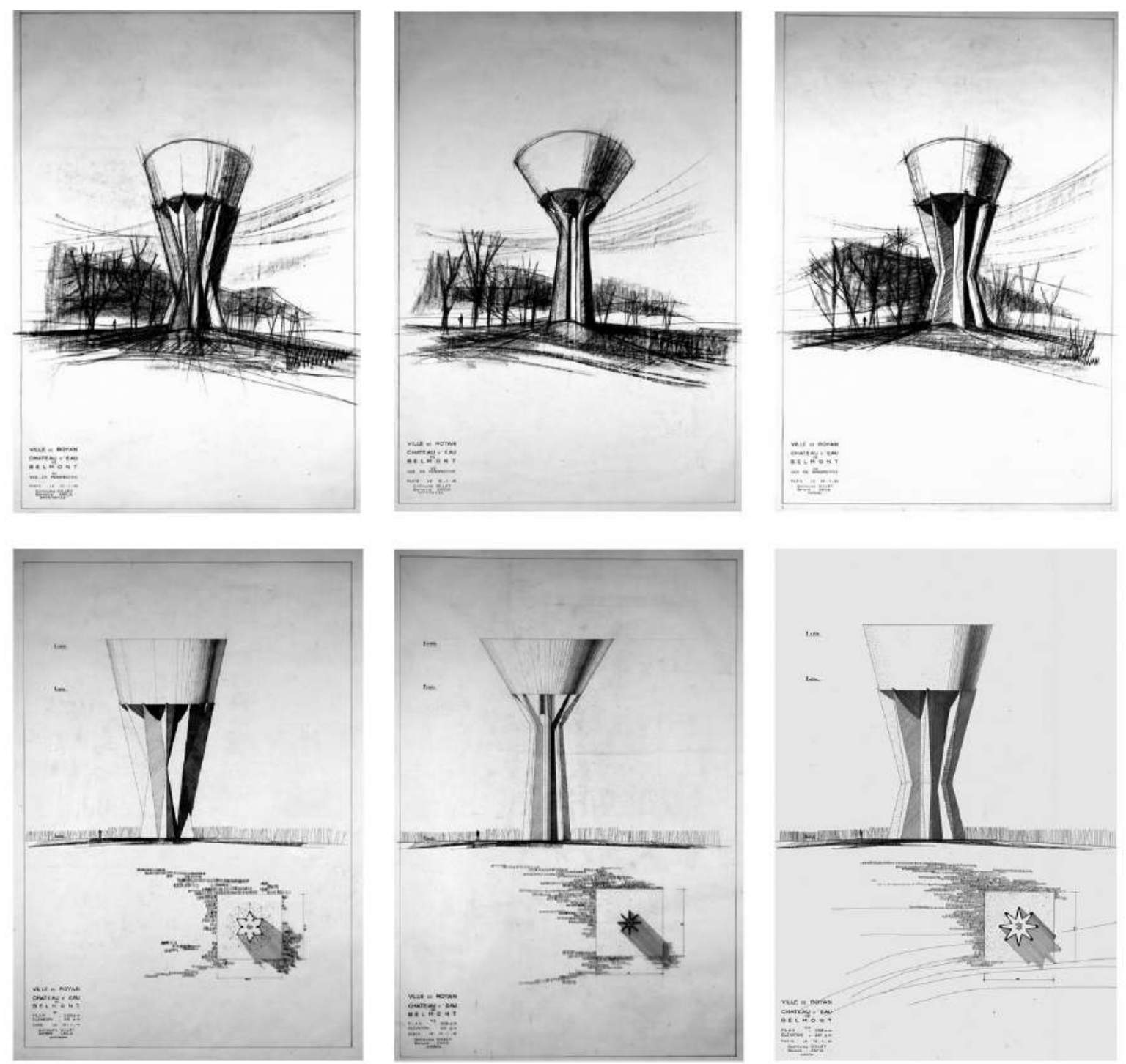

2.4.195

Guillaume Gillet, Torre de Água de Belmont, Royan, França, 1960. Estudos.

\section{4 .196}

Guillaume Gillet, Torre de Água de Belmont, Royan, França, 1960.
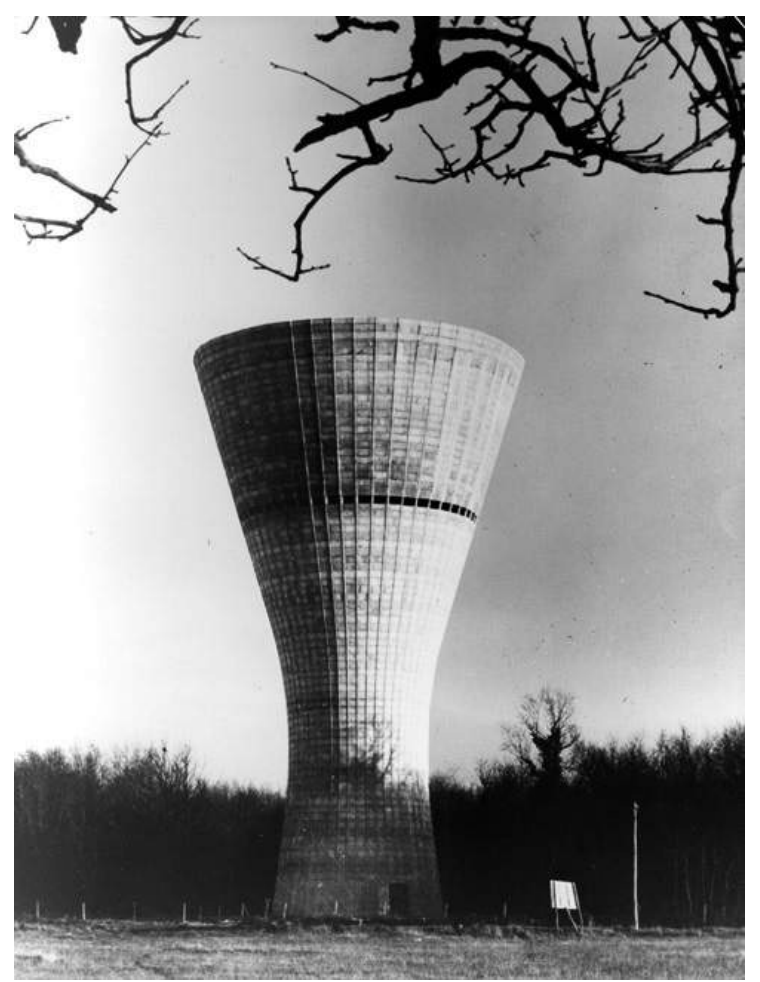

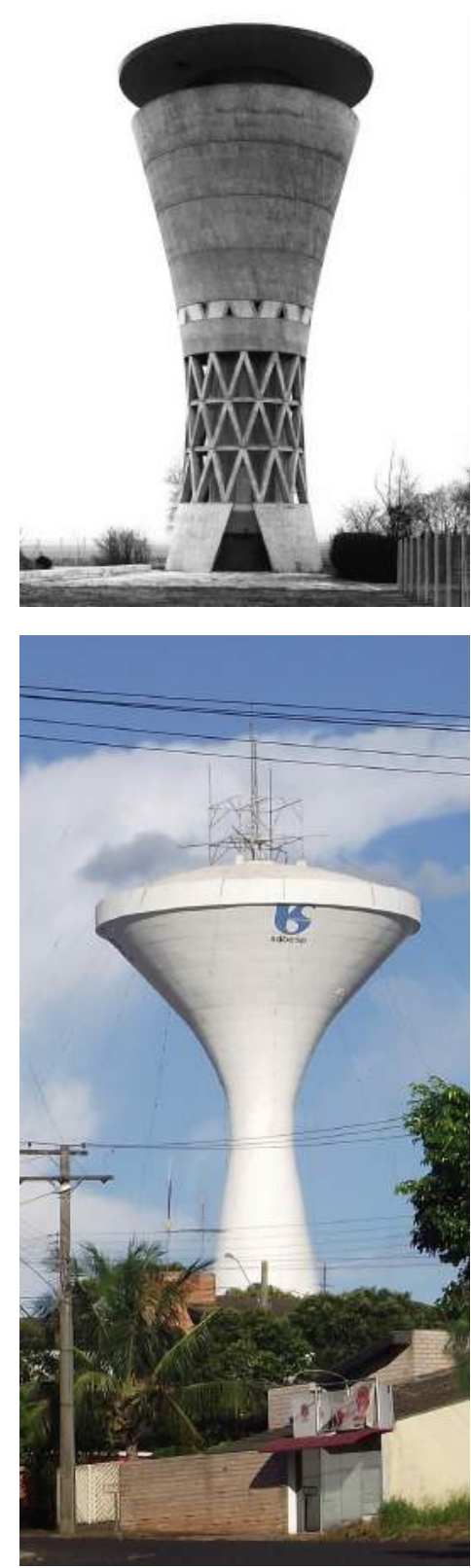

2.4.197

R. Kessler, Torre de Água de Möglingen, Alemanha, 1964.

\section{4 .198}

Torre de Água de Jales, São Paulo, Brasil.
A torre de água da cidade de Möglingen, 035 Alemanha, projetada em 1964 pelo arquiteto R. Kessler, é um exemplo singular de torre no formato de hiperboloide de revolução (fig. 2.4.197). A torre, com capacidade para armazenar $400 \mathrm{~m}^{3}$ de água, possui uma altura total de 36,00 e o hiperboloide tem um diâmetro máximo de 15,50 metros e uma garganta de 9,60 metros. ${ }^{153}$ Aqui opera uma distinção clara entre a estrutura de suporte e o reservatório de água, realizada pelo tratamento distinto da estrutura da torre. A estrutura de suporte assume a forma de uma malha treliçada hiperbólica e o reservatório apresenta-se como uma casca de concreto. O piso do barrilete é facilmente identificado por meio das janelas triangulares posicionadas na base do volume superior, assim como o volume fechado do embasamento aponta para a existência da sala de bombas e manobras. É digno de nota o belo trabalho realizado com as formas para concreto, marcadas em toda a fachada, explicitando a construção racional com réguas retas de madeira no alinhamento da geratriz reta do hiperboloide de revolução.

No Brasil podemos citar como exemplos de torres de água no formato de hiperboloide de revolução as torres de Vila Alpina e Vila Nova Cachoerinha, na cidade de São Paulo, e a torre de água da cidade de Jales (fig. 2.4.198), construídas pelas Companhia de Saneamento Básico do Estado de São Paulo (SABESP).

No início de década 2010 houve na França uma profusão de novas torres de água na forma da hiperboloides, construídas para substituir antigas torres construídas durante as décadas de 1950 e 1960. Dentre estas novas torres, destacamos: Saint-Rambertd'Albon, 600 m³, 2009; Machecoul, 2.500 m³, 2012; e Saint Fulgent, $4.000 \mathrm{~m}^{3}, 2016$ (fig. 2.4.199). A figura 2.4.200 mostra a antiga torre de água com reservatório tipo Intze de 500 m³ que foi "aposentada" e demolida com a construção da torre de Machecoul.

153 OHLSSON, Eber. Ebers vattentorn: Cirkulation 7/2011. VA-tidskriften Cirkulation. Örebro, jul. 2011. 

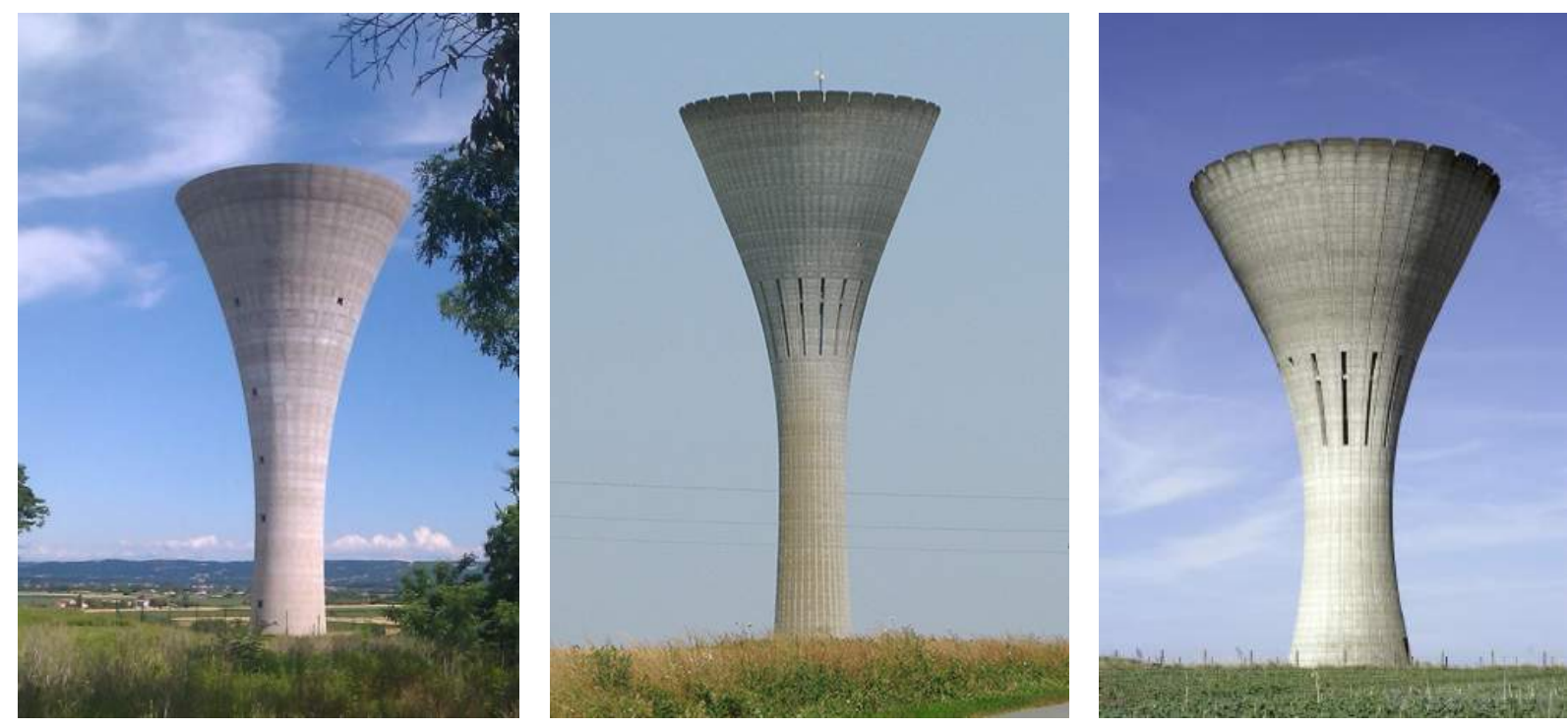

2.4.199

Torres de água hiperbólicas, França.

a) Saint-Rambert-d'Albon, 600 m3, 2009

b) Machecoul, 2.500 m3, 2012.

c) Saint Fulgent, 4.000 m3, 2016.

2.4.200

Torre de Machecoul e a antiga torre tipo Intze, França, 2012.

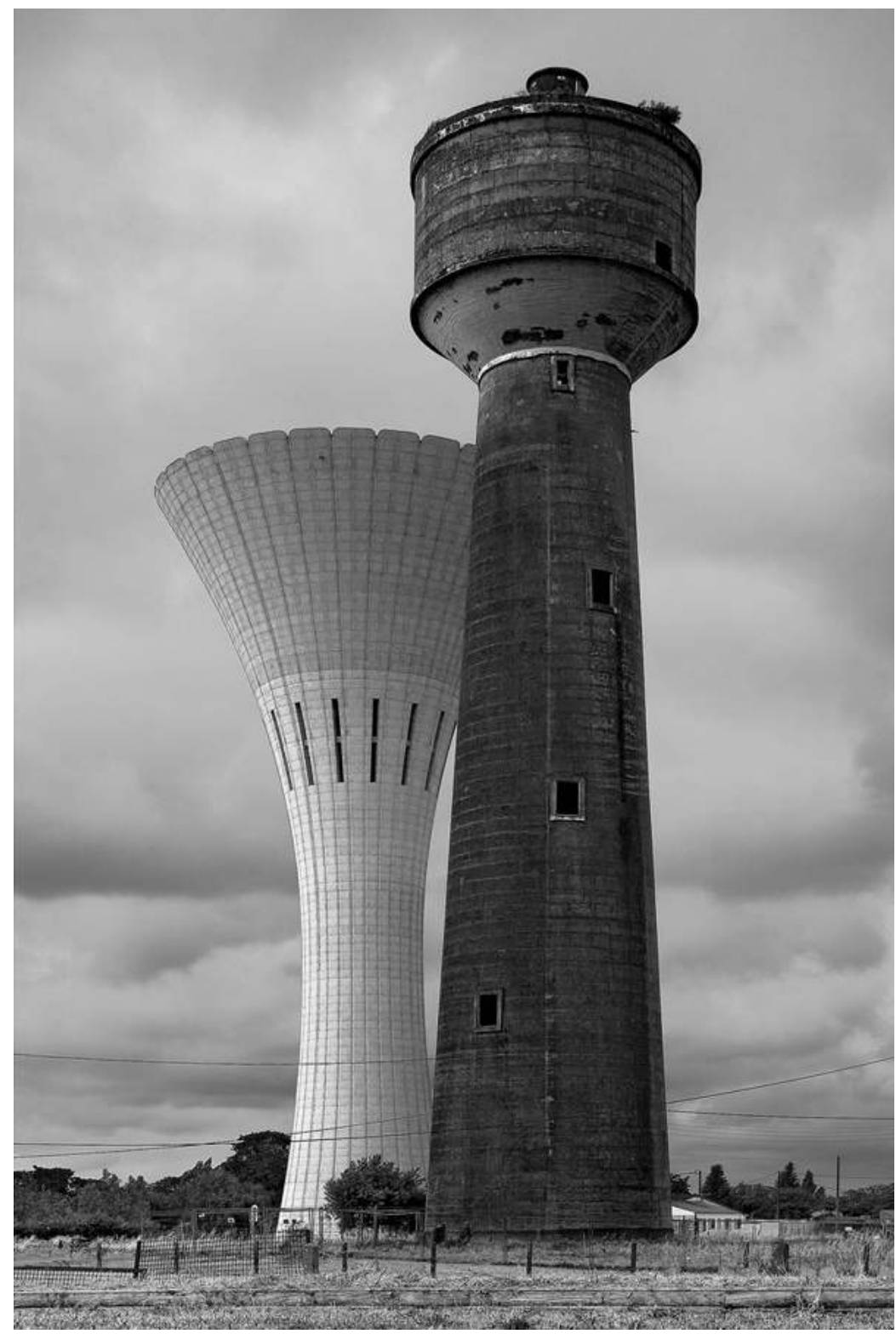




\subsubsection{O Futuro das Torres de Água}

O futuro das torres de água é incerto. Atualmente, tanto nos grandes setores industriais quanto nos sistemas centralizados de abastecimento de água, nos casos em que é necessário garantir pressões nas redes hidráulicas, cada vez mais se decide usar sistemas de água pressurizada por meio de "boosters" ou de tanques hidropneumáticos, alternativas técnicas que combinadas com reservatórios de água apoiados sobre o solo têm se mostrado mais econômicas do que a construção de torres de água. As modernas bombas hidráulicas de velocidade variável transformaram os sistemas de água pressurizada em uma alternativa economicamente viável para o tradicional sistema de bombeamento, armazenamento e distribuição por gravidade. Como de costume as opiniões profissionais sobre este novos sistemas variam e muitos projetistas de sistemas de abastecimento têm grandes reservas com relação a sistemas operando inteiramente por meio de equipamentos impulsionados por energia elétrica que, na falta desta, poderiam causar um enorme problema de desabastecimento. Para operar de maneira adequada este novos sistemas dependem, além de bombas de reserva para substituir as principais no caso de falhas mecânicas, de um sistema de geradores elétricos de prontidão, preparadores para serem acionados no caso de interrupções no fornecimento de energia elétrica, evitando assim o colapso do sistema de abastecimento de água. ${ }^{154}$

Além das torres de água que continuarão a funcionar nas grandes redes centralizadas de abastecimento de água, é provável que o número de torres de água desativadas aumente nos próximos anos como um resultado das fusões das redes de abastecimento nas grandes metrópoles. Atualmente a interligação de redes de abastecimento têm se tornado cada vez mais frequente, uma alternativa para garantir que uma determinada área da cidade possa ser abastecida por mananciais diferentes, evitando assim problemas de desabastecimento de água em virtude das recentes

${ }^{154}$ BARTON, 2003, op. cit., p. 9. 
2.4.201

Torres de água destruídas pelo Estado Islâmico, Síria, 2018. crises hídricas que têm afetado várias localidades ao redor do mundo. A torre de água, que pode estar presente em uma pequena rede, geralmente não se encaixa no sistema de abastecimento geral e acaba perdendo a sua função. ${ }^{155}$

Um grande número de torres de água do século XIX e do início do século XX já foram demolidas em todas as partes do mundo e muitas outras desaparecerão nos próximos anos, sendo substituídas por sistemas mais eficientes ou ainda por novas torres com maior capacidade de operação. Em casos como o do Brasil, por exemplo, é necessário realizar um inventário de nossas torres de água para poder avaliar o valor dos edifícios individuais, bem como para reconstruir a história nacional deste objeto amplamente negligenciado.

A fatalidade dos desastres naturais e o horror da guerra também têm sido responsáveis pela destruição de torres de água na atualidade. Assim como as tropas alemãs em retirada destruíram deliberadamente as torres de água holandesas no final da Segunda Guerra Mundial, as tropas do Estado Islâmico destruíram as poucas e preciosas torres de água que abasteciam as pequenas cidades do interior da Síria (fig. 2.4.201), uma infraestrutura vital para as populações, não apenas para o consumo humano mas também para a irrigação de culturas agrícolas. ${ }^{156}$
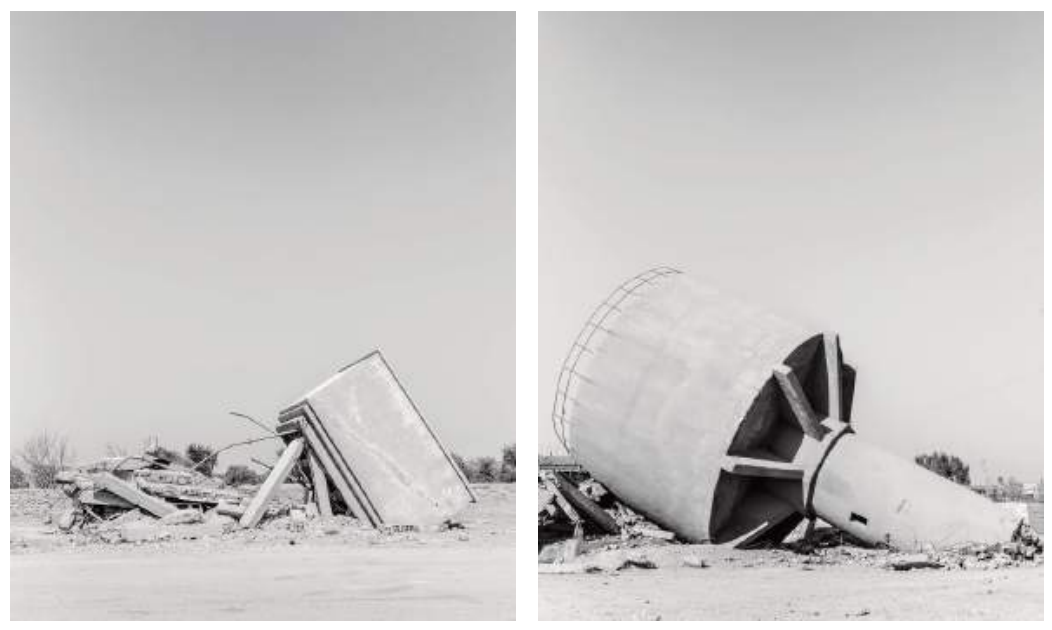

155 VEEN, 1989, op. cit., p. 6.

${ }^{156}$ BAUER, Wolfgang. Das große Verhängnis. Zeit Magazin, n. 5/201826. 01 jan. 2018. Disponível em: http://www.zeit.de/zeit-magazin/2018/05/nordsyrienislamischer-staat-wassertuerme-existenz-fotoreportage/seite-7. Acesso em: 11 set. 2018 . 

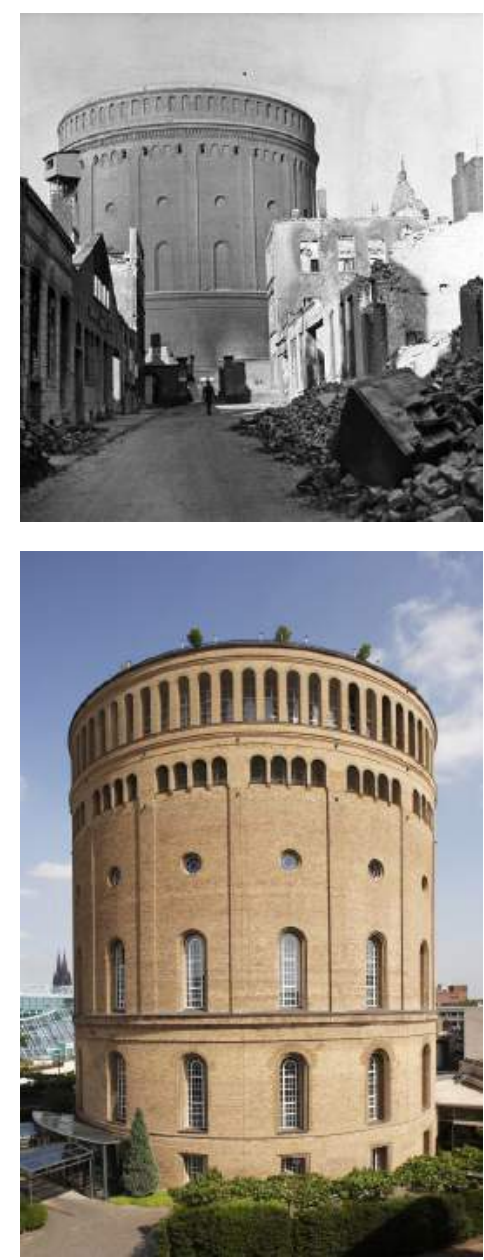

2.4.202

Torre de água de Colônia, Alemanha (1872), convertida para hotel em 1990. valor histórico-arquitetônico de muitas torres de água, que em vários casos levou ao tombamento de muitas destas construções pelos órgãos nacionais de patrimônio, abre a discussão sobre a possibilidade de se desativar uma torre de água colocada na lista de monumentos históricos. Muitas das torres de água ainda existentes citadas neste trabalho são protegidas como monumentos arquitetônicos, seja em nível local ou nacional, especialmente nos exemplares localizados no continente europeu.

Nos anos recentes muitas torres de água na Europa têm sido desativadas para receberem um segundo destino. Pequenas torres converteram-se em residências unifamiliares, enquanto que torres gigantescas hoje abrigam museus, centros culturais e até mesmo hotéis. Uma das torres de água da cidade de Colônia, Alemanha, construída em 1872 e que chegou a ser a maior torre da Europa com capacidade para armazenar $3.683 \mathrm{~m}^{3}$ de água, foi convertida no ano de 1990 em um hotel cinco estrelas (fig. 2.4.202). Porém, na grande maioria das vezes, uma torre de água pode ser melhor mantida se continuar a cumprir a função para a qual foi originalmente projetada.

Ainda sim, por hora, a construção de novas torres de água não está completamente descartada. Na França, na última década, houve um "boom" de novas torres de água construídas para substituir antigas torres construídas na década de 1950. Concursos de arquitetura para projetos de novas torres de água têm sido realizados com frequência em países como Bélgica, Luxemburgo e Suécia em anos recentes.

No ano de 2006 foi construída na cidade de Pacé, França, o Château d'eau "Zéro Énergie", 064 uma torre de água que não utiliza bombas para o seu enchimento, uma espécie de reservatório de serviço elevado sobre uma estrutura que, obviamente, se viabiliza devido a condições específicas da topografia da localidade e das características do sistema de abastecimento que garantem um gradiente ideal de pressões hidrostáticas sem necessidade de uso de bombas hidráulicas. Segundo o autor do projeto, o arquiteto 
Philippe Madec, a altura do reservatório e seu ponto mais baixo foram determinados pela pressão da rede que serve para preenchêlo e pelo efeito da gravidade que garante o seu esvaziamento sem perda de pressão, permitindo também que o abastecimento de água continue durante períodos de interrupção no fornecimento de energia elétrica.

A torre de água de Guijo de Coria, 066 construída na cidade de Cáceres, Espanha, no ano de 2009, parece buscar influências fora do universo das torres de água. A obra do estúdio GRG Arquitectos, é claramente inspirada por outro tipo de infraestrutura, as torres de transmissão de energia elétrica com sua treliças do tipo schwedler. A escolha do tipo do reservatório também é curiosa, tanques cilíndricos de aço inox dispostos na horizontal, como aqueles utilizados em sistemas de aquecimento de água.

O terremoto que atingiu o Chile em 2010 destruiu ou danificou algumas das torres de água do país. A ESSBIO, companhia responsável pelo abastecimento de água, contratou o arquiteto Mathias Klotz para desenvolver projetos para reconstruir ou reparar algumas destas torres. O desafio imposto pela ESSBIO era de que não os arquitetos não deveriam alterar a geometria ou a estrutura das torres danificadas, pois estas já haviam se tornado pontos de referência conhecidos nos bairros em que foram edificadas. As intervenções nas obras, portanto, só poderiam ser feitas nas superfícies externas. A torre de Rancagua 067 teve sua estrutura de concreto armado revestido com painéis metálicos que balançam com o vento. A torre de Santa Cruz 068 ganhou um revestimento em um baixo relevo frisado nos painéis de sua estrutura de concreto.

A mais recente torre de água construída na Bélgica, 069 um projeto do estúdio $\mathrm{V}+$ Architects, foi construída entre os anos de 2010-2014. Segundo os arquitetos o projeto responde diretamente à função de uma torre de água. Um reservatório cilíndrico de fundo plano, com 20,00 metros de diâmetro e capacidade para armazenar $2.000 \mathrm{~m}^{3}$, é apoiado sobre uma "mesa" de concreto armado com pernas de 50,00 metros de altura formadas por um $\mathrm{V}$ 
e um X entrecruzados. O princípio da "mesa" oferece flexibilidade na possibilidade de reconversão da torre de água no futuro. $O$ reservatório cilíndrico envolto por um fechamento semitransparente de chapas metálicas perfuradas e a iluminação noturna do topo da torre conferem um ar de mistério ao tanque flutuante.

Vencedores de um concurso promovido no ano de 2018 pela concessionária de águas da cidade de Varberg, Suécia, o estúdio de arquitetura White Arkitekter apresenta um proposta para reinventar as tradicionais tipologias de torres de água. Ao invés de uma estrutura mais vertical, os autores do projeto propõem uma estrutura mais horizontal e estreita, modulada, que pode ser adaptada e ampliada conforme a necessidade (fig. 2.4.203). Idealizada para armazenar $10.000 \mathrm{~m}^{3}$ de água em dois grandes reservatórios a estrutura executada com elementos pré-fabricados de concreto pode ser ampliada horizontalmente à medida que a cidade e a demanda por água crescem. Os arquitetos descrevem a intenção do projeto com as seguintes palavras:

"À medida que a luz do sol varia durante o transcurso do dia, a expressão das formas sinuosas da estrutura da caixa diágua vão se transformando através de um dinâmico jogo entre luz e sombra. Este projeto procura dar voz a fluidez de seu conteúdo, uma estrutura rígida que ao mesmo tempo se revela leve e dinâmica como a água, e isto se torna instantaneamente reconhecível a partir de grandes distâncias quando vista a partir de qualquer ponto da paisagem plana da região. O município de Varberg estava procurando chamar à atenção para este recurso essencial à vida, de tal forma que interpretamos à nossa maneira e procuramos criar um símbolo, uma estrutura icônica que busca inspiração em seu conteúdo." 157

\footnotetext{
157 Mathias Lind, estúdio White Arkitekter. In: AGGARWAL, Vasundhra. White Arkitekter reinventa a tipologia de caixa d'água através de uma estrutura horizontal de concreto. ArchDaily Brasil, 20 dez. 2018. Tradução Vinicius Libardoni. Disponível em: <https://www.archdaily.com.br/br/907839/whitearkitekter-reinventa-a-tipologia-de-caixa-dagua-atraves-de-uma-estruturahorizontal-de-concreto?ad_medium=gallery>
} 
As mais recentes torres de água construídas e os vários projetos em curso têm demonstrado que os arquitetos ainda têm fôlego para responder às necessidades do programa com soluções cada vez mais criativas e inovadoras. Como já mencionado as torres de água como as conhecemos hoje remontam a meados do século XIX e são um produto da cidade industrial e da revolução técnica e social que desencadeou a introdução de grandes sistemas infraestruturais para suporte da vida nas grandes cidades, entre estes os sistemas centralizados de abastecimento de água. As torres de água, no entanto, existem de uma forma ou de outra desde o mundo antigo e tudo indica que o uso destas infraestruturas, ou de estruturas para armazenamento e distribuição de água por gravidade similares a estas, se farão necessárias um longo tempo,

\subsubsection{3}

White Arkitecter, Projeto para a Torre de Água de Varberg, Suécia, 2018. ainda mais considerando a demanda cada vez maior por água potável e a busca por sistemas tecnológicos e infraestruturais de baixo consumo energético.
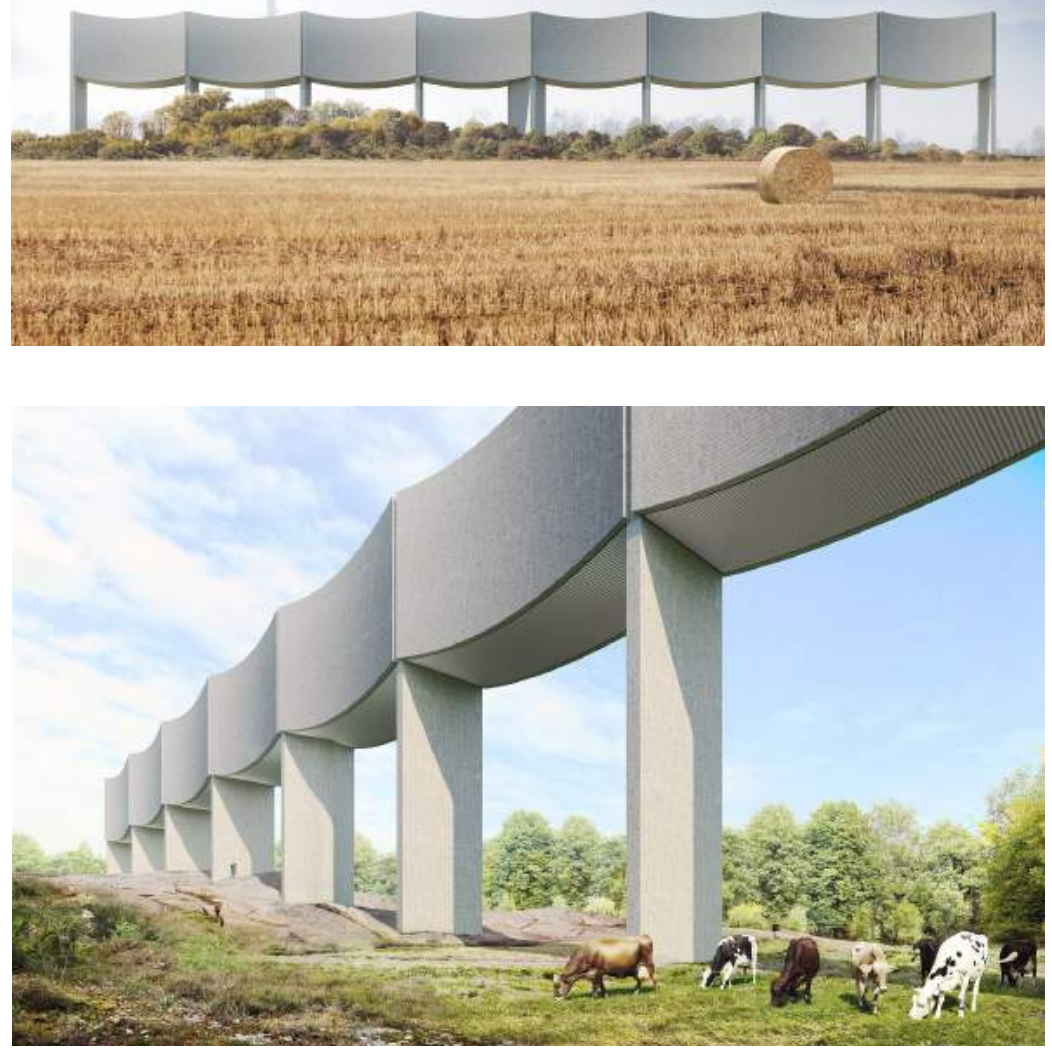
CONCLUSÃO

Em geral, durante o século XIX e o início do século XX, a arquitetura das torres de água para abastecimento público procurou se adaptar aos gostos e aos estilos arquitetônicos vigentes no período. Os reservatórios e as estruturas destas novas construções eram partes geralmente escondidas, envoltas em uma pele formal, disfarçando a função do edifício pelo lado de fora e fazendo com que as torre de água parecessem outros tipos de edificações com o objetivo de torna-las mais "aceitáveis" em um ambiente urbano que estava em pleno desenvolvimento. Uma exceção a esta regra foram as primeiras torres de água vitorianas, na Inglaterra, nas quais os reservatórios de ferro fundido, ainda que devidamente ornamentados, eram aparentes e informavam a função do edifício.

Com o passar do tempo, no entanto, a torre de água se transformou para um edifício com forma e linguagem próprias e que, ao mesmo tempo, demonstrava a função que desempenhava na cidade. Neste sentido, os primeiros exemplares de torres de água a expressarem uma linguagem formal própria e a explicitar a sua função podem ser encontrados principalmente entre as torres industriais e ferroviárias, construídos como edifícios puramente funcionais cuja execução era determinada em grande medida por considerações exclusivamente técnicas e econômicas. Foi de modo muito lento que as torres de água para abastecimento público encontraram a sua própria linguagem formal. Assim chegou-se à formas externas correspondentes à função, que não ocultam a forma do reservatório mas, ao contrário, enfatizam deliberadamente esta forma.

A introdução do reservatório tipo Intze em meados da década de 1880 pode ser considerado como o primeiro passo deste percurso em direção a uma linguagem formal própria para as torres de água. Na típica torre Intze a "cabeça saliente", que enfatizava a existência do reservatório de água e a separação entre este e a estrutura de suporte, gerou uma nova possibilidade formal para as torres de água. Durante as primeiras décadas do século XX 
a solução formal das torres de água tipo Intze, com o reservatório saliente e o esqueleto estrutural aparente, se tornaria um símbolo para a torre de água aos olhos do público em geral.

O desenvolvimento das torres de água com esqueletos estruturais aparentes de ferro e de aço, incialmente na Europa e posteriormente nos Estados Unidos da América, aqui com uma ênfase em construções mais econômicas e funcionais, também contribuiu significativamente para uma mudança de paradigma na arquitetura das torres de água na transição entre os séculos XIX e $\mathrm{XX}$.

No início do século $X X$ a introdução do concreto armado como material de construção para as torres de água foi inicialmente caracterizada pela reprodução das já conhecidas tipologias de reservatórios metálicos e estruturas de suporte em alvenaria, agora construídas com o novo material. O reconhecimento das possibilidades técnicas e plásticas do concreto armado por parte dos arquitetos e engenheiros levou, no entanto, ao desenvolvimento de formas próprias e de uma linguagem própria para as torres de água construídas em concreto armado, gerando formas únicas que seriam de difícil execução na construção metálica. Posteriormente, - desenvolvimento das tecnologias de formas deslizantes, protensão e heavy lifting estabeleceram o concreto como o material de excelência para a construção das grandes torres de água da atualidade.

Outro momento emblemático neste percurso é o desenvolvimento do reservatório troncônico por Badani e Esquilan, experimentado pela primeira vez na torre de água de Cocody (1953), cuja forma, surgida da falta de material para fabricação de formas para concreto armado, não apenas se mostrou como ideal para a função a ser desempenhada tanto do ponto de vista estático quanto do ponto de vista hidráulico, mas também criou uma forma "original" para a torre de água, que informa a função do edifício e de seus elementos funcionais ao mesmo tempo que impede que este seja confundido com qualquer outro tipo de edificação. 
Ainda que em dados momentos da história das torres de água os projetistas tenham encontrado possíveis "formas" que melhor expressassem a "função" destes novos edifícios, isso não significou um acolhimento total e irrestrito por parte dos arquitetos e engenheiros pelo uso destas novas "formas". Conforme relatado a tipologia de reservatório Intze, por exemplo, era utilizada por vários projetistas com grandes ressalvas, que optavam em seus projetos por soluções formais que anulavam a forma típica deste reservatório. Orquiteto francês Auguste Perret (1870-1954), por exemplo, era um grande detrator das típicas torres Intze, classificando-as como "verrugas de concreto com patas, mutilam a paisagem e ao lado das estações, tanques de gás e silos de grãos, ocupam um lugar de honra no museu dos horrores arquitetônicos. "158

O arquiteto Alvar Aalto também criticou o "boom" de torres de água ocorrido entre as décadas de 1950 e 1970 nas cidades da Finlândia, onde predominou a construção de gigantescas torres de água de concreto armado com reservatórios troncônicos:

"No meu país, quase todas as cidades são dominadas por uma torre de água. Não é nem a prefeitura, nem a igreja, nem qualquer outro monumento que domina a silhueta das cidades, mas sim a torre de água. E a água não é o sinal da espiritualidade. Estas torres de água, dominando os povoados, são realçadas com as mais diversas formas decorativas; ao lado delas há restaurantes, mirantes e às vezes até galerias de arte. Parecem grandes flores moldadas em concreto armado... Aqui vemos os efeitos nefastos das artes decorativas na arquitetura. Eu denuncio esse gênero de arquitetura decorativa, chamando-a de 'arte aplicada ao ar livre'. "159

158 Apud GENICOT, L. F.. De watertoren: architectuur, landschap. In: VAN CRAENENBROECK, W.. Eenheid in Verscheidenheid: Watertorens in Belgie. Brussel: Navewa, 1991, p. 162.

${ }^{159}$ Alvar Aalto em diálogo com Karl Fleig, verão de 1969. In: FLEIG, Karl. Alvar Aalto: Obras 1963-1970. Barcelona: Gustavo Gili, 1971, p. 12. 
Tanto Perret quanto Aalto projetaram e construíram suas torres de água e apresentaram suas alternativas para soluções formais características que ambos achavam inadequadas. ${ }^{160}$ Opiniões à parte, podemos considerar que atualmente a arquitetura das torres de água é caracterizada pelo uso de formas e linguagens próprias ao programa funcional que estas desempenham e que estes edifícios não são mais construídos para se assemelhar a algo que não são, como acontecia no passado, quando uma torre de água poderia assumir a forma de um castelo medieval, de uma fortaleza normanda ou de um moinho de vento.

Em resumo podemos dizer que a arquitetura das torres de água, que inicialmente era baseada em construções cujas formas e linguagens já conhecidas eram adaptadas para desempenhar uma nova função, foi se transformando lentamente até chegar aos dias de hoje como edifícios com formas e linguagens totalmente independentes.

A torre de água contribuiu e vem contribuindo durante mais de 150 anos para o bem estar diário das populações e podemos considerar que muitos edifícios que fazem parte da história da arquitetura são torres de água. Ainda, são edifícios que parecem não ter sido alvo da aversão e da hostilidade pública que geralmente é direcionada contra outros tipos de construções funcionais como, por exemplo, o postes e torres de transmissão de energia elétrica e as antenas de rádio, televisão e telefonia. Uma provável explicação para isto pode ser encontrada na enorme variedade de soluções arquitetônicas que não se faz presente nos demais tipos de edifícios funcionais. Tamanhos, formas e linguagens variadas produziram uma infinidade de torres únicas e cada pessoa pode considerar que a torre de água mais próxima de sua residência é distinta das demais, senão única. Abre-se aqui a hipótese para um novo estudo sobre as torres de água.

${ }^{160}$ As torres de água de Auguste Perret e Alvar Aalto são as obras de números 017 e 043, respectivamente, incluídas no Quadro Referencial de Obras apresentado como um volume anexo a este. 
Para além de qualquer nostalgia ou anseio pelo passado, estudos mais aprofundados sobre as torres de água tornam-se urgentes. Especialmente no Brasil, onde muito pouco acerca da história de nossas torres de água está documentado, esforços devem ser empreendidos para impedir que o edifício "torre de água" desapareça como parte do patrimônio arquitetônico público. 


\section{BIBLIOGRAFIA}

\section{LIVROS}

ABRAHIM, Roger. Poesia na Floresta: A Obra de Severiano Porto no Amazonas. Manaus: Reggo, 2014.

AGRICOLA, Georgius. De Re Metallica. New York: Dover Publications, 1950. Tradução para o Inglês da primeira edição em Latim de 1556 por Herbert Clark Hoover e Lou Henry Hoover.

ANDERSON, Stanford (Ed.). Eladio Dieste: Innovation in Structural Art. New York: Princeton Architectural Press, 2004.

ARGAN, Giulio Carlo. Arte Moderna. São Paulo: Companhia das Letras, 2013.

ARTIGAS, Rosa (Org.). Paulo Mendes da Rocha: projetos 1957-1999. 3. ed. São Paulo: Cosac Naify, 2006.

ARTIGAS, Rosa (Org.). João Walter Toscano. São Paulo: Editora Unesp, 2002.

ASCHENBECK, Nils; SCHMIDT, Jens U.. Wassertürme im Nordwesten. Oldberg: Isensee, 2003.

ASOLA, Ismo. Vesitorni - yhdyskunnan maamerkki. Water Tower - Landmark of the Community. Helsinki: RIL, 2003.

BANHAM, Reyner. Teoria e Projeto na Primeira Era da Máquina. São Paulo: Perspectiva, 2013.

BARTON, Barry. Water Towers of Britain. Londres: Newcomen Society, 2003.

BAUR, Albert. Historiche Entwicklung der Wasserspeichrung. In: MERKL, Gerhard et al. Historische Wassertürme: Beiträge zur Technikgeschichte von Wasserpeicherung und Wasserversorgung. München: Oldenburg Verlag, 1985. p. 9-61.

BECHER, Bernhard; BECHER, Hilla. Die Architektur der Förder und Wassertürme. München: Prestel-verlag, 1971.

BECHER, Bernd; BECHER, Hilla. Water Towers. Cambridge: Mit Press, 1988.

BECKH, Matthias. Hyperbolic Structures: Shukhov's lattice towers - forerunners of modern lightweight construction. West Sussex: John Wiley \& Sons, 2015.

BENEVOLO, Leonardo. História da Arquitetura Moderna. 5. ed. São Paulo: Perspectiva, 2017.

BERLAGE, Hendrik Petrus. Moderne Boukunst in Nederland: No 11 - Gebouwen voor

Technische Doeleinden. Rotterdam: W.I. \& J. Brusse N.V., 1932.

BÖCKLER, Georg Andreas. Theatrum machinarum novum. Nuremberg: Paul Fürst, 1661.

BOTEY, Josep Ma.. Oscar Niemeyer: Obras y proyectos. Barcelona: Editorial Gustavo Gili, 2008. 
BRASIL. AGÊNCIA NACIONAL DAS ÁGUAS. Conjuntura dos Recursos Hídricos no Brasil 2017. Brasília: Ministério do Meio Ambiente, 2017.

BROOKS, H. Allen. Le Corbusier's Formative Years: Charles-Edouard Jeanneret at La Chaux-deFonds. Chicago: The Chicago University Press, 1997.

BRUAND, Yves. Arquitetura Contemporânea no Brasil. 4. ed. São Paulo: Perspectiva, 2002.

BRUNEL, Isambar. The Life of Isambar Kingdom Brunel, Civil Engineer. London: Longmans, Green And Co., 1870.

BURDEN, Ernest. Dicionário Ilustrado de Arquitetura. São Paulo: Bookman, 2006.

BURTON, W. K.. The water supply of towns and the construction of water works. 2. ed. London: Crosby, Lockwood and Son, 1898.

CALAFATI, Michael et al (Ed.). The Bell Labs Charrette: a sustainable future, 2008. New York: DOCOMOMO - US, 2008.

CASSINELLO, Pepa. Libro Catálogo del Museo Eduardo Torroja. Madrid: Fundación Eduardo Torroja, 2016.

CAVENDISH, Marshall. Pequena História das Invenções. São Paulo: Abril Cultural, 1976.

CHAMPIGNEULLE, Bernard. Perret. Paris: Arts et Métiers Graphiques, 1959.

CHARRINGTON, Harry; NAVA, Vezio (Ed.). Alvar Aalto: The Mark of the Hand. Helsinki: Rakennustieto Publishing, 2011.

CHING, Francis D. K.. Dicionário Visual de Arquitetura. São Paulo: Martins Fontes, 2003.

CHRISTOFER, John. The Lost Works of Isambard Kingdom Brunel. Gloucestershire: Amberley Publishing, 2011.

COHEN, Jean-louis. O Futuro da Arquitetura desde 1889: Uma história mundial. São Paulo: Cosac Naify, 2013.

COMBA, Michela (Ed.). Maire Tecnimont: I Progetti FIAT Engineering 1931-1979. Milano: Silvana Editoriale, 2011.

CORONA, Eduardo; LEMOS, Carlos A. C.. Dicionário da Arquitetura Brasileira. São Paulo: EDART, 1972.

COSTA, Lucio. Arquitetura. Rio de Janeiro: José Olympio Editora, 2011.

CURL, James Stevens. A Dictionary of Architecture. Oxford: Oxford University Press, 1999.

DEMPSEY, Amy. Estilos, Escolas \& Movimentos. São Paulo: Cosac Naify, 2003.

DIESTE, Eladio. Introducción. In: TORRECILLAS, Antonio Jiménez (Org.). Eladio Dieste: 19431996. Junta de Andalucía: Consejeria de Obras Públicas y Transportes. Dirección General de Arquitectura y Vivienda, 1996. 
DUPUIT, Jules. Traité Theórique et Pratique de la Conduite et de la Distribution des Eaux. Paris: Carillian-Goeury et V. Dalmont, 1854.

DUPUIT, Jules. Traité Theórique et Pratique de la Conduite et de la Distribution des Eaux: Atlas. Paris: Carillian-Goeury et V. Dalmont, 1854.

EMPERGER, Fritz. Handbuch für Eisenbetonbau: Füfter Band - Flüssigkeisbehälter, Röhren, Kanäle. 2. ed. Berlin: Wilhelm Ernst \& Sohn, 1923. 14 v.

EMPERGER, Fritz. Handbuch für Eisenbetonbau: in Vier Bänden. Erster und Zweiter Teil. Berlin: Wilhelm Ernst \& Sohn, 1907. 4 v.

FLEIG, Karl. Alvar Aalto. São Paulo: Martins Fontes, 1994.

FLEIG, Karl. Alvar Aalto: Obras 1963-1970. Barcelona: Gustavo Gili, 1971.

FLORIO, Riccardo. Christian de Portzamparc: Disegno e forma dell'architettura per la città. Roma: Officina Edizioni, 1996.

FORÉS, Jaime J. Ferrer. Jørn Utzon: Obras y proyectos. Barcelona: Editorial Gustavo Gili, 2006.

FRAMPTON, Kenneth. História Crítica da Arquitetura Moderna. São Paulo: Martins Fontes, 1997.

FRAMPTON, Kenneth. Studies in Tectonic Culture. Chicago: Graham Foundation for Advanced Studies in the Fine Arts, 1995.

FRONTINUS, Julius Sextus. De Aquaeductu Urbis Romae. 97. Tradução para o inglês de: R. H. Rodgers. Cambridge: Cambridge University Press, 2003.

GARNETT, William. Little Book on Water Supply. Cambridge: Cambridge Univesity Press, 1922.

GENICOT, L. F.. De watertoren: architectuur, landschap. In: VAN CRAENENBROECK, W.. Eenheid in Verscheidenheid: Watertorens in Belgie. Brussel: Navewa, 1991.

GIACINTO, Jean de et al (Org.). Château d'eau Le Corbusier à Pondesac: Restauration de la première oeuvre de Le Corbusier en France. Bordeaux: Association Groupe des Cinq, 2007.

GIEDION, Sigfried. Mechanization Takes Command: a contribution to anonymous history. 3. ed. New York: Oxford University Press, 1948.

GLAESER, Ludwig. The Work of Frei Otto. New York: MoMA, 1972.

GOCKEL, Bernd. Bilddokumente historischer Wassertürme. In: MERKL, Gerhard et al. Historische Wassertürme: Beiträge zur Technikgeschichte von Wasserpeicherung und Wasserversorgung. München: Oldenburg Verlag, 1985. p. 169-305.

GOODWIN, Philip L. e SMITH, G. E. Kidder. Brazil Builds: architecture new and old $1652-$ 1942. New York: The Museum of Modern Art, 1943.

GÖSSEL, Peter; LEUTHÄUSER, Gabriele. Arquitectura no Século XX. Colônia: Taschen, 1996.

GRAY, William Samuel. Concrete water towers, bunkers, silos, and gantries. London:

Concrete Publications Limited, 1953. 
GUADET, Julien. Éléments et théorie de l'architecture: cours professé à l'École nationale et spéciale des beaux-arts. Paris: Aulanier et Cie, 1907. 4 v.

HAZLEHURST, J. N.. Towers and tanks for water works. 3. ed. New York: John Wiley \& Sons, 1907.

HEIKINHEIMO, Marianna et al. Rakennushistoriaselvitys Otaniemen Vesitorni. Otaniemi: Arkkitehtitoimisto Ark-byroo, 2017.

HIPELI, Mia (Ed.). Alvar Aalto Architect: Volume 13 - Helsinki University of Technology 1949-1974. Helsinki: Alvar Aalto Foundation, 2008.

HOBBS, Aubrey Thomas (Ed.). Manual of British Water Supply Practice. Cambridge: Heffer \& Sons, 1954.

HOUAISS, Antônio. Dicionário Houaiss da Língua Portuguesa. São Paulo: Objetiva, 2009.

HOUWINK, Pauline. Watertorens in Nederland: (1856-1915). Nieuwkoop: Uitgeverij Heuff, 1973.

INTZE, Otto. Nachweis über die Konstruktion und die Verbreitung von 280

Wasserthürmen und Gasbehältern nach dem System und den Berechnungen von Professor O. INTZE in Aachen. Aachen: F. A. NEUMAN / C. H. Georgi, 1894.

KAHN, Louis. The New Art of Urban Design: Are We Equipped? Discurso, 1960. In: TWOMBLY, Robert (org.) Louis Khan Essential Texts. New York: W. W. Norton \& Company, 2003. p. 75-80.

KAHN, Louis. First International Congress of Architects, Isfahan, Iran. Palestra 1970. In: WURMAN, Richard Saul. What Will Be Has Always Been: The Words of Louis I. Kahn. New York: Access Press / Rizzoli International Publications, 1986.

KOCH, Wilfred. Dicionário dos Estilos Arquitetônicos. São Paulo: Martins Fontes, 2004.

KÜHL, Beatriz Mugayar. Arquitetura do Ferro e Arquitetura Ferroviária em São Paulo: Reflexões sobre a sua preservação. Cotia: Ateliê Editorial, 1998.

LIMA, Cecília Modesto; ALBERNAZ, Maria Paula. Dicionário Ilustrado de Arquitetura. São Paulo: Pro Editores, 1998. 2 v.

MAGNUSSON, Roberta J.. Water Technology in the Middle Ages: Cities, Monasteries, and Waterworks after the Roman Empire. Baltimore: Johns Hopkins University Press, 2001.

MARREY, Bernard. Nicolas Esquilan: Un Ingénieur D’Entrepise. Paris: Picard, 1992.

McVARISH, Douglas. American Industrial Archaeology: A Field Guide. New York: Routledge, 2016.

MERKL, Gerhard et al. Historische Wassertürme: Beiträge zur Technikgeschichte von Wasserpeicherung und Wasserversorgung. München: Oldenburg Verlag, 1985.

MEVIUS, Walter. Baustile und Wassertürme. In: MERKL, Gerhard et al. Historische Wassertürme: Beiträge zur Technikgeschichte von Wasserpeicherung und Wasserversorgung. München: Oldenburg Verlag, 1985. p. 151-165.

MICHELIS, P. A.. Esthétique de L'Architecture du Béton Armé. Paris: Dunod, 1963. 
MIGNOT, Claude. L'Architecture au XIXe Siècle. Paris: Moniteur, 1983.

MINDLIN, Henrique E. Modern Architecture in Brazil. Rio de Janeiro / Amsterdam: Colibris Editora Ltda., 1956.

MURATORE, Giorgio; LAZZARO, Antonella (Org.). Francesco Palpacelli: Architetto. Milano: Skira, 2007.

MUWANGA, Christina. South Africa: a guide to recent architecture. London: Ellipsis, 1998.

NEUFERT, Ernst. A Arte de Projetar em Arquitetura. 17. ed. Barcelona: Gustavo Gili, 2009. 17a edição em português, correspondente a 35a edição alemã.

NIETO, Fuesanta; SOBEJANO, Enrique (Ed.). Jørn Utzon. Salzburg - Munchen: Verlag Anton Pustet, 1999.

NOZHOVA, Ekaterina; HASSLER, Uta. Networks of Construction: Vladimir Shukhov. München: Hirmer Verlag, 2016.

OTTO, Frei (Ed.). Tensile Structures. Cambridge: MIT Press, 1977.

PFEIL, Walter; PFEIL, Michèle. Estruturas de Aço: Dimensionamento Prático. Rio de Janeiro: LTC Livros Técnicos e Científicos, 2000.

PISANI, Daniele. Paulo Mendes da Rocha: obra completa. São Paulo: Editorial Gustavo Gili, 2013.

PROKKOLA, Janne; LEHTOVUORI, Panu. Haukilahden vesitorni: rakennushistoriaselvitys. Espoo: Livady Osakeyhtiö, 2010.

PEVSNER, Nikolaus; FLEMING, John; HONOUR, Hugh. A Dictionary of Architecture. New York: The Overlook Press, 1976.

QUINCY, Quatremère de. Dictionnaire Historique d'Architecture. Paris: Librairie d'Adrien le Clere et Cie, 1832.

RAJA, Raffaele. Arquitetura Pós-Industrial. São Paulo: Perpectiva, 1993.

RAMELLI, Agostino. Le Diverse et Artificiose Machine del Capitano Agostino Ramelli. Paris, 1588.

RAPPAPORT, Nina; STOLLER, Erica. Ezra Stoller: Photographer. New Haven / London: Yale University Press, 2012.

REBELLO, Yopanan C. P.. A Concepção Estrutural e a Arquitetura. São Paulo: Zigurate, 2001. REES, Abraham. The Cyclopaedia; or Universal Dictionary of Arts, Sciences and Literatutre. Plates, v. 4. London: 1820.

RILEY, Terence. Light construction. Nova York: MoMA, 2004.

ROBBINS, F. W.. The Story of Water Supply. London: Oxford University Press, 1946.

ROCHA, Paulo Mendes da. Maquetes de Papel. São Paulo: Cosac Naify, 2007. 
SANGSTER, Bart. Hendrik Sangster: Watertorens en ander werk. Raleigh: Lulu Enterprises, 2013.

SALBACH, Bernhard. Das Wasserwerk der Stadt Halle: erbaut in den Jahren 1867 und 1868. Halle: G. Knapp, 1871.

SAYLOR, Henry H.. Dictionary of Architecture. New York: John Wiley \& Sons, 1963.

SEGAWA, Hugo. Arquiteturas no Brasil: 1900-1990. 3. ed. São Paulo: Edusp, 2010.

SCHOKLITSCH, Armin. Tratado de Arquitectura Hidráulica. Tomo Primero. Barcelona: Gustavo Gili, 1946.

SHAWLY, Hassan H.. Urban Water: Integrated Resource Planning to Meet Future Demand in Jeddah - Saudi Arabia. München: Oldenburg Industrieverlag, 2008.

SMITH, G. E. Kidder. The new architecture of Europe. Middlesex: Penguin Books, 1961.

STURGIS, Russel. Dictionary of Architecture and Building: Biographical, Historical and Descriptive. New York: The Macmillan Company, 1905. 3 v.

SWYNGEDOUW, Erik. Social power and the urbanization of water: flows of power. Oxford: Oxford University Press, 2004.

TESTA, Peter. Álvaro Siza. São Paulo: Martins Fontes, 1998.

THE AGA KHAN AWARD FOR ARCHITECTURE. Water Towers: Kuwait City, Kuwait. Geneva: Aga Khan Foundation, 1980. Project Brief.

TOMORY, Leslie. The History of the London Water Industry, 1580-1820. Baltimore: John Hopkins University Press, 2017.

TORRECILLAS, Antonio Jiménez (Org.). Eladio Dieste: 1943-1996. Junta de Andalucía: Consejeria de Obras Públicas y Transportes. Dirección General de Arquitectura y Vivienda, 1996.

TSUTIYA, Milton Tomoyuki. Abastecimento de Água. 3. ed. São Paulo: Departamento de Engenharia Hidráulica e Sanitária da Escola Politécnica da Universidade de São Paulo, 2006.

VAN CRAENENBROECK, W.. Eenheid in Verscheidenheid: Watertorens in Belgie. Brussel: Navewa, 1991.

KELKAR, Vasant S.; SEWELL, Robert T.. Fundamentals of the Analysis \& Design of Shell Structures. Englewood Cliffs: Prentice-Hall, 1987.

VASCONCELOS, Augusto Carlos de. Concreto no Brasil: Recordes - Realizações - História. São Paulo: Copiare, 1985.

VEEN, Henk van Der. Watertorens in Nederland. Rotterdam: Uitgeverij 010, 1989.

VERÍSSIMO, Gustavo de Souza; CÉSAR JUNIOR, Kléos M. Lenz. Concreto Protendido:

Fundamentos Básicos. Viçosa: Universidade Federal de Viçosa, 1998.

VIERENDEEL, Arthur. L'Architecture métallique au XIXe Siècle et L'Exposition de 1889, à Paris. Bruxelles, Ramlot, 1890. 
VITRUVIUS. The Ten Books on Architecture. New York: Dover Publications, 2015. Republicação inalterada da primeira edição da tradução para o Inglês por Morris Hicky Morgan, originalmente publicada pela Harvard University Press em 1914.

VON RÖLL, Victor. Enzyklopädie des Eisenbahnwesens: Zehnter Band - ÜbergangsbrückenZwischenstation. Berlin: Urban \& Scharzenberg, 1923. $10 \mathrm{v}$.

VON WALDEGG, Edmund Heusinger. Handbuch für specielle Eisenbahn-Technik. Leipzig: Verlag von Wilhelm Engelmann, 1870.

WAYSS, Gustav Adolf. Das System Monier: Eisengerippe mit Cementumhüllung. Berlin: A. Seydel \& Cie., 1887.

WEINREB, Ben; HIBBERT, Christopher. The London Encyclopaedia. London: Macmillan, 1995.

WERTH, Jan. Ursachen und technische Voraussetzungen für die Entwicklung der Wasserhochbehälter. In: BECHER, Bernhard; BECHER, Hilla. Die Architektur der Förder und Wassertürme. München: Prestel-verlag, 1971. p. 323-428.

WESTON, Richard. UTZON: Inspiration - Vision - Architecture. Hellerup, Denmark: Editions Bløndal, 2008.

WESTON, Richard. Alvar Aalto. London: Phaidon, 1995.

WITT, Dennis J. de. Fantastic Water Towers: An 1890 Design Competition. Boston: Metropolitan Waterwoks Museum, 2017.

\section{TESES E DISSERTAÇÕES}

BARBOSA, Leonardo Cassimiro. As Redes Técnicas Sanitárias na Estruturação do Território: Análise da Cidade de Maringá - PR, Entre 1947-1980. 2016. 345 f. Tese (Doutorado) Curso de Programa de Pós-graduação em Arquitetura e Urbanismo, Instituto de Arquitetura e Urbanismo, Universidade de São Paulo, São Carlos, 2016.

BERNARDO, Joaquín Antuña. Las Estructuras de Edificación de Eduardo Torroja Miret. 2002. 356 f. Tese (Doutorado) - Escuela Técnica Superior de Arquitectura, Universidad Politécnica de Madrid, Madrid, 2002.

BRAGA, Milton Liebentritt de Almeida. Infra-estrutura e Projeto Urbano. 2006. 202 f. Tese (Doutorado) - Faculdade de Arquitetura e Urbanismo, Universidade de São Paulo, São Paulo, 2006.

CORULLON, Martin Gonzalo. A plataforma rodoviária de Brasília: infraestrutura, arquitetura e urbanidade. 2013. 151 f. Dissertação (Mestrado) - Faculdade de Arquitetura e Urbanismo, Universidade de São Paulo, São Paulo, 2013.

DUBIE, Carol Ann. The Architecture and Engineering of Elevated Water Storage Structures: 1870-1940. 1980. 163 f. Dissertação (Mestrado) - Curso de American Civilization, School of Arts and Sciences, The George Washington University, Washington, 1980.

MOREIRA, Renata Maria Pinto. Distribuição de água na Região Metropolitana de São Paulo: tecnologias da universalização e produção do espaço. 2008. 210 f. Dissertação (Mestrado) Curso de Programa de Pós-graduação da Faculdade de Arquitetura e Urbanismo, Universidade de São Paulo, São Paulo, 2008. 
OLSON, Richard. The water-supply system in Roman Pompeii. 2015. 132 f. TCC (Graduação)

- Department Of Archaeology And Ancient History, Lund University, Stockholm, 2015.

PAULITSCH, Vivian da Silva. Rheigantz: Uma Vila Operária em Rio Grande - RS. 2003. 414 f.

Dissertação (Mestrado) - Curso de História da Arte e Cultura, Departamento de História,

Universidade Estadual de Campinas, Campinas, 2003.

PEREIRA, Vinicius Carvalho. O Tombamento da Caixa d'água da Ceilândia no Contexto da Política de Patrimônio do Distrito Federal. 2017. 119 f. Dissertação (Mestrado) - Programa de Pós-graduação em Ciência da Informação, Faculdade de Ciência da Informação, Universidade de Brasília, Brasília, 2017.

SILVEIRA, Aline Montagna da. De fontes e aguadeiros à penas d'água: reflexões sobre o sistema de abastecimento de água e as transformações da arquitetura residencial do final do século XIX em Pelotas - RS. 2009. 340 f. Tese (Doutorado) - Programa de Pós-graduação em Arquitetura e Urbanismo, Faculdade de Arquitetura e Urbanismo, Universidade de São Paulo, São Paulo, 2009.

TZAMOU, Ekaterini. Arts Plastiques et Architecture en France Depuis 1950: Le Sculpteur Philolaos. 1995. 2 v. Tese (Doutorado) - U.F.R. Histoire de L'art Contemporain, Université de Paris I - Panthéon-Sorbonne, Paris, 1995.

VAZ, Rita de Cássia. Luiz Nunes: arquitetura moderna em Pernambuco, 1934-1937. 1988. 1 v. Dissertação (Mestrado) - Programa de Pós-graduação em Arquitetura e Urbanismo, Faculdade de Arquitetura e Urbanismo, Universidade de São Paulo, São Paulo, 1988.

\section{ARTIGOS EM PERIÓDICOS DE ARQUITETURA E ENGENHARIA}

\section{AFASIA ARCHZINE}

Depósito de agua y plataforma en quartier du kiem. AFASIA ARCHZINE. Barcelona, 8 set. 2016. Disponível em: <http://afasiaarchzine.com/2016/07/amann-canovas-maruri-magalhaes-2/>. Acesso em: 17 dez. 2017.

\section{ArchDaily}

AGGARWAL, Vasundhra. White Arkitekter reinventa a tipologia de caixa d'água através de uma estrutura horizontal de concreto. ArchDaily Brasil, 20 dez. 2018. Tradução Vinicius Libardoni. Disponível em: <https://www.archdaily.com.br/br/907839/white-arkitekter-reinventa-a-tipologia-decaixa-dagua-atraves-de-uma-estrutura-horizontal-de-concreto?ad_medium=gallery>

Depósito de Água / Pedro Bandeira + João Figueira e Associados. ArchDaily Brasil, 7 set. 2015. Tradução Victor Delaqua. Disponível em: <https://www.archdaily.com.br/br/772929/deposito-deagua-pedro-bandeira-plus-joao-figueira-e-associados>. Acesso em: 17 dez. 2017.

Caixa d'Água V+. ArchDaily Brasil, 17 mai. 2016. Tradução Victor Delaqua. Disponível em: <https://www.archdaily.com.br/br/787660/caixa-dagua-v-plus>. Acesso em: 18 jan. 2018. 
General Motors Technical Center. Architectural Forum, New York, v. 101, n. 5, p.100-119, nov. 1954.

\section{Architectural Record}

Bell Labs' Mirrored Superblock. Architectural Record, New York, v. 132, n. 10, p.145-152, out. 1962.

\section{Arkitekttävlingar}

VATTENTORN i Malmö. Arkitekttävlingar, Stockholm, n. 1, p.33-40, 1967.

\section{A+U: Architecture and Urbanism}

WATANABE, Hiroshi. Las Vegas Water Tank. A+U: Architecture and Urbanism, Tokyo, n. 395, p. 120-121, ago. 2003.

\section{BAUWELT}

WIRTZ, Schemel. Château d'eau in Leudelange. Bauwelt, Berlin, v. 101, n. 10, p. 26-29, mar. 2009.

MADEC, Philippe. Château d'eau in Pacé. Bauwelt, Berlin, v. 101, n. 10, p. 30-31, mar. 2009.

HÖHNS, Ulrich. Konstrukteur der modernen europaischen Stadt. William Lindley (1808-1900).

Bauwelt, Berlin, v. 100, n. 39-40, p. 2, 2008.

\section{BETONI}

HOVINEN, Juha. Haukilahden vesitornin peruskorjaus 2011-2012. Betoni, Helsinki, v. 82, n. 4, p. 7683, out/nov/dez. 2012. Trimestral.

\section{C.J. Arquitetura}

Reservatórios de Água para a Companhia de Saneamento de Manaus COSAMA. C.J. Arquitetura, São Paulo, v. 2, n. 7, p. 54-56, 1973.

\section{Casabella: Rivista Internazionale di Architettura e di Urbanistica}

GREGOTTI, Vittorio. Classicitá e Razionalismo di Auguste Perret. Casabella, Milano, n. 229, p. 6-11, jul. 1959. 
KOTTENMEIER, E.. Der Stalbehälterbau. Der Stahlbau, Berlin, v. 3, n. 2, p. 17-23, 1930.

\section{DEZEEN}

FREARSON, Amy. Water Tower in Rancagua by Mathias Klotz. DEZEEN. London, 10 set. 2013.

Disponivel em: <https://www.dezeen.com/2013/09/10/water-tower-in-rancagua-by-mathias-klotz/>. Acesso em: 31 jan. 2018.

TUCKER, Emma. V+'s Chateau d'Eau water tower rests on crossed concrete struts. DEZEEN. London, 21 dez. 2015. Disponível em: <https://www.dezeen.com/2015/12/21/v-plus-chateau-d-eauwater-tower-ghlin-badour-belgium-concrete/>. Acesso em: 31 jan. 2018.

WARMANN, Catherine. Water Storage Tower by Mendaro Corsini, Isasi Zaragozá and Gutiérrez Rodríguez. DEZEEN. London, 19 jan. 2011. Disponível em:

<https://www.dezeen.com/2011/01/19/water-storage-tower-by-grg-arquitectos/>. Acesso em: 31 jan. 2018.

\section{DOMUS}

La Torre dei Venti, Yokohama. DOMUS: Monthly Review of Architecture Interiors Design Art, Milano, v. 1, n. 691, p. 40-43, fev. 1988.

KULTERMANN, Udo. Acqua Arabia. DOMUS: Monthly Review of Architecture Interiors Design Art, Milano, n. 596, p. 44-45, fev. 1976.

\section{EL CROQUIS}

Torre de los vientos. El Croquis, Madrid, v. 14, n. 71, p. 50-55, 1995.

\section{Engineering News}

MARSTON, Anson. The Elevated Water Tank of the lowa State Agricultural College. Engineering News, New York, v. 39, p. 371-373, jan-jun. 1889.

\section{Habitat}

KORNGOLD, Lucjan. Arquitetura Industrial: Conjunto de Indústrias Farmacêuticas. Habitat: Revista das Artes no Brasil, São Paulo, n. 21, p. 15-21, nov. 1955.

\section{IABSE Periodica}

THOMSEN, Kjeld. Water tower at Tyrsted, Denmark. IABSE Periodica, Zürich, v. 8, n. P-79, p. 117$128,1984$.

AEBERHARD, H.U.. Water tower in Cutro (Italy). IABSE Periodica, Zürich, v. 6, n. C-22, p. 58-59, 1982. 


\section{Informes de La Construcción}

3 depósitos de agua en Alençon, Francia. Informes de La Construcción, Madrid, v. 25, n. 246, p. 45-51, dez. 1972.

Depósito de agua para la exposición universal de Roma. Informes de La Construcción, Madrid, v. 17, n. 161, p. 93-101, jun. 1964.

Depósito elevado de agua en Baydon. Informes de La Construcción, Madrid, v. 32, n. 325, p. 29-32, jun. 1980.

Depósito elevado para la Fiat. Informes de La Construcción, Madrid, v. 18, n. 172, p. 581-23, jul. 1965.

Depósito pretensado Orebro. Informes de La Construcción, Madrid, v. 11, n. 103, p. 581-14, ago/set. 1958.

TORROJA, José Antonio. Aplicación de las superficies cónicas a la construcción de depósitos elevados. Informes de La Construcción, Madrid, v. 16, n. 157, p. 95-110, jan/fev. 1964.

La cuba hiperbólica de Fedala. Informes de La Construcción, Madrid, v. 14, n. 137, p. 581-18, jan/fev. 1962.

La cuba hiperbólica de Fedala. Informes de La Construcción, Madrid, v. 10, n. 98, p. 581-13, jan/fev. 1958.

\section{JA: The Japan Architect}

ITO, Toyo. The Tower of Winds. JA: The Japan Architect, Tokyo, v. 62, n. 361, p.12-14, maio 1987.

\section{L'Architecture d'Aujourd'hui}

PORTZAMPARC, Christian de. Monuments et instruments. L'Architecture d'Aujourd'hui, Paris, v. 51, n. 212, p. 82-89, dez. 1980.

PORTZAMPARC, Christian de. Symbolisme et utilitaire. L'Architecture d'Aujourd'hui, Paris, v. 51, n. 212, p. 82-89, dez. 1980.

Château d'eau Belmont, Royan, France. L'Architecture d'Aujourd'hui, Paris, v. 31, n. 91-92, p. 2, set-nov. 1960.

Centre d'Industries Pharmaceutiques a São Paulo. L'Architecture d'Aujourd'hui, Paris, v. 26, n. 62, p. 81-83, nov. 1955.

\section{L'ARCA}

CASTELLANO, Aldo. La Torre dei Venti a Yokohama. I'ARCA, Milano, n. 15, p.30-35, abr. 1988. 


\section{Le Béton Armé}

Les Réservoirs. Le Beton Armé, Paris, n. 369, p. 1895-1900, nov. 1938.

\section{Nouvelles Annales de la Construction}

Série des Gares et Stations n 13. Nouvelles Annales de la Construction, Paris, v. 3, n. 3, jan. 1857.

\section{Revista D.A.E. / Boletim R.A.E.}

MALTA, José Maria de Toledo; IPPOLITO, Antonio Luiz. Torre d'água de Sant'Ana. Revista D.A.E.: Revista do Departamento de Águas e Esgotos, São Paulo, v. 5, n. 13, p. 120-150, set. 1941 a.

MALTA, José Maria de Toledo; IPPOLITO, Antonio Luiz. Torre d'água de Sant'Ana. Revista D.A.E.: Revista do Departamento de Águas e Esgotos, São Paulo, v. 5, n. 12, p. 4-76, mar. 1941 b.

NETTO, José Martiniano de Azevedo. Cronologia do Abastecimento de Água (até 1970). Revista D.A.E.: Revista do Departamento de Águas e Esgotos, São Paulo, v. 44, n. 137, p. 106-111, jun. 1984.

NETTO, José Martiniano de Azevedo. Arquitetura das Torres d'Água (IV). Revista D.A.E.: Revista do Departamento de Águas e Esgotos, São Paulo, v. 33, n. 91, p. 15-27, set. 1973.

NETTO, José Martiniano de Azevedo. Arquitetura das Torres de Água - III. Revista D.A.E.:

Revista do Departamento de Águas e Esgotos, São Paulo, v. 28, n. 70, p. 13-25, dez. 1968.

NETTO, José Martiniano de Azevedo. Arquitetura das Torres de Água - II. Revista D.A.E.: Revista do Departamento de Águas e Esgotos, São Paulo, v. 24, n. 51, p. 27-38, dez. 1963.

NETTO, José Martiniano de Azevedo. Arquitetura das Torres d'Água. Revista D.A.E.: Revista do Departamento de Águas e Esgotos, São Paulo, v. 21, n. 38, p. 7-24, set. 1960.

QUEIROZ, Victor Oscar de Seixas. O Abastecimento de Água na Cidade de São Paulo. Revista D.A.E.: Revista do Departamento de Águas e Esgotos, São Paulo, v. 25, n. 52, p. 29-48, mar. 1964.

REIS, Eduardo Gomes dos. Normas para projeto e construção de reservatórios de distribuição. Boletim R.A.E.: Boletim da Repartição de Águas e Esgotos, São Paulo, v. 13, n. 23, p. 3541, jun. 1951.

REVISTA D.A.E.: Revista do Departamento de Águas e Esgotos. São Paulo: SAEC, n. 82, 1971.

THOMPSON, Oswaldo B.. Dados sobre o abastecimento de água de São Paulo. Boletim R.A.E.: Boletim da Repartição de Águas e Esgotos, São Paulo, v. 4, n. 9, p. 32-48, mar. 1940.

WHITAKER, Plínio Penteado. Abastecimento de água da cidade de São Paulo: sua solução. Boletim R.A.E.: Boletim da Repartição de Águas e Esgotos, São Paulo, v. 8, n. 17, p. 3-99, nov. 1946. 
NIEMEYER, Oscar. Estudo de um "stand pipe". Revista Municipal de Engenharia, Rio de Janeiro, v. 6, n. 5, p. 510-511, set. 1939.

\section{The Builder}

Worthing Water-Tower and Engine-House. The Builder, London, v. 14, p. 243, 2 maio 1857.

\section{The Engineer}

Engineering Details at the Crystal Palace. The Engineer, London, v. 91, p.108-109, fev. 1901.

The Nijni-Novgorod Exhibition. The Engineer, London, v. 83, p. 292-293, mar. 1897.

The Norton Tower of the Vyrnwy-Liverpool Water Supply. The Engineer, London, v. 72, p. 230-232 e 234, set. 1891.

Colchester Water Tower. The Engineer, London, v. 57, p. 129-133, fev. 1884.

\section{The Engineering Record}

A Steel Water Tower. The Engineering Record, New York, v. 35, n. 18, p. 273-274, fev. 1897.

\section{urban NEXT Digest}

KLOTZ, Mathias. Water Tower. Urban NEXT Digest. New York, 2016. Disponível em: < https://urbannext.net/water-tower/>. Acesso em: 31 jan. 2018.

\section{VA-tidskriften Cirkulation}

OHLSSON, Eber. Ebers vattentorn: Cirkulation 7/2011. VA-tidskriften Cirkulation. Örebro, jul. 2011.

OHLSSON, Eber. Ebers vattentorn: Cirkulation 3/2010. VA-tidskriften Cirkulation. Örebro, mar. 2010.

OHLSSON, Eber. Ebers vattentorn: Cirkulation 2/2006. VA-tidskriften Cirkulation. Örebro, fev. 2006.

OHLSSON, Eber. Ebers vattentorn: Cirkulation 1/1999. VA-tidskriften Cirkulation. Örebro, jan. 1999.

OHLSSON, Eber. Ebers vattentorn: Cirkulation 8/1998. VA-tidskriften Cirkulation. Örebro, ago. 1998. 
ERBKAM, G.. Verschiebebahnhof Hausbergen und Verlegung der Strecke Straßburg. Atlas zur Zeitschrift für Bauwesen. Berlin: Ernst \& Korn, v. 58, p. 25, 1908.

ERBKAM, G.. Wasserthurm in Mannhiem. Atlas zur Zeitschrift für Bauwesen. Berlin: Ernst \& Korn, v. 42, p. 31, 1892.

ERBKAM, G.. Wasserversorgung des Bahnhofs Hannover. Atlas zur Zeitschrift für Bauwesen. Berlin: Ernst \& Korn, v. 39, p. 68, 1889.

ERBKAM, G.. Hochreservoir der Stadt-Wasserkunst in Lübeck. Atlas zur Zeitschrift für Bauwesen. Berlin: Ernst \& Korn, v. 20, p. 45-46, 1870.

\section{ARTIGOS, ANAIS E DOCUMENTOS EM MEIO ELETRONICO}

ADDIS, Bill. The Crystal Palace and its Place in Structural History. International Journal of Space Structures, Brentwood, v. 21, n. 1, p.1-19, mar. 2006.

ALCOCER, Atxu Amann; ALCARAZ, Andrés Cánovas; MENDOZA, Nicolás Maruri. Concurso Internacional CHATEAU D'EAU, Luxemburgo. 1er Premio. 2016. Memorial do Projeto. Disponível em: <http://amanncanovasmaruri.blogspot.com.br/2016/07/concurso-internacionalchateau-deau.html\#more>. Acesso em: 17 dez. 2017.

ATELIER CHRISTIAN DE PORTZAMPARC. TOUR VERTE - NOISIEL: 1971-1974. Memorial do Projeto. Disponível em: <http://www.christiandeportzamparc.com/fr/projects/tour-verte-noisiel/>. Acesso em: 27 dez. 2017.

BAECK, Saskia. Bauten aus ungeliebter Epoche. Waz. Essen, p. 1-2. 03 set. 2009. Disponível em: $<$ https://www.waz.de/staedte/velbert/bauten-aus-ungeliebter-epoche-id171254.html . Acesso em: 3 fev. 2018.

BANDEIRA, Pedro; FIGUEIRA, João. Depósito de Água da Luz (1996-2002). Memorial do Projeto. Disponível em: <http://www.pedrobandeira.info/Deposito-de-Agua-da-Luz-1996-2002>. Acesso em: 17 dez. 2017.

BAUER, Wolfgang. Das große Verhängnis. Zeit Magazin, n. 5/201826. 01 jan. 2018.

Disponível em: http://www.zeit.de/zeit-magazin/2018/05/nordsyrien-islamischer-staat-wassertuermeexistenz-fotoreportage/seite-7. Acesso em: 11 set. 2018.

BERNARDO, Joaquín Antuña. Prestressed Constructions without Steel. A Project of the Spanish Engineer Eduardo Torroja. In: INTERNATIONAL CONGRESS ON CONSTRUCTION HISTORY, 3., 2009, Cottbus. Proceedings... . Cottbus: Brandenburg University Of Technology, 2009.

BERNARDO, Joaquín Antuña. Prestressed Masonry for Reservoirs: A Project of the Engineer Eduardo Torroja. In: 8th International Seminar nn Structural Masonry, 8., 2008, Istambul. Conference Publication. Istambul: Istanbul Technical University, 2008. p. 11 - 16.

BOTAS, Nilce Cristina Aravecchia. Concreto, muxarabis e cumeeiras para os industriários: a arquitetura e o urbanismo de Carlos Frederico Ferreira na produção do IAPI. In: Encontro Nacional de Pós-Graduação e Pesquisa em Arquitetura e Urbanismo, 1., 2010, Rio de Janeiro. Anais... . Rio de Janeiro: PROURB, 2010. p. 1 - 24. 
BUCHANAN, Angus; JONES, Stephen K.; KISS, Ken. Brunel and the Crystal Palace. Industrial Archaeology Review, London, v. 17, n. 1, p. 7-21,1994.

BYFORENINGEN SVANEKES VENNER. Utzons Vandtårn. Em Dinamarquês. Disponível em: $<$ http://www.svanekesvenner.dk/Utzons vandtaarn/Svaneke Venner Utzon.html>. Acesso em: 25 jul. 2017.

Caixa d'água, de Ceilândia, agora é patrimônio histórico. Gazeta de Taguatinga. Taguatinga, 20 nov. 2013. Disponível em: <http://www.gazetadetaguatinga.com.br/cidades/item/1259-caixa-d'águaagora-é-patrimônio-histórico>. Acesso em: 20 jul. 2016.

CAMPOS, Elizabete Rodrigues de. A arquitetura brasileira de Severiano Mario Porto. Arquitextos, São Paulo, ano 04, n. 043.08, Vitruvius, dez. 2003.

<http://www.vitruvius.com.br/revistas/read/arquitextos/04.043/631>.

Château d'eau, Podensac, France, 1917. Disponível em:

<http://www.fondationlecorbusier.fr/corbuweb/morpheus.aspx?sysld=13\&lrisObjectld=4699\&sysLan guage $=$ fr-fr\&itemPos $=14 \&$ itemSort $=$ fr-

fr_sort_string1\%20\&itemCount=79\&sysParentName=\&sysParentld=64>. Acesso em: 29 jun. 2017.

EDWARDS, Paul N.. Infrastructure and Modernity: Force, Time and Social Organization in the History of Sociotechnical Systems. In: MISA, Thomas J.; BREY, Philip; FEENBERG, Andrew (Ed.). Modernity and Technology. Cambridge: MIT Press, 2003. p. 185-225.

GANDY, Matthew. Rethinking Urban Metabolism: Water, Space and the Modern City. City, Abingdon, v. 8, n. 3, p. 363-379, dez. 2004.

GOULD, Michael H.. The Development of All-Metal Water Towers. Industrial Archaeology Review, London, v. 23, n. 2, p.113-123, 2001.

GRAY, Harold Farnsworth. Sewerage in Ancient and Medieval Times. Sewage Works Journal, Alexandria, v. 12, n. 5, p.939-946, set. 1940.

GÜRZ, Dieter. Teilsperrungen in der Tiergartenstrasse: Ursache ist der Sanierungsbedürftige Historische Wasserkanal aus dem Veitshöchheimer Hofgarten. 2014. Disponível em: <http://www.veitshoechheim-blog.de/article-stra-ensperrma-nahmen-in-dertiergartenstra-e-ursache-ist-der-historische-abwasserkanal-aus-dem-vei-124446195.html>. Acesso em: 25 nov. 2018.

HAMM, Sara. The Watertower as Decor: Exceeding Generic Concepts in Art Nouveau. In: Historical Lab 3: Art Nouveau \& Decoration, 2006, Riga. Proceedings.... Bruxelles: Bruxelles Urbanisme \& Patrimoine, 2006.

HANSEN, Hofman. Stykker til Fanøs kultur, natur og historie: Båkerne langs Jyllands vestkyst. 2013. Em Dinamarquês. Disponível em: <http://www.aldus.dk/fanoe/kaaver/jyllands-baaker.html>. Acesso em: 25 nov. 2017.

HESPANHA, Sérgio Augusto Menezes. Severiano Porto. Entre o regional e o moderno. Arquitextos, São Paulo, ano 09, n. 105.05, Vitruvius, fev. 2009

<http://www.vitruvius.com.br/revistas/read/arquitextos/09.105/76>. 
JENSEN, Eigil. Blev Svaneke Vandtarn tegnet af arkitekt Jørn Utzon allerede i 1946? Byforeningen Svanekes Venner. Svaneke, p. 1-13. abr. 2016. Disponível em:

<http://www.svanekesvenner.dk/Utzons vandtaarn/Blev vandtårnet tegnet i 1946.pdf>. Acesso em: 15 nov. 2017.

KEMPE, Marcis. New England Water Supplies: A Brief History. Journal Of The New England Water Works Association, Boston, v. 120, n. 3, p.2-157, set. 2006.

KOŹNIEWSKI, Edwin; ORLOWSKI, Marcin. Geometria Poprzez Analizee Obiektów Budowlanych. In: CONFERENCE GEOMETRY GRAPHICS COMPUTER, 22., 2015, Cracow. Proceedings... . Slaska: Silesian University of Technology Publishing, 2015. p. 45 - 47.

Le château d'eau - Le Corbusier. Disponível em:

<http://www.chateaudeaulecorbusier.sitew.fr/\#LE_CHATEAU_D_EAU.A>. Acesso em: 29 jun. 2017.

LIEDTKE, Gerd. Richtungs-, Signal- und Landerkennungs. Em alemão. Disponível em: <www.baken-net.com>. Acesso em: 15 nov. 2017.

MAINSTONE, Rowland J.. Structural Analysis, Structural Insights, and Historical Interpretation. Journal Of The Society Of Architectural Historians, Oakland, v. 56, n. 3, p. 316-340, set. 1997.

MARQUES, Sonia; NASLAVSKY, Guilah. Eu vi o modernismo nascer... foi no Recife.

Arquitextos, São Paulo, ano 11, n. 131.02, Vitruvius, abr. 2011

<http://www.vitruvius.com.br/revistas/read/arquitextos/11.131/3826>.

MAYS, L. W.; KOUSTSOYIANNIS, D.; ANGELAKIS, A. N.. A brief history of urban water supply in antiquity. Water Science \& Technology: Water Supply, London, v. 7, n. 1, p.1-12, jan. 2007.

MONTEVIDEO. Facultad de Arquitectura, Diseño y Urbanismo. Universidad de La República (Org.). Eladio Dieste: Tanque de agua Complejo América. 2007. Disponível em:

$<$ http://www.fadu.edu.uy/eladio-dieste/obras/tanque-de-agua-complejo-america/>. Acesso em: 26 jan. 2018.

PEREIRA, Vinicius Carvalho. A Caixa d'água da Ceilândia e o Reconhecimento da Memória dos Construtores de Brasília. In: SEMINÁRIO INTERNACIONAL EM MEMÓRIA SOCIAL, 2., 2016, Rio de Janeiro. Anais... . Rio de Janeiro: Programa de Pós-graduação em Memória Social, UFRJ, 2016.

POMPEU, Ana. Cercada de história e simbologia, caixa d'água de Ceilândia é tombada. Correio Brasiliense. Brasília, 21 nov. 2013.

REED, Cory A.. As Imagens Científicas e Tecnológicas do Quixote. Revista USP, São Paulo, n. 67, p. 294-303, set./nov. 2007. Tradução de Silvia Massimini.

REYES, Julio Jerez. Essbio inauguró estanque de agua potable en Santa Cruz. El Tipógrafo. Rancagua, p. 1-2. 16 maio 2012. Disponível em: <http://eltipografo.cl/2012/05/essbio-inauguroestanque-de-agua-potable-en-santa-cruz/>. Acesso em: 3 fev. 2018.

RIENKS, H.. Nederlandse Watertorens. RDMZ RV, Amsterdam, n. 14, RVblad, p. 9, 1989.

Serbatoio pensile dello stabilimento Fiat Mirafiori. Disponível em:

<http://www.museotorino.it/view/s/0edab9745ac4426796a1b54da131fe4f>. Acesso em: 17 jul. 2016. 
SILVA, Terezinha J. P. et al. Um Novo Mirante para Descortinar a Paisagem do Sítio Histórico de Olinda, Pernambuco, Brasil. In: COLÓOUIO IBERO-AMERICANO PAISAGEM CULTURAL, PATRIMÔNIO E PROJETO, 4., 2016, Belo Horizonte. Anais... . Belo Horizonte: UFMG / IPHAN / IEDS, 2016.

SPIRN, Anne Whiston. The Poetics of City and Nature: Towards a New Aesthetic for Urban Design. Landscape Journal, Madison, v. 7, n. 2, p.108-126,1988.

STEWART, Gary. Water Tower Plans Thrown out for the Seventh Time. The Advertiser. Ormskirk, 2 ago. 2007

THOMPSON, F. H.. The Roman Aqueduct at Lincoln. The Archaeological Journal, London, v. 111, n. 1, p.106-128, jan. 1954.

TORAYA, Juan de las Cuevas. A Era do Cimento (1). Arquitextos, São Paulo, ano 03, n. 028.01, Vitruvius, set. 2002.

<http://www.vitruvius.com.br/revistas/read/arquitextos/03.028/748/pt>

\section{ARQUIVOS PÚBLICOS}

\section{Acervo de Projetos da Biblioteca da FAU / USP}

TOSCANO, João Walter ; FERRAZ, Figueiredo. Título: Estação Largo 13 de Maio da FEPASA Santo Amaro. Data: 1984. Classificação: PE T639es/725.31 LT. Folhas: 10 e 18.

\section{CEHOPU - Centro de Estudios Históricos de Obras Públicas y Urbanismo, Madrid, Espanha}

CEDEX / CEHOPU (Org.). ETM-400 - Depósito de agua de Fedala, Mohamedia

(Marruecos). Madrid: Centro de Estudios Históricos de Obras Públicas y Urbanismo, 2008a.

CEDEX / CEHOPU (Org.). ETM-421 - Depósito de Sidi Bernoussi en Casablanca

(Marruecos). Madrid: Centro de Estudios Históricos de Obras Públicas y Urbanismo, 2008b.

CEDEX / CEHOPU (Org.). ETM-458 - Estación de agua en Khouribga (Marruecos). Madrid: Centro de Estudios Históricos de Obras Públicas y Urbanismo, 2008c.

CEDEX / CEHOPU (Org.). ETM-458-006 - Alimentation en eau de Khouribga. Réservoir surélève de 600 m3 [Exp. 893]. Madrid: Centro de Estudios Históricos de Obras Públicas y Urbanismo, 2008d.

CEDEX / CEHOPU (Org.). ETM-115-004 - Reparación de edificios, nuevo abastecimiento y Depósito elevado en el Hipódromo de la Zarzuela [Exp. 246]. Madrid: Centro de Estudios Históricos de Obras Públicas y Urbanismo, 2008e.

\section{DGP - Direction Générale des Patrimoines, Paris, França}

DGP Ministère de La Culture. Liste des Edifices ou Ensembles Labellises Patrimoine du XXe Siecle: entre 2000 et 2015. Paris: Ministère de La Culture, 2016.

DGP Ministère de La Culture / DRAC Rhône-Alpes. Château d'eau de Valence. Lyon: Ministère de La Culture, 2004. 
TATUM, Laura et al (Comp.). Guide to the Eero Saarinen Collection: MS 593. New Haven: Yale University Library, 2006. Revisado em 2014.

\section{NORMAS TÉCNICAS}

ABNT - Associação Brasileira de Normas Técnicas

ASSOCIAÇÃO BRASILEIRA DE NORMAS TÉCNICAS. NBR 12211: Estudos de Concepção de Sistemas Públicos de Abastecimento de Água. Rio de Janeiro: ABNT, 1992.

ASSOCIAÇÃO BRASILEIRA DE NORMAS TÉCNICAS. NBR 12217: Projeto de Reservatório de Distribuição de Água para Abastecimento Público. Rio de Janeiro: ABNT, 1994.

ASSOCIAÇÃO BRASILEIRA DE NORMAS TÉCNICAS. NBR 12218: Projeto de Rede de Distribuição de Água para Abastecimento Público. Rio de Janeiro: ABNT, 1994.

ASSOCIAÇÃO BRASILEIRA DE NORMAS TÉCNICAS. NB 594: Elaboração de projeto hidráulico de redes de distribuição para abastecimento público. Rio de Janeiro: ABNT, 1977.

\section{$\underline{\text { SABESP - Companhia de Saneamento Básico do Estado de São Paulo }}$}

COMPANHIA DE SANEAMENTO BÁSICO DO ESTADO DE SÃO PAULO. NTS 023: Reservatórios Elaboração de Projetos. São Paulo: SABESP, 1999.

COMPANHIA DE SANEAMENTO BÁSICO DO ESTADO DE SÃO PAULO. NTS 024: Redes de Distribuição de Água - Elaboração de Projetos. São Paulo: SABESP, 1999.

COMPANHIA DE SANEAMENTO BÁSICO DO ESTADO DE SÃO PAULO. NTS 061: Estudo de Concepção de Sistema de Abastecimento de Água. São Paulo: SABESP, 2002.

COMPANHIA DE SANEAMENTO BÁSICO DO ESTADO DE SÃO PAULO. NTS 231: Reservatório Apoiado de Aço Carbono Soldado. São Paulo: SABESP, 2014.

\section{PATENTES}

\section{United States Patent Office}

UNITED STATES PATENT OFFICE (EUA). Clarence D. Miller. Elevated Storage Tank. EUA $n^{\circ}$ US 2.961.118, 2 out. 1958, 22 nov. 1960. p. 1-6.

UNITED STATES PATENT OFFICE (Washington). George T. Horton. Elevated Tank. EUA n ${ }^{\circ}$ US 2.495.724, 24 jan. 1945, 31 jan. 1950. p. 1-4.

UNITED STATES PATENT OFFICE (Washington). George T. Horton. Elevated Tank. EUA n ${ }^{\circ}$ US 2.462.101, 28 set. 1944, 22 fev. 1949. p. 1-5.

UNITED STATES PATENT OFFICE (Washington). George T. Horton. Spherical Tank. EUA $n^{\circ}$ US 2.427.676, 1 mar. 1945, 23 set. 1947. p. 1-4. 
UNITED STATES PATENT OFFICE (Washington). George T. Horton. Elevated Tank. EUA $n^{\circ}$ US 2.358.805, 4 nov. 1942, 26 set. 1944. p. 1-3.

UNITED STATES PATENT OFFICE (Washington). George T. Horton. Elevated Steel Tank. EUA n ${ }^{\circ}$ US 2.341.100 A, 4 nov. 1942, 8 fev. 1944. p. 1-4.

UNITED STATES PATENT OFFICE (Washington). George T. Horton. Elevated tank. EUA $n^{\circ}$ US 2.264.668, 4 maio 1940, 2 dez. 1941. p. 1-3.

UNITED STATES PATENT OFFICE (Washington). George T. Horton. Tank. EUA n ${ }^{\circ}$ US 2.264.667, 17 junho 1938, 2 dez. 1941. p. 1-4.

UNITED STATES PATENT OFFICE (Washington). George T. Horton. Tank. EUA n ${ }^{\circ}$ US 1.844.854, 18 abr. 1929, 9 fev. 1932. p. 1-8.

UNITED STATES PATENT OFFICE (Washington). George T. Horton. Container. EUA $n^{\circ}$ US 1.622.787, 5 nov. 1925, 29 mar. 1927. p. 1-15.

UNITED STATES PATENT OFFICE (Washington). George T. Horton. Tank. EUA n ${ }^{\circ}$ US 1.517.006, 15 dez. 1923, 25 nov. 1924. p. 1-5.

UNITED STATES PATENT OFFICE (Washington). Otto Intze. Fluid Reservoir. EUA $n^{\circ}$ US 348.912 A, 13 jun. 1885, 7 set. 1886. p. 1-4.

\section{CATÁLOGOS E MANUAIS TÉCNICOS}

CALDWELL, W. E.. Tanks \& Towers: Wood and Steel. Louisville: W. E. Caldwell Co., 1905.

Catálogo Técnico.

CALDWELL, W. E.. Tanks Towers and Tubs: Large water tanks a specialty. Louisville: W. E. Caldwell Co., 1931. Catálogo Técnico.

CB\&l (Chicago Bridge \& Iron Company). Reservoirs and Stand Pipes: Water Storage. Woodlands: Chicago Bridge \& Iron Company, 2016. Catálogo Técnico.

CB\&l (Chicago Bridge \& Iron Company). Waterspheroid: Elevated Water Storage. Woodlands: Chicago Bridge \& Iron Company, 2016. Catálogo Técnico.

CB\&l (Chicago Bridge \& Iron Company). Engineers and Contractors for Metal Structures. Chicago: Chicago Bridge \& Iron Company, 1912. Catálogo Técnico.

VSL. VSL Heavy Lifting: Feasibility Studies, Design and Planning, Handling of Exceptional Loads, Special Equipment. Berne: VSL International Ltd., 2013.

VSL. Roihuvuori Water Tower, Helsinki - Finland: Lifting of the Storage Tank. Berne: VSL International Ltd., 2008.

VSL. Concrete Storage Structures: Use of the VSL Special Construction Methods. Berne: VSL International Ltd., 1983.

VSL. Water and Telecommunications Tower Mechelen, Belgium. Berne: VSL International Ltd., 1979. 


\section{INSTITUIÇÕES CONSULTADAS}

\section{BRASIL}

Universidade de São Paulo

- Escola de Engenharia de São Carlos - Biblioteca

- Escola Politécnica - Biblioteca Central

- Escola Politécnica - Biblioteca da Engenharia Civil

- Escola Politécnica - Biblioteca da Engenharia Mecânica

- Faculdade de Arquitetura e Urbanismo - Biblioteca

- Faculdade de Filosofia, Letras e Ciências Humanas - Biblioteca

\section{COLEÇÕES DIGITAIS CONSULTADAS}

\section{ALEMANHA}

Architekturmuseum der Technische Universität Berlin

(Museu de Arquitetura da Universidade Técnica de Berlim)

https://architekturmuseum.ub.tu-berlin.de

Bayerische Staatsbibliothek

(Biblioteca Estadual da Baviera)

https://www.bsb-muenchen.de

Sächsische Landesbibliothek - Staats- und Universitätsbibliothek Dresden (Biblioteca Estadual da Saxônia - Biblioteca Estadual da Universidade de Dresden) https://www.slub-dresden.de

Universitäts- und Landesbibliothek Sachsen-Anhalt

(Biblioteca Universitária e Estadual da Saxônia-Anhalt)

http://digital.bibliothek.uni-halle.de

Universitätsbibliothek Rheinisch-Westfälische Technische Hochschule Aachen (Biblioteca da Universidade Técnica da Renânia do Norte-Vestfália Aachen) http://www.ub.rwth-aachen.de

\section{BRASIL}

Biblioteca Digital Brasileira de Teses e Dissertações http://bdtd.ibict.br

Biblioteca Digital da Universidade Estadual de Campinas http://www.bibliotecadigital.unicamp.br

Biblioteca Digital de Teses e Dissertações da Universidade de São Paulo http://www.teses.usp.br/ 


\section{BÉLGICA}

Universiteitsbibliotheek Gent

(Bliblioteca da Universidade de Gent)

https://lib.ugent.be/

\section{ESPANHA}

Archivo Digital Universidad Politécnica de Madrid

(Arquivo Digital da Universidade Politécnica de Madri)

http://oa.upm.es/

Centro de Estudios Históricos de Obras Públicas y Urbanismo (Centro de Estudos Históricos de Obras Públicas e Urbanismo) http://www.cehopu.cedex.es/

Instituto de Ciencias de la Construcción Eduardo Torroja (Instituto de Ciências da Construção Eduardo Torroja)

http://informesdelaconstruccion.revistas.csic.es

\section{ESTADOS UNIDOS}

Hathi Trust Digital Library

(Biblioteca Digital Hathi Trust)

https://www.hathitrust.org/

Internet Archive

https://archive.org/

United States Patent and Trademark Office

(Escritório de Marcas e Patentes dos Estados Unidos)

https://www.uspto.gov/

Yale University Library

(Biblioteca de Universidade de Yale)

https://web.library.yale.edu

\section{FRANÇA}

Bibliothèques de I'Université de Strasbourg

(Bibliotecas da Universidade de Estrasburgo)

http://docnum.u-strasbg.fr

Bibliothèque Nationale de France

(Biblioteca Nacional da França)

https://gallica.bnf.fr

Bibliothèque numérique de Institut national d'histoire de l'art (Biblioteca Digital do Instituto Nacional de História da Arte) https://bibliotheque-numerique.inha.fr/ 
Centre d'archives de la Cité de l'architecture et du patrimoine (Centro de Arquivos da Cidade da Arquitetura e do Patrimônio)

https://archiwebture.citedelarchitecture.fr

Les collections en ligne des musées de la Ville de Paris (As coleções online dos museus da cidade de Paris) http://parismuseescollections.paris.fr

\section{HOLANDA}

Digitale Bibliotheek voor de Nederlandse Letteren (Biblioteca Digital de Literatura Holandesa) http://www.dbnl.org

\section{SUÍÇA}

\section{Bibliothek Werner Oechslin}

(Biblioteca Werner Oechslin)

https://www.bibliothek-oechslin.ch

ETH-Bibliothek Zürich

(Instituo Federal de Tecnologia de Zurique - Biblioteca) https://www.library.ethz.ch 


\section{Torres de Água Incursão em sua Arquitetura}

Volume II Quadro Referencial de Obras

Dissertação apresentada à Faculdade de Arquitetura e Urbanismo da Universidade de São Paulo para obtenção do título de Mestre em Arquitetura e Urbanismo

Orientador: Prof. Dr. Francisco Spadoni Area de Concentração: Projeto de Arquitetura 
Autorizo a reprodução e divulgação total ou parcial deste trabalho, por qualquer meio convencional ou eletrônico, para fins de estudo e pesquisa, desde que citada a fonte.

E-mail: tiagooliveandrade@gmail.com 


\section{Quadro Referencial de Obras ${ }^{1}$}

Considerando que a bibliografia especializada sobre torres de água produzida até o momento ocupou-se da análise do objeto tema desta pesquisa até meados do século XX, o Quadro Referencial de Obras foi elaborado com o objetivo de ajudar a preencher as lacunas existentes na historiografia das torres de água até a atualidade. Ainda, é importante destacar que para a reconstrução do panorama histórico das torres de água a pesquisa não deve se restringir a bibliografia especializada já publicada sobre o tema e deve se apoiar também na pesquisa, levantamento e investigação de obras desconhecidas e ou ignoradas pela bibliografia específica, inserindo estas obras na linha do tempo do desenvolvimento do objeto até a atualidade, por isso ampliamos o recorte temporal da pesquisa para montagem do quadro, iniciando o levantamento de torres projetadas ou construídas a partir do início do século XX.

Para a elaboração do quadro foi realizada pesquisa bibliográfica em monografias de arquitetura e engenharia, periódicos especializados em arquitetura, engenharia, abastecimento de água e saneamento, trabalhos acadêmicos (teses, dissertações, trabalhos de conclusão de curso e artigos), jornais, revistas, anais de congresso e sites de internet.

Foram selecionadas 70 torres de água para compor o Quadro Referencial de Obras. A primeira obra relacionada data de 1907 e a última data de 2016. Os critérios de seleção para as obras incluídas no quadro foram os seguintes: torres de água projetadas durante todo o século XX e nas primeiras décadas do século XXI, privilegiando a relevância dos autores, a relevância das obras e também a dedicação do autor (arquiteto ou engenheiro) ao tema, visto que alguns profissionais pouco conhecidos tanto no cenário nacional quanto internacional foram prolíficos projetistas de torres de água. Considerando a extensa produção de alguns destes profissionais optou-se por relacionar apenas as obras mais significativas de cada autor.

O Quadro Referencial de Obras foi elaborado como um conjunto de Fichas Técnicas com os dados de cada obra divididos nos seguintes grupos: Informações Gerais, Créditos do Projeto, Dados do Reservatório, Dados da Estrutura de Apoio do Reservatório, Dados do Revestimento e Referências Bibliográficas (inserções em bibliografia específica sobre torres de água, inserções em bibliografia geral e inserção em periódicos). Cada ficha técnica é acompanha por uma página com material iconográfico e fotográfico de cada torre de água apresentada.

\footnotetext{
${ }^{1}$ O Quadro Referencial de Obras é parte integrante da Dissertação de Mestrado, intitulada Torres de Água: Incursão em sua Arquitetura. Programa de Pós-Graduação em Arquitetura e Urbanismo - Faculdade de Arquitetura e Urbanismo - Universidade de São Paulo (FAU-USP) sob orientação do Prof. Dr. Francisco Spadoni - Área de Concentração: Projeto de Arquitetura.
} 
Relação de Obras

\begin{tabular}{|c|c|c|c|c|}
\hline & OBRA & AUTOR & DATA & LOCAL \\
\hline 001 & Torre de Mykolaiv & Vladimir Shukhov & 1907 & Mykolaiv, Ucrânia \\
\hline 002 & Torre de Winterhude & Hans Poelzig & 1907 & Hamburgo, Alemanha \\
\hline 003 & Torre em Posen & Hans Poelzig & 1911 & Posen, Polônia \\
\hline 004 & Torre em Yaroslavl & Vladimir Shukhov & 1911 & Yaroslavl, Rússia \\
\hline 005 & Torre da Fábrica Fagus & Walter Gropius e Adolf Meyer & 1916 & Alfeld, Alemanha \\
\hline 006 & Torre em Pondesac & Le Corbusier & 1918 & Pondesac, Aquitânia, França \\
\hline 007 & Torre em Breda & Sybold van Ravesteyn & 1927 & Breda, Holanda \\
\hline 008 & Torre em Wassenaar & Mart Stam & 1927 & Wassenaar, Holanda \\
\hline 009 & Torre em Pelotas & Escritório Saturnino de Brito & 1927 & Pelotas, Rio Grande do Sul, Brasil \\
\hline 010 & Torre em Aalsmeer & Hendrik Sangster & 1928 & Aalsmeer, Holanda \\
\hline 011 & Torre do Araçá & [Hyppolito Gustavo Pujol Jr.] ? & 1930 & São Paulo, São Paulo, Brasil \\
\hline 012 & Torre em Domburg & Hendrik Sangster & 1933 & Domburg, Holanda \\
\hline 013 & Torre do Sanatório de Paimio & Alvar Aalto & 1933 & Paimio, Finlândia \\
\hline 014 & Torre de Água do Alto da Sé & Luiz Nunes & 1937 & Olinda, Pernambuco, Brasil \\
\hline 015 & Torre de Ribeirão das Lajes & Oscar Niemeyer & 1939 & Rio de Janeiro, Rio de Janeiro, Brasil \\
\hline 016 & Torre de Svaneke & Jørn Utzon & 1952 & Svaneke, Bornholm, Dinamarca \\
\hline 017 & Torre do CEA - Saclay & Auguste Perret & 1953 & Saclay, Île-de-France, França \\
\hline 018 & Torre do Centro Técnico da GM & Eero Saarinen & 1955 & Warren, Michigan, EUA \\
\hline 019 & $\begin{array}{l}\text { Torre da Indústria Fontoura- } \\
\text { Wyeth }\end{array}$ & Lucjan Korngold & 1955 & $\begin{array}{c}\text { São Bernardo do Campo, São Paulo, } \\
\text { Brasil }\end{array}$ \\
\hline 020 & Torre de Fedala & Eduardo Torroja & 1957 & Mohammedia, Marrocos \\
\hline 021 & Torre de Örebro & Sune Lindström & 1957 & Örebro, Suécia \\
\hline 022 & Torre de Guérinière & Guillaume Gillet & 1957 & Caen, Normandia, França \\
\hline 023 & Torre Velbert BKS Hochhaus & Krieger-Jähnert-Schütte & 1958 & Velbert, Rheinland, Alemanha \\
\hline 024 & Torre do EUR & Sergio Varisco & 1958 & EUR, Roma, Itália \\
\hline 025 & Torre do Hipódromo de Zarzuela & Eduardo Torroja & 1959 & Madrid, Espanha \\
\hline 026 & Centro Idrico de Acea & Francesco Palpacelli & 1959 & Aurelio, Roma, Itália \\
\hline 027 & Torre de Belmont & Guillaume Gillet & 1960 & Royan, Nova Aquitânia, França \\
\hline 028 & Centro Idrico dell'EUR & Francesco Palpacelli & 1961 & EUR, Roma, Itália \\
\hline 029 & Torre de Sidi Bernoussi & Eduardo Torroja & 1961 & Casablanca, Marrocos \\
\hline 030 & Torre dos Laboratórios Bell & Eero Saarinen & 1962 & Holmdel, New Jersey, EUA \\
\hline 031 & Torre de Khouribga & Eduardo Torroja & 1962 & Khouribga, Marrocos \\
\hline 032 & Torre da Fábrica FIAT Mirafiori & Pier Luigi Nervi & 1963 & Turim, Itália \\
\hline 033 & Centro Idrico della Cecchina & Francesco Palpacelli & 1964 & Bufallota, Roma, Itália \\
\hline 034 & Torre de Myllypuro & Bertel Saarnio & 1965 & Helsinque, Finlândia \\
\hline 035 & Torre de Möglingen & R. Kessler & 1965 & $\begin{array}{l}\text { Möglingen, Baden-Württemberg, } \\
\text { Alemanha }\end{array}$ \\
\hline 036 & Torre do Balneário Las Vegas & Eladio Dieste & 1966 & Canelones, Uruguai \\
\hline 037 & Torres de Alençon & $\begin{array}{c}\text { Serge Ketoff + Maurice } \\
\text { Novarina }\end{array}$ & 1967 & Alençon, Baixa Normandia, França \\
\hline 038 & Reservatório Elevado de Urânia & Paulo Mendes da Rocha & 1968 & Urânia, São Paulo, Brasil \\
\hline 039 & Torre de Haukilahti & Erkko Virkkunen & 1968 & Haukilahti, Espoo, Finlândia \\
\hline 040 & Torre de Cockfosters & Edmund C. Percey & 1968 & Londres, Inglaterra \\
\hline 041 & Torre de Maringá & Gerhard Leo Linzmeyer & 1969 & Maringá, Paraná, Brasil \\
\hline 042 & Torre de Eindhoven & Win G. Quist & 1971 & Eindhoven, Holanda \\
\hline 043 & Torre da Politécnica de Otaniemi & Alvar Aalto & 1971 & Otaniemi, Espoo, Finlândia \\
\hline
\end{tabular}




\begin{tabular}{|c|c|c|c|c|}
\hline & OBRA & AUTOR & DATA & LOCAL \\
\hline 044 & Torres de Valence & $\begin{array}{c}\text { André Gomis + Philolaos } \\
\text { Tloupas }\end{array}$ & 1971 & Valence, França \\
\hline 045 & Reservatórios da COSAMA & Severiano Porto & 1972 & Manaus, Amazonas, Brasil \\
\hline 046 & Torre de Ciechanow & Jerzy Michal Boguslawsky & 1972 & Ciechanow, Polônia \\
\hline 047 & Torre de Hyllie & Göran Kjessler + Karl Ivar Stål & 1973 & Malmö, Suécia \\
\hline 048 & Torre de Marne-la-Vallée & Christian de Portzamparc & 1974 & $\begin{array}{c}\text { Marne-la-Vallée, Île-de-France, } \\
\text { França }\end{array}$ \\
\hline 049 & Torre de Ceilândia & Gerhard Leo Linzmeyer & 1974 & Ceilândia, Distrito Federal, Brasil \\
\hline 050 & Torre de Baydon & Edmund C. Percey & 1974 & Wiltshire, Inglaterra \\
\hline 051 & Torre de Khuzam & Sune Lindström & 1977 & Gidá, Arábia Saudita \\
\hline 052 & Kuwait Towers & $\begin{array}{l}\text { Sune Lindström + Malene } \\
\text { Björn }\end{array}$ & 1977 & Cidade do Kuwait, Kuwait \\
\hline 053 & Torre de Mechelen & Fernand Mortelmans & 1978 & Mechelen, Bélgica \\
\hline 054 & Torre de Roihuvuori & Simo Lumme & 1978 & Helsinque, Finlândia \\
\hline 055 & $\begin{array}{l}\text { Torre da Indústria Refrescos del } \\
\text { Norte }\end{array}$ & Eladio Dieste & 1979 & Salto, Uruguai \\
\hline 056 & $\begin{array}{l}\text { Torre do Complejo Habitacional } \\
\text { America }\end{array}$ & Eladio Dieste & 1983 & Montevideo, Uruguai \\
\hline 057 & Torre de Tyrsted & Holger Koch Nielsen & 1983 & Horsens, Dinamarca \\
\hline 058 & $\begin{array}{l}\text { Torre da Estação Largo } 13 \text { de } \\
\text { Maio }\end{array}$ & João Walter Toscano & 1985 & São Paulo, São Paulo, Brasil \\
\hline 059 & Torre dos Ventos & Toyo Ito & 1986 & Yokohama, Kanagawa, Japão \\
\hline 060 & Torre da Universidade de Aveiro & Álvaro Siza & 1989 & Aveiro, Portugal \\
\hline 061 & Centro Idrico di Vigna Murata & Francesco Palpacelli & 1989 & EUR, Roma, Itália \\
\hline 062 & Torre de Midrand & GAPP Architects & 1996 & Gauteng, África do Sul \\
\hline 063 & Torre da Nova Aldeia da Luz & $\begin{array}{c}\text { Pedro Bandeira + João } \\
\text { Figueira }\end{array}$ & 2002 & Luz, Portugal \\
\hline 064 & Château d'eau "ZÉRO ÉNERGIE" & Philippe Madec & 2006 & Pacé, Bretanha, França \\
\hline 065 & Torre de Leudelange & Schemel Wirtz & 2008 & Leudelange, Luxemburgo \\
\hline 066 & Torre em Guijo de Coria & GRG Arquitectos & 2009 & Cáceres, Espanha \\
\hline 067 & Torre em Rancagua & Mathias Klotz & 2012 & Rancagua, Chile \\
\hline 068 & Torre em Santa Cruz & Mathias Klotz & 2012 & Santa Cruz, Colchagua, Chile \\
\hline 069 & Torre de Ghlin-Baudour & $V+$ Architects & 2014 & Mons, Bélgica \\
\hline 070 & Torre de Água de Kirchberg & Amann - Cánovas - Maruri & 2016 & Kirchberg, Luxemburgo \\
\hline
\end{tabular}




\section{Torre de Mykolaiv}

001 Vladimir Shukhov

\begin{tabular}{|c|c|}
\hline Informacões Gerais & \\
\hline Localização & Mykolaiv, Ucrânia \\
\hline GPS & $46^{\circ} 58^{\prime} 8.36^{\prime \prime} \mathrm{N}-31^{\circ} 58^{\prime} 34.17^{\prime \prime} \mathrm{E}$ \\
\hline Data de Início do Projeto & 1906 \\
\hline Data do Término da Obra & 1907 \\
\hline Uso da Torre & Abastecimento público urbano \\
\hline Situação Atual & Desativada \\
\hline Créditos do Projeto & \\
\hline Proprietário / Contratante & \\
\hline Projeto de Arquitetura & Vladimir Shukhov \\
\hline Projeto Estrutural & Vladimir Shukhov \\
\hline Construção & Alexander Bary \\
\hline Dados do Reservatório & \\
\hline Capacidade $\left[\mathrm{m}^{3}\right]$ & 615 \\
\hline Forma / Tipologia & Cilíndrico tipo Intze II \\
\hline Material & Metálico \\
\hline Altura $[\mathrm{m}]$ & 9,30 \\
\hline Diâmetro [m] & 10,50 \\
\hline Altura da Água - h [m] & \\
\hline Número de Câmaras & 1 \\
\hline Dados da Estrutura de Apoio do Reser & \\
\hline Tipologia & Estrutura treliçada hiperbólica \\
\hline Material & Aço \\
\hline Altura do Fundo do Reservatório - H [m] & 25,60 \\
\hline Altura Efetiva - $\mathrm{H}+\mathrm{h}[\mathrm{m}]$ & \\
\hline Altura Total da Torre - Ht [m] & 34,90 \\
\hline Dados do Revestimento & \\
\hline Tipo & \\
\hline Material & \\
\hline Referências Bibliográficas & \\
\hline Inserções em Bibliografia Específica & nenhum registro encontrado \\
\hline Inserções em Bibliografia Geral & [NOZHOVA, 2016] \\
\hline & [BECKH, 2015] \\
\hline Inserções em Periódicos & nenhum registro encontrado \\
\hline
\end{tabular}


- Torre de Mykolaiv

001 Vladimir Shukhov
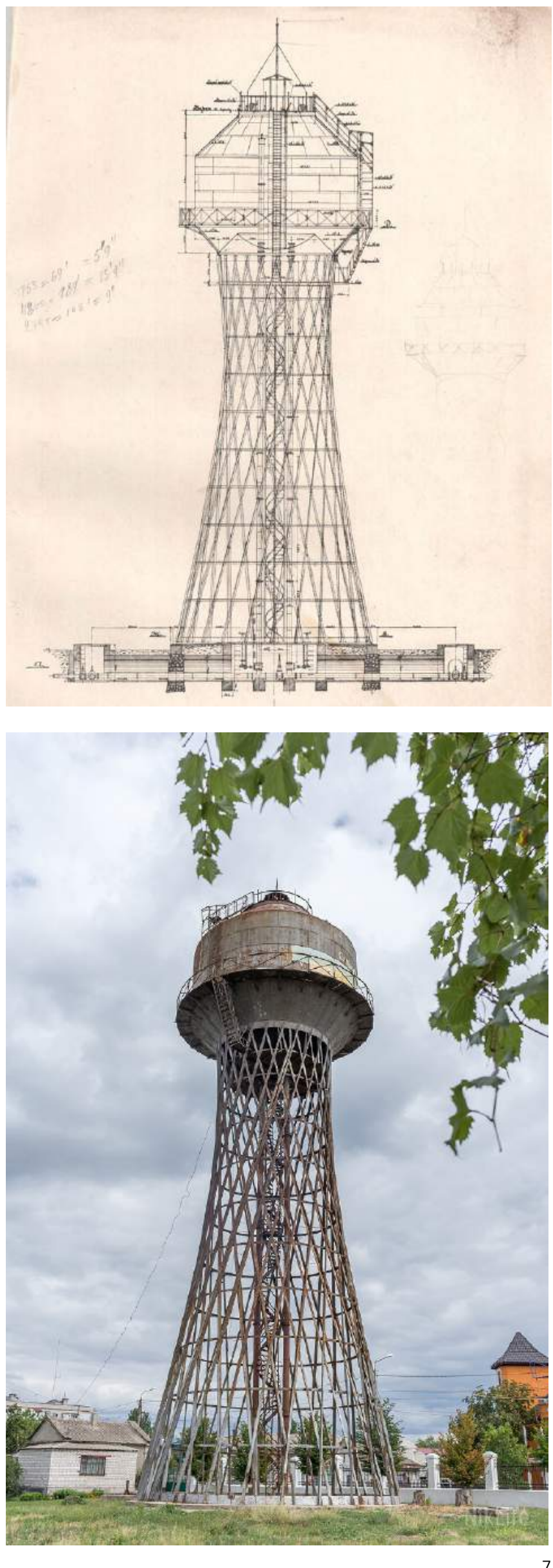
Torre de Winterhude

002 Hans Poelzig

\begin{tabular}{|c|c|}
\hline Informacões Gerais & \\
\hline Localização & Hamburgo, Alemanha \\
\hline GPS & $\mathrm{N} / \mathrm{A}$ \\
\hline Data de Início do Projeto & 1907 \\
\hline Data do Término da Obra & Não construído \\
\hline Uso da Torre & Abastecimento público urbano \\
\hline Situação Atual & N/A \\
\hline Créditos do Projeto & \\
\hline Proprietário / Contratante & \\
\hline Projeto de Arquitetura & Hans Poelzig \\
\hline Projeto Estrutural & \\
\hline Construção & $\mathrm{N} / \mathrm{A}$ \\
\hline Dados do Reservatório & \\
\hline Capacidade $\left[\mathrm{m}^{3}\right]$ & 2.000 \\
\hline Forma / Tipologia & Cilíndrico/ Fundo suspenso \\
\hline Material & Metálico \\
\hline Altura $[\mathrm{m}]$ & 6,70 \\
\hline Largura $[\mathrm{m}]$ & 23,00 \\
\hline Altura da Água - $\mathrm{h}[\mathrm{m}]$ & 6,50 \\
\hline Número de Câmaras & 1 \\
\hline Dados da Estrutura de Apoio do Reser & \\
\hline Tipologia & Paredes portantes \\
\hline Material & Alvenaria \\
\hline Altura do Fundo do Reservatório - H [m] & 36,00 \\
\hline Altura Efetiva $-\mathrm{H}+\mathrm{h}[\mathrm{m}]$ & 42,50 \\
\hline Altura Total da Torre - Ht [m] & 62,00 \\
\hline Dados do Revestimento & \\
\hline Tipo & \\
\hline Material & \\
\hline Referências Bibliográficas & \\
\hline Inserções em Bibliografia Específica & [MEVIUS, 1985] \\
\hline Inserções em Bibliografia Geral & nenhum registro encontrado \\
\hline Inserções em Periódicos & nenhum registro encontrado \\
\hline
\end{tabular}



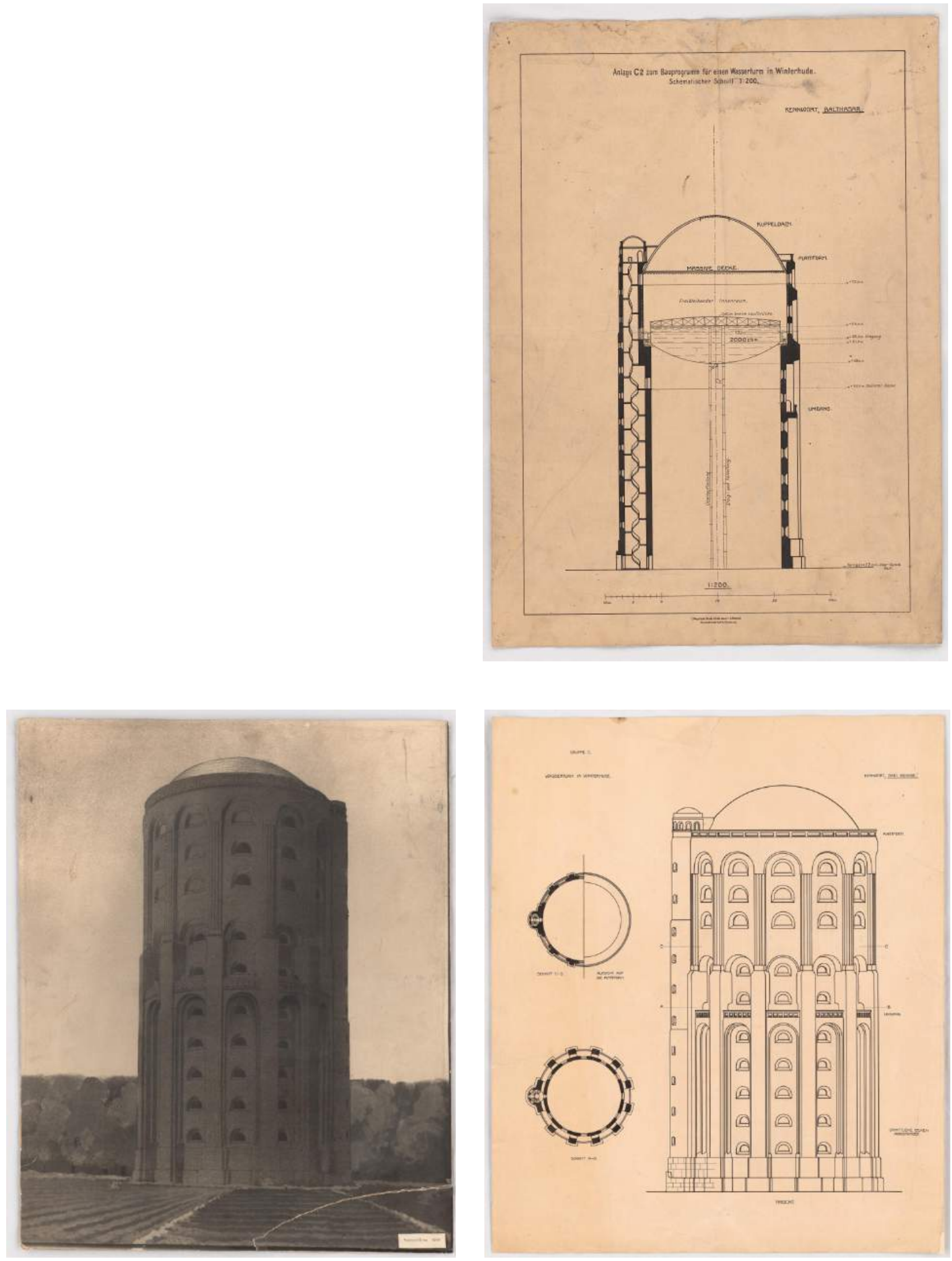
Torre em Posen

003 Hans Poelzig

\begin{tabular}{|c|c|}
\hline Informacões Gerais & \\
\hline Localização & Posen, Polônia \\
\hline GPS & \\
\hline Data de Início do Projeto & 1910 \\
\hline Data do Término da Obra & 1911 \\
\hline Uso da Torre & Abastecimento público urbano \\
\hline Situação Atual & Demolida \\
\hline Créditos do Projeto & \\
\hline Proprietário / Contratante & \\
\hline Projeto de Arquitetura & Hans Poelzig \\
\hline Projeto Estrutural & \\
\hline Construção & \\
\hline Dados do Reservatório & \\
\hline Capacidade $\left[\mathrm{m}^{3}\right]$ & 4.000 \\
\hline Forma / Tipologia & Cilíndrico / Fundo plano \\
\hline Material & Metálico \\
\hline Altura $[\mathrm{m}]$ & \\
\hline Largura [m] & \\
\hline Altura da Água - h [m] & \\
\hline Número de Câmaras & \\
\hline Dados da Estrutura de Apoio do Reser & \\
\hline Tipologia & Sistema de pilares e vigas treliçadas \\
\hline Material & Metálico \\
\hline Altura do Fundo do Reservatório - H [m] & 32,50 \\
\hline Altura Efetiva - $\mathrm{H}+\mathrm{h}[\mathrm{m}]$ & \\
\hline Altura Total da Torre - Ht [m] & 51,20 \\
\hline Dados do Revestimento & \\
\hline Tipo & Fechamento em caixilhos e alvenaria \\
\hline Material & Vidro e tijolos de barro \\
\hline Referências Bibliográficas & \\
\hline Inserções em Bibliografia Específica & [MEVIUS, 1985] \\
\hline Inserções em Bibliografia Geral & [BANHAM, 2013] \\
\hline Inserções em Periódicos & nenhum registro encontrado \\
\hline
\end{tabular}


Torre em Posen

003 Hans Poelzig
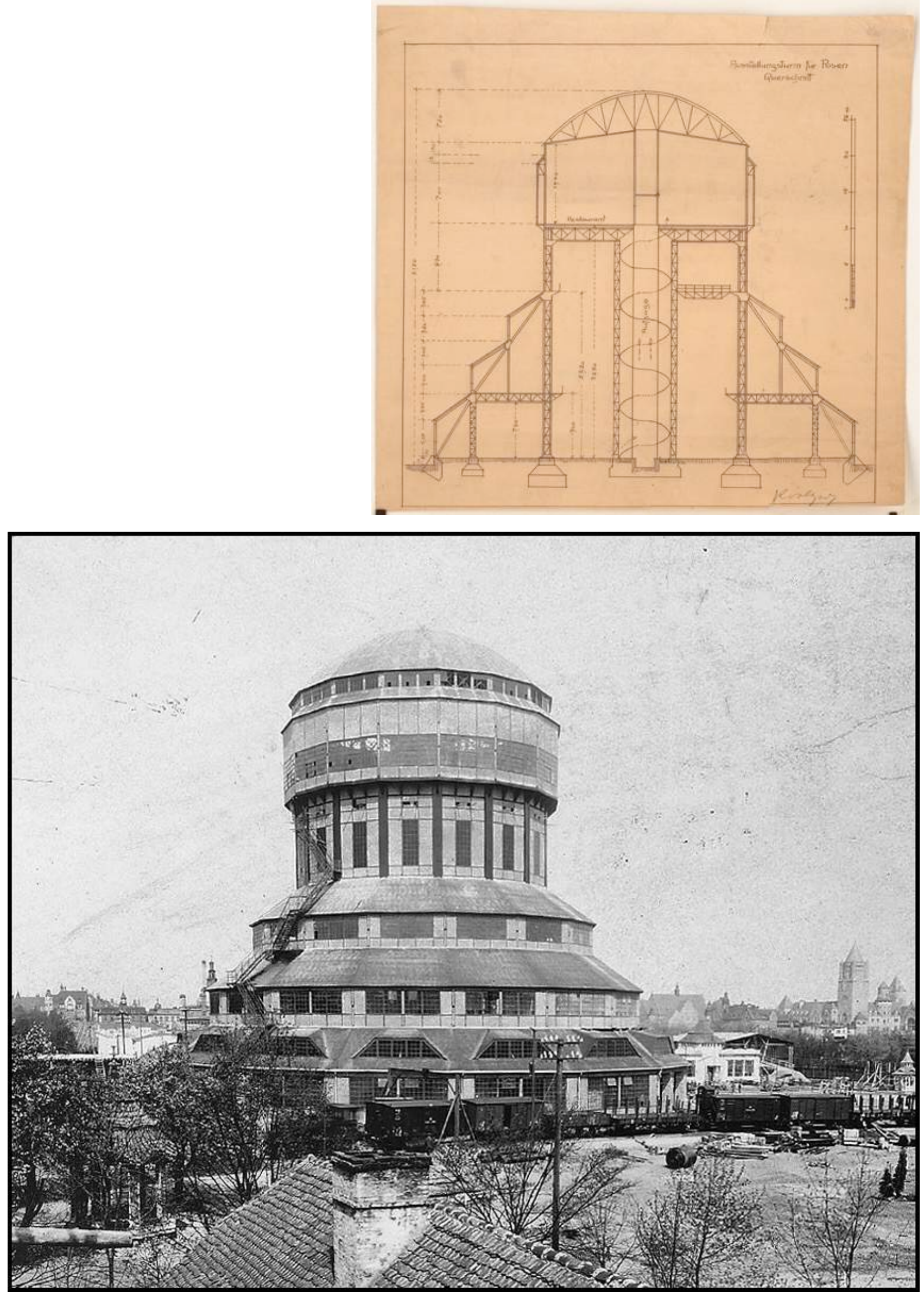
Torre em Yaroslavl

005 Vladimir Shukhov

\begin{tabular}{|c|c|}
\hline Informacões Gerais & \\
\hline Localização original & Yaroslavl, Rússia \\
\hline GPS & \\
\hline Data de Início do Projeto & \\
\hline Data do Término da Obra & 1911 \\
\hline Uso da Torre & Abastecimento de Terminal Ferroviário \\
\hline Situação Atual & Desconhecida \\
\hline Créditos do Projeto & \\
\hline Proprietário / Contratante & \\
\hline Projeto de Arquitetura & Vladimir Shukhov \\
\hline Projeto Estrutural & Vladimir Shukhov \\
\hline Construção & Alexander Bary \\
\hline Dados do Reservatório & \\
\hline Capacidade $\left[\mathrm{m}^{3}\right]$ & $194,25+116,55$ (inferior + superior) \\
\hline Forma / Tipologia & Cilíndrico/ Fundo suspenso \\
\hline Material & Metálico \\
\hline Altura $[\mathrm{m}]$ & 5,38 e 5,10 (inferior e superior) \\
\hline Diâmetro [m] & 7,47 e 5.87 (inferior e superior) \\
\hline Altura da Água - h [m] & \\
\hline Número de Câmaras & 1 \\
\hline Dados da Estrutura de Apoio do R & \\
\hline Tipologia & Estrutura treliçada hiperbólica \\
\hline Material & Aço \\
\hline Altura do Fundo do Reservatório - $\mathrm{H}$ & \\
\hline Altura Efetiva - H + h [m] & \\
\hline Altura Total da Torre - Ht [m] & \\
\hline Dados do Revestimento & \\
\hline Tipo & \\
\hline Material & \\
\hline Referências Bibliográficas & \\
\hline Inserções em Bibliografia Específica & nenhum registro encontrado \\
\hline Inserções em Bibliografia Geral & [NOZHOVA, 2016] \\
\hline & [BECKH, 2015] \\
\hline Inserções em Periódicos & nenhum registro encontrado \\
\hline
\end{tabular}


- Torre em Yaroslavl

005 Vladimir Shukhov
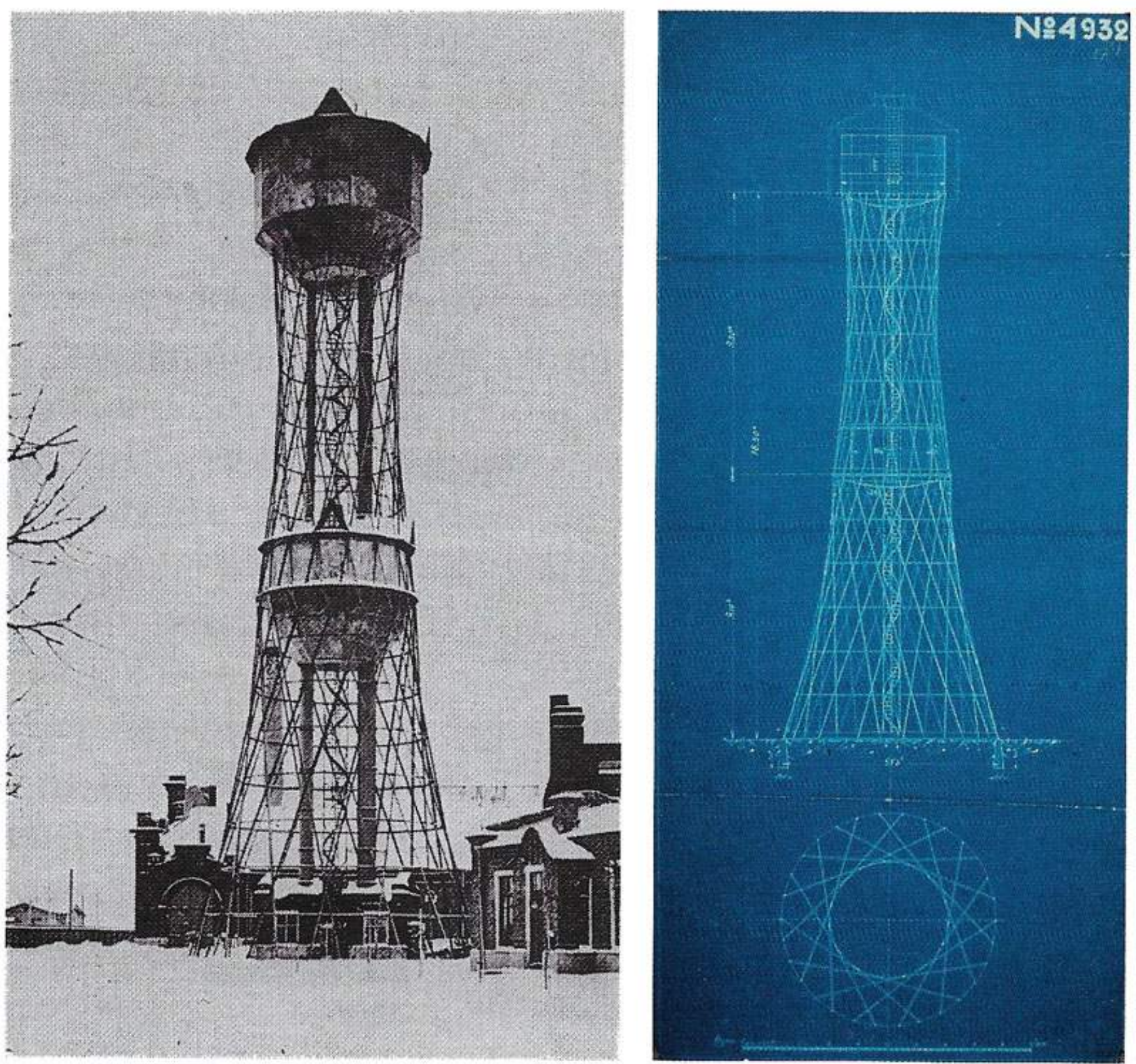
Torre da Fábrica Fagus

005 Walter Gropius e Adolf Meyer

\begin{tabular}{|c|c|}
\hline Informacões Gerais & \\
\hline Localização & Alfeld, Alemanha \\
\hline GPS & $51^{\circ} 59^{\prime} 3.43^{\prime \prime} \mathrm{N}-9^{\circ} 48^{\prime} 43.05^{\prime \prime} \mathrm{E}$ \\
\hline Data de Início do Projeto & 1911 \\
\hline Data do Término da Obra & 1916 \\
\hline Uso da Torre & Abastecimento industrial \\
\hline Situação Atual & Desconhecida \\
\hline Créditos do Projeto & \\
\hline Proprietário / Contratante & Fagus Werk \\
\hline Projeto de Arquitetura & Walter Gropius e Adolf Meyer \\
\hline Projeto Estrutural & \\
\hline Construção & \\
\hline Dados do Reservatório & \\
\hline Capacidade $\left[\mathrm{m}^{3}\right]$ & 0 \\
\hline Forma / Tipologia & Reservatório de chaminé \\
\hline Material & Alvenaria \\
\hline Altura $[\mathrm{m}]$ & \\
\hline Diâmetro [m] & \\
\hline Altura da Água - h [m] & \\
\hline Número de Câmaras & \\
\hline Dados da Estrutura de Apoio do Re & \\
\hline Tipologia & Chaminé de exaustão \\
\hline Material & Alvenaria \\
\hline Altura do Fundo do Reservatório - $\mathrm{H}$ & \\
\hline Altura Efetiva - $\mathrm{H}+\mathrm{h}[\mathrm{m}]$ & \\
\hline Altura Total da Torre - Ht [m] & \\
\hline Dados do Revestimento & \\
\hline Tipo & \\
\hline Material & \\
\hline Referências Bibliográficas & \\
\hline Inserções em Bibliografia Específica & [MEVIUS, 1985] \\
\hline Inserções em Bibliografia Geral & nenhum registro encontrado \\
\hline Inserções em Periódicos & nenhum registro encontrado \\
\hline
\end{tabular}




\section{Torre da Fábrica Fagus}

005 Walter Gropius e Adolf Meyer
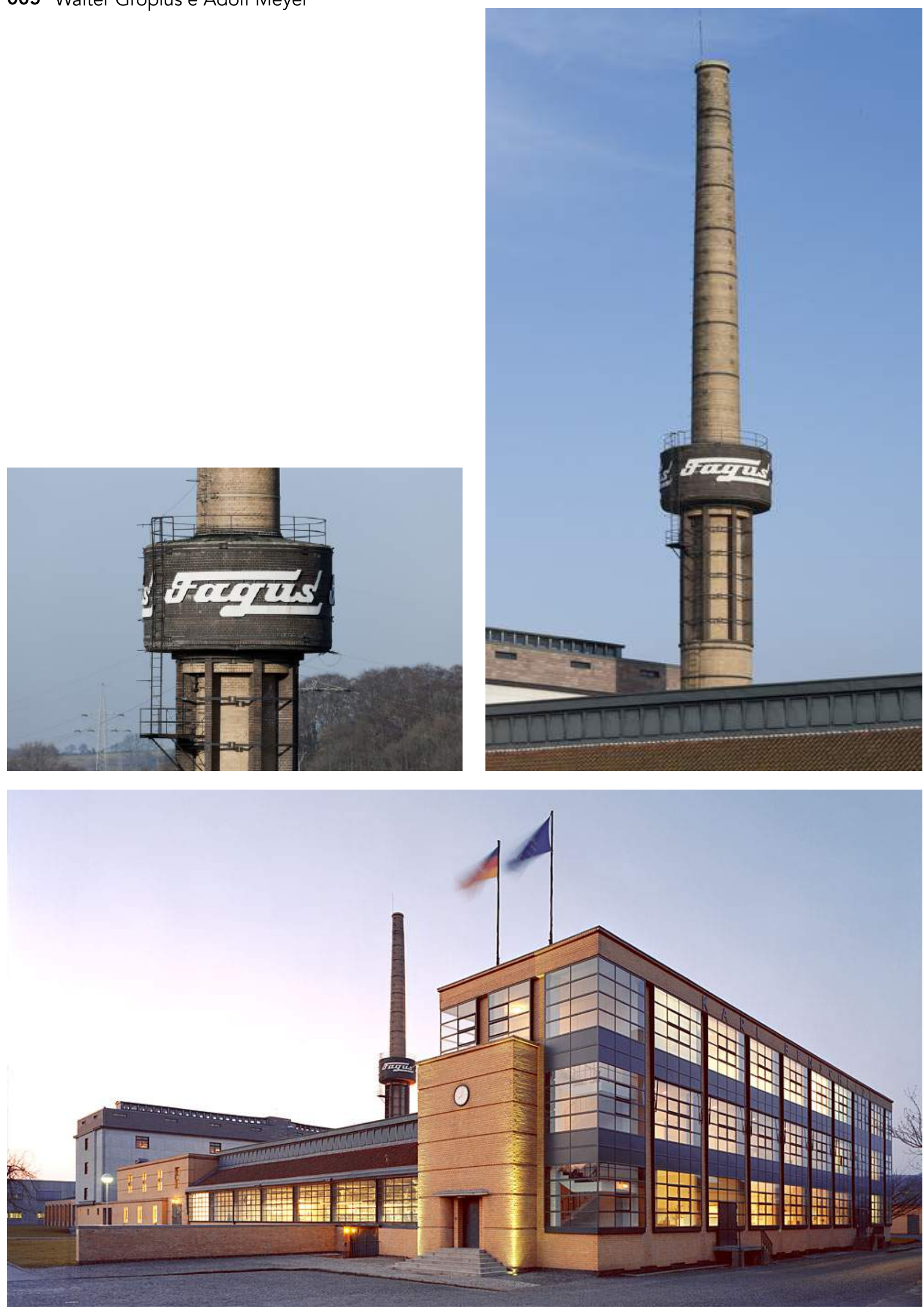
Torre em Pondesac

006 Le Corbusier

\begin{tabular}{|c|c|}
\hline \multicolumn{2}{|l|}{ Informacões Gerais } \\
\hline Localização & Pondesac, Aquitânia, França \\
\hline GPS & $44^{\circ} 39^{\prime} 18.06^{\prime \prime} \mathrm{N}-0^{\circ} 21^{\prime} 35.93 " \mathrm{~W}$ \\
\hline Data de Início do Projeto & 1917 \\
\hline Data do Término da Obra & 1918 \\
\hline Uso da Torre & Abastecimento de propriedade rural \\
\hline Situação Atual & Desativada \\
\hline \multicolumn{2}{|l|}{ Créditos do Projeto } \\
\hline Proprietário / Contratante & François Thévenot \\
\hline Projeto de Arquitetura & Le Corbusier \\
\hline \multicolumn{2}{|l|}{ Projeto Estrutural } \\
\hline Construção & Société d'Application du Béton Armé (SABA) \\
\hline \multicolumn{2}{|l|}{ Dados do Reservatório } \\
\hline Capacidade $\left[\mathrm{m}^{3}\right]$ & 80 \\
\hline Forma / Tipologia & Cilíndrico / Fundo em cúpula \\
\hline Material & Concreto armado \\
\hline \multicolumn{2}{|l|}{ Altura [m] } \\
\hline Diâmetro máximo [m] & 0 \\
\hline \multicolumn{2}{|l|}{ Altura da Água - h [m] } \\
\hline Número de Câmaras & 1 \\
\hline \multicolumn{2}{|c|}{ Dados da Estrutura de Apoio do Reservatório } \\
\hline \multicolumn{2}{|l|}{ Tipologia } \\
\hline Material & Concreto armado \\
\hline \multicolumn{2}{|l|}{ Altura do Fundo do Reservatório - H [m] } \\
\hline \multicolumn{2}{|l|}{ Altura Efetiva $-\mathrm{H}+\mathrm{h}[\mathrm{m}]$} \\
\hline Altura Total da Torre - Ht [m] & 25,00 \\
\hline \multicolumn{2}{|l|}{ Dados do Revestimento } \\
\hline \multicolumn{2}{|l|}{ Tipo } \\
\hline \multicolumn{2}{|l|}{ Material } \\
\hline \multicolumn{2}{|l|}{ Referências Bibliográficas } \\
\hline Inserções em Bibliografia Específica & nenhum registro encontrado \\
\hline \multirow[t]{2}{*}{ Inserções em Bibliografia Geral } & [GIACINTO, 2007] \\
\hline & [BROOKS, 1997] \\
\hline Inserções em Periódicos & nenhum registro encontrado \\
\hline
\end{tabular}




\section{Torre em Pondesac}

006 Le Corbusier
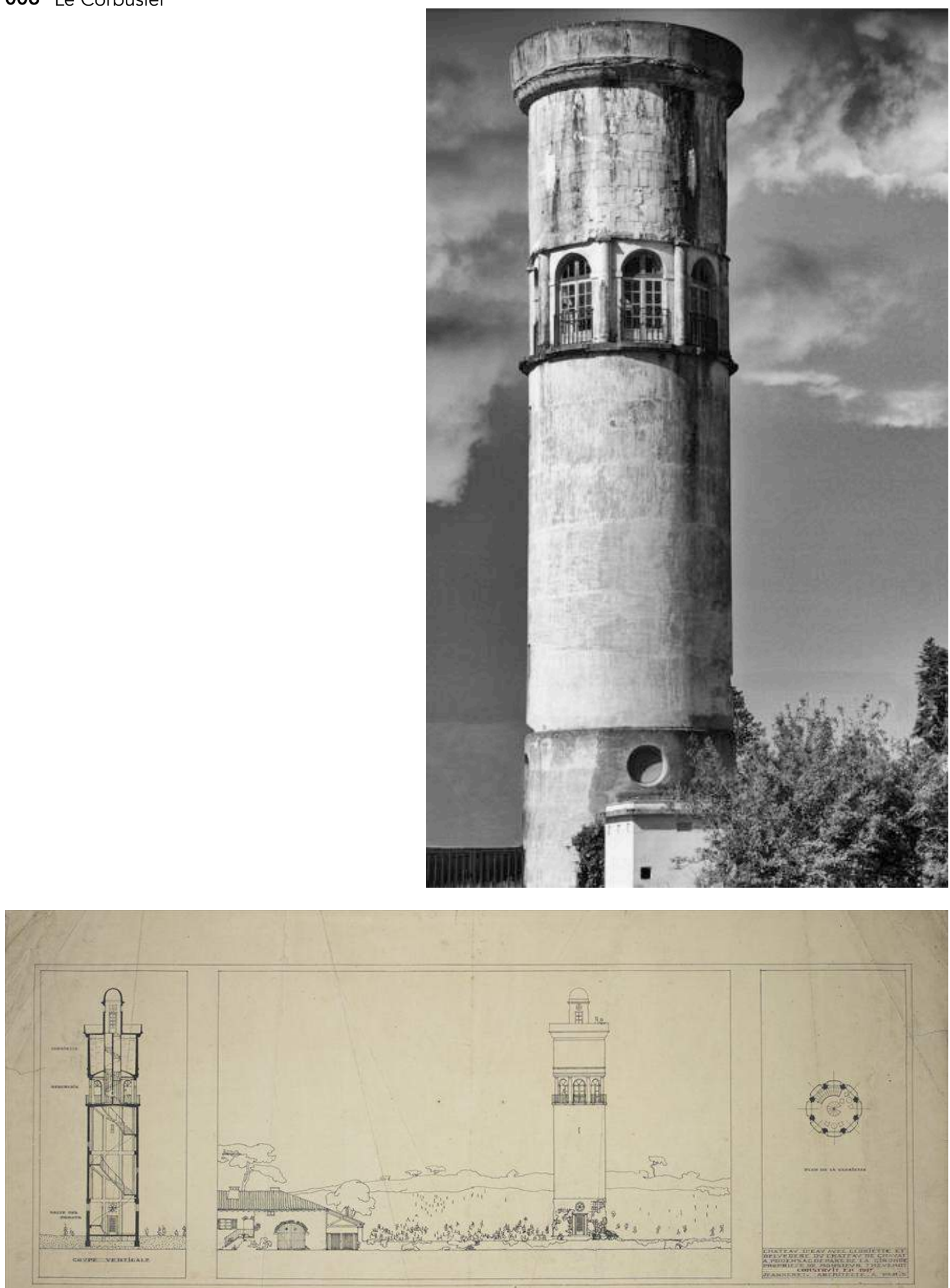
Torre em Breda

007 Sybold van Ravesteyn

\begin{tabular}{|c|c|}
\hline Informacões Gerais & \\
\hline Localização & Breda, Holanda \\
\hline GPS & $51^{\circ} 35^{\prime} 42.77^{\prime \prime} \mathrm{N}-4^{\circ} 47^{\prime} 0.62^{\prime \prime} \mathrm{E}$ \\
\hline Data de Início do Projeto & 1926 \\
\hline Data do Término da Obra & 1927 \\
\hline Uso da Torre & Abastecimento de terminal ferroviário \\
\hline Situação Atual & Demolida \\
\hline Créditos do Projeto & \\
\hline Proprietário / Contratante & \\
\hline Projeto de Arquitetura & Sybold van Ravesteyn \\
\hline Projeto Estrutural & \\
\hline Construção & \\
\hline Dados do Reservatório & \\
\hline Capacidade $\left[\mathrm{m}^{3}\right]$ & 300 \\
\hline Forma / Tipologia & Cilíndrico / Fundo plano \\
\hline Material & Concreto armado \\
\hline Altura $[\mathrm{m}]$ & \\
\hline Diâmetro máximo [m] & 0 \\
\hline Altura da Água - h [m] & \\
\hline Número de Câmaras & 1 \\
\hline Dados da Estrutura de Apoio do R & \\
\hline Tipologia & Sistema de pilares e vigas \\
\hline Material & Concreto armado \\
\hline Altura do Fundo do Reservatório - $\mathrm{H}$ & \\
\hline Altura Efetiva $-\mathrm{H}+\mathrm{h}[\mathrm{m}]$ & \\
\hline Altura Total da Torre - Ht [m] & 31,50 \\
\hline Dados do Revestimento & \\
\hline Tipo & \\
\hline Material & \\
\hline Referências Bibliográficas & \\
\hline Inserções em Bibliografia Específica & [VEEN, 1989] \\
\hline Inserções em Bibliografia Geral & [BERLAGE，1932] \\
\hline Inserções em Periódicos & nenhum registro encontrado \\
\hline
\end{tabular}


- Torre em Breda

007 Sybold van Ravesteyn
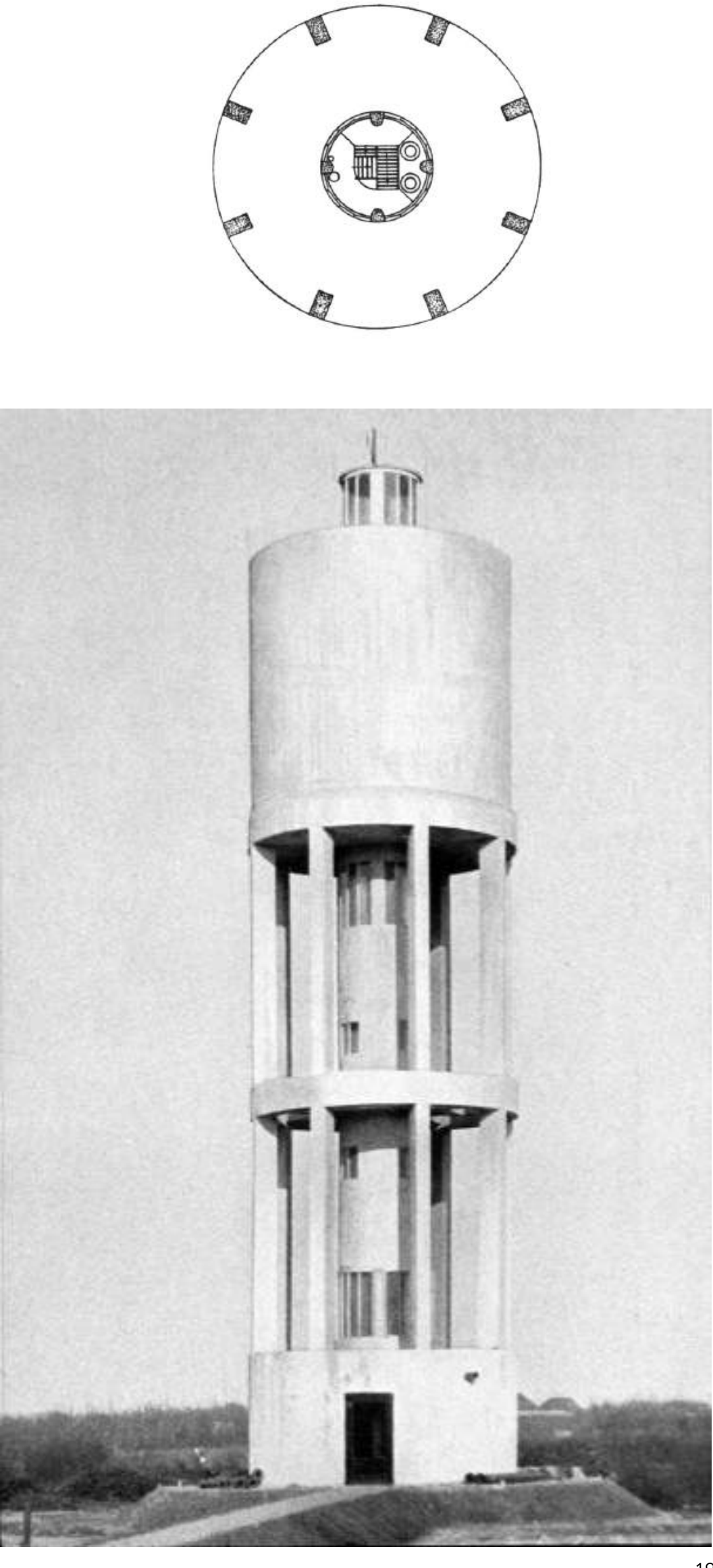


\section{Torre em Wassenaar}

008 Mart Stam

\begin{tabular}{|c|c|}
\hline Informacões Gerais & \\
\hline Localização & Wassenaar, Holanda \\
\hline GPS & $\mathrm{N} / \mathrm{A}$ \\
\hline Data de Início do Projeto & 1927 \\
\hline Data do Término da Obra & Não construído \\
\hline Uso da Torre & Abastecimento público urbano \\
\hline Situação Atual & N/A \\
\hline Créditos do Projeto & \\
\hline Proprietário / Contratante & \\
\hline Projeto de Arquitetura & Mart Stam \\
\hline Projeto Estrutural & \\
\hline Construção & $\mathrm{N} / \mathrm{A}$ \\
\hline Dados do Reservatório & \\
\hline Capacidade $\left[\mathrm{m}^{3}\right]$ & 450 \\
\hline Forma / Tipologia & Cilíndrico / Fundo em cúpula \\
\hline Material & Concreto armado \\
\hline Altura $[\mathrm{m}]$ & 7,00 \\
\hline Diâmetro máximo $[\mathrm{m}]$ & 10,00 \\
\hline Altura da Água - $\mathrm{h}[\mathrm{m}]$ & 6,20 \\
\hline Número de Câmaras & 1 \\
\hline Dados da Estrutura de Apoio do Reser & \\
\hline Tipologia & Sistema de pilares e vigas \\
\hline Material & Concreto armado \\
\hline Altura do Fundo do Reservatório - H [m] & 38,00 \\
\hline Altura Efetiva $-\mathrm{H}+\mathrm{h}[\mathrm{m}]$ & 44,20 \\
\hline Altura Total da Torre - Ht [m] & 47,70 \\
\hline Dados do Revestimento & \\
\hline Tipo & \\
\hline Material & \\
\hline Referências Bibliográficas & \\
\hline Inserções em Bibliografia Específica & [VEEN, 1989] \\
\hline Inserções em Bibliografia Geral & nenhum registro encontrado \\
\hline Inserções em Periódicos & nenhum registro encontrado \\
\hline
\end{tabular}



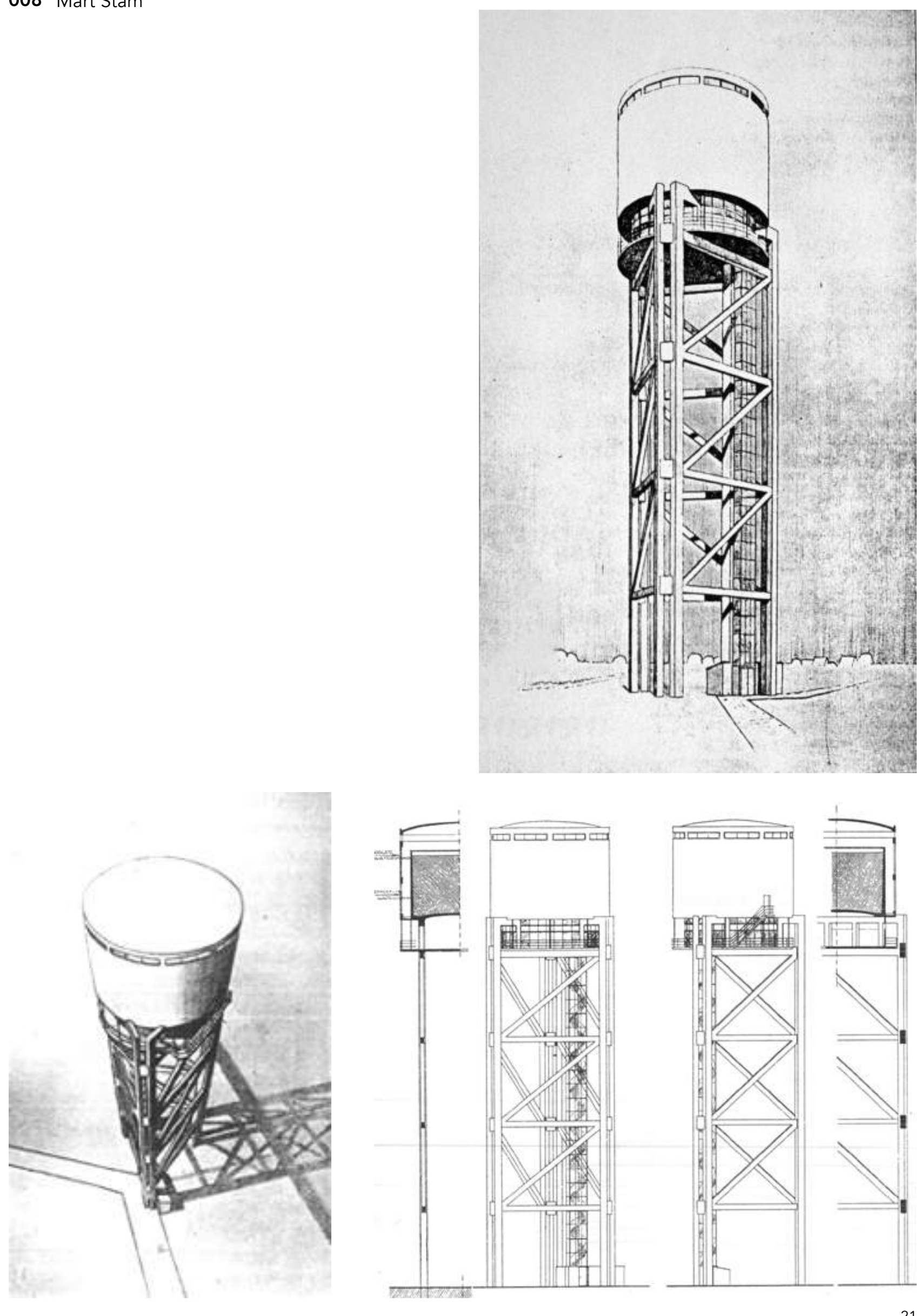
Torre em Pelotas

009 Escritório Saturnino de Brito

\begin{tabular}{ll}
\hline Informacões Gerais & \\
\hline Localização & Pelotas, Rio Grande do Sul \\
GPS & $31^{\circ} 45^{\prime} 9.93^{\prime \prime} \mathrm{S}-52^{\circ} 20^{\prime} 7.81^{\prime \prime W}$ \\
Data de Início do Projeto & 1927 \\
Data do Término da Obra & 1951 \\
Uso da Torre & Abastecimento público urbano \\
Situação Atual & Operacional \\
\hline
\end{tabular}

\section{Créditos do Projeto}

Proprietário / Contratante

Projeto de Arquitetura

Escritório Saturnino de Brito

Projeto Estrutural

Construção

\section{Dados do Reservatório}

Capacidade $\left[\mathrm{m}^{3}\right]$

2.000

Forma / Tipologia

Cilíndrico / Fundo plano

Material

Concreto armado

Altura [m]

Diâmetro máximo $[\mathrm{m}]$

Altura da Água - $h$ [m]

Número de Câmaras

\section{Dados da Estrutura de Apoio do Reservatório}

\begin{tabular}{ll}
\hline Tipologia & Sistema de pilares e vigas \\
Material & Concreto armado
\end{tabular}

Altura do Fundo do Reservatório - H [m]

Altura Efetiva - $\mathrm{H}+\mathrm{h}[\mathrm{m}]$

Altura Total da Torre - Ht [m] 0,00

\section{Dados do Revestimento}

Tipo

Material

Referências Bibliográficas

Inserções em Bibliografia Específica

nenhum registro encontrado

Inserções em Bibliografia Geral

nenhum registro encontrado

Inserções em Periódicos

[Revista D.A.E., São Paulo, v. 24, n. 51, dez. 1963] 
Torre em Pelotas

009 Escritório Saturnino de Brito

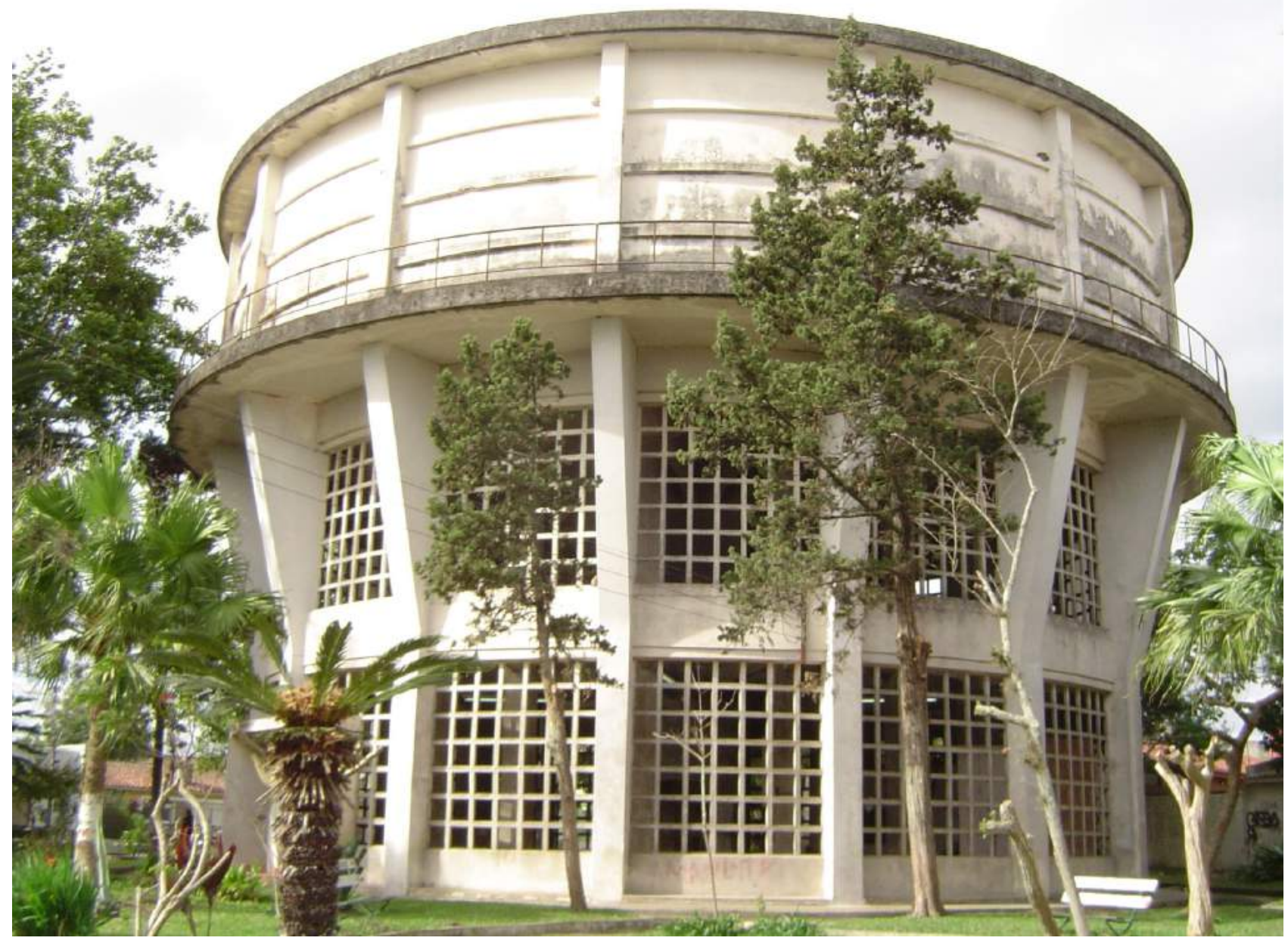


Torre em Aalsmeer

010 Hendrik Sangster

\begin{tabular}{|c|c|}
\hline Informacões Gerais & \\
\hline Localização & Aalsmeer, Holanda \\
\hline GPS & $52^{\circ} 15^{\prime} 17.69^{\prime \prime} \mathrm{N}-4^{\circ} 45^{\prime} 26.59^{\prime \prime} \mathrm{E}$ \\
\hline Data de Início do Projeto & 1927 \\
\hline Data do Término da Obra & 1928 \\
\hline Uso da Torre & Abastecimento público urbano \\
\hline Situação Atual & Desativada \\
\hline Créditos do Projeto & \\
\hline Proprietário / Contratante & PWN - Waterleidingbedrijf van Noord-Holland \\
\hline Projeto de Arquitetura & Hendrik Sangster \\
\hline Projeto Estrutural & \\
\hline Construção & \\
\hline Dados do Reservatório & \\
\hline Capacidade $\left[\mathrm{m}^{3}\right]$ & 1.160 \\
\hline Forma / Tipologia & Cilíndrico / Fundo plano \\
\hline Material & Concreto armado \\
\hline Altura $[\mathrm{m}]$ & \\
\hline Diâmetro máximo [m] & 0 \\
\hline Altura da Água - h [m] & \\
\hline Número de Câmaras & $3[1 \times 160 \mathrm{~m} 3,1 \times 480 \mathrm{~m} 3$ e $1 \times 520 \mathrm{~m} 3]$ \\
\hline Dados da Estrutura de Apoio do R & \\
\hline Tipologia & Sistema de pilares e vigas \\
\hline Material & Concreto armado \\
\hline Altura do Fundo do Reservatório - $\mathrm{H}$ & \\
\hline Altura Efetiva - $\mathrm{H}+\mathrm{h}[\mathrm{m}]$ & \\
\hline Altura Total da Torre - Ht [m] & 50,00 \\
\hline Dados do Revestimento & \\
\hline Tipo & Alvenaria \\
\hline Material & Tijolos de barro \\
\hline Referências Bibliográficas & \\
\hline Inserções em Bibliografia Específica & [VEEN, 1989] \\
\hline Inserções em Bibliografia Geral & [SANGSTER, 2013] \\
\hline Inserções em Periódicos & nenhum registro encontrado \\
\hline
\end{tabular}




\section{Torre em Aalsmeer}

010 Hendrik Sangster
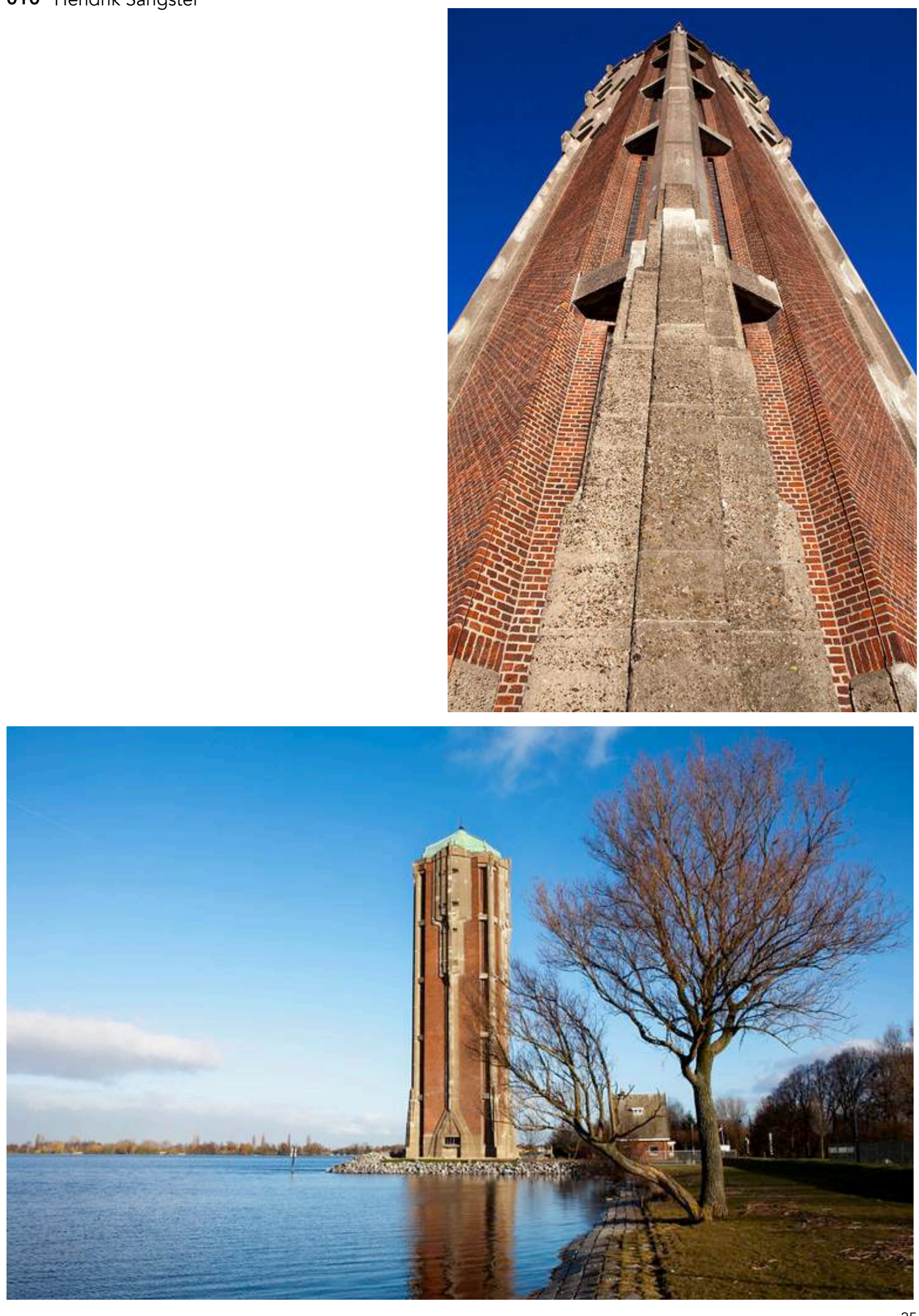
Torre do Araçá

011 [Hyppolito Gustavo Pujol Jr.] ?

\begin{tabular}{|c|c|}
\hline \multicolumn{2}{|l|}{ Informacões Gerais } \\
\hline Localização & São Paulo, São Paulo, Brasil \\
\hline GPS & $23^{\circ} 32^{\prime} 38.75^{\prime \prime} \mathrm{S}-46^{\circ} 40^{\prime} 55.08^{\prime \prime} \mathrm{W}$ \\
\hline Data de Início do Projeto & 1928 \\
\hline Data do Término da Obra & 1930 \\
\hline Uso da Torre & Abastecimento público urbano \\
\hline Situação Atual & Operacional \\
\hline \multicolumn{2}{|l|}{ Créditos do Projeto } \\
\hline Proprietário / Contratante & RAE - Repartição de Águas e Esgotos \\
\hline Projeto de Arquitetura & [Hyppolito Gustavo Pujol Jr.] ? \\
\hline Projeto Estrutural & [Escritório Técnico Pujol Jr.] ? \\
\hline \multicolumn{2}{|l|}{ Construção } \\
\hline \multicolumn{2}{|l|}{ Dados do Reservatório } \\
\hline Capacidade $\left[\mathrm{m}^{3}\right]$ & 300 \\
\hline Forma / Tipologia & Cilíndrico tipo Intze I \\
\hline Material & Concreto armado \\
\hline \multicolumn{2}{|l|}{ Altura $[\mathrm{m}]$} \\
\hline Diâmetro máximo [m] & 0 \\
\hline \multicolumn{2}{|l|}{ Altura da Água - h [m] } \\
\hline Número de Câmaras & 1 \\
\hline \multicolumn{2}{|c|}{ Dados da Estrutura de Apoio do Reservatório } \\
\hline Tipologia & Sistema de pilares e vigas \\
\hline Material & Concreto armado \\
\hline \multicolumn{2}{|l|}{ Altura do Fundo do Reservatório - H [m] } \\
\hline \multicolumn{2}{|l|}{ Altura Efetiva - $\mathrm{H}+\mathrm{h}[\mathrm{m}]$} \\
\hline Altura Total da Torre - Ht [m] & 0,00 \\
\hline \multicolumn{2}{|l|}{ Dados do Revestimento } \\
\hline \multicolumn{2}{|l|}{ Tipo } \\
\hline \multicolumn{2}{|l|}{ Material } \\
\hline \multicolumn{2}{|l|}{ Referências Bibliográficas } \\
\hline Inserções em Bibliografia Específica & nenhum registro encontrado \\
\hline Inserções em Bibliografia Geral & nenhum registro encontrado \\
\hline \multirow[t]{3}{*}{ Inserções em Periódicos } & [Revista D.A.E., São Paulo, v. 21, n. 38, set. 1960] \\
\hline & [Revista D.A.E., São Paulo, v. 8, n. 17, nov. 1946] \\
\hline & [Revista D.A.E., São Paulo, v. 4, n. 9, mar. 1940] \\
\hline
\end{tabular}




\section{Torre do Araçá}

011 [Hyppolito Gustavo Pujol Jr.] ?

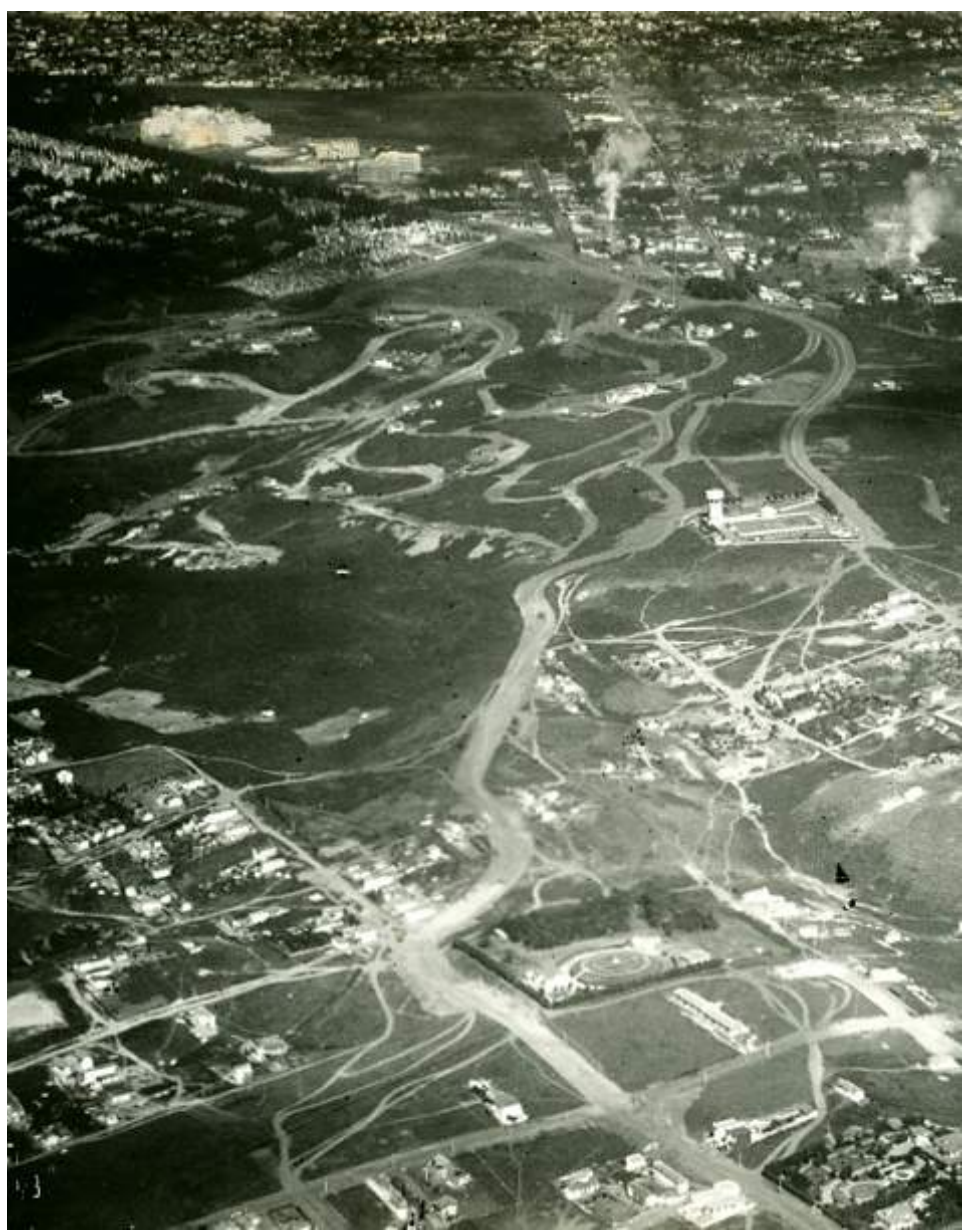

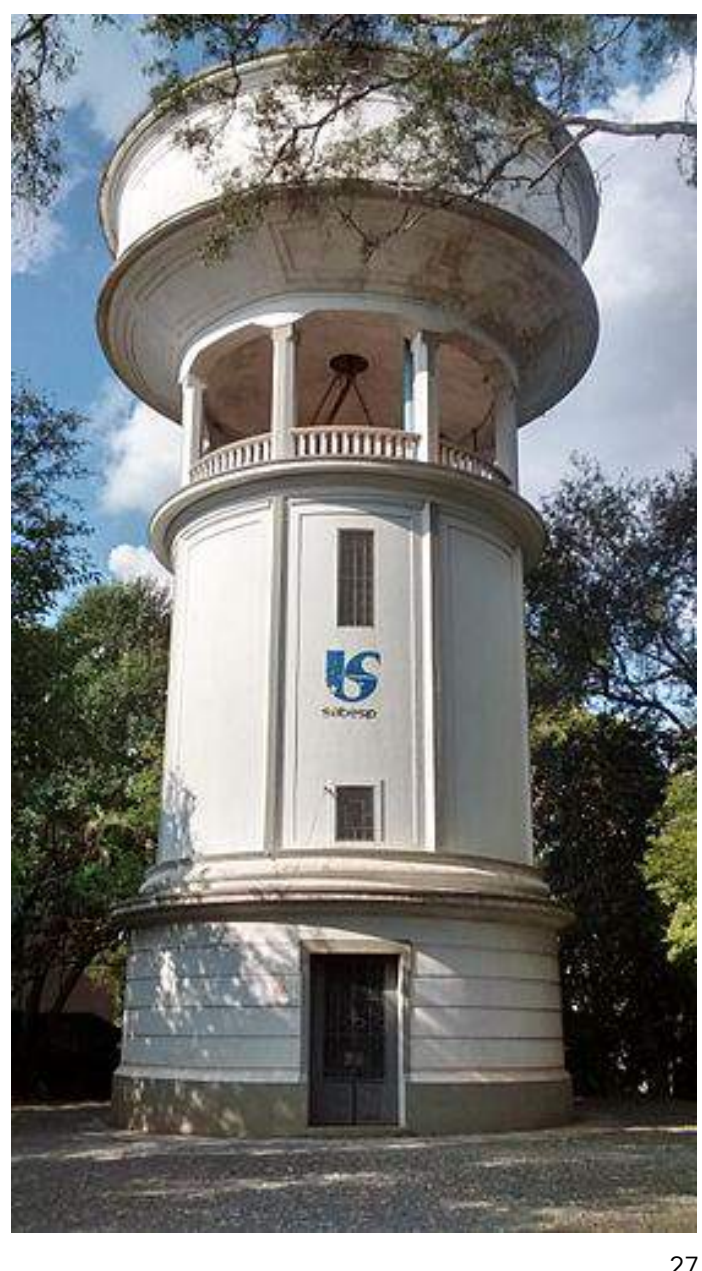


Torre em Domburg

012 Hendrik Sangster

\begin{tabular}{|c|c|}
\hline Informacões Gerais & \\
\hline Localização & Domburg, Holanda \\
\hline GPS & $51^{\circ} 34^{\prime} 0.45^{\prime \prime} \mathrm{N}-3^{\circ} 30^{\prime} 3.33^{\prime \prime} \mathrm{E}$ \\
\hline Data de Início do Projeto & \\
\hline Data do Término da Obra & 1933 \\
\hline Uso da Torre & Abastecimento público urbano \\
\hline Situação Atual & Desativada \\
\hline Créditos do Projeto & \\
\hline Proprietário / Contratante & \\
\hline Projeto de Arquitetura & Hendrik Sangster \\
\hline Projeto Estrutural & \\
\hline Construção & C. van Prooyen \\
\hline Dados do Reservatório & \\
\hline Capacidade $\left[\mathrm{m}^{3}\right]$ & 200 \\
\hline Forma / Tipologia & Cilíndrico / Fundo plano \\
\hline Material & Concreto armado \\
\hline Altura $[\mathrm{m}]$ & \\
\hline Diâmetro máximo [m] & 7,10 \\
\hline Altura da Água - h [m] & \\
\hline Número de Câmaras & 1 \\
\hline Dados da Estrutura de Apoio do Re & \\
\hline Tipologia & Sistema de pilares e vigas \\
\hline Material & Concreto armado \\
\hline Altura do Fundo do Reservatório - $\mathrm{H}$ & \\
\hline Altura Efetiva $-\mathrm{H}+\mathrm{h}[\mathrm{m}]$ & 23,10 \\
\hline Altura Total da Torre - Ht [m] & 28,50 \\
\hline Dados do Revestimento & \\
\hline Tipo & \\
\hline Material & \\
\hline Referências Bibliográficas & \\
\hline Inserções em Bibliografia Específica & [VEEN, 1989] \\
\hline Inserções em Bibliografia Geral & [SANGSTER, 2013] \\
\hline Inserções em Periódicos & nenhum registro encontrado \\
\hline
\end{tabular}


Torre em Domburg

012 Hendrik Sangster

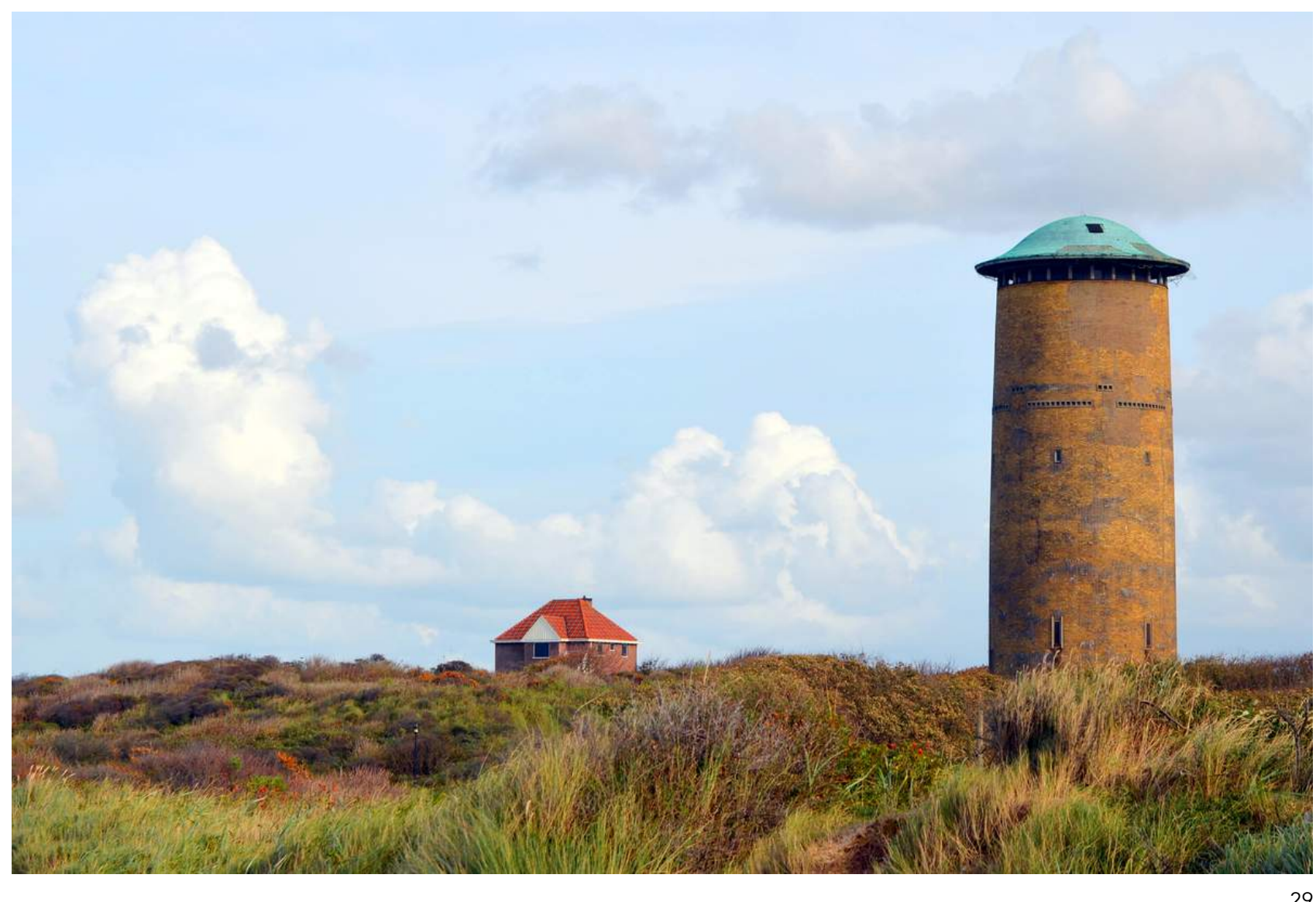


Torre do Sanatório de Paimio

013 Alvar Aalto

\begin{tabular}{|c|c|}
\hline Informacões Gerais & \\
\hline Localização & Paimio, Finlândia \\
\hline GPS & $60^{\circ} 27^{\prime} 54.73^{\prime \prime} \mathrm{N}-22^{\circ} 44^{\prime} 6.41^{\prime \prime} \mathrm{E}$ \\
\hline Data de Início do Projeto & 1929 \\
\hline Data do Término da Obra & 1933 \\
\hline Uso da Torre & Abastecimento de instalação hospitalar \\
\hline Situação Atual & Desconhecida \\
\hline Créditos do Projeto & \\
\hline Proprietário / Contratante & \\
\hline Projeto de Arquitetura & Alvar Aalto \\
\hline Projeto Estrutural & \\
\hline Construção & \\
\hline Dados do Reservatório & \\
\hline Capacidade $\left[\mathrm{m}^{3}\right]$ & 0 \\
\hline Forma / Tipologia & Reservatório de chaminé \\
\hline Material & Concreto armado \\
\hline Altura $[\mathrm{m}]$ & \\
\hline Diâmetro máximo [m] & 0 \\
\hline Altura da Água - h [m] & \\
\hline Número de Câmaras & 1 \\
\hline Dados da Estrutura de Apoio do R & \\
\hline Tipologia & Chaminé de exaustão \\
\hline Material & Alvenaria \\
\hline Altura do Fundo do Reservatório - $\mathrm{H}$ & \\
\hline Altura Efetiva - $\mathrm{H}+\mathrm{h}[\mathrm{m}]$ & \\
\hline Altura Total da Torre - Ht [m] & 0,00 \\
\hline Dados do Revestimento & \\
\hline Tipo & \\
\hline Material & \\
\hline Referências Bibliográficas & \\
\hline Inserções em Bibliografia Específica & nenhum registro encontrado \\
\hline Inserções em Bibliografia Geral & [WESTON, 1995] \\
\hline & [FLEIG, 1994] \\
\hline Inserções em Periódicos & nenhum registro encontrado \\
\hline
\end{tabular}


Torre do Sanatório de Paimio

013 Alvar Aalto
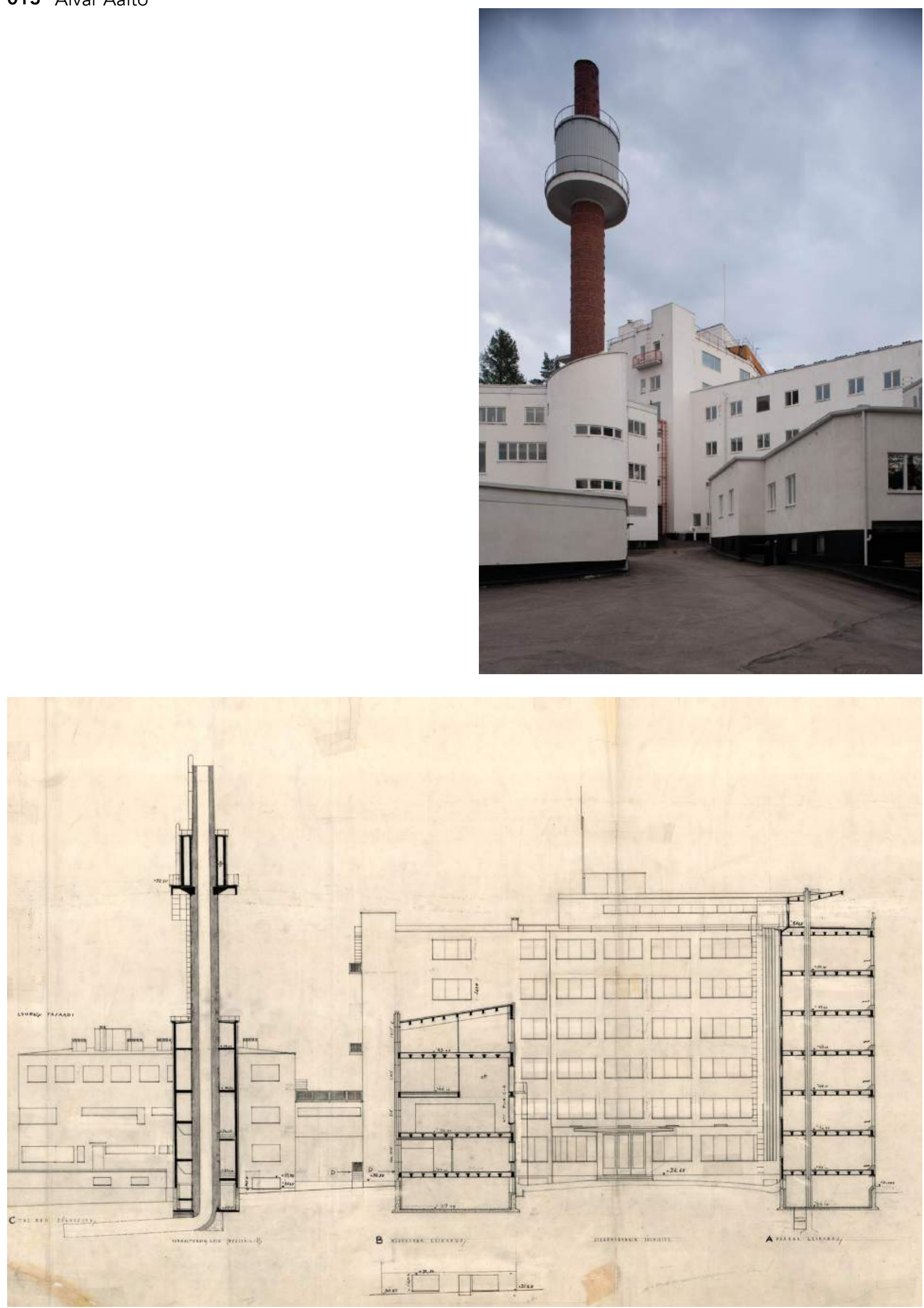
Torre de Água do Alto da Sé

014 Luiz Nunes

\begin{tabular}{|c|c|}
\hline \multicolumn{2}{|l|}{ Informacões Gerais } \\
\hline Localização & Olinda, Pernambuco, Brasil \\
\hline GPS & $8^{\circ} 0^{\prime} 48.48^{\prime \prime} \mathrm{S}-34^{\circ} 50^{\prime} 59.88^{\prime \prime} \mathrm{W}$ \\
\hline Data de Início do Projeto & 1934 \\
\hline Data do Término da Obra & 1937 \\
\hline Uso da Torre & Abastecimento público urbano \\
\hline Situação Atual & Desativada \\
\hline \multicolumn{2}{|l|}{ Créditos do Projeto } \\
\hline Proprietário / Contratante & COMPESA - Companhia Pernambucana de Saneamento \\
\hline Projeto de Arquitetura & Luiz Nunes \\
\hline \multicolumn{2}{|l|}{ Projeto Estrutural } \\
\hline \multicolumn{2}{|l|}{ Construção } \\
\hline \multicolumn{2}{|l|}{ Dados do Reservatório } \\
\hline Capacidade $\left[\mathrm{m}^{3}\right]$ & 0 \\
\hline Forma / Tipologia & Retangular / Fundo Plano \\
\hline Material & Concreto armado \\
\hline \multicolumn{2}{|l|}{ Altura $[\mathrm{m}]$} \\
\hline Largura $[\mathrm{m}]$ & 0 \\
\hline \multicolumn{2}{|l|}{ Altura da Água - h [m] } \\
\hline Número de Câmaras & 1 \\
\hline \multicolumn{2}{|c|}{ Dados da Estrutura de Apoio do Reservatório } \\
\hline Tipologia & Sistema de pilares e vigas \\
\hline Material & Concreto armado \\
\hline \multicolumn{2}{|l|}{ Altura do Fundo do Reservatório - H [m] } \\
\hline \multicolumn{2}{|l|}{ Altura Efetiva - H + h [m] } \\
\hline Altura Total da Torre - Ht [m] & 20,00 \\
\hline \multicolumn{2}{|l|}{ Dados do Revestimento } \\
\hline Tipo & Cobogós \\
\hline Material & Concreto \\
\hline \multicolumn{2}{|l|}{ Referências Bibliográficas } \\
\hline Inserções em Bibliografia Específica & nenhum registro encontrado \\
\hline \multirow[t]{4}{*}{ Inserções em Bibliografia Geral } & [SEGAWA, 2010] \\
\hline & [BRUAND, 2002] \\
\hline & {$[V A Z, 1988]$} \\
\hline & [GOODWIN, 1943] \\
\hline Inserções em Periódicos & [Revista D.A.E., São Paulo, v. 28, n. 70, dez. 1968] \\
\hline
\end{tabular}




\section{Torre de Água do Alto da Sé}

014 Luiz Nunes
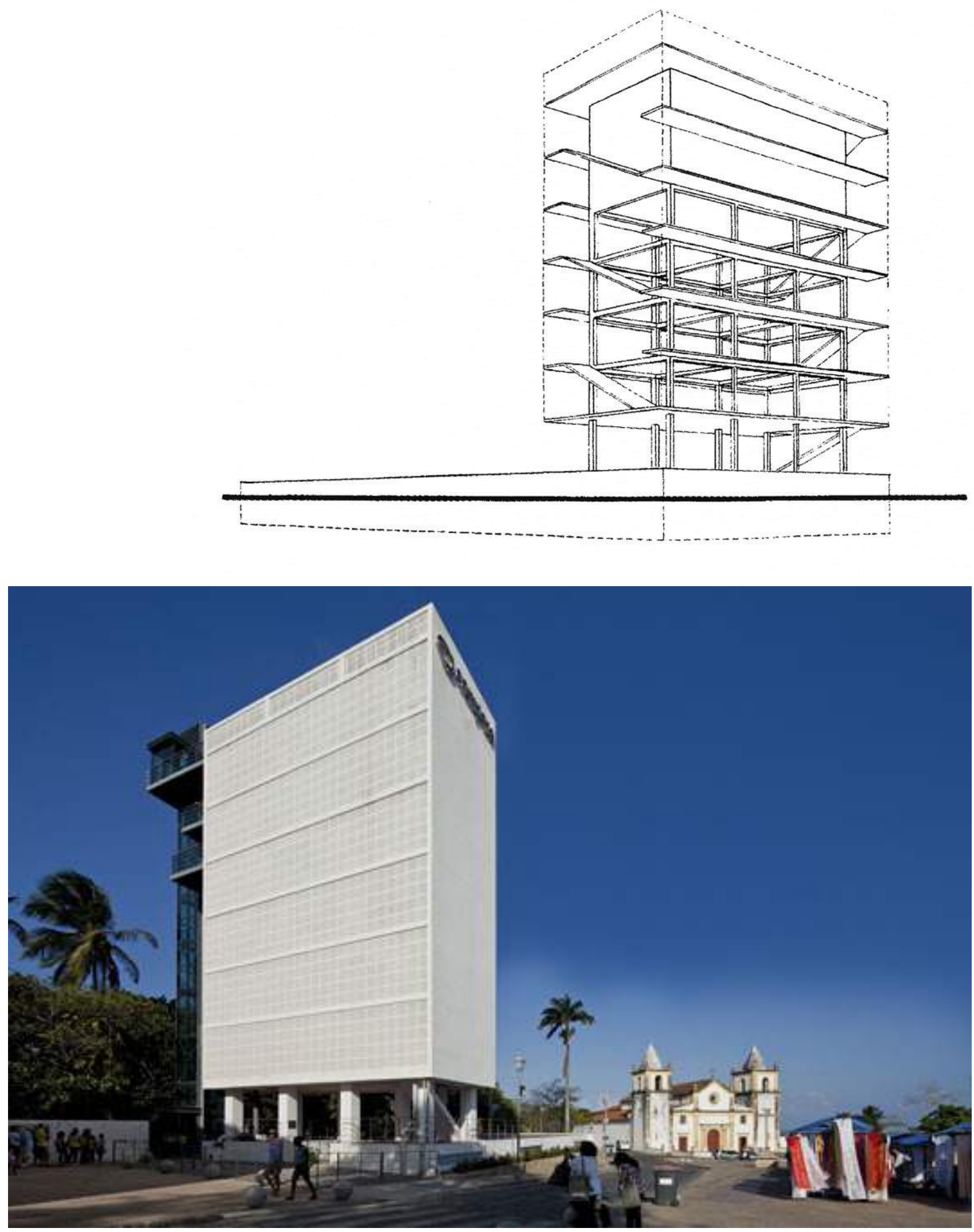
Torre de Ribeirão das Lajes

015 Oscar Niemeyer

\begin{tabular}{|c|c|}
\hline Informacões Gerais & \\
\hline Localização & Rio de Janeiro, Rio de Janeiro, Brasil \\
\hline GPS & $\mathrm{N} / \mathrm{A}$ \\
\hline Data de Início do Projeto & 1939 \\
\hline Data do Término da Obra & Não construído \\
\hline Uso da Torre & Abastecimento público urbano \\
\hline Situação Atual & $\mathrm{N} / \mathrm{A}$ \\
\hline \multicolumn{2}{|l|}{ Créditos do Projeto } \\
\hline Proprietário / Contratante & Inspetoria de Águas e Esgotos \\
\hline Projeto de Arquitetura & Oscar Niemeyer \\
\hline \multicolumn{2}{|l|}{ Projeto Estrutural } \\
\hline Construção & $\mathrm{N} / \mathrm{A}$ \\
\hline \multicolumn{2}{|l|}{ Dados do Reservatório } \\
\hline Capacidade $\left[\mathrm{m}^{3}\right]$ & 820 \\
\hline Forma / Tipologia & Standpipe \\
\hline Material & Concreto armado \\
\hline Altura $[\mathrm{m}]$ & 42,00 \\
\hline Diâmetro máximo [m] & 11,00 \\
\hline Altura da Água - h [m] & 26,50 \\
\hline Número de Câmaras & 1 \\
\hline \multicolumn{2}{|c|}{ Dados da Estrutura de Apoio do Reservatório } \\
\hline Tipologia & N/A \\
\hline Material & N/A \\
\hline Altura do Fundo do Reservatório - H [m] & $\mathrm{N} / \mathrm{A}$ \\
\hline Altura Efetiva - H + h [m] & 26,50 \\
\hline Altura Total da Torre - Ht [m] & 41,00 \\
\hline \multicolumn{2}{|l|}{ Dados do Revestimento } \\
\hline \multicolumn{2}{|l|}{ Tipo } \\
\hline \multicolumn{2}{|l|}{ Material } \\
\hline \multicolumn{2}{|l|}{ Referências Bibliográficas } \\
\hline Inserções em Bibliografia Específica & nenhum registro encontrado \\
\hline Inserções em Bibliografia Geral & [BOTEY, 2008] \\
\hline Inserções em Periódicos & [Revista Municipal de Engenharia, Rio de Janeiro, v. 6, n. 5, set. 1939] \\
\hline
\end{tabular}


Torre de Ribeirão das Lajes

015 Oscar Niemeyer
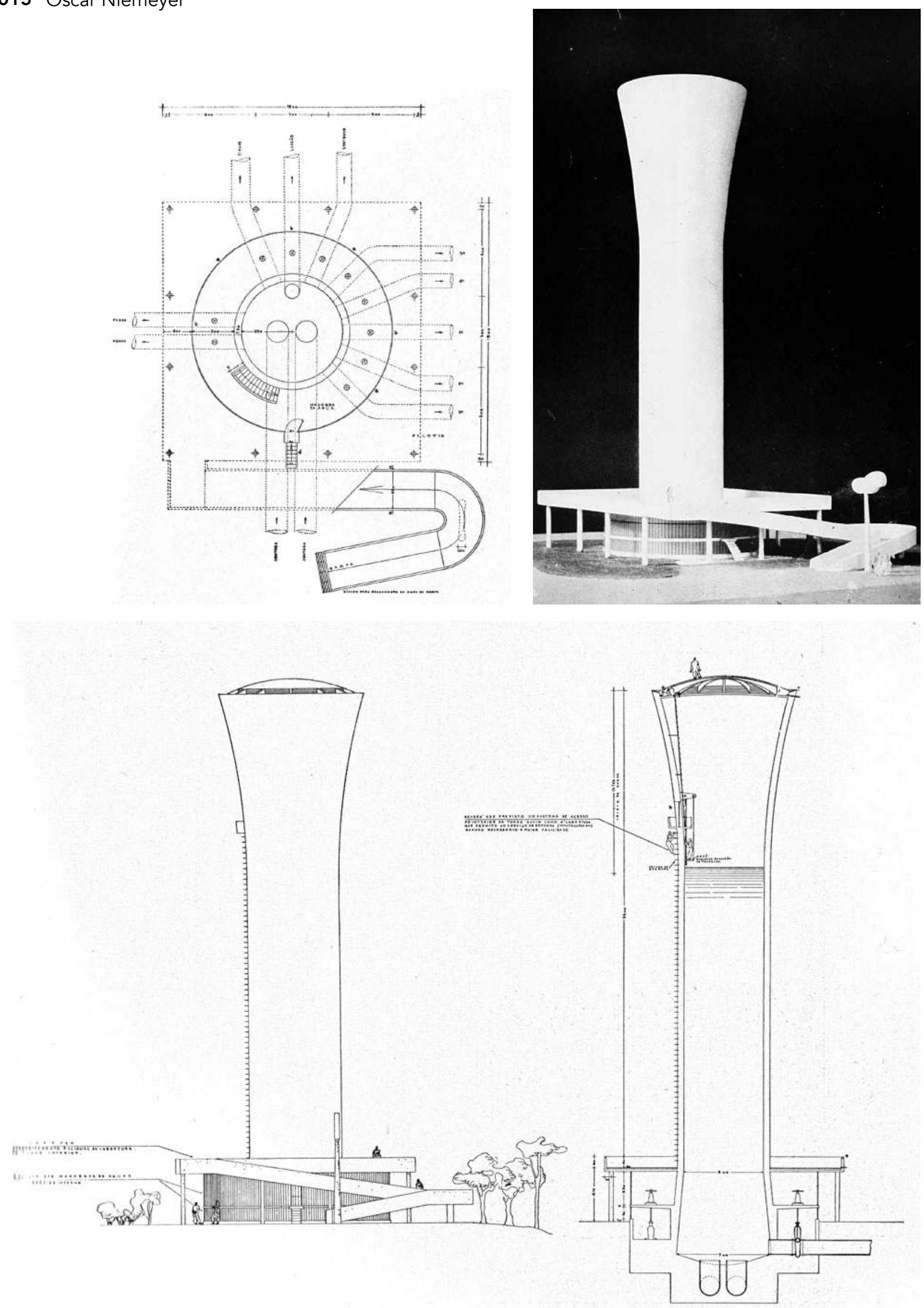


\section{Torre de Svaneke}

016 Jørn Utzon

\begin{tabular}{|c|c|}
\hline Informacões Gerais & \\
\hline Localização & Svaneke, Bornholm, Dinamarca \\
\hline GPS & $55^{\circ} 8^{\prime} 20.52 " \mathrm{~N}-15^{\circ} 8^{\prime} 0.50 " \mathrm{E}$ \\
\hline Data de Início do Projeto & 1951 \\
\hline Data do Término da Obra & 1952 \\
\hline Uso da Torre & Abastecimento público urbano \\
\hline Situação Atual & Desativada \\
\hline Créditos do Projeto & \\
\hline Proprietário / Contratante & Svaneke Vandværk \\
\hline Projeto de Arquitetura & Jørn Utzon \\
\hline Projeto Estrutural & Preben C. Wistisen e Jørn Klindt-Jensen \\
\hline Construção & V. Jensen Overgaard \\
\hline Dados do Reservatório & \\
\hline Capacidade $\left[\mathrm{m}^{3}\right]$ & 120 \\
\hline Forma / Tipologia & Formato especial \\
\hline Material & Concreto armado \\
\hline Altura $[\mathrm{m}]$ & 6,38 \\
\hline Largura $[\mathrm{m}]$ & 8,95 \\
\hline Altura da Água - h [m] & \\
\hline Número de Câmaras & 1 \\
\hline Dados da Estrutura de Apoio do Reser & \\
\hline Tipologia & Pilares oblíquos \\
\hline Material & Concreto armado \\
\hline Altura do Fundo do Reservatório - H [m] & 13,75 \\
\hline Altura Efetiva - $\mathrm{H}+\mathrm{h}[\mathrm{m}]$ & \\
\hline Altura Total da Torre - Ht [m] & 28,85 \\
\hline Dados do Revestimento & \\
\hline Tipo & \\
\hline Material & Madeira \\
\hline Referências Bibliográficas & \\
\hline Inserções em Bibliografia Específica & nenhum registro encontrado \\
\hline Inserções em Bibliografia Geral & [BYFORENINGEN SVANEKES VENNER, 2017] \\
\hline & [JENSEN, 2016] \\
\hline & [WESTON, 2008] \\
\hline & [FORÉS, 2006] \\
\hline & [NIETO, 1999] \\
\hline & [FRAMPTON, 1995] \\
\hline Inserções em Periódicos & nenhum registro encontrado \\
\hline
\end{tabular}


Torre de Svaneke

016 Jørn Utzon

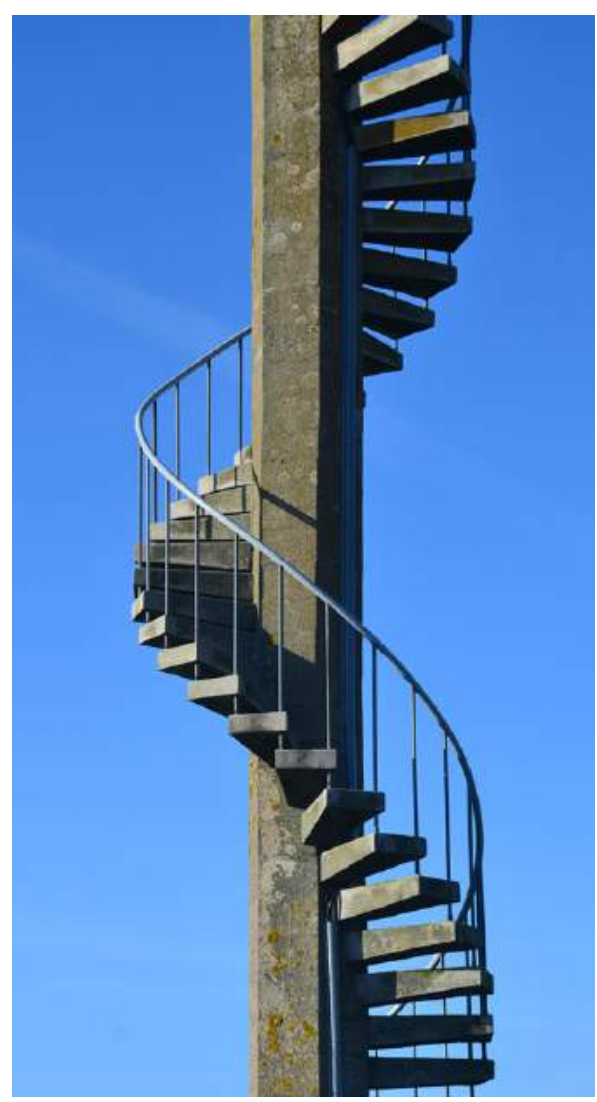

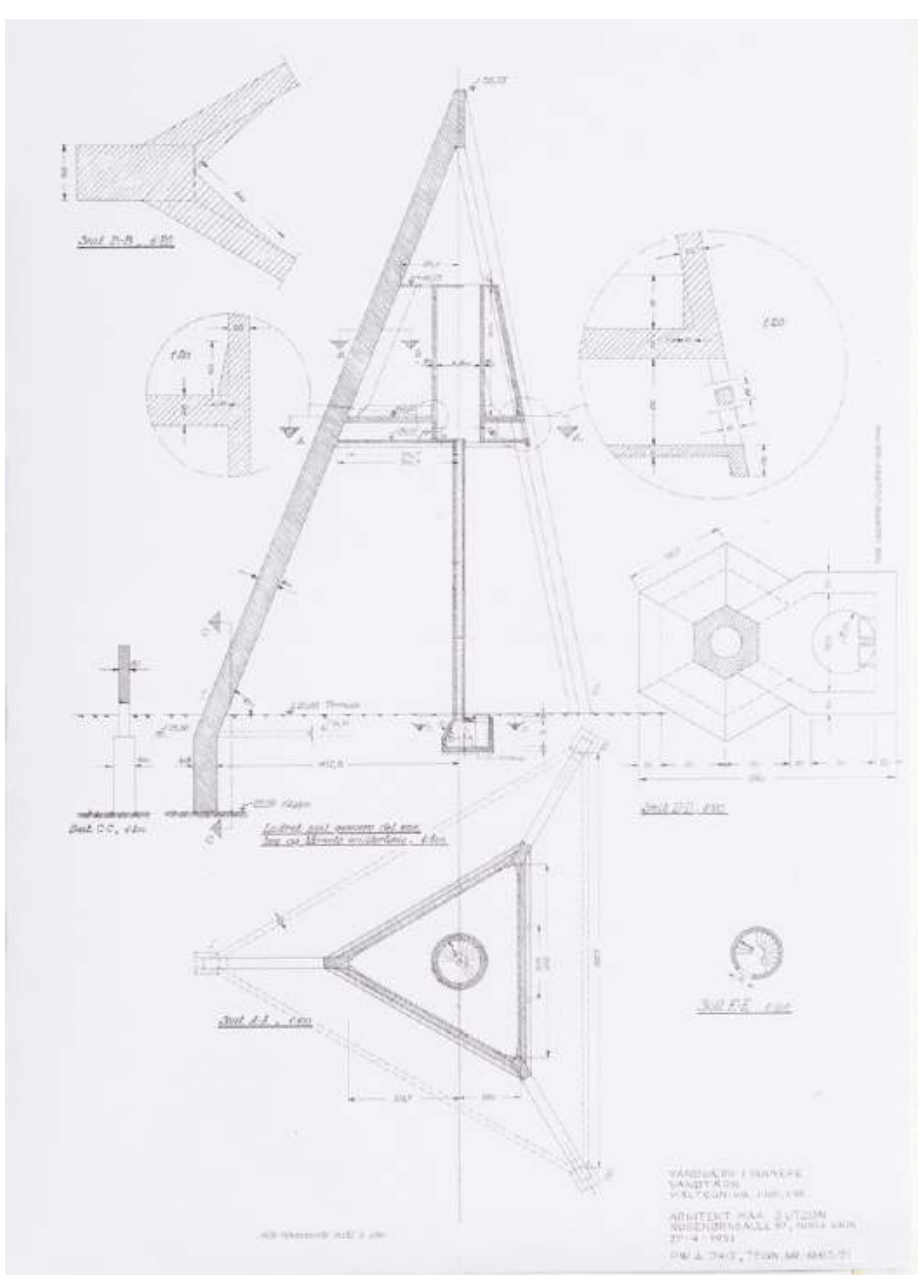

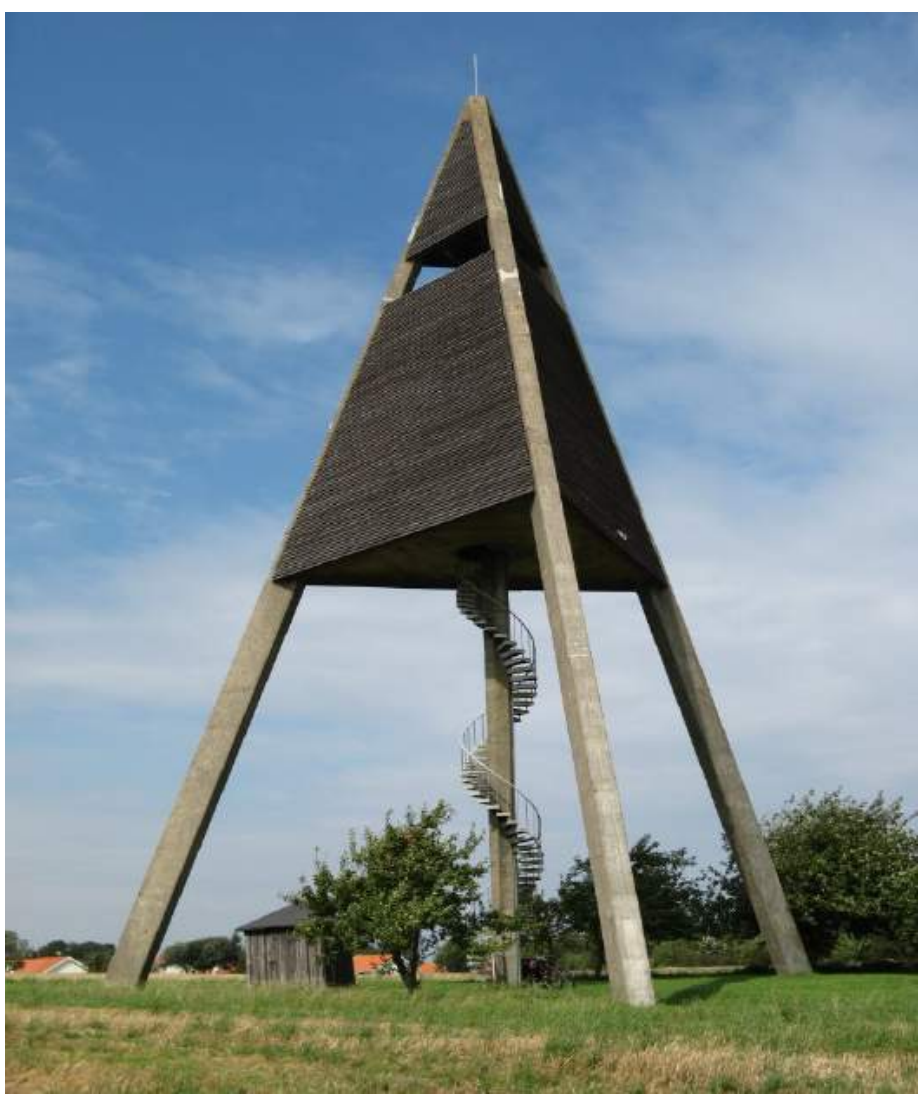


Torre do CEA - Saclay

017 Auguste Perret

\begin{tabular}{ll}
\hline Informacões Gerais & \\
\hline Localização & Saclay, Île-de-France, França \\
GPS & $48^{\circ} 43^{\prime} 32.93^{\prime \prime} \mathrm{N}-2^{\circ} 9^{\prime} 8.56$ "E \\
Data de Início do Projeto & 1948 \\
Data do Término da Obra & 1953 \\
Uso da Torre & Abastecimento de centro de pesquisas \\
Situação Atual & Desconhecida \\
\hline Créditos do Projeto & \\
\hline Proprietário / Contratante & CEA - Commissariat à l'Énergie Atomique et aux Énergies Alternatives \\
Projeto de Arquitetura & Auguste Perret \\
Projeto Estrutural & \\
Construção & \\
\hline Dados do Reservatório & \\
\hline Capacidade [m ${ }^{3}$ ] & 0 \\
Forma / Tipologia & Troncônico / Fundo em cúpula \\
Material & Concreto armado \\
Altura [m] & \\
Largura [m] & \\
Altura da Água - h [m] & \\
Número de Câmaras &
\end{tabular}

\section{Dados da Estrutura de Apoio do Reservatório}

Tipologia

Material

Concreto armado

Altura do Fundo do Reservatório - $\mathrm{H}$ [m]

Altura Efetiva - $\mathrm{H}+\mathrm{h}[\mathrm{m}]$

Altura Total da Torre - Ht [m]

0

\section{Dados do Revestimento}

Tipo

Material

Referências Bibliográficas

Inserções em Bibliografia Específica

nenhum registro encontrado

Inserções em Bibliografia Geral

nenhum registro encontrado

Inserções em Periódicos

[Casabella: Milano, n. 229, jul. 1959] 
Torre do CEA - Saclay

017 Auguste Perret
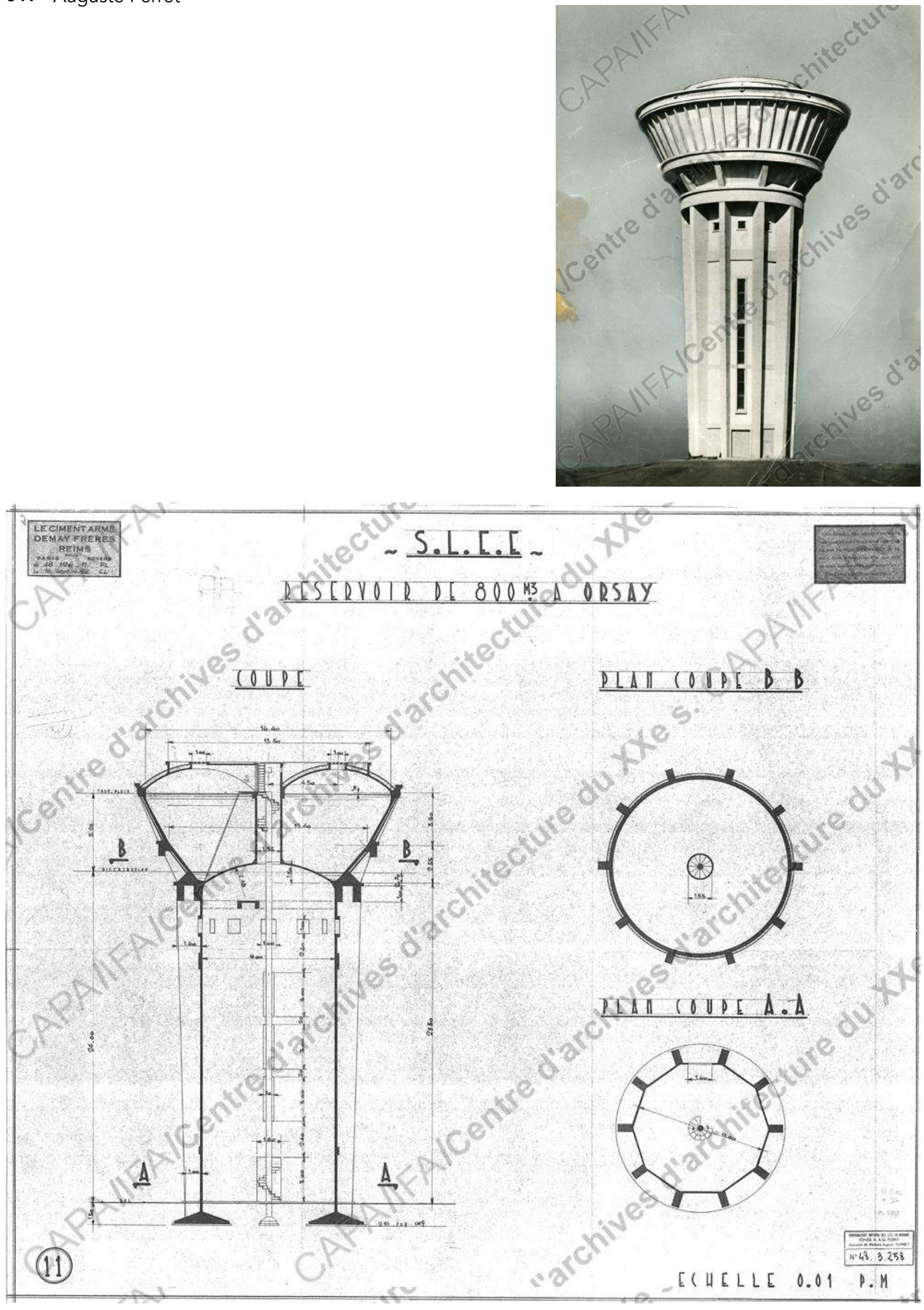
Torre do Centro Técnico da GM

018 Eero Saarinen

\begin{tabular}{|c|c|}
\hline Informacões Gerais & \\
\hline Localização & Warren, Michigan, EUA \\
\hline GPS & $42^{\circ} 30^{\prime} 52.28^{\prime \prime} \mathrm{N}-83^{\circ} 2^{\prime} 29.45^{\prime \prime} \mathrm{W}$ \\
\hline Data de Início do Projeto & 1949 \\
\hline Data do Término da Obra & 1955 \\
\hline Uso da Torre & Abastecimento industrial \\
\hline Situação Atual & Operacional \\
\hline Créditos do Projeto & \\
\hline Proprietário / Contratante & General Motors Corporation \\
\hline Projeto de Arquitetura & Eero Saarinen \\
\hline Projeto Estrutural & Smith, Hinchman \& Grylls \\
\hline Construção & Bryant \& Detwiler \\
\hline Dados do Reservatório & \\
\hline Capacidade $\left[\mathrm{m}^{3}\right]$ & 0 \\
\hline Forma / Tipologia & Esferóide \\
\hline Material & Metálico [aço inox] \\
\hline Altura $[\mathrm{m}]$ & \\
\hline Diâmetro [m] & \\
\hline Altura da Água - h [m] & \\
\hline Número de Câmaras & \\
\hline Dados da Estrutura de Apoio do Re & \\
\hline Tipologia & 3 fustes cilíndricos ôcos \\
\hline Material & Metálico [aço inox] \\
\hline Altura do Fundo do Reservatório - $\mathrm{H}$ & \\
\hline Altura Efetiva $-\mathrm{H}+\mathrm{h}[\mathrm{m}]$ & \\
\hline Altura Total da Torre - Ht [m] & 40,23 \\
\hline Dados do Revestimento & \\
\hline Tipo & \\
\hline Material & \\
\hline Referências Bibliográficas & \\
\hline Inserções em Bibliografia Específica & nenhum registro encontrado \\
\hline Inserções em Bibliografia Geral & [TATUM, 2014] \\
\hline Inserções em Periódicos & [Architectural Forum, New York, v. 101, n. 5, nov. 1954] \\
\hline
\end{tabular}


Torre do Centro Técnico da GM

018 Eero Saarinen
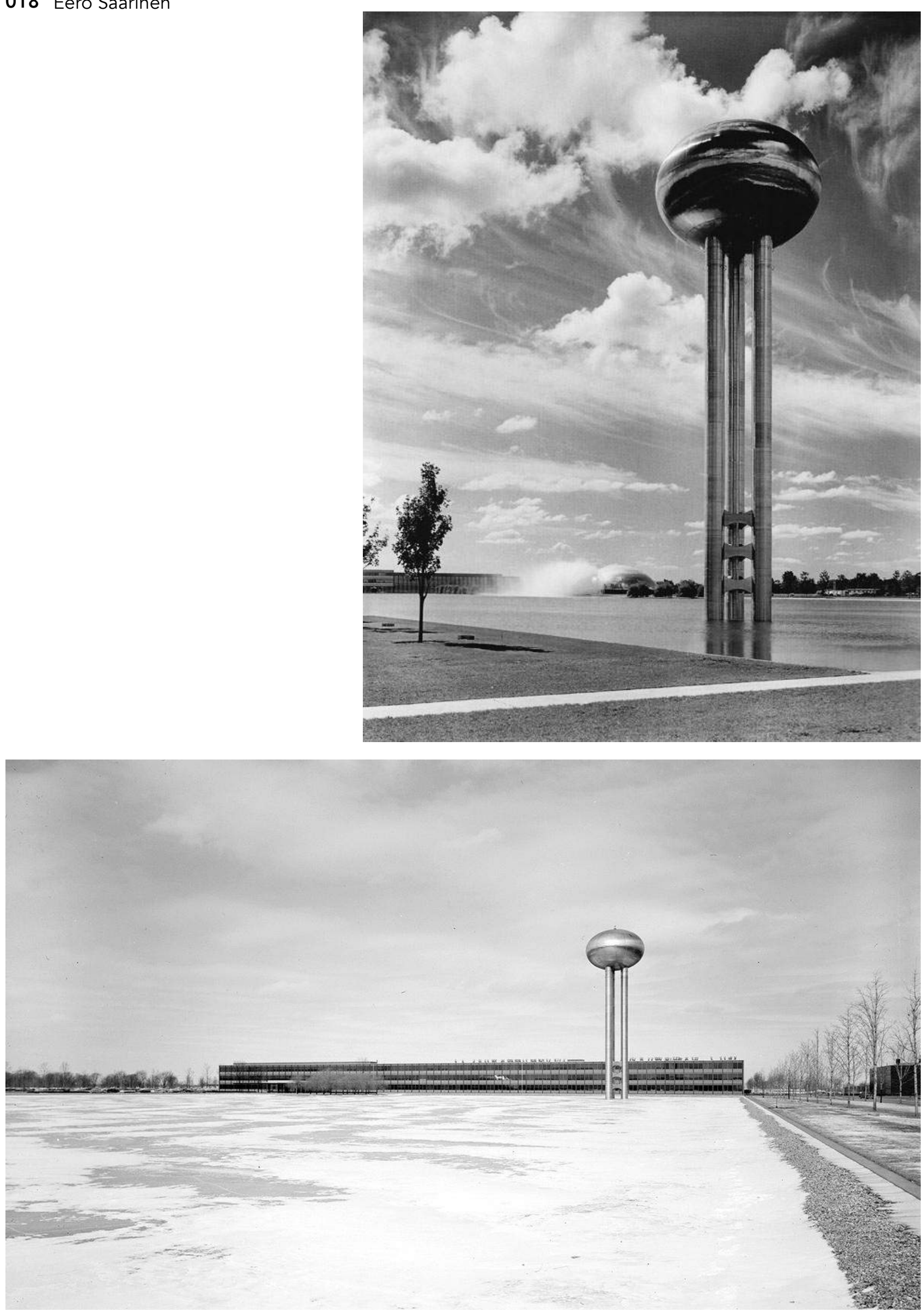
Torre da Indústria Fontoura-Wyeth

019 Lucjan Korngold

\begin{tabular}{|c|c|}
\hline Informacões Gerais & \\
\hline Localização & São Bernardo do Campo, São Paulo, Brasil \\
\hline GPS & $23^{\circ} 39^{\prime} 17.70^{\prime \prime} \mathrm{S}-46^{\circ} 34^{\prime} 57.24^{\prime \prime} \mathrm{W}$ \\
\hline Data de Início do Projeto & 1952 \\
\hline Data do Término da Obra & 1955 \\
\hline Uso da Torre & Abastecimento industrial \\
\hline Situação Atual & Operacional \\
\hline Créditos do Projeto & \\
\hline Proprietário / Contratante & Indústrias Fontoura S/A \\
\hline Projeto de Arquitetura & Lucjan Korngold \\
\hline Projeto Estrutural & Mário França \\
\hline Construção & França, Ferraz Ltda. \\
\hline Dados do Reservatório & \\
\hline Capacidade $\left[\mathrm{m}^{3}\right]$ & 0 \\
\hline Forma / Tipologia & Troncônico / Fundo em cúpula \\
\hline Material & Concreto armado \\
\hline Altura $[\mathrm{m}]$ & 9,50 \\
\hline Dimensão máxima [m] & 6,50 \\
\hline Dimensão mínima [m] & 5,00 \\
\hline Altura da Água - h [m] & \\
\hline Número de Câmaras & 1 \\
\hline Dados da Estrutura de Apoio do Reserv & \\
\hline Tipologia & Fuste central ôco \\
\hline Material & Concreto armado \\
\hline Altura do Fundo do Reservatório - H [m] & 31,00 \\
\hline Altura Efetiva - $\mathrm{H}+\mathrm{h}[\mathrm{m}]$ & \\
\hline Altura Total da Torre - Ht [m] & 39,50 \\
\hline Dados do Revestimento & \\
\hline Tipo & \\
\hline Material & \\
\hline
\end{tabular}

\section{Referências Bibliográficas}

Inserções em Bibliografia Específica

nenhum registro encontrado

Inserções em Bibliografia Geral

[HERBST, 2007]

[MINDLIN, 1956]

Inserções em Periódicos

[Revista D.A.E., São Paulo, v. 21, n. 38, set. 1960]

[L'Architecture d'Aujourd'hui, Paris, v. 26, n. 62, nov. 1955]

[Habitat, São Paulo, n. 21, nov. 1955] 

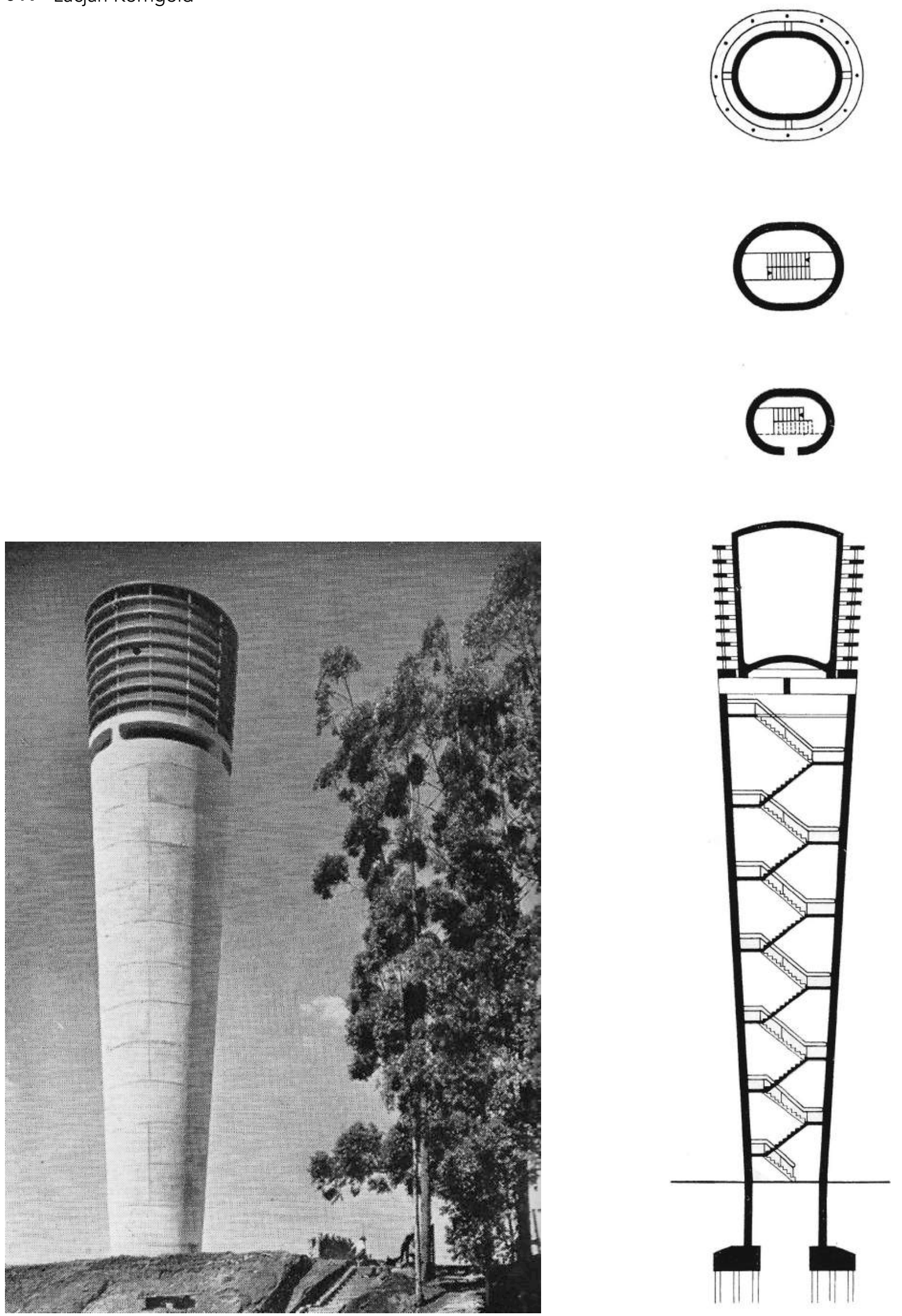
Torre de Fedala

020 Eduardo Torroja

\begin{tabular}{|c|c|}
\hline Informacões Gerais & \\
\hline Localização & Mohammedia, Marrocos \\
\hline GPS & $33^{\circ} 41^{\prime} 32.62^{\prime \prime} \mathrm{N}-7^{\circ} 23^{\prime} 16.71^{\prime \prime} \mathrm{W}$ \\
\hline Data de Início do Projeto & 1956 \\
\hline Data do Término da Obra & 1957 \\
\hline Uso da Torre & Abastecimento público urbano \\
\hline Situação Atual & Desconhecida \\
\hline Créditos do Projeto & \\
\hline Proprietário / Contratante & \\
\hline Projeto de Arquitetura & Eduardo Torroja \\
\hline Projeto Estrutural & Eduardo Torroja \\
\hline Construção & Société Marocaine d'Exploitation des Entreprises Fernández \\
\hline Dados do Reservatório & \\
\hline Capacidade $\left[\mathrm{m}^{3}\right]$ & 3.500 \\
\hline Forma / Tipologia & Hiperbólico / Fundo toraidal \\
\hline Material & Concreto protendido e alvenaria \\
\hline Altura $[\mathrm{m}]$ & \\
\hline Largura $[\mathrm{m}]$ & \\
\hline Altura da Água - h [m] & \\
\hline Número de Câmaras & 1 \\
\hline Dados da Estrutura de Apoio do Re & \\
\hline Forma / Tipologia & \\
\hline Material & Concreto Armado \\
\hline Altura do Fundo do Reservatório - $\mathrm{H}$ & \\
\hline Altura Efetiva $-\mathrm{H}+\mathrm{h}[\mathrm{m}]$ & \\
\hline Altura Total da Torre - Ht [m] & 0 \\
\hline Dados do Revestimento & \\
\hline Tipo & \\
\hline Material & \\
\hline Referências Bibliográficas & \\
\hline Inserções em Bibliografia Específica & nenhum registro encontrado \\
\hline Inserções em Bibliografia Geral & [CASSINELLO, 2016] \\
\hline & [CEDEX / CEHOPU, 2008a] \\
\hline Inserções em Periódicos & [Informes de La Construcción, Madrid, v. 10, n. 98, jan/fev. 1958] \\
\hline & [Informes de La Construcción, Madrid, v. 14, n. 137, jan/fev. 1962] \\
\hline
\end{tabular}




\section{Torre de Fedala}

020 Eduardo Torroja
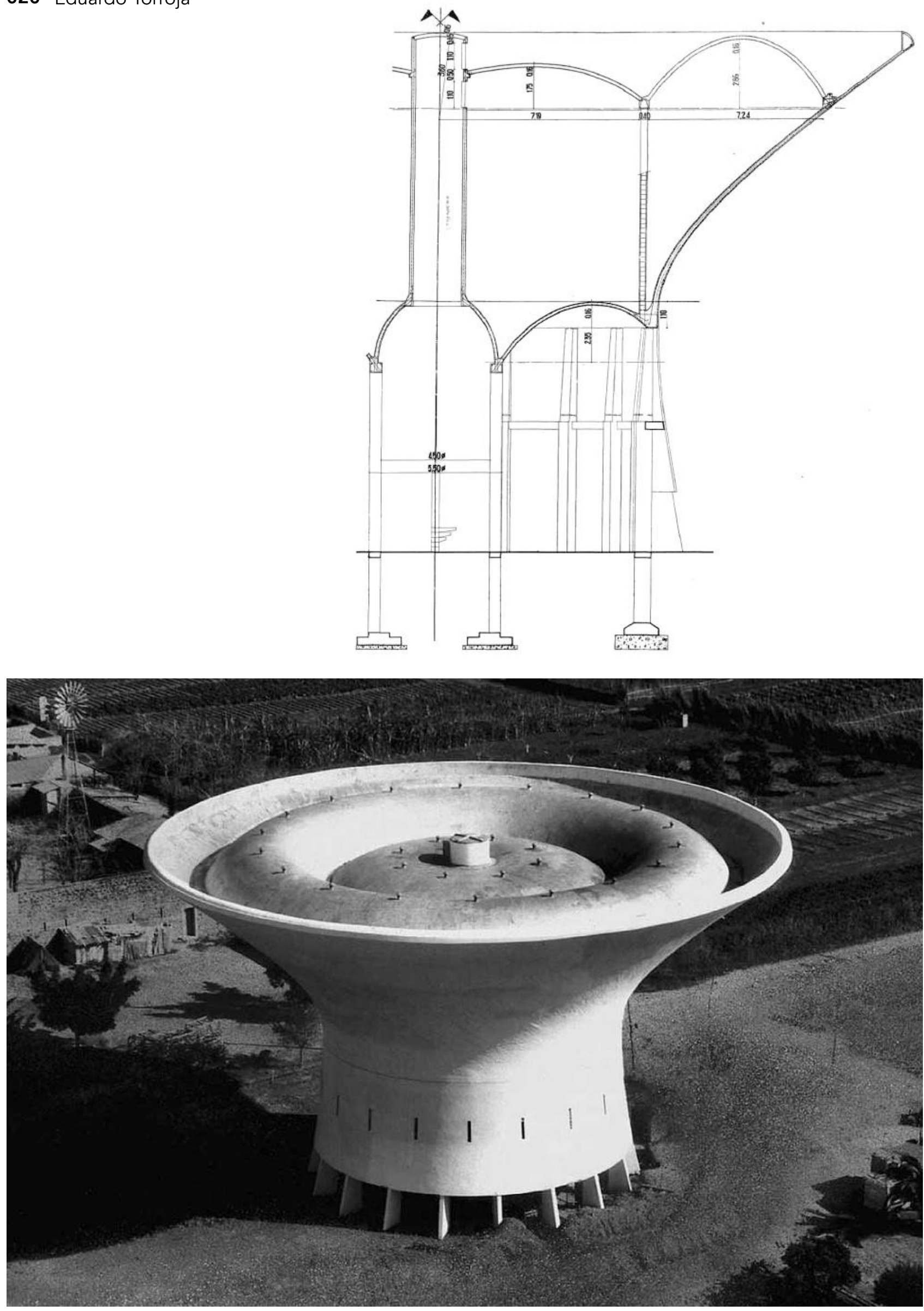
Torre de Örebro

021 Sune Lindström

\begin{tabular}{|c|c|}
\hline \multicolumn{2}{|l|}{ Informacões Gerais } \\
\hline Localização & Örebro, Suécia \\
\hline GPS & $59^{\circ} 17^{\prime} 17.52^{\prime \prime} \mathrm{N}-15^{\circ} 13^{\prime} 31.83^{\prime \prime} \mathrm{E}$ \\
\hline \multicolumn{2}{|l|}{ Data de Início do Projeto } \\
\hline Data do Término da Obra & 1957 \\
\hline Uso da Torre & Abastecimento público urbano \\
\hline Situação Atual & Desconhecida \\
\hline \multicolumn{2}{|l|}{ Créditos do Projeto } \\
\hline Proprietário / Contratante & Departamento de Obras Públicas de Örebro \\
\hline Projeto de Arquitetura & Sune Lindström \\
\hline Projeto Estrutural & Kurt Eriksson \\
\hline Construção & A. B. Svenska Stenbelaggningar \\
\hline \multicolumn{2}{|l|}{ Dados do Reservatório } \\
\hline Capacidade $\left[\mathrm{m}^{3}\right]$ & 9.000 \\
\hline Forma / Tipologia & Troncônico [cogumelo] \\
\hline Material & Concreto protendido \\
\hline \multicolumn{2}{|l|}{ Altura $[\mathrm{m}]$} \\
\hline Diâmetro [m] & 45,60 \\
\hline \multicolumn{2}{|l|}{ Altura da Água - h [m] } \\
\hline \multicolumn{2}{|l|}{ Número de Câmaras } \\
\hline \multicolumn{2}{|c|}{ Dados da Estrutura de Apoio do Reservatório } \\
\hline Tipologia & Fuste central cilíndrico ôco \\
\hline Material & Concreto armado \\
\hline \multicolumn{2}{|l|}{ Altura do Fundo do Reservatório - H [m] } \\
\hline Altura Efetiva $-\mathrm{H}+\mathrm{h}[\mathrm{m}]$ & 47,30 \\
\hline Altura Total da Torre - Ht [m] & 57,30 \\
\hline \multicolumn{2}{|l|}{ Dados do Revestimento } \\
\hline \multicolumn{2}{|l|}{ Tipo } \\
\hline \multicolumn{2}{|l|}{ Material } \\
\hline \multicolumn{2}{|l|}{ Referências Bibliográficas } \\
\hline Inserções em Bibliografia Específica & [WERTH, 1971] \\
\hline Inserções em Bibliografia Geral & [SMITH, 1961] \\
\hline Inserções em Periódicos & $\begin{array}{l}\text { [Revista D.A.E., São Paulo, v. 21, n. 38, set. 1960] } \\
\text { [Informes de La Construcción, Madrid, v. 11, n. 103, ago/set. 1958] }\end{array}$ \\
\hline
\end{tabular}




\section{Torre de Örebro}

021 Sune Lindström
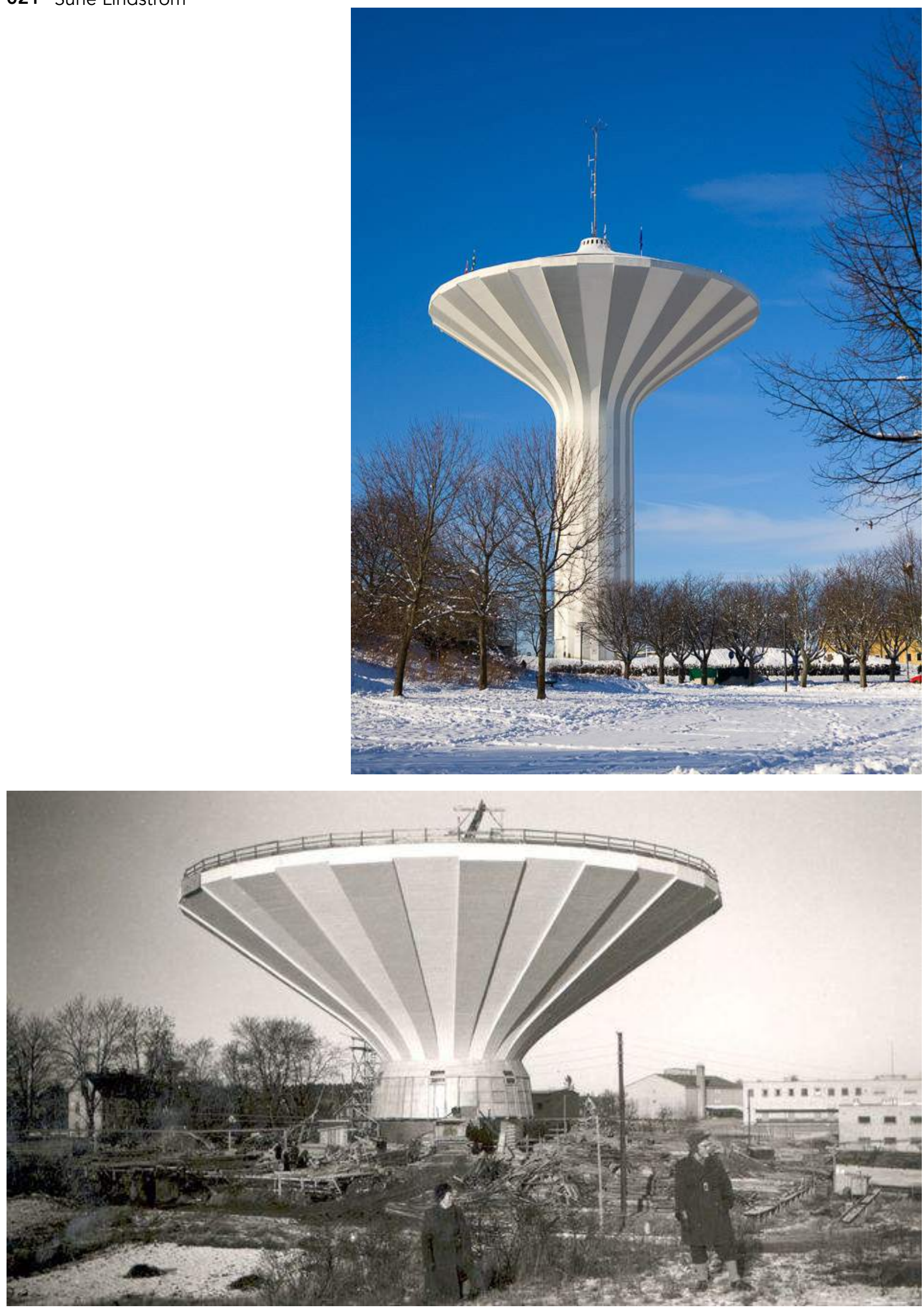
Torre de Guérinière

022 Guillaume Gillet

\begin{tabular}{|c|c|}
\hline Informacões Gerais & \\
\hline Localização & Caen, Normandia, França \\
\hline GPS & $49^{\circ} 9^{\prime} 43.22^{\prime \prime} \mathrm{N}-0^{\circ} 20^{\prime} 38.46^{\prime \prime} \mathrm{W}$ \\
\hline Data de Início do Projeto & 1955 \\
\hline Data do Término da Obra & 1957 \\
\hline Uso da Torre & Abastecimento público urbano \\
\hline Situação Atual & Operacional \\
\hline Créditos do Projeto & \\
\hline Proprietário / Contratante & \\
\hline Projeto de Arquitetura & Guillaume Gillet \\
\hline Projeto Estrutural & René Sarger \\
\hline Construção & \\
\hline Dados do Reservatório & \\
\hline Capacidade $\left[\mathrm{m}^{3}\right]$ & 3.000 \\
\hline Forma / Tipologia & Troncônico com fundo plano \\
\hline Material & Concreto armado \\
\hline Altura $[\mathrm{m}]$ & \\
\hline Diâmetro máximo $[\mathrm{m}]$ & 31,80 \\
\hline Altura da Água - h [m] & \\
\hline Número de Câmaras & \\
\hline Dados da Estrutura de Apoio do R & \\
\hline Tipologia & Sistema de vigas e pilares oblíquos \\
\hline Material & Concreto armado \\
\hline Altura do Fundo do Reservatório - $\mathrm{H}$ & \\
\hline Altura Efetiva $-\mathrm{H}+\mathrm{h}[\mathrm{m}]$ & \\
\hline Altura Total da Torre - Ht [m] & 32,00 \\
\hline Dados do Revestimento & \\
\hline Tipo & \\
\hline Material & \\
\hline Referências Bibliográficas & \\
\hline Inserções em Bibliografia Específica & nenhum registro encontrado \\
\hline Inserções em Bibliografia Geral & nenhum registro encontrado \\
\hline Inserções em Periódicos & [Revista D.A.E., São Paulo, v. 21, n. 38, set. 1960] \\
\hline
\end{tabular}


022 Guillaume Gillet
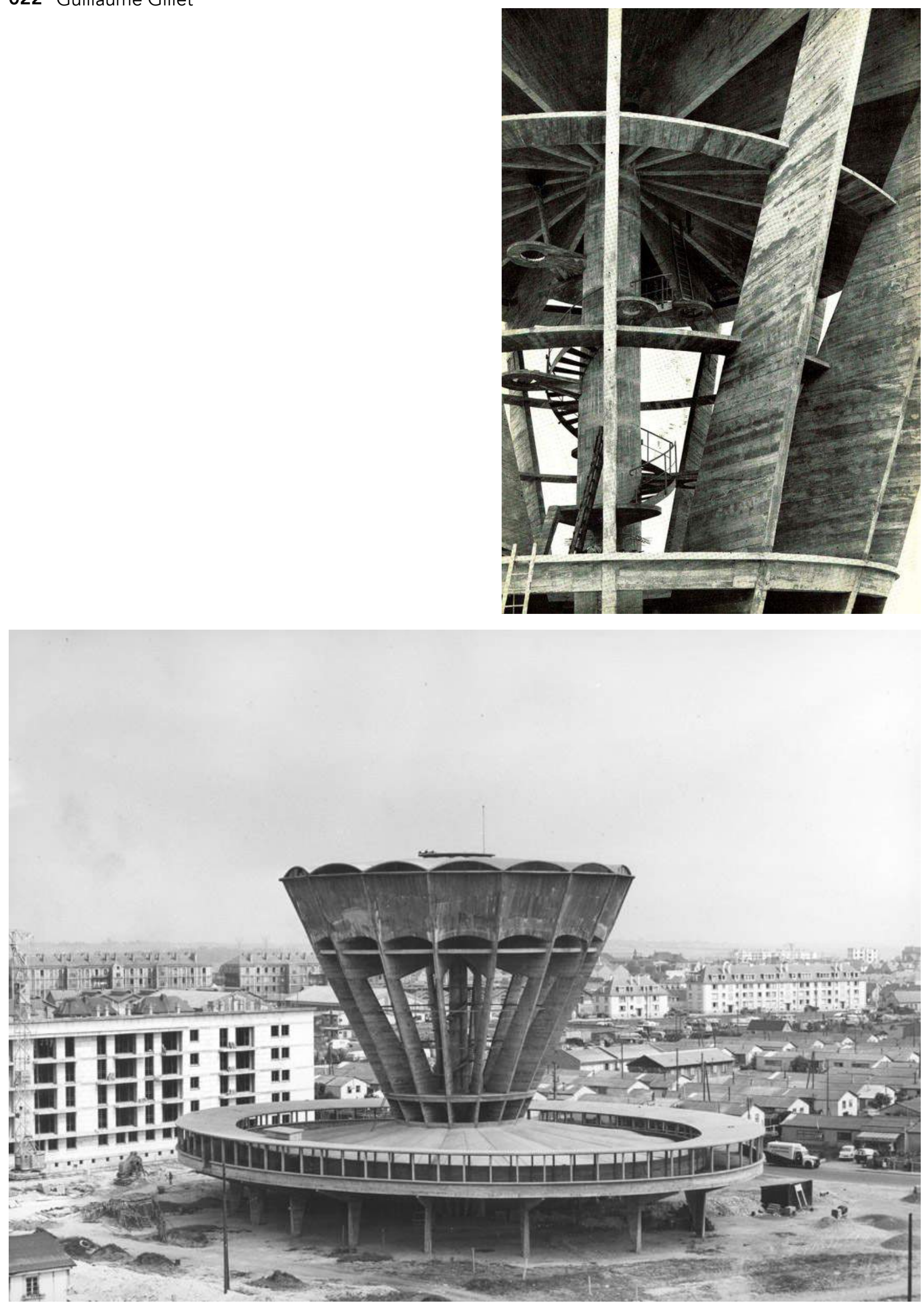
Torre Velbert BKS Hochhaus

023 Krieger-Jähnert-Schütte

\begin{tabular}{|c|c|}
\hline \multicolumn{2}{|l|}{ Informacões Gerais } \\
\hline Localização & Velbert, Rheinland, Alemanha \\
\hline GPS & $51^{\circ} 19^{\prime} 56.74^{\prime \prime} \mathrm{N}-7^{\circ} 2^{\prime} 45.72^{\prime \prime} \mathrm{E}$ \\
\hline Data de Início do Projeto & 1957 \\
\hline Data do Término da Obra & 1958 \\
\hline Uso da Torre & Abastecimento público urbano \\
\hline Situação Atual & Operacional \\
\hline \multicolumn{2}{|l|}{ Créditos do Projeto } \\
\hline Proprietário / Contratante & Velberter Stadtwerke \\
\hline Projeto de Arquitetura & Krieger-Jähnert-Schütte \\
\hline \multicolumn{2}{|l|}{ Projeto Estrutural } \\
\hline \multicolumn{2}{|l|}{ Construção } \\
\hline \multicolumn{2}{|l|}{ Dados do Reservatório } \\
\hline Capacidade $\left[\mathrm{m}^{3}\right]$ & 3.000 \\
\hline Forma / Tipologia & Cilíndrico / Fundo plano \\
\hline Material & Concreto armado \\
\hline Altura $[\mathrm{m}]$ & 12,00 \\
\hline Diâmetro máximo $[\mathrm{m}]$ & 18,00 \\
\hline \multicolumn{2}{|l|}{ Altura da Água - h [m] } \\
\hline \multicolumn{2}{|l|}{ Número de Câmaras } \\
\hline \multicolumn{2}{|c|}{ Dados da Estrutura de Apoio do Reservatório } \\
\hline Tipologia & Sistema de pilares e vigas \\
\hline Material & Concreto armado \\
\hline \multicolumn{2}{|l|}{ Altura do Fundo do Reservatório - H [m] } \\
\hline \multicolumn{2}{|l|}{ Altura Efetiva - $\mathrm{H}+\mathrm{h}[\mathrm{m}]$} \\
\hline Altura Total da Torre - Ht [m] & 47,00 \\
\hline \multicolumn{2}{|l|}{ Dados do Revestimento } \\
\hline Tipo & Torre envolvida por edifício de apartamentos \\
\hline \multicolumn{2}{|l|}{ Material } \\
\hline \multicolumn{2}{|l|}{ Referências Bibliográficas } \\
\hline Inserções em Bibliografia Específica & [BECHER, 1988] \\
\hline Inserções em Bibliografia Geral & [BAECK, 2009] \\
\hline Inserções em Periódicos & [VA-tidskriften Cirkulation. Örebro, fev. 2006] \\
\hline
\end{tabular}


Torre Velbert BKS Hochhaus

023 Krieger-Jähnert-Schütte

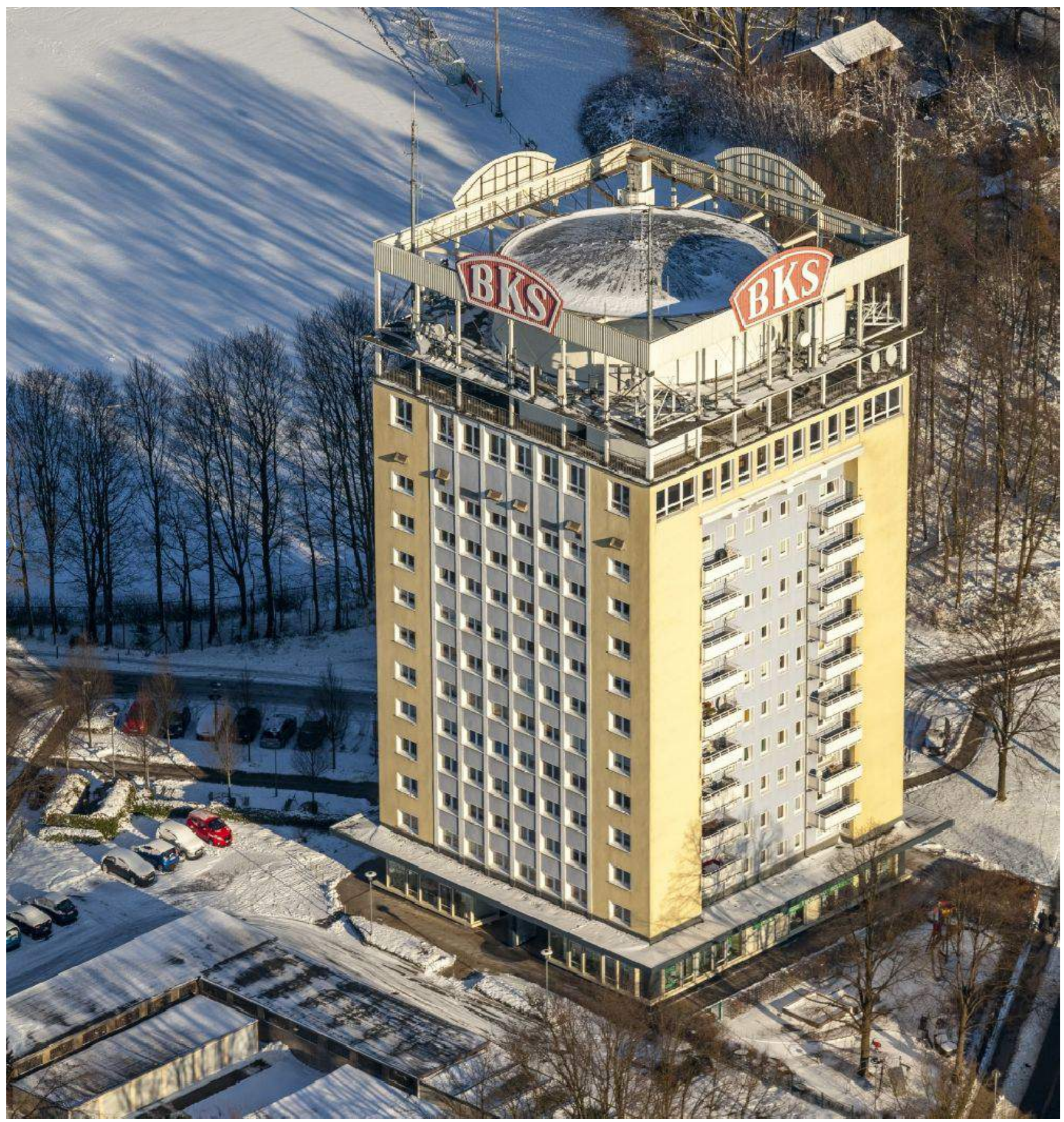


Torre do EUR

024 Sergio Varisco

\begin{tabular}{|c|c|}
\hline Informacões Gerais & \\
\hline Localização & EUR, Roma, Itália \\
\hline GPS & $41^{\circ} 49^{\prime} 27.92^{\prime \prime} \mathrm{N}-12^{\circ} 27^{\prime} 46.11^{\prime \prime} \mathrm{E}$ \\
\hline \multicolumn{2}{|l|}{ Data de Início do Projeto } \\
\hline Data do Término da Obra & 1958 \\
\hline Uso da Torre & Abastecimento público urbano \\
\hline Situação Atual & Operacional \\
\hline \multicolumn{2}{|l|}{ Créditos do Projeto } \\
\hline \multicolumn{2}{|l|}{ Proprietário / Contratante } \\
\hline Projeto de Arquitetura & Sergio Varisco \\
\hline Projeto Estrutural & Roberto Colosimo \\
\hline \multicolumn{2}{|l|}{ Construção } \\
\hline \multicolumn{2}{|l|}{ Dados do Reservatório } \\
\hline Capacidade $\left[\mathrm{m}^{3}\right]$ & 2.500 \\
\hline Forma / Tipologia & Troncônico / Fundo plano \\
\hline Material & Concreto armado \\
\hline Altura $[\mathrm{m}]$ & 9,72 \\
\hline Diâmetro [m] & 23,30 \\
\hline Altura da Água - $\mathrm{h}[\mathrm{m}]$ & 7,10 \\
\hline Número de Câmaras & 1 \\
\hline \multicolumn{2}{|c|}{ Dados da Estrutura de Apoio do Reservatório } \\
\hline Tipologia & Pilares oblíquos e consoles \\
\hline Material & Concreto armado \\
\hline Altura do Fundo do Reservatório - H [m] & 41,48 \\
\hline Altura Efetiva - H + h [m] & 48,58 \\
\hline Altura Total da Torre - Ht [m] & 51,90 \\
\hline \multicolumn{2}{|l|}{ Dados do Revestimento } \\
\hline \multicolumn{2}{|l|}{ Tipo } \\
\hline \multicolumn{2}{|l|}{ Material } \\
\hline \multicolumn{2}{|l|}{ Referências Bibliográficas } \\
\hline Inserções em Bibliografia Específica & nenhum registro encontrado \\
\hline Inserções em Bibliografia Geral & nenhum registro encontrado \\
\hline Inserções em Periódicos & [Informes de La Construcción, Madrid, v. 17, n. 161, jun. 1964] \\
\hline
\end{tabular}




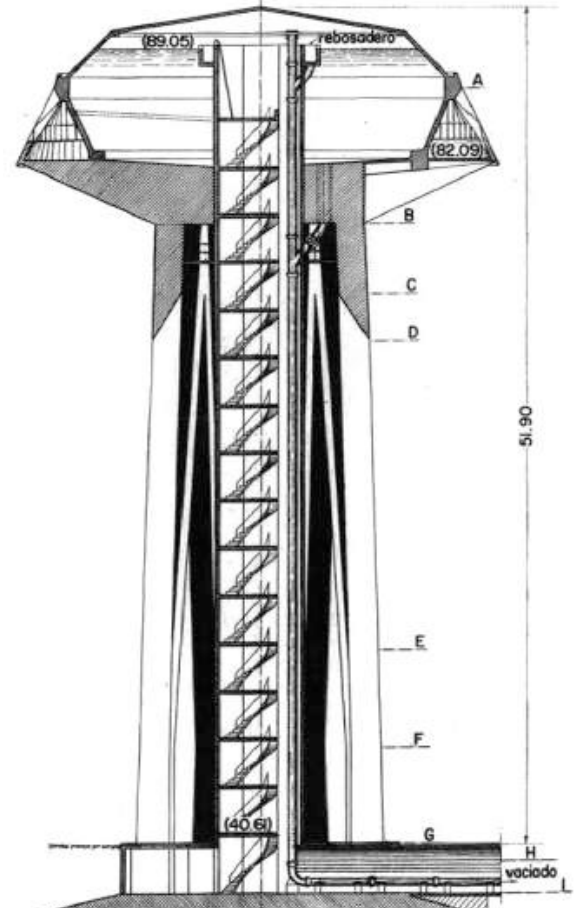

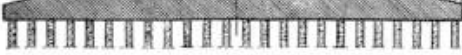
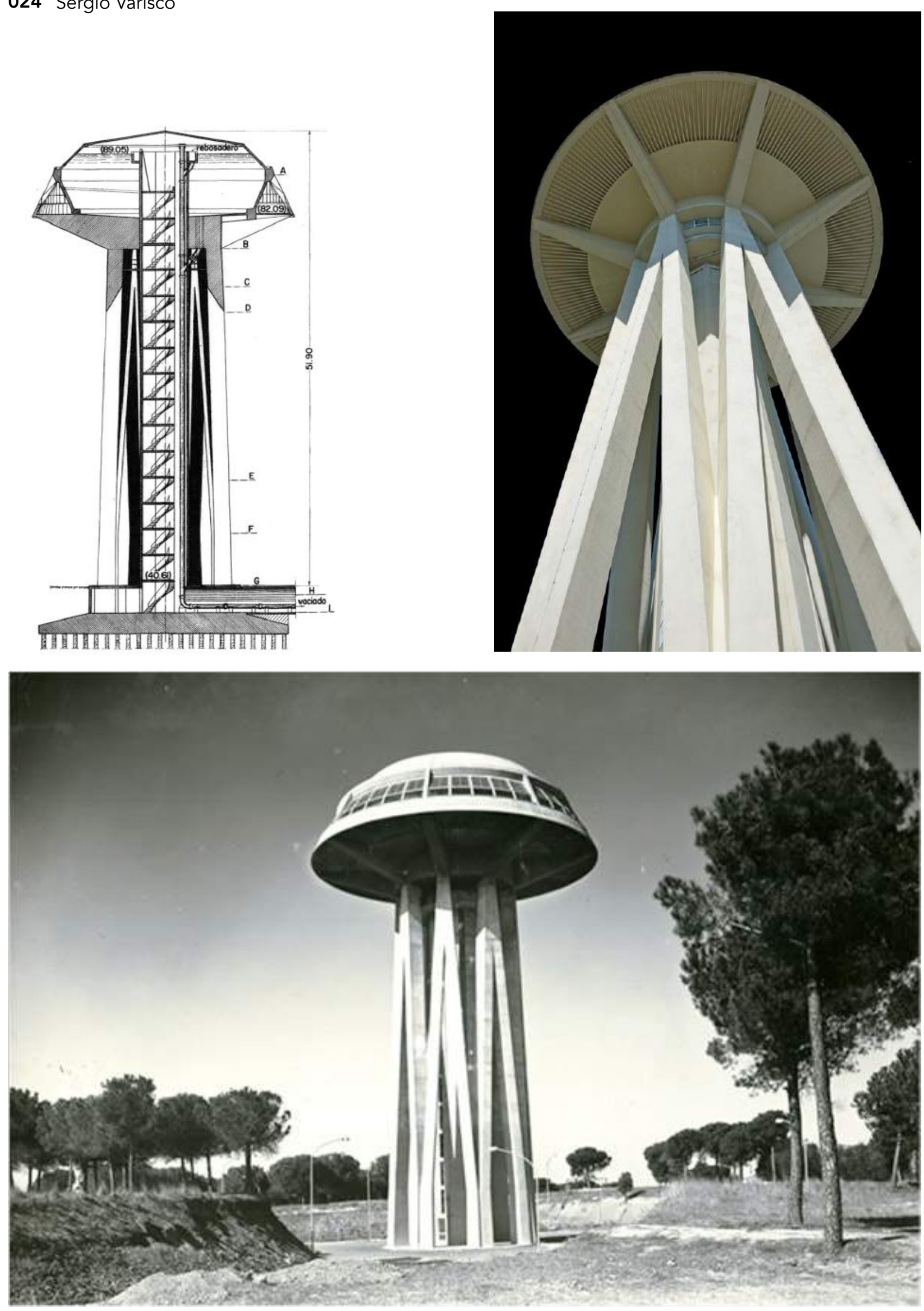
Torre do Hipódromo de Zarzuela

025 Eduardo Torroja

\begin{tabular}{|c|c|}
\hline Informacões Gerais & \\
\hline Localização & Madrid, Espanha \\
\hline GPS & $40^{\circ} 28^{\prime} 7.80^{\prime \prime} \mathrm{N}-3^{\circ} 45^{\prime} 49.24^{\prime \prime} \mathrm{W}$ \\
\hline Data de Início do Projeto & 1941 \\
\hline Data do Término da Obra & 1959 \\
\hline Uso da Torre & Abastecimento de hipódromo \\
\hline Situação Atual & Desconhecida \\
\hline \multicolumn{2}{|l|}{ Créditos do Projeto } \\
\hline Proprietário / Contratante & Gabinete Técnico de Accesos y Extrarradio de Madrid \\
\hline Projeto de Arquitetura & Eduardo Torroja \\
\hline Projeto Estrutural & Eduardo Torroja \\
\hline Construção & Agromán S. A. \\
\hline \multicolumn{2}{|l|}{ Dados do Reservatório } \\
\hline Capacidade $\left[\mathrm{m}^{3}\right]$ & 670 \\
\hline Forma / Tipologia & Hiperbólico \\
\hline Material & Concreto armado \\
\hline Altura $[\mathrm{m}]$ & 4,30 \\
\hline Diâmentro Máximo [m] & 5,70 \\
\hline Altura da Água - h [m] & 4,30 \\
\hline Número de Câmaras & 1 \\
\hline \multicolumn{2}{|c|}{ Dados da Estrutura de Apoio do Reservatório } \\
\hline Tipologia & Paredes estruturais em alvenaria \\
\hline Material & Tijolos de barro \\
\hline Altura do Fundo do Reservatório - H [m] & 6,70 \\
\hline Altura Efetiva - H + h [m] & 11,00 \\
\hline Altura Total da Torre - Ht [m] & 11,00 \\
\hline \multicolumn{2}{|l|}{ Dados do Revestimento } \\
\hline \multicolumn{2}{|l|}{ Tipo } \\
\hline \multicolumn{2}{|l|}{ Material } \\
\hline \multicolumn{2}{|l|}{ Referências Bibliográficas } \\
\hline Inserções em Bibliografia Específica & nenhum registro encontrado \\
\hline Inserções em Bibliografia Geral & [CEDEX / CEHOPU, 2008e] \\
\hline Inserções em Periódicos & nenhum registro encontrado \\
\hline
\end{tabular}


Torre do Hipódromo de Zarzuela

025 Eduardo Torroja
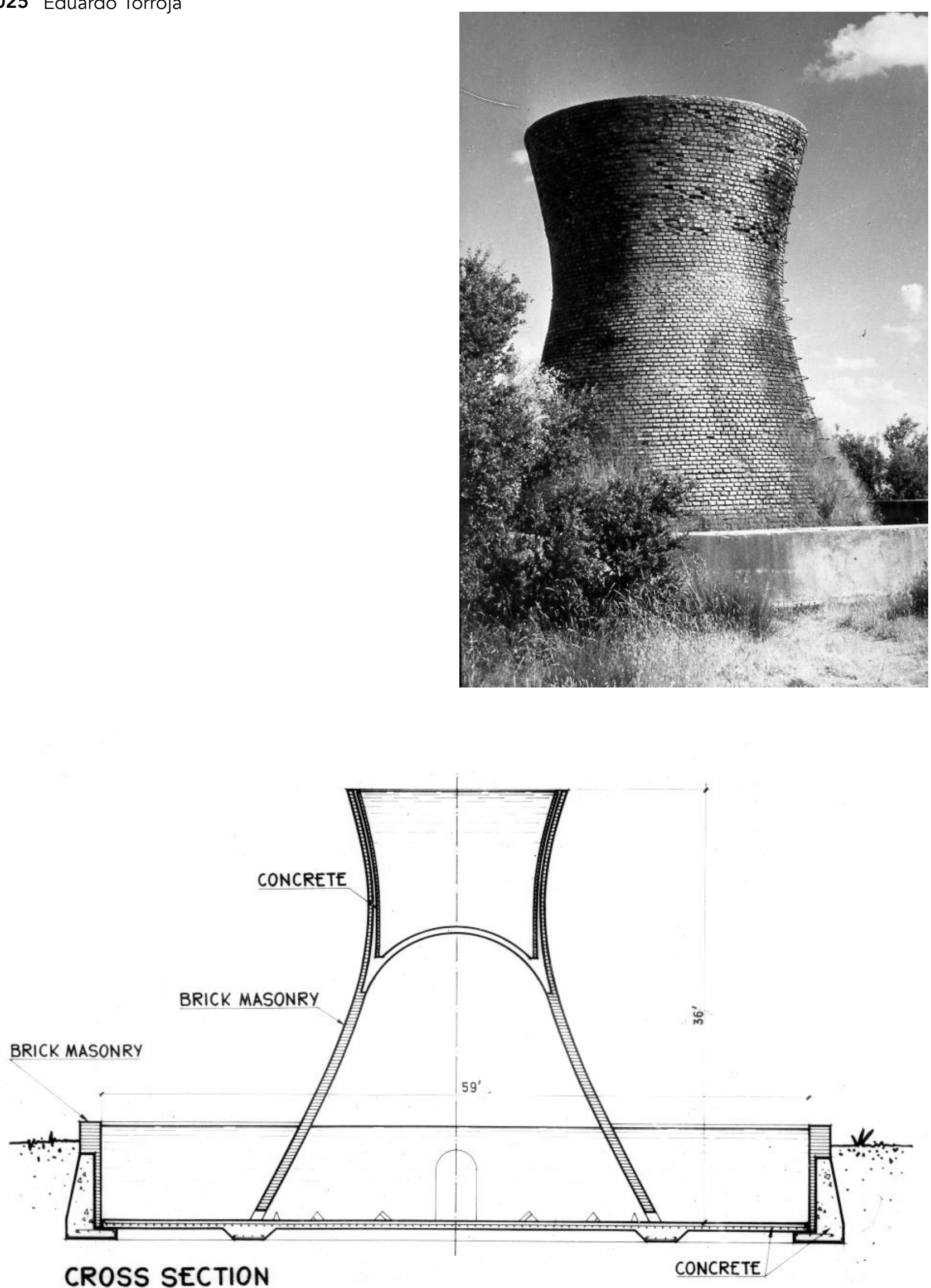
Centro Idrico de Acea

026 Francesco Palpacelli

\begin{tabular}{|c|c|}
\hline \multicolumn{2}{|l|}{ Informacões Gerais } \\
\hline Localização & Aurelio, Roma, Itália \\
\hline GPS & $\mathrm{N} / \mathrm{A}$ \\
\hline Data de Início do Projeto & 1959 \\
\hline Data do Término da Obra & Não construído \\
\hline Uso da Torre & Abastecimento público urbano \\
\hline Situação Atual & $\mathrm{N} / \mathrm{A}$ \\
\hline \multicolumn{2}{|l|}{ Créditos do Projeto } \\
\hline Proprietário / Contratante & ACEA - Azienda Comunale Elettricità e Acque \\
\hline Projeto de Arquitetura & Francesco Palpacelli \\
\hline \multicolumn{2}{|l|}{ Projeto Estrutural } \\
\hline Construção & $\mathrm{N} / \mathrm{A}$ \\
\hline \multicolumn{2}{|l|}{ Dados do Reservatório } \\
\hline Capacidade $\left[\mathrm{m}^{3}\right]$ & 0 \\
\hline Forma / Tipologia & Anular / Fundo plano \\
\hline Material & Metálico [aço] \\
\hline \multicolumn{2}{|l|}{ Altura $[\mathrm{m}]$} \\
\hline Diâmetro máximo [m] & 0,00 \\
\hline \multicolumn{2}{|l|}{ Altura da Água - h [m] } \\
\hline Número de Câmaras & 1 \\
\hline \multicolumn{2}{|c|}{ Dados da Estrutura de Apoio do Reservatório } \\
\hline Tipologia & Sistema de pilares \\
\hline Material & Concreto armado e aço \\
\hline \multicolumn{2}{|l|}{ Altura do Fundo do Reservatório - H [m] } \\
\hline \multicolumn{2}{|l|}{ Altura Efetiva - H + h [m] } \\
\hline Altura Total da Torre - Ht [m] & 0,00 \\
\hline \multicolumn{2}{|l|}{ Dados do Revestimento } \\
\hline Tipo & Painéis metálicos \\
\hline Material & Aço \\
\hline \multicolumn{2}{|l|}{ Referências Bibliográficas } \\
\hline Inserções em Bibliografia Específica & nenhum registro encontrado \\
\hline Inserções em Bibliografia Geral & [MURATORE, 2007] \\
\hline Inserções em Periódicos & nenhum registro encontrado \\
\hline
\end{tabular}


026 Francesco Palpacelli
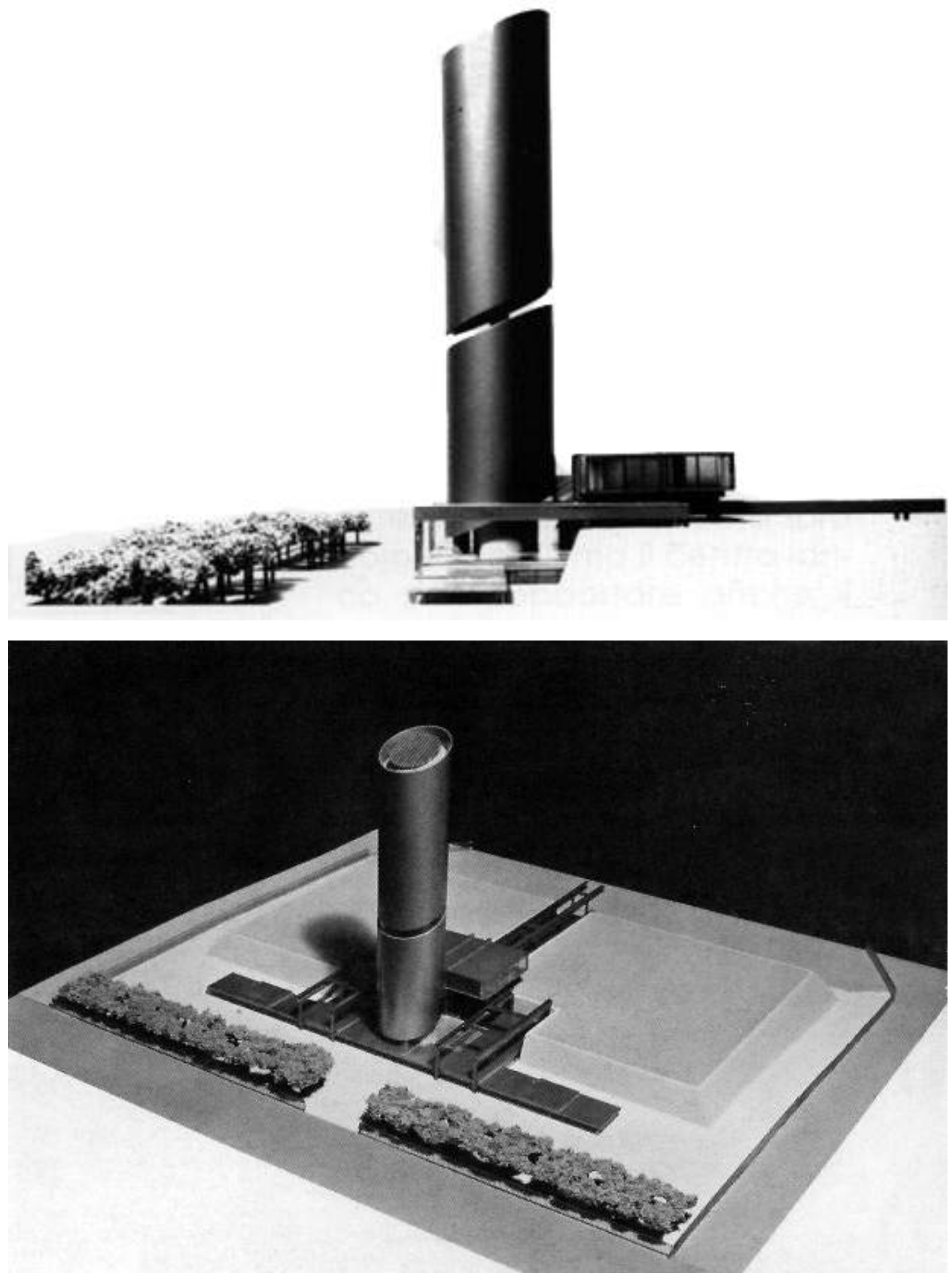
Torre de Belmont

027 Guillaume Gillet

\begin{tabular}{|c|c|}
\hline \multicolumn{2}{|l|}{ Informacões Gerais } \\
\hline Localização & Royan, Nova Aquitânia, França \\
\hline GPS & $45^{\circ} 37^{\prime} 37.07^{\prime \prime} \mathrm{N}-0^{\circ} 59^{\prime} 49.51^{\prime \prime} \mathrm{W}$ \\
\hline Data de Início do Projeto & 1959 \\
\hline Data do Término da Obra & 1960 \\
\hline Uso da Torre & Abastecimento público urbano \\
\hline Situação Atual & Operacional \\
\hline \multicolumn{2}{|l|}{ Créditos do Projeto } \\
\hline Proprietário / Contratante & Ville de Royan \\
\hline Projeto de Arquitetura & Guillaume Gillet \\
\hline Projeto Estrutural & Henri-Louis Trezzini \\
\hline Construção & André Delau et fils + Société Eiffel d'entreprise générale \\
\hline \multicolumn{2}{|l|}{ Dados do Reservatório } \\
\hline Capacidade $\left[\mathrm{m}^{3}\right]$ & 2.400 \\
\hline Forma / Tipologia & Hiperbólico \\
\hline Material & Concreto armado \\
\hline \multicolumn{2}{|l|}{ Altura $[\mathrm{m}]$} \\
\hline Diâmetro máximo [m] & 0,00 \\
\hline \multicolumn{2}{|l|}{ Altura da Água - h [m] } \\
\hline Número de Câmaras & 1 \\
\hline \multicolumn{2}{|c|}{ Dados da Estrutura de Apoio do Reservatório } \\
\hline Tipologia & Paredes estruturais \\
\hline Material & Concreto armado \\
\hline \multicolumn{2}{|l|}{ Altura do Fundo do Reservatório - $\mathrm{H}$ [m] } \\
\hline \multicolumn{2}{|l|}{ Altura Efetiva - H + h [m] } \\
\hline Altura Total da Torre - Ht [m] & 45,00 \\
\hline \multicolumn{2}{|l|}{ Dados do Revestimento } \\
\hline \multicolumn{2}{|l|}{ Tipo } \\
\hline \multicolumn{2}{|l|}{ Material } \\
\hline \multicolumn{2}{|l|}{ Referências Bibliográficas } \\
\hline Inserções em Bibliografia Específica & nenhum registro encontrado \\
\hline Inserções em Bibliografia Geral & nenhum registro encontrado \\
\hline Inserções em Periódicos & [L'Architecture d'Aujourd'hui, Paris, v. 31, n. 91-92, set-nov. 1960] \\
\hline
\end{tabular}


Torre de Belmont

027 Guillaume Gillet
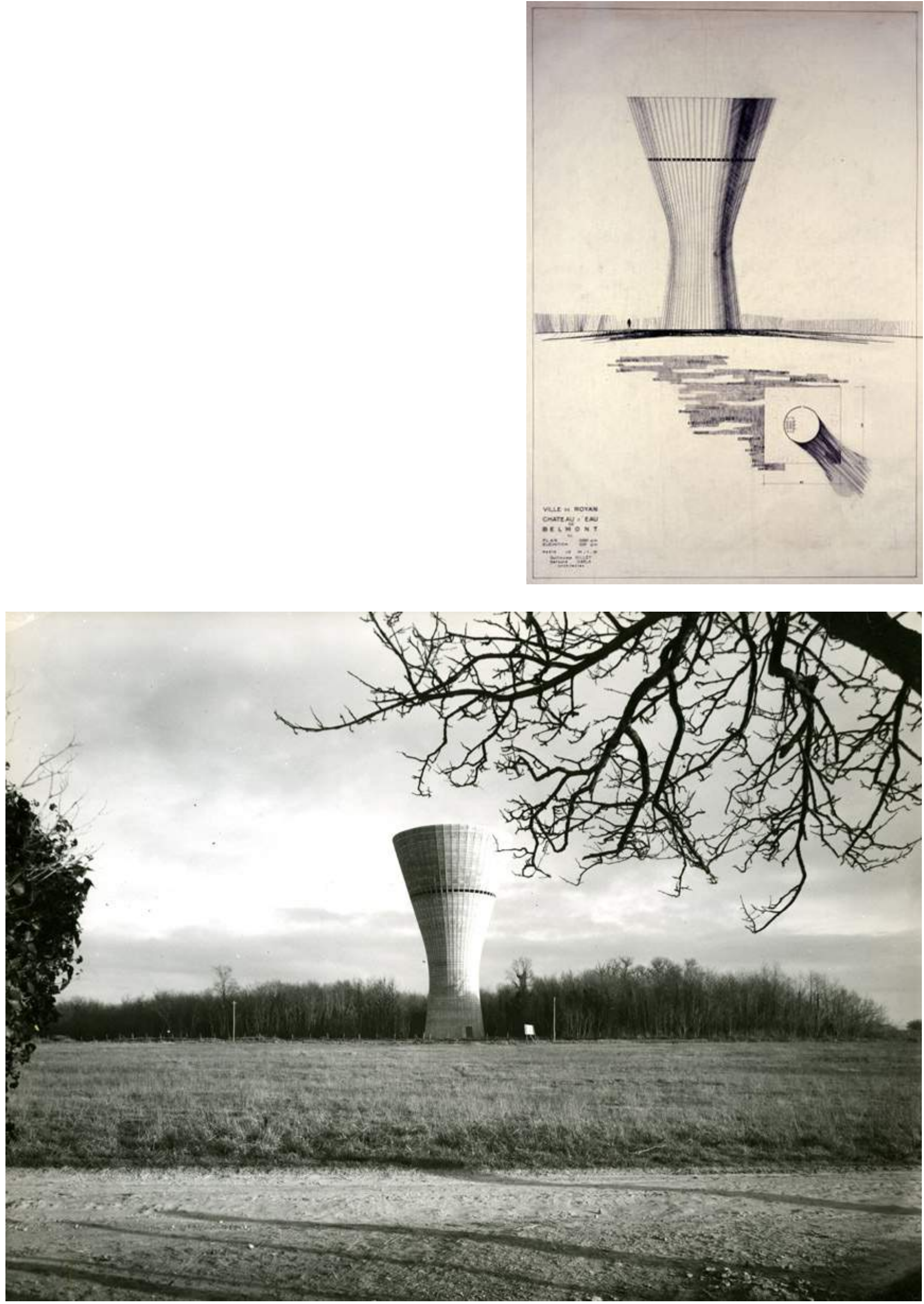
Centro Idrico dell'EUR

028 Francesco Palpacelli

\begin{tabular}{|c|c|}
\hline \multicolumn{2}{|l|}{ Informacões Gerais } \\
\hline Localização & EUR, Roma, Itália \\
\hline GPS & N/A \\
\hline Data de Início do Projeto & 1961 \\
\hline Data do Término da Obra & Não construído \\
\hline Uso da Torre & Abastecimento público urbano \\
\hline Situação Atual & N/A \\
\hline \multicolumn{2}{|l|}{ Créditos do Projeto } \\
\hline Proprietário / Contratante & ACEA - Azienda Comunale Elettricità e Acque \\
\hline Projeto de Arquitetura & Francesco Palpacelli \\
\hline \multicolumn{2}{|l|}{ Projeto Estrutural } \\
\hline Construção & N/A \\
\hline \multicolumn{2}{|l|}{ Dados do Reservatório } \\
\hline Capacidade $\left[\mathrm{m}^{3}\right]$ & 0 \\
\hline Forma / Tipologia & Troncônico / Fundo plano \\
\hline Material & Concreto armado \\
\hline \multicolumn{2}{|l|}{ Altura $[\mathrm{m}]$} \\
\hline Diâmtero máximo [m] & 0 \\
\hline \multicolumn{2}{|l|}{ Altura da Água - h [m] } \\
\hline Número de Câmaras & 3 \\
\hline \multicolumn{2}{|c|}{ Dados da Estrutura de Apoio do Reservatório } \\
\hline Tipologia & 3 pilares cilíndricos ôcos \\
\hline Material & Concreto armado \\
\hline \multicolumn{2}{|l|}{ Altura do Fundo do Reservatório - H [m] } \\
\hline \multicolumn{2}{|l|}{ Altura Efetiva - $\mathrm{H}+\mathrm{h}[\mathrm{m}]$} \\
\hline Altura Total da Torre - Ht [m] & 0 \\
\hline \multicolumn{2}{|l|}{ Dados do Revestimento } \\
\hline \multicolumn{2}{|l|}{ Tipo } \\
\hline \multicolumn{2}{|l|}{ Material } \\
\hline \multicolumn{2}{|l|}{ Referências Bibliográficas } \\
\hline Inserções em Bibliografia Específica & nenhum registro encontrado \\
\hline Inserções em Bibliografia Geral & [MURATORE, 2007] \\
\hline Inserções em Periódicos & nenhum registro encontrado \\
\hline
\end{tabular}



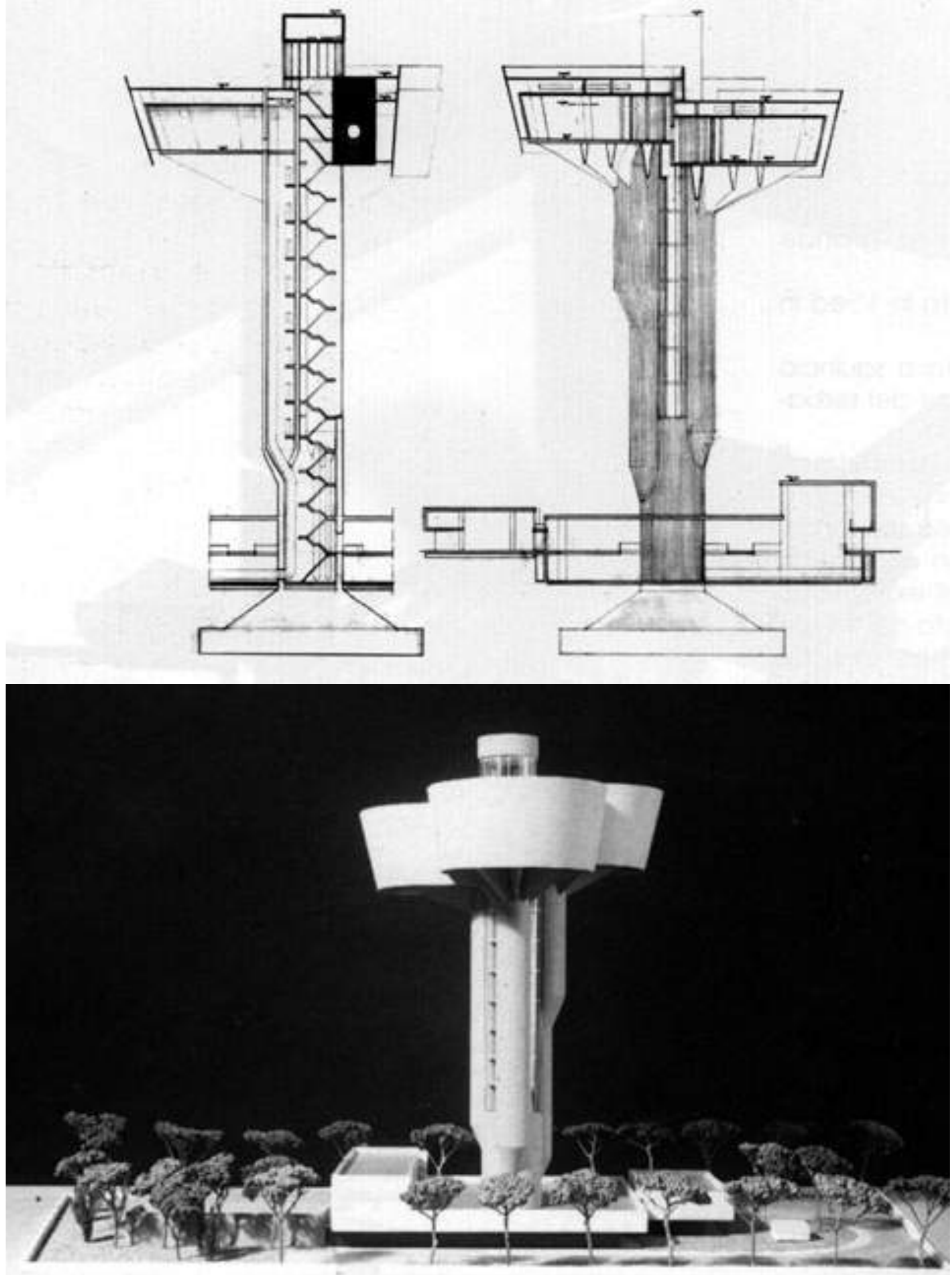
Torre de Sidi Bernoussi

029 Eduardo Torroja

\begin{tabular}{|c|c|}
\hline Informacões Gerais & \\
\hline Localização & Casablanca, Marrocos \\
\hline GPS & $33^{\circ} 36^{\prime} 32.80^{\prime \prime} \mathrm{N}-7^{\circ} 30^{\prime} 4.31 " \mathrm{~W}$ \\
\hline Data de Início do Projeto & 1959 \\
\hline Data do Término da Obra & 1961 \\
\hline Uso da Torre & Abastecimento público urbano \\
\hline Situação Atual & Desconhecida \\
\hline \multicolumn{2}{|l|}{ Créditos do Projeto } \\
\hline Proprietário / Contratante & Régie Autonome de Distribution d'Eau et d'Electricité \\
\hline Projeto de Arquitetura & Eduardo Torroja \\
\hline Projeto Estrutural & Eduardo Torroja \\
\hline Construção & Société Marocaine d'Exploitation des Entreprises Fernández \\
\hline \multicolumn{2}{|l|}{ Dados do Reservatório } \\
\hline Capacidade $\left[\mathrm{m}^{3}\right]$ & 1.000 \\
\hline Forma / Tipologia & Casca cônica com diafragmas radiais \\
\hline Material & Concreto armado e protendido \\
\hline Altura $[\mathrm{m}]$ & 8,20 \\
\hline Diâmetro [m] & 29,42 \\
\hline Altura da Água - $\mathrm{h}[\mathrm{m}]$ & 5,80 \\
\hline Número de Câmaras & 8 (interligadas) \\
\hline \multicolumn{2}{|c|}{ Dados da Estrutura de Apoio do Reservatório } \\
\hline \multicolumn{2}{|l|}{ Tipologia } \\
\hline Material & Concreto armado \\
\hline Altura do Fundo do Reservatório - H [m] & 21,50 \\
\hline Altura Efetiva - $\mathrm{H}+\mathrm{h}[\mathrm{m}]$ & 27,30 \\
\hline Altura Total da Torre - Ht [m] & 28,75 \\
\hline \multicolumn{2}{|l|}{ Dados do Revestimento } \\
\hline \multicolumn{2}{|l|}{ Tipo } \\
\hline \multicolumn{2}{|l|}{ Material } \\
\hline \multicolumn{2}{|l|}{ Referências Bibliográficas } \\
\hline Inserções em Bibliografia Específica & nenhum registro encontrado \\
\hline Inserções em Bibliografia Geral & [CEDEX / CEHOPU, 2008b] \\
\hline Inserções em Periódicos & [Informes de La Construcción, Madrid, v. 16, n. 157, jan/fev. 1964] \\
\hline
\end{tabular}




\section{Torre de Sidi Bernoussi}

029 Eduardo Torroja
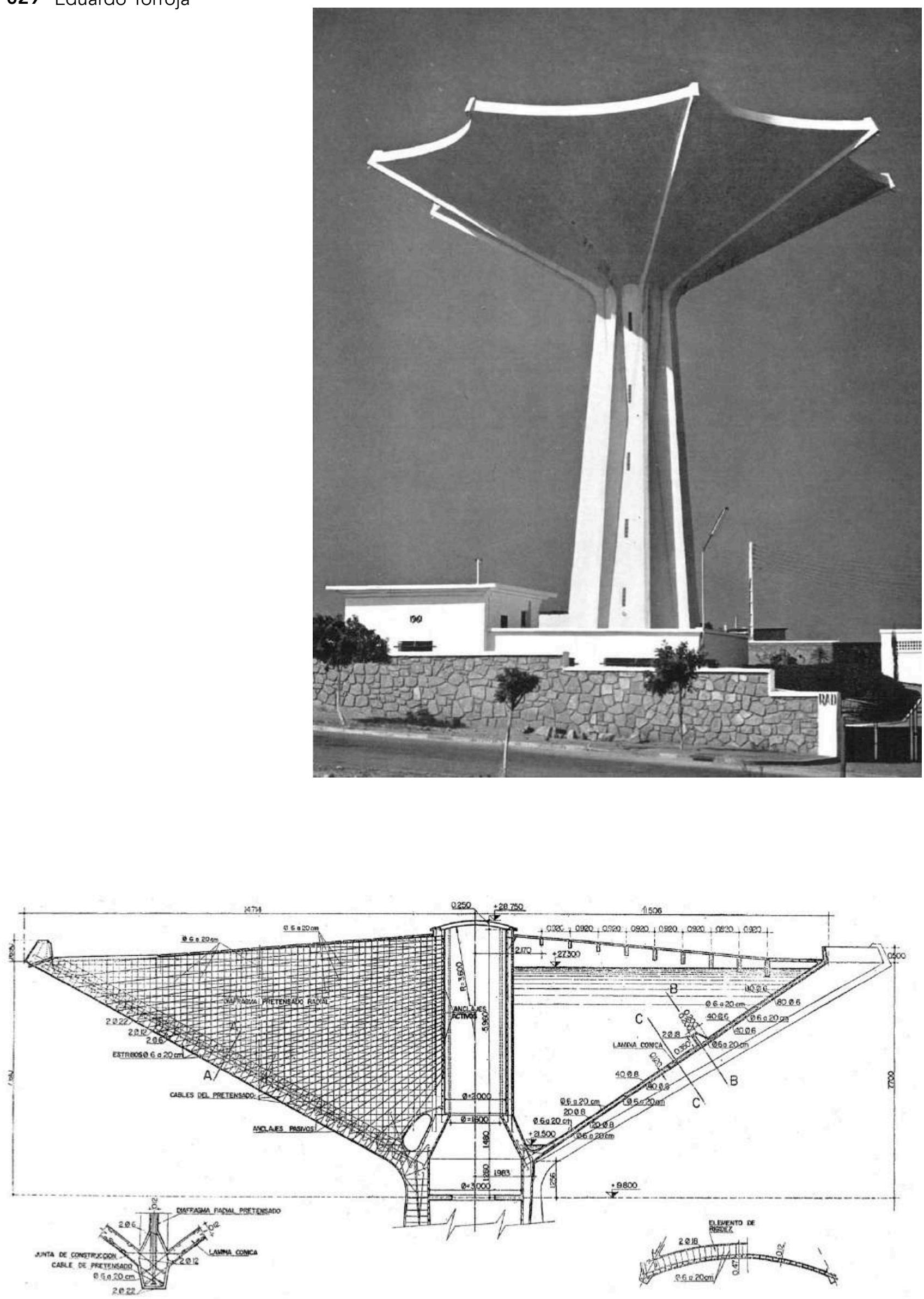
Torre dos Laboratórios Bell

030 Eero Saarinen

\begin{tabular}{|c|c|}
\hline \multicolumn{2}{|l|}{ Informacões Gerais } \\
\hline Localização & Holmdel, New Jersey, EUA \\
\hline GPS & $40^{\circ} 22^{\prime} 16.29^{\prime \prime} \mathrm{N}-74^{\circ} 9^{\prime} 38.15^{\prime \prime} \mathrm{W}$ \\
\hline Data de Início do Projeto & 1957 \\
\hline Data do Término da Obra & 1962 \\
\hline Uso da Torre & Abastecimento de centro de pesquisas \\
\hline Situação Atual & Desconhecida \\
\hline \multicolumn{2}{|l|}{ Créditos do Projeto } \\
\hline Proprietário / Contratante & Bell Telephone Company \\
\hline Projeto de Arquitetura & Eero Saarinen \\
\hline Projeto Estrutural & Severud-Elstad-Kruger Associates \\
\hline Construção & Frank Briscoe Construction \\
\hline \multicolumn{2}{|l|}{ Dados do Reservatório } \\
\hline Capacidade $\left[\mathrm{m}^{3}\right]$ & 1.135 \\
\hline Forma / Tipologia & Hemisférico \\
\hline Material & Metálico [aço] \\
\hline \multicolumn{2}{|l|}{ Altura $[\mathrm{m}]$} \\
\hline Diâmetro [m] & 21,95 \\
\hline \multicolumn{2}{|l|}{ Altura da Água - h [m] } \\
\hline \multicolumn{2}{|l|}{ Número de Câmaras } \\
\hline \multicolumn{2}{|c|}{ Dados da Estrutura de Apoio do Reservatório } \\
\hline Tipologia & 3 fustes elipticos ôcos \\
\hline Material & Metálico \\
\hline \multicolumn{2}{|l|}{ Altura do Fundo do Reservatório - H [m] } \\
\hline \multicolumn{2}{|l|}{ Altura Efetiva - $\mathrm{H}+\mathrm{h}[\mathrm{m}]$} \\
\hline Altura Total da Torre - Ht [m] & 38,70 \\
\hline \multicolumn{2}{|l|}{ Dados do Revestimento } \\
\hline \multicolumn{2}{|l|}{ Tipo } \\
\hline \multicolumn{2}{|l|}{ Material } \\
\hline \multicolumn{2}{|l|}{ Referências Bibliográficas } \\
\hline Inserções em Bibliografia Específica & nenhum registro encontrado \\
\hline \multirow[t]{2}{*}{ Inserções em Bibliografia Geral } & [TATUM, 2014] \\
\hline & [CALAFATI, 2008] \\
\hline Inserções em Periódicos & [Architectural Record, New York, v. 132, n. 10, out. 1962] \\
\hline
\end{tabular}




\section{Torre dos Laboratórios Bell}

030 Eero Saarinen
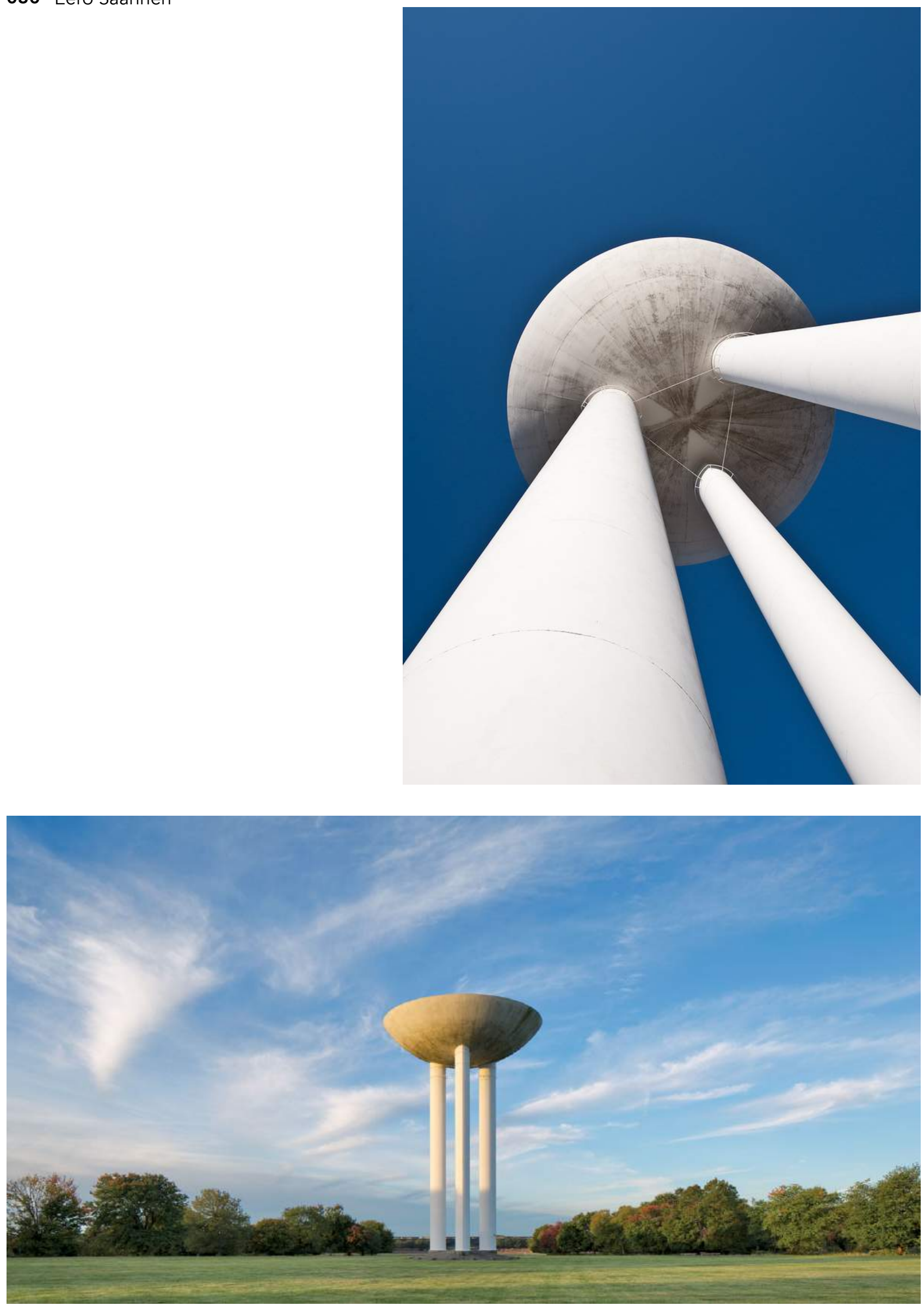
Torre de Khouribga

031 Eduardo Torroja

\begin{tabular}{|c|c|}
\hline \multicolumn{2}{|l|}{ Informacões Gerais } \\
\hline Localização & Khouribga, Marrocos \\
\hline GPS & $32^{\circ} 52^{\prime} 55.39^{\prime \prime} \mathrm{N}-6^{\circ} 54^{\prime} 32.34^{\prime \prime} \mathrm{W}$ \\
\hline Data de Início do Projeto & 1960 \\
\hline Data do Término da Obra & 1962 \\
\hline Uso da Torre & Abastecimento público urbano \\
\hline Situação Atual & Desconhecida \\
\hline \multicolumn{2}{|l|}{ Créditos do Projeto } \\
\hline Proprietário / Contratante & Office Cherifien des Phosphates \\
\hline Projeto de Arquitetura & Eduardo Torroja \\
\hline Projeto Estrutural & Eduardo Torroja \\
\hline Construção & Société Marocaine d'Exploitation des Entreprises Fernández \\
\hline \multicolumn{2}{|l|}{ Dados do Reservatório } \\
\hline Capacidade $\left[m^{3}\right]$ & 600 \\
\hline Forma / Tipologia & Casca cônica com diafragmas radiais \\
\hline Material & Concreto Armado e Protendido \\
\hline Altura $[\mathrm{m}]$ & 7,40 \\
\hline Diâmetro [m] & 25,00 \\
\hline \multicolumn{2}{|l|}{ Altura da Água - h [m] } \\
\hline Número de Câmaras & 8 (interligadas) \\
\hline \multicolumn{2}{|c|}{ Dados da Estrutura de Apoio do Reservatório } \\
\hline \multicolumn{2}{|l|}{ Tipologia } \\
\hline Material & Concreto armado \\
\hline \multicolumn{2}{|l|}{ Altura do Fundo do Reservatório - H [m] } \\
\hline \multicolumn{2}{|l|}{ Altura Efetiva - $\mathrm{H}+\mathrm{h}[\mathrm{m}]$} \\
\hline Altura Total da Torre - Ht [m] & 30,15 \\
\hline \multicolumn{2}{|l|}{ Dados do Revestimento } \\
\hline \multicolumn{2}{|l|}{ Tipo } \\
\hline \multicolumn{2}{|l|}{ Material } \\
\hline \multicolumn{2}{|l|}{ Referências Bibliográficas } \\
\hline Inserções em Bibliografia Específica & nenhum registro encontrado \\
\hline \multirow[t]{2}{*}{ Inserções em Bibliografia Geral } & [CEDEX / CEHOPU, 2008c] \\
\hline & [CEDEX / CEHOPU, 2008d] \\
\hline Inserções em Periódicos & [Informes de La Construcción, Madrid, v. 16, n. 157, jan/fev. 1964] \\
\hline
\end{tabular}




\section{Torre de Khouribga}

031 Eduardo Torroja
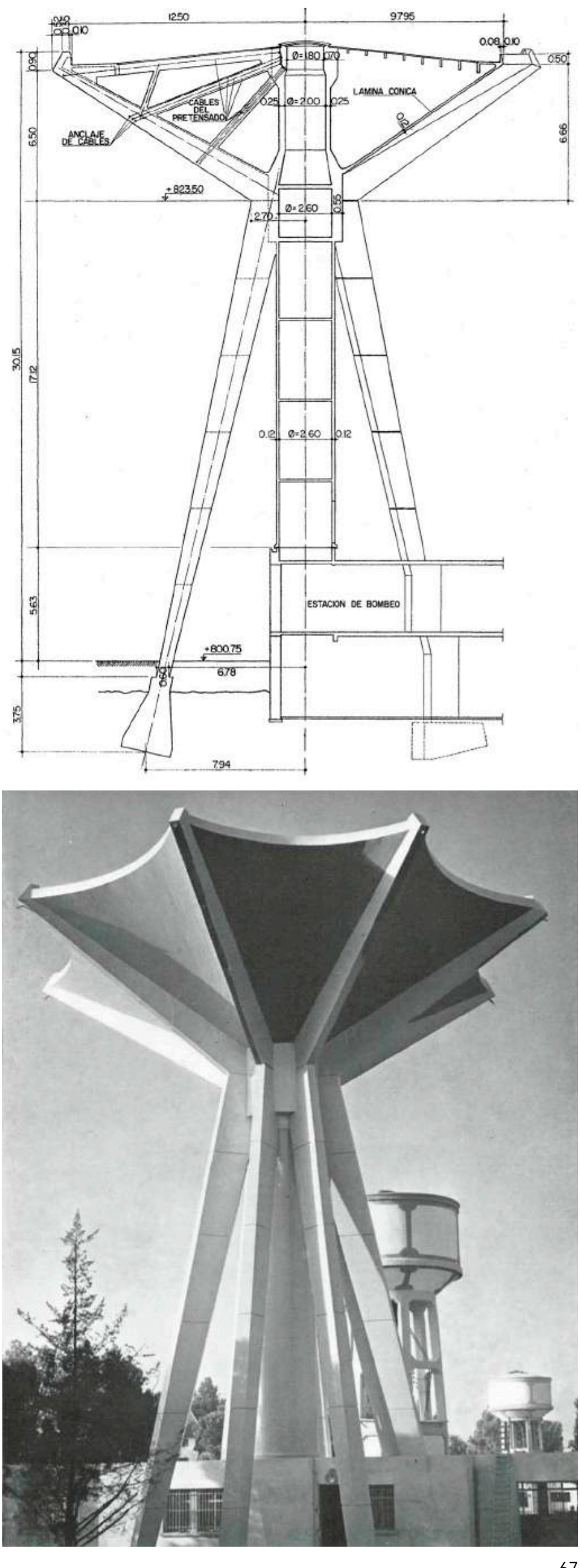
Torre da Fábrica FIAT Mirafiori

032 Pier Luigi Nervi

\begin{tabular}{|c|c|}
\hline \multicolumn{2}{|l|}{ Informacões Gerais } \\
\hline Localização & Turim, Itália \\
\hline GPS & $45^{\circ} 1^{\prime} 27.71 " \mathrm{~N}-7^{\circ} 37^{\prime} 14.10^{\prime \prime} \mathrm{E}$ \\
\hline Data de Início do Projeto & 1961 \\
\hline Data do Término da Obra & 1963 \\
\hline Uso da Torre & Abastecimento industrial \\
\hline Situação Atual & Operacional \\
\hline \multicolumn{2}{|l|}{ Créditos do Projeto } \\
\hline Proprietário / Contratante & Servizio Costruzioni e Impianti Fiat \\
\hline Projeto de Arquitetura & Pier Luigi Nervi \\
\hline Projeto Estrutural & Pier Luigi Nervi \\
\hline Construção & Nervi e Bartoli \\
\hline \multicolumn{2}{|l|}{ Dados do Reservatório } \\
\hline Capacidade $\left[\mathrm{m}^{3}\right]$ & 2.000 \\
\hline Forma / Tipologia & Hiperbólico \\
\hline Material & Concreto armado \\
\hline Altura $[\mathrm{m}]$ & 15,00 \\
\hline Diâmetro máximo [m] & 25,00 \\
\hline Altura da Água - h [m] & 14,50 \\
\hline Número de Câmaras & 1 \\
\hline \multicolumn{2}{|c|}{ Dados da Estrutura de Apoio do Reservatório } \\
\hline Tipologia & Fuste central cilíndrico ôco \\
\hline Material & Concreto armado \\
\hline Altura do Fundo do Reservatório - H [m] & 45,00 \\
\hline Altura Efetiva $-\mathrm{H}+\mathrm{h}[\mathrm{m}]$ & 59,50 \\
\hline Altura Total da Torre - Ht [m] & 63,00 \\
\hline \multicolumn{2}{|l|}{ Dados do Revestimento } \\
\hline Tipo & Painéis pré-fabricados \\
\hline Material & Ferrocimento \\
\hline \multicolumn{2}{|l|}{ Referências Bibliográficas } \\
\hline Inserções em Bibliografia Específica & nenhum registro encontrado \\
\hline Inserções em Bibliografia Geral & [COMBA, 2011] \\
\hline \multirow[t]{2}{*}{ Inserções em Periódicos } & [Revista D.A.E., São Paulo, v. 28, n. 70, dez. 1968] \\
\hline & [Informes de La Construcción, Madrid, v. 18, n. 172, jul. 1965] \\
\hline
\end{tabular}


Torre da Fábrica FIAT Mirafiori

032 Pier Luigi Nervi
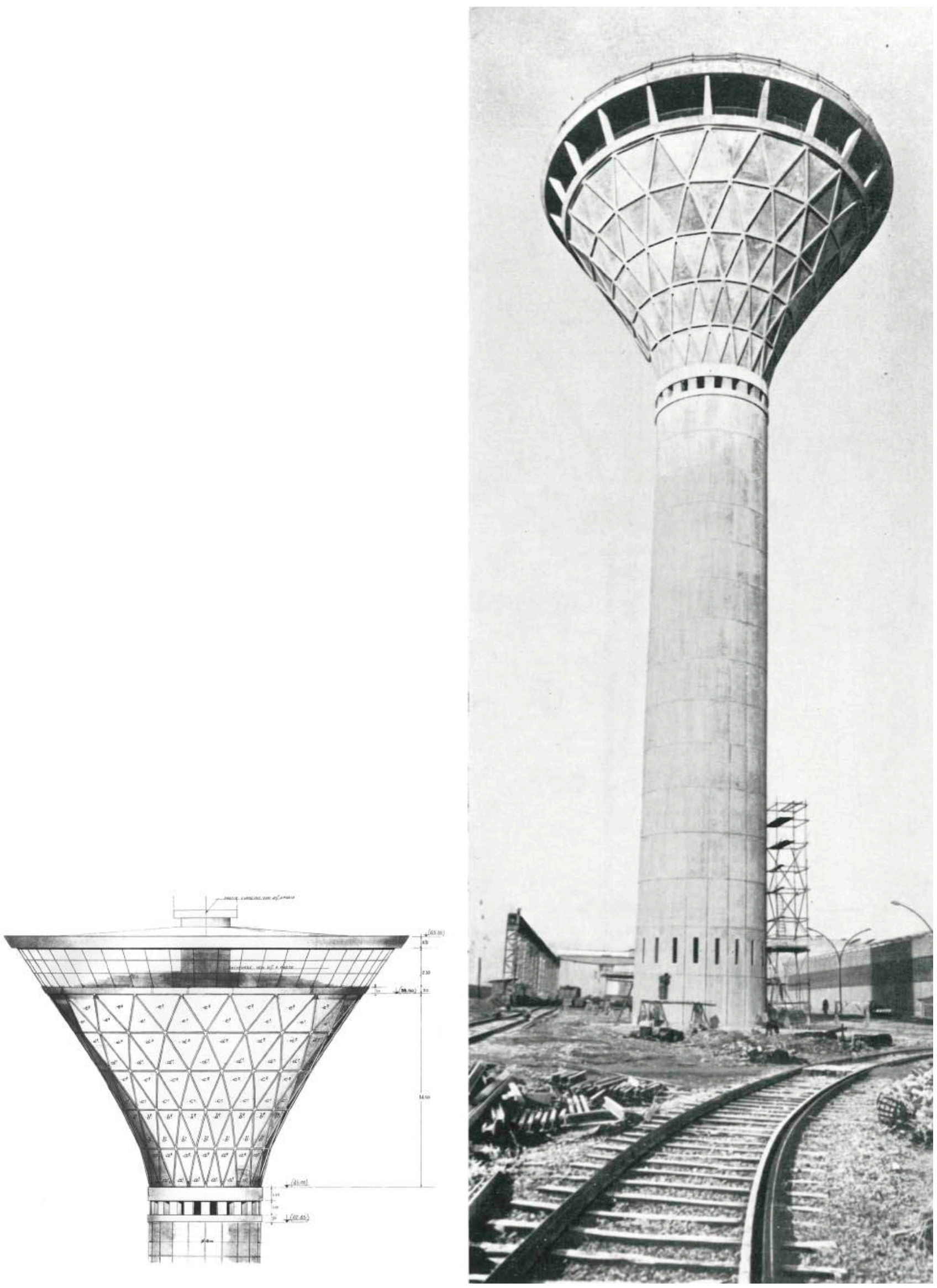
Centro Idrico della Cecchina

033 Francesco Palpacelli

\begin{tabular}{|c|c|}
\hline \multicolumn{2}{|l|}{ Informacões Gerais } \\
\hline Localização & Bufallota, Roma, Itália \\
\hline GPS & $41^{\circ} 57^{\prime} 24.52^{\prime \prime} \mathrm{N}-12^{\circ} 32^{\prime} 44.70^{\prime \prime} \mathrm{E}$ \\
\hline Data de Início do Projeto & 1959 \\
\hline Data do Término da Obra & 1964 \\
\hline Uso da Torre & Abastecimento público urbano \\
\hline Situação Atual & Operacional \\
\hline \multicolumn{2}{|l|}{ Créditos do Projeto } \\
\hline Proprietário / Contratante & ACEA - Azienda Comunale Elettricità e Acque \\
\hline Projeto de Arquitetura & Francesco Palpacelli \\
\hline \multicolumn{2}{|l|}{ Projeto Estrutural } \\
\hline \multicolumn{2}{|l|}{ Construção } \\
\hline \multicolumn{2}{|l|}{ Dados do Reservatório } \\
\hline Capacidade $\left[\mathrm{m}^{3}\right]$ & 0 \\
\hline Forma / Tipologia & Troncônico / Fundo plano \\
\hline Material & Concreto armado \\
\hline Altura $[\mathrm{m}]$ & 5,60 \\
\hline Diâmetro máximo [m] & 20,30 \\
\hline \multicolumn{2}{|l|}{ Altura da Água - h [m] } \\
\hline Número de Câmaras & 1 \\
\hline \multicolumn{2}{|c|}{ Dados da Estrutura de Apoio do Reservatório } \\
\hline Tipologia & 3 pilares cilíndricos ôcos \\
\hline Material & Concreto armado \\
\hline Altura do Fundo do Reservatório - H [m] & 31,25 \\
\hline Altura Efetiva - $\mathrm{H}+\mathrm{h}[\mathrm{m}]$ & 34,55 \\
\hline Altura Total da Torre - Ht [m] & 50,15 \\
\hline \multicolumn{2}{|l|}{ Dados do Revestimento } \\
\hline \multicolumn{2}{|l|}{ Tipo } \\
\hline \multicolumn{2}{|l|}{ Material } \\
\hline \multicolumn{2}{|l|}{ Referências Bibliográficas } \\
\hline Inserções em Bibliografia Específica & nenhum registro encontrado \\
\hline Inserções em Bibliografia Geral & [MURATORE, 2007] \\
\hline Inserções em Periódicos & nenhum registro encontrado \\
\hline
\end{tabular}


Centro Idrico della Cecchina

033 Francesco Palpacelli
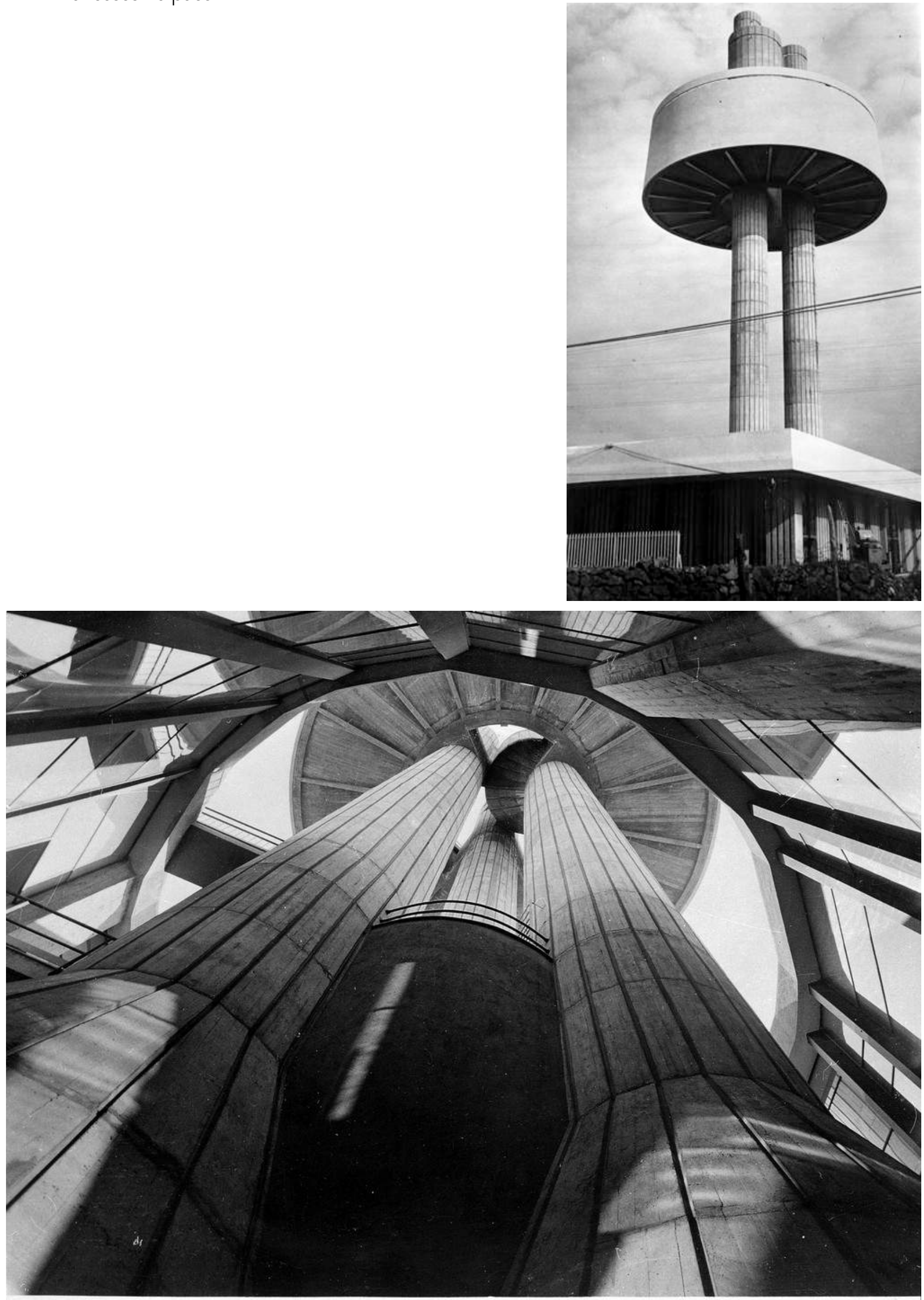
Torre de Myllypuro

034 Bertel Saarnio

\begin{tabular}{|c|c|}
\hline Informacões Gerais & \\
\hline Localização & Helsinque, Finlândia \\
\hline GPS & $60^{\circ} 13^{\prime} 5.29^{\prime \prime} \mathrm{N}-25^{\circ} 3^{\prime} 19.74^{\prime \prime} \mathrm{E}$ \\
\hline Data de Início do Projeto & \\
\hline Data do Término da Obra & 1965 \\
\hline Uso da Torre & Abastecimento público urbano \\
\hline Situação Atual & Operacional \\
\hline Créditos do Projeto & \\
\hline Proprietário / Contratante & \\
\hline Projeto de Arquitetura & Bertel Saarnio \\
\hline Projeto Estrutural & Paavo Simula \\
\hline Construção & Silta e Satama Oy \\
\hline Dados do Reservatório & \\
\hline Capacidade $\left[\mathrm{m}^{3}\right]$ & 13.500 \\
\hline Forma / Tipologia & Troncônico / Cogumelo \\
\hline Material & Concreto protendido \\
\hline Altura $[\mathrm{m}]$ & \\
\hline Diâmetro máximo $[\mathrm{m}]$ & 0 \\
\hline Altura da Água - h [m] & \\
\hline Número de Câmaras & 3 \\
\hline Dados da Estrutura de Apoio do R & \\
\hline Tipologia & Fuste cilíndrico ôco \\
\hline Material & Concreto armado \\
\hline Altura do Fundo do Reservatório - $\mathrm{H}$ & \\
\hline Altura Efetiva $-\mathrm{H}+\mathrm{h}[\mathrm{m}]$ & 30,00 e 47,50 \\
\hline Altura Total da Torre - Ht [m] & 49,50 \\
\hline Dados do Revestimento & \\
\hline Tipo & \\
\hline Material & \\
\hline Referências Bibliográficas & \\
\hline Inserções em Bibliografia Específica & [ASOLA, 2003] \\
\hline Inserções em Bibliografia Geral & nenhum registro encontrado \\
\hline Inserções em Periódicos & nenhum registro encontrado \\
\hline
\end{tabular}



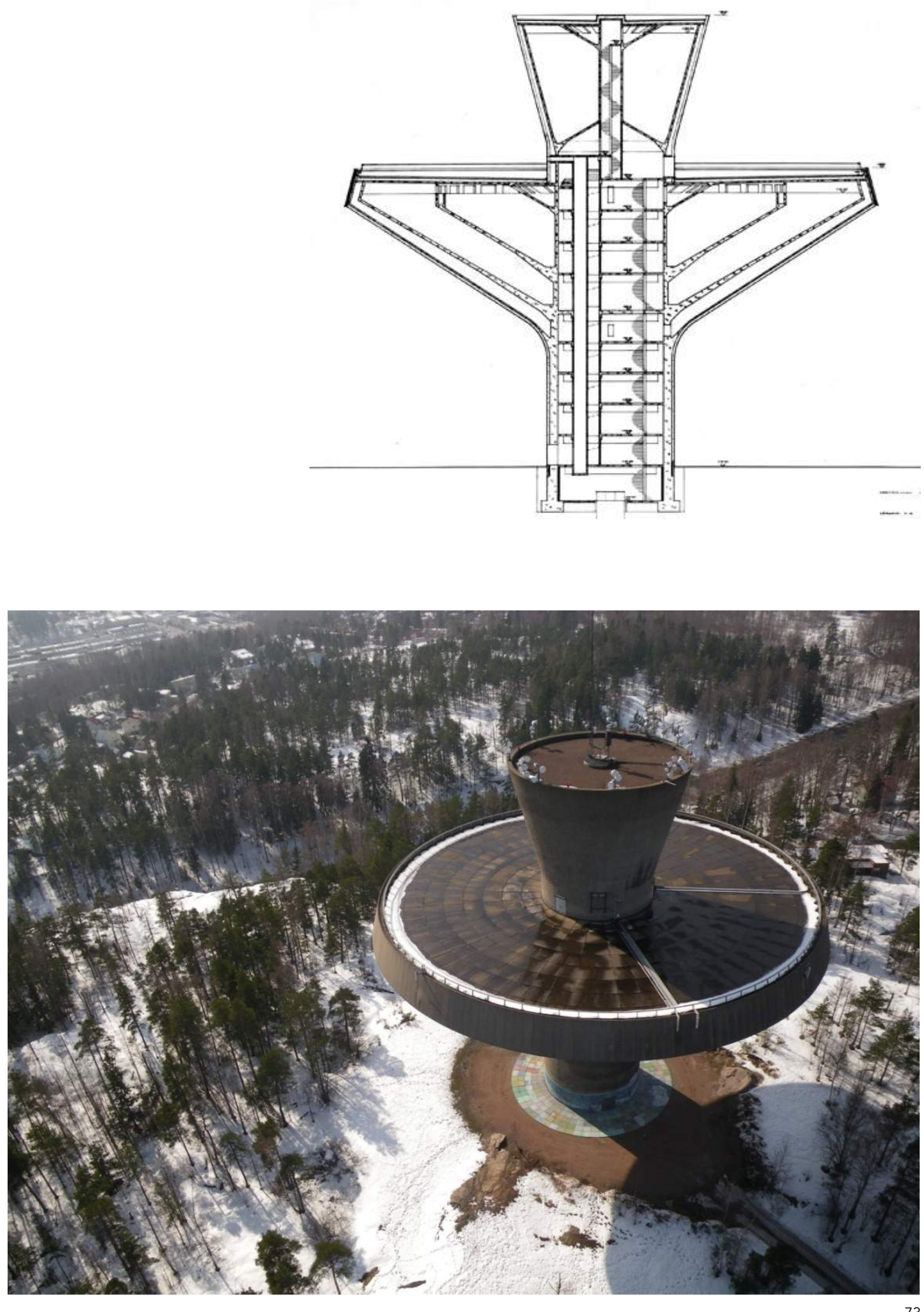
Torre de Möglingen

035 R. Kessler

\begin{tabular}{|c|c|}
\hline \multicolumn{2}{|l|}{ Informacões Gerais } \\
\hline Localização & Möglingen, Baden-Württemberg, Alemanha \\
\hline GPS & $48^{\circ} 52^{\prime} 17.70^{\prime \prime} \mathrm{N}-9^{\circ} 8^{\prime} 17.07 \mathrm{\prime E}$ \\
\hline Data de Início do Projeto & 1964 \\
\hline Data do Término da Obra & 1965 \\
\hline Uso da Torre & Abastecimento público urbano \\
\hline Situação Atual & Operacional \\
\hline \multicolumn{2}{|l|}{ Créditos do Projeto } \\
\hline Proprietário / Contratante & Município de Möglingen \\
\hline Projeto de Arquitetura & R. Kessler \\
\hline Projeto Estrutural & F. Cenek \\
\hline Construção & Ludwig Bauer \\
\hline \multicolumn{2}{|l|}{ Dados do Reservatório } \\
\hline Capacidade $\left[\mathrm{m}^{3}\right]$ & 400 \\
\hline Forma / Tipologia & Hiperbólico \\
\hline Material & Concreto armado \\
\hline \multicolumn{2}{|l|}{ Altura $[\mathrm{m}]$} \\
\hline Diâmetro máximo [m] & 15,50 \\
\hline Diâmetro mínimo [m] & 9,60 \\
\hline \multicolumn{2}{|l|}{ Altura da Água - h [m] } \\
\hline Número de Câmaras & 1 \\
\hline \multicolumn{2}{|c|}{ Dados da Estrutura de Apoio do Reservatório } \\
\hline Tipologia & Paredes estruturais e estrutura treliçada hiperbólica \\
\hline Material & Concreto armado \\
\hline \multicolumn{2}{|c|}{ Altura do Fundo do Reservatório - H [m] } \\
\hline \multicolumn{2}{|l|}{ Altura Efetiva $-\mathrm{H}+\mathrm{h}[\mathrm{m}]$} \\
\hline Altura Total da Torre - Ht [m] & 36,00 \\
\hline \multicolumn{2}{|l|}{ Dados do Revestimento } \\
\hline Tipo & \\
\hline Material & \\
\hline
\end{tabular}

Referências Bibliográficas

Inserções em Bibliografia Específica

[BECHER, 1988]

Inserções em Bibliografia Geral

nenhum registro encontrado

Inserções em Periódicos

[VA-tidskriften Cirkulation. Örebro, jul. 2011] 
Torre de Möglingen

035 R. Kessler
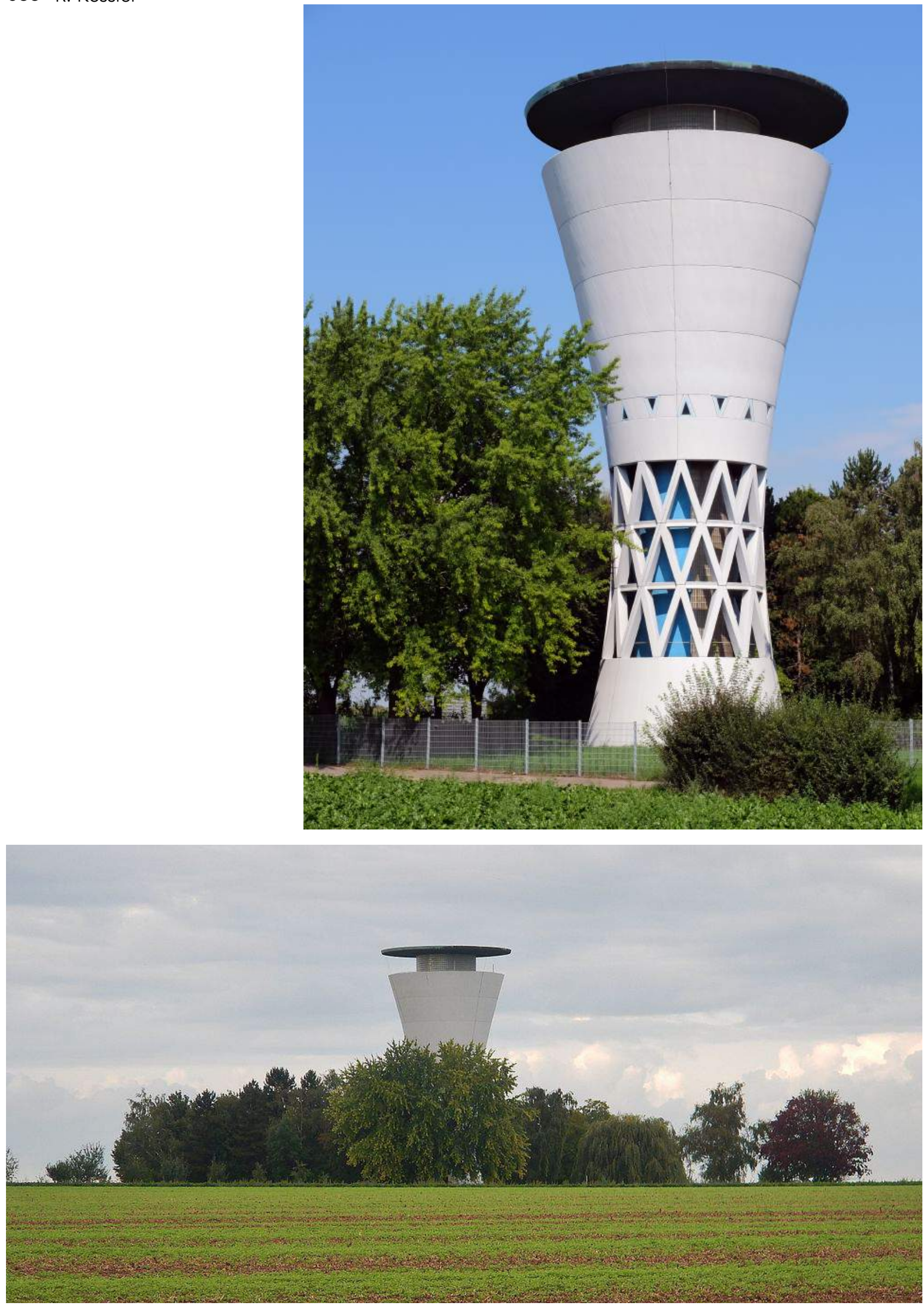
Torre do Balneário Las Vegas

036 Eladio Dieste

\begin{tabular}{|c|c|}
\hline \multicolumn{2}{|l|}{ Informacões Gerais } \\
\hline Localização & Canelones, Uruguai \\
\hline GPS & $34^{\circ} 45^{\prime} 3.28^{\prime \prime} \mathrm{S}-55^{\circ} 41^{\prime} 44.89^{\prime \prime} \mathrm{W}$ \\
\hline Data de Início do Projeto & 1964 \\
\hline Data do Término da Obra & 1966 \\
\hline Uso da Torre & Abastecimento público urbano \\
\hline Situação Atual & Operacional \\
\hline \multicolumn{2}{|l|}{ Créditos do Projeto } \\
\hline Proprietário / Contratante & Comisión Balneario Las Vegas \\
\hline Projeto de Arquitetura & Eladio Dieste \\
\hline Projeto Estrutural & Eladio Dieste \\
\hline Construção & Dieste y Montañez S.A. \\
\hline \multicolumn{2}{|l|}{ Dados do Reservatório } \\
\hline Capacidade $\left[\mathrm{m}^{3}\right]$ & 120 \\
\hline Forma / Tipologia & Tronco de cone / Fundo troncônico \\
\hline Material & Alvenaria \\
\hline \multicolumn{2}{|l|}{ Altura $[\mathrm{m}]$} \\
\hline \multicolumn{2}{|l|}{ Diâmetro Máximo [m] } \\
\hline \multicolumn{2}{|l|}{ Altura da Água - h [m] } \\
\hline Número de Câmaras & 1 \\
\hline \multicolumn{2}{|c|}{ Dados da Estrutura de Apoio do Reservatório } \\
\hline Tipologia & Fuste troncônico ôco em alvenaria \\
\hline Material & Tijolos de barro \\
\hline \multicolumn{2}{|l|}{ Altura do Fundo do Reservatório - H [m] } \\
\hline \multicolumn{2}{|l|}{ Altura Efetiva - $\mathrm{H}+\mathrm{h}[\mathrm{m}]$} \\
\hline Altura Total da Torre - Ht [m] & 27,00 \\
\hline \multicolumn{2}{|l|}{ Dados do Revestimento } \\
\hline \multicolumn{2}{|l|}{ Tipo } \\
\hline \multicolumn{2}{|l|}{ Material } \\
\hline \multicolumn{2}{|l|}{ Referências Bibliográficas } \\
\hline Inserções em Bibliografia Específica & nenhum registro encontrado \\
\hline \multirow[t]{2}{*}{ Inserções em Bibliografia Geral } & [ANDERSON, 2004] \\
\hline & [TORRECILLAS, 1996] \\
\hline Inserções em Periódicos & [A+U: Architecture and Urbanism, Tokyo, n. 395, ago. 2003] \\
\hline
\end{tabular}



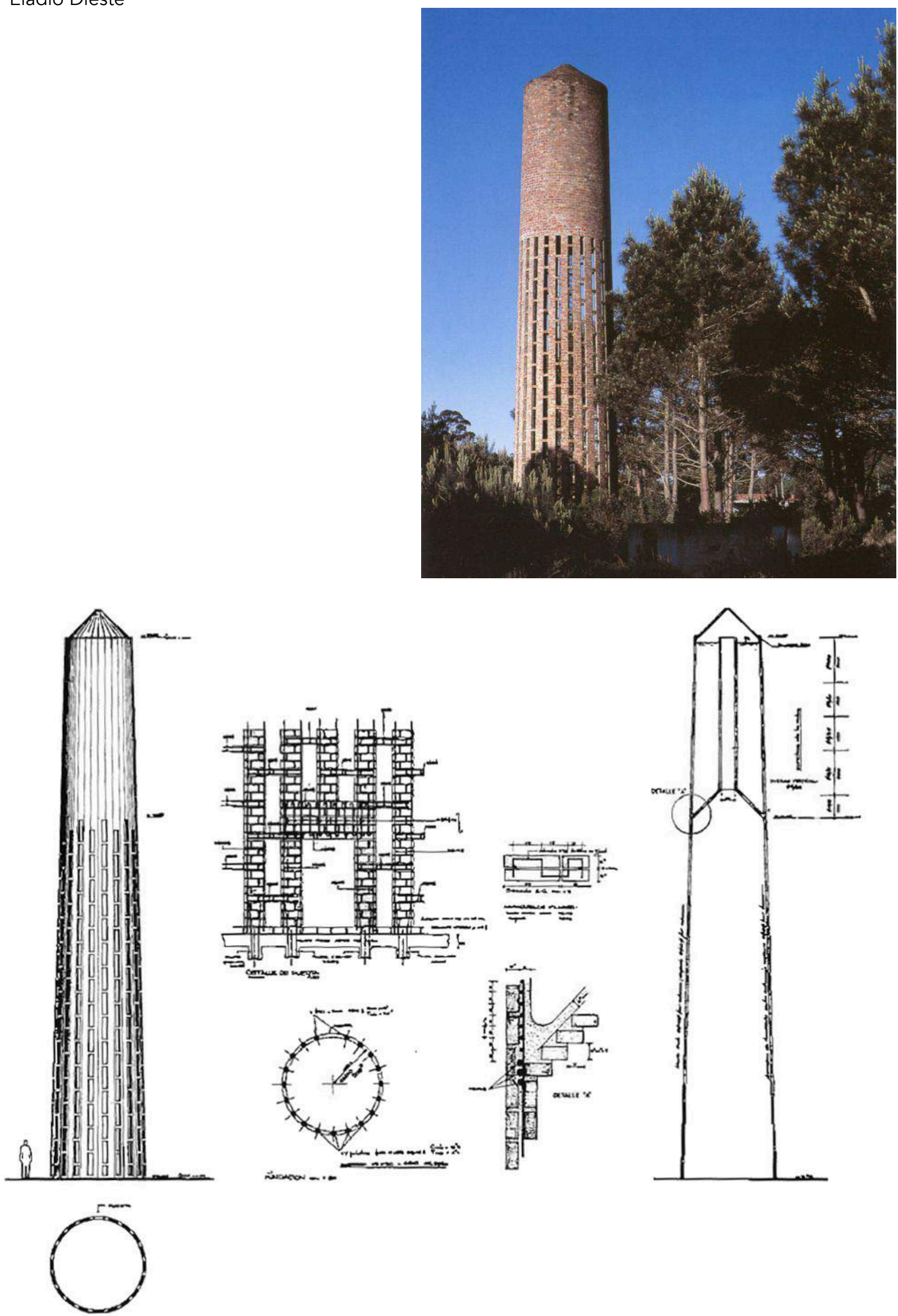
Torres de Alençon

037 Serge Ketoff + Maurice Novarina

\begin{tabular}{|c|c|}
\hline \multicolumn{2}{|l|}{ Informacões Gerais } \\
\hline Localização & Alençon, Baixa Normandia, França \\
\hline GPS & $48^{\circ} 26^{\prime} 54.23^{\prime \prime} \mathrm{N}-0^{\circ} 5^{\prime} 16.47^{\prime \prime} \mathrm{E}$ \\
\hline Data de Início do Projeto & 1960 \\
\hline Data do Término da Obra & 1967 \\
\hline Uso da Torre & Abastecimento público urbano \\
\hline Situação Atual & Operacional \\
\hline \multicolumn{2}{|l|}{ Créditos do Projeto } \\
\hline Proprietário / Contratante & Ville d'Alençon \\
\hline Projeto de Arquitetura & Serge Ketoff + Maurice Novarina \\
\hline Projeto Estrutural & Serge Ketoff \\
\hline \multicolumn{2}{|l|}{ Construção } \\
\hline \multicolumn{2}{|l|}{ Dados do Reservatório } \\
\hline Capacidade $\left[\mathrm{m}^{3}\right]$ & $3 \times 2.000$ \\
\hline Forma / Tipologia & Troncônico \\
\hline Material & Concreto armado \\
\hline Altura $[\mathrm{m}]$ & 10,80 \\
\hline Diâmetro máximo [m] & 25,00 \\
\hline Diâmetro mínimo [m] & 11,00 \\
\hline Altura da Água - h [m] & 8,50 \\
\hline Número de Câmaras & 1 \\
\hline \multicolumn{2}{|c|}{ Dados da Estrutura de Apoio do Reservatório } \\
\hline Tipologia & Fuste cônico ôco e suportes oblíquos \\
\hline Material & Concreto armado \\
\hline Altura do Fundo do Reservatório - H [m] & 31,5 \\
\hline Altura Efetiva - $\mathrm{H}+\mathrm{h}[\mathrm{m}]$ & 39,50 \\
\hline Altura Total da Torre - Ht [m] & 42,60 \\
\hline \multicolumn{2}{|l|}{ Dados do Revestimento } \\
\hline Tipo & \\
\hline Material & \\
\hline
\end{tabular}

Referências Bibliográficas

Inserções em Bibliografia Específica

[MERKL, 1985]

Inserções em Bibliografia Geral

[Informes de La Construcción, Madrid, v. 25, n. 246, dez. 1972]

Inserções em Periódicos

nenhum registro encontrado 
Torres de Alençon

037 Serge Ketoff + Maurice Novarina
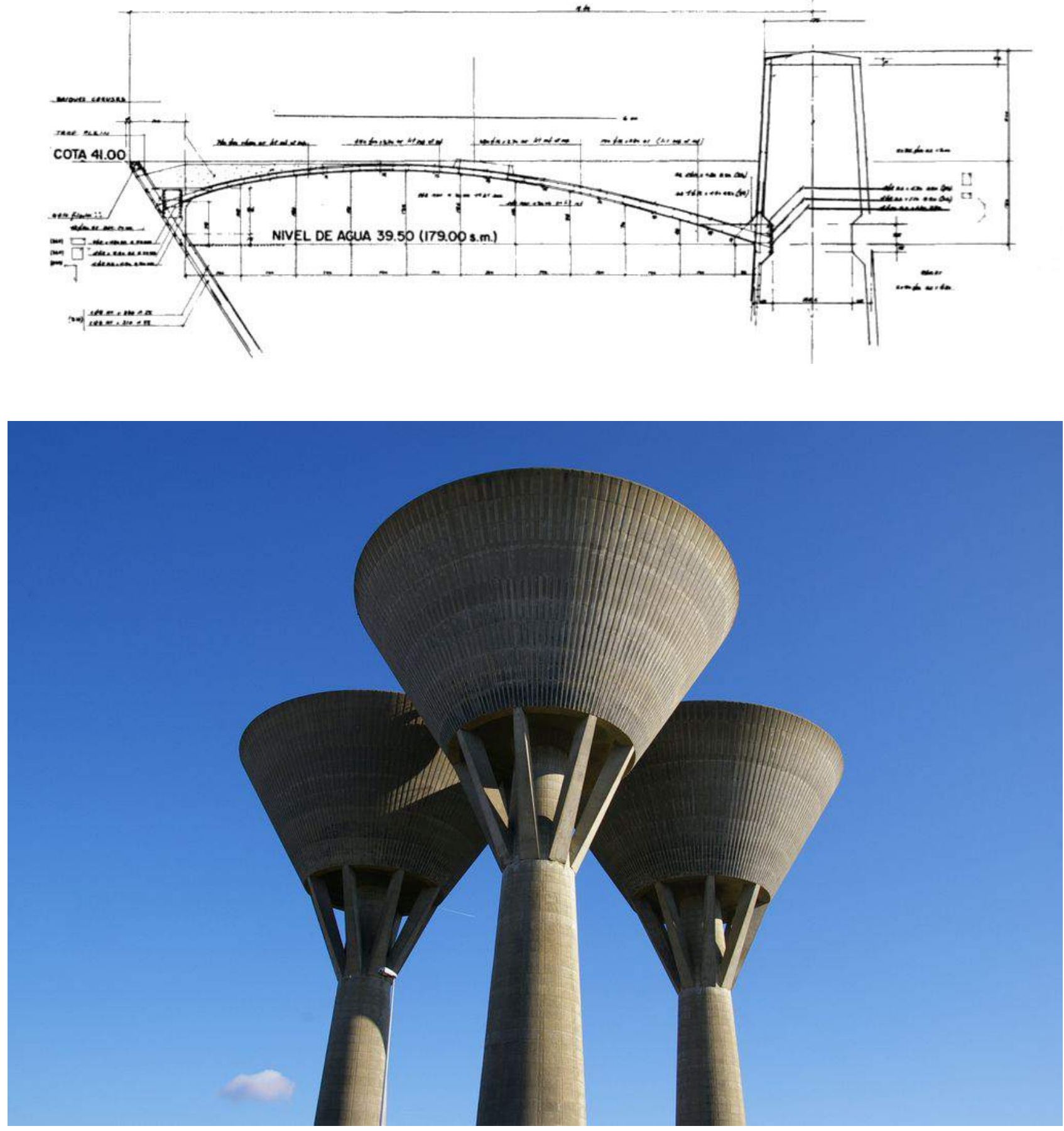
Reservatório Elevado de Urânia

038 Paulo Mendes da Rocha

\begin{tabular}{|c|c|}
\hline Informacões Gerais & \\
\hline Localização & Urânia, São Paulo, SP \\
\hline GPS & N/A \\
\hline Data de Início do Projeto & 1968 \\
\hline Data do Término da Obra & Não construído \\
\hline Uso da Torre & Abastecimento público urbano \\
\hline Situação Atual & $\mathrm{N} / \mathrm{A}$ \\
\hline Créditos do Projeto & \\
\hline Proprietário / Contratante & DOP - Departamento de Obras e Projetos \\
\hline Projeto de Arquitetura & Paulo Mendes da Rocha \\
\hline Projeto Estrutural & Julio Cerqueira César Neto \\
\hline Construção & N/A \\
\hline Dados do Reservatório & \\
\hline Capacidade $\left[\mathrm{m}^{3}\right]$ & 500 \\
\hline Forma / Tipologia & Cilíndrico / Fundo plano \\
\hline Material & Concreto armado \\
\hline Altura $[\mathrm{m}]$ & \\
\hline Diâmetro $[\mathrm{m}]$ & 5,00 \\
\hline Altura da Água - h [m] & \\
\hline Número de Câmaras & 3 \\
\hline Dados da Estrutura de Apoio do R & \\
\hline Tipologia & Paredes estruturais \\
\hline Material & Concreto armado \\
\hline Altura do Fundo do Reservatório - $\mathrm{H}$ & \\
\hline Altura Efetiva - $\mathrm{H}+\mathrm{h}[\mathrm{m}]$ & \\
\hline Altura Total da Torre - Ht [m] & 40,00 \\
\hline Dados do Revestimento & \\
\hline Tipo & \\
\hline Material & \\
\hline Referências Bibliográficas & \\
\hline Inserções em Bibliografia Específica & nenhum registro encontrado \\
\hline Inserções em Bibliografia Geral & [PISANI, 2013] \\
\hline & [ROCHA, 2007] \\
\hline & [ARTIGAS, 2006] \\
\hline Inserções em Periódicos & nenhum registro encontrado \\
\hline
\end{tabular}


Reservatório Elevado de Urânia

Paulo Mendes da Rocha
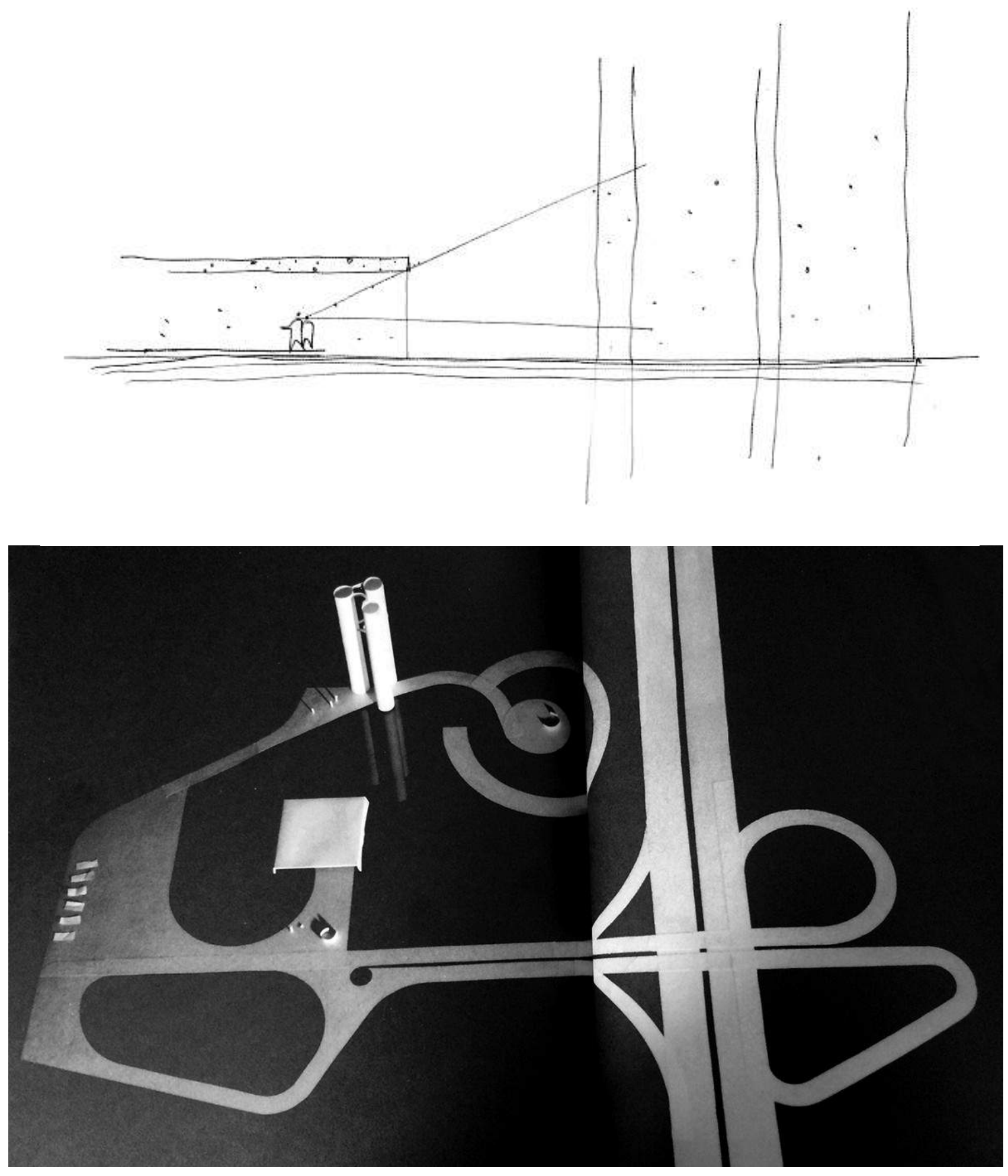
Torre de Haukilahti

039 Erkko Virkkunen

\begin{tabular}{ll}
\hline Informacões Gerais & \\
\hline Localização & Haukilahti, Espoo, Finlândia \\
GPS & $60^{\circ} 9^{\prime} 41.41$ "N $-24^{\circ} 45^{\prime} 53.83^{\prime \prime} \mathrm{E}$ \\
Data de Início do Projeto & 1967 \\
Data do Término da Obra & 1968 \\
Uso da Torre & Abastecimento público urbano \\
Situação Atual & Operacional \\
\hline Créditos do Projeto & \\
\hline Proprietário / Contratante & Espoo Commercial Waterworks \\
Projeto de Arquitetura & Erkko Virkkunen \\
Projeto Estrutural & Ilmari Hyppänen \\
Construção & Vesipojat Oy, Vesi-Pekka Oy eTuomas Savolainen \\
\hline Dados do Reservatório & \\
\hline Capacidade [m ${ }^{3}$ ] & 4.100 \\
Forma / Tipologia & Hemisférico \\
Material & Concreto protendido \\
Altura [m] & \\
Diâmetro máximo [m] & 45,00 \\
Altura da Água - h [m] & \\
Número de Câmaras & 2 (1.200 + 2.900) \\
\hline
\end{tabular}

Dados da Estrutura de Apoio do Reservatório

Tipologia Fuste central cilíndrico ôco e seis colunas circulares

Material

Concreto armado

Altura do Fundo do Reservatório - H [m]

Altura Efetiva - H + h [m] 37,00

Altura Total da Torre - Ht [m] $\quad 45,40$

\begin{tabular}{ll}
\hline Dados do Revestimento & \\
\hline Tipo & Casca pré-fabricada \\
Material & Concreto protendido \\
\hline
\end{tabular}

Referências Bibliográficas

Inserções em Bibliografia Específica

[MERKL, 1985]

Inserções em Bibliografia Geral

[PROKKOLA, 2010]

Inserções em Periódicos

[Betoni, Helsinki, v. 82, n. 4, out/nov/dez. 2012] 
Torre de Haukilahti

039 Erkko Virkkunen
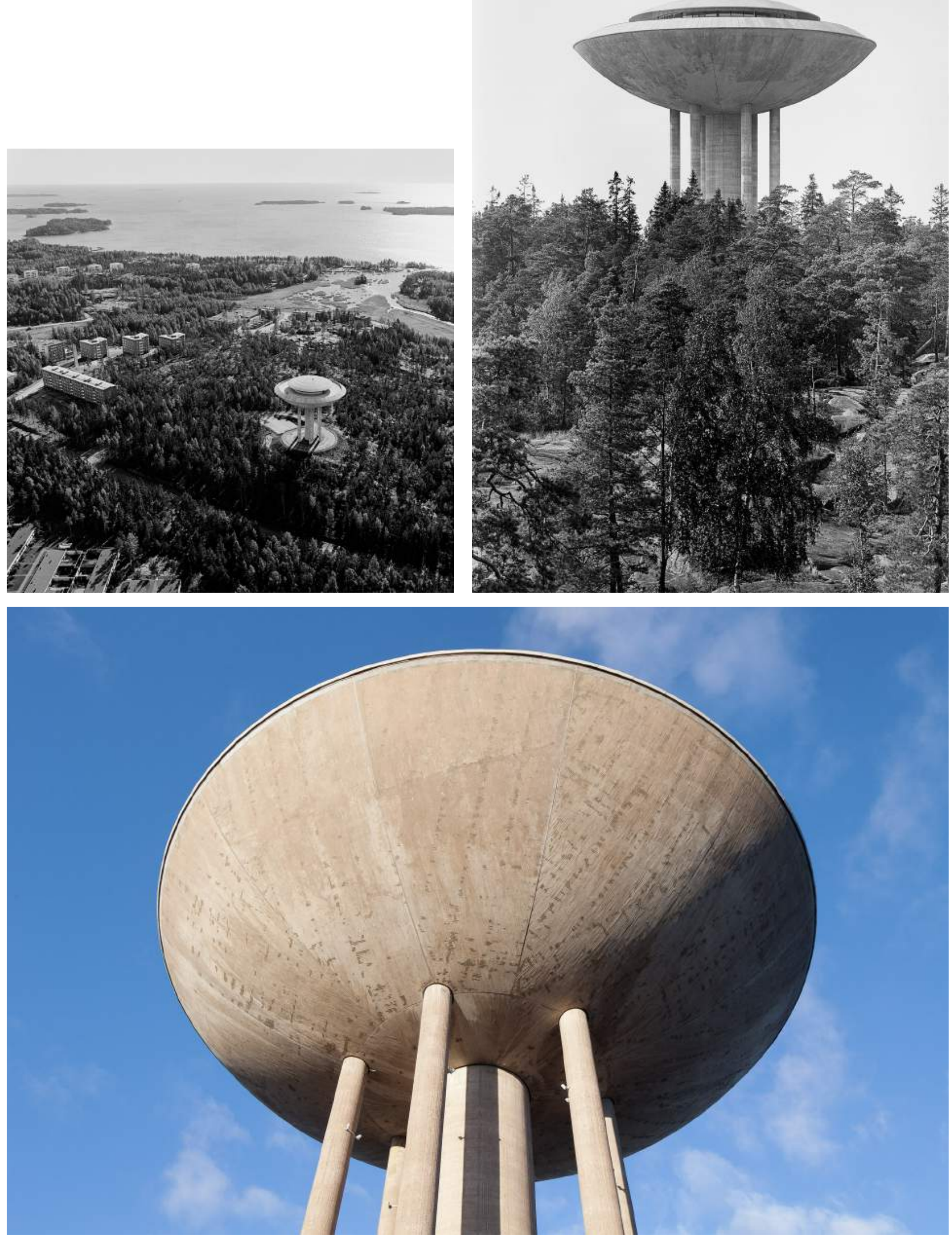
Torre de Cockfosters

040 Edmund C. Percey

\begin{tabular}{|c|c|}
\hline Informacões Gerais & \\
\hline Localização & Londres, Inglaterra \\
\hline GPS & $51^{\circ} 39^{\prime} 31.68 " \mathrm{~N}-0^{\circ} 9$ ' $8.93 " \mathrm{~W}$ \\
\hline Data de Início do Projeto & \\
\hline Data do Término da Obra & 1968 \\
\hline Uso da Torre & Abastecimento público urbano \\
\hline Situação Atual & Operacional \\
\hline Créditos do Projeto & \\
\hline Proprietário / Contratante & Lee Valley Water Company \\
\hline Projeto de Arquitetura & Edmund C. Percey \\
\hline Projeto Estrutural & J.W. Milne \\
\hline Construção & \\
\hline Dados do Reservatório & \\
\hline Capacidade $\left[\mathrm{m}^{3}\right]$ & 1.130 \\
\hline Forma / Tipologia & Cilíndrico / Fundo plano \\
\hline Material & Concreto armado \\
\hline Altura $[\mathrm{m}]$ & 6,50 \\
\hline Diâmetro máximo [m] & 20,00 \\
\hline Altura da Água - h [m] & \\
\hline Número de Câmaras & \\
\hline Dados da Estrutura de Apoio do Re & \\
\hline Tipologia & Estrutura treliçada hiperbólica \\
\hline Material & Concreto armado \\
\hline Altura do Fundo do Reservatório - $\mathrm{H}$ & \\
\hline Altura Efetiva $-\mathrm{H}+\mathrm{h}[\mathrm{m}]$ & \\
\hline Altura Total da Torre - $\mathrm{Ht}[\mathrm{m}]$ & 25,00 \\
\hline Dados do Revestimento & \\
\hline Tipo & \\
\hline Material & \\
\hline Referências Bibliográficas & \\
\hline Inserções em Bibliografia Específica & [BARTON, 2007] \\
\hline Inserções em Bibliografia Geral & nenhum registro encontrado \\
\hline Inserções em Periódicos & [VA-tidskriften Cirkulation. Örebro, mar. 2010] \\
\hline
\end{tabular}



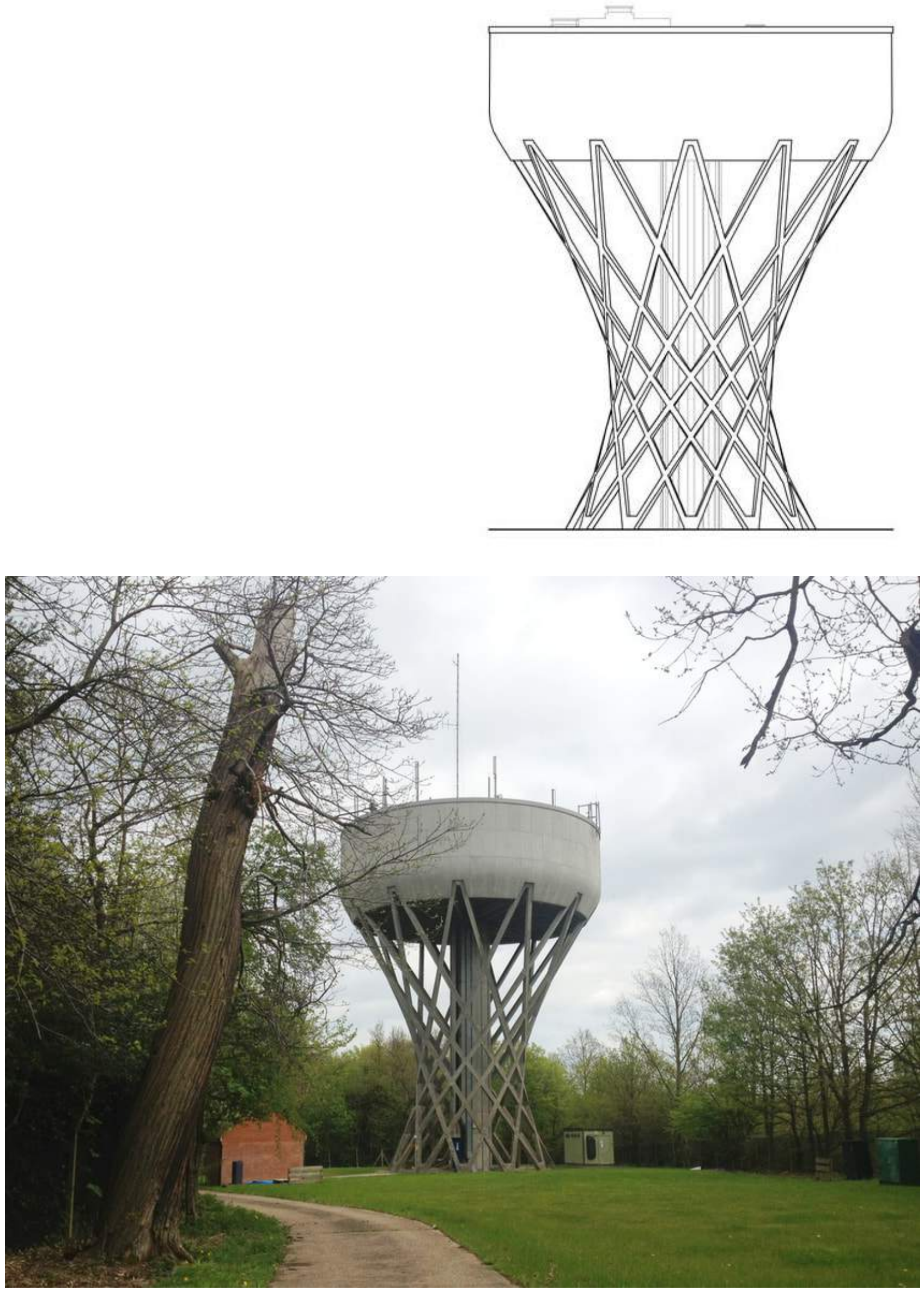
Torre de Maringá

041 Gerhard Leo Linzmeyer

\begin{tabular}{|c|c|}
\hline \multicolumn{2}{|l|}{ Informacões Gerais } \\
\hline Localização & Maringá, Paraná, São Paulo \\
\hline GPS & $23^{\circ} 24^{\prime} 33.87^{\prime \prime} \mathrm{S}-51^{\circ} 55^{\prime} 27.85^{\prime \prime} \mathrm{W}$ \\
\hline Data de Início do Projeto & 1965 \\
\hline Data do Término da Obra & 1969 \\
\hline Uso da Torre & Abastecimento público urbano \\
\hline Situação Atual & Operacional \\
\hline \multicolumn{2}{|l|}{ Créditos do Projeto } \\
\hline Proprietário / Contratante & CODEMAR - Companhia de Desenvolvimento de Maringá \\
\hline Projeto de Arquitetura & Gerhard Leo Linzmeyer \\
\hline \multicolumn{2}{|l|}{ Projeto Estrutural } \\
\hline \multicolumn{2}{|l|}{ Construção } \\
\hline \multicolumn{2}{|l|}{ Dados do Reservatório } \\
\hline Capacidade $\left[\mathrm{m}^{3}\right]$ & 0 \\
\hline Forma / Tipologia & Casca cônica com diafragmas radiais \\
\hline Material & Concreto armado \\
\hline Altura $[\mathrm{m}]$ & 7,00 \\
\hline Diâmetro Máximo [m] & 23,00 \\
\hline Altura da Água - h [m] & 5,15 \\
\hline Número de Câmaras & 8 (interligadas) \\
\hline \multicolumn{2}{|c|}{ Dados da Estrutura de Apoio do Reservatório } \\
\hline Tipologia & Conjunto de pilares travados por vigas \\
\hline Material & Concreto armado \\
\hline Altura do Fundo do Reservatório - H [m] & 24,50 \\
\hline Altura Efetiva - $\mathrm{H}+\mathrm{h}[\mathrm{m}]$ & 29,65 \\
\hline Altura Total da Torre - Ht [m] & 31,50 \\
\hline \multicolumn{2}{|l|}{ Dados do Revestimento } \\
\hline \multicolumn{2}{|l|}{ Tipo } \\
\hline \multicolumn{2}{|l|}{ Material } \\
\hline \multicolumn{2}{|l|}{ Referências Bibliográficas } \\
\hline Inserções em Bibliografia Específica & nenhum registro encontrado \\
\hline Inserções em Bibliografia Geral & [BARBOSA, 2016] \\
\hline Inserções em Periódicos & [Revista D.A.E., São Paulo, v. 28, n. 70, dez. 1968] \\
\hline
\end{tabular}




\section{Torre de Maringá}

041 Gerhard Leo Linzmeyer
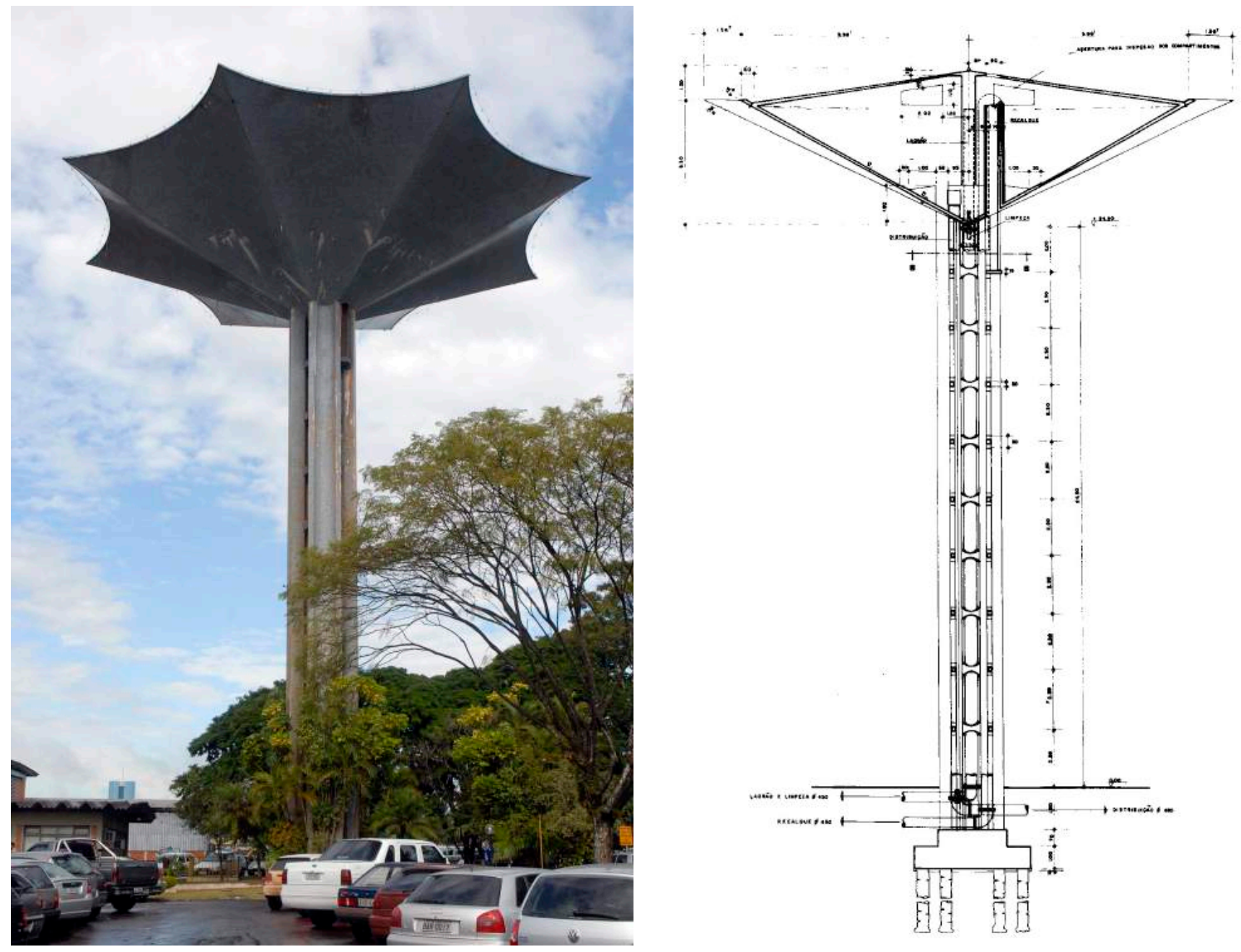
Torre de Eindhoven

042 Win G. Quist

\begin{tabular}{|c|c|}
\hline Informacões Gerais & \\
\hline Localização & Eindhoven, Holanda \\
\hline GPS & $51^{\circ} 24^{\prime} 59.43^{\prime \prime} \mathrm{N}-5^{\circ} 28^{\prime} 46.46^{\prime \prime} \mathrm{E}$ \\
\hline Data de Início do Projeto & 1970 \\
\hline Data do Término da Obra & 1971 \\
\hline Uso da Torre & Abastecimento público urbano \\
\hline Situação Atual & Opercaional \\
\hline Créditos do Projeto & \\
\hline Proprietário / Contratante & Brabant Water \\
\hline Projeto de Arquitetura & Win G. Quist \\
\hline Projeto Estrutural & \\
\hline Construção & D.L. Sluimer \\
\hline Dados do Reservatório & \\
\hline Capacidade $\left[\mathrm{m}^{3}\right]$ & 1.500 \\
\hline Forma / Tipologia & Esférico \\
\hline Material & Metálico [aço] \\
\hline Diâmetro [m] & 10,00 \\
\hline Altura da Água - $\mathrm{h}[\mathrm{m}]$ & \\
\hline Número de Câmaras & $3 \times 500 \mathrm{~m}^{3}$ \\
\hline Dados da Estrutura de Apoio do R & \\
\hline Tipologia & Fuste central treliçado \\
\hline Material & Metálico [aço] \\
\hline Altura do Fundo do Reservatório - $\mathrm{H}$ & \\
\hline Altura Efetiva $-\mathrm{H}+\mathrm{h}[\mathrm{m}]$ & \\
\hline Altura Total da Torre - Ht [m] & 43,45 \\
\hline Dados do Revestimento & \\
\hline Tipo & \\
\hline Material & \\
\hline Referências Bibliográficas & \\
\hline Inserções em Bibliografia Específica & [VEEN, 1989] \\
\hline Inserções em Bibliografia Geral & [VA-tidskriften Cirkulation. Örebro, jan. 1999] \\
\hline Inserções em Periódicos & nenhum registro encontrado \\
\hline
\end{tabular}


Torre de Eindhoven

042 Win G. Quist
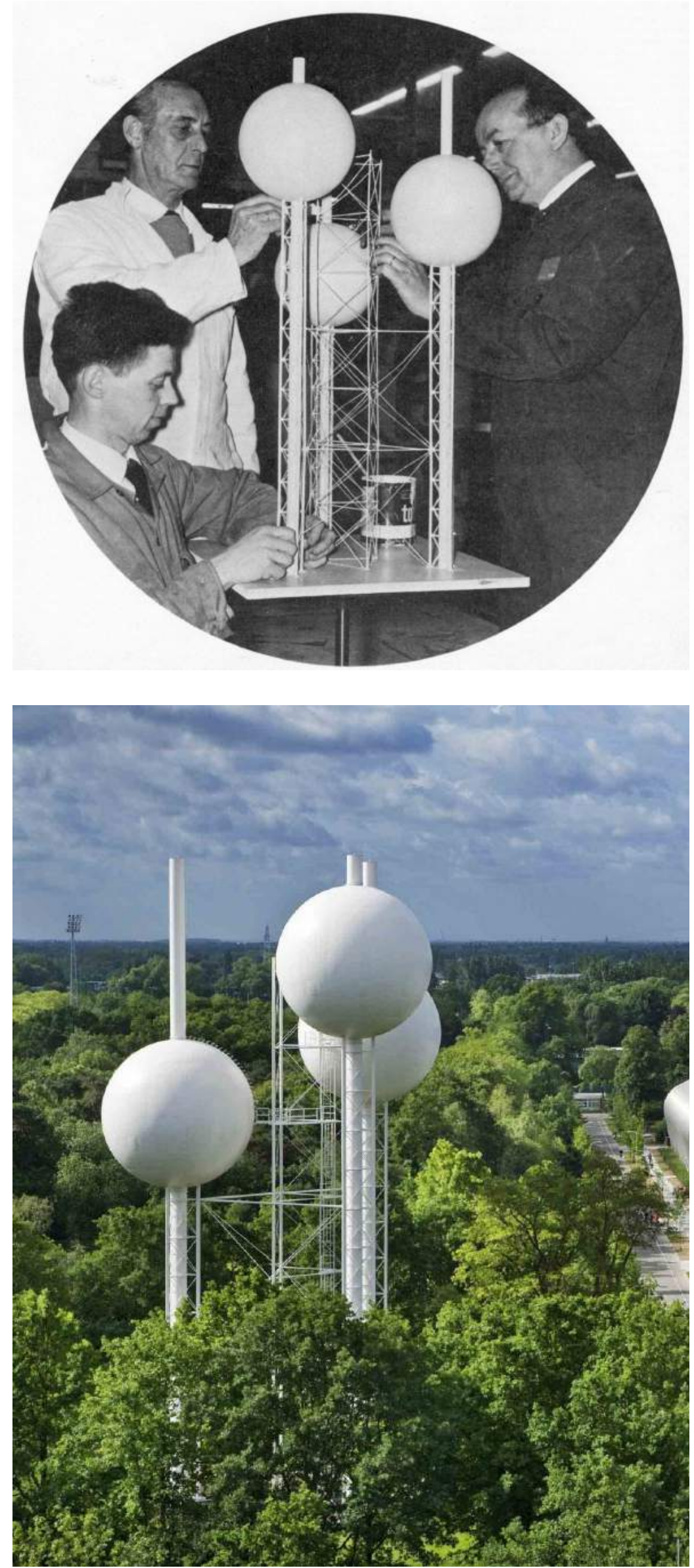
Torre da Politécnica de Otaniemi

043 Alvar Aalto

\begin{tabular}{|c|c|}
\hline \multicolumn{2}{|l|}{ Informacões Gerais } \\
\hline Localização & Otaniemi, Espoo, Finlândia \\
\hline GPS & $60^{\circ} 10^{\prime} 52.45^{\prime \prime} \mathrm{N}-24^{\circ} 49^{\prime} 11.75^{\prime \prime} \mathrm{E}$ \\
\hline Data de Início do Projeto & 1968 \\
\hline Data do Término da Obra & 1971 \\
\hline Uso da Torre & Abastecimento público urbano \\
\hline Situação Atual & Operacional \\
\hline \multicolumn{2}{|l|}{ Créditos do Projeto } \\
\hline Proprietário / Contratante & HSY - Helsinki Region Environmental Services Authority \\
\hline Projeto de Arquitetura & Alvar Aalto \\
\hline \multicolumn{2}{|l|}{ Projeto Estrutural } \\
\hline \multicolumn{2}{|l|}{ Construção } \\
\hline \multicolumn{2}{|l|}{ Dados do Reservatório } \\
\hline Capacidade $\left[\mathrm{m}^{3}\right]$ & 6.000 \\
\hline Forma / Tipologia & Prismático / Fundo Plano \\
\hline Material & Concreto armado \\
\hline \multicolumn{2}{|l|}{ Altura $[\mathrm{m}]$} \\
\hline Diâmetro máximo [m] & 38,00 \\
\hline \multicolumn{2}{|l|}{ Altura da Água - h [m] } \\
\hline Número de Câmaras & $2 \times 3.000 \mathrm{~m}^{3}$ \\
\hline \multicolumn{2}{|c|}{ Dados da Estrutura de Apoio do Reservatório } \\
\hline Tipologia & Fuste central cilíndrico ôco e 12 pilares retangulares \\
\hline Material & Concreto armado \\
\hline \multicolumn{2}{|l|}{ Altura do Fundo do Reservatório - H [m] } \\
\hline \multicolumn{2}{|l|}{ Altura Efetiva - H + h [m] } \\
\hline Altura Total da Torre - Ht [m] & 45,00 \\
\hline \multicolumn{2}{|l|}{ Dados do Revestimento } \\
\hline \multicolumn{2}{|l|}{ Tipo } \\
\hline \multicolumn{2}{|l|}{ Material } \\
\hline \multicolumn{2}{|l|}{ Referências Bibliográficas } \\
\hline Inserções em Bibliografia Específica & [ASOLA, 2003] \\
\hline \multirow[t]{2}{*}{ Inserções em Bibliografia Geral } & [HIPELI, 2008] \\
\hline & [FLEIG, 1994] \\
\hline Inserções em Periódicos & nenhum registro encontrado \\
\hline
\end{tabular}



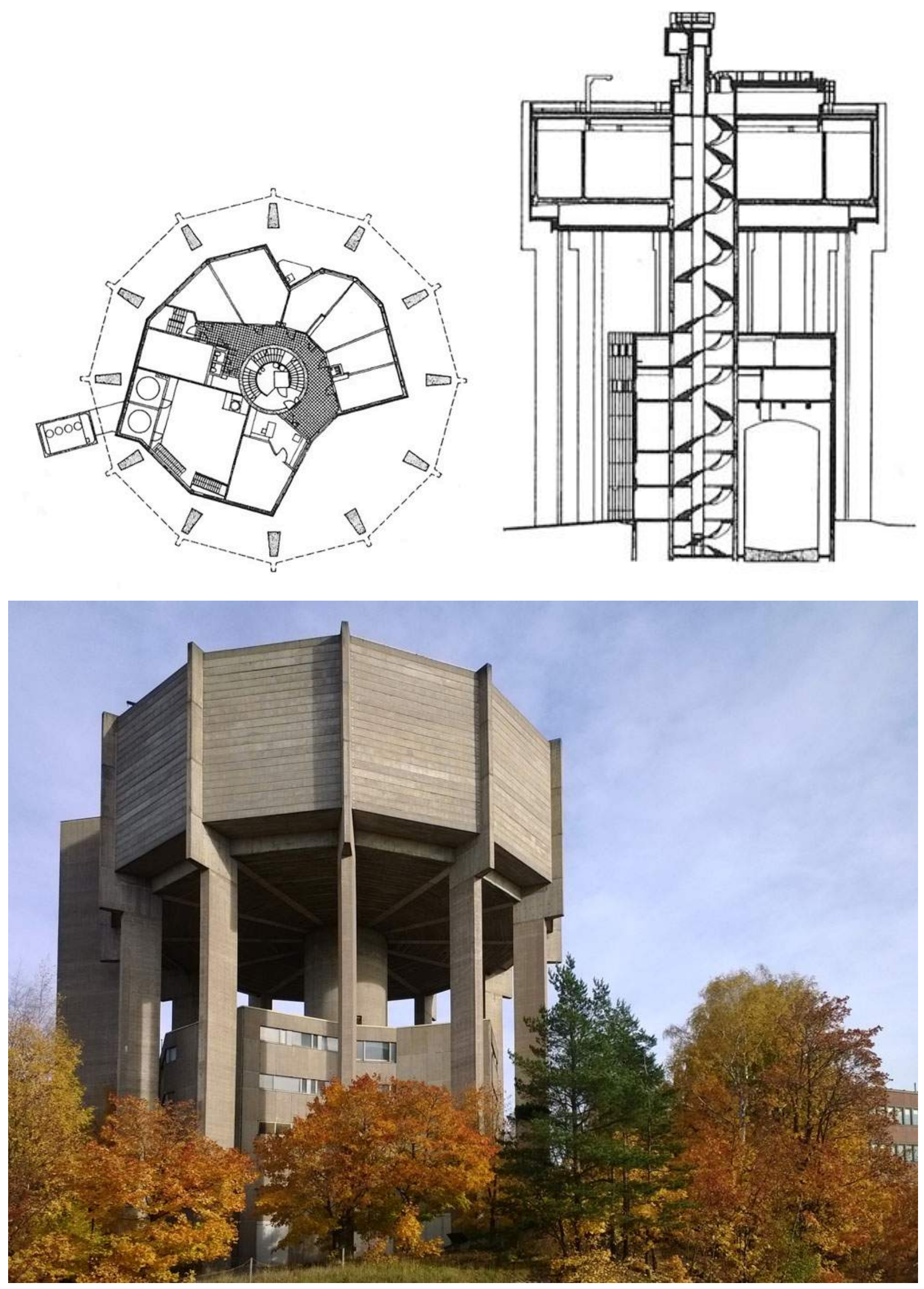
Torres de Valence

044 André Gomis + Philolaos Tloupas

\begin{tabular}{|c|c|}
\hline \multicolumn{2}{|l|}{ Informacões Gerais } \\
\hline Localização & Valence, França \\
\hline GPS & $44^{\circ} 56^{\prime} 10.11^{\prime \prime} \mathrm{N}-4^{\circ} 55^{\prime} 27.50^{\prime \prime} \mathrm{E}$ \\
\hline Data de Início do Projeto & 1963 \\
\hline Data do Término da Obra & 1971 \\
\hline Uso da Torre & Abastecimento público urbano \\
\hline Situação Atual & Operacional \\
\hline \multicolumn{2}{|l|}{ Créditos do Projeto } \\
\hline Proprietário / Contratante & SEDRO - Societé d'Equipement de la Drôme, Ville de Valence \\
\hline Projeto de Arquitetura & André Gomis + Philolaos Tloupas \\
\hline Projeto Estrutural & J. C. Stribrick \\
\hline \multicolumn{2}{|l|}{ Construção } \\
\hline \multicolumn{2}{|l|}{ Dados do Reservatório } \\
\hline Capacidade $\left[\mathrm{m}^{3}\right]$ & 2.840 \\
\hline Forma / Tipologia & Formato especial \\
\hline Material & Concreto armado \\
\hline Altura $[\mathrm{m}]$ & 19,00 [torre A] e 14,00 [torre B] \\
\hline Dimensão máxima [m] & 19,37 [torre A] e 27,57 [torre B] \\
\hline Altura da Água - h [m] & 10,60 \\
\hline Número de Câmaras & $1 \times 850 \mathrm{~m} 3$ [torre A] e $1 \times 1.990 \mathrm{~m} 3$ [torre B] \\
\hline \multicolumn{2}{|c|}{ Dados da Estrutura de Apoio do Reservatório } \\
\hline Tipologia & Parede estrutural \\
\hline Material & Concreto armado \\
\hline Altura do Fundo do Reservatório - H [m] & 38,00 \\
\hline Altura Efetiva - H + h [m] & 48,60 \\
\hline Altura Total da Torre - Ht [m] & 57,00 [torre A] e 52,00 [torre B] \\
\hline \multicolumn{2}{|l|}{ Dados do Revestimento } \\
\hline \multicolumn{2}{|l|}{ Tipo } \\
\hline \multicolumn{2}{|l|}{ Material } \\
\hline \multicolumn{2}{|l|}{ Referências Bibliográficas } \\
\hline Inserções em Bibliografia Específica & [MERKL, 1985] \\
\hline \multirow[t]{3}{*}{ Inserções em Bibliografia Geral } & [DGP, 2016] \\
\hline & [DGP, 2004] \\
\hline & [TZAMOU, 1995] \\
\hline Inserções em Periódicos & nenhum registro encontrado \\
\hline
\end{tabular}




\section{Torres de Valence}

044 André Gomis + Philolaos Tloupas
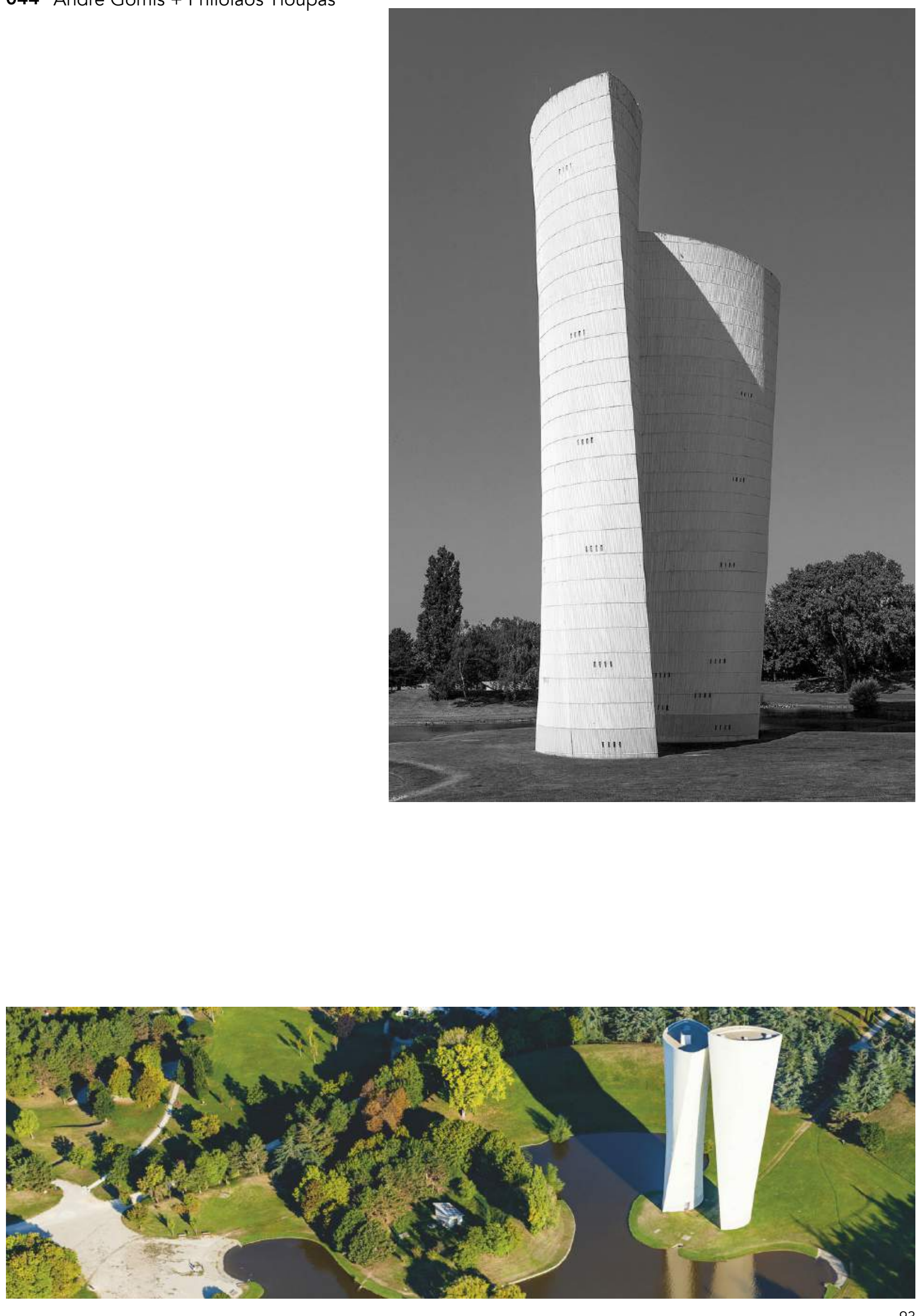
Reservatórios da COSAMA

045 Severiano Porto

\begin{tabular}{|c|c|}
\hline \multicolumn{2}{|l|}{ Informacões Gerais } \\
\hline Localização & Manaus, Amazonas, Brasil \\
\hline GPS & $3^{\circ} 6^{\prime} 35.46^{\prime \prime} \mathrm{S}-60^{\circ} 2^{\prime} 22.65^{\prime \prime} \mathrm{W}$ \\
\hline \multicolumn{2}{|l|}{ Data de Início do Projeto } \\
\hline Data do Término da Obra & 1972 \\
\hline Uso da Torre & Abastecimento público urbano \\
\hline Situação Atual & Operacional \\
\hline \multicolumn{2}{|l|}{ Créditos do Projeto } \\
\hline Proprietário / Contratante & COSAMA - Companhia de Saneamento de Manaus \\
\hline Projeto de Arquitetura & Severiano Porto \\
\hline Projeto Estrutural & Navarro Adler \\
\hline \multicolumn{2}{|l|}{ Construção } \\
\hline \multicolumn{2}{|l|}{ Dados do Reservatório } \\
\hline Capacidade $\left[\mathrm{m}^{3}\right]$ & 5000 \\
\hline Forma / Tipologia & Cilíndrico / Fundo plano \\
\hline Material & Concreto armado \\
\hline \multicolumn{2}{|l|}{ Altura $[\mathrm{m}]$} \\
\hline Largura $[\mathrm{m}]$ & 0 \\
\hline \multicolumn{2}{|l|}{ Altura da Água - h [m] } \\
\hline Número de Câmaras & 5 (interligadas) \\
\hline \multicolumn{2}{|c|}{ Dados da Estrutura de Apoio do Reservatório } \\
\hline Tipologia & Paredes estruturais \\
\hline Material & Concreto armado \\
\hline \multicolumn{2}{|l|}{ Altura do Fundo do Reservatório - H [m] } \\
\hline \multicolumn{2}{|l|}{ Altura Efetiva $-\mathrm{H}+\mathrm{h}[\mathrm{m}]$} \\
\hline Altura Total da Torre - Ht [m] & 0 \\
\hline \multicolumn{2}{|l|}{ Dados do Revestimento } \\
\hline \multicolumn{2}{|l|}{ Tipo } \\
\hline \multicolumn{2}{|l|}{ Material } \\
\hline \multicolumn{2}{|l|}{ Referências Bibliográficas } \\
\hline Inserções em Bibliografia Específica & nenhum registro encontrado \\
\hline \multirow[t]{3}{*}{ Inserções em Bibliografia Geral } & [ABRAHIM, 2014] \\
\hline & [HESPANHA, 2009] \\
\hline & [CAMPOS, 2003] \\
\hline \multirow[t]{2}{*}{ Inserções em Periódicos } & [Revista D.A.E., São Paulo, v. 33, n. 91, set. 1973] \\
\hline & [C.J. Arquitetura, São Paulo, v. 2, n. 7, 1973] \\
\hline
\end{tabular}


Reservatórios da COSAMA

045 Severiano Porto

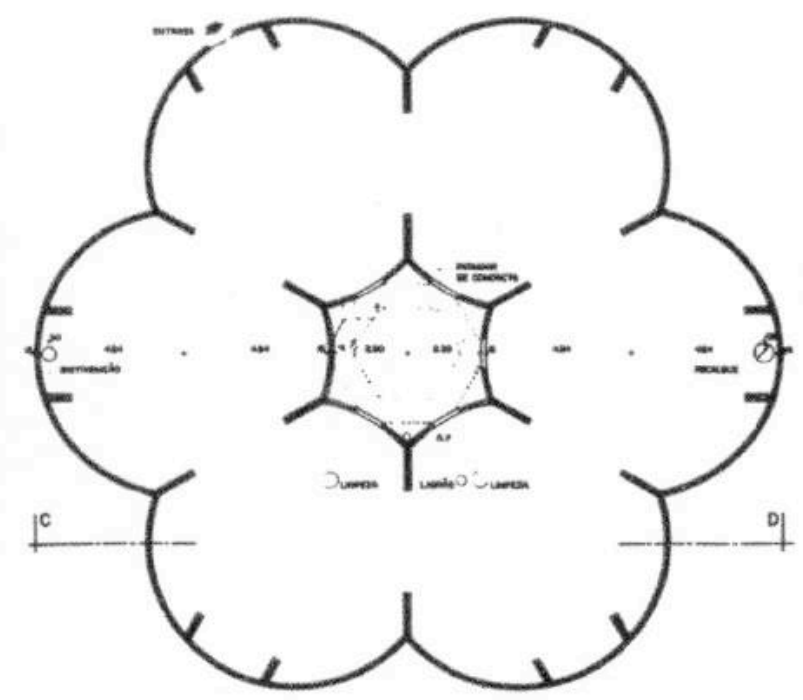

PLANTA AO NÍVEL DO TERFENO

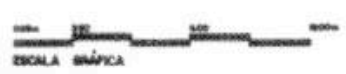

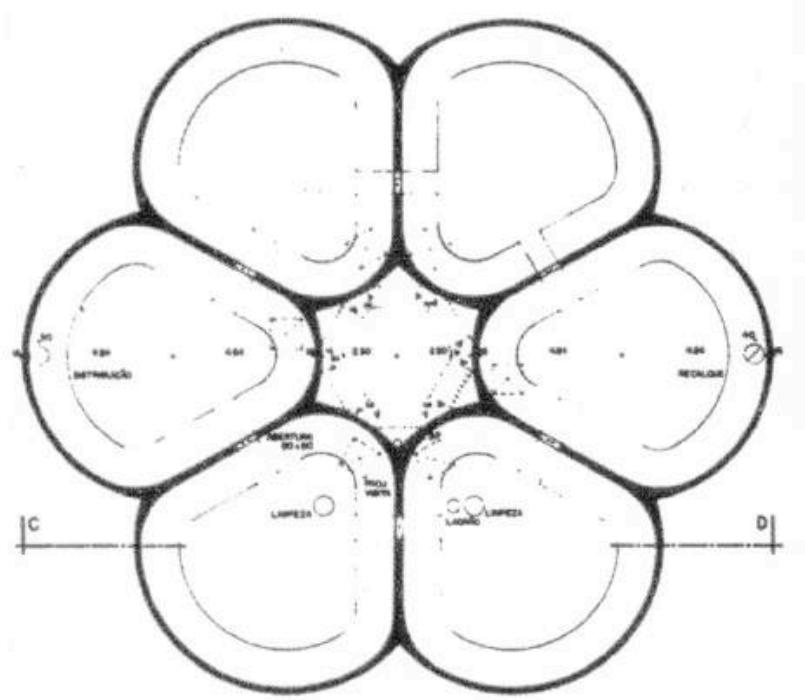

PLANTA DA CAIXA D'IRQLA

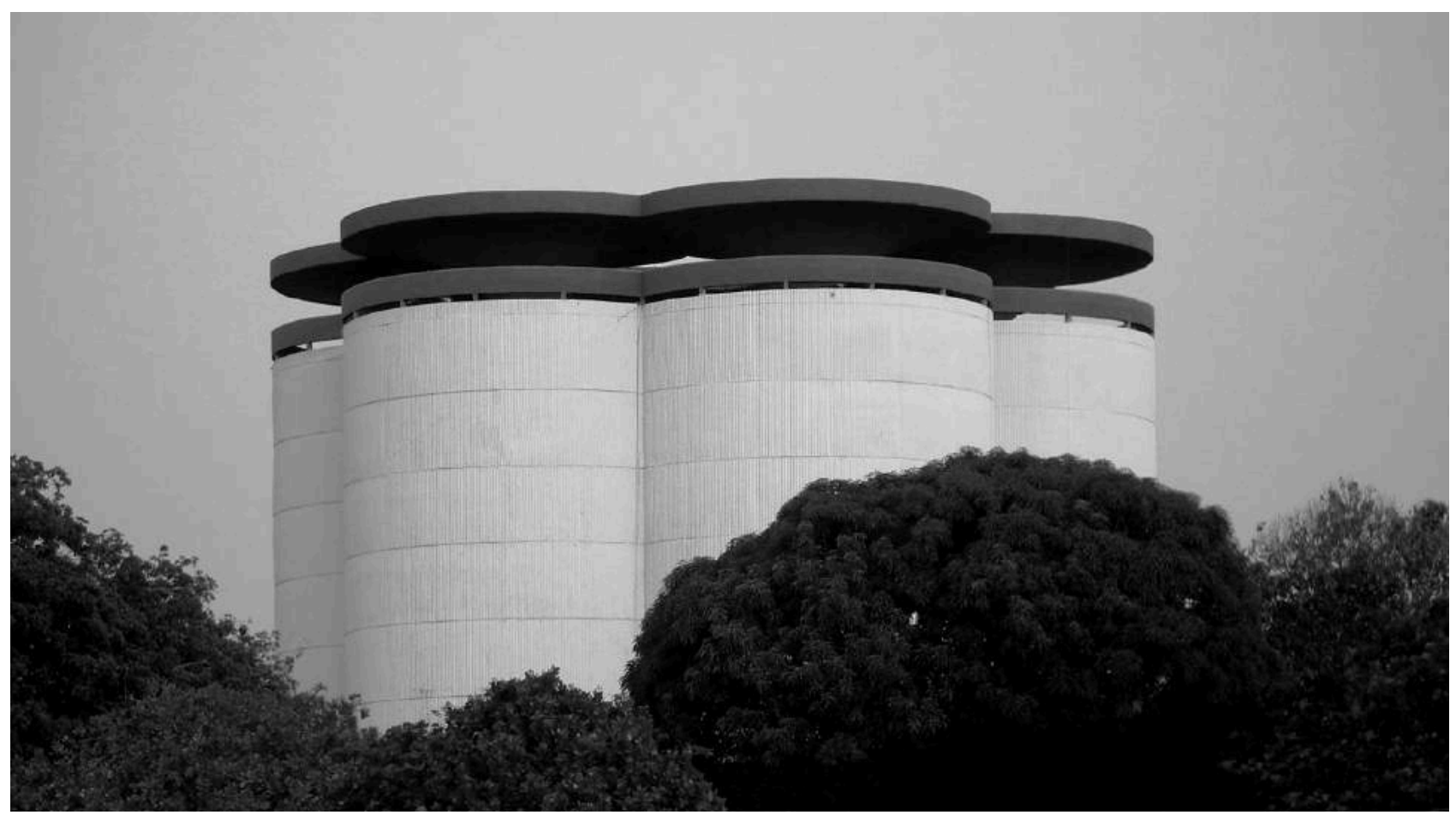


Torre de Ciechanow

046 Jerzy Michal Boguslawsky

\begin{tabular}{|c|c|}
\hline Informacões Gerais & \\
\hline Localização & Ciechanow, Polônia \\
\hline GPS & $52^{\circ} 52^{\prime} 6.50^{\prime \prime} \mathrm{N}-20^{\circ} 35^{\prime} 50.00^{\prime \prime} \mathrm{E}$ \\
\hline \multicolumn{2}{|l|}{ Data de Início do Projeto } \\
\hline Data do Término da Obra & 1972 \\
\hline Uso da Torre & Abastecimento público urbano \\
\hline Situação Atual & Desativada \\
\hline \multicolumn{2}{|l|}{ Créditos do Projeto } \\
\hline \multicolumn{2}{|l|}{ Proprietário / Contratante } \\
\hline Projeto de Arquitetura & Jerzy Michal Boguslawsky \\
\hline Projeto Estrutural & Jerzy Wiblik, Stanislaw Gajowniczek e Bohdan Szczeszeek \\
\hline \multicolumn{2}{|l|}{ Construção } \\
\hline \multicolumn{2}{|l|}{ Dados do Reservatório } \\
\hline Capacidade $\left[\mathrm{m}^{3}\right]$ & 1.560 \\
\hline Forma / Tipologia & Toroidal \\
\hline Material & Metálico [aço] \\
\hline Altura $[\mathrm{m}]$ & 6,00 \\
\hline Diâmetro máximo $[\mathrm{m}]$ & 23,70 \\
\hline \multicolumn{2}{|l|}{ Altura da Água - h [m] } \\
\hline Número de Câmaras & 1 \\
\hline \multicolumn{2}{|c|}{ Dados da Estrutura de Apoio do Reservatório } \\
\hline Tipologia & Estrutura treliçada hiperbólica \\
\hline Material & Metálico [aço] \\
\hline Altura do Fundo do Reservatório - $\mathrm{H}$ [m] & 22,00 \\
\hline \multicolumn{2}{|l|}{ Altura Efetiva - $\mathrm{H}+\mathrm{h}[\mathrm{m}]$} \\
\hline Altura Total da Torre - Ht [m] & 28,00 \\
\hline \multicolumn{2}{|l|}{ Dados do Revestimento } \\
\hline \multicolumn{2}{|l|}{ Tipo } \\
\hline \multicolumn{2}{|l|}{ Material } \\
\hline \multicolumn{2}{|l|}{ Referências Bibliográficas } \\
\hline Inserções em Bibliografia Específica & nenhum registro encontrado \\
\hline Inserções em Bibliografia Geral & [KOŹNIEWSKI, 2015] \\
\hline Inserções em Periódicos & nenhum registro encontrado \\
\hline
\end{tabular}


Torre de Ciechanow

046 Jerzy Michal Boguslawsky
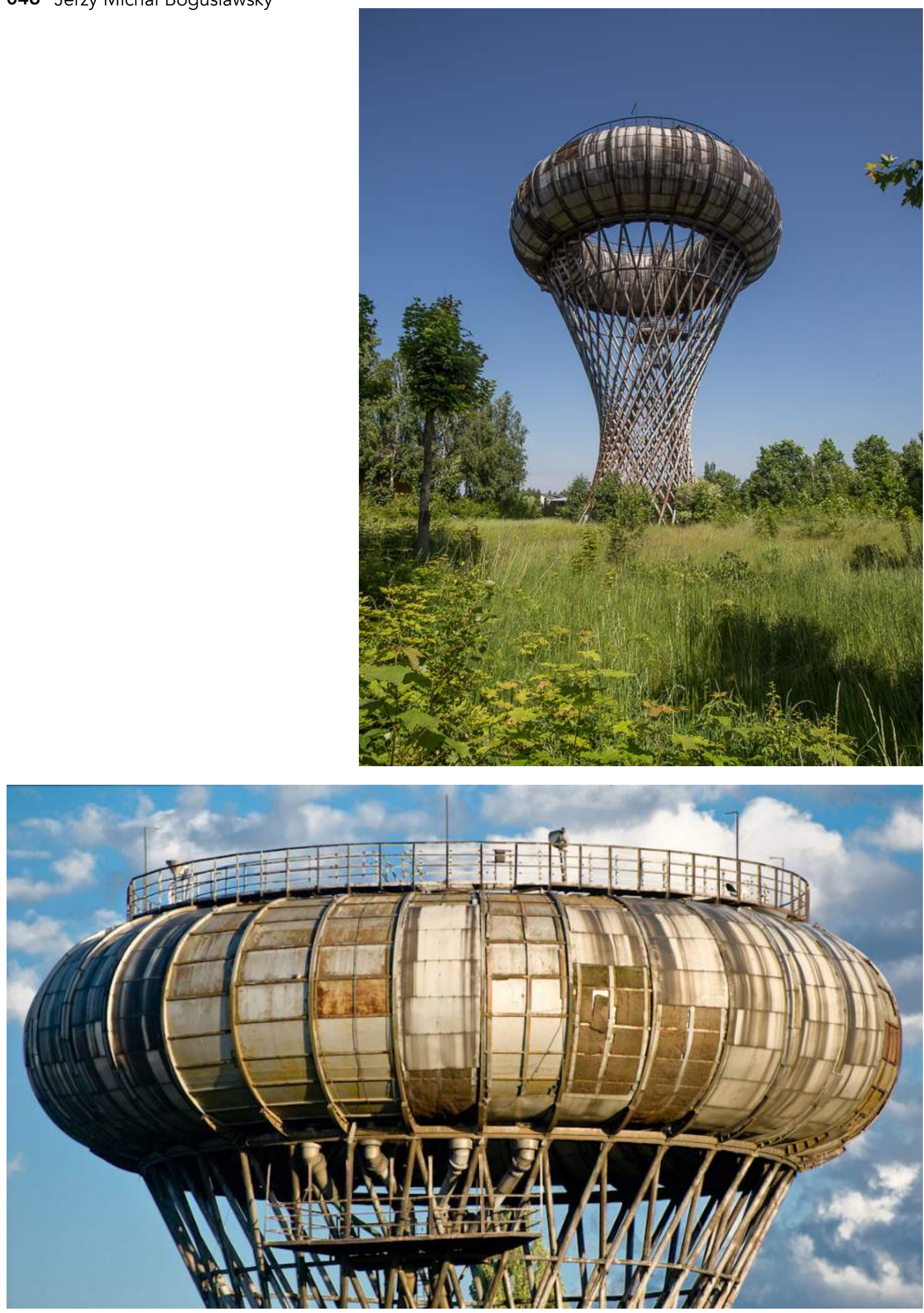


\section{Torre de Hyllie}

047 Göran Kjessler + Karl Ivar Stål

\begin{tabular}{|c|c|}
\hline Informacões Gerais & \\
\hline Localização & Malmö, Suécia \\
\hline GPS & $55^{\circ} 33^{\prime} 54.54^{\prime \prime} \mathrm{N}-12^{\circ} 58^{\prime} 44.10^{\prime \prime} \mathrm{E}$ \\
\hline Data de Início do Projeto & 1967 \\
\hline Data do Término da Obra & 1973 \\
\hline Uso da Torre & Abastecimento público urbano \\
\hline Situação Atual & Operacional \\
\hline Créditos do Projeto & \\
\hline Proprietário / Contratante & Cidade de Malmö \\
\hline Projeto de Arquitetura & Göran Kjessler + Karl Ivar Stål \\
\hline Projeto Estrutural & Edvard Kruse \\
\hline Construção & \\
\hline Dados do Reservatório & \\
\hline Capacidade $\left[\mathrm{m}^{3}\right]$ & 10.200 \\
\hline Forma / Tipologia & Troncônico / Cogumelo \\
\hline Material & Concreto protendido \\
\hline Altura $[\mathrm{m}]$ & \\
\hline Diâmetro máximo [m] & 52,00 \\
\hline Altura da Água - h [m] & \\
\hline Número de Câmaras & 2 \\
\hline Dados da Estrutura de Apoio do R & \\
\hline Tipologia & Quatro pilares circulares ôcos \\
\hline Material & Concreto armado \\
\hline Altura do Fundo do Reservatório - H & \\
\hline Altura Efetiva - $\mathrm{H}+\mathrm{h}[\mathrm{m}]$ & \\
\hline Altura Total da Torre - Ht [m] & 62,00 \\
\hline Dados do Revestimento & \\
\hline Tipo & \\
\hline Material & \\
\hline Referências Bibliográficas & \\
\hline Inserções em Bibliografia Específica & nenhum registro encontrado \\
\hline Inserções em Bibliografia Geral & [Arkitekttävlingar, Stockholm, n. 1, 1967] \\
\hline Inserções em Periódicos & nenhum registro encontrado \\
\hline
\end{tabular}




\section{Torre de Hyllie}

047 Göran Kjessler + Karl Ivar Stål
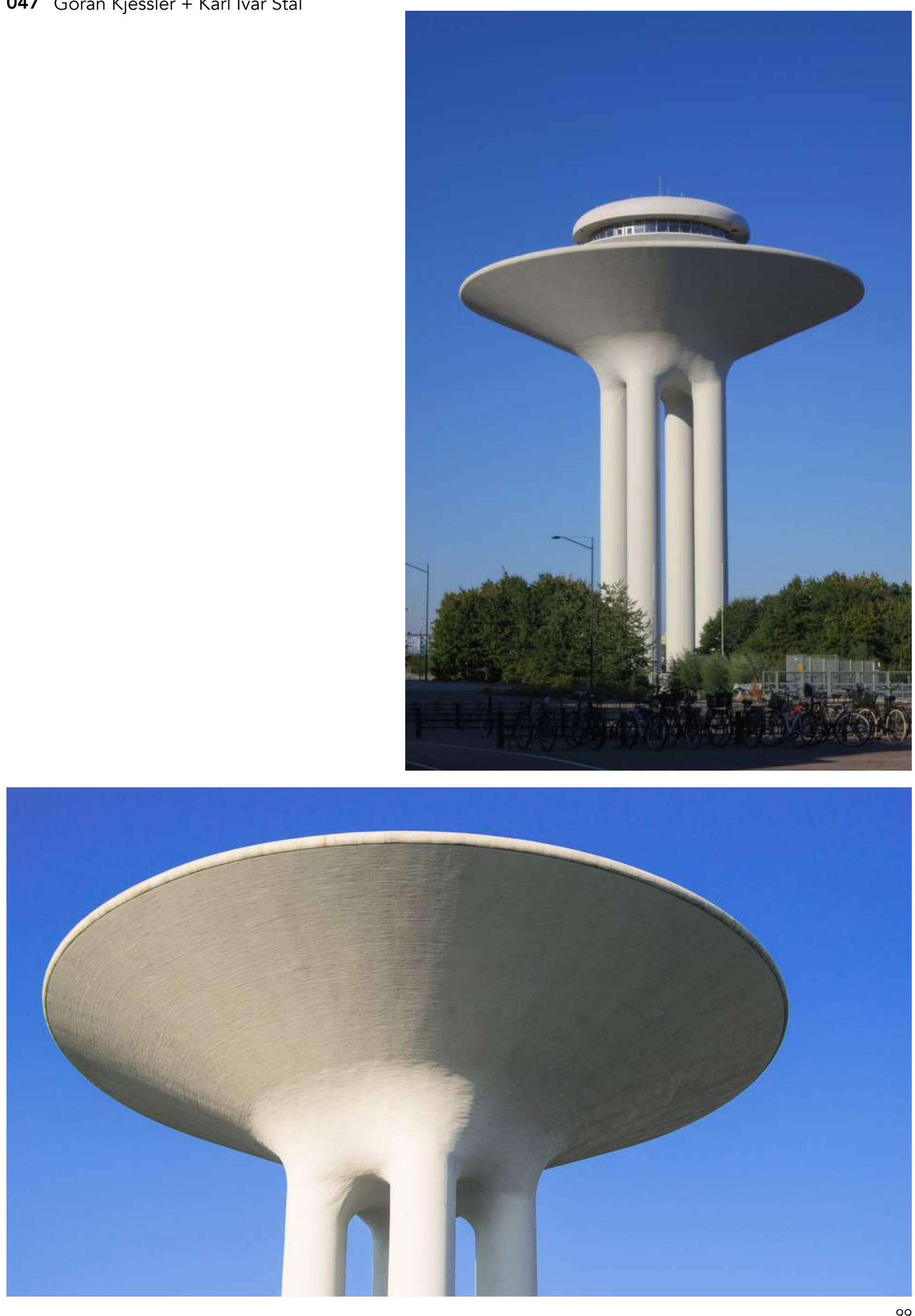
Torre de Marne-la-Vallée

048 Christian de Portzamparc

\begin{tabular}{|c|c|}
\hline \multicolumn{2}{|l|}{ Informacões Gerais } \\
\hline Localização & Marne-la-Vallée, Île-de-France, França \\
\hline GPS & $48^{\circ} 51^{\prime} 5.38^{\prime \prime} \mathrm{N}-2^{\circ} 37^{\prime} 15.98^{\prime \prime} \mathrm{E}$ \\
\hline Data de Início do Projeto & 1971 \\
\hline Data do Término da Obra & 1974 \\
\hline Uso da Torre & Abastecimento público urbano \\
\hline Situação Atual & Operacional \\
\hline \multicolumn{2}{|l|}{ Créditos do Projeto } \\
\hline Proprietário / Contratante & Établissement Public d'Ameénagement de la ville de Marne-la-Vallée \\
\hline Projeto de Arquitetura & Christian de Portzamparc \\
\hline \multicolumn{2}{|l|}{ Projeto Estrutural } \\
\hline \multicolumn{2}{|l|}{ Construção } \\
\hline \multicolumn{2}{|l|}{ Dados do Reservatório } \\
\hline Capacidade $\left[\mathrm{m}^{3}\right]$ & 2000 \\
\hline Forma / Tipologia & Prismático / Fundo Plano \\
\hline Material & Concreto armado \\
\hline \multicolumn{2}{|l|}{ Altura $[\mathrm{m}]$} \\
\hline Diâmetro máximo $[\mathrm{m}]$ & 23,00 \\
\hline \multicolumn{2}{|l|}{ Altura da Água - $\mathrm{h}[\mathrm{m}]$} \\
\hline Número de Câmaras & 1 \\
\hline \multicolumn{2}{|c|}{ Dados da Estrutura de Apoio do Reservatório } \\
\hline Tipologia & Sistema de pilares e vigas \\
\hline Material & Concreto armado \\
\hline \multicolumn{2}{|l|}{ Altura do Fundo do Reservatório - H [m] } \\
\hline \multicolumn{2}{|l|}{ Altura Efetiva - H + h [m] } \\
\hline Altura Total da Torre - Ht [m] & 37,00 \\
\hline \multicolumn{2}{|l|}{ Dados do Revestimento } \\
\hline \multicolumn{2}{|l|}{ Tipo } \\
\hline \multicolumn{2}{|l|}{ Material } \\
\hline \multicolumn{2}{|l|}{ Referências Bibliográficas } \\
\hline Inserções em Bibliografia Específica & nenhum registro encontrado \\
\hline \multirow[t]{2}{*}{ Inserções em Bibliografia Geral } & [ATELIER..., 2017] \\
\hline & {$[$ FLORIO, 1996] } \\
\hline Inserções em Periódicos & [L'Architecture d'Aujourd'hui, Paris, v. 51, n. 212, dez. 1980] \\
\hline
\end{tabular}


Torre de Marne-la-Vallée

048 Christian de Portzamparc
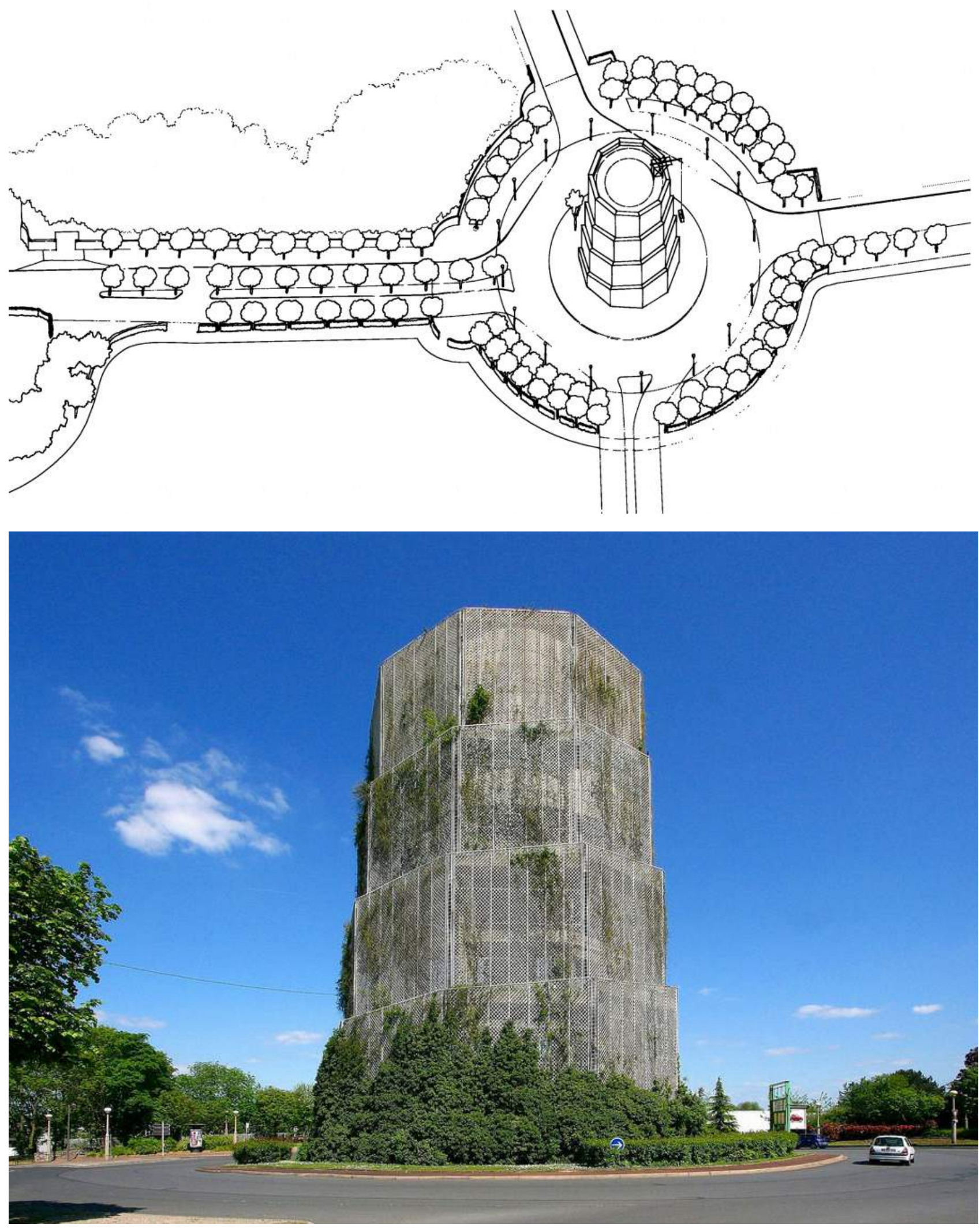
Torre de Ceilândia

049 Gerhard Leo Linzmeyer

\begin{tabular}{|c|c|}
\hline \multicolumn{2}{|l|}{ Informacões Gerais } \\
\hline Localização & Ceilândia, Distrito Federal, Brasil \\
\hline GPS & $15^{\circ} 49^{\prime} 1.67^{\prime \prime S}-48^{\circ} 6^{\prime} 18.82^{\prime \prime} \mathrm{W}$ \\
\hline Data de Início do Projeto & 1971 \\
\hline Data do Término da Obra & 1974 \\
\hline Uso da Torre & Abastecimento público urbano \\
\hline Situação Atual & Operacional \\
\hline \multicolumn{2}{|l|}{ Créditos do Projeto } \\
\hline Proprietário / Contratante & CAESB - Companhia de Saneamento Ambiental do Distrito Federal \\
\hline Projeto de Arquitetura & Gerhard Leo Linzmeyer \\
\hline \multicolumn{2}{|l|}{ Projeto Estrutural } \\
\hline \multicolumn{2}{|l|}{ Construção } \\
\hline \multicolumn{2}{|l|}{ Dados do Reservatório } \\
\hline Capacidade $\left[\mathrm{m}^{3}\right]$ & 500 \\
\hline Forma / Tipologia & Cogumelo \\
\hline Material & Concreto armado \\
\hline \multicolumn{2}{|l|}{ Altura $[\mathrm{m}]$} \\
\hline Diâmetro máximo [m] & 18,00 \\
\hline \multicolumn{2}{|l|}{ Altura da Água - h [m] } \\
\hline \multicolumn{2}{|l|}{ Número de Câmaras } \\
\hline \multicolumn{2}{|c|}{ Dados da Estrutura de Apoio do Reservatório } \\
\hline Tipologia & Fuste central cilíndrico ôco \\
\hline Material & Concreto armado \\
\hline \multicolumn{2}{|l|}{ Altura do Fundo do Reservatório - H [m] } \\
\hline \multicolumn{2}{|l|}{ Altura Efetiva - $\mathrm{H}+\mathrm{h}[\mathrm{m}]$} \\
\hline Altura Total da Torre - Ht [m] & 27,00 \\
\hline \multicolumn{2}{|l|}{ Dados do Revestimento } \\
\hline \multicolumn{2}{|l|}{ Tipo } \\
\hline \multicolumn{2}{|l|}{ Material } \\
\hline \multicolumn{2}{|l|}{ Referências Bibliográficas } \\
\hline Inserções em Bibliografia Específica & nenhum registro encontrado \\
\hline \multirow[t]{2}{*}{ Inserções em Bibliografia Geral } & [PEREIRA, 2017] \\
\hline & [PEREIRA, 2016] \\
\hline \multirow[t]{3}{*}{ Inserções em Periódicos } & [Correio Brasiliense, Brasília, 21 nov. 2013] \\
\hline & [Gazeta de Taguatinga, Taguatinga, 20 nov. 2013] \\
\hline & [Revista D.A.E., São Paulo, v. 33, n. 91, set. 1973] \\
\hline
\end{tabular}


Torre de Ceilândia

049 Gerhard Leo Linzmeyer
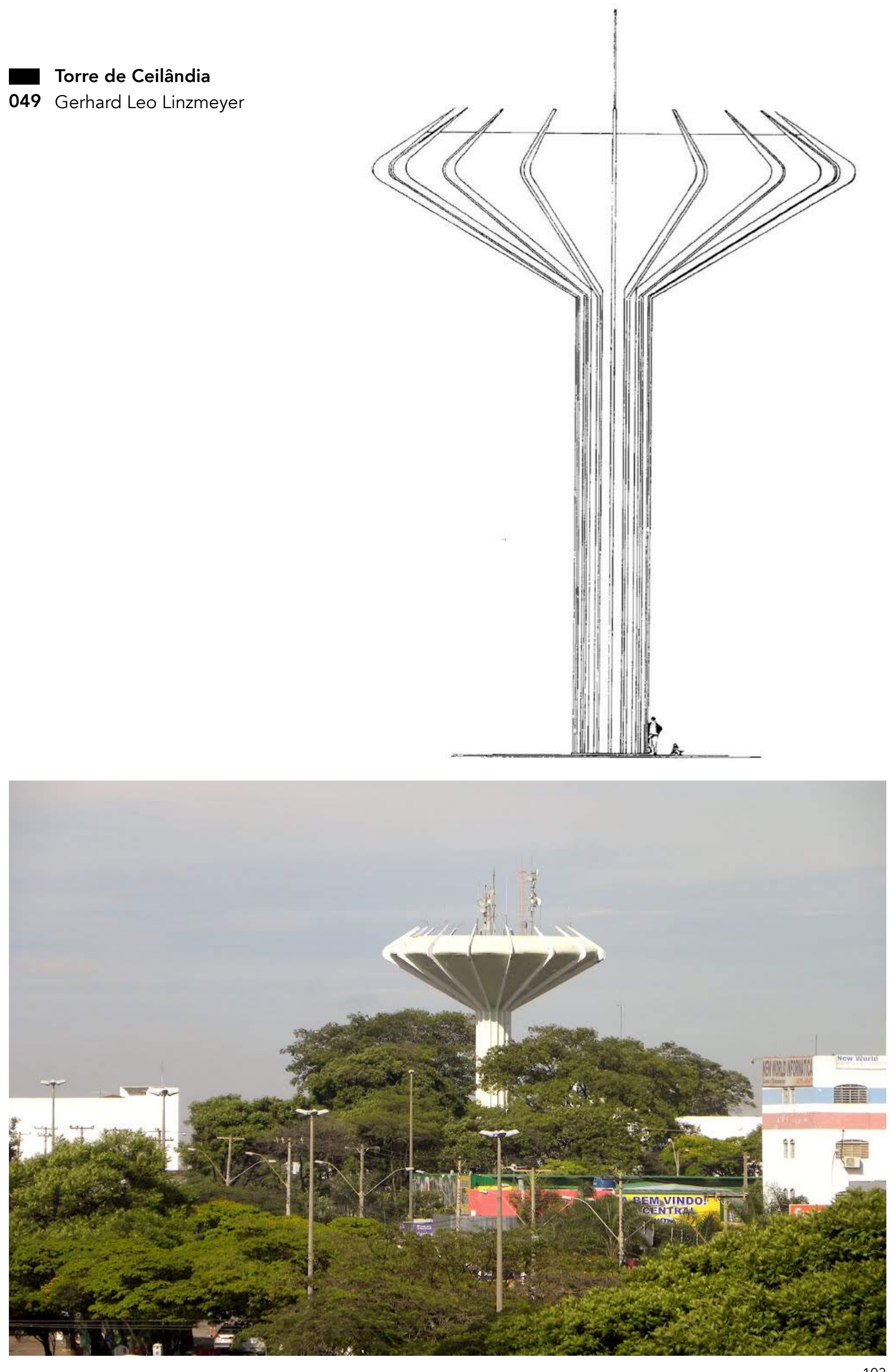
Torre de Baydon

050 Edmund C. Percey

\begin{tabular}{ll}
\hline Informacões Gerais & \\
\hline Localização & Wiltshire, Inglaterra \\
GPS & $51^{\circ} 29^{\prime} 56.19^{\prime \prime} \mathrm{N}-1^{\circ} 35^{\prime} 13.93^{\prime \prime} \mathrm{W}$ \\
Data de Início do Projeto & \\
Data do Término da Obra & 1974 \\
Uso da Torre & Abastecimento público urbano \\
Situação Atual & Operacional \\
\hline
\end{tabular}

\section{Créditos do Projeto}

Proprietário / Contratante

Projeto de Arquitetura

Edmund C. Percey

Projeto Estrutural

Construção

\section{Dados do Reservatório}

Capacidade $\left[\mathrm{m}^{3}\right]$

50

Forma / Tipologia

Troncônico

Material

Concreto armado

Altura [m]

5,5

Diâmetro Máximo [m]

15,00

Diâmetro Mínimo [m]

12,00

Altura da Água - h [m]

Número de Câmaras

2

Dados da Estrutura de Apoio do Reservatório

Tipologia

Fuste circular ôco e pilares oblíquos

Material

Concreto armado

Altura do Fundo do Reservatório - H [m]

12,8

Altura Efetiva - $\mathrm{H}+\mathrm{h}[\mathrm{m}]$

Altura Total da Torre - Ht [m]

18,30

\section{Dados do Revestimento}

Tipo

Painéis pré-fabricados

Material

Concreto

Referências Bibliográficas

Inserções em Bibliografia Específica

[BARTON, 2007]

Inserções em Bibliografia Geral

[Informes de La Construcción, Madrid, v. 32, n. 325, jun. 1980]

Inserções em Periódicos

nenhum registro encontrado 

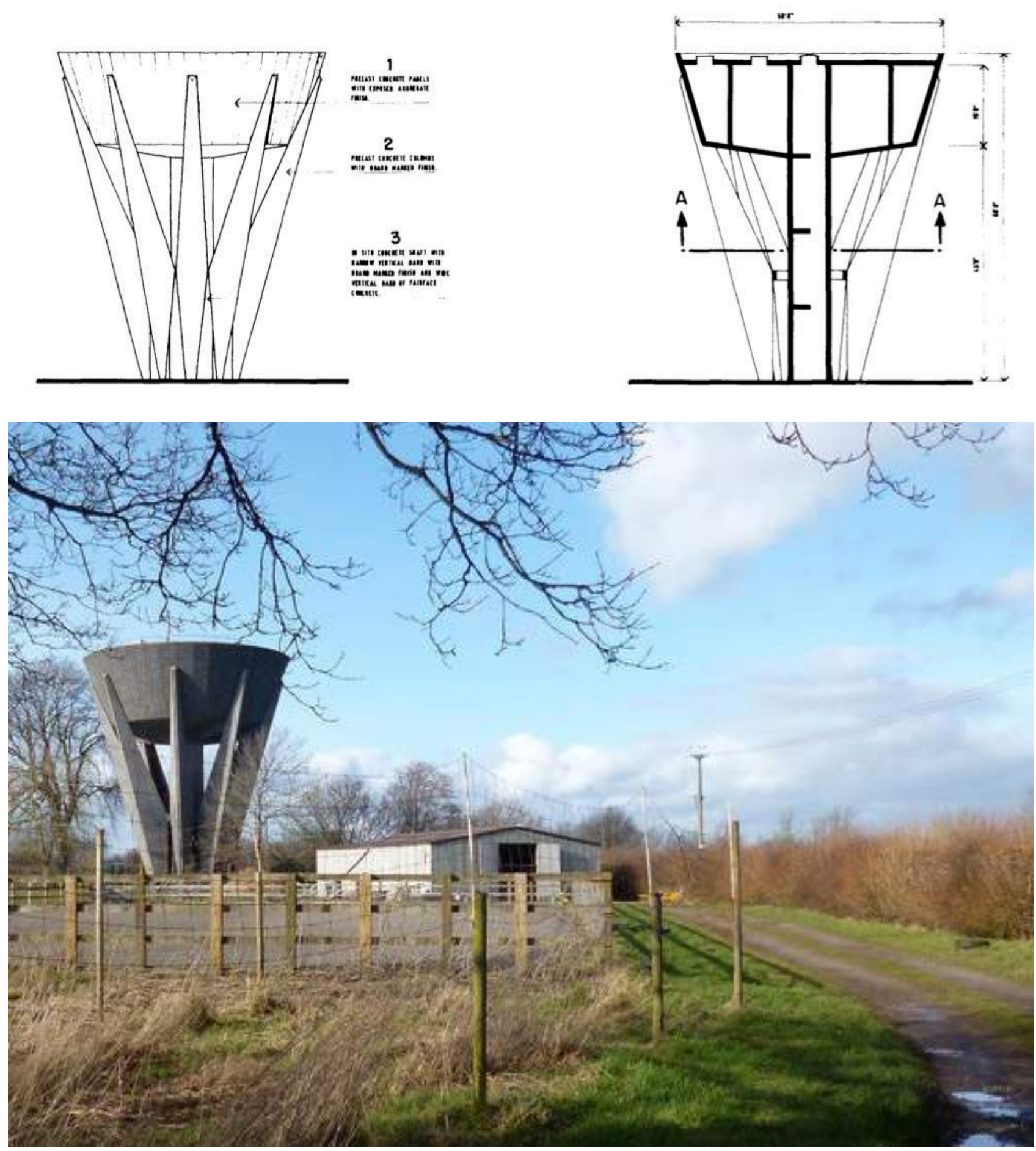
Torre de Khuzam

051 Sune Lindström

\begin{tabular}{|c|c|}
\hline Informacões Gerais & \\
\hline Localização & Gidá, Arábia Saudita \\
\hline GPS & $21^{\circ} 28^{\prime} 41.18^{\prime \prime} \mathrm{N}-39^{\circ} 12^{\prime} 19.77^{\prime \prime} \mathrm{E}$ \\
\hline Data de Início do Projeto & 1973 \\
\hline Data do Término da Obra & 1977 \\
\hline Uso da Torre & Abastecimento público urbano \\
\hline Situação Atual & Operacional \\
\hline Créditos do Projeto & \\
\hline Proprietário / Contratante & \\
\hline Projeto de Arquitetura & Sune Lindström \\
\hline Projeto Estrutural & VBB Stockholm \\
\hline Construção & \\
\hline Dados do Reservatório & \\
\hline Capacidade $\left[\mathrm{m}^{3}\right]$ & 18.000 \\
\hline Forma / Tipologia & Troncônico / Cogumelo \\
\hline Material & Concreto protendido \\
\hline Altura $[\mathrm{m}]$ & \\
\hline Diâmetro Máximo [m] & 55,00 \\
\hline Altura da Água - h [m] & \\
\hline Número de Câmaras & 1 \\
\hline Dados da Estrutura de Apoio do Re & \\
\hline Tipologia & Fuste cilíndrico ôco \\
\hline Material & Concreto armado \\
\hline Altura do Fundo do Reservatório - $\mathrm{H}$ & \\
\hline Altura Efetiva - H + h [m] & 50,00 \\
\hline Altura Total da Torre - Ht [m] & 76,00 \\
\hline Dados do Revestimento & \\
\hline Tipo & \\
\hline Material & \\
\hline Referências Bibliográficas & \\
\hline Inserções em Bibliografia Específica & nenhum registro encontrado \\
\hline Inserções em Bibliografia Geral & [SHAWLY, 2008] \\
\hline & [RAJA, 1993] \\
\hline Inserções em Periódicos & nenhum registro encontrado \\
\hline
\end{tabular}


Torre de Khuzam

051 Sune Lindström
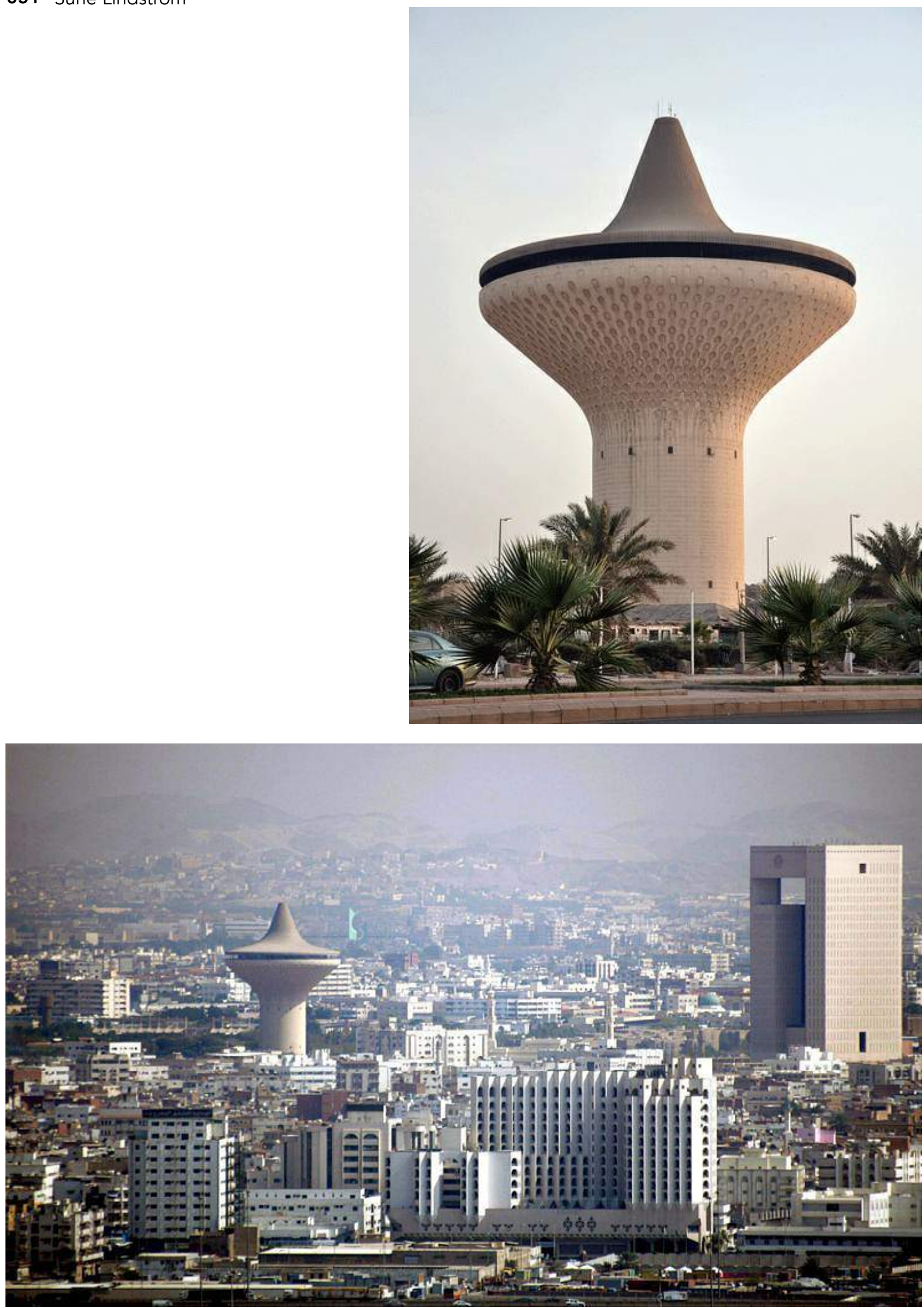
Kuwait Towers

052 Sune Lindström + Malene Björn

\begin{tabular}{|c|c|}
\hline Informacões Gerais & \\
\hline Localização & Cidade do Kuwait, Kuwait \\
\hline GPS & $29^{\circ} 23^{\prime} 22.84^{\prime \prime} \mathrm{N}-48^{\circ} 0^{\prime} 11.47^{\prime \prime} \mathrm{E}$ \\
\hline Data de Início do Projeto & 1967 \\
\hline Data do Término da Obra & 1977 \\
\hline Uso da Torre & Abastecimento público urbano \\
\hline Situação Atual & Operacional \\
\hline Créditos do Projeto & \\
\hline Proprietário / Contratante & Kuwait Ministry of Electricity and Water \\
\hline Projeto de Arquitetura & Sune Lindström + Malene Björn \\
\hline Projeto Estrutural & VBB Stockholm \\
\hline Construção & Union Engineering \\
\hline Dados do Reservatório & \\
\hline Capacidade $\left[\mathrm{m}^{3}\right]$ & $2 \times 4.500$ \\
\hline Forma / Tipologia & Esférico \\
\hline Material & Concreto protendido \\
\hline Altura $[\mathrm{m}]$ & 30,00 e 25,00 \\
\hline Diâmetro máximo [m] & 30,00 e 25,00 \\
\hline Altura da Água - h [m] & \\
\hline Número de Câmaras & 2 \\
\hline Dados da Estrutura de Apoio do R & \\
\hline Tipologia & Fuste central cônico ôco \\
\hline Material & Concreto armado \\
\hline Altura do Fundo do Reservatório - $\mathrm{H}$ & \\
\hline Altura Efetiva - $\mathrm{H}+\mathrm{h}[\mathrm{m}]$ & \\
\hline Altura Total da Torre - Ht [m] & 185,00 e 140,00 \\
\hline Dados do Revestimento & \\
\hline Tipo & \\
\hline Material & \\
\hline Referências Bibliográficas & \\
\hline Inserções em Bibliografia Específica & nenhum registro encontrado \\
\hline Inserções em Bibliografia Geral & [THE AGA KHAN..., 1980] \\
\hline Inserções em Periódicos & nenhum registro encontrado \\
\hline
\end{tabular}


Kuwait Towers

052 Sune Lindström + Malene Björn
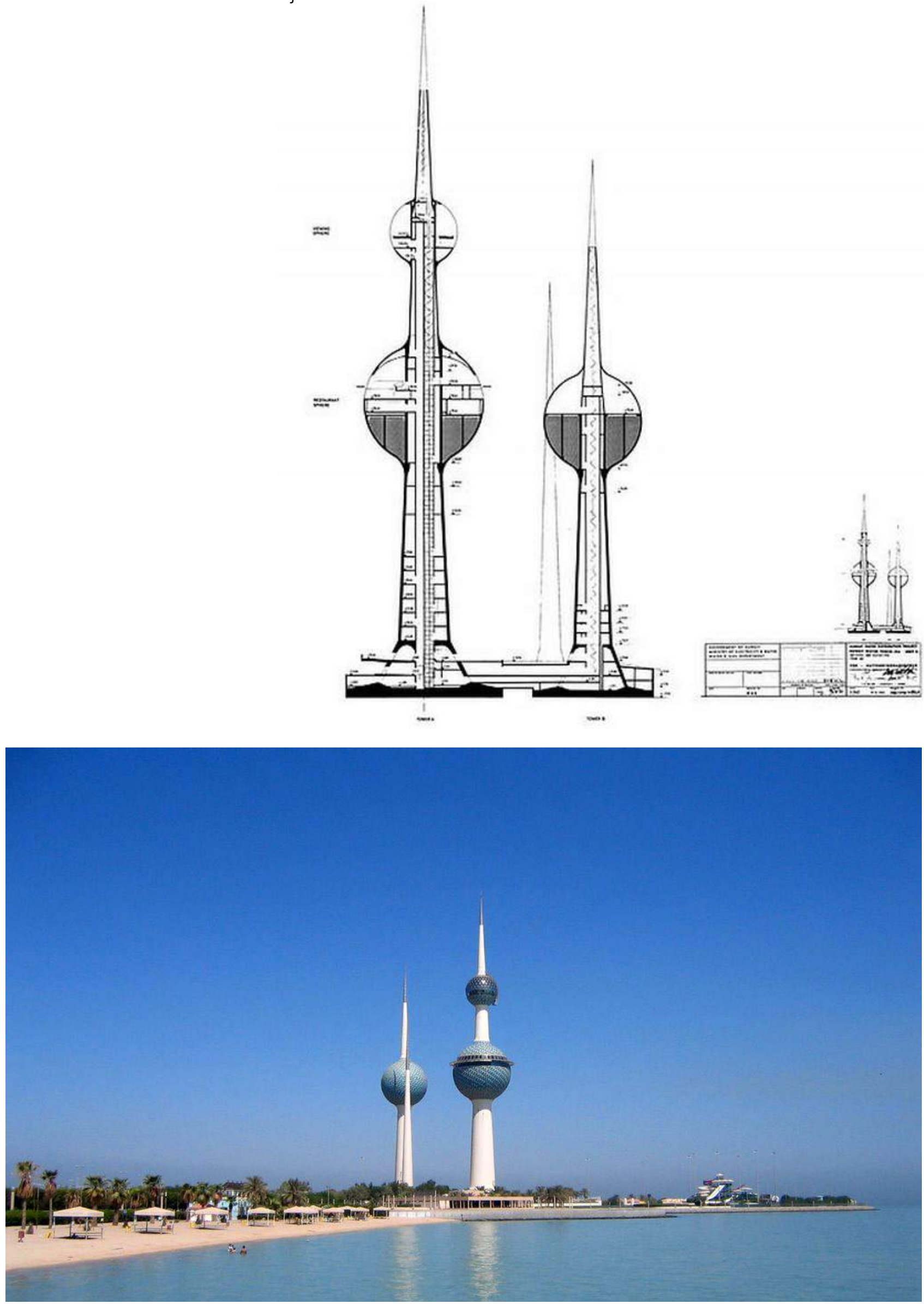
Torre de Mechelen

053 Fernand Mortelmans

\begin{tabular}{|c|c|}
\hline Informacões Gerais & \\
\hline Localização & Mechelen, Bélgica \\
\hline GPS & $51^{\circ} 0^{\prime} 39.98 " \mathrm{~N}-4^{\circ} 27^{\prime} 47.01^{\prime \prime} \mathrm{E}$ \\
\hline Data de Início do Projeto & 1977 \\
\hline Data do Término da Obra & 1978 \\
\hline Uso da Torre & Abastecimento público urbano \\
\hline Situação Atual & Operacional \\
\hline Créditos do Projeto & \\
\hline Proprietário / Contratante & Cidade de Mechelen \\
\hline Projeto de Arquitetura & Fernand Mortelmans \\
\hline Projeto Estrutural & Fernand Mortelmans \\
\hline Construção & Vanhout Vosselaar N. V. \\
\hline Dados do Reservatório & \\
\hline Capacidade $\left[\mathrm{m}^{3}\right]$ & 2.500 \\
\hline Forma / Tipologia & Casca cônica com diafragmas radiais \\
\hline Material & Concreto protendido \\
\hline Altura $[\mathrm{m}]$ & 9,26 \\
\hline Diâmetro máximo [m] & 40,00 \\
\hline Altura da Água - h [m] & \\
\hline Número de Câmaras & 16 interligadas \\
\hline Dados da Estrutura de Apoio do R & \\
\hline Tipologia & Fuste cônico ôco \\
\hline Material & Concreto protendido \\
\hline Altura do Fundo do Reservatório - $\mathrm{H}$ & \\
\hline Altura Efetiva - H + h [m] & 52,00 \\
\hline Altura Total da Torre - Ht [m] & 143,00 \\
\hline Dados do Revestimento & \\
\hline Tipo & \\
\hline Material & \\
\hline Referências Bibliográficas & \\
\hline Inserções em Bibliografia Específica & nenhum registro encontrado \\
\hline Inserções em Bibliografia Geral & [VSL, 1979] \\
\hline Inserções em Periódicos & nenhum registro encontrado \\
\hline
\end{tabular}


Torre de Mechelen

053 Fernand Mortelmans
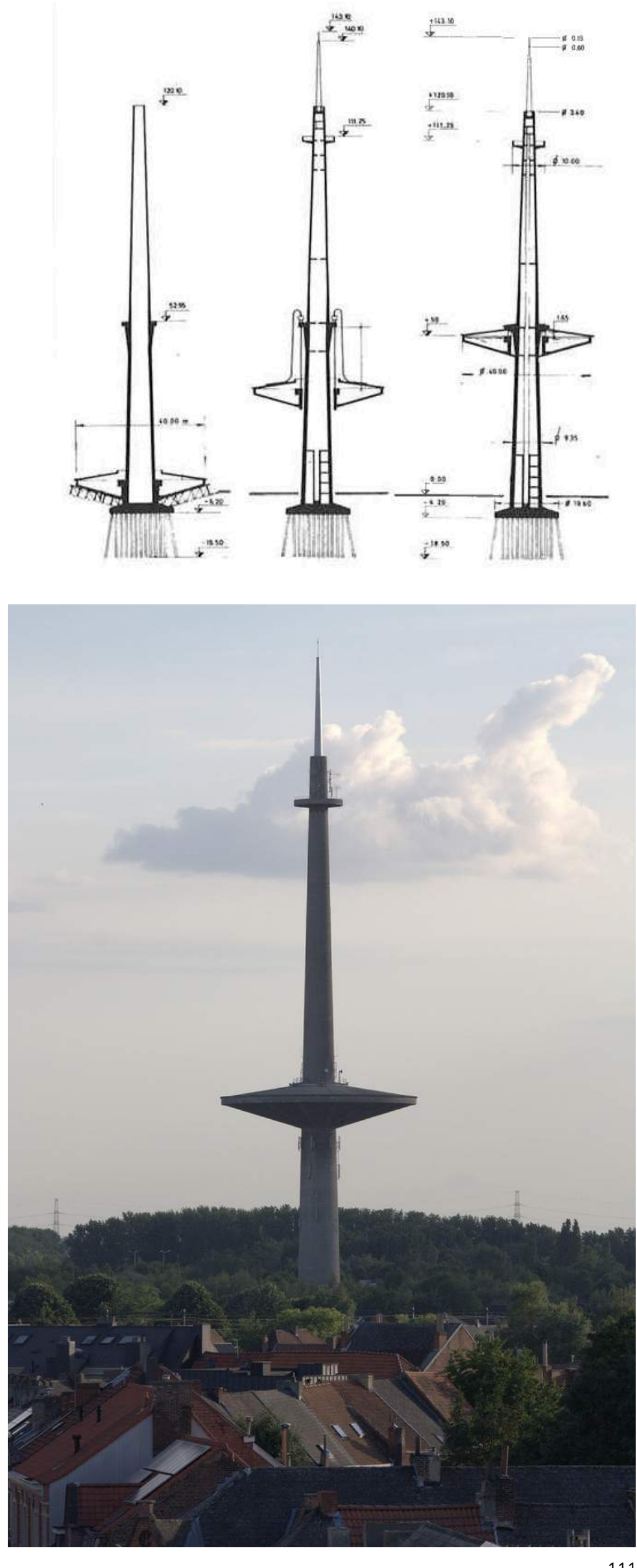
Torre de Roihuvuori

054 Simo Lumme

\begin{tabular}{|c|c|}
\hline \multicolumn{2}{|l|}{ Informacões Gerais } \\
\hline Localização & Helsinque, Finlândia \\
\hline GPS & $60^{\circ} 11^{\prime} 50.91 " \mathrm{~N}-25^{\circ} 2^{\prime} 56.99 " \mathrm{E}$ \\
\hline Data de Início do Projeto & 1977 \\
\hline Data do Término da Obra & 1978 \\
\hline Uso da Torre & Abastecimento público urbano \\
\hline Situação Atual & Operacional \\
\hline \multicolumn{2}{|l|}{ Créditos do Projeto } \\
\hline Proprietário / Contratante & HSY - Helsinki Region Environmental Services Authority \\
\hline Projeto de Arquitetura & Simo Lumme \\
\hline Projeto Estrutural & Arto Pitkanen \\
\hline Construção & Hartela / ET / Losinger \\
\hline \multicolumn{2}{|l|}{ Dados do Reservatório } \\
\hline Capacidade $\left[\mathrm{m}^{3}\right]$ & 12.600 \\
\hline Forma / Tipologia & Troncônico / Cogumelo \\
\hline Material & Concreto protendido \\
\hline \multicolumn{2}{|l|}{ Altura $[\mathrm{m}]$} \\
\hline Diâmetro máximo [m] & 66,70 \\
\hline \multicolumn{2}{|l|}{ Altura da Água - h [m] } \\
\hline Número de Câmaras & 1 \\
\hline \multicolumn{2}{|c|}{ Dados da Estrutura de Apoio do Reservatório } \\
\hline \multicolumn{2}{|l|}{ Tipologia } \\
\hline Material & Concreto armado \\
\hline \multicolumn{2}{|l|}{ Altura do Fundo do Reservatório - H [m] } \\
\hline \multicolumn{2}{|l|}{ Altura Efetiva - H + h [m] } \\
\hline Altura Total da Torre - Ht [m] & 52,00 \\
\hline \multicolumn{2}{|l|}{ Dados do Revestimento } \\
\hline \multicolumn{2}{|l|}{ Tipo } \\
\hline \multicolumn{2}{|l|}{ Material } \\
\hline \multicolumn{2}{|l|}{ Referências Bibliográficas } \\
\hline Inserções em Bibliografia Específica & [ASOLA, 2003] \\
\hline \multirow[t]{2}{*}{ Inserções em Bibliografia Geral } & [VSL, 2008]; \\
\hline & [VSL, 1983]; \\
\hline Inserções em Periódicos & nenhum registro encontrado \\
\hline
\end{tabular}


Torre de Roihuvuori

054 Simo Lumme
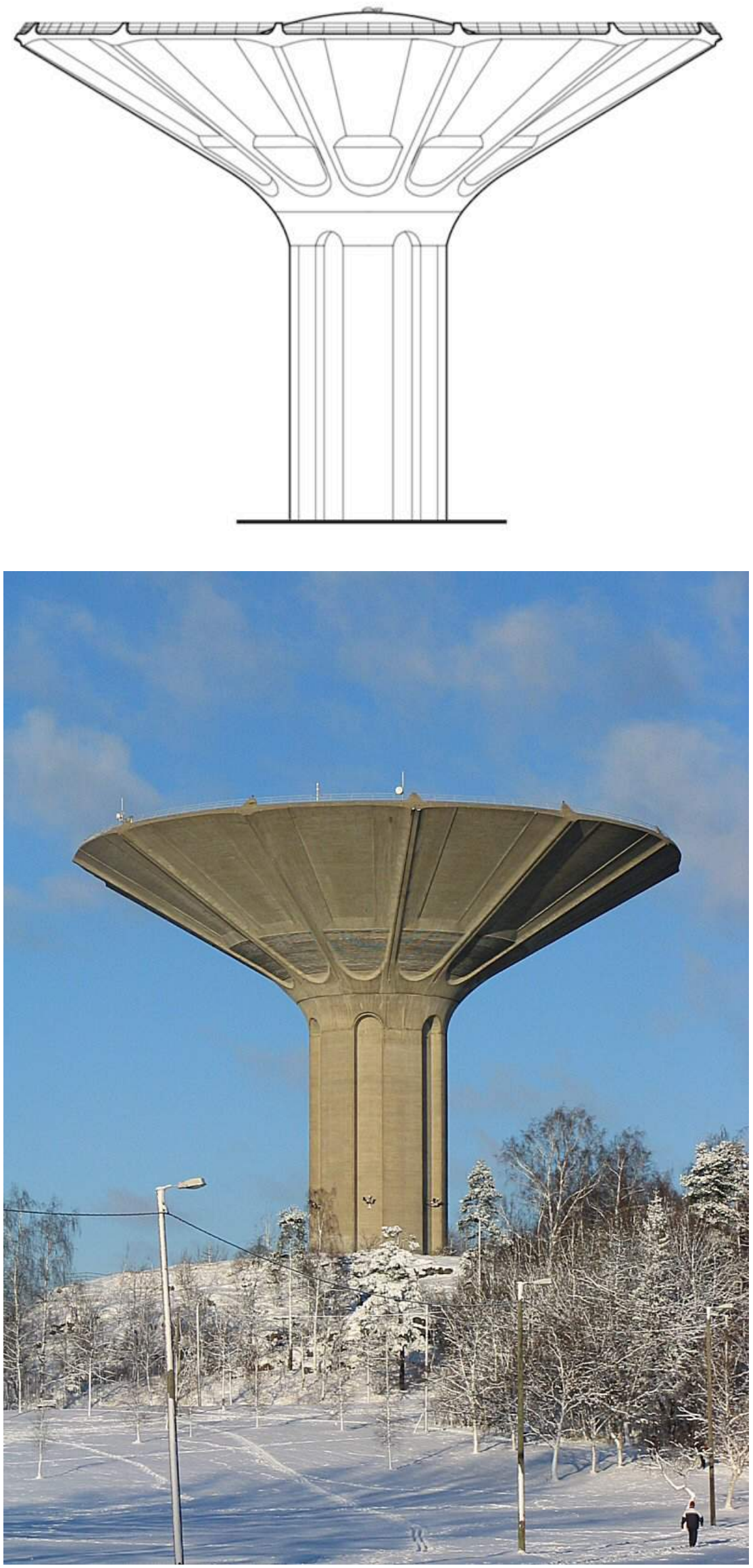
Torre da Indústria Refrescos del Norte

055 Eladio Dieste

\begin{tabular}{|c|c|}
\hline \multicolumn{2}{|l|}{ Informacões Gerais } \\
\hline Localização & Salto, Uruguai \\
\hline GPS & $31^{\circ} 24^{\prime} 38.47^{\prime \prime} \mathrm{S}-57^{\circ} 56^{\prime} 40.22^{\prime \prime} \mathrm{W}$ \\
\hline Data de Início do Projeto & 1978 \\
\hline Data do Término da Obra & 1979 \\
\hline Uso da Torre & Abastecimento industrial \\
\hline Situação Atual & Operacional \\
\hline \multicolumn{2}{|l|}{ Créditos do Projeto } \\
\hline Proprietário / Contratante & Refresos del Norte S.A. \\
\hline Projeto de Arquitetura & Eladio Dieste \\
\hline Projeto Estrutural & Eladio Dieste e Antonio Dieste \\
\hline Construção & Dieste y Montañez S.A. \\
\hline \multicolumn{2}{|l|}{ Dados do Reservatório } \\
\hline Capacidade $\left[\mathrm{m}^{3}\right]$ & 50 \\
\hline Forma / Tipologia & Tronco de cone / Fundo troncônico \\
\hline Material & Alvenaria \\
\hline Altura $[\mathrm{m}]$ & 7,20 \\
\hline Diâmetro máximo $[\mathrm{m}]$ & 4,20 \\
\hline \multicolumn{2}{|l|}{ Altura da Água - h [m] } \\
\hline Número de Câmaras & 1 \\
\hline \multicolumn{2}{|c|}{ Dados da Estrutura de Apoio do Reservatório } \\
\hline Tipologia & Fuste troncônico ôco em alvenaria \\
\hline Material & Tijolos de barro \\
\hline Altura do Fundo do Reservatório - $\mathrm{H}$ [m] & 16,00 \\
\hline \multicolumn{2}{|l|}{ Altura Efetiva - $\mathrm{H}+\mathrm{h}[\mathrm{m}]$} \\
\hline Altura Total da Torre - Ht [m] & 23,20 \\
\hline \multicolumn{2}{|l|}{ Dados do Revestimento } \\
\hline \multicolumn{2}{|l|}{ Tipo } \\
\hline \multicolumn{2}{|l|}{ Material } \\
\hline \multicolumn{2}{|l|}{ Referências Bibliográficas } \\
\hline Inserções em Bibliografia Específica & nenhum registro encontrado \\
\hline \multirow[t]{2}{*}{ Inserções em Bibliografia Geral } & [ANDERSON, 2004] \\
\hline & [TORRECILLAS, 1996] \\
\hline Inserções em Periódicos & nenhum registro encontrado \\
\hline
\end{tabular}



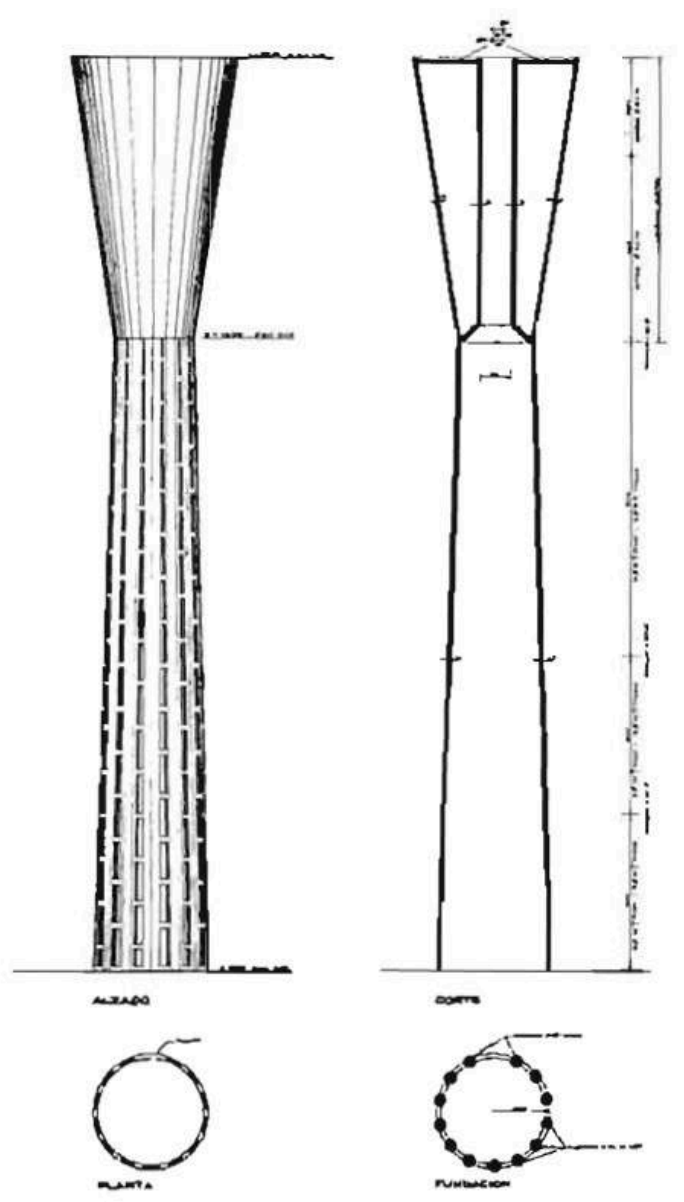
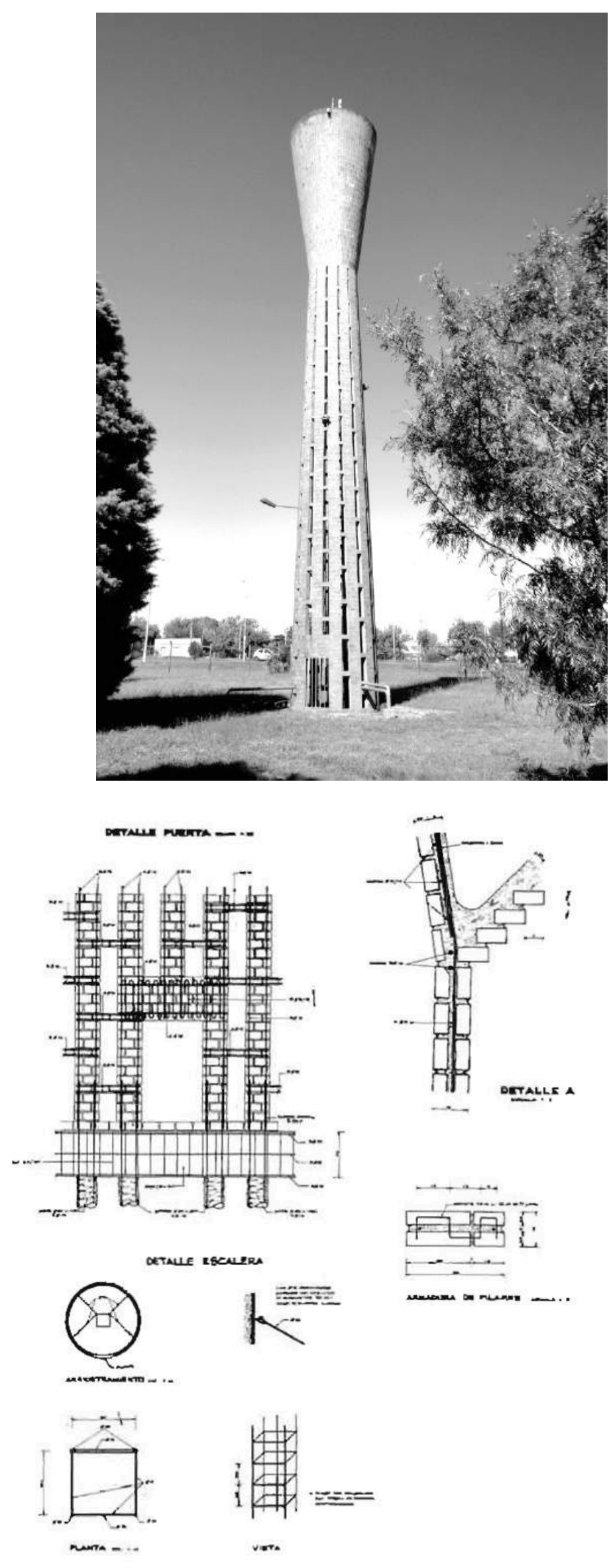
Torre do Complejo Habitacional America

056 Eladio Dieste

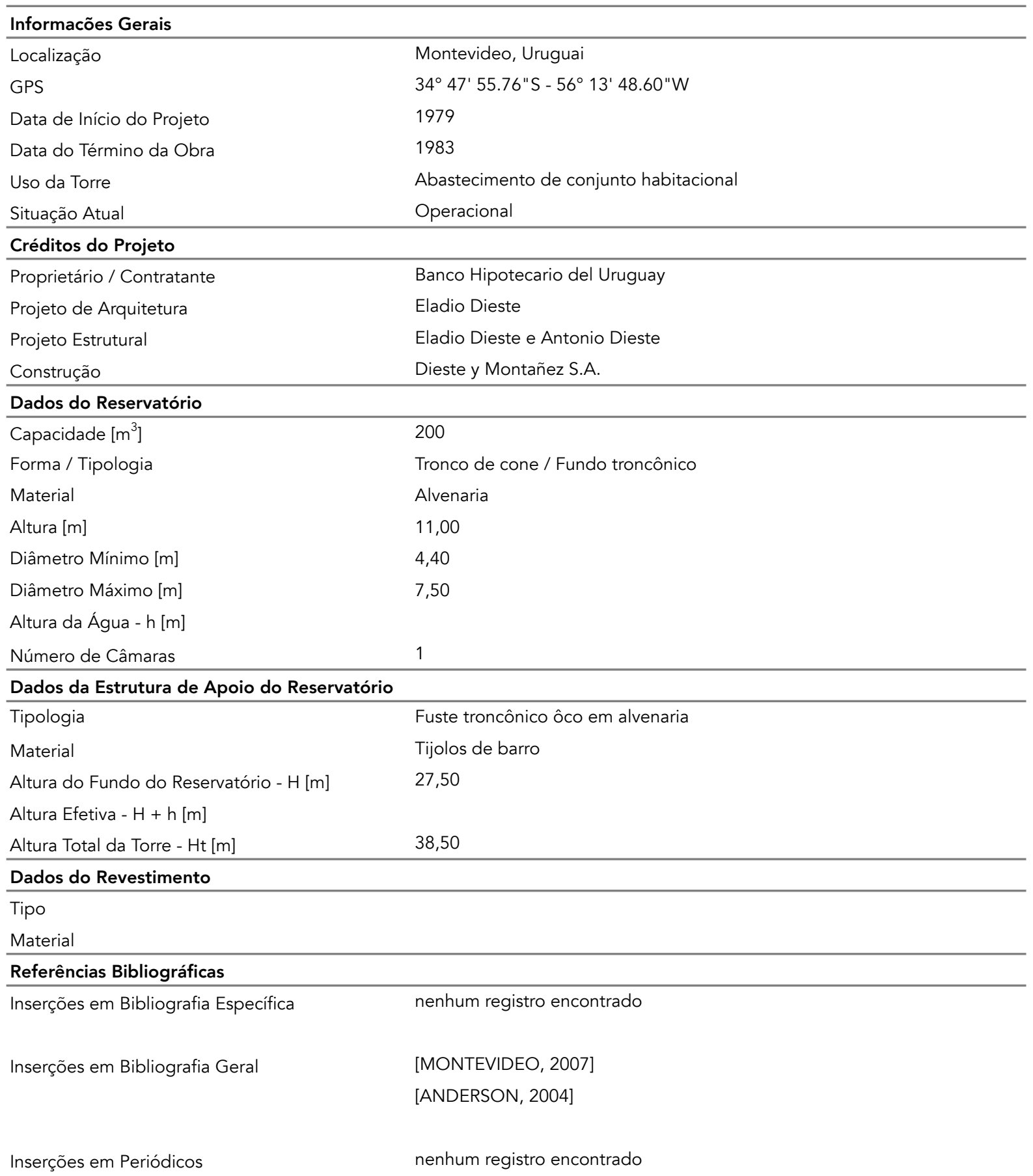




\section{Torre do Complejo Habitacional America}
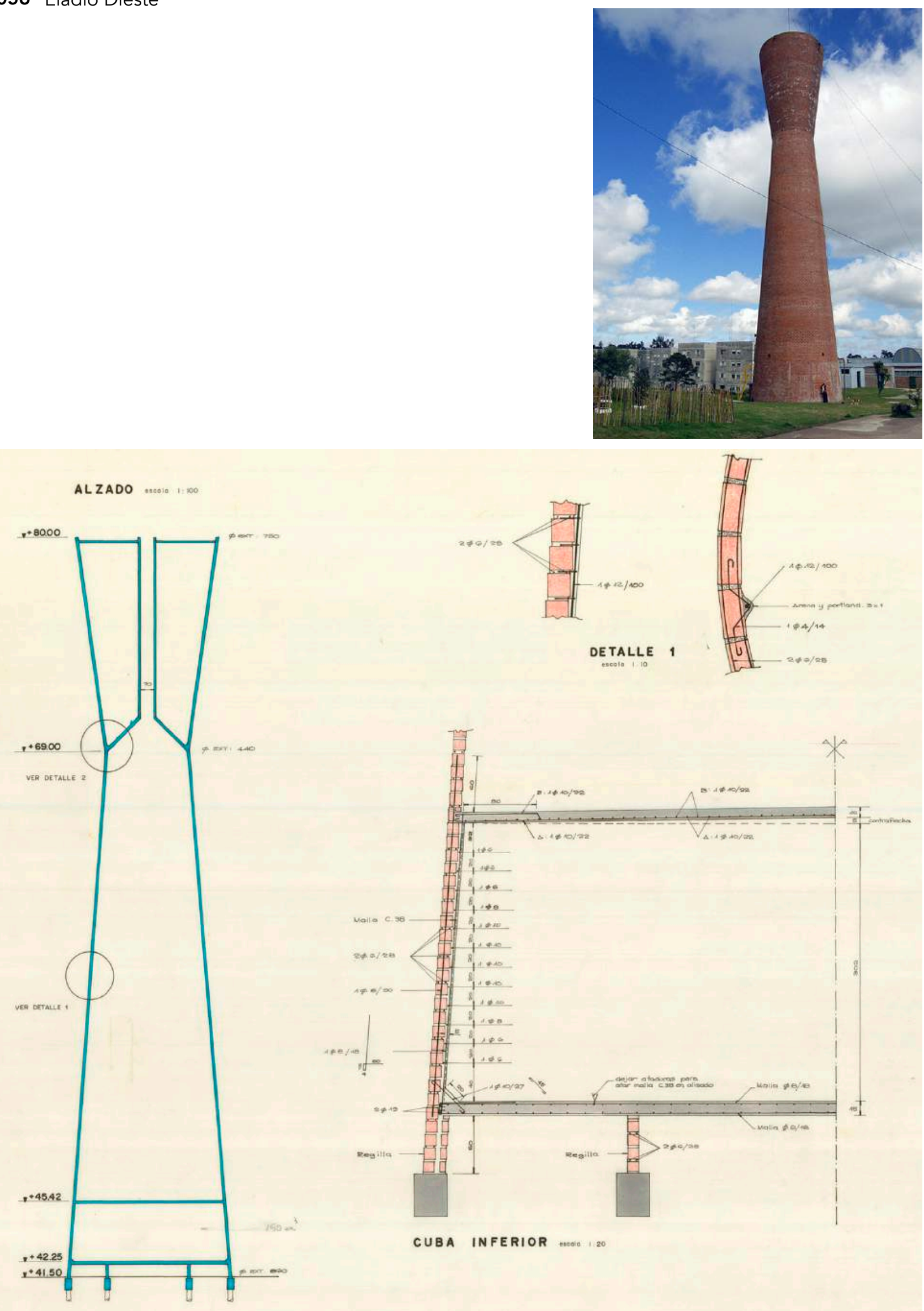
Torre de Tyrsted

057 Holger Koch Nielsen

\begin{tabular}{|c|c|}
\hline \multicolumn{2}{|l|}{ Informacões Gerais } \\
\hline Localização & Horsens, Dinamarca \\
\hline GPS & $55^{\circ} 49^{\prime} 32.24^{\prime \prime} \mathrm{N}-9^{\circ} 50^{\prime} 29.59^{\prime \prime} \mathrm{E}$ \\
\hline Data de Início do Projeto & 1982 \\
\hline Data do Término da Obra & 1983 \\
\hline Uso da Torre & Abastecimento público urbano \\
\hline Situação Atual & Operacional \\
\hline \multicolumn{2}{|l|}{ Créditos do Projeto } \\
\hline Proprietário / Contratante & Horsens Municipality \\
\hline Projeto de Arquitetura & Holger Koch Nielsen \\
\hline Projeto Estrutural & International Steel Consulting A/S \\
\hline \multicolumn{2}{|l|}{ Construção } \\
\hline \multicolumn{2}{|l|}{ Dados do Reservatório } \\
\hline Capacidade $\left[\mathrm{m}^{3}\right]$ & 2.000 \\
\hline Forma / Tipologia & Formato especial \\
\hline Material & Metálico [aço] \\
\hline \multicolumn{2}{|l|}{ Altura $[\mathrm{m}]$} \\
\hline Diâmetro máximo [m] & 23,40 \\
\hline Diâmetro mínimo [m] & 2,30 \\
\hline \multicolumn{2}{|l|}{ Altura da Água - h [m] } \\
\hline \multicolumn{2}{|l|}{ Número de Câmaras } \\
\hline \multicolumn{2}{|c|}{ Dados da Estrutura de Apoio do Reservatório } \\
\hline Tipologia & Fuste octogonal ôco e colunes tubulares oblíquas \\
\hline Material & Metálico [aço] \\
\hline \multicolumn{2}{|c|}{ Altura do Fundo do Reservatório - H [m] } \\
\hline \multicolumn{2}{|l|}{ Altura Efetiva $-\mathrm{H}+\mathrm{h}[\mathrm{m}]$} \\
\hline Altura Total da Torre - Ht [m] & 40,00 \\
\hline \multicolumn{2}{|l|}{ Dados do Revestimento } \\
\hline Tipo & \\
\hline Material & \\
\hline
\end{tabular}

Referências Bibliográficas

Inserções em Bibliografia Específica

[MEVIUS, 1985]

Inserções em Bibliografia Geral

nenhum registro encontrado

Inserções em Periódicos

[VA-tidskriften Cirkulation. Örebro, ago. 1998] 
Torre de Tyrsted

057 Holger Koch Nielsen

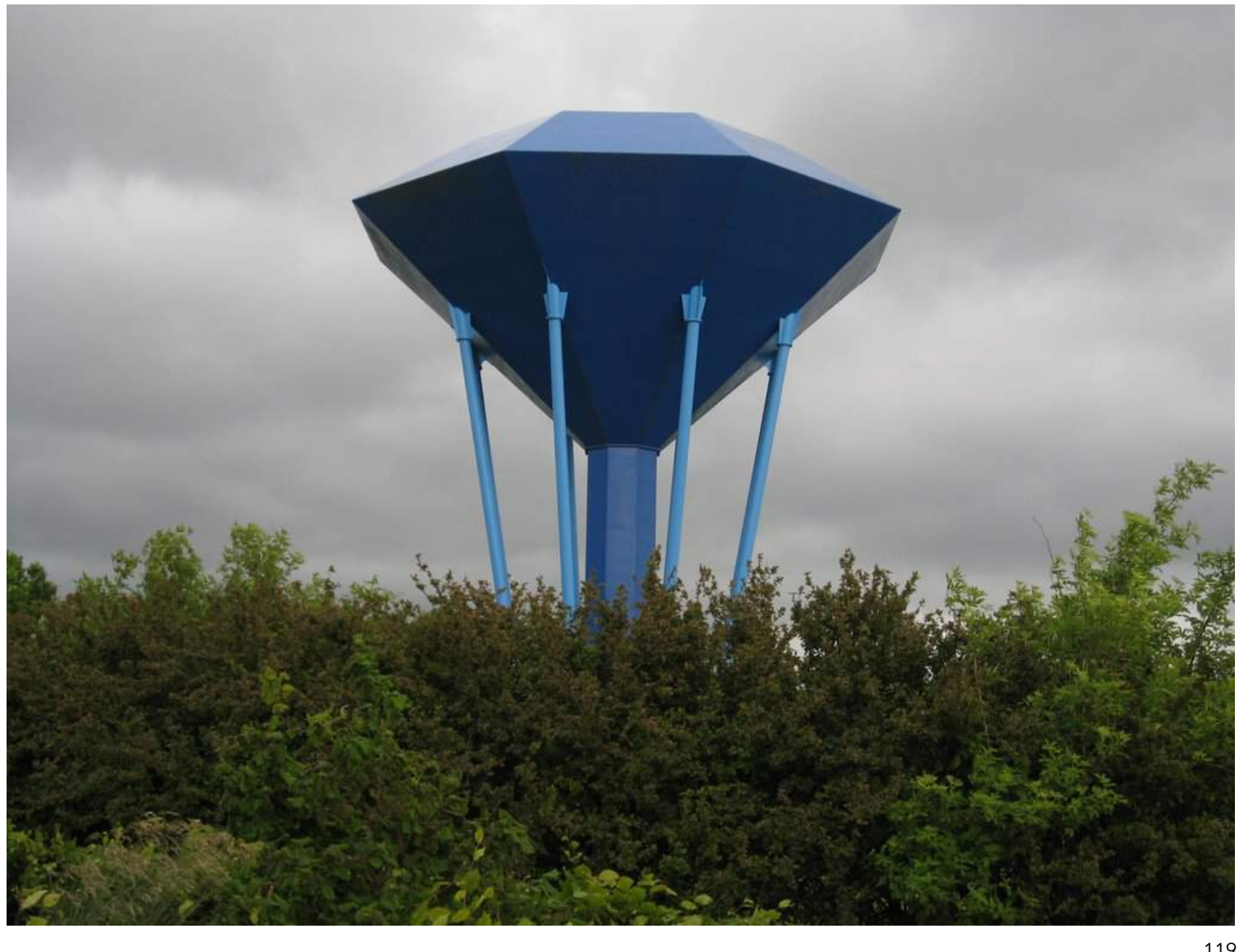


Torre da Estação Largo 13 de Maio

058

João Walter Toscano

\begin{tabular}{|c|c|}
\hline Informacões Gerais & \\
\hline Localização & São Paulo, São Paulo, Brasil \\
\hline GPS & $23^{\circ} 39^{\prime} 21.77^{\prime \prime} \mathrm{S}-46^{\circ} 43^{\prime} 9.32^{\prime \prime} \mathrm{W}$ \\
\hline Data de Início do Projeto & 1984 \\
\hline Data do Término da Obra & 1985 \\
\hline Uso da Torre & Abastecimento de estação ferroviária \\
\hline Situação Atual & Operacional \\
\hline Créditos do Projeto & \\
\hline Proprietário / Contratante & FEPASA - Ferrovia Paulista S.A. \\
\hline Projeto de Arquitetura & João Walter Toscano \\
\hline Projeto Estrutural & Figueiredo Ferraz \\
\hline Construção & \\
\hline Dados do Reservatório & \\
\hline Capacidade $\left[\mathrm{m}^{3}\right]$ & 7,5 \\
\hline Forma / Tipologia & Retangular / Fundo plano \\
\hline Material & Metálico [aço] \\
\hline Altura [m] & 4,20 \\
\hline Comprimento $[\mathrm{m}]$ & 1,53 \\
\hline Largura $[\mathrm{m}]$ & 1,30 \\
\hline Altura da Água - h [m] & 3,80 \\
\hline Número de Câmaras & 1 \\
\hline Dados da Estrutura de Apoio do Reser & \\
\hline Tipologia & Pilar parede e vigas de travamento \\
\hline Material & Metálico [aço] \\
\hline Altura do Fundo do Reservatório - H [m] & 18,90 \\
\hline Altura Efetiva $-\mathrm{H}+\mathrm{h}[\mathrm{m}]$ & 22,70 \\
\hline Altura Total da Torre - Ht [m] & 29,14 \\
\hline Dados do Revestimento & \\
\hline Tipo & \\
\hline Material & \\
\hline
\end{tabular}

Referências Bibliográficas

Inserções em Bibliografia Específica

nenhum registro encontrado

Inserções em Bibliografia Geral

[ARTIGAS, 2002]

Inserções em Periódicos

nenhum registro encontrado

Acervo de Projetos da FAU / USP

[TOSCANO; FERRAZ, 1984. Classificação: PE T639es/725.31 LT] 
Torre da Estação Largo 13 de Maio

058 João Walter Toscano
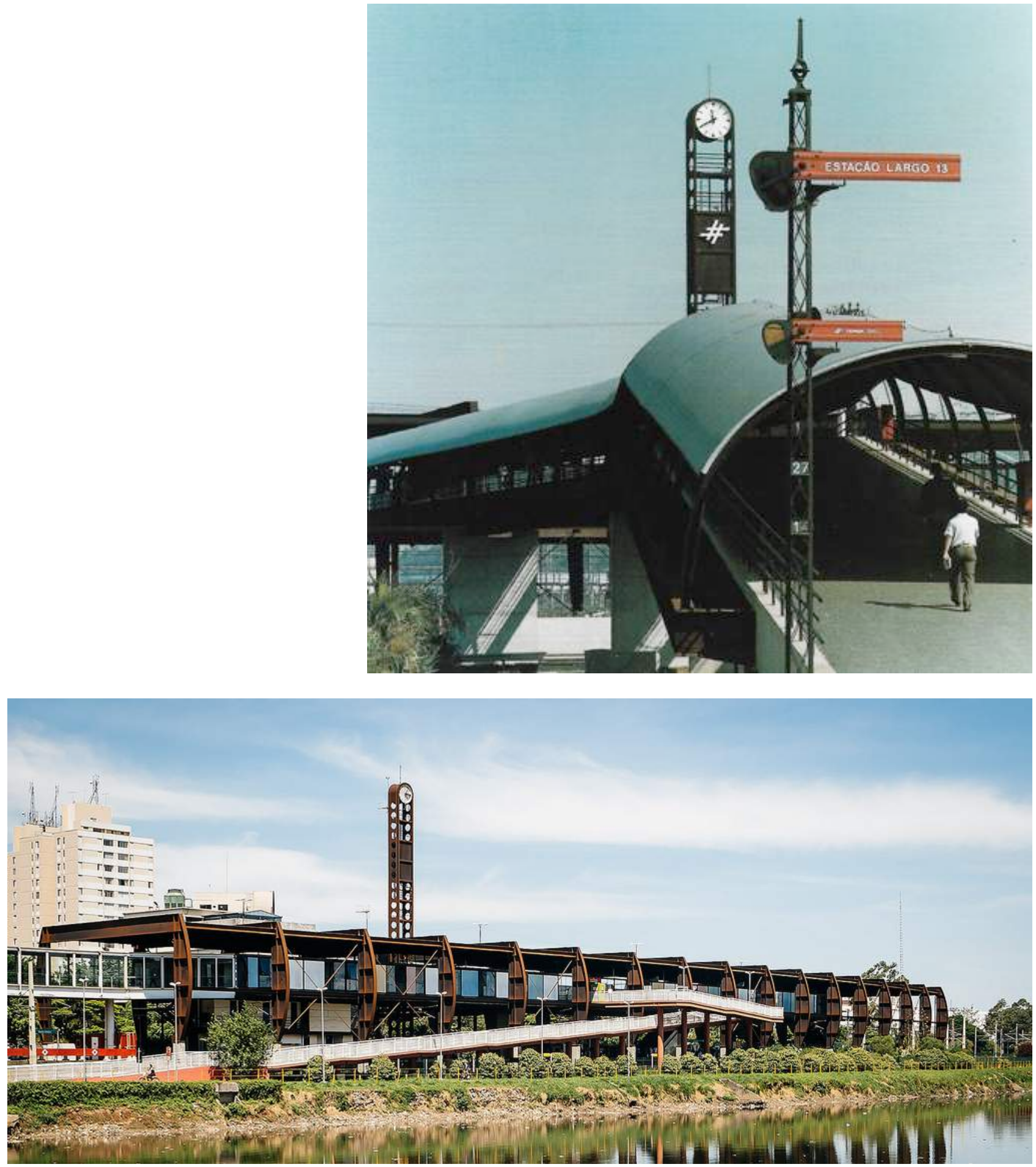
Torre dos Ventos

059 Toyo Ito

\begin{tabular}{|c|c|}
\hline Informacões Gerais & \\
\hline Localização & Yokohama, Kanagawa, Japão \\
\hline GPS & $35^{\circ} 28^{\prime} 1.07^{\prime \prime} \mathrm{N}-139^{\circ} 37^{\prime} 15.89^{\prime \prime} \mathrm{E}$ \\
\hline Data de Início do Projeto & 1986 \\
\hline Data do Término da Obra & 1986 \\
\hline Uso da Torre & Abastecimento de centro comercial \\
\hline Situação Atual & Desmontada em 1995 \\
\hline Créditos do Projeto & \\
\hline Proprietário / Contratante & Governo de Kanagawa \\
\hline Projeto de Arquitetura & Toyo Ito \\
\hline Projeto Estrutural & Gengo Matsui + ORS \\
\hline Construção & Ohbayashi Corporation \\
\hline Dados do Reservatório & \\
\hline Capacidade $\left[\mathrm{m}^{3}\right]$ & 0 \\
\hline Forma / Tipologia & Retangular / Fundo plano \\
\hline Material & Concreto armado \\
\hline Altura [m] & 6,25 \\
\hline Largura $[\mathrm{m}]$ & 3,60 \\
\hline Altura da Água - h [m] & \\
\hline Número de Câmaras & \\
\hline Dados da Estrutura de Apoio do Reser & \\
\hline Tipologia & Sistema de pilares e vigas \\
\hline Material & Concreto armado \\
\hline Altura do Fundo do Reservatório - H [m] & 15,45 \\
\hline Altura Efetiva - $\mathrm{H}+\mathrm{h}[\mathrm{m}]$ & \\
\hline Altura Total da Torre - Ht [m] & 20,70 \\
\hline Dados do Revestimento & \\
\hline Tipo & Painís em chapa perfurada e sistema de iluminação \\
\hline Material & Aço e alumínio \\
\hline Referências Bibliográficas & \\
\hline Inserções em Bibliografia Específica & nenhum registro encontrado \\
\hline Inserções em Bibliografia Geral & [RILEY, 2004] \\
\hline Inserções em Periódicos & [El Croquis, Madrid, v. 14, n. 71, 1995] \\
\hline & [l'ARCA, Milano, n. 15, abr. 1988] \\
\hline & [DOMUS, Milano, v. 1, n. 691, fev. 1988] \\
\hline & [JA: The Japan Architect, Tokyo, v. 62, n. 361, maio 1987] \\
\hline
\end{tabular}




\section{Torre dos Ventos}

059 Toyo Ito

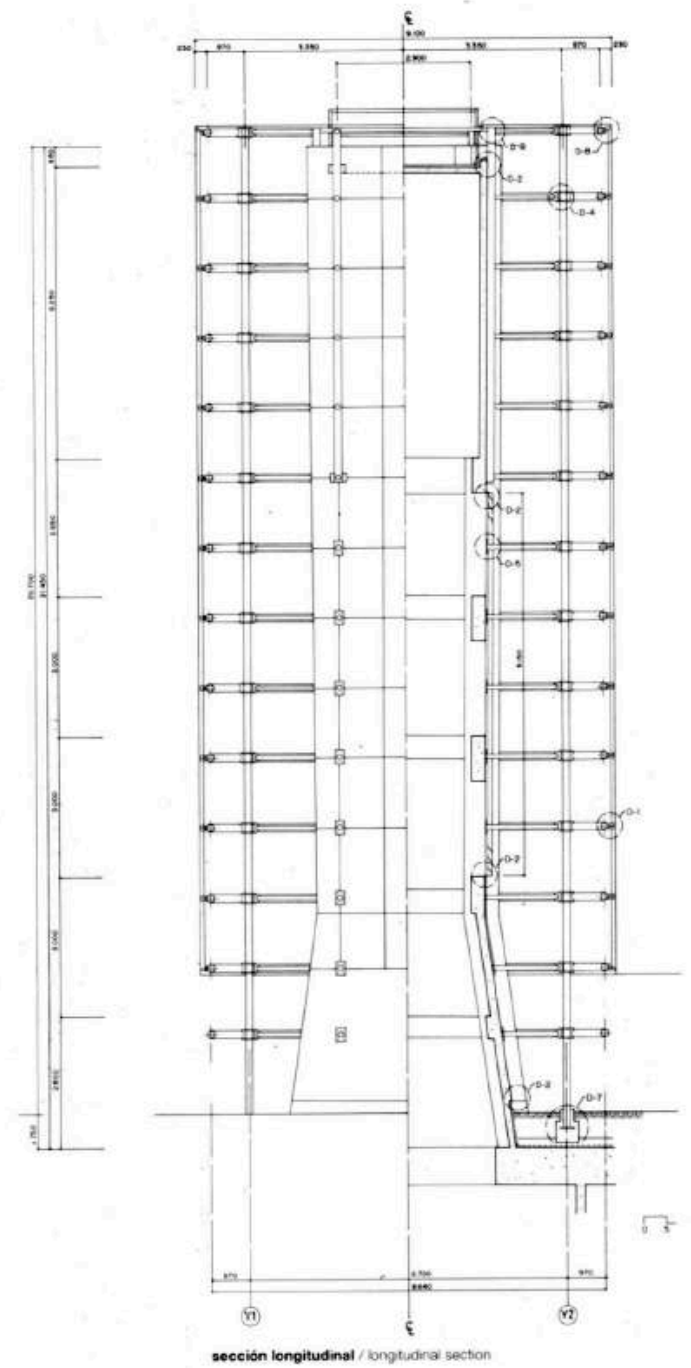

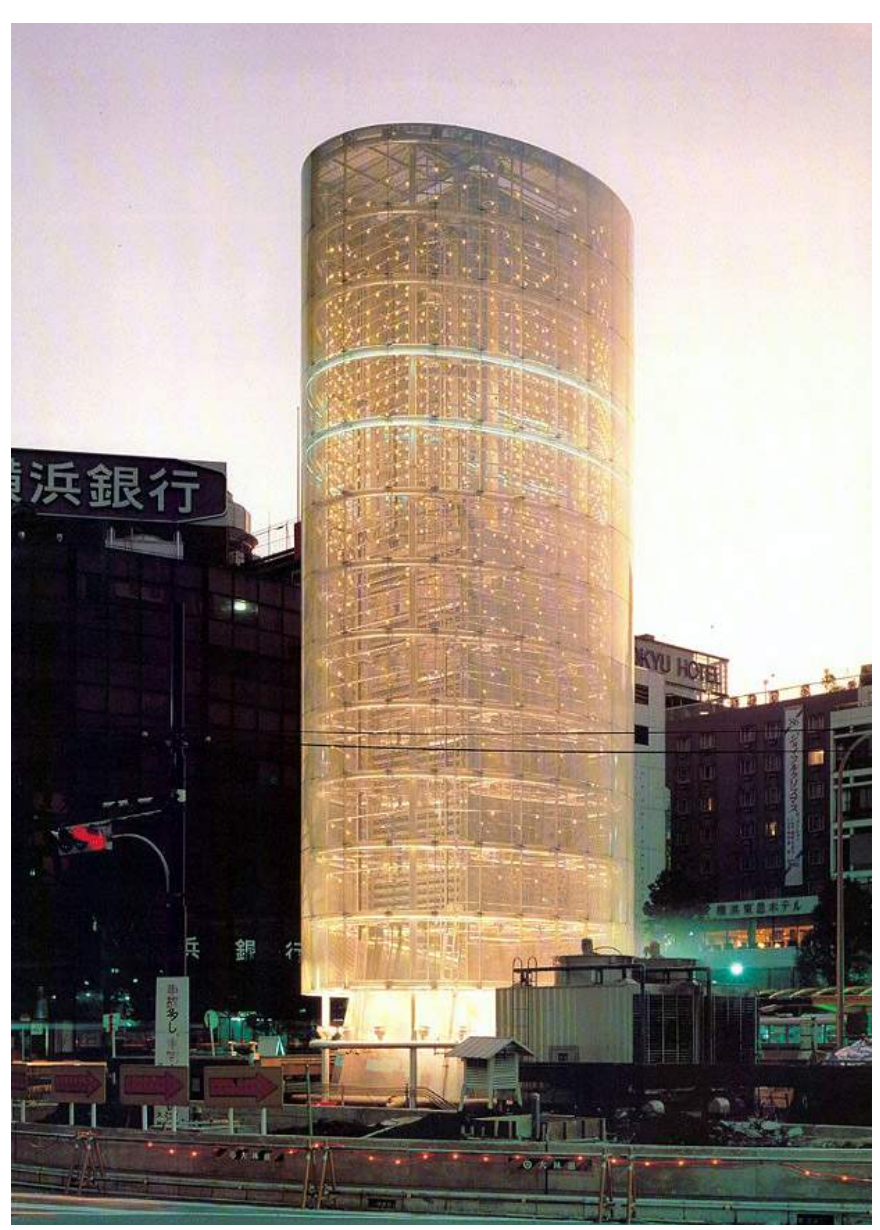
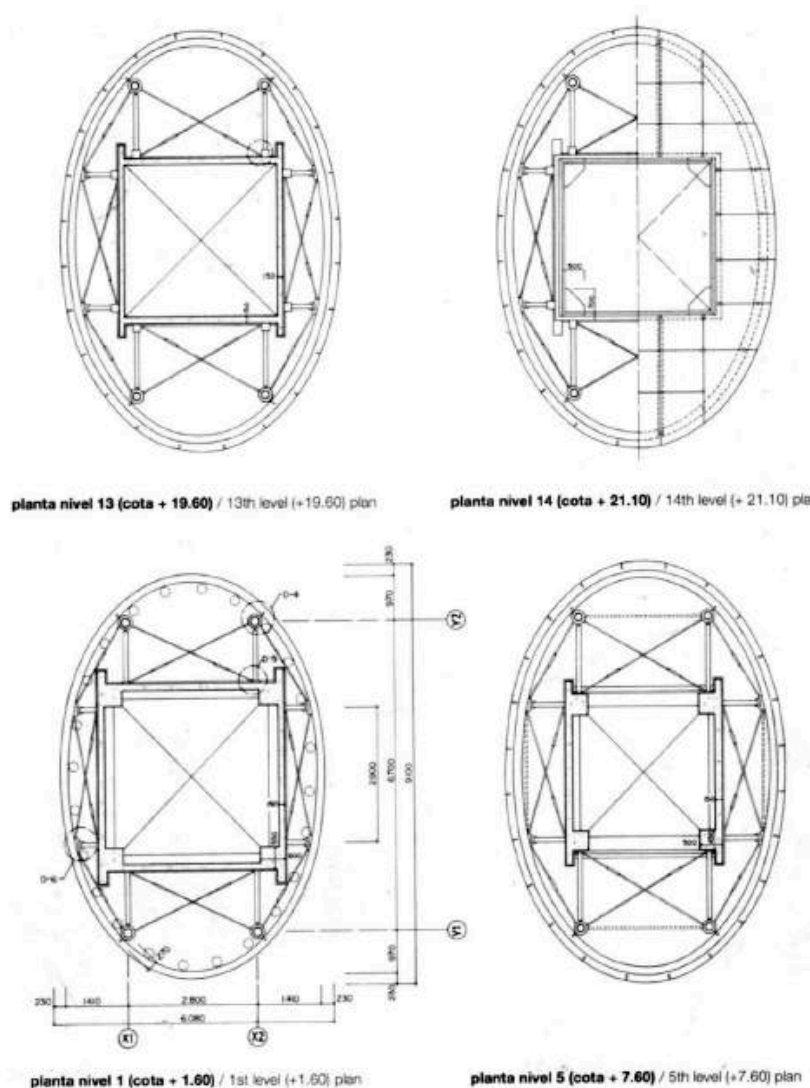
Torre da Universidade de Aveiro

060 Álvaro Siza

\begin{tabular}{|c|c|}
\hline Informacões Gerais & \\
\hline Localização & Aveiro, Portugal \\
\hline GPS & $40^{\circ} 37^{\prime} 44.54^{\prime \prime} \mathrm{N}-8^{\circ} 39^{\prime} 19.47^{\prime \prime} \mathrm{W}$ \\
\hline Data de Início do Projeto & 1988 \\
\hline Data do Término da Obra & 1989 \\
\hline Uso da Torre & Abastecimento de campus universitário \\
\hline Situação Atual & Operacional \\
\hline Créditos do Projeto & \\
\hline Proprietário / Contratante & Universidade de Aveiro \\
\hline Projeto de Arquitetura & Álvaro Siza \\
\hline Projeto Estrutural & \\
\hline Construção & \\
\hline Dados do Reservatório & \\
\hline Capacidade $\left[\mathrm{m}^{3}\right]$ & 60 \\
\hline Forma / Tipologia & Retangular / Fundo plano \\
\hline Material & Concreto armado \\
\hline Altura $[\mathrm{m}]$ & 3,50 \\
\hline Comprimento $[\mathrm{m}]$ & 8,50 \\
\hline Largura $[\mathrm{m}]$ & 3,50 \\
\hline Altura da Água - h [m] & 2,60 \\
\hline Número de Câmaras & 1 \\
\hline Dados da Estrutura de Apoio do Reser & \\
\hline Tipologia & Fuste cilíndrico ôco e pilar parede \\
\hline Material & Concreto armado \\
\hline Altura do Fundo do Reservatório - H [m] & 25,20 \\
\hline Altura Efetiva - $\mathrm{H}+\mathrm{h}[\mathrm{m}]$ & 27,80 \\
\hline Altura Total da Torre - Ht [m] & 28,50 \\
\hline Dados do Revestimento & \\
\hline Tipo & \\
\hline Material & \\
\hline Referências Bibliográficas & \\
\hline Inserções em Bibliografia Específica & nenhum registro encontrado \\
\hline Inserções em Bibliografia Geral & [TESTA, 1998] \\
\hline Inserções em Periódicos & nenhum registro encontrado \\
\hline
\end{tabular}


060 Álvaro Siza
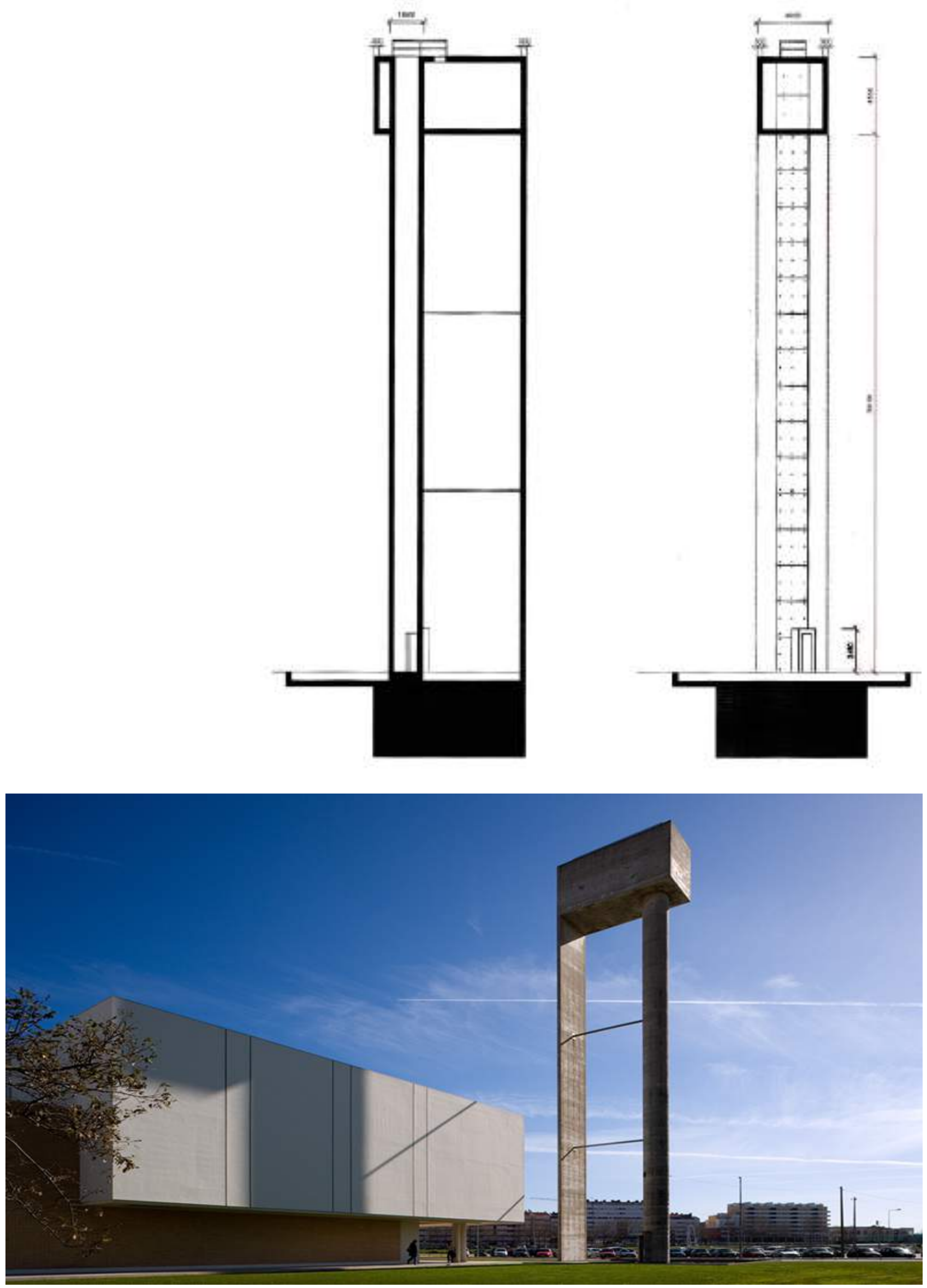
Centro Idrico di Vigna Murata

061 Francesco Palpacelli

\begin{tabular}{ll}
\hline Informacões Gerais & \\
\hline Localização & EUR, Roma, Itália \\
GPS & $41^{\circ} 49^{\prime} 21.86^{\prime \prime} \mathrm{N}-12^{\circ} 29^{\prime} 48.89^{\prime \prime} \mathrm{E}$ \\
Data de Início do Projeto & 1973 \\
Data do Término da Obra & 1989 \\
Uso da Torre & Abastecimento público urbano \\
Situação Atual & Operacional \\
\hline Créditos do Projeto & \\
\hline Proprietário / Contratante & ACEA - Azienda Comunale Elettricità e Acque \\
Projeto de Arquitetura & Francesco Palpacelli \\
Projeto Estrutural & \\
Construção & \\
\hline Dados do Reservatório & \\
\hline Capacidade [m ${ }^{3}$ ] & 2.500 \\
Forma / Tipologia & Anular / Fundo plano \\
Material & Metálico [aço] \\
Altura [m] & 6,70 \\
Diâmetro externo [m] & 34,00 \\
Diâmetro interno [m] & 26,00 \\
Largura [m] & 4,00 \\
Altura da Água - h [m] & 5,00 \\
Número de Câmaras & $1 \times 1700 \mathrm{~m} 3+1 \times 800 \mathrm{~m} 3$ \\
\hline Dados da Estrutura de Apoio do Reservatólo & \\
\hline
\end{tabular}

Dados da Estrutura de Apoio do Reservatório

\begin{tabular}{ll}
\hline Tipologia & Pilares cilíndricos ôcos \\
Material & Metálico \\
Altura do Fundo do Reservatório - H [m] & 49,50 \\
Altura Efetiva - H + h [m] & 54,50 \\
Altura Total da Torre - Ht [m] & 80,50
\end{tabular}

Dados do Revestimento

\begin{tabular}{ll}
\hline Tipo & Painéis metálicos \\
Material & Aço inox \\
\hline
\end{tabular}

\section{Referências Bibliográficas}

Inserções em Bibliografia Específica

nenhum registro encontrado

Inserções em Bibliografia Geral

[MURATORE, 2007]

Inserções em Periódicos

nenhum registro encontrado 
Centro Idrico di Vigna Murata

061 Francesco Palpacelli
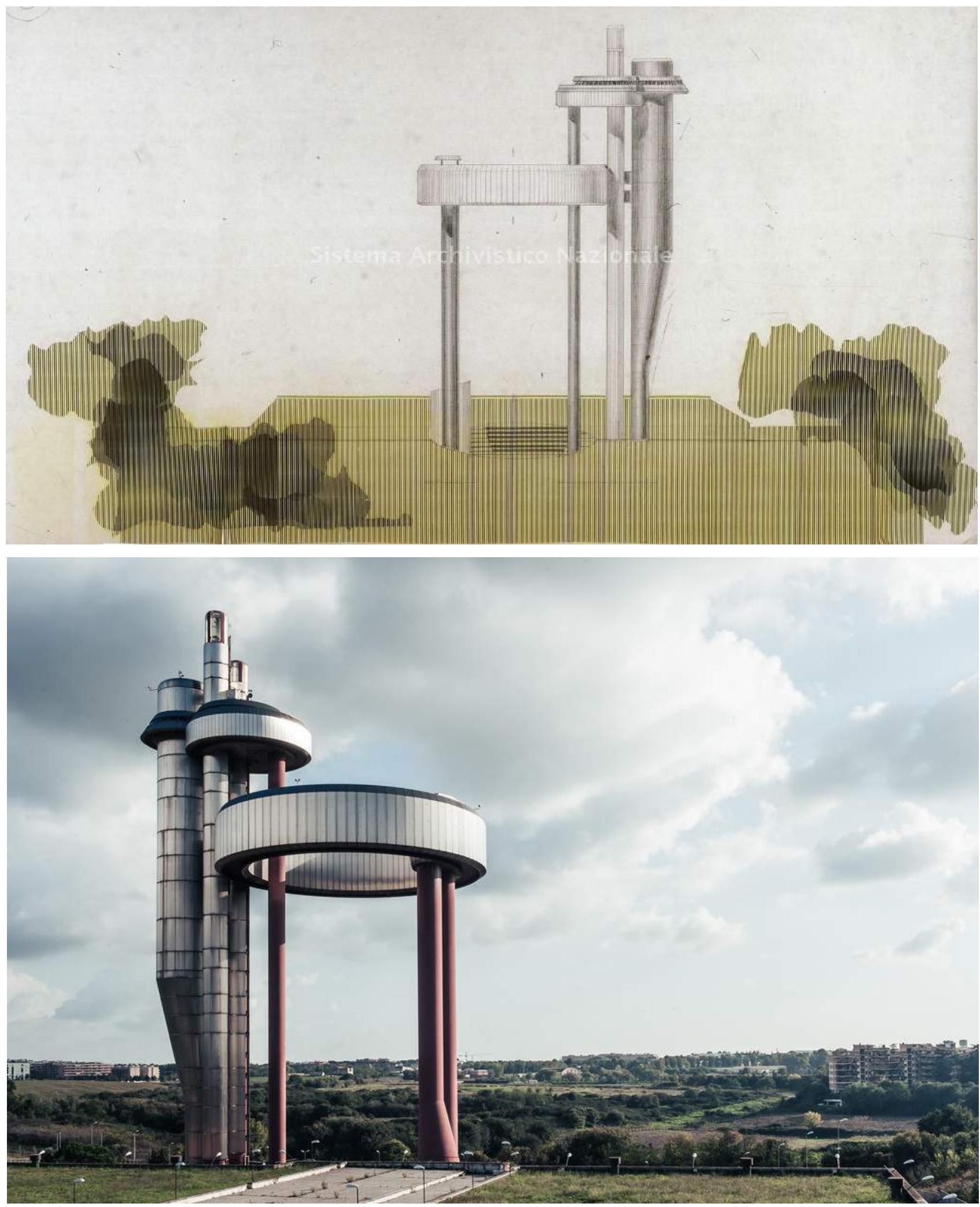
Torre de Midrand

062 GAPP Architects

\begin{tabular}{|c|c|}
\hline Informacões Gerais & \\
\hline Localização & Gauteng, África do Sul \\
\hline GPS & $25^{\circ} 59^{\prime} 37.69^{\prime \prime} \mathrm{S}-28^{\circ} 8^{\prime} 19.37^{\prime \prime} \mathrm{E}$ \\
\hline Data de Início do Projeto & 1989 \\
\hline Data do Término da Obra & 1996 \\
\hline Uso da Torre & Abastecimento público urbano \\
\hline Situação Atual & Operacional \\
\hline Créditos do Projeto & \\
\hline Proprietário / Contratante & Midrand Town Council \\
\hline Projeto de Arquitetura & GAPP Architects \\
\hline Projeto Estrutural & BKS Inc. \\
\hline Construção & Stocks Civils \\
\hline Dados do Reservatório & \\
\hline Capacidade $\left[\mathrm{m}^{3}\right]$ & 6.500 \\
\hline Forma / Tipologia & Troncônico \\
\hline Material & Concreto protendido \\
\hline Altura $[\mathrm{m}]$ & \\
\hline Largura $[\mathrm{m}]$ & 0,00 \\
\hline Altura da Água - h [m] & \\
\hline Número de Câmaras & 1 \\
\hline Dados da Estrutura de Apoio do $\mathbf{R}$ & \\
\hline Tipologia & Paredes estruturais em balanço \\
\hline Material & Concreto armado \\
\hline Altura do Fundo do Reservatório - H & \\
\hline Altura Efetiva - H + h [m] & \\
\hline Altura Total da Torre - Ht [m] & 40,00 \\
\hline Dados do Revestimento & \\
\hline Tipo & \\
\hline Material & \\
\hline Referências Bibliográficas & \\
\hline Inserções em Bibliografia Específica & nenhum registro encontrado \\
\hline Inserções em Bibliografia Geral & [MUWANGA, 1998] \\
\hline & [VSL, 1997] \\
\hline Inserções em Periódicos & nenhum registro encontrado \\
\hline
\end{tabular}


Torre de Midrand

062 GAPP Architects
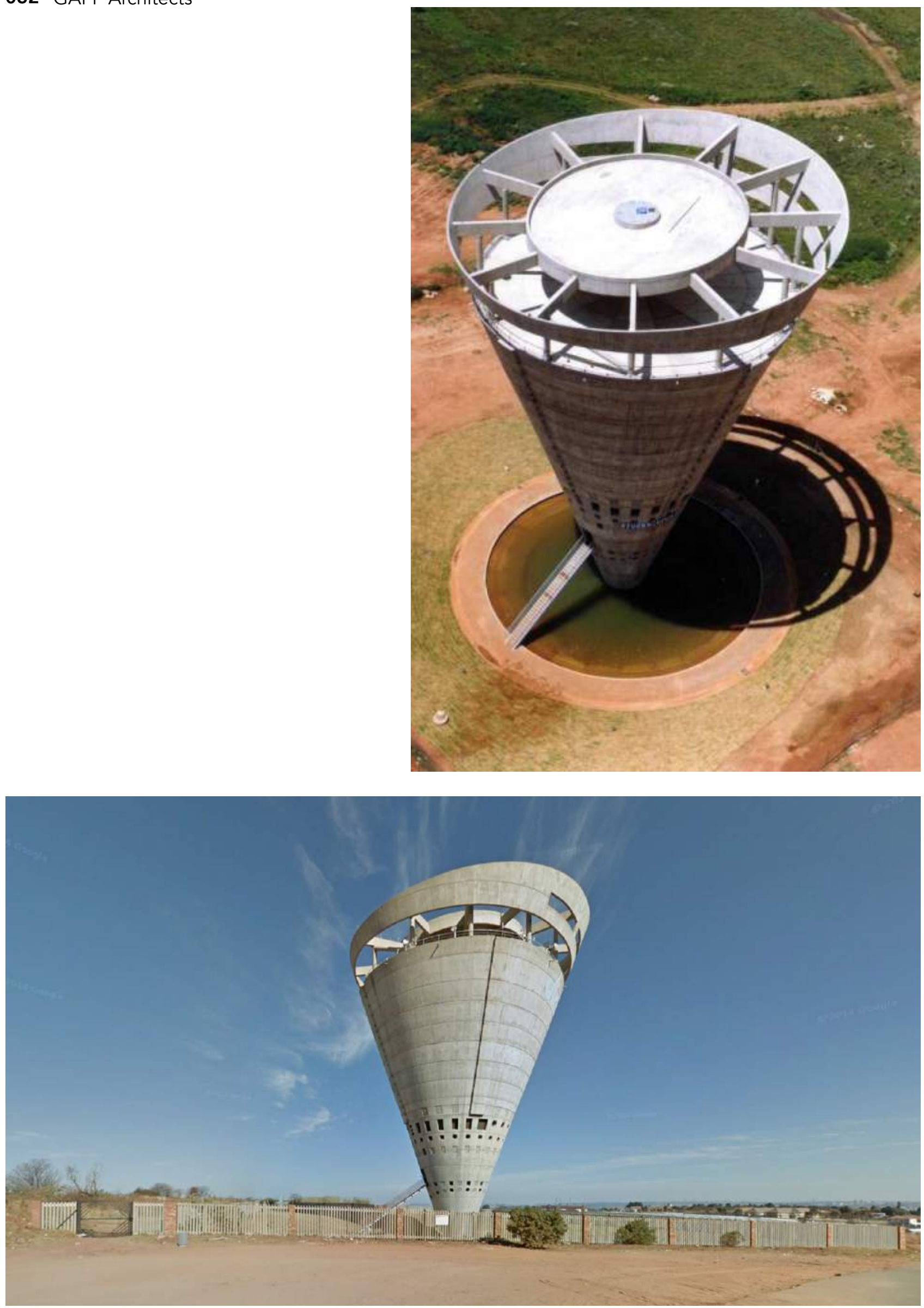
Torre da Nova Aldeia da Luz

063 Pedro Bandeira + João Figueira

\begin{tabular}{|c|c|}
\hline \multicolumn{2}{|l|}{ Informacões Gerais } \\
\hline Localização & Luz, Portugal \\
\hline GPS & $38^{\circ} 20^{\prime} 33.21^{\prime \prime} \mathrm{N}-7^{\circ} 22^{\prime} 16.17^{\prime \prime} \mathrm{W}$ \\
\hline Data de Início do Projeto & 1996 \\
\hline Data do Término da Obra & 2002 \\
\hline Uso da Torre & Abastecimento público urbano \\
\hline Situação Atual & Operacional \\
\hline \multicolumn{2}{|l|}{ Créditos do Projeto } \\
\hline Proprietário / Contratante & EDIA - Empresa de Desenvolvimento e Infra-Estruturas de Alqueva \\
\hline Projeto de Arquitetura & Pedro Bandeira + João Figueira \\
\hline \multicolumn{2}{|l|}{ Projeto Estrutural } \\
\hline Construção & EDIA - Empresa de Desenvolvimento e Infra-Estruturas de Alqueva \\
\hline \multicolumn{2}{|l|}{ Dados do Reservatório } \\
\hline Capacidade $\left[\mathrm{m}^{3}\right]$ & 0 \\
\hline Forma / Tipologia & Formato especial \\
\hline Material & Concreto armado \\
\hline \multicolumn{2}{|l|}{ Altura $[\mathrm{m}]$} \\
\hline Largura $[\mathrm{m}]$ & 0,00 \\
\hline \multicolumn{2}{|l|}{ Altura da Água - $\mathrm{h}[\mathrm{m}]$} \\
\hline Número de Câmaras & 1 \\
\hline \multicolumn{2}{|c|}{ Dados da Estrutura de Apoio do Reservatório } \\
\hline Tipologia & Paredes estruturais \\
\hline Material & Concreto armado \\
\hline \multicolumn{2}{|l|}{ Altura do Fundo do Reservatório - H [m] } \\
\hline \multicolumn{2}{|l|}{ Altura Efetiva - $\mathrm{H}+\mathrm{h}[\mathrm{m}]$} \\
\hline Altura Total da Torre - Ht [m] & 18,40 \\
\hline \multicolumn{2}{|l|}{ Dados do Revestimento } \\
\hline \multicolumn{2}{|l|}{ Tipo } \\
\hline \multicolumn{2}{|l|}{ Material } \\
\hline \multicolumn{2}{|l|}{ Referências Bibliográficas } \\
\hline Inserções em Bibliografia Específica & nenhum registro encontrado \\
\hline Inserções em Bibliografia Geral & [BANDEIRA, 2017] \\
\hline Inserções em Periódicos & [ArchDaily Brasil, 7 set. 2015] \\
\hline
\end{tabular}


Torre da Nova Aldeia da Luz

063 Pedro Bandeira + João Figueira
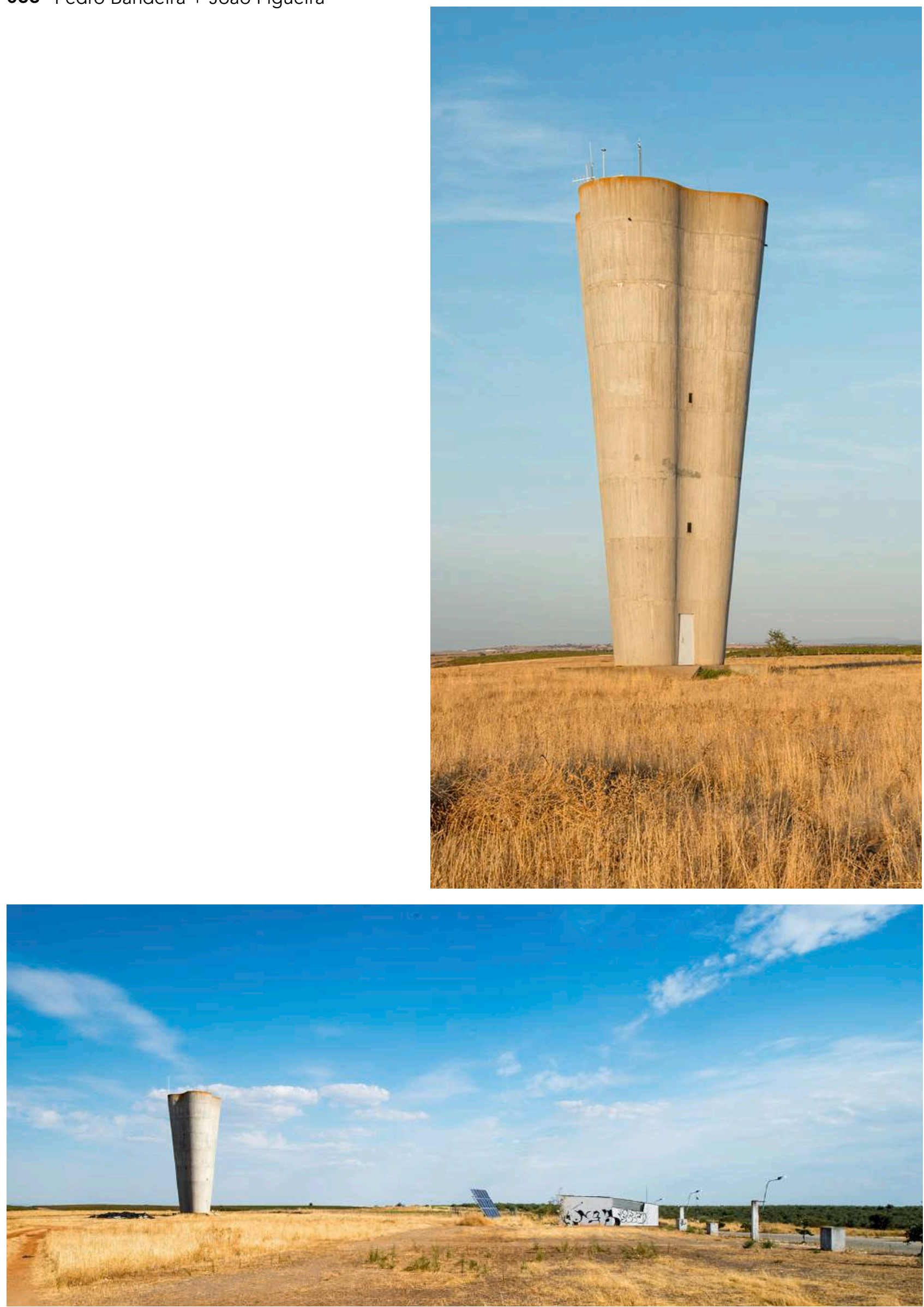
Château d'eau "ZÉRO ÉNERGIE"

064 Philippe Madec

\begin{tabular}{|c|c|}
\hline \multicolumn{2}{|l|}{ Informacões Gerais } \\
\hline Localização & Pacé, Bretanha, França \\
\hline GPS & $48^{\circ} 8^{\prime} 28.67^{\prime \prime} \mathrm{N}-1^{\circ} 45^{\prime} 54.47^{\prime \prime} \mathrm{W}$ \\
\hline Data de Início do Projeto & 2000 \\
\hline Data do Término da Obra & 2006 \\
\hline Uso da Torre & Abastecimento público urbano \\
\hline Situação Atual & Operacional \\
\hline \multicolumn{2}{|l|}{ Créditos do Projeto } \\
\hline Proprietário / Contratante & Syndicat des Eaux Pacé Saint-Gille Vezin Le Coquet \\
\hline Projeto de Arquitetura & Philippe Madec \\
\hline Projeto Estrutural & I2C ingénierie \\
\hline \multicolumn{2}{|l|}{ Construção } \\
\hline \multicolumn{2}{|l|}{ Dados do Reservatório } \\
\hline Capacidade $\left[\mathrm{m}^{3}\right]$ & 1.400 \\
\hline Forma / Tipologia & Retangular / Fundo plano \\
\hline Material & Concreto armado \\
\hline \multicolumn{2}{|l|}{ Altura $[\mathrm{m}]$} \\
\hline Largura $[\mathrm{m}]$ & 0 \\
\hline \multicolumn{2}{|l|}{ Altura da Água - h [m] } \\
\hline \multicolumn{2}{|l|}{ Número de Câmaras } \\
\hline \multicolumn{2}{|c|}{ Dados da Estrutura de Apoio do Reservatório } \\
\hline Tipologia & Pilares parede \\
\hline Material & Concreto armado \\
\hline \multicolumn{2}{|l|}{ Altura do Fundo do Reservatório - H [m] } \\
\hline \multicolumn{2}{|l|}{ Altura Efetiva - $\mathrm{H}+\mathrm{h}[\mathrm{m}]$} \\
\hline Altura Total da Torre - Ht [m] & 20,00 \\
\hline \multicolumn{2}{|l|}{ Dados do Revestimento } \\
\hline \multicolumn{2}{|l|}{ Tipo } \\
\hline \multicolumn{2}{|l|}{ Material } \\
\hline \multicolumn{2}{|l|}{ Referências Bibliográficas } \\
\hline Inserções em Bibliografia Específica & nenhum registro encontrado \\
\hline Inserções em Bibliografia Geral & nenhum registro encontrado \\
\hline Inserções em Periódicos & [Bauwelt, Berlin, v. 101, n. 10, mar. 2009] \\
\hline
\end{tabular}


Château d'eau "ZÉRO ÉNERGIE"

064 Philippe Madec
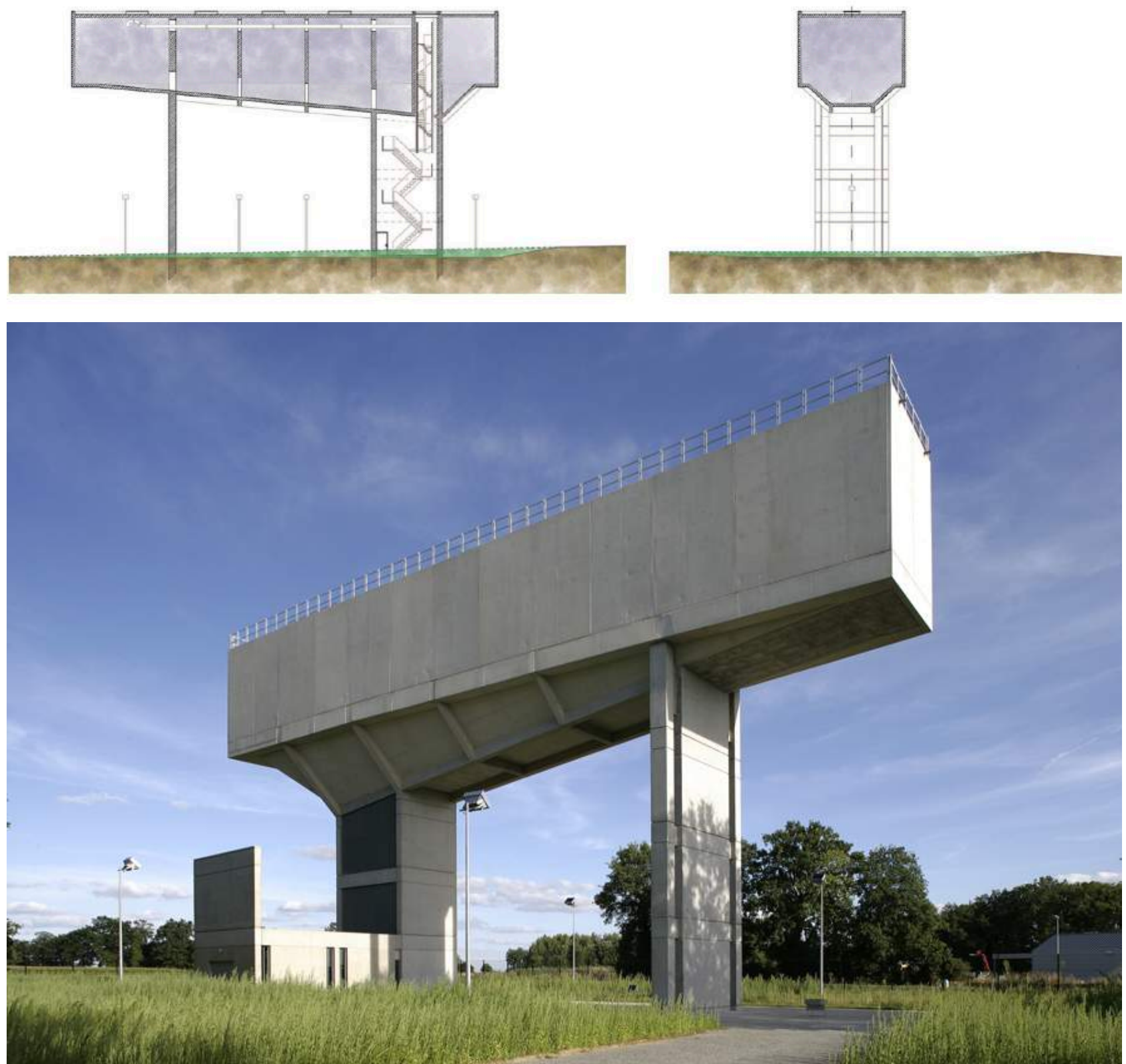
Torre de Leudelange

065 Schemel Wirtz

\begin{tabular}{ll}
\hline Informacões Gerais & \\
\hline Localização & Leudelange, Luxemburgo \\
GPS & $49^{\circ} 33^{\prime} 49.62^{\prime \prime} \mathrm{N}-6^{\circ} 4^{\prime} 41.00 " \mathrm{E}$ \\
Data de Início do Projeto & 2005 \\
Data do Término da Obra & 2008 \\
Uso da Torre & Abastecimento público urbano \\
Situação Atual & Operacional \\
\hline Créditos do Projeto & \\
\hline Proprietário / Contratante & Commune de Leudelange \\
Projeto de Arquitetura & Schemel Wirtz \\
Projeto Estrutural & Schroeder \& Associés \\
Construção & \\
\hline Dados do Reservatório & \\
\hline Capacidade [m ${ }^{3}$ ] & 1400 \\
Forma / Tipologia & Retangular / Fundo plano \\
Material & Concreto armado \\
Altura [m] & \\
Largura [m] & 0 \\
Altura da Água - h [m] & \\
Número de Câmaras & $2 \times 250 \mathrm{~m} 3+2 \times 450 \mathrm{~m} 3$ \\
\hline
\end{tabular}

Dados da Estrutura de Apoio do Reservatório

Tipologia Paredes estruturais

Material

Concreto armado

Altura do Fundo do Reservatório - H [m]

Altura Efetiva - $\mathrm{H}+\mathrm{h}[\mathrm{m}]$

Altura Total da Torre - $\mathrm{Ht}$ [m]

58,10

Dados do Revestimento

Tipo

Material

Referências Bibliográficas

Inserções em Bibliografia Específica

nenhum registro encontrado

Inserções em Bibliografia Geral

nenhum registro encontrado

Inserções em Periódicos

[Bauwelt, Berlin, v. 101, n. 10, mar. 2009] 
Torre de Leudelange

065 Schemel Wirtz
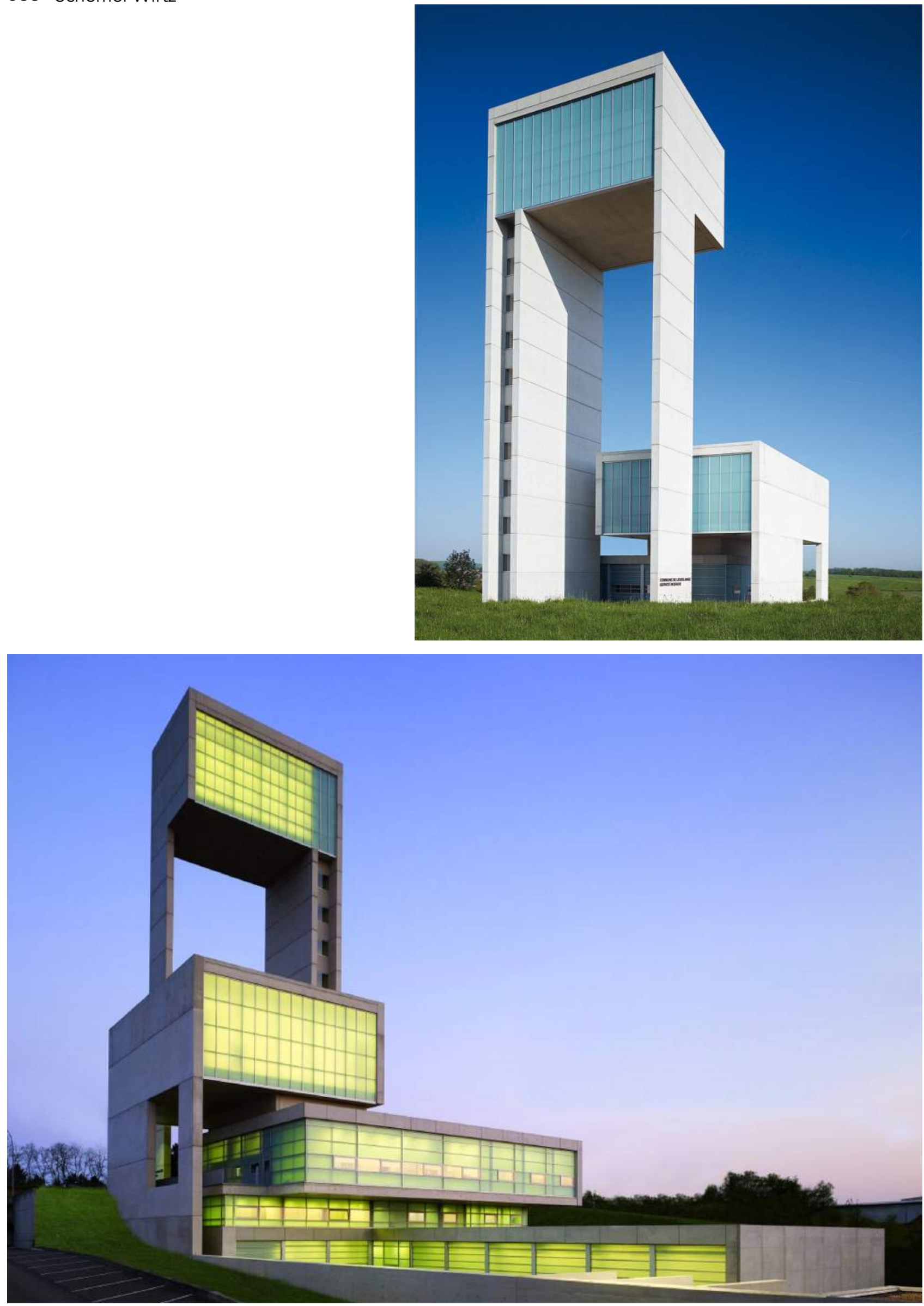
Torre em Guijo de Coria

066 GRG Arquitectos

\begin{tabular}{|c|c|}
\hline \multicolumn{2}{|l|}{ Informacões Gerais } \\
\hline Localização & Cáceres, Espanha \\
\hline GPS & $40^{\circ} 6^{\prime} 17.57^{\prime \prime} \mathrm{N}-6^{\circ} 27^{\prime} 57.07^{\prime \prime} \mathrm{W}$ \\
\hline Data de Início do Projeto & 2007 \\
\hline Data do Término da Obra & 2009 \\
\hline Uso da Torre & Abastecimento público urbano \\
\hline Situação Atual & Operacional \\
\hline \multicolumn{2}{|l|}{ Créditos do Projeto } \\
\hline Proprietário / Contratante & Ministerio de Fomento, Gobierno de Extremadura \\
\hline Projeto de Arquitetura & GRG Arquitectos \\
\hline \multicolumn{2}{|l|}{ Projeto Estrutural } \\
\hline Construção & Andiajoa S.L. \\
\hline \multicolumn{2}{|l|}{ Dados do Reservatório } \\
\hline Capacidade $\left[\mathrm{m}^{3}\right]$ & 80 \\
\hline Forma / Tipologia & Cilíndrico \\
\hline Material & Metálico [aço] \\
\hline \multicolumn{2}{|l|}{ Comprimento $[\mathrm{m}]$} \\
\hline Diâmatro máximo [m] & 0 \\
\hline \multicolumn{2}{|l|}{ Altura da Água - h [m] } \\
\hline Número de Câmaras & $2 \times 40 \mathrm{~m} 3$ \\
\hline \multicolumn{2}{|c|}{ Dados da Estrutura de Apoio do Reservatório } \\
\hline Tipologia & Estrutura treliçada \\
\hline Material & Metálico [aço] \\
\hline \multicolumn{2}{|l|}{ Altura do Fundo do Reservatório - H [m] } \\
\hline \multicolumn{2}{|l|}{ Altura Efetiva - H + h [m] } \\
\hline Altura Total da Torre - Ht [m] & 22,00 \\
\hline \multicolumn{2}{|l|}{ Dados do Revestimento } \\
\hline Tipo & $\mathrm{N} / \mathrm{A}$ \\
\hline Material & $\mathrm{N} / \mathrm{A}$ \\
\hline \multicolumn{2}{|l|}{ Referências Bibliográficas } \\
\hline Inserções em Bibliografia Específica & nenhum registro encontrado \\
\hline Inserções em Bibliografia Geral & nenhum registro encontrado \\
\hline Inserções em Periódicos & [DEZEEN, London, 19 jan. 2011] \\
\hline
\end{tabular}


Torre em Guijo de Coria

066 GRG Arquitectos
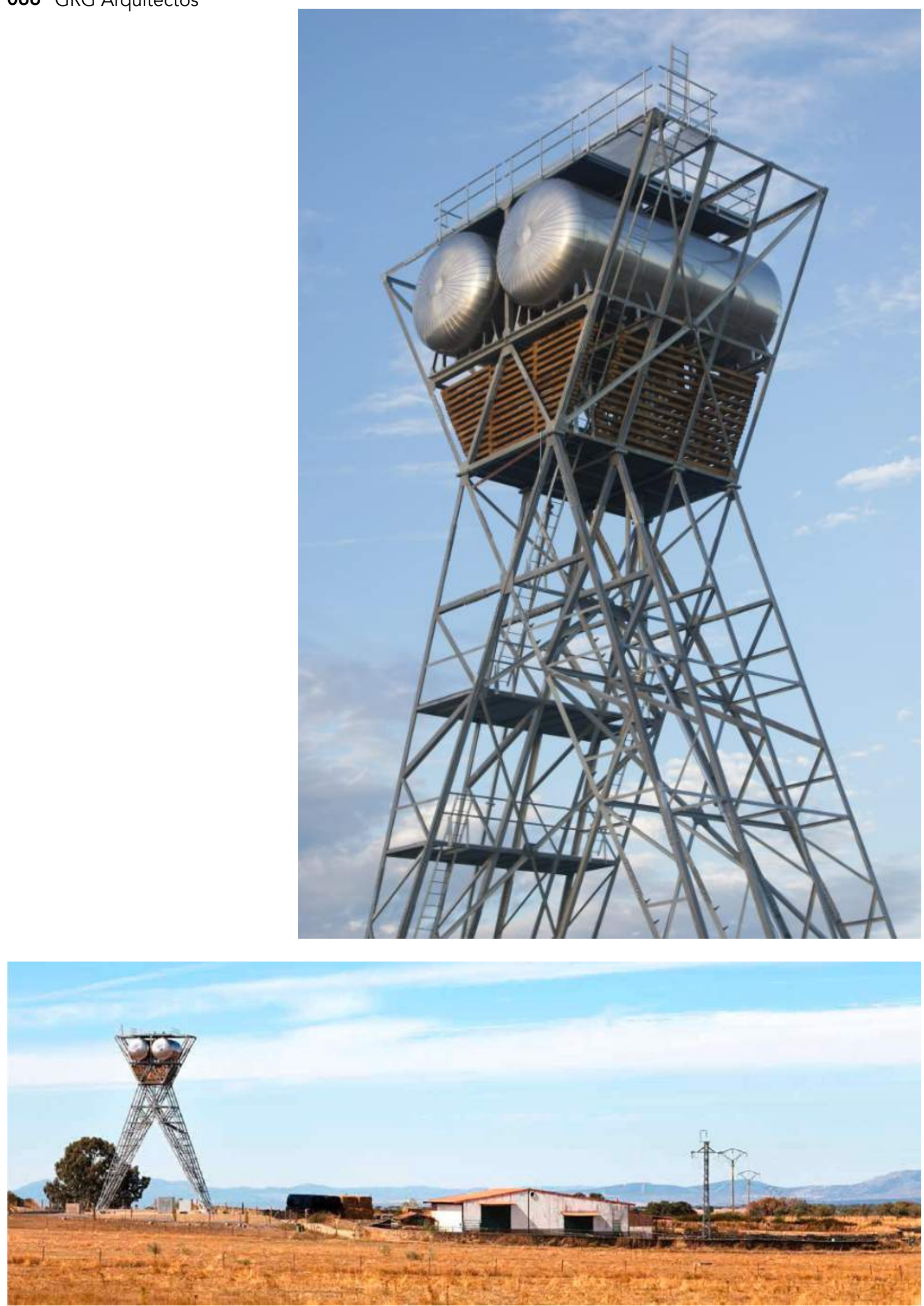
Torre em Rancagua

067 Mathias Klotz

\begin{tabular}{|c|c|}
\hline Informacões Gerais & \\
\hline Localização & Rancagua, Chile \\
\hline GPS & $34^{\circ} 10^{\prime} 15.53^{\prime \prime} \mathrm{S}-70^{\circ} 43^{\prime} 38.60^{\prime \prime} \mathrm{W}$ \\
\hline Data de Início do Projeto & 2010 \\
\hline Data do Término da Obra & 2012 \\
\hline Uso da Torre & Abastecimento público urbano \\
\hline Situação Atual & Operacional \\
\hline Créditos do Projeto & \\
\hline Proprietário / Contratante & ESSBIO S.A. \\
\hline Projeto de Arquitetura & Mathias Klotz \\
\hline Projeto Estrutural & \\
\hline Construção & \\
\hline Dados do Reservatório & \\
\hline Capacidade $\left[\mathrm{m}^{3}\right]$ & 0 \\
\hline Forma / Tipologia & Hiperbólico \\
\hline Material & Concreto armado \\
\hline Altura $[\mathrm{m}]$ & \\
\hline Diâmetro máximo $[\mathrm{m}]$ & 20,00 \\
\hline Altura da Água - h [m] & \\
\hline Número de Câmaras & \\
\hline Dados da Estrutura de Apoio do $R \epsilon$ & \\
\hline Tipologia & Paredes estruturais \\
\hline Material & Concreto armado \\
\hline Altura do Fundo do Reservatório - $\mathrm{H}$ & \\
\hline Altura Efetiva $-\mathrm{H}+\mathrm{h}[\mathrm{m}]$ & \\
\hline Altura Total da Torre - Ht [m] & 30,00 \\
\hline Dados do Revestimento & \\
\hline Tipo & Painéis metálicos móveis sob a ação do vento \\
\hline Material & Alumínio \\
\hline Referências Bibliográficas & \\
\hline Inserções em Bibliografia Específica & nenhum registro encontrado \\
\hline Inserções em Bibliografia Geral & nenhum registro encontrado \\
\hline Inserções em Periódicos & [Urban NEXT Digest, New York, 2016] \\
\hline & [DEZEEN, London, 10 set. 2013] \\
\hline
\end{tabular}




\section{Torre em Rancagua}

067 Mathias Klotz
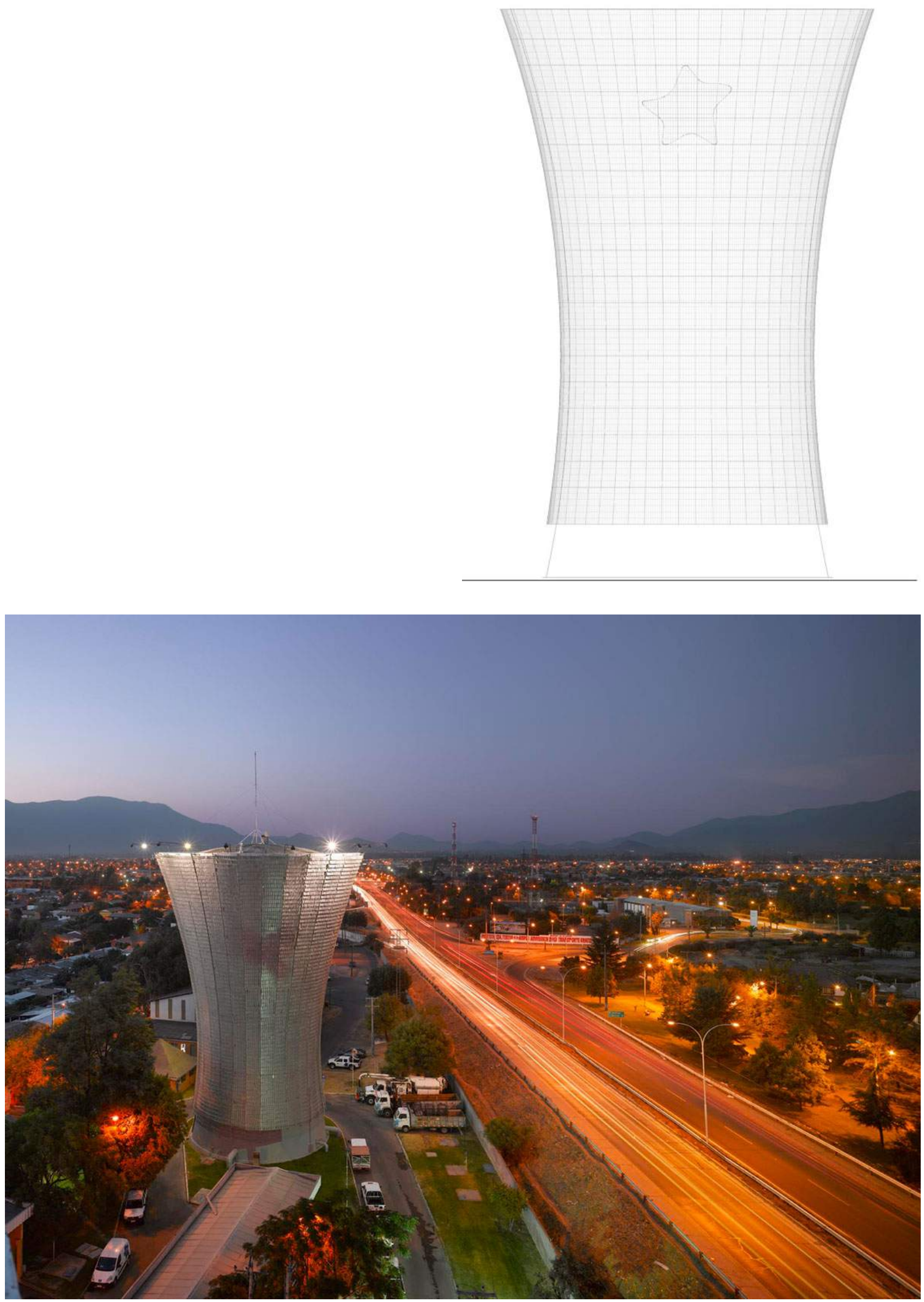
Torre em Santa Cruz

068 Mathias Klotz

\begin{tabular}{|c|c|}
\hline Informacões Gerais & \\
\hline Localização & Santa Cruz, Colchagua, Chile \\
\hline GPS & $34^{\circ} 37^{\prime} 51.36^{\prime \prime} \mathrm{S}-71^{\circ} 21^{\prime} 0.14^{\prime \prime} \mathrm{W}$ \\
\hline Data de Início do Projeto & 2010 \\
\hline Data do Término da Obra & 2012 \\
\hline Uso da Torre & Abastecimento público urbano \\
\hline Situação Atual & Operacional \\
\hline Créditos do Projeto & \\
\hline Proprietário / Contratante & ESSBIO S.A. \\
\hline Projeto de Arquitetura & Mathias Klotz \\
\hline Projeto Estrutural & Geolamba Ingenieria Ltda. \\
\hline Construção & \\
\hline Dados do Reservatório & \\
\hline Capacidade $\left[\mathrm{m}^{3}\right]$ & 1.100 \\
\hline Forma / Tipologia & Troncônico \\
\hline Material & Concreto armado \\
\hline Altura $[\mathrm{m}]$ & \\
\hline Diâmetro máximo [m] & 19,25 \\
\hline Diâmetro mínimo [m] & 12,30 \\
\hline Altura da Água - h [m] & \\
\hline Número de Câmaras & \\
\hline Dados da Estrutura de Apoio do Re & \\
\hline Tipologia & Fuste central cilíndrico ôco \\
\hline Material & Concreto armado \\
\hline Altura do Fundo do Reservatório - $\mathrm{H}$ & \\
\hline Altura Efetiva - H + h [m] & \\
\hline Altura Total da Torre - Ht [m] & 30,60 \\
\hline Dados do Revestimento & \\
\hline Tipo & \\
\hline Material & \\
\hline Referências Bibliográficas & \\
\hline Inserções em Bibliografia Específica & nenhum registro encontrado \\
\hline Inserções em Bibliografia Geral & [REYES, 2012] \\
\hline Inserções em Periódicos & nenhum registro encontrado \\
\hline
\end{tabular}


Torre em Santa Cruz

068 Mathias Klotz
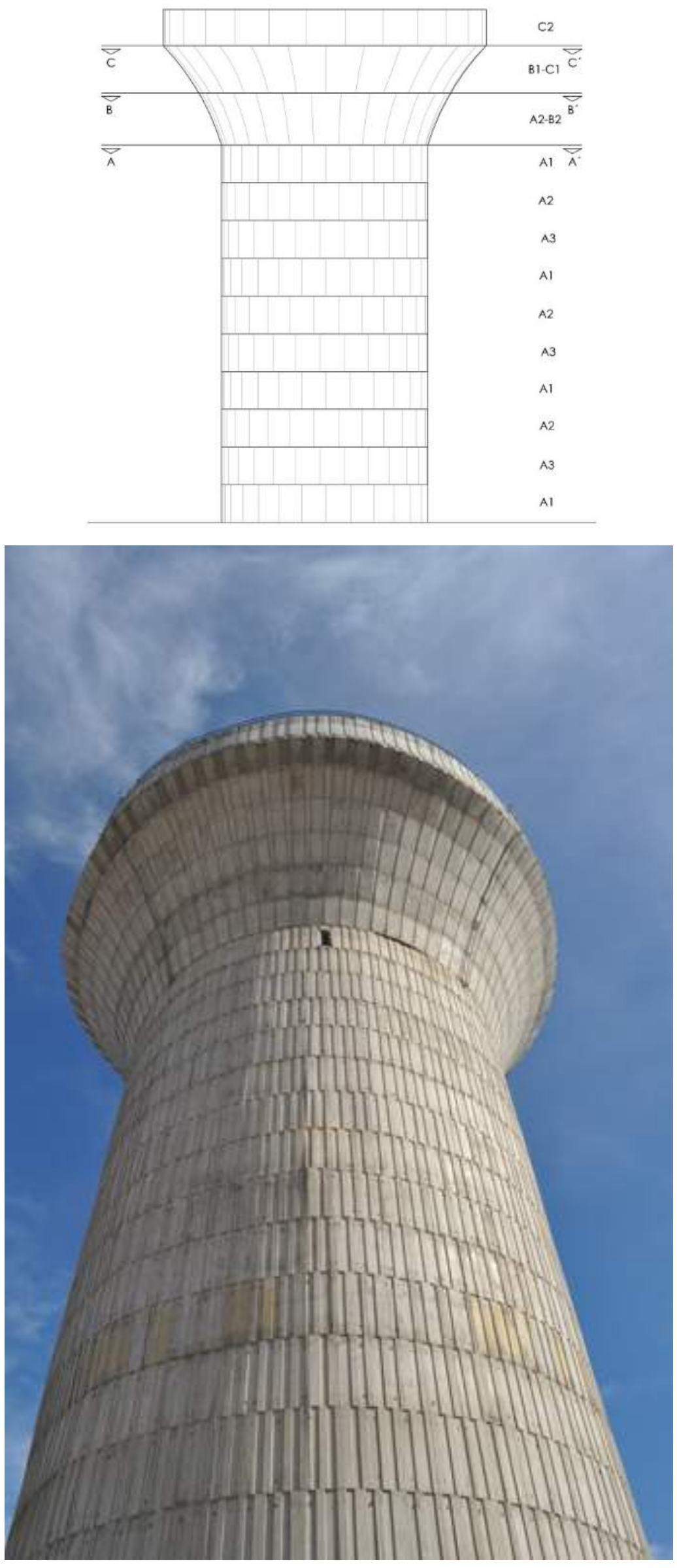
Torre de Ghlin-Baudour

$069 \mathrm{~V}+$ Architects

\begin{tabular}{|c|c|}
\hline Informacões Gerais & \\
\hline Localização & Mons, Bélgica \\
\hline GPS & $50^{\circ} 28^{\prime} 47.57^{\prime \prime} \mathrm{N}-3^{\circ} 53^{\prime} 15.78^{\prime \prime} \mathrm{E}$ \\
\hline Data de Início do Projeto & 2010 \\
\hline Data do Término da Obra & 2014 \\
\hline Uso da Torre & Abastecimento público urbano \\
\hline Situação Atual & Operacional \\
\hline Créditos do Projeto & \\
\hline Proprietário / Contratante & IDEA - Commune de Mons Ghlin \\
\hline Projeto de Arquitetura & $V+$ Architects \\
\hline Projeto Estrutural & Greisch \\
\hline Construção & \\
\hline Dados do Reservatório & \\
\hline Capacidade $\left[\mathrm{m}^{3}\right]$ & $2.000,00$ \\
\hline Forma / Tipologia & Cilíndrico / Fundo plano \\
\hline Material & Metálico [aço] \\
\hline Altura $[\mathrm{m}]$ & 11,00 \\
\hline Diâmetro máximo [m] & 17,00 \\
\hline Altura da Água - h [m] & \\
\hline Número de Câmaras & 1 \\
\hline Dados da Estrutura de Apoio do Reser & \\
\hline Tipologia & Pilares oblíquos e fuste quadro ôco \\
\hline Material & Concreto armado \\
\hline Altura do Fundo do Reservatório - H [m] & 41,00 \\
\hline Altura Efetiva $-\mathrm{H}+\mathrm{h}[\mathrm{m}]$ & \\
\hline Altura Total da Torre - Ht [m] & 55,60 \\
\hline Dados do Revestimento & \\
\hline Tipo & Painéis em chapa perfurada \\
\hline Material & Aço pintado \\
\hline Referências Bibliográficas & \\
\hline Inserções em Bibliografia Específica & nenhum registro encontrado \\
\hline Inserções em Bibliografia Geral & nenhum registro encontrado \\
\hline Inserções em Periódicos & [ArchDaily Brasil, 17 mai. 2016] \\
\hline & [DEZEEN, London, 21 dez. 2015] \\
\hline
\end{tabular}



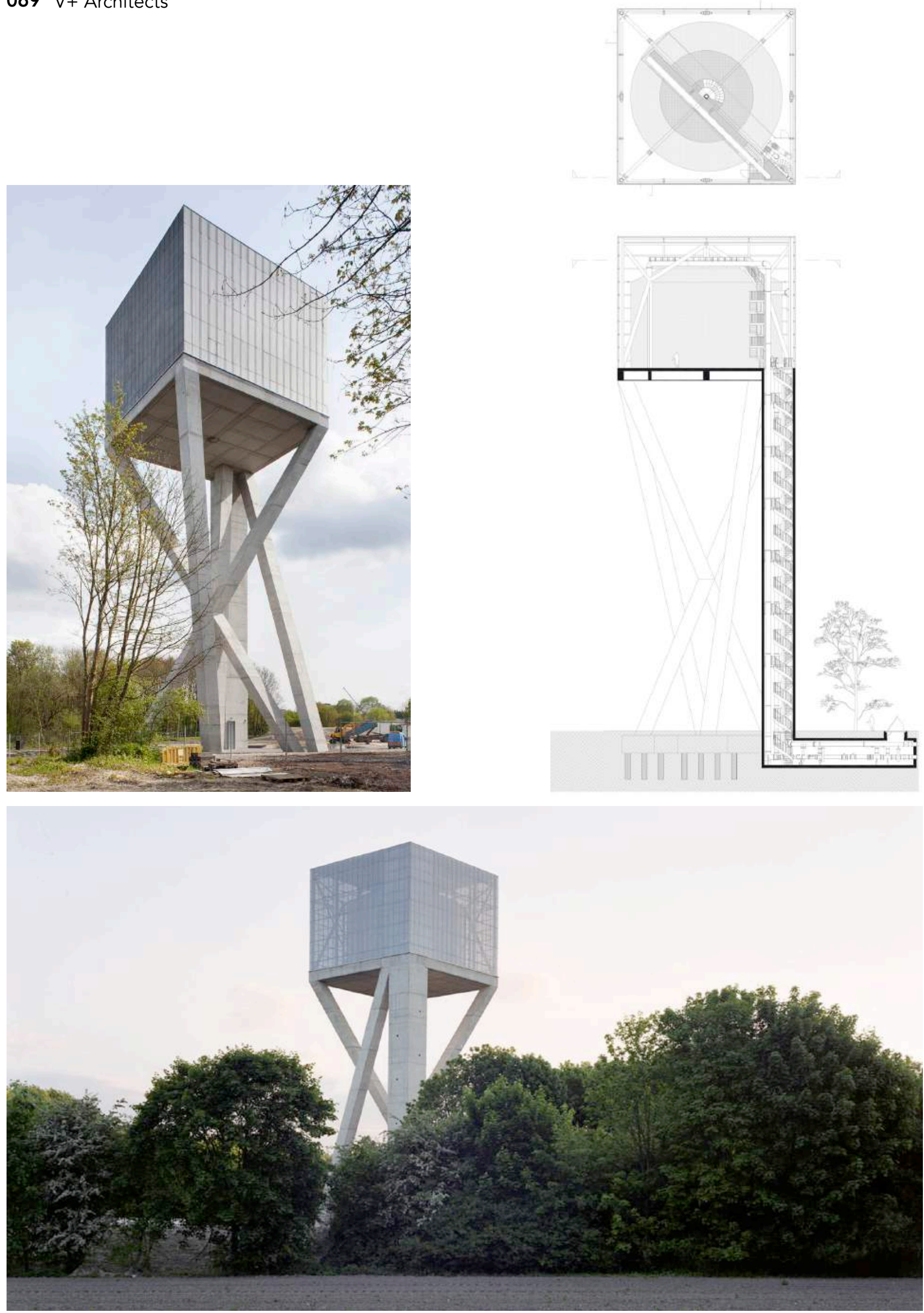
Torre de Água de Kirchberg

070 Amann - Cánovas - Maruri

\begin{tabular}{ll}
\hline Informacões Gerais & \\
\hline Localização & Kirchberg, Luxemburgo \\
GPS & 2016 \\
Data de Início do Projeto & Previsto para 2019 \\
Data do Término da Obra & Abastecimento público urbano \\
Uso da Torre & Em projeto \\
Situação Atual & \\
\hline Créditos do Projeto & Ville de Luxembourg \\
\hline Proprietário / Contratante & Amann - Cánovas - Maruri \\
Projeto de Arquitetura & Simon-Christiansen \& Associés S.A. \\
Projeto Estrutural & N/A \\
Construção & \\
\hline Dados do Reservatório & 1.000 \\
\hline Capacidade [m ${ }^{3}$ ] & Cilíndrico / Fundo plano \\
Forma / Tipologia & Concreto armado \\
Material & 6,00 \\
Altura [m] & 0 \\
Diâmetro máximo [m] & \\
Altura da Água - h [m] & $1 \times 600 m 3+1 \times 400 m 3$ \\
Número de Câmaras &
\end{tabular}

Dados da Estrutura de Apoio do Reservatório

Tipologia

Material

Fuste central cilíndrico ôco

Concreto armado

Altura do Fundo do Reservatório - H [m] $\quad 31,00$

Altura Efetiva - $\mathrm{H}+\mathrm{h}[\mathrm{m}]$

Altura Total da Torre - Ht [m] 48,00

\begin{tabular}{ll}
\hline Dados do Revestimento & \\
\hline Tipo & $\begin{array}{l}\text { Lâminas de brise em estrutura de madeira laminada } \\
\text { Material }\end{array}$ \\
\hline Referências Bibliográficas & \\
\hline Inserções em Bibliografia Específica & nenhum registro encontrado
\end{tabular}

Inserções em Bibliografia Geral [ALCOCER; ALCARAZ; MENDOZA, 2016]

Inserções em Periódicos [ [AFASIA ARCHZINE. Barcelona, 8 set. 2016] 
Torre de Água de Kirchberg

070 Amann - Cánovas - Maruri
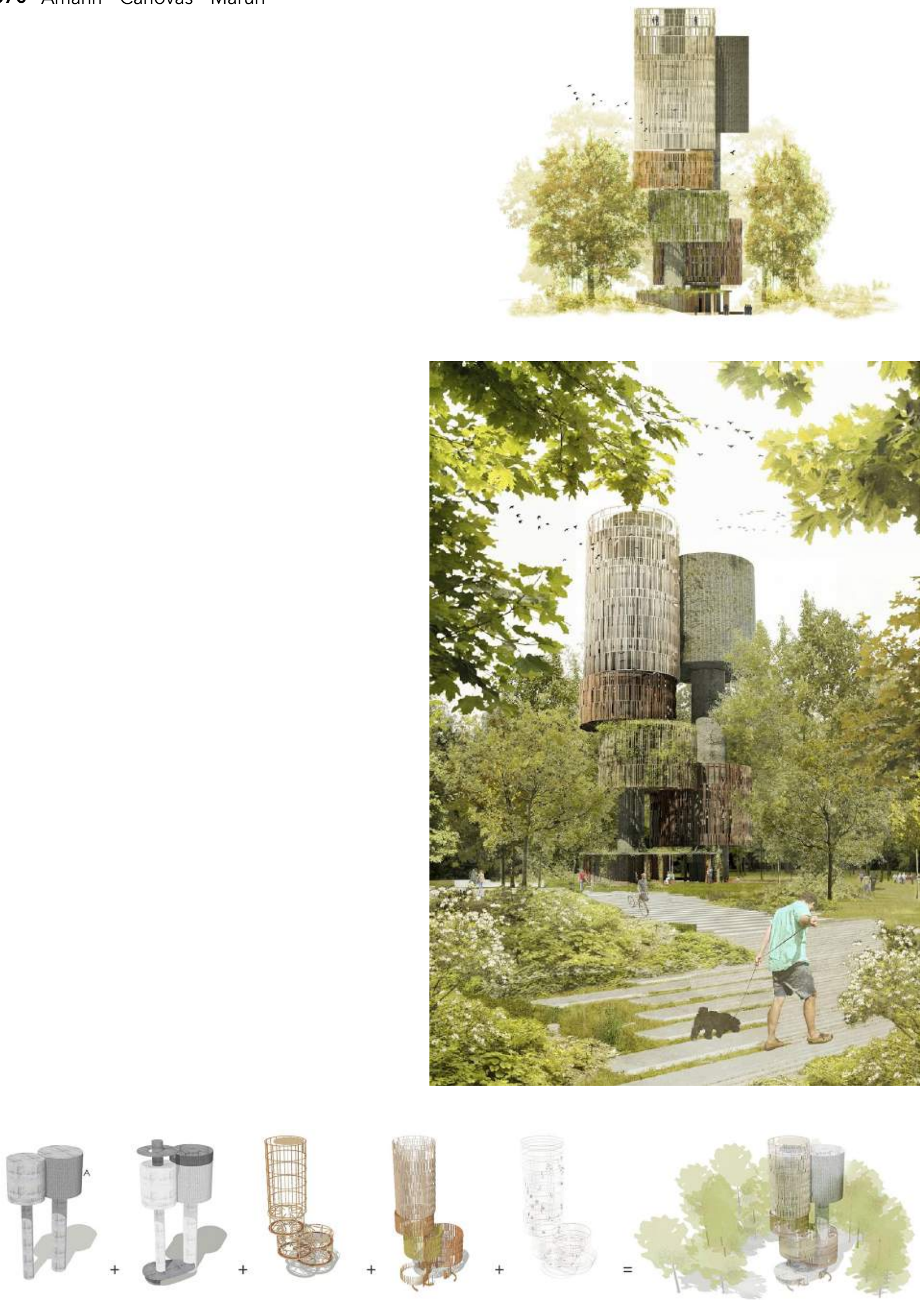